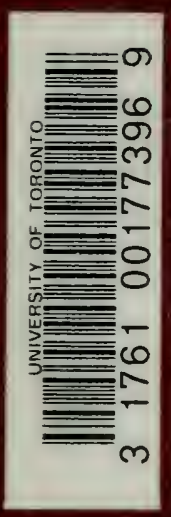




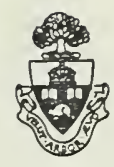

Presented to the

LIBRARY of the

UNIVERSITY OF TORONTO

by 





\section{思的 Wiltall.}

\section{Befdreibung und (jefdidite de Rosmog}

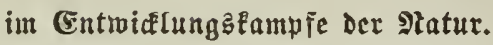

Alten Freuden ber Ratur gerwidmet

Dr. O. YIl

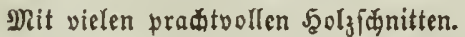

Dritte verbeflerte, woblfrile Aluflage.

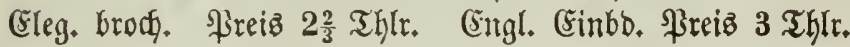

Die Berliner Nationalzeitung sagt über die früberen Auflagen am Schlusse einer höchst anerkiennenden Kecension: ,, So reich und anziehend hiernach der Inbalt dieses Werkes, so gründlich und geistvoll ist die Behandlung des Stoffes, so klar, sınnig und voll eller Popularită die Form der Darstellung. Die kosmische Weltanschauung, der Gedanke der Einheit ron Natur und Geist durchdringt den Verfasser mit wahrhaft religiöser Weihe ur.d giebt seinen Worten einen unwiderstehliche Zauber... Wï empfehlen dieses Werk allen Freunden der Natur, die wabre Geistes - und Herzensbildung aus den unendlichen Tiefen der Natur zu schöpfen trachten. Wir empfelılen es dem Maune der im Sturm der Zeiten den Hafen sucht, wie dem weiblichen Gemüthe, das so gern in den lieblichen Wundern der Natur weilt; und wir sind überzeugt, dass in der Seele des Lesers mehr als eine Ahnung ron dem erwachen werde, was dem Verfasser als beiliges Original vorschwebte."

\section{大ำ}

"Unire Recenfenten", fagt Bieorg Forfter in feitrer Bejedicte

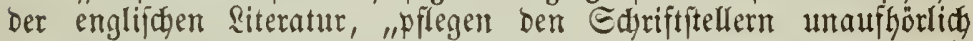

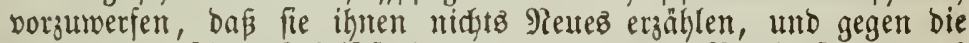
meiften beutja)en Edyrifffteller, beren einzigez Berbienjt in noch nicht gejagten zactis beftelyt, mag ber Borwurf nicht ganz unbillig fein. In anbern Rändern hingegen freht man mehr Darauf, wie ein Sdriftellerbent, wieer ba Befannte burd neue Berfnüpungen feines benfenden (b)eifteg zu etwas ifm eigenthuml id Reuem umbildet unb bem gegenwärtigen

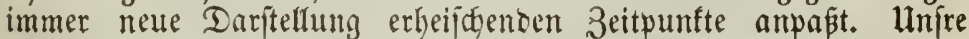

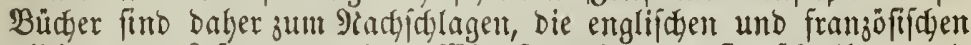
allein zum Rejen gemadjt. WBir ftoppeln, - fie fidreiben und

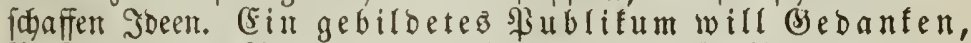
Reflexionen, $\mathfrak{A}$ negungeneinezeigenthüliden Joen= ganges, zarte Berúgrungen, leide le ebergänge, $u$ m= faflenbe Blide, - mit einem sisorte: (s) eift und Bse=

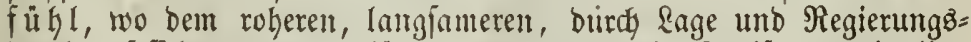
bruf gefefielten unb verfümmerten nur grobe Epeije, uutmittelbar zu bemubenber unb zun nothbürftigen $\mathfrak{l} n$ terbalt anmenbbarer $\mathfrak{l} \mathfrak{n}=$ terridgt oder auch berbe Eriçütterungen nöthig find." 
Diefes SRort Foriter's finset jeit Der gropent Epodte, welde mit

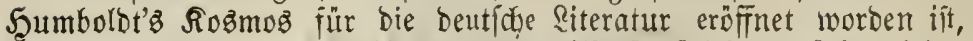
wenigitens für einen Theil der natumififemíthaftlichen Bücher feine Beltung mehr. Whir haben jebt nidjt mehr blob ๔ammler und \$e= Danten, fonbern, was forfter will, ibeenvolle Befammtanifhaumnem,

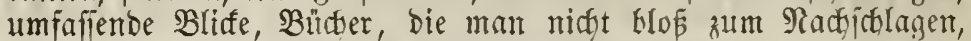
conbern in ber That zum Rejen brauchen fann. Ju biejen Büdern hat bie Fritif auth Ule's Weltall gesähl, und Das Bebunrfmíp einer

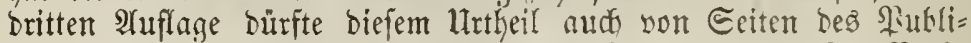
cumsె bie volle Beftätigung fidyern. Ter Berf. hat in biejem Budse

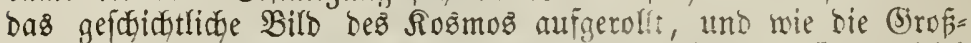
artigfeit jeiner (Semälde ben Rejer anzieht, fo fiithlt er fidh zugleith an Semüth utmb Seift wohlthätig angeregt. (Er betraditet funädit

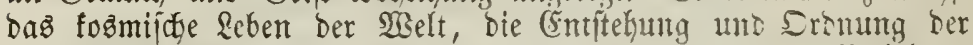
Beftirne und bas planetarifde Reben Der (Erbe mit itren Beziehum=

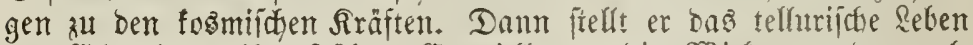
ber Erbe Dar, ifre frithere Entwidfung, bie SBinfuntgen Der vul=

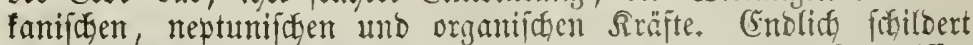

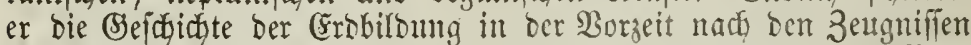

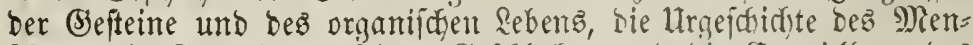

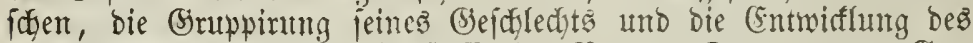
Bölferlebens unter dem Cinfluje der Matur. Das ganze (5) $e=$

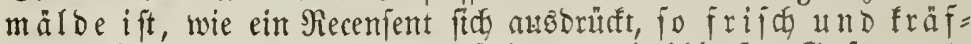

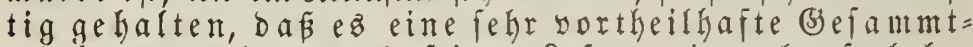
wirfung gewinnt und feinen rejern eine ebenfolehrs

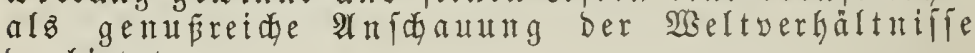
barbietet.

Die weit serbreitete Anterfenmung, weldye ber $\mathfrak{B e r f}$. Durct bie

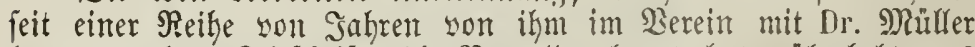

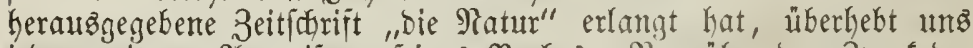

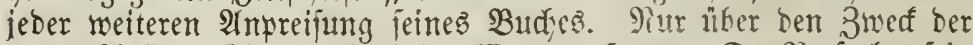

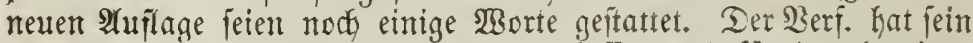
$\mathfrak{B}$ erf nidyt alfein innerlidy wejentlidy serbefiert atmo für bent leutigent

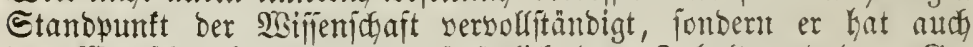

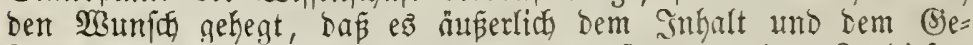

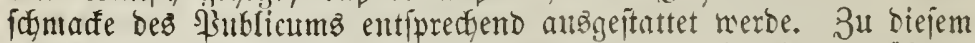
Zwecte hat fid ber $\mathfrak{B}$ erleger bereit gejunden, es in einem gröperen

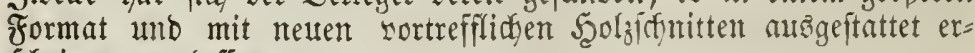
idyeinen zu lafient.

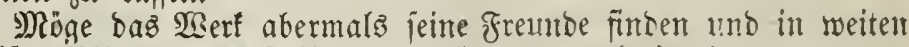
Sreifen Bilbung Des (Seiftes und Scersens verbreiten!

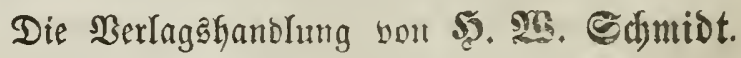

5alle, Druf non 5.. 20. ธdmibt. 


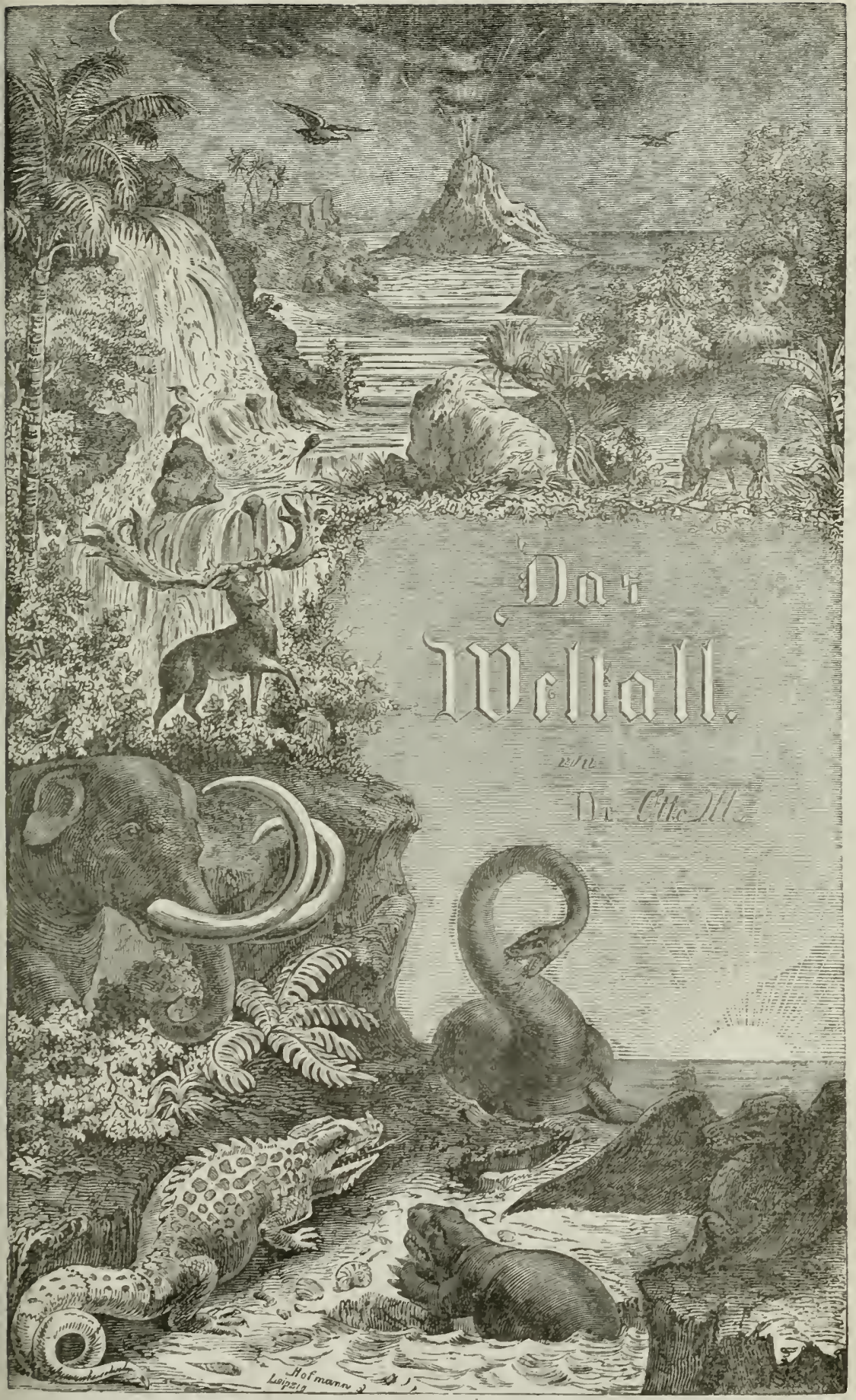





\section{Das Weftafl.}

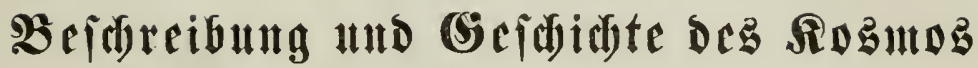

im

EEntwidhlungskampfo Der Matur.

Aren Freuben ber Ratur gewibmet

volt

Dr. Dtto $\mathfrak{n} \mathfrak{e}$.

Dritte vermegrte suflage.

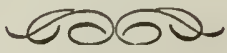

(f) $\mathfrak{a l l e}$,

Druat und Berlag vou 5. 2 . Sdutid.

1859 . 

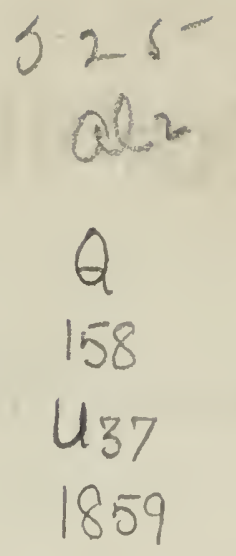

Dienhiftopheles.

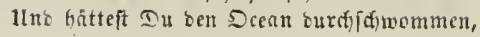
Das (j)renzenlofe sort geingaut,

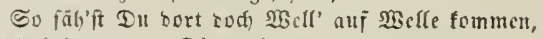
Colbft went es Dir vur'm lntergange grant. Du fäf'it tod etwas. Găb'it in cer (brüne (Sicfitter Mieere freidjentse Detpline;

Säfif Sgoten jielien, Sonne, Miono uno Eterne; Sidit) wirit Du fefm in ervig leeter Ferne, Den Edritt niwt hörch, ten Du thuit, Yitifts Jeftes fincen, wo Du rubft.

$$
\text { ก เ น คี. }
$$

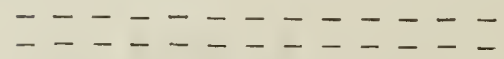

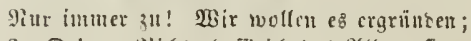

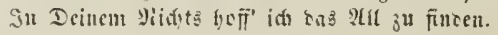

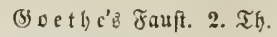

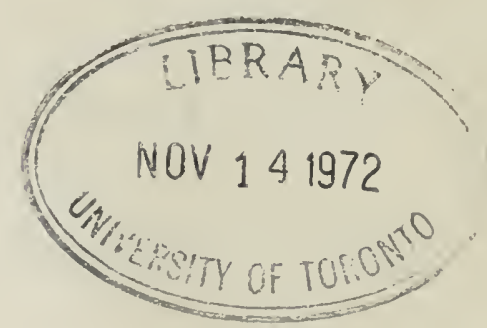




\section{Borrede jut criten 2 fuflaye.}

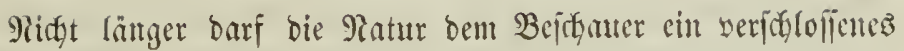

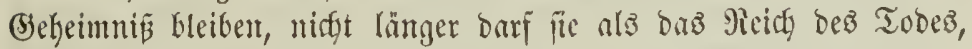

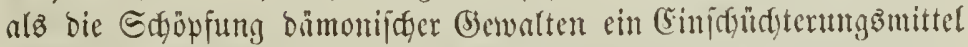

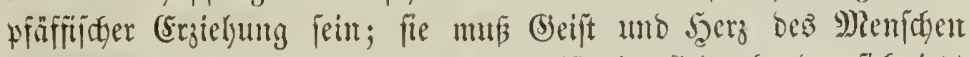

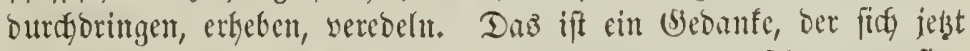

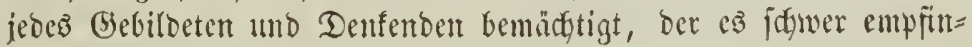

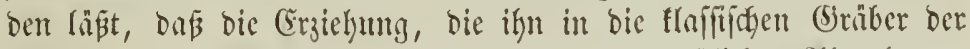

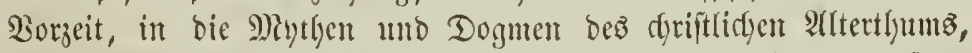
in bie Difftumgen uno Träume philojopgijacher Epeculation verjenft hat, ign bie heiligfte Etätte, feire nädjpte limgebumg, fein $\mathfrak{B} a t e r=$

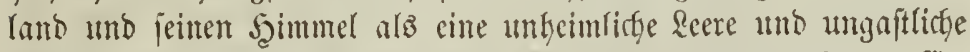
Frembe femnen lelyte. Diefer Bebaffe war ez, der burdy bas êr=

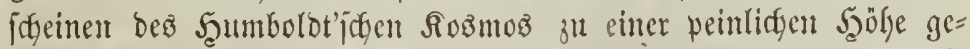

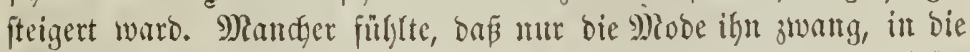

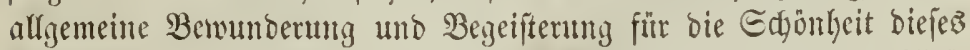
Meifterwerfs einzuftimmen, wälrento ifm fellojt bie geiftige Tiefe

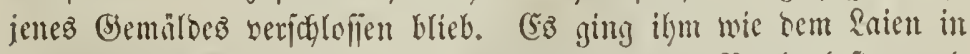

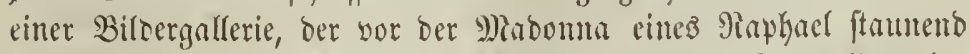
weilt, weil fie ben Renner mit $\mathfrak{A n b e t u n g ~ e r f u ̈ l l t . ~ D a s ~ a l f g e m e i n e ~}$

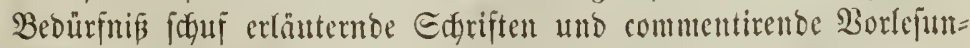
gen in Mentge. Man zerglieberte bab Semäloe umb zerítörte feine

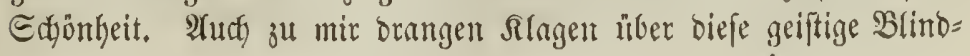




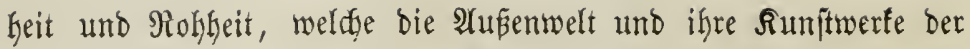
Eeele serfüllte. Sh wurbe im Sisinter 1847 und 1848 veranlạ̈t, offentlidje Borleputgen in meiner bamaligen Seeimat Franffurt a. D.

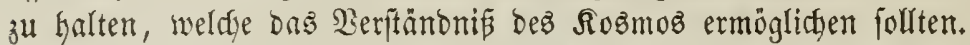
Sch fah aber ein, baßi, ehe man baz Meifterwerf einer Biffenifaft verjtehen lebre, man erft Siebe und sujt für bieje felbit erweden mijfie. Darum gab idy feinen Commentor zum Sosimoz, feime (5r= läuterungen uno Zerglieberungen, fonbern serjutgte jelbft ein Banzez

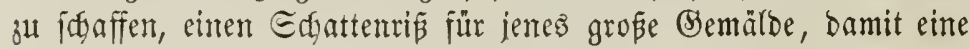

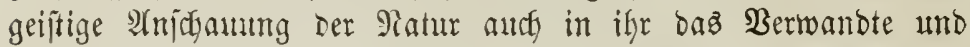
Rebendige ergreifen, fie nahe führen, in ige fühlen uno benten lehre.

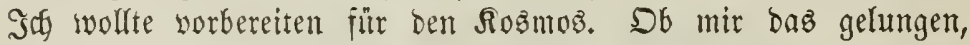
weip idg nidut. Sch fand aber gegen (Erwarten meiner Freunde ein zahlreiches \$ublifum unter ben gebildetiten Betwohnern, Seerren und Damen Franffurts. Die unermildete Theilnahme meiner $3 \mathrm{u}=$ hörer zeigte mir menigitens, daß̃ meine Beftrefungen in ber erwact)= ten Raturliebe meiner 3uförer Antlang fanden. Exbon bamalz vielfach aujgeforbert, bicje Borlefungen Dem Drut zu übergeben,

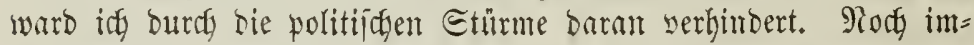
mer fint biefe jwar nicht voribergebraut, nod höre id in meiner Gimjamfeit bie branbenden 2 Sogen ber 3eit; aber mitten ausz ben Etrubeln jende idy bieje Ectopjung res zriebens in ben fitlfen

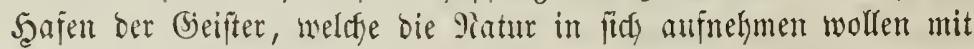
ifren etwigen Sebanfen uno Tröjtungen, mit ifren erhabneren

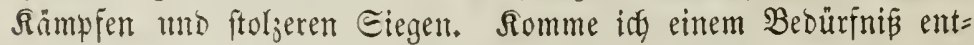
gegen, uno ids hoffe es zur Egre ber 3eit, jo ijt mein SGerf tein überfluifïges, trob ber zahlreicyen Echöpfungen gleidyer $\mathfrak{A}$ rt. Täuidge idy midy aber, ift bas Bemuétjein biejer Rüfe in ber Dildung nody fein allgemein empfundenes, fo wiro bies Buth wenigitens Denen eine fremblicfe erinnerung feit, bie midy yor swei Safyren fo mandte

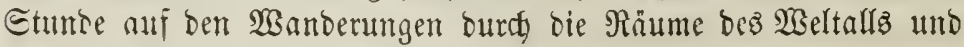
burdy bie Tiefen feitrer (S)ejefidgte begleiteten.

Die urprüngliche Form uno Beftimmung biejes $\mathfrak{B e r f e s}$ wird

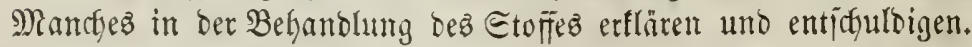
Borlejungen bürfen nicht burdy Sin̈ublidfeit ermilben, nidyt burdy

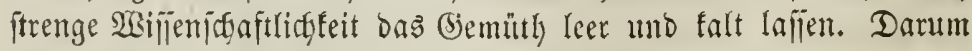

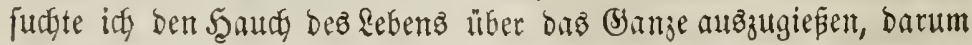




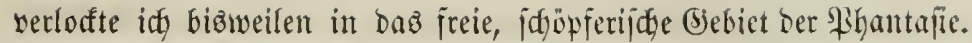
Sal wollte ein Giemälde ber lebenbigen Matur entwerjen, eine (jes= fafidte geiftiger Entwiflung und Bernollfommmng oer \$iselt fabil= bern, Darum muste idy Mialer unb Didjter werben, mit Farben

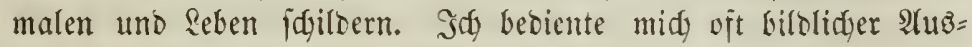

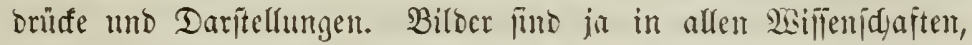

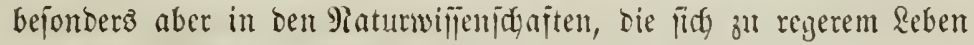
und geiftigeren Anjabuungen erboben haben, ganz gewöhnlidg. Ier

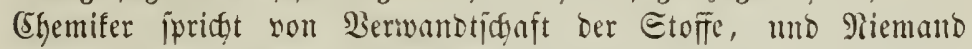

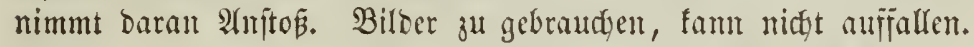
Wir leben ja in einer selt von Biloern, jebes 2 sort iịt mur ein

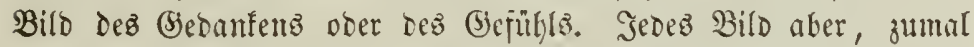
wenn es auz bem Reben gejrifien ijt, wirb leidyt balo eine zu enge, bald eine zu weite $\mathfrak{A}$ mjohaung bes wahren (jegenjtunbes gewähren;

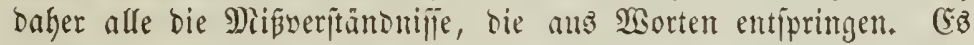

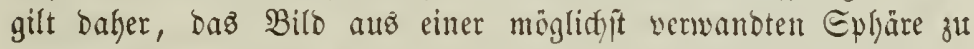

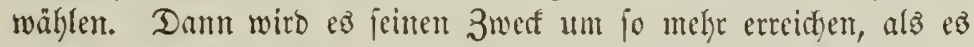
Das Frembartige, Neue in die 2 selt des Befanten, Bewohnten

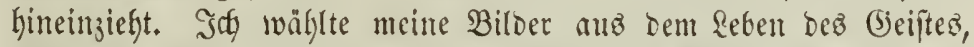
benn ich fenme nichts, waz bem Seben ber Siatur näher ftünde. Sh fenne feine tobte Natur, mir ift bie ganze Matur lefendig, auts bie Materie lebt. Darum fprndy idy bon einem Eehnen Der Matur. Das Eehnen gehört allerbings bem Rebentigen an, es fintet feine Gödyite Bebeutung in ber 9lenjaymatur; Dem es ift bas jumers= liche, faft hoffnungslofe Berlangen beş Seerzens nach cinem (Slüce, baz ilym unentbehrlidy erjdent. Aber getnbe weil bnz Eehnen bem Rebell angehört, wällte idy bies Bilb. Demn wer bie Eelynjugt Des Saerzens empfindet, ber wird fie audy in ber Matur veritelyen lernen. Das war bie Augabe meiner Arbeit: ió wolfte bie Ratur

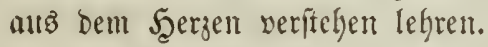

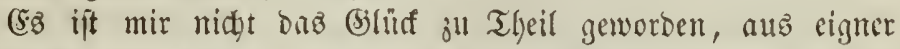

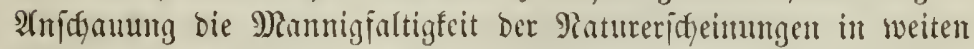

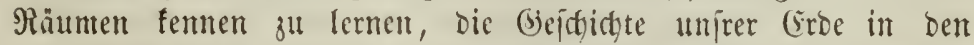
Driginalen iljer llrfunben zu ergrünben. Sth muß̈te meine Ducllen auв ben Mittgeilungen glütlidgerer Foridger fdÿpfen. In Der Ma=

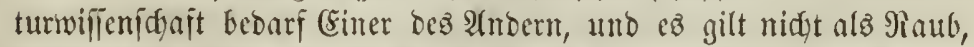
wenn bie Erfahrungen bes Einen bem $\mathfrak{A}$ thern zur Grunblage bienen. 
Shth habe bie Pamen Derer, Seren Edyriften id benubzte, im Raufe bes Mertes nidgt immer genannt. Sht erwályne Darum hier unter Den Borzunglicyten: 2 . v. Sumboldt, Stie de Beaumont, Studer,

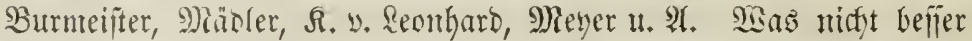
gejagt werben fonnte, habe ich wötlich aufgenommen, Anteres mit bem Meinigen verflochten und umgeftaltet.

lleber ben (Segenftand meiner Ectrift habe idy midy in ber

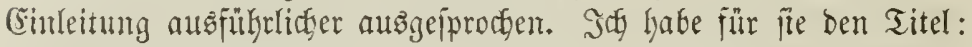

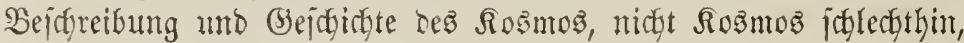
gewihlt, weil ber lebtere 2ame burdy Jumbold's Borgang eine ganz bejimmte Bebeutung, bie einer phylichen siseltbejdreibung, eines Naturgemäldes erhalten hat. Mir aber ftand bie Meltgeldidyte im Boriergrumb, ju weldyer alles Andre nur vorbereitendes Material fein foffte. Sch molfte bas MBerben ber Yatur aus ifrem Eein, Die Zergangenkeit im Epiegel ber Siegentwart erfennen lefren. Sta soollte allerbings bie Patur in ifrer Cinfeit und Sarmonic zujam= menfañen ju cinem grojen Gemülde; aber idy wolfte bieję \$ortrït Der Patur Durdforingen mit Dem belelenden Sgand Der Sejdyidte.

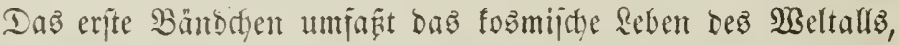

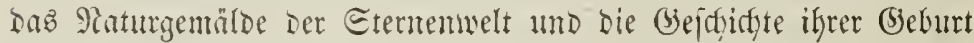

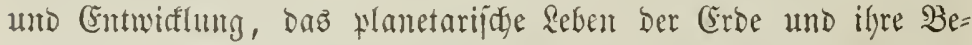

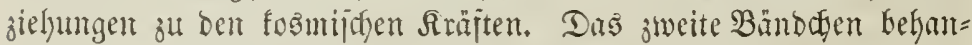

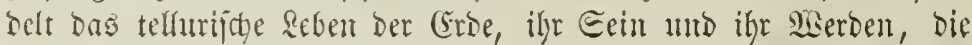

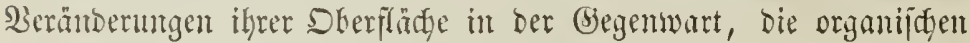

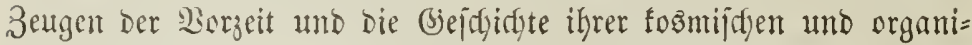

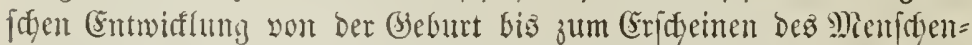

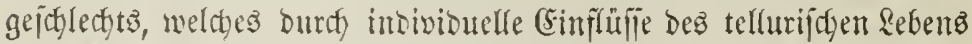
feite CGarafterweridgiedenkeiten entwifalt ljat.

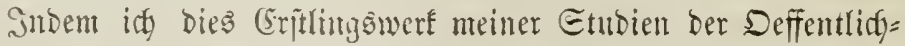

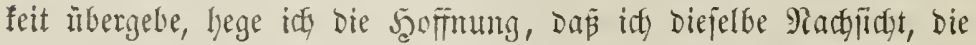
mir von meinen 3ubören 3u Theil ward, aud bei meinen Rejern finten werbe. Sch wente mich an gebildete Sejer, id verlange nidgt wifienichaftlidse Bortenntnifie, aber jene Bildung Des (beijtes und Serjens, bie, verbunden mit Riebe zur Matur, int Etande ift, in

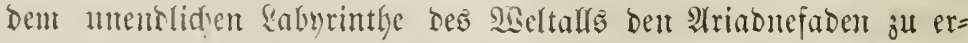

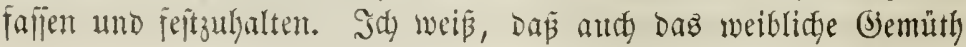




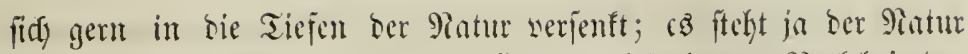

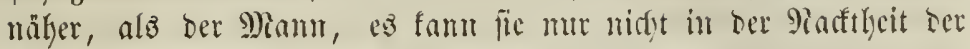
abitraftion ertragen. Darum wembe idy mid) auch an ben weib=

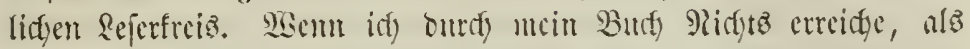

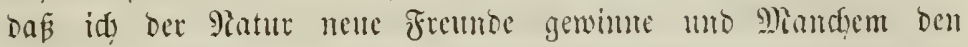

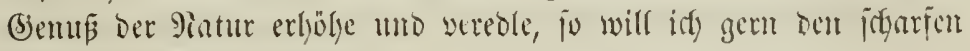
Tabel ber Sritif ertrigen.

Dueg, den 16. December 1849 .

\section{Otto llle.}

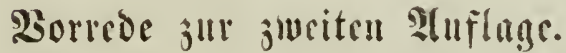

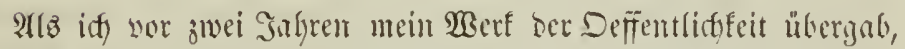

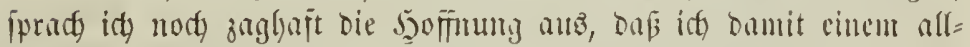

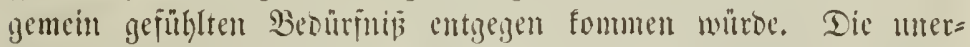

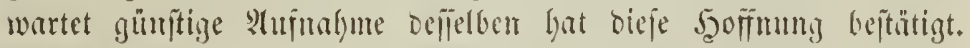

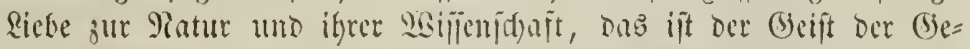

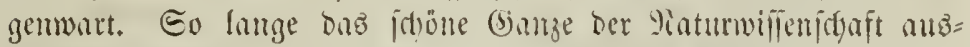
einandergefallem, cin ungel)eures Şatwerf you Material war, bem

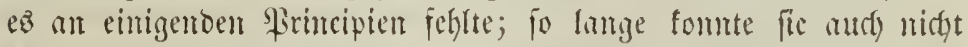
Enche des Bolfz, geiftiger uno fittlițer Bifoung, fomte fie mut

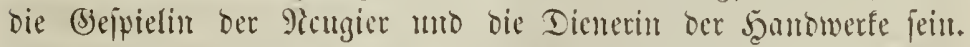
Raum aber begam fie ilyre ewige (Eintgeit ju abmen, bie Rräfte

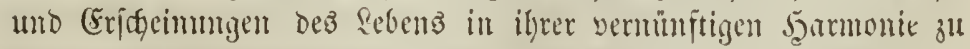

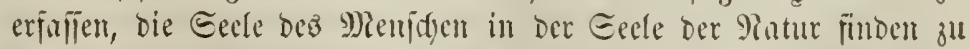
lehren; fo erwadte in Dem Solfe das Berwustjein, das diefe Wifien=

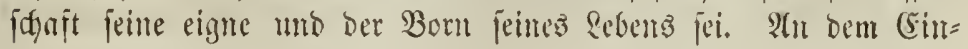


zelnen bafteno blieb bie sînifenidart ber Patur ein engherzigez Menjhenwert, minudbtbare Ratheberweisheit; auj bas Samje ge=

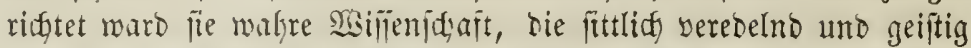

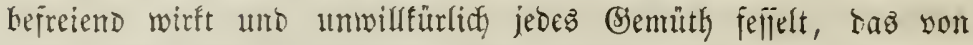
ifren Zauberfeijen einmal umidglungen warb.

3ablreiche Edyriften baben auf nllen (Sebieten ber Saturwifien= joajt bieje neue \$oee ber organijden (sinteit zur Eeltung zu frin= gen und gleidyzeitig in ebler und verftandlicher form hem weiteften

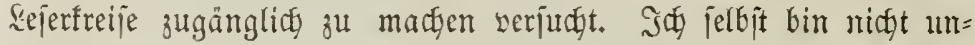
thätig geblieben uno Durch bie immer beutlidger rebenden Zeichen Der 3eit zu eimem llntermefmen getrichen worben, welches ber $\Re(n=$ turwifienichaft aufy einen Flas neben Romanen, Siovellen und Mobejournalen einrüumen jollte. Die auperorbentlidg günitige 2 uf $=$ nabme, weldye bie im Derein mit melyeren Freunden yon mir her=

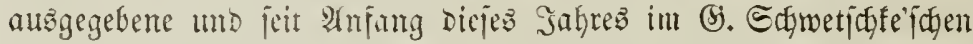
Berlage ericteinembe 3citicyrift: "Iie Ratur" gejunden bat, beweift mir, Daj ich ren Eimn ber 3eit ridtig erfaumt habe.

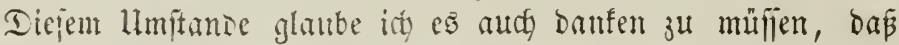

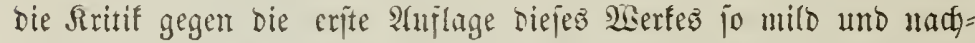

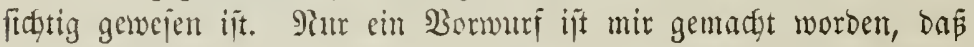

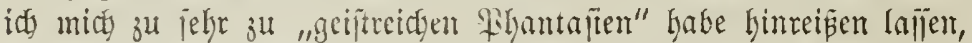

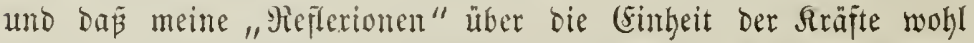
micht gecignet jeien, ben naturtwijlenjळajtlichen Bejtrebungen einen Göheren Etandpunft anjumeijen. İh fam barauj mur erwibern,

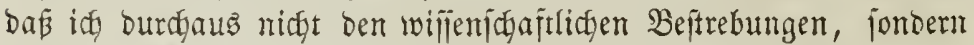
allein Der Anjdaunng bes Rejers labe einen Etanopmtt anmeijen

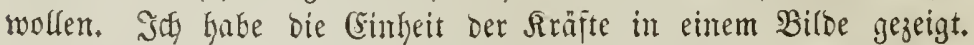
(5Ẻ ging mir wie Mathan Dem Weifen, Dem Eultan gegenüber, alz er ifm Die (Ëinlyeit und (Sleidberectigung Der Fieligionen begreiflich

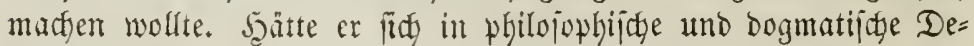
Ductionen eirgelailen, er wire fither nidgt beritanden worben. Er erjählte Die (Scjedidte yon Den Singen und - warb veritanden.

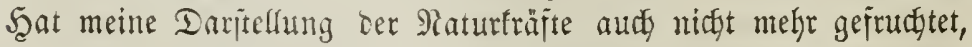

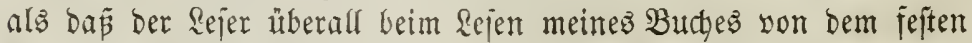
(Glauben an ifre Einfleit erfüllt war, jo habe id gemug erreidgt.

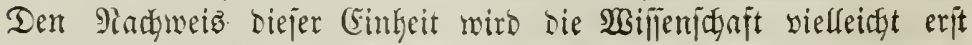

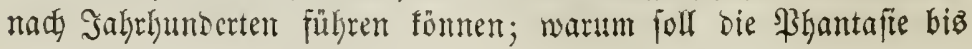


bahin nidgt bie geaknte und gejoronerte Einkeit fidh malen? Sine

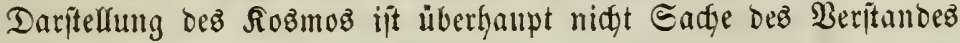
allein, fondern audb ber ßhantajie. (Sleidy Den Bifronen eines Traumes fommen uns die Bebanten, und gleidy Eomtenitrahlen weben fie fid ein in bie Bifienjagft. Die fosmijge Auffajlung Der Ratur ift eine poetijae, uno ber \&ejer begreift fie, weil ex fie fühlt.

In ber neuen Âfuflage have ids midy bemilht, audf bie zahl= reichen Ermeiterungen, weldye die Bijienjøait in ber lüngiten 3eit erfahren hat, aufjunehmen uno mit bem frïheren zu berweben.

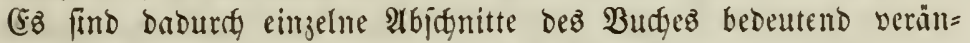
bert und vermehrt worden. In bem ajtronomijaen Theile hat bies bejonbers die âjanitte über bie Firjterne und bie \$laneten be= troffen, für weldge jedes Sabr neue und widntige Sntbeffungen bringt. Int sweiten und britten Bande berilfren bie Betänberungen

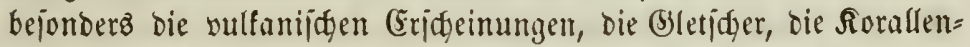
riffe und einjelne (Stegenftände aแz Der (Sejdjidte Der (Erbbiloung.

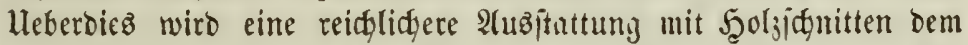

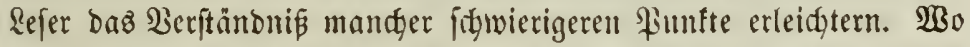
aber bieje nidgt lyinreidgen follten, empjeble idg als ganj norzüglid

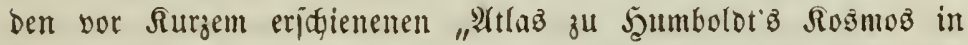
42 col. Taf. mit Tert, herambig. v. Traugott Bromme; Stuttgart, bei Лraiz \& Şof̈manur."

Mröge benn Das Wert in feiner neuen (Beftalt fïd eben fo viele Freunde gewimmen und bejiflben Beifalls erfreuen, das ifm bei feinem erften Eridgeinen zu Theil mard!

Şalle, im शruguit 1852.

Stto Ille. 


\section{Borrede jur oritten 2uflage.}

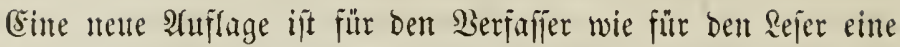
gleidy wilfommente Erffjeinmt. Dem Berfaffer giebt fie Sielegen= Geit, jeine Âtbeit ju verbejiern, ilyre Form zu serbolffommmen, ifren Intyalt bem Fortidyritte Der 3eit anzupaffen. Das ijt auth in bie=

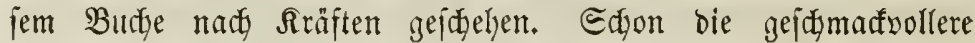

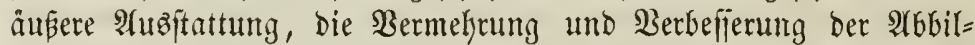
Dungen wirb bavon hiberjeugen. Ather auch ber Suljalt hat mantse wejentliche Umarbeitung erfafren. So iit namentlidy bie Sejobicte Der Silanetenentbefungen vervolfftantigt worben, cz find bie nettern Beobadyungen und Anficten über bie Oberflädse ber Eonne, das 3oriafallidyt, Das Sorblidgt madgetragen, bie neuern Eridgeinungen

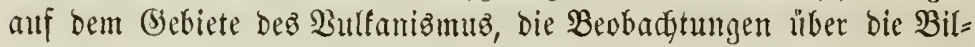
bung Der Cisberge, bie Anfidten über die Sataftrophen ber (5rd=

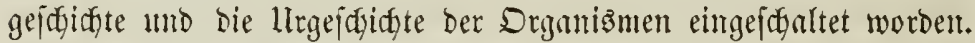

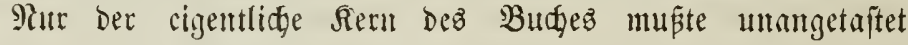

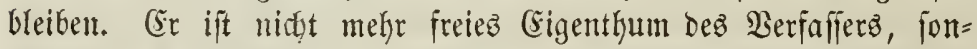

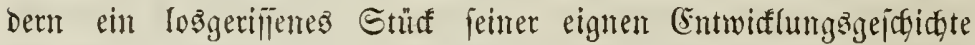

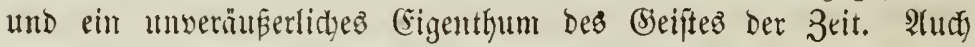
wo Der Berfafier unter bem fortwirfenden (Sinflü ber Siffenidaft ein 2 ntoerer geworben, musten bie eimmal ber Deffentlibgteit preis̈ge= gebenen Anfiften und 9leinungen ifm beilig und unverleşliç bleitien.

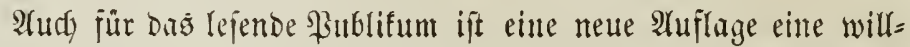

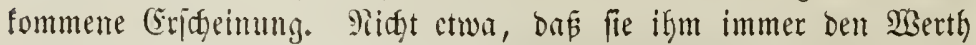

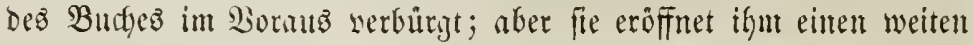
Sreis von gleidgeînnten, gleidyempfïtbenden Freunden, unb biefer

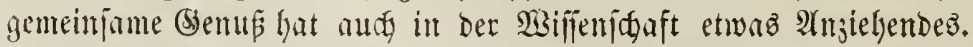

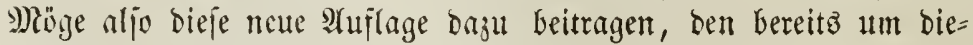

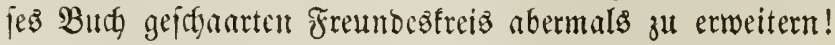

Scalle, int Rowember 1858.

Stio Ille. 


\section{$\mathfrak{J} \mathfrak{i} \mathfrak{a} \mathfrak{l} \mathfrak{t}$.}

Geite

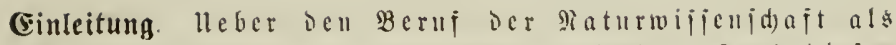

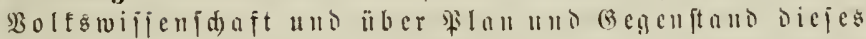
SBerfe ill bejondere.

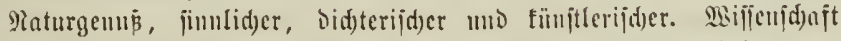

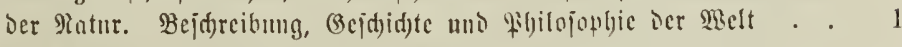

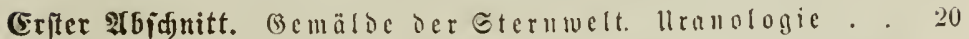

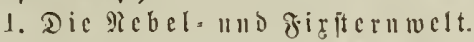

Ridutuebel. Mebeliterne. Eternbaufen. Mildjitraje. Emtjernugs.

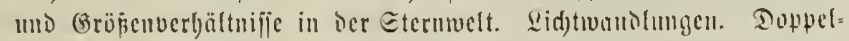

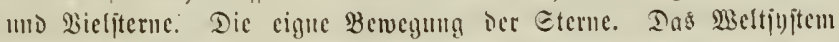
ImD Dic Centraljome. Die Sromm ter Mebeluelten . . . .

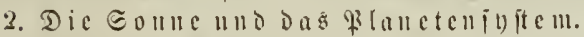

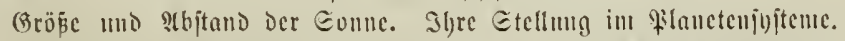
Die Eome als Duelle der Bärme umb Des Sidjts. Centrale mo planctarijde förper. Die Dbcrifläde ocr Somme . . . . . . T0 Dic Planeten uno ibre Maturbejdaffienbeit . . . . . . . . 85 Die Trubanten. Der Eromond und bie Ratur feiner Duerflithe . . 105 Dic Rometen mid ibr Alberglaube . . . . . . . . . . 117

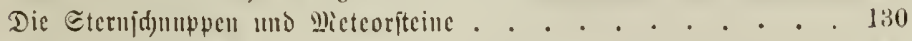
Dą 3odiafallidst . . . . . . . . . . . . . 141

3. Die Eutwi tung gejd) idjte Der Melt.

Berind) Der alten. Der Basball. Die Minubbiltung. Entwictlung Der Rebelfterne mo Eomnenjufteme. . . . . . . . . . . .

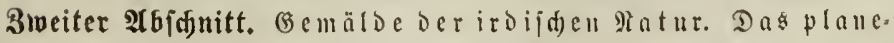

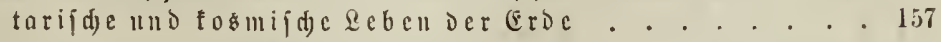

1. Die E

Arendrelung und Gejtalt Der Eroe. Babuberoegumg. Bejtalt und Lage Der Erobahn. Gtörungen. Bewegung um Die Centraljome. 
Die Erbe al\$ Centralförper und bie Babnberwegung Des Mombes. Die Finjternilïe. Die 3eitredunng . . . . . . . . . 163

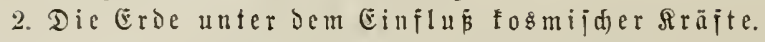

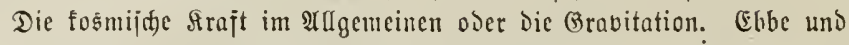
Fluth. Decanijdue Etrönungen. \&ujtitrömungen . . . . . . .

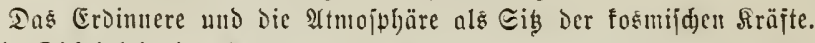

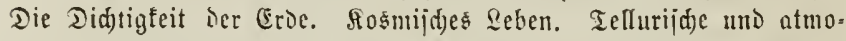

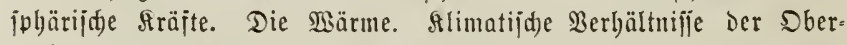

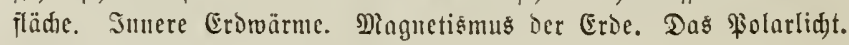
Die Clectricität und die Gervitter

Dritter Abfunitt. Gejdidte Der irbijden $\Re$ atur in Der Ge. gentart. Die Erde als jelbitüudiger Drganismus . . 273

A. Die Wirkungen ๖er vulkanif̣den Earäfte. . . . . . . . 276

1. Die Erdbeben un ibre $\mathfrak{B}$ irfungen.

Die Erjdütterungen unD Erijütterungeffreije. Erobebenzonen. Sebun= gen Des Bodens. Bulfaniidye Sujelbiloung

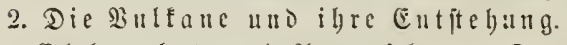

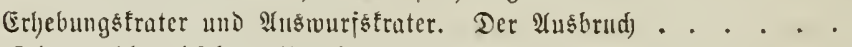

3. Die vultanijat en robute.

Die Flanmen. Die Dämpic und Gaje, Diofeten, Gasunlfune, Ealjen, Edjlamubulfauc. Mljue, Gano und Rapilli, vulfauijose Bomben. Die

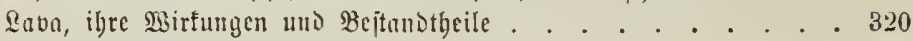

4. Die e rlojdenen $\mathfrak{B}$ ulétane . . . . . . . . . . . 344

5 Die llijaden Der $\mathfrak{B}$ ulfanc. . . . . . . . . . . 349

B. Die Wirkungen der neptuni(d)en Earn̈fte. . . . . . . . . 354

1. Die Duellen nud ibre C゙utitelung.

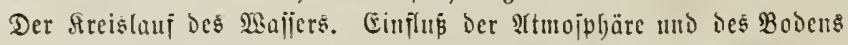
auj Die Suellenbiloung. Die artejijaen Brmnen. Die Ratabotbra und Edylotten. Die periodijden Suelleu und Epringquellen. Die Mineralquellen un Thermen . . . . . . . . . . .

2. Die $\mathfrak{B}$ irtungen ber flïje und meere.

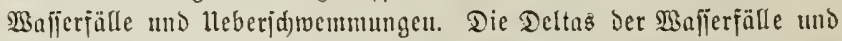
Ueberjdwenmungen. Die Delta der Mildbäcbe und Etröme. Die Etrandbildungen. 3eritörungen Des Meeres an fiiften. Mieeres: Durdbrüdje . . . . . . . . . . . . . . . . . .

3. Die Birfungen Des atmoiphärijaen $\mathfrak{B a f j e r s . ~}$

Die Erofion. Die Thalbildung. Erofionsthäler und Stromthäler. Bergitürze uno Erdjälle. Dic Selïeltgäler uno Suertbäler. . . 406

4. Die Birfungen Des Eijes.

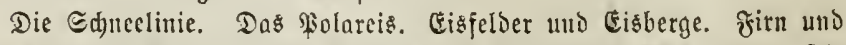
Gletjøer. Berwegung Der Bletider. Bloränen und Eduttroälle. Die

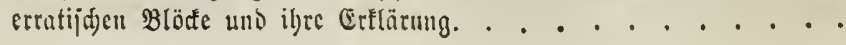




\section{XIII}

C. Die Wirkungen Der organijめen ER räfte

1. Die $B$ a uteu Der $\mathfrak{B} f$ lanzentwelt.

Bildung von Dammerde uno Iorf. Ilnterjecijd) Mälber und Treibhol 463

2. Die $\mathfrak{B} a$ uten ber Thierwelt.

Die Slorallen, ihre Rcbensweife und ibre Banten. Strandriffe. Damm. riffe. Atolle. Sebungen und Eenfungen der Rorallenriffe. Die

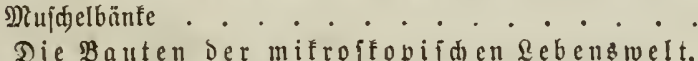

Die Diatomeen oder Stäbdenpflanzen. Sufujorienlager. Die frora. miniferen oder Moosforallen

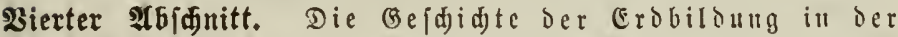

Borgeit . . . . . . . . . . . . . 493

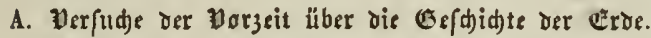

(Bejdidjte Der Geologie. Grieden. Mittelalter. Steno. Repler.

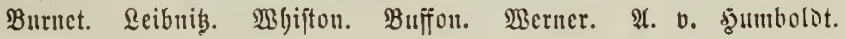
\&. o. Bud . . . . . . . . . . . . . . . 498

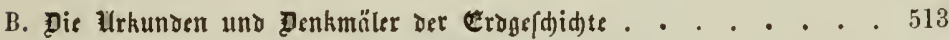

I. Die Befteine oer Erorinde al Dentuäer Der 3 orzeit 515

1. Die Eruptionsgejte ine.

Granit, Syenit, Borphyr, (Srünjtein, Serpentiu, Bafalt, Tradyt, Saven 515

2. Die Gediucutgeiteine.

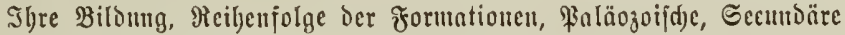
uno Tertiärgebilde

3. Die metamorplojirten Gefteine.

Metamorphiśnu\&. Sirbftallinifd)e Edjiẹer, Marmor, Dolomit. Erz. gänge . . . . . . . . . . . . . . . 542

4. Die conglomerate.

Ganofteine, Mtolafie uno Ragelflue . . . . . . . . . . 554

II. Das organifde $\mathfrak{L}$ eben als $\mathbb{L}$ tunden ber $\mathfrak{B}$ ormelt. 556

1. Der $\mathfrak{l}$ rtbegriffiu ber \&eben welt . . . . . . . 563

2. Die $\mathfrak{L}$ ebens tuelt der Begentwart . . . . . . . . 569

a) Daร Siflangeureid) . . . . . . . . . . 569

b) Das Thicreid) . . . . . . . . . . . . . . 585

3. Geograpbifde Derbreitung Der Pjlauzen und Thiere in ber Gegentrart... . . . . . . . . . 600

4. Die Lebenswelt oer Borgeit. . . . . . . . . 611

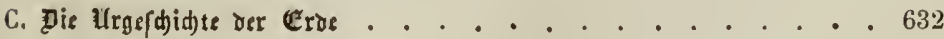

1. Das Cha . . . . . . . . . . . . 636

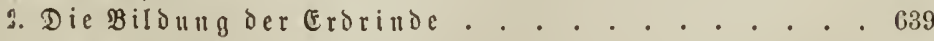

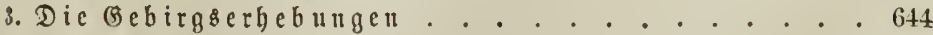

4. Das Erroad)en und fortjdreiten de\& organijdan Lebens 654

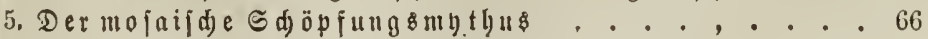




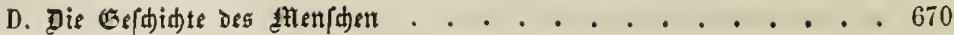

1. Die (stuppen ves menjuengefdredts.

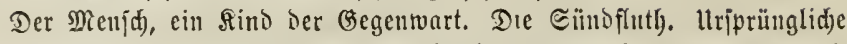

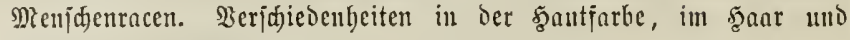
๔ä̈belban. Gruppen . . . . . . . . . . . . . 672

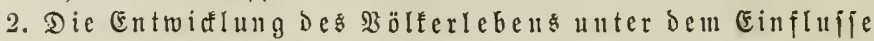
Der Patur.

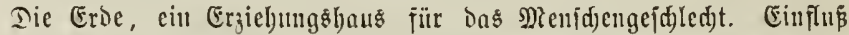

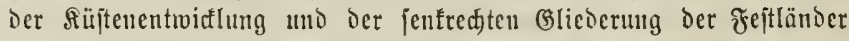

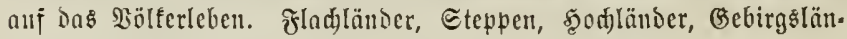

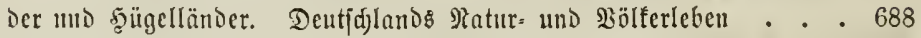
Ead)regifter . . . . . . . . . . . . . . 703 
Dả 2 Seltall. 



\section{(E)inlcitıll}

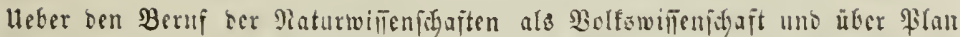
แno Giegentano biefé niberfes inabejonore.

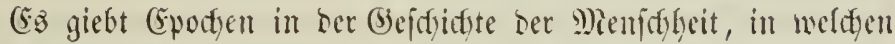

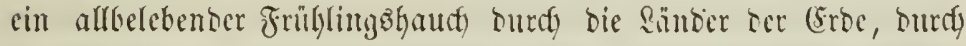

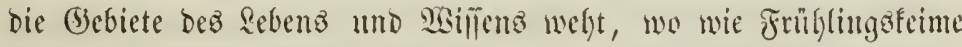

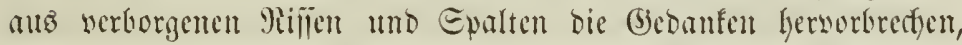

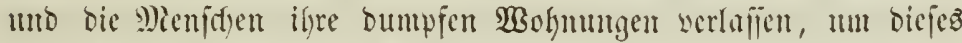
neue Reben einjujangen. (Eine joldye 3eit mar bic fürzlid) burds)= lebte. Mandfe Reime fint wieder bathingenelft unter bem wernidy=

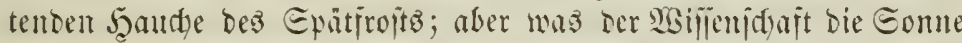
Der Beit wecte, grünt fröhlich fort, mo nidyt melyr Činjelne find

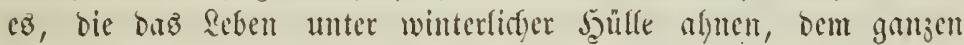
Bolfe hat es̉ fid cridylolien.

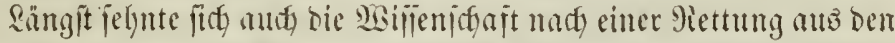
Banden, in bie fie arberglaube und Serblentung, Deșpotic Imo Saierardjie gejdylagen butten. Eie jdumadytete unter bem Druffe

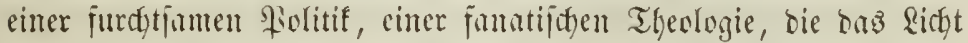

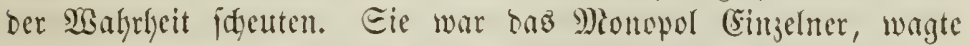

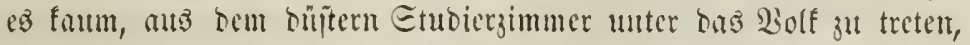
war werwiejen in ftaubige $\mathfrak{B i b l i o t h e f e n ~ u n d ~ a u j ~ t w u r m i t i d y i g e ~} \mathfrak{\Re}_{n}=$

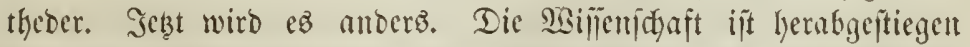
von ifrem luptigen Throne, um mittent unter dem Bolfe und in

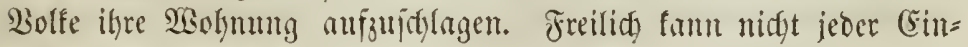
Itle, 2ocitall. 3. 2uศ. 


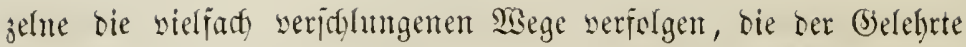

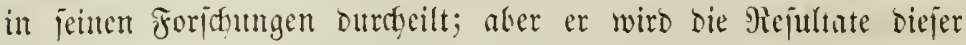

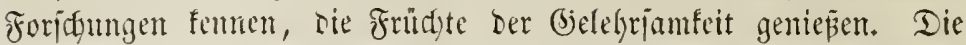
2Bifienifa aft wird mit tem Bolfe verwadjent und mit ifrem bele=

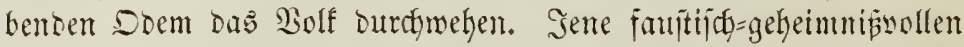

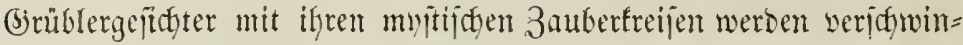

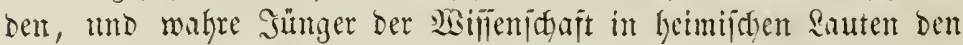
oringenden Fragen des aus jelbjtgejaffifener Finjternís erwad)ten

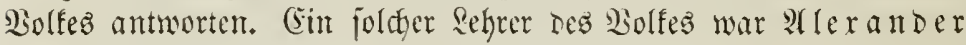
you $\mathfrak{S} u$ mbolot.

Pidyt im fitllent Etübdyen - Dranten in Der freien Miatur, in fernen Rändern und Meeren, im Rampi Der Elemente hat er bent Edyas jeiner Wreiaheit gejammelt, unto nifyt in ftaubige Bibliothe=

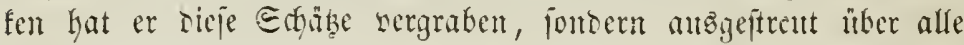
Bölfer als jruduturingenden Ennen. Sisie Der belebende Than bie

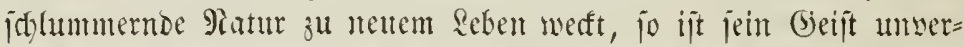

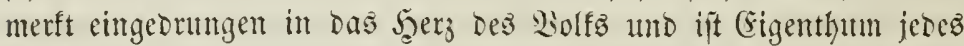
Eimgehnen gewornen. Ere hat ein Band gewoben, Das alfe bisher

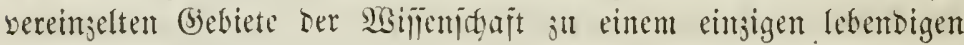
Ganjen umidglingt, fo daj feines sem andern mehr fremb und

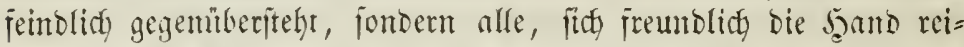

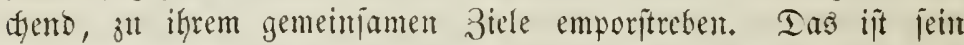

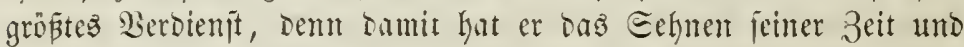

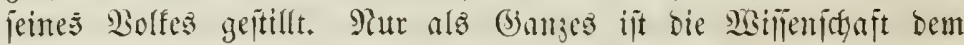
Bolfe zugänglid, alo eimzelme. famu jie wohl (jelehrte bilden, aher

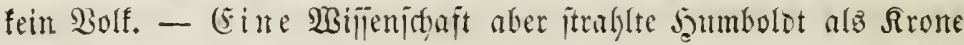

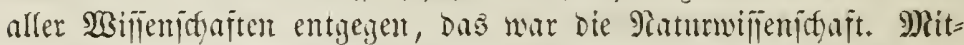

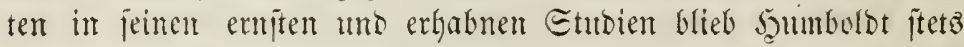
Menja, Darum zog es ifn hin jut ber ewig gütigen Freunbin bez

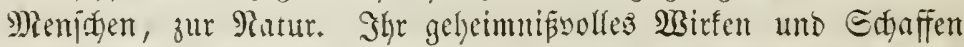
regte feinen gropen foridyergeift an, und jeine Riebe ju ify, bie Eelynjuft, fie itr allen iffen mannigfaltigen formen zu benundern unto ju beobadten, trieb ifgn binnus in ferme, wilde biegenten, bie

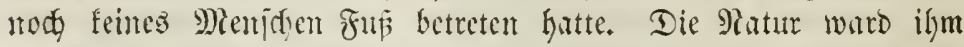

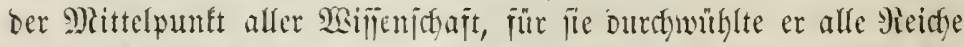

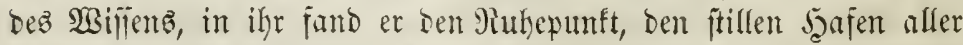

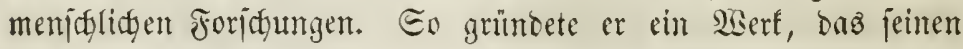


Ramen unfterblich macten wiro, eine Sisifienidajt, bie wahrhajt

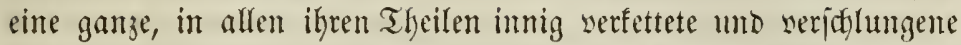

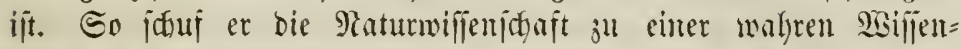

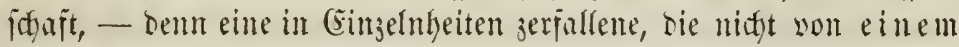

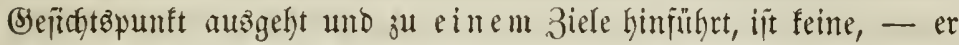

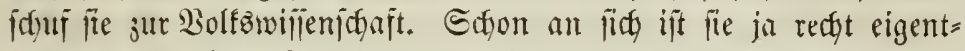

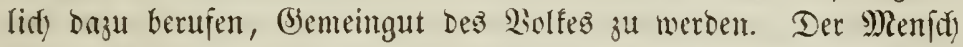
lebt in ber Patur und mit ber Natur; aus ifre jieft er feine $\Re a l)=$ rung, feine Bienulife, fie ijt bie Bedingung jeines Rebens, fie weft

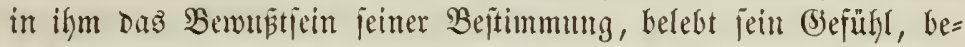

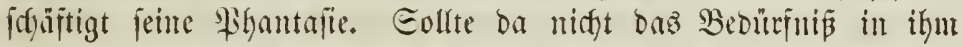
erwadten, einmal einen Bliff in ihr inmeres seben ju werfen, ben

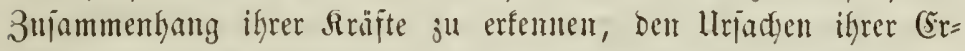

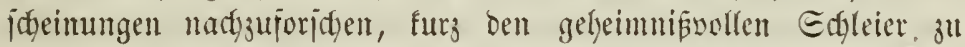
lïijten, unter bem fie lith jeintem unbejangenen Blife verhüllte?

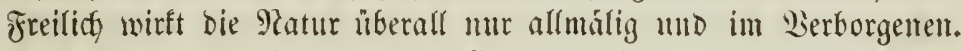

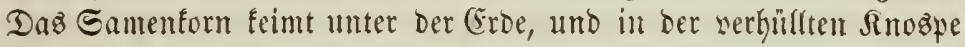

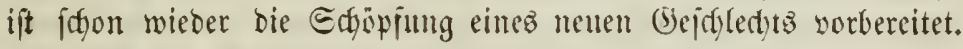

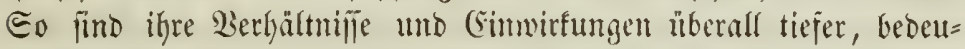

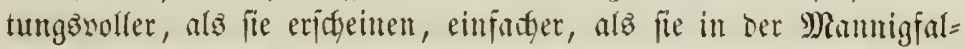
tigfeit ifreer jormen entgegentreten; umb bod) ift es eine jtiffe ein= jadye bewalt, bic fie Gersorruft, unt bie einer ebenjo cinfadjen uno fitllen Eeele bebar, um die Minfterien ifrees Aflerlyeligiten ju ent= Güflen. Itm eine nerwandte Eeele zu begreịen, bedar ez oft mur

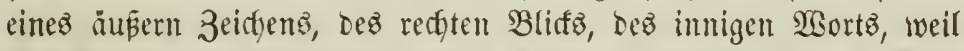

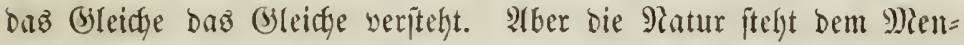

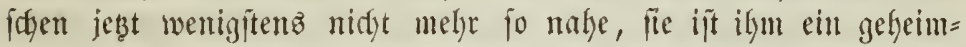

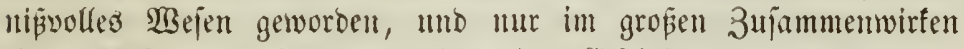

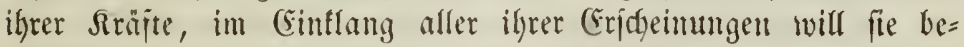
tradytet fein. Danm erfit jtrahglt jie Sidyt und Reben als auj alle

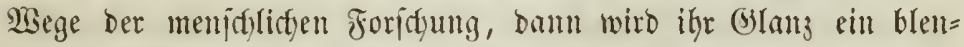

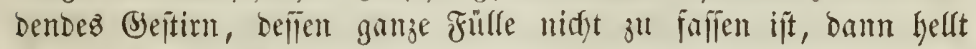
fie alle Bergältnifie ber Edjopjung, Der belebten unto wnbefebten,

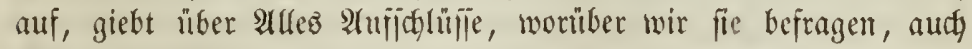
über uns jelbjt.

Coll aber eine jo allgemeine und tieje Anfdyaung ber Matur zu einer gewififen Rlarkeit gebradgt werbent, fo bebarf es baju einez 


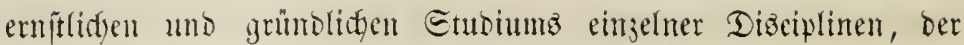

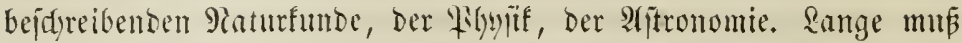

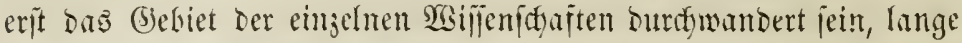
gemeilen, beobudtet, experimentirt werden, ehe ein flares Bild des Saturganjen vor unire Eefe tritt. Darum wird es immer Patur= willenifaften und Gelelyrte geben mülïn, bie uns bie Materintient ju einem jo großsurtigen Bau funmeln, bie uns dic Farben mifcten

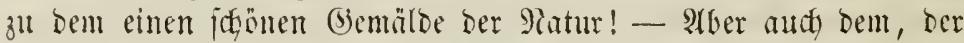

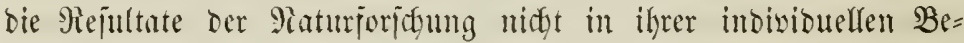

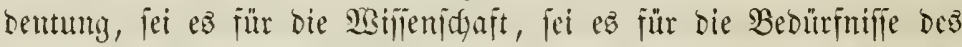
gejelligen Rebens, fontern in igrer gropen Begiefung auj bie ge=

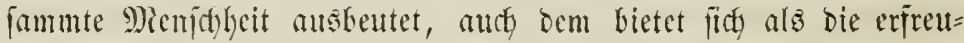

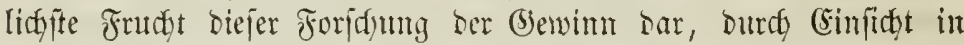

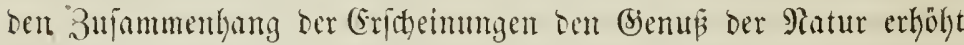

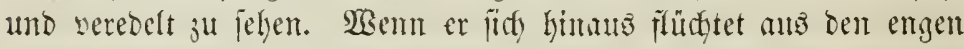
Edyratfen des bürgerlicten ?ebens, "errötbent, Dap er fo lange

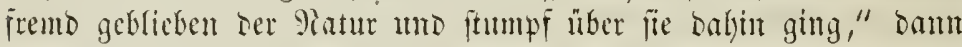

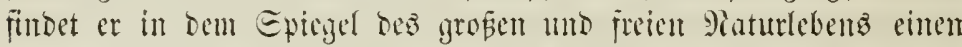

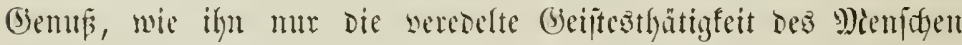
gewähren fam. Sicue Ergane cruaden in ifm, Die lange jolums merten, er tritt in imnigeren Berfehr mit oer Pfupemwelt, uno 9ichts blcift ilym melyr fremo uno gleidgültig, waz den inouftriellen fort=

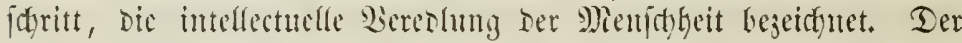

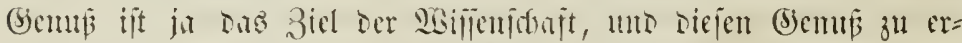

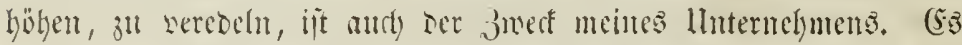

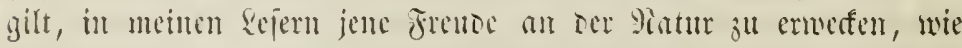

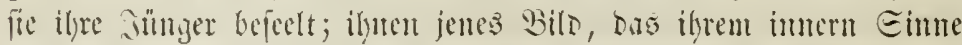

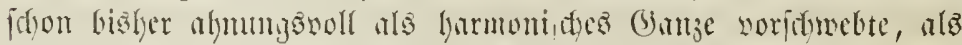

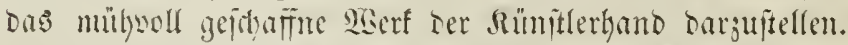

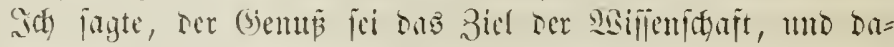
mit werde ith freilid) mandfem ftrengen (bielefyten als cin arger

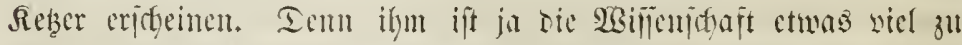

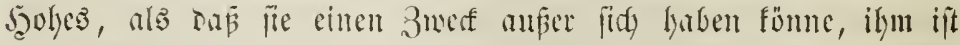

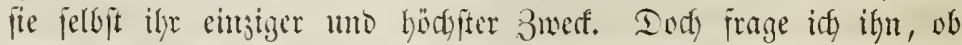

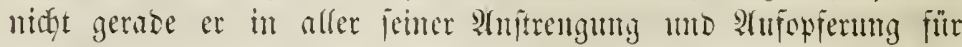

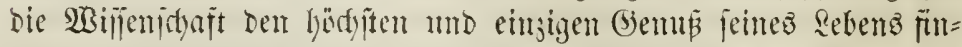

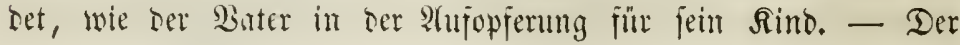




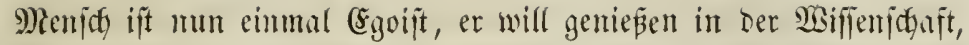

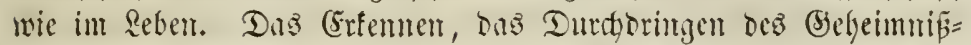

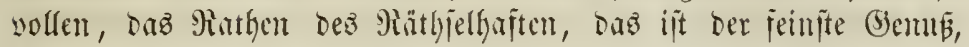

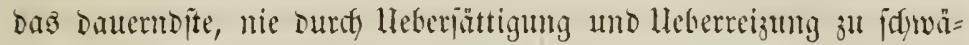

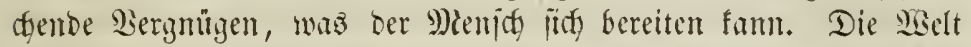

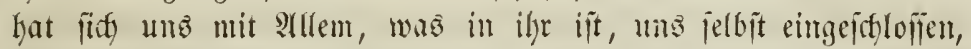

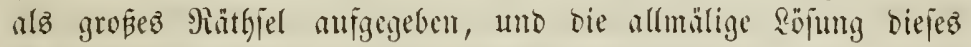

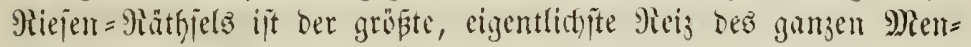

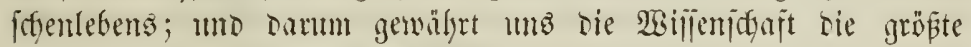
Bepricoigung, die edeliten (Semuilic.

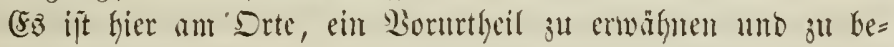

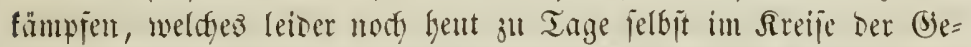

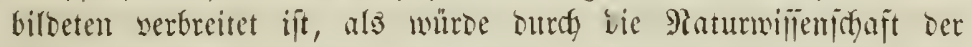

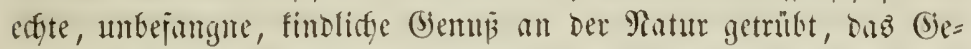

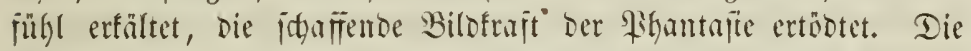

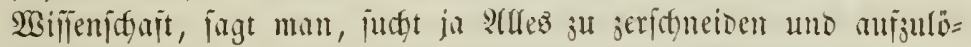
jen, Durdy iffe lunterjutyungen beraubt fie sie giatur ifyes poeti=

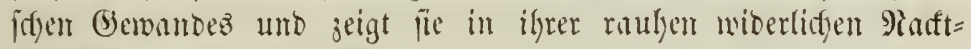

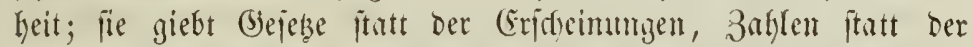

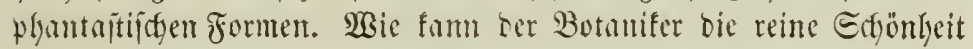

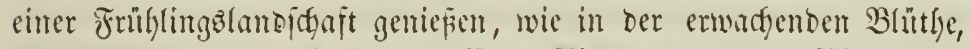

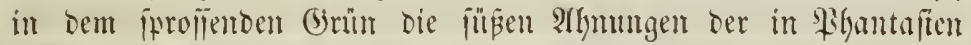
fpielenden Rinbesjeele empfinoen, Der Botmifer, ber in oer Blume

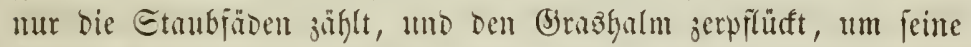
bejäpe und Fajern zu jergliedern? SGie fonm ben 3oologen ber

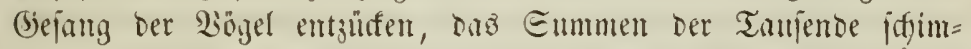

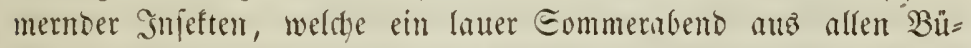
idjen unt Bäumen hervorzaubert? Shn Ioft ja vielmefer eime arm=

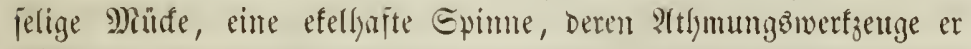
erforfden, ober beren Blutlauf er ftubiren fam. Waie finn ben

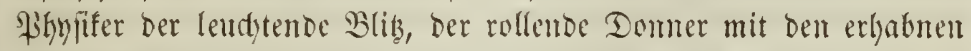

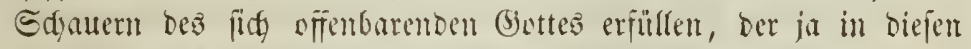

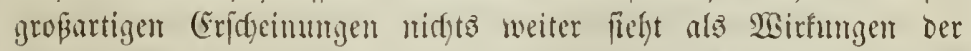

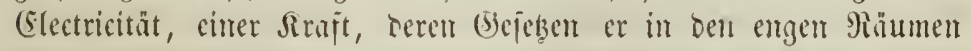

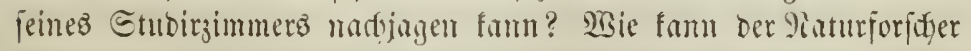
liberlyaupt nod) son 9taturigönheit, son fanten und erlyabnen

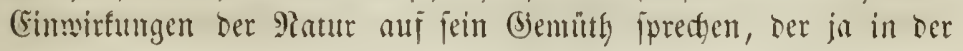


Matur nidftz fitht, alz eine finftlitge Majctine, bie burds fefte

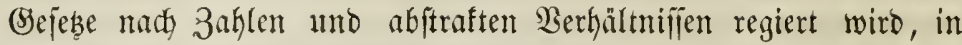

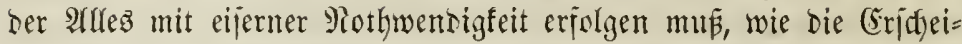
mung es lehrt? Eoldfe llntheile nannte id Borutheile, uno gewie

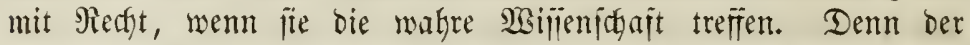

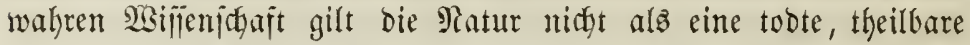
Maffe Gunter Singelfeiten, ifr ift fie Gintheit in aller Bielgeit, In=

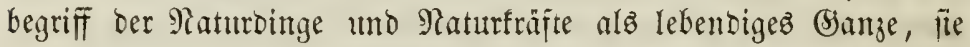
reicht über bie engen (5rïment der Sinmenwelt hinauz, unb bie

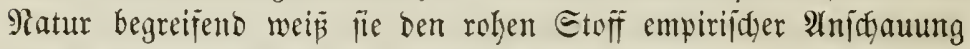

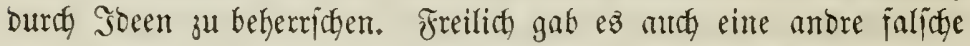
Sijijenjchaft (bie aber gluffliderweije in bie \$olterfiammer ber Ber= gangenheit furthfgewiejen zu jein jogeint), bie über bem äupern Gerüjt bas Gebauttoe jelbjt vergañ, und bie unjern genialen (söthe jeinem biabolijchen Kritifer Miephiftopheles jene $\mathfrak{B o r t e}$ bez bitteriten

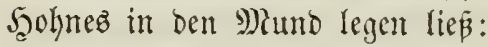

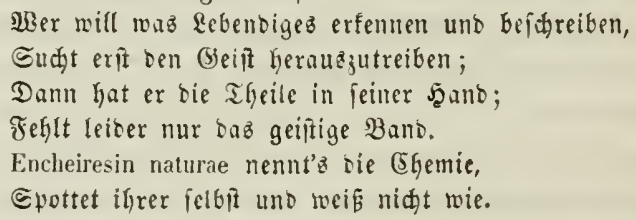

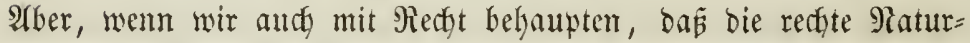

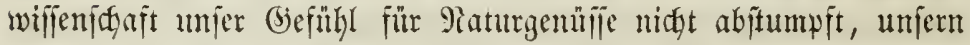
Paturimn nidft töbtet, jo:toenn belebt; einen Unteridted giebt es bennod) zmifhen Dem (jemns, Den findidge Afnjtgaung, umb Dem,

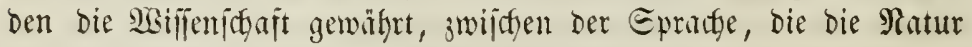
ju Dem Einen und ju Dem 2lndern jpridtt!

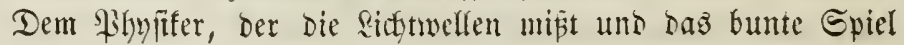

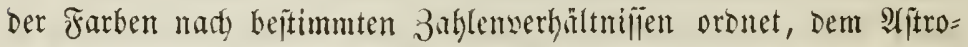
nomen, befien Blif ben $\mathfrak{B e l t r a u m}$ Durtioringt und bie in faum ertennbarem Rebel jufmmernben Eterne jerlegt, bem Botanifer, ber bie freifende Berwegung Dez Eaftez in Den mifroffopijathen 3el= len ber Bĭlanjen beobacfet und aus bem immen Bau bie ver= wandidgaftlichen Bejiefungen Der Familien unb Siejhlecter erfent: ifnen gewähren bie Şimmelşräume, wie ber Blüthenteppich ber

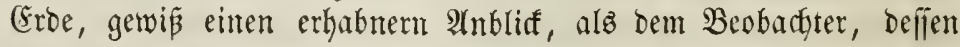
Raturfirm noch nicht burdy bie Einficht in ben 3ujammenfang ber 


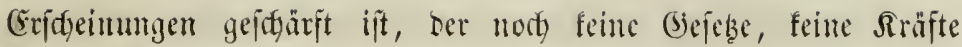

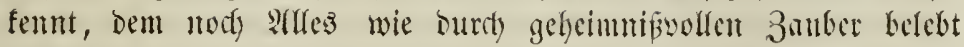
ericheint.

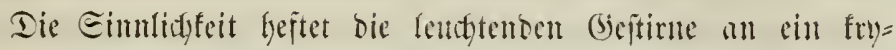

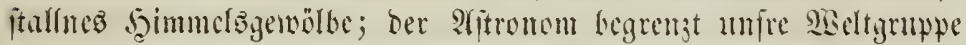

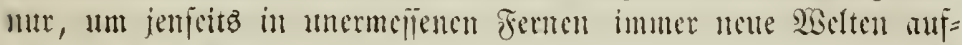

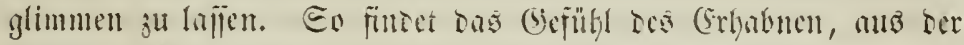

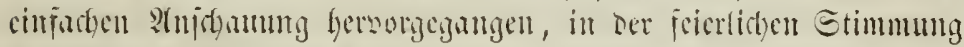

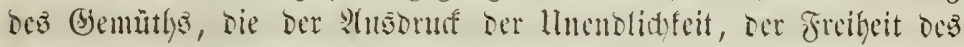

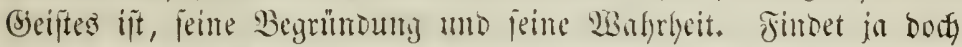

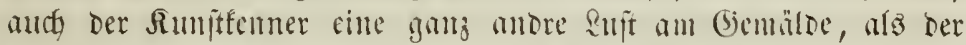

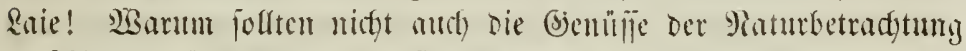

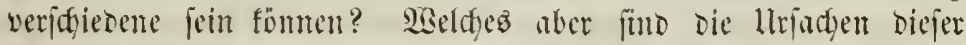
Berfotiebentyeit?

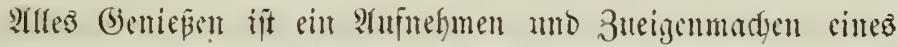

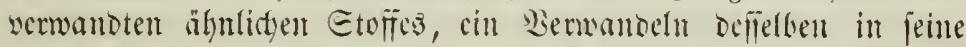

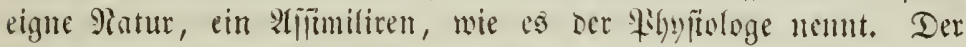

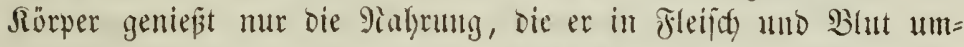

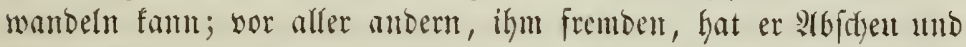

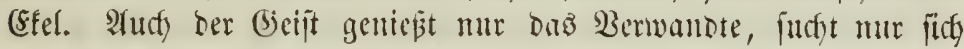
ferbjt in alfen feinen Gemintien. Da crtappent wir wicoer bea

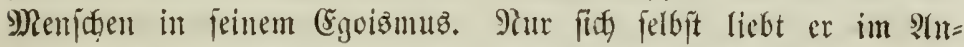

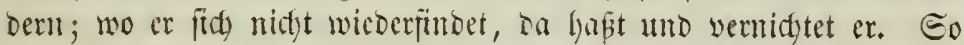

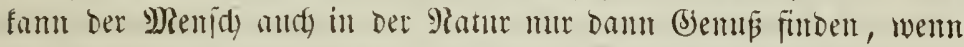

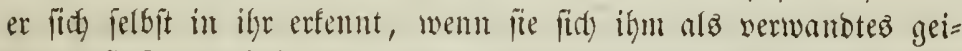

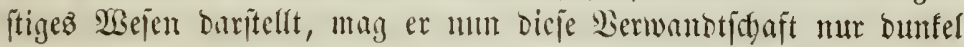

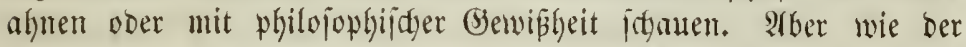

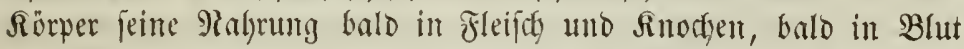
uno Miervent verwandelt, fo fintet audy ber beifit in Der Matur gar

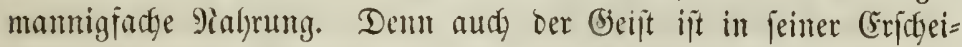
mung ein mannigfaltiger, ber firf entwiffelt unt bildet buret) ver=

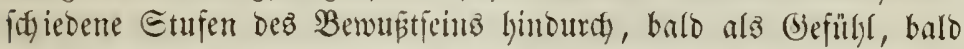

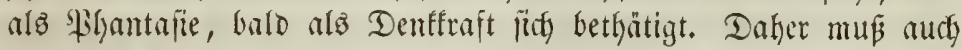

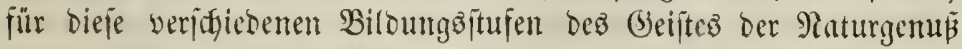

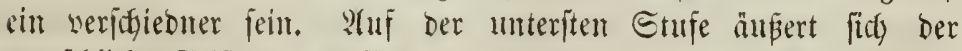

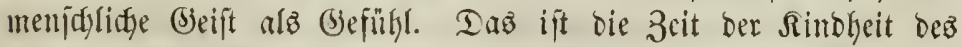

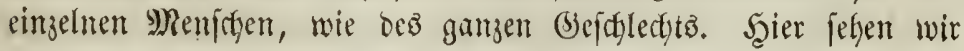




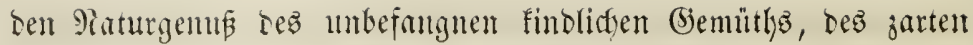

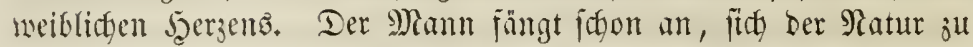
foimen, er magt eş nidgt megr, fidh jeinen (befühlen ganz hinju= geben, er brängt fie gewaltiam zurntef in Den Seintergrumb feiner Eecle. Der Rampi ijt jir jein Etolj. Das meidhe (Senunth Ies

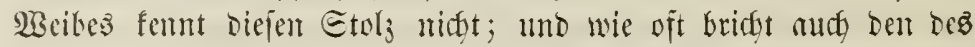

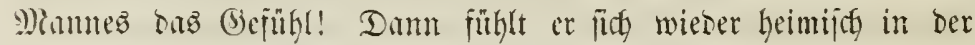
Matur, oum ift fie ifm nody bie liebende Mutter, bie ifhn geboren,

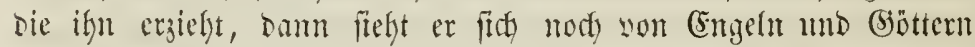
umgeben, und jobe Blume, jeder \&ufthauth fpridgt zu ifm in Den nod) serftindiden Enten der Matur. Bald fojet fie mit ifm in tämbefnoen Eplelen, balo oroht fie ifm furdtbar mit Bernidytung

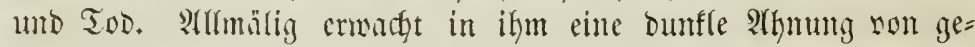

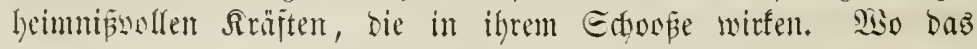

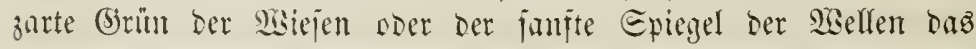
2huge in grengenloje Fernen idweifen läpt, voer wo fimmelamitre= bense Berge ilym oen Blidf serhüllen, hilerall ourdyoringt ifn Dam Das (bejïg) Dor freien Ratur und ein Alynen ifres Bejtehente naty enigen bejetzen. Seeilige Echauer Durbbeben ifn; tief im Smmern idymerslid) eridyütert, nom wilden Drange Der Setoenidaften Durdy= ftürmt, fühlt er jein Gentilth erlyeitert uno gejtürft, bejänfigt uno

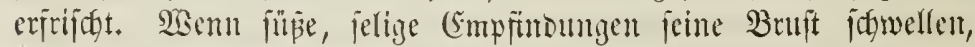
wenn son Eefmiudt unb Riebe fein jees jeripringen möbte, Dann

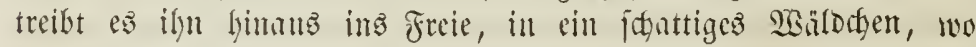

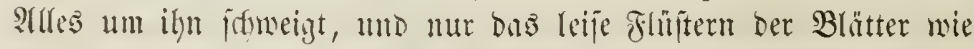
ciure wohlbofunte Frumbegitimme ju jeinem Sntern jpridgt; Dann fefyrt and) Die Jinfe ber Matur in jeinem Sgergen ein, Die WGogen glätten fich, und Das fumpte Epiel Der Filyantafie umganfelt ifn mit Den lieblichiten Irnumigebirsen oer 3ufunt. - Wemn berber Edymerz die munde Eecle des Unglinflidyen crïllt, wemn traurige Erimte= rumgen, Sram uno Reue ften, wemn feinten Blifen fidh ein trojtlofes unlyeilvolles Bilo ber 3ufunft eröfinet; Dann eilt er and hinnus ins greic, auf einen fornigen Jälgel, wo er rings bas frobe Reben ber Pratur fids unter

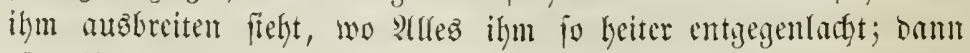

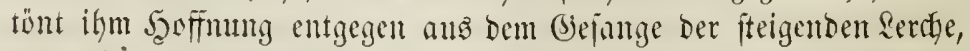
Dann frugt er mit Den Bienen auB Duftenden Blumentelden ben 


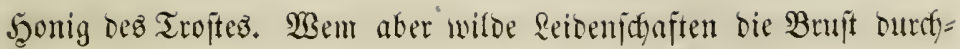
ftürmen uno in losernden flanmen baz Marf feines Smment ver=

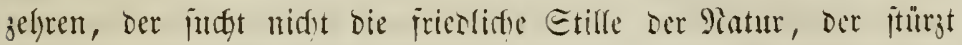
hinaus in bie finjte Vindft, wo ber Eturmmind braut, unto ber Siegen fitrönt, wo alle (Slemente in feinsliden Rampje mütlen, mo Blike jufen, uno rollende Donner die lant tobende Etimme

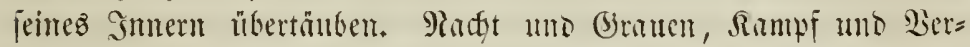

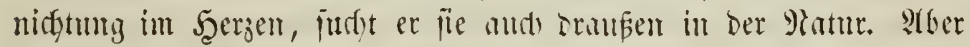

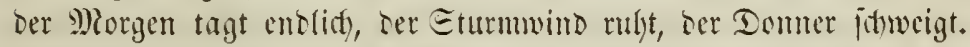

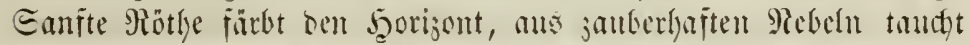

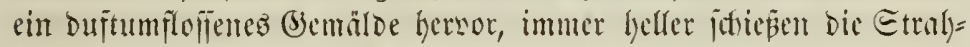

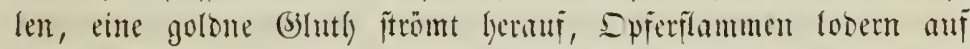

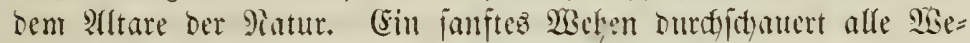
jen, da erwaden bie Blumen bes Feldes, bic bigel in ocr ?ujt,

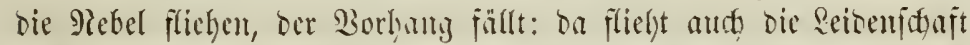

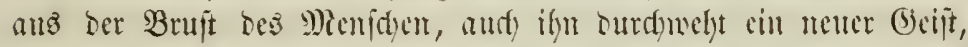

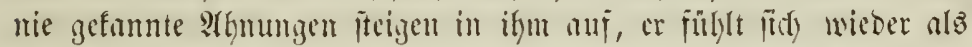

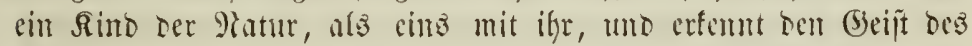

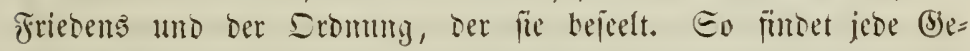
mütf-sitimmung in Der Siatur ifere harmonirendent Töne und Farbent.

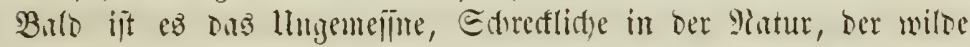

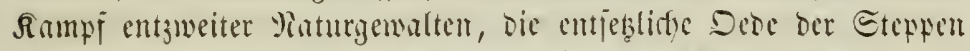

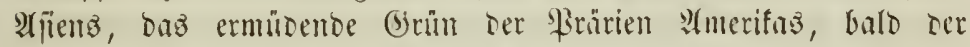

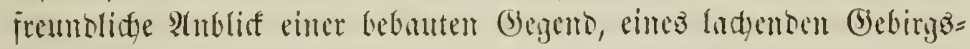

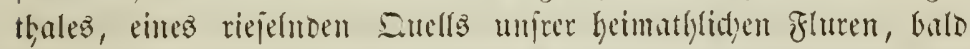

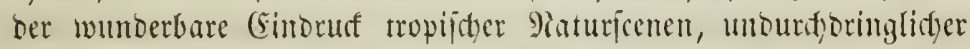

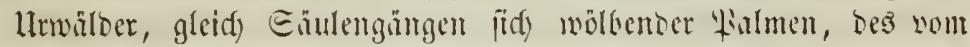

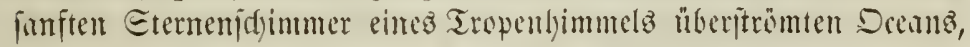
Gald ber Friebe, bald oer Rampf, buld die sisunder, fuld die

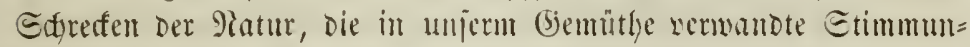

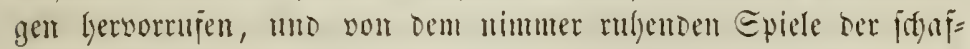

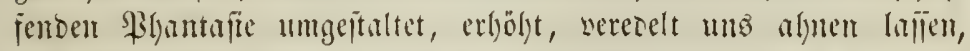

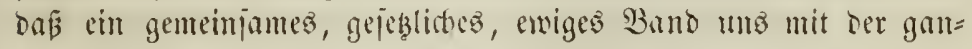

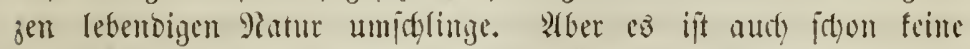

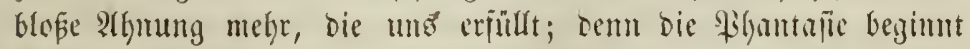

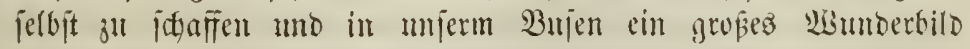
aufjubauen, das fie unbewupt mit ber burdy bie Eime offentrattul 


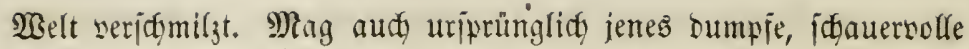

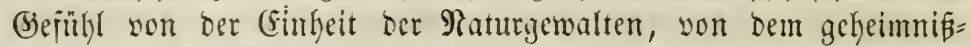

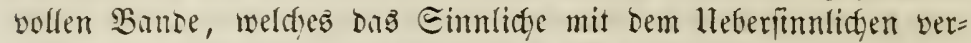

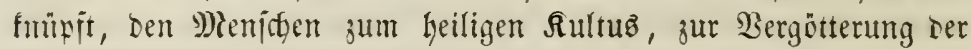

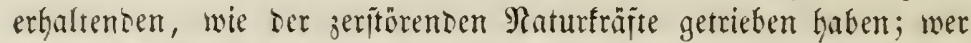
fith Den Feffeln ber Eimulidffeit entrungen, wer fide jur geî́tigen

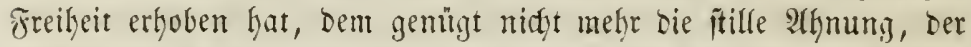
beginut ju jergliesern und ju oromen, ju foridgen unt ju benfen,

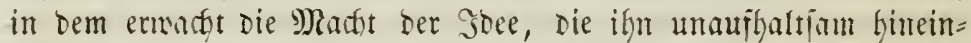
treibt in das imere $\mathfrak{B}$ ejen, in ben urjadylidfen 3ujammentyang ber Eriffeimungen. Dodf nidft iogleid) mirb ber robe funtildye Matur= menth in einen Pigilojophen serwantelt, io wenig wie bas Rino in einen Mann. Er mü erît Didnter und Rinmitler werden, um

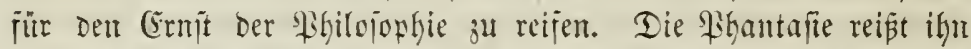

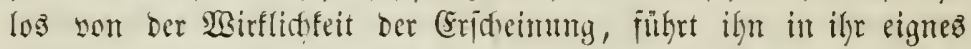

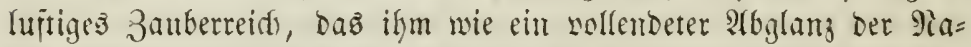
tur erjdyeint, gleidgfum eine Ratur son Steen. Fr madt bie (5r= idfeimungen ju Biloern, ju Eymbolen geiftiyer Berfültnilïe, zu einem Epiegel jeiner intellectuellen uno moralijaten Эaatur. Eo idgante ber (jriectie bie 9atur an, Dem ber Griedye war ein ge= bonter Didfter. SGie zart Dadjte er fid ben Edymetterling als Bild Der Eeele, bie in tird gemuntene Edylange als Bild ber Emigfeit,

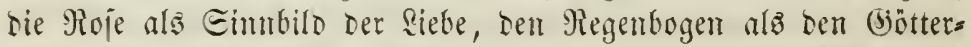

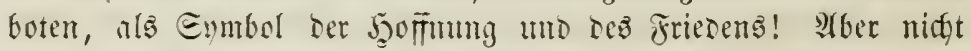

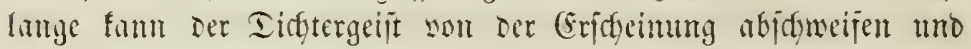

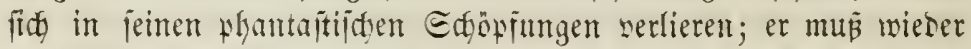

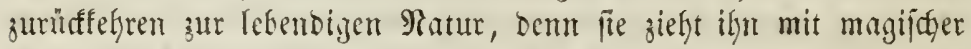

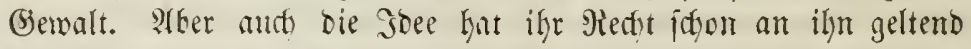

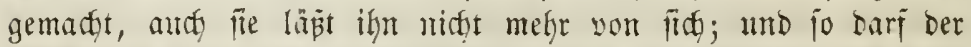

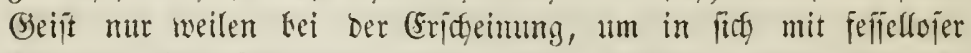

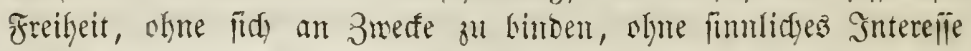
bie Soce Der Edjünteit zu entwiffeln. Co mirb her Tidfter zum Rünitler. 2Bem Dem Tidfter bie Mature alz eine Baelt von Bil= Dern eridien, yon Bildern jeines eignen Eeelentebenb, jo eridfeint

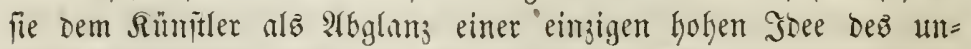

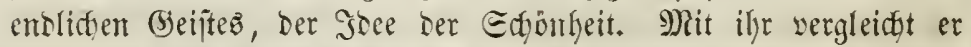
Fie, nad ifren Berbasltmilien judyt. er jie zu orbnen unt umzujtgaf= 


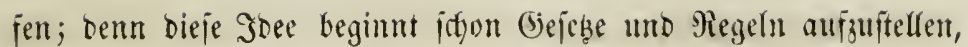

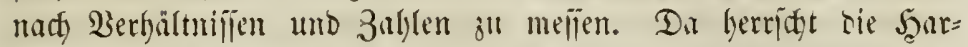

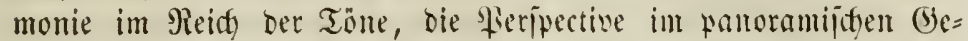

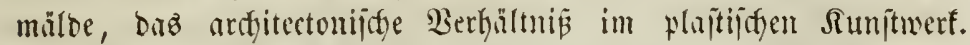

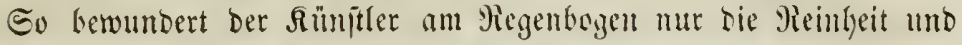

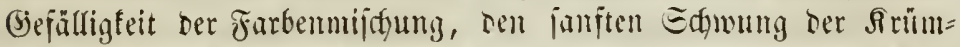
mung, er ftubirt im (Sejange Der Bögel Den ergreifenden Silang ber Melobie, in ber malerijajen Randiffajt baz leije Berjamimnten von \$olfen und Mieer uno Siliten, an ben idjüten Formen feincz

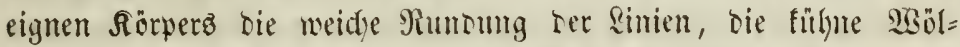

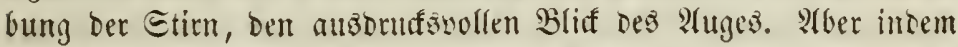

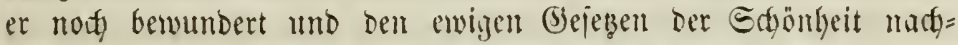

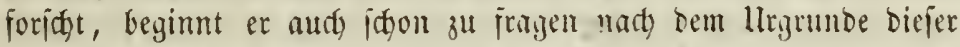

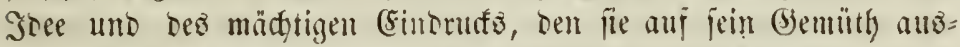
n̈bt. (Er bringt ein in bie yeheime Sumititätte der Mintur, um ifre weijen Refren jul vernefymen, uno bald jeil̈elt ifgn nidyt mely ber

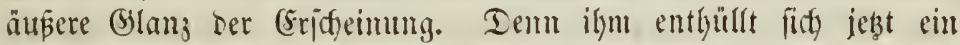
bisher unbefamntes Mieidy son aneinander gefetteten lirjadyen und

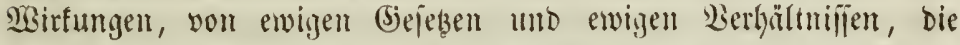

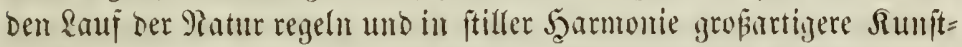

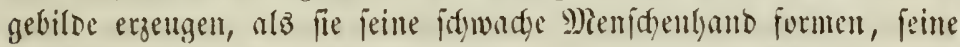

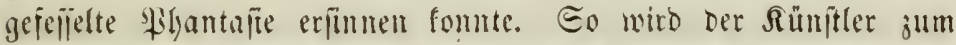

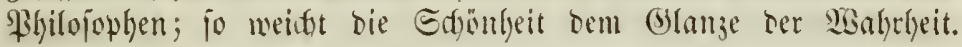
תlare (Erfenntnis tritt all Die Etelle sumfter Algnung, gejez̧lojer Phantafie. Reue Srgane merden geidaffen, bie Matur zu bejra=

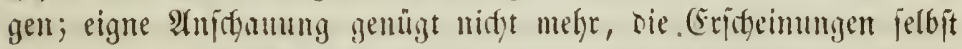

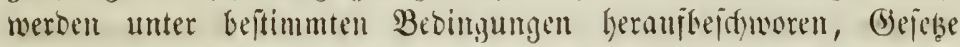
werben gefunden, siselten gemej̈en, bie 3ufunft bereffinet; der

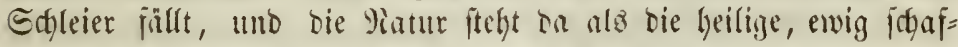
fende Unfraft Der Siselt, Die alle Dinge aus fitd) felloft erzengt und wertthätig herborbringt. Sn Der Mamnigfaltigfeit bie Einlyeit zut

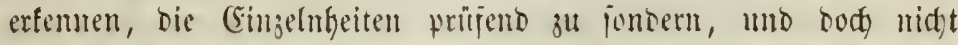
if̧rer Mafie zu unterliegen, Der erhabnen Bejtimmung Des Menijten eingebent, Den bejeift ber Miatur zu ergreifen, weldyer unter ber

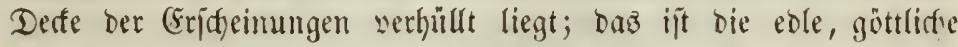

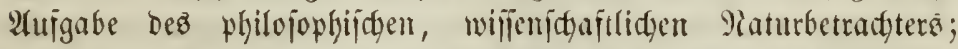
uno von ilym gilt bie Gerrlidye Edjilderung unjerz unjterblidgen 
Edjiller in feinem Epaziergang:

Ster im fitlen (Semadi entwirft bebeutenbe Birfel

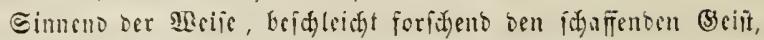

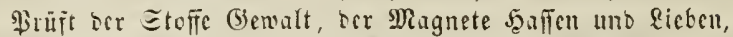

Folgt barch bie Rüfte rem Rlang, folyt burdh ben शether bem Strahl,

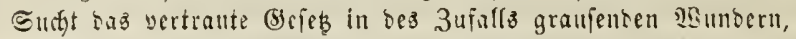

Sudft ben rubentien Fol in ber Erideinungen Fludt.

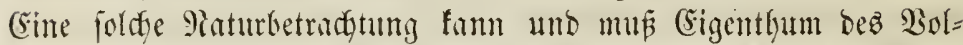
fes werden. Demn fïe allein giebt ein ganjez uno allgemeines Bild ber Matur, fie allein erpint fie in ifher Eingeit, in ifrer innern Protfwendigfeit; fie allein gewilgrt jene eblen, des whren Menjoen

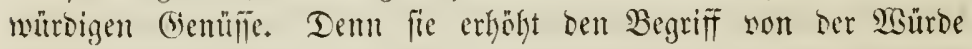
แnd Gröpe Der Siatur, fie läutert unb berubigt sen Beift, wie fie

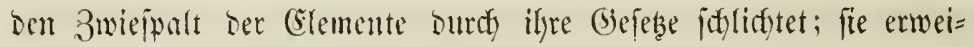

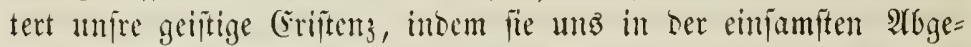
fifiedenfeit in Berthrung jetst mit bem gumjen sieltall. Eo rer=

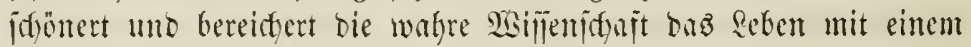

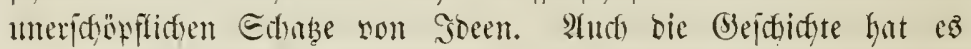
แmb gelebrt. Dort unter jenter glinhenten Tropenfome, wo son

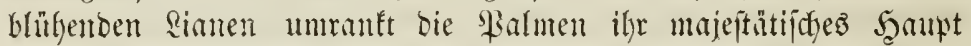

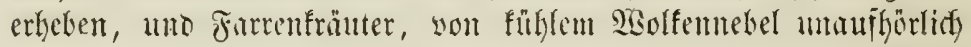
getränft, Ginmelon freben, wo alfenrojen mit purpurnem (bitr=

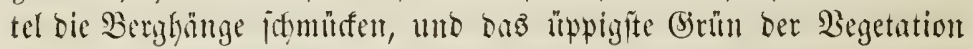

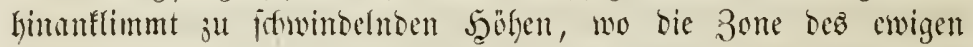

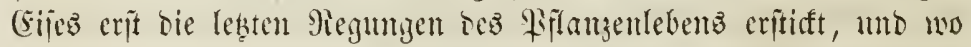
jelbit unter ben fdneeigen bipfeln glodenjörmiger Bergriejent bie

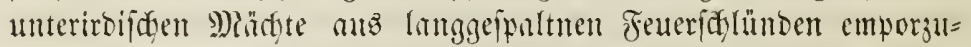
brecten orohen; bort mag wohl Bewunderung uno bumpfes Errfiul= nen bie Bemother erfïllen, aber ber innere 3ujammentyang jenter

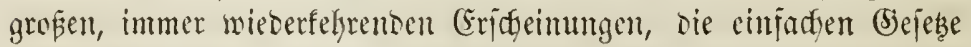
ihrer (Siruppirung, bie fitf grabe bort bem \&uge jo offen barbieten, fint grabe bort unbeadtet und unerforidyt gebliefen. Da aber,

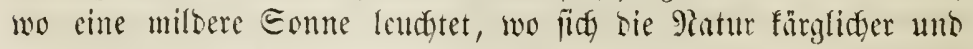
ärmer in ber Ergettgung ifrer Siebilto jeigt, wo mannigfadje Eto"= rungen in ben ?haturprocefien Des Dunffreifes, wie in ber flimati=

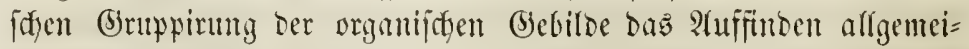
ner Bejebe erjoweren; Da ift bennody bie geiftige Thätigteit zuerit erwadyt, ba ift ber Urîh aller Sultur, von ba erit ijt sififen= 


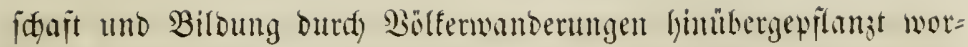
bon in bie üppigen Tropentegionen. Şier im trautigen Piorben, Dem Etieffinde Der Matur, herrịdt ein thätiges, reges Reben, gei=

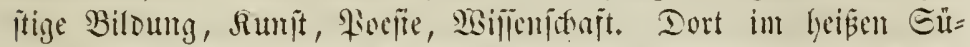

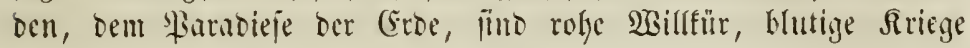
3u Saaje; bort haujen wilbe Bülfer, und jelbit ter gebildoetje Frembling, ben uncriättliche Şabgier oder 3erjalfenlyeit mit feinem Baterlande dortlgin verpflangten, finft balo herab ju cinem gedon=

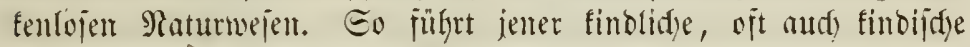
Maturgemus zur Mohgeit, biefe senfenbe Betradytung cince allgemei= nen Berfettung Der Erridgeimungen jur bödjiten Bildoung aller Siräfte

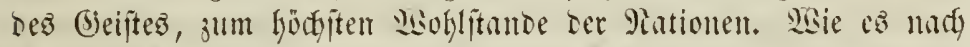

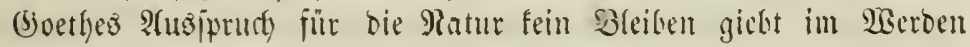

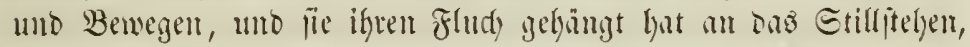

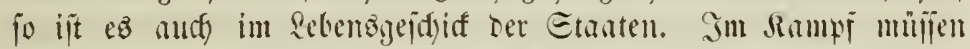

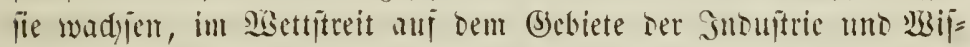

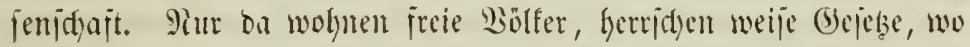

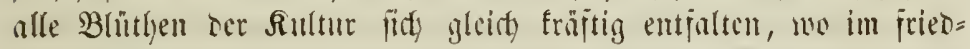
lidjen giingen feine der andern verderblids wird. Wian frage nidyt

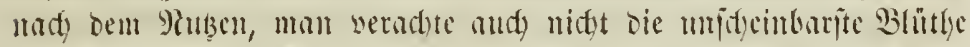

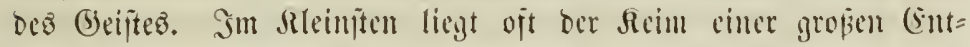

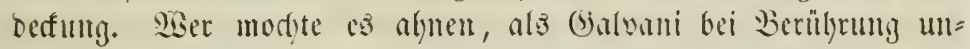

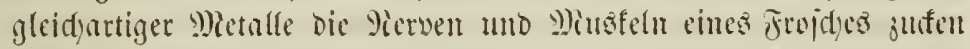

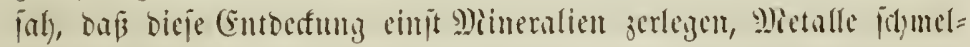

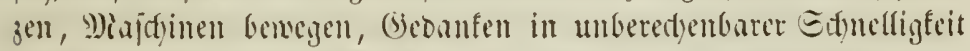

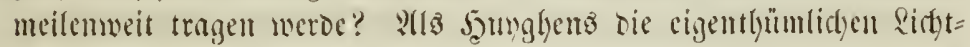
erideinumgen des Doppelipatho bemerte, wer aljute Da, Dar cin jo

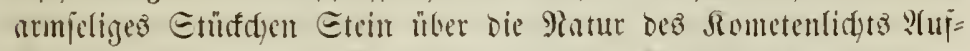

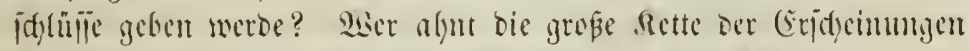

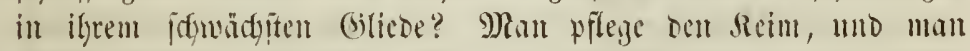

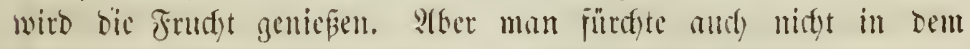

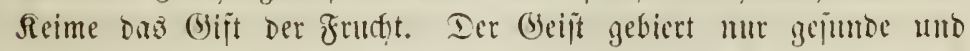

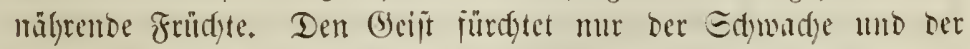

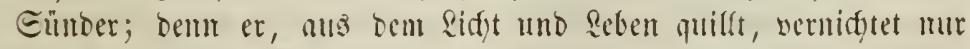

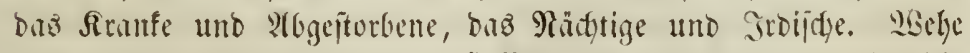

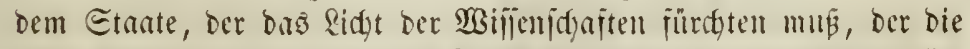

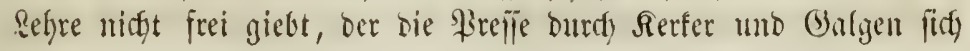


bienitbar madtt! Er gleidyt jenen fiecten Ecibern, welche bie reine

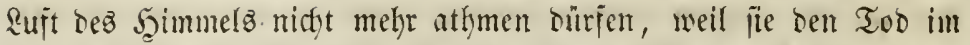

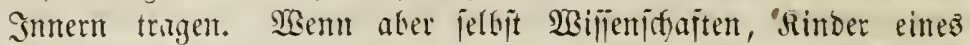
(beijtes, einander bentiten ober verfolgen, jo verleugnen jie ifre

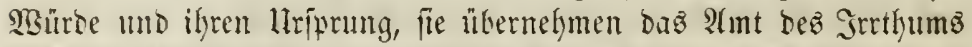
uno bes atkerglaubenz, denen es allein gejient, ju bajjen uno ju

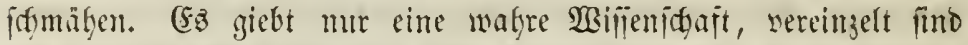
alle nur unsolffommene Edyattenbiloer biejer einen. J̧and in Şanb mit einanber füfren fie bie Bilfer zur Bilbung, bie $\mathfrak{W e l t}$ zum sidyt; vereingelt werjen fie um jo idantere Edyatten, je gröpere Sontrajte fire bilden. Sümite uno Biffeniftaften fumb bie Trophäen bes Minidyengeifes unber bie 3eit; aber Trophäen jerreift man nifft gern. Iarum: 3um Giuten das Ectöne! Das̃ jei umper Wahliputh, wie er es einjt im itoligen Epurta mar!

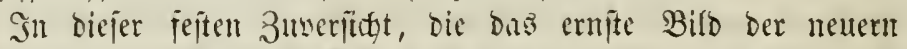

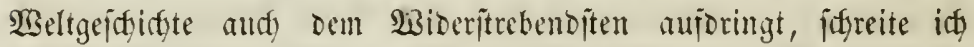

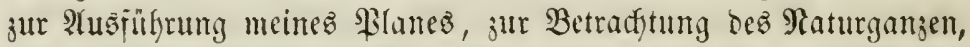

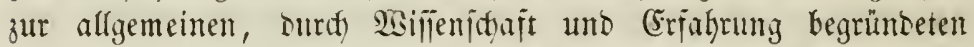

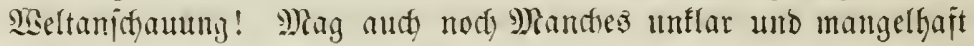

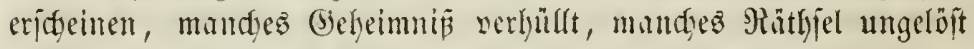
bleiben, audh in tor Berlÿllumg liegt ein geheimnifwoller Zauber.

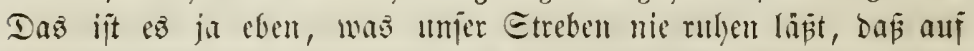
Den Groboden, wie in Der umgethenden enfthülle, in Den Tiefen Des Scents, wie in ben Tiejen bes șimmels tem fühnen Grobe= rer audy mad) Safutaujenden oer Wecltram nidyt jellen wirb!

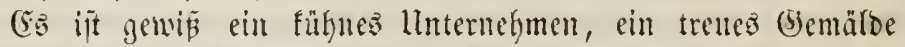
Des ganjen seltulls entwerjen ju wollen, won ben ferniten Eter= nen bis jum tleinjten Eandforn, von den Miejenthieren ber Bor=

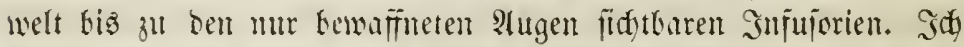

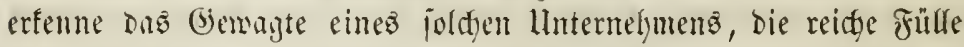

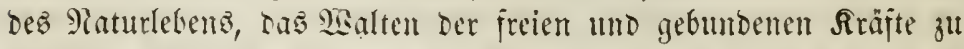
ourdyoringen. Sक fühle es um fo mely, als idy eitten fo grofen, fo umerreidbaren Borgañnger an Eleranter von Şumbolot habe, ju

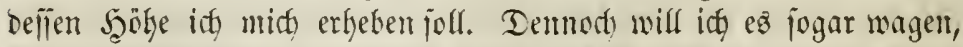

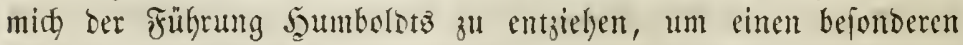
Weg zu gleidgem 3iele ju wälylen. Dieje Miandem vielleidgt an=

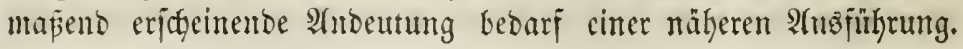




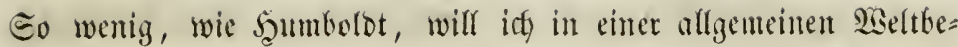

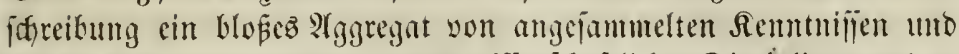

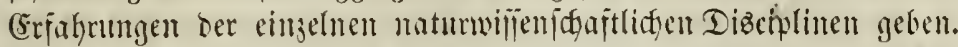

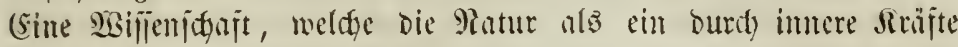
beewegtes und belebtes bianjes betradtet, lgat einen gants andern, eigenthümlichent (sharafter. Eie bedarf zmat aller jener bejondem

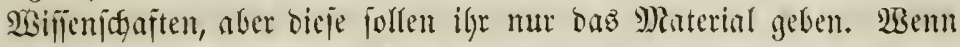

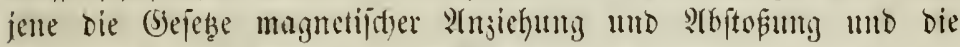

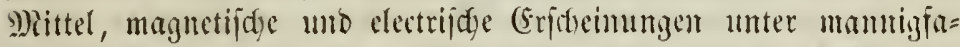
d)en Bedingungen lyervorjurufen, lehren, wenn fie dic Sidgtwellen

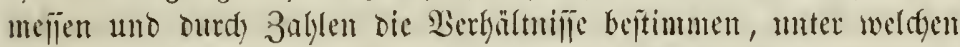

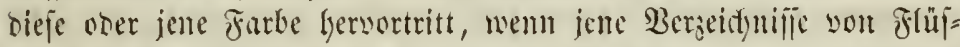

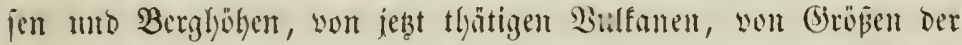
Etromgebiete, von mincralvgijden formen unb (bebirgasaten auj= ftellen, wem jene entidg alle organiigen Geptaltungen in ilyer

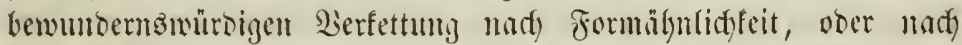

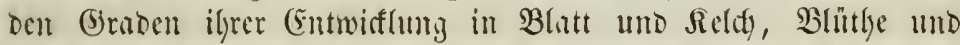
Frudft her Bfiflanjen, oder im Eletett, in hen Yiersen, im Bluttauf ber Thiere betradsten; io leljet dieje Dagegen bie Bertheilung bes

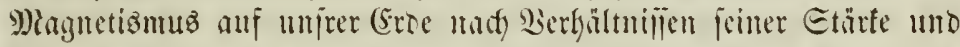

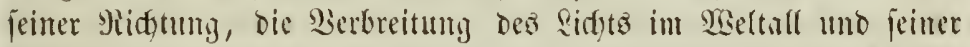
Eimmirfungen auf die Beleudftung und Drganifation des (5rbför=

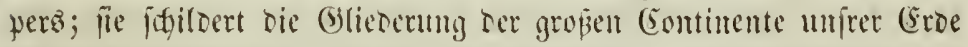

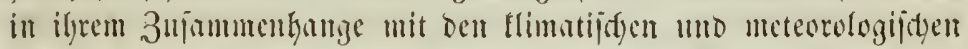

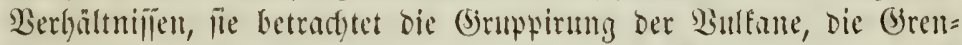
jen ibrer Eriduitterumgatreije, jie lehrt das Gemeinjame in bem Raufe grober Ströme, wie fie bald Bergfetten Durdyuredgen, bald neben ifnen firs thingielyen, wie fie burdy ifre Deltabildoungen bie Edjöper newer frudjtbarer :änder werbon; fie berfettet bie 'Tlier =

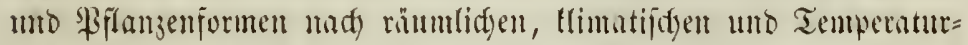

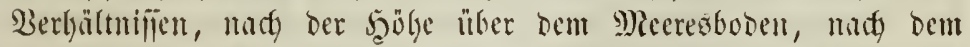

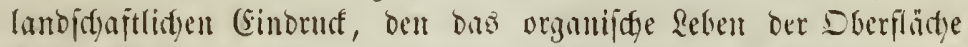

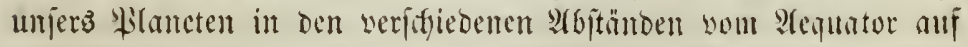

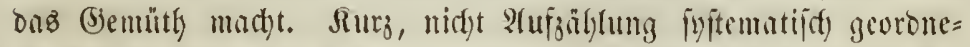

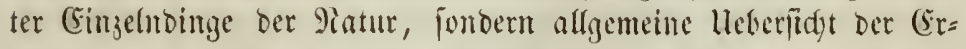

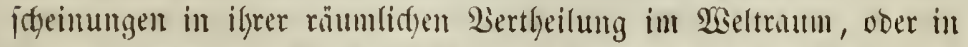
ifrer Bejiefung fum EGharafter Der Erojonen ijt ber Besgeliftand 


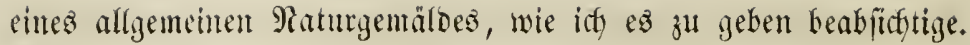
2flle bie zeritrenten Etraffen bez gejanmten 9laturwiffens mill idy in einem Brentpunft vereinigen, fuden den ruhenden \$ol in ber Erjacinumgen Fludt. Demn in Der ganzen Ratur herridyt mur ein

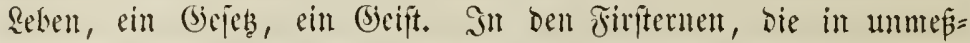
baren Fernen fojmmern, wie in Den Blaneten uno gepenfigen Meteoren ift ein Trieb Der Bewegung, ein Rhythmus Der 3eiten, in allem Rebendigen ber Thier = und \$filangenwelt nur ein $\mathfrak{B i f l e}$

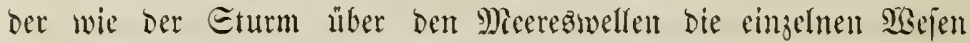
alle erregt unb bemegt jum barmonifoen 3njammentrirfen. Wenn Der Rreislauf Der Bejtine unjern Fluren bie belebende Bärme Des

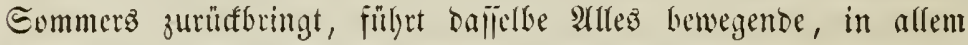

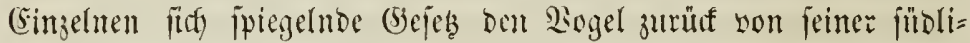
den Wanbernng, Den Bewolyer Der Meerestieje aus Dem Rorben, wo er ben 2 sinter limburdy in jenen von feiner $\Re$ älte berüfyten

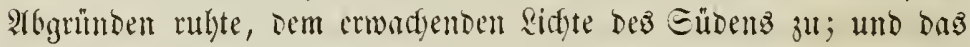
gemeimame (bijeb, ธaв

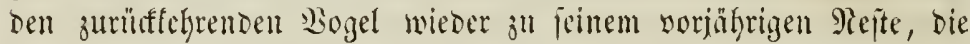

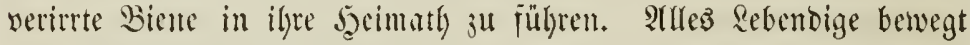
fitf harmontidy in einntmoer, weil oer freie, nimmer fid änoentoe,

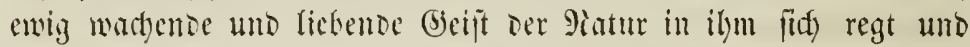
heweyt, in ifym liebt uno jutft, flielyt mo meidet. Ein joldhes Bito Der Patur wilf iff entwerfen, som Reben Durdyantde, won (Einlyeit ourdyormingen, und eine jolde imniz verfettete sielt neme

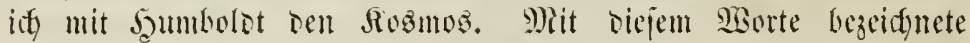

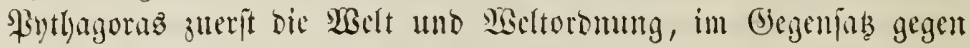
bas nod) ungeoroncte, formloje (Shave, und in biejem Eime foll

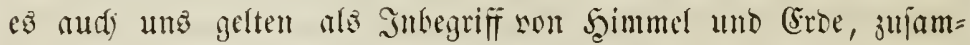

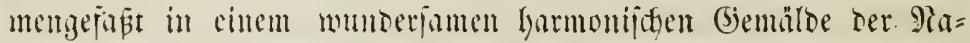

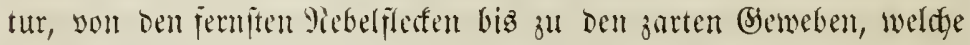

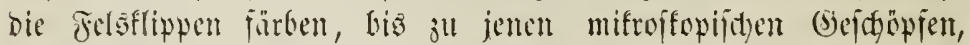

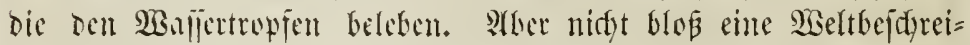
fung möfte id) liejern, fonbern anth. eine Beltgejeficfte, und

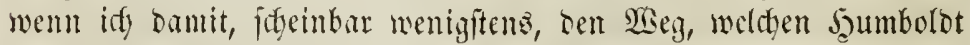
vorgejdrieben hat, werlajie, glaube id) midy redytfertigen zu miljen. Die Piatur barj nidat blas als cine jeiende, D. h. ruhende, gegen= wärtige betradytet werben, Denn alles Eein wirb in jeiner Wabrbeit 


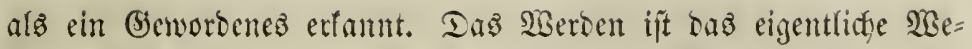

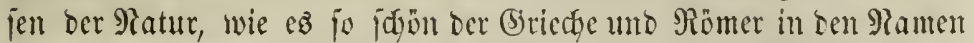

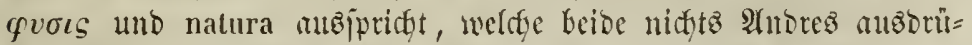

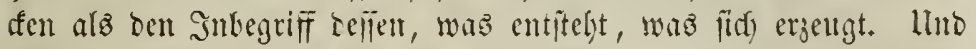
nidyt affein Das Drganijae ift ununterbrodyen im SBerben und Der= gehen begriffen; bas ganje Reben ber Srelt malynt in jebem Rugen= blife feiner Crijtenj an jeine fruber burdylaufenen 3ujtünde. SBenn gleidy flüđtigen Bildern einer nädtftidjen Trummelt, in benten fich uns eine ferne Bergangenlyeit ahpipiegelt, bie Bifoer uno Eleidyniffe einer weit entjenten Ridgtwelt über umprer abyejdyiebnen Snjel want=

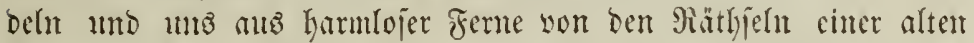
Bergangentyeit ergifly 3eit eine verhüllte Ephint fdylummert, unt wie cin Piejt ber Bergnt= genteit, cine $\mathfrak{B e l t}$ unterirbijace Beifter, bei beren Emporjteigen Die Sewölbe ber fejten Erorinbe erbefen; wenn fo liber und anter

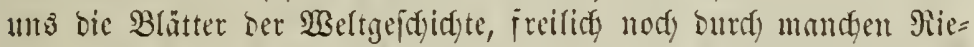

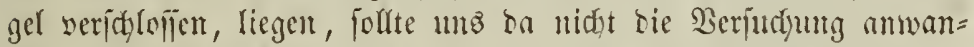

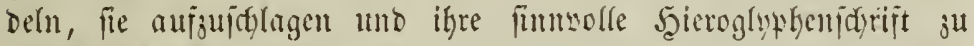
entziffern? Sise funnen wit die Gegemmart fafien olyne bie ber= gangenlyeit? Sisie fönuen wir unje Etantsuerfajumg, unfern Bil= bungsijuitund, umire Epradje begreijen, wenn wir nidgt bie Ge=

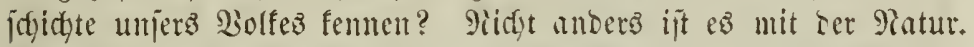
Gegentwart und Bergangenlyeit minjen fids and in bem Paturge=

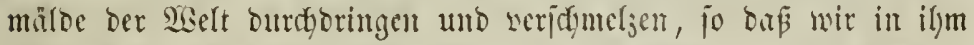

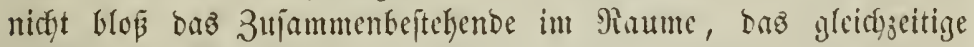

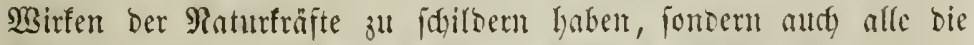

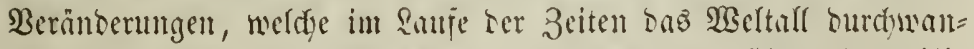
Dert hat, won ben neuen Eternen an, bie an f̧immelg̈gemölbc

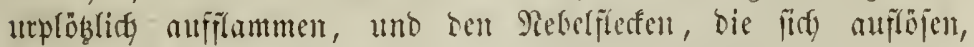
um neten Welten ilye Dafein z"l geten, bis̄ zu Een fleinften Dr= ganismen bes Thier = und Piflanjenteidfez, weldye nody lente bie ftebenden Gewäljer und bie werwitternden Sinden ber Bäume liber=

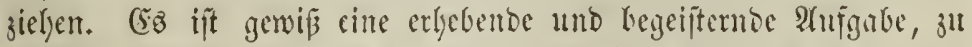
erzäblen won ben Thaten ber Satur, bie fie sor Safurtulfenten, ja

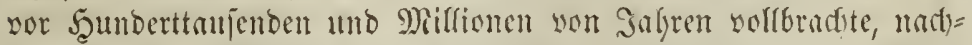

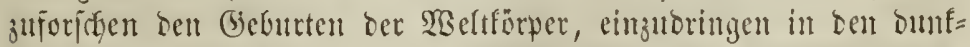

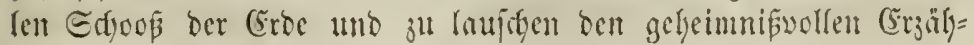

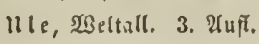


lungen, bie fich bie Eteine felbjt juflüjten von ben Dingen, bie fie erlebt, son den Ecfifjalen, bie fie Durifwandern musten bis zu ifyem jebigen 3uftante verzauberter Erfturrung.

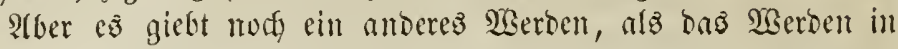
ber 3rit, ein Werben in ber Soce, in Ser Bebantenwelt bes Bei=

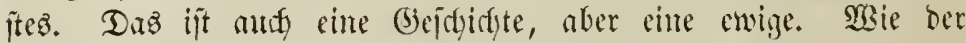

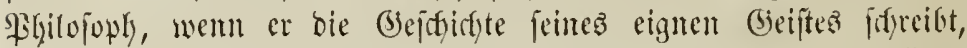
ansigcht won der niebrigiten Etufe bes Erfentens und vou ber funts

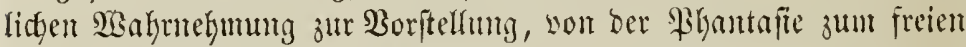
Denfen ber Bermunft auffteigt, fo faum er aud in ber Siatur vou

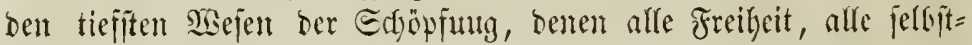
thätige Entwifflung mangelt, bom fturten Etein zur ßflanze, bie mit bejondern Srganen begabt eigner Entwialung fähig ift, jll bem fid frei regentoen who empfintemben Thiere, who fo bie gamse Etu= fenleiter ber 2sejen fimburdy bis zur Srome ber Eebopfunis, bem wernurftbegabten, benfenten Menjogengeifte fortidgreiten, fann ans Dem jurten bewebe Durdh Ilmmandung ber Zelfen bie Siflanze, aus Dem einfuchen (si bas Ihier entitelen jelen, wie er im Sinde ben Reim grober Thaten ahnt, Eo läpt ber Philofowly bie ganje Sia=

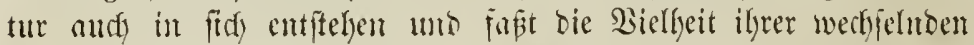

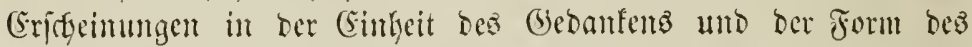
rein vernünfigen 3ujammenlyangs. Miag autb ein fold)ez benten=

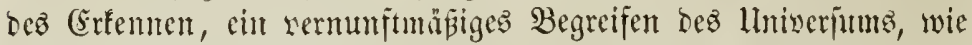

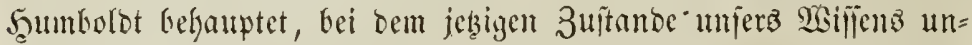
möglid) fein; ja ming bie Zeit aud nody fern fein, wo fidy alle

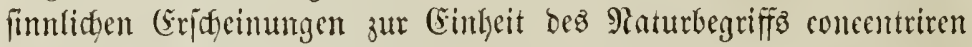
- uno ity glanbe, fie wirb es nody lange bleiben, ba bie (Erfah)=

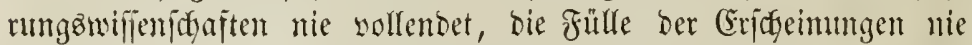
zu eridjöpfen ift; - aber mag das and fein, ein Berjud ju einer

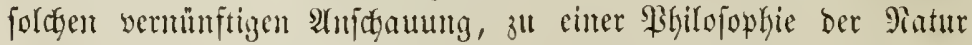
follte bod nie meterlaffen werben, folfte ftetż bas erfabne Biel, ber

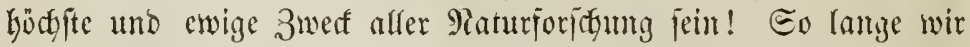
bie Totalität ber Ericteinnugen nidft ju überiehen vermögen, mögen wir fie in (S)ruppen fontern, mögen bieje mit bem $\mathfrak{B}$ adbjen miferer Erfenntnip ermeitern und bic bejebe, bie fie beherridgen, veralfye= meinern. Die Erfabrung mag ma bazu bie Mittel forffen, fie mag beobadyten und experimentiren, mag in Sgypothejen ben innern 
Bujammenlang ber Paturoinge unto Paturfräfte ahnen, aber nie

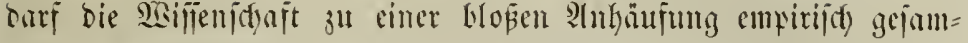

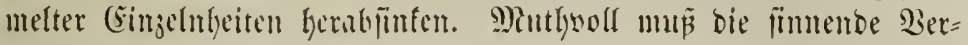
munft bie ftarren Formen zerfredfen, welde ben miberittebenden Etoff wie mit cifentu Bansen gejangen halten! Rie wiro cine walkre Saturphilojophie, menn fie mifflid) Das remunftige Begrei=

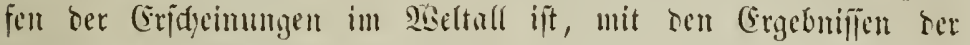

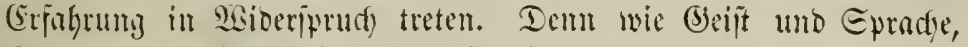
(Bebante umb SEort, fo gefeimnipsoll, unjertremutidy uno unz un=

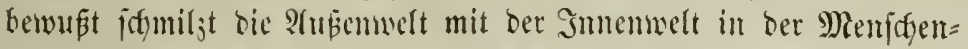

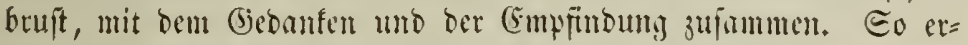

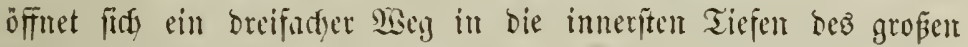

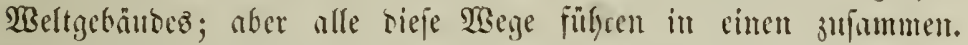

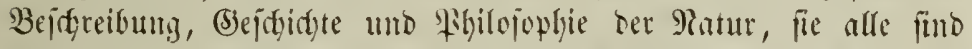

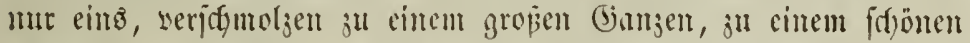

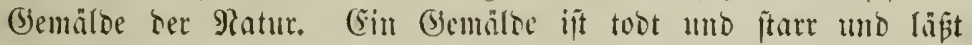

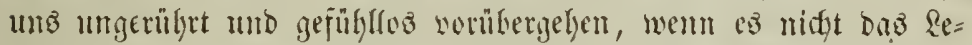
ben in jeiner hödjiften foullle, in bem ergreifenbiten Momente jeiner

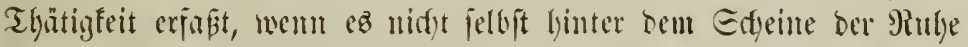

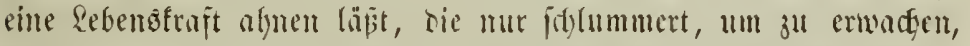

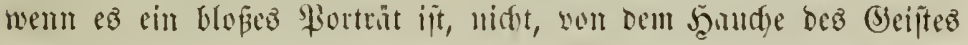

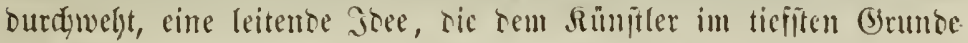

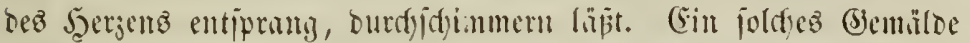
will idf entwerfon, bos nid)t Glok ein treues Foeträt ber Piatur,

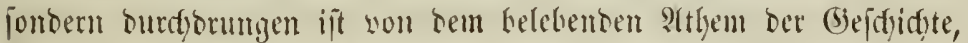

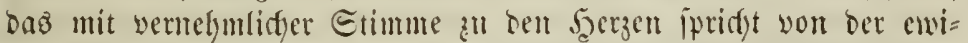

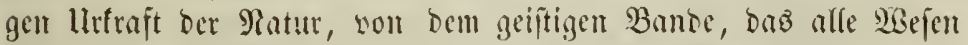

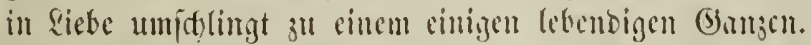

(5eben meine 28 orte nud mur cinen umbüroigen Sialymen für

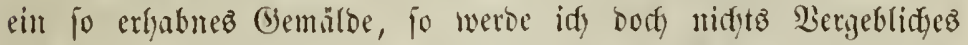

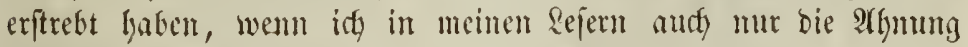
won bem ermerte, waz mir in der Eeele alz heiligez Driginal woridywebt. 


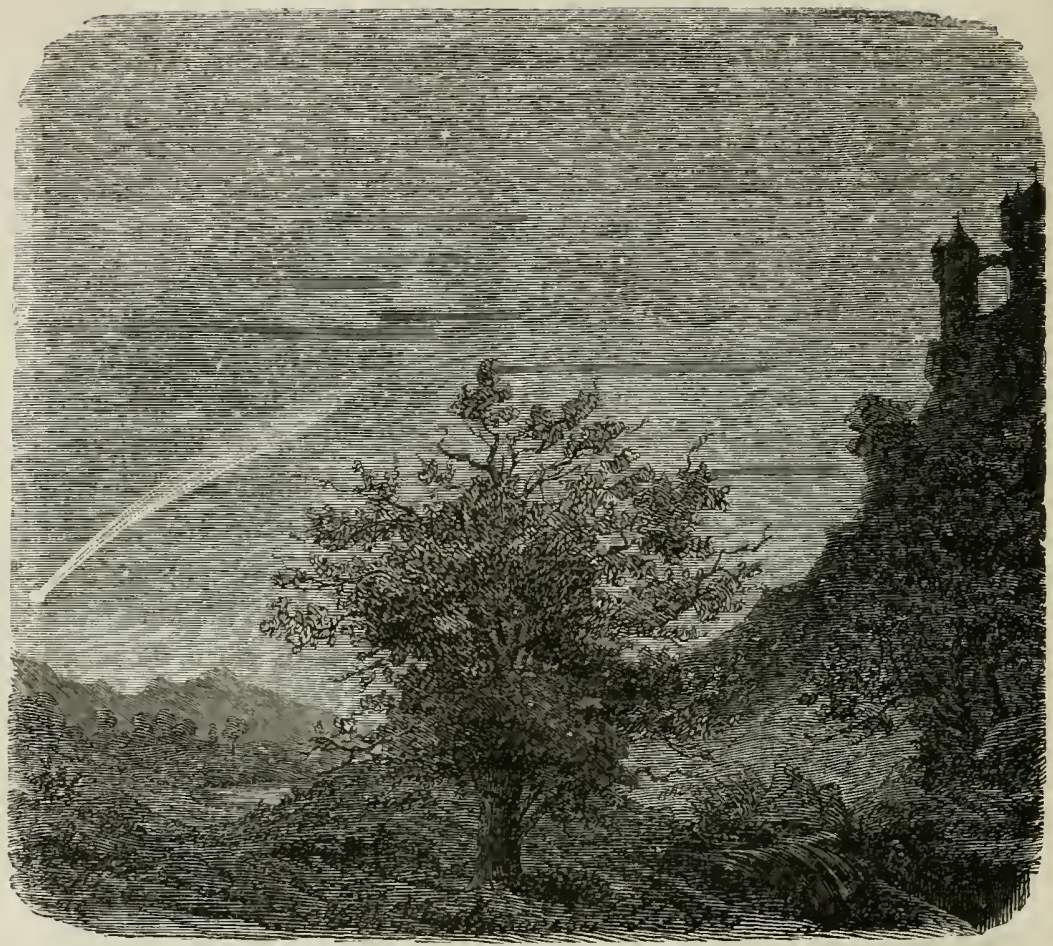

\section{(Everer 2qbidsutitt.}

Gemäles ber Cternentelt. Irandegie.

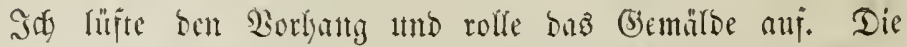

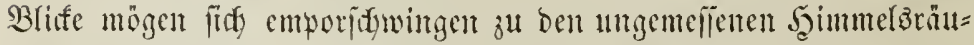

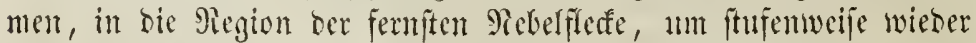
herabufteigen burch die Etenentreije unjers \&lanetenjuftems zu

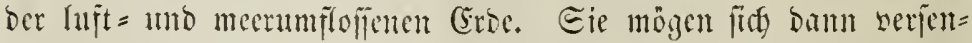

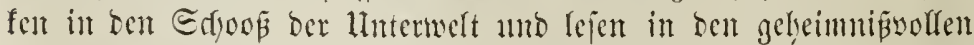

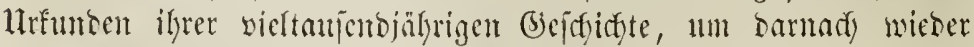

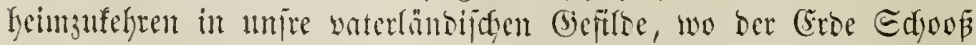
Blittlen und Blantter entfaltet, wo er bie zabllojen Bejdyledter ber

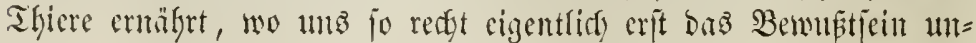


free Berwandiffaft mit ber Patur aufgeht. Dort braupen in jenten glanjwollen Etermenwelten, unter Den julltojen Edyaren fid) orïn=

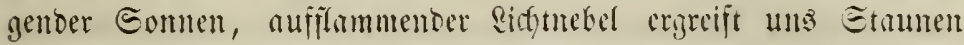

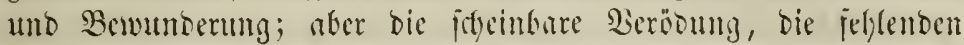

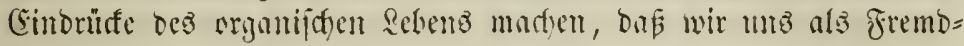

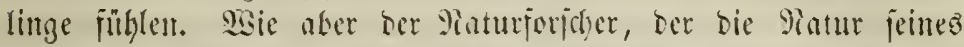

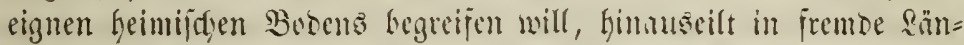

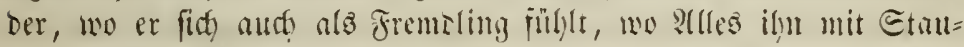

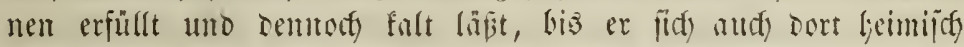

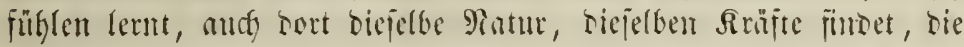

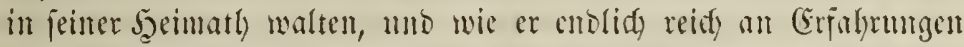

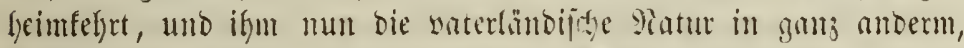

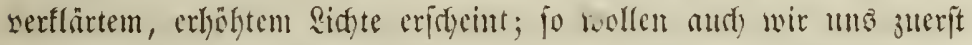
it jene Scimmelöräume begeten, wo wir anjung jowr fromblinge jein werben, aber bald uns immer lyeimijacr fïlylend andy fort bie

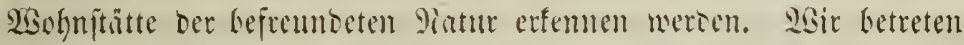

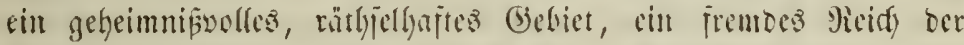

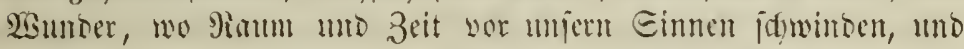

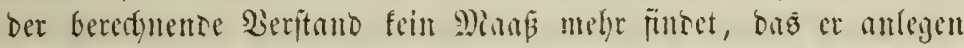

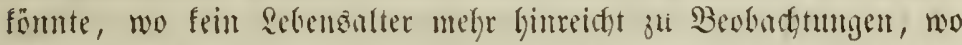
man nidyt experimentiren fonn, furz wo alle gewohnten fountumittel unamwenobar werben.

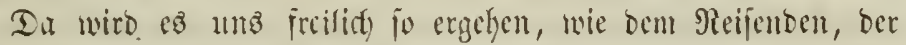

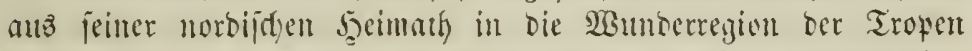
fommt uno, yon feimen Eimmen getüujd, bie gerihngelten $\mathfrak{B}$ hütlyen Der Srdyideen für Edymetterlinge, bie in bumten Farbenjidmutaf

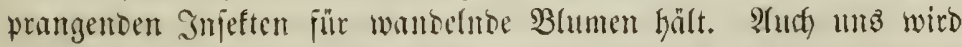
Die Bhantafie mandyen Etreich fpielen uno in ifrer verjülyrerifden

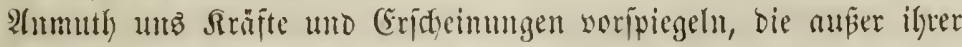

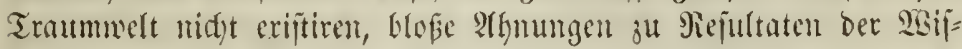

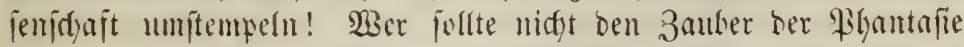
fennen, zumal wemn fids ifr cin fo grenzenloję, you bujtigen Edhleien verlülltes Bebiet eröfint; wer follte nid)t jene Trughiloes fentent, weldye bie Eelnufudt nady unerreidtem Befiz, jene Eelyn= fudyt nad) Der Ferne, nady dem Senfitigen erjengt, jene Eelyn= furdt, bie lange yor bor Entbefung ber neuen SEett bic Bewohmer Der Enmarijgen Smjeln und ber $\mathfrak{H}_{j}$ oren, wie Trammgebilbe, ferne 


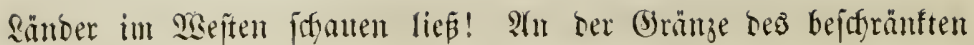

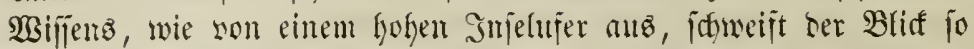

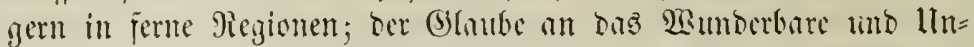

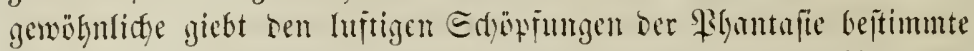

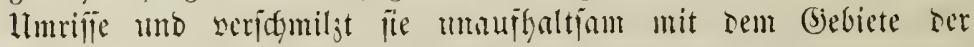

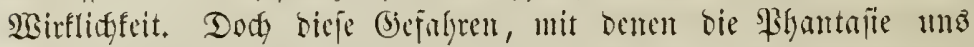

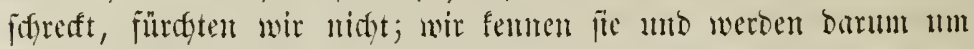

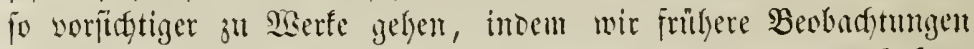

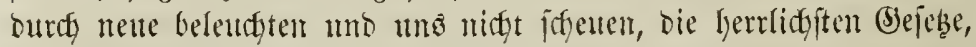

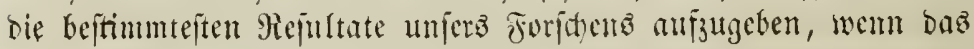
sidft neutr Forifungen, ftatt fie ju bejejtigen, fie verbunfelt. Der

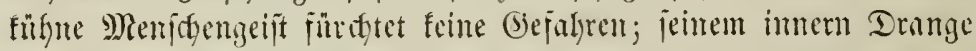
folgeno, ftürmt er jelbjt jum şimmel lyinan. Er gleidft bem ein= famen Bewohner cines engen, rings won jühen Felşwänten unt=

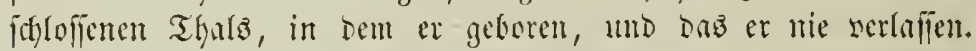

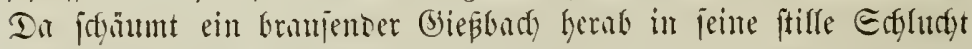
uno ipült fremoe Siruter uno Blumen, unbefannte Siefteine แmb

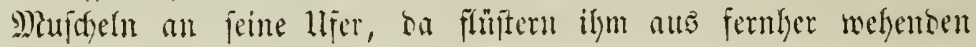

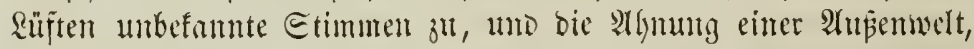
in ber gleich ifm lebente $\mathfrak{x e j e n}$ athmen, bie jene jeltjamen Hffan=

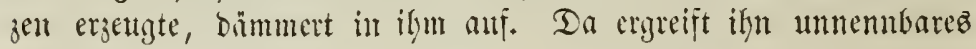

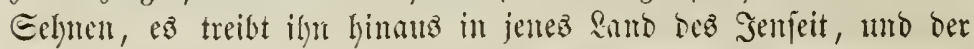

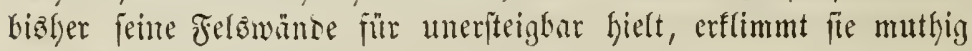
uno ftürgt fint mitten in bas wild kewegte Treiben jener frembarti=

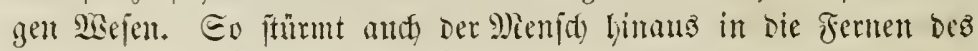

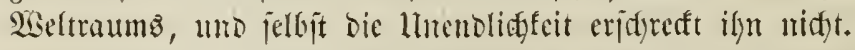

Es gewährt einen eigentlyülidyen Meiz, in ber Borftellung ber

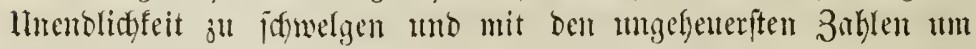
fid z"l werjen, baj auds lier ein foldes Epielwerf wohl geitattet fein Durrte. Sidyt um einen Begriff vou ber Unenolidhteit ber Edyopfung ju geten, bemn Itroty Zalylen irlangt man ifn nidft;

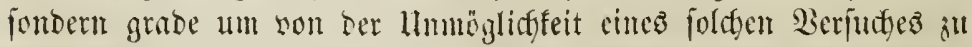
liberzengen umb zugleid einen Blif in bic räumlidgen Berbältnifie

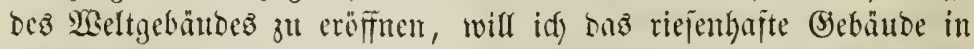
ein Miniaturbilo jufanmendrängen. Denten wir uns bie Eroe

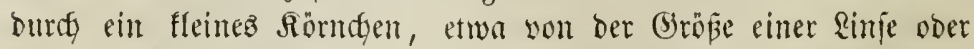

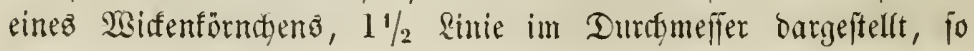


baben wir ein Mooelf yon rectyt anjehnlidter Rleinkeit, unb ntan follte meinen, ber ganje grope Eroball wirbe nady einem foldjen

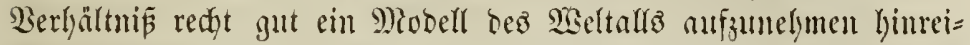
dyen. Eefhen wir ju! Bir ftellen umire fleine Somne auf, bie im Berbältnip zum Eromodell eine Suget won 14 3rll Durdymefier Darftellen wird. Estwa 24\% Ecfritte non der Enule fäme das

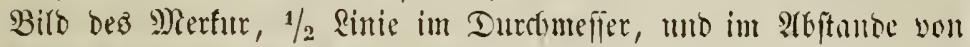
$45 \frac{1}{2}$ Edyritten folgte Bemus, $1 \frac{1}{2}$ Sinie im Durdymejer, Darnuf non

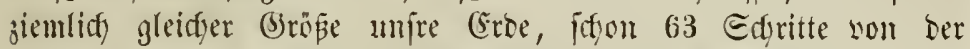
Enne entfernt. Damn folgte im Stoftand von 90 Edyritten Mars,

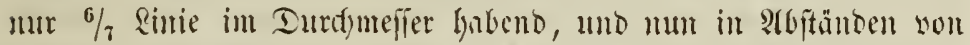

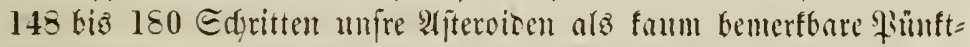

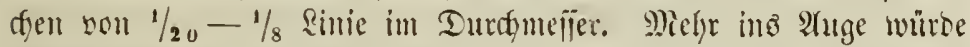
32!) Exthtte von bem Eonnenbilde bie 17 Simien in Durdymefier haltente Rugel Des Supiter faller, mo aud) Enturn, ber idjon 6]6 Edytitte entient wäre, jeigte fith noch als anjehnlictye Sugel von 15 Rinien im Durfmejper, wifhrend Hramts mit einem Durdy=

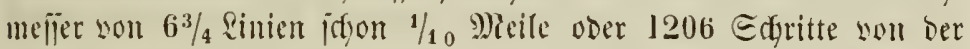

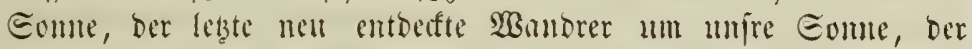

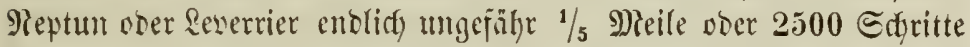
entfernt fut ftelyen fommen wirbe. Die Someten aber, bie boes

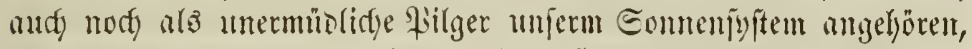
jatweifen freilidy etwaz weiter in ben Siseltraum binnts. 9Refment

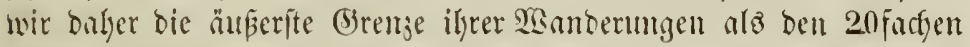
abjtano Des llramb von unjrer Eome an, jo wäroc bicje Grenje jagn 2 Meilen weit won biejer fallen. Endjen mir aber mun wei= ter ben Bunft, wo wir ben mïdjten Firitern, etwa ben Eirius himzuftellen bätten, jo whirben wir vielfeidyt meinen, in ben Gren=

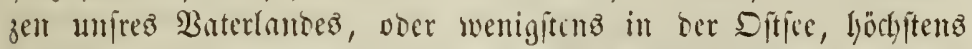

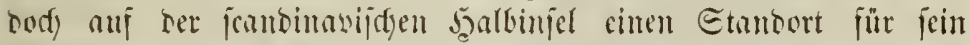

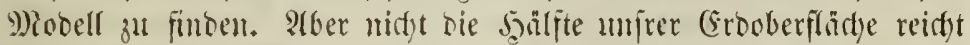
bin, un foldje Bilodyen zmeier Padjbarjomen in Dem Berbälmí ifree (brösen und 2tbjtände anjuftelfen. Eript meit üher ben fiol

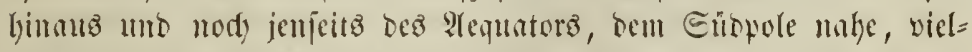
leidyt ani sem nenentorften Elidentinent, bem Sictorialande,

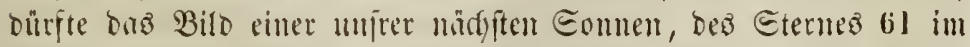

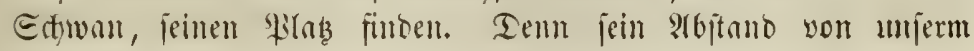


Eommenmobelf würoe 3110 Meilen, alio über 208 Erograbe, ๖. Ł. fajt $3 / 5$ bes ganjen Eroumfangs betragen.

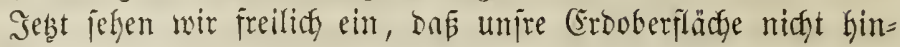
reicyt, um unjer jo fleimes Mvodell dez Weltallz aujzunefymen.

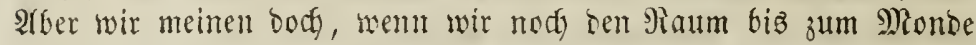
Ginjunefmen, fo wilrben wir wenigiteng unje s)ildyftrape barin

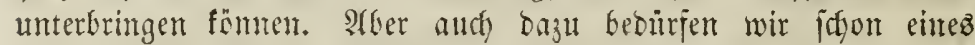

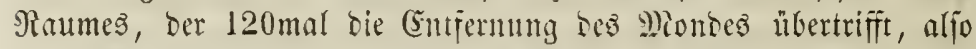
eines R6jtandes vout 6 Millionen Meilen. WBollten twir mun für

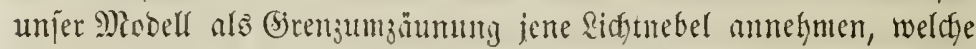
alz äu feines 40 füüigen Teleffors erreidyt wurden, fo würoen wir faum

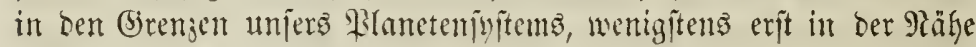

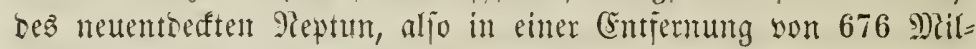
lionen Meifen ben nötfigen Panm finden. Ienn bie Berectymung

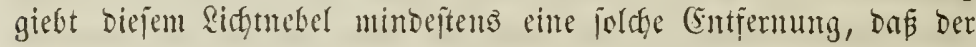
Sictitrafl, ber ouch in 1 Eecunde 41,515 \$leilen, in 1 Erumbe 145 Millionen Mleilen burfhläuft, erit in 2 Mrillionen Jahren unire

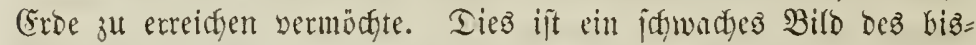

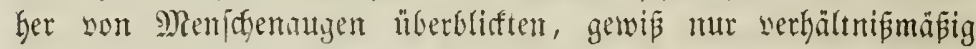

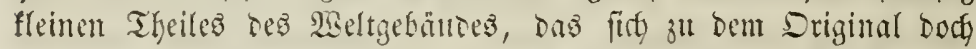
nur wie ein 2Biffenforndfen ju iem 2660 פhillionen Subifmeiten umfaffenden Erofürper serfält. -

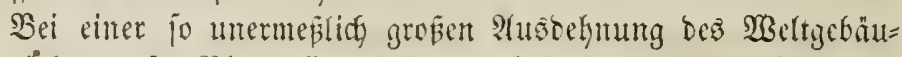

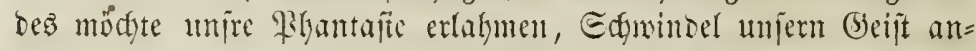
wandeln! lino bod, wäre ber Sisttraum nod) (Eentillionen mal

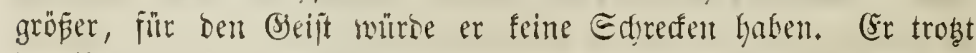

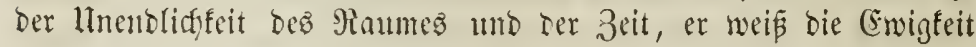

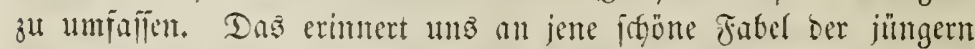

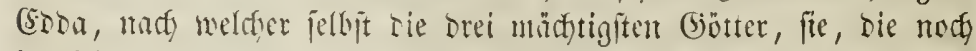

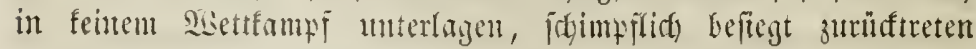
musten, weil fie mit ifjer, wenn anch nod) jo ungeheuren, förper= licten Siraft gegent etwis Beiftiges anfämpjen wollten. Eo erliegt

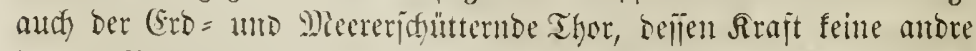

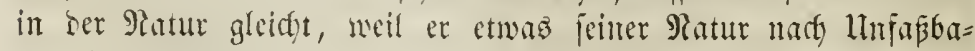

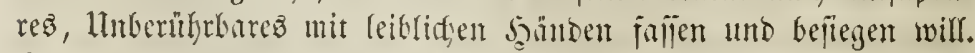

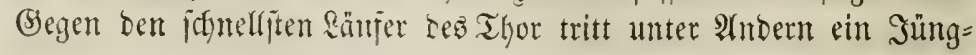




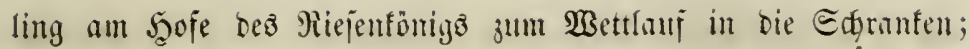

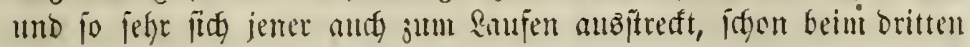

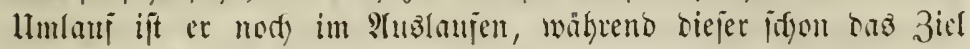
ber Bafyn erreidft hat. WBunore bidy nidft, fpridyt ber $\mathfrak{R}$ butig beim

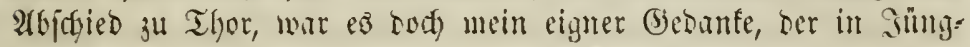

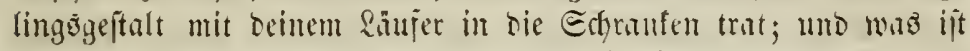

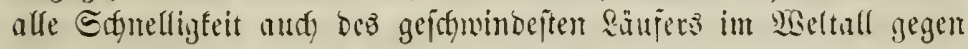

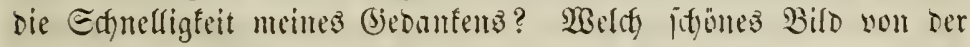

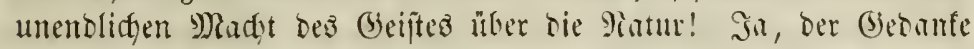

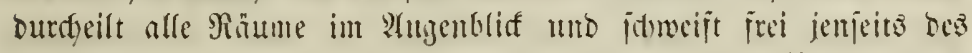
unermep̧lidgen Paumeș! Dem vor ifm giebt es feine Llmenolidtfeit, vor ifm giebt es and feinen Syimmel bort oroben, feim Sempeits,

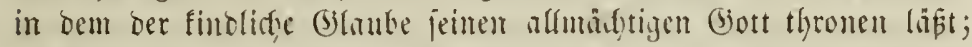

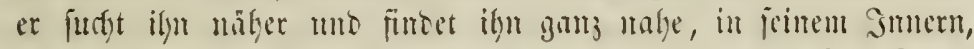

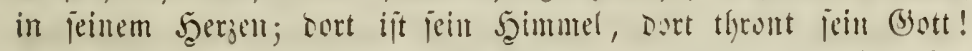

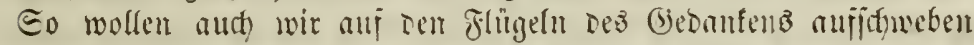

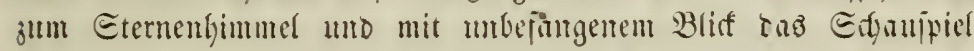

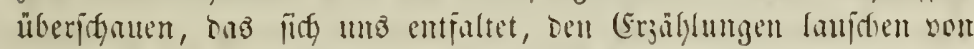

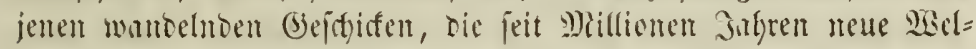
tell jajujell uto alte jertrummerten!

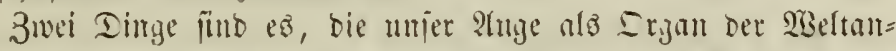

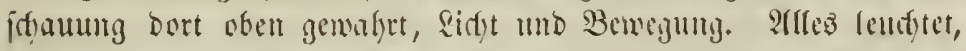

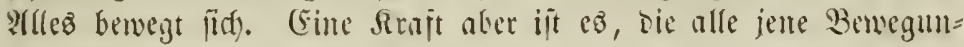

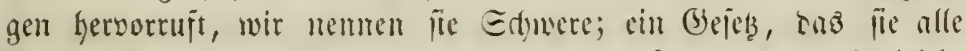

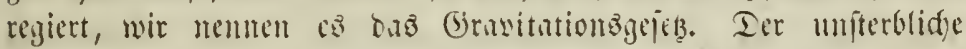
Jiewton war ez, ber biejez erbabue Gejés eryrindete, maty meldyem

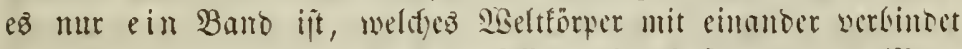

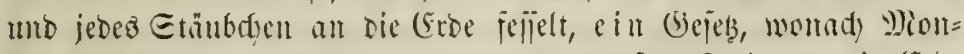

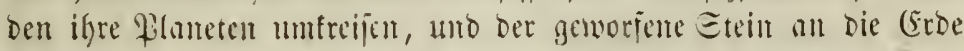

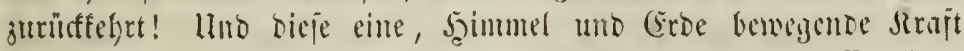

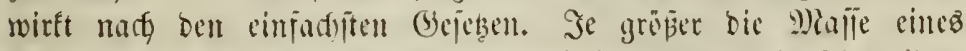

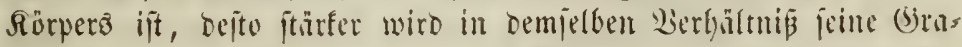

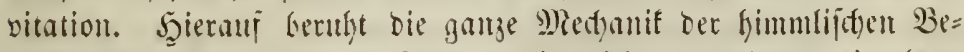
megungen. Eo mur die Eomme, die nidjt mur jeden cimzelnem

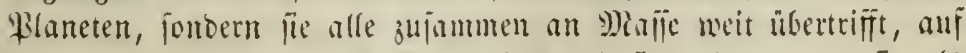

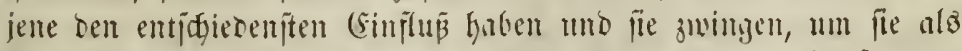

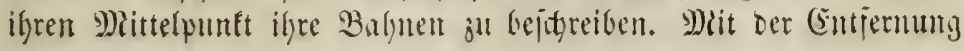


5on bent anjielyenden Centralförper nimmt aber aud bie (3ravita=

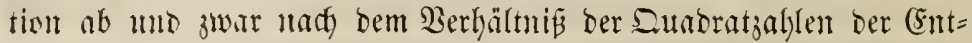

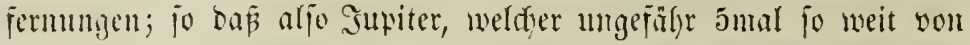
Der Eomne entfernt ijt als bie Erbe, mur mit Dem 25jen Theile oer Sraft angezogen mird, weldye unje (srbe an bie Eonne feflelt.

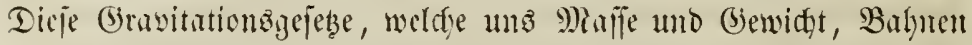
und llmlaujzzeiten Der Plancten berectuen lajien, ja felbjt bie Stì= mutgen, welthe fie beim Borübereilen an eimander erleiben, berritfen ands im ganzen Weltall, jwifhen ben jerniten Firfternen und ben

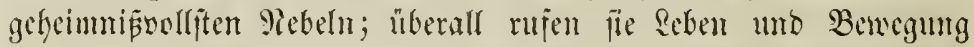

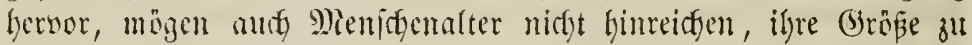

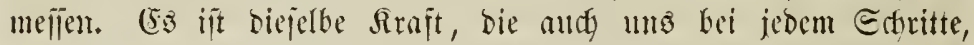
bei jeder Bowegung an unje irbijche Patur erimnert, uno bie unz mit

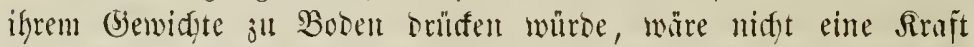

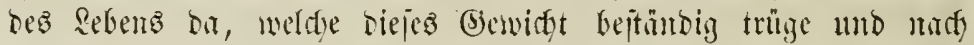
ifrem eigenen böheren biejebe bemegte. So waltet nud in jemen Riümen nod cine anbre gefeimnipodfe Rraft, und wir nennen fie

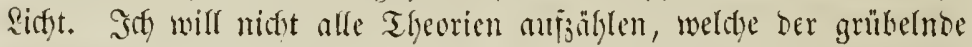

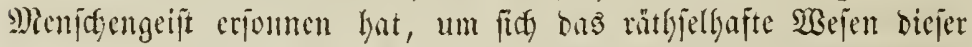
Rraft ju erflären; idg will mur leife 9lnoeutungen weriuchen über bie innere Patutr bes Qidytż und jeine Bebeutung in bem gropen

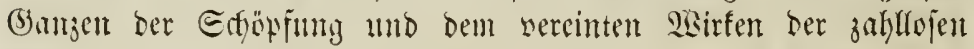
Sräfte.

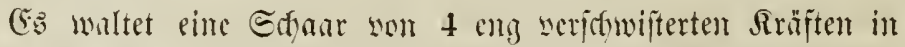
ber Sintur, Die allem Bejtelyendon Lrjprung, Dumer, Reben und Entwiffung geben, bie aber jo zart mo werboryent wirfen, bas fie

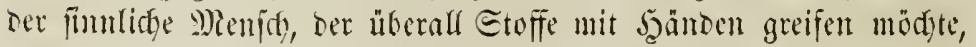
nidyt zu foljen gewust uno jie im unfumigiten Wiserponds für nictyt jowere, D. ho. jtoffloje Etoffe enflüt hat. Dieje Sräfte find

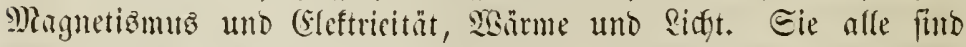
fo eng und unjertremlich serbunden, baß fie nidgts als bejondere Erjofeinungen cinter cinjigen gemeinjamen lutrajt fint; unb biefe Ulrfaft ftelyt wieber ju ber alfgemeinen Bravitationgfraft in Maffer Bejiclyung, ift fie vielmelyr jelbjt, mur als ifh polarer Begenfab.

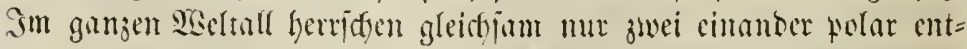

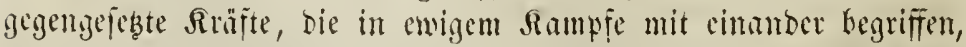
ewig einanber anjullyeben und ju vernidyten ftreber. Die eine Sraft 


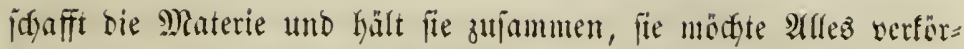
pern, Âtez in einen Mittelpuntt jufammentoringen. Die anbre

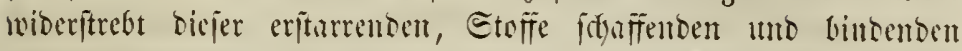
Sraft, fie mödte alle Etoffe vernidftent, verflüthtigen, vergeiftigen, jie bringt Reben in bie todte Materie, rujt Berninderungen, (Eriftei=

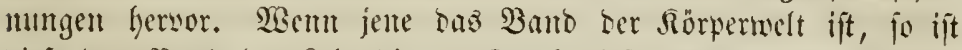

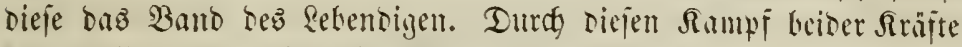
fommt Bewernung in bie 9iatur; Dem Deweguny iit mur, wo

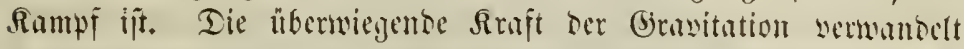

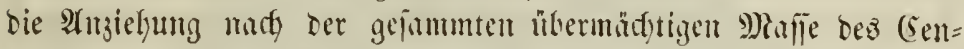

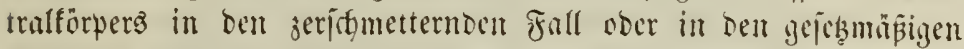

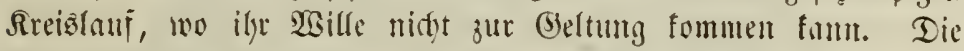

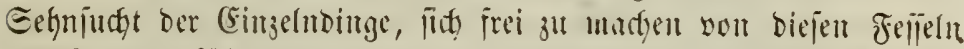
ber Mhaterie, fülynt aud) ju einer Bemegung, aber ju einer zarteren,

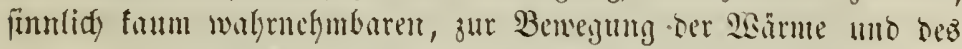

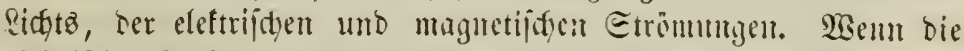

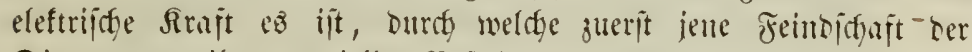
Dinge gegen ilge materiellea beftehen ermadjt, bie magnetipase aber, burdh weldye jener Trieb nad Bergeifitiguny mur nod cin blopes

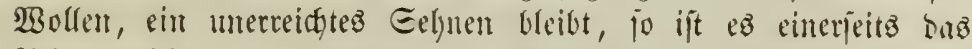
Ridjt, weldes jentes Eelynen jut lebentigent That erlebt unt bent Junfent ber Geiftigfeit, ben bie ESeftricität in Die Dinge legte, zur

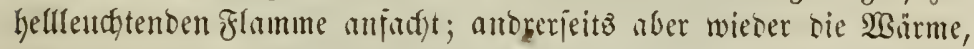
bie audf biefem mindtigen Drange Feffeln antegt und in bem $M_{0}=$ mente ifres Antifidwetens nad) oben bie Dinge wieber jujammen=

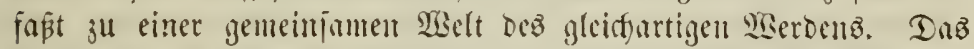

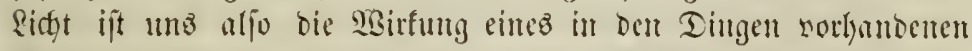

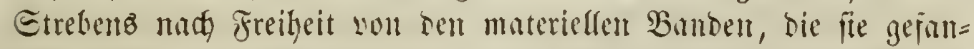

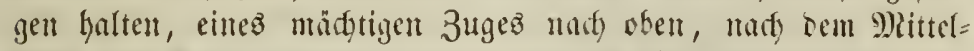

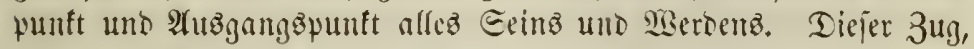

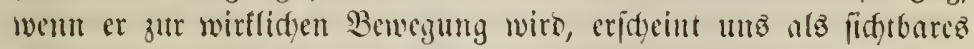

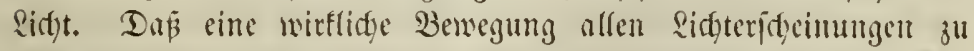

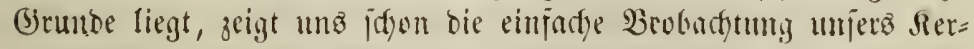

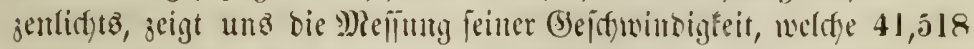
Meilen in einter Eecmito betringt. Die Bewegung aber bodorf do

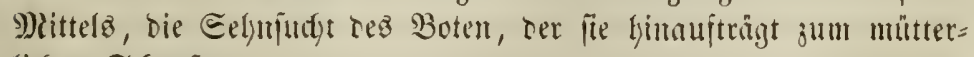
lidjen Edjooker. 


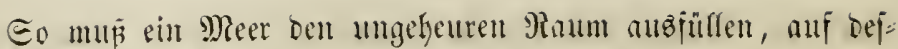

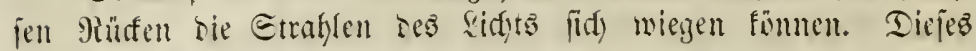

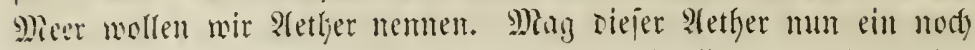

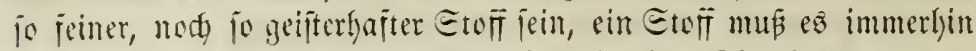
jeir, Dor allen (jejegen ber Mnaterie gelyord)t. Sit aber ber ganje

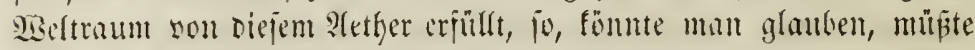

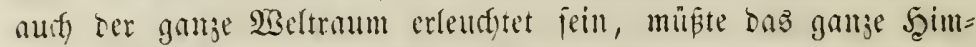

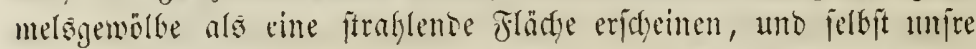
Mitternafyt Iagresglan; olyne Eterne pein. P(ber bas friestithe

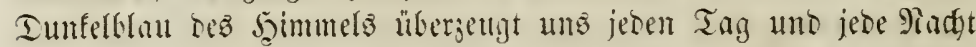

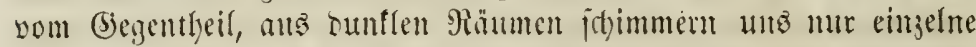

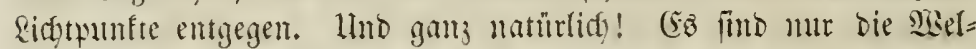
len Der Brontoung, bie bas Mjer eriffüttern. Tas Ridgt ift eine polare Sirnft, D. f. fie fommt mur an ifren Grenten, an ifrem

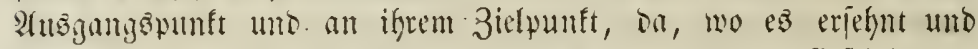

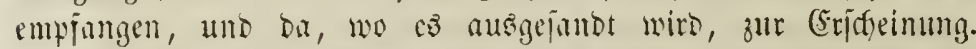

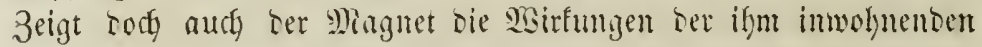

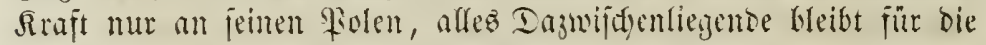

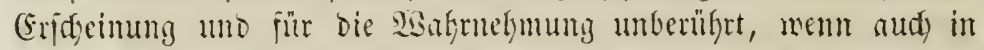

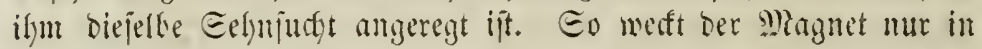

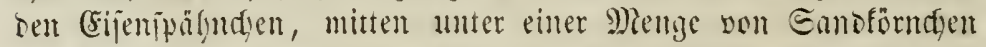

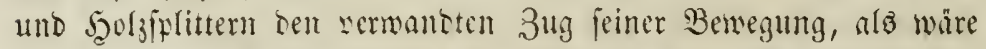

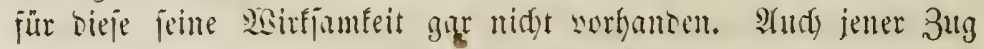
nach bim gemeinjamen Wittelpunft alles Eeins mo wiseroens, ber

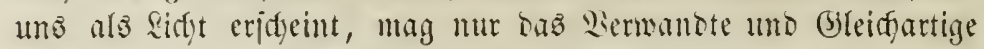

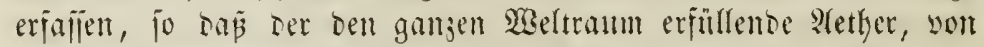

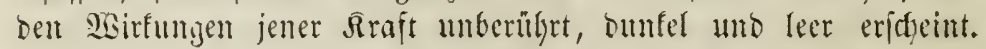
Töten Dod) jefbit mit dem lautmerbenten Tone einez Eaiteninjtru=

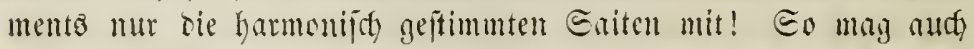
Das Sidat jenen Rlängen gleidjen umo uns an jene Ephärentarmonie erinnern, wou der bie alten Griecten träunten, jente farmonifge

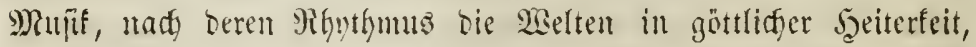

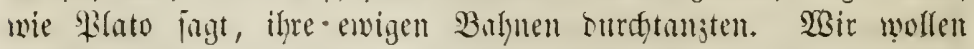

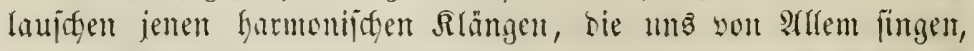
was pid) Dort oben bemegt, unt mit ben idjwatfen Eidfiffimmern

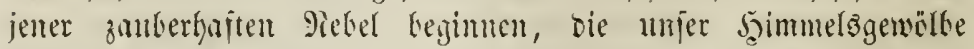

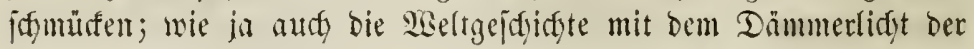


mythijden Borzeit beginnt. Ienn wo bie Wirflidfeit zu entidumin=

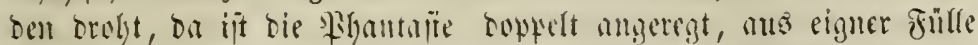

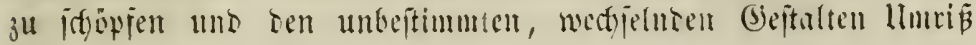
und Daner ju gelien.

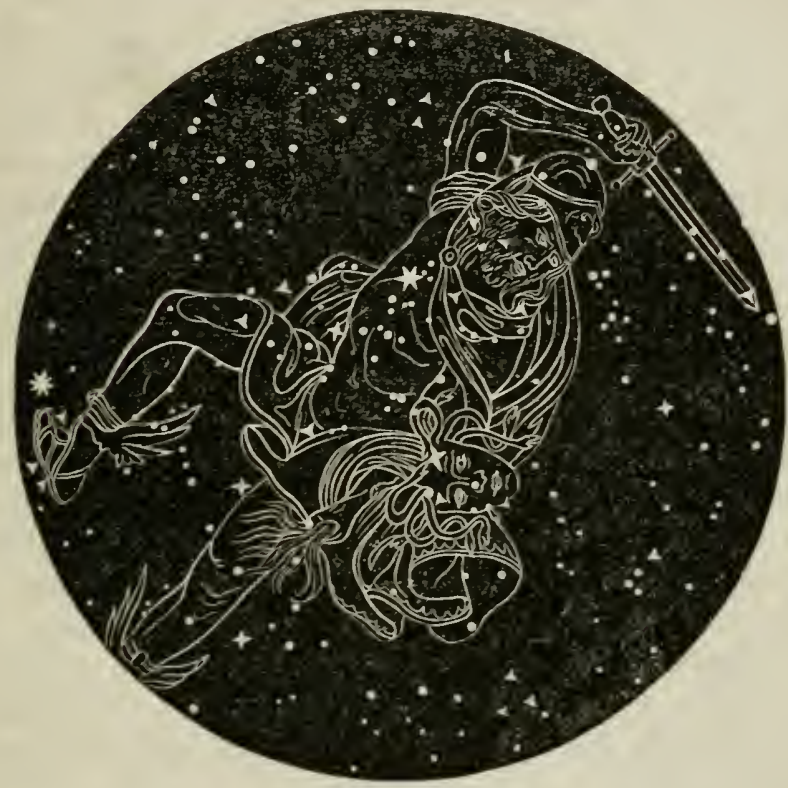

Ins Eucrubito res Perfut.

\section{Die Rebel = uno Jixfternwelt.}

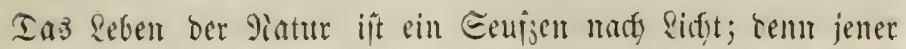
3ug, ber burth bie ganje \$aclt des Eimulidyen geht, you Der Erbe zur Eomte und von ciner Eomte jur anbern, jener 3ug, weldjer

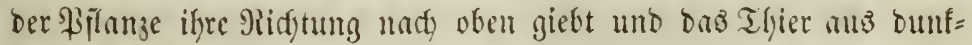

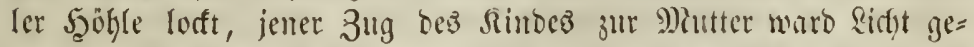

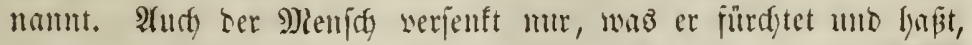

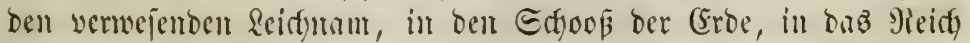
ber Sinfternis mo ber unjecien Materialität. Nber wa er liebt 
und anbetet, jeinen Giott, feine unjerblidge Eeele, werjebt er nady

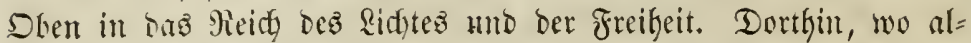

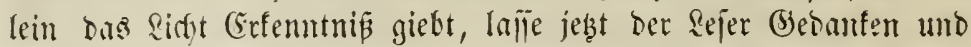
Stugen igfmeijen.

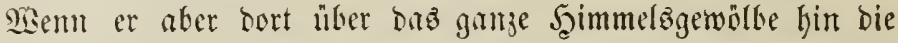

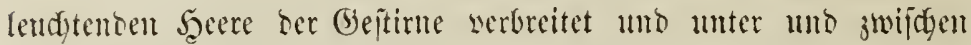
ihnen einen mildyatigen Edfinmer gewaljet, in meltfen bas Fern=

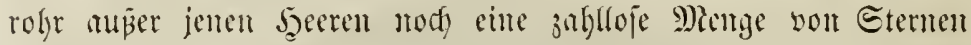

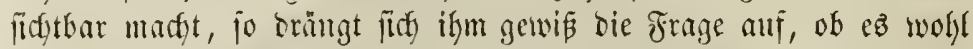

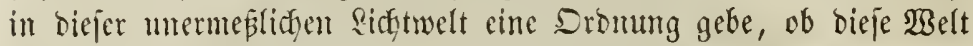

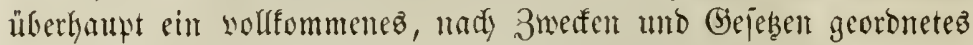
(b)anje, ober ob fie, burdy Glinben Medtanizimnz fich anziekenter

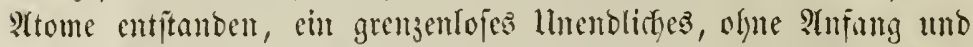

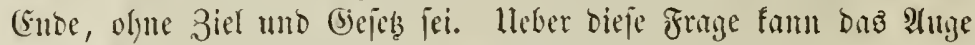
allein $\mathfrak{2}$ us̃funft geben, unt mic weit bicje reidyt, werben wir mit Bewumberung und Etaunen jetyen.

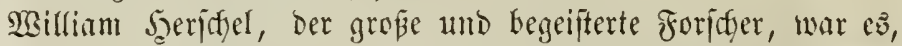
Der, ein zmeiter Rolumbus, juerít bie Sagonen des unbefannten

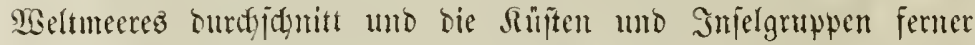

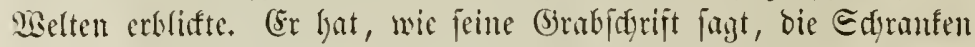

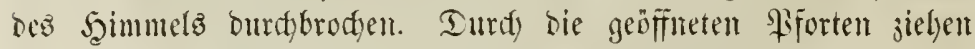

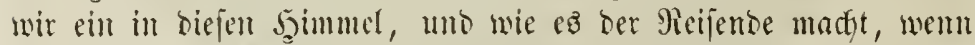
er cine fremto Etadt, cin unbefanntez santo betritt, futsen wir

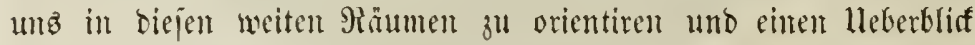
34 gerwinten über bie Sidftwelten!

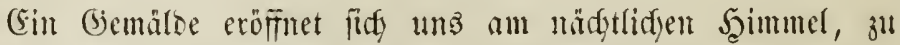

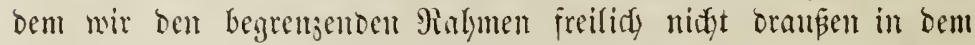
unendidyen Deent, fontern in ben Edyranfen wirer eignten Men=

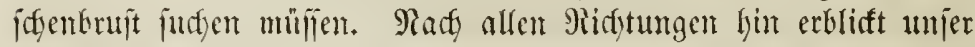
2huge Eterne, aber feinesmegs in gleidjer Fritfe wertheilt, fondern bald in bidgte Giruppen zulammengeorängt, Gar's weite Piegionen bunfet uno leer lajient. Miag anch biejes 3ujammengejefltjein ber

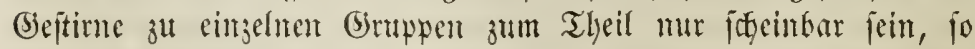

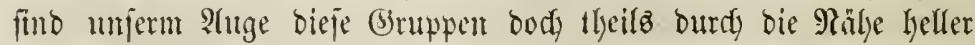
Eterne, theila burch ifre gegenjeitige Etellung ober igre Sjotirtheit

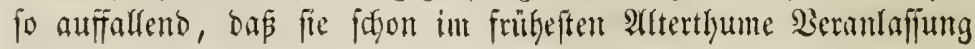


gaben zur Erfindung uno Benemmung Der cinzefnen Eternbilder.

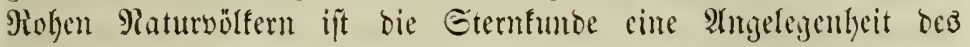

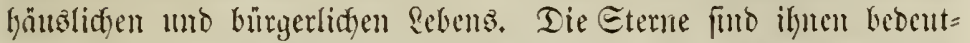

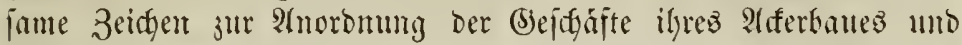

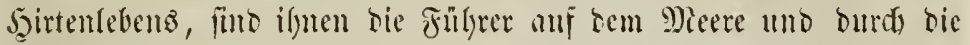

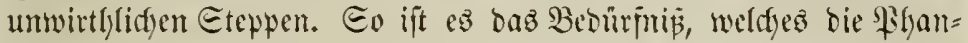
tafie anregt, bie bedentjamen Gteme son ben üloigen abjujonbern

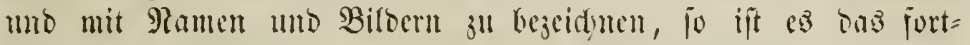

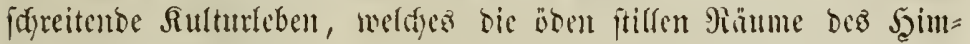

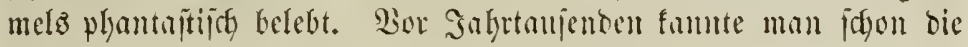

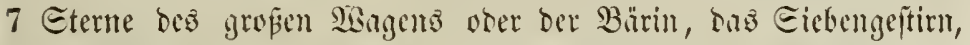

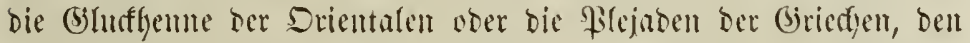

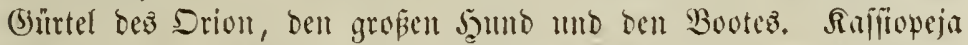

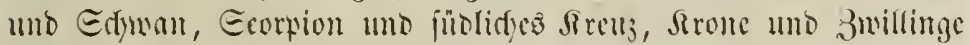

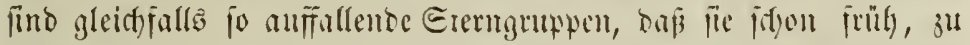

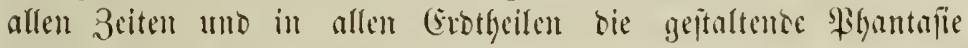

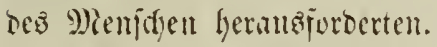

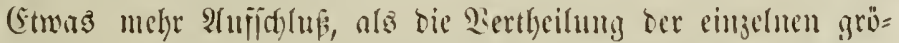

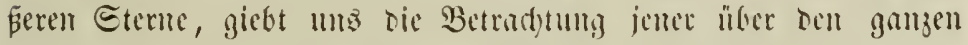

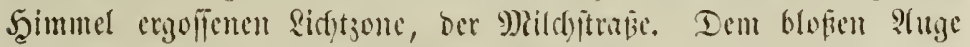

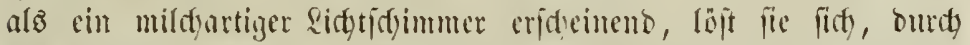

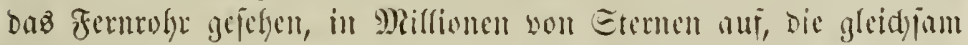

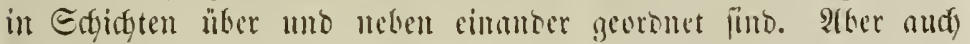

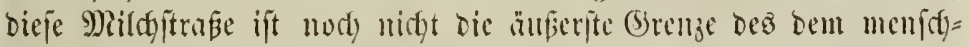

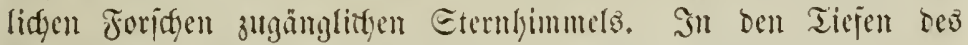
W3eltraums, mitten am nädytlidyen beimmel, begegnet umb cine

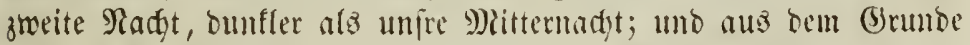

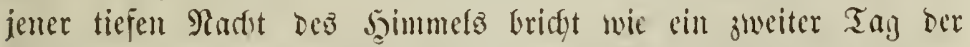
Edjimmer einer anbern Eterntmuclt, ciner siselt netur, nunterjamer

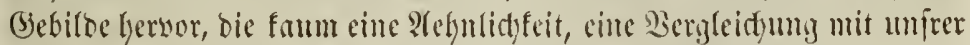

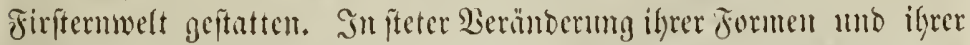
Didytigfeit begriffen, jehen wir jene metelartigen Sidstgebiloe balo alz runbe ober elliptijace Edyeiben, bald einfact), ballo partweife, oft burdy zante Ridftifteifen werbunden, bald vielyeftaltig, bald lang=

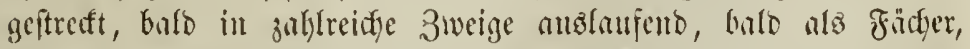
bald alz faffarf begrenjte 9iinge mit bunfem Innern erifdeinen. Dieje jetrjamen Ridjtwejen nemten wir ganj paljent gebelfifefe unto 


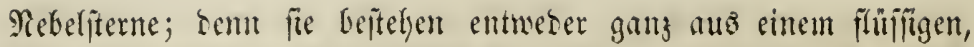

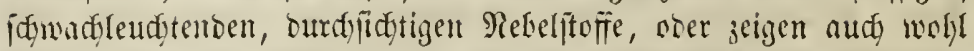

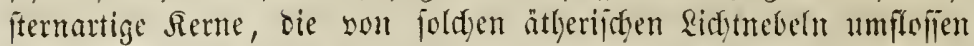
futb. Sin antorer Theil biejer Rebelgejtine jeigt umz aber audy

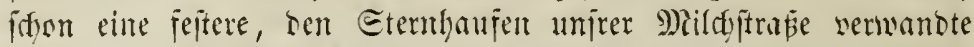
Siatur. Biele unter ifyner fino in fugetartige Eyjteme zujammen=

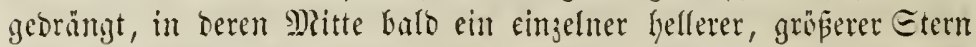

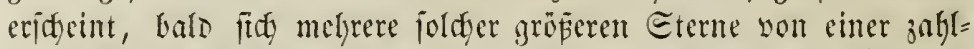
lojen Extaun fteinerer umgeben zeigen, bie firth nady ber Mitte zu immer bidyer zujammendriänget.

Dieje breifadyen veridjiebenartigen Eternenmelten fieten fints unfrer Beobadyung bar: Die grïeren, um unjer Eonnenjytem her=

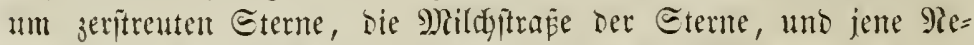

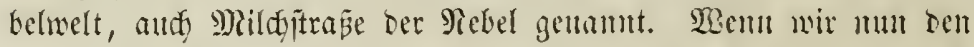
zanzen $2 B$ eltranum mit einem unjer injelreidfen Wieere rergleiffen,

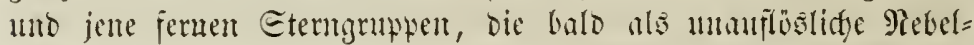
flecefe, bulo als um einen ober melyere Serne verbidytete Mnaterie, bald als Eternbuten, bald als ijolitre Eporndent erideinten, alo

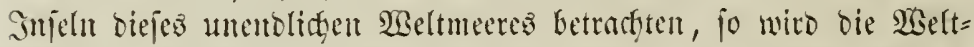
imjel, zu weldyer unjer Eommenjyjtem geljärt, eine linjenjörmig abs

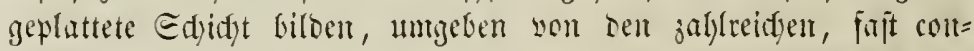

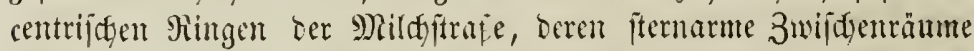
Durdy brüfenartige 3wijtgetglieber verbutten für. Dieje $23 e l t$, bie wir unjere Secimath nemen bunrfen, uma appt, io weit wir fie mit

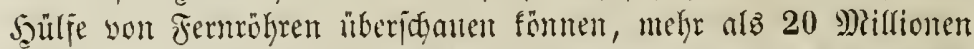

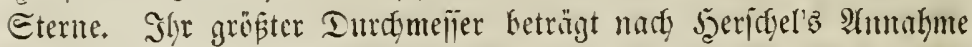
7-800 Eternweiten, ifr fleinfter 150. Eine Eternmeite nber umfät cine Million (Eroweiten uno jeoe (Eroweite wieberum $20_{3}^{2}$

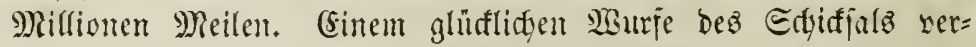

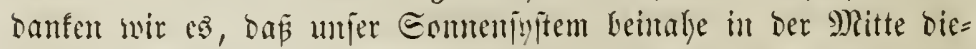

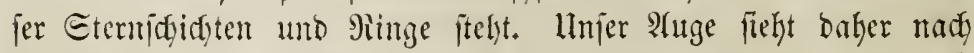
Der Sitd)tung Der Rängennre berfelben bie meijten Eterne, uno biefe

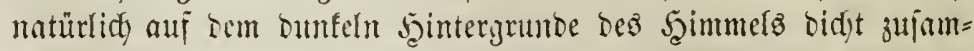

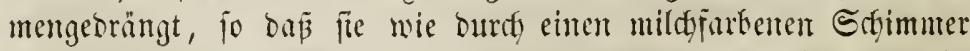

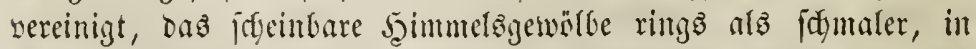
3weige getteilter (jiütel umziefen, Der init pradtwollem, Gie uno Da yon bunflen Etellen unterbrod)enem Ridgtglanz ftrablt. Etünden 


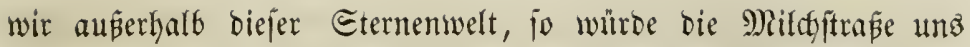
nidyt mefre als ein joldyer (Sürtel, jombern als nebelartiger Sing, ober gar in nod gröperer (Entfermung als sidbtwolfe, als ein un=

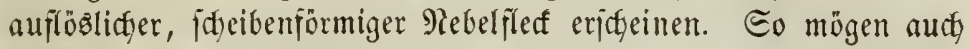
wohl jene fernen Rebel, bie wir jenfeits unfrer Mlildyjtrape aus

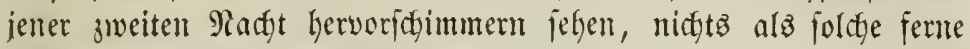
Injelgruppen im grōenen $\mathfrak{B e l t m e e r e ~ j e i n ! ~}$

Biloen aber aud jie cin gropes (s)anzes untereinander, ober

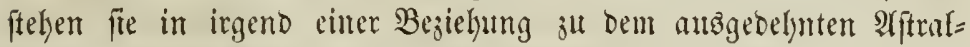
injteme unjer Mildgitrnße? Bei Bentwortung biejer Frage weift

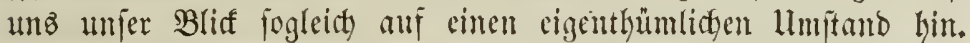
Dieje Rebelflecten eridgeinen nämlidy fajt immer an jenen bunfeln

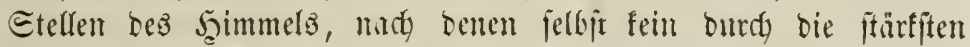

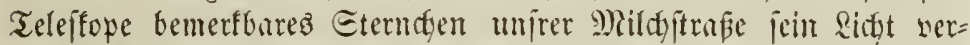
breiten fann. Eo ringsum von lidytlojer Rere umgeben, liegen jene Sebel boch gewobnlith zwijden einjelnen größeren Eternen einge= bettet. Dieş jobeint uns auj cinen 3ujammenfang hinzubuten. Aber wir müjë unter jenen Rebelflefen Diejenigen unterjociben,

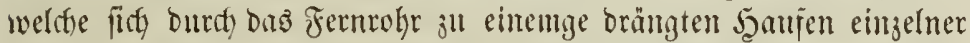
Eterne auplofen, und bie bisljer zwar nidyt aufgelöten, aber gröpe= ren Teleftopen, wie dem Siofiejtyen, bods eimpit weithenten, poge= mannten ätherifden Rebel. Die eriteren Rebel, ober vielmegr Eternbanjen, liegen alle in ber Mälle voer gar in mirer Mild $=$ frape jelbjt ziemlidy gleictyääig vertbcilt; uno mur an ztwei Stelfen,

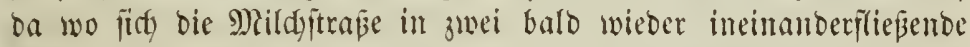
Urme theilt, unb ba wo fid ilyr verengter Etrom son neuem 3 u verbreiten anjängt, in ber Gegend bez Drion, exjueinen jene Eternbaufen in aufiallentor Menge zufammengebrängt, während wieber andre Stellen ganz bawon entblö̈t jogeinen. Sene bumflen, ganz fternleeren Regionen nannte Seridjel Deffnungen im Şimmel, und fie find in ber That gleiffam Deffmungen in jenem bunten Eternenteppich, ber bas ganje fateinbare Scimmelögewölbe bebedt, burdy weldse wir in ben ferniten Beltraum blifen, ben nufi, nod Eterne erfülfen mögen, bie aber für unire bejten Injtrumente un= erreidybar fint. Sil ber Singe foldger Defïmungen befinden fid ge=

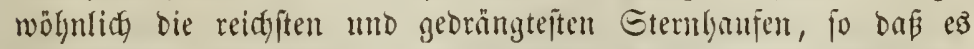
fajt facint, alo habe hier eine befondere haufenbildonte Rrajt ge= แI 6 , खettnll. 3. Жนกี. 
waltet uno to grope Bermilifungen in unjer Eternenmelt angerid)=

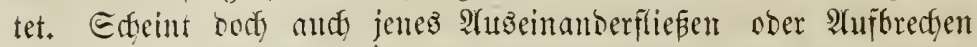
- wie es Satubold menut - unirer Mildyftraße in igre beiben

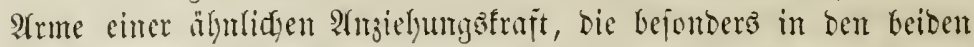
glänjenden Sunter, in benen fid jene Zweige rereinigen, ifjen Eis baben mödyte, ifye Entjtefurg ju verbanfen ju baben! -

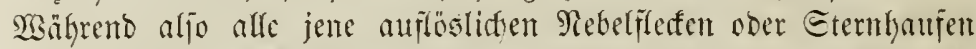

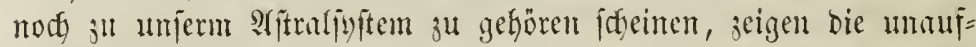

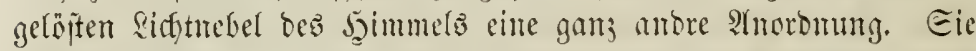

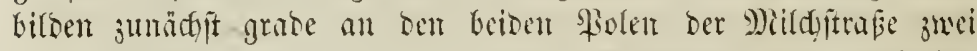

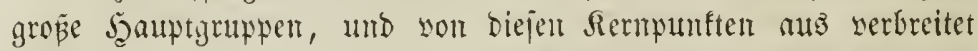

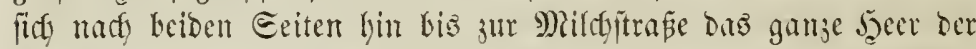
Rebeffleffer in 4 fint zum Theil wieder vergmeigenden Etraflem.

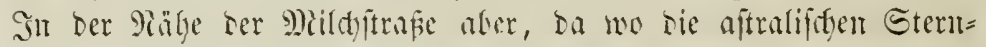
bauten exidyeinen, bredgen jene Siebelftrablen whoblidy ab. Eo um= geben aljo jene fernen Mebelwelten gleidjan wie cin jweites Şim=

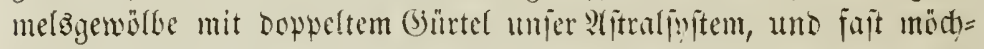

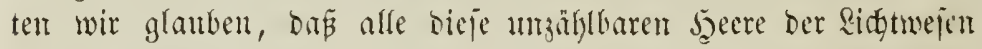
ein molyerbundenes, vollendetes bimje unter einander bilden, bei=

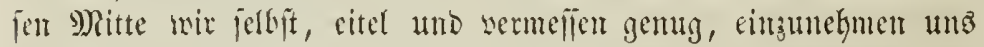

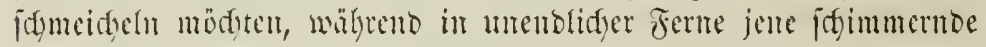

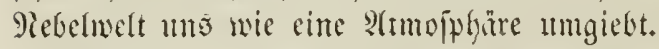

28 ent wir mun auj unirer Reije burdy ben unermeslidgen Etermenfinmel uns als Bemohner einer einjamen Weltinjel erfannt haben, die wieber rings son mebelartigen Etreifen räthjelhafter

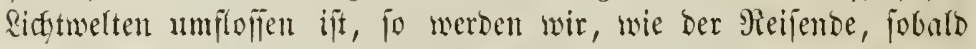
er fid üter ric enge uno bie Hmgebungen eitter fremben Etabt,

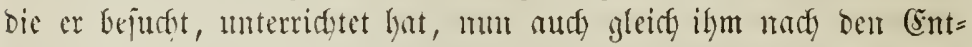
fermungen unb (s)

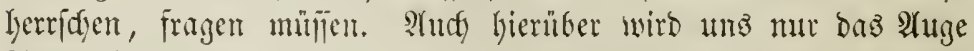

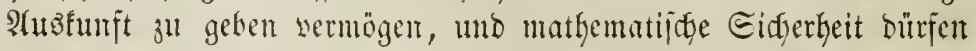
wir Dafjer nicft erwarten.

Die fidseriten Mesilmgen Der geringeren Entfermungen beruben

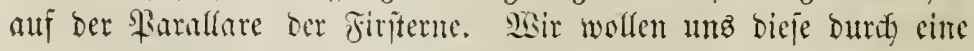
furze Betradtutug bentlict) zu madfen judfut. Bemegen wir unz auf cinter Ehaufier nur menige Edyritte sormants, fo jefyen mir

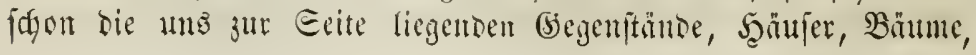




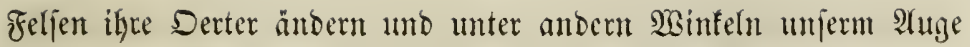
erjdeiner. 2 semn wir 3. B. in einer graben sintie finter einanoer brei Begentäntoe in veriffiebener Ëntjernung, cinen Baum, einen Thurm, eine $\mathfrak{B}$ ergipitige fefen, fo bemerfent wir, wern wir uns eitte

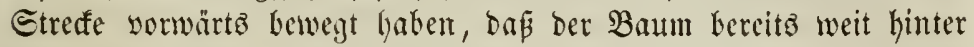
unz liegt, aud ber Thurm jurüfgewidgen ift, mo mur nodh bie

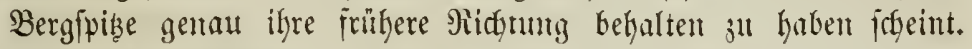
Wir erfenuen baraus, buß Der Baum näher als ber Thurm, und

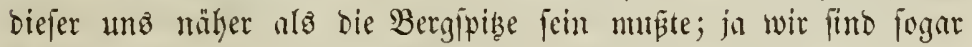
im Etmbe, ats bent veridjicbenen sisinfeln, unter benent fie uns

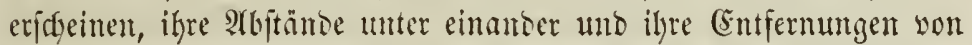

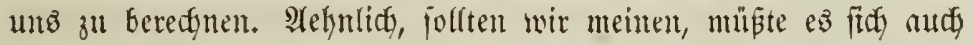
mit ben Firitement verlyalten. Llnfere (Erbe nimmt ja im Raufe einez Galben Safres jwei um den Raum von $41 \frac{1}{3}$ Millionen Meilen von einander entfernte Etmoorte cin. (Sine fo ungefeure Reije follte unz bod wohl Drtäverïnberungen ber Eterne bemerffar ma=

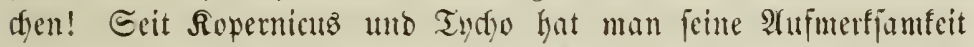
Darau geridftet, aber vergeblidf; bic Eterne Glieben unverrüft, jener Sisinfelunteridjied, bie Fiarallare, zeigte find nidyt. Freilidy fonnte

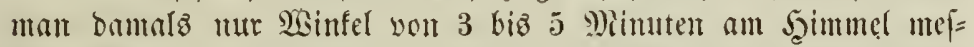
fen. Stber bie Gnftrumente wurben verwolffommutet, Scoofe lehrte Mimuten, Flamiteed Galbe unto Biertelminutem, Brabley jelbjt $\widetilde{E}_{e}=$ cunben beofadjten; unb bod) jah mun alfe Syoffnung getïufdgt. Wie

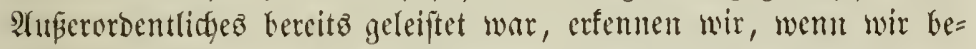

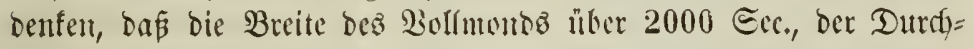

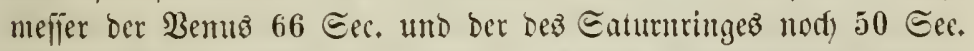

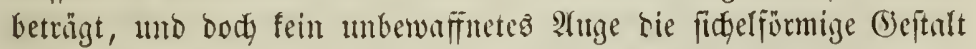
Der Bemız ober ben Ming dez Eaturn "' unterífeiben vermag.

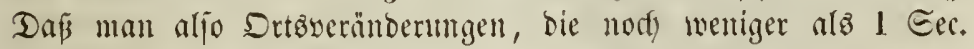

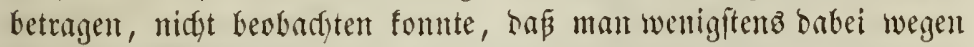
Der Unvollfonmentgeit. Der Inftrumente ben gröbften Täufdumgen

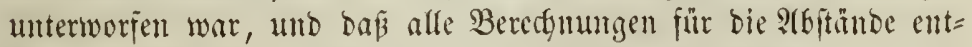

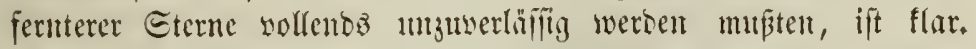
(Endlich alz bie Bollendung ber Miesintrumente fo weit gebielyen

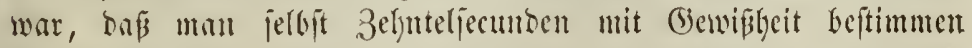

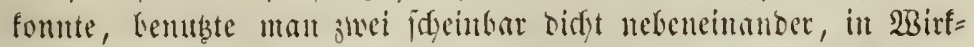
lidffeit aber Gintereinander jielyente Eterne, bie fdyeinbaren Doppel= 
fterme, wie ljintereinander ftelgento Bäıme, beobadhtete ifhre gegen= Feitigen Drtşverïnderitngen uno erreidste fo bas müfyolf erftrebte

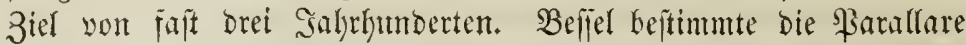

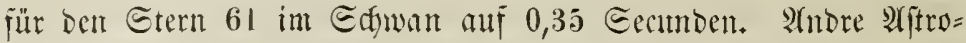
nonent, namentlidy Etrune uno Peters folgten ifm auf biefem

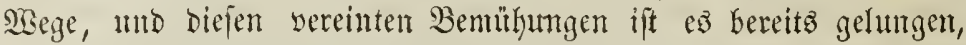
für eine fleine Zahl von Eternen Farallaren zu finden, utmter benen

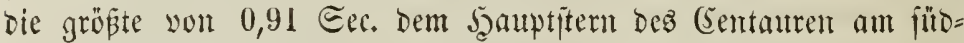
licfen Şimmel, bie fleinfte won 0,046 Ees. Der Rappelfa angegürt.

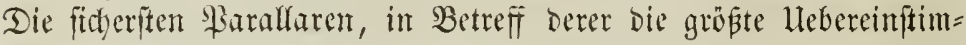

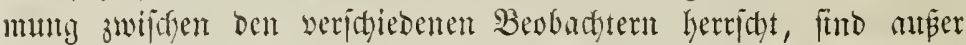
Den angeriülyten nod die ber $238 e g n=0,26$ Eec., bes Siriuz $=$

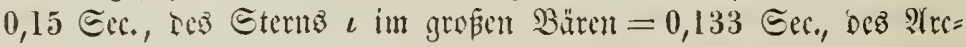

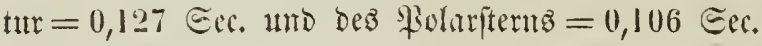

Salten wir unz baher an biefe mit einiger Zuvertaffitgteit it ifyren

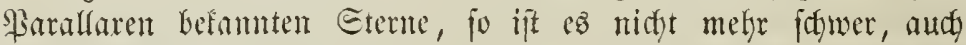

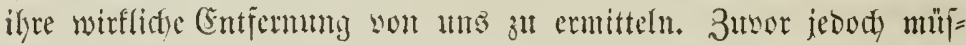
fen wir uns über einen M) Jajijtab eintigen, nad) Dem wir in jenent

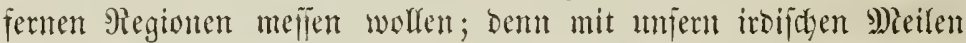

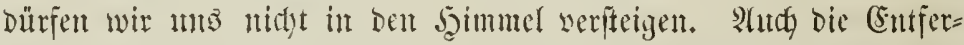

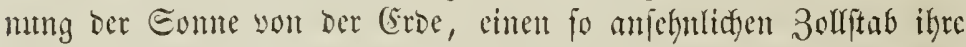

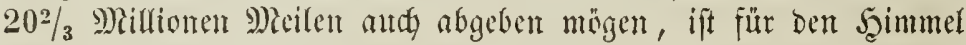

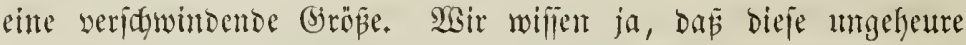
Etreffe nidgt einmal Gjutreidfte, cinte Sttäneränbenung in ben Eter= un beobadyten ju laffen. So madyen wir es denn wie ber Rei= fende, ber midft mady Meilen, fombern nady Etumben fragt, wällen aber cinen fodmelleren \&äufer als ben langjamen menjidliçen Fuß voer felbit unfere flübditigen Rocomotiven, und biefer Räufer fam fein

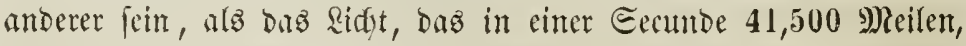

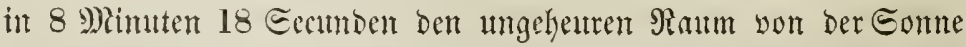

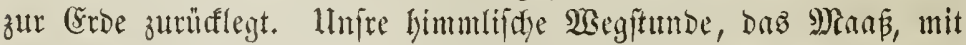
Dem wir unter betr Sternen ju meffen wagen, fei aljo baz Sidftjahr, Der Ratum, Den Das Ridjt in eintem Eroenjalfre butcdlüuft, ein

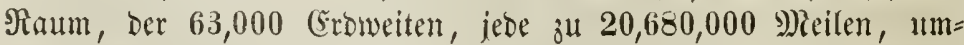

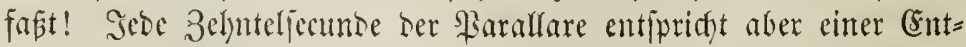
fornumy won 20,621,618 Groweiten ober befier 323/4 Ridytjaffren.

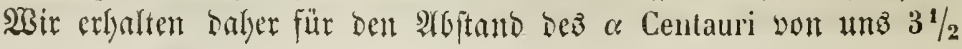


Doer genauer 3,62 Ridtjahre, für ben Etern $6 \mathrm{l}$ im Edywan 9,43

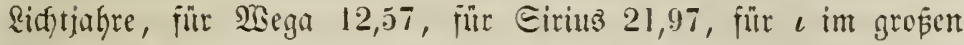

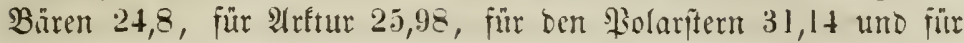

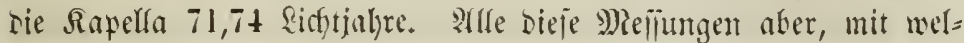
cher Stenauigfeit fite auch angeitellt find, feken bod nidss neiter fejt, als bie Grenze Der Enternung, immerhalb meldyer bie beobady= teten Eterne fith gewif nidgt befinden. 3 ser sen abitand bez

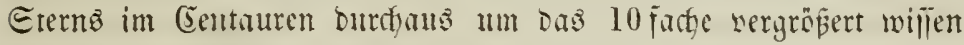

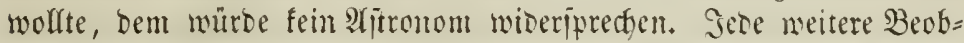

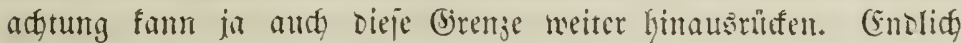

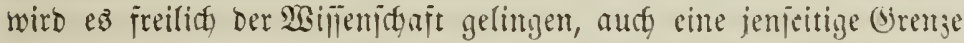
feitzuftellen, über weldbe himants ein beobadteter Etern nidyt gerintt

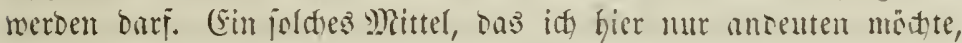
fodeint in ber genauen Beobadutung Der Iopfefiterne fereits gejumben.

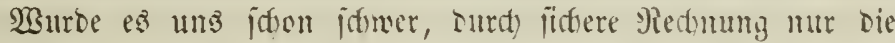

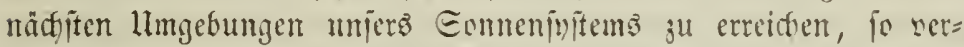

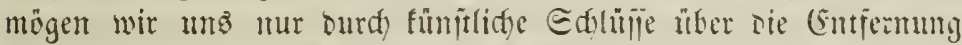

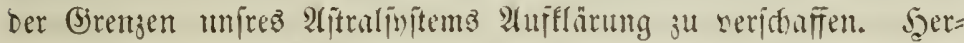
idhel hat unter ben Eternen, weldbe on untemaffnete Pluge erblift,

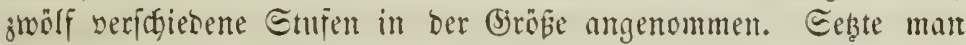

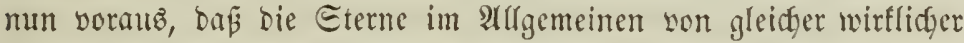

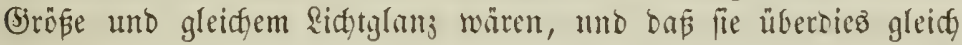
weit von einander itänoen, fo müren bie lebsten Eterne, weldse baz unbewaffnete 2 uge erreicht, 12 mal weiter abitehen, als bie

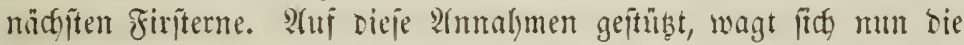

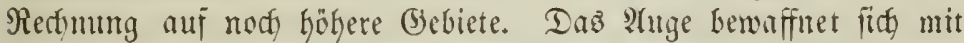
Teleffopen und bringt $100=$, ju 200 mal weiter in ben siseltraum

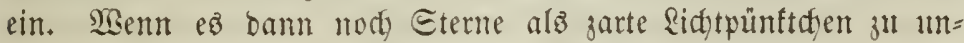
teriducioen bermag, jo milffen bieje $200 \mathrm{mal}$ weiter alछ Eterne 12 ter Sröß̈e oder 2400 Etermweiten entfernt fein, wenn wir bie

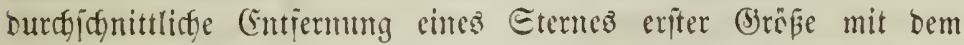

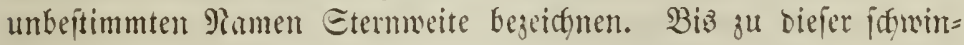

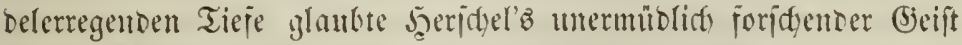

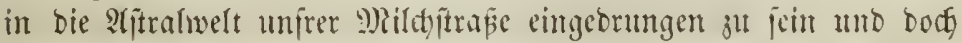
now feine Grenje gefunden jul haben; tenn wo felbjt Telejtope fein Sidjt mebr ju entbüllen vermögen, ba jaubert uns bie \&han= tafie immer nody Eterne, ja groß̈e Enfteme hervor. WBie num, 
wenn jenter lebte Etern, Delt Saerjhel's Fernrohr erreidyte, tein ber= einzelter wäre, wenn Şumberte, ja Milfionen von Eternen fich nur zu einem bidften Şaufen jujammengebrängt hätten, wie unendich viel gröfer müp̈te bann ilyre Entjernung fein? Uno wie, wenn alle jene umauflöğlidgen Nebelilecfen, bie jelbjt Dem jouärfiten Fern= rohr nody als fdywadger Edbimmer eridgeinen, aud nur foldye Etern= Gaufen wären, wie wollten wir bann nod cin Maẩ für ifre (Sntfermung Findent?

Eelbit Saeridyel gefteht idyon, Dẩ jein İnitrument ihm nod Eidftwelten fidtbar zll madyen vermöge, die 300,000 Eternmeiten son uns entfernt wären. Die Entfermungen biejer fleineren tele=

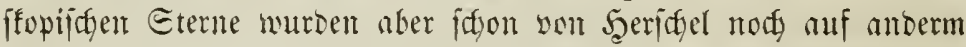
Wege bejtimmt burd bie Eternjälylumgen noer Eternaidungen.

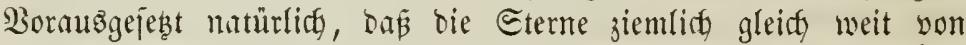
eimanber abftefen, umb raz auf ons ganze Bsebiet bes Fernrohrb, welches in 70,000 Feloer getheilt ift, 1 Etern erfter Sröpe fommt, fo werben narf bem Sejebe der Rerpective im Durchidynitt 8

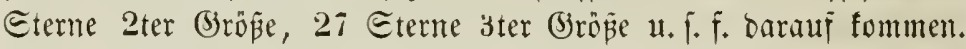
Frmo Serichel aljo auj jeoem Felde jeines Teleifopz burchichnittlidy 1 Etern, fo musten bie entjerntepten biejer Eterne 41 Eternweiten won uns abjeken; fanto er in eintem felde 64 Eterne, fo ergab fits Daraus ber abftand des entferntejten auf 4 mal 41 , aljo 161 Eternweiten; fano or gar gegen 8000, io muste die äuferfite (S)renze $20.41=820$ Eternweiten betragen. Bismeilen war eine foldhe Menge noch unterjaciobarer Eterne aui ein Felo jujammengebrängt,

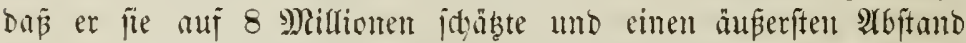
von 8,200 Etenmeiten berectnete. Eo mift die znl = uno abneh= menbe Etermmenge die Tiefe der Edjidt, wie daš Eenfblei bie Tiefen bes \$leeres mist. Afber fo wenig wie das Eenfblei immer bie Tiefe ergrünot, to menig vermag afle Redgnung bie Errenzen Des Meltraums zu erreidgen. (Es jeflt uns julest an Maajen, mur Der Bedanfe Durdffliegt nody dieje Belten, in denten jelbjt bie Edymingen bes Ridtes ju erlafmen fdeinen. Wie eine Schnede

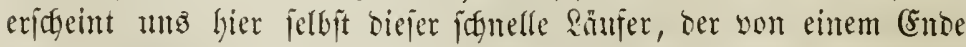
unjerz jeb̧t fo erweiterten Eomenjyftems zum anberm, etwa 1600 Millionen Meilen, in nod nidyt ganj 11 Etumben fliegt. Wir mödten uns wohl allenfalls eine foldye Richtreije naty jenem naben 
Eterne des (Sentauren gefallen Kafien, bie 4 tnz freilich fogon $3 \frac{11}{2}$

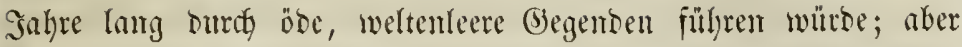

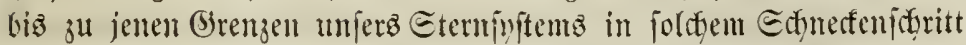
rorjubringen, bajll witrbe weder unje Sicould nod umire Rebents= Dauer atsereityen, Da eine 3eit yon 1200 bis 2000 Sahren erfor= berlich wire. Diefe Weltinjel aber gar zu verlafjen unt zu jenten

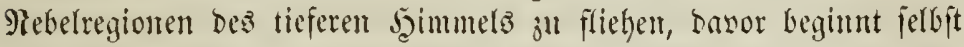
unjerm Sebanfen ju fdwinteln, ber eine foldje Ewigfeit non Mil= lionen won Safyen faum zu faflen sermay! Eidftitrablen, bie vor Entitefung umjerz Eroförpers von jetren fernen Welten anşingen, trefien jebt erit unjer 2 fuge, uno wesn jebt Tanjente jener 2 belten zertrïmmerten, แnjer Blicf müroe nichte̊ gewahren, würbe nach 9) Xiffionen won Saljten erjt ftaunen liber bas Beriffwinden won WBelten, bie längit nidht mehr ba iwaren. Eo ijt Bieles linngit ent=

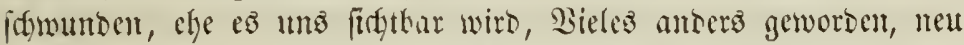
geboren, ehe bie 3ufunjt ben Edyleier ber Bergangenlyeit lüftet.

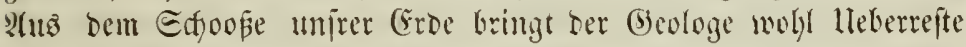

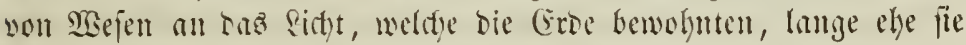
ilgre jebige form uno beftultung gemann, unto biefe lleberefte er= idheinen unz wohl heute wie 3eugen einer längit sergangenen 2 Ra tur ober wie cim trophetijdes Borgefidgt alfer ber Serïnberungen uno wedfelnoen formen, weldye bie Paatur won jentem Tage an burd)laufen follte. 2Bas jollen wir aber ju jenem prophetijden Tranme jagen, in weldfen uns bie Erjapeinungen einer Ridbtwelt

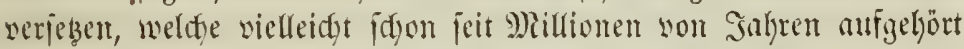
bat ju jein? Sene Sidtitrahlen, Die ung heute son Dort entgegen=. frömen, gingen vielleicht ju cinter 3eit aus, wo bie Matur juerit sen Bebanfen ciner mannigfaltigen Bildung fäte, wo bie Materie fid) zuerit in ilyser unvollfommeniten Seftaltumg zeigte. So wie fidy un jeb̧t jene Ridftwelten zeigen, waren fie vielleidjt einft, aber

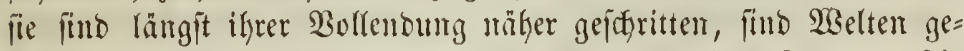

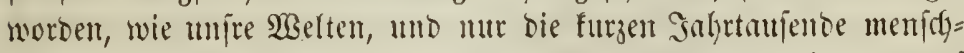

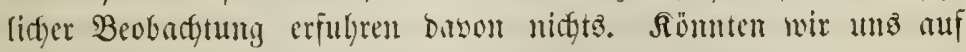
Den Edywingen Dez Bebantens in jene Belträume arbeben, von

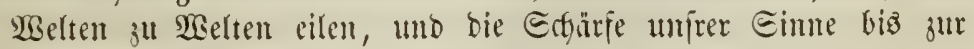

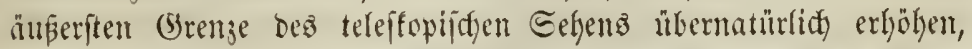

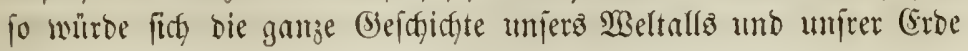


nor unjern Bliqfen aufrollen. Denn überall würben wir sidgtjtrahts len begegnen, bie in jebem einjelnen $\mathfrak{A}$ ugentlife jeit Millionen

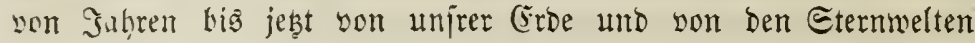
ansizegangen fino, unb bie uns die Bilder aller biejer Zeiten ab=

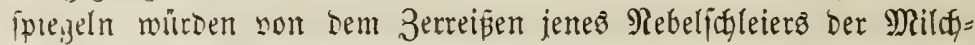

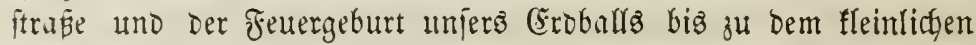
Treiben jener Erromürmer, bie wir bas Menjđyengeidfledft nennen.

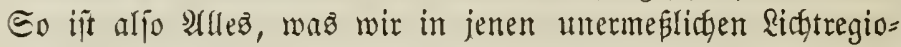
wen erblifen, nur ein Traumbild ber Bergangenbeit. Dari uns

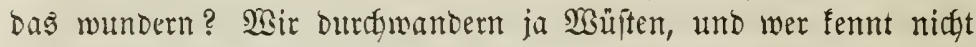
jene zuuberfajten Nebelgebilde, meldge Denen unjer (rroe eigen find ! 2(ber wenn Der 23 anderer in jenen 26 üjten 2 fitens ober 2 ffrifas früh vor Sonnenaufigang nahe Gebirge, Waaldungen uno Stäbte mit Thürmen und Manuerzinner żt erblifen wähnt, fo überzeugt ifn Dod jeder Edyritt, mit bem er fith bei wadjendem Tageslidyt jenen

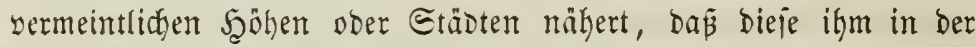
Dämmerung eridgienene $\mathfrak{B e l t}$ ein Epiel ber Fata Morgana, ein Traumgebilde aus einer jeinten Einnen nidgt mefir erjaß̧baren, lufs

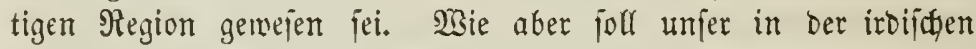
Sinnenmelt feitgebamntes Forichen mur üfer ben nädjiten Echritt finnusgelangen, un zu erjahren, ob bas, was jene noch unendlich viel ferner fetliende, frembartigere siselt unjern in bie enige Däm=

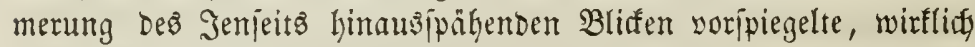

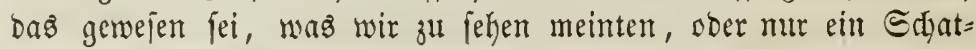

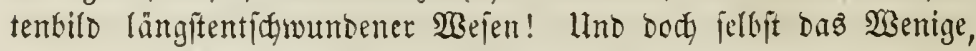

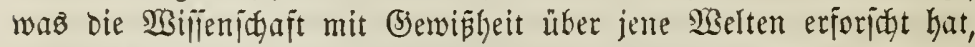

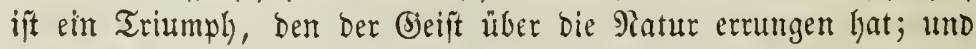

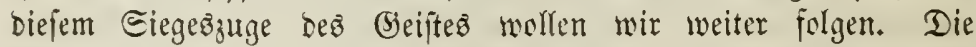

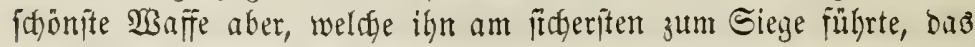
ift bie ewige Beleutfunt feiner gewornnenen Wahtheiten burdy bas

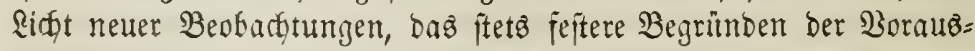

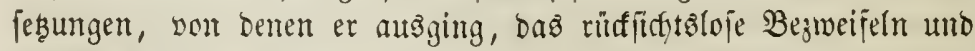

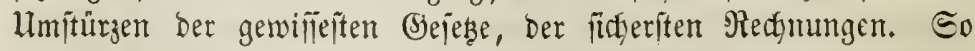

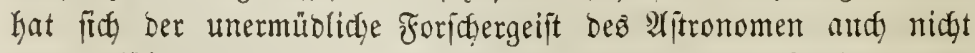
etwa erfüfnt, jene eben erwähnten Beredgungen Der Entfernungen

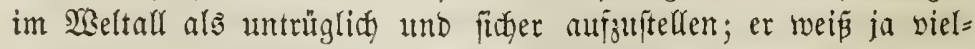

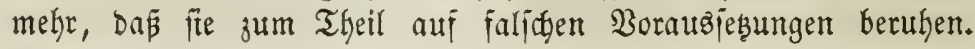


Sene Eterne, bie wir am Şimmelögewölbe jehen, ftehen ja weber

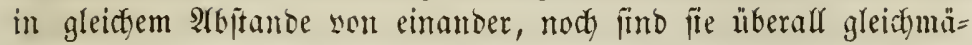

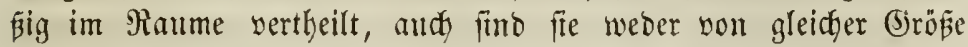
nod) Eidftitärfe. Brnoe unter ben Eleinfiten Eternen finben wir

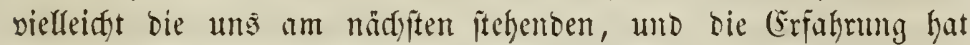

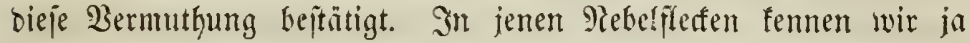

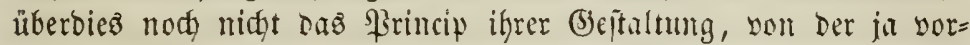

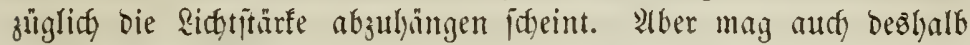

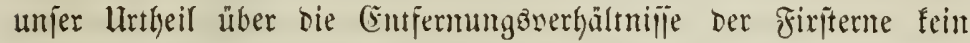

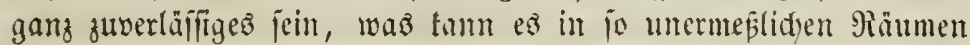
auf Mitrionen son Meilen anfommen, um fo melyr, wenn swir

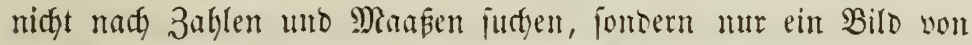
Der Afnorbnung Diejer răumlidjen Berbä!tmifīe gewinnen wollen?

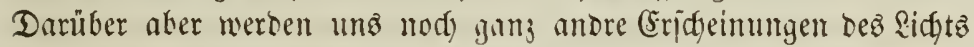
in jener Sternemwelt weitere 2 hużunjt gebent.

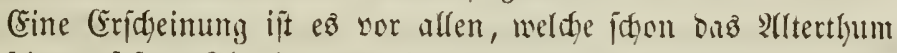

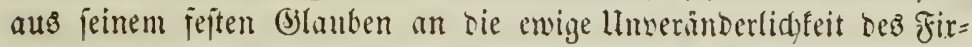

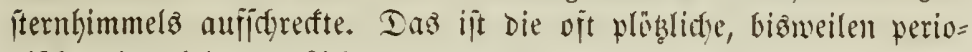
bijd wieberfefrende Ridtwantumg oer Eterne. Mritten in einer

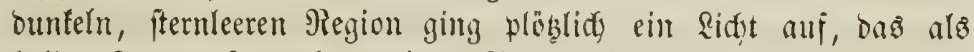

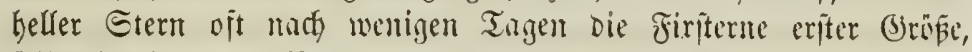
jelbjt Supiter uno Benuz, n̈berifraly/te. Diandye diejer gejpenjter= hajt aufitammenten Eterne blieben MBonte, Jaţre lang ann Şim=

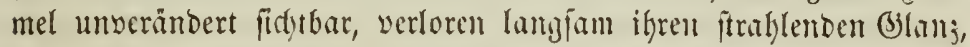
um wohl gar in $D a z$ idjwadje Edjimmern eines Etertes geringerer

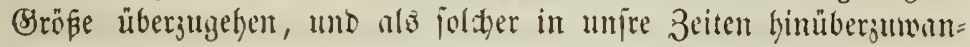
beln. Dit idfeint Derjelbe Etern am jelben Drte zu weridjedenten 3eiten biejes Epiel midberbolt jul hatben. Eo war wobly ter Etern,

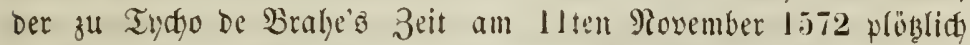

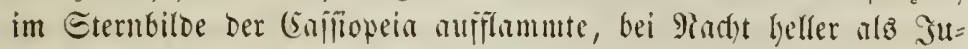

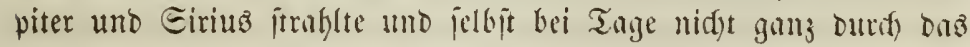

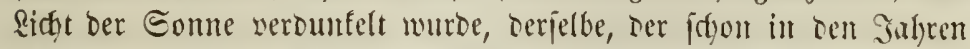

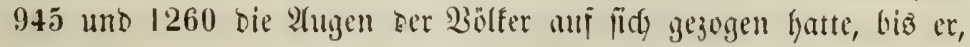

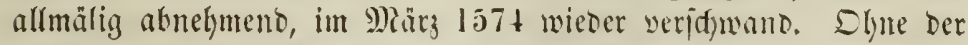
andern zahlteidgen Eterne ju crmähnten, Die im \&auje ber Gnhr= hunberte plöglidg eritgiencen uno mieder veridfwanden, will id) mur an bie Sidfnwanthungen erintern, bie wir nody jebgt an manchen 
Eternen ziwar fidwädyer, aber an beftimmte \$erioben gebunben

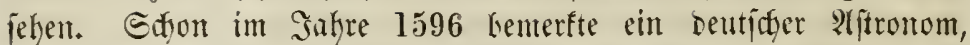

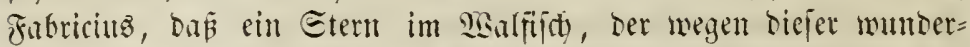

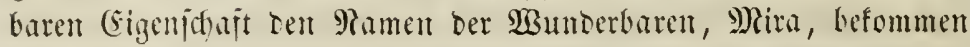

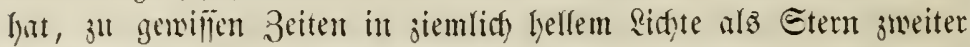

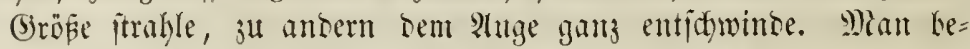
fitmmte anfange bieje Dauter ber Eidtwanthung auf $33+$ Tage. Aber Mini binset fith menig an bieje vorgejdriebene Zeit. Biz= weilen verharrt fie nut Tage lang in ifrer bejteionten Duntelheit, um id)nelf wicoer zu ifrem solfen bihnze aujuflammen, bismeilen

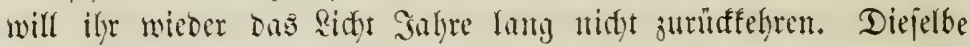
(Erjageimung jeigt auth ein Etern ime Edjman, ber ziemlidy regel=

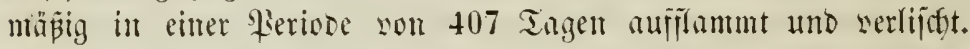
lunter ber gropert 3ahl anderer diejen \&idftwedjel jeigentoen Eterste

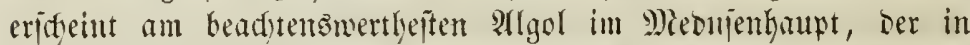

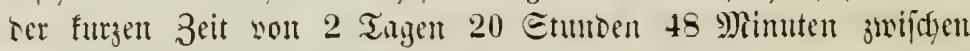

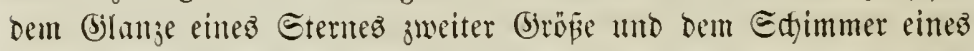
vierter (brö̈pe wedjelt. Sn naher Bermantijgaft mit biejent Ridjt=

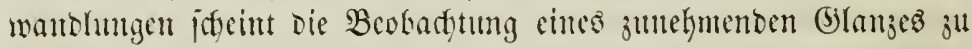

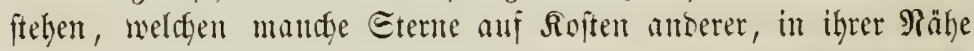

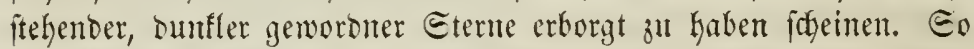

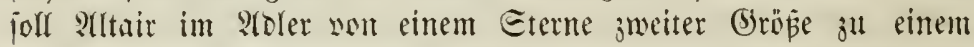

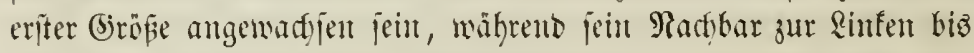

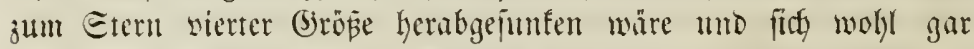
won jentem intfernt hätte. Afelynlidy hat man won ben 3millingen

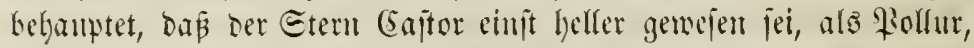
mälyento er gegenmärtig yon siejem weit an Gilanls übertroffen wiro. Den jelfjamjten Peidftyum an Beränterungen, bie bişer nody nidft eimmal bie geringite periobijdye Fiegelmäpigfeit entbeden

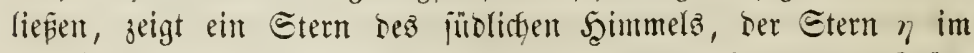

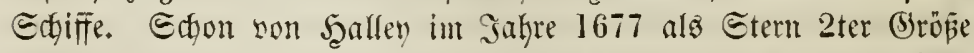
beobadftet, war er im Jafre 1811 bis jur 4ten Grö̈pe herabgejun=

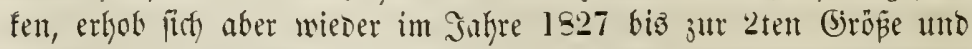
behauptete diejen (5)hanj 10 Jahre lantg. Stautren aber ergriff dent betannten 2(jtronomen Sohn Seerictel, ats er am 16. Dec. 1837

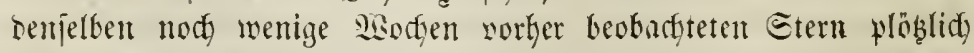

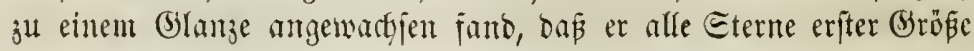


auper Canopuz und Siriuz üteritrahlte. Paad wentigen 2 Bodfent war biefer (S)lanz wieber serid)wmben; ater im 2tpril 1843 flammte

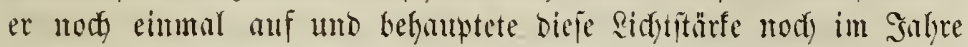

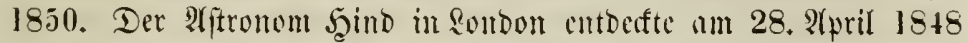
cinen netten rötblidgen Etern fümfter Größ̄pe im Edylangentrïger, ber aber bereitz im Gallye 1850 wieder verichmund.

Mehr alz 40 joldyer werintocrlidgen Eterne lat man bereitz aufgefunden, unb boi mehr als $2+$ mit ziemliffer Genntigfeit bie

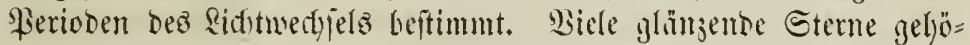
ren Darunter, wie ber praditwolle Etern an ber redten Edrulter

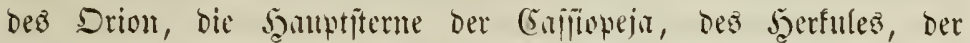

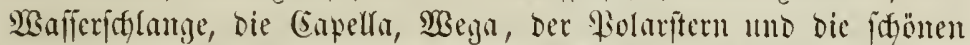

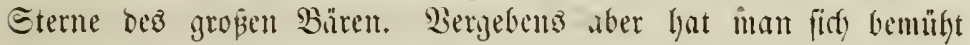
aud mur ammäfernoe Erflinumgen für biefe mannigfaltigen und wumberbaren Ridterideimungen ber Sternmelt ju finten. Man hat

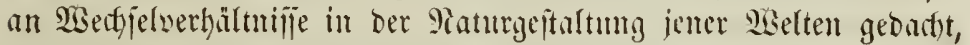

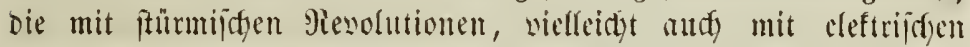

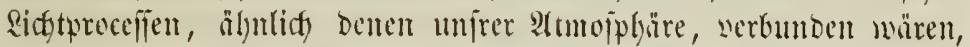

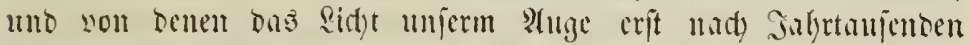

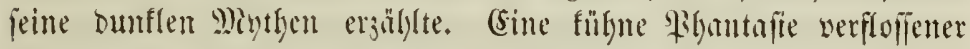

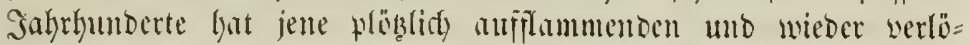
ityenton Eternc ju Fenerabunniten in böberem Einut gemndft, in weldgen $\mathfrak{W e l t e n}$ fid berjefren, und bie, wem daz altgeworbene Plïberwert ber Eomen einft auß Den Fugen geht, im 3ufammen= fturs bieje ergreifon und mijlojen whroen, um fie einer nemen (be= fraltung entgegenzufülyeu. Diejer furdytharen Didgtung wiocripridt

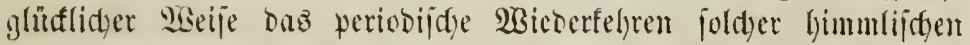

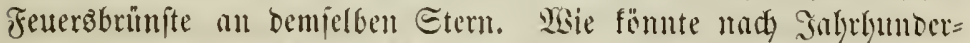

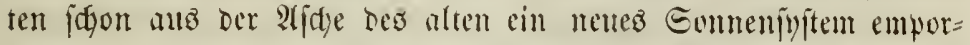
feiment, um in eben fo furzer 3eit witoer in Flammen ju enden? Seridgel glumbte baher bie llrjadge jenes periodifden Ridgtwedjels eher in einer 2 (rentorehung ber Eterne zu finden, woburd) uns bald hellere, fald Dumflere Eeiten Der Eteme zugefelyet müroen, wie ja auty bie Eonne bei ifrer 2.jthigigen Jiotation uns yon ber einen Geite ein helleres Sidyt jแzแjenten fdyeint, alz yon ber moern. Aber hiergegen iprifft mieber eimmal bie Unregelmäßigfeit ber \&idgt=

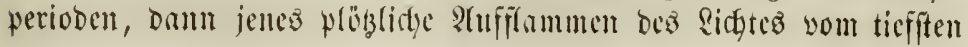




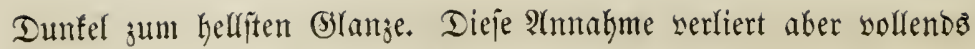

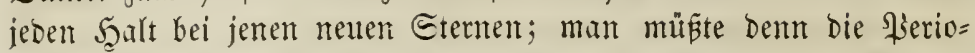

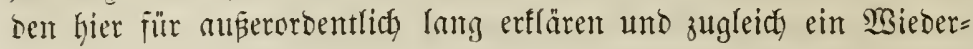
eridjeinen ber veriftwumbenen Eterme naffweijen, wie es in ber That bei bem. Sterne Tydjo's getungen jut jein focheint, ber wohl mit ben in ben Jafiren 945 und 1260 an berjelben Etelle bes Saimmels plöblid auflobernten Sternen übereirifitimmen töntute.

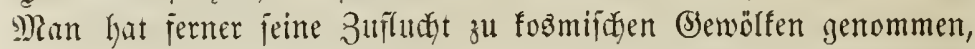

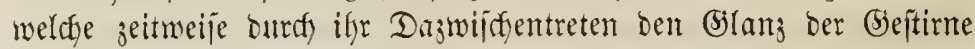

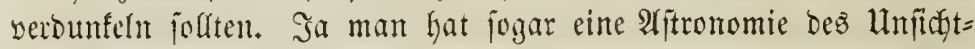
Garen keranfbefdyworen und buntle Sommen erfunben, welche son ben Yeudtenten umfreijt werben follent. Tiods hat bie Foridung nidfţ crwicjen, nod) gehören alle bieje (Ẽtlärungen, wie Şumbolot fagt, einem mutfiiden Gebiete ber artronomie an. Ridet mit ma=

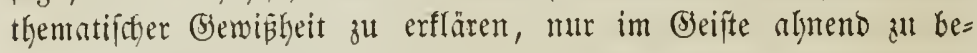
greifent iit Gier erlaubt.

SSir erfannten bas Ridft als jenco Eefnen der Patur mach Freikeit, mady Errlöjung von ben beengendent Bantent ifres mate=

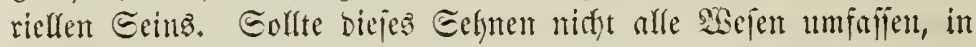
inniger Semeinidfaft emporziefent zun gemcinjamen Biele? Eoll

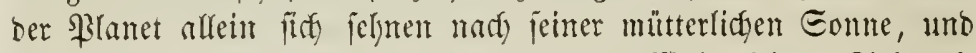

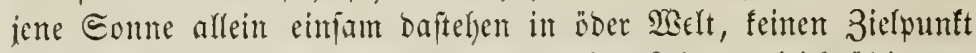

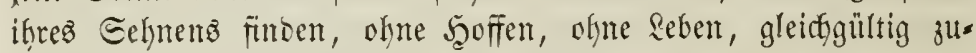

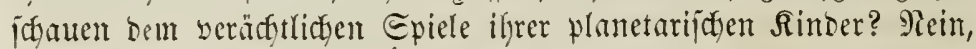
gewi

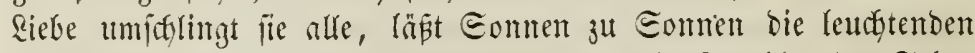
Boten ifter Şoffmung jenden, und alle bieje Etraffen ber Eefyn=

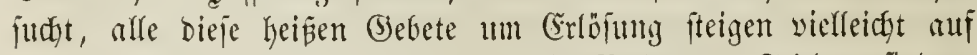
zu einem einzigen Afltare, wo fire alfe siufye unto frieben finden.

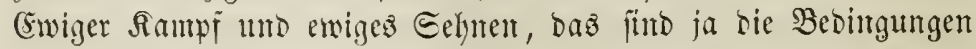

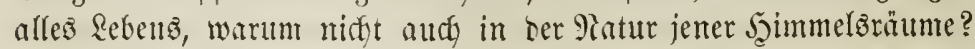
Mrag mun aud bei ben meijten jener fernen Welten ber Samuf

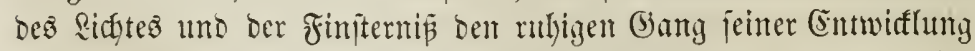
gefen, wie wir cỏ in unjerm Eonnenjyiteme fehen; fomn nidft audf $\mathfrak{B e l t e n}$ geben, bie, in iffrer Entwifflung begriffen, nod nidyt zu foldfer Piuthe gelangt fint, in benen jenes Eefnen ftürmi= icher mogt, unt bie Ectale des Eieges find bald anf bie Eeite ber 
Materie, bald auf bie des sidftes neigt, bie balo in jener, balo in

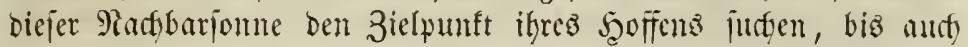

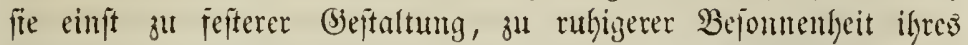
Etrebenz gelangt fein uno burch emize Banthe fich mit ben ver=

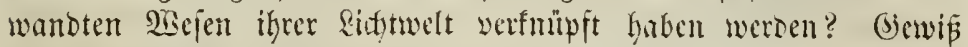
nidyt feindlidjer $\mathfrak{S e a j}$, Deflien flammen siselten verjethen, jontoent

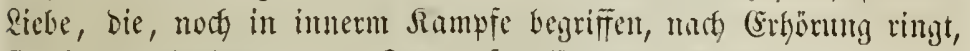

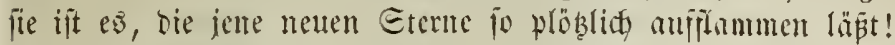

Reute 2 Bunber werben unz aufgelgen, went wir mit ber raum= Durdjoringenden Edyäre unjerer ferntöbe über sie (orenjen unjeres

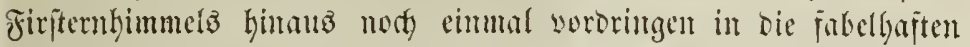
Rebelregionen jener zmeiten Madj. Deme and Dort erblifen wir

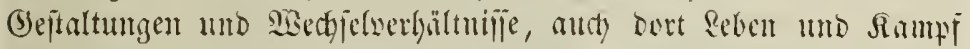

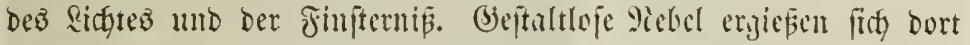

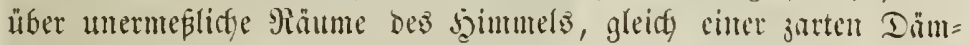

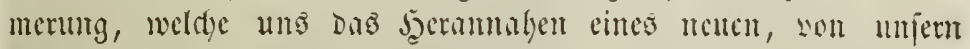
Eimmen norb nie cmpjimbenten Tages vertünot, gleidy jenten 230 fengebilton, weldfe unz in fernen Miceren rie siliten frember,

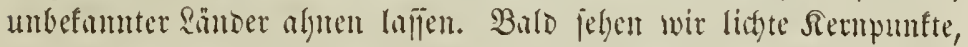

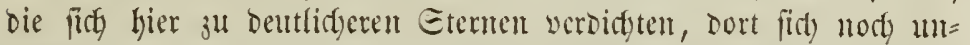
mertlich in Den umyebendent Ridftäther verlieren. Bald jehen wir um eine bunfle Mritte fidy einen nelelortigen Eternenring mit nady auben zunefymendem Stanze verbreiten. Sjier gewaljeen wir breite,

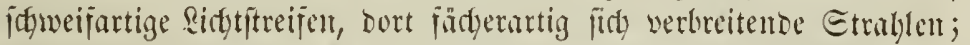
bier gleidyen fie bem Eaturn mit jeinem ßinge, Dort geídyweiften

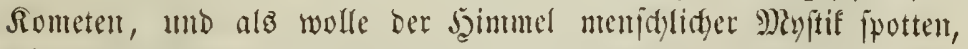

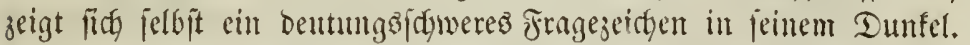

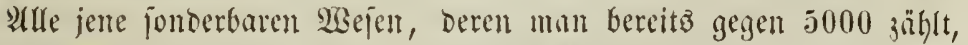
fofinmern in einer bunten farbenprad)t, wie unjer s(uge fie nur

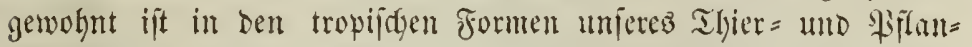

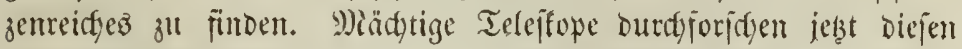

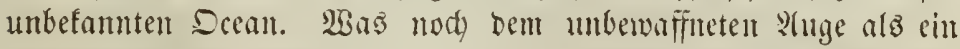

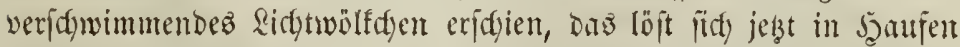
zafllojer einzelner Eterne auf, äljulich jenen prä̈gtigen Eterngrup=

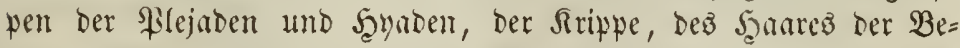

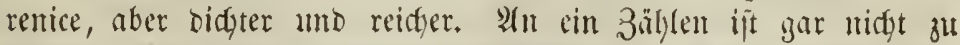
benten. Huf einem freisjürmigen Piaume won 8 Minuten Durdh= 


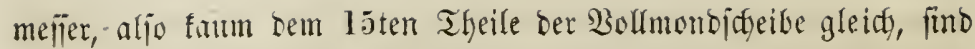
ojt megre als 5000 glänjender Eterne, melje aljo, als wir mit blo=

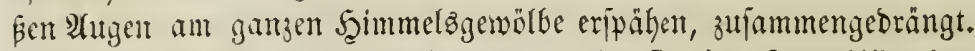
Eoldye pradyrgolfe Eternfaujen, wie wir fie in Etennbilde bez Syerfules (roig. 1) unto im Eternbilded. Bintilermanns (Fig. 2) Felyct, jutro zaljulcos „üfer ben ganjen bुimmel yerbreitet, sit einem şaự (boldjano gleidy, bişmeilen in Ser Mitte yon einem

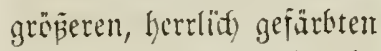
Eterne, wie tem æut cinem Dinbem, geidjunurt.

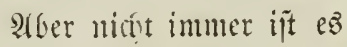
fo leidt, sen 3auteridfleier 3u zerreipen, Dent verifgrwim= menoen giebil in Eterne aujülöjer. Da ridjtet ber ₹ıg. 1 .

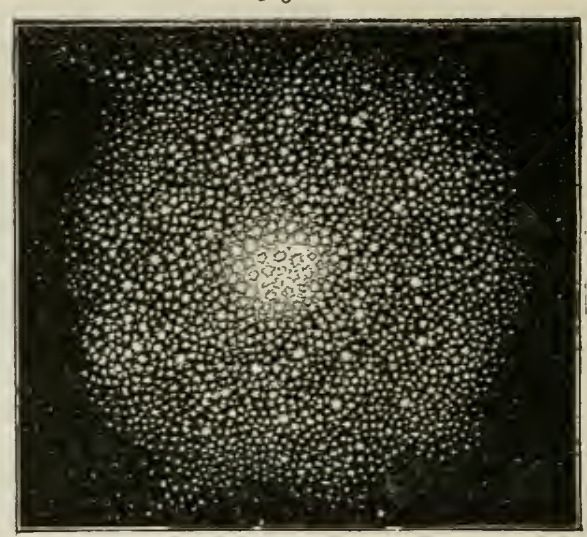

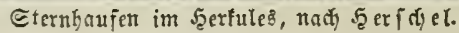

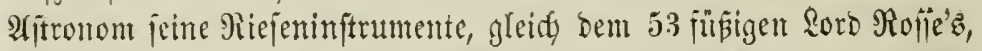

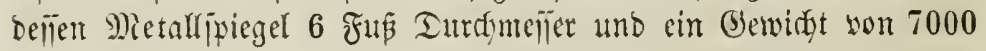

Si.j. 6.

Fig. 8.

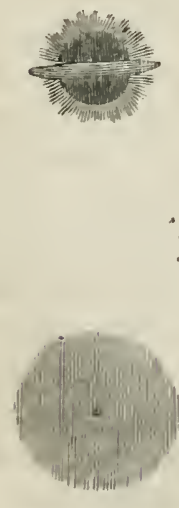

Fig. 7.

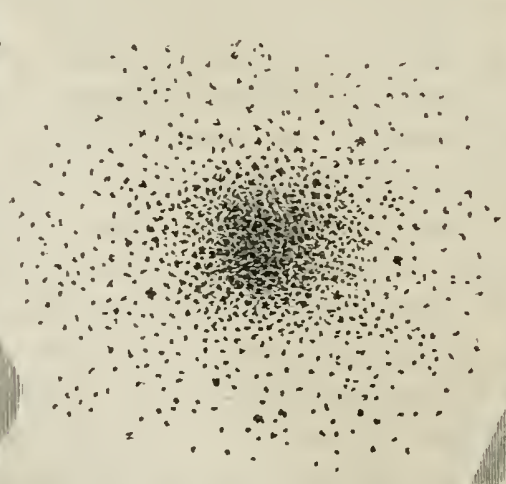

ซig. 2.

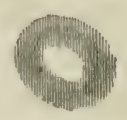

Fig. 3 o. 


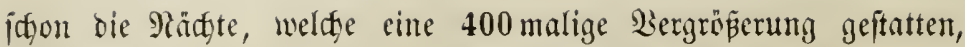
obgleidy eine boppelt umb breifady jo groß̧e zu Bebote fteffen mürbe.

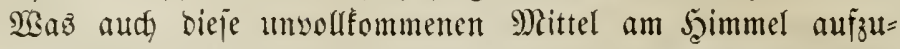
Deffen wermögen, ift immerljin munterkar gentug. Jener langgezo=

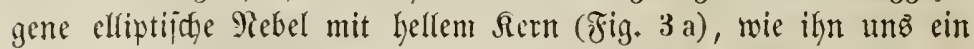
gutes Fernrohr im Eternbilde dez gropen sömen jeigt, nimmt im

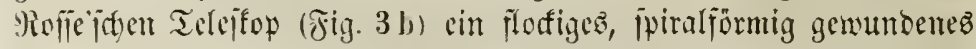
anjelyen an. Die beiben fternartig glänjenten, einander faft be= rillyrenden fleinen Rebel in ben 3willingen

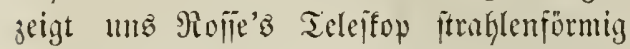
aแs̆laufent und gleictjam non einter zueiten Rebelgülle umflofien (જị. 4). Tem ähnli= chen Doppelnetel in groß̧en Sinwent nimmt

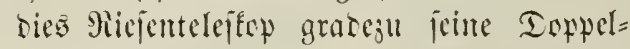
rorm, inbem eả ben cinen Rern in eine gebringte Eterngruppe auflojt, und in jei= nen ipiralförmigen SLintungen ten andern idjwidteren Rern fajt ganj veriftwimmen

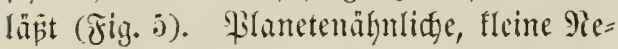
bel you freişrumber, fidarf begrenzter Ecthei= Doppelnebel in ten 3willingen, benform, wie wir beren eimen in Mafier=

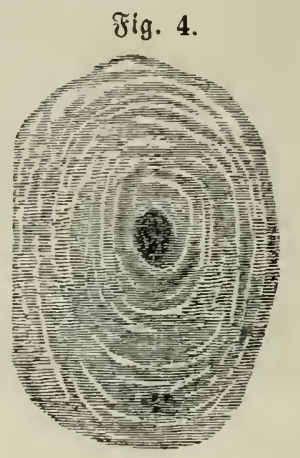
mann mit bläulidfem Sidfte jofimmern fefyen, werlieren im Roffe? =

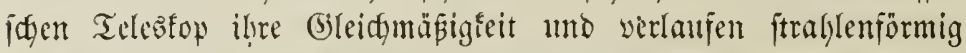

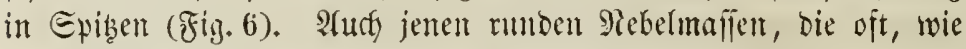
im Eternbilde Dez Etierz (Fig. T), hellglänzende Firifterne umgeben ober ganje Eternbilder umfliefen ober nur ourd, lange, fotmale

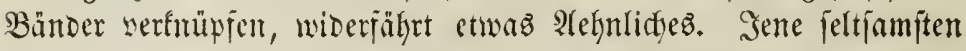

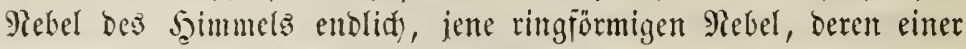

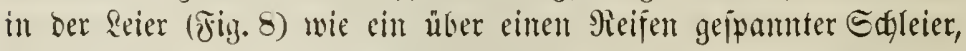

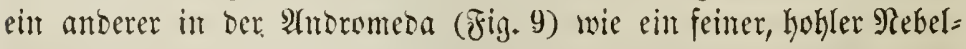
ftreif eridgeint, wälyrent cin britter in Den Singofunden (Fig. 10a) jogar einen rumben, lidften $\mathfrak{R e r n}$, son eintem concentrifden, sum Theil Doppelten Nebelringe umgeben, zeigt, audi bieje Wrumber, in

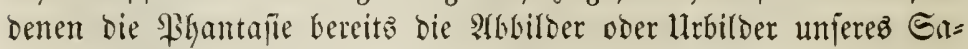

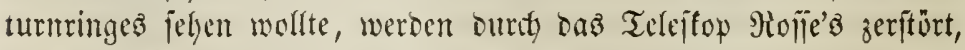
Das jente in ungemein fleine Eterne zerlegt, biejen (Fig. $10 \mathrm{~b})$ alş

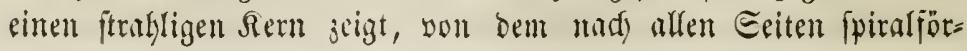


Fig. 10 a.

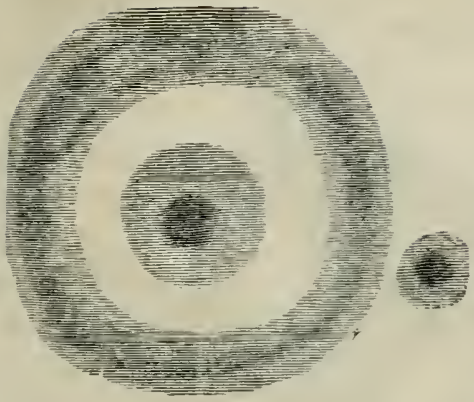

mige, von fleisten Eternen erfüllte geinoungen atsigelyen.

Fue Sradty uno Eeltjamfeịt biejer Bilser ift aber nidts gegen bie Serrlichfeit bes gropen Drion= nebels, ber fidh fait in Wollmono= gröpe in ter glähe der glüujenten Eterne Des Safobjtabez anabrei= tet. 1 sab lith unt Eeltantes in (bejtaltung und eidsturedfel ben= fen läpt, ธaร entialtet fiç bier ซig. $10 \mathrm{~b}$.

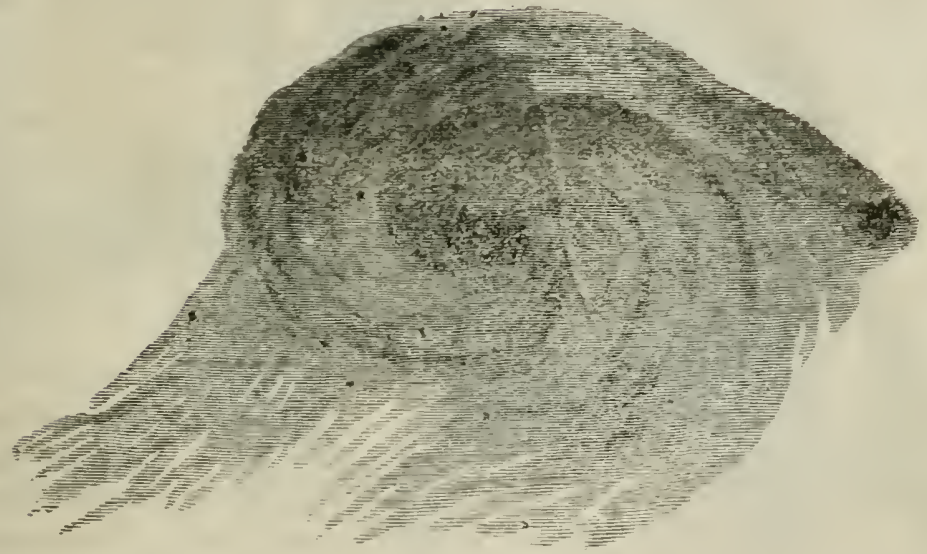

Singnebel in ten Jagthuncen, a. nad Sgexidgel, b. nad) Ro fie.

im Fernrobr. Die älteren afitronomen sergliden feine Beftalt bem

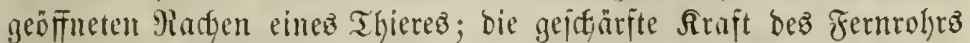

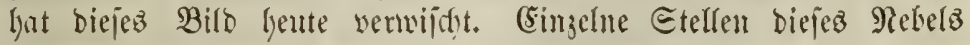
(ร̧ig. II) idjeinen in beweglidyen flammen zu lotern, anbre zeigen

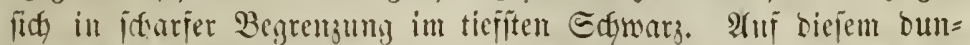
feln Grunbe bilben it ber Ditte bes Melelos 4 belle Eterne eit

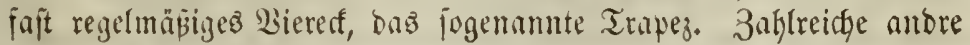

\footnotetext{
IIle, weltafl. 3. Ituศ.
} 


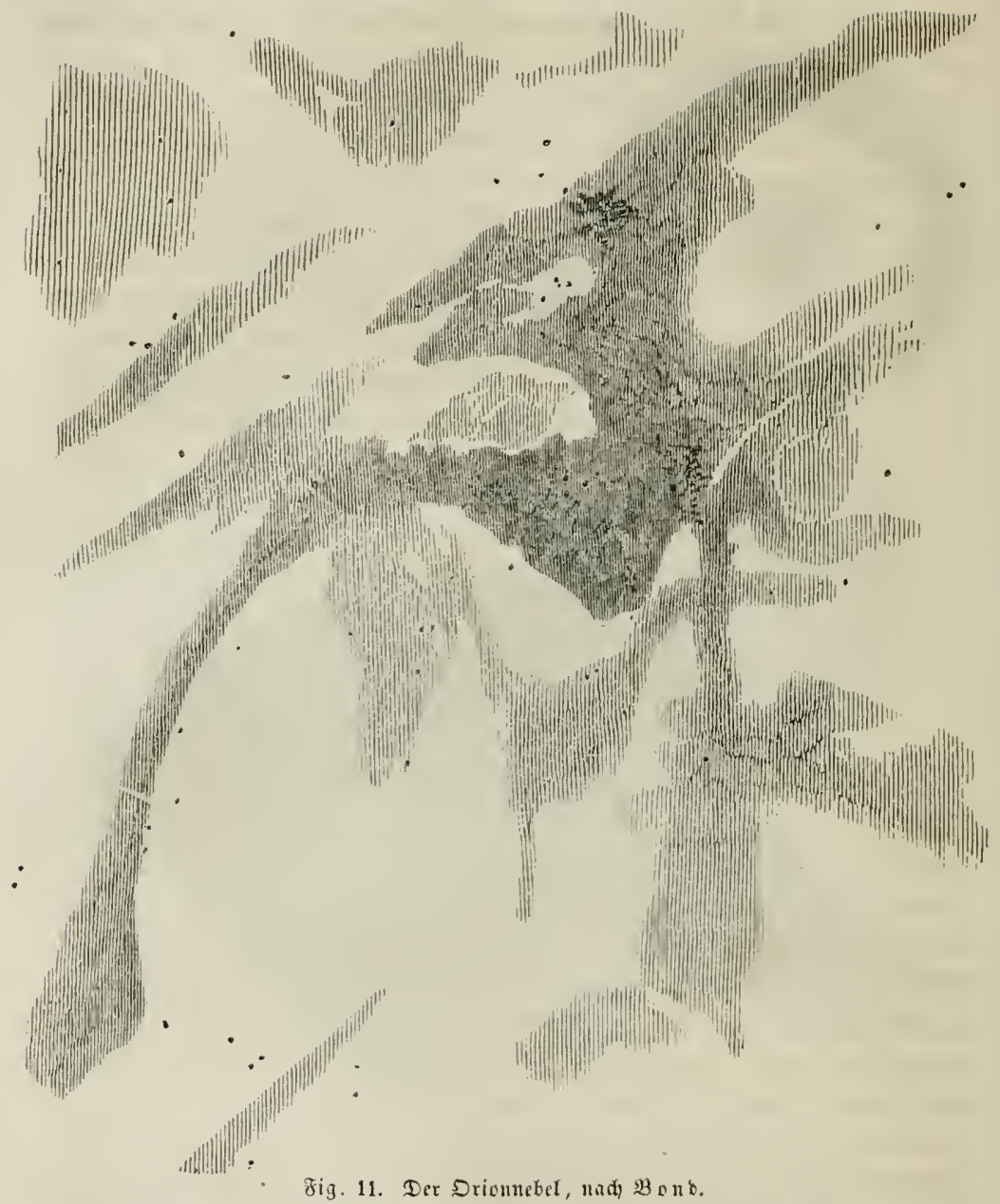

Eterne bliben burty den flodigen Rebel, ber ę umgibt, herbor, und rings um feine Etreifen und 3weige fdimmern in büfterm Ridfte viele Taujent fleiner Etemdyen. Dft glaubte man wunber= bare Borgänge in biejer Pebelwelt ju gewahren, und neue Sterne

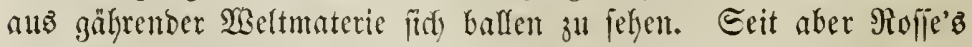
Teleifop biejen Mebel in Mrillionen won Etenten aufgelöt bat, mufte man auf bas $\mathfrak{W}$ mnerbare verzidyten uno es als cinen Beweis 
hinnehmen, wie imnig oft Das befehene burd bie Mittel bes $E_{e}=$

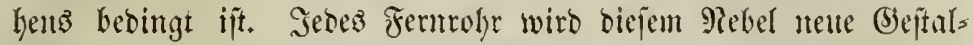
tung und neue Sterne geben.

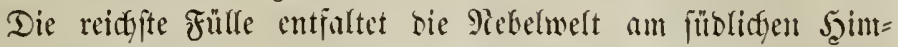

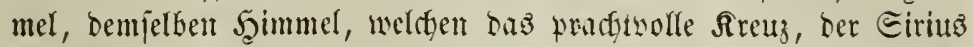

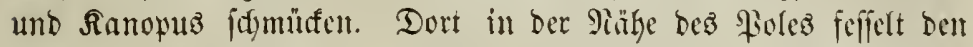

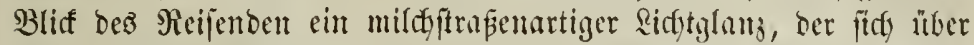
einen Raum von 42 Sundratgrnoen voer won 12 Solfmondbreiten im Durdfyejer ausbreitet. (Es if ber Gilanj einer muberbaren Bereinigung yon Sternen

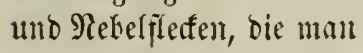
bie grope Magellantioge ober $\Re$ apmolfe nemut, uno

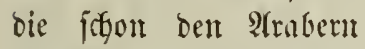
nath) iffer Bepitalt muter bem Ramen dez ,"weiken Ddjen" befaunt war (Fig. 12). J̧eridjel zählt in ihr alfein 582 grö $=$ Fere Eterne, 291 Metel= fleffe unto 46 Etern= haufers.

Trotz ber wutuberba= ren Bervolfommmung ber ajtronomiidgen Sinjtut= mente fint nods immer Taujende von Rebelfle= đen übrig, bie aud, für bie ftärffiten Fernröhre ungelöfter Ridefirdiummer bleibert. Es ift baher รig. 12.

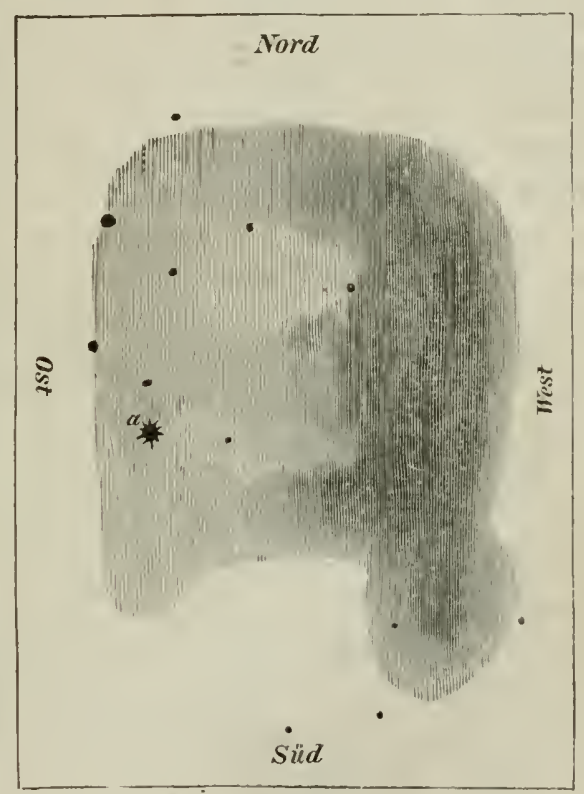

Die grop̉e Rapwolfe, mit blopiem Inge gejelyen.

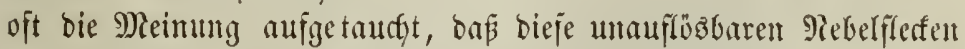
gar nidft ats Eternen, jonbern aus eituer fometenartig serbünnten,

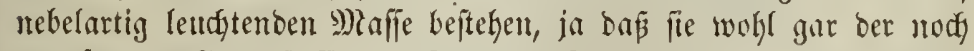
ungeformte Grunsitoff ber Someten felbjt feicn. Dagegen aber

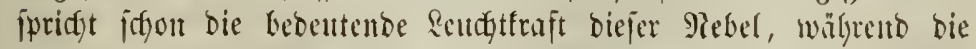

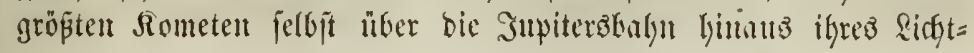


mangels megen midyt melyr serfolgt werben fönten. Dagegen ipriłht nod) megr bie ungeheure Entfermung berjelben, Die ifrer Unverän= Derlidfecit wegen mindeftens ber ber Firiternwelten gleidgejebt werden muß. Sirosartig, wie immer in jeinen Soeen, erblifte Şerfdyd in

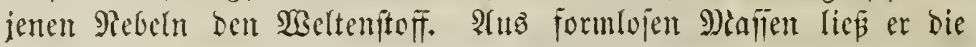

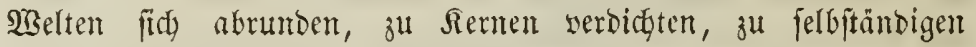
Eomen auflojen und entidy flaneten und Monbe auşidseiben. Şm war Das Univerinm eine Berfitantte von Meltenbiloungen,

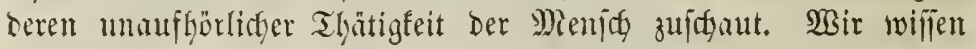

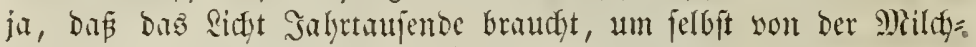

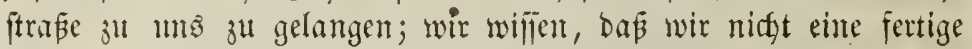
Begenmat, fonbern eine werdende $\mathfrak{B e r g a n g e n t g e i t}$ am Scimuel er=

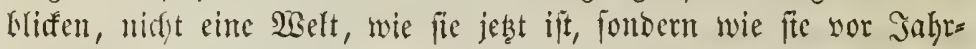
bumerten uno Jahrtaujenden war. Se tiejer bas Teleffop in ten Fiam wororingt, in cine bepto fernere Beit blifen wir. SBatum folfen wir aljo nidyt ein Werben nom formlojejten, dyaotifid wer=

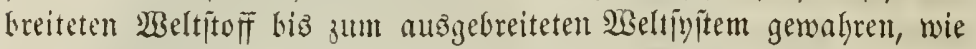
wir etwa in eimem ltrwalde Das organijase Reben in affen Etujen Feiner Entmiffung jeben, nom feimenden Samen und jugendidgen Eprïbling bis zum mädgtigen Baumriejen? Wir ftrüuben unş $D a=$ gegen nur, weil wir gewohnt fino, bie welt als eine fertige zu benfen, obwolyl ung bie Bülfergefdidgte ber Gigenmart feim ande=res Bil' bietet. SBir werben bennody biejen Sedanten nidyt zurüaf= weijen fontmen, wenn bie Forjanth uns bieje Rebel innerhalb un= jerer Finjternwelt nactweift. Bon vielen anfigetöjten Rebelflecten

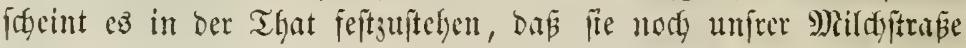
angelyören, viellcidbt ifyren äntererten llmfung bilden. Sie mögen Sternlyaufen fein, bie, burdy gegenfeitige Afnjefung zufammenge= Galten, vielfeidht um einen gemeinjamen Centralfern fidy fammel= ten. Anbre aber erfogeinen fo bidftgebrängt, nidgt Jeunderte, fondern

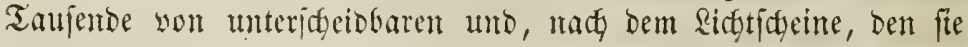

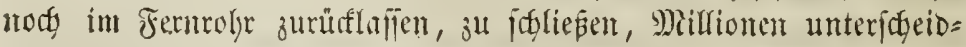
barer Eterme umfajfend, und babei von fo geringem Durdymefier,

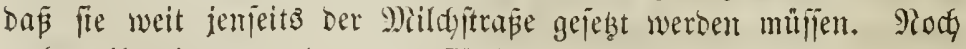
melyr gilt bies von ben unamflöbaren Pebeln, bie ilfre regullofe, oft abenteutrlide form nad) bon Bejeben bor Edywere unmöglich

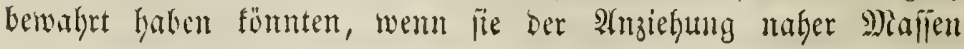




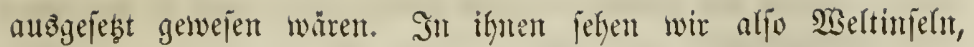
wie unje Firftermwelt, bie aus einem Punfte ifres Smmern viel= reidft Denfelben AnGliaf Darbieten wärben, wie uns ber Firftern=

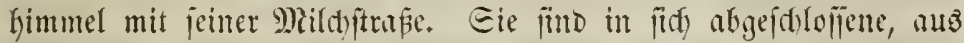
jelbjtändigen Eternen bejtehende Evjteme; denn mu folden ijt es geitattet, wie unjer Eonneniyjtem, ungeometrijate, felbit veründer= licke Formen anjunefymen. Die meiften funben fidt in ber Nähe

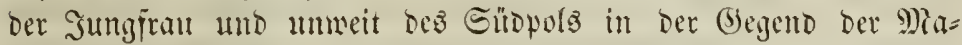

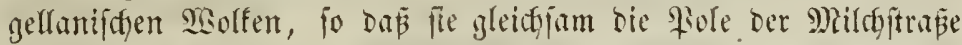

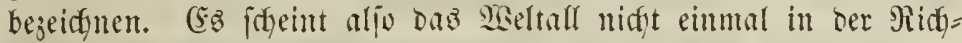

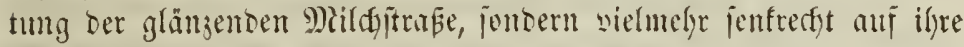

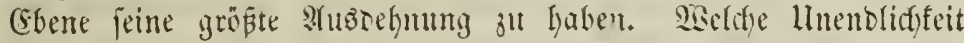

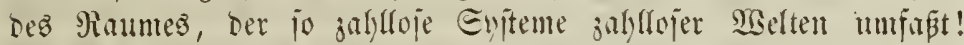

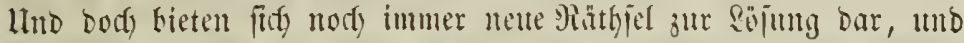

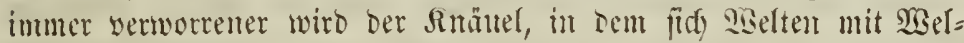
ten veridblingen.

In jener feltamen Mebelwelt Gatten wir Bejtalten entbedt, bie gleictjant alz Doppelmejen, als tratticy nerbundene Sejdyifter=

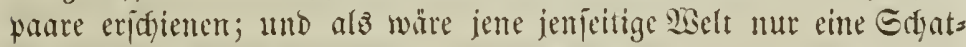
tentwelt, einte $2 B$ elt von Bildern, yon Eymbolen ber wirflidgen Fir= fternwelt, jo felen wir andf jente 3willingsbiloungen, nur in be= ftimmterer, flarerer Form wiederholt in Dem Mieidye oer Firfterme.

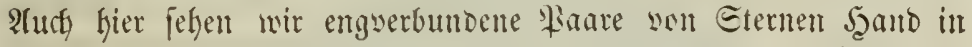

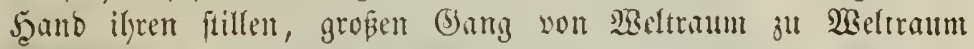
wandeln. Diefe nenen 2 Bumber find bie Doppeliterne. Prlo yor

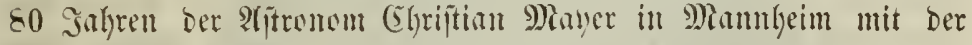
Behauptung aufrat, Firjtentrabanten beobadytet ju haben, ver=

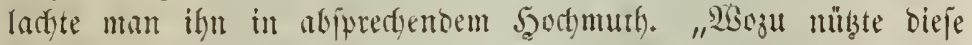

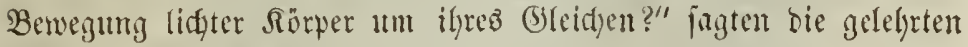

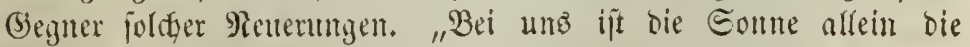
wirfende ltrjacte oer Bewegung unjeres und ber übrigen Flanteten

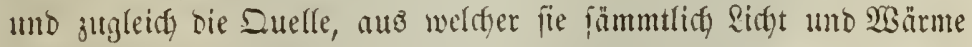
fhoupfen; bort würben es Eyfteme von lauter Eomnen jein, bie

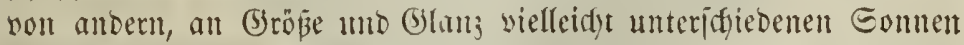

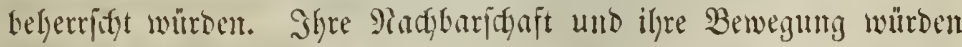
olme 3werf und ibre Etrahlen obne 9umben fein, weil fie nidft Röper mit Ridjt zu verjorgen braudten, Denen ez jelbit zu Theil 
warb. SBen bie Trabanten lidte Rörper find, was ift ber Zwed ifrer Bewegung?"

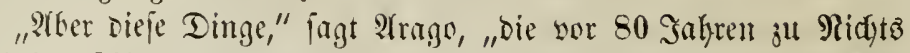
bienlich eridgienen, Dinge obne Zwerf und Puben, fino wirflidh

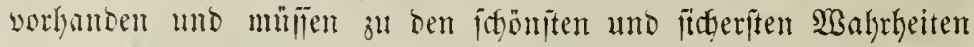
in oer affronomie gezählt merden." WBillam Şerfat ftellte nur

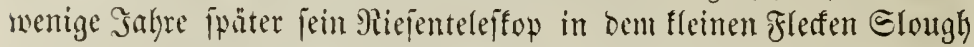
an mo erleudftete mit ber Faffel feines (s)eiftez bie nädytlidyen

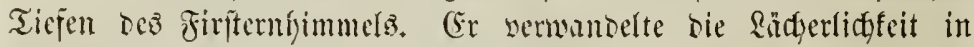
Wirflidfteit, er entoerfte die Doppeliterne.

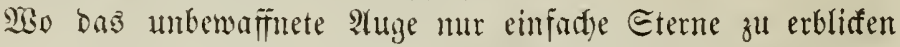
meint, on jeigt das Fermohr zwei und mefr oft an Silanz und

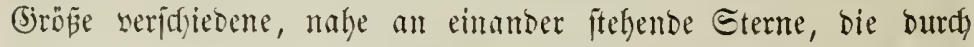

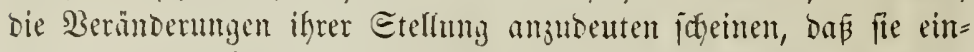
anter, wie bie \$ifnten ifre Eommen, umtreijen. Eš ijt allerbing nod nidgt nothwenbig, bus juci fo nalye, oft weniger als 8 , felten melyr alz 16 Eecundent won cinmoer entfernt erjaeinende Steme wirffidy nake neben eimanber ftelgen; fie foumen ja auds in faft gleidyer 9lidgtung linter einmoer uno wirflich weiter yon einander

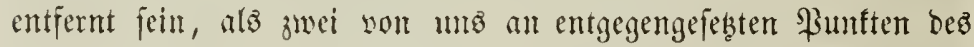

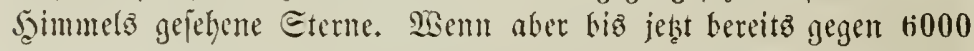

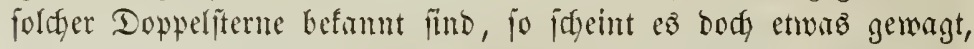

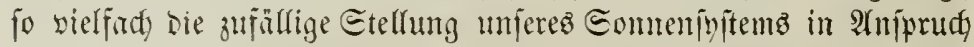
ju nelumen. Shit Redyt hat Errme Darauf aufmerfan gemadyt,

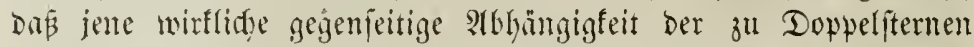
gepanten Eterne jüt cin jourfes : bliff cinez Berzeidnnifles oer Doppeliteme herworgehen müpte. Sine

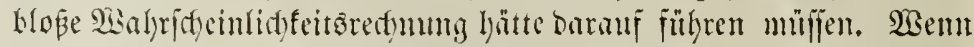
naan nämlid eine Samb voll (Setreibeföner über ein Gdadbrett

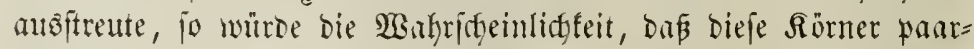
weije in ben einzelnen Felbern beş Brettes liegen meroen, offenbar

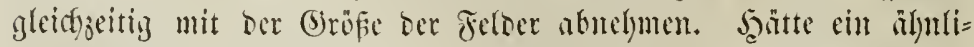

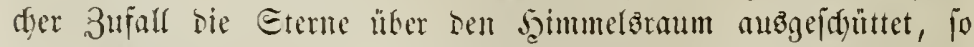

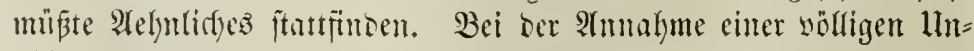
abhängigfeit zwijchen alfen über ben Şimmel verbreiteten Sternen whrbe afjo matürlich bic 3afyl Der gefanten Eterme um fo geringer

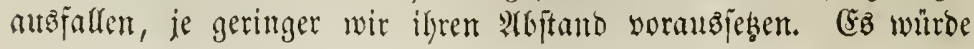


aller $\mathfrak{B a h r i d g e i n t i d j e i t ~ n a d y ~ w e n i g e r ~ E t e r n e ~ g e b e n , ~ b i e ~ u m ~} 4$ Ee=

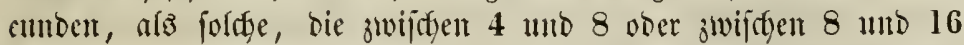
Eecuntoen oder gar bariber entipent fint. Run funden fich aber in

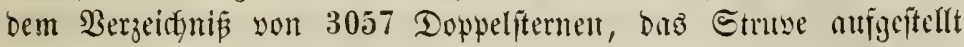
hat, 987 Eternpane mit cinem slbftunde non weniger als 4 Eec.,

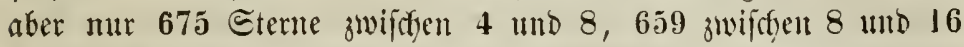

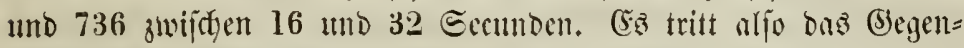

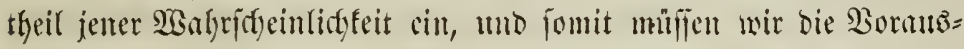

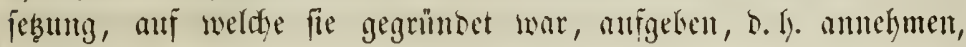

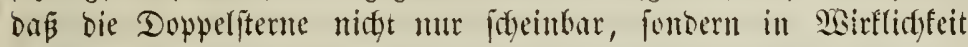
einander nake ftehen und mit einander verbundene Eyfteme bilden.

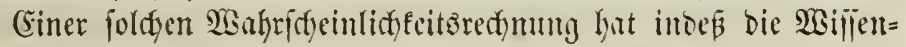

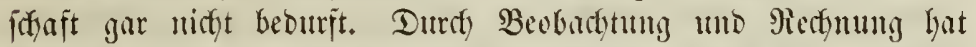
fie bas Dafein um cinnuber freifenter Eterne n̈ber alfen 3meifel

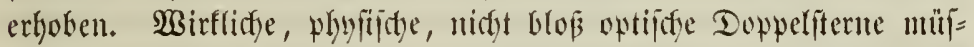

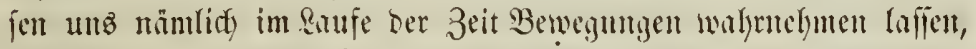

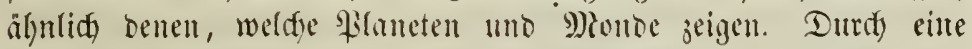

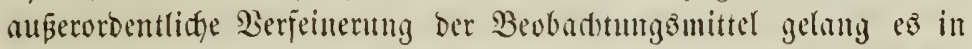

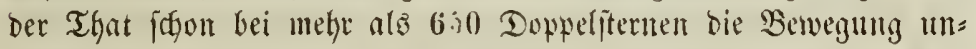
zweifellyaft nadzumeifen, bei 58 fogar bie Balnnen mit größserer ober geringerer Sidgerbeit nady bem Miemton'figen (Bejebe zu beredyen.

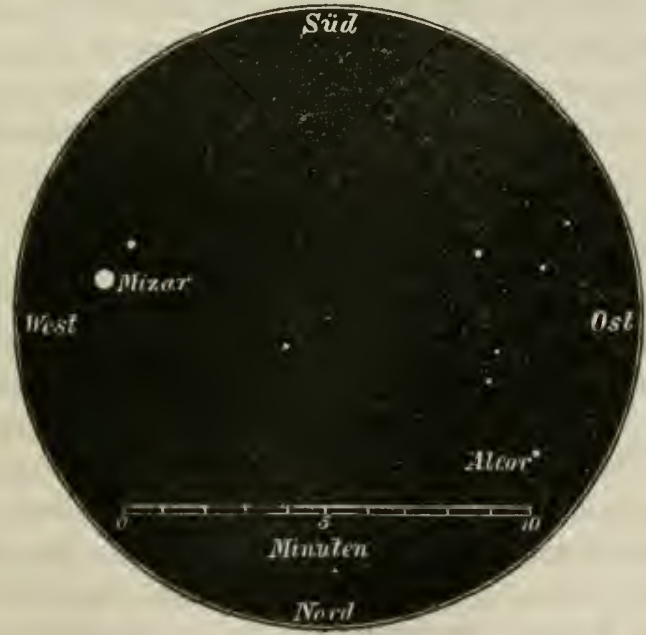

Der Doppelftern Drizan im grō̄en Bären. 


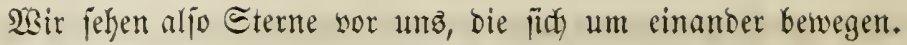
Beibe fint Eommen, beibe jelbjtleuctento, feiner bunfel uno falt; beibe bewegen fint in Gillipjen um einen gemeinjamen Edjwerpunft;

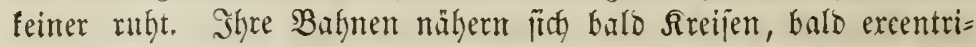
iffen Rometenbahnen. Eie werben balo in mentigen, bald erft in Taujenten von Sathen Durdflaufer. Bei bem Doppelftern $\zeta$ Herculis betrïgt bie Ulmlaujşzeit 31 Sahre, bei $\gamma$ in ber firone 43, bei $\xi$ Des gropen Bären und $\zeta$ im Rrebje 58 Sahre. Behaupten fich bieje UmIaufäzeiten noch innerbalb ber 3afjen, welde ben llmläujen umirer \$ranteten Supiter und Eaturn um bie Eonme

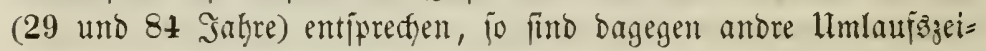
ten mit ziemlidfer Eidferbeit bejtimmt worben, bie, wie beim Dop= peliftern (Eajtor 253, bei $\sigma$ in ber Rrone 287, beim 61 Eterne im Edyman 452 Jahre errcidyen. Bei nody andern founte jogar in

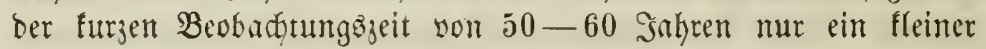

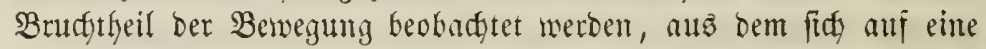

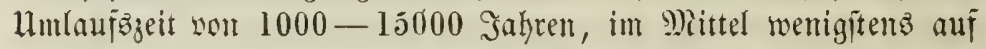

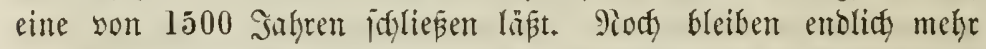
alz 2000 Doppelifterne hibrig, bie bei aller Edyärfe ber Beobadtumg nod, gar feime Benregung verriethen, und bie man bodh für wirk=

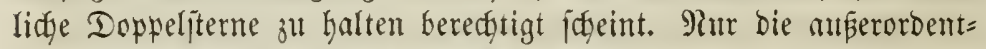

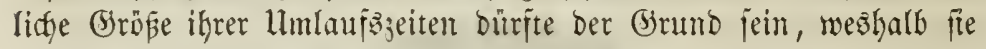
in einem halben Gahthuntert nod, nidgt einen erfennbaren $\mathfrak{B}$ nudd)=

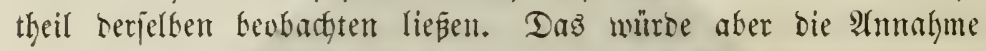
yon mefre als 15000 Sagren für bie Dauer ifrer Bahnbewegung eriorbern.

Girabe bieje Doppelfiterne find es, bei benen fits bie räthjel=

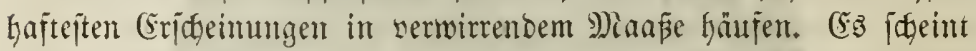

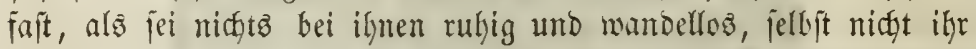

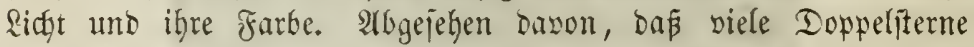

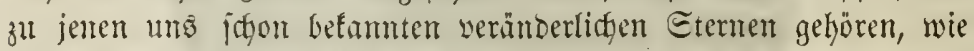

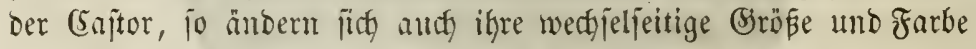
bejtändig. Burlo leudftet oer eine mit grünem, ber allore mit ro= them Ridgte, bald erjogeint ber eine im glänjenteften (belb, Der anbre im ichönten Blau. Wăhrento nody vor wenigen Sahren ber eine

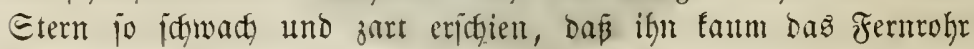

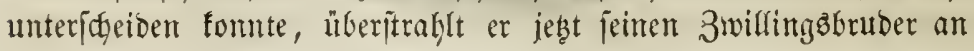


SIang. Frnilger beutlidy getrennte find fajt zu einem Stern jujam= mengeflofien. Bisher einjacte hatben fid in Doppelwejent jertheilt. Dort haben fith jogar 3,4,6, ja noth viel mely foldjer Eomen ju einem Eyjteme vereint, und umfreifon, einem gemeimjamen 3uge folgend, einen Mittelpunft. In joldfen Bieliternen hat man Daber oft einen llebergang zu jenten jofon erwïhnten Єternhaten erbliffen

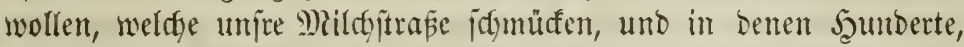

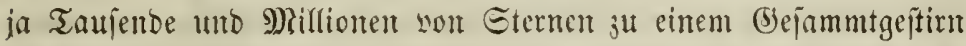
verfoflungen fint. Miertwüroig gentug wire es bam, sap bieje zaflreicteren 3ufammentäufungen mur in ben von unt entlegeneren Regionen bes $\mathfrak{B}$ eltalls erjotenen, während in ben matybarlidgeren Gebieten unjeres @ternllimmels mur jolche Grutpirungen won we=

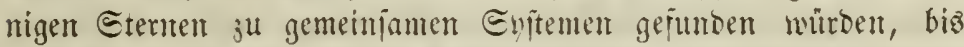

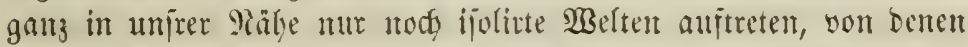

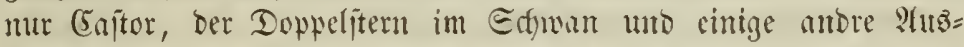
mahmen madyen. Lleber 6000 foldher Inpweliterne hat mat idgon beobactet, ungeredynet jene lodén Etengruppen bes Eiebongejtimb uno ber Srippe uno jente inniger veridmolgenen Etenthanfen ber

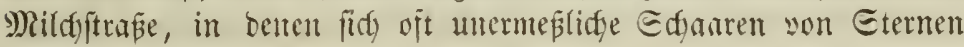
zujammengefellen.

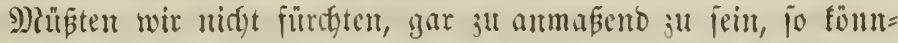
ten wir wieder verjuctyt jein zut glauben, wir ftủnoen in 9littel=

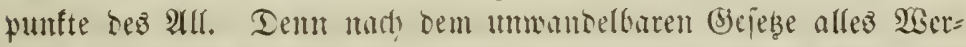

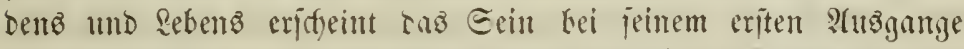

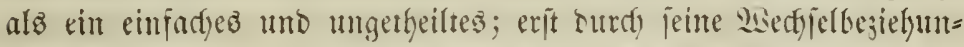
gen auf bie vielen (S) noflen ber Edjöplumy wiro es jelbjt ein man= migfindges, vielgetheiltez und gegliedertez. Co verjweigt fict) ber

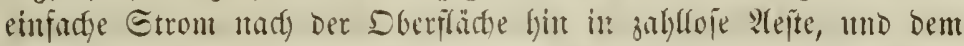
einfachen Etamm entjproficn Inujende von Zweigen. So fömte

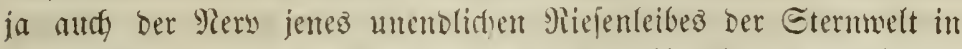
jeiner Mitte einfach, nad) feinen Grenzen hiu inmer vielfadjer, mamigjacter fid) gefralten umb verïtelut.

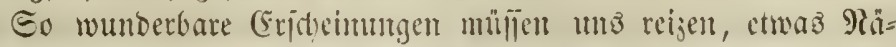

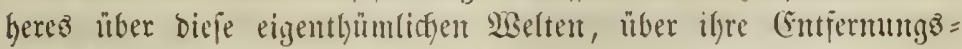

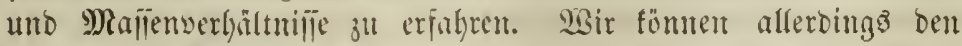
ideinbaren 2(bjtand zweier geparten Eteme am 5gimmel nad)

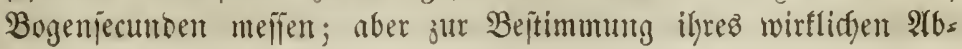


ftandes wird bie Renntni位 ihrer Entfernung von unz erforbert.

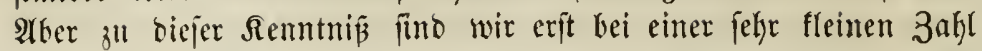
von Eternen andy nur mit aumähernoer Bemifbeit igelangt, uno unter biejen menigen Eternen befinsen fint leiber mur 2 Doppel= fterne, Der Szauptftern des Centauren und ber $61 \mathrm{im}$ Edywan, von benen leb̧terer fogar nod) alz Dappelítern bezmeifelt wirb. Für jenen haben wir, wie man fich crimnern wirb, eine Entfernung won $31 / 2$ Sidgtjafyen ober 228000 Şalbmeffern ber Erobahn, für biefen eine Entfermung von $91 / 4$ Ridftialjen ober 594000 (Erboveiten ge= funden. Da mu ber gegenjeitige Prbftund der in biefer Eternen

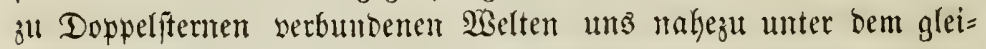

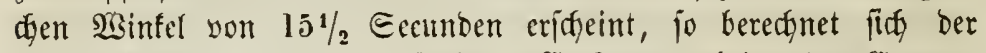

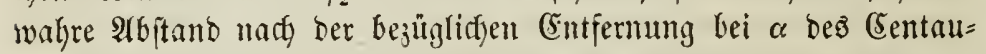
ren alf 17 Erowweiten ober 352 Mifll. Meilen, bei 61 in Sdywan auf 41 (sroweiten ober 848 Mill. Meilen.

Sogar über bie Malien Der Doppelifterne if́t es uns vergönnt,

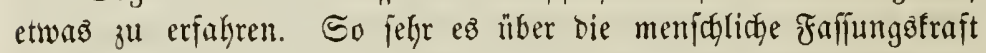

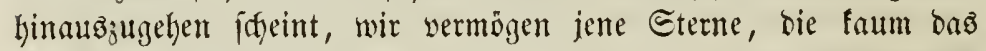

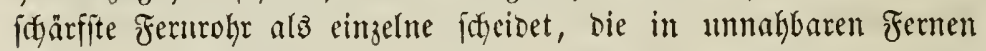

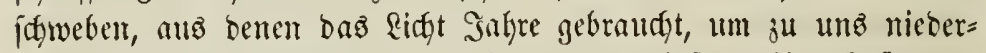
ưtrömen, wir vermögen jene Stene, wenigitens ihre Bejammt=

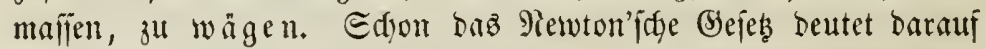

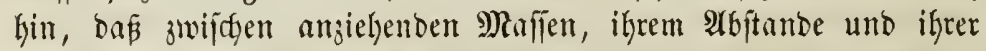

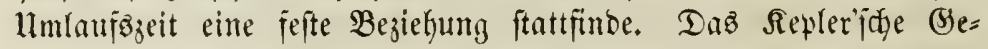

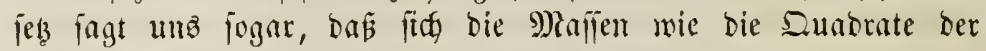

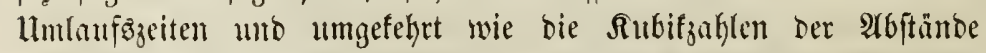
berlyalten. WBir bürfen uns aljo wolyl für beredftigt halten, baz,

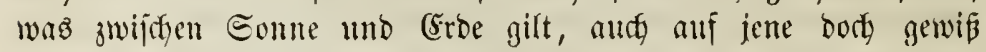
gleicfem giaturgejege unterworfonen Doppefiwelten anjumenten.

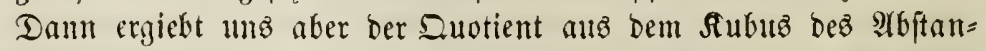

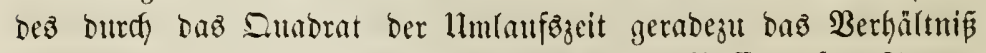

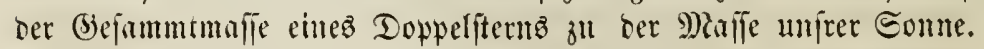
Sene Doppelifterne gelyören num freilitef ju benjenigen, bie nodh feine fidfere Bahnberecfymung geitatteten; jebody läpt fich mit ziemlicher

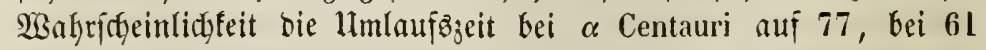
im Edywan auf 452 Sahre annefymen. Danad beredfunen fith ifgre Bejamntmaffen beim $\alpha$ Centauri auj 0,82 , bei 61 Cygni auf 0,33 


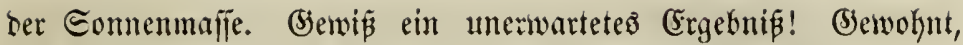
mit ungehpeuren 3ahlen um uno zu merfen, glaubten wir in jener

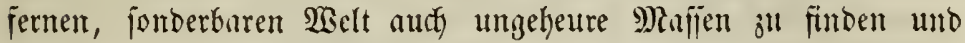
fehen fie mun nod) nidgt einmal ber unfrer Somme gleidsfomutent. Mag ez aud majjentyaftere $\mathfrak{B}$ elten unter jenen Doppeliternen geben, mag aud bie Miehrzahl unje Sonne meit titherterffen, Der Eajtor vieffeidyt um das Doppelte, Der Doppelftern w beš Rönent minde=

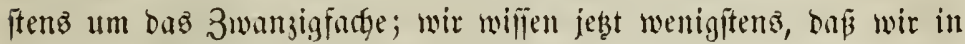
feine ganj frembe siseft geruthen fint, und das bas Befremtende

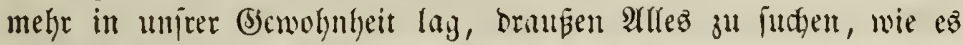
bei unz ift, unb bie Dronungen fut madfen, wie wir fie gern haben mörgten uno braudyen fönnem.

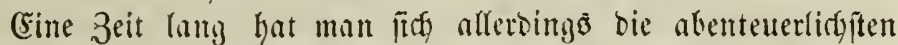
Borfteflungen von ben Maturverhältuifïen jenter jernen $28 \mathrm{elt}$ gemadjt.

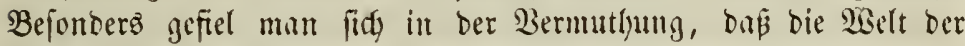
Doppel = und Bielfiteme in einer näberen Bermantiffyaft ju bem

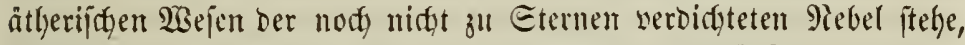

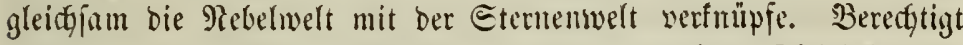
glaubte man fid Daju befouberz Durd) Die geringe Didstigfeit ber

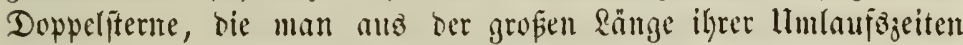

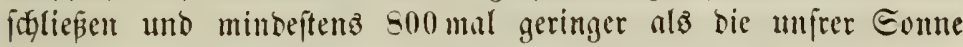
anneלmen зu müifien glaubte.

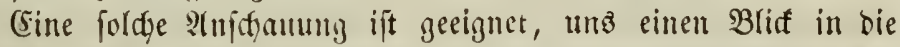

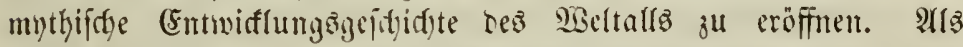

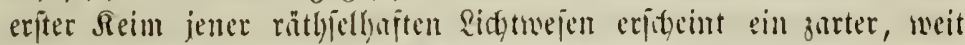

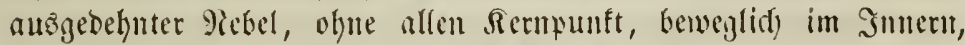

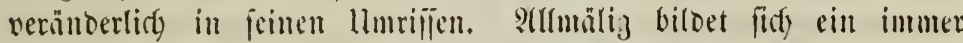

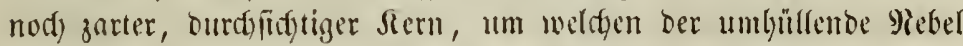
gleidjpam zu treijen jideint. Bald nerboppelt fids woljl gar biejer Rern, und wie im 3willingzei bic benad)barten Dotter, amfangz

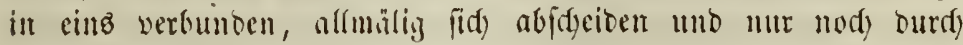
einten immer fifmäler wersenden, immer melye fid bufpizenten Etreifen in Berbindunty Weitem, fo idjeinen anfings and bie

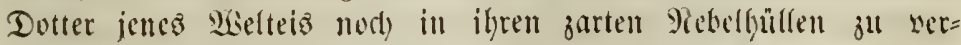
fojwimmen, bis fie immer feifer fird geitalten, uno foum ein jojim= mernber Ridytiftreif ilye gemeinjane Şerfunft anbeutct. Dft wieber=

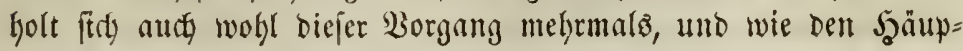


tern ber Rernaiifden Syyber entwadjen jebem Rernpunft neue Serne,

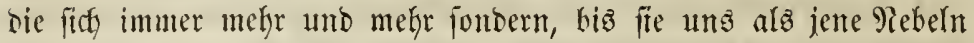

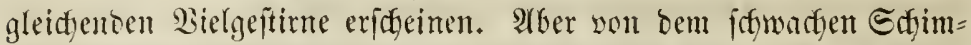
mer des ätherifaten Rebelz biz zum funtelnden BjIans bez Sternes

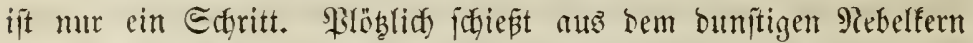

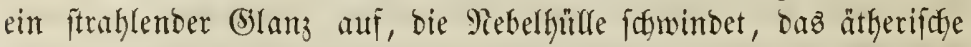
Bant, Das fie bişer nod, verfmüpfte, zerreift, umb die nebetlojen Doppel = mo Bielferne fint geborent. Biefleidyt lojen autd fie einft bie geiffywifterlicten Banbe, bie fie an einanber fetten, bann viel=

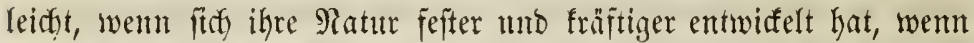

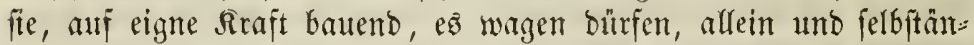
big Trob ju bieten ben rings aut fie einoringenden Sräften benad $=$

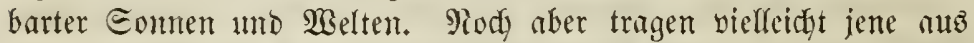

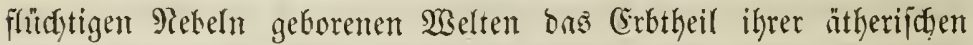

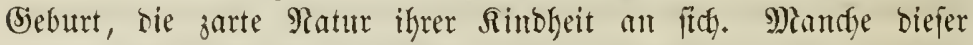

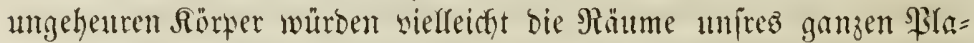
neteniyftems exfülfert. Bäten fie alfo bidjte $\mathfrak{R}$ örper, went audf mur von ber Beidsaffentyeit utmfrer Some oder bez Eaturn, fo würben

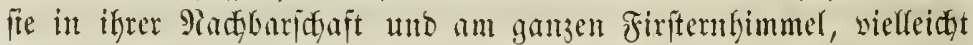

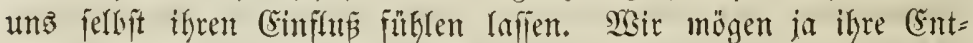
fermung amehnen, wie wir wollen: feben mir fie größer, fo wachjen

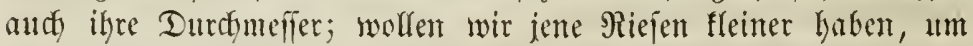

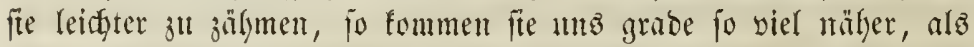

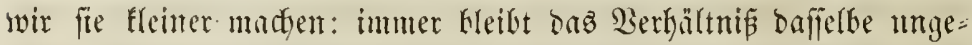

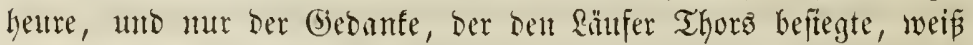
aud) biejen Sdfrectfildern entgegenjutteten uno jente Miejen in ftumme Echatten zu vermanbeln, bie macht = umb fofreffloz bie

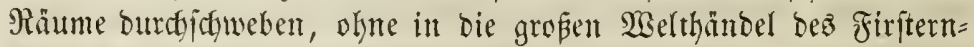
himmels einjugreifen.

Darum wollen wir audh jente riefigen Rebefwejen, bie ıtız mit

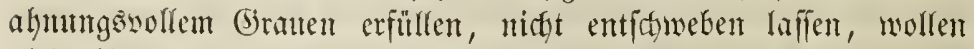

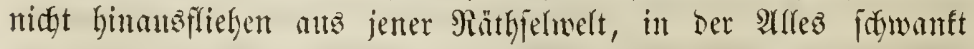

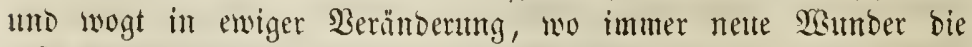
gefunbente Drommin ftören, neute Beobadtungen bie entmorfenen

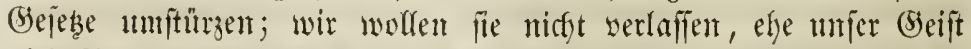

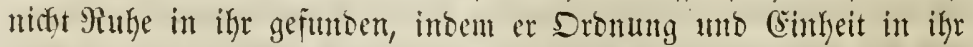

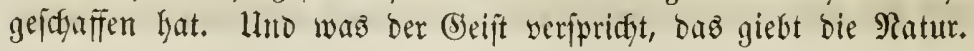




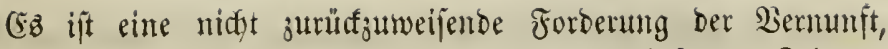

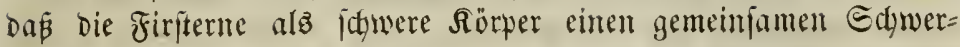
punft laben, um Den fie freijen, der fie zu cinem gropen Enfteme

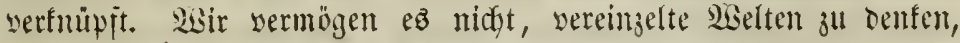
wir verlangen Sronung! Aber nidt unje Denfigejebe affein, and

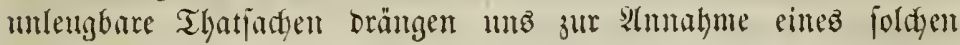
Ectwerpuntō, fei er mun matericlf, eine.Centraljonme, ober ein

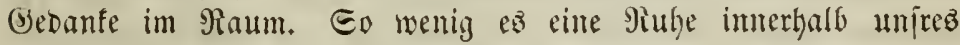

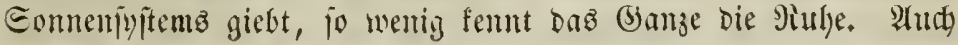
unje Conte eilt mit ifrem zablreidgen planetnrijgen Sbjolge burdy

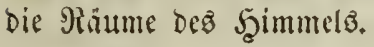

Edyon nor 100 Sabren wurbe man burdy bie Arbweidyungett, weldye fith bei einer Bergleidyung älterer Beobadtungen mit Dent neucren ergaben, auf Die Bermutlung gefülyt, Daß́ die firfterne

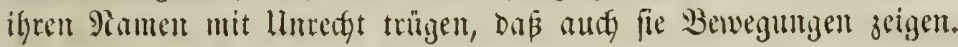
(Segenvärtig ijt man Durdy gentuere $\mathfrak{U}$ rbeiten jur Remutnip eimer foldaen eignen Bewegung von mehr als 800 Sternen gelangt, die allerbings bei menigen jwif̧en 2 und 7 Eecunden, bei den meiften unter $1 / 10$ Eecunde in eitem Salyre betringt. Für bie Unjadye biejer eignen Benegungen bieten fith uns jogleids zwei entigegengejebte Amtatymen Dar. (Entweder die Eterne benegen fid wirflich im Jiaume, ober mur bie Eomte mit unjer (Eroe bewegt fid und ver=

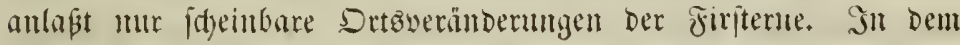

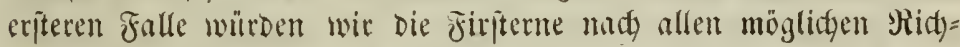
tungen bineilen, in Dem lebsteren alle fid einem beftimmten Wunte

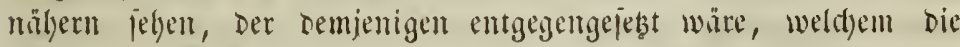

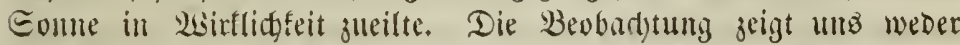

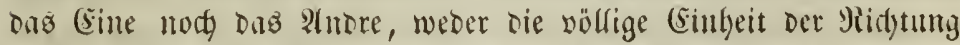

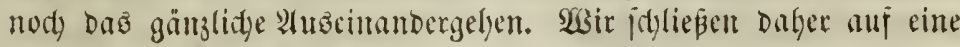
gemeimjame wirtung beioer Mrjadyen, auj eine gleityzeitige Bewe= gung Der Eomte und der firjterne.

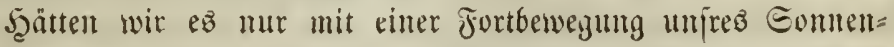
Iyjtems im sGeltraum ju thun, fo fönnten wir auf Den Bedanten fommen, Dẩ unire Eonne einem Doppeliterniyjteme angegöre. Ber= geblidy aber judgen wir mad) eimem Eterne, Der ilyr fo malje ftände,

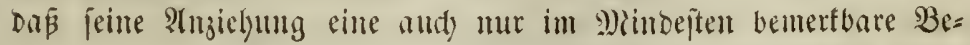
wegung herbornjen fönte. Der nädyjte. Firitern \& Cientauri fteft 


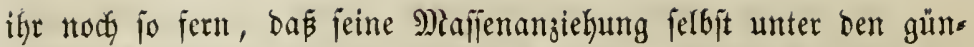
ftigiten Annalymen mur eine Bewegung von $\frac{1}{83}$ Erobeiten in einem Sahre berwirfen fönnte, eine Bewegung, bie faum bem 1000 ften Theile ber wirflidy beobactteten entipriç, alfo Beobactuntungen von melyr als zwambig Jahrtaujenden vorauseę̧t, um in einer Bewegung jümmtlidjer Fixiterne bemerfbar zu werben.

Dehnen wir aber bie Fortberwegung unfrer Eonne auf bie gejammte Firfternwelt aus, jo werben wir auf cinte alfgemeinere urjacte berjelben Kingedrängt, auf ein Raturgejes, bas fie alle

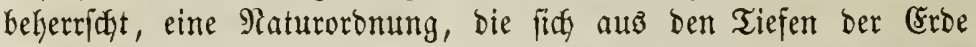

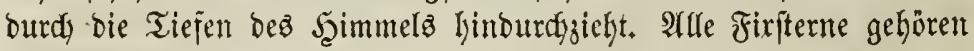
eintem gropen Enfiteme an und freifen um einten gemeinfament Edfwerpunft.

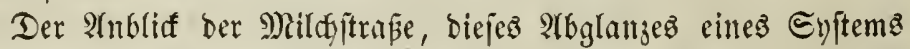

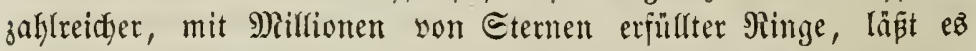
natürlidy ericheinen, wenn wir ben Edywerpunft für biejen WSelten= verbant da fudfen, wo der Edfwerpunft der Mildjftrafentringe liegen $m u \tilde{p}$.

Ständen wir im Mittelpunft biejer Ringe, fo würben wir einen einzigen, nady allen Eeiten bin gleid) Lebgaften (j)lanz yer=

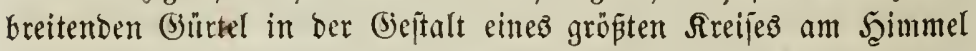

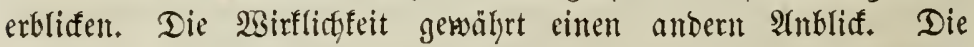

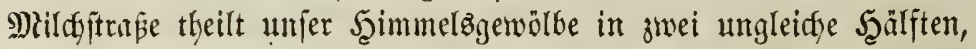
beren gröpere ben Şerbftpunft umfapit. Sie vergmeigt fid in ber

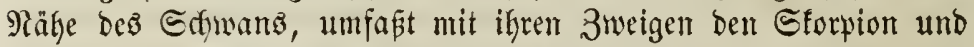

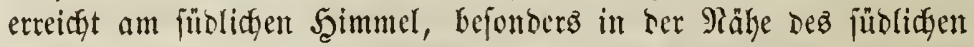
Freuzes einen jo lebhaften Blanz, bas berjelbe in Berbinoung mit Der Mammigfaltigfeit fnotenartiger Berbidfungen unb injelartiger Unterbrecfungen Sohn Şeriffel zu ber Aeuperung bewog, bie Milddy=

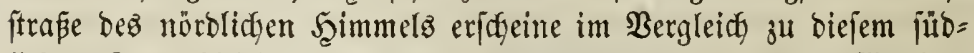

- Yichen 3uge bleidy, unbeitimmt, ia ftellenweiz faum auffindobar.

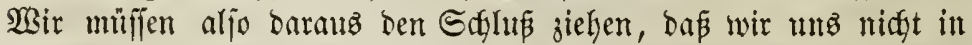

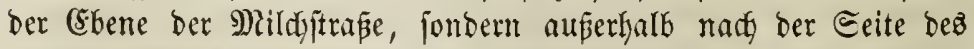

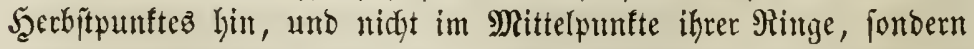
näher sem getheilten 3uge, aljo bem Eternbilbe beż Etorpion be=

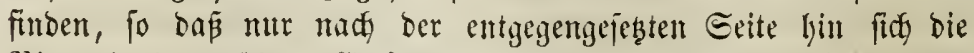

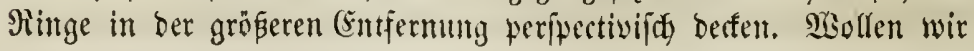




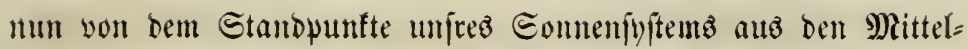

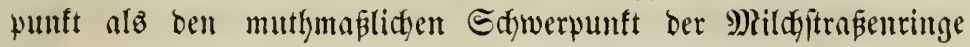

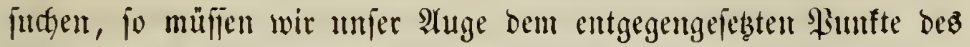

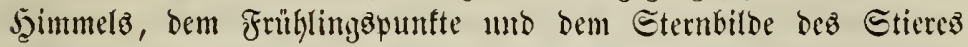
jumenten. So fenten wir fagn Brenjen, die unire Eentraljonte

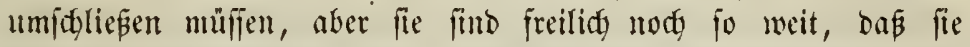
mehrere Stentilder umfafien. Wir mujfen baher zu ben Beme= gungen ber Sterne felbft unire 3ufludyt nelgmen.

Bereitz im vorigen Saljrhumbert beyann man mady eimer maj= jentgaften Serridyerin im (Sebiete Der Firitermwelt, einer Eentral=

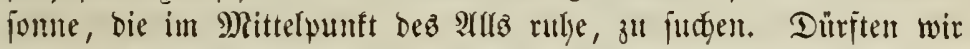
biejen Anfirgten folgen unb den Edwerpunt bes Şimmels in einte

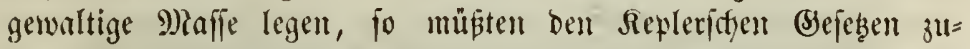
folge in ber Rätge biefes Centralförperz bie Bewejuntgen bie fdynell= ften, in ber Ferne bie langfamiter fein. Sill foldyer Etern aber zeigt fid am ganzen Şimmel nidft, unt body fönnte grabe er wegen ber fobnellen Bervegungen in feiner 9älye felbjt ber gröberen Beob= adgtung nidgt entgungen jein. Fingen wir uns bager in bie ent= gegengefeste, unjeren gewohnten Borftellutgen freilid) wiberipredfente Thungme, ber Edyerpunft fei maffenloz, ober bod) feine llmge= bung nur mit 9)injen erfülut, weldgen bem (b)anjen gengeniber feine

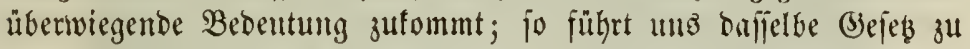
Den entgegengeferten Folgerungen: bie Bewegungen müfïen in ber Pähe bez Centralpunftes bie langfanften, in ber Entfermung bie

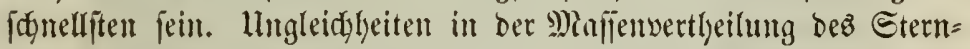
jyitemb werben natürlidj Etörungen in biefen Bewegungen, $\mathfrak{B}_{e}=$ fotlemrigung ober Berz̈̈gerung an einzelnen \$iłnften hervorbringen, und bie bidftere (Errüflung ber äußeren Mildyftrapentringe maments lidy muß eine Befdleunigung in ber Benegung ber entfernteren Eterne jur Folge baben. Eo find wir in Etande, burdy einte Ber= gleidung ber Eternberwegungen nidyt mur "iber bie \&age bez (5en= tralpuntes, fondern felbit liber bie Maffenvertlyeilung unb (s)eftal=

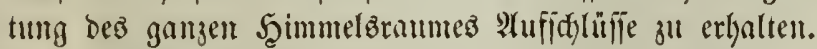

Jebe Bewegung ber Sterne ift aber eine boppelte, zufommen= geję̧t aแz ber eignen unt mis einer fdeinbaren, weldye nur burdy bie Fortbervegung unjes Eomneminftems erzengt wirb. Die Midd)= tung biejer lek̨teren ift burdy $\mathfrak{A}$ rgelander's und Etruve's Bemühun= 


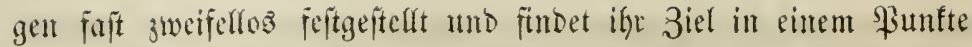
Des Jyerfules unter $257^{\circ} 49^{\prime}, 7$ ber graben Afufiteigung uno $28^{\circ}$

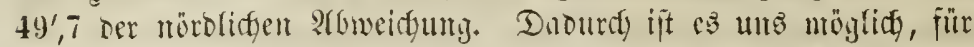

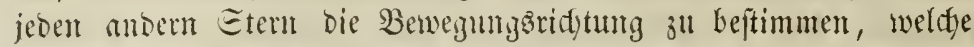

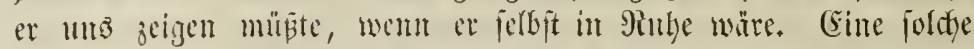

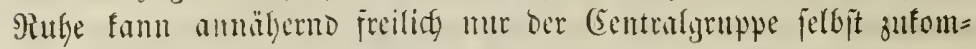
men, atfe übrigen Eterne mitifen mit oer Entfermung zuneffmente 2fomeidgungen jeigent.

Die Bergleidfung Der Bewegungen vou imefre alz 800 -Eter=

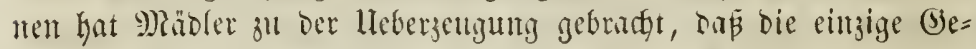

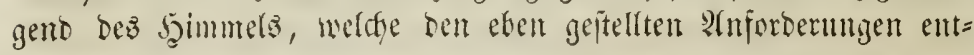

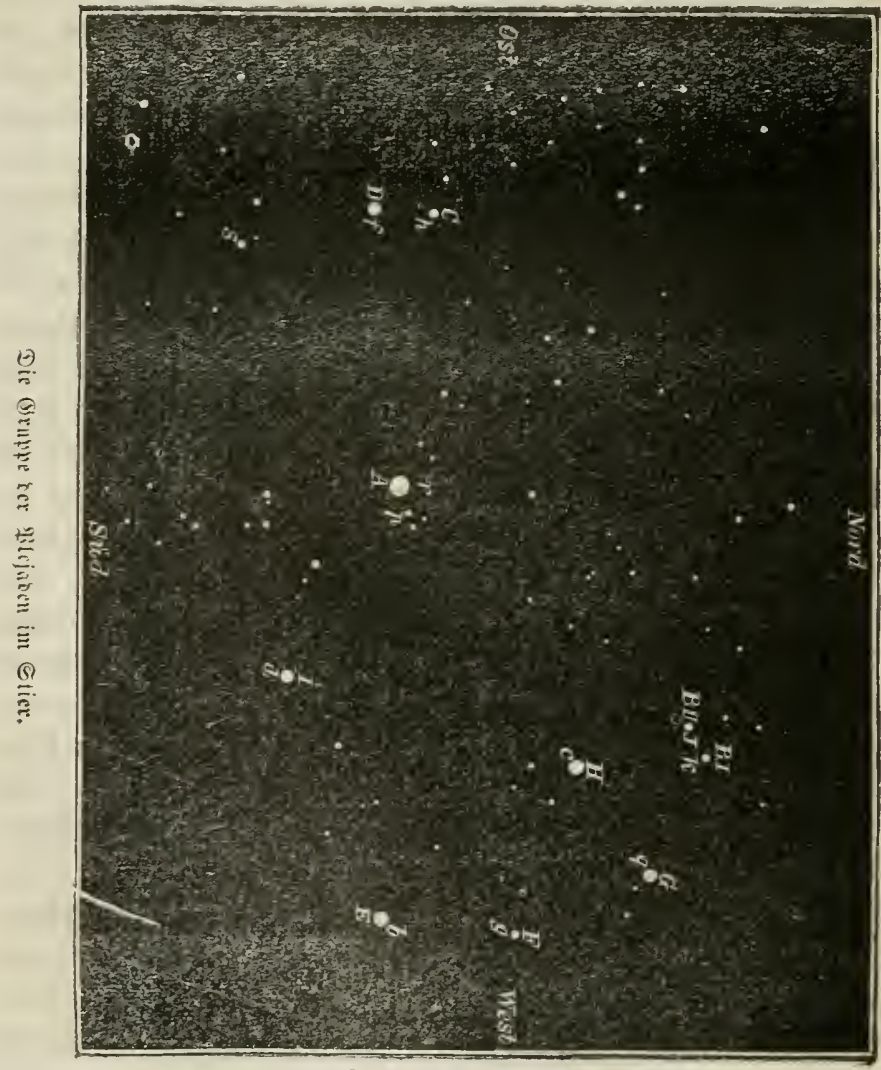


ipridft, umb in weldye fomit ber allgemeine Edjmerpuntt ber Etern= welt gelegt werben famt, bie \$lejabengruppe im Eternbilde bez Etierez ijt. Dieje reidje und glänzende Eterngruppe, bie unz bie

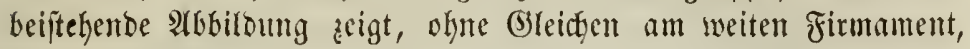
ift baz allgemeine Bemegungäcentrum für alle bie Milltonen Eon= nen mit ifren Eyjtemen bis zu ben fernften Brenjen ber Mild =

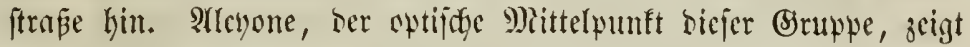

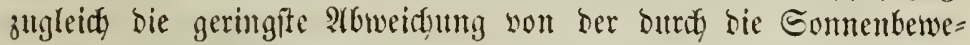
guntg bebingten Pridfutung, barum bie wollfommenfte Piulfe; fie hat

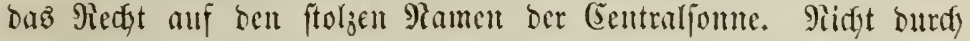

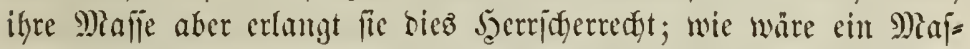
jenübergewidgt gegeniber Millionen von Eternen zu benfen! Biel=

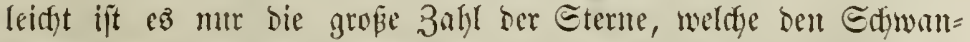

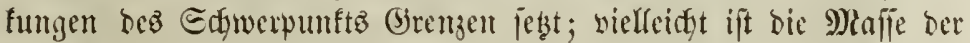

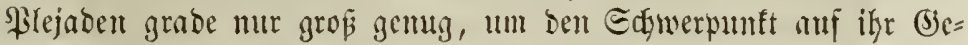
biet zu banment! Aflcyone ift ein Etern, wie alfe Eterne, bent glei=

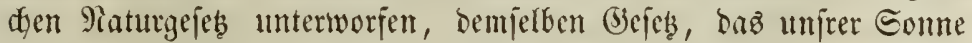
bie Syerridgaft über ilyr \$raneteniyjtem werlieh.

WBir wollen jeģt den berjudt madyen, umb ein Bilto von ben Raum = unt Formberbilltnifien ber Firfiternwelt ju entwerfen. Im alfgemeinten Centrum ftelyt eine (joruppe, reidy an gropent, glänzent= Den Eternen, bie Bjhtuffenne mit ben Rüdyeldyen, wie bie Bibel

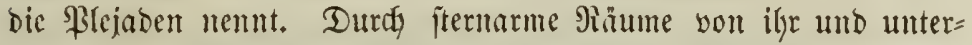

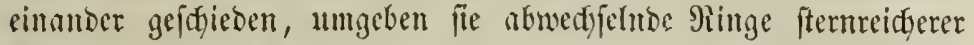
Regionen, beren Bjanzes eine fladfe, linlẹnförmige Edjidjt bilbet,

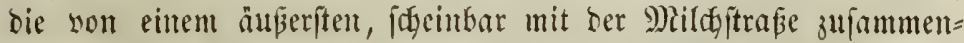
fulfenden Etcruringe begrenjt wirb. Die Mildyjtrẩe felbjt, bie

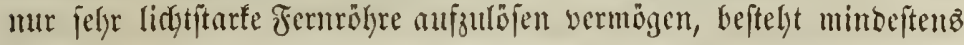
nuв zwei lintereinanber liegenben, jajt concentrijacn Mingen, beren fternarme 3wijdfenräume brĭfenartig verbumben fint. Der unauf= gelöfte Ridstidscin, ben ands bie fräftigiten Inifrumente nody Ginter

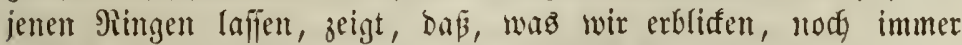

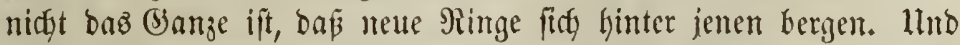

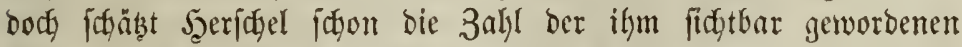

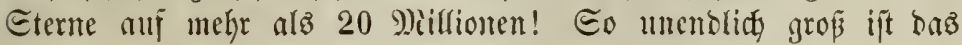
Weltall, uno body finto wir in Etante, felbjt baljin mit unjern Maẫen vorgubringen!

แle, Weltall. 3. 2นศ̆. 


\section{6}
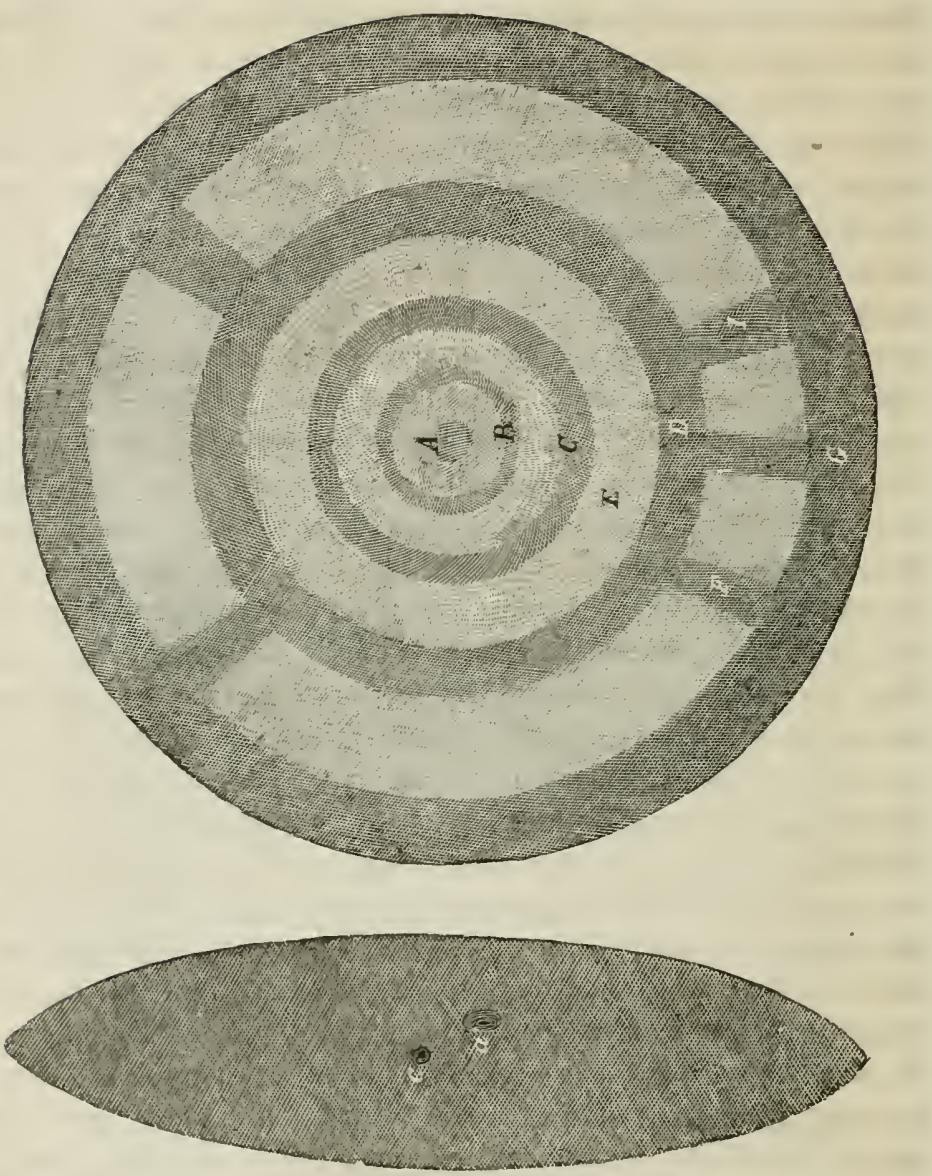

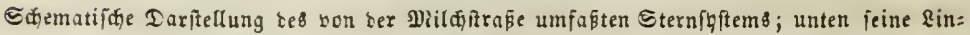
fenform, $c$ bie Blejaten, a Das Eonnenifftem; ober ein Durdidnnitt in ber (8bene ber

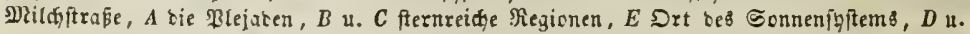

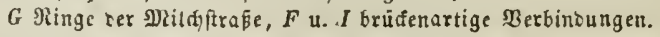

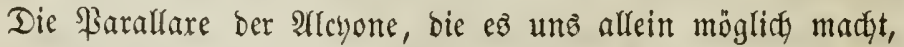
ifree Entfermung von uns zu meffen, fömen wir zwar nidgt beob= adten, aber wir fämmen fie berectjen. Der Stern 61 Cygni, Def= fen Paralfare uno Enttermung wir fennen, fteht ungefähr in glei=

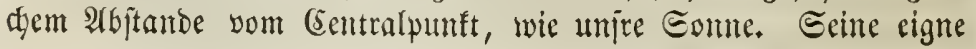




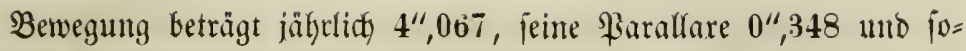

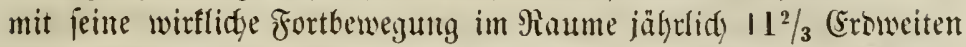
oder 240 Mifrionen Meilen, jo ons er jeinen Umlauf in 18 Mril=

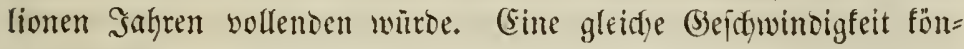

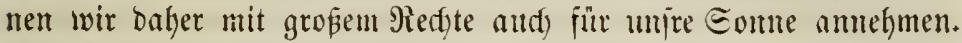
Die Benergung unferer Sonne fpiegelt fith aber treu wieber in ber ideinbaren Sigenbewegung ber atlyone, bie $0^{\prime \prime}, 0$ - betrïgt. Lluter einem foldten WSintel ericteinen aljo bie vont unjer Eorme jährlich burdylaufenen 11\%/3 (Eroweiten von ber Ellcyone auв, uno fomit jebe einjelne Eroweite unter bem wistfel von $0^{\prime \prime}, 106$, und biejer

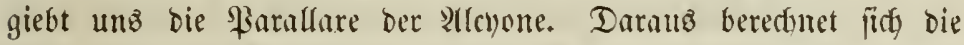

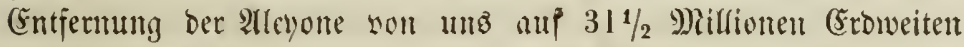
ober befier $4981 / 2$ Ridftjahre. (Eine Bergleitfung biejer (Entjermung mit ber Rage ber \$llejabentyruppe gezen bie Mildfitraße uno mit

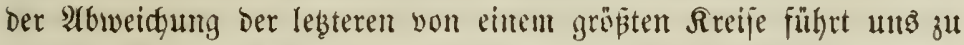

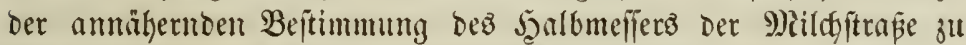

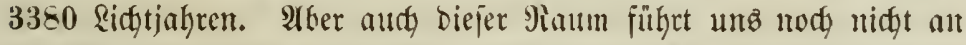
bie (Sremzen unjerer Eternwelt; wohl melyr als 4000 Suljee mö̈tyte

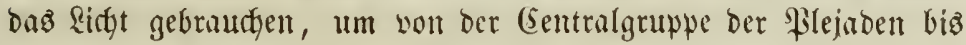
zu Den äußerften Mingen Der Mrildyiträe vorzubrittgen!

Beldye ungeheure $23 e l t$ breitet fid wor unferen Blicfen aus! Der Siebante fohminbelt vor biefent Bahlen, und Doch ift es mur

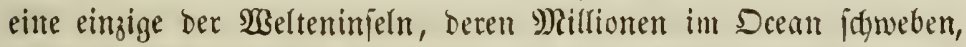

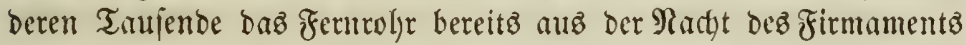

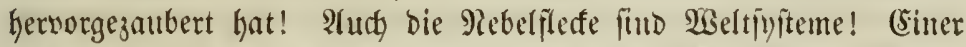
Der grösten unt Darum vermuttylid) näctjten Rebefflecten ift ber Drionnebel, Der unz unter cinem Befidtżninfel won 34 M)inuten erjdeint. 2uf Erben ift aber ein Elegenftand won foldjer idjein=

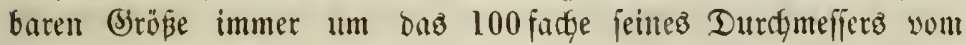

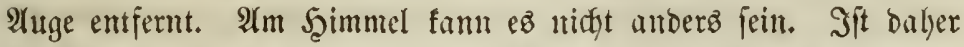

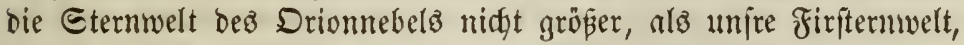
umfapt aljo ifyr Durdsmefier nidft mehr als 8000 Ridjtjahre, fo ift feine Entfermung bon uns auf 800,000 Sichtjahre anjujकlagen.

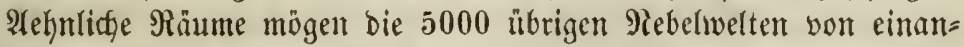
Der trennen; weldfes Maaß mißst bann noch bie entfernteften! Die fleinften Rebelfleffen zeigen faum nodh einen jojeinbaren Durdymeffer von 8-10 Eecumben, umb wären fie audy nod) cimmal fo flein 


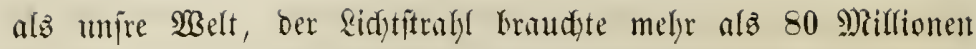
Galfre, um ats iffrer Ferue ju

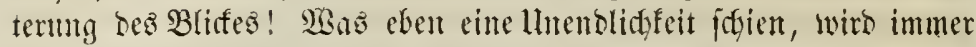

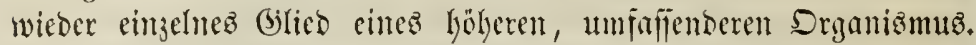

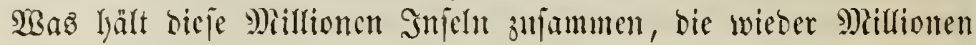
Eommen umfaijen?

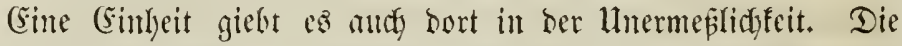

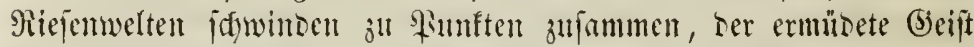

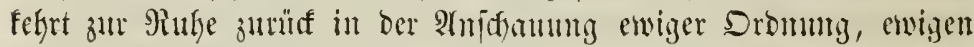

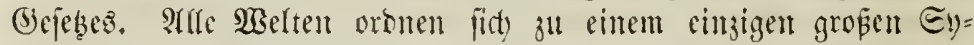

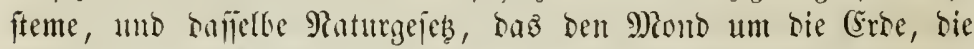

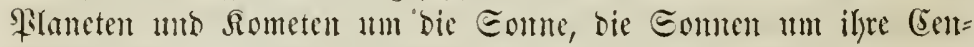

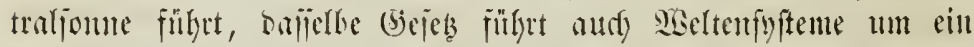
Eentralfyitem auf vorgejdricbentu Barbnen in gemefienen Zeiten.

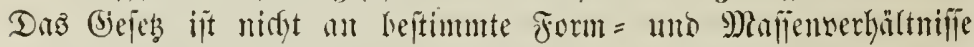

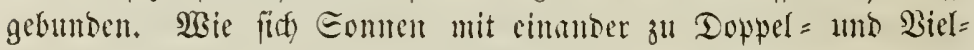
fternen grttpiren, jo haben fid Mebelnelten zu Doppel = unb viel=

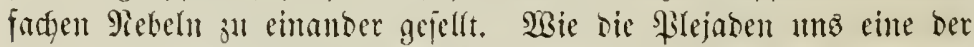

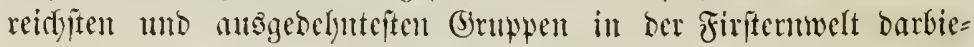
ten, fo bie Magellanijchen $\mathfrak{B}$ olfen Dez EüDpolz in ber höheren

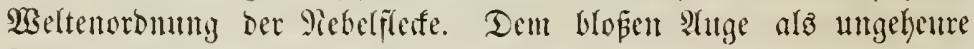
Sidgtnebel erifgecinent, zeigt bas Telesfop in ihnen Taujente unauf=

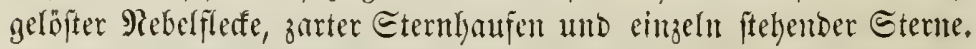

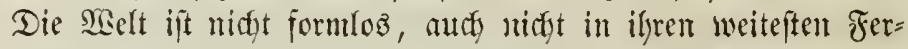

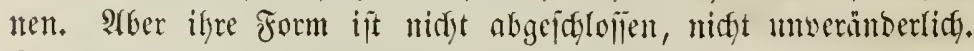
Eie hat ein alfgemeines Eentrum, ungeben son zahllojen anbern (bravitationsmittelpumften: Daz ift ber (S) banfe ifrer (swigfeit unb

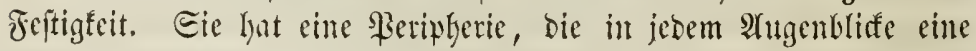

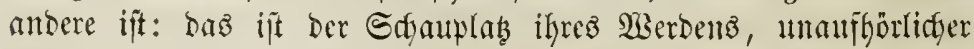
Bemegung unt Entwiflung. SBie im Rleinftu, in Edynute ber

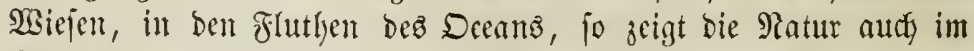

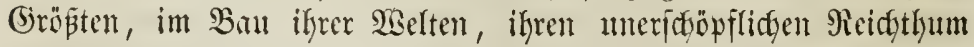

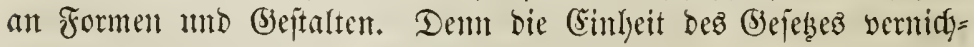

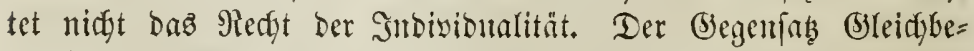
redjtigter iit ber (jumb allez Revenz. SRidgt bie Bewalt einer Mialle, bie gegenjeitige 3ugfraft ift

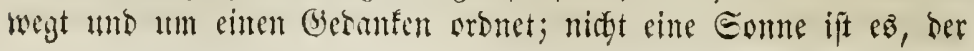


bas Borredft ju Theil ward, alfein bunfle $\mathfrak{B}$ ilten ju erleuthten

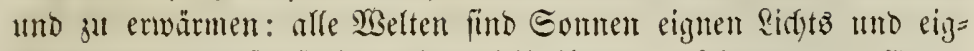

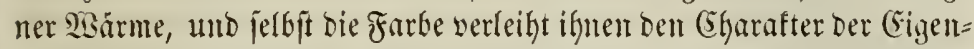

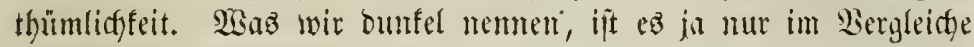

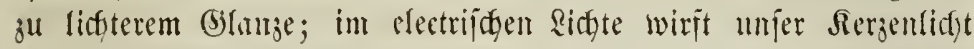
Ectyatten. Sidgt uno 2 Bärme finto mat Erzengnifife gegenfeitiger (sin=

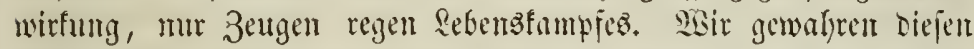

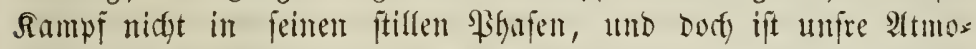

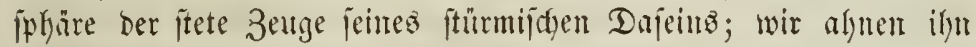

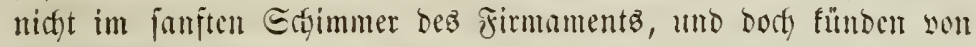

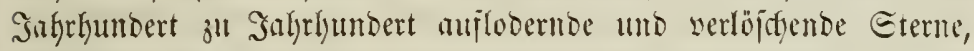

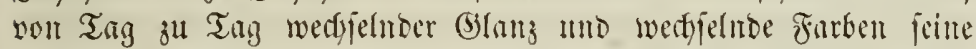

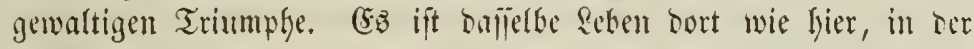
Welt Der Eterne, wie ber Menjiden, bort georbutet burds emige

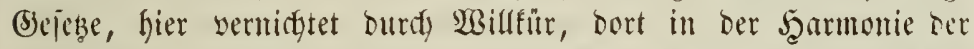

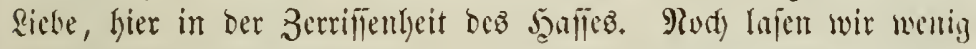

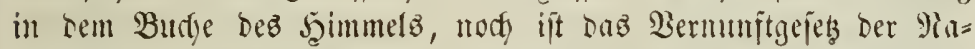
tur in ben Einridgtungen uno Dromungen un|rez Rebenz nidyt vers wirflicyt.

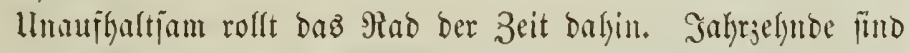

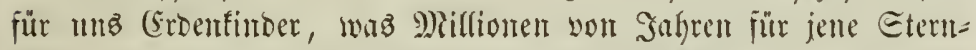

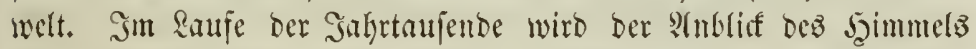
ein anbrer werben, Eternbilber werben serfjuinden, anbre auf= tauchen. Ferme Enfel merben nidgt melye sen großen Şumb, ben Drion, das Brantenturgiidge Eeepter jehen; aber der (Sentaur, bus

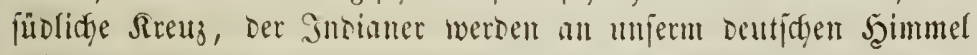

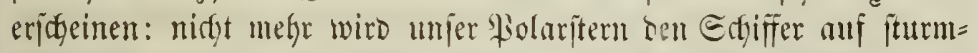
bewegter $E_{e e}$ leiten, andere Eteme werben nady cintanber feime

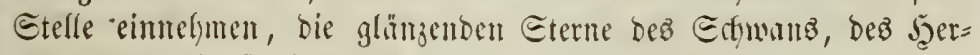

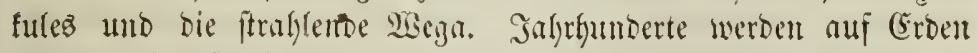

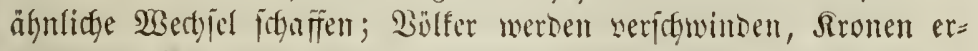

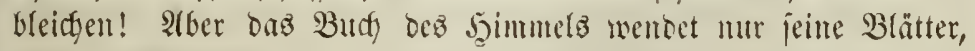
uno ber Menjag wiro andy bann nedy in ifim son jenen befez̧en

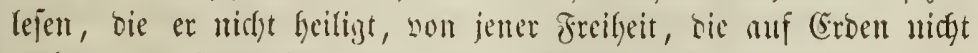

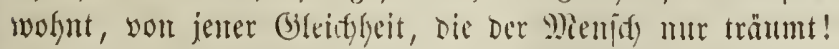

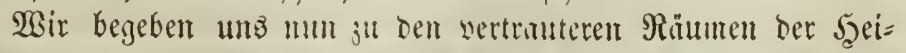

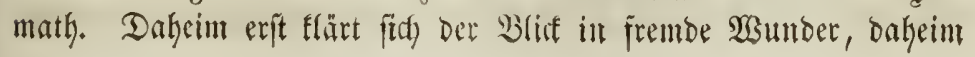


erft erfennen wir Befect und Dromung in ber Mannigfaltigfeit, be= greifen wir bie innige Berwandtiffaft ber fremben Ratur mit ber Seeimath. Die bunfle Algnung, bie unz bort braukent aufgintg non einem gemeinjamen Bante Der Riebe, baz alfe Siselten umidglingt,

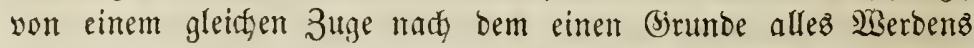

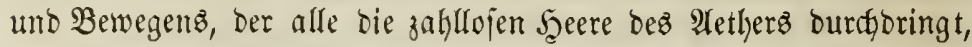

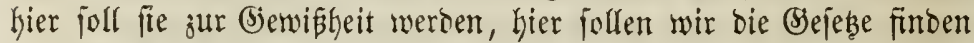

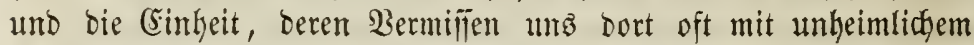

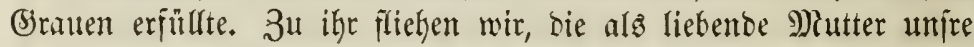
Erroe wärmt unto erleutftet, zu ber allez irbifide Eefnen empor= fteigt, zut bem Duell allez \&ebenz, bem Feebel aller Bewegung,

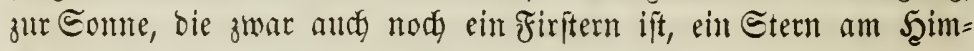
meläzelt, ber aber unz gefjört, ber 4 mo regiert.

\section{Die Eonne und bas FIanetenfyitem.}

Feft und uneriffütterlif, wie ein Felz im Meere, ben bie

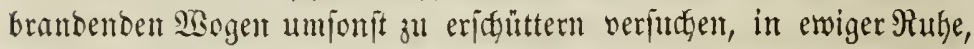

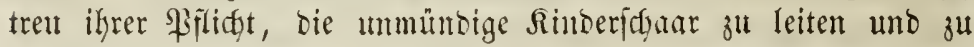

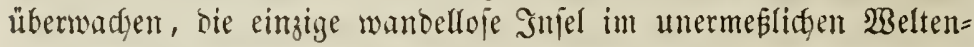

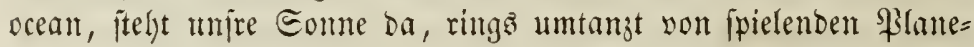
ten, umichwarme won fern keranjigleidenden Rometen, bie fie ver=

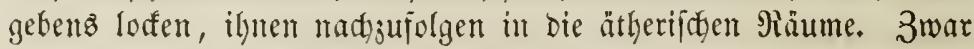

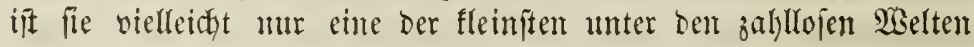

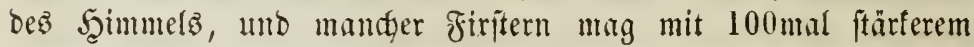

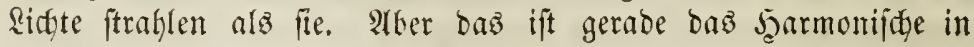

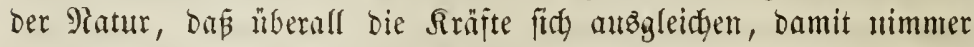

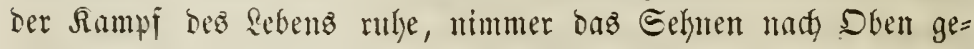
ftiut werbe. Darnm lenthytet unz bie Eome mur fanft als groß̉e

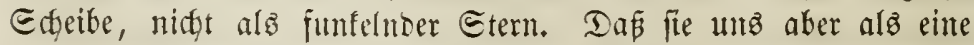

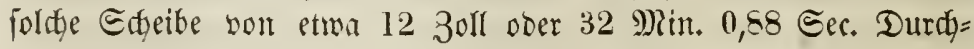
mefier eridgeint, barauz murbe ifon ron ben älteren âtronomen

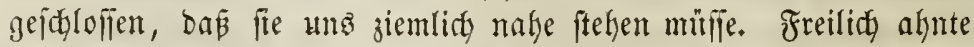

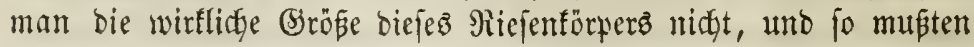




\section{1}

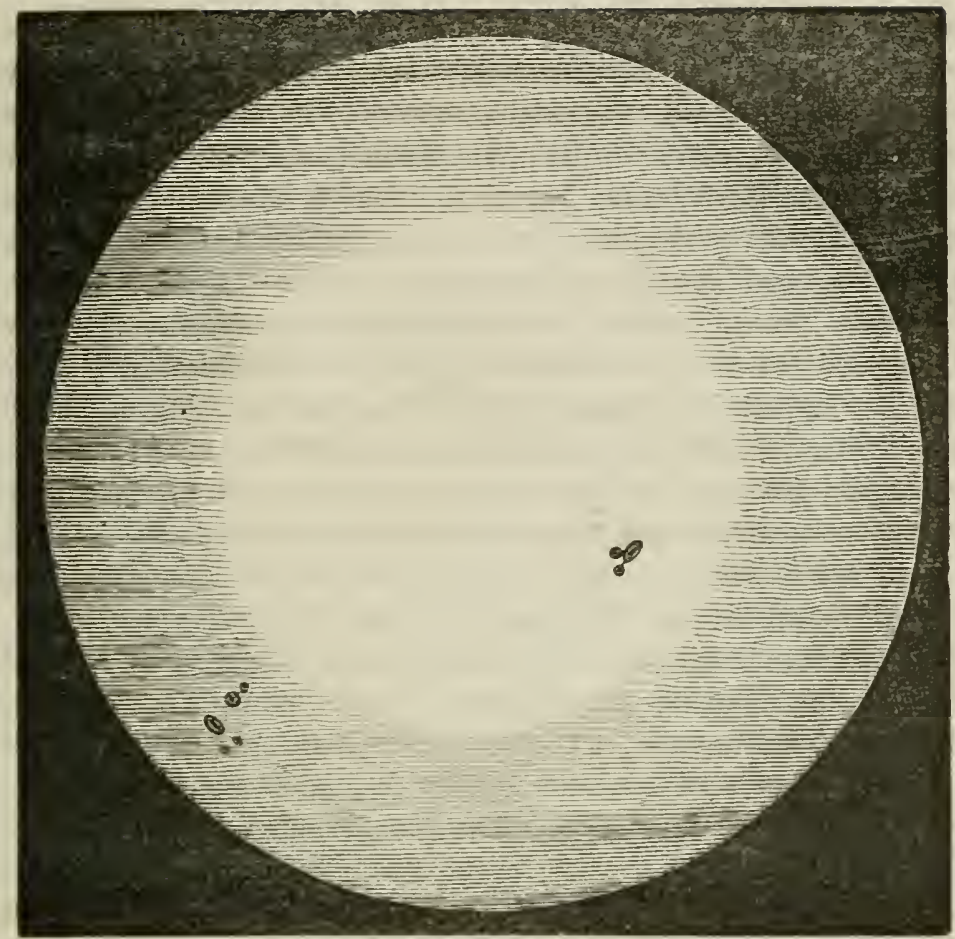

Photographildes sito ber Sonnenideibe.

alle Bermuthungen l̈ber jeinen wahren abftand, felbft bie bes fith = nen fiepler immer nody in siel zu jofübterner Ferme ftehen bleiben. Erit ben neueren Afitronomen zeigte fith endidy eill fidyrer $\mathfrak{W e g}$ fur Beredgnung biejer Entfermung und fomit autb fur Bejtimmung

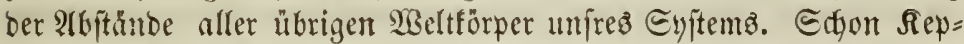

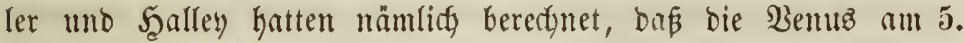

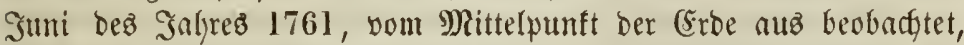
genau in einem beftimmten Momente ben idseinbares Nand ber Sonnendyeibe berügren, liber fie hinweggetgen unb nady eben fo genau beftimmter 3eit aแz ber Eonnenjøeibe wieber herbortreten würbe. Alfer $\mathfrak{A} u g e n$ ridfteten fidg in geppannter (Srwartung auf

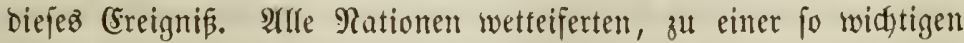
Bereidgerung ber Biffenidyajt beizuftemern, und fanoten nadb allen Baltgegenton bie berühmteitent ifrer Belehrten aus. Co wurbe 
zugleid an sielen weit bon eimander entlegnen Punften ber Ero= oberīlädge, auf ber Injel Robriguez und in Tobolä, in Finnland unb in Ralfutta, auj Єt. Şelena und auf bem $\mathfrak{T} a p$, Drten, Deren Abjtänbe unter einander, wie yom M) dittelpuntte ber (Erbe befannt waren, jener Boribergani der $\mathfrak{B e n u b}$ sor Der Eonnenjdeibe beob= adtet. Durdy Bergleidgung ber Rejultate fonnte man ben Rbjtano Der $\mathfrak{B} e n u s$ yon Der (Erbe und nacf bem britten Sepleridgen Gejeze,

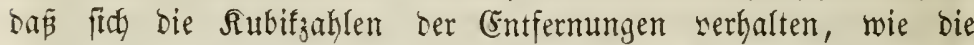
Duabratzahlen ber Umlaujsiseiten, audy bie Entfermung ber (Erbe von ber Eonte beredyen. Mady biejen Beredyungen, bie Durdy Den 1769 nodymals exfolgten Durdgang ber Benus burd bie Eon= nenjueite gröpere Eidgerheit erbielten, ergab fich bie mittlere (Ent= fermung ber Conne auf 20,680,000 Mteilen ober auf 21 $t_{42}$ ifrer eignen Dutrdymejer, jo baj son ifgr aus gejehen unje Erbe nur als ein Edyeibden von 17 Eecunden Durdmefier erideinen würbe. Der wirfliche Durdymefier bes Eommentörpers beträgt baher 192608 Meilen uno übertrifit jonady unire Erbe $112 \mathrm{mal}$ an Durdymejier, an Rauminfyalt aber 1,409725mal; uno went wir alle łlanten unjres Eyjtems nit ifren Monden in eine grope Nugel zujummen= ballten, fie whitrbe faum ben 2000 iten Theil unjer Eonnentugel in fith failen.

MGie einen majeptätijøen Dom mit ithwerfälligem fluge eine Edgar son Dohlen umflattert, Die ifre Mejter in Den Rilien und Eödyern bez Semäuers aujgejdlagen haben, 10, meinen wir, fteft

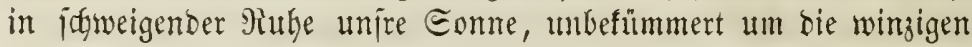
WBelten, bie fie umfreijen. Iod) audy fie hat ber Errom bes Rebens ergriffen und fortgerifien in ben allgemeinen Etrubel ber Betwegung. Wir jahen ja jogn, da mer beibe zugleidy fith um ifren gemeinjamen Edyerpuntt betwegen. WBir lemten in Den Doppeljternen $\mathfrak{B e l t e n}$ fennen, bie fid in Ellipien um einanber berwegen, wie unje planetariften, beren Be= fammtmalle nidyt notfwentig gröper ijt, als bie ber unjrigen, แno beren Patur, aud wemu fie cine wejentlidy yerjobiedene wäre, feinen

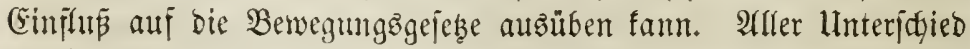
benuft nur anj Dem Mallenverfätnijie der eimander umfreijenden Belten. Unire Eonne htbertrifit bie Bejammtmaje ifrer \$Haneten um bas 720fache. Bei Dent Doppeliternen aber ift ein joldges 9) Rajs 
fenübergetwidyt einez Centralförperz, wie wir ez unz zu benfen ge=

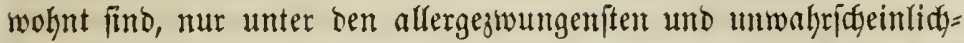

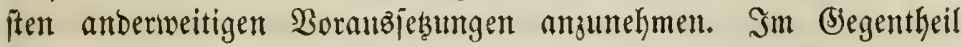
mögen in nicht feltnen rällten bie Majien beiber Sterne nahegu

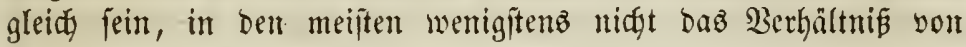

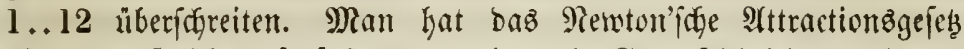
oft gam falfog aufgefast, man hat bie Begenjeitigfeit babei ver= geffen, bie $2(n z i e f u n g$ ber fleineren Maffen über ber übermiegentoen

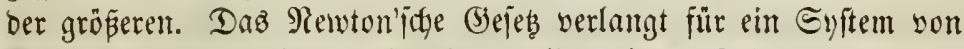
Rörpern nidftz meiter, als eimen allgemeinen Edfmerpuntt, auf ben alle übrigen Berwegungen fid bezieher. (Ës verlangt aber nidft, wie man bei ber Eonne antunehmen pilegt, bas ein bejtimmter Centraltörper biejen Edfwerpunlt materieï erfïlle, umo nod) weni= ger, baß́ biejer Förper an Mafle bie Summe aller andern über= wiege. Ie größer übrigens die Mlaffe des einen gegenüber ber ber

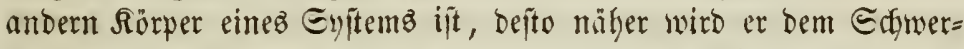
punft ftehen. Bei jo wenig non einander veriffiedenten Mafien, wie fie ben Rörpern ber als Doppelifterne uns befannten Syfteme jufommen, liegt natürlidy ber Edjwerpunft zwiffen ifnen, niemals in bem אörper bes einen. Trement wir beshalb bus 3ufällige und als joldfes hat fid unz doz Mrafiferverlyältutís ergeben - vom Pothmentigen, fo haben wir aud in unjerm Filaneteninfteme nifft mefgr zuerít- ben Sentralfïrper, fondern ben Extyerpunft befielben aufzufudfen uno bame erft ju prüfen, ob biejer wirflidy ein mate= riefler jei. Die neteren Beobadtungen haben unz aber erwiejen, Das aud, unire Eonne ifre Beweegung habe, eine Rotation um fidd felbit, bie fie in 25 Tagen 17 Etumben 7 Mimuten vollendet, bie aber verbunden ift mit ber Bewegung in einer fleinen Eslipje um einen unbetaunten Bromunuft. Diefer \$antt, Derjelbe, um ben fich bie gejammten PHlanetent dez Eyjitemz bewegen, ijt ber

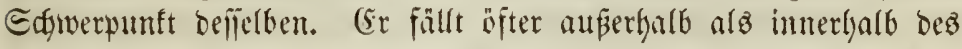
Sonnentörpers und mit jeinem Mitte(puntte mur in ivenigen $\mathfrak{M}_{0}=$ menten zujammen. Die Eomne alfo ijt \$lanet, wie alle anbern Bilaneten, unt nur, weil fie firch nie weit son nem Extyerpuntte Dez Eyjtemz entjernt, hat fie bie Ehre, jeine Seerridyerin zu heiß̄en.

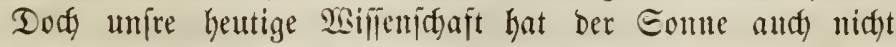

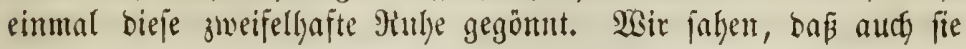


mit bem gangen ifgr unterwürfigen Seeere von Trabanten, von bem

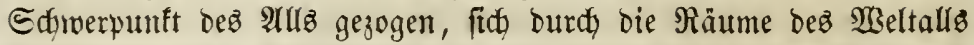
fortberwegt, mit einer Siejdwintigfeit, bie täglid 834000 Meilen betrïgt. Єo rüfen wir allmälig an fernen Єternen vorüber, wie an eintem Edyiffe bie fernen 1 fer eines Flulfes voriberzuziehen

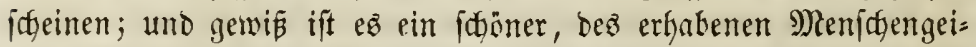
ftes mürdiger Siedante, ber હonnen mit Sonnen in geidynifterlidgen

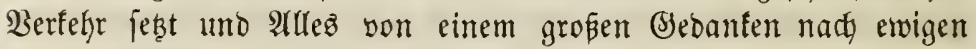
(S)ejeken orbmen uno berwegen läß̈t.

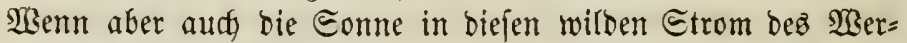
bens, ewigen 2 Bedtels, ewiger Unruhe fortgerifien ift, wo bleibt bann ber গukepuntt unjerz Sehnens, weldher Sull ipendet Sraft in Dem Rampfe beş Ridjtż uno Der Materie? Auth bie felbfit leben= big gewordene Comne bleibt für unż, waz fte mar, bie belebende

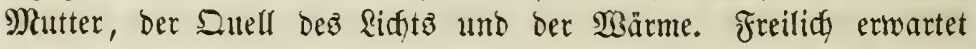
unz eine große Edfwierigleit in ber Grflärung ber belebenden Bärme, weldhe unire Sonme überalf serbreitet, uno die wir feiner unirer irbijtgen Sidftquellen in biejem Maaje entiptrömen jehen. 3 war jhlummert auch in den Tiefen unjer froe eine verborgene Sluth, welde furtotbar und geroaltig ba, wo fie mirft, jelbit bas

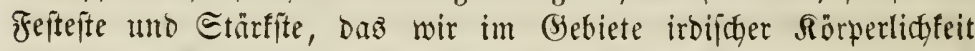
fennen, auflöt mo zeritört. Atber wenn audy zumeilen biefer in= nere glühenbe אampf Der (Stemtente nach oben hin fithtbar wirs,

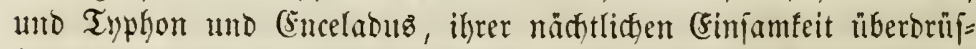
fig, in Gunbert emporbrüllenden Fetterftlünon bie Mauern iffes

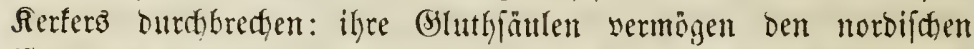

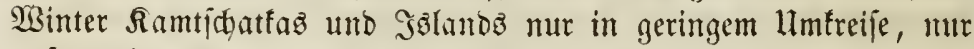
auf wenige Monate zu veridyeudben, ibr rothez Ridyt beleutbtet mur ben Ednee der nädyten Thäler und Şöhen mit blutigem Tagez= glanje, und ilyre innere SBänme läß̈t juar unter bem Ectunee ber

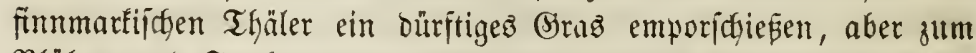
Blühen mo Frutfttagen vermag fie eв nidyt zu zmingen. Atuch bez Porblidytz matter Edyein erlyebt fid wohl eimmal zu frahlendem

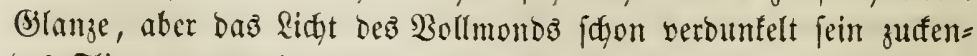
bes Flimmern, und wenn ez aud bie falte Magnetnabel in zit=

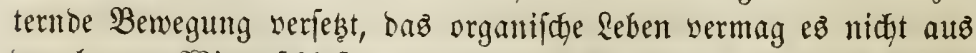
bem langen Winteridlafe zu wefen. - $\mathfrak{A} b e r$ lange bevor bie $\Omega_{0 ̈ n}=$ 
gin bes Tages mit bem äuperften Єaum ihrer Edyeibe ben Feori= zont berührt, fhwinden alle Eterne ber 9adgt, und jelbit Deg Boll= monds (Sllang erftirbt ju bleidyem Edyimmer. Mit ihr ermadht allez

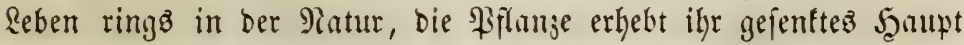

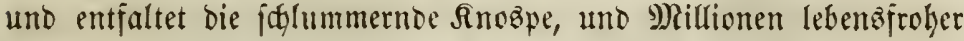
Wejen zaubert ihr märmender 2 them aus bem Edyoofe ber Croe,

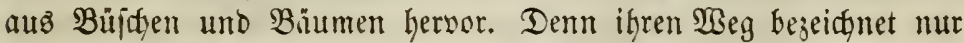

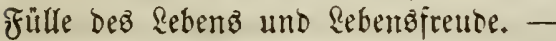

Sn älterer Zeit hat man gewöhnlid) bie Conne mit einem burdy und burch flammenden Feuermeere vergliden, beilen (S) ohne merflidge alonahme ober 3unalgme, freilidy unertlärlidy gemug,

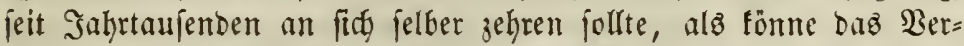
brannte immer wieder zum Bremmenden werben. Mit Recht haben bie neweren Affronomen fid) vou biejer niebrig = finnlidgen Boritel= lung abgewandt, und eine jorgäältigere Beobadtung ber Erjöhei= nungen an ber Connenoberiläbe hat lie eine anbre Erflärung bez

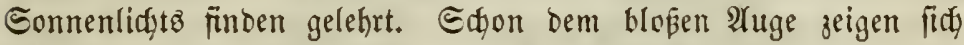
bisimeilen bunfle Eonnenfleden, melde, Durdy Fernröhre gejehen, in

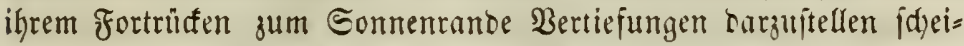

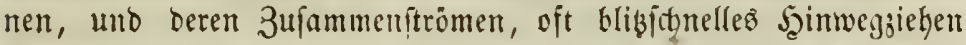

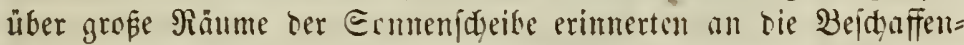
beit uno ben plöblidyen 23 moel unjer atmoiphärijden Grideinum= gen. Fuds jene hin und wieber walliörmig fids aufthitrmenten ober in rumblithe Majien jujammenballenden Eommenfafeln forber=

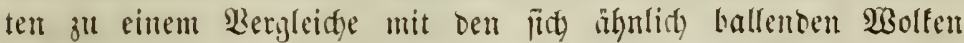

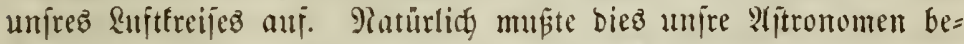
jtimmen, audy ber Eonue eine ähnlidge Atmofphäre zu ertheilen,

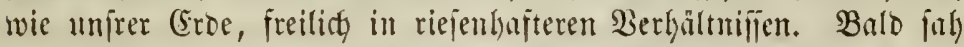

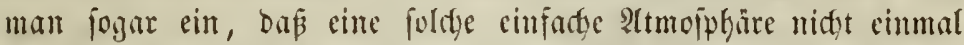

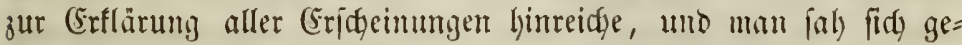
nōtfigt, brei foldter Dunjt = ober Ridthüllen anzunelymen, beren theilweifes 3erteifen ober 3ufammenziehen jente Eomnenflecten und Eomtenjafeln bilde แnd unz bismeilen eincm Blif auj bie bunfle, wahre Dberflädye des Eomentörperz merfen lajje. Wesu bie sidyt= bülle zerreipe, fagten bie ajtronomen, thürme fid bie "eidgtmaterie"

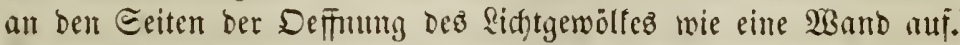
Eo entitunden bie Eomnenfatelu. Bon ben lendytenben $\mathfrak{B a ̈ n d e n}$ 


\section{6}

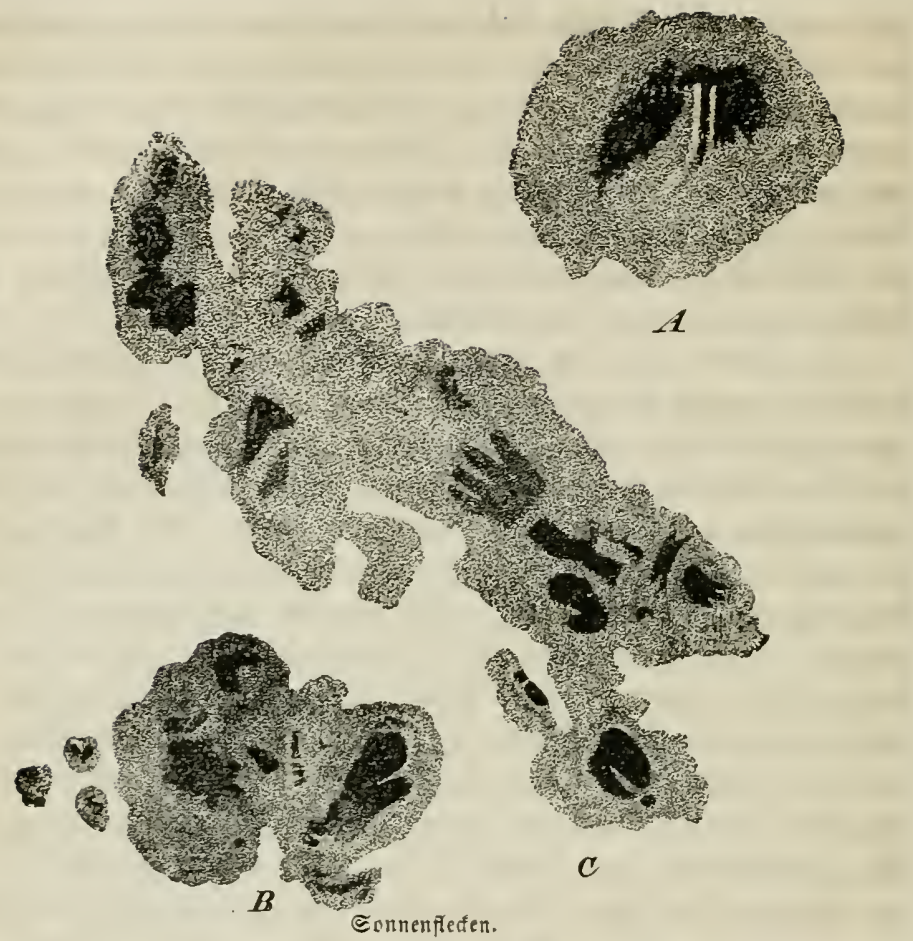

aแz jollten bann bie Eicttitrahlen

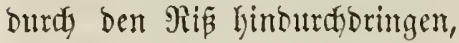
burct eitte jweite, burtafidtige,

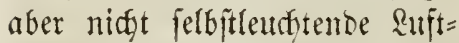
fojidgt geken und fooann auf eine britte undurch/tetige $\mathfrak{W O L}=$

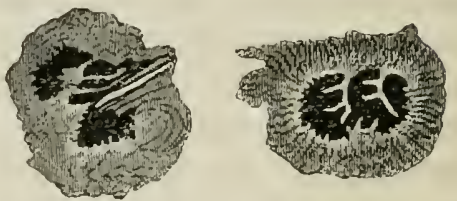

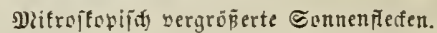

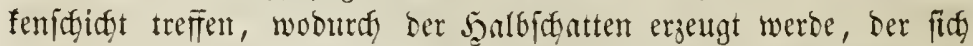
ftets an ten Ränsern Der Eonnenflerfen jeigt. Die Beobadytung Der totalen Eonnenfinftemijife in ben Safren 1842, 1850 und 1851 bradte aber mene Edwierigfeiten. Man fah ftets eime filber=

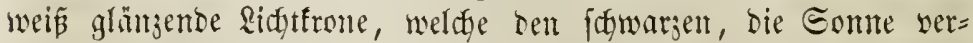
Decfenten Mono umgat. Sie war in einer keftig waflenten und

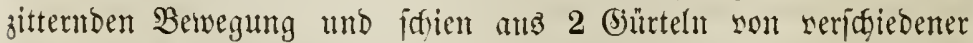
Ridjtitärfe und 3 biz 15 Mimuten Breite zu beftehen. Innerbalb

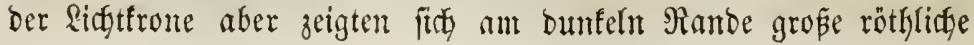


Seersorragungen, $\mathfrak{B}$ olfen ober Flammen gleitfend, unveränterlid unto sour fatarfen llmrifien. Berge modjte man barin nidft jeben; fie idjienen vielmehr fommt jener Ridjtfrone und ihren Etrahlen= büidjeln ber Eonnenatmofphäre anzugehören uno gaben biejer fomit eine Şöhe son minbeftens 10000 Meilen nilber ber Sberfläde der Somme. 3ur Erflärung Diejer Eoronn fowohl, wie der figgenamnten \$rotuberanzen, reidfte aber bie kisherige 2 Golfentheorie nictit aus.

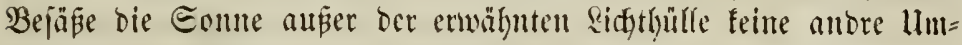
lyulllung, fo müpte in Dem SHgenblife, wo der Mono, der, wie wir fehen werben, feine ober minbejtenz mur eine jehr bünne 9

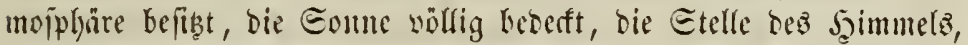

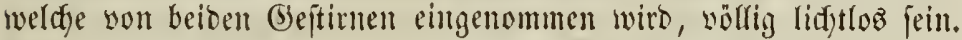

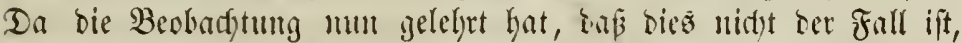

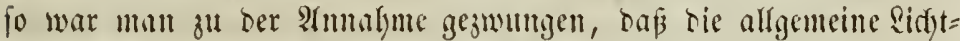
fülfe ber Eome nod) non jwei andern Sätlfen umigeben jei, Derent eine in rothem Ridfte leudite, wälyent tie antre ämperite meipes

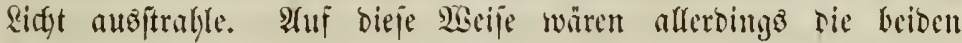

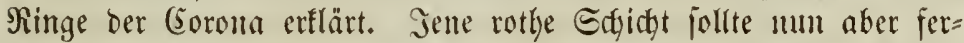

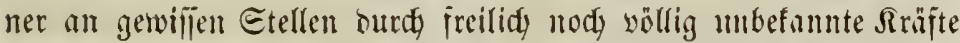
emporgetrieben werben und fo bie unter bem Ramen ber Protu= beranzen befannten Ridtbüidgel bilion.

Eine foldye Berniffelung Der anfangs fo cinfads eridgeinenden

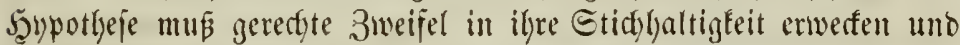

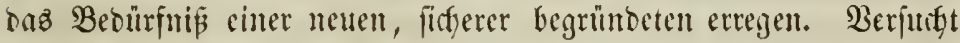
iit eine foldje in ber jüngften 3eit allerbings. Man ift babei frei= lidy mieber zu ber alten Borftellumg eintes emigen Ennenfeutza

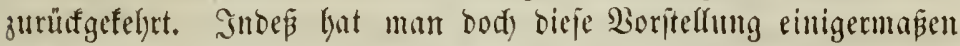
Dem neueren wifienifaaftlidjen Etandpunft angepapt, inbem mant

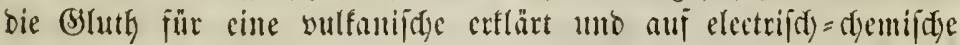

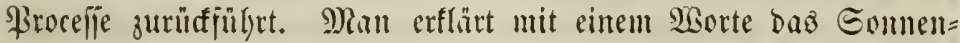

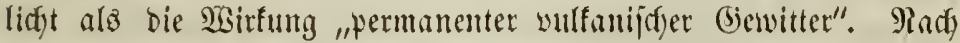

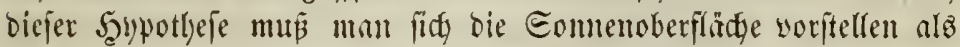
ein rogendez Feuermeer. Der ganze Sommenball ift nod) immer in feurigen fluffe; aher wegen des beftänoig nuth ausen ftattfins

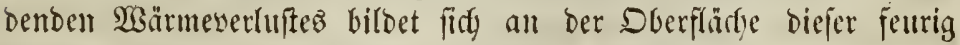

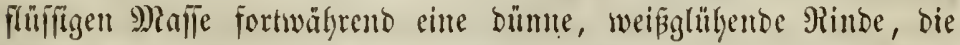

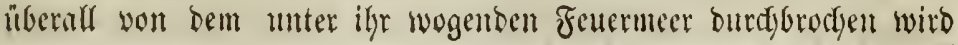


uno fth abwechielno bald hebt bald jentt. Da wo 2uäbrüde itatt= finten, müilen fity in oer Umgebung Mafien aufthürmen, fo ba am Ende in Folge biejer Maffenantäufung bie $\mathfrak{A} u$ borücte fich felbft ein Şindernifí idgarfen. Während mun an andern Etellen bie kef= tigen vulfanijøen 2 (usbrüdbe fortbauern, jenfen fith bie bort auf= gethürmten Majien wieber. In Folge biejer abwectjeltroen Seebun= gen und Eentungen bleibt zwar bas mittlere Siveau ber Sonnen= oberîlä̆be daffelbe. Afuch werden in tor Regel bie Scebungen eine

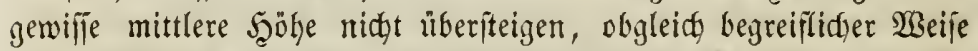

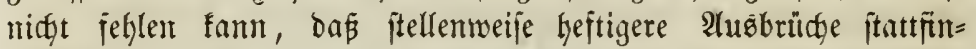
Den, welche um io gröpere (Stuthmafien auj Der, Sonnenober= fläche auftlựmen, je länger fie an demielben Drte bauern. Die Eridgeinumg ber fith weithin auşbehnemben wellenförmigen rothen Etreifen, fowie der ftellemweife höher fich erhebenden rothen \$rotu= beranzen, meldae man bei totalen Eonnenpinjternifien an bem Rande

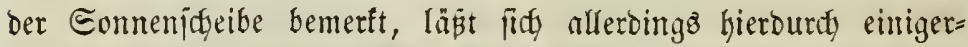

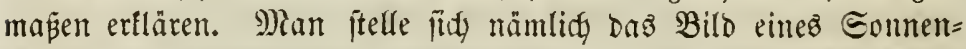
thales bor, weldaes in vertifaler siidtung yon ben in bie Âtmo= iphäre emporgejdleuberten fliifitgen (s)lutbuafien, in borizontaler Richtung won electrijden Sidgtbogen erfïlft ijt. Die bunfle llmge= bung wirb von ben auşarworjenen (Sluthmafjen gebildet, weldye

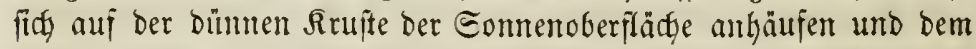
Sommenlidgte gegenüber fdyarz eridgeinen, wie es ja befannt ift,

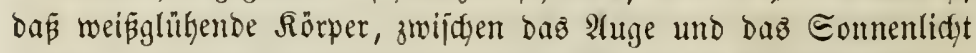

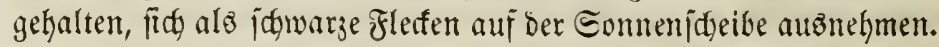

Weldge biejer beiden Stypotheien, die Wolfentheorie ober bie vulfamijhe, mun audy bie ridtige jein mag, immer bleibt ber Sons

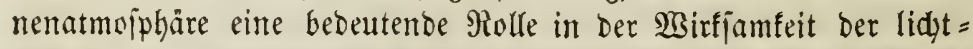
und wärmejtrahlenden $\mathfrak{K}$ raft Der Sonne vorbehalten. Sinen Beweiz

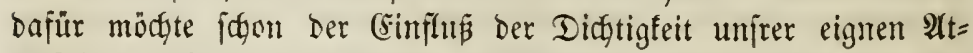
moiphäre auf́ bie ßerîtärfung ober Edymädung ber Wirfungen bes Sonnenlidytö liejern. Denn Derjelbe Strahl, befien Stuth in ben

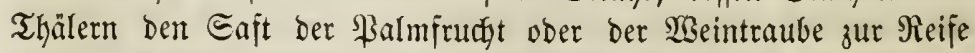

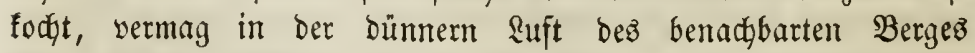
nidat mehr ben Edynee zu jantelzen.

3ur Deutung aller biejer Ericheinungen nehmen wir unjer

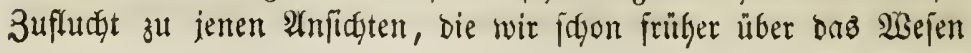




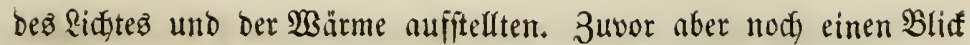

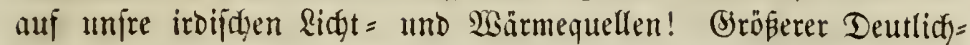

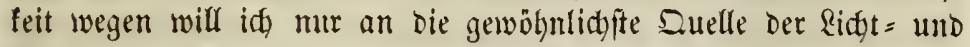
Wärmeentwifflung erinnern, an bie Berbrennung. Alleళ Berbren= nen befteht meift mur in ber fojnellen Berbindung eineż feiteren Sörpers, Des jogeninnten Brenmitoffes, mit einem luffförunigen (Saje, bem Eauerftoff. Die brennbaren אörper find aber mannig=

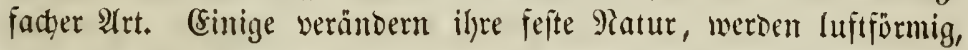
andre bleiben feft, wie fie waren. Sente verbrennent wirtlid, biefe

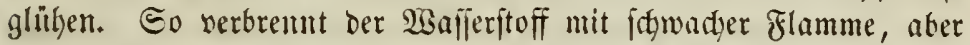

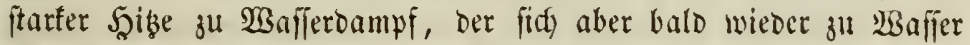

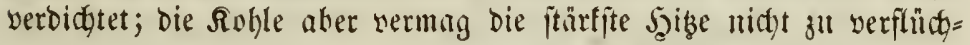
tigen; ifre entftrönt mur ein fidjwadjez (j)lüblidyt. Etrablender, blendender Bstam aber bridst herbor, wem beide Eritgeinungen fids

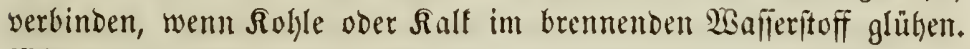

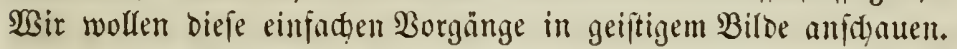

In Der Miaterie rufft ein inneres Eehnen nad, Freiherit, nad) Bernidgtung. 9lur gegmungen behartt fie in ben Feijeln, in bie fie

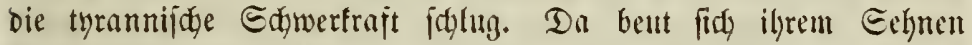
Befriedigung Dar, eళ̉ naht ein Befrcier, Der felbft fdyon geif́tiger, aud) fie zur (stlofung füljen, im Berein mit iht ben beengentent

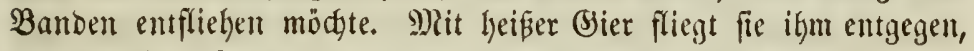
ein mädytiger Drang treibt afte Theile iłres Snnernt herauz, erwei=

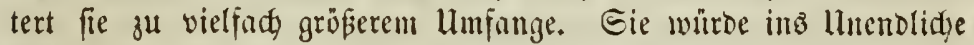

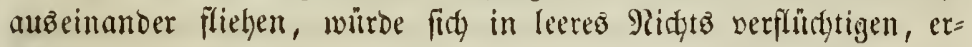
wadyte nidgt zugleid) mit jentem Eefnen anth bic Erimnerung, bie

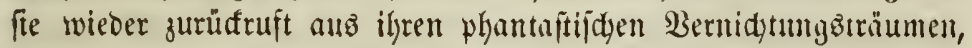
fie wieber liebgerwinmen läpt, was fie verlaffent wollte, audy bie Formen, bie fie feflelten: Die Errinnerung, die daz Eehnen wieber

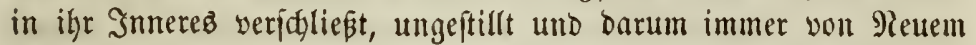

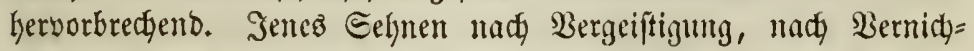
tung Der Form ift daz licht, biefe Erinnerung, bie wieder geftaltet und formt, bie $\mathfrak{B a a r m e . ~ S e ~ j o j w a ̈ d y e r ~ b e r ~ \Re a m p f ~ i f t , ~ j e ~ l e i d g t e r ~}$ jenes Gehnen unterliegt, befto fajwäder find bie sidgt = uno Wsär=

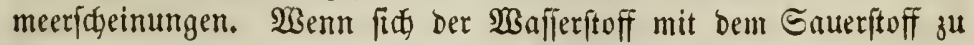
Waffer verbindet, io ift zrwar ber Drang nad, reciheit in ifhnen

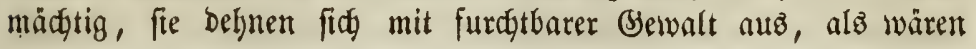


Tie ifton frei; aber grabe in biejer Berblendung liegt ihre Sdywädje.

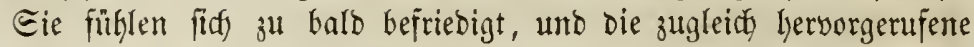
WBärme bejwingt fie leifgt unt jogmiebet fie in engere zeffieln, alz fie vorker trugen. Darum regt fid im $\mathfrak{B a f f e r}$ jene Eefunfudgt nidyt mehr. Co fiegt hier bie 2särme, und fie weí̈ fich aud als Sie=

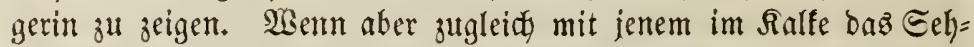
nen erwadyt, ruhiger, bejomnener, barum aber weniger leidgt zu befriebigen, baun wirb ber Siampi heftiger, ftïrmifdjer; benn um jo jurdetbar mädytiger erwadyt jener Drang, je unmöglidjer er feine Befreiung erfennt, je heftiger die Madgt ber Wärme ihn in feine alten હdyranfen zurüffumeifen jtrebt. Darum ftrahlt in biejem Sampfe ber Berzmeiflung jentes Eehnen alz Glenbendez Ridjt her=

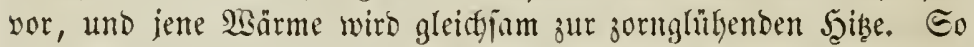

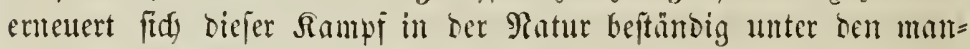

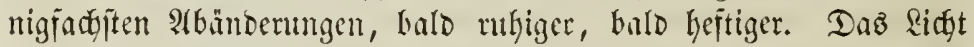
möd)te bie Mtaterie hermuzreisen auz ihrer ftarren Form, gejtaltloz verflüdytigen, bie 2ärme will fie crhalten uno bewahren und bietet

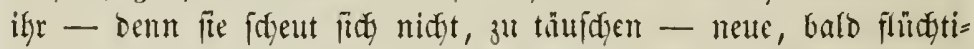

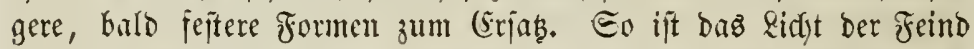
jeber Form, bie $\mathfrak{B a ̈ r m e}$ ilyre Freunbin, beite aber bie Sdjöpfer

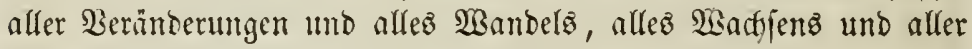
Bervollfommung. Piflanzen uno Thieren verteiten lie Rebent uno

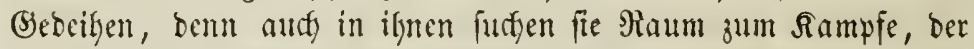
freilich entridf mit igrer Bernidgtung enbet. -

$2(\mathfrak{m}$ mädytigiten mus natürlid) bie Eefmiluft nad) greibeit,

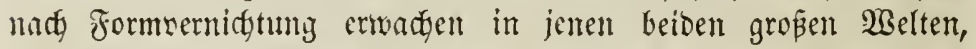
weldye bie (s)ewalt ber Edjwere voll einanber jern, in felbftänbigem, getremtem Dajein erfält, in Eome mo Erbe. F(udg in ifnent wohnt ja Der Trieb dez Rebens, unb Das Reben famn fich ja nur betfätigen in ewigen 2 nufbeben ber materiellen Exiftenj, im ervigen Bernidgten ber bejtehenden Formen. Dieje Rebensfraft erwadyt und mit iffr bie Afynmg son eintem gemeinjamen Banbe, bas fie un= fdjlingt. Wir entweilen ben Ramen nifft, went wir fagen, Riebe

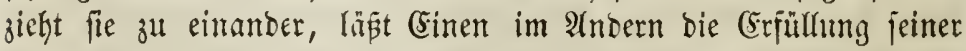
Boflenbung jehen. Ienn audy daz Eelynen ber Weitem nadt Bergeiftigumg zeigt fiø in bem Berlangen, mit einander zu ver=

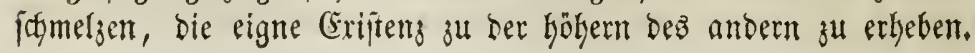


Mäątig brängt biejer Refenştrieb von imment heraus, unt bie ganje gerwaltige Majie erjittert bor biejem ftitrmiftsen Drange. Dả Eelnen fteigt empor auf Den $\mathfrak{B}$ ogen Dez Setherz, bie Materie wirb frei und fliegt einander von (Froe und Eomme her entgegen. Dody bem fliefentiden Ridfte eilt bie rettente $\mathfrak{B a r m e}$ nadd und bin=

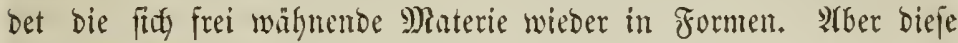
Formen find lofker, ätherifter, benn aud baz sidftht hat einent Sieg errungen, und bie Trophäen biejes Siegez, freilidy aud bie Mertzeidgen ber Mieberlage, füt bie attmofphären. In ignen ift bie Materie frei gemorden, aber wieber in Formen gefangen, unt

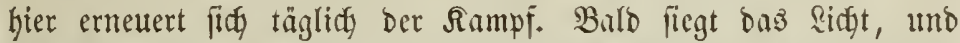

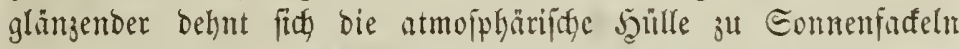

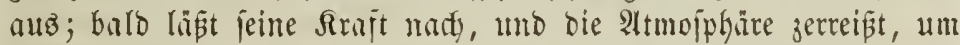
Dunfle Flecten deż Connentörpers zu zeigen. Wie ez aber bei irbi= foben Ridfterzengungen immer zwei Miaterien fimb, bie gegenjeitig ifre Unterifgiede ju vernidgten ftreben, fo erwadbt audf bier in Eonne und (Groe jugleidy bie Eefrijutt, bie fie zu cinander führt,

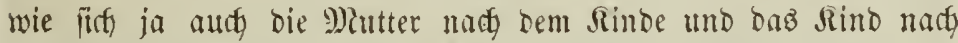

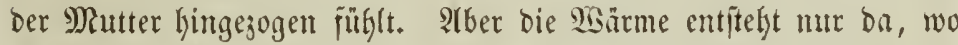
fie bie entfelielte Miaterie ju binden hat, aljo mur in Den $\mathfrak{A}$ tmo= fphären, über bie fie nidjt hinausgehen fann. Darum fam ber

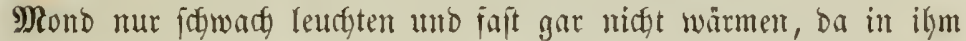

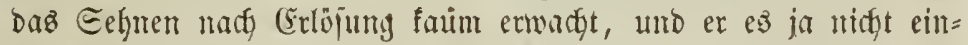
mal zur Bitdung einer eigentlicţen Atmojpgäre bringen fann. Die

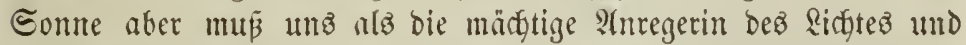

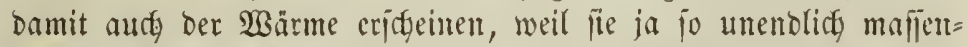
hafter alo unire (5roe ift, weil in ifre alfe Miaterie von ungleids ftärferen Banben zujammengelyalten ift. Darum mus andy in ilyr um fo ftärfer bic Rraft erwadten, weldye biejen 3ujammenfang ou löen fitrebt, um fo fräftiger baz Reben afle Theile eridjüttern unto felbjt ben 2 ether zittern madfen, um fo wirffamer freilid, alz ifyr eime gleid) innige, tiefe (Empfänglidfteit für biejen (Einfluz son ber (Eroe her begegnet.

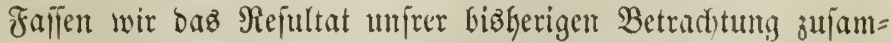

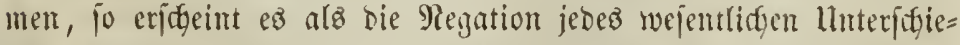

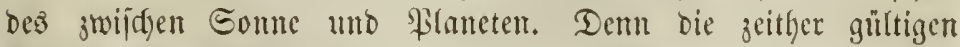
Senuzeitgen eintes (Eentrafförpers find unlyaltbar gemordent. Früher

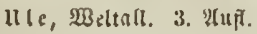


Fagte 'man wohl, Der Eentralförper oder bie Eonne fei Der fejte, ruthende $\mathfrak{3}$ elttéprper, um ben fich andere bewegen. Das geht heut nidft mefr, wo wir millen, ba a auch bie Eome, fo gut, wie bie

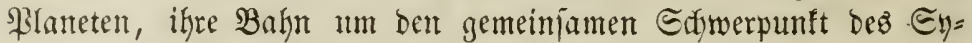
ftems bejđfreibt. Man jagte ferner, bas sidjt gebe eine Befitimmung für ben (Eentralförper ab; Denn biejer leudgte allein mit eignem, alle andern nur mit frembem, erborgtem Ridftc. Affrerbings fehen wir, Daß bie Mitplaneten unjer Eroe bunfel ericteinen, wem fie bie Sonne nidft erleuctetet, Das unire (Erbe ja jelbjt in Mactyt ge= Güllt wiro, went jene feklt. Die Fortfofritte unfrer neueren \$lygit haben unz jogar ein Mittel an bie Saand gegeben, um genalt ju

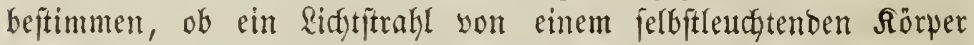
ummittelbar, ober erít vort andern zurüfgemorien zu unz fomme, ob er won fejten אörpern herrithe, ober burch flüifige und gaşför= mige gegangen jei. Diejes Mittel befteht in Den eigentlyümlidyen

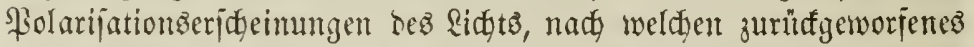
ober reflectirtes Sidjt polarifirt wiro, b. h. cigenthümlidge Farben=

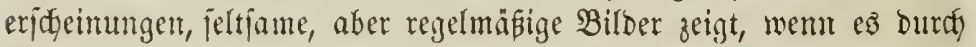
ein bünes Blättchen eines Mineralsa, 3. B. Dez Doppelipatbs, auf=

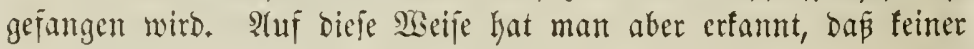

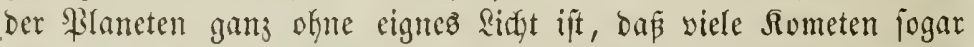

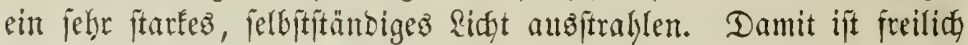

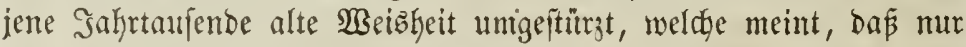
ron ber Sonne bas licht ausiftrahle. Dann müpte ia auch bie

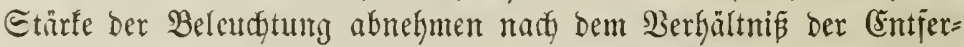
mungen, unb boch fehen wir grabe bie ferniten \$IIaneten, Supiter sor=

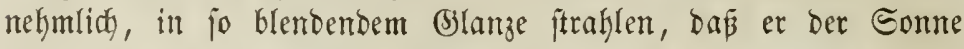

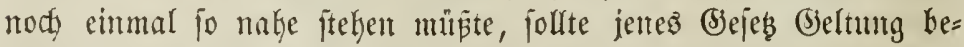

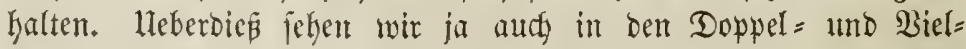
fternen Eonten um Eomnen freifen. Darum ift ber Unterjojied zwifaten Come und \$raneten fein nothwendiger. Ess fann im Weltraun Enjteme geben, in Denen es teine Altes bewegende und erleuctetende Esme giebt. Sll unferm Eyfteme ift allerbings ein

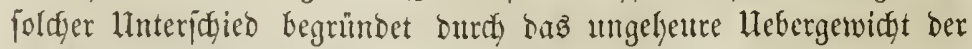
Mafie unirer Eonne über bie Brefammmajife alfer \$laneten, ver=

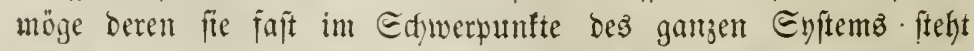
und einen gewaltigen (Sinflü auf bie ganıe Enttwifflung ber n̈brigen 


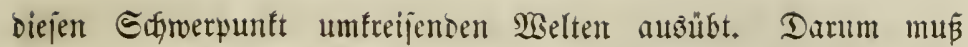

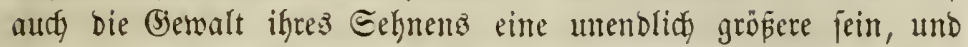

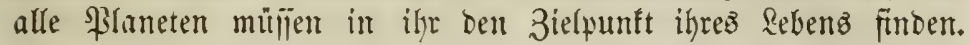

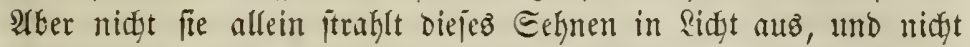

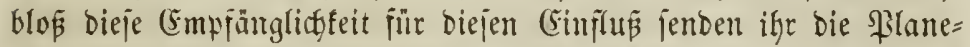
ten entgegen, fondern in jebem regt fity oafielbe Reben, jeber fitrebt

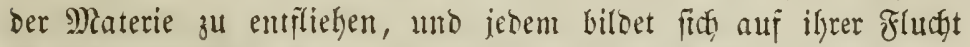

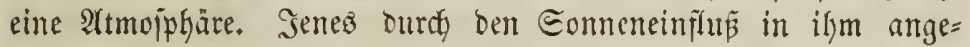
regte Ridft wirb uns als erborgteß, reffectirtes Ricfft zugelandot, bies yon ifm jelbit geborme wirb unmittelbar son unjer Erbe alo jelbjt= itünbiges mieberempjunten.

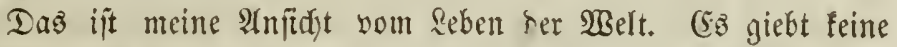
Connen, um berent rufbenden Mittelpunft fict bienende $\mathfrak{S e l t e n}$ be= megen, beren Etrablen Dumfle \$llaneten erlenditen uno erwärmen.

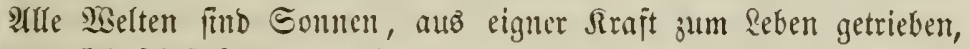

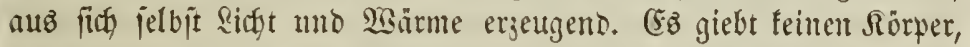
ber mur bie anbern an fich jöge, fondern jeber wird wieder gezogen,

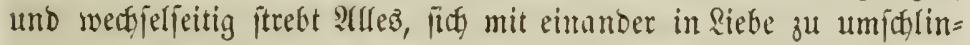
gen. Dort, wo wir bie Eonue im ruhenoen MRittefpunft wihnten,

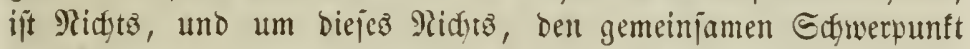
bez Enjtemts, freifen alle $\mathfrak{s e l t e n}$ in trauter Bemeinjofaft, Sonne,

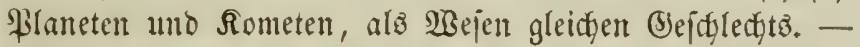

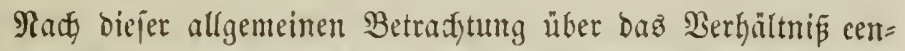

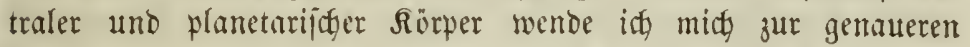

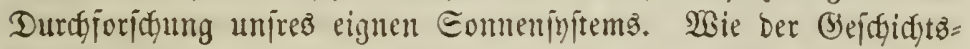

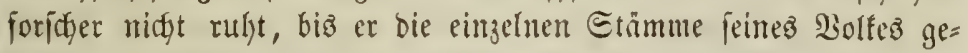
fonbert, nady Sharafter uno Eitte erfamnt, ihren atntheil an ber

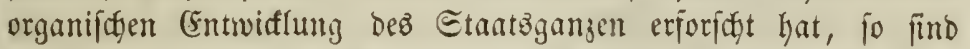
aude bie vielfadjen formen geballter Materie, bie unjer Sonnen= initem barbietet, nady Charafter und Sitte in Bruppen zu fondern.

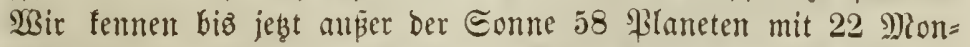

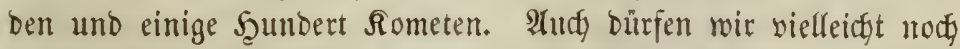

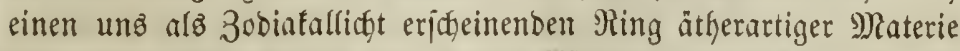

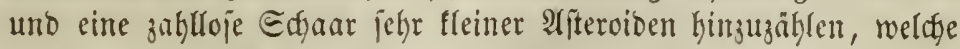
uns bišweilen bie Erijdeinungen von faltenten Eternjanuppen und Meteorjteinen barbieten. 


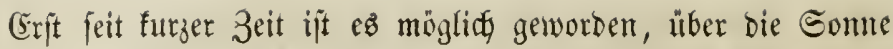
jelbjt unb ihre Maturbejdaffengeit aud mur bas bereits Mitgetbeilte zu erfahren. Beponters hat bie Beobadfung Der Enmenflecten, Die befanntlich um bas Sagh 1610 von bem frieliifden Siftronomen Solann Fabricius entbeft murben, ber zugleidy aus biejer Beobadt)=

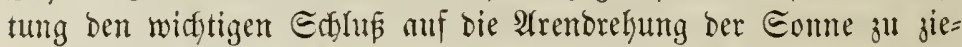

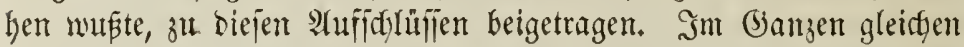
bie Eommenfleften Definmungen, wie fie fint bei unz bismeilen in

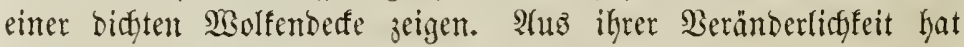
man baber auf äbnlidfe Särjte und Bebingungen in ber Somnen=

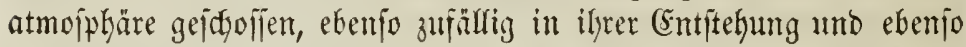
mädftig in ifren \$Birfungen, wie bei umb. Folgt man ber befann=

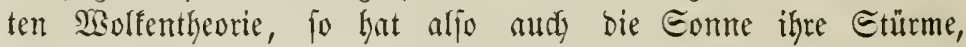
wem $\mathfrak{B}_{0}$ rgänge, bie in wenigen Tagen eine Etreffe won 10-12000 Meilen im Durdymeifer von Sidftgewölf entblöpen, wie man ez öfters an ber Eonnenoberfialde beobactytet hat, mit biejem Samen

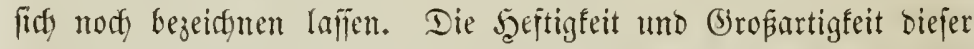
Etürme übertrifitt jedenfallz alfe ähnlident irdifđen ßorgänge. Stber in ifrer Uneejtänbigfeit, in ifren Edfwantungen tragen fie gan

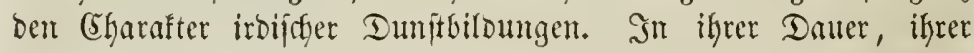

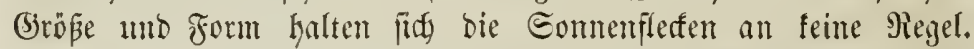

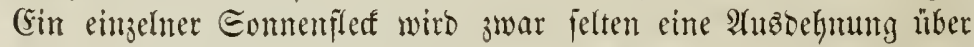
meyr als 12000 Meilen ereeiden; aber (Srappen von Eomenfle=

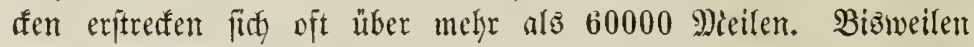
baures joldge Entblößungen nur wenige $\mathfrak{T}_{\mathrm{g} e}$, Dann wieber meh= rere Monate. Eeltamer $2 B$ eije jeigen fid bie Eomenflecten vor= zunglidy in zwei 3onen zu beiben Eeiten des Aequatorz, in biefem jelbjt bagegen jelten uno niemalż an ben \$olen, überlsupt nicft jenfeitz des $35^{0}$ nöroblidger und jüblictyer Breite; withrento body

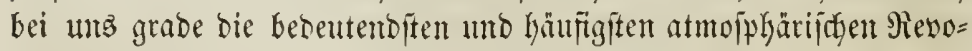
futionen aukerbalb ber heipen Zone anzutreffen fint.

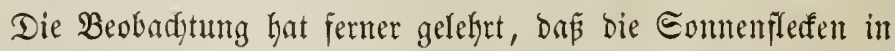

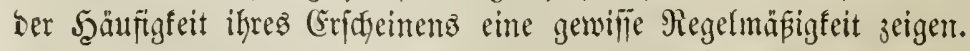

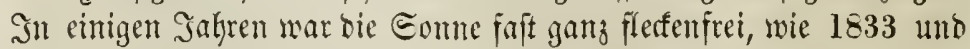
1843, bie 3ahl ber Flecten nalkm allunălig ju, Gis fie, wie 1837 unt 1847, ifr Marimum erreitfit hatte unb wieber abnatgm, um 
cin abermaliges Minimum in ber erften Şălfte dez Sahtę 1856 zu finben. F(us einer porgfältigen Bergleidung ber biskerigest

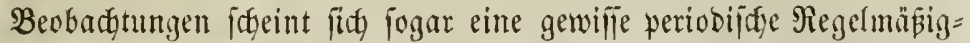
feit ber Eounemflefen zu ergeben. Die am auffallenditen lectsor=

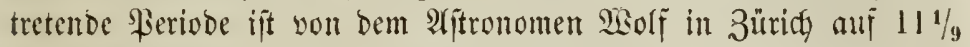
Sulgr Feftgeftellt, und bie nahe llebereinftimmung biefer Perivoe nit ber llmlaufszeet bes Supiter, wie einer andern fürzeren mit dom

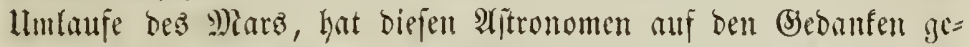

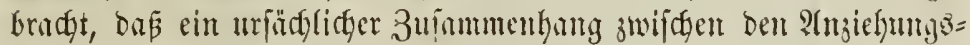
mirfungen ber \$ilaneten unto ber Biloung ber Eomenflecte beftelyen

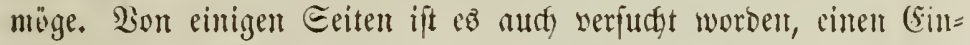

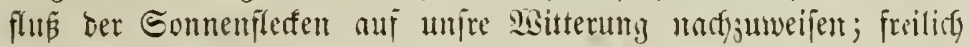

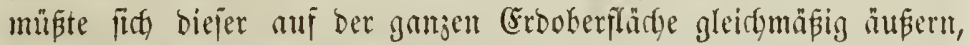
ba cin ferter Şinmedstörper nictit lofale Esinwirfungen geftattet. In einer Bejiefung idfeint aflerbings bie neuere Foridjung cintu

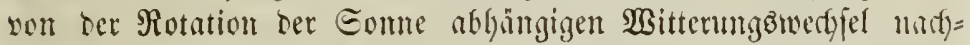

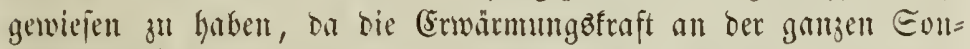

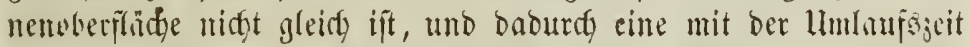
der Eomme zufammenfaflende Beriobe unirer Temperatur bebingt.

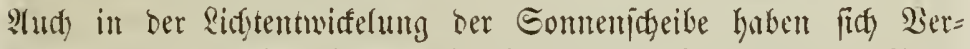
fajiebenfeiten gezcigt, intom bie Mitte mehr Ridgt als ber 9ianto

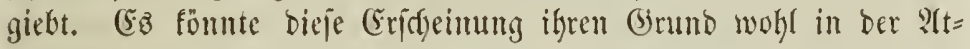
mofplyäre ber Eonme haben, bie man in ju 400 Meilen Şöhe an=

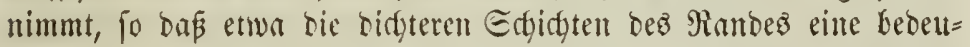
tendere Scfwädyung Dez Sidjtez herworbridjten, als bie ber Mitte.

WBir gefen intoefien vou ber Eonme über zu ber Betradjung

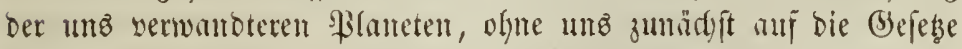
einzulafien, weldye ilye Bafuen und llmlaupsiciten beftimmen.

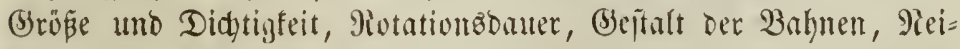

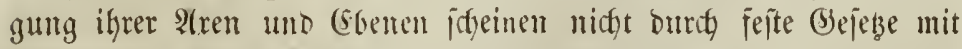

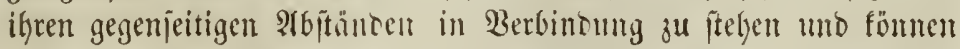
unz baher bier wenig Sintereile Darbieten. Daż fint Thatfachen 
Der Ratur, Kervorgegangen vielleidyt auż Dem Conflicte vielfacher, einit unter unbefaunten Bebingungen wirfender Rräfate. Zưâallig

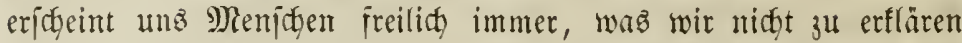
vermögen. Denn gewí haben audh hier Maflennngiefungen uno

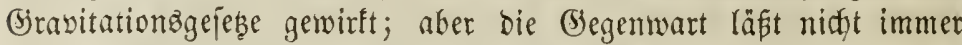
mit Eidgerfeit auf ben ganzen \&auf ber Bergangenteit ídhlię̧en. Darum wollen wir umb hier mur mit bem Kejđäftigen, was fleipige

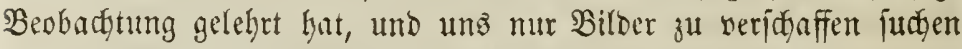

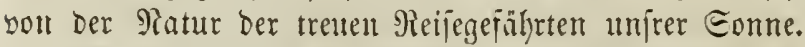

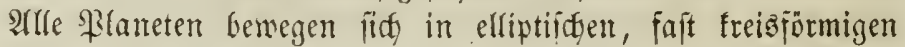

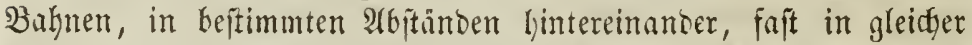
SGbene um ben Centralpunft unjres Eyjtems. Atle haben eine

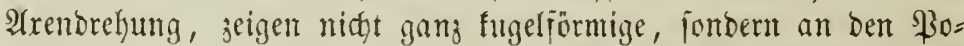

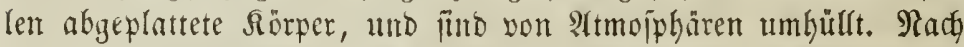
ihren darafterijtijden Beridgedentheiten jondern wir fie in 3 Gruppen.

Die erĩte bilden jette 4 ber Eonne zunädjift ftehenden, unfrer

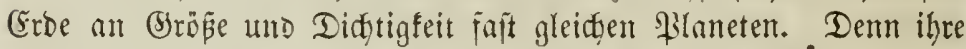

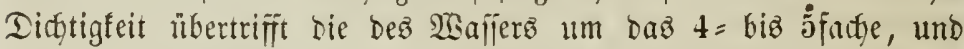
aud) ihre Tageblänge ift faft bei allen gleid, hödfftens um 40

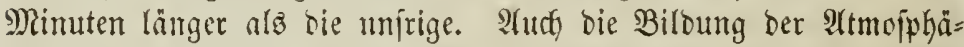
ren biejer \$Hlaneten hat viel llebereinjitimmenbes mit ber unjer Eroe uno mit ifgrem Raturberbaltniffen. Dort wie hier ftrahlt fie das Ridgt ber Dämmerung jutruf, and bort wirb fie von $\mathfrak{B i n b e n}$

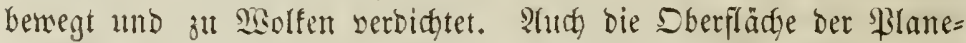
ten icheint mie bie Der (Erthe eine gebirgige Form zu bahen, unt

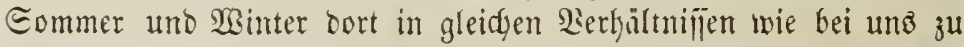

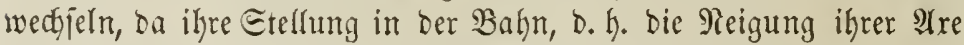
auf Der Ëbene ber $\mathfrak{B a h n}$, ganz übereinftimmend gefunden wirb.

Derienige son biejen 4 Planeten, welder ber Eonme am

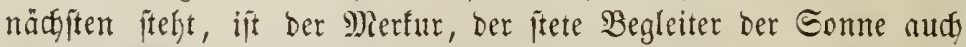
am fđeinbaren 5̧immelägemölbe, ber unş nher ethen Darum immer mut furs yor Eonnenarfgang uno furz nady Eonnenuntergang firfyt= bar ift, uno bennod mitter in ber kellen Dämmerung bem auf= merfiamen $\mathfrak{A}$ uge burd) fein flarez demantartiges eicht auffälut.

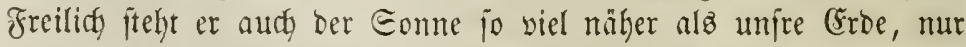
8 Millionen Meilen im Mittel von ifr entfernt, fo ba je feinem

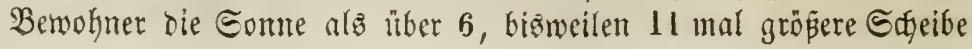




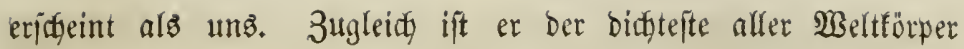
unferş Enjtems, über $7 \mathrm{mal}$ biçter als $\mathfrak{B a}$ afier. Eeine Etellumg

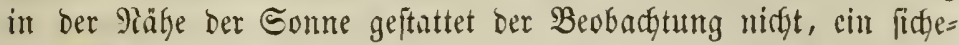
reв Bild von feiner Dberfläfe zu gewimnen. Wenn baljer Edyrö= ter feinen Bergen bie zu jeinem Durcfmefijer von 671 Meilen tm=

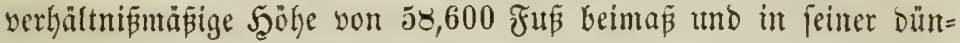

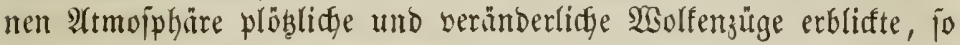
berufft bas wohl auf einter jehr lebenbigen \$shantafte.

Diejem zunädjit, 15 9)till. Mieilen von ber Eonne entfernt,

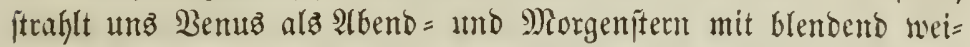
fem Ridjte entgegen. Sft verburfelt fie alle Eterne bes Şimmelo und läpt bie von ifr Gelendjetent Gegenfitände ber Eroe Edautten merfen. atber midft immer leudgtet fie is hell. Demn fie jowohl wie Merfur ftefen zwifden unz unt ber Somne, umb werbent baher nidit inmer von biefer ganz belendfet. Darum erfigeinen fie uns, wie ber Mono, bald alz vollerteutctete Edjeibe, bald alz zarte Eidyel, Gald wentent fie unș, wie Der Reumono, ifre unbelendftete

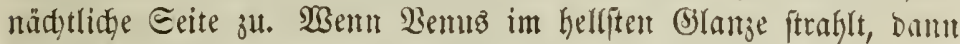
ift ile bismeilen, wie in ben Jahrent 1716, 1750, 1794 unt im Mrai unt Şuni bes Sahres 1852 am hellen Tage fitgtbar. Hoer

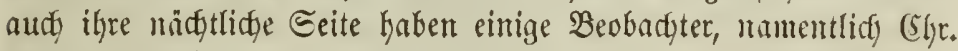
Mayer utno Scarbing, in einem eigenthümfidfen, ajdy farbenten Ridjte

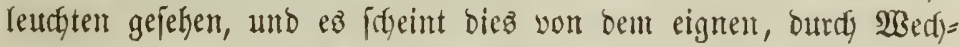

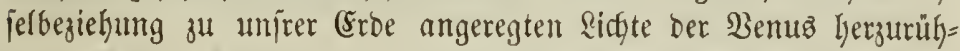

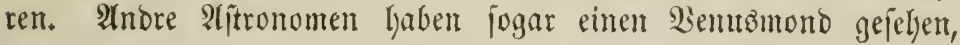
Der aber jebenfalla in midytz meiter als einer Eeitenabipiegelung

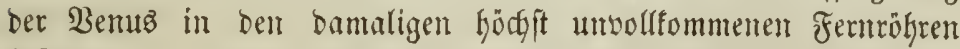
beftant.

In Der Größe und Didftigfeit fommt bie Betms urirer Eroe faft ganz gleidy, Denn ifgr Durrdymeifer beträgt 1717 Mieilen, uno

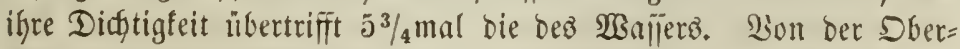
flädge berfélben willen wir aber nod) felyr menig. Eelten ift ez ge:

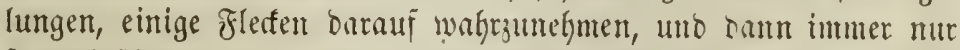

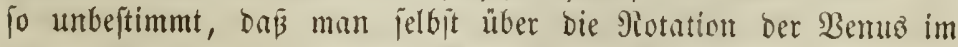
Ungemiffen blieb. Sisibrent Cafini ilgre Tageblänge auf $23 \%$

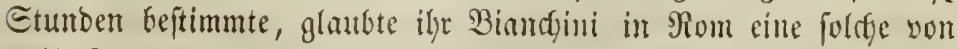

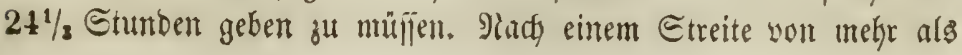


andertfalb Sithrhunderten wurbe erft in ben Safren $1840-42$ Durab Die Beobactumgen son be Bico Die Rotation auf 23 Sto.

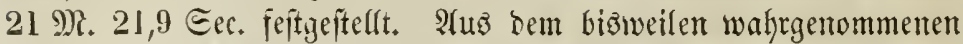
feingejühnten 2njehen ber Rictgrenje ber Benus in ifren Bierteln ober iffer Şorngeitalt läpt fith aud auf gebirgige Unebenheiten

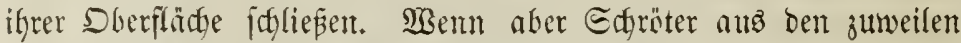

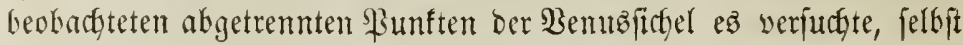
bie Şöhe ber Bentsoberge zu beftimmen, uno fie auj 5 beutiche Meilen angab, to ijt das eben nidyts als ein Epiel ber \$hantafie

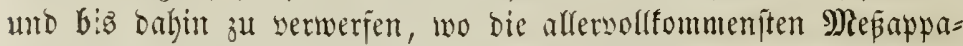

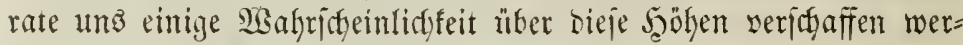
ben. Son $\mathfrak{B o l f e n}$ uno 2 tmophtäre wifien wir eben fo wenig uno müilien ums wohl hüten, anders als mit ber gröften Borfidyt umb Behutfamteit aus Beobadtungen Edylüfie anf bie Patur non Şim= melśförpern ju zielgen.

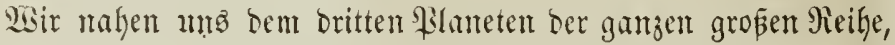

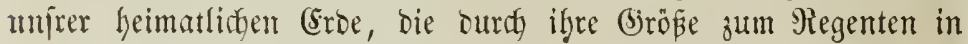

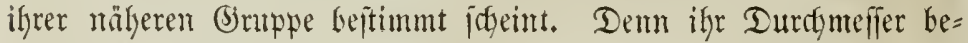
trägt 1719 s)eilen. Sie allein genieft auth Das Borredft, fich Durdy einten Mono auf iffer einfamen Reife begleiten zu lafjen.

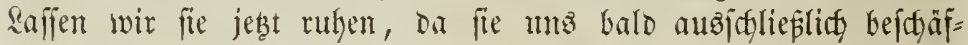
tigen wirt.

Der leste Flanet in Der angenommenen (Sruppe ijt Der Mars, 32 Millionen Meilen wou ber Eonne enternt, aber nur 892 9)ei= len im Durtymejier, aljo fleiner ala umire Eroe. Durdy feinte Beobarbtumg gelang es zuerit im Sabre 1735 ben Aftronomen Sacaille am Sap Der guten Şoffunng und $2 B a r j e n t i n$ in Stodfyolm, die Eommenparallare und baburdy aud bic (sntfermung ber Eomne von uns amäherno zu 17 Millionen Meilen zu bejtimmen. Durch

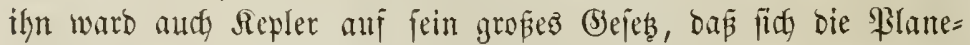
ten in elliptifdyen Babnen bewegen, gefüfrt. Er erickeint unz faft

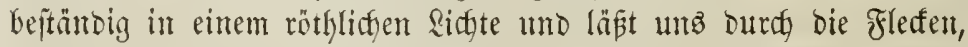
bie er in guten Ferntobren zeigt, anth einige Ectliffe auf feinte

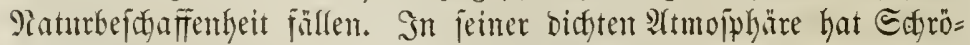
ter eime ber unjrigen ägnlidge Wolfenbilbung uno mit ähnlidger (Se=

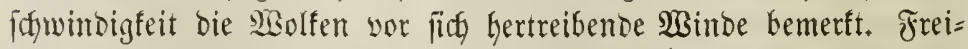
lich hat bas nur Edbröter gejehen, uno ber keutige ajtronom weiß 
wohl, bá er nur unter aukerorbentlicfent Umitänoen foldhe atmo=

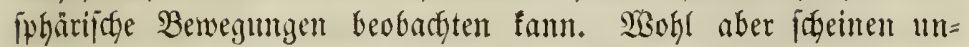

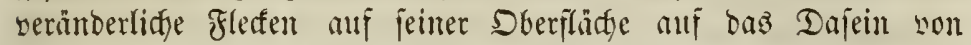
zefitand und sieeren binjubeuten, uno bejonbers zwei weibe, hell=

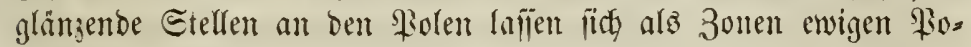

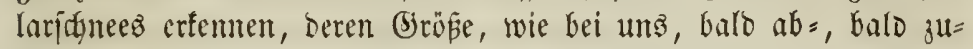

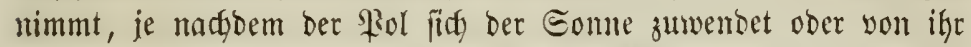

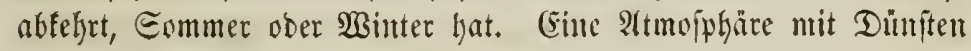

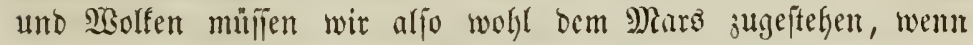

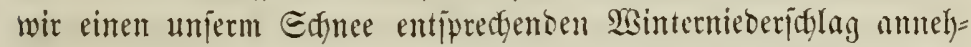

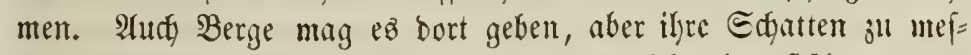
fen, werben wir nidft vermögen, wemt fie nidft eine Sgöhe von 20

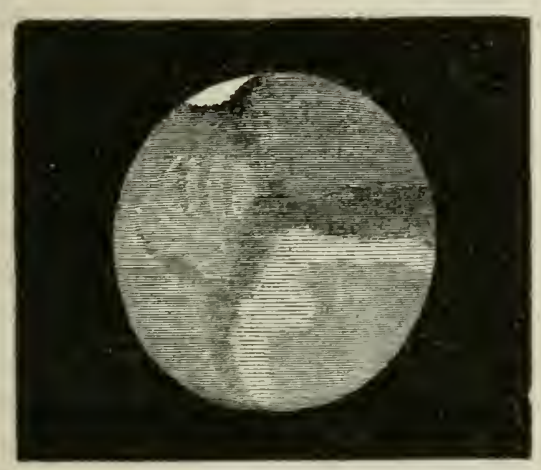

unt unchr Meilen befiken. Die keiftethende arbilloung jeigt ung bie Marzober= flädye, wie fie burdy ong zernrolyr bem Beobadter erifteint.

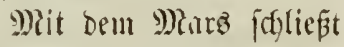
fird) num sie Pieilye jenter Pilanten, weldge in allen ihren Raturverbältmiflem aum nüdjten mit unfrer Sroe verwand fint ; und inbem twir bie Gromppe von 50 und vielfeidyt mehr fonderbaren fleinen Plameten einftweilen überipringen, wendent wir unz jenter ber 4 fonnenfernen \$lanteten zu.

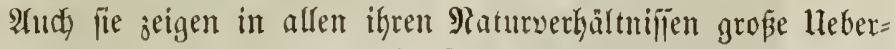

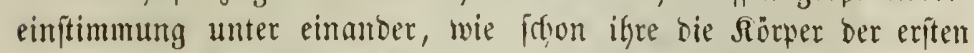

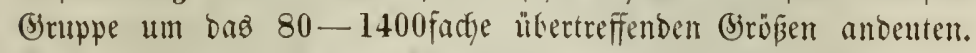

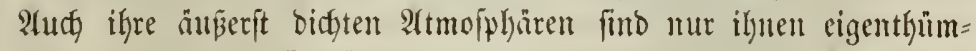

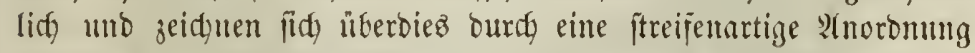

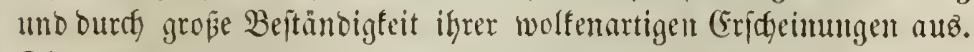

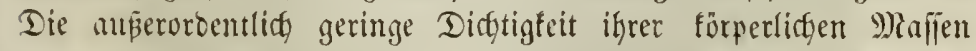
aber erinnert unż bei alfen an einen faft flüjiligen 3ujtano, ber um fo

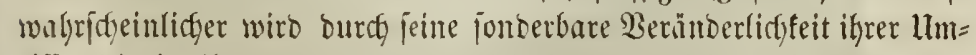
riffe, bie in iffer großen, aber nidgt immer gleidgen 2foplattung an 
ifren Folen bemerft wirb. Auperben babe idy fayon bie auker=

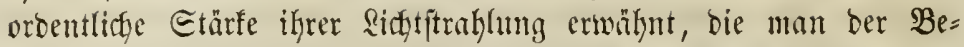

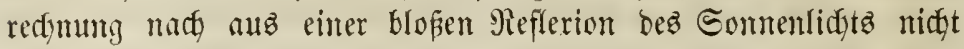
erflären fonnte, umb bie balyer anf eine ganz befonbre, freilidy un=

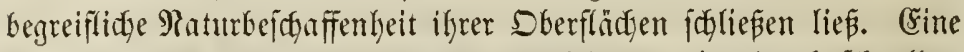
zaflecidge Begleitung son Mionden enblid) und einte burdy fifnellere 2rembrehung bewirfte, faum halb fo lange Tagezlänge, als auf

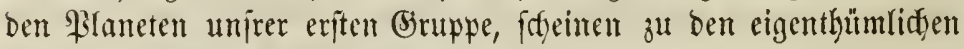
Borreçten jener Piejemplaneten 孔u gehören.

Der vornefyite unter ifhen mo ber Sonne am nädjiften fte= hente ift Iupiter, freilify fdon über 108 Mitr. Mieilen son ber

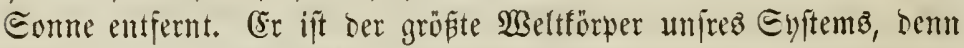
jein mittlerer Durdymefier beträgt 19270 Meilen, umo feime Mafie nllein ḧberwiegt bie Majfen aller übrigen \$laneten zufanmen noch um bas 3fadfe unb fommt bem 104siten Theile ber Eonneumafie

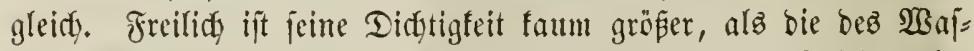
jerż, 4 biz 5 mal geringer alz bie ber Eroe, und entipridyt bafer an ber Dberflädye, ba er nady innen bidjter wirb, ungefähr bem

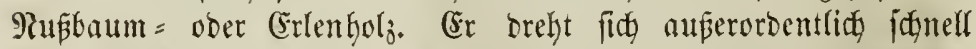
um jeine $\mathfrak{A r e}$, in 9 Etb. 55' $26^{\prime \prime}$ unt hat beshalb bie bebentente Abplattung bon $\frac{1}{17}$ jeiner $\mathfrak{A r e}$. Seine auperorbentlidy bidfte $\mathfrak{A} \mathrm{t}=$

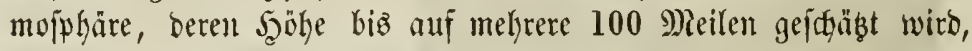
zeigt uns bie jonberbarîten Ěricteinungen. Die beiftehente $\mathfrak{a}$ (bbil=

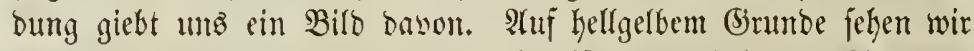
zahlreidge graue ober grautbrame Etreifen paralfel dem Alequator

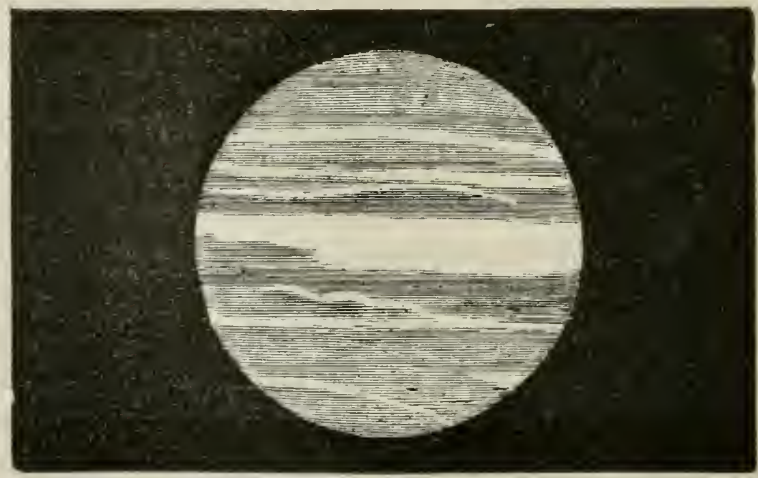




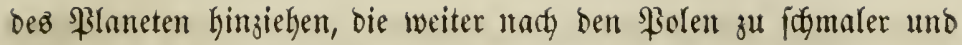
Inatter werben uno endich in ein mattes bleifarbenez, zuweilen auth) noch geftreifteo Grou übergehen. Die mittleren Streifen änoern fich oft, werden matter unb heller, nehmen zu unb ab und zeigen

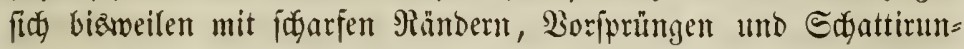
gen. Eimzelme helle Fleffen treten unter ifnen herwor, bie bald plöglicy verfdwinden, balo wieber erideinen uno oft eine auper= orbentlich idnelle Bewegung zeigen. Wahridgeinlich find bie Strei= fen Bolfentaufen uno Bolfenjonen ber Aftmojphäre, bie fith bei Der bebeutenden Ränge und ber burdh bie geringe Aremneigung be= bingten Unveränderlidgfeit ber Sabresijeiten viel beftändiger zeigen

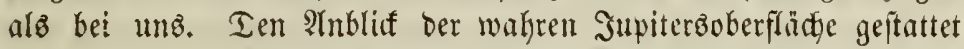

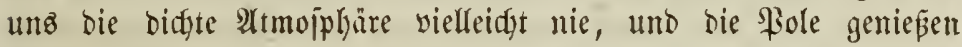
wohl aud nie einen heitern Szimmel, her felbit ben hlbrigen Segen= ben nur unvolltommen ju Theil werben mag. Dagegen follen

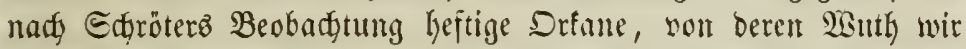
teine Begriffe mehr haben, biomeilen bie SBoltennafien bewegen.

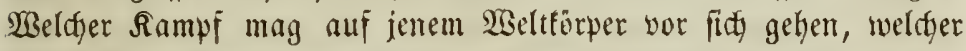
(5ntwidflung iffreitet er nod entigegen, und meldyez Reben farm bort gedeifen, wo bie Materie jelbit nod) jut teiner ruffigen Bejonnen= heit gelangt ift? Bon ben vier Monben, weldse ifn begleiten, wol= len wir fpäter fpredyen.

Wir fonmen jebst 孔u bem feltjamiten aller \$laneten, zum $\mathcal{S}_{\mathfrak{a}}=$ turn, ber, fait fo großj alo Supiter - temn fein mittlerer Durdf)= meffer betrïjt 15,769 \$leilen - , fron 197\% Millionen Mleilen

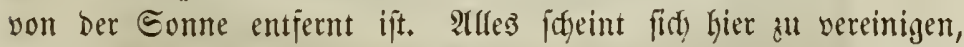
um unjer Etaumen rege zu marben. Eeine Didftigfeit ift faum

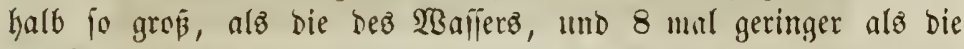

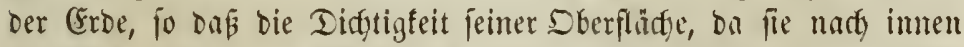

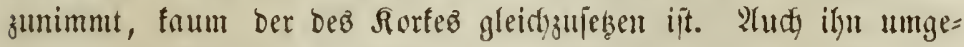
beu graue Etreijen, bie nuth bell Folent zu matter werden, unb

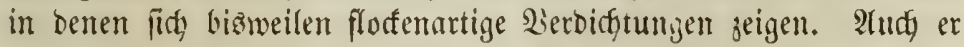
idgeint aljo eine auperorbentlid, bidfte und in ifren 1 Bolfenbiloun=

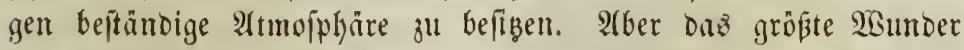
Des Eaturn bleibt fein Ping, ber unz gleity jam alz eine unbollen=

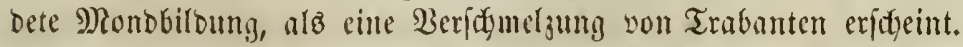
Und Dody bejizt Der Gaturn liberbies nody 8 Monbe! Diejer Ming 
wurbe zuerfit sou Repler 1612 bemerft, aber erfít won Scuyghens 1660 als foldyer erfannt; Serfdel endidy beobadytete ifn genauer uno fand ifn als Doppetring mit vielfadyen Streifen. So fegwebt aljo ringz um ben Rörper bes Gaturn zunäbjit ein 3733 Meilen

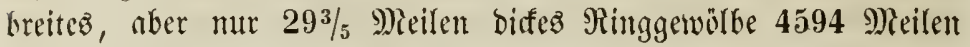
von feiner Dberflärthe entfernt; bann folgt in einem 3wifhenraume won 387 Meilen ber nur 1927 Meilen breite äupere, walyrjdjeinlidy

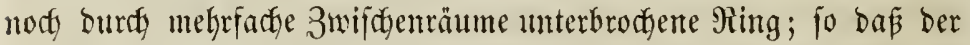

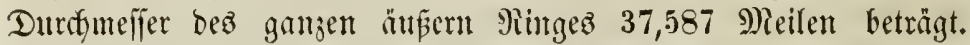

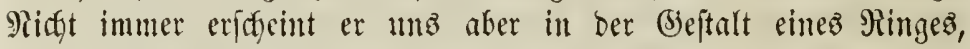
ba er ja mit bem Caturn fidf um feine Ire breht, und mit işm in feiner Bahn um bie Eonte fortriaft. Deshalb zeigt er unz

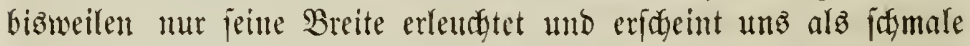

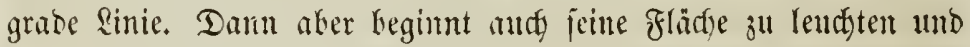

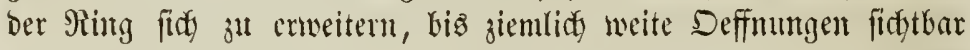
werben. Diez wieberfolt fits etwa in Beitrïumen won 15 Sahren, natïrlich 2 mal in feiner gantzen Uumlaufzzeit um bie Eonne, weldye 29 Sakre und 166 Tage bautert. Sie aber erfdeint er unz

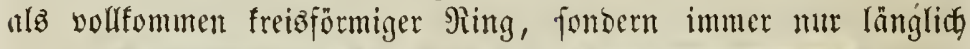

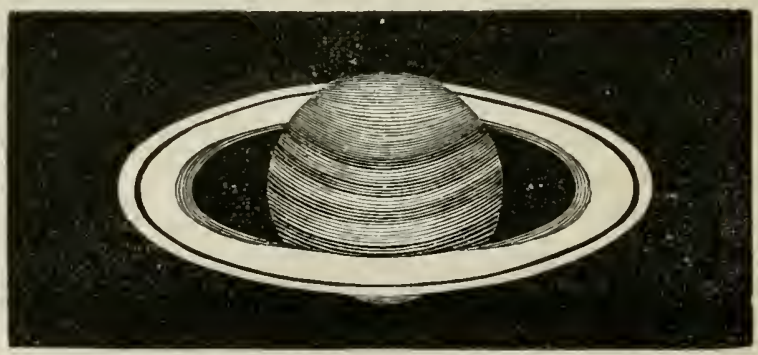

Into fdyief won ber Sonne beleuthtet, fo baj ein Theil burdy ben Edjatten bes Gaturn berbunfelt wirb. Alber er felbift befdyattet auth ben Gaturn, und jahrelang verbreitet er bort über ungeheure

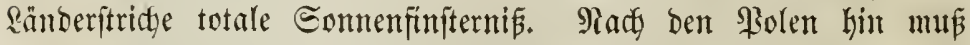
biejer ßing Den Bewohnern bez Gaturn ganz umfteftbar bleilen, in nttoern Begenden aber alz ein (jürtel yon ber boppelten Breite unferş Bollmontos rings ım den Şorizont fafweben. Die granten Etreifon, weldye man auf feiner Dberfläche erblict, rühren wahr= fateinlich vou Fluthwellen her, bie bort in ben flutifigen Maflen 


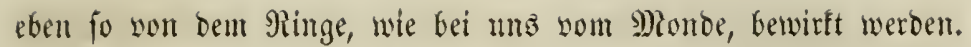
Die Plbbildung jeigt ben Eaturn mit jeinem Minge. WSie ber ভa=

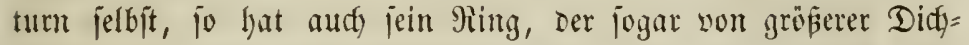

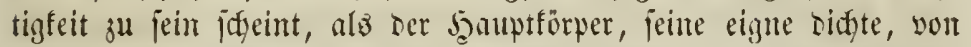

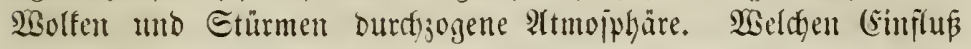

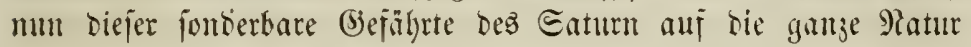
peiner Sberfiădfe, auj (Erleudjtung uno Erwärmutg haben mag,

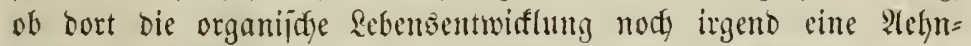
lidffeit mit unjer irsijgen haben fanm, bas find Miathjel, welde

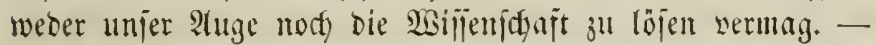

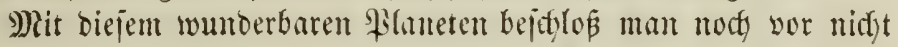
gar langer Zeit bie MReife Der 2 Selttörper unjerz Eyjtemz, Deren man aljo mur 6 fannte. Da erweiterte Syerichel am 13. Whär

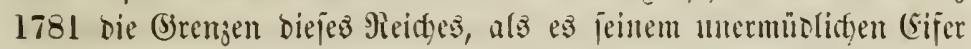

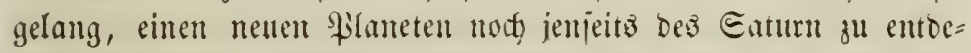
fen, bem er Den Pamen Uranus gab. Bereitß $396 \% \frac{1}{2}$ Mitlionen Meilen von ber Eonme entfernt, ift er ber fleinjte in ser (Sruppe biejer jonnenjernen riejenplantetn, Demt fein Durdfmejier beträgt mur 7466 Meilen. Ał Sonderbarfeiten liberbietet ar aber faft

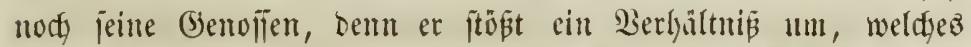
fomit allgemein gilt, und wonady die (Ébene des Hequators der \$laneten nur wentig von Der (Sbene ifter Bafynen abweidyt. Beim

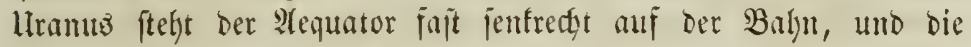

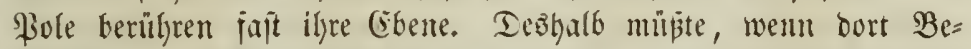
leudftung unt (Erwärmung eben fo von ber Eonne abjängig wäre,

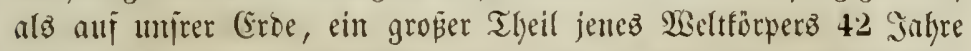

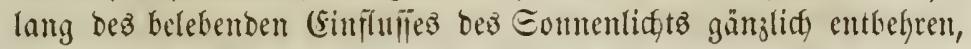

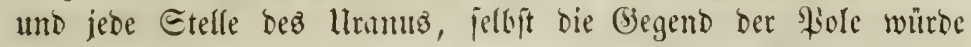
wenigitenz einmal in bem 84 Erdenjalge Dauernben Urambsabre

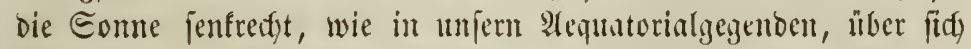
jethen jehen. Semís läpt jidy wenigitenz feine gerechtere Bertheis

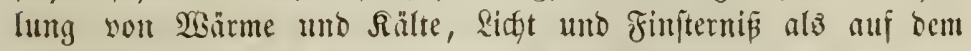

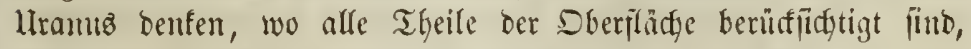

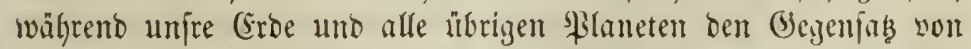
begünítigten uno völlig verwaryelojen 3onen zeigen. Daß̉ aber

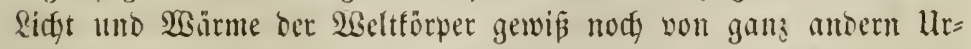
fadyen lyernilyren, als von ihrer Entfernung son ber Eonne uno 
iffrer Etellung gegen biejelbe, baß ifre Entwidfung vielmebr in Der

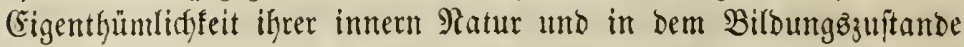

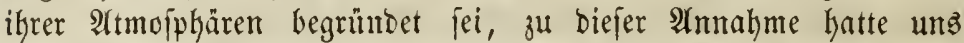

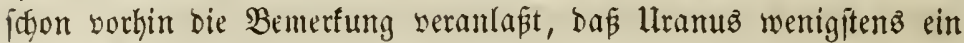
4 mal helleres \&idjt auşitrahlt, als ifm von ber fernen Eonme ju= gejanbt werben fanm. Ianit ftimmt audg wieber bie auferorbent= likge Didftigfeit jeiner Atmojphäre liberein, meldye bie bes Intiter unb Eaturn nod übertrifft. Bon ben adyt Monden, weldge audy ifn unfreijen, foll jpäter bie Rebe pein.

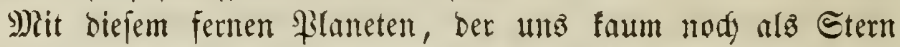

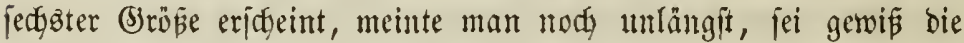
3ahl biefer Welttörper wollendet; ę jei bent, baß bie Sraft ber Jernröhre eimunal bis inz llnerhörte gefteigert werbe, fönme man ja einen netten Slaneten, aud sem er ba märe, nidft auffinden. Die ipectlative Paturphilojoplie bemies jogar, baj es feinent meuen Silaneten mekr gebe. Der aftronom bat anders geurtheilt, er hat

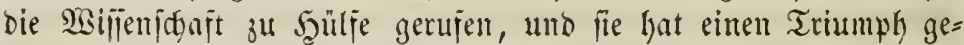

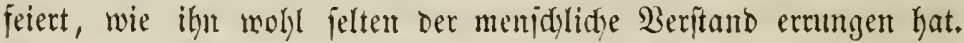
Die unbebeutenden Untegelmäpigfeiten in ber Bemegung Des llra=

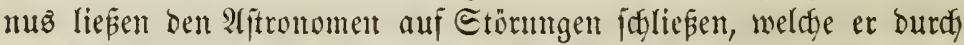
bie Anjiehung eines nody unbetannten benadybarten \&laneten erlitt.

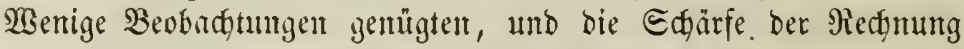
entwarf mun mit untrỉglidger (Sieniéfheit bie ganze Bahn biejez noch

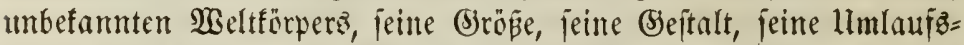

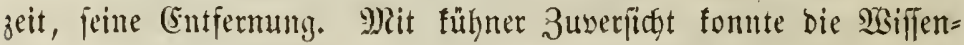
idgaft heraustreten und ber Welt zurtien: Deffnet ente Augen,

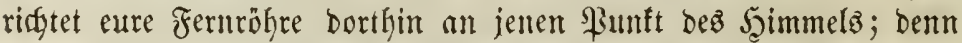
Dort wird in einem beftimmten 9 ?oment ein neuer Slanet fid) euren Blifen entlyullen! Man offnete bie Afugen, uno ber Planet ftand ba. Rewerrier war eş, ber bieje fühne Beredgmung unternalyn und

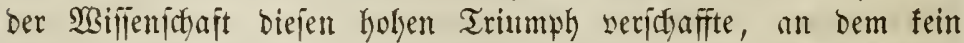
3ufall, jelbjt faum bie Berbefierung Der Snftrumente cinen Antheil hatte. 3war hatte idyon 7 Monate frilyer ein junger englijher

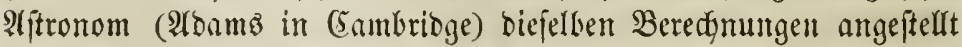
und war zut bempelben গejultat gelangt; aber er hatte in allzugro= Ber Bejteibenteit gejdmiegen oder body nur $\mathfrak{W e n i g e n}$ jeinen Fund mitgetheilt, uno io ift ifgm severrier juvorgetommen uno hat ifm 
Dent wohlwerbienten Rorbeer entriffen. Severrier beridjtete am 31 . Augujt 1846 das Ergebnip jeiner Etudien an bie Berliner Ajtro= nomen Enfe und Balle, welde im Beft'ber ausagezeidnneten Ber= liner atabemijajen Eternfarten waren, und mit $\mathfrak{5 y i l l f e ~ b i e j e r ~ f a n d ~}$ Balle iffon in ber eriften Madft am 23. Eeptember 1846 alle jene

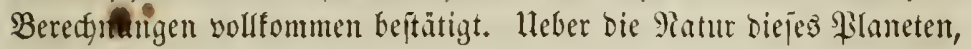
Den man Reptun genumnt hat, Gat wegen ber aüerorbentlidjen (Gint= Fernung wou 62.2 Millionen Wieilen aud bie Beobadtung Der

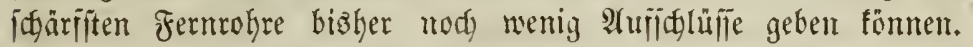

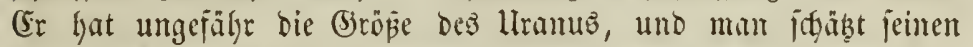
Durdymeñer auf 3700 biz 8400 Meilen. (Er ijt jwar viel bidfter

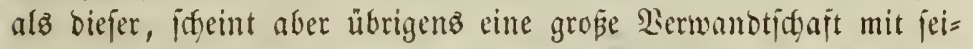

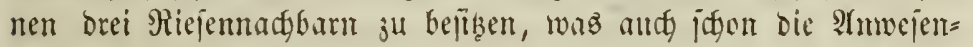

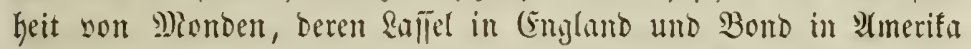
bereita einen mit Eidjerbeit entseft haben, andeutet. Beibe wollent

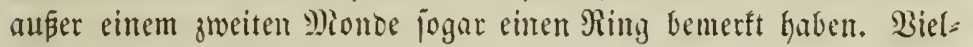

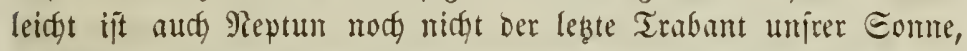

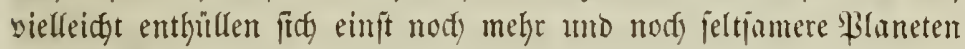
unjerm 2Auge; Denn bie 2 sumberbarfeit und Frembartigfeit jojeint mit ber Entjermung wenigitenz nidjt abjunefymen.

WGir haben mun mod cine Gruppe von planetarifden $\operatorname{Sörpern}$

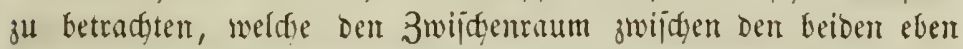

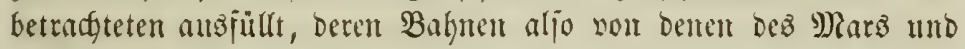
Dez Supiter eintgeifflofien werbent. Şier hat fidh erît in neuejter

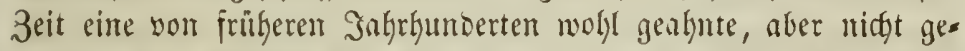

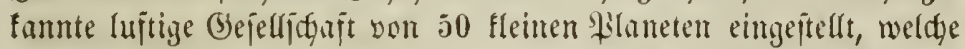

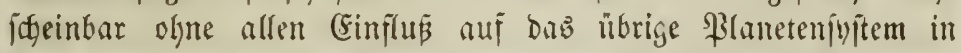

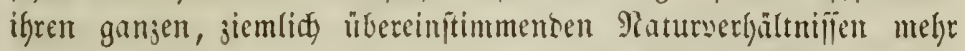
an bas Bejejlectyt ber Rometen, als an eigentlidje \$laneten erin= nern. Man fat liee baher audy mit bem gemeimjamen Ramen ber

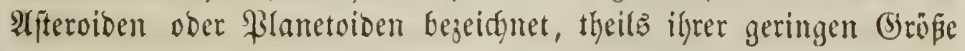
wegen, theils weil pie wirflidt ein Berbinoungosglied zwifden Pila= neter und Someten zu bilden idfeinen. Plads ifferm mar wenig veridjiedenen abjtande von ber Eome, Der im allgemeinen 46-67 Millionen Meilen betright, ftehen fie etwa in Folgenoer Pieilge zwi= iden Mars unb Supiter:

Flora, Santmonia, Melpomene, Bictoria, Euterpe, Befta, 


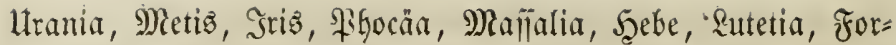

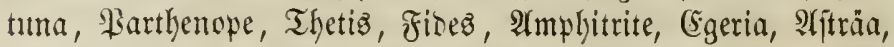
Pomona, Irene, Thalia, Sunomia, \$rojerpina, Sirce, Suno,

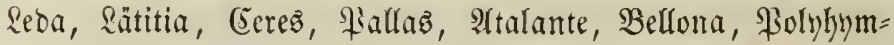

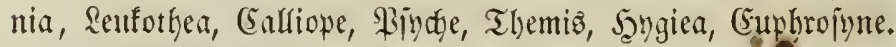
Die zuleşt entbeften \$ilanteten fino zum Theil nody nidyt himeidgeno beobadytet, um mit Eidjerfeit ȟter ifre Etellung in biejer Reihe entidgeiden zu fömen. Dody idgeint Yriabne, der erife ber im Jahre 1857 entbeften \$ilanetoiben, ber Eonme am nädujten, aljo nody zmijden Flora uno Mars zu jethen.

Mit ifren unter fid rerjiflungenen, langgeftreften Babnen eriddeinen bieje zwergartig fleinen siseltfürper auj ben erften Bliff wie sermaifte Monbe, bie verlafien ron einem feiten $\mathfrak{B}$ Biflen, ber jie führe, weit alifdweifen hiber unt unter ber Gbene aller übrigen Planetenbahnen, auj Eeitempjaben, welde jonjt nur son bem feidttfertigen $B_{0}$ lf Der Rometen eingeithlagen werben. Demnodh fint alle bieje fürfitlidy veridflungenen Babnen jo gelegen, Dá jie fich

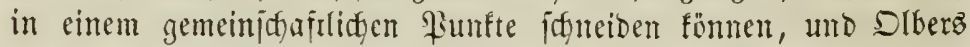
judfte jogar burdf Beredfun ein 3ujammentreffen jener gejdjwifter=

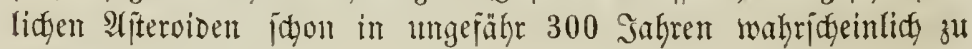
madien.

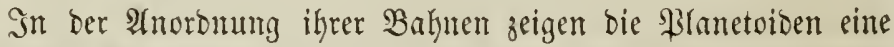
wejentlitge Abweidfung von allem bişer in ber Planetenoronumg Beobadjeten. Eie fint nidjt mie bie ber \$laneten in veridjiebenen

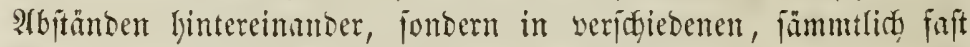

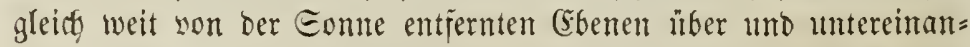

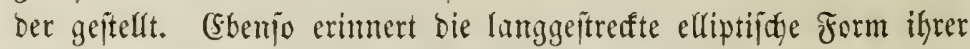

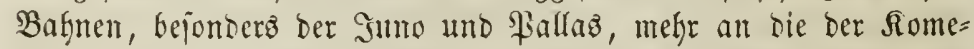
ten, alz an bie fajt freiø̄örmigen Balynen jümmtliçer Planeten. Man glaubte früher aud, Daß̄ fie eine unverhältniß̄mäpig große

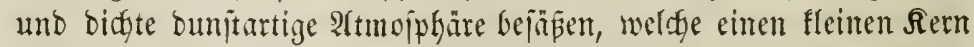

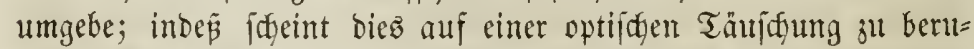

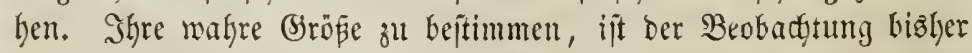

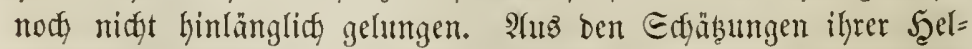

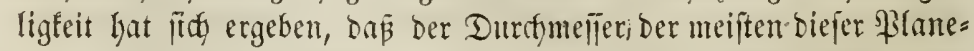
toiben nody nidyt 60 Mreilen erreidt, bei einigen mohl famm 8 bis 9 Meilen überjteigt. Die $\mathfrak{A} n g a b e n$ \&amont's uno andrer afitronoment, 


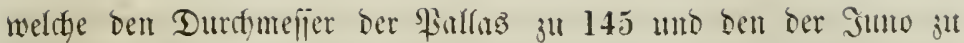

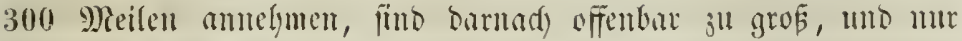

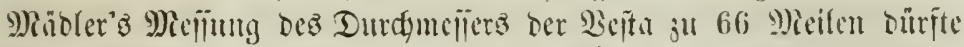

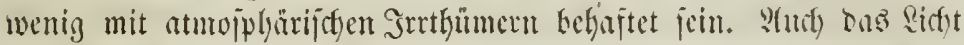

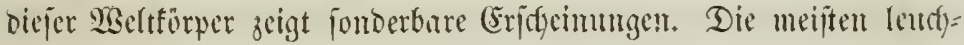

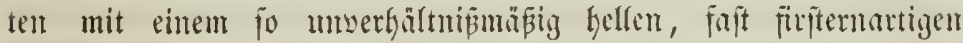

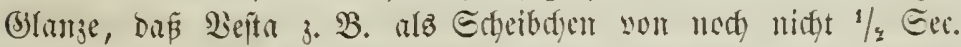

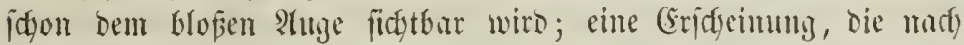

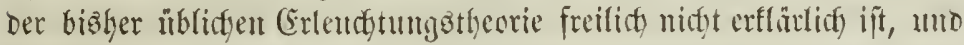
fintr bie man cin planetarijates Eelbjtendten annefmen nur. Lleber= biez zeigen bie meiften 2literoiben eimen merfwhrbigen Farbentwer(f)= fel iffres eidgtz, ftralylen balo mit weiflif,

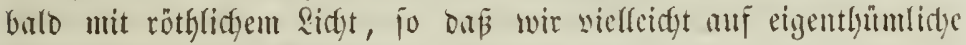

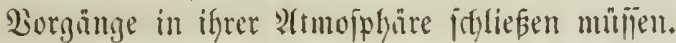

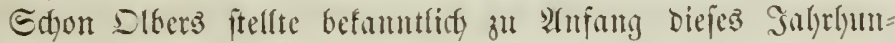
berts bie Bermuthung auj, Daj bicje ffeinen Wfanten nur bie

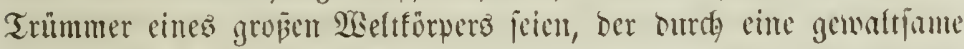
Satajtrophe in jablreidye Etincte jertfeilt wurde. Wenn nadh bicjer

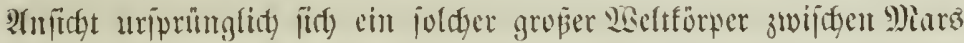
uno Supiter in elliptijofer Babn um die Eome bemegt lyat, io muijen matïrlid) maty oer Satujtrophe feine Etüffe fümuntlidy mahe

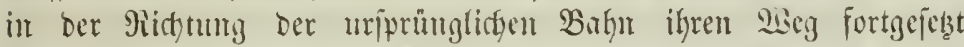

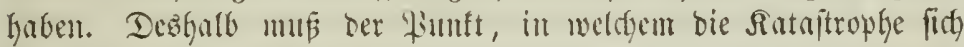

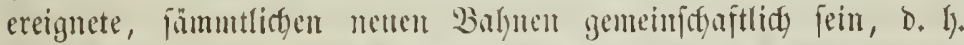

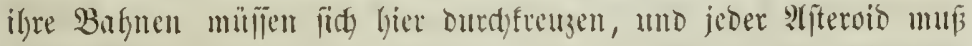

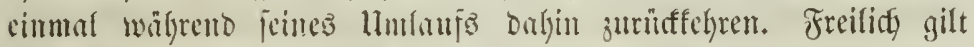
bies ftreng genommen mur für bie midjpte Fotgezeit nad) ber Satn=

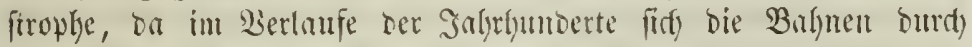

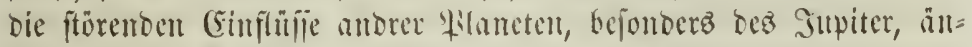

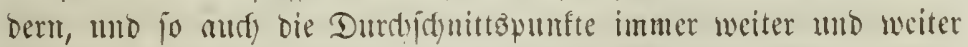

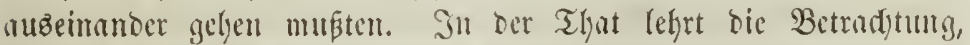

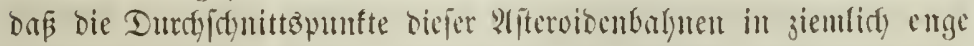

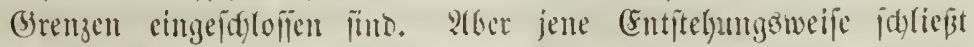

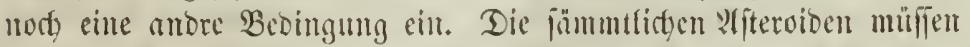

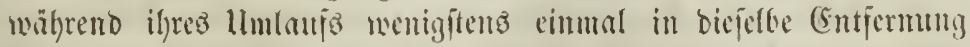

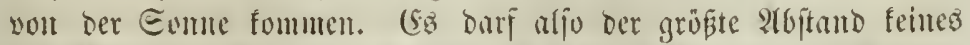
Der eliterviben fleiner fein alz ber fleinfte afbitand bex übrigen.

ule, wetrall. 3. «uศ. 
Pur bei ber Şugien und Themiz fintet fidh ein foldyer fall, ba

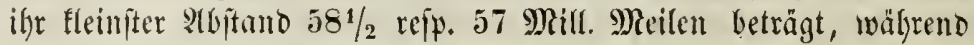

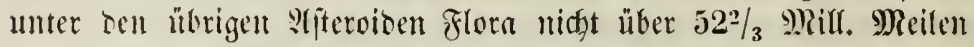

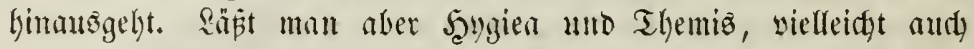

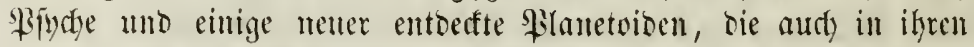
fonftigen Berhältmifien von ifgen Befährten beträdftlid) abweidgen unb, wie Ramont meint, bejonderen afferoibengruppen anjugefören idfeinen, anker 2 (d)t, fo swirb bie obige Bedingung sollfomment er= fülft. WGollte man alio eine foldye Rataftrophe ber Bertüumerung autuefmen, fo müpte fie fith in ber (Entifermung vou $522 / 3$ Millionen Meiten von ber Eomme ereignet haben.

Ein amerifaniffer Sfitronom Daniel Ritfwood in Botàville

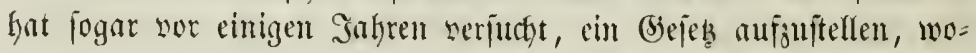

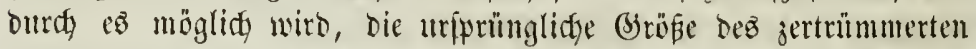

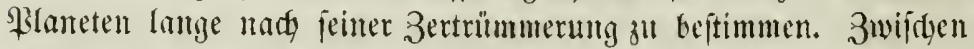
ie zwei auj einnonber folgenten Wlaneten gieve es einen \$3unft, in

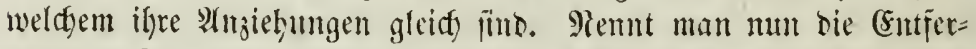

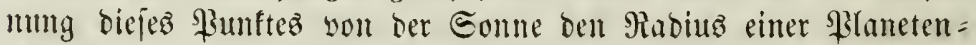

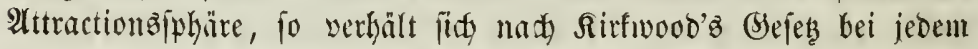

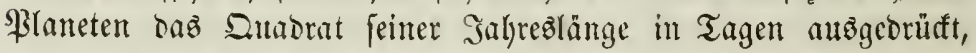

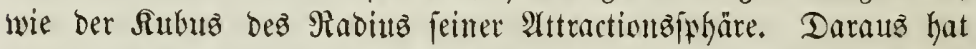

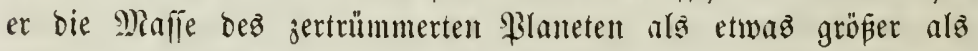
Marż, feinen Durdjmeffer auf ungefähr 1085 geograptifíge Meilen beftimut.

Wan aber bie Matur ber Ratajtrophe felloft betrifft, fo wollen fie bie gegenwärtigen 2 fitronomen nidyt mefhr, wie fonit gewölynlid, einem Rometen zufdreiben, meil befien s) affe ju unbebeutento ift.

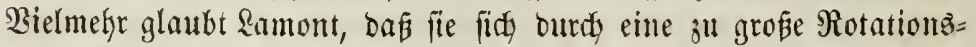
gejdjwindigfeit des uriprünglidgen Flaneten, wie fie bie ifhm viel= leidyt verwanoten \$Ilaneten ber äuperen Bruppe, Supiter, Eaturn 2 .

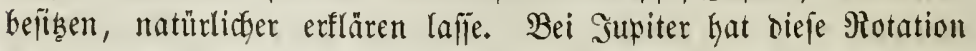
nur eine bedeutente argplattung herworgebradjt uno vier Monbe

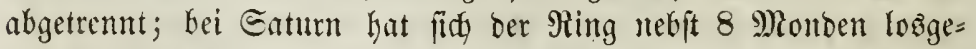
rifien, uno bei unjerm angenommenen \$lanten hat fidy jogar bie

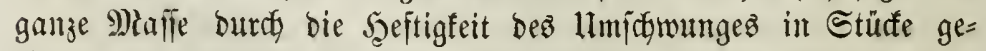

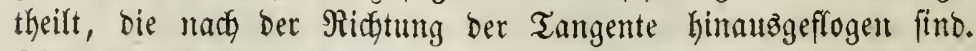
Dieje $\mathfrak{B u r f f r a f t , ~ w e l d g e ~ i m ~ B e r b a ̈ r t n i f f e ~ z u r ~ B a h n g e i d g m i n b i g f e i t ~}$ 


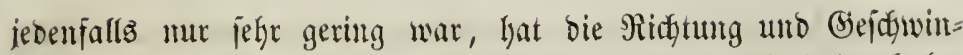
bigkeit ber einjelnen Gtüffe ein wenig verändert mb baburd be=

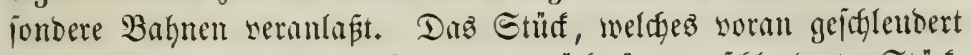

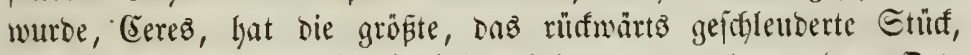
Flora, bie fleinjte Bejedgwindigfeit betommen, und ant bem Drte

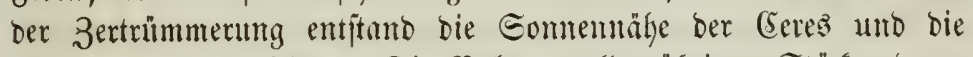
Eommenferne der Fflora. Die Babnen aller übrigen Etüffe, beren

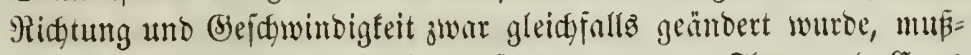
ter aber nothwentiger $\mathfrak{B}$ eife juifthen Denen Der Flora und Gerez eingeidgloijen bleiben.

Diefe ganze Dlbers'ithe Salyotheje aber, burdi weldye man

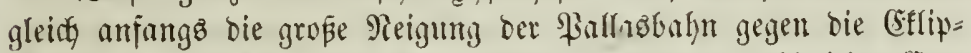

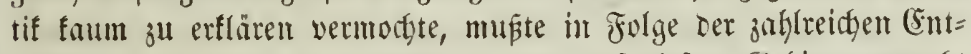
Decfungen, weldge in ben leb̧ten Sahtrent auf Diejem Bebiete gemadit murben, und burdy weldye bie Zahl ter ben forderungen biejer

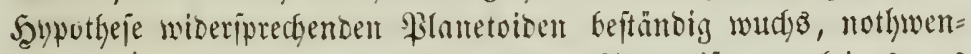

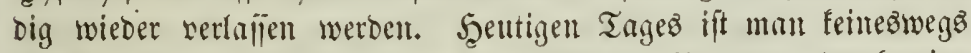
jehr gentigt, bie Entitehumg biejer fleinen Filameten burch einte

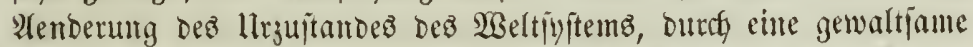

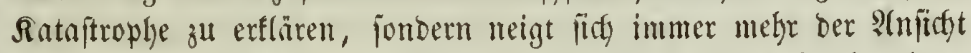

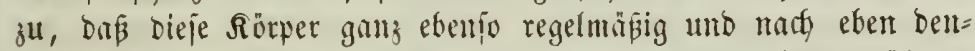

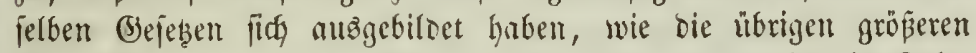

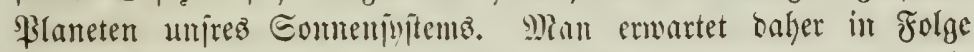

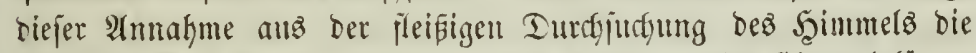

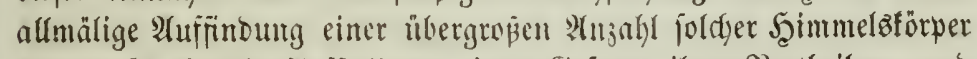

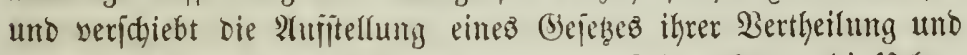

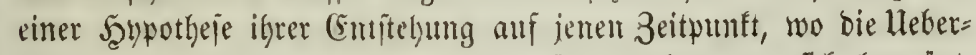
ficht eine volffommmere jein miro. Für jekst hat man jief begnügt, burch eine forgfältige \$srüjung ber ftörenden $\mathfrak{W}$ Birfungen, weldge

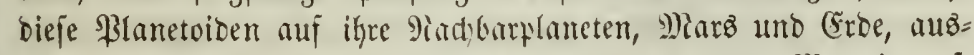
äben, eine ofere (Sirenje für dic (bijanmtiumme von Materie auf=

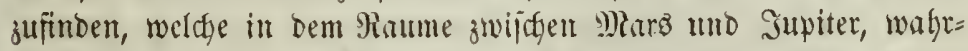

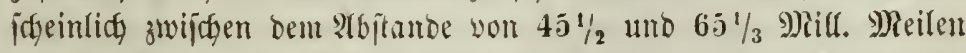

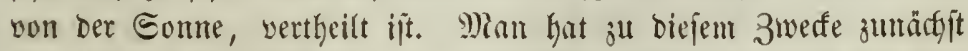
bie Stönungen beredinnet, weldye erfolgen müß̈ten, wenn bie Błe=

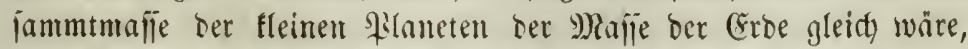

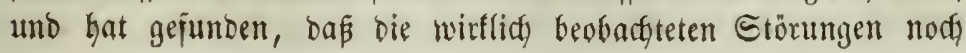


nidgt Den bierten Theil biefer beredynten Etönung erreidyen. Mian

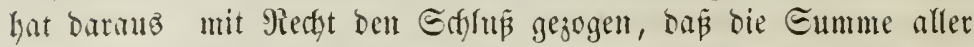

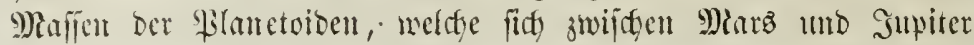
norfinden, nimbejtens ben vierten Theil Der Eromajie nicht luber= idgreiten fám.

Die lïberajatende 3ahl ber Entberfungen, weldye bie atitrono=

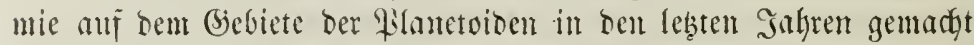
loat, fängt bereits an antb einiges sidyt auj bie Theorie zu werfen.

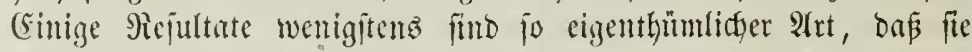

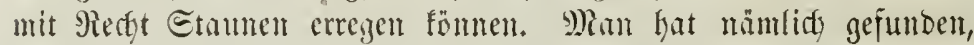
dap bie Formen umb Die Peigungen tiejer \$lanetoibenbahnen burch Die Etörungen son Eeiten Der übrigen \$ilaneten im Wefentlichen feine Beründerung erfagren fömen uno aljo im imnigiten 3 jam= menhange mit Der erjten llafactye ifrer Bildung ftehen müjlen. Man yat fermer gejumben, dar bieje Etnbilitüt freilidg mur für foldhe Silantetoiden gilt, beren mittlere Entjermuty von ber Eonne größer ift als ber Doppelte Whitand unjer (Erde non ber Eonne. Mert=

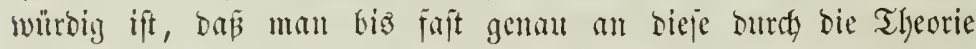
angezeigte Etabilitätşgrenze foldye Flantoiden gefunden lyat, jen= feits berfelben aber nody feinen eimjigen. (Gz ift arjo anjunelymen,

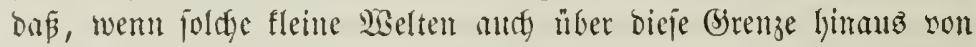
jener Entitefungsurjache sertheilt jein follten, fich igre Balbmen theils fo fometenartig verlängert, theils fo bebeutente Neigungen

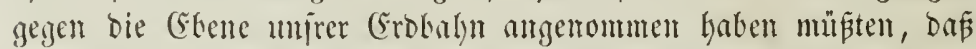

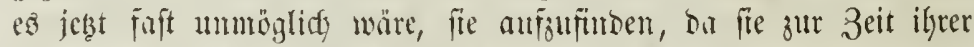
Gomemnähe der Eonme ju make itänoen uno butrdy bas Tagestidgt unfirftbar gemadt würoen, zur Zeit der Eommenferne aber mieber 3u weit non uแล entfernt mären.

Die biejoidte biejer Slanetnibenentberfungen, bie ganz bem gegenwärtigen Safyrfundert angehört, ift einer ber interefianteften

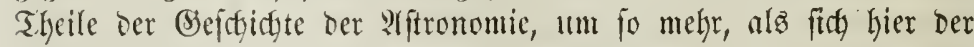
3ufalf mit Der fortidgreitenten Bervolfommmung ber Şülfismittel

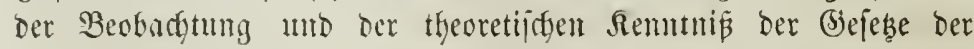
Seimmelsmedfanif in mifalfender $23 e i f e$ wereinigt hat. 3ut Ende Des vorigen Sabrfunderts batte man bie Bemerfung gemadt, Daf

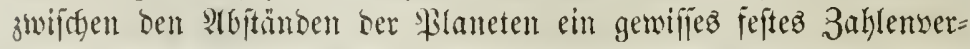

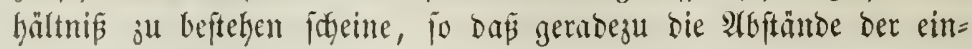




\section{1}

zclnen \$lantenbalumen won ber Mirfursbalyn fid werboppelten.

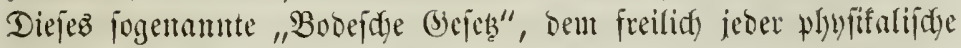

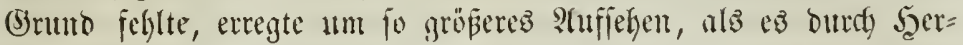

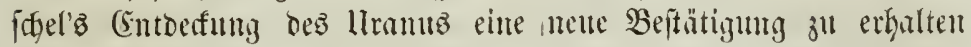

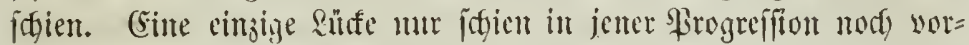

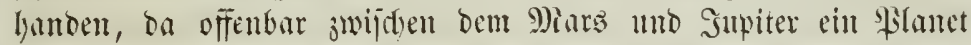

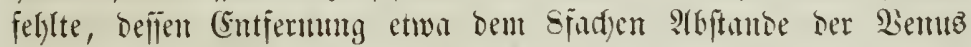
vom Merfur bütte entipredgen mülīen. Man fing an einten unbe= fantent Fianeten in bicjer süfe ju vermuthen, unb ez trat jogar

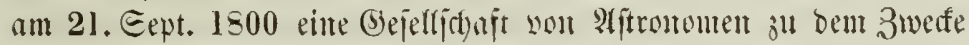
zuanmen, Diefen vermutgeten \$ilaneten zu judjen. 2lber ber 3ufall

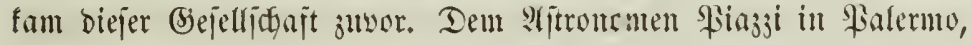
Der bereits feit 9 Salyren mit ber Anfiftellung eines neuen umfañen=

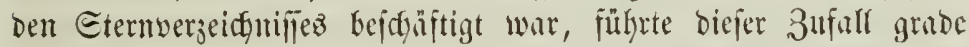

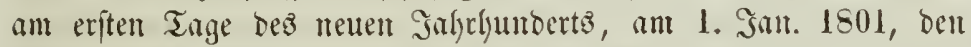

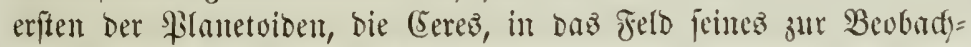
tung eitrez gant; nubern Gternes anfgefteflten Ferurohrs. Shne ben $\mathfrak{B}$ ertl) feitrer (Entoefunt ju alynen, notirte er ben Drt bicjes

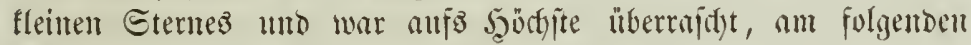
Fbenbe einten gant anbent Drt Deffelben zu erhalten. Fortgejebte

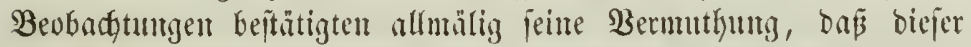
Etern fith wirflidy bewege, baj er zu bem Gefdyledyt ber wantol=

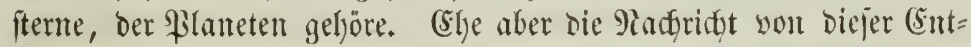
befung, wegen bes burdy bic Siapoleonifgen Sriege bamals fo er=

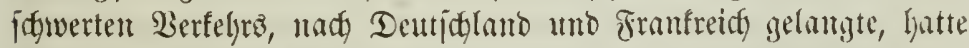
fid bie jugendidye (5ereg langit ivieber in ben Eommenftralylen ver= borgen, uno juwerlidy wäre fie anters als burdy 3ufall wicber

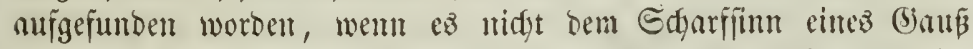

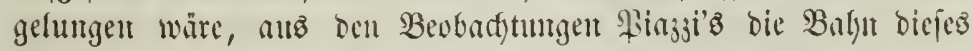
SHIaneten zu beredynen, in weldyer man ifyn verfolgen und wieber finben fonnte und wirflict wieber fant.

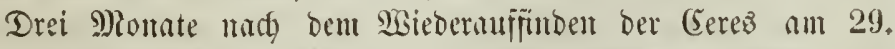

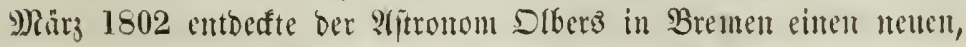

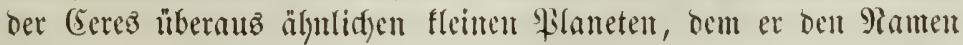
Walfas gab. Es war etwas jo lleberrajdendez und jo gauz allen

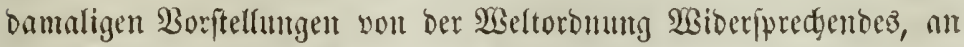

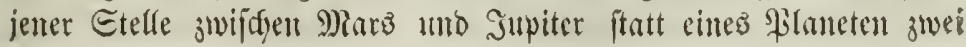


ober wohl gar melyere neben unb miteinander freijende zu erbliffen,

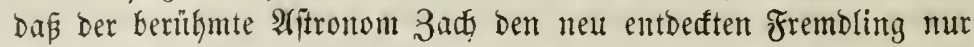
unter Dem Pamen einte Someten zu vertünden wagte, und baß jelbit Serjdyel ifm wie Der (Serez nur bie Benennung yon arjeroi= Den zugeftehen wollte. Alber bie Beredyungen bez icharifinnigen

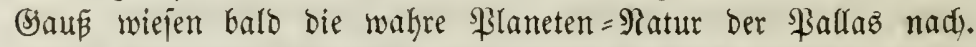
Der Lmitand, Der fich Dabei ergab, da bie Bafnen beider \$lane= ten in einem \$umfte einander jelyr nafe fommen, vernulafte Slbers zu ber geift=, aber freilidy audy phantajiereidfen Sgypotheje, Daß

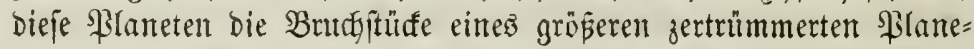
ten feier, utno bieje Şypotheje mieder regte Dlbers an, nady meite=

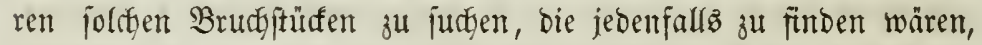

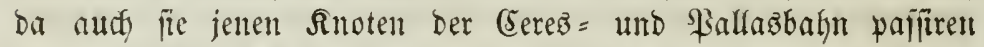
müpten. Shye ifm bies nody gelang, entbefte Sarbing in Rilien= thal bei $\mathfrak{A}$ njertigung feinter yortrefflicyen Şimmeläarten am 1. Sept. 1804 bie Snno. Die Mebereinftimmung, weldye die Bahn biefes neuen ßlaneten mit Der Slberżichen Sytpotheje zeigte, trieb ben Begrünber Derfelben, jeine Radbforidungen mur nods eifriger fort=

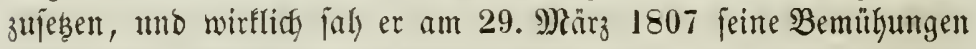
Durd) Die Entbefung Der Befta gefrönt.

Faft bolle 39 Sahre verflofien, ohne daßj audh nur bie Epur eines neuen $\mathfrak{P}$ lameten entbect murbe, und fayon war man baran, bie 3ahl biejer fleimen 3 selten alz abgejoflofien zu betradyten. Wäfrend biejer Zeit aber hatte bie Berliner affabemie ber Wifien= fichaften jene vortrefiflidben Şimmelätarten anfertigen lafien, weldhe

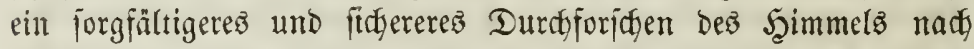
umbefannten mandernden Eternen erleidferten. Eo geidjah ez denn am 8. Dec. 1845, Daßj Sente in Driejen, ein Dilettant Der arfitro= nomie, Der aber jeine \$ofthalterei auz Siebe für bieje Wifienidaft

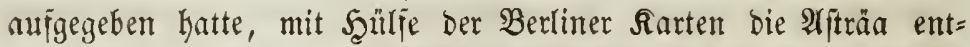
Defte. Dieje rulnmolle Entbecfung eröfintete mun eine Epoche, bie ofne Beifpiel in Der (Sejujidte Der eljtronomie Dafteht. Afftronomen und Dilettanten alfer Pationen metteiferten mit einander, unje Beltorbnung mit neuen Bürgent zu bevöltern. Dieje Fülle firg

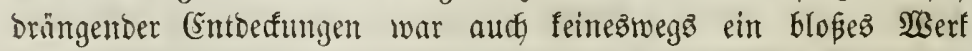
Des 3ufalls, fonbern wejentlidy eine Folge glüflidyer Bemub̧ung

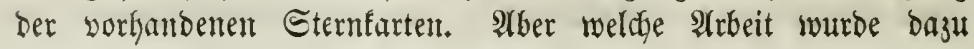


erjorbert! Die fleinen \$ilaneten, bie man entbecten wollte, Gelïken

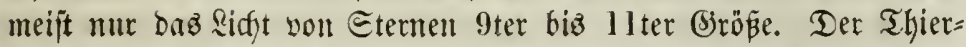

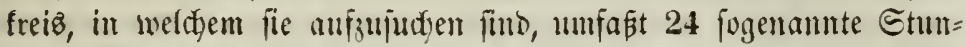
Den. Cine jolde Etunde, bie zu ben frernärmiten gehört, enthält

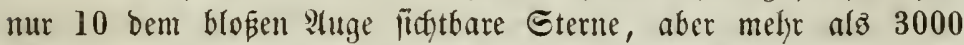

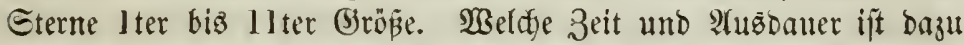
erjorberlich, nidjt allein joldye ßarten herzuttellen, etwa, wie ez Şenfe unt âtubre getfran haben, bie Berliner $\mathfrak{R} a r t e n$, bie mur

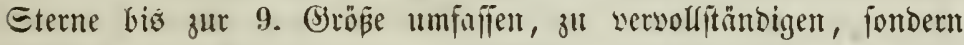
vollento bieje $\mathfrak{R} a r t e n$ mit bem wirflicfen Şimmel beftänbig zll ver= gleiffen! Eo mutite ber 3ufall allerbingz dem Euchenden wentigitenz 3u Şülfe fonmen, und in ber That lyat er bişweilent eine mert=

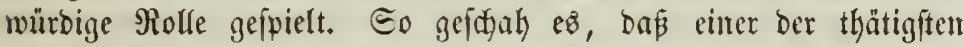

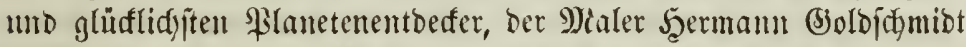

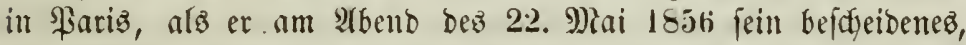
im jedjfen Etorwert getegenez 3immer, Daz itym gleidyzeitig alz Malerwerffitatt, Edjlaftammer unto Etermwarte bient, gejdettert

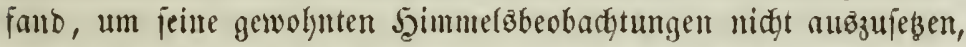

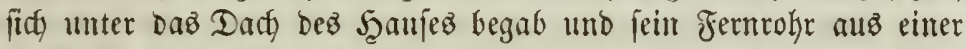
Dadjlufe auj eine Syimmelägegent ridgtete, bie er von feintem 3im= mer auz nidgt einmal hătte feljen fönnen, - unb fielye ba, er er= ipäht einen neuen \$llanetell, Die Daphne! Die Pieige biejer Ents

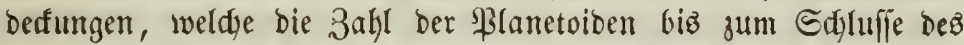

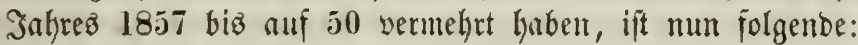

Im Sahre 1847 entbedte zunñd)jt Şente in Driejen am 1 . Suli feinen zweiten \$laneten, bie Şebe; barauf folgte am 13. Auguit bie (Entbefuutg ber Jriz und am 18. Detober bie ber Flora

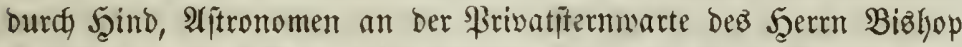

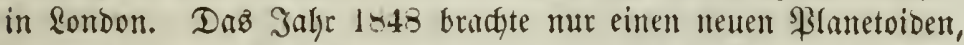
bie Metiz, entbeft am 25. 2(pril burd) (3raham, 2(fitronom an ber Sternwarte zu Martree= (anftle in Jrlanb. Das Sahr 1849 ift

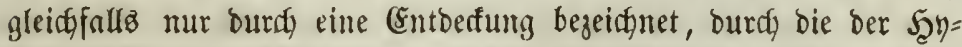
giea, welche ber Afitronom be (b)äpariz in Meapel auffand. Zah reict)er waren bie Entrbefungen in Den folgenden Gahrent. Sm

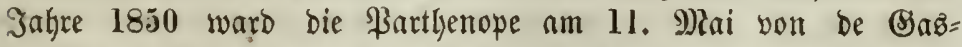
pariz, bie Bietoria am 13. Eeptember von F̧ino, bie Egeria am 2. Robember abermals non be Baspario entbeft. Darauf fand 


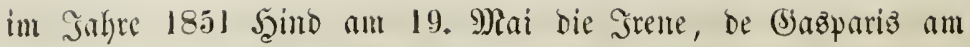

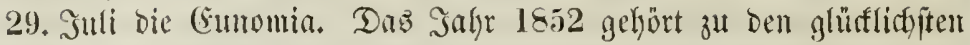

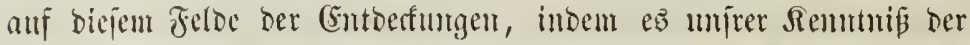
Flaneten adyt mene zufingrte: zuerit bie \$indye, am 17. Mär yon De (5)aparis cutbeat, Dant bie Thetis, am 17. April won \&uther, Direftor der Etermmarte zu Bilf bei Düfildori anrgefumben, Dam

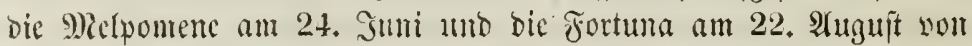
Seind entocat, Daranf bie 9) Maflalia, am 19. Eeptember von de (S)appariz, bie Rutetia, am 15. Rovember vom Mlaler Seermant

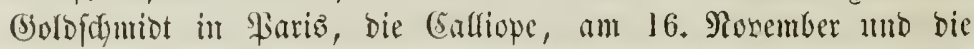
Thalia ant 15. December, beibe von J̧into entbect. Daş Jalyr 1853 bract) wieber vier mene \$lanetvident: am 5. Itpril bie The=

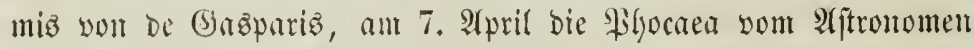

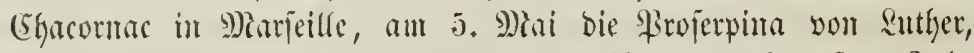
und an 8. Povember bic (Euterpe von Şind entbeeft. Daz Jalyr

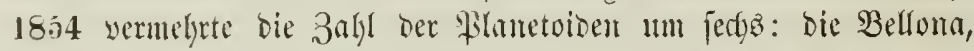
an 1. Maing won Suther, bie ATmpritrite, an bemfelfen Tage vom Aftronomen Marth in Sonbon cutbect, bie Urania, am 22. Inli yon Şind, bis Euphrofme, an 2. Eeptember yom amerifanifaen Piptronomen Fergufon in 23 nifyington, bie Fomoina, am 26. Scto=

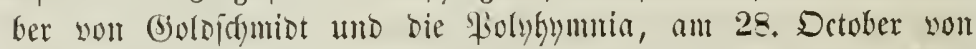

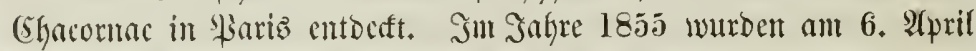

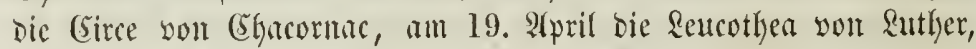
am 5. Drtober fogar zuei Planeten, die 2talante von Bsoldidymid unb bie Fibes you Ruther aujgefurben. Fünf nete Entbefungen bractete Das Salyr 1856, am 12. Jamuar bie ber Reba uno am 8 , Februar bie ber entitia burd) (5haconnac, am 31. Mär bie ber

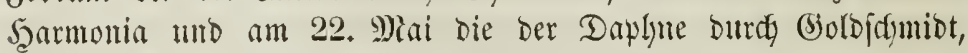

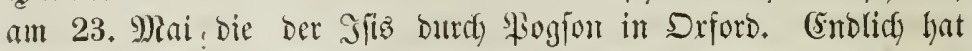

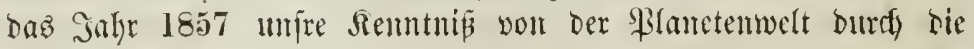
Entberfung won adyt neuen \$lanetoiben wermegrt. Fogjon entberfte

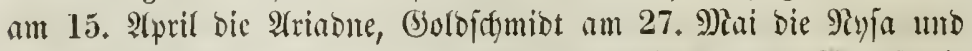
am 27. Suni bie (5ngenia, Bogjon abermals am 16. Angujt bie Seffir, Enther am 15. Eeptembir bic 2rglaja. 21m 19. Eeptember ereignete fidy fogar bie unterbürte Thatjadye, baß ein nuto berjelbe

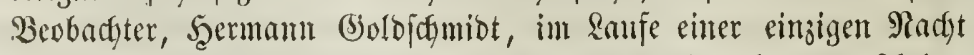
owei Slancten entbedte, wou benen ber cine nody unbenanut fdeint, 
Der anbre ben Paumen \$alez erljelt. Enolid) entbectte Suther am 19. Detober den 50ften ber \$lantetwibn, Der aber bereits am 4 . Detober von James gergufon in siajbington aufgefunden war und von biefem mach bem Piecte sez Entocfers Birginia getauft wutroe.

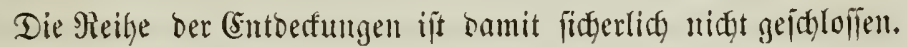
(5z ift ber vermefienfite und thöridytefte Şodfmutth, wad) S(rt ber joge=

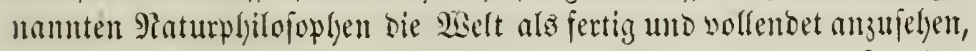
weil man in feinem Şirn eine vortreffrfide SrDnung entworfen hat,

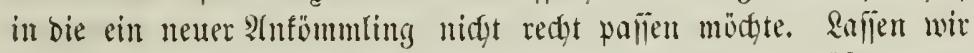
bie Zeit immer weiter ben Edjleier verfüllter 2 Belten lüften uno

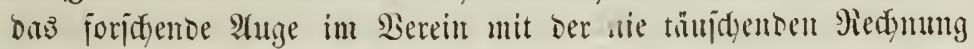

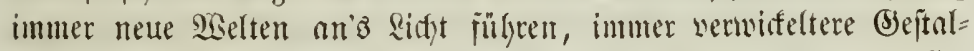
tumgen unb Dromangen aupecfen! Demu je verwiffelter bie (5r=

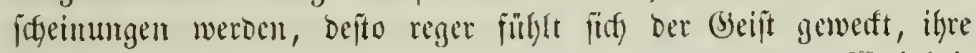

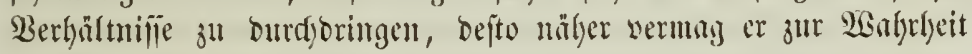
3n jogrciten!

Eo wenig wie unire Gomne ein cinfadyer, einjan weilenber

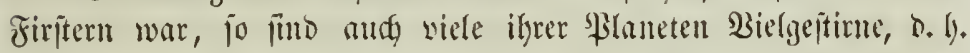

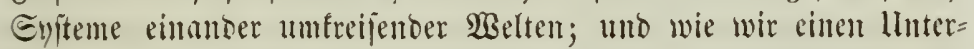

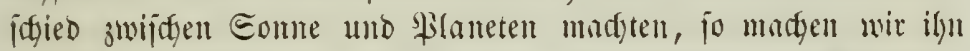

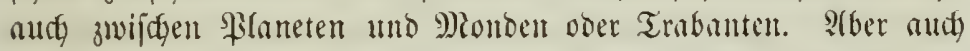

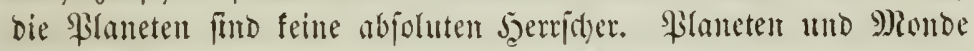
bewegen fid um einen gemeinfamen Edfywerpunt, umb unr bie

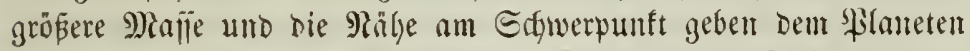

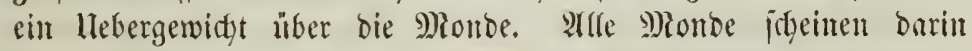

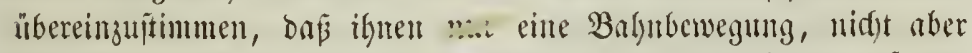

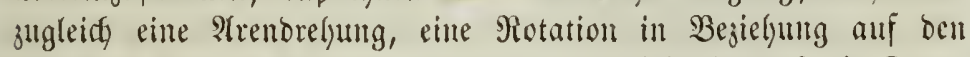

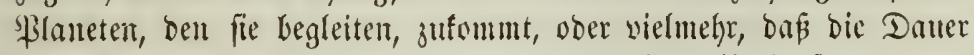

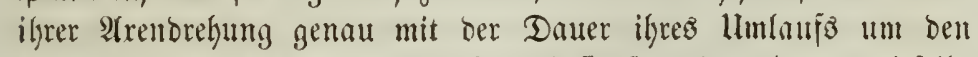

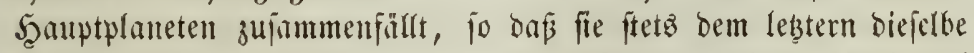
Erite zumenben. Eo bewegt fird unfer Mond, währento er cinmal feinen llnulauf um bie (Erbe vollenbet, genau in berjelben 3eit auds

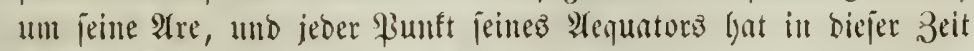

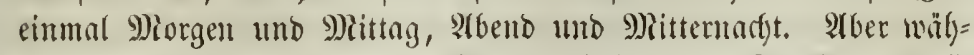
reno bie Bahnbewegung des Mentoes bald einen fognellern, bald 


\section{6}

eimen Iangiamen berlauj hat, je nadbem er ber (Grbe näher ober ferner jteft, bleibt jeine rotirente Bewegung, unabfängig won bem

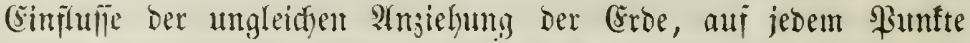
Der Barly inmer in ifrem gleidumä̈̈igen Edyritte. Heberhaupt

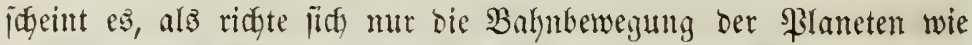
Det Monto nadb den gewöhnlidien Bejeken Der Anjiebung unb

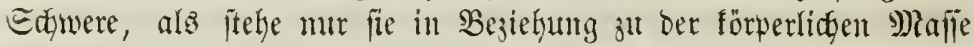
und ber Davon abhängigen (Sejtalt Der Bahn, währent bie rotirente

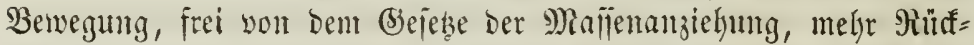

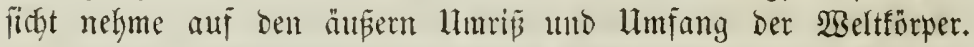
Dalyer mögen wohl aud jente fleitten Edywanfungen unb lunregel= mäpigfeiten rüfren, bie wir in Der rotirentoen Bewegung unjers Mondes gemahren, und bie uns bis̄weilen bald etwas mehr vom bjtlicten und nörolidgen, balo etwas megr voun füblichen und weft=

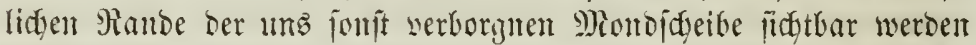

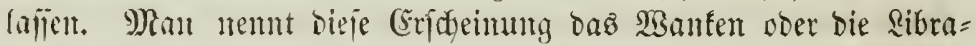
tion Des Monbes, und Mäbler enflärt fie ats einer ungleidfen Bertheilung Der Mionomane. Dennoch bleiten $3 / 7$ ber gangen Mond=

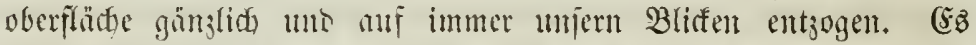

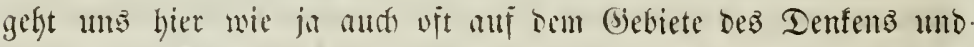

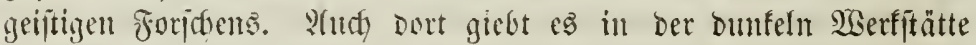
Der Siatur mo iffoffenten llifraft gar mande ung abgewanbte,

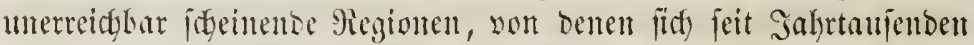
Dem Menidyengeidyledte son 3cit ju 3eit, bald in wahrem, bald in tringerijdsem Ridgte idsimmerns, cint jomaler Emm gezeigt hat.

Wie mit unjerm Monbe, it is mit aflen mben Trabanten.

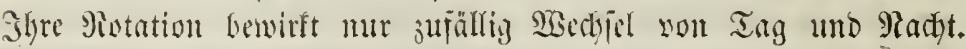

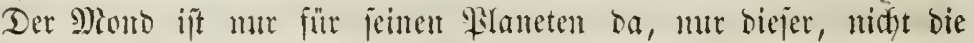
Eome, hat unmittelbaren (Sinflus auf ilyn, und Darum ift wohl audy jeine Ratur eine ganj unähntlide, naty ganj anberm \$rincip geitaltete, als die jeines \$lanteten. Bei ben brei innern Stupiters= monden wirb fogar burth ifre Etellung ber Sinflup der Sonne gröftentheils ganz unwirfiam gemadgt. Demn fie empfangen auf Der bem Supiter jugewambten Eeite blos bie fawwadyen Etrahlen

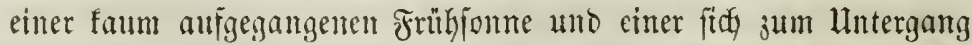
neigendent Spätonne. Stutt bes belebenten Mittagz umfängt fie täglich in bem ungelyeuren હdyatten ifyres riejenbaften (Sentralförpers 


\section{7}

eine Finfterni立, bunfler alz unjre Mitternadyt, weil fie bem $\mathfrak{T} a g e$

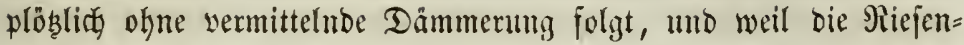

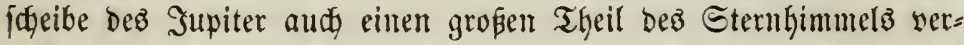

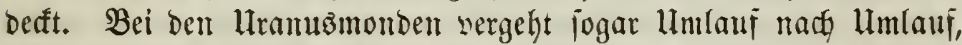

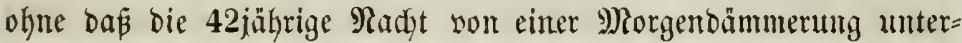
brochen mürbe. Die Sterne gehen auf und unter, aber mur bas

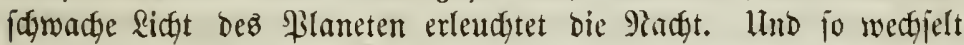
bort in 84 Jahren eine einjige Radgt unt ein einziger Tag ab. Wer will nod, begaupten, da bie Matur jene Trabanten mur zu lentgtenden Dientern ihrer Planeten geidjaffen habe! -

W3enn wir annelymen fünnten, Dá bie Matur aller Monte unjerz Eyftems einte ähnlidje jei, jo hätten wir alferbingz eine jelye gute Selegentheit, foldge 13 eltförper genauer femten ju lernen. Unjer eigner Mono ftelyt ber Eroe jo nale, one wir ihn alj einer (sijen= bahn ganz bequem in 15 bis 16 Monaten erreidgen fömten; Denn feine mittlere Enttfermung betrïgt ja mur 51,315 Mieilen. Die

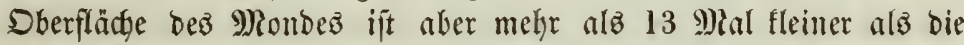

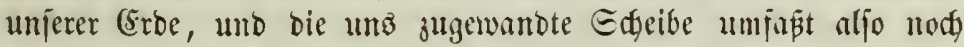

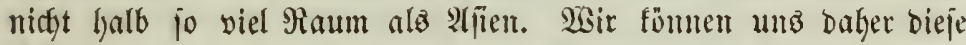
Sdyeibe als eine Randfarte benten, auj weldyer jeber ?andiftidy vou

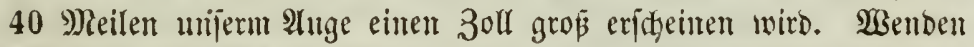
wir mun ein Ferntrohr an, fo nähern wir amb bem Mionbe um fo

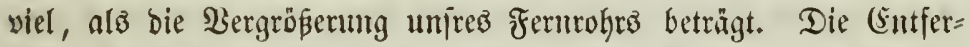
nung bis zum Mionbe beträgt etwa 5l,000 Mieilen. Sitt ez unz aljo möglid, cinen Menichen ober ein \$jero noch in ber Entrer= mung von einer Mieile zu erblifen, fo bebürfte ez einer $51,000 \mathrm{ma}=$

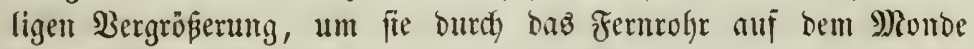

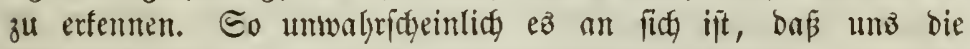
ferne 3ufunft eine foldye Berbefierung utfrer Eehwerf

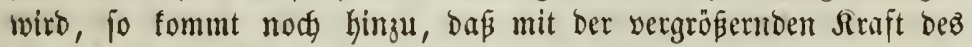

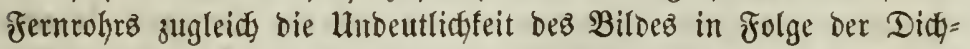

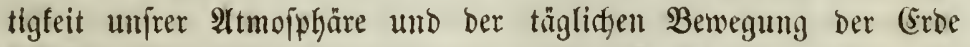

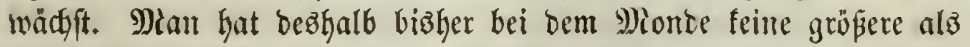

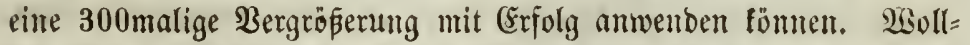
ten wir alfo Menfiden und Thiere auf bem Monbe fehen, fo be=. bürften mir einer faft 170 Mal ftärferen Bergrößertung alz ber biz= her äflichen. Boolten wir audh nur $\mathfrak{B}$ aumerfe mahntelymen, wie 
bie größten unjer (Eroe, bie wir in fün Meilen (sutfernung nod) erfennen, fo müpte die Sirnft unfrer Feruröbre im Berein mit ber

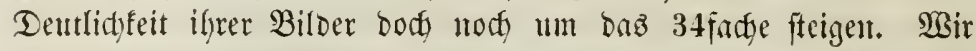

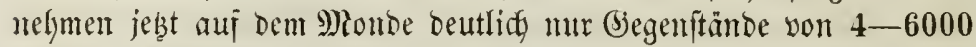

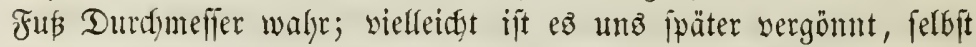

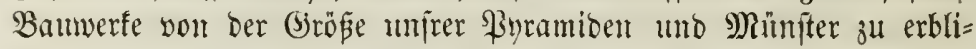
đfen; aber immer werben fie unz zutr als zarte \$ünftdjen erịgeinen, Deren Gefftalt zu beuten wir unz vergeblid bemühen werben.

Bon bem organifjen Rebent dez Mondes, den Erzeugniffen

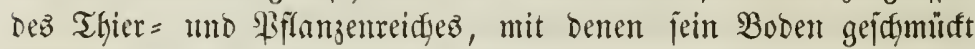
und belebt ift, erfalten wir aber burch bas Fernrofr feine $\mathfrak{B o r}=$

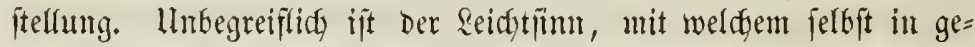
bildeten Sreijen vor nod) nidgt 20 Sahren bie Mlündygaujeniade

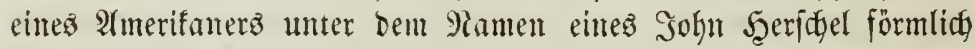
(Eingantg unto (j)kntben funt, bie yon forberbaren Edyafen, Men=

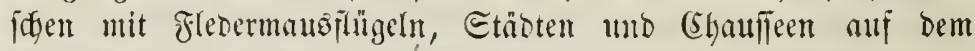
Monde fabelte. Bon der phyiridgen Matur unfres Madabarn aber, you feinen Bergen uno Thÿllern geben unz audy fdyon bie Edjat= tenrifie, bie wir jebt fehen, einen affgemeinen Begrifi; mur bietet

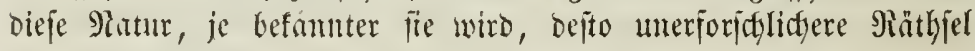
bar. -

Niejentajte, idari emporragentbe Sebirge bebecten bie Sber=

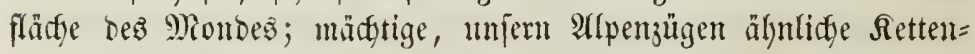
gebirge, bodf olne Berzweigungen, ofme Thäler, erftreffen fidh über Ränderítridfe sou 90 s)eilen, of̆t mur in einer Breite won einer Meile, uno ergeben fidg in ilyren pifförmigen (Bipféln biz zu 15000,

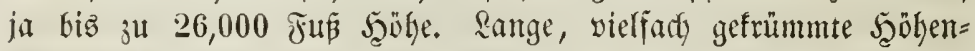

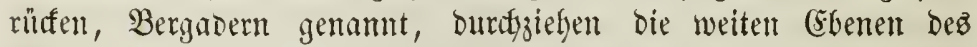
Mondes, oft n̈ber eine Meile breit, faum 50, felten 1000 ₹ú yod, und baher mur bei niebrigem Etande ber Sonne auz ihren Edyatten erfentbar. Zahluje einzeln jtehende bergfegel bebeffen

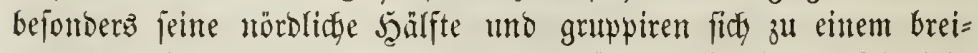
ten, 200 Meilen langen (Sürtel von Şügeflandidgaften. Die felt=

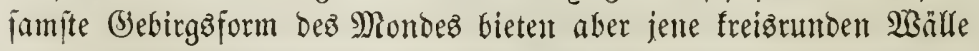
Dar, bie bald weite (SGenten, barb jäbe Tiefen yon 2-10 Meilen im Durdymefier umidgließ̈en. Man nemt bie erfteren $\mathfrak{B a f f e b e n e n , ~}$ bie leb̨teren Pinggebirge unb bezeidfutet bie fleinjten unb regelmä= 
Bigften Formen als Frater und Gruben, wiewohl man auz tem

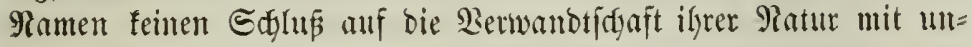
fern iroijđen Bulfanen ziehen barf. Die $\mathfrak{s a f f e b e t e n t ~ g e y o ̈ r e n ~ j e r e n t = ~}$

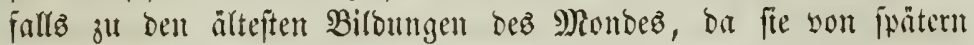

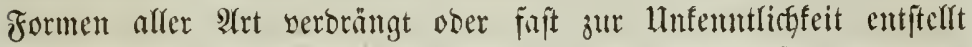

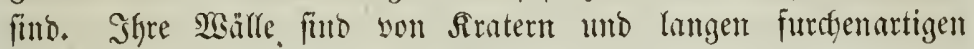

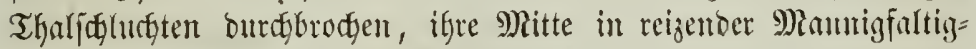

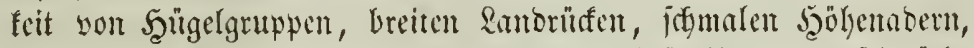

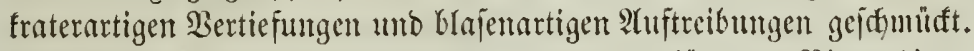

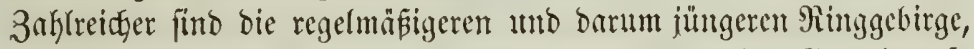
Deren man bereitz über 1000 fernt, unto bie cinzelne Gegenten fo

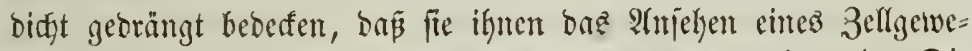

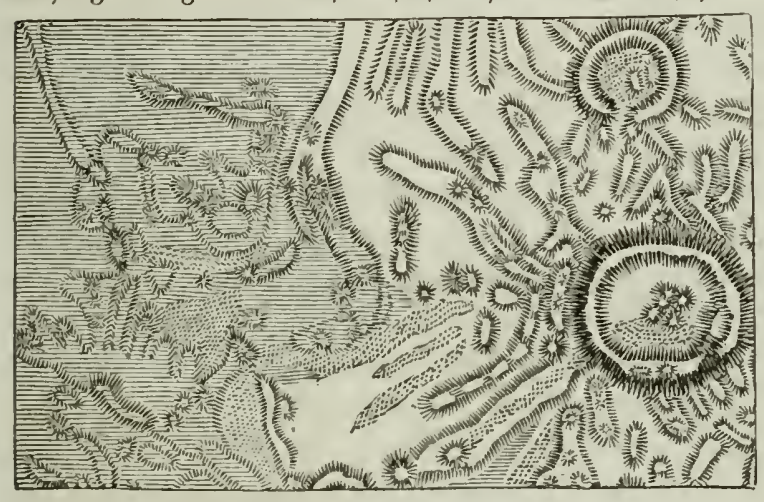

bergeber. Die nebenitelyente Siarte, weldye eine Flätye dę Monocio unge= fäbr volt ber (S)

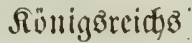
Baiern bar: fitellt, jeigt juei foldse benads = barte Minigge=

birge, beren $\mathfrak{B a ̈ l l e ~ e i n z e l n e ~ B i p f e l ~ t r a g e n ~ u n d ~ m a d ) ~ S m m e n ~ u n o ~}$ 2uß̈en in Terrafien abfallen ober âtzlänfer nady aflen Eeiten fenben. Im Smnern fteft gewöhntidg ein (5entralberg, ein nicberer

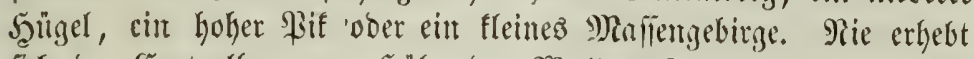
fidy der Centralberg zur Şöhe bes Wallez, felten felbit zur Şöhe ber angrenzenden Ebene. Sinzelne ragen wohl 4-5000 Fuß aus

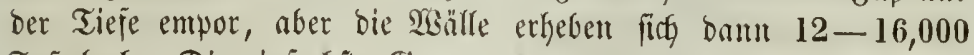
Fuf hod. Die einfadjte (Be= ftalt eines Ringgebirges, wie

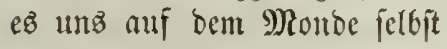
eriffeinen witroe, zeigt bie ne= benftekende arbilloung.

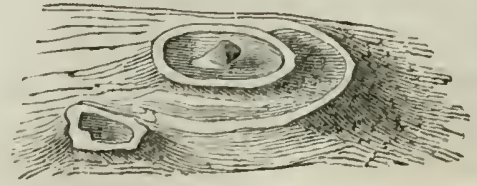




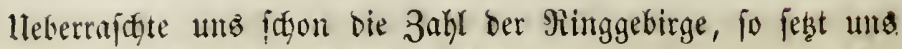
bic ber flcinen Rrater sollends in Erftaumen, ba felbjt ein mä̈ig jturfes Fernrohy uns deren gejen 20,000 jeigt. Daz nebenjtehende

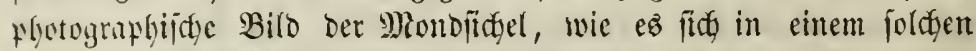
mäвigen Fentrohr Daritellt, zeigt unz einen Theil ber Mrondober= flidte mit Bulfangruppen wie likerjäet. Sit ftürzen bieje fleinen

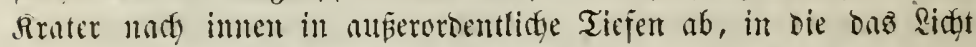
Der Eonne felbjt bei jiemlich hohem Stande nidpt bringent fann,

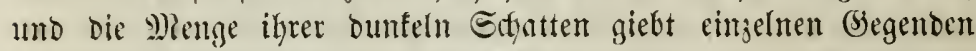
fuit cin Durdblöbertes anjehen. Sinige ftrahlen im Sollmono mit ftartem Glanje, Da das Eomtenlidgt von ifren Şöhlungen wie voit einem Brentipiegel zurüggeworfen mirb, währento anbere nur ifren lentfftenton 9iant, wie einen Riffring um baz Dunfle Smuere, zei= gent. Dit fint fie wie \$erlenjomutre atteinander gereigt, balo burdy Ranäle ober Bergabern verbunden, bald son eimem gemeinjamen WBalle umidhlollen. Die Abbiloung zeigt einte (3ruppe yon Sratern, d und b ohne (5en= trallerg, a verbunden, c und e von andern umichlofien. 2(m meijten befremben unt bie jonderbaren Rillen des Mondez, die unz im Bollmono als glänzende Sidgtitreifen, fonft als jomwarge Fäben eridgeinen und tiefe Fur= dyen von mefyreren Taujent Fü Breite be= jeidynen, bie fith faft grablinig burds (56enen und Giebirgglanditajten ziehen, jelbit אra= ter Durdfiduteiden ober fith zu Sratern er:

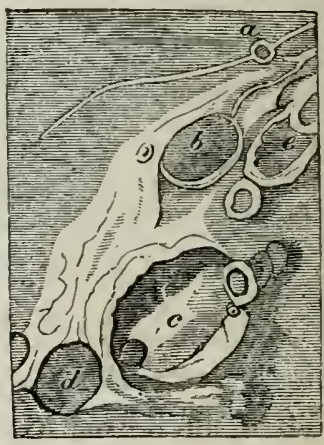
weitern. Die feine teleftopiffye Unterfutfung zeigt fie als ein mit ber Sraterbildung in Reihen verwandtes Shänomen. Auf Erben haben wir nidhtz ihnen zur Seite zu jeben, Demn jelbit bie furcht= baren Epalten, weldye bie \$rärien von Teras burchj̈nneioen, ver=

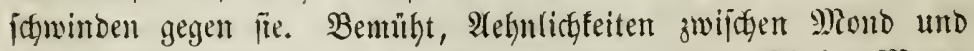
(Erbe zu finten, fah) man, wie in ben gropen grauen flecten Meere,

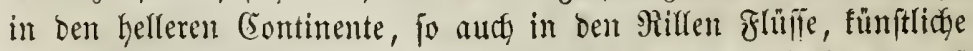

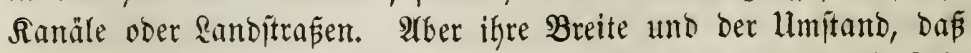

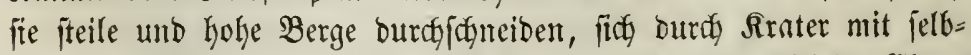

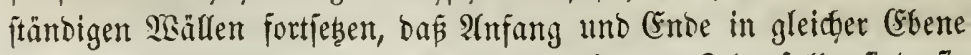
liegen, wiberpredyen biejer Antutyt Durdaus. Sebenfalls fint fie 


\section{1}

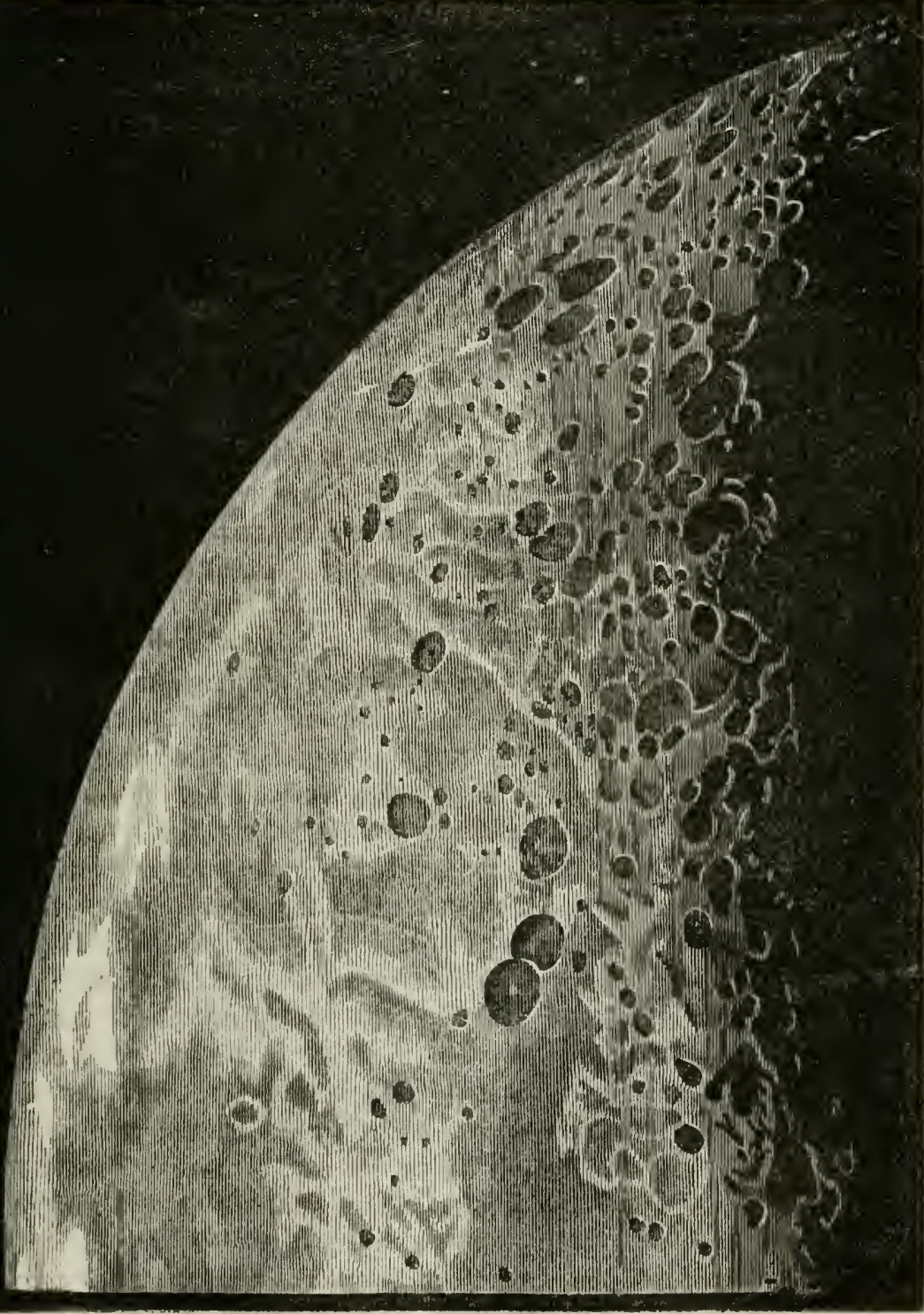

Photographifter sild eines Theil\$ ber Mlonbfitfel. 


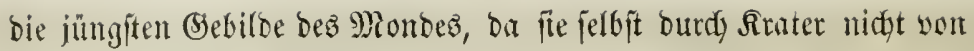

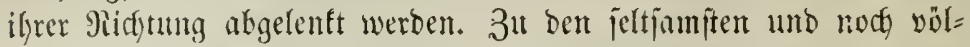

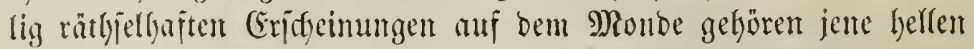
Etreifen, weldge son eimzelnen gró̧en Rratern, wie Tydjo, (Eoper= nicus, Sepler, auslinufen unt bei geringer Breite oft mefreere hun= bert Meilen weit hiber bie höbjten Berge wie burdy bie tieffiten

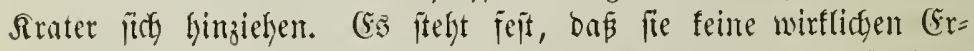
böhuntgen bilden, ba jie niemals Edgatten werien. Eie idjeinen vie(mehr mur auf eigentgüumlidgen \&idftrefleren zu berthen, aljo ifren (S)uno in gewilien jtreifenweijen Berünberungen ber Monboberflübe, gleidjam in Berglajungen zu Gaben, Durds weldse eine vermethte Sidgtreflerion enflärlich würbe. Miobler Gat ifre Entjtefung bafin

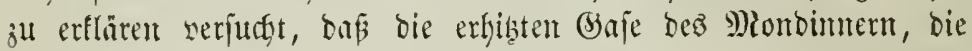

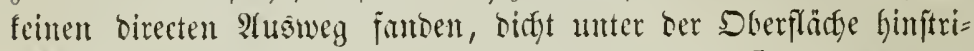
d)en und fo jenre Beränderungen bewirften, biz fie entweder in

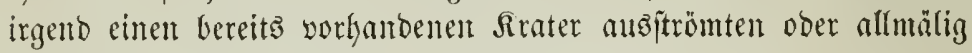
erfirlteten.

Die gemeinjame 9ieigung aller biejer Errjebungen mb Ber=

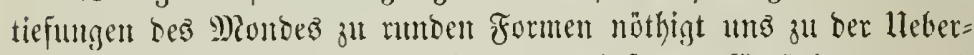

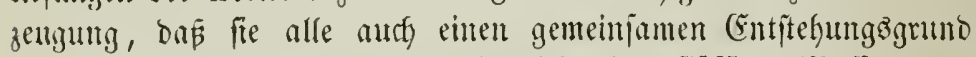
hatten. Der Miond war uriprüuglicts eine flüipige Mafie, uno

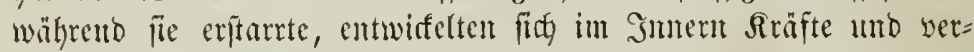

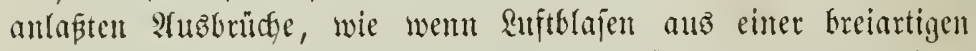
Mañe aufgetrieben werben unto an ber Sberflädge zerplakento cinten

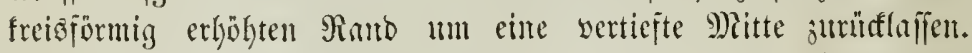
Eoldyer (Ereignifife folgten megrere nady einanter, wie siallebenten,

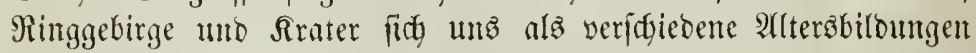

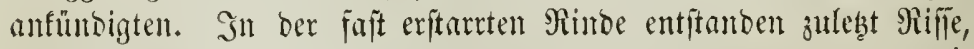

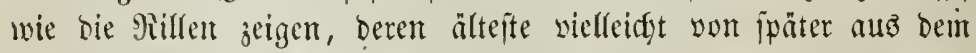
Smern quellenben Siluthmanten wieber erfüllt murben und fo bie Bergadern bilbeten. $2(m$ thätigiten arbeitete bie innere Bewalt an

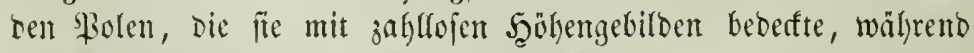

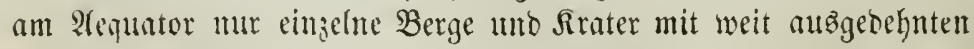

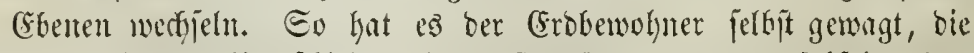

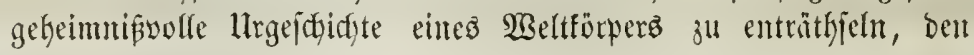
nie jein Fuß betrat. 
Benn man an bie Bewohntarfeit bes Mendes bachte, fo fah mant fidy sor Pffem immer nact ben irbifden Rebenselementen, nads Ruft und SBaffer um. Damit aber freilid fand mant es bort oben

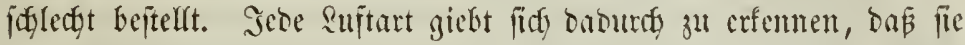

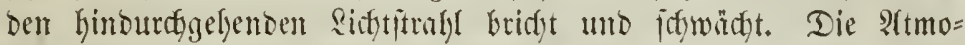
fphäre Dez Mlontez zeigt nidyt baz Geringite non Beibem. Die Ranbicfaften bes Piandes erfideinen in berjelben Dentlichfeit wie bie Der Mitte, tnd ein Etern zeigt bei feitrem (Eintritte in ben Mono=

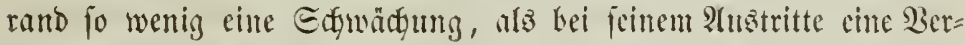

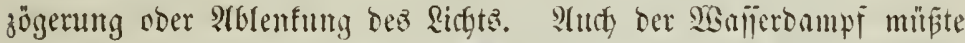
fich Durdh Etralylenbredyung vernatlen, went er it jenter 2 tmo= fphäre aufgelọ̈t, ober wemn bie Sberflätye mit Wajfer bededft wäre,

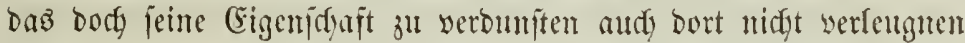

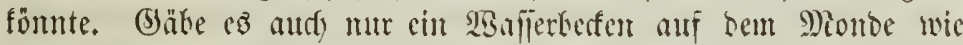

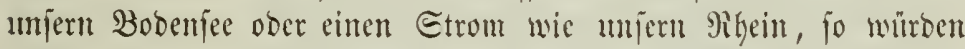
fie fid bod als glatte (Sbenent werrathen; ober flojfen bort and mur

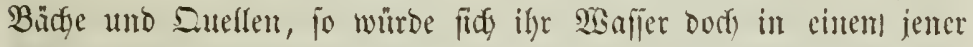

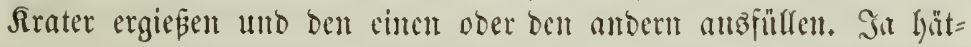
ten aurb mur in früheren Zeiten, wie anf unfer (Erbe, WBafjerftu= then auf bem Monbe gewirft, fo wintben wir bods nidft jo gans

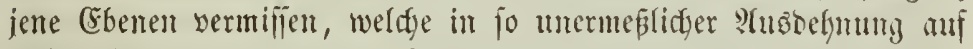
umirer (Eroe bie eljemuligen (5renzen bez Meerez, wie in ben Sand=

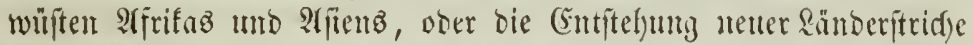
Durth Anfowemmung ber Ströme verratfen, wic an ben Miun=

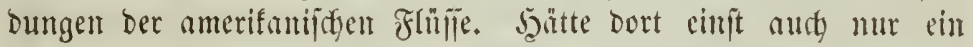
eimziges Mreer wie unjee Ditjee gefluthet, hätte fid) nur cin cinji= ger Flü in bie fdroffen Tiefen jener Rruter geftürat, wir würben bods Die Epuren bez ebutenten unto glättenten sisafferz erfenten. Die mildo Deffe Der Begetation würoe jene idroffen, zarfigen uneben= Geiten überffeiben, bic jeber \$iunft ber Mlonboherflüdye bem bewaff= neten Auge Darbietet. Utber nirgends zcigt fids einte Epur weder yon Waffer, nods son jeinen Wirfmugen in ber Gegentwart ober Der Dorjeit. Eelbịt bic Atmojphäre mit ilyen llmwölfuntgent ent= geht alfer Feinheit menjoblidyer Injtrumente. 2Gollen wir aber nidyt, wie ez Mandfe, auf ben flügeln ber \$ibantajic getragen, gethan

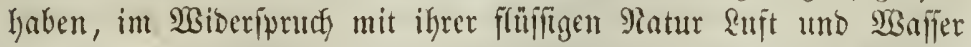

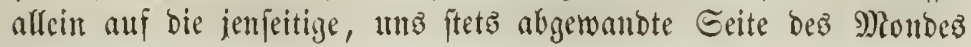

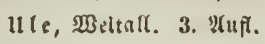


sermeijen, un Dort ungejtört son parabiejichen Befilben, riejeln=

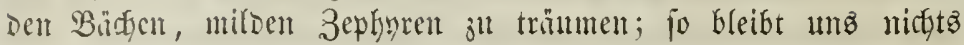
übriy, als cine Mondatmojphäre von fo geringer Difytigfeit und

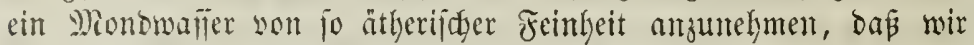

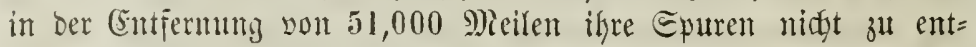
Decfen vermigen. Iie forgfinltige Berectumng Beffel's erigab als äu= Berite Mighlidfeit einer Mionduft cine 968 M)al geringete Didytig= feit als bie unjer iroijhen \&njt; ein Bemeis, wie wenig wir an

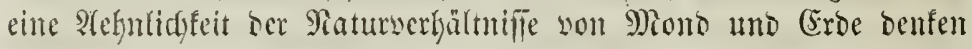

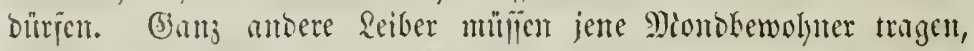

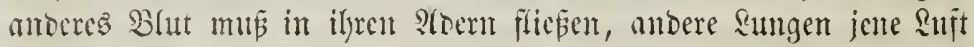
eintatgmen; wir sermödten in foldyer 2 elt nidgt ju leben!

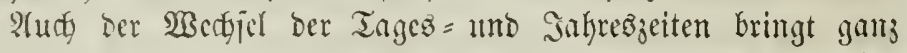
eigentyüntide ?ebeng̈bebingungen für ben Monblenolyner mit fid. Der Iang lyat bort gleidye sünge mit bem Jafire und währt gleid) unjerm 9) Honat 29 Tage 12 Etunden 44 9)inuten. (Ein Unter=

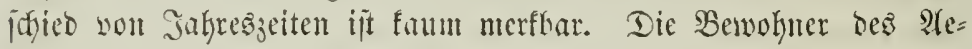
quatore haten emigen Eommer, bie bet fole ewigen Winter. Dort

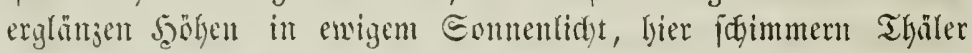
in farfter Dämmerung, bie meder Tag nody Madyt fentent. Die Tage find bas ganje Jaljr hinburth fint gleidy lang, alle Tage gleich bell, alle Riädte gleidy bunfel. 2uj ber uns jugewanten

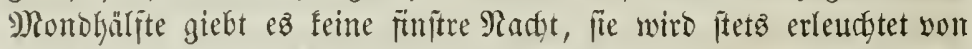
Der (Erse und mit 14 Mal helferem Ridgte, als unire Sadyt yom

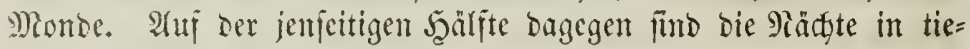

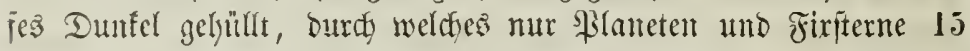
Tage lang ant Dem fđjwarzen Şimmelşzelt funfeln. Der Mangel eimer frahlentrectemben Atmofphäre raubt bie 2isohlthat ber Däm= menung, und blibichnell whirbe dem glänjentiten Tage bie bunfelite Pacht folgen, went nidyt bie Rangfamfeit bes Somenauf = uno Un= tergange Den llebergang etwas milberte. Mit unjern Fugen wür=

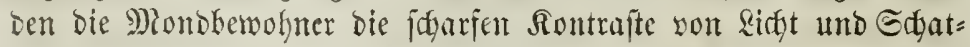
ten Dort nicyt ertragen, soürben lie bie janften Bermittelungâfarben

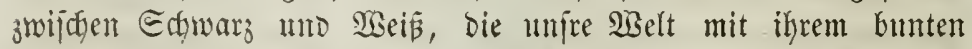
Epiel veridönen, vermifien. Slynen eridgiente ber Şimmel nidgt blau wie uns, fondern felbjt an Iage fdwarz, und die Eterne würoen neben ber itralylenden Eonne nidyt fobminden. 


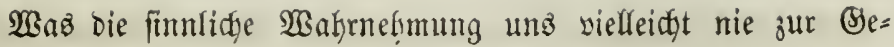

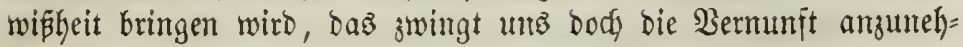
men: bie Bewothntfeit Dez Miondez wie aller 2 seltförper yon ver=

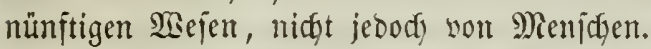

Ev wenig, mie einen Baum ofne Blätter uno fructit, vermö=

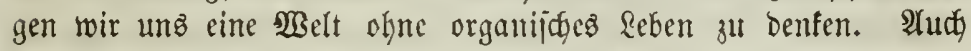

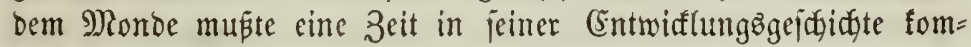
men, gleidfyicl, ob Sahrtaljende früher ober jpäter, wo benfende Bejen jeinem Etaube entfeimter. Sit aber audi bie Materie bort feine anbre, als unjre irbijaje, fo finb ez bod bie Rebensbedingun= gen, und barum audf bie Rebenzprobufte. SBie bie Erone in ihren veridgiebenen Edappiungsepodjen veridjiebne Edjöpungen, bie aber

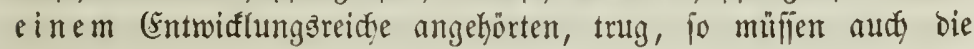

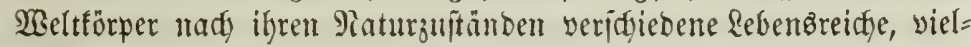
leidft aud in ber Goee verwandte, tragen. Wir fenten nohl bie

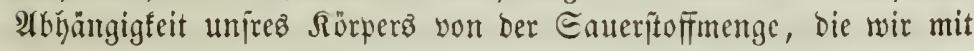

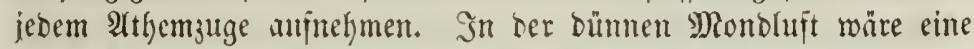

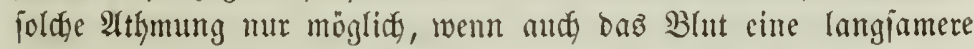
Berbrennung forderte. (Ebout fo wirb aber audi) in biejer bünen

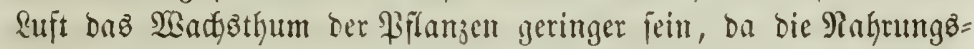
mittel ifnen ja um jo verbunnter jugepühyt werben. Der ftoffliche Ertrag ber Monowegetation fam aljo in gleidger 3eit nur ber $968 f t e$ Theil von bem ber irbifdjen jein. Da mun bie Thierwelt mieber

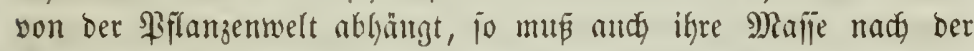

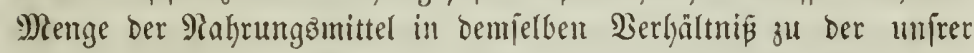
Thiermelt itefen. Wian hat bismeilen werjudgt, mittelit foldyer

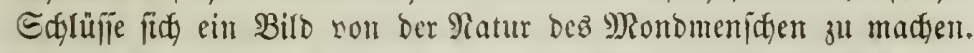

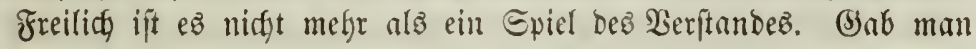
Dem Monobemohner biejefbe Dicftigfeit ber Sinodeen und Miułfeln,

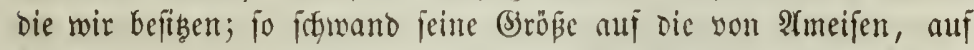

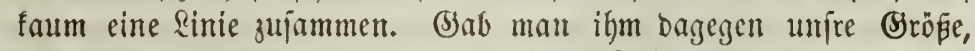
fo mufte man ilgn mit einem ätheriidgen Reibe beffeiben, ba feine Dichtigfeit faum ber unjerer Rujt gleidg fäme. Fügte man Gierzut

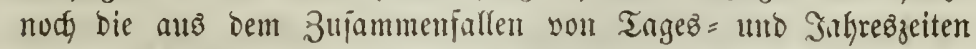

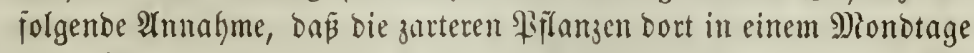

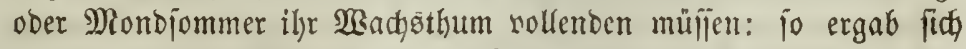
3!gleid, auf bem Monbe ein 12 Mal idnnellerer Sreis̆lauf bez $\mathfrak{S}_{e}=$ 
bens, eine idnellere Arthmung und ein türzeres Reben, das der Entfaltung geifitiger Sultur nur Cintrag thun fonnte.

Sebenjalls nijo ifit bie Rebensiwelt Des Mondez einte ganz anbre, frembartige, und ber Mienich, Der überall nady (bleidgem und $\mathfrak{B e r}=$ wandem judt, mus, wenn er fith in eine ftille Betradhtung ber

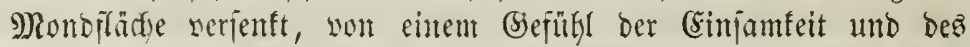
Frembjeins ergriffen werben, wie es ber $\mathfrak{B a n b e r e r}$ empfindet, wenn er, itr uniern alpengegenden serirrt, fid rings nur vom ewig ftar=

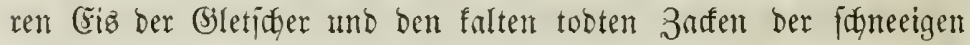
Berghăupter umringt jebt. Bleibt uns aber auth in emige $\Re$ ăthy=

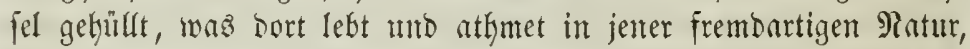

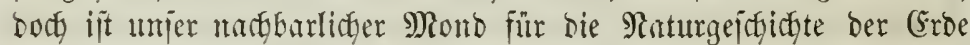
und für bie beredynenoe aftronomie nibt ofne jegnenden Sinflus

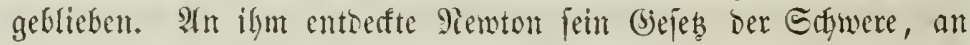

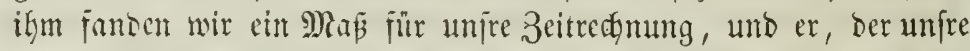
langen Binterstäbte mit milsem Ridft erfyellt, bleibe uns imurer cin lieber, treuer biefăhnte! -

Aber and ambre \$laneten befiben foldye Trabanten, Supiter

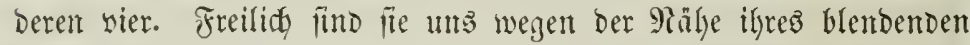
Centralförpers erft Durdy Erfindung Der Fernröbre befaumt und von

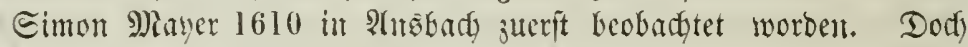
fdeinen audg fie eime ähnlidge Piaturbejdaffentheit zu baben, wie un=

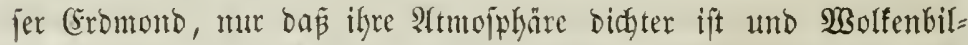
Dungen geitattet. Auth Gaben fie eine befiere Beleuchtung, ba if=

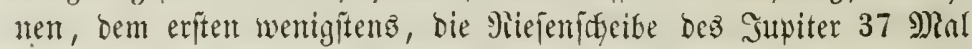

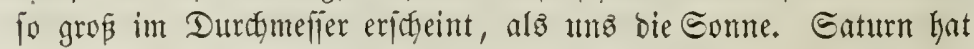
acht zun Theil nur Durdy føarfe Fernibre bemerfbare Monde, von benen fait bafjelfe gilt, wie son ben biakger genannten, mur baß fie in ungewöhntidber 9ăhe bei ifgrem Blaneten ftehen. Bon ben adyt Monden bes ltramb wifient wir mur wenig, zwei bavon find erit in ber jungften 3eit entbeft worben. Aufinllig finto fie uns

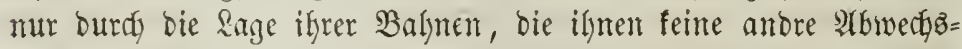
fung won Tag und Pacfit zu geítatten fifeint, als bie burd ben

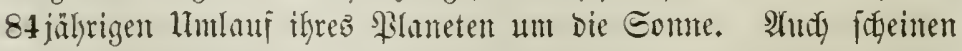

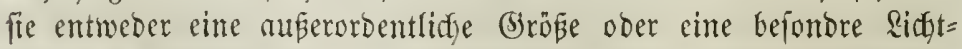

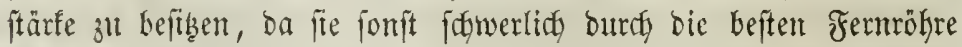
Gätten crfaunt werben fömen. Darum mögen leidyt ben llanus 


\section{7}

nody melyrere foldyer Trabanten umfreijen, bie viefleidyt aud eimjt

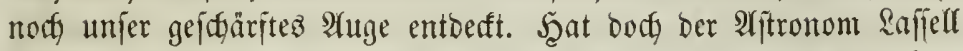
nuf ber Snjel Mialta im Sahre 1852 felfoft am jüngft entbeften

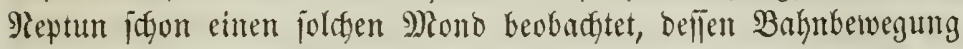
jogar, nady Seint's Bemerfung, abweidyento von alfent übrigen Mion= ben ber $\mathfrak{H}$ lanetenwelt, retrograd zu jein jofeint!

BBenn nun nadf einer Risftung hin in unjerm Syfteme bie \$3laneten mit ifren Monben bie Eoune untreijen, uno riber biejen

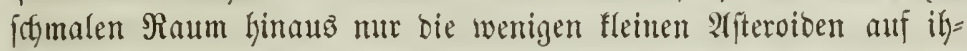

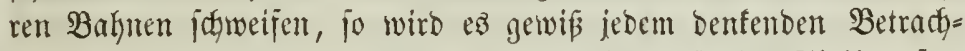

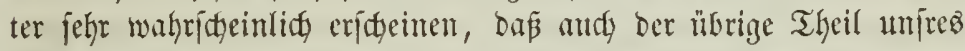

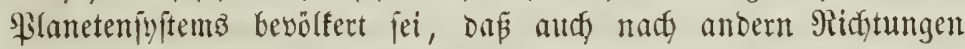

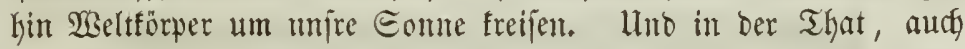

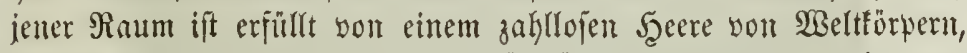

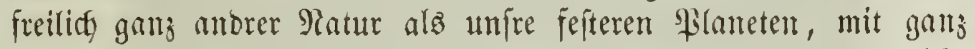
anberen meitgeptreften Bahnen, bunifförnigen Meteoren, weldye

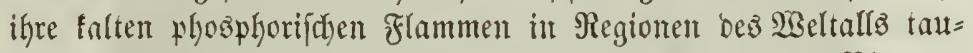
den, bie feit Den Sahtraujenden, jeit weldjen Sonne und \$laneten beftanden, nie ein \$ilanet ober Mond burctiwandelt gat. Dieje fremb= artigen $\mathfrak{B e f e n}$ fint bie Someten.

3afllos nammte idy bie Edyaar ber Rometen, und Repler fagt

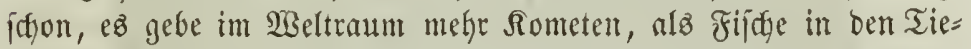
fen bez Deeanz. Freilidf fennen wir faum 4-500, umb faum von 180 find bie Bafunen berectunet. Afber freilidy reidft audf bie Grenze unfrer Beobadtumgen mur in wertige Saljehunberte hinauf,

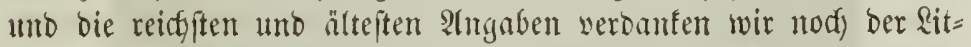

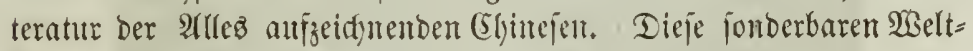
förper, Deren fleine Rörpermaffe faum Den 5000ften Theil unfrer (Eromafie crreidyt, erfütlen bemnody mit ifren weit auz̧ebreiteten

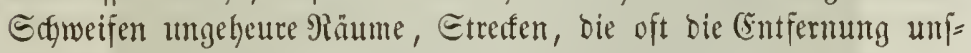

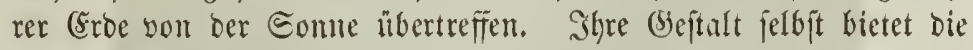
größte Mamnigfaltigteit Dar. Bald ericteinen fie mur burds bas Jernrohr fidftbar ohne eigentlidgen Edgweif, Mitbeliternen ähntidy,

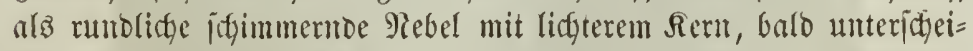
Det man seutlidy Den Rern oder Ropf yon Dem bumitartigen Edjweife.

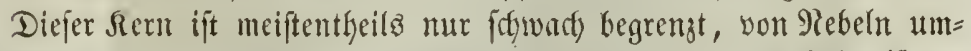
hüllt, oft gar burch einen bunfelni Siaum von feinem Edgweif ge= 


\section{8}

trennt. Eelten ericteint er in befitimmterer Brößje, wohl gar als Gtern eriter und zweiter Sröß̈e, wie er bei bem gropen Siometen von 1813 in Rorbamerifa jelbjt am Keflen Tage fid zeigte, ober

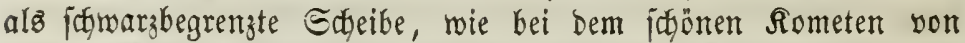
1811. Auch bie Edumeife zeigen gar mannigfacte Formen, balo find fie einfach, bald boppelt, wie bei Dem Someten bon 1823, bald vielfact, balo grabe, bald nady anten ober innen gefrümmt, wie 1811, oft gar flammenartig gewunden. Immer jeboch find fie genau von ber Gonne abgetwand. Die beiftehende Arbbildung zeigt einen joldben. Rometen mit vielfach getheiltem, fapt fächerartigen

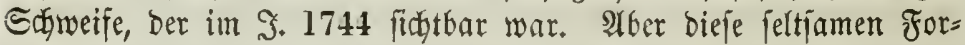
men ber Fometen und iffer Ectweife find nidgt einmal beftänbig,

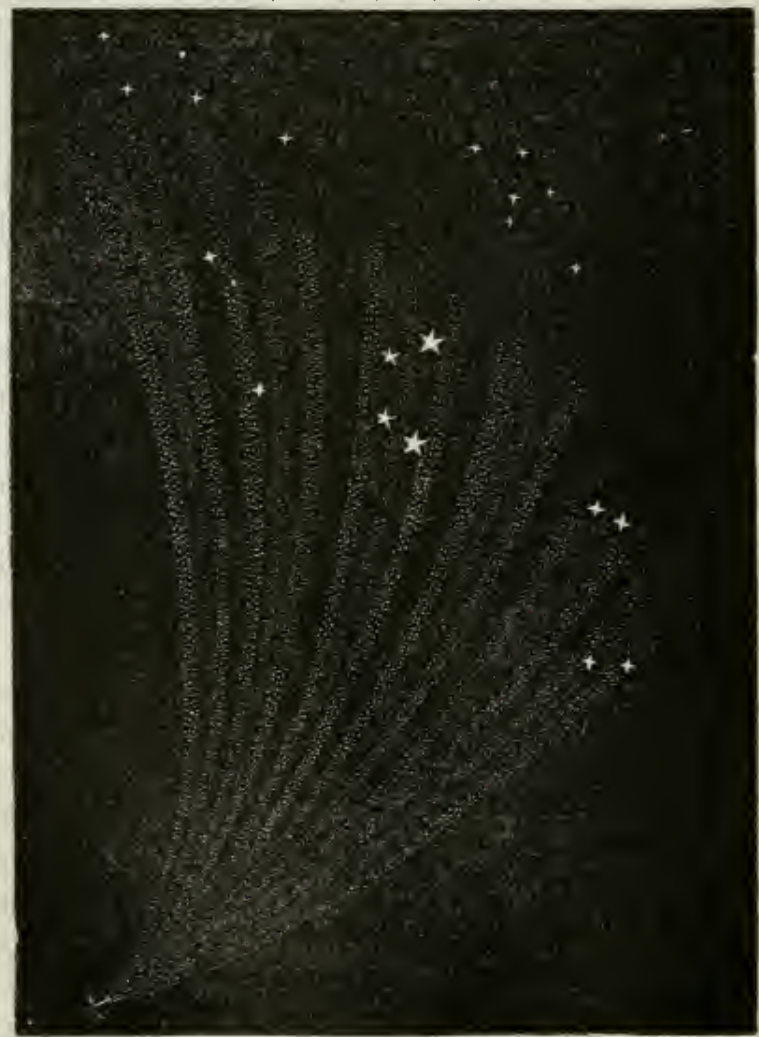

Fåd)erartiger Romet bom Sabre 1744 . 
fondern oft einem idynelfen Bedjel ber Beftaltung unterworjen. Co beobactete Befiel 1835 beim Saalfer'jøen Someten an bem vorbern, ber

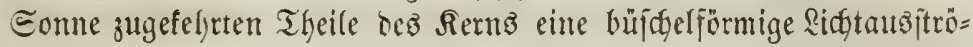

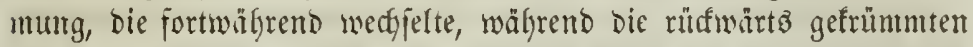
Strahlen bes Sdgweifes einer brennenden Sinfete glidben, weldye burdy

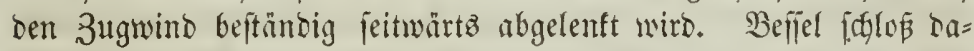
her auf eine orelgente ober formingente Bemegung bes fonten=

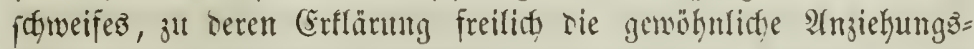
fraft ber Eonnte nidft hinreidgt und vielleidft bie Aunahme ciner polaren $\mathfrak{A}$ raft nöthig mürbe, weldye immer bic eine Seite bez $\Omega_{0}=$ meten ber Eomne zujuwendon, bie andre abjumendan ftrebt, äfnlich wie eş fid mit ber magnetifaen Polarität unjer (5rbe serbält.

Eo tief mun aud Das menidylidye Ange in neuefter 3eit in Die Beheimnifife bes WEeltraums eingebrungen ift und mit ber Siect)= nung bieje bald exidyeinenben, bald entictmintenten Meteore in

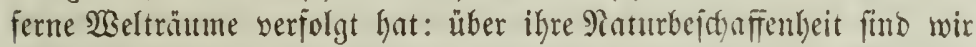
nod inmer jehr im Dunfeln geblieben. Mandje Beobacftungen jwar haben einigez Ridgt bariber verbreitet. Man hat bemerft,

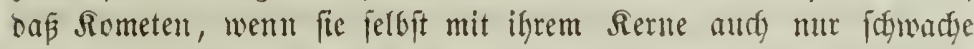
Firfterne bederften, Demmody onz Rifyt berjelben nidyt ablenften uno

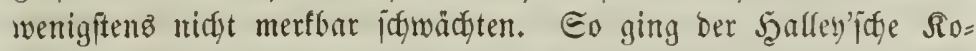
met am 29. Eeptember 1835 mit bem fehr bidhten Piebel feines $\mathfrak{I} v=$

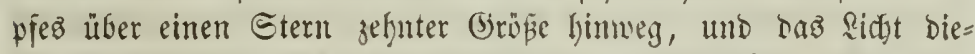
jes Cternz murbe nidgt im (Seringiten abgelenft. WSir mifjen aber,

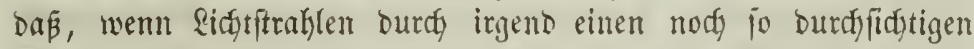

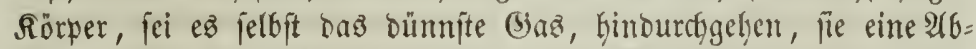
lenfung son ifyer graben Ridstung, cine Bredyung erleiben. Um

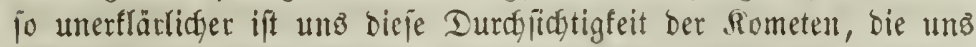
nidgt einmal eine gabförmige Didftigfeit fïr ifgre Patur amefymen

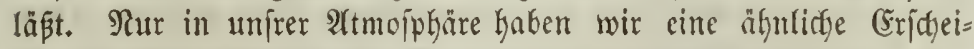

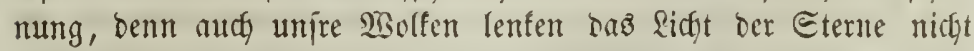
ab; aber fie befteken aus getrennten Theilen. Für foldye fosimifoce (Sewölfe bieje Someten zul lalten, fommt uns freilid) etwas fifwer an. Und bod muß̈ ifre Materie eine auferordentlidy bỉnte fein, ba fie audh nidgt bie geringite Etörung in bem \&aufe ber Planeten be= wirfen, obmohl fre ifynen bis̈weilen äuperit nake fommen, unb ber eine jogar zweimal, 1767 und 1779, mitten zwiidyen ben vier Ju= 


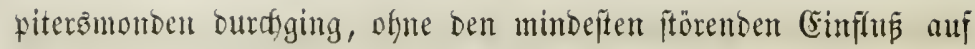
ifre $\mathfrak{B a l y n b e w e g u n g . ~}$

Fatd über ba: Sidft ber Rometen hat man merfwürbige (Er=

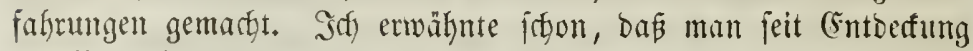
ber Folariation Deş Ridhts burdy farbige Bilder, weldge ein Rictst= ftrafl erjeugt, wenn er burch ein Raltêpathelättchen aufgefangen wird, an ber llngleidfbeit and an ben Farben ber Bilber erfemen fam, ob biejer Ridftîtrahl, meldfer vielleidft auz Millionen Meilen weiter Ferne herfommt, Direftes ober zunulffgeworfnez Ridgt, of bie

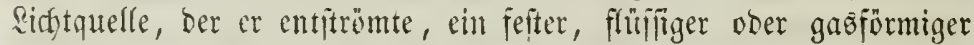

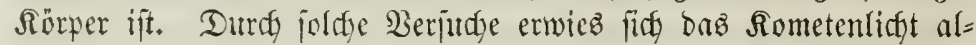

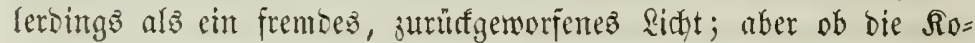
meten nidft auperbem aurdy cignes Ridjt baben, bas bleibt nody un=

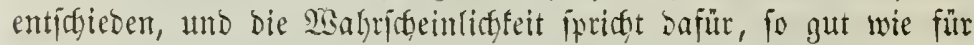

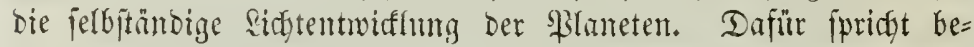

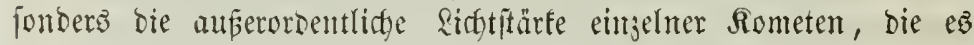

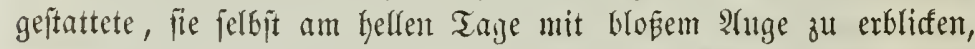
wie es von ben Rometen non 363, 1106, 1402, 1532, 1577,

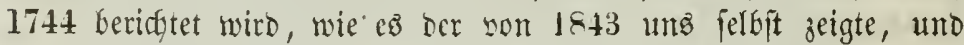
wie ber von Şinto entoefte Siomet im Safyre 1847 mur $2^{0}$ von ber Come am Mittng an mefreeren Sorten burdy Das Fernrohr gejehen

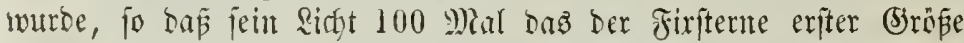
übertreffen muspte. Dafür frrifft audf nody bie Berinnberung ber Sidfteftärfe ber Siometen, umabhängig von ifrer Etellumg in ber Bahn und von iffer Entfermung yon Ser Eomue. Bei mefreren

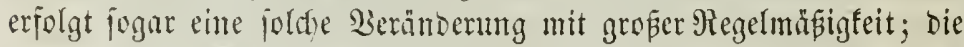
(3) vergrëpert pich mit ihrer Entfermung. Bielleidyt beutet bies hin auf

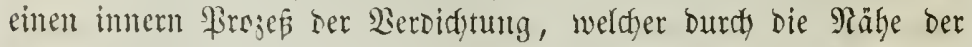
Eomme beförbert nirb unt in 3ufammenfang fteft mit ben größ̄e=

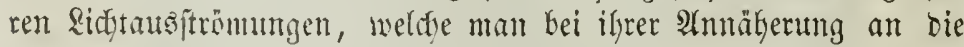
Eome bemerft bat. (Es mag die Sefeftigfeit ifres natürlidyen (Ent= wiffungsfamples jein, weldfer yon ber Eonne belebt wird, und

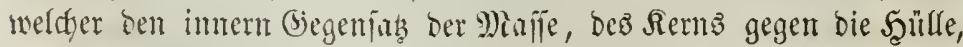

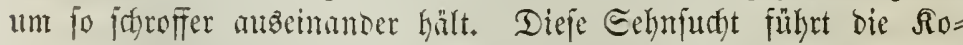

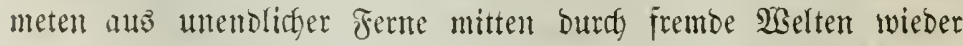
bin zur Eonne, und je nifiger er fommt, bejto fräfitiger regt fich baz 


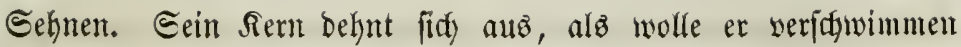
in feiner Rebelfülle, alz wolle er fid gan und gar in ätherifdyen

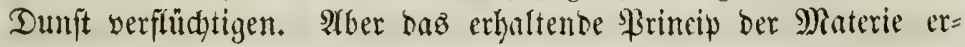
wadjt auds, uno fregreidy fülyrt co ben crmatteten Someten wieber fort in Fernen, wohin faum nod) bie mäd)tige Sonme ifren Şerr=

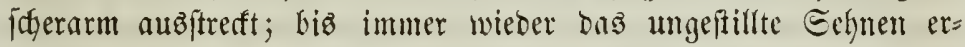
wadft und inmer mieber zur belebenden Eomte zurïf(fity)t.

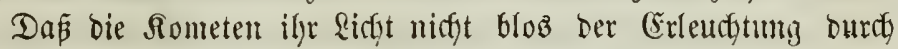

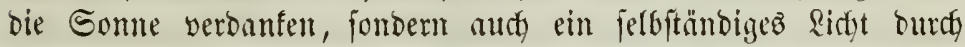
intmere Rebenz̧frajt erzetgen, dafür ifit aud ein Beweiz jene uner=

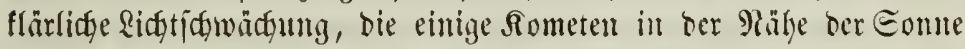
erleiben. Şaben fie aber ein eignez Ridgt, fo giebt bież ben $\mathfrak{A} n=$

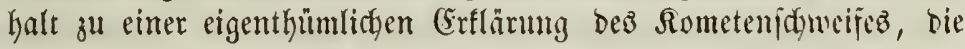
unabhängig von ber Anmahme einer nebelartigen Maffie beffelben

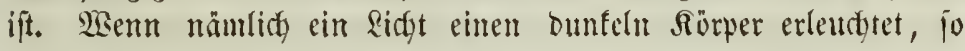

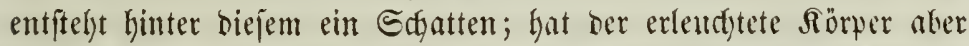
felbjit ein eignes fidjwädjeres lidft, jo wirb biejer Sdyatten nidjt mehr

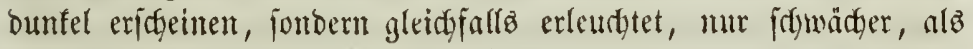

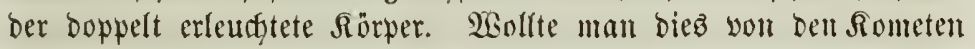
geften Iaffen, jo wäre ifgr Sdgweif mur ifyr von ifyrem eignen Sidjte erleuchteter Edgatten im $2 B$ eftraum. Damit wäre freilidy bie $(5 r=$

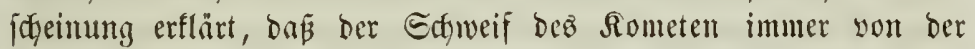
Sonne abgemandt ift, in ber Bahn aljo bem bictsteren Rerne balo

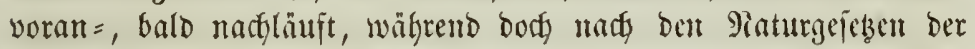
werniger bidfte Rürper immer bem bidfteren folgen mmifte. Heter ez jpridgt gegen cine joldfe (Erflärung boch muth wieber bie That=

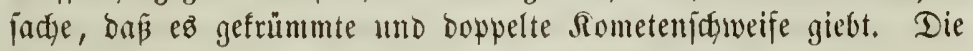
Beobadytung mus hier entidjeiden uno wird gewín undy bie Dun= felgeit aufgellen, weldye über bie Raturbefdaffenheit ber Sonteten und ifferer Sdyweife bis jekzt herrift.

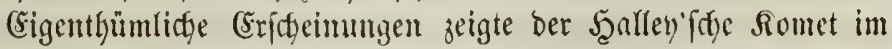
Gahre 1835. Alla er fidy ber (Erbe biz auf eine halbe (Eroweite ge= näbert hatte, bemerfte Befjel, Daß son feinem faum 30 Mleilen

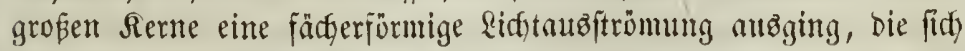

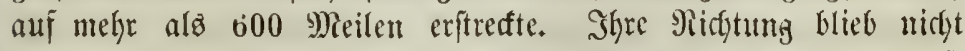
immer ber Sonne zugenvantot, jondern änderte fidy befitunbig, oft

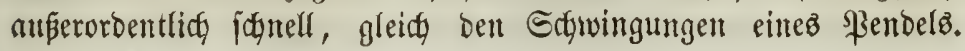




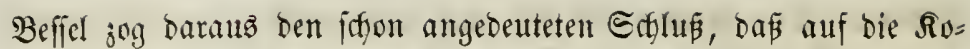
meten eine andre $\mathfrak{R} r a f t$ als bie gewöhnlidge 2 ttraction witfe, eine Bolarinait, ber magnetijaen und electrijtien entipredgend, woourda

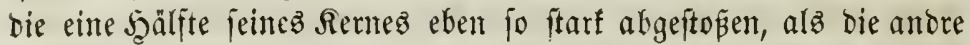

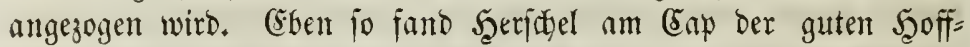

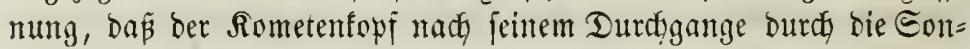
nemühe an Durdymefler bedentend jugenommen hatte und nads 17 Tagen auf das 79 fadje angewadjent war. Der Biela'fue $\mathfrak{I} 0=$ met gab uns im Sabre 1846 fogar Das feltjame Edampiel einer Theilung. C5z bilbete fin ein Rebentorf, ber einen Sthweif aubz= jenbete unb alfmälig an Ridttfärfe jo jutahm, dap er ben Şaupt= fopf eine Zeitlang übertraf. Bei ber Whiebererftyeinung bez Some= ten im Sahre $18 \tilde{2} 2$ gelang ez bem Pftronomen Eecthi in Rom am 16. Eeptember abermals ben зmeiten Rern befielben aujufinden,

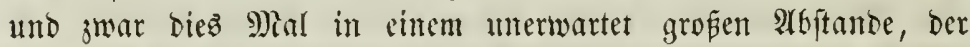
48-49 Erobalbmefier erreidte. (5z̧ gelang jogar für beibe fome= tenfertte getrennte Bafnbererfmungen anzuftellen, und merfwỉnbiger Weije zeigten fith beibe Balynen röllig mabhängig von einanber. Dennoch ijt es unzweifellyaft, Dá eine imnige Bejiehung jwijden beiben Rernen ftattintoet. (5B bürfte wahridseinliog aud in 3ufunft gelingen, bei jeber Errjotmung bes Rometen ben \&auf jebes ber beiben $\mathfrak{R}$ öple getrennt barzuftelfen ohne Finjunahme einer andern Sraft alä ber alfgemeinen Bravitationt.

Eo jurberbare Gigenthünlidfeiten minjen uns von bem $\mathfrak{b e r}=$ juche abhalten, ans : Yelynlichteiten in ber Flanetenwelt Rräfte und

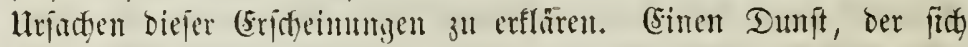
auf 12 9)iflionen 9)eilen in regelmäp̈iger Form atbbrettet, ber ein

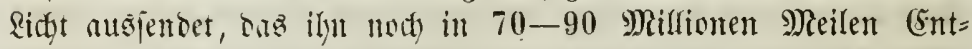
fermung fadtbar madst, fement wir im Silametenfyiten fonft nidgt. Die Sdywierigfeit einer Erflärung, wie bieje lofferen Maffen wie=

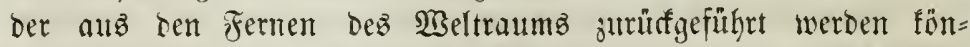
nen, hat Daher s)landye zu Der Ammahme veranlapat, bap fie gar nidyt jurtuffełren, jonbern fid im Raunte auflöjen, jeritreuten.

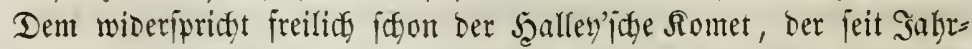
taujenton regelmäpig in jeine $\mathfrak{B a h n}$ wiederfehrt, ohne materielle

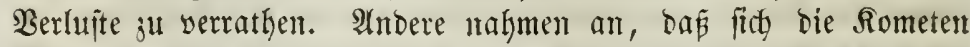
allmälig serbidgteten und in Planeten übergingen. Möctste auth 
biefe Berbidftung nidft unmöglid fein, möbten aud bie Babnen im wiberftehenben Aetther fich verengen unt ber Rreisform nähern fön= nen; woher follte bie Mafie für bieje \$ianteten fommen? $\mathfrak{B a r u m}$ überhaupt eine foldhe frufenmeife Entwiflung ber $\mathfrak{B}$ elten, eine

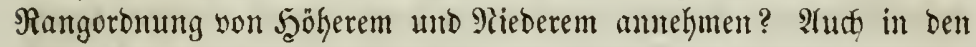
Drganiżmen ber Eroe jehen wir mur Etufenfolgen nebentinander, nidgt nadyeinander, uno fein Thier, teine Siflanze ift feit bent älteften

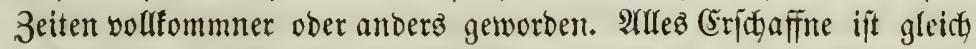

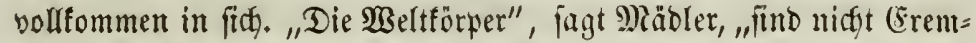

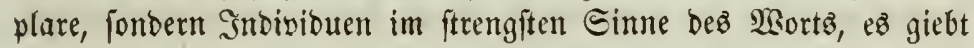

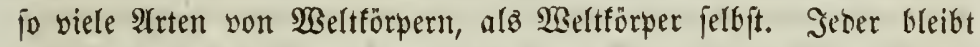
burd alle 3eiten fimburd im 2 sejentlidfent $b a b$, waz er einmal ge=

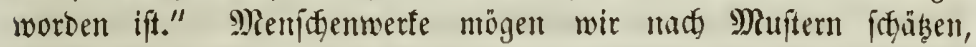
bie $\mathfrak{E}$ serfe ber Ratur funo Driginale.

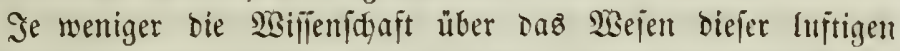
Sörper jagen fann, befto eifriger hat fie bent Bejeken ifter Bewe=

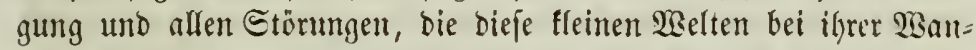
Derung burdh frembe Giebiete mädtigerer Scerrifder erfalfren muifien,

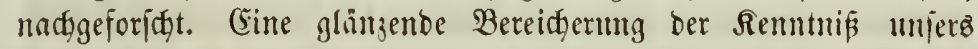

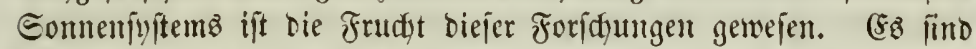

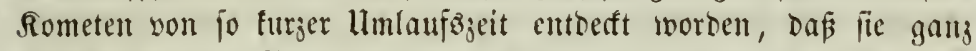
innerhalb unirer Planetenbahnen bleiben, nidgt über Den Saturn,

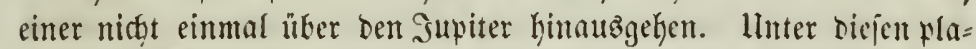

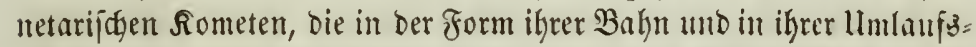
zeit ben Pranetoiben nalye fommen, ift Der von (Enfe 1818 entoefte

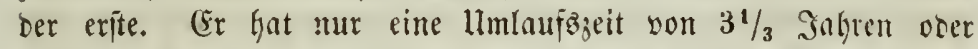
1208 Tagen, unto merfwürbig genuy verfürat fid bieje regetmäpig,

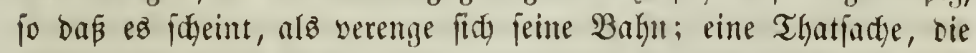
jelbit burd bie vielfadyen Etörungen ber slaneten nidat ganı ju

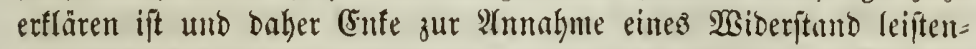

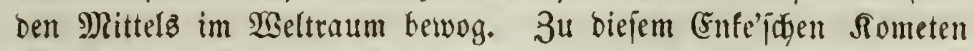
gefellte fich 1826 ein zweiter planetarifder Romet, won Biela ent= Defft, mit einer $\mathcal{U}$ mlaufäzeit von $62 / 3$ Jahren. Diejer hat eine ge= fahrorohento Bahn, ba fie unjer (srobahn nahe vorbeigeht, wenn man ein 3ujammentreffen mit einem joldhen gejpenftigen $\mathfrak{R}$ örper gefährlid nennen will. $2 \mathfrak{m}$ 29. Detober 1832 waren wir einter

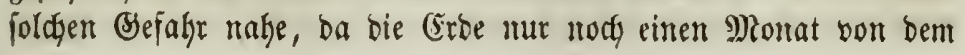




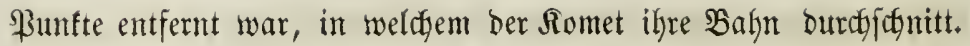
Ein wentiger bedroflictes, wunderbares Ergaufpiel fönnte unz aber nody ber Rampi zmeier joldger Rometen gewälyren. Denn biefe bei=

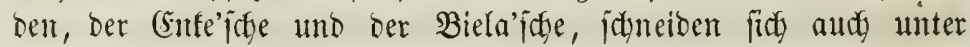
einander in ifren Bafnen un fönnten wofl einmal eimander begeg=

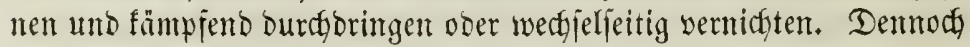

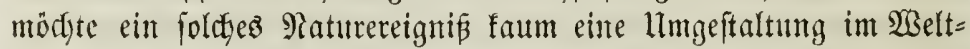

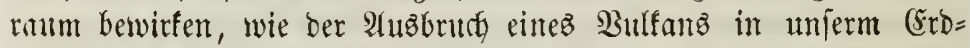
freiz! Sin britter §omet von ber furzen Umlaufzzeit von $75 / 12$

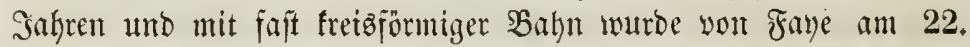
Povember 1843 entbeft. Er ift im November 1850 zu Eambribge wieber aufgerumben worben umb erreidyte fein Pierifgel in berfelben Stunde, weldye Reverrier norausberedynet hatte. De Bico entbefte in Fiom im Jahre 1844 einen andern Rometen, Der in $5^{1 / 2} \mathfrak{J a h}=$ ren jeinen Umlatf beentet, uno ben Bjordichmibt im Jahre 1855 wiebergefefyen haben will, obwobl biefe Beobaututng nod einigem 3weifel unterliegt. Brorjen in Riel beobadtete im Sagre 1846

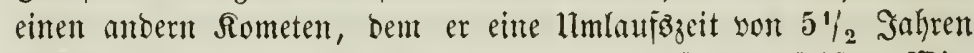

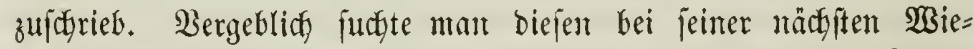
Derfehr in Iahre 1851 mieber aujzufinden; bie Mähe ber Somte

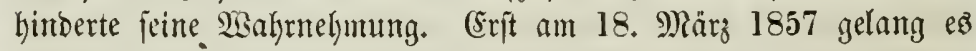
Brufns bei feinter abermaligen 2 Sieberfehr biefen Siometen zu er=

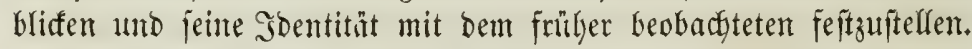
Err ift fomit Der 3te berienigen Someten von furzer Uumlaufz̈zeit,

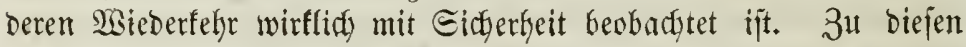
gefellt fich endlich ber von b'atreft 185 l berectnrete Somet, bem eine Umlaufşzeit von $6 \%$, Эahren zugejdrieben mirb. Die übrigen $\mathfrak{I}_{0}=$

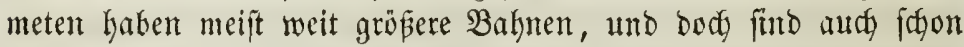

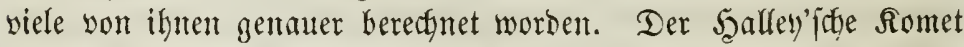

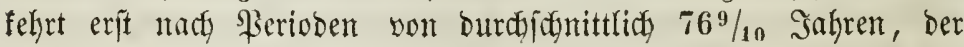

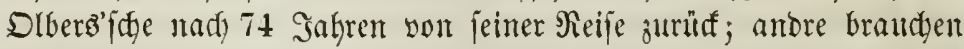
jogar Şunberte, jelbjt Taujende von Gahren. Eo gebraudgt ber

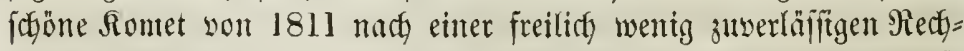
mung 3065, ber futruttbar grobe von 1680 jogar 8800 Sahre, fo

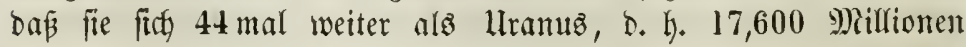
Meilen your ber Sonne entfernest, und body fteht der nächjite Firs =

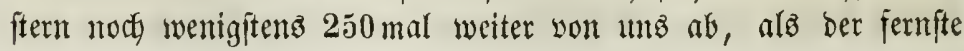


aller bizkger befannten Someten. Heberbies find bie Bahnen diejer Someten äแnerft vern̈nberlid, ba fie bei ifher geringen Didftigfeit

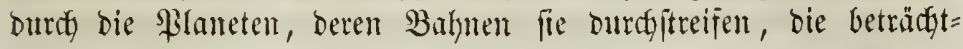
lidyften Störungen erleiben. Mandyer Romet, 3. B. Der volt 1769,

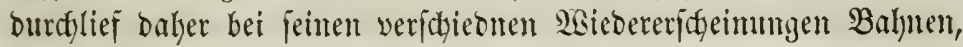
bie nidyt bie geringite 2 ehnlidffeit mit einander hatten. Daher

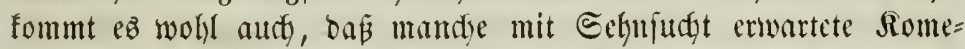
ten Sakre lang jelbjt aitrontomijogen (Erwartumgen fpotten fömen.

(sine foldye Täujhung miderfubr uts nod) in ben leţten Sab)= rent. Gs ift befannt, baj bie Soentität jweicr zu veridfiebenen Zei= test gejelenen Sometent nur aus ber llebereinftimmung ifyer bered $=$ neten Bahnelemente gejolofien werben farm. Shun hatte fith fidon

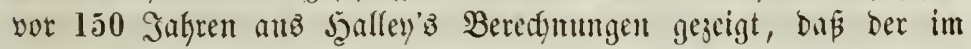
Sngre 1556 erjoienene groß̈e Somet, weldyer Sarl V. befamtlidy

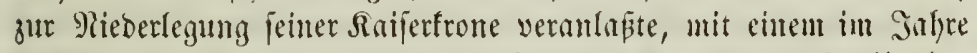
$126 \pm$ gejebenen, weldjer ben Tod \$abft llrban IV. proplezciht ha= ben follte, in feinen Bahnelementen, menn autdy midft wöllige (Sleid)=

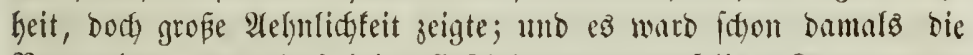
Bermuthung rege, baß beibe Eridjeinutgen bemfelben Rometen ant= gehörten. Die B̉nlyn Des Rometen won 15506 ließ fít) mady Den

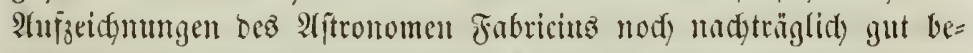
ftummen, und ebenjo ließen fich bie Etörungen menigitens ammïlyento

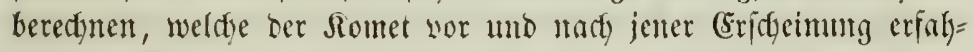
ren laben müite. Şind in Eonoon und Bomme in Mribollourg unternalymen biefe fofwierige Berefynung. Das gemeinjame Sieful= tat war eine llmlantigzzeit bes genannten Someten von 308 Jah)s

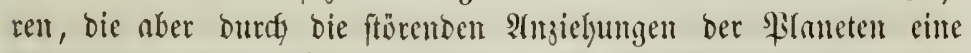
Berfürzung von 10\% Sabren erfakren fömue. Bomme glaubte bar=

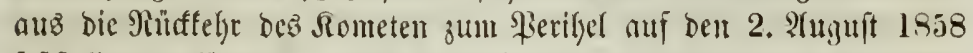

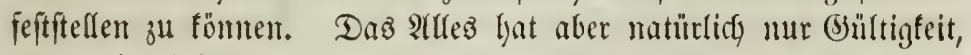
wenn bie biş⿻er nur vermuthete Soentität ber beiben Rometen won

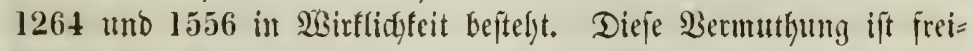
lidg in neuejter 3eit bebeutento erfoüttert worden. Einerjeitz find yon Rittrow alte, bişger utbefante Beobatghntgen beż Someten von 1556 aufgefunden worben, andrerjeits hat Şoof bie altell, mentlich chinefifden Beobadytungen Des Someten von 1264 genatuer unterjudt; und es ergiebt fid baraus eine größere Serfdyiedentyeit 
beiber Bahmen, als man uripringlid angenommen. Die $\mathfrak{W a h k}=$

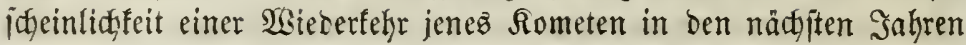
ift bamit zwar nod nidgt aujgehoben, aber bod jefre vermindert.

(5'z ift befannt, weldes lunkeil bereitż bie vermeintlidye \$rophe= zeifung von ber Siebertehr jenes ßlaneten im vergangenen Jahre über bas ganze gebildete Europa heraufbejdyoren hat. (Fin müpi= ger Sopj hatte fith leider ben unzeitigen Epaṕ gemadt, einen be= fitimmten Tag, ben 13. Suni, für bie Wiebererjdyeinung jeneş $\mathfrak{\Omega} 0=$ meten anzugeben uno bamit eimige nidhtige, ben Seift ber Nenge bethörende Borausiangungen son einem burdh ifn brokenden $\mathfrak{B e l t}=$ untergang in Berkindung ju bringen. (Er fand leiber mur zu viel

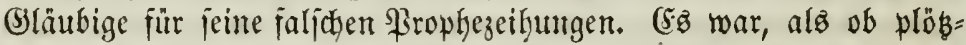
liđ̆ ein füftrez (Sejpenft bes Mittelalterz zum Edyrefen aller wahr=

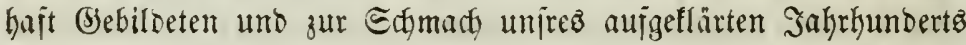

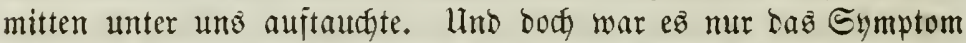
einer tiejer liegenden $\mathbb{R}$ rumfgeit. Durite man ez bod in jenen $\mathfrak{T} a$ gen bes 13. Iuni "frommen" Reuten gegemüber nidyt einmal wa= gen, über biejen heillojen Ilberglauben ju jpotten, "weil. ber Unter= gang ber Welt ein driftlides Dogma jei!" Wurben Dod, Eatholi=

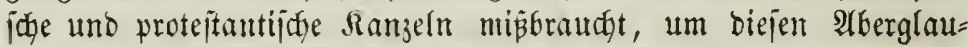
ben alo Mahmung zur Bǚ ju predigen!

Wenn nun aud bisweilen Rometen theils wegen faljuer $\mathfrak{B o r}=$

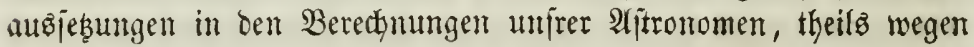
ungefantter Etörungen auf ifrem Raufe burdy bie ßlanetenwelt,

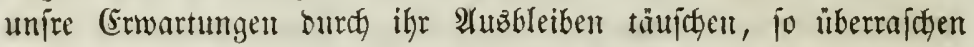

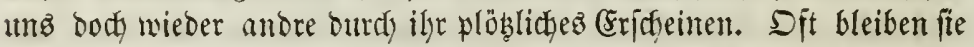

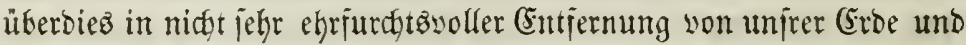

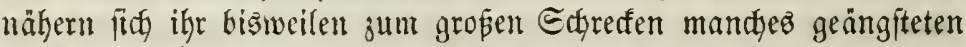
Frobewohners. 2Am 28. Stmi 1770 itant ber Rerell'icte Romet nur 6 mal jo weit alz Der Mono son unz ab. 2tm 26. Suni 1819

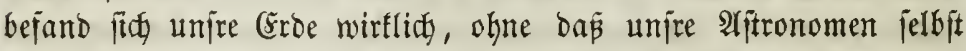
etwaz bavon wup̄ten, einige Etunten lang im Echweife eineż erit einige Tage ipäter entbecten Someten. Sener Tag war fo warm uno jăon, wie bie Commertage jeneş Sabres überhaupt; tein be= jonderes (Ereigni bezeidnete ihn, weber Eturm nod) Ungewitter,

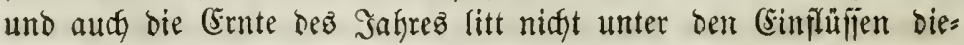

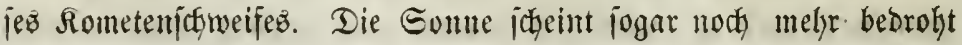


3u werben; Denu $16 \varsigma_{0}$ rüfte ify ein ungeheurer Romet biz auf $\%$ unjer 9)ionsweite, aljo auj 36,000 Mieilen nabe; und boch hat feinter von allen audy mur bie geringfté fïrente Sirfung auf

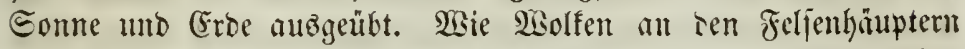
Der Siebirge find fie vorilbergegangen. Siidyt um Eecunden haben fie bie (sroe in ifrem sauje verzögert.

(Simit gab es eine 3eit - und bas vergangene Jalye lat uns ja liberzeugt, ba glauben mödten, und baj oer Aberglaube feine Edatten nod weit

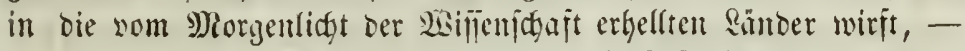
eร̉ gab eine 3̧eit, wo man dic Someten jür \&ufterjocimungen hielt, weld)e bie (jottheit als Borbotent grö̈er Eandplagen am Şimmel

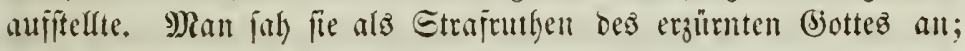

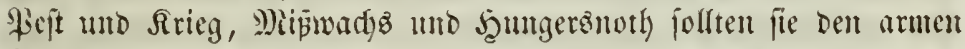

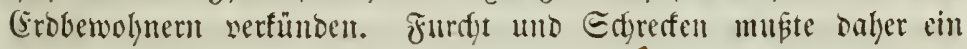
joldyer unwillfommuer Bote bringen. Dep̈balb ergählen bie alten Edriftifeller, went fte won ber Eridgeimutg eines Rometen fpre= chen, immer auty won ben traurigen Begebenleiten, die fie nady

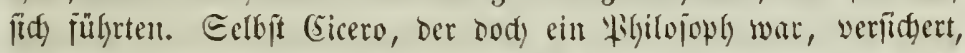

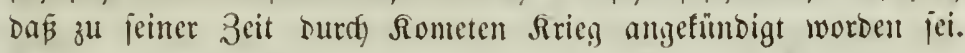

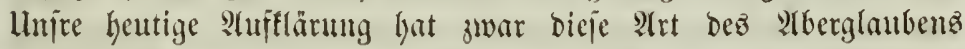
gröptentheils sornidtet, aber body regen fitd and jebt nod in ei=

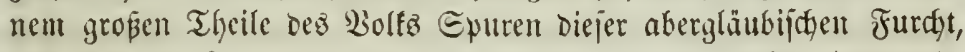
und mandyer Ranburam fiefyt nody inmer mit Edyreffen brennente

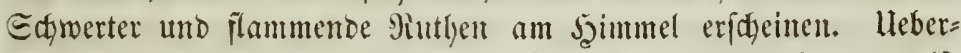
Dies hat wieber eine nene Bejorgnis die zaghaften Mienidgen ergrif=

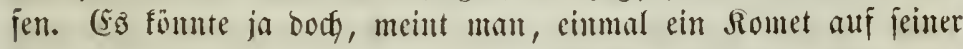
WBanderumg burdh unje madbbarlidgen Sin̈ume mit unjer (Erbe zu=

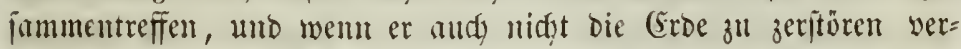

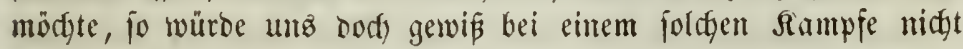
wohl zu 9) Juthe fein. Pody yor nidyt gar langer Zeit lyabent foldhe

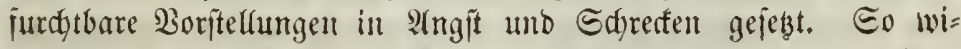
berjubr ez bem berilfmten 2(jtronomen Ralande zweimal, baß̄ er zum Urbeber joldyer Edyrectengigerïd)te geftempelt wurbe. Im Sahre

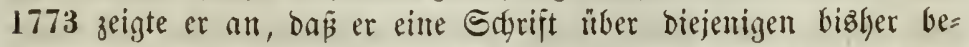
fannten Someten Geraubageben molle, weldye der Eroe nalye fommen

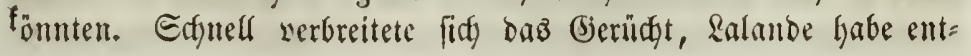




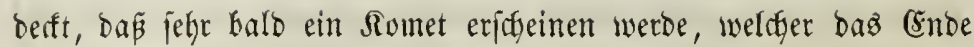
Der Welt herbeiführen folle. Afllgemeine Furdft verbreitete fid), und ber afitronom jah jüh genötlight, eiligit befannt zu machen, baj

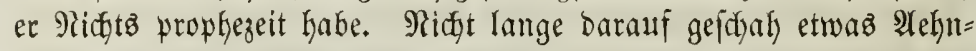
liçes. (Sin muttywilliger Menjch macte befannt, ez würben in

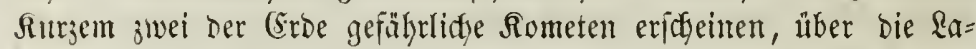

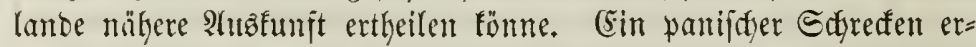
grifi bie ßarifer, uno wieber mupte ber (jelehrte offentlich erflären,

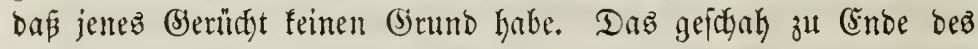
worigen Jahrlyunberts; ijt baร hentige ärmer an \&ädberlidbfeiten?

Freilidy loben fidy jebt wifieniffaftlicte Senntmifie neben un= grünblicher Şalbheit in größeren Sreijen bes gejelligen Rebenz ßlab̧ gemadgt; aber bie Bejorgnifje yor wentigitene möglidyen llebeln ichei=

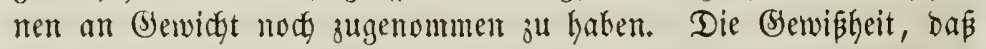

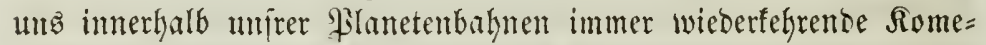

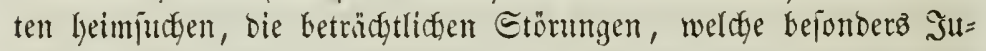
piter uno Enturn in ifren Bafnen hervorbringen, und weldye un=

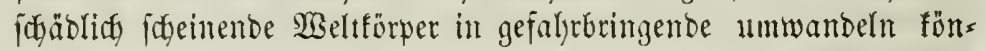
nen, bie Berjdiebenheit ber cinzefnen Rometenförper, weldge beträdgt= liche âfitufungen in ber Didtigfeit ber Maffe bes Rerns vermu=

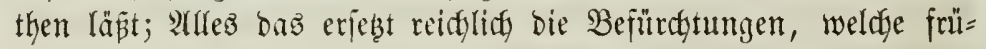
here Safrhumberte bor brennenten Eifwertern mo vor einem burdh Szaariterne gebrohten Weltbranbe hegten. Eo fann bie Wiillenjdaft felbit Bejorgnifie erregen, bie fie zwar nidyt theilt, bie fie aber bow vergebenz zu berubigen frrebt. Cie fann es ja gar nidgt leugnen, Dá möglidjer $\mathfrak{B}$ eije ein Romet einmal mit unjer Erbe zujammen= ftope. Freilidy hat feine ber bctannten Rometenbalynen cine joldge Rage, baß ein 3ujammentreffen mit bem Ropfe bes Someten we= nigitenz zu erwarten wäre. Co weit die Rometen eine Bahnbe= recfinung geitatten, ift ber vom Salje $168+$ nody ber brohendite, ba er ber (Srbbalin - wohlwerftanden, nicht ber Erbe jelbjt - auf 216 Erohalbmeffer D. h. 185,000 Mieilen nahe fommt. Sejebst aber aud, bấ ipäter noch andre Someten ifre Bahnen und viefleidgt

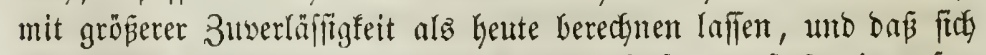
unter biejen einer finbet, befien wirflidyen 3ufammenjto Srbe bie 2 fitronomen vorberjagen fönnten, io würben bie Folgen

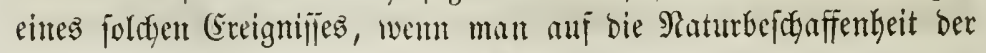


Someten Rücfildgt nimmt, Dennod feiner Beadtung werth fein. Die Someten find ja jelbit in ifrem תerne burdffertig und nidyt im Stande, hindurdjgebende Ridftitrahlen von ifrem Sisege abzulen= fen; fie fint alfo weber flüfftge nody Iuftförmige Rörper. Sie fön=

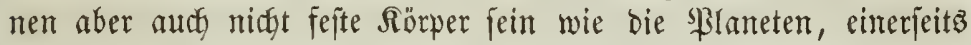
wegen ber gropen Beränderlidfeit ifyer Umrilie, anbrerjeitż wegen

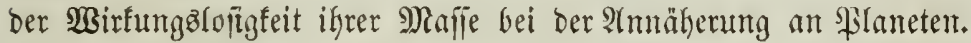
Mit Der Echärje unirer Beobactumigen wädjit nun aber auth bie Eicherung unjer $\mathfrak{B a ̈ g u n g e n ~ D e r ~ S e i m m e l a ̈ f o n t p e r . ~ C i m e ~ M a f i e , ~ b e = ~}$ ren Wirtungen wir nidyt nidyt mehr wahrnefymen fönten, múp alio

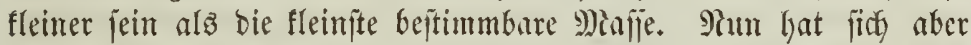
ergeben, daj ber Romet von $17 i 0$ nody nidgt ben 5000 ften Theil Der Cromajie haben fam, weil man jonft feine $\mathfrak{A}$ njelumgsinirfun= gen bätte wahrnehmen milfen. Maf̈enlog find bie Rometen barum nod) nidft. A(ber went man ifren gewaltigen Raumumfang $b e=$ benft, ber meiff ben jämmtlidyer Blaneten, wolyl felbft ben ber Sonne ubertrift, fo bleibt für fie eine fo anterorbentlidge Dün= heit übrig, baß̄ wir auf Erben feinen Bergleidy mehr bafür habest.

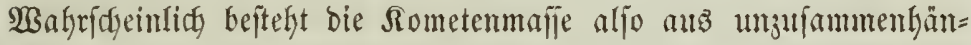
genben, ftaubartig verbreiteten Theilen, bie wir in unntittelbarer Rähe gar nidyt einmal wahrnefmen wḧrben, und bie uns audy in

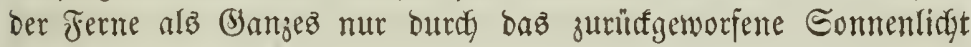
fictbar werben.

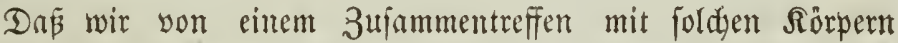

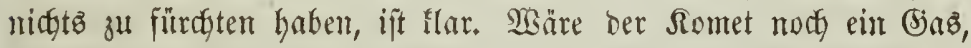

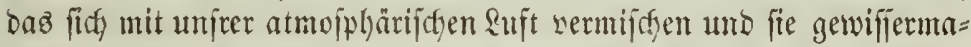

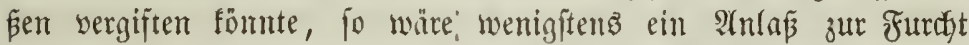
rochanden. Aner was fam es̉ fđaben, went fidy einige frembe Etwubtheildyen auf unirer (Erbe niederidylagen! Sedenfalls ift ein famitgroper Meteorftein furchtbarer als ein Somet. Stecten wir felbft mitten in einem Someten, ex wïtbe uns fein Scan frümmen; wir müsten beun alle aftronomijaten Thatjadjen lengnen wollen. YIber vergeblidy miro bie Wifilenfdaft fid bemühen, ber grofen Mienge

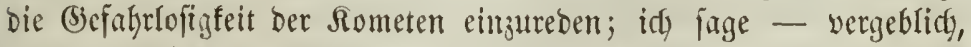
benn alle ifre ber Sledfunng entlelynten Gründe wirfen mur auf Den benfenden Berftand, nidyt alif bie bumpfe Etimmung ber $5 e=$

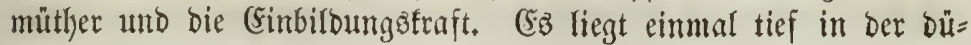
ut $\mathfrak{e}_{\text {, }}$ Bettalf. 3. 2uft. 


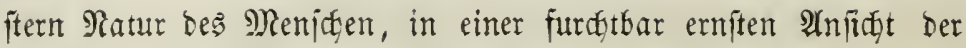
Dinge, ba Freube ober Şoffnumg erregt. Tie $\mathfrak{B}$ undergeitalt eines großen

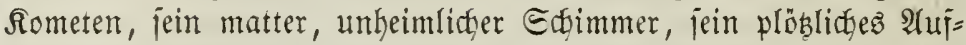

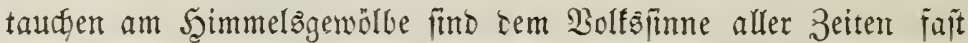
immer als eine neue, grattenvolle, Ler altefrnürbigen Berfettung

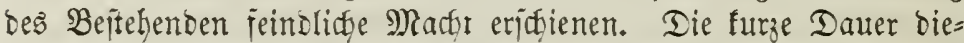

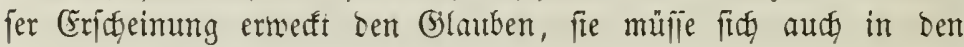

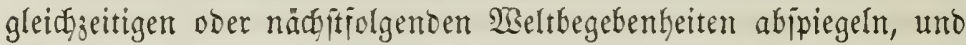
Dem Gilauben bietet fich leidgt bar, was ifm als vertündetes Ultheil

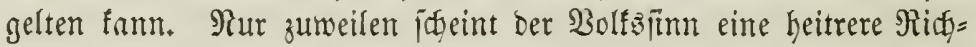
tung anjunthmen. Ier jäñne Romet tes Sahres 1811 hat ben

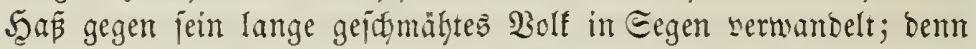

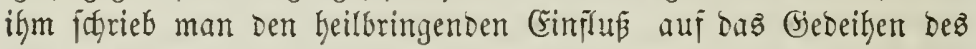

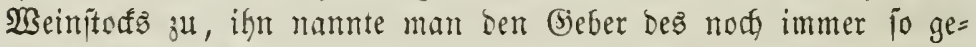

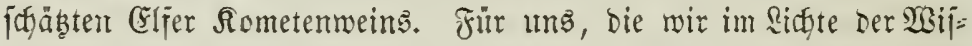

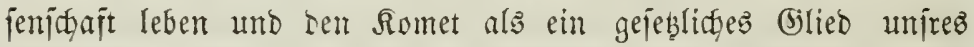

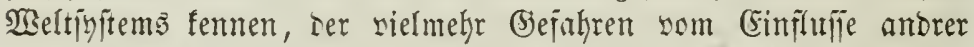
Weltförper ž fütrdften, als bei jeiner geringen Maije zu bringen Hat, follte boct, ber Romet jeime Edyrefen verloren baben. Den=

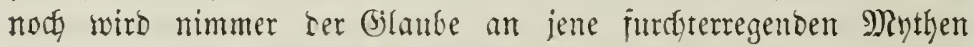

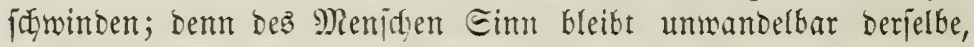

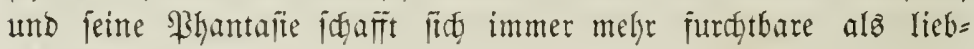
lifye Bilier!

Furdftlob wenten wir uns von biejem lujtigen Rometenvolfe ab zu andern, gleidyfalla umjerm Evjteme angehärenden 2 Selttör $=$ pern. Denn noch ifit bie bunte झicitge von Formen gebaulter Materie

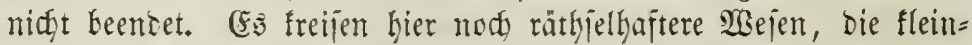

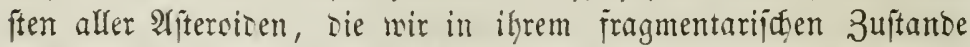
und in Den Bereidf miner Âtmojphäre gelangt mit bem Hamen

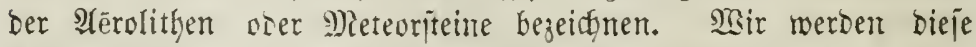

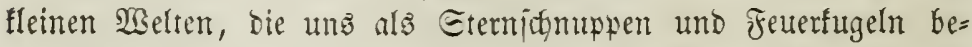

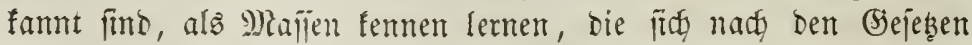
Der allgemeinen Ectwerfrajt in länglidgen veridflungenen Balynen

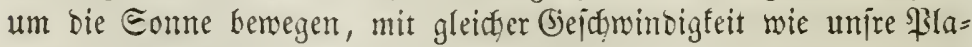
neten, D. h. zmifden vier und adgt Meilen in ber Eecunte burch = Iaufend. Bis̄meilen begegnen dieje Mafijen in ifrem Raufe ber Erde, 
merben von ith angezogen und leuthten, biameilen lafien fie glü= Gente, mit jofwarjer, glänenber Rinte überzogene Eteinmajien her= abfalfen. Dinn fitherlid, bürjen wir Eternjamppen und Jeuterfu= geln nidft trement. Beibe Erridseimungen jeften unir in gleichzeitig,

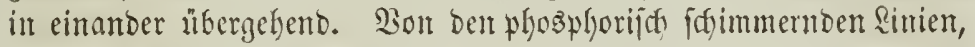
in benen iid bie Eternidgnuppen wie fortgleitenbe \$unfte zeigen,

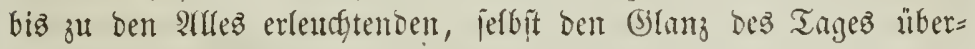

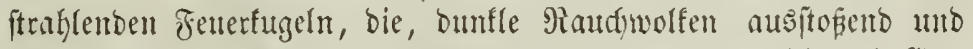
mit furchtbarem Rradjen jerplakzend, einen Eteinregent über bie Crobe

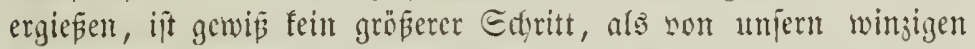

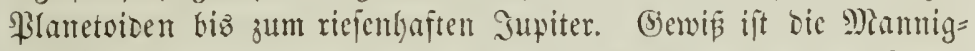

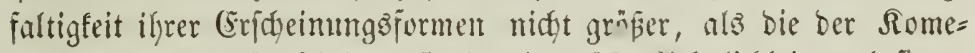

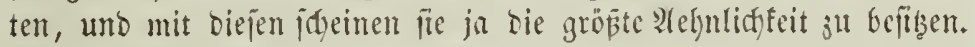

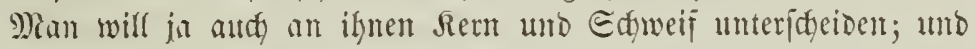

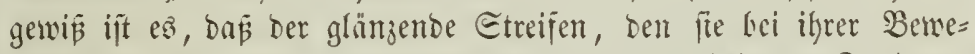
gung wic eine feurige Epur jurrinflafien, nicft alfein ber Fortboner

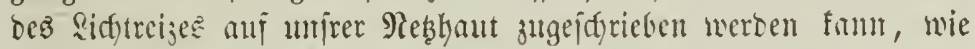

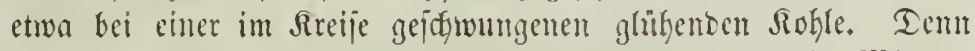

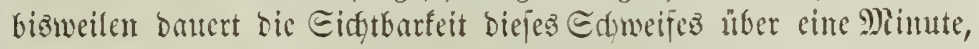

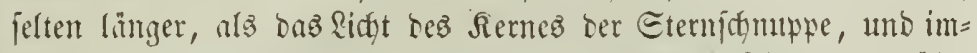
mer bleibt er unberweglidy fejt ftehen. Die bejte 2 (ufflärnmg barüber vermögen uns mur Beobachtungen in jenent Tropengegenten auf ben

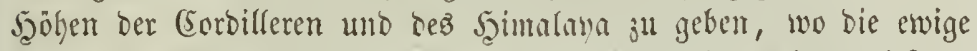

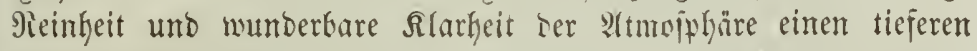

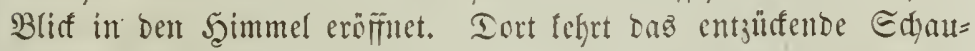

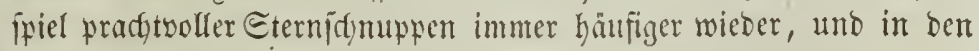

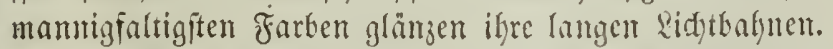

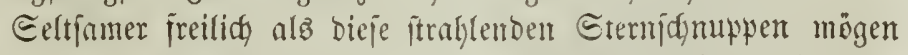

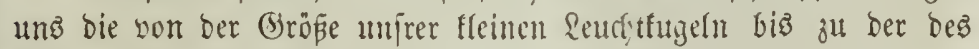
Bollmonos medpélnoen Fenerfugeln erict)einen, aus benen Me=

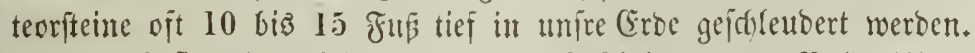
Dodf audf fie zeigen jelyr abweidgente Erridfeimungen. Bald bilben fid bei heiterm Szimmel plöb̨lidy fleine buntle Bemölfe, aus benen

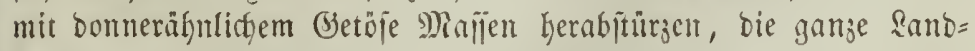

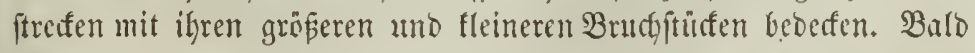
ftürjen p̈e, wie nody yor wenigen Salfren am 16. Eeptember 1843 unweit Mühlhaujen, auz leeiterem Szimmel hernieber. Itber fam 


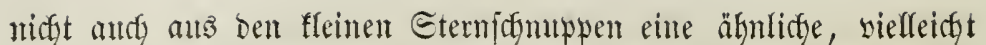
mur ftatbartige Meteormaffe berabjallen? 23 as überfaupt in $j$ s= nen jdwarzen Wolfen wäfrend Des frachenden Donmers vor bem Serabfallen ber Eteme vorgeht, ob fid erft bunftöntmige Theile ju flammenten Fenterfitgefn verbidten, ober ob fie fogon zu bichten Mafien gebalft bie Eonne umfreijen, das Alles ift uns bis jeb̧t in tiefes Dunfel gefülft. Dod wiro es uns mehr als unwahridgein=

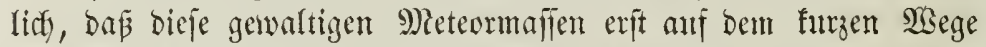
son ben (Srenjen anjer Atmojphäre bis gur (Eroe aus bem bunit= förmigen 3uitande zll einem feften Rerne Jujammengeronnen fein follten, zumal went wir bie anperorbentlide Bejdyindigteit ifrer Bewerung bebenfen und Die Srö̈e bicfer Mafjen, bie bod nur Fragmente son bem fino, was in ber Fetterfugel ober bem bunfeln

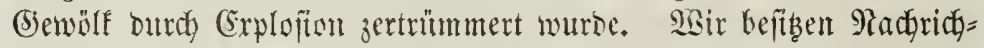

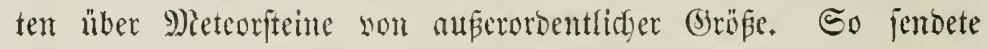
nodh yor wentigen Sahren eitle Jeutertigel bei Bratuau in Böhmen

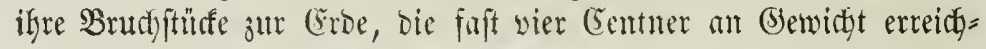

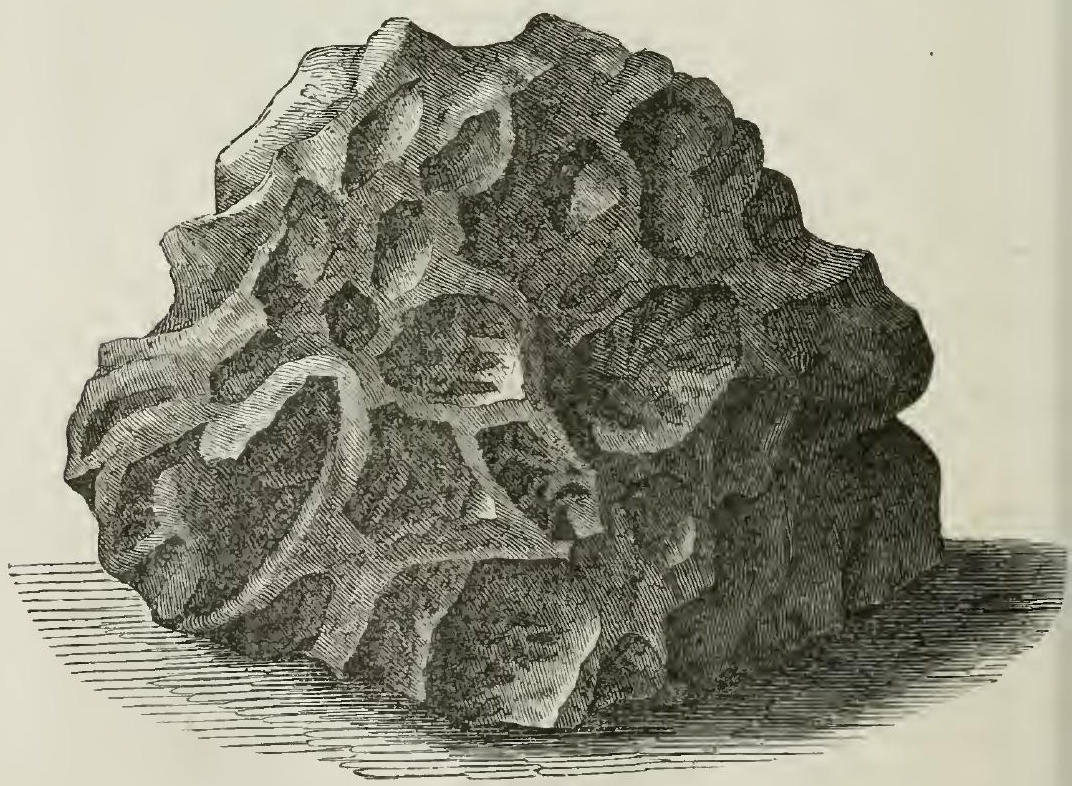

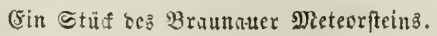




\section{3}

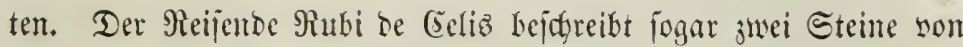

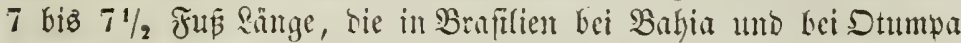

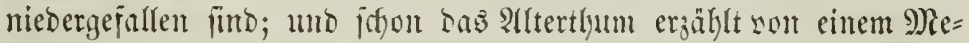

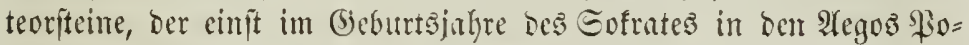

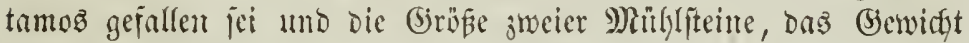

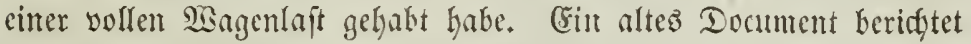

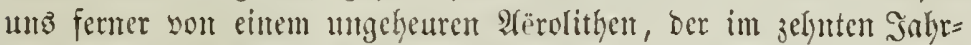
fundert in Den Flup bei Marni in Stalien gefalfen fei unt cine (Elle hoch liber Dem Waller kerworgeragt bake. Alte Eagen crälf)= Ien nody eritaunlidjere Dimge. Co lebt nody unter Dent Mongolen eine Bolfsinnthe, nady weldyer nahe an ben Duellen bez gelben

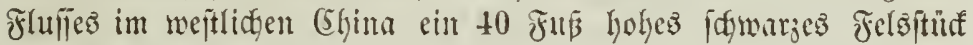
vom Şimmel gejallen jei.

Boher aber fommt allen biejen Matlen ber eigenthümlidge

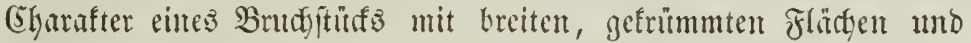
abgerumbeten Effen? Römten fie bieje als rotirente Rörper beiptzen? Uno wemn fie bieje erjt burd) cime plöblide (suthünoung an ben (Grenzen unjer 2tmofphäte erlangen, mober bieje Entjünoung, bieje Sidytentwidung in Jabien, in renten faum nody cine Epur

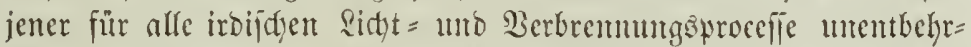

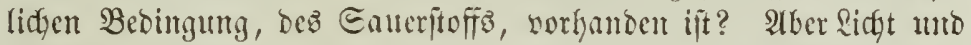
SBärme, haben wir fogn gejehen, fömten fids aud olne biegen= want bes umgebenton Eaueritoffos entwiffelı, fie finto alfgemeine Rebenseridycinmmen, Folgen imterer Bewegung, herworgenufen burdh ein verwandtes Eelynen aller Materie nad) Sercinigumg. Dartm

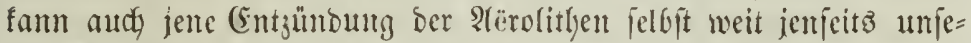
rer Attmofphäre vorgehen, fobald fie unt in eine lähe ju unfrer Erbe fommen, weldye eine 2 sectjelwirfung swijtgen ifnen möglidh madyt.

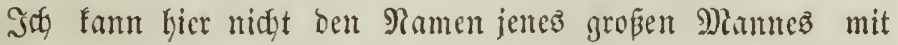
Stilljumeigen libergehen, ber zuerfit ben erfabenen Gebanfen faß̧te, baß bie auฮ ber Atmojphäre hernbgejallenen Eteine im 3ufammens hang mit den Feuerfugeln fosmijden urjprungs jeien, D. h. Daß̃ fie Weltförper jeien, wie unjre \$lanteten, von gleidgen (Bejetzen regiert und nur von ber mäcţtigen 3ugfraft ber (5rbe aus ifren ätherijden Bahnen herabgerijien würoen. Diejer Mamn war (5hlabni, der 1794 jeine idarifmnige Anfidyt ausiprady. Die neuere 3eit hat 


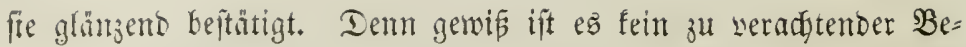

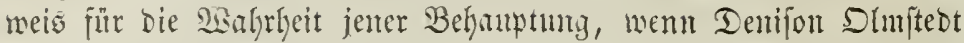

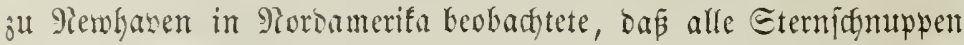
uno Feuterfugeln, Die in zalflojer Menge wie ein Fetterregen in ber Madjt yom 12. zum 13. Tiovember 1833 eridjenen, fämmtlich son

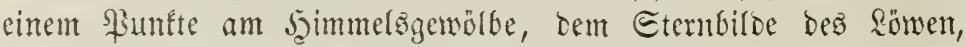
ausigingen und bie ganje Piadyt hindurd, trok der Motation ber

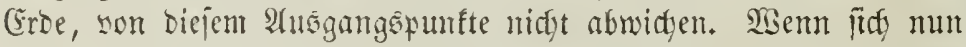
bieje Beobadjung immer wieber bejtätigt hat, wem alfe ifgre Edjaa=

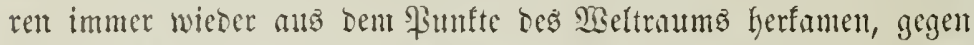
Den gerate bie Bewegung Ier (Erbe geridatet war, fömen nir nody

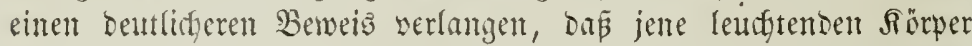

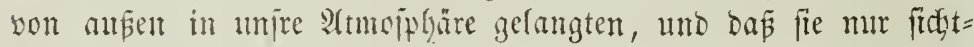
Gar wurben, weil fie in iffent unter fich fait parallelen Baflynen ber anjielyendent (Eroe begegneten?

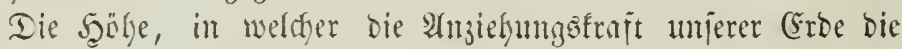

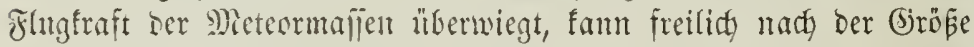

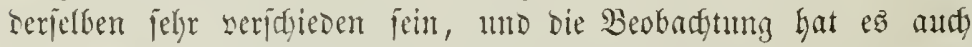
to erwiejen. Eelten betringt fie unter $5-6$ Meilen, gewöhnlidy 16-20, oft über 100 Mieifen. Iann aber ergiebt bie Miefintug

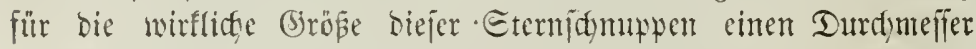
won 80 - 120 Fus, bei jehr großjen Feuerfugeln wohl aud 500 3000 ช̌ 3-4 Meilen Rantge geben, wie Mehrere thun, fo ift ifge Milie immer nod) in feinen Sergleidy zu bringen mit ber bez Eleinften unirer Blantoiben, Der Thetis, beren Durctmeffer nicft unter 8 Meilen beträgt. $\mathfrak{A}$ ber gró genug beiben fie immer, um jente fo lange hodgeelyte Theorie nom llriprunge ber $\mathfrak{A}$ ërolithen aus Mond=

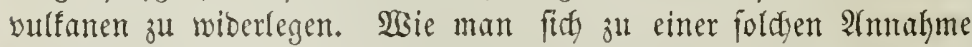
bequement fornte, wie fie zuerit ein italienijder \$ignjifer Ramens Terjago 1660 bei Gelegentyeit eines 2Aërolithenfaltz, burdy ben ein

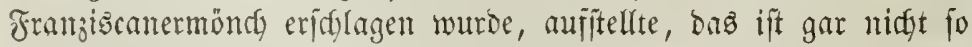

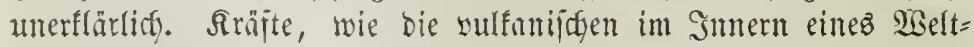

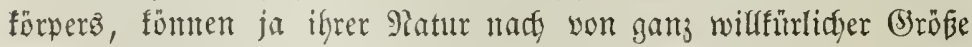
angenommen werben. 2 Garum foll man aljo nidyt bie bienalt ber

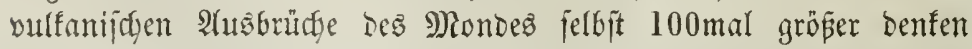
fönnen, alb bie unfrer (Erowulfune? Freilith aber mürbe man eine 


\section{5}

foldge Scypotheje won einer fo gropen Menge von Bebintgungen ab=

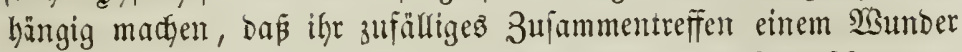
ähalidyer jeben mödte, als das Erideinen von Stermidnmmpen und Meteoriteinen ofne cine joldge (Enflänng. SNan hat berech=

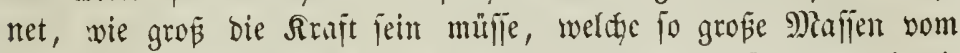
Monde bis auj unje Eroe ju werfen im Etambe jei, zumal mit

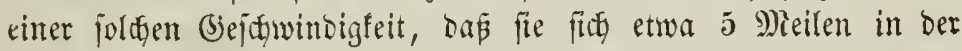
Secunde bervegten, und man hat gçundent, das fie mindeitenz 70

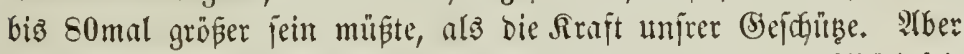
feine Beobuttung beredtigt ung, für bie Gegentwart eine Thantigfeit

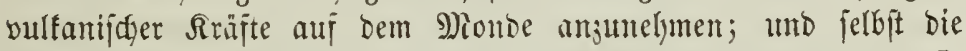

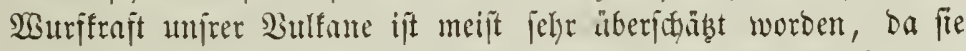
faum um bas 2-3jadje urje (jefdühfraft übertreffen mödgte.

Da man fith Die Ritdtung Der Bewegung Der Metere nidtst з erflären muste, fo fam Raplace ju Der jondertaren Befauptung,

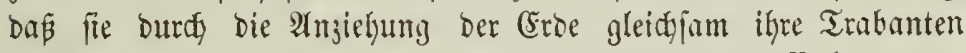
würben und biefe in fpiralförmig fid, verengenden Bahnen um= freiften, biz fie nach vielfachen llmläufen in bie Ptmofphäre ber Erde fänen und num Kernbgejogen whirben. Cinfadger und einer

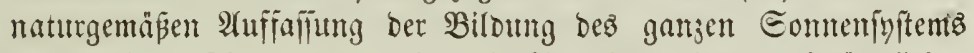

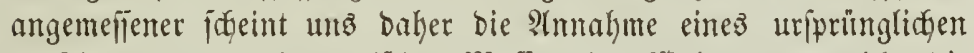
Dajeins Eleiner planetarifder Maffen in Siseltraum, weldye bie

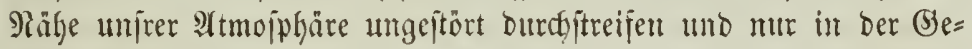
ftalt ifyer Bahnen burd bie Anjiefung Der Erbe Beründenungen erleiben, io baßj fie แtz nath melyreren llmläufen um bie Eonne. immer wieder fithtbar werben. Darin beitinft unz befonders bie Erfahrung, daß̄ nidgt immer Etermidnuppen unb Feuerfugeln to bereinzelt und felten erfaeinen, fondern bisweilen in Edyärmen

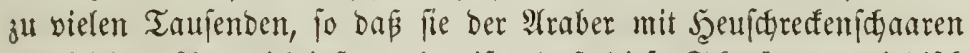
vergleidgt. $\quad 2 m$ widytigften aber ift, baj bieje Edywäme periobiich fint, D. b. zแt beftimmten 3eiten wiedertebren. Shon eine alte Trabition ipridgt von. Den fourigen Tlyränen bes heil. Raurentius, bie biejer Şeilige jäfyrliç an feinem Fefte bem 10. Autgujt weinte. Aber erjt in neuejter 3eit ift man aufmerfjamer geworden auf bie

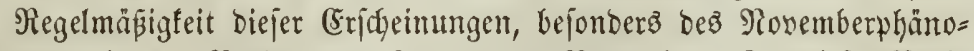

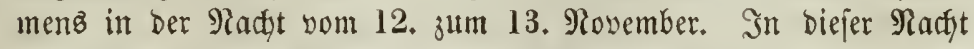
war fdyon in ben Jahren 1823 und 1832 fajt burdf ganz (suropa 
und ferfit in einem Theile der jüblicfen Erobgäffte ein auffaltend

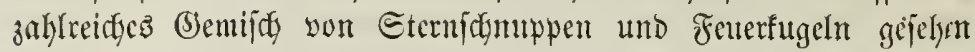
worben, aber erfit ber ungeheure Eternifhnuppenregen am 12. und 13. Nobember 1833 , in weldyem wälyend 9 Stunden werigitenz 240,000 wie Edfneefloffen fiedy brängend Kerabfielen, bradten Sorm=

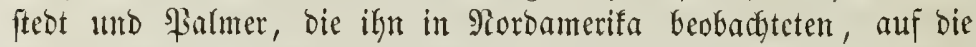

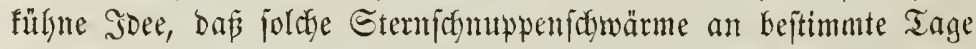

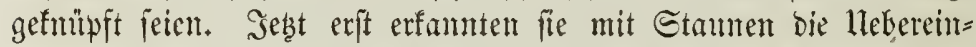
fitimmung frülecrer (Eriffcimungen mit ifren jeşigen Beobad)tungen und fanben ifre fühne Beknuptung gerectiffertigt, als fith im fol= gendent Saliee in Der Padbt vom 13, Jum 14. Plovember in Denjel= ben Segendent Rorbamerifins jencs munberbare Edyanfpicl mit fajt midft geringerer \$radfyt wieberholte. Seģt ward man audf auf an=

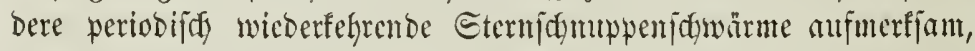
bejonders auf ben Єtrom bes beiligen Rautrentius zwiicten bem 9. und 14. Fluguit, unto mit ber 3eit wirb man gewiß nord mehrere foldfer regefmäfigen Ströme entbef́en. Bemerfungen alter Beiten

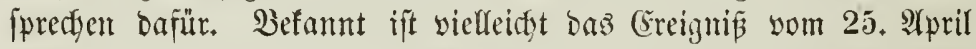

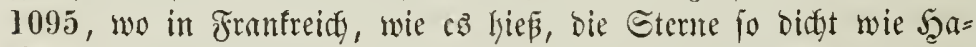

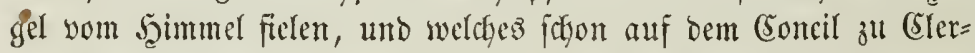
mont als cine Sorbedeutung für bie großje Beweegung ber CGhriften=

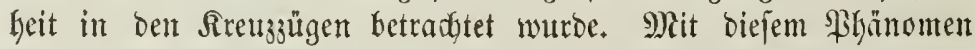

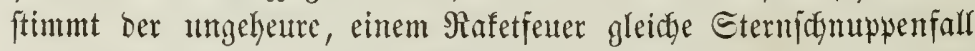
in Sirginien am 22. Ifpril 1800 überein. Iftch bie 3eit yom 27. Giz 29. November ffecint von Bedeutung für biefe periobiffeci Me=

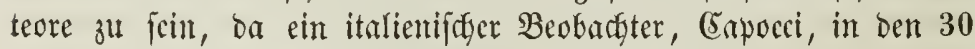

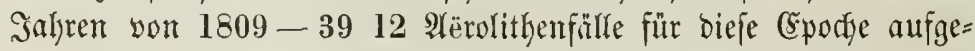

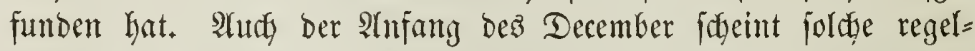
mäßig wieberfegrende Ströme herbeijuführen, wie namenttich ber

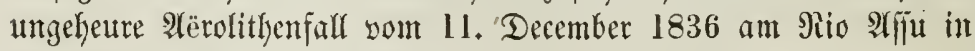
Brafilien anzudeuten fafeint. -

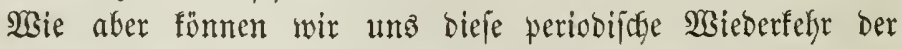
Stermfontuppenfülle erflären? Rad Erman's Theorie fonteiben bic Bahnen Der verfđjictenen Metcorftröme, bie jeber aแ Millionen

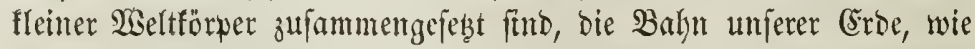

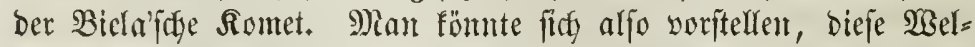

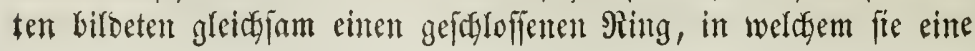


gleidye $\mathfrak{B a h n}$ verfolgten, ähnliđ wie ez unjere 50 fleimen \$ilanetoi= ben in ifren engwerjdhungenen Bahnen jeigen. Bielleidyt hat bie=

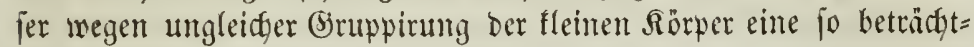

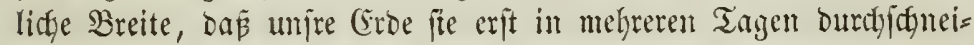
ben tann. Eoldyer Ainge, unter nelden wir uns die Bubnen ber periobijatyen Etröme voritelfen, liegen vielfeidyt aud mefyrere neben einamber, und wenn in iljnen bie 2literoiden mur in wenige didyte (bruppen zujammengebrängt finto, jo ift ez leidst erflärlid), meßl)alb fo jelten jente glüngenden Piatureridyeinungen, wie bie in Plovember 1833, eintreten und bam aut meijt nur fïr io ifmale giäume

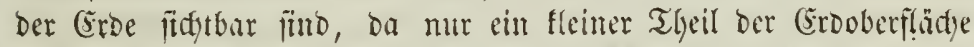
in ben Bereidy Der bidgteren (Sirtupen fommen famm. So war jener Edfwarm von 1799 mur in : $($ merifa, Der von 1832 mur in Entropa, Der yon 1834 mur in Den Dereinigten Etuaten und Der yon 1837 jogar nur in England fidytbar. M) lun lyat fityon serjudt, bie \$ie= rioben joldyer Eternjdmuppenjälle und bie Babnen diejer Ajteroiben= jyiteme ju beredyen, uno fid) babei auf bie uller 2000 Snlye alten Beobadtungen ber Shitsejen gejtütst. Freilidy treffen oieje Beredy= nungen nod nicht immer ju, luno es verigeljen oft Jalye, it bentu nirgendz die bižler erjorjhten Etröme fidytbar werden. 2tber Daz

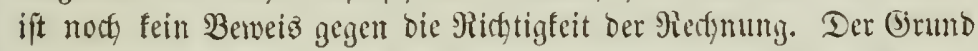
jener Unterbredunt fann ja in Der (Sinppenvertbeilung bes Singes, ober in Der Beränberung ber Sejtalt umb Rage ber Bahnen liegen, weldye fie burdy bie ftorende (Fimwirfung anjiel)ender ßlanten exleider:

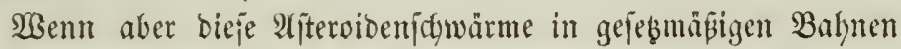
bie Somne umfreifen, fo follte man body meinen, müpten fie auth wieber in entipredyenden Ferioden vor der Eonne vorilbergehest. Die Errahrumg fdyeint audy bieje Bernuthung beftätigen ju wollen. Edon im Mittelalter lyatte man fid vergeblich bemülyt, fonderbare Berfinjterungen der Eommenjacibe zu erflären, weldye bie Eterne an Mittag fichtbar werben liepen uno bisiveilen brei Tage lang anfielten, wie im Jafre $1547 \mathrm{um}$ bie 3eit Der verhämgnif̧wollen

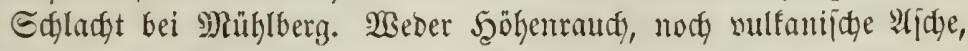

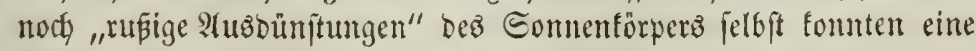

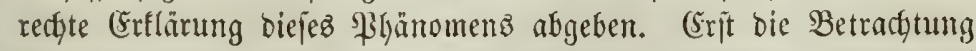

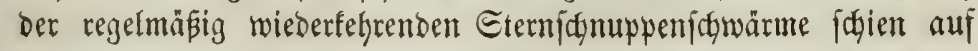


einen merfwüroigen 3ujammenhang mit jenen räthjelłhâten Şim= metsericheinungein binzutouten. Man fand, dak die 2uguftafteroi= Den genta um bie Zeit bes $\overline{7}$. Februar, bie Movemberịdwärme um Die 3eit Des 12. Mai in ihrer Banth vor ber Eonne vorübergehen müster. Regtere Sieriode fiteht in einem bebeutjamen 3ujammen=

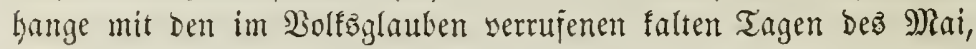
Dem Mamertus, Paneratius und Eervatuz. Reidgt wäre es zu er= flaren, daj eine jo ojt beobactetete und fo anjefnlidge Temperatur= erniebrigung an jenen Tagen Durdy Das $\mathfrak{B}$ orüberjiehen biduter

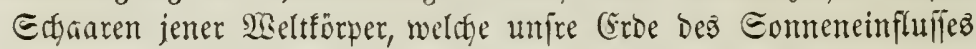
berauben, berwirft weroe, uno mirflidy will man in neuerer Beit

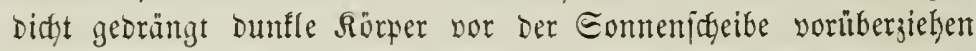
gejefen haben. Freilidy hat Done in neuerer Zeit eine einleutcten= Dere Erflärung jener falten Tage gegeben, weldefe fie auf meteoro=

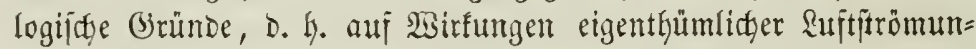
gent zurüufführt.

Remnen wir aber mun bie Bjejeţe diejer jing in fometenähnli=

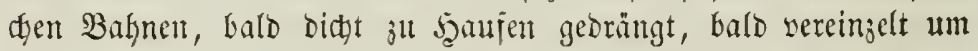

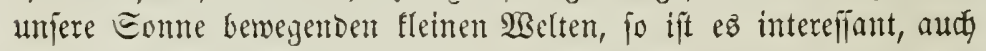

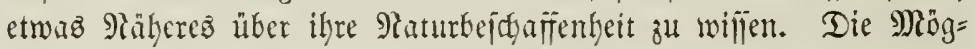
lictfeit Daju geben uns aher bieje 2 selttërper jelbit, bie einzigen, bie in einen unmittelbaren Berfegr mit unz treten uno unz ihre

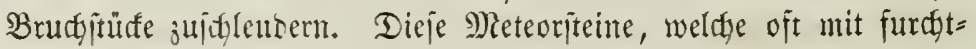
barem Betüje als einem fleinen Bemölfe meifít jiemlid heí, body nie rothglübent zur Eroe fillen, jeigen an Form und Snhalt ganz unverfennbare Hebereinjimmung. Eie bejtehen gröptentheils aus Eijen, Miifel uno einigen andern Metallen, verwunden mit. Dlivin = uno Afugittryjtallen, unto erhalten iłren eigenthümlicfen (Sharafter

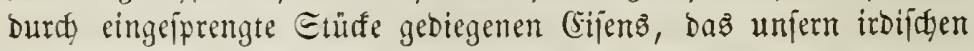
Bejeiteinarten fo burdfaus fremo iijt. Faft immer iit bieje hellgraue Mafie von einer idfmarzen pectartig glämsenben Rinbe umgeben,

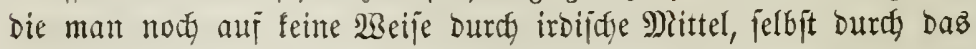

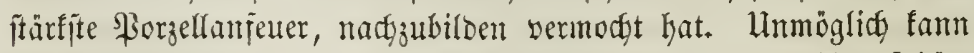

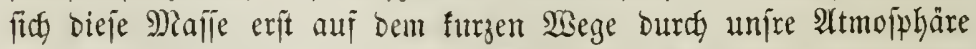

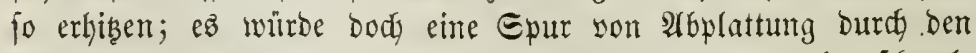
furctytbaren zall bemertbar fein, wäre fie im Snnern nody gejdymol= zen gemejen, als fie nieberfiel. Man hat wohl daraus, baß bie 
Beitandtheile ber Meteorîteine burchauz unjer (Erde angehören,

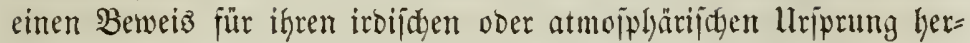
nefymen wollen. \&tGer warum follen ridt Etofie, bie zu einem

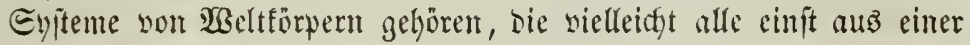
grofien Gejammtmajie Gervorgingen, biejelben jein fönnent? 23 arum wolfen wir fie iroijde nemmen, weil fie grabe audy Der (Erde ange=

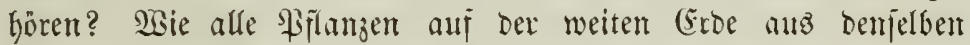
(Elementaritoffen fidd bilden und body in ifeer Entwifflung bie man= nigfaltigften formen zeigen, bie tropifden (jeifhledter burds bie

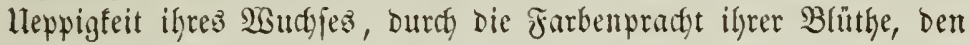
Duft iffes Relches Den Sharafter iffer Tropentheimath verrathent, währeno bie nordicte Piflanje in tem jwergartigen, aber fernigen Bau, in bent milderen farben ber Bhütye, Dent bejdeibneren, ein=

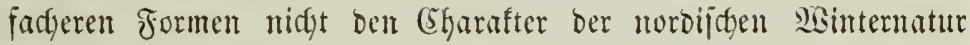
verleugnen faun, ber fie entiprop̈te; jo mögen aud, biefelben (Ele =

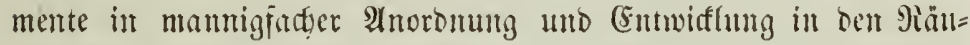

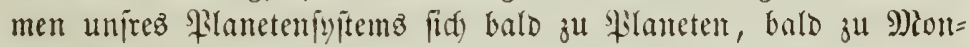
Den, bald zu bumftartigen Someten, bald zu zwergartigen 2 Aëroli= then geftaltet haben.

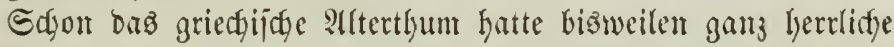

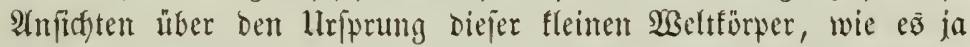
immer uneridjopflidy in Dentungen uno Bermuthungen gewejen ift.

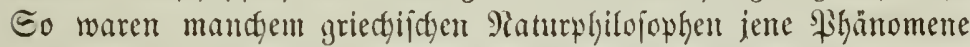

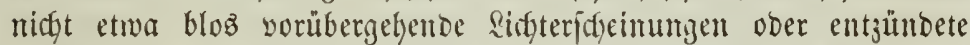
Ruftarten, bie find) in ben obern Siegionen gefammelt hätten, fonbern "ein Fall himmlijder Sörper, bie Durdy ein gewiilies Padjlafien ber

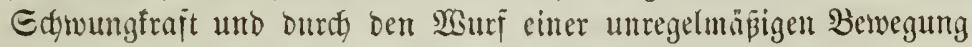
herabgeidjettoert werben, nictyt bloz auf bie bewolynte (srbe, fondern audy auferfalb in baz grope Meer, wo man fie nidjt fiutoct". Dio= genes yon Ifpollonia nannte fie fogar "unfictutbare Eteme, bie fids namenloz mit ben fidgtbaren jufammen bewegen". Frübere Wijilo=

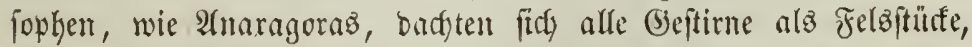
bie Der feurige Atether in feinem llmidymunge won ber (Sroe abge= rifien, entzüntoet und zu Sternen gemadyt habe. H(ber bie (Jrieden fielten ja bie (Erbe für einen (Sentralförper, um den fids leer einft

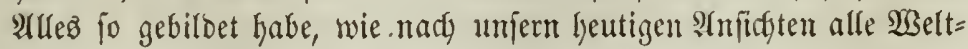

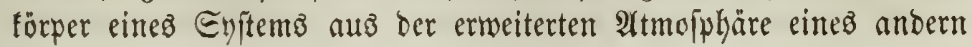


Gentralförpers, Der Eomme, entitanden. Eo Gatten aljo fidon bie alten Briecten cine Borjtellung son einem fosmijhen Uriprunge uno Dajein Der Eternidyuppen, D. h. von ifrem Entitehen im 2 Belt= raume, cine Şöhe ber Anjđaumg, zu ber fid bas Mittelalter und Felbit ber freiere Gieijt Der lebten Salyrhunderte nidyt erkeben fonnte. Blinoe 3weifeljuctst lyatte jich Der Menjofen bemäctigt, fie fahen

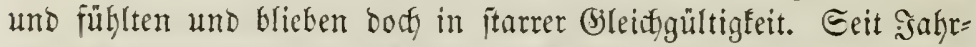
taujenden waren vor ben $\mathfrak{A}$ ugen Der Mienjthen Meteoriteine gefallen,

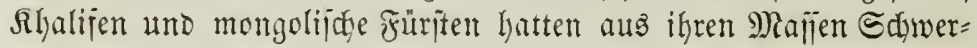
ter idgmieben Ialien, Menjden waren burdh ifren Fall zeridymettert,

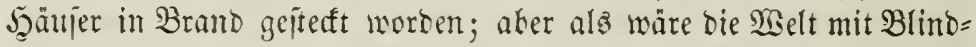
heit gejalagen worben, açtete man auj bieje prädtigen und furcht= baren Eridgeimungen nidft, hielt iie für Epiele des 3ujalls, bis Egladni ifren innigen 3ujammentang mit bem ganjen ßlaneten=

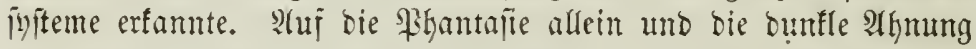
Der $2 o ̈ l f e r$ vermoditen bieje łgänomene zu wirfen. Plöblidy jah man Bewegung eintreten mitten auj Dem Єdauplab̧e nädytlidyer

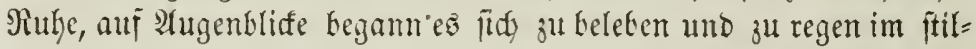
lett (Slange Des Firmamente, lange Feneritreifen flammten auf, und mit milDent Ridte tauctse ein vergänglidfer Єtern auj. Collte bas

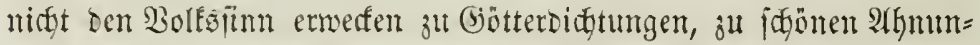
gen einer unfefanten jenjeitigen Welt? $\mathfrak{W} \mathrm{em}$ märe nidyt bie eble शnjwaung befannt, Die fid uns nod jeģt in Den Eagen und bem findidyen 2rberglauben Der Bölter offenbart? Die Epinnerin, to

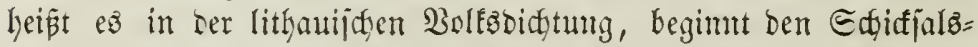
faben bes neugefornen Rimbes am Şimmel ju fpinmen, und jeber Diejer Fäben endet in eimen Etern. Naht bann ber Tob bes Men=

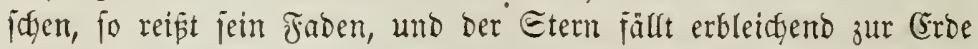
nieber. Nicht minder ebel jeigt fich bie bilonerijate Cinbiloungstraft

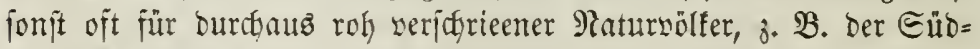

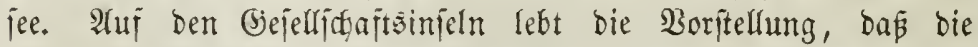
Eterne Die Geijter Der Beritorbenten jeien; Darum giebt man ihnen audy bie Namen jeiner Sieben. Ein fallenber Etern ijt ein Seift auj ber Jfutht yor eimem mähtigen böjen Botte, unb zur Groe flieht ber Gieift zurït, weil er bort noch Sählje erwartet in ber Riebe ber 3urüfigebliebenen. Ier Mentid fettet ja jo gern jein Edjiffal an bie Eterne, bort will er lejent, was ifm der bunfle Echleier ber 


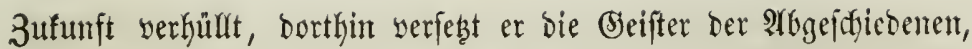

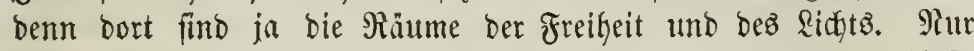

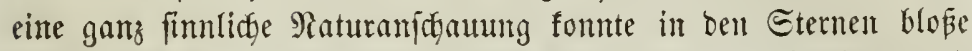

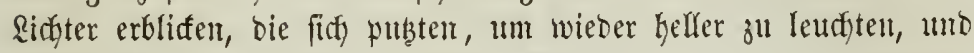

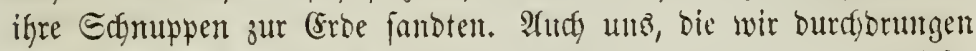
fint yon bem Bilauben an ben inneren 3urammenfang biejer

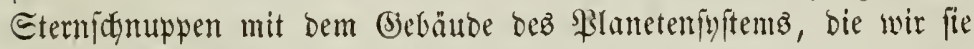

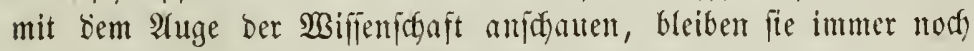
eine reidge Duefle gebeimni immer mit erniten Betradftumgen erfülfen. M)it ber ganzen Ratur

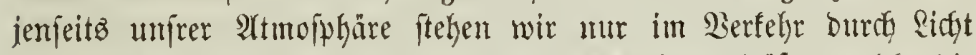

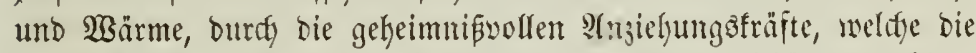

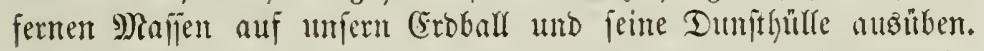

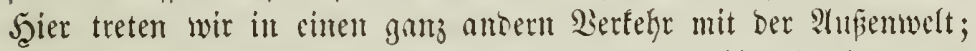

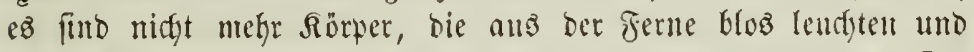

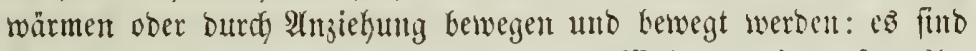
Theile ifrer Materie felbit, bie aus bem $\mathfrak{B e l t r a u m}$ in umjere $\mathfrak{N t}=$ moiphäre getangen und unjerm Eroförper verbfeiben. Sgier fömten

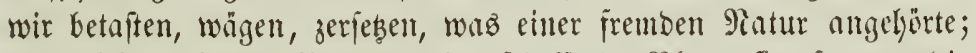
uno nidgt mehr bie Bergänglidez fadaffente \$igantakie, fondern bie red)nende, bentende Bermunft beginut ihre Thätigfeit, lä̈t in fleine

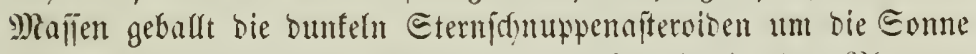
freijen, fometenartig die Bafynen ber großen Letddenden Filaneten

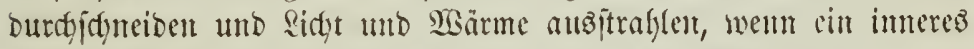
Eelynen fie in bic belebente 9iathe unferes (Erbförpers fülyrt. -

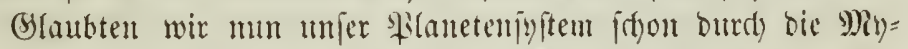

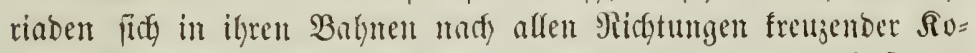
meten fo berwidelt uno verwirrt ju fintoen, Das wir felbjt Gefallyen

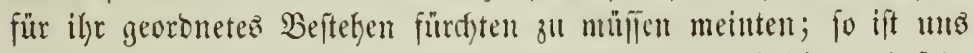

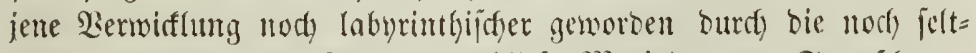

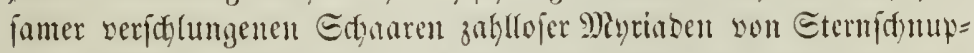

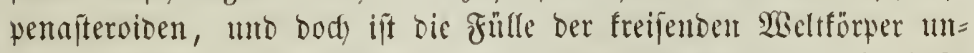

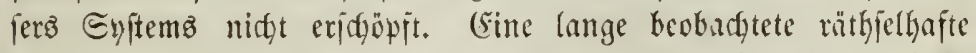

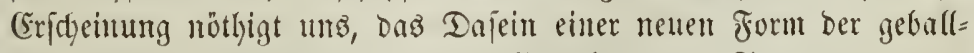
ten Materie anjutrefment. Dem Bewohner ber Tropenzone, ber emig Geitern Şeimath ber Paluten und Gaumartigen Farnutrüuter,

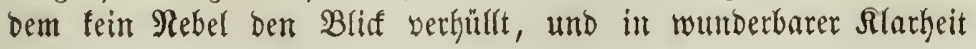


ein milber Gomnenfimmel ladft, ifym fann jene lieblidfe Errfdeinung

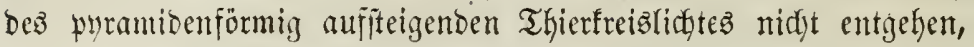

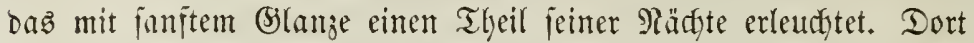

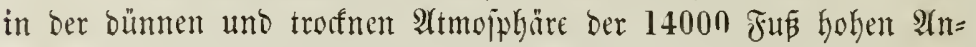
besgipfel, auf den gränzenlofen Brazafluren der Slanoz von Bene= juela und ber Firnirien Merico's, an bem Meerešufer unter bem ewig heitern Şimmel son (Eumana in ber wunderbolf burdfiftutigen Atmojpgäre ber હübjee, an ben weîtliden Riujten son ßern uno Merico, bort erideint das Zobiafallidft in unnennbarer \$ract,

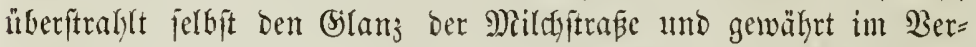

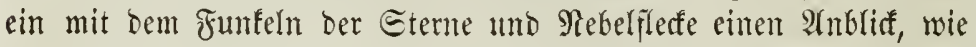

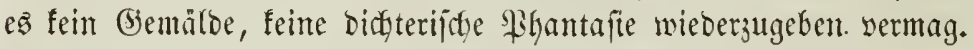
Borjüglid, in ber Mitte bez Manrs und Eeptember, um bie 3eit

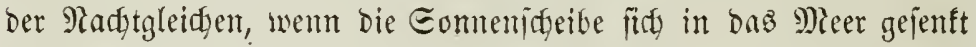
hat, unt völlige Finiterni位 bie furje Tropendänmernng werorängt

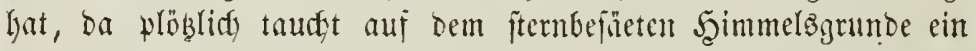

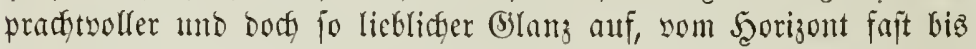

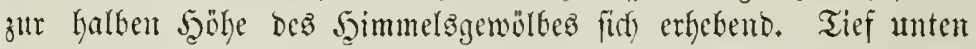
am Syorizont eridgeinen wie aui gelbem Teppidy fifmale langgedefnte

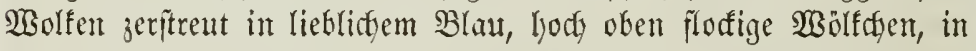
ber bunten Fradjt aller Farben ipiclent. Áţa jollte eine neue

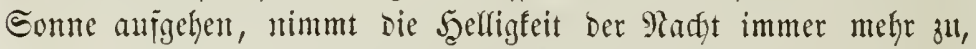
Giz fie endlich gegen Mitternadjt gänjlity veridgwinbet. So wiro

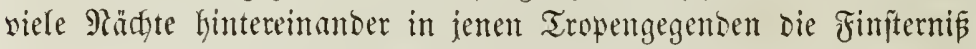

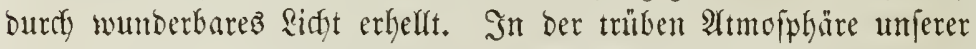

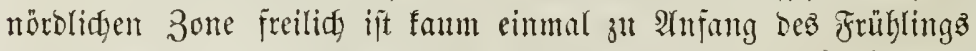

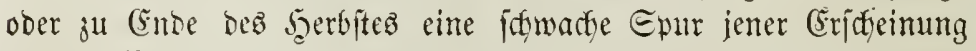
vor ber Morgensämuterutg uno nadf ber RGenobämmerung zu ent= befen, und meijt verliert fidh aud biejer Edfimmer nodf im sidfte bes anbredtentent Tages.

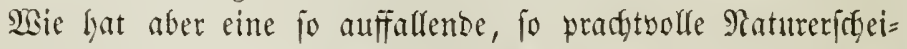

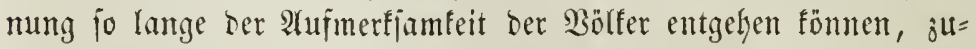
mal ber fo cifrig beobadtenten atraber in Bactrien und am (ru=

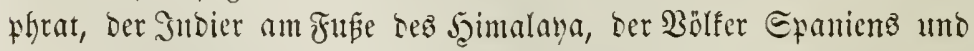

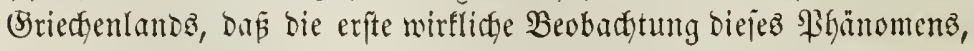

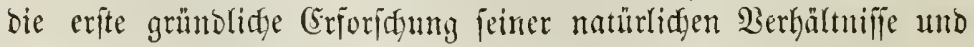
Utráaten, won ber wir Sunbe haben, aus bem Entoe bes 17ten 


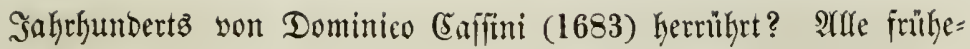
ren Errwähnungen einer joldsen Errịteimung fheinen auf vielfadtem Srrthume ju beruhen, bejonbers auf ber Berwedystung berfelben mit

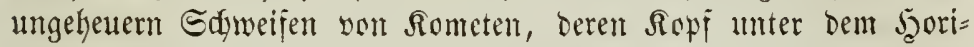
zonte verborgen war, wie wir ja nod) 1843 einen äbnliden Srr= thum erlebt haben. Phur bas merfwürbige, von ber (Srbe fyrami=

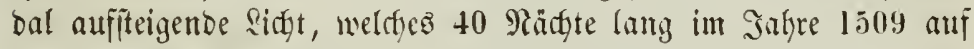
Der Şodjebene von Merico den öftliden Şimmel erlendftete, umb mel=

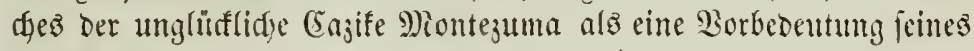
Edgiffals anjah, fdpeint ein wirflidfes 3odiatallidyt gewejen ju jein. -

Eeit man gentauer bie fo part befamnt gemortene und bod fo uralte Erricheinung erforidgt fyat, ijt man felbjt in den Etand gejeght

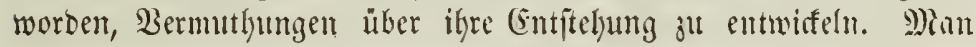
meinte mohl anjangz, bie leudtende Sommenatmojplyare jellojt jei ez, bie uns barin fidftbar werde, aber bie birenzent Derjelben lajien fids)

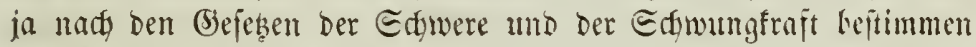
und fömren nicft

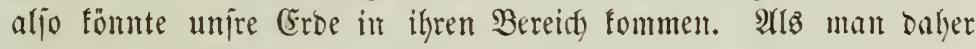

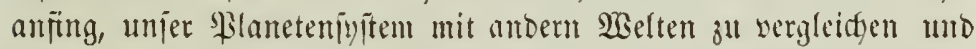
unfre Sonne als einen Sebelitern ju betradyten, fanto man, oá̈ ihre

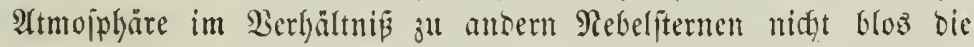

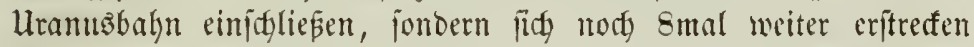

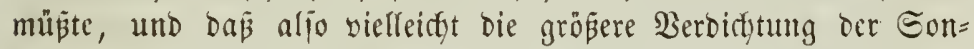

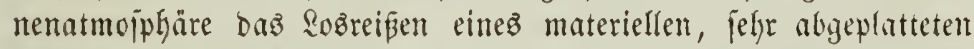

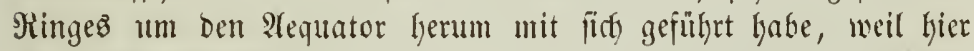

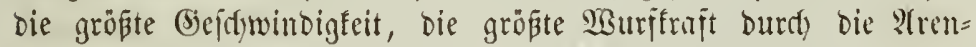

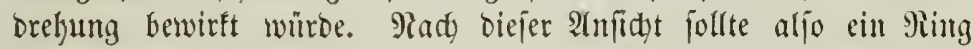
bunftö̈rmiger Materic umfre Eomne umfdmeber, nod) iumer wedy= felno in feiner bieftaltung, bald fid bidgter zufammenziehent, bald

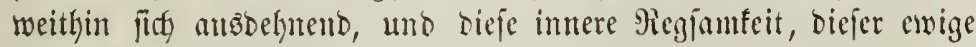

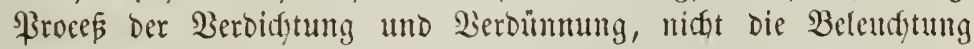
Der Eonne allein würbe jein phosphoriadsez Ridft erflären. Eollte

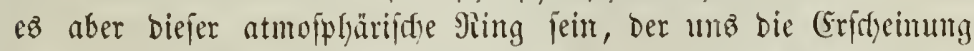
Dez 3obiafallitytes giebt, wem bie Erbe in jeine Ebene eintritt,

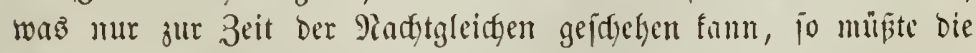
(Erifgeinung natürfidy unter verif̧iedenen Breiten ju gleidyer Zeit, aber nidgt in gleidyer Bjeftalt und an gleidger Etelle bes Şimmelo, 


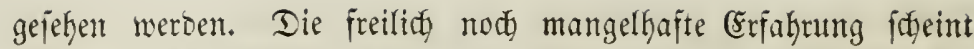

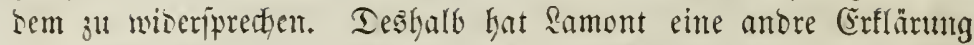

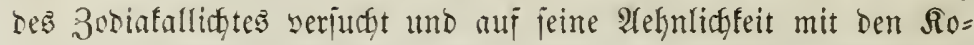
metemijhweifen Gingemiejen. Die unetlathliche, sit viele Millionen

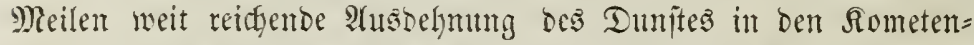

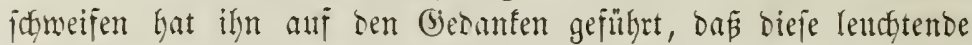

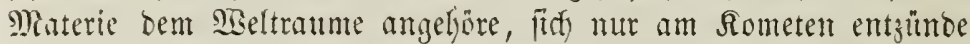

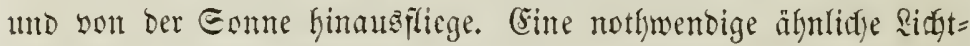
entwifflung an Den \$laneten würbe Dann bie Erriffeimung beb $30=$ biafallidftes abgeben. In neuefter 3eit hat fith Sultins Edymiot in

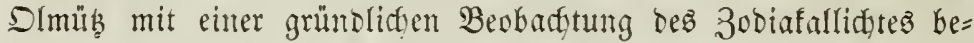

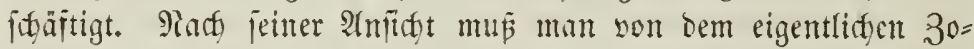

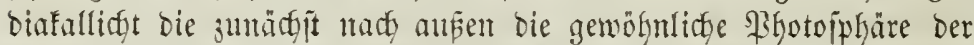
Eonne untgebenoe lumfütllung untericheisen, welde uns während

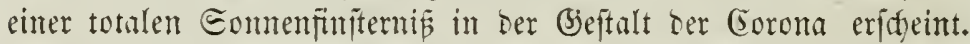
Dieje nädgite Llmfülfung mag genau an ber Rotation Der Eomre theilnefymen und unmerflidy übergelyen in bie Materie bes 3odiafal=

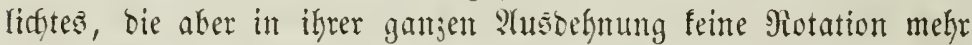

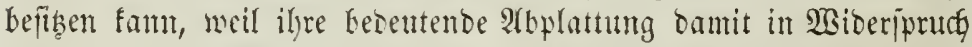

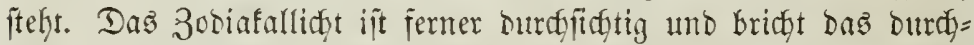
gehende Eternenlidgt efenjo menig wie ein Porblidjt ober ein $\Re_{0}=$

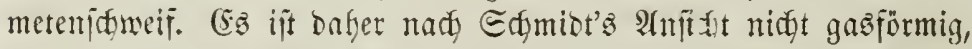

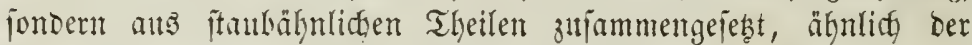

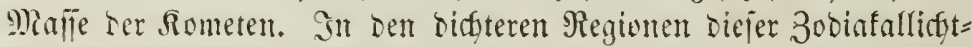

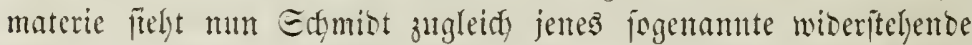

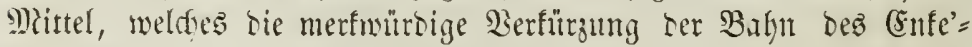
iden Rometent bei feintem jescesmaligen Gintandent in Die Eomnen=

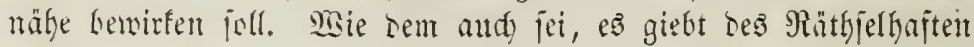
nod) Pandtes in siejem \$yänomen, unt bie Seränterungent in ber

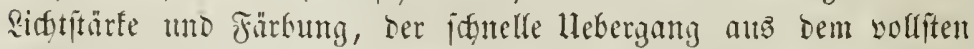
(blanje in idfmadten Edfinmer, und bas leife 3uten und glim=

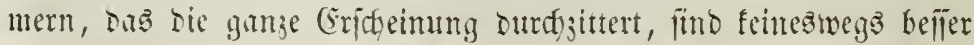

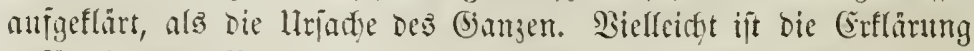

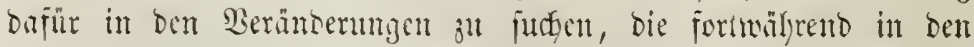

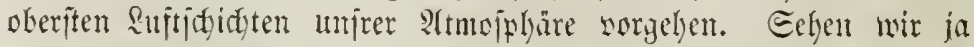
bod aud) bie Sometenjdyeife oft feltian erzittent, flammento auf= lobernt und hin uno her fidwanfen! 
Rodh giebt es fo manden munberbaren $\mathfrak{B o r g a n g}$ in unjerm Eulftreife, ben wir nidgt ju erflären vermögen. $\mathfrak{B}$ oher rïhrt jente merfwüroige (Erfellung ganzer Mäadte, in benen man, wie im Safhe

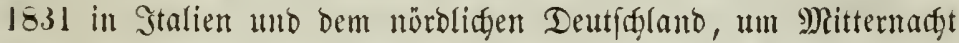
die fleinfte Edfrift lefen fonnte; woher bie fonberbaren Berlänge= rungen ber Dänumerumg, bie nidjt einmal immer mit bem Srte ber Eonne unter bem feorijonte ïbereinftimmten? Piäthjel giebt ez

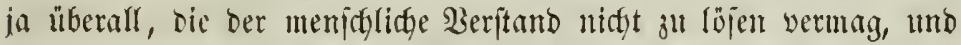

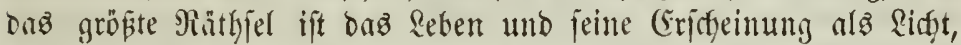

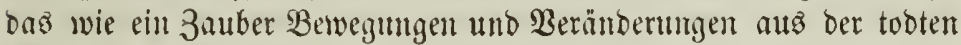
Miaterie ermeft.

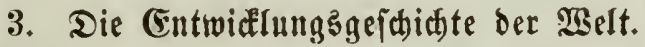

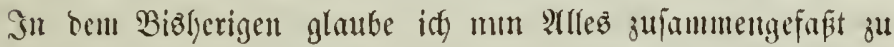

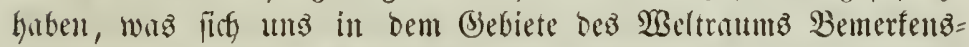

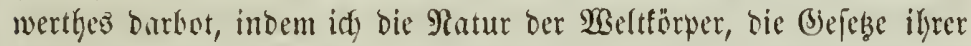
Bewegutg uno (jeftaltung, iffe (Srößen uno (Entfernmtgen betrad)= tete, fo weit es für meinen 3weef bienlide fojien, der ja nur eine

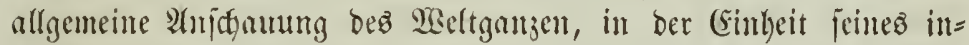
neren 3ujammenlyangz, fein follte. Borzüglidy) habe idy bie 2 tuf = merffamfeit auf bie heimatllicheren Begenten bes SGeltranms, auf unjer Planetenjyitem gelenft, weil biez alż ein Bild ber $\mathfrak{B e l t}$ in

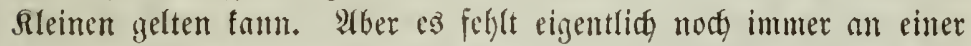

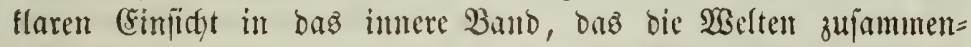

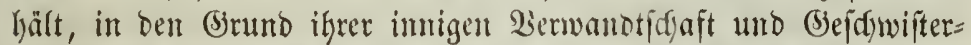

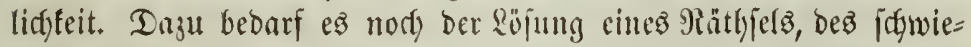

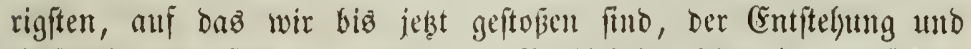

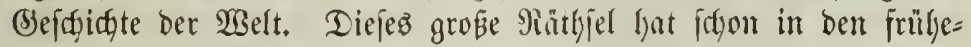
fiten Zeiten bie \$Gantafie ber Menjiden gereizt, ez icheinbar wenig=

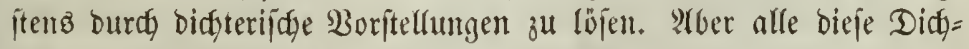

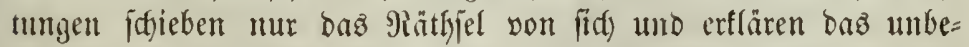
greifflidge (Entftelyen ber 2Gelt für bie arbeito = unb mühetofe That

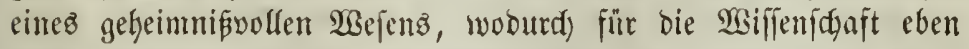

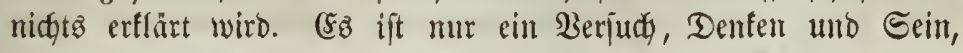




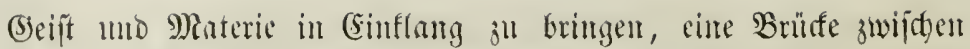

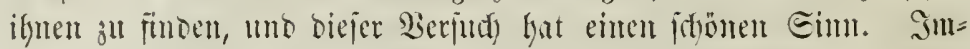

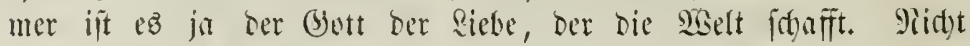

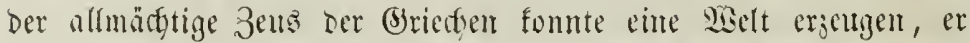

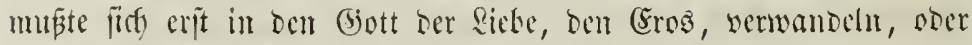

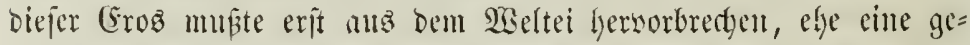

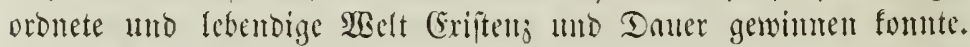

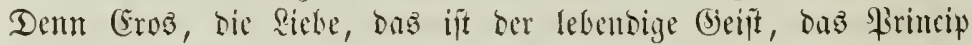

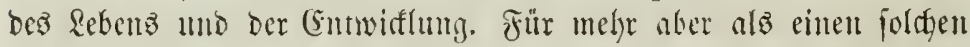

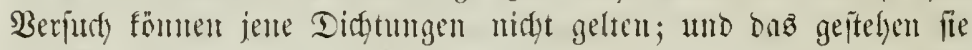

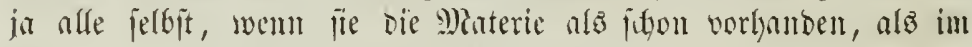
(Shaos ober bem 2 Beltei veridgloijen antelyment.

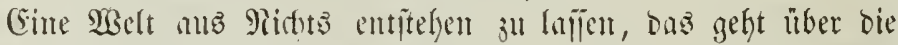

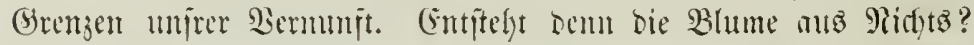

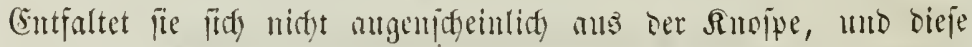

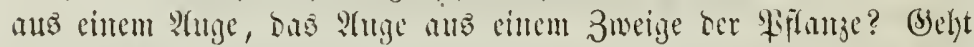

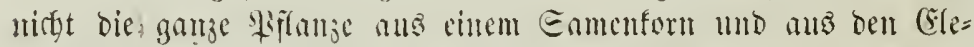
menten ber (Eroe utnd \&uft hersor, in bie fie wieber jurhaffehrt?

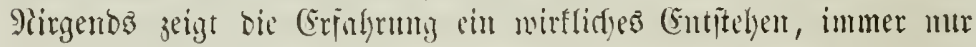

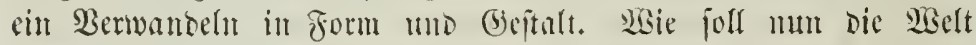

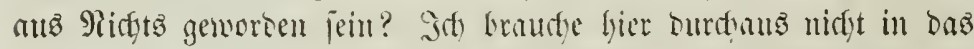
Gebiet ber Theologie linüler ju idfweifen. Midgt ber Theologe

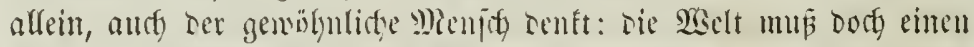

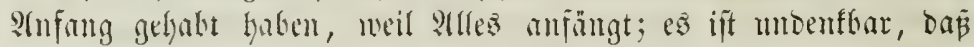

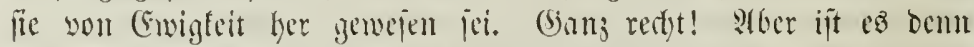

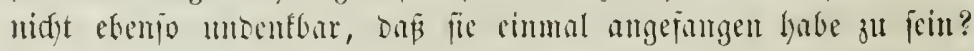
Die Soefie mag freilidy die fülyniten, abentenerlidyten Didtungen

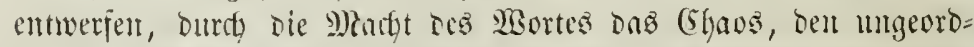

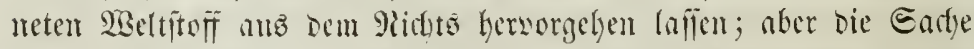

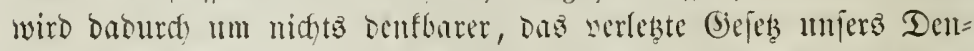

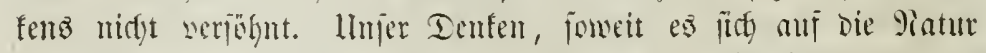

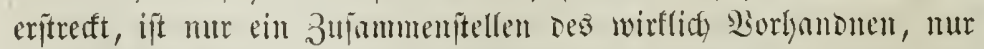

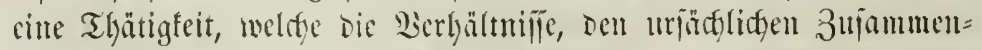

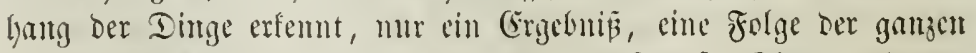

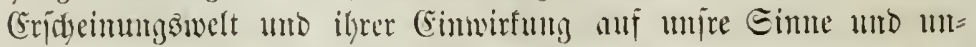

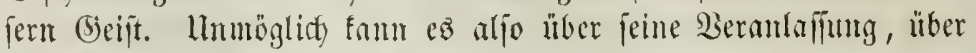

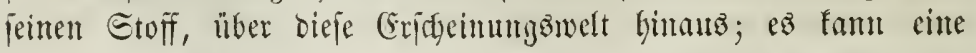




\section{7}

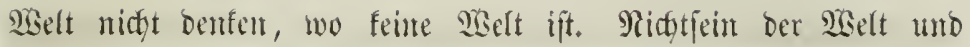
Ilnmöglidfteit, ifgr 9ridgtjein zu denfen, find unjertrennlidy cin und

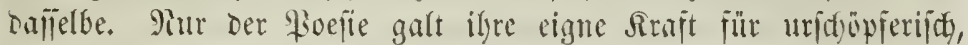

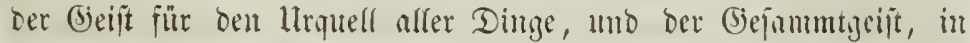

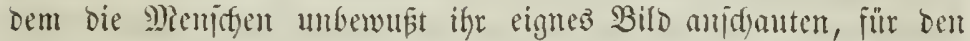

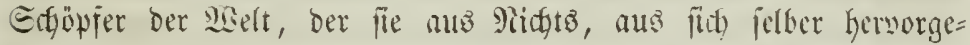

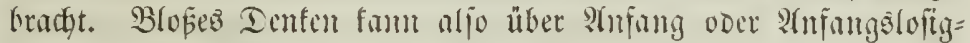

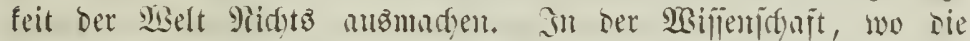

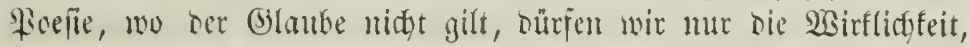

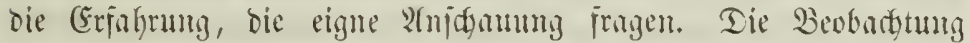

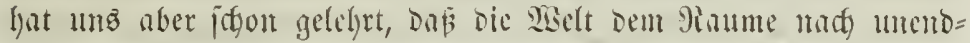
lidf) jei. Son ben fermiten Eternen, bic unjer \&ltige erreidfte,

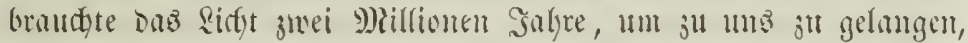

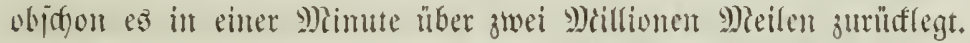

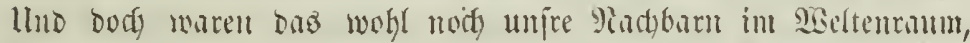
Doth waren jene fernen Sebel mohl gar iolite Eterngrupten wic

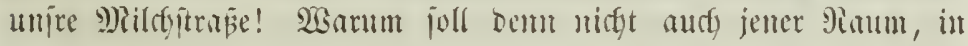

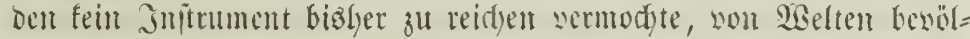
fert jein? Wierlangt bodt jelbjt Das Gejeb ber Edwere, Der gegen=

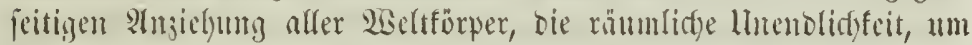
alle einzeluen Eyfteme im (j)leidggemingt ju erbalten uno nidyt balt=

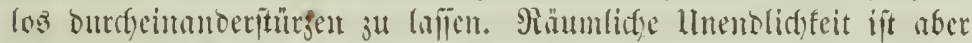

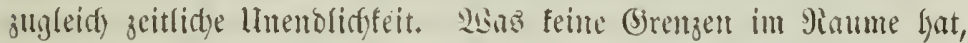

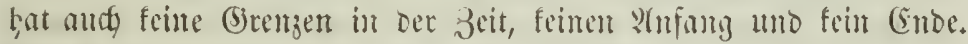
Sinum unt 3eit fint eng in unjer Boritellug verbunden. Wem Dillionten Gabre vergingen, efle ein Eichtitrabl wou ben fernften

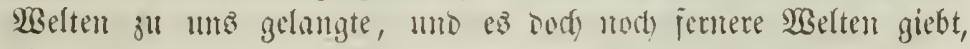

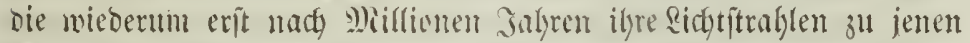
Wielten jenten, jo sermigen wir jaden gur nidft mebr bem fluge

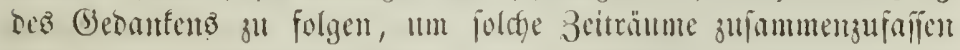

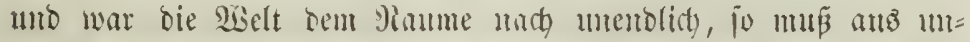
endiden (Entfermungen aud) mad) unenoliden 3eiten erit bas seidyt ju umb getangen. Eo ijt aljo für unje Boritcllutg, fïr uníre

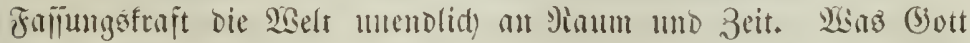
für bieje untendlidfe wselt jei, ijt ljer nidgt zu entidgeioent. Gott

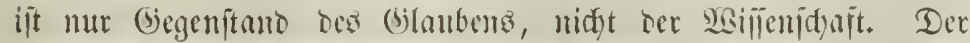

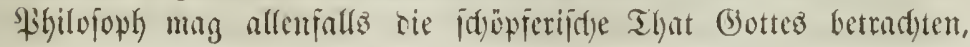


Ser Paturforfder barf ç̉ nidyt. Darum fömen auth wir jeb̨t nidyt vou einem wirflidjen Entitefen ber SGelt, fondern nur vou eituer Entwifflung iffer jetzigen Form ipredgen. -

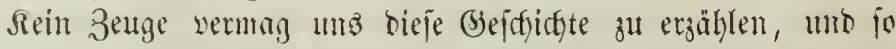
mülien wir beun jujehen, ob wir im gegenwärtigen 3ujtunde ber

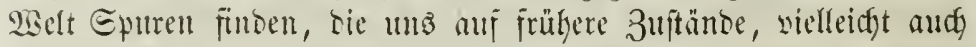

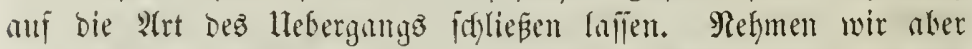

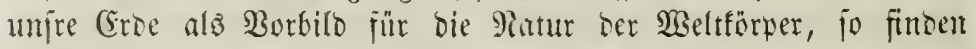

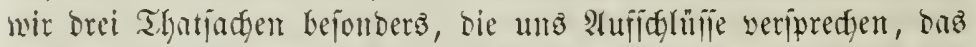

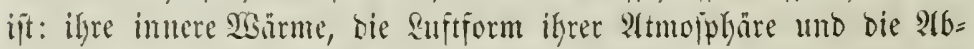
weidfung won ber Sugelgejtalt. Dicje brei Gigenifaften benten

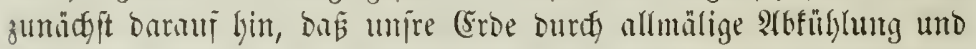
Erftarrung ifrer änfern Pinbe zu ifrem jebigen bemohntbaren $3 u=$

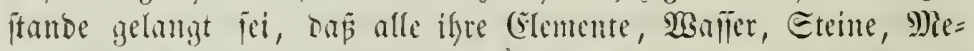

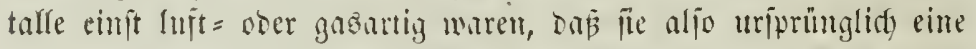

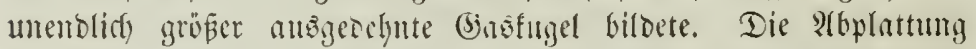
ser Eroe an ifen Folen, hefanntlid) eine Folge ber Edumungfraft

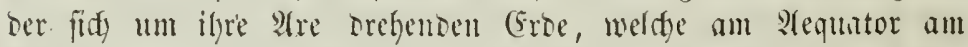

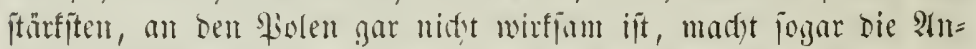

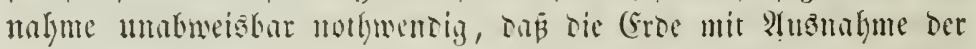
fturren Pimbe nect) jebt cine meide, freiartige Manje jei. Wir

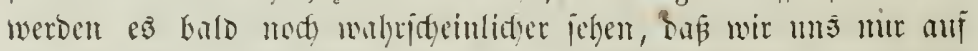

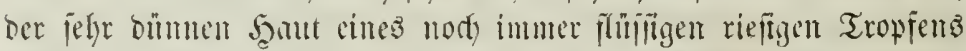
befinden. 2solger ijt aber biejer Tropfen gejlofien? woher jtammen bie zalyllojen andern siseltföper, Filaneten, Rometen und Rërolitlyen, bie mit ifm jugleidy bie Eomme umfreifen? woher ftammt endidy

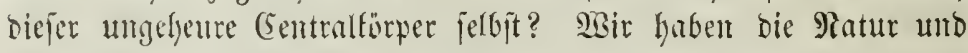
Bewegung Diejer $\mathfrak{B e l t f o ̈ r p e r ~ u n j e r ~ B e t r a d t u m g ~ u n t e r w o r f e n , ~ h a b e n ~}$ ifre Entrermungen, igre Bahnen, ifre Brößen, ihre Mafien gemeí=

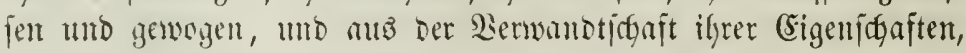

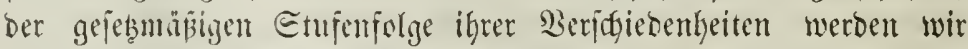
and) bie Rojung unjers Piäthjels gewinnen.

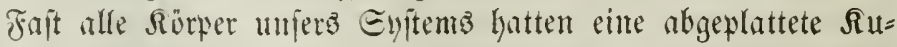
gelgejtalt. Eomme uno Planeten orelyten fitg erweislich um fich jelbit, und dic theneten mit igren M)onden um bie Eonne, alle

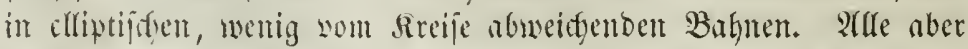

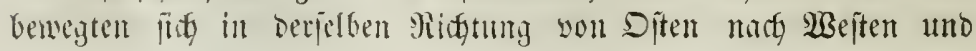


fajt ganj in ber (Ébene dez Comnenäquntorz. Dic Bejefmindigfeit

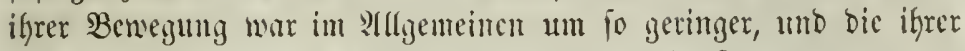
Arenbrelyung um fo grȫer, je größer ilfre Entfermung won ber Eonte war. Afud bie Didftigfeit ber BHoneten ichien mit menigen

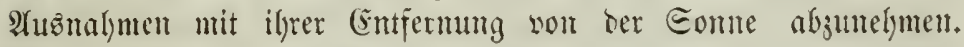
Die Eonne jelbit bemeyte fid um fidf jelfit, unt ben gemeinjamen

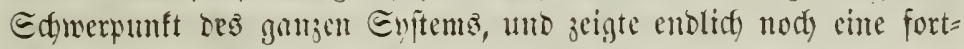

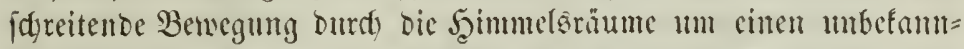
ten Edywerpunft melorerer, wieber zu eintm Granjen verbundener Eyjteme. Huz biejen alfyemeinen Eigenjofajten unjers Eyjtems

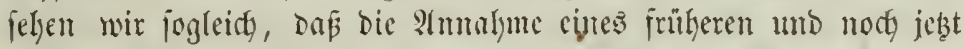

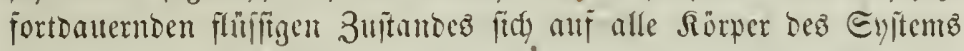

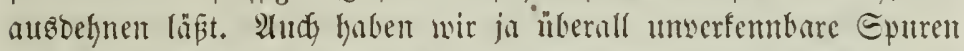

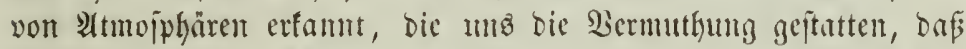

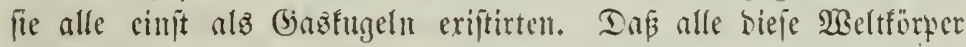

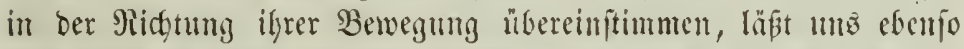
anf eine gemeinjame ltrjacte follefien, auf cine fie alle in gennuem 3ujammenfange umiafiende Ranjt.

WBir wollen unz baher cimmal biejen frilleren 3ajammenhang

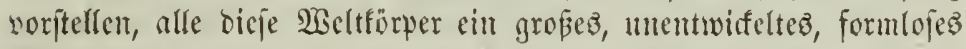

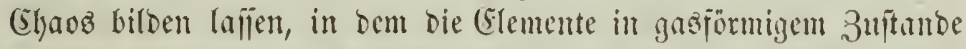

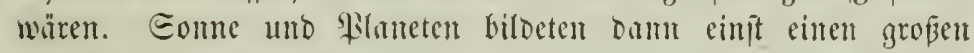

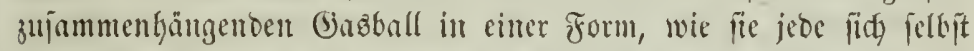

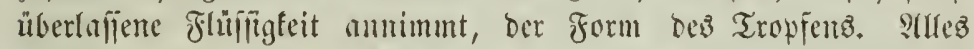

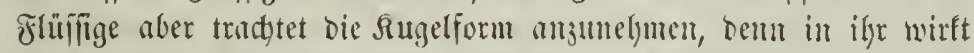

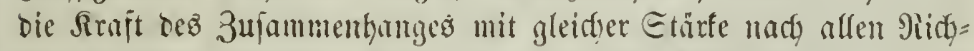
tungen, jedes Theildsen ftrebt jid) nach alfen Eeiten lin mit allen

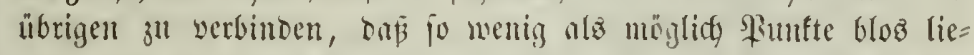

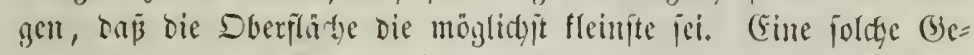

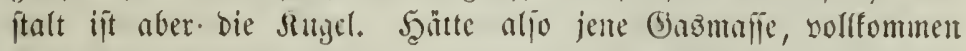

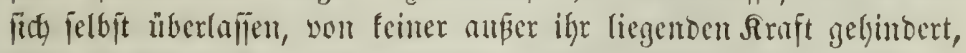

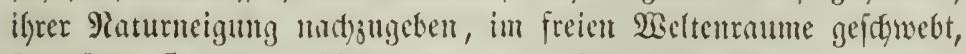
fo whïro fie eine solfommen gentute Singel gebiloct lyaben. Woir

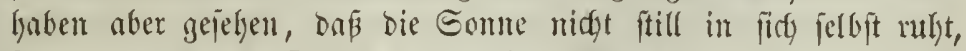

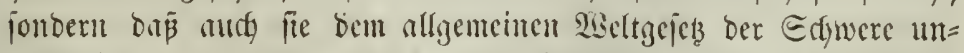
termorfen, won eincm unbefanuten Punfte gejogen, fortidereitet.

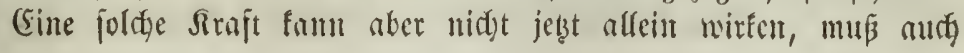




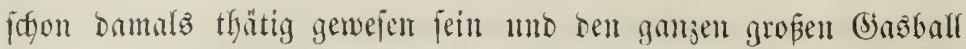

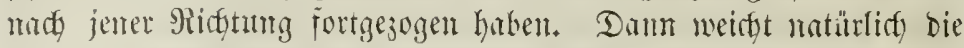
Form Der frülīigfeit son Der Rutgelgeftalt ab; bom ithe Theile wer=

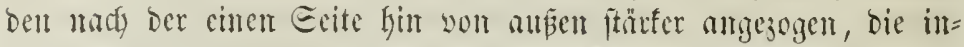

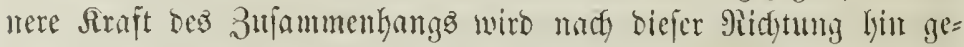

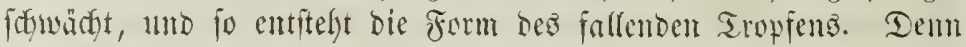

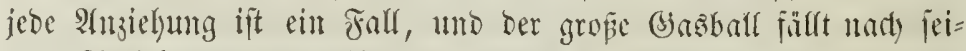

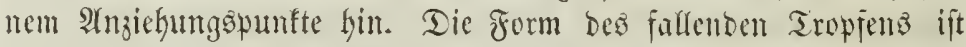
aber bie Siform. Eo haben wir als sie cimftige Gejtalt mipers

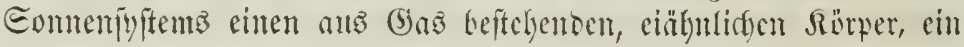
Weltei, uiber bem bie Mustyologie ben (botteßzgeift gleich eincm rie=

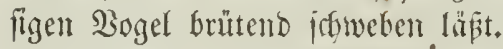

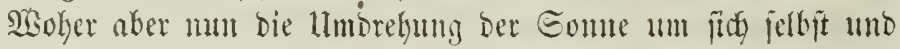

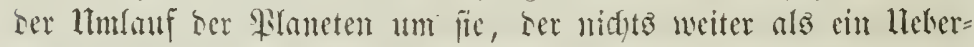

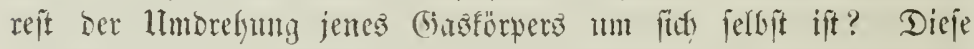

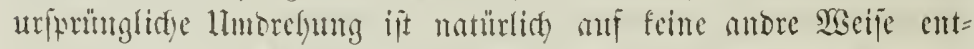

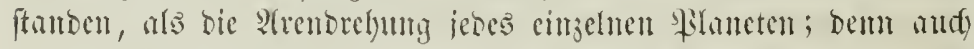

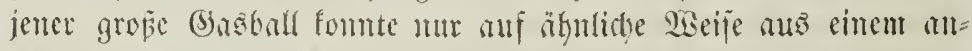
Dern grö̈en, Dem (Eentralföper feines höferen Enjtems bernonge=

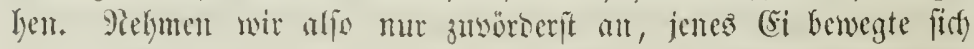

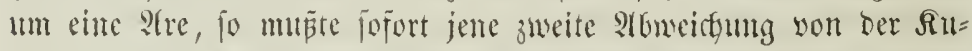

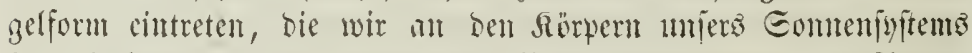

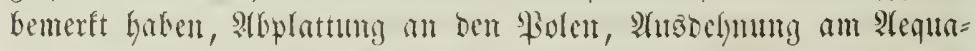
tor. Formt man eine Rugel aus meidfem Tou uno jeb̧t biefelbe

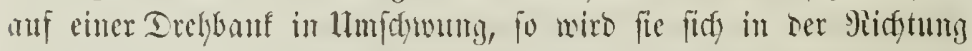

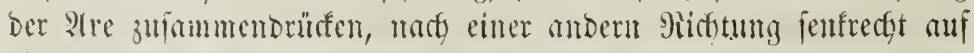

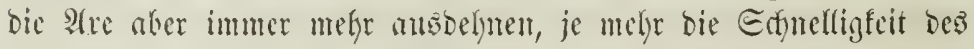

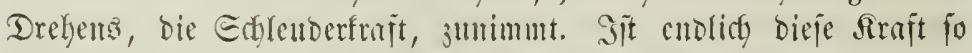
weit gewadhjer, Dap fie die Rraft bes 3ujammenhanges ber einzel= nen Theilden überwiegt, fo werben biefe zulebt zerreipent und ans=

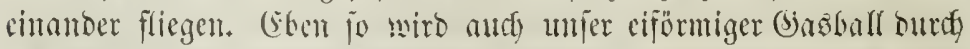
eine foldefe Drelyung midgt muserändert Gleiben. Eeine Form wiro

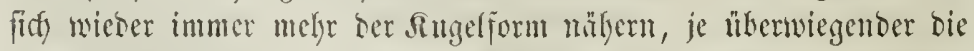

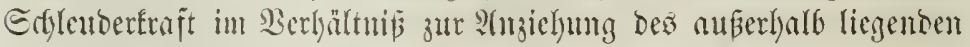
Falfpunts wirb. Sther eine wollfoumene Singel wiro fie nie wer=

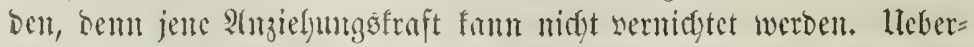
fteigt unt sie Edjlenderfiaft, weldye jesent fiutnt fo weit afo mög= 


\section{1}

(id) vom Edjwerpuntt ber ganzen Miajie ju entfernen jtebt, bie

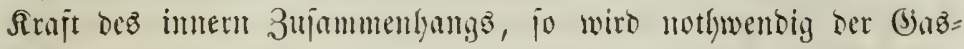

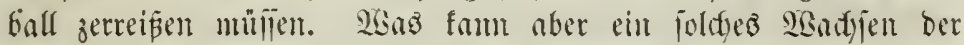
Edfleudertraft veranlajien? Die 3ujanmenjiefumg, Berbidytumg, bie

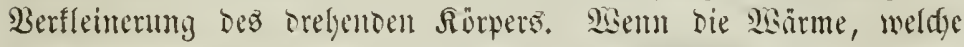

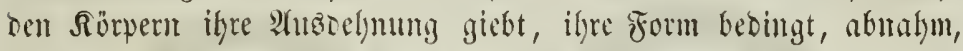

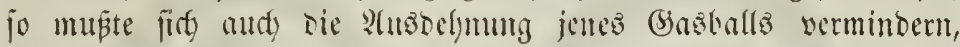

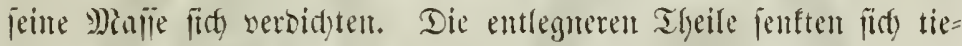

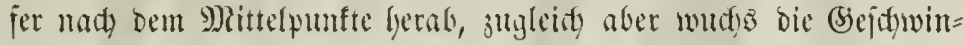

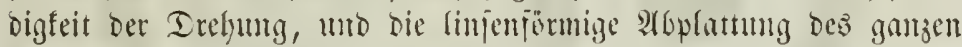
Rörpers nagm zu. Die folge biejer gleidfzeitigen, eintuber ent=

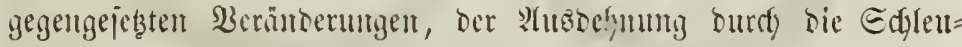

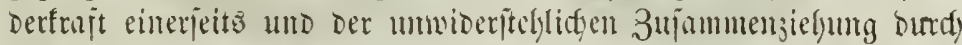

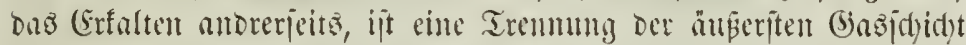

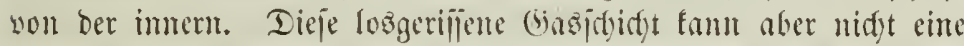
Gohle, den übrigen Theil des Gastörpers wie cine Edgate um= idsließ̄ente Sinjenform bethalten, fondern mus nothwentig bie form

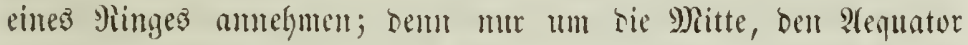
Der Basfuget herum unlym dic Edywugfrajt cinte jo grope bewalt

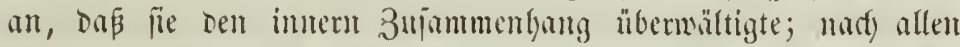

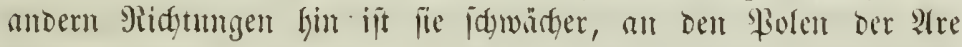
gantz unthistig. Diejer fefmale Gjazring bat aber vou bem ganzen

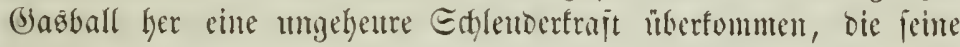

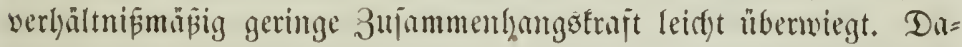
her wiro er leidft wieder jerreipent uro un fo megr, da jeine form som Rreife abweidft, bie Epannming jeinter Theile aljo verifficben jein múp. Aber er jonoert nidjt etwo einen ucuen Siing ab, fon= Dern svirb mirflid) jerithuft. Sn oemjenigen \$untte, wo ber roti=

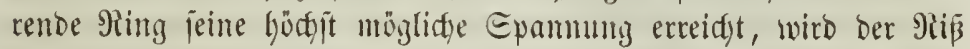

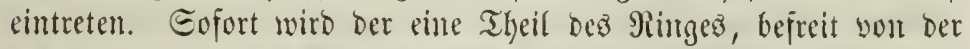
3ufammenflatenten Srajt ber benadjbarten Theile, der Edjleuber= fraft folgen und weit abmeidfent, wälrent der anbere Theil bes.

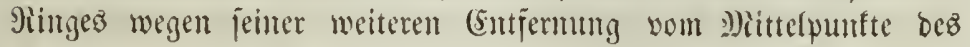
(bräballz eine jd)nellere Bewegumg hat, zugleid) aber; von ben un= ter ifm liegenton Theilen geffalten uno von Den folgenten gebrängt,

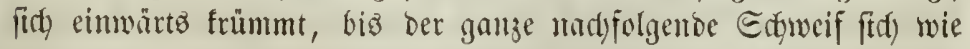

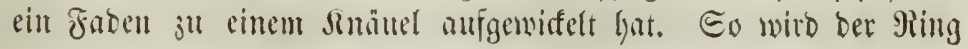




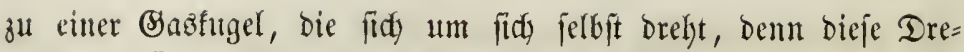
fung loat fie butrif ilye Alufrollung erbalten; uno in einer bem frü=

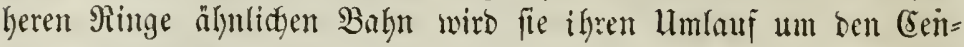
tralfürper fortiegen.
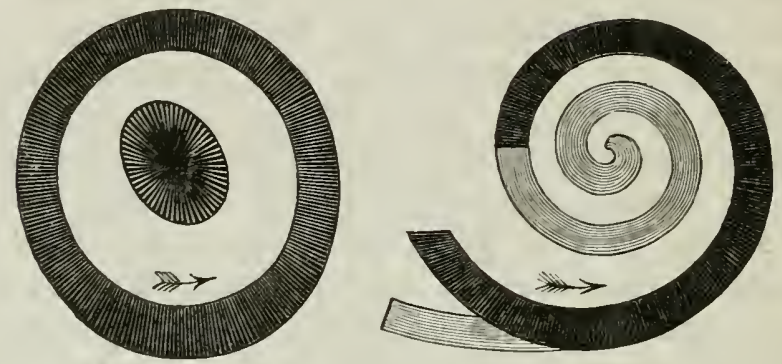

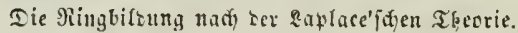

Sn bem fo enifindoenen (Sag̊planeten famn fid biejer Borgang wieberfolen. Nene Ringe föntuen fid abjondern, bie entweder jer= reífen unb Monto bilden, ober bie fefter zujammenhalten, erfalten

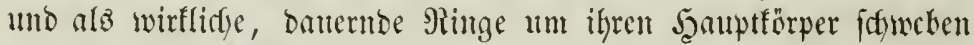

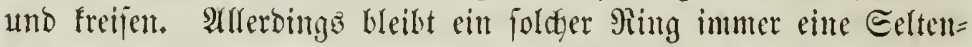
heit, ba er eitre Siegelmäpigfeit in bem Prozefic ber Grfaltung und Erftarrung verlangt, wic jie nidyt oft eintritt. Darum lyat unz bie Ratur bis ję̧t mur cin Beippiel einez jolden $\mathfrak{B u m b e r s}$ in un= ferem Blaneteniyiteme gejeigt, das Mingiyftem bes Eaturn. Soldye Ringabjonberungen wom gropen Sieltei fönnen fid natïrlid, wenn bie Berbidytung unt zugleid) bie Ednelligfeit ber Drefung zunimmt, mehrmals wieberfolen, bis fidy bie grope Sinje wieber fo weit ber

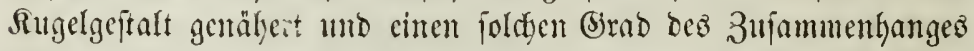
erreidyt Lat, baj ihre Edyungfraft denfelben nidyt mehr zu über= wältigen sermag. Fhud fant cin (Sasring in mebrere Etüafe zer=

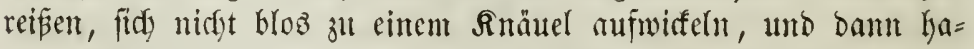
ben wir ein Eyftem melyerer in seridhngenen Bahnen um bie Gomt freifender Rörper, wowon ums die 50 flemen \$lanetoiben swifden Marz und Iupiter ein Beipiel barbieten. Zerreipt ein foldyer Sing gar in zalllofe Theile, bie nod) immer cinell gewifien 3ufammentyang behalten uno fid zu Edywärmen idyanren, fo haben

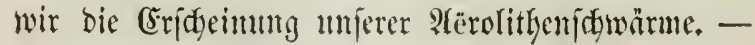




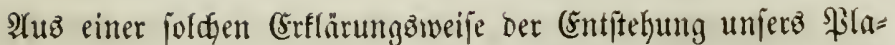

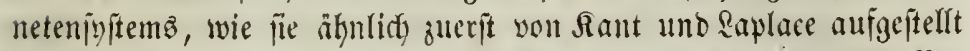
wurbe, läpt fich ganz ungezwumgen bie llebereinfituming bor $\mathfrak{B} e=$

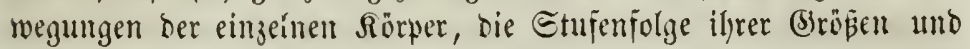
Didgtigfeiten, bie Form ihrer Baljnen uno Deren Peigumg gegen

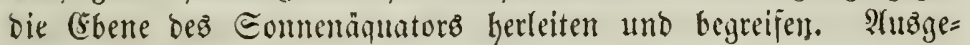

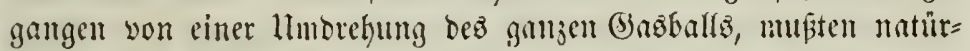

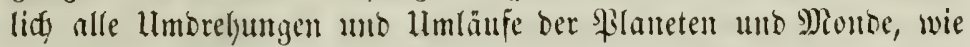

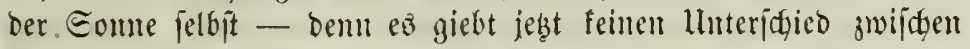

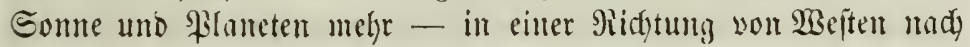
Sften wor fids gefen. Die Form der $\mathfrak{B a h n e n t}$ fonnte feine antbere

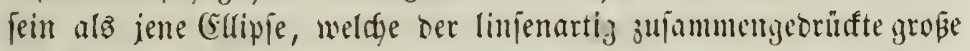

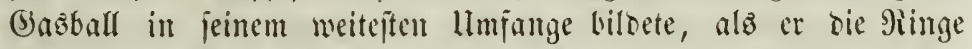

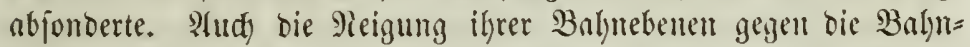
ebente ber Eomme fonnte nidyt bebeutent werben, wemu nidgt be= jonbere Bern̈nderungen in Der Didstigfeit und Wärme Der cinzefnen Theile jenes (5haoz mandje Afoneidjungen hervorbradjen. Die be=

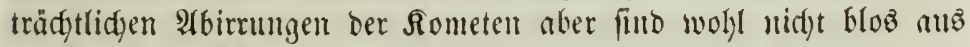

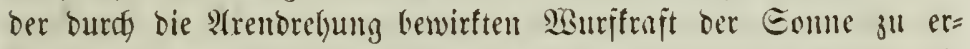

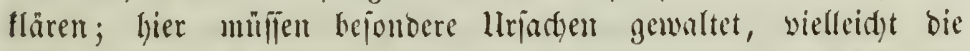
Edymutgfraft, meldte. bie Sonute burdy ilyren ltmlauf um jenten un=

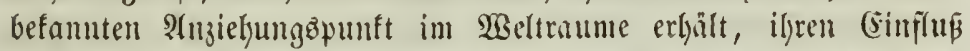

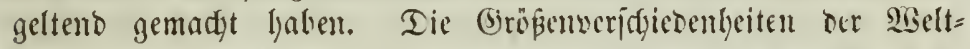

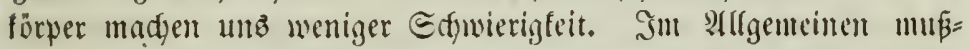

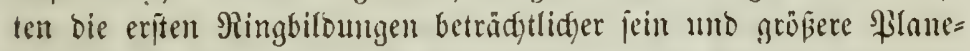

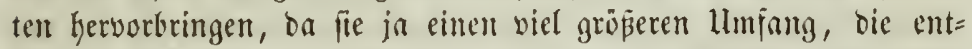
jtehenden Rugeln aljo einen viel größeren Siingîtreifen aujüurulten hatten. 3ugleid, waren aber audh bie sberifen Edjidjten bie am

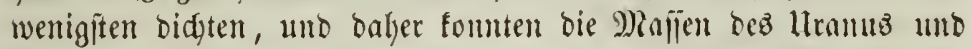
Reptun vom Supiter übertroffen werben, zumal bie er|teren idfuel= ler erfalteten und fidg verbidfteten. Neberlgapt idjeint fid bei ben meiften unifer \$ilaneten ber förperlidge limfang auf eime merfwür= bige $\mathfrak{B}$ eife mit ber Didftigfeit auzzugleiđgen. Dnß̧ ber Eomnenför=

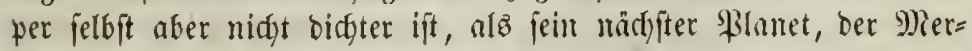
fur, baß er von ber (Srbe fogar um baz Bierfactye an Didjtigfeit übertroffen wiro, widerftreitet eben fo wenig Der Midfytigteit umijer Annalyme. Die Eonne ift ja ber un einen Sern werbidytete Lleber= 


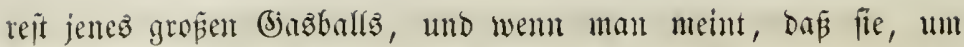
Der Entuenjolge her Didtigkeit ju entipredyen, bidfter fein müpte a(8 ) Mertur, jo vergi

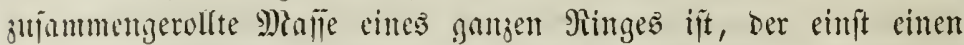
(j)itutel ber io weit ausgebefnten Eonnentugel bildete. Sin bün= ner und jumafer Sing ber jebigen Eonnenmajie miltrbe olyte Zwei=

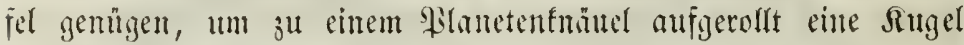
von nod grïßerer Didtigfeit ju bilden, als Merfur.

Der franjofitude Sifyfter \$latenut hat es verjucht, biefe Ent= ftehumg bes Filanetenigitems anjandidy zu mathen. (Er füflute ein

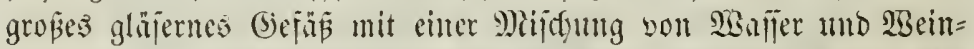

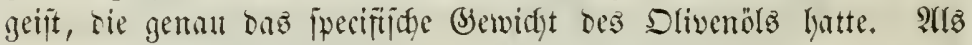

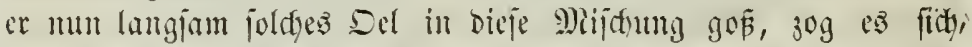

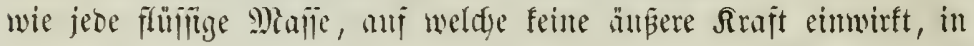

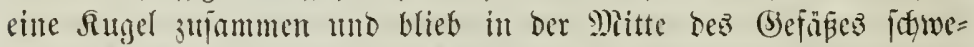
6en. Er ferfte Darauf eine Are Durd) bie Mritte Der Delfugel und begamn fie mit Şulfe cimer $\Re$ urbel zu brelgen. Die Delfugel folgte ber Drelung, und ie idneller dieje wurbe, bejto melyr erhob fidh ifre Mitte, Der 2 (equator, Dejto mehr plattete fie fits an bent Polen ab, indem ilye stre immer fleiner wurbe. Endidy breitete fith bie

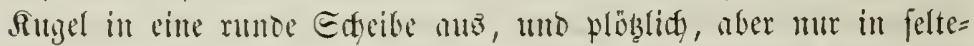

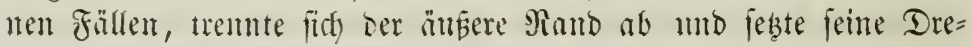
lytutg als fladyer Sing fort, wälremb ber mittlere Theil fich-wieder in bie form ciner abgeplatteten $\Re$ ugel zujanmenzog. S)ieiftentbeil

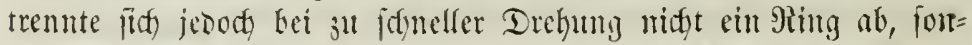

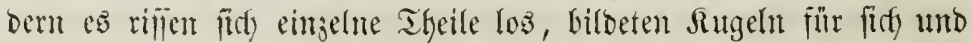
jebten ihren Umidywung un ben uriprünglidsen M)ittelpunft fort. Sebe Singel nahm Dabei wieber sine Siotation nm ilyre eignte ?tre alt.

2Bir jefyen in Diejem 2erjudye bie volffommente Llebereinftim= mung mit Der Eaplace'jden Theorie ber Filantenbildung unter ben

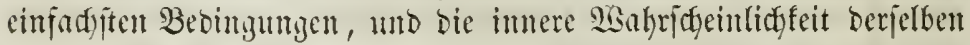
wiro hierourch géwiés erbïgt. Saplace judfte eime Beptintigung aber nod) mehr in Den Formen ber Mebelwelt, indem er mit jeridjel

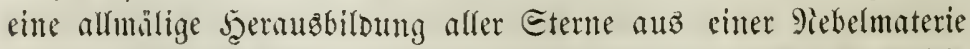
annatym. Die Tiefen bes Şimmels jeigen uns nad) feiner 2 (nftedt gleidjam ein vollitüniges Siaturalienfabinet won 2 belten, in bem 


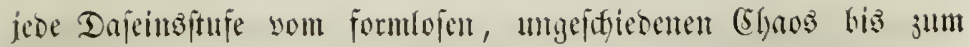
wollenbeten Etermigytem werteten wirs. Dort jeffen wir lidfte, form=

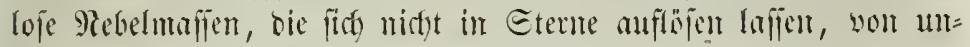

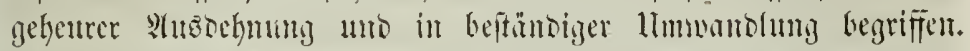

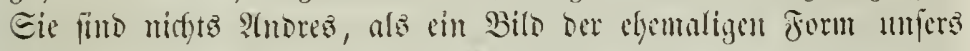

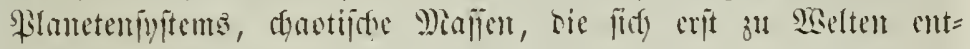

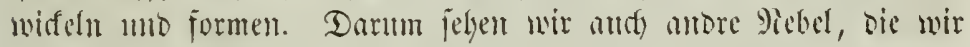

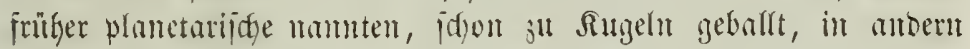

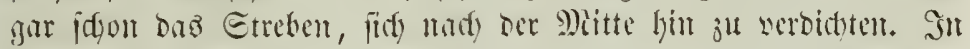
mefreren ift biefe Berbitfunty foron meiter gigangen mo erimtert

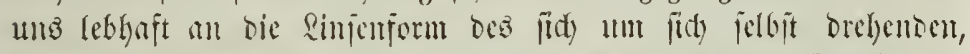

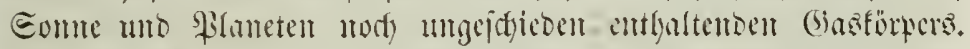

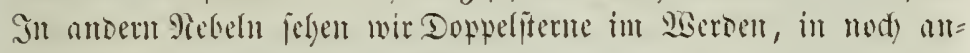
Dern fogar Riurgbiloungen, wie fie ber filmetentildung sorferge=

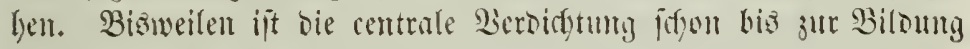
cines beftimmten Eternes vorgejortitten, und in ben bidfen Etern=

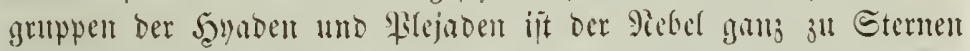

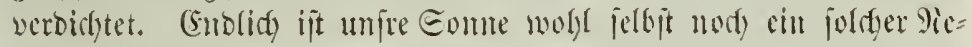

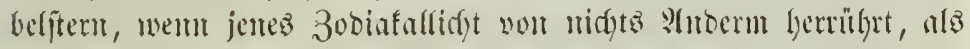

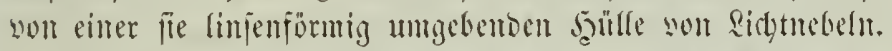

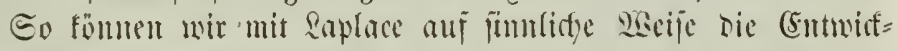

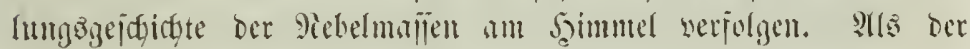
volfenderfte 3uftanto erfacinen uns dic fogennment firfterne. Den= fen wir uns in eirrem unenolidy weit antogebelynten Rid)tnevel eine

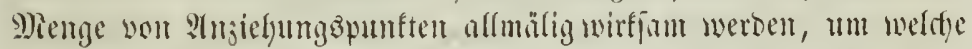

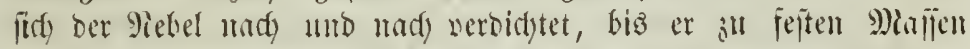

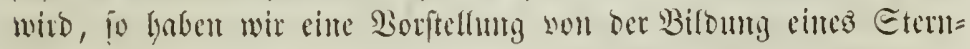
iyftems, wie unje s)ildyjtaje famm allen fiddtbaren Eternen eins ift, uno wie wir antore in jenen Pebehn gemahren, bie fids

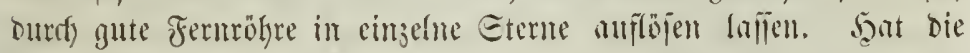

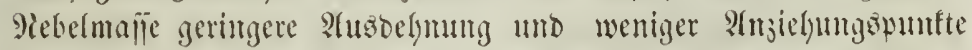

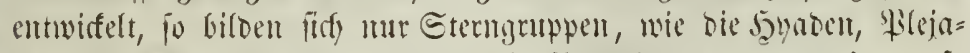
Den, bie Srippe und antre. Sit bie :Husbelyumg nod) geringer, fo entifelyen entweber bloz eimfadge Eterne, oder bie viefädyen Eterne,

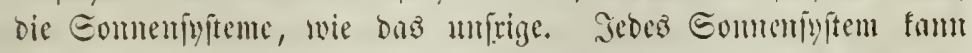
mun die Eridgeimugen des ganzen Eternigytems mederlyolen, und fo fimben mir and in bem unfrigen wiebor einzelue Eterne, wie 
Eume, Merfur, Semus, Marz, Doppelte, wie bie (Frde, sielfadye, wie Supiter, Eaturn, Uranus nund Sieptun, beringte, wie ben Eaturn,

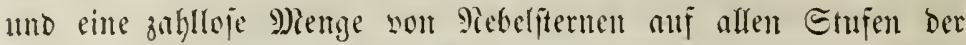

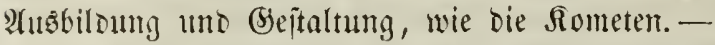

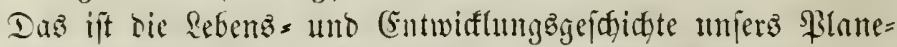

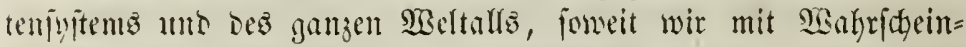

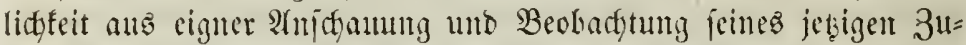

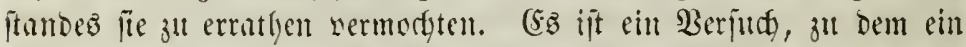

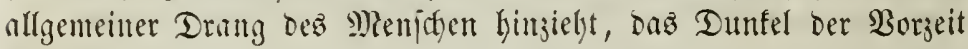
зu linftert.

Der urandogiide Theil unjer Giaturbetradtung ift hiermit

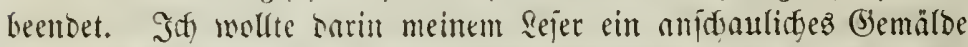

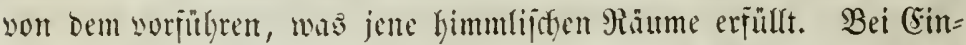

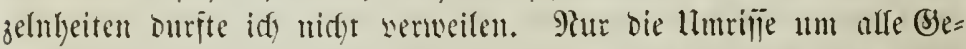
genitänte dicjes reiden Bildes jolften verseidunt merden, Damit ber Totaleinbruf́ Des (jemälses nid)t geftört werbe. Die 2tusfüthrung von Einjelngeiten würoe die Blife won (Banzen auj bicje geteitet baben.

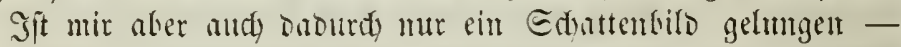

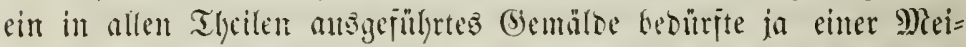

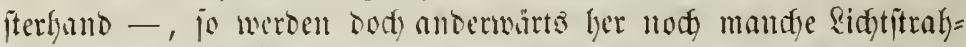
lent anj bieje gelyeimnisuollen Edgattenrifie fallen. Inmer flarer

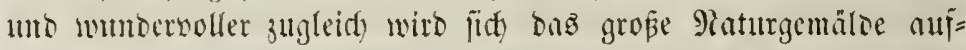
roflen, wemn wir jenes $\mathfrak{B}_{\text {utd }}$ mifidflagen, ous im eignen Bufen

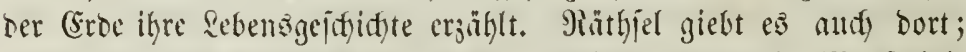

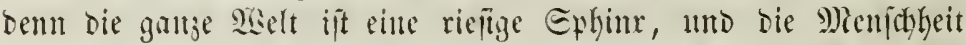

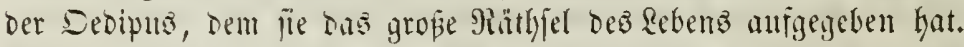

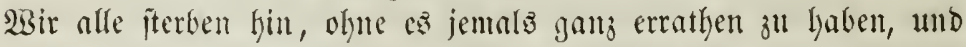
oody ijt biejes figüne Etreben, biejes Eimnen, weldyez ben Echjeier immer weiter uno weiter lüjtet, biejer (jemuß bez wadjenden (Er=

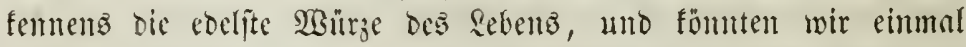
guntz zu Entoe fommen, wahrlids, fo lohnte ez firdy nidgt länger ber Mlithe, zu feirt.

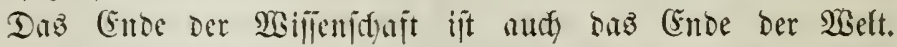

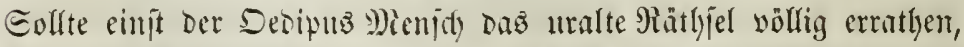

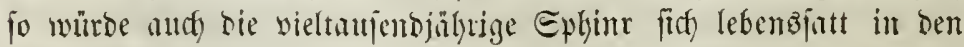
Tod fturgen. 
muthungen aufiftelfen über bie bejonbre 97atur ber Etoffe biejez nder jente Weltförpers. Sgier fönnen wir unmittelbar beobachten, mit

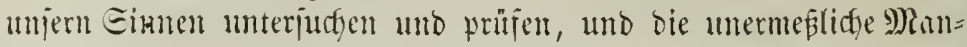

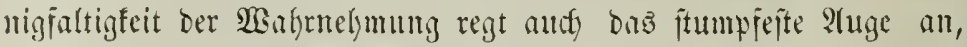
treibt and ben trägiten bieifit jul Yebendiger Thätigfeit, ju benfen=

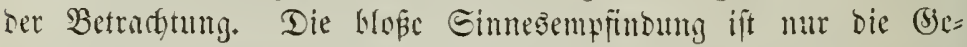

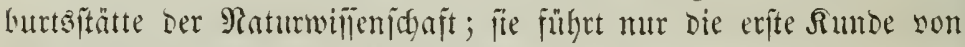
Den Dingen außer uns unjerm Bemuptíein zu.

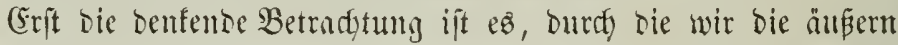
Dinge nifft vereingelt, fonbern in gegenjeitigen Beziefungen, in

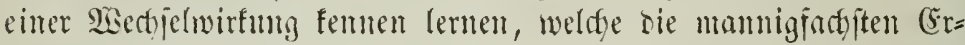
fdgeimungen uno Serändermugen an ifnen herworruft. Shr allein

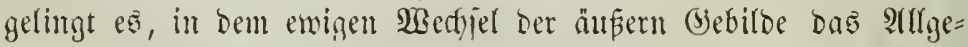
meine, bie (Eintheit in Der 2ielheit, bie 2erbinoung bes Manmig=

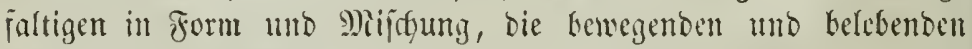
Sräfte und Die (jefebe, nady weldgen die Sräfte wirfen, ju ent=

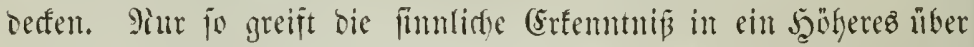
uno n̈ber de blope Eimnemwelt hinats, mo hierin eben liegt ber werborgene Trieb utb Der ahmungswolle heis, welder afler Denfen=

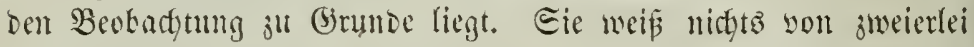
neben cimander beftelyenden 9aturen, yon renen bie eime belebt, bie andre toot ijt; ifr ift bie ganje Siatur ein lebendiges Sanje, ber Snbegrifi ber Maturbinge und Maturfräpte. Dns ift Maturwijien=

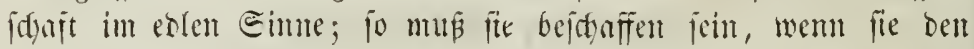
Ramen einer Biplenitgaft serbienen foll, und mer fo foll fie un=

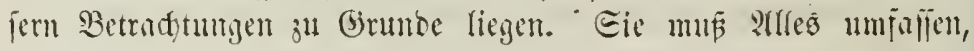
was Der Geijt ber Salyrlumberte erjoment und entberft hat, muß Die liberliejerten Irrthümer und Die 3eugntije idfedt leobachteter Thatiodyen wioerlegen, bari in Den Expheimungen fein mores Bie= Geimmiz judfen, als bas einer geregelten mo fortichreitemben (Ent= wifflum, mus in Der (jegenwart ben Epiegel ber Bergangenlyeit

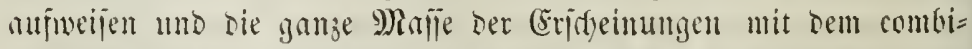

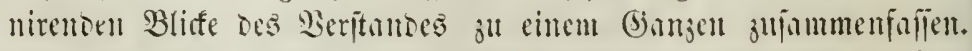

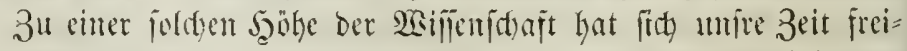

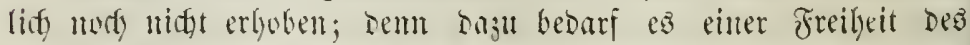

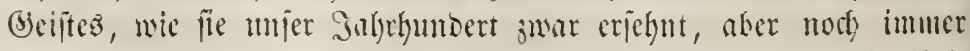

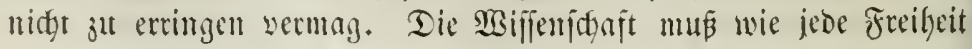


erfämpft werben. Es giebt feine lIrweisheit, bie etwa, sem erften

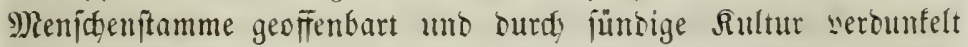
uno sergefien, nur allmälig wie eime Crimnerung zurüffelyre. Sigohl

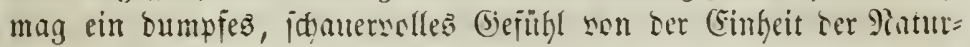
gemalten im Bujen bes swilon aupiteigen, aber ein foldyez bejühl

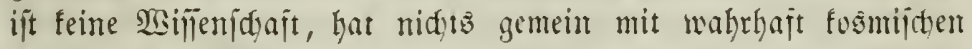

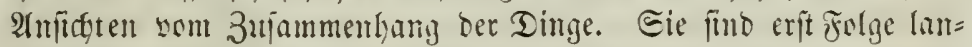

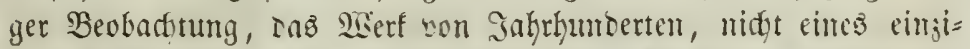
gen $\mathfrak{B o l f z}$, Futern bie Frudyt gegenjeitiger Mittheilung eines all=

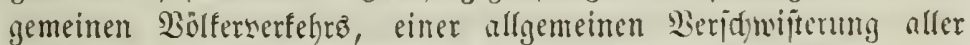

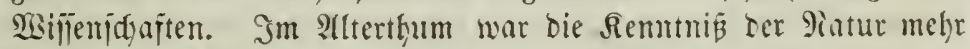
aนรี inneren 2)

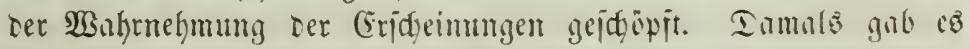
noch eine frieblide, ungetheilte Einhcit aller Ertemmif, aller For=

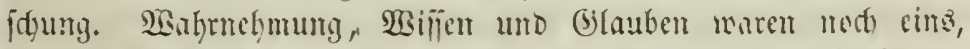

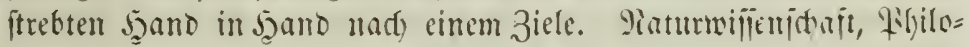
jophie, Meligion waren nidyt gejdiesen. Danm gewinnt \&llez

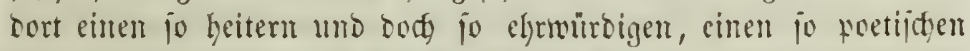

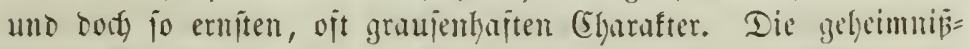
sollen 9laturfrajte waren balo mädtige, mad) jreient sisiflen mal= tente Siotter, bald Soeen des Gerijes, 3ablen uno Buthïlnille. Die Eroe war Der Seerd ber Giöter, rer Şimmel ihre 230 hmmg. Dann waren es aher wieder förperloje formen, Jocen, bie jente

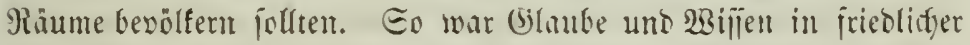
Eintradgt. Da bradjte Das (Shriftenthum Das Edjwert unter bie Bülfer; Der Rampi zwijden (Slauben Imb 2Bifilen, Religion uno

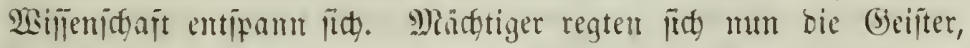

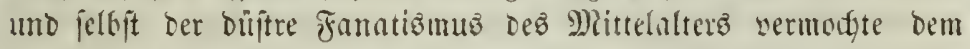

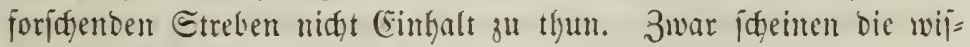

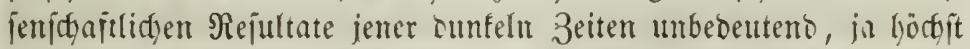

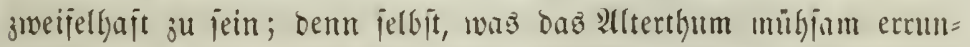
gen hatte, waro mit Ssewalt nicoer jurḧfgeorängt umo semidtet,

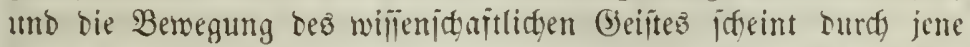

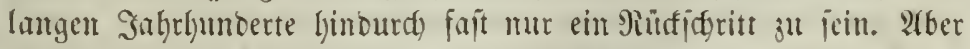

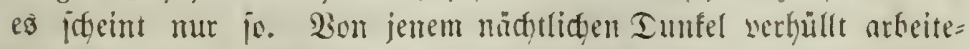
ten Mtämner, eble, bodbegabte, freie Eelbjtonfer an jenemr gropen Bau jort, ben bie nette Zeit sollenden joll; groß̉e 9amen tauden 


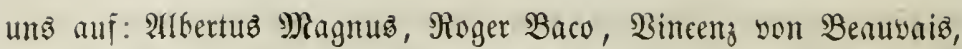

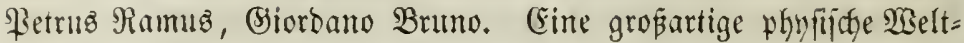
anifanumg bebari nicht blos ber reiffen grülle ber Beobadtungen als bes MRaterials jur Berullgemeinerung Der Soeen, tie bebarf aud) Der sorbereitenden $\mathfrak{R}$ räftigung ber (bemüther, un in ben fite=

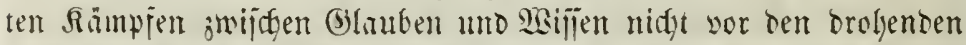

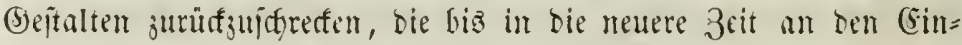

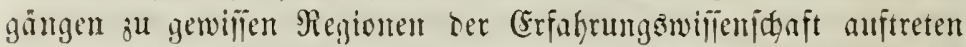

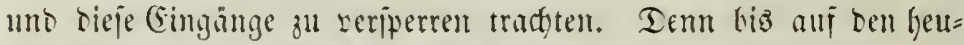

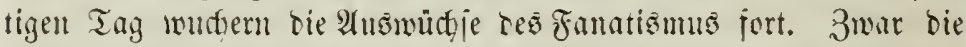

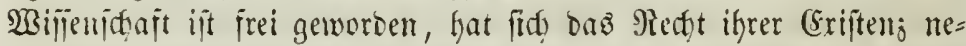

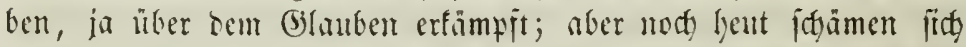

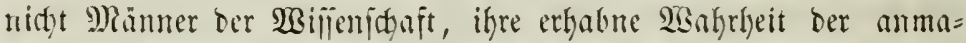

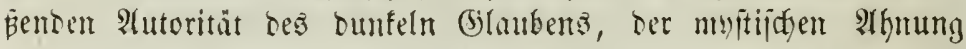

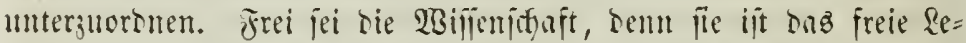

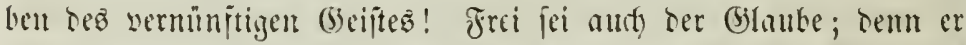
ijt tas ungejtillte Eefmen nady bem emigen Suell aller $\mathfrak{W e i g h e i t , ~}$

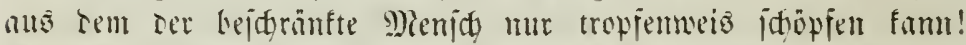

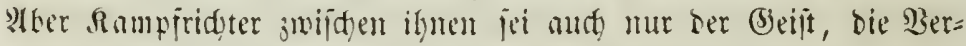

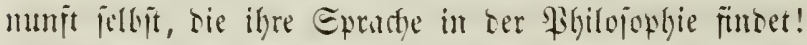

Die leutige sillienidgaft, fo weit fie frei geworben ift, ner=

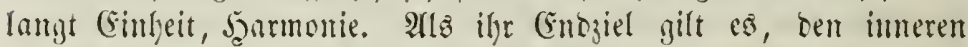

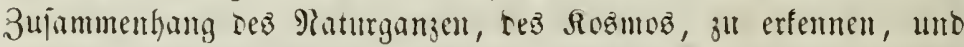

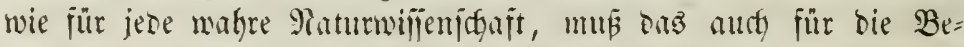
tradjuntg unjer Croe maßjebent jein. Diejen inneren 3ujumen= hang, bieje fosmijaje Bebeutung ber Mantur crfannten mir aber in jenem Reben ber Matur, weldes bie Sisten bemegt unt fre nady

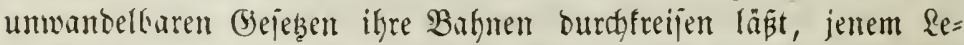
ben, weldes cinjt Ridft in bie Finjternip janote und burd bie Wärme

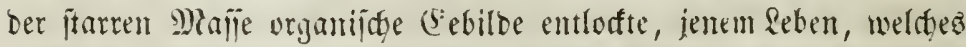

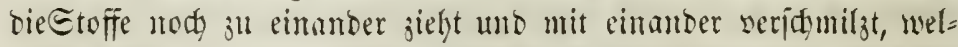

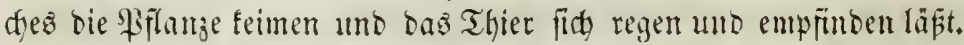

Ties seben lernten wir bisher jreilidy mur in jeiner einfactjten, niebrigiten Gejtaltung fennen, als räumlidge Bemegung ber plane=

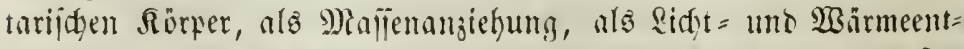

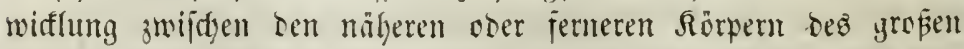

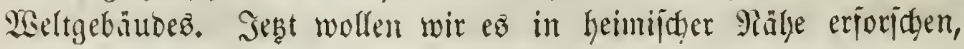


in feinen gropartigftent uno furchtbariten, wie in jeinen zarteften uno lieblichjen Eridgeimutgen auf Der Erbe jelbit beobacbten. Die= jes marme irbijfye Reben und jenes falte limmlijcte find aber einz.

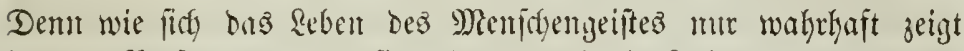
in bem Beridjmelzen Der Einzelnen Durdy bie Riebe, jei ez in ber

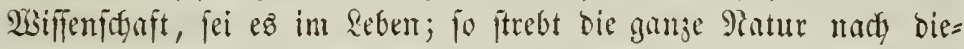
jem innigen Berjdmelzan aller linterjojiede, diejer Eelbjutvernidytumg im Bseifte. Rebent ift Riete aud in ber Ratur. Rber auf ber un= tern Ențe bleibt jentes Biel mur ein exielyntes; in rajtlojer llurube jagen bie Siselten ifrem Ziele nact), cine locft bie anbre, unto fo tommt ę zu einer ewigen, aber burd) (5icję̧e geregelten Bewegung.

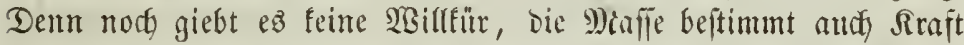

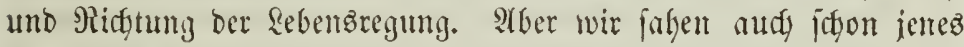
Reben fidh freier geftalten. Die $\mathfrak{B c l t e n}$ traten zu Eyjtemen jujant= men, beren Slieber fid mäthtiger unter cinattoer anregten, in be= nen jenes Gelnten nady Bergeiftigung lebentiger wutre unb zu ei= nem wectjeluben Sampje Der Materie fïlyrte, ben wir in ben (5r=

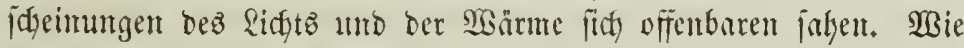

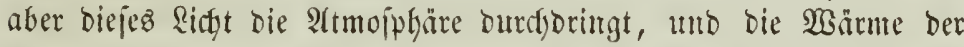

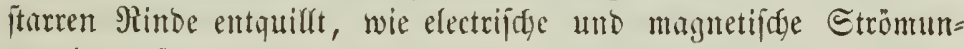
gen in biejen planetarijden $\mathfrak{B e l t e n}_{\text {jids }}$ regen, und wie all biejer 3auber ben Rebentsjunten in ben organijgen Sebilden ber Sber= fläche erwedt unb năhrt, Daż blieb unż nod) verborgen. Denn baż

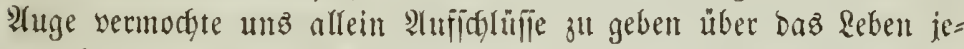

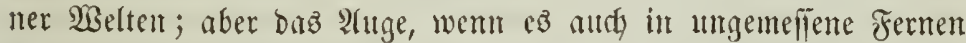
reifft, futbet dody feime Srenzent. Şier erit, mo wir uns heimifd jüblen, wo unz alle Eimne zu Bebote ftelgen, wo wir in ber Siälye

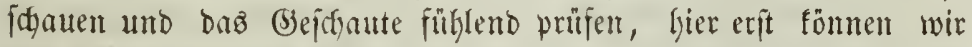

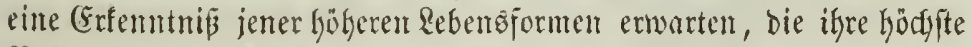
Bolfendung im Bernumftleben Dez Menidjen finden.

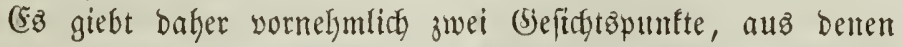
wir unire Erbe zu betractent haben. Eimmal tritt fie uns entge=

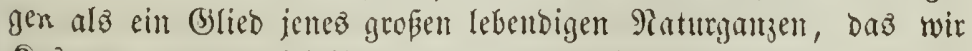
Fosmos wannten, Theil melymend an Dem Reben und ber Betwegung Defielben, Durdy jrembe (Einnirfungen befjerridyt und bervegt, furz alz $\mathscr{W e l t f o ̈ r p e r ~ i m ~} \mathfrak{B e l t r a u m , ~ a l s ~ S l a n e t ~ i m ~ S o n t r e n i p i t e m . ~ D a n n ~}$

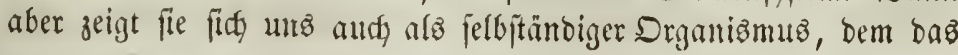

IIle, 2Bettall. 3. ?tuff. 
Beftreben intmewohnt, fid vermittelit ber in ifm liegenden Patur=

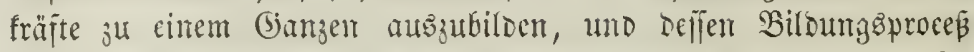
ein theils nod) Daternder, theils nergangner ift. (ses ergeben fidt)

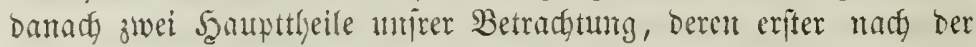

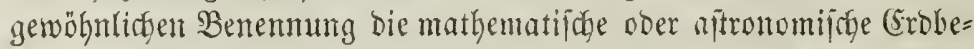

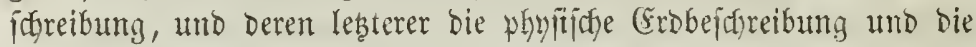

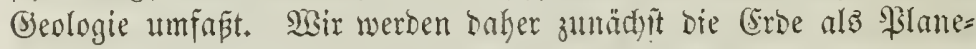
ten ober in Beziefung aū bas seltgebätto betradytem. Eie gilt

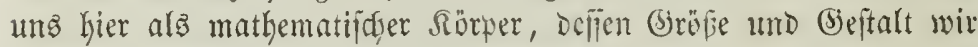
zu Gejtimmen Kaben, befien Bewegutgen uno Cimwirtungen auf andre Szimmelaforper and burch anbre wir femen lernen wollett. Dant aber wollen wir dab planetarijaje Reben ber (Srbe entwiffeln, wie es unter bem (Sinftufie jenter has ganje 2 Beltall burdftrömen=

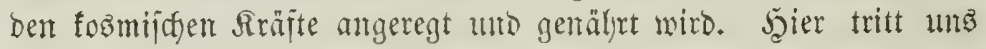
Das Reben in Der reideren finfle feiner Ericheintungen entgegen, und fier gewährt es uns, mas cir freles, fid) yom immen aus fräftig entfaltendes Reben immer bieten jolfte, eine Befryichte. Fiefe Bies fofidyte ber Croe bilbet Daher Den interefintteften Theil unjer $\mathfrak{B} e=$

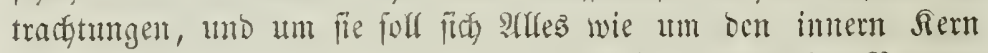
oronen, fo Daf Die ganje siatur wie ein offnes Budy ifrer Bergan= gentheit uno (s)eyenwart fït ung enthüllte.

Wie bie Eroe als eill (ba)ring fich wou bem grofen, unjer ganjes Comnenizitem umichliepentben (S)azball loztrennte uno jelb= ftändig zu einem (jaball jujammenrollte, haben wir bereits gefelyen,

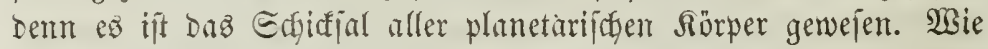

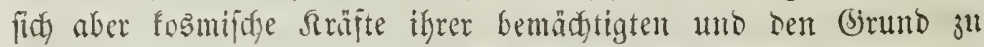
höherer Rebentreyung in fie legten, wie fidh bie (Groe von ifyrer er= ften einfadyen (bictalt allmälig ummantbelte, verbidytete, Rontinente

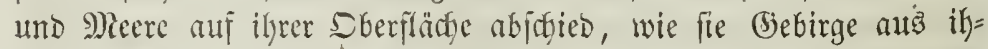

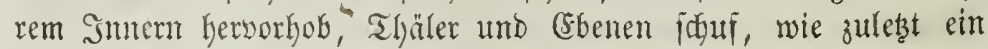
organiīthes Reben auf ilyr ermachte, bas inmer wieber burch gewal= tige Revolutionen gefjenmt 11 to vernichtet ward, aber immer wieber wie ein \$fyonix aus feiner 2 lifge emporfeinte, in immer neuerch

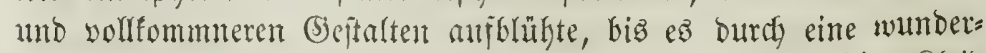
bare Etufenfolge bon formen uno Bitbungen jenes febenbige Rleio

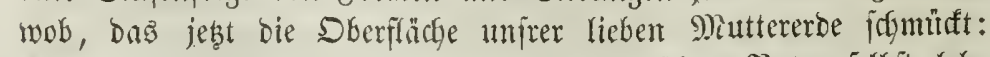

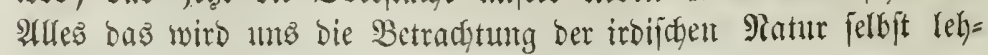




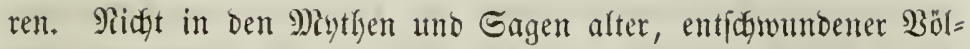

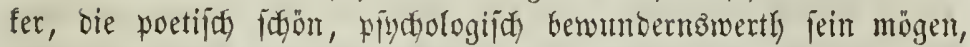

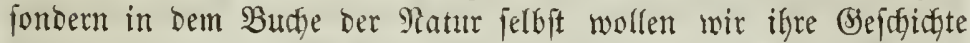
lejen; Darin liegt mebr Whahrljeit, alo in Den taujenbjührigen lleber=

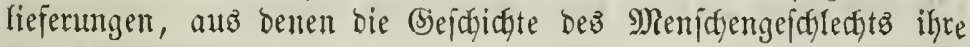
Duellen ifoppft.

\section{1) Die Eroe alo Dilanet.}

Pody einmal betradten wir unfre (Frbe alछ cin untergeorbnetes

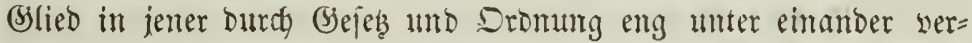
bunbenen Bruppe yon wiselförpern, bie wir umjer Eonnenjpitem nannten. SWir begimen mit ber finntidyen 2 Babnefymung jelbjt.

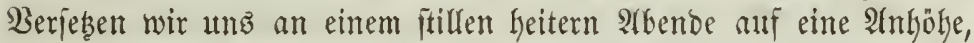
bie rings bem 2 utge einen freien Bliff geftattet. Die Dämmerung ift verglommen, und am bumfeln saimmelsgewölbe gelot eine zahl= loje fumfelnde Eternenjaat auf. Der Zeitraum ciner Stumbe reidyt Gin, uns ju überzengen, daß alfe biefe Eterne cine gemeinjame $\mathfrak{B} e=$

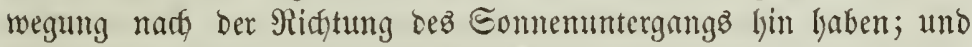
Diefe gemeinfdyaftlidye Bemegung, weldye weber (Entfermung nod) gegen= feitige Etellung Der Eterne änoert, berleitet unซ, fie einer Bewe= gung Der ganjen Szimmelätugel, an weldyer bie Eterne befejtigt zut fein japeinen, jujujdreiben. Darin werben wir nod burdy bie $\mathfrak{B} e=$ obadfung beitärft, Dấ im Piorben viele Eterne gar nidyt auf = nod, untergeken, uno ein Etern im fleinen Bären, Der Folarjtern, fajt ganz unbewegliđ bleibt. Whir meinen baher, baz Şimmelsgewölbe Drehe fidf um eine fejte 2 ree, berent cines (Gnde burch ben Folar = ftern gefyt, in je 24 Etunden, unire Erbe aber ftehe unbeweglich in. Der Mitte. Dodh wir haben fdon bie ungeheuren Entfernungen Der Firfterne fennen gclernt, wir wifien, wie riejenhafte Mnfien fie fint, bie felbit unje Eomme libertreffen, bie body ichon $1_{2}^{\frac{1}{2}}$ Millio= nen mal größ̈er ijt, als umire Eroe, und wir beginnen zu zweifeln, dap jo gewaltige Mafjen fid täglid) um unje fleine Eroe berwegen follen, und Daß in biejer cine jo ungeheure Srajt wohnen foll, bie Dody feine anore als bie Edywertraft fein fann, weldye alfe jene Welten um fith herumzufüfren vermag, wäbrend fie body nidyt ein= mal einem fleinen Magncten zll welyren im Etande ift, cin Etül Eijen als Beute an fidy ju reipen. Heberbies lebrt unz bie Erfah= 


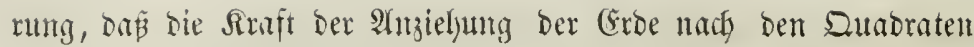
Der Entfermung abrinmt; mo bod, felyent wir alle Eterne, bie ent= fernteften wie die nädyften, mit gleidyer fojeinbarer Bejebminbigfeit, in gleidger 3eit ifren llunlauf wollenten. Sam bies antors gejđe= Ken, als went bie Erbe einen mädtigeren Einflü anf jene fenten Eterne anthübt, unt wie follent wir es Dann mit Dem Siepege ber Errahrung vereinigen? 2(ber nody mehr! Die meiften Gtente be= fafreibent in ifre Sreife nidht um Den Mittelfunft Der Crobe jelbit, fondern un jene Sseltare, bie liber unfere Groe Kinaugliegt, bie

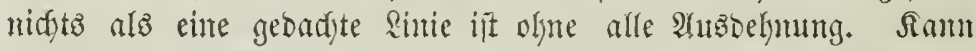
Denn aber eine Fraft wirfen, bie an leine raumerïlllende MJaterie

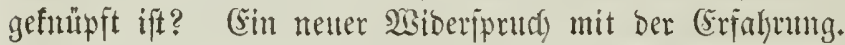

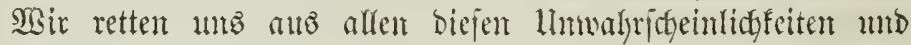

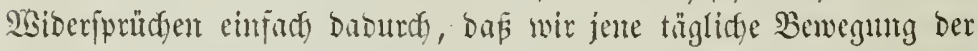
(Sejtirne für cine Eimmentänjoung enflätent, wie fte wohl bem Siei= fendent auf eintem Dumpfichiffe wiberfäfyt, memt er bie Ufer an fid

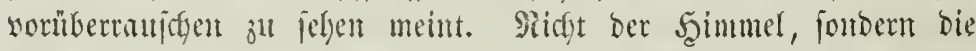

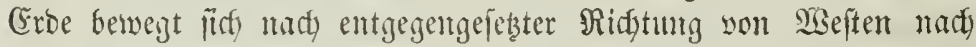
Sften; Der Şimmel ruft, uidyt Die Eroe. Die Eridfeitumgen blei=

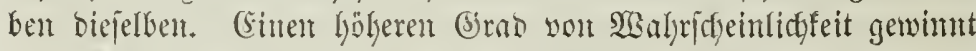

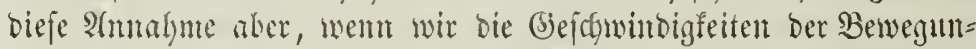
gen betraduten. Sady jener früheren Alutahme ber Bewegung Des Seimmelz̈gemölber müpte bie Eontme in jeder Eecunde 1450 Mei=

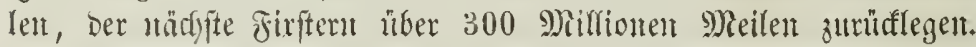

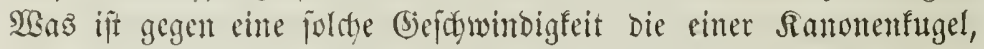

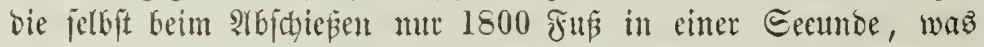

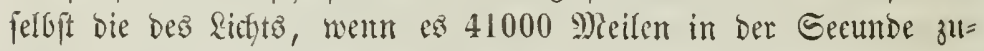
rildfegt? Linb Doch giebt es nod unendich fernere siriterne in jenen. Rebelu, bie wohl mehrere 100000 Sternmeiten son uns entfernt fein

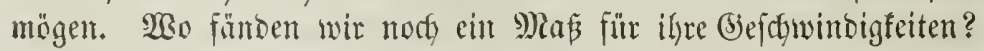
Sisie viel impofanter wirb bies Edaupiel noch, went wir bie ant= gehente Größje biejer Miflionen anfglimmenter Welten bedenfen, weldye affe biejes Stäbdyen Srbe in unfapbarer Sile untan=

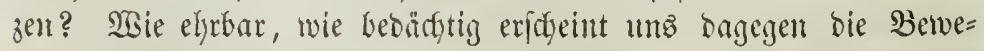

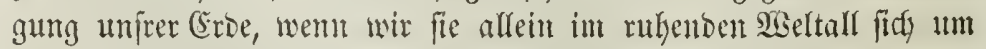

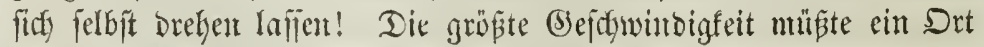
auf Dem arequator baben, uno bieje beträgt mur $1427 \frac{1}{2}$ Fnß in ei= 


\section{5}

ner Secunbe, erreidyt aljo nody nidyt bie 2Anfangägejdymindigfeit einer $\mathfrak{R}$ anountufugel.

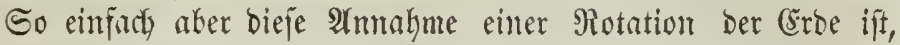

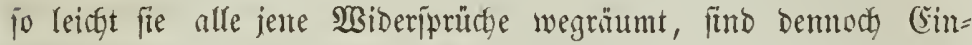
würfe gegen fie erfyobent worben, bie aber alle Gei näherer Unterju= chung nidgt mur gefyoben finto, fontoen fith fogar in birecte Berweife

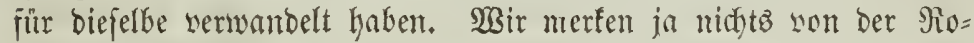
tation, fagt man. Wisogl merfen wir fie; jene in ber geipen Zone

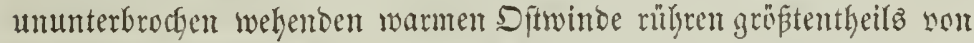

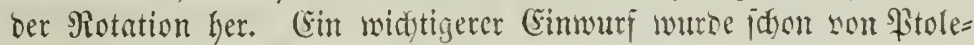
mätв, fpäter yon Tycho de Brahe erhoben. Crin Stein, Der yon Der Spize cines Thytrms herrbfalle, meinten fie, fönne nie genat am Fußse beffelben nieberfallen. Dem während der Stein falle, brehe fich ja bic (Erbe yon sisejt uady Sit; in bem Itugenbliffe alfo, wo ber Etein ben Boben erreidge, jei ber Thurm foron offwärts

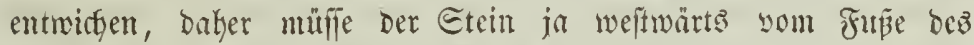
Thurmz ben Boben treffert. Elllein fie bedactsten nidyt, bur ber Etein nidgt auflöre cin Theil Der (Eroe zu fein, uno eben fo gutt

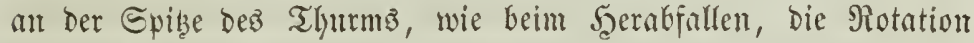
um bie Gronre mitzumadyen Gabe. Ulnmöglid) fam baher ber Stein weftlidy youn Thurme herabfallen, im Gegentbeil mus or bei hin=

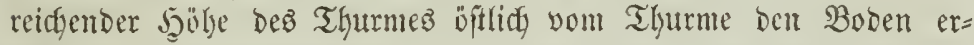

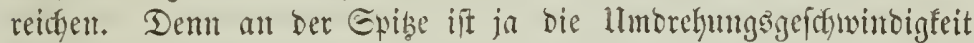

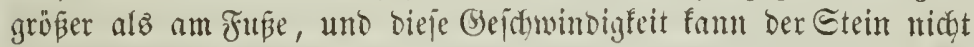
angenblifflidg verlieren, er befält fie beim Fall uno bemegt fich

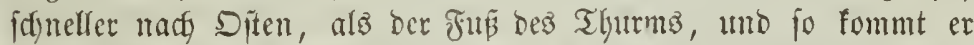

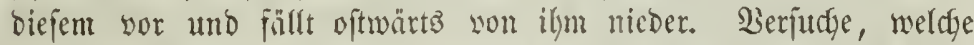

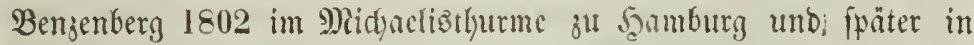

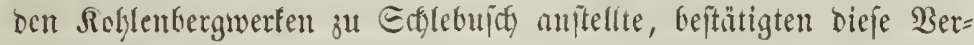

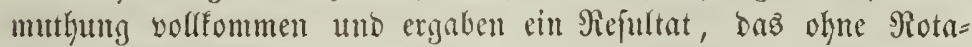
tion nicht for erflären fein würoe.

WBenn audh bie Rehre von ber Atrenbrelynng Der Erbe bereits jeit langer 3eit in Fleija) und Bhent bes Boffes übergegangen ift uno vou ben Sinden fajt mit ber Mitutermilds anfgefogen twirb,

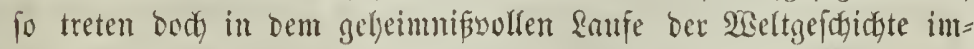
mer wieber fierioben ein, gleidfan Finfterniffe am hellen Tage,

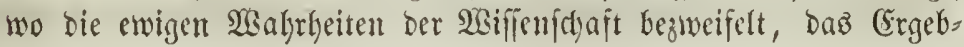




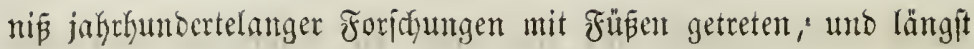
begrabener Unifinn aus Dem Moder ber Bergangentgeit wieber her= aufigeholt wirb. Der Satholticismus zwang vor länger als zwoi

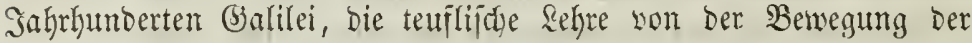
Eroe abaluffwören, und noch Gent za Tage nerjudyte er Denjelben

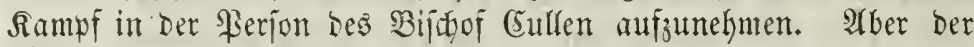
Brotefitantismus jalbit tritt ifm hülfreich zur Eeite, um bie gemein= fame 24utorität ber Bibel zu retten. Sn einer Berfammlung yon

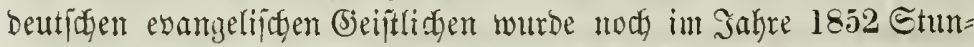
Den lang Dariber geftritten, ob die (sroe fich bewege ober nidgt.

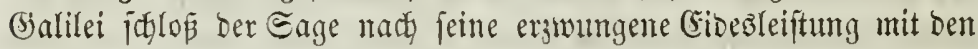
Wortent: Uno fie bewegt fid bods!

Die heutige sisijenjugaft rufft den Ungläubigen ober vielmehr

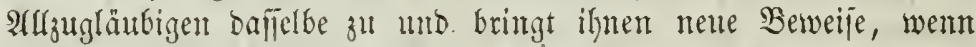
fie bie altent veracten. (Sin jolcher neuter Bemeio berufgt auf ben

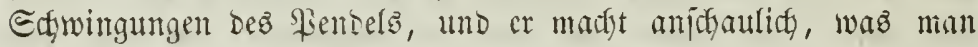

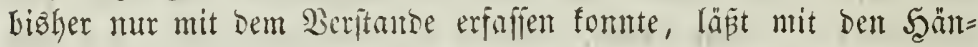
ben greifen und mit Den P(ugen jelyen, was man jo gern uvegleug=

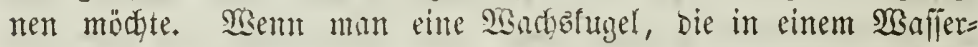

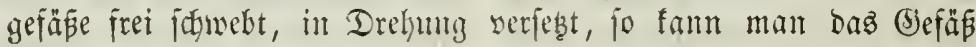
aufheben, umhertragen, furz in jese möglidje sage verjęen: bie

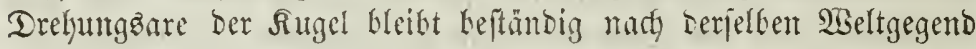

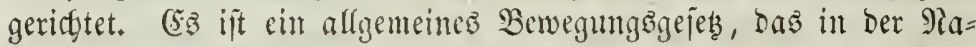

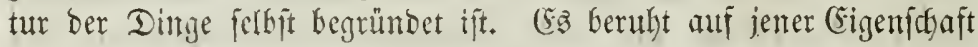
Der Materie, bie ntan Trägheit nemnt, und bie ben bewegten $\mathcal{\Omega} 0 ̈ r=$

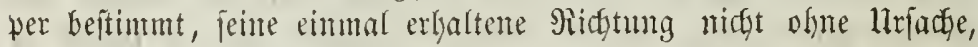

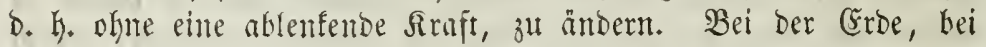

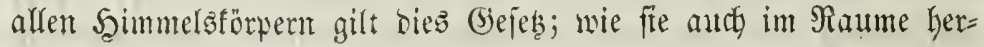

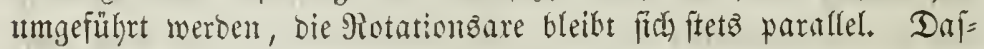

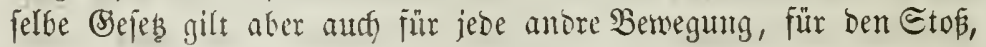

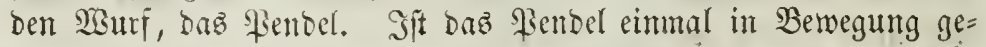

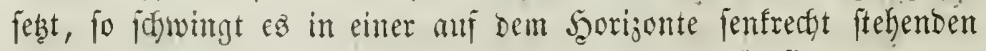
(Ebene, mb es hat gar feine linjache, bie Rage biejer Crbene zu ver=

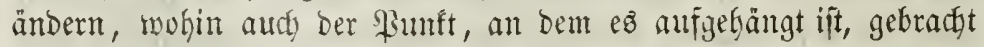

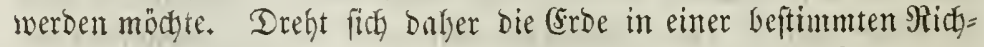

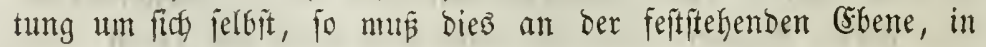
welcher bas Penbel fotwingt, bemerft werben, bie Ébene muk eine 
icheintare, ber Bewegung Der Errbe entgegengeję̧te Drehung zeigen. כo fönnen wir uns mit unjern eignen 2 (ugen won ber Bewegung Der Eroe überzeugen, uno der Farifer Belelyte ?éon Foucault hat

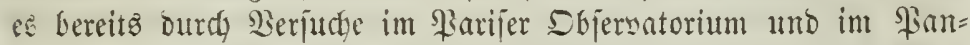
theon im Sahre 1851 bargethan. Bald Daralif wurbe berjelbe Ber=

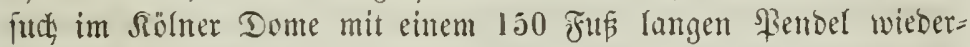
holt, und jeitbem ifit er in ben meiften größeren Etäbten Tentīith=

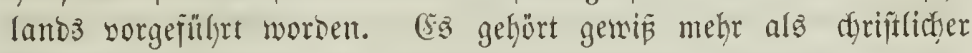

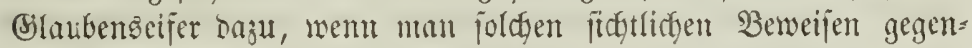
über blind bleibt.

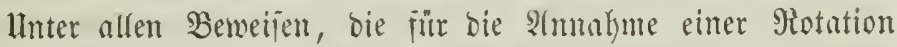

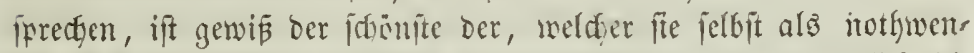

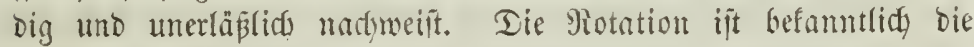

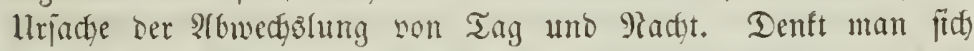
nun bie (Eroe anfangs als nidjt rotitent, jo witrben Tag und Eom=

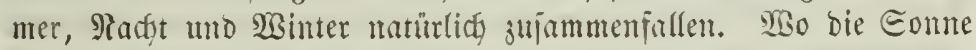
ebent aufgeht, Füngt ber Eommer an uno ift ter Moment der grö $\beta=$

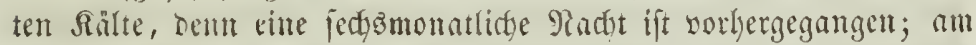
gegemäberliegunoen Untergangåpunfte Gerridgt Dagegen bie größjte

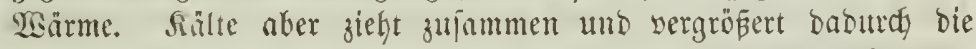
relative Echmere. Der \$iumft, wo bie Eome aufgelyt, ift idfwerer

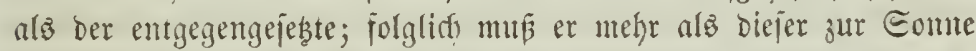
gravitiren, was eine Piotation und zmat in bem Einne, wie fie

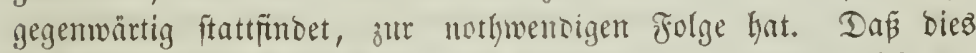

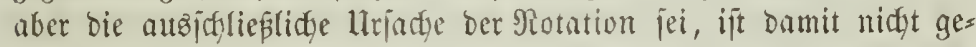

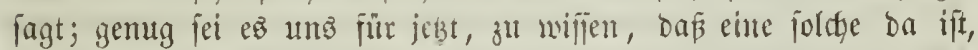
mag fie num burdy einen uripringlidjen $\Theta_{\text {tó }}$ ooer jonjt wie herbei= gefühtert jeirt. -

3u eirer fo einfadten (Erflärung ber Şimmelsbemegung burd) bie Rotation ber (Eroe, follte man meinen, müifie malt bod) idyon

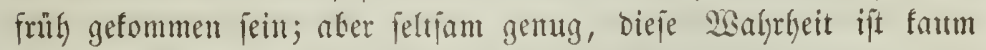
einige Salyrfunberte alt. Bei ben alten Bölfern ging bie allgemeine

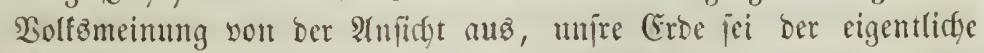
Sern ber $\mathfrak{W}$ elt, Eonne, Miond und Etene nur ein unbebeutendes 3ubehö, bas pith in ben obem euftregionen mifhatte tmo bewege.

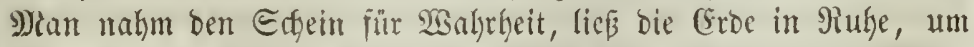
fich an ber Bewegung ber zafflofen Eternentheere zul ergïzgen. 
3war feflte es audh midgt an Mämern, bie beobadyteten und barum Daz $\mathfrak{B a h r e}$ ahnten. Edjon 200 Salgre vor Shrifto lehrte Arriftard

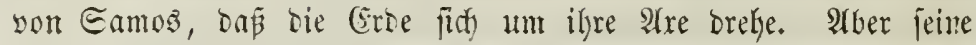
Refre gerieth in Bergefienteit, umb als brei Sahthbunterte päater Ser

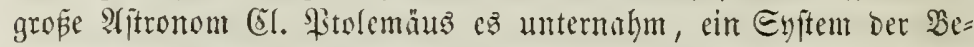
wegungen aujzuftellest, ging audf er von ber allgemein herrfdentoen Borittellung von ber linbeweglictfeit ber (Erbe in ber Mritte Des

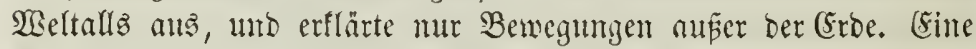
Ifles umfaliento Epfäre, von Der lirfraft umgürtet, follte bas ganze Limmlifdse Şeer Der Firfterne, Blanteten, Rometen, Eonne uno Mono in 21 Etunden um bie (robe herum führen, uno in bejon= beren Epfären jollten bie bejonberen Bewegungen vorgehen. Dieję ptolemäifote Eyjtem murbe sout dent Arabern überietst und war un=

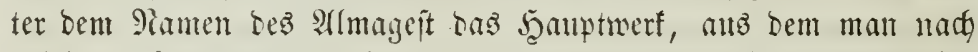

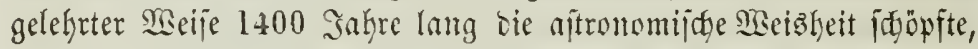

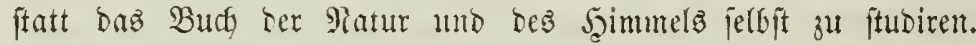
Gahrhumberte bes trourigiten Berfalls ber sisifienjidaft folgen auf Btolemüuz. Statt fortzujfreiten mi ben Bafnter, weldye bie Ulten geebret, gefiel man fid in gebnufentofer 9iadbeterei; alte, längît übermunbene Srtthümer tautbent wieber auf, murben geheiligt

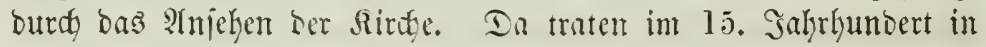
untierm beutiden Saterlanto shanner nui, bie jelbit beobadjteten,

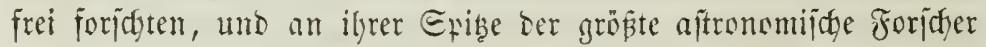

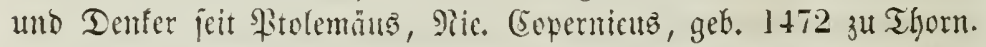

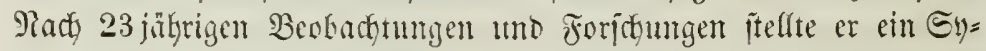

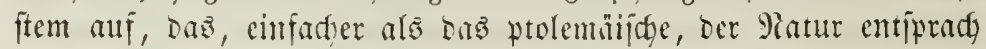

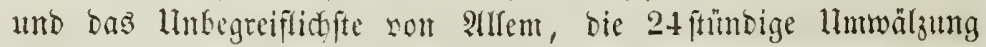

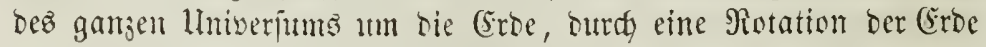
um jith jelbjt alifgol, bie gleidförmig in ocr (Eberte ber Hequatorz

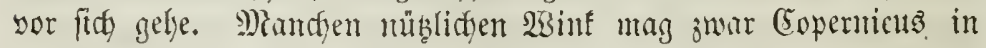

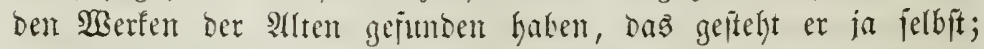

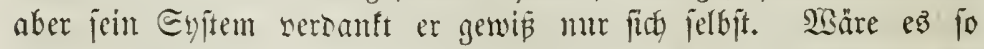

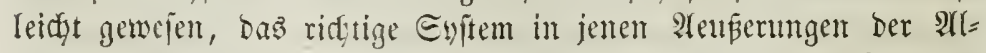

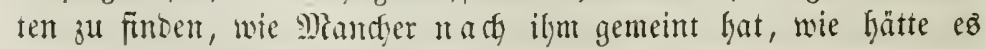
jo lange 3eit jelbit benen serborgen bleiben fönnen, bie auf bas (Eifrigfte banady judten? Alber nod nie hat es bei irgento einer (Epodfe madgenden Entbefung an Reuten gefehlt, bie jogleidg mit ben alten 
(Eitaten zur Şano waren, bie fie mun mit einem Male zu benten

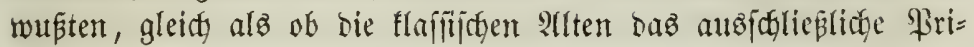
vilegium bes eignen Edjaffens gehabt hätten, uno wir uns barmu bejdränfen unüsten, fie ju jtubiren. Sant man body jelbjt bie Edfiefi= baumwolle uno bie Daguerreotspie zul Erfintumgen Der alten Brie= dyent ftempeln wollent! Eopernicus ftubirte bie Matur, bicfe envige Rehrmeifterin benfender Beifter. 2 Enz aber auts tem Etubium Der

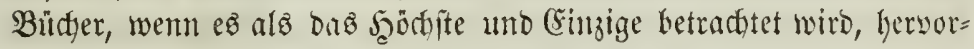

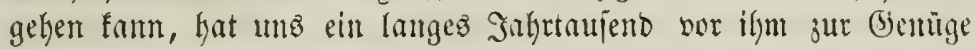
gejeigt. -

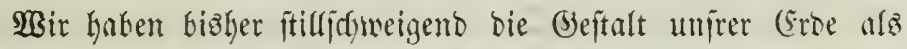

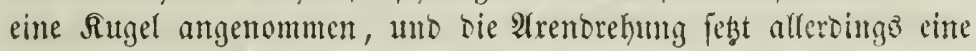

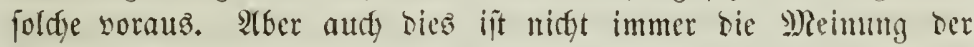

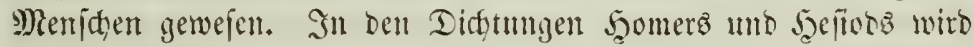
bie Eroe alo eine rings som Dreamb umflofiene Ectribe vorge= ftellt, und erit bie Beobad)tungen und Nefifimgen ber fräteren

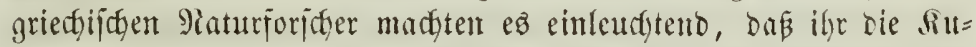
gefgeitaft zutomme. Sm Finftern Mittelalter wiro bie Eroe, arj bie Qlutorität ber beiligen Edyrift biu, wieber zur flactyen Ectyeibe, beren Bölfern allen bie Eonte zugleidy auf = uno untergel)t. Seentzutrige ift bie Boritellung bon Der Siugelgeftalt ber Eroe fo alligemein verbrei=

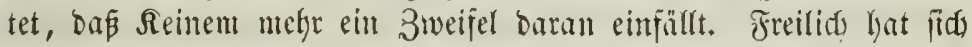

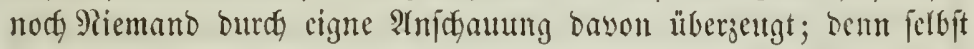

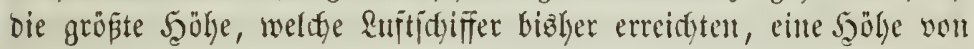

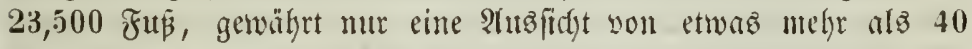

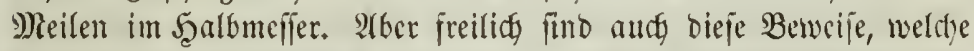

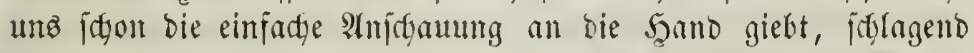

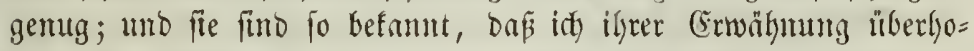
ben bin. Trobsem find früher von Beleften und Theologen gegen bie Rugelgeftalt ber (Erbe mtandhe, oft lädyerlidfe 3weifel erlyobent worben. Unter Anberm bielt man ç für undfrifttlidge Reşerei, an

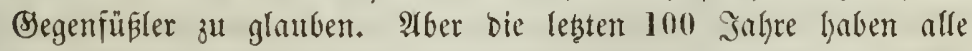
jene Edymady bes Borurtheils unt ber Berblendung wieber gut ge= madft. Denn man hat Edjarfinmu, Rräfte uno (jeld geopfert, um bie Frage nady ber Beidgaffentyeit uno Beitalt ber (Eroe ju beamt= worten, wie es faum irgento einem andern 3tweige ber Wifilenithaf= 


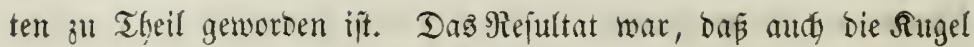
nidyt genall bie Geitalt ber (5roe jei. -

Um einen beitimmten Begriff non ber Sieftalt ber Sroe fu er= hatten, mus man Berge uno eändor fimwegbenfen, alfo für bie

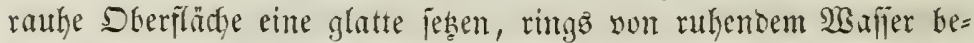
Defft. In Der That aber ift auch bie Majie felbit der mähtigften

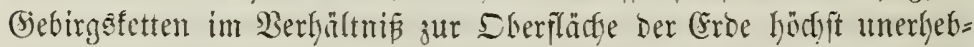

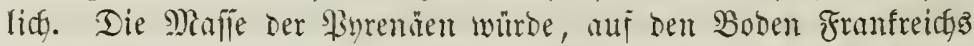
zerftreut, Das Ramb un um 108 Frus erhöhen, und die Siafie der

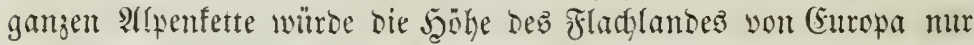
um 20 Fũ vermegren. Die Grflärung Der Erboberfläche, Dap fie

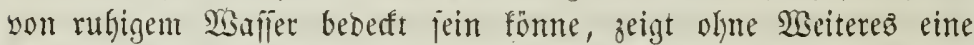
incjentlictge Eigenjdyaft Derfelben, Daßi nämlich alle Sräfte, bie auf fie wirfen, eine jentredgte Plidutung auj Die Sberflädse haben müjīen. Denu jeber nody io fleitre, nidht jenfrecht wirfente Dnuff würbe bie

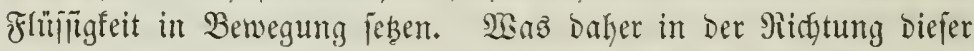

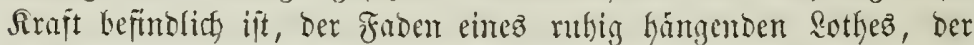

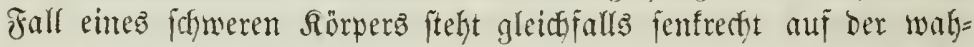
ren Srooberflätje. Reşteres, Der Fall cines Rörpers, giebt jogar

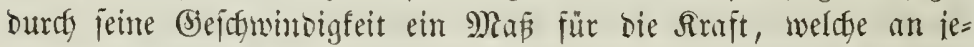
Dem Wumfte Der Erbe wirft. Eo offenbar Diefe Eigenidtaft ber Erd = oberflädge ijt, fo reidbaltig ift fie in ifyen Folgermngen. Eie ift

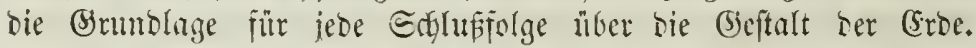

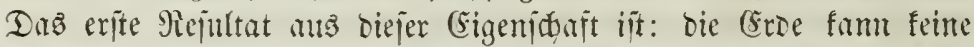

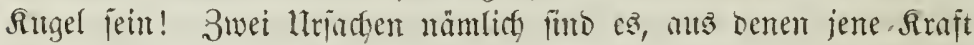

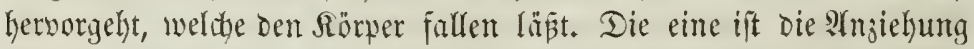
alfer Theilden Des gamber Erbförpers auf jeben Wunft ber Sber=

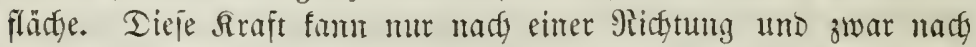
Dem Mittelyunft ber Croe hin wirfen. Die andore Urjadye ift bie Drehung Der Sroe um ifye 2tre, weldje jeoem \$utte Der Dber= flätbe jeine bejtimmte Bemegung entheilt. Dies ift biejelbe $\mathfrak{R}$ raft, die ein Rörper erlyält, wenn er an einem Faben jünell im Sreije Gerumberwegt wirs, und Darum nenut man fie Fliehfraft. Seber

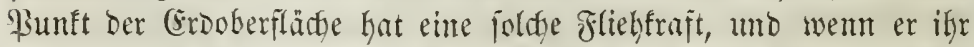

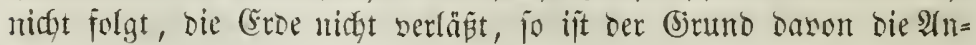

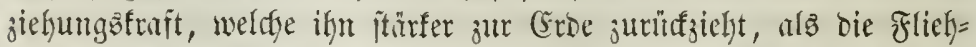
fraft ifn ju entjernen judbt. Dieje beiben Aråfte wirfen aljo in 


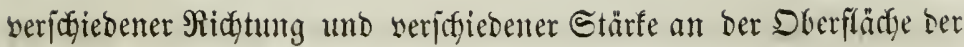

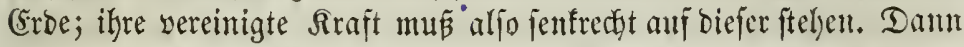

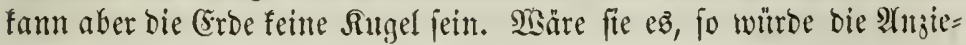
humgegfraft nady ifrem Mittelputnte, aljo an und fïr fids jenfredgt auf bie

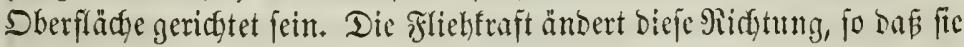
nicht mefre jenfred)t bie Sberffädhe treffen fann; baumit fie bies aber thute,

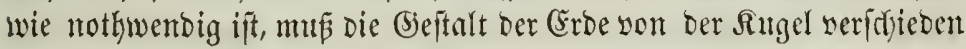
fein. Diejenige (Seftalt mun, auf Deren Dberflädye bie ganze Iruft jent=

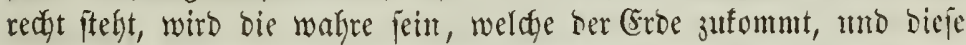

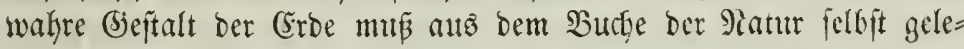

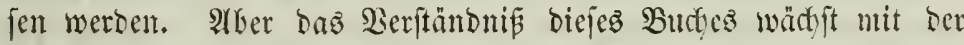

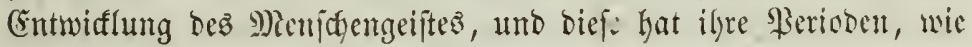
jebe Entwifflung. Sn ber erfiten fümmerte man fich um Das Buth noch nicht, man lernte geben unto trieb Rintberpiele. Die

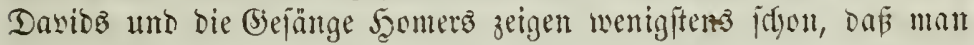
feine Budfitaben fannte, wemn man aud ben Eim einter 3ujam=

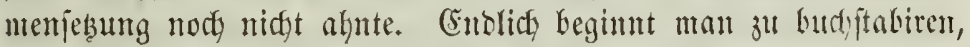

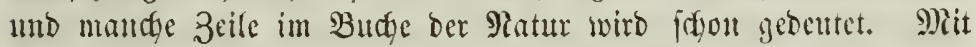
Penton beginut erfít bie \$eriobe bes Rejens; unto int ber futrent 3eit

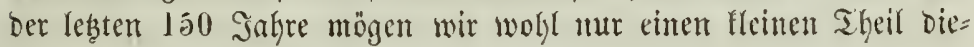

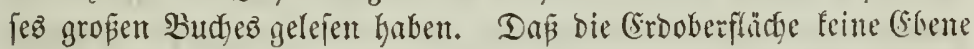

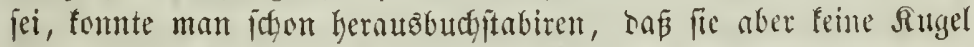

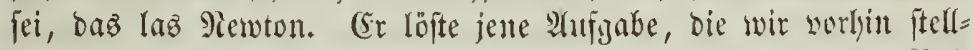
ten, zeigte, da sie Meribiane, s. h. Sinien, weldye von cinem Fole zum andern gesogen werben, nidgt Sreife, fondern Estiplen fein

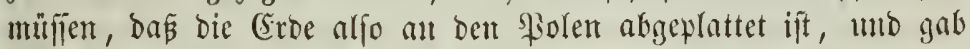

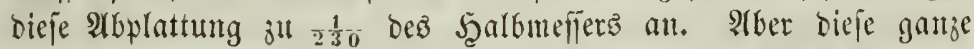

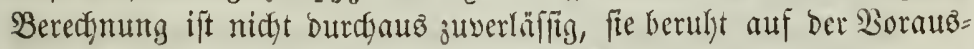

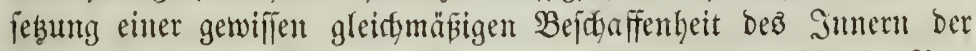
Eroe, bie man boch nidgt völlig fenut. Denn ungleidjpörmitge Ber= theilung ber Mafien wirb auth Middftung und Etärfe ber $\mathfrak{R}$ raft ver= ändern. WSill man aljo bie wahre Figur ber (srbe fentent lenten,

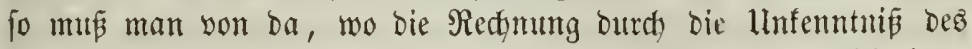
Snnern aufgehalten wiro, burdy bie Beobadytutg weiteridgreiten. Drei veridfiebne $\mathfrak{B s e g e ~ h a t ~ m a n ~ b i s ~ j e k ̧ t ~ g e f u t o e n , ~ a l f ~ w e l d e n t ~ m a n ~}$

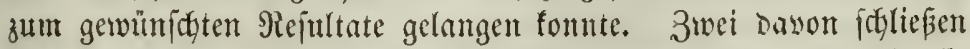
yon gemiffen beobadgteten $\mathfrak{B}$ crwegungen auf bic Siräfte, weldye fie 
erzentgen, mb won biejen ars anj bie llrjache berjelben, auf bie P(Gplattumy Der Crob; ber oritte geht grabenus burdy bie Meflung z" feinem Biele.

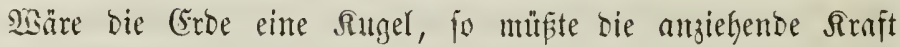
an jebem Sintte ber Erboberfläcte eine gleidye Srö̉e baben; ift fie aber an Den Polen alugeplattet, fo mird bieje Rruft unter bem Aequator am fleinften jein und nady ben Polen hin matfen. Die

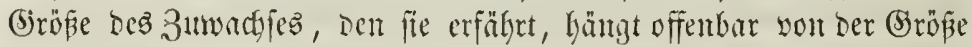

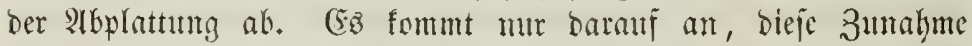

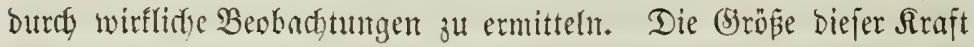
fam jwar grabezu burdh die Sgohje gemefien werben, weldhe ein jofwerer Sörper in einer beftimunten 3eit, 3. B. einer Eecunde, Durdf=

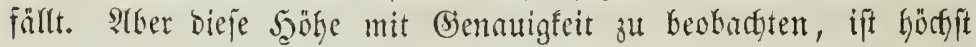
fotwierig, unt man lyat Dalyer eine anbere Ericteinnth bum biegen= ftand Der Bevbactung gewifhlt. Dieş ijt bie Rünge besjentigen

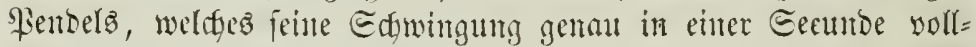
endet. Dent auts bas Siendel ift nur ein fallenter Rörper mo

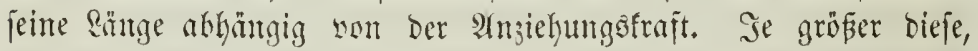

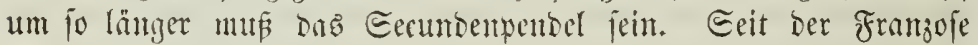
Ridyer im Salgre 1672 juerit bie Beobadytumg machte, baj er ju Enyente fein son Fariz mitgebradtes Eecundenpendel verfürzen muste, mo Damit bic iphäroibijage Beftalt der Sirde bewicz, finto jablloje Berjutbe mit ber allergrö̈tent Senaugfeit an ben entfernte= ften Siunften ber Erse angeftellt worben; umb nots immer fentent Engländer und Franjojen Eec=Expebitionen aus, um Fendelwerjudye anjujtellen. Der reidye Estab alfer diejer Beobadjungen hat unz bie Albplattung ber Erde alo $\frac{1}{8} \overline{8}$ fennen gelehrt.

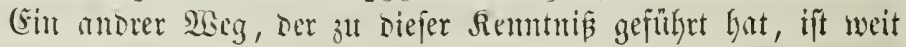
idfmieriger ju veriolgen; idf will ihn Daher mut antouten. WSie

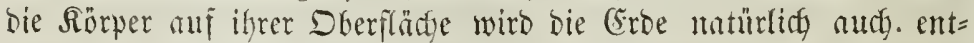
ferntere mit seridjiebner Sraft anjiehen minfen, je madjoem fie eine Sugel ift ober nidft. Dieje Berjoficontheit muß aber audy ilyen

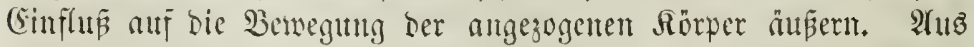

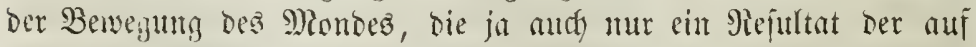

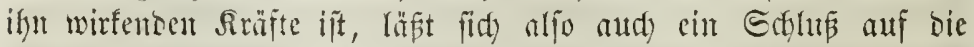
2loplattuny Der Eroe grünocn. Deun wir find im Etante, genau gu Keredtuen, weldye Bewegung Der MRond baben mifte, wenn bie 
Srbe eine volffommente Suget mitte. Zeigen fid bafjer linteriftede

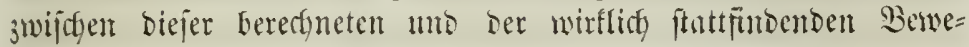
gung, jo beuten bicje anj febler in ber Borantsjetzung, welde eben Die ber Sitgelgeftalt war. Die (Sirïe Der llnteridfiede Deutet aber

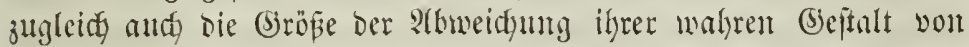

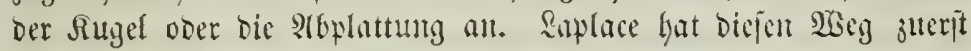

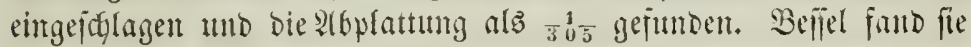
in nenerer Beit als $\frac{1}{2} \frac{1}{y}$. Fin Den, Der unbefant if mit Der gro=

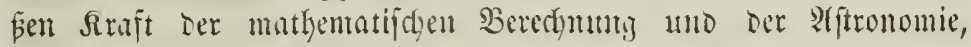
fant faum etwas Fuffallenderes gebadt werben, als bie Behaup= tung, Dâj ber Pfitronom bie Jigur Dor ganzen Croe bejtimmen föme, ohne jeine Etermwarte ju verlajien, Daj er fie Durd bie Beobach= tungen cines Saimmeloförperz bejtimme, weldger feime Epur von Der Abplattung Der (Erbe an fid) trïgt. F(ter Durd) bas ganje

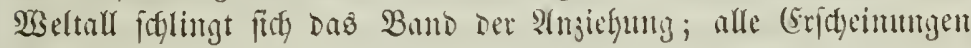

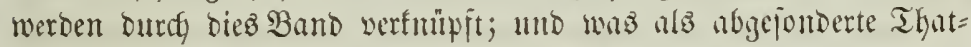
fache cridjeint, wird jelbjt in gröpter (Entfermun! burd) bie vour

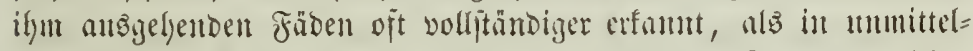

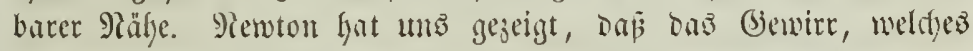

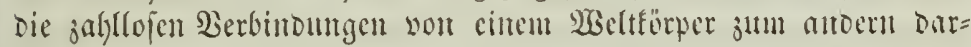
ftellen, burdy Berjulgumg eines fabens abyewidfelt werden fann. Diejer Faben ift Die matlyematijge Beredyntuty, jeine Abwidflung Die $\mathfrak{A}$ itronomie.

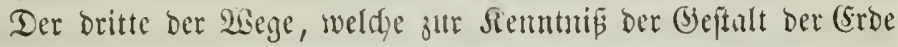
fillyten, ber grabeite von allen, geht von unmittelbaren s)) lejintugen

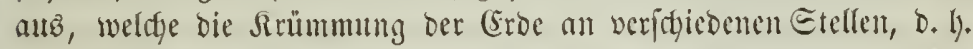

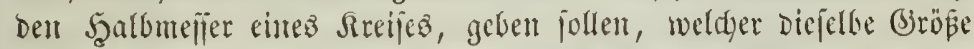
Der Sirunmung hat. Ienn wenn bie Mcridiune Ellipjen fint, to

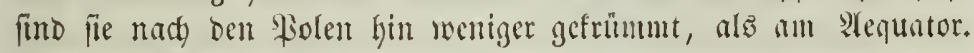
llm bieje Rrümmung zu finben, Darf man aber nut die \&ätge ei= neв Bogens, aljo nur die (Entfermung jweier Fintte beffelbent 9) ie= ribians meflen, um baun ben 2 sintel ju fentmen, weldyen bie von

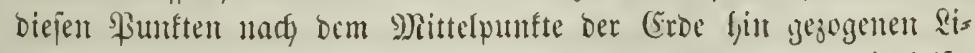
nien eiridblieben, ober was baflelbe ift, jll willen, Der wievielite Theil won cinem ganzen sreije biejer Bogen ijt. Diejen $\mathfrak{W}$ sinfel aber findet man, wenn man an beiden Drten bie Entfermung Des 3enitfy yom \$olarftern bcobadtet. Der lnteridyied biejer Entfer= 


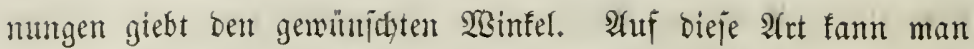

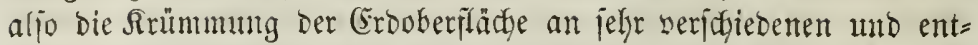
legenten Etellen mellen mo jo die Brö̈e oer âplattung beftimmen. Die erfe erjolgreidge Internehmung biejer $\mathfrak{A}$ th wurbe burdy einen

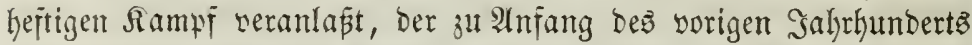
zwijhen den (Engländern und Franjojen liber bie Nhplattung ber

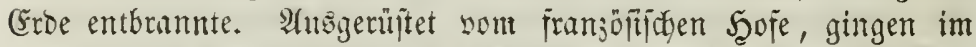
Jahre 1735 zwei zahlreidhe Gejellidgaften von aftronomen: Bou= guer, de la Conbamitte und Giobin nad \$eru, Maupertuiz, Clai= raut uno (Sclïus nach Eapplano. Die Bergleidyng Der Rejultate Diejer beiben linternefumm Erbe aus. Tiejer Erjoly reigte buld 2rndere, und nody nor bem Enbe bes Safrkunberts waren adgt anbere Girabmefinngen unter= nommen, welde, freilid nibt inmer mit ber nöthigen llmfidyt ge= leitet, of̣t zmeiountige Errolge gewährten.

3ur 3eit ber framjöriften Piendution trat aber ein ähnlidjes Unternelymen Kersor, weldes megen Der Männer, bie es leiteten (benn Borda ftand an Der Epike, Delambre und M)éctain, Biot und Arago nolführten die 2(rbeit), wegen bes Glanjes, wontit es Gervortrat, mo wegen jeiner mäheren Beranlajiung bejondere $\mathfrak{A} u \tilde{j}=$ unerffamfeit seroient. Mian benbirdytigte bie Meffung bon 121/2 (3ra=

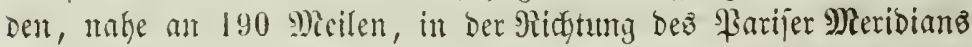
von Dïnfiriţen bis zormentera. Diejer grope Bogen follte in meh)= rere fleine getheilt und fü jeden bie אrummung bejonders beredunet werben. Ties grofartige linternchmen murbe fint cine Sationalan= gelegenteit ertlüt und jogar io Dargejtelft, als ginge es ron einem

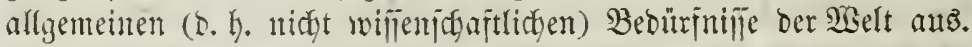
Die Revolution mar Pirinip geworben, fie mollte Reutes an ber

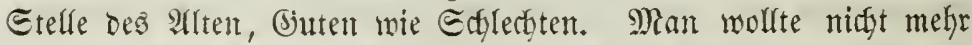

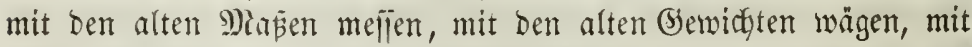
Dem alten Stelde zablen. Eine Sommififton won Belehrten alfer Ränoer wurbe niebergejest und biejer bie Netsolution affer Mafein= leiten übertagen. Dody Dantit bieje Aenberungen in Der ganzen Felt gelten fonnten, wollte man bas Mlä aus ber Natur jelbft

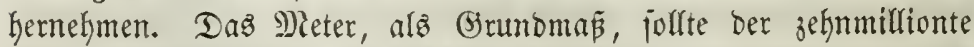
Theil Der Gutfermung yom Fequator bis zul Den \$olen Der Groe fein, und baran follte die Bejtimnung ber Flächenmaje und Be= 
widyte gefnitpft werden. Darum wolfte mant Durth jene neue gro $\hat{\beta}=$

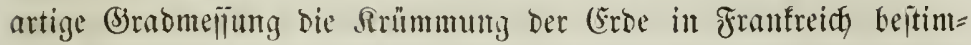
men und Daraus bie Entermung vom Hequator bis z"t ben Folen

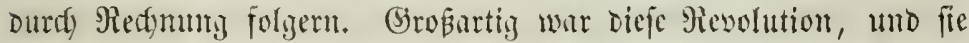
fand aud Cingany; aber ilyr Eyftem war anf fowadjent Grumbe

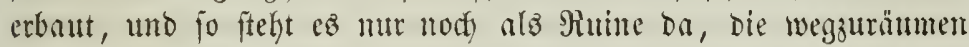

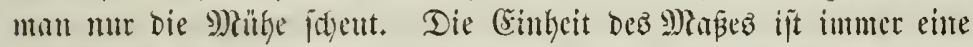
willfürlidge Ränge; wie man fie wählt, ift gleidggültig; mur muю man fie unveränderlid erfalten, damit man ju jeber Beit genau

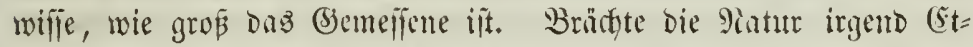
waz inmer in gentau gleidger finge hervor, fo wïroe man mifelyl=

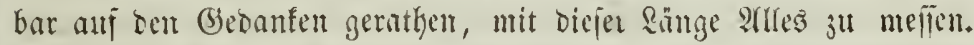

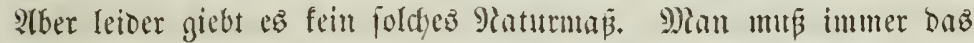
(bemeffene zum \$) lafe madhen. Das aber ift cint Jebler, Dor fid rädt. Bir fünten ja nidgts mefien, mur nîhern tönten wir แmz dem

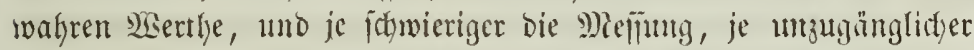
ilye (Biegenitand ift, Defto fiärfer treten bie llebel ifrer llnvolffont= menteit bervor. Das Meter fümute aber mur burdy bie afferweit=

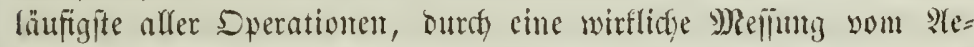

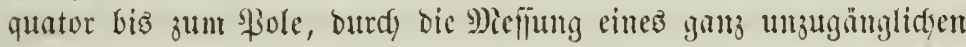
(Sicgenjtandez, burch eine linmöglidfeit gejunden merden. Demnds gab man jente Soee nicht anf und mollte fie burdy jene Giramei=

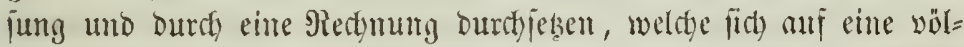

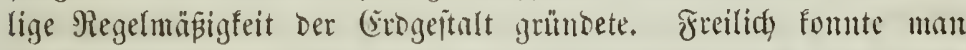

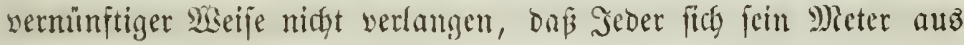
Der Dutelle jelbit bolen jolle, uno jo gab man bem Meter eine be= fitimmte Ränge, becretirte, dẩ ez 443,293 Rinien der Toije enthal= ten folle. Das war aljo bie ganje folge jener gropent Soee: ftatt

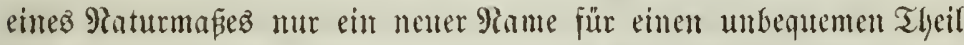

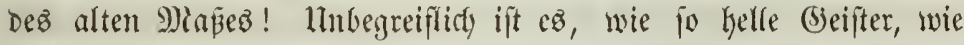
Borba und Eaplace, eine fo umitmige Soce verfecten fonnten, wenn fie nicht vielleidyt antore Sntereffen verfolgten, vielfeidgt mur jene

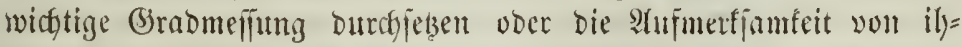
ren wiffenfafaftlidyen bejdäftigungen ablenfen wollten. Daun lan= bent fie ifren 3wed erreidjt, aber jene Soee einez Maturmakez, ei=

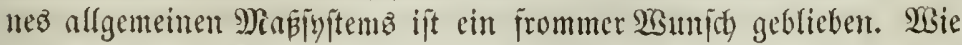
will man auth Bölfer im Meffen unt sBägen vereintigen, bie jelbit 
Durch die Eprache getrennt finto? Eehen wir ja bod, Daß̧ Bölfer,

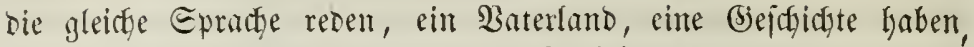

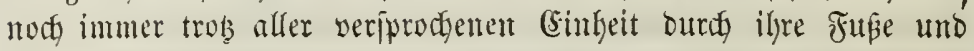

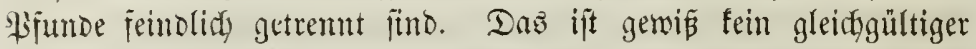

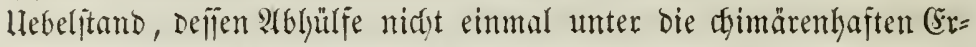

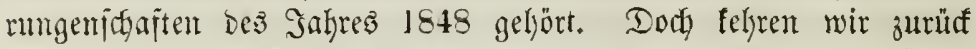
ju unjern Sirabmeflungen. Senes widhtige Internehmen ber fran=

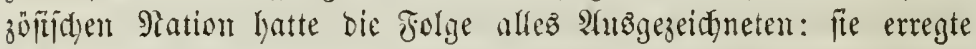
Eifer und Radyalymung. Su Ëngland mo Eçottlano füfrte mant eine älytlictye linterntefmung aln, in Frantreich eine von wepten nach Siten gehende Durify ganj Sheritalien biö jum abriatifaten Meere fortigejețte; in Ditindin folgte eine britte, in Dänemarf,

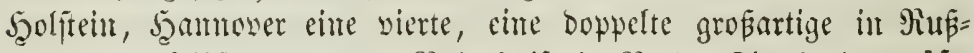

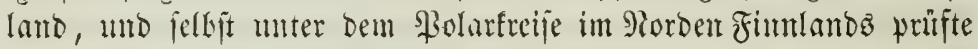

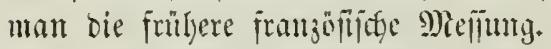

Das Endrejutat affer biejer Hnternefymungen war, baß fich feine regelmäfige Figur ber (Erbe angeben läßt, weldye allen jenen M) Mefintugen

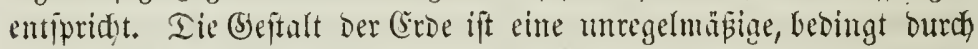

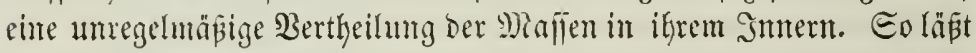
aljo alle Eorgfalt, bie gröpte Dervolffommmung Der J̧ülfïmittel nicht

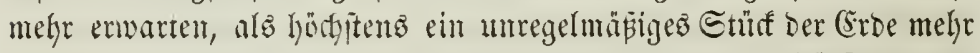

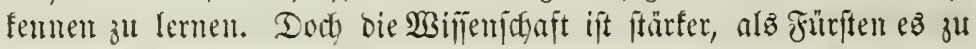

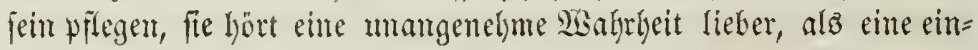

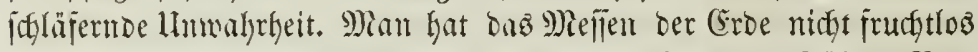
anfigegeben, im Eiegentheil für notbwentiger erfannt als früher. Bor= 3üglid) erfennt man bie Sicftigfeit ber Berbintoung Der vorkanbenen (5rabmefïmgen untereinander, mb bald wird man umunterbrodene

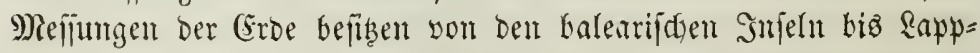
land und yom Torden Edyottlanbs bis mady Dalmatien. Das lebte (stied, weldyes nody in Der groben, fait ganz (Europa burdy=

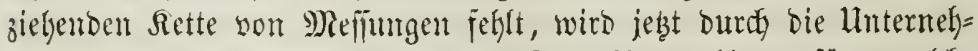

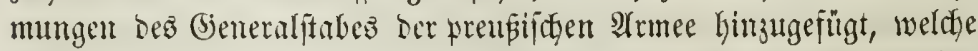

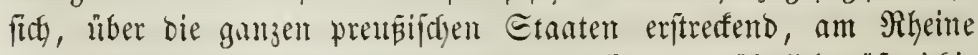

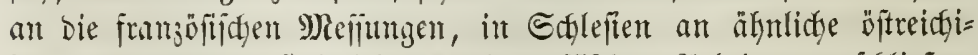

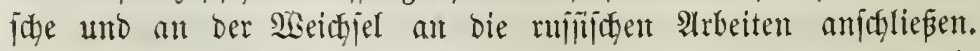
Man wirb mun endich überiehen fömen, meldye Bejdaffentheit bie Hurregelmäpigfeiten ber (jejtalt ber Groe lyaben, uno wie weit fie 


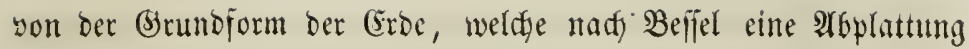
yon $\frac{1}{300}$ zu befilizent idfeint, abmeidyt.

Eime nähere Erörterung Dea ganzen Şerganga biejer widftigen

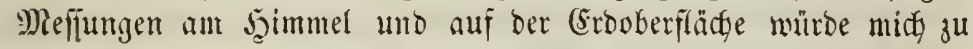
weit fülyen. Der irbifdje Theil biejer Sperationen ift rein geometri=

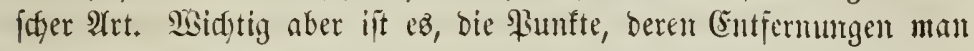

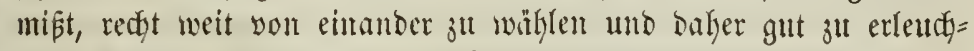

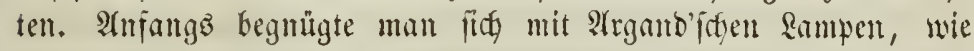
Fie auf Rendgtthürmens anyewand werben; Dann aber erfant (baup

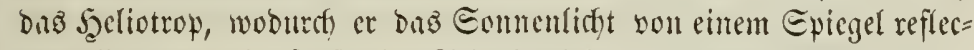

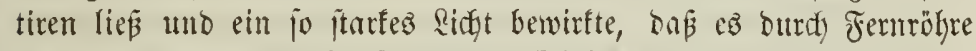

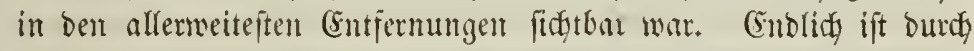

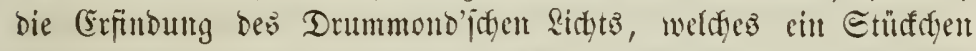

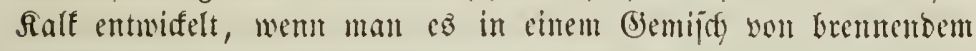

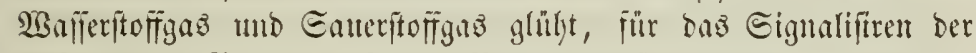
entferntepten \$iunfte auf bas Bollfommenfite gejorgt. Surz alle

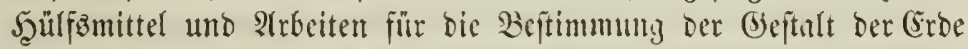
lafien faum nodg etwas zu wünjden übrig.

Whir haben bisher bie (Eroe jiemlidy ijolint betradtet, als ob

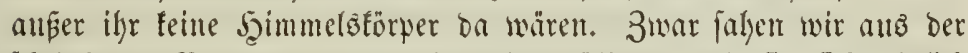

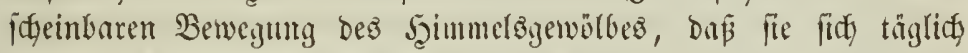

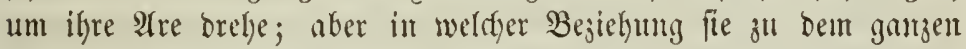

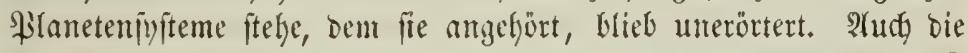
Eonne fahen woir täglidy mit bem ganjelt Sacete ber Sterne auf=

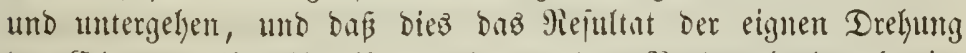

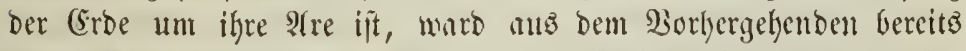
flar. Afoer fie behauptet nidgt, wie bie übrigen Eterne, unverän= bert ifren \$ilaģ am șimmel. Eie gelft täglidy an cinem anberm Drte auf uno unter, unto ifye Zeitbauer liber bem Szorizonte wird

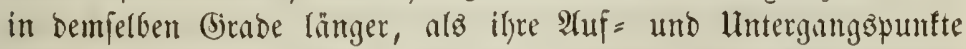

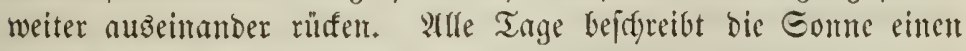
andern Sreiz am Şimmel, gleidy als lyabe fie nody auper ber Drelynug Des Şimmels eine eigne Berwegung. Eine fo widftige (Eridjeinung formte natürlidy idfon ben erften Beobadjtern bez Şim= mels nidgt entgelyen, unto man bemülyte fidy frith, den \&aul ber Sonne 3u beftimmen. Da bie Sonne aber alle Eterne in ifrer 9räbe er= hleidfen madft, ridjtete fidy bie atufmerfiamteit anf bic gegenüber= ule, Wettall. 3. 2tuf. 
fteghenton Eterne, weldye eben aufgehen, wenn bie Somte untergeht

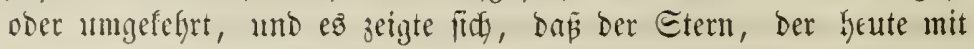
Eomenmutergang aujgeht, morgen bei Eonnemmtergang idyon bo: Ger ferht, währent ein andrer tiefer liegender aufgeht, ba ü übermorgen andy biejer fofon bei Eommentutergang höher fteht, furz baj bie Eomne fidd gleidfiam $\mathfrak{T} a g$ für $\mathfrak{T} a g$ gegen bie Eterne veripätet. Die eigne $\mathfrak{B}_{\text {ewegung }}$ der Eonne mukte baljer in einer ber Drelyung Dez

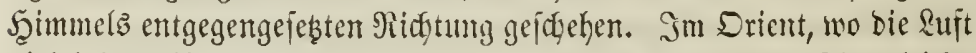

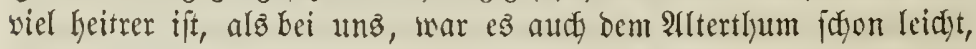
bie Eternbildor zu befitmmen, in neldyen bic Eonne naḑ uno nady auf = und unterging, D. Fo. Fich bejant. Die Rette biejer Stentil, Der, weldge bie Eome in cintem Sahre burdfläuft, Keip̄t ber Thier= freis oder 3obiafus. Die Drte ber Eonne jelbjt bilden einen Sireiz am Şimmel, bie CÉliptif. Der Thjerfreis jelbjt entthält 12 હtern= billber, unb besthalb hat man aud, bie Eefliptif in 12 Theile getheilt, weldyen man bie Zeidjen ber entiprectyenden Eternbilder gab und

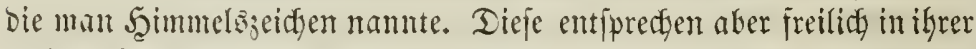
jeşigent Rage midjt melgr bent gleidgnamigen Eternbildern; Denl Srund werben wir ipäter fennen lernen. Shre Mamen und bie Mionats= tage, all weldyen bie Eomte unter biejenigen Eterne tritt, von be, rent (S)ruppe bas Zeidgen ben Rauten lyat, furto folgende: $\curlyvee$ Wibder

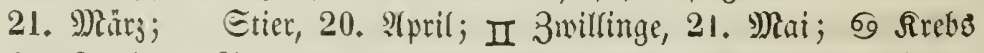

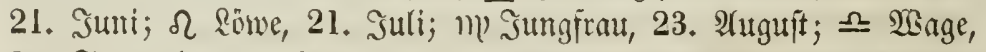
23. Eeptember; $m$ Ecorpion, 23. Oftober; $\neq$ Edjüze, 22. Novem= ber; 万 Eteinborf, 21. December; $\approx$ Siafifermaun, 20. Sanuar; x Fiijde, 18. Februar.

Die Eefliptif jelbjt ift gegen bie Esbene Des Aequators der Eroe

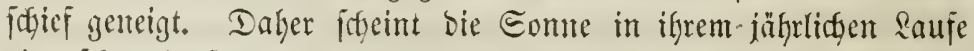

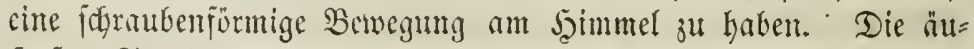

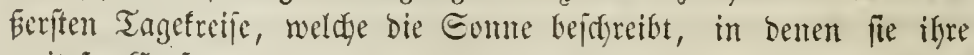

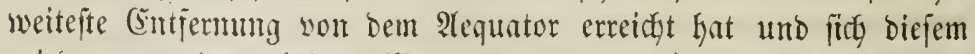

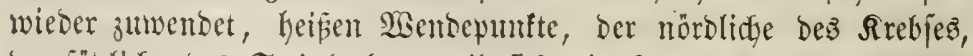
ber fintlidte tes Eteintoofz, weil firds bie Eoune bann gerabe in

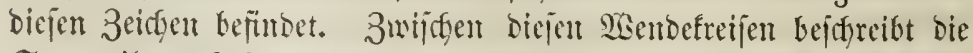

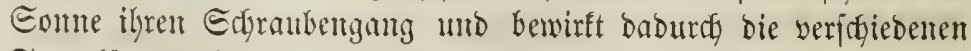

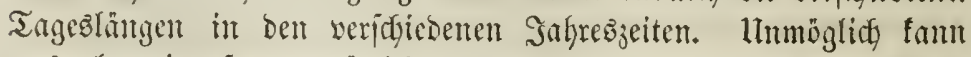
uns aber eine fo mmatintlidye Bemegung Der Eomne als bie wahre 
erifteinen, und wie wir bie Drehung ber J̧immelätuger in eine täg= lidge Arenbrehung ber (Erbe umbandelten, werben wir wolgl auds

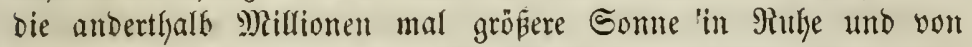
ber fleinen (Srbe umfreijen Iajjen fömmen. Die Eriducimungen blei= ben biejelbent. Alber anth gegen bieje Bewvegung ber Erbe hat man

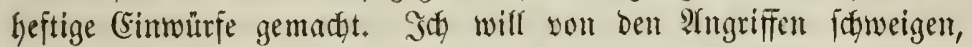
weldge religiöjer fanatismus gegent fie riçtete, will nidjt erwälynent, wie man Salilei Durby Serfer und Drohungen zwang, Den SIlauben an bie Berwegung ber (Erbe feierlid) abjuldwören, als föme man eine ewige Wakrkeit burdy einen (Sio vernidyten. Benng fei ed, hier Der wiflenfwajtlidsen Eimwïrfe zu gebenfen. Ciner ber eriten war bie Seldywinbigleit, weldhe nody bie ber Sioiation übertrifft. A(ther= bings berwegt fie fin in einer Eecumbe liber vier Meilen, einte (5)e= idywindigfeit, für bie wir auf Eroen feinen Sergleich laben. 2aber alfe Bejamindigfeit ift ja boch mur ein relativer Begriff. Wenn wir freilich ben (S)ang cines Weltförpers mit bem eimes Menjaen auf (Srben vergleidgen, bam ift jene Edynelligfeit ungeheuer. F(ber

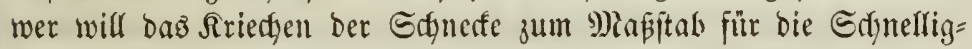
feit besె Bogelz nelymen? Melīen wir barum bie Bewegungen ber Şimmelätörper unter eimander uto mit iferer eignen (3rö̈ß̈e, bann verliert bie Borftellung von ifrer Befdywindigteit gar - viel von ifrem Wunberbaren.

Der bedenflidgite CEmwurf you allen, ben firb felbit Copernicus madyte, war ber, Daßj, ungeadhtet bic Erbe im Berlauf von fechs Monaten ifren Drt um mehr alß 41 9)illionen Mieilen verändert, Dennody bei ben Fixpternen feine periobifłe Drtäveränderung, feine Barallare wakngenommen wirb. Den Durchmeffer ber Erobalyn, 41 Millionen Meilen, gegen bie (Entformung Der Firfterme als et= maz Beridninbenbes, als einen \$untt im Weltall anzujelyen, bas fabien Bielen boch zu unglaublidy; licber wollte man bie jülyrlicte

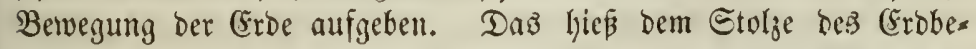

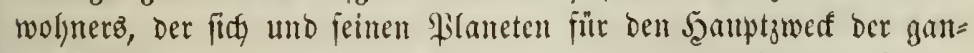

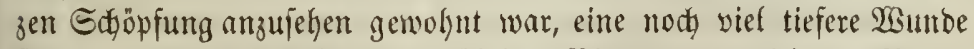
id)lagen, ala bie (Srbebung Der übrigen ßlancten zu gleid)em Range

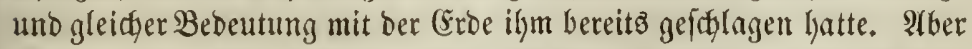
eв gab und gicbt bennod) immer Männer, weldse bie fejte lleber=

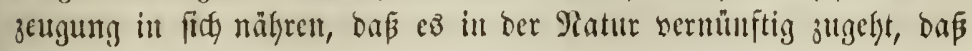




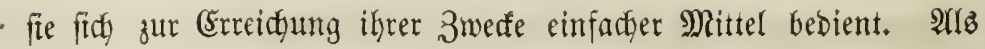

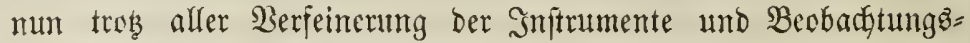
methoben fid nod immer feine Firfternparallare zeigen wollte, als man einsig bem Copenticaniften Eyfteme zu Riebe bie Eterne fifon mehr als 100,000 mal ferner alz bie Sonne annefment muste, ba entbectte ber Engländer Brabley eine anbre, allen Firfternen ge= meinjame Drtšveränderung, bie fein Edjarfiunn atı ber gemeinja= men Bewegung der (Eroe und Deş Ridets erflärte, und bieje (Ent=

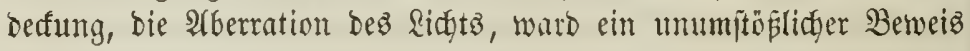
für bie jäfrlidge bemegung Der (Erobe. Brabley) bemertte nämlidf, Dás alle Eterne genau in einem Eroenjahre einen fleinen Sireiz am Seimmel bejdfrieben. Satürlidy fornte bies mur eine ficheinbare

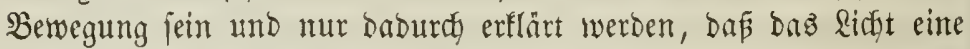

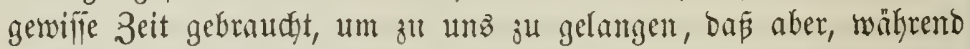

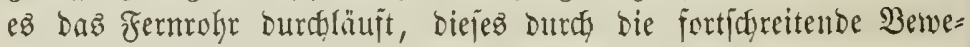

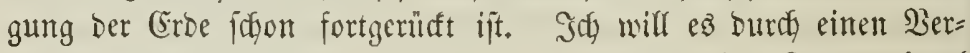

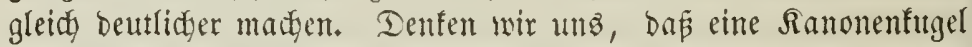
burch beite Eeiten eines Edjiffes joflage, fo wirb bie Rimie, weldye

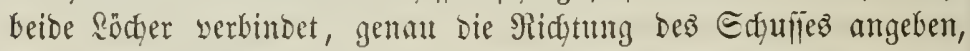

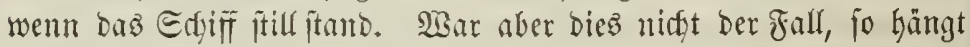

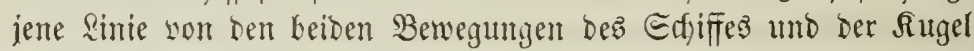

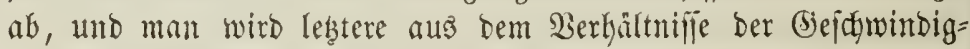
feiten beiser Bemegungen, ober umgetefrt, wenn man bie wahre

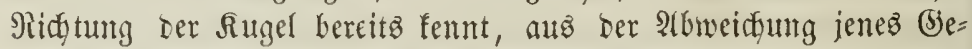

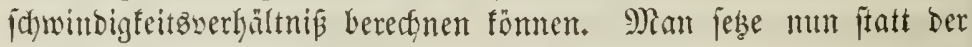
Ranonentugel baz Ridyt, ftatt ber Ectiffamuanto die beiben Bläjer

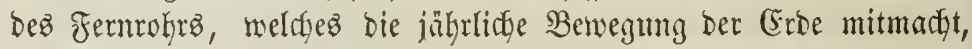

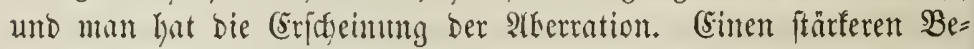
weis für bie jăfgrlicte Bewegung Der (Erbe als biefent fannte man

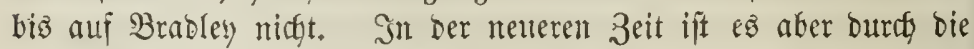
Entbefung von Jiriternparallaren gelungen, audy bie leşten 3weifel 子u bejeitigen. -

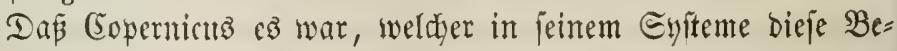
wegung ber (Eroe zur Bieltung bradjte und Damit Den munberlicfen

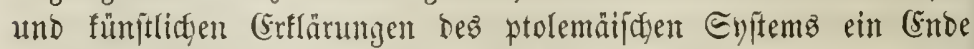

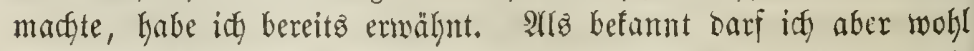

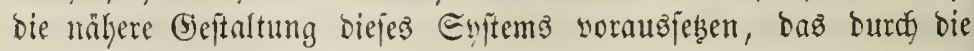




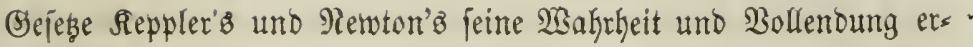
hielt.

Slidyt mindere Edwwierigfeiten verurjabyte bie Seitalt und Rage bie= jer Erobahn. (Sopernicus ertlïtte fre jür einen $\mathfrak{\Omega}$ reis. In biejem falle

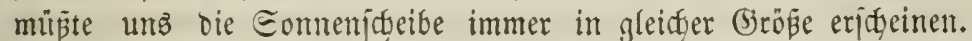
(Ein aujmerfjamer Beobadter aber bemertt, da je biejelbe ungleid,

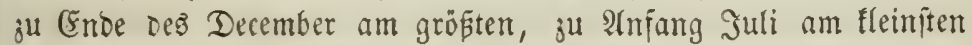
ift. Die Form Der Erobahn it baher eine (Ellipje, bie zwar wenig yom Sreife abmeidgt. Die Eonne fteht auth nidjt in ifyer Mitte, jonbern in einem iffer jogenannten Brennpuntte. Denn ftände jie in ifrer Mritte, jo müsten wir jälrlids jweimal bie Eonnen= jageibe in ifrem grö̈ten uno fleimiten Durdfmejer jehen. Sene bei= ben Buntte, in benen bic (Erbe Der Gonne am nädyiten und am ferniten fteht, nenmt man Sonnemähe (Peribelium) uno Eonmen= ferme (Aphelium). In exíterer fteft fie am 31. December oder 1. Gamuar, in leb̧terer am 1. Suli. Bollen mir aber bie Atnnahme biejer elfiptifigen (Sejtalt ber Grobahn gelten lajien, jo müjien mir fie aud in iffen llrjacten zu begreifen judben. Wir jaben vorher,

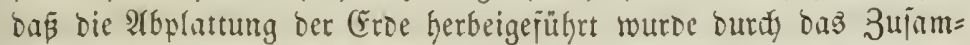

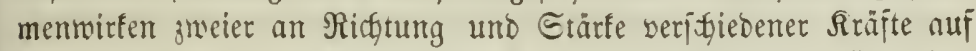

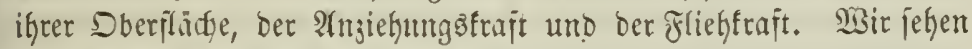
hier etwa Aehnliches. Die Erobe jteht zur Eonne in bemjelben Berbältniß̈, wie ber fallende Etein zur (̌roe. Aluty auj bie Gonne

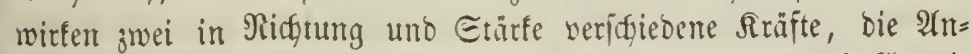
ziefungstrajt bes Mittelpunfts oder die (s)ravitation, auds Centri=

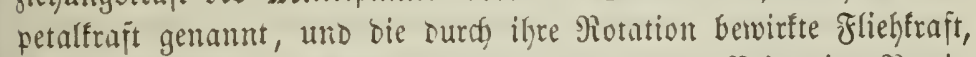
Tangentialfajp ooer Centrif̈ugalfnịt genumnt. Beide im Berein

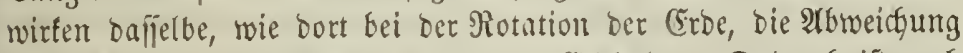
vom Sreije, bie elliptijde form Der Erobuhn. Daburch ijt audh die ungleidförmige Betwegung Der Erobe bedingt. Sn ber Eronăhe

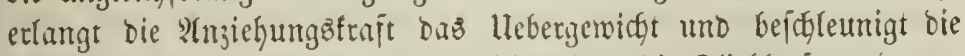
Bewegung, in ber Eonnenjerne liberwiegt bie Fliehfraft und ver= mindert bie Sejøroindigfeit. In einem allgemeineren Єinne werben wir dieje Erflärung fpăter fennen lernen. -

Die Ebene, in weldger Die Eroe ifren jäfrlidgen Sreislauf be= ichreibt, und welde ganz Der iđeinbaren Bahn ber Eonne am Şim= mel entipridyt, haben wir idyon vorfin als Efliptif bezeidynet. Sene 
içiefe Reigung Derjelten gegen ben Aequator, bie wir fđjon er= wïfnten, Gerulgt nun in ber idgejen Etellung ber (Eroare auf ber (sbene iffrer Bahn. Etånoc jie jenfrectyt auf Derjelben, fo müroe

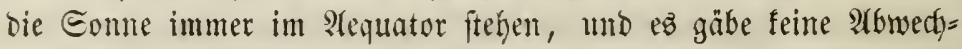
felung ber Sahreżzeiten, feine Beridjiebentyeit ber Tagezlängen auf Der Erdooberfläctse. Stber mur jweinal im Salhre fallen bie Eon= nenitrahlen jenfrecht auf sen Aequatur ber Erie, unb bann aller= bings fint alle Tage auf ber (sroe gleich) lang, uno überall herrifat Fribfling ober Şerbit. Dieje beibent Funfte ber Erobahn heipen Alequinoctien ooer Miadtgleidfen. Brwifden biejent \$isutten rilft mun bie Sinie, weldge jentredjt yon ben Eomenitruflen getroffen mirb,

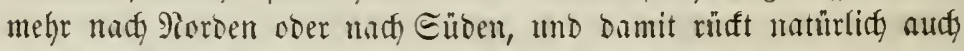

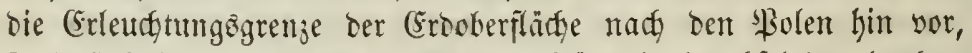
fo ba

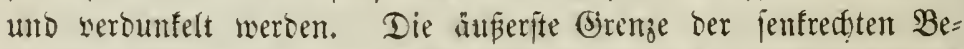

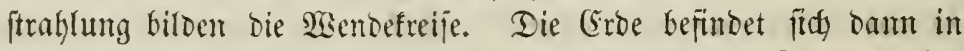
ifren Eomenwenden voer Eolfitien. Sm Eommeroolititium hat aljo bie nörolidge (Erohälfte ilyen Eommer, ihren hödjten Sonnen=

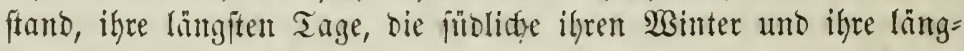

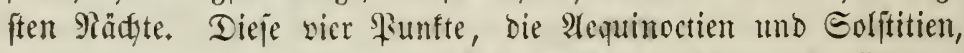

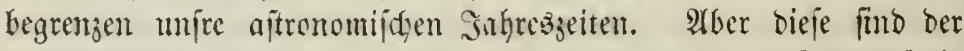

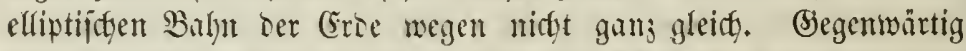
hat der 2 sinter der nörslidyen Şalbfugel \&9 Tage 1 Etunde, ber Frühfling 92 Tage 22 Etunden, Der Eommer 93 Targe 14 Ettut= Den, Der $\mathfrak{5 e r b i t} 89$ Tange 17 Etumben. Die Reigumg Der Ebbente

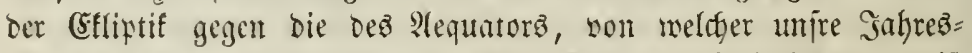
zeiten abgangen, uno bie man audy Edgieje ber Effliptif nemnt, ift

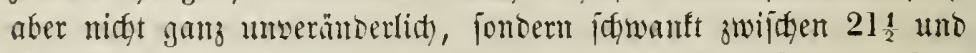

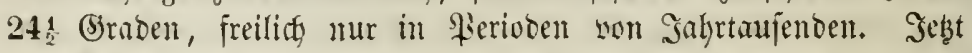

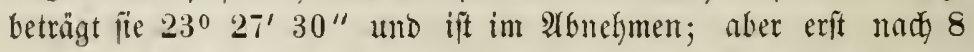

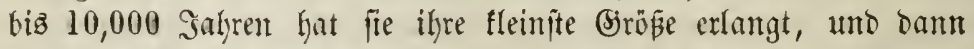
würoen unire Eommertage um 25 Minuten fürzer, unjre $\mathfrak{B}$ Sinter= tage um jo viel länger merben, bic Eonnenwärme fith aber hö dh= ftens um $\frac{1}{2}$ o vermintern, mas burdy eine gleiche $\mathfrak{B}$ erringerung ber WBinterfälte wieber erję̧t würde.

Sisie man nady ber Beleud)tung nod) jeb̧t bie Eroboberflädfe in bie befaunten 3onen eintheilt, fo wollte man fite früher grabesu 


\section{3}

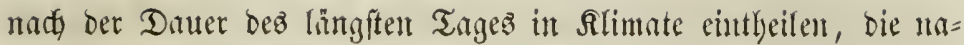
türlich für. gleidge 3unalymen ber Tage fefre ungleidy groß ausfallen müten. Denn wenn unter bem :Hequator Der lämgite Taig 12 Stutioen willyt, fo nimmt er erit bei $16^{\circ} 44^{\prime}$ geographijoger Breite um I Stunde ju, bei $30^{\circ} 48^{\prime}$ erft um 2 હtminom, bei $49^{\circ} 2^{\prime}$ bautert er aber figon 16 Etmben, bei $54^{0} 31^{\prime} 17$ Entutben, bei $63^{\circ} 23^{\prime}$ bamert er 20 Etunder, bei $64^{\circ} 50^{\prime}$ foron 21 Etmoen, bei $66^{\circ}{ }^{\circ} \mathrm{s} 2^{\prime}$ grade 24 Etumben, bei $67^{\circ} 23^{\prime}$ juon 1 Mronat, bei $73^{\circ} 40^{\prime} 3$ Montate, bei $83^{\circ} 5^{\prime} 5$ Monate. Dicje Rlimate aber entipredyest eben jo wentig als bie 3omen übernll ber witflidgen ffi=

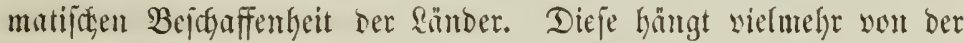
Bodengeftultumg, Der Form und Rage ber Riijten, bejonders nber von ber Säbe ïber Dem Meere ab. Int alligemeinen nimmt aller= bings bie mittlere Temperntur yom arequator gegen bie Pole zu ab;

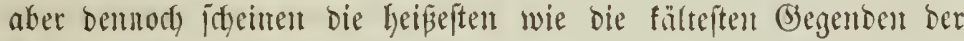
(5roe nahe an ben Birenjen der nörolidgen gemä̈igten 3 one ju judjen zu jein, lebtere in ber Eahara, jene im tiefen Smmern Sibiriens und in ben arftiçen Ranbitridyen Pordanerifus. Futy trifft bie $2(b=$

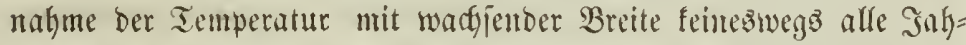

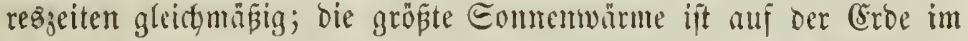
(Sanzen wenig veridyieden, ber hauptiäd)lidjife llnteriffied liegt in Der Datuer uno Etrenge deş $2 B$ Binters. -

Der eben betradgtete \&nuf umirer Eroe um bie Enmte geht

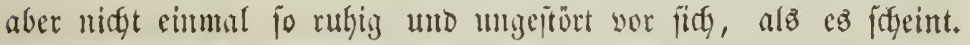
Er Gat vielmelgr mannigfadge Etörungen von allen Eeiten, von Eomre, Monto, ßlaneten und Someten, zu erleiben. Sh erwähnte

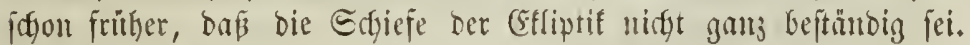

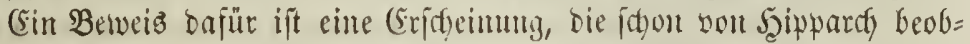
adytet wurbe, baz Borrilfen oder bie Friecifion Der Eternte genau in ber Ridgtung ber Brbbalyn. Was fant bie lirjadje bavon feit? Dffentar nidyt ein wirffidję Beneyen beş gejummten Seeres ber

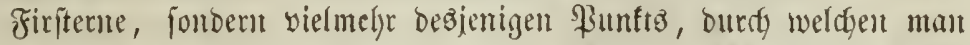

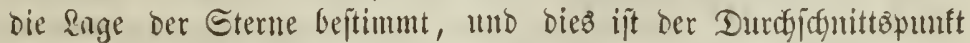

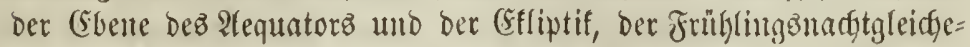
punft. 2Auz ber abgeplatteten Seftalt ber (Eroe folgt cine Maffen= antgäufung rings um ben A2equator kerum. Stegen bieje wiro baher 
bie Eonne eine ftärfere Anjiefyng äufent alo gegen bie Pole, und ba fie non ber Sfliptit aus mirtt, jo wiro ihre Ziehfraft fetz be= ftrebt jein, Den Aequator in bie Effiptif linein zu bringen. Dies

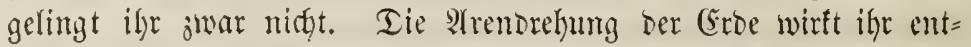

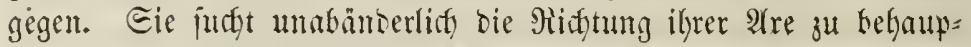

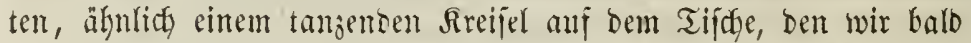
rach ber einen bald nach ber andern Geite neigen. Die lumbrefung

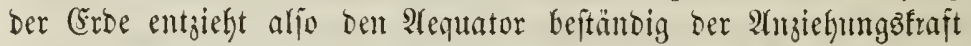

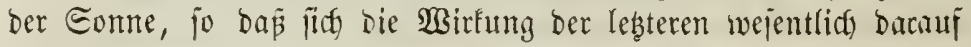

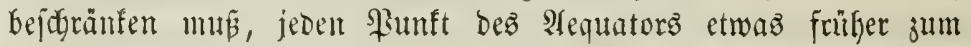

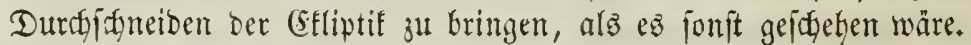

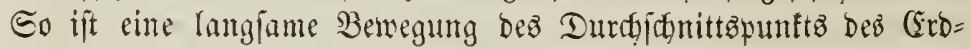
ăquators mit ber (sbene ber CEfliptif in einer ber Umberbung ent=

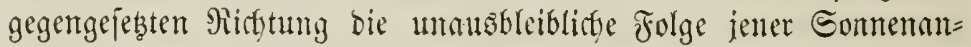

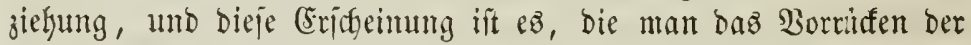
Radtgleidyen nennt. Nllerbings änoent fï babei jugleich aud bie Edfiefe der Efliptif etwas. Sie wiro aljährlid wectfelshmeije in Den Eolfititien berringert, in ben $\mathfrak{A}$ equinoetien vergrößert, uno nimmt im Sanzen jeit ben lebeten 2000 Sahrent af. P(ud ber Mrond übt

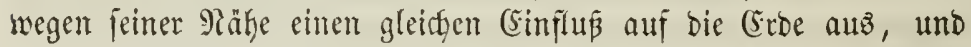

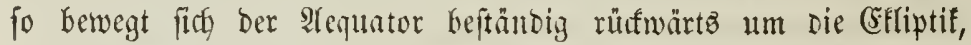

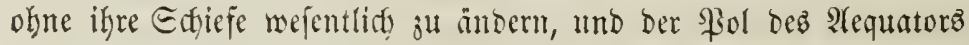

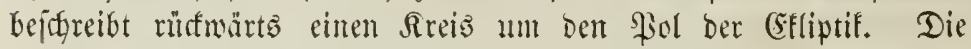
Bräcefinon ber Madjtgleidfen bedar jul ifrer Bollenbung burdh bent ganzen Sacis Der Cffliptif eines Zeitraums non 2600 Snhren; bie Edwantungen ber Edjefe Dir CEliptif jwifhen $21_{2}^{1}{ }^{0}$ und $24 \frac{1}{2}^{0}$ hängen fogar son \$erioben ab, Deren eitte 92,930 Sahre, bie anbre 40,350 Jafire betriigt.

Eine fleimere Periobe biejer Prt rührt von Der Beränberlidgfeit ber Neigung ber Monbbakn gergen bie (Efliptif Ker. Denn bieje kat natürfich auth cine verănoerlidge Reigung ber Monbbahn gegen ben Aequator jur Folge und bamit eine $\mathfrak{A b}=$ und 3unafme bez $\mathfrak{A} n=$

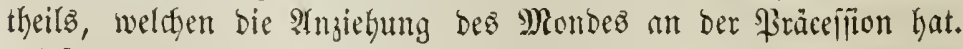

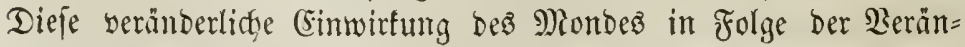
berliçfeit ber Neigung feiner Bałnn gegen Den Groảquator wirb Nutation, D. F. Wonten Der Erbare, genannt und if an eine $\mathbb{B}_{e}=$ riobe von $18 \frac{2}{3}$ Sahren getnupft. Die 2rnjiefungen, weldhe bie \$lla= 
neten uno Someten auf bie Erob bewirfen, fint gleidfälls mit ei= ner Aenterung ber Edfiefe der Effliptif verbunben. In Folge aller biefer Cimwirfungen ift bie Exticfe ber Effliptif 30,000 Sahre vor

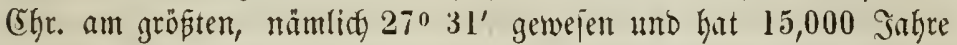
v. (Shr. ifren fleiniten $\mathfrak{B}$ erth von $21^{\circ} 20^{\prime}$ erreidyt. Eeitbem nahm fie wieber zu biz 2000 v. Eghr., wo fie bie (Gröpe von $23^{\circ} 53^{\prime}$ batte, und rimnt mun wieber ab, bis fie $6000 \mathrm{n}$. EGr. ifren flcin= ften $2 B e r t h$ von $22^{\circ} \quad 55^{\prime}$ erhalten wirb. Diefe \$erioben find aljo fämmtlich jefre gró men äußerfit flein, faum um $7^{0}$ von cinamber veridjieben. Da aber yon ber Edjiefe ber (Efliptif mire Sahreszeiten abjäıgen, fo gab ez wohl Zeiten, und fie werben im Raufe ber Sahtatajente wicber=

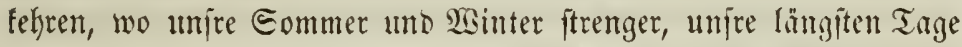
uno Räđțte länger waren, als jeb̧t. 2(ber ber linteriftico fonnte

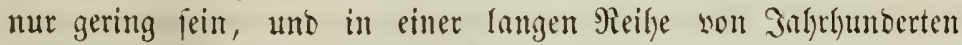
werben fird bie Safrezijeiten im Althgemeinen eben fo regetmäfig fol=

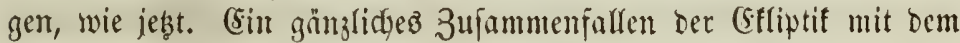
Aequator aber, wie Mandjer fo gern idfliépen möd)te, wirb nie ein=

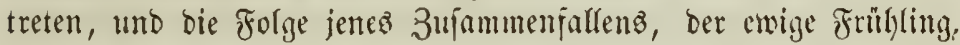
ift ber (Erbe eben fo fern, als ber emige Friebe.

Eine andere Etörung in bem regelmäpigen Raupe ber Erthe

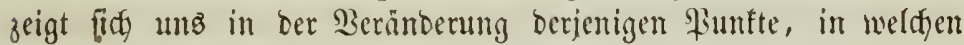

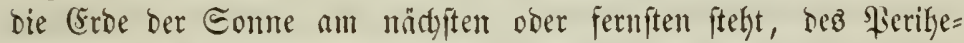
liums und atpheliums. Dffenbar ift bie llrjadge bavon bie Berrin= gerung ber Bravitation ber Eroe zutr Eomue und bamit ifrer (B)e=

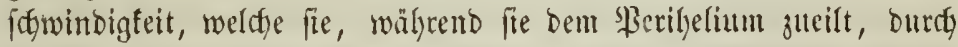

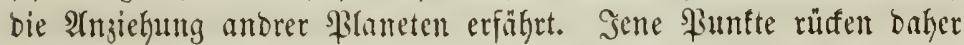
burch bie gange Bafn ber (srbe fort und vollenden ifgen (5yclus in 110,000 Galyen. Wäre bie Beftalt ber (Erbe melyr elliptijó, weniger freisförmig, fo würbe aแz biejen Störungen allerbingz ein merflider Cinfluß auf die Temperatur ber (Erbe herworgehen. So

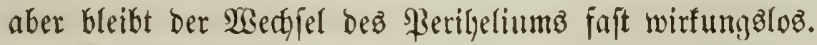

Aebnlidge Störungen, wie biefe, erleiben natürlidy audy alle übrigen Planeten in ifrer Bafnbemegung.

atber eB find feine Etörungen in Der Dromung Der Patur, in Der Einfadbeit und Enigfeit ihrer Brejeze, bie jie vielmegr auf

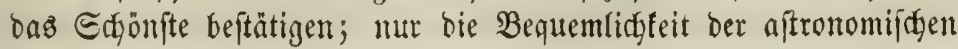




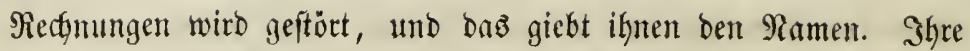
ungebeuer langen \$iserioben, bie faft immer niber bie Kiftorifdye Dauer

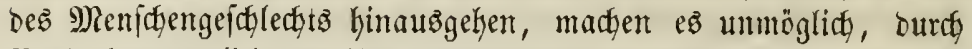
Beofactung allein zut ifrer Beftimmung zu gelangen. Seier rettet affein bie Theorie, unb boch führent bie feinften uno fdarfinturigften

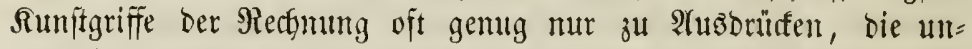

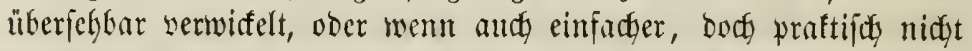
anventbar futb, weil fie bie Exhwierigteit nidgt heben, fontoent auf cin anbres unerreictgares zelo Gimüberipielen. Eritaunlict) siel hat swar bie Begemwart geleiftet, aber unendlids viel meffr ift ber $3 \mathfrak{U}=$ funft aufgefoben. SBor allen Dingen mü bie Beobadtung ber

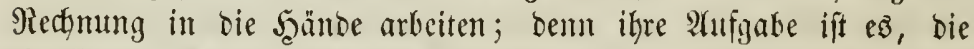
Mafien ber \$laneten ficterer tennen zu lehren alz die bizherigen Ingaben, weldye Srrthümer zuließen, bie beim Merfur fogar bie Şälfte feiner Mafife erreidften. Dam erft werbent wir eine flare Einfictst in bie Bebeutfamfeit bicjer Etöruntgen nuth für ftelyen unirer iroijcten $\mathfrak{B}$ of

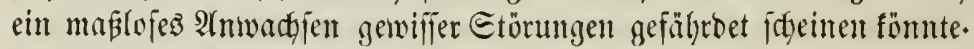
(5s fönte ja bie (Erbe in igrem Saufe einem ihrer riepentgaftem (Beifdiwifter entgegengeführt uno im 3 ujammenfito je jetrümmert wer= ben. CEs fümten jelbit nur bie (Slemente ber Balynen fo verändert werben, ¿a

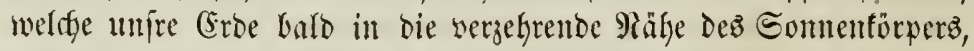

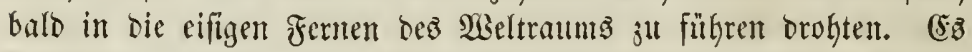
fömte entlich unfrer (Erbe bas twiberfahren, was Ente an feitem

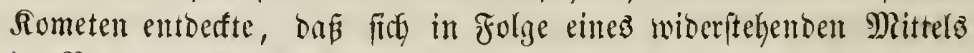
im Raum bie Bahn fpiralförming serengte, um enblich bie Errbe im Sdyooke ber Sonne veridgwinden zu lafien, wie bie Milufe inmer

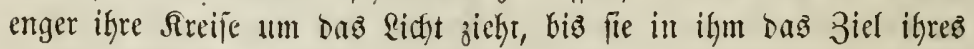
Eehnens, Den Tod finbet. Marg oer Beitpunft fortser Rataftrophen audf noch jo viele Taujente unto Mitlionen vont Saljen entfernt jein; Des Menjiften beiff gehört ber 3ufunft an, jein Didgten und

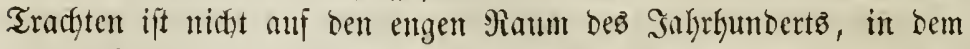
er mit foinen 3eitgenofien lebt, bejobänft. Demu er lebt nicht ficth,

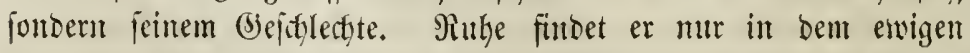

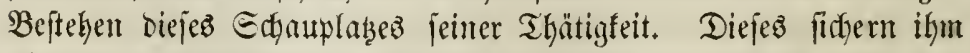

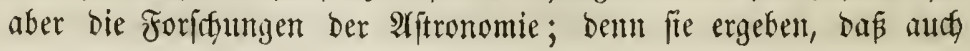




\section{7}

unter bem Einflü aller biejer Anziehungen bas widytigfte Element aller ßlantetenbalynen, ifge mittlere Entfermung bon ber Eonne, un= veränbert bleibt. Das ift einez jener ewigen, dem bejarïntten Ber= ftande unbegreiffictent (Sejebe, Durch weldye bie Ratur bie Etürme

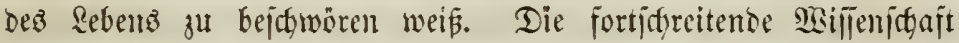
wirb immer megr alle bieje Etorungen nls bie mejentliden Blieber ber allgemeinen siseltoromung nadweijen. Edgon jebt werben fie

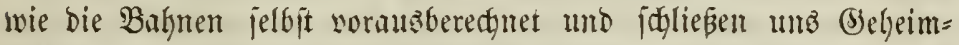
nifie auf, bie ohne fie envig veridglofien blieben. Eie führten zu ber

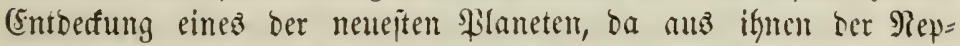
tun, nody elge feine Exiftens geabut ward, auf bas Gienauefte nact feiner Bafn, jeiner (Entfernung, jeiner s, Rajpe berednet worten ift.

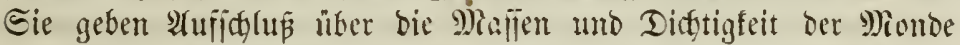
und ser monolojen \$lancten, bie Durds bieje Etönmyen ifre Birt= jamteit befumben. Eie lajien unz jelbjt bie Edfmertrajt an ber Sterfläche biejer Rörpermajien berertynen und baburdy Edylijje auj

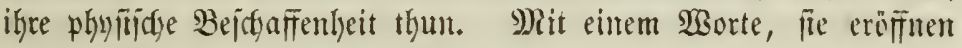
umjerm Bliafe tie Tiejen her Edopprung.

2lber wie tief aud bieje Blife eingedrungen fein migen in bie

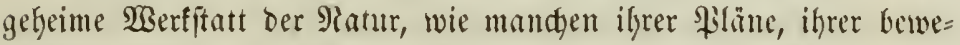
genden Szebel und treibenten Fräfte wir and expälyt Gaben, nod) immer ift uns gar Bielez buntel und unbegreiflid geblieben. WBir jaken Bewegurgen, fomten Etörungen uno lunregelmïfigfeiten beob= adten unb mejen, aber bie lurjadye blieb uns in Räthjel gehült. 2An ber Rojung Diejer Rätbjel arbeitet bie Wifienjoaft nod fort, fie

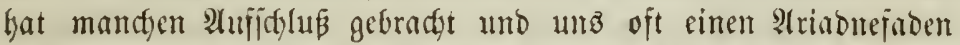

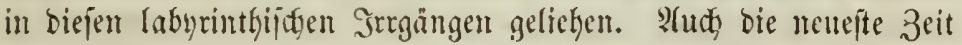
hat wieber eimen joldben faben gejponnen, ber freilidg nods feincr Absifflung bebari. Das ijt bie Entbectung ber eignen fortid)rei= tenten Berwegung ber Eonne mit ifrem ganzen Enjteme fernfin Durdb ben weiten f̧immelögarten, gezogen yon einter fernen unbe=

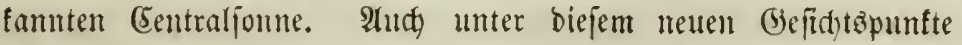

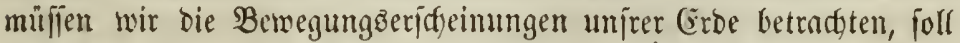

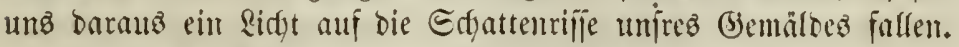

Durdy die Erjatgrungen und Beobadtungen ber Salyrgunderte

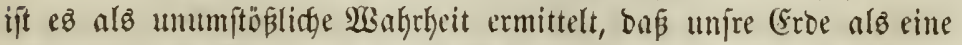

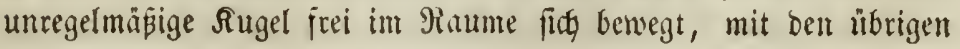




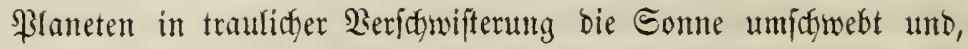
menn baz Edjanjpiel yollendet, ez yon Mieuem beginnt, ihre Etel=

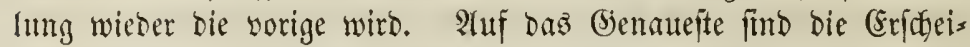
mungen beobadtet, auj bas Benautefte burdf bie (Erfahrung voraus= gejagt, wie bie gegenfeitige Stellung ber \$ilaneten in jebem 2 (ugen= bliffe ift und fein mird. Afre bieje Erjofyeimungen musten aber er= flärt und nady ben (Erjahrungen in ein Eyjtem gefaßst, bie Mrjache mußte erfannt werben, wodurdy fie ihre Berwegungen erhalten. Das

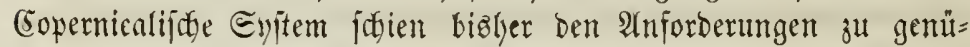
gen; aber freilich haben fidg bieje mit bem Fortjdreiten ber 2 Biffen=

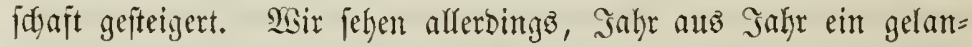
gen wir immer wieber auf benfelben \$Hunft, von bem wir aügin= gen; bas ift eine Thatjacte, bie uns ber ganze Eternentimmel be=

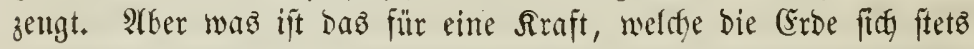
wieber um bie Conne bemegen läpt, ftetz mit berjerben Beifdrwin= bigfeit, ftets in ierejelben Zeit, jene Sraft, bie fidt felbit gebiert und

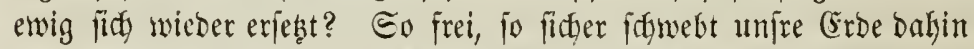

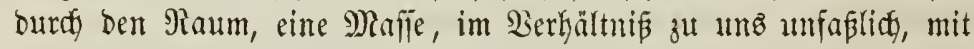

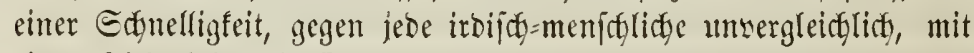
einer Eictertycit, wie fie feine Befaht ahnen läpt!

(Sine Şupotkefe mur fonnte bieje Eridgeinung enflären; ein

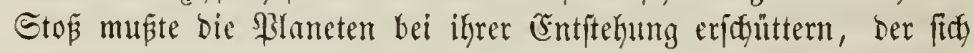
ftetō neu erję̧t, umb ba bie Anjiehung ber Sonne lim verfefrten

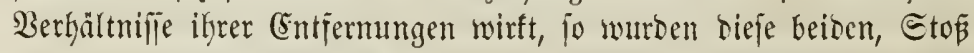

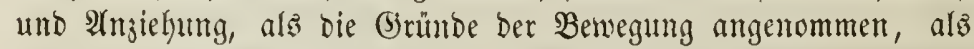

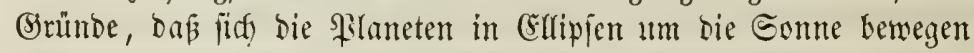
müffen: zmei Grïnde, von Denen Der eine eine fünftlifye Rraft yor=

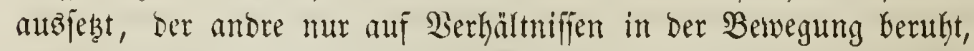

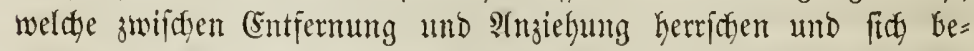

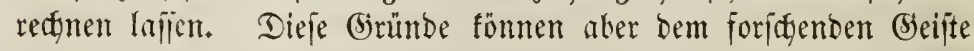
feine Edyranten ieģen, Der überull jonjt mur mit bem Unendlidfen

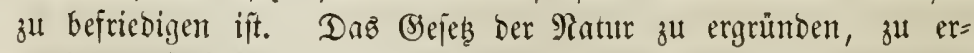

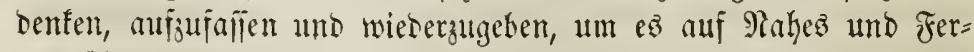

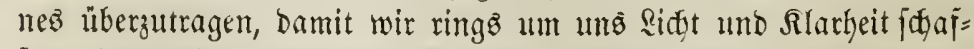
Fen, Das miro immer bie Alufgabe ber Menjdykeit Gleiben. Diez

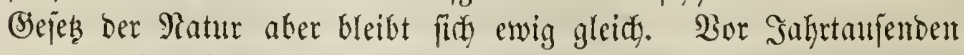
war ez jo swie heut, biejelben ltrjachen bringen biejelben folgen 


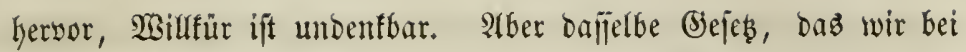
unz auf Errben erfenmen, verpfilanjen mir audy auf bie Sterne und überall, wokin unjer 2 tuge auch nur zu reidgen vermug. (Sin Bese=

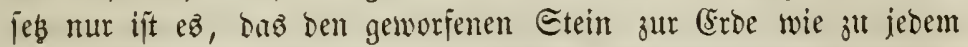

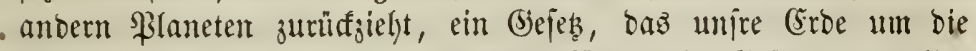

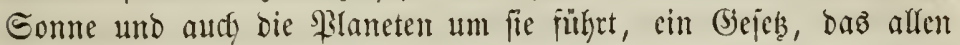
Flaneten ihre Rugelgeitalt gab, oaż jebem cinen Dunjttreiz idjuf, jebem Reben unto 2 actathum gemïfrte. Sin Befects waltet im gan=

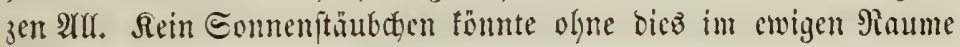

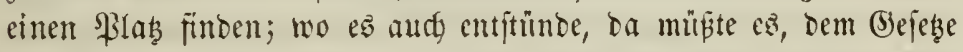
unterworjen, jaffen Dortfin, won wo es angesogent würde. Stber wie vereinigen wir bie \$iannigfaltigfeit ber (Eridgeinumgen mit ber

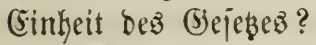

Allez, was auf unjerer (Erobe frei unb lebloz wirb, das jieft bie (Erbe an fird; was aber angezogen wirb, bas fällt. Dartm ijt bie Anziefungäfraft bie Edyopferin ber Bewegung, wie auf Der (Erbe, fo aud auf ben झlaneten, auj ber Eome, auf ben Firiternen unto im ganzen $\mathfrak{S e l t r a u m e . ~}$ Ifer wo ift jener mädjtige $\mathfrak{A}$ tm, ber unz unb alle \$laneten in einer Entfermung von Millionen Mcilen ewig, ohne fie zu berinfren, treu in berjetben Bafn gerumpührt? $\mathfrak{B}_{0}$ ruft jene Rrajt, bie joldfe Malien in ihrem Falfe erbillt? Die

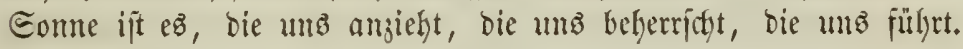
Dods nie gelangen wir zu igr. Saftraujende freijen mir, uno immer fommen wir wieber in bie voriährige Entfermung, wir niffern

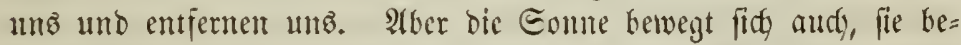
wegt fidy in einer ber unjrigen äfnlidfen Bafn. Wasaz bewegt benn fie? non weldgem Rörper wirb fie angezogen zu fo jdunellem \&aufe? Römen wir hier nod) Beobadtungen, Eridgeinungen uno Ratur= gejes vereinigen? Dann muß andf bie Conne angejogen werben yon einem $\Re$ örper, ber fie zu beherrfdyen vermag. Cie fällt mit unz unb wir um fie herum, fie zieft unz an uno fenbet unz sor=

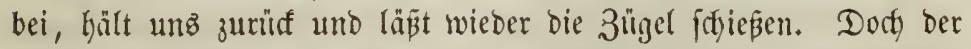
ganze Eternentimmel? Est iftwebt uno wantert andy, bie Eterne fajwinden uno fommen wieber, fie bemegen fich mit uns, burd cine

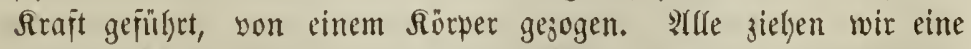

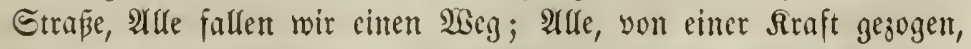
bewegen wir uns, jeber in ber Entjermung, bie bas bejeję ihm vor= 


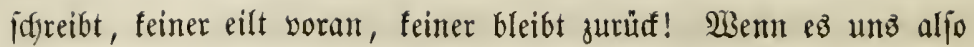

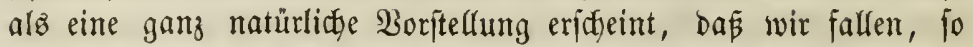

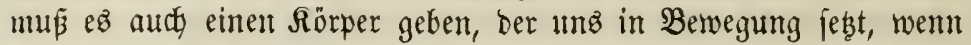
wir ifg audy nody nidgt gejeken haben. Dem eine anbere Ulijadye würbe ummatürlidy fein. Wisem audy Erobe, Eomme uno \$laneten.

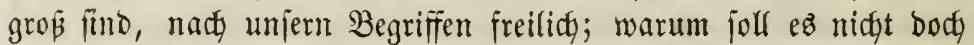
nod) einen אörper geben, ber audf bieje Mtafien gleidy Etaub an= zujielyen im Stande wäre? Co weit fönnen wir immerbin unire Fibantafie ungezügelt jpielen lafien; wir haben nod lange nidgt ge= mug erfannt, wie flein wir fïnb! - Ntber wie fönnen wir auf eben fo natürlidfe $\mathfrak{B}$ Beije bie Eridfeinungen, bie wir am Seimmel mahr= nehmen, mit jener Mrjađje vereinigen? WBir wollen eв verjudyen, unz einmal mitten in biejen allgemeinen Fall ber 2 Belten bintein= zubenten! -

Wir Arfe, Eonne und Eteme werben aljo yon einem unbe= fannten Rörper ober Edywerpunft angezogen, ben wir natürlid in

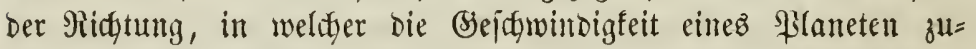

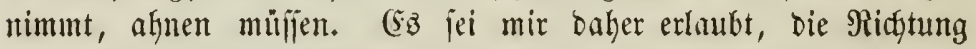
nad) biejem fiumfte hin, nady weldyem aljo audd unjer $\mathfrak{B e g}$ ge= ridstet ift, unterbalb, ben entgegengeję̧ten oberhalb zu nennen. Die

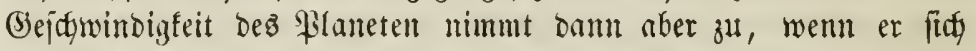
oberhalb der Eome befindet, benn bann wirfen beibe, Sonne uno Sentralionne, wie wir jenen unbefaunten $\Re$ ïrper nennen mögen, zugleidy anziegento auf ifn. Dies geiffieft bei ber Erobe zur 3eit

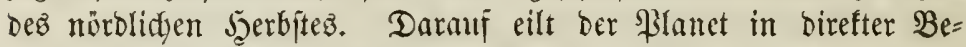

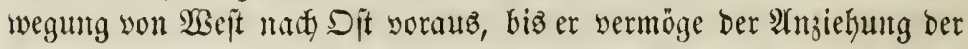
Somte angehalten wird und feine bejdjwindigfeit verringert. $\mathfrak{B e n n}$ er mun. zu 2tnfang bes Eonmers awijdent bie Eonne und bie Cen= tralionne tritt, zur Zeit Der grö́pten Entfernung von ber Sonne, To ift jeine Bejegwindigteit bie fleinjte, benn bie Sonne jteht über ifm uno wirft ber (Eentraljonte feindlidy entgegen. Atber ber \$la net idfreitet weiter yor, jeine Bejejywindigfeit wädyft wieber, bie Sonne

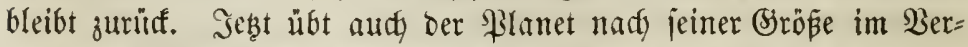
ein mit ber Sentraljonne cin rajderez Fortidyreiten auf bie Eome aนż. Die Eonne fällt am \$łlaneten vorüber, biz biejer wieber ben

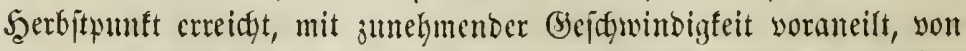
beiben $\Re$ örpern angezogen, ber Soune vorbeigefülyrt wirs. - Wie 


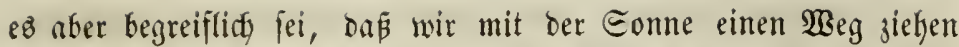

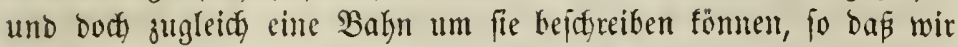

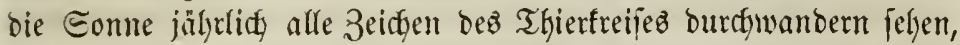

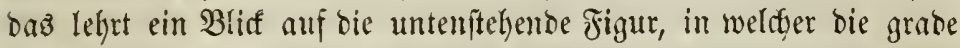
Sinie bie Balyn ber Eonne, bie gemundene bie Bafn ber (Erbe bar= ftellt, und bie punftirten Sinien bie Piidstung anbenten, nach weldyer mir bie Conte im Thierfreije erblifen.

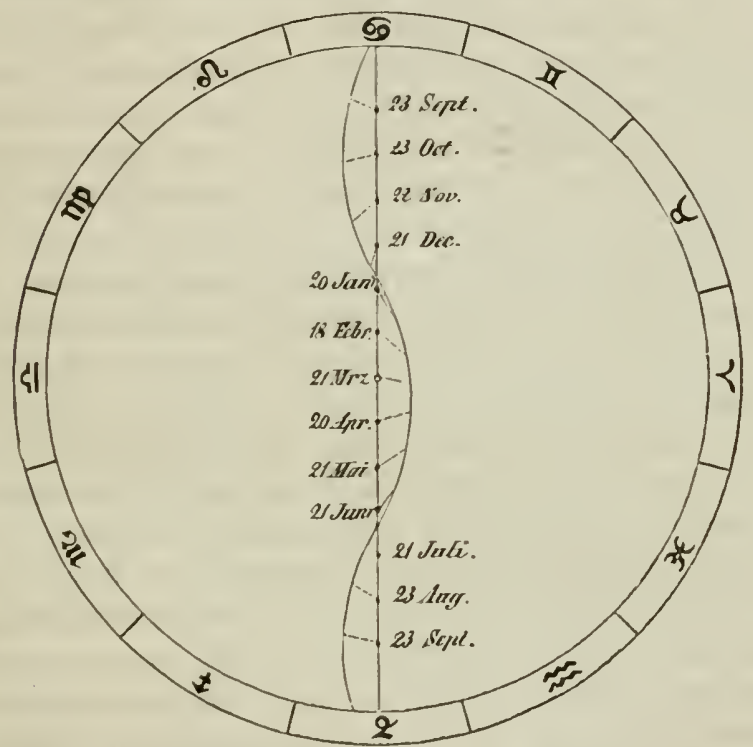

Crine pendelartige Bewegung mödten wir es faft nemen, in weldyer Eonne, \$laneten uno alle Beptitme burdy ben WSeltraum

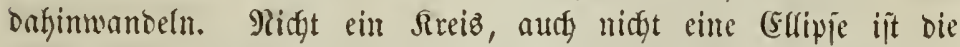
wahre Form unjrer \$ilanetenbalynen, fonbern jene eigenthümlidye Sformige Sinie, weldye entijeft, wenn wir ein giad in einem Rreije umlaufen lajien, umb den $23 e g$ verfolgen, welden ein bejtimmter

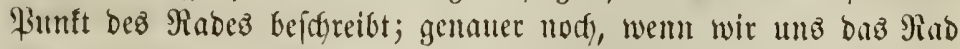

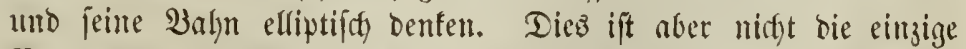

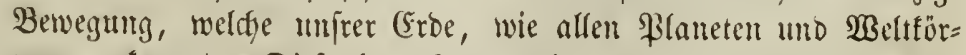
pern, zufommt. Diefe betradfteten wir nur in ber Midjtung ifrez Falles nady bem Centralförper zu, und barum wollent wir fie ihre 
Rängenbewegung nennen. Wir fdouten ber Betwegung unfrer Eroe gleidjam von cinem Pole bes Thierfreifes zu. WBir tönten unz aber audy umern Beobadytungsont in ber Ébene bes Thierfreifes in einem jeiner 3eidjen jelbit mälfen, unb würben bann noch ein bop= peltes Bild yon ber Bafnjorm ber Erroe erlyalten, je nadjoem wir

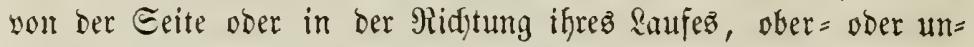
terhalb auf fre fifauten. Bon ben Eeiten dez Thiertreijez, yom

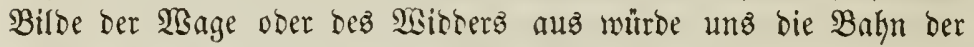
(rrbe in äfhnlider form erldseinen, wie bie jenter pentelartigen \&än= genberwegung, mur nidjt in folchem (Sirabe abweidjend. Die britte

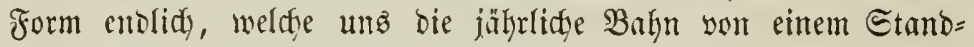

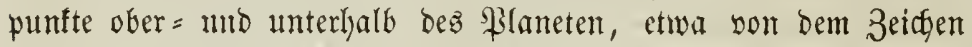
Des Eteinbod́s ober Rivebjes aus betradjtet, Darbieten würbe, itt ge=

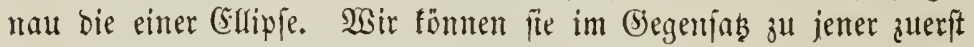
erwäḩnten Rängenberwegung bie Breitenberwegung nement. Eine foldye Form mü̈ten uns eigentlidy beftändig bie Bafnen bes Mer= fur unt ber Bents am Şimmel zeigen, Da wir unts ja ftetż über ifnen befinten; freilid) aber nur, wenn wir fie son einem feften Siunte aus beobadften fönten. Afber wir berwegen uns ja felbjt in Der (srbbafn fort und fömen bafer muds bieje Breitenbeivegung nur in gewiijent Etellungen unto unregelmäpig beobadjtern. In ben

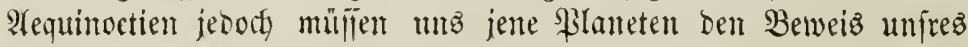
Enjtems geber. Shre Balyn läpt fich ja genau vorber beftimmen, und jene elliptiifte form hat bonn burds bie Breitenveränberung Des Planeten in jenen SHuntten bie einer Edjlinge angenommen, beren Form freilidy noch Etörungen burdy bie anbern \$laneten un= - terworfen ift. WBerben uns aber aud, biefe Exylingen in ber $\mathfrak{B} e 0 b=$

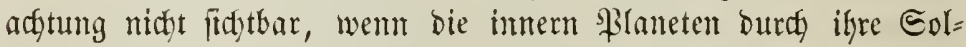
ftitien gehen, fo entgeken fie uns vielfeidgt mur barum, weil wir nidat jo lange verweilen, biz einer von ifnen ungejäghe ein Biertel= jahr bejdrieken hat. $\mathfrak{B g}_{0}$ hy aber müfier wir bie Edjlingen beob= adten tönnen, weldye unfre Erroe jelbft madyt, wenn fie burdh ihre Eolfitien gelyt; uno eine genaue Beobadtung des Eternhimmelz wiro unz bies gení̄ zeigen.

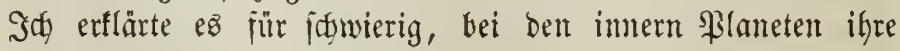
Edflingen zu beobaditen; temods hat man fie beim Merfur fajon wahrgenommen jur grȩ́en berwunberung manther S(ftronoment, 


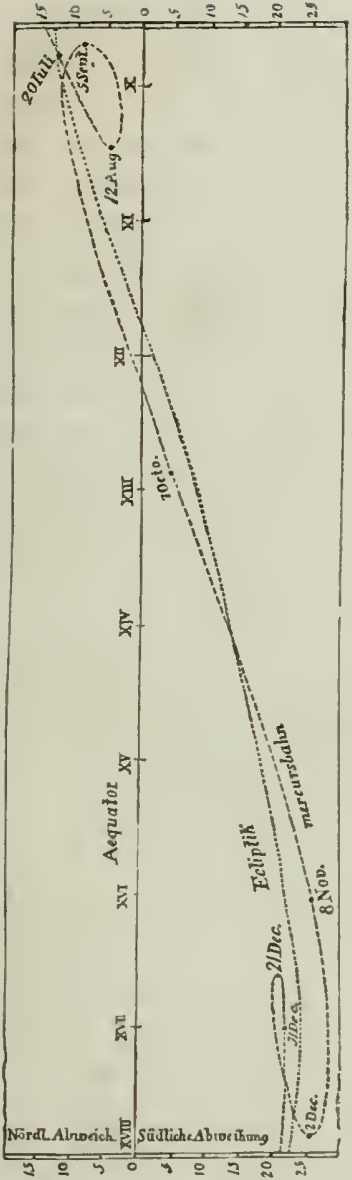

Der fđeinbare \&auf́ beß शertur.
3. B. Rittrows, bie fith bie lltiandye nidht ou erflären wupten. Saf) faum uridgt um= hitt, Gier nod) (Finiges über jene Beob= adytung mitzutbeilest, ba fie ben frint = ften Beweiz für bie Sidttigfeit ber Theo= rie liefert. Denn aแs bloz elliptijgen Bewegungen wintoe find nie cinc foldte Edblingenform in ben Eolftitien enflä= reil lafien. -

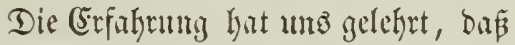
jene intreren filaneten am Şimmel für

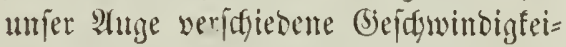
tent antefmen, bald fonteller, balo lang= famer gefen, Dam eiste Zeitlung fitll ftehen, ftationär werben, svie man es nennt. Diefes Etationürwerben findet beim llebergang vou eitrem arequinoc= tium jum andern ftatt, aljo wenn fie jene Exblingen bejegreiben. Die imnem \$laneten werben fo oft ftationtir, als einer won ifynen mit ber (Erbe zugleids die Eolftitien burdylüft; bods werben wir Durd Die Etellumg und bas Ridyt ber Eomme meift verbindert, bieje Erjogeimng zu beobadgten. Tie ämp̈en Pllameten fönmen mur bam ftationår twerden, wem unire Crobe burdy ifje eigute Balyn in ben Golititien eå veranlapt. Bei Den Fixiter= nen werifwintet bie Erjdyermung.

Betradten wir mun ben \&auf Des 9) Merfur, wie ifn Enfe vom Suli bis Decentber bes Salyrez 1846 beobactet hat, und wie es bie vorftefende Figur barftellt! Weldje llnregelmitigteit! Biermal

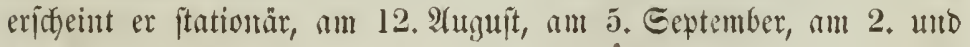
22. Decentber. Daker ift er rüfläufig, 0 . h. bewegt fid won Dit uach $\mathfrak{W e f t}$ yom 12. ATuguft bis 5. Eeptember und vom 2. bis 22. December. Nicht minber unregelmäpig ijt feine \&age gegen ben

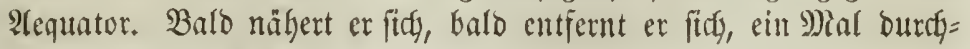




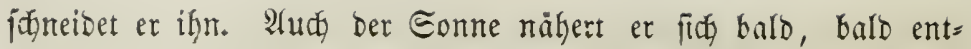

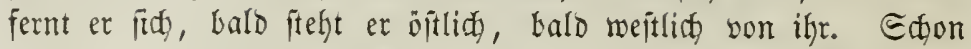
Sittrow erfannte, on

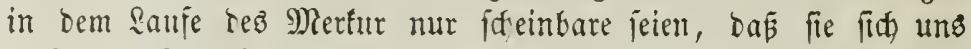
einjt éen jo einjact barifelfen mulroen, als bie ber Eonne uno des

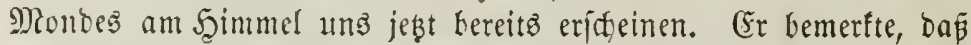
jene Edfingen immer in ber Rähe eines Etillitanbes uno um bie 3eit ftattfinten, no der Merfur bei Der Eonne, ober bei oberen \$las neten, wo fie ifr gerabe gegenüberftehen, und wo ifre Durctimefier am grösten erídeinen, aljo wo bie \$3laneten felb́t uns am nädfften find. Sisenn fid auth bie Srte mit jebem Safue ändern, wo am Şimmel bieje Etillytände unto Edylingen ftattrinden; Die Etellung Des Filaneten gegen bie Eonne zur 3eit jener Esrifteinungen bleibt immer biejelthe, und bie Zeiten, bie yon einer Zuriluffunft bes \$la= neten bis̄ zur antern rerfilię̧en, fint immer biejelben. -

Bier Bemegungen waren $e^{\mathfrak{B}}$ alio, bie wir als umirer (Erbe, Den SHlaneten, ber Eoune und allen Eternen zutommend erfanten. Shme fie ijt das Dejtegen einez freien Sörperz undenfbar. Dies waren bie rotirenbe $\mathfrak{B} e$ emegung um fid felbjt, bie fortiffreitente ober fallente zu bem entfernteren uno bie beiben penbelartigen um ben näheren (5entraltörper. Anjiefyung war bic urjaḑe aller biejer $\mathfrak{B} e=$

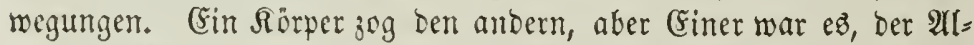

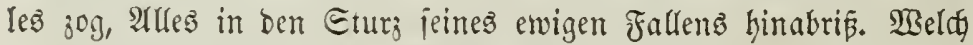

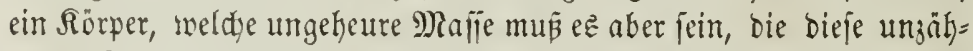
ligen 2 selten ju beherriden vermag? Unjer bjeift sermag es nicht zul failen; er würoe lumöglidez veriudten. Jene Anjehung, weldhe

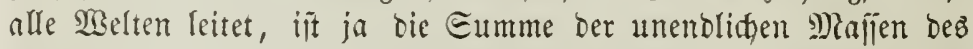

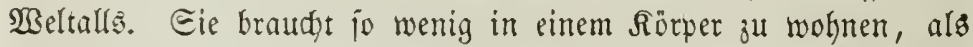

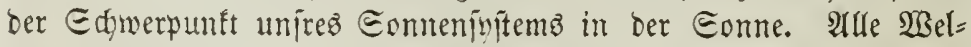
ten ziefhen einander an, bie größere bie fleinere; alle fallen uno bes wegen fich und bem emigen (jeję̧e ber Patur, weldes wir Bleidy=

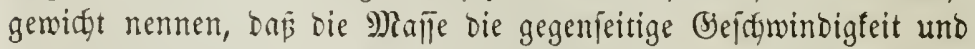

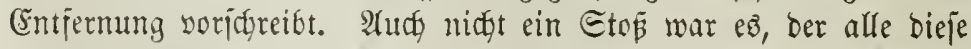

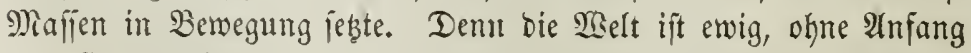
und Enbe; mit ifrem Seben erwadgte audf iffe Berwegung, Denn ifre Seben ift Berwegung. Riemand benft baran, ein Ende ber Bewe= gung in ber $\mathfrak{W}$ elt anz̧unefmen, uno bod wifl man nadh einem 
Injange forjdyen. Niemand bentt baran, ben 2tnfang ber Materie erflären zu wollen, und bods will man ben 2 nffang ifrer Beme= gung begreifen. Die Materie ift an uno für fith berwegt, rukeno fann fie richt beftelyen; Denn Dann wäre fie tobt. (Sienug, eine Rraft rief bie Bewegung Gerbor: bieje Sraft aber ift ewig, benn fie ift die Materie jelbit.

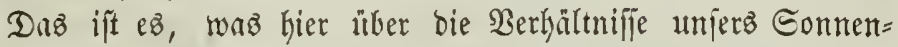
Iyftems und der $\mathfrak{W e l t e n}$ liberfyaupt ju jener unbetannten Central= fonne mitzutfeilen war, bie uns Mäbler in ber (Sruppe ber \$leja=

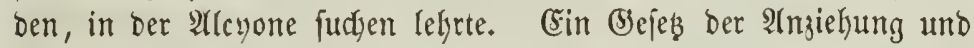

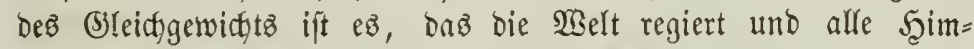
melätörper in ifren Edyranten erbält. Die bisherigen Theorien reidjen nidft meljr gुanlz bin, bie immer verwiffelter werbenoen (5r=

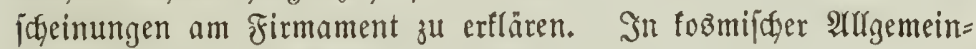

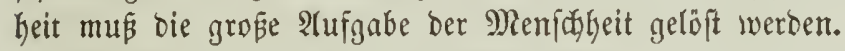

Radbem wir alle bie mannigfacten Bewegungen ber Crrbe, jelbit ifre Ctörungen fennen gelerut und von ganj verfdyiebenen Gtanbpunften aus beleucbtet haben, fönnten wir bamit bie Betrads= tung ifrer planetarijden Beziefungen zum Sonnenfyftem alz been= bigt anjehen, wenn nidgt bie Erbe jelbit fidy nod ein eignes jelb= fitänoiges Enitem bildete, in weldyem fie als Eentralförper auftritt, furz, wenn fie nicht ifgren Trabanten, ben 9) lond, lyätte.

(biezogen yout ber Errbe als jeinem (Eentraltörper, beivegt fid ber Mono um bieje. Aber audy ber Mond zieft bie (Eroe an und wirft auf bie Bewegung ber (5rbe ein; fo baß̧ fidt) vielmebr beibe un ben gemeinjagftliden Edwwerpuntt belwegen, ber freilids wegen bes gropen Unterichiebes ber Maffen nake au best Mittelpuntt ber Erbe felbft fälat. Go bewegt fich bie Erbe mur rotirend um ifgre Are, ber Mond aber fortid)reitend in elliptifder $\mathfrak{B a l} u$ um bie (5roe, weldye Bahn aber, in Bezug auf bie Conne betradtet, wergen ber fortigreitenden Bewegung ber (Frbe in jene fdjon erwähnte pendel= artige Rablinie übergeht. Der Beweis für bie Bewegung bes 9)ondes

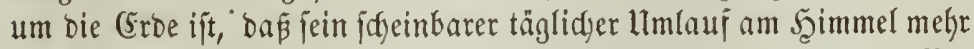
Zeit erforbert, alz eine volle Ilmmälzung ber Grbe bebarf; ber $\mathfrak{B} e=$ weis jür bie elliptijđe Gejtalt jeiner $\mathfrak{B a l y n}$ ift bie Berfajebenkeit in Den fafeinbaren Gröpen feiner Edjeibe, in ber Eronähe und Ero= ierne. Die Frage nady ber 3eit, welche ber Mlond gebraudst, $\mathfrak{u m}$ 
bieje $\mathfrak{B a h g}$ zu burdflaufen, ift nidgt melgr eine fo einfacte, wie bei Der (Erbe. Denn mir befinden unz auf Dem Sörper, um ten uno mit bem fid ber Mond bewegt, und fehen ben 2Nufangspunt, won bem wir feine Bemegung zühyten, zugleidy fortrinfen, wenn wir ihn nidft unabänberlich im 2 eltraume felbjt mählten. Thun wir aber Reģteres und nennen bie Zeit, weldye ber Mond gebraudgt, um wie= ber an bemjelben Drte bez Seimmels, bei bemfelben Sterne zu er= fajeinen, feinen Umlauf, fo erhalten wir ben fiberifden Monat, wel= der 27 Tage und 7 Etumben $43^{\prime} 11^{\prime \prime}, 5$ boulert. Begielest wir $b a=$

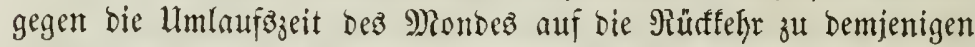
Puntte, wo er mit Erobe unt Eonme in geraber Sinie fteht, fo men= nen wir fie ben fynobijffen Monat. Diefer ift natürlidy länger

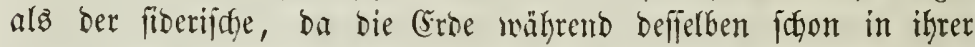

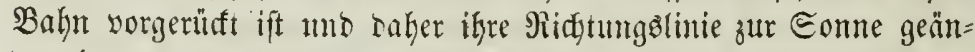
bert hat; er beträgt im Mittel 29 Tage $12^{h} 44^{\prime} 2^{\prime \prime}, 9$. 2(ber er

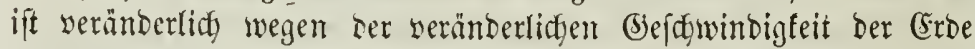
in ifreer $\mathfrak{B a h y n}$.

Ueberbiez erteibet aud Der Mono in feiner Bewegung man=

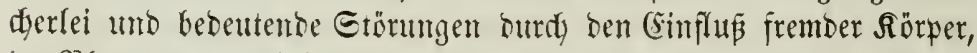

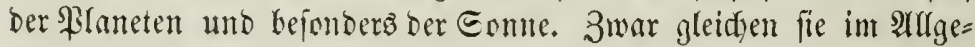
meinen ben früher erwähnten, uur raß ifre \$erioden nady eben fo

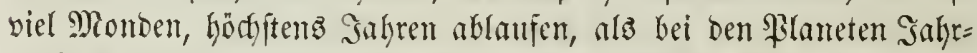
taujende erforberlidy waren. Ien bebcutenbjten und augenfälligften

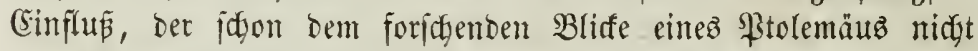
entgeken fonnte, übt aber bie Sonne auf Den Mond aub. Denn bei feiner Bemegung um bie (Erre nimmt er fo veridfiebente Ster=

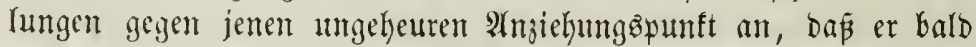
ftärfer, bald fotwidter gejogen wird und Darum fich bald langjamer, bald fifneller bemegt. Etelyen Eome, Erbe und Mond in graber Sinie, fo wird Das eine Mal bie (Erbe, bas andre Mal ber Mond

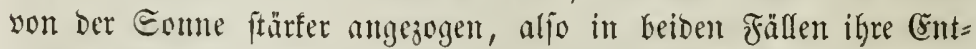

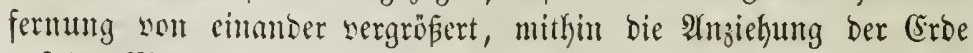

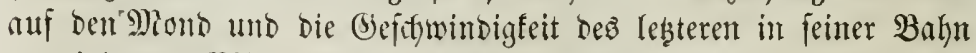
vermindert. Billoen Dagegen Soune, Eroe unb Mento einen redt)=

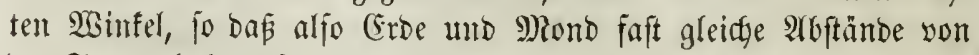
ber Sonne laaben, fo werben beibe zwar gleidy frart angezogen, aber

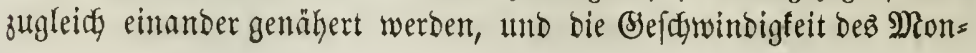


bes wird bejuleunigt. So wiro wedyfelz̈meife ber Lauf bes Mondes langjamer uno fdnefler werben, am langjanifen im Sinter, am

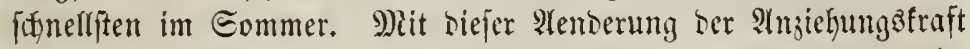
Der (Grbe zum Monde wirb aber zugleid bie (Sejtalt ber Mionobahn geändert. Denn in Folge biejer Etönng butrdy bie Eome wirb Der Mond feiner mütterliffen (Erde entfrembet und jögert, fith ifr wieber fo weit zu mäjern, als er bei Beginn feines cinmaligen Umlaufz bereits mar, biz bieje jelbjt ifn zu feiner Bflidyt jurüt= ruft. Co rüct ber \$unft jeiner Eronähe, baz̉ \$erigäum, beftün= big in jeiner Balyn nor, bis es nach 8 Jalyen 310 Tagen $13^{h} 48^{\prime}$ 53" Den ganzen Sireislauf yollenbet hat. Co werintorlich, wie bie Beftalt ber Bafut, ijt aud bie Reigung ifrer Ebene gegen bie ber Gfliptif, wiewohl bie Exwanfung hier mur unbebentento, swifhen 50 und $5^{\circ} 18^{\prime}$ ift. Eelbit bie \$intte, in welden beibe Sbenen einanber fanteiden, bie Mrondsfnoten, fund nicht beftïndig bei biejem

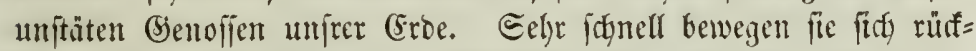
waits in ber (Effiptif, jo bap fie fdon Mady 18 Jabren 218 Tagen $21^{h} 22^{\prime} 46^{\prime \prime}$ die ganze Efliptif burdilanfen habent.

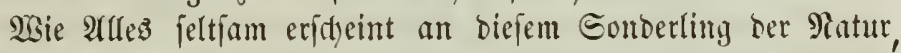
to ift auch feine Fotution eine cigenthumlidte, benn fie fällt ber 3eit nady genau mit feitter Bahnbemegung um bie (5rbe zujammen.

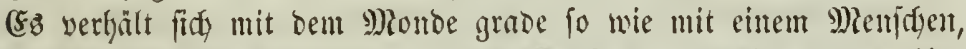

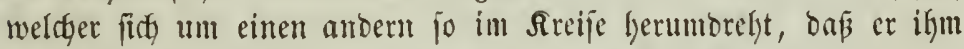

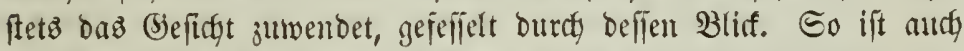
bie Rotation Des Monbez gleidyfam burdy bie (5rbe gebunden, baß

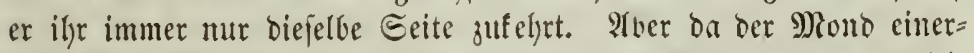
jeits Ungleidheiten uno Etörungen in feiner Balynbenegung erlei= bet, an weldsen bie Siotation feisen ifntlyeif nimmt, andrevjeitz lowohl feine âte gegen bie (Ebene feiner $\mathfrak{B a l y n}$ alz jeine $\mathfrak{B a h} n$ ge=

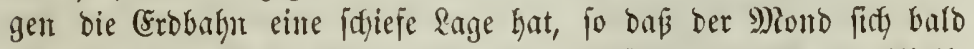
über, bald unter ber Erobahn bewegt; fo erjefeinen unt auts Theile

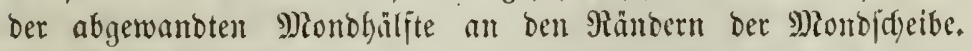
Der Mond facint gleidyan hin unt her zu manten, unb barum nennt man bieje Ericheinung die Eibration. Woflen wir eine Grflärunt Dicjer fontorbaren Motation bez 9londes, fo mifffen wir fie in ben

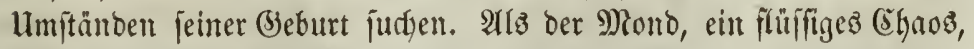

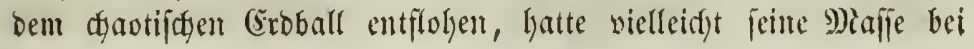




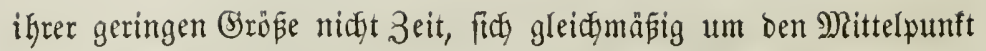
子u verbidften. Sie erlag bei bem auferorbentlid fidnellen Errtarren

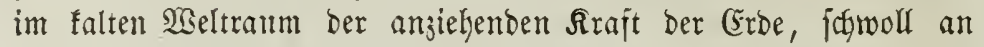

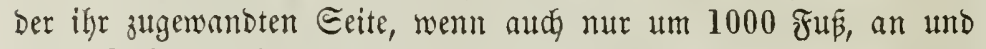
warb io jeinem Centralförper imiger verbunben, als bie grȫëeren Blanetenmajïen, bie, vielleidgt audy glühenderem Edfoope entquollen, Zeit gemannen, zu fin jelbjit zu fommen, fird in fid jelbjt zu jam= meln. -

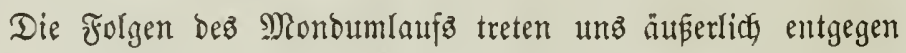
in ben wectjelnden Ridgtgeftalten ber Mondicteibe in Den Mond= phajen. Da unjer Trabant uadh Den gewöhnlicten Begrifien fein felbitteuthtenter Sörper ift, fondern jein Rifift von Der Eomne em= pfängt, fo fann nur bie ber Eonne zugewantse Monbfalbfugel er= leudstet jein. Eteht baljer der Mond in Dppofition mit ber Eonne,

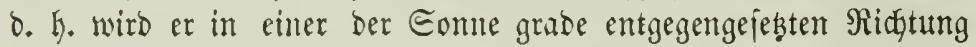
won ber Erroe aus gejegen, jo fefret er untz jeine ganze erleudjtete

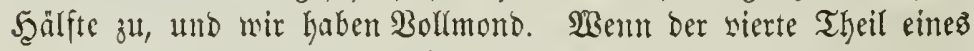
innobijaten Ulmlaufs verflofien ift, alio nach $\tau^{3} / 8$ Tagen, ift ber Mond nach Siten fortgerüft und fteht fentrecfit anf Der Rinie, weldye Eonne und Erob verbindet. Dann wenbet er uns natürlich nut

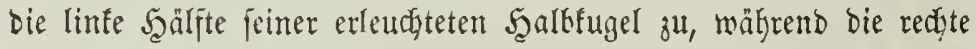

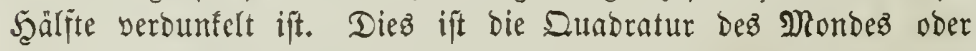

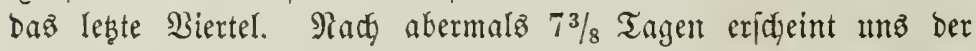

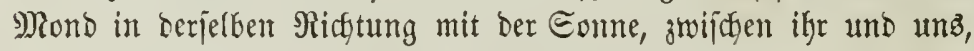
er fehrt unz alio jeine bunfle, unerlentedtete Seite zu, ez ifit Reu= mont, utho ber Mond felyt in jeiner (5onjunction mit ber Sonne. (Endtich nach weiteren $73 / 8$ Tagen befindet fid ber Mond wieber in

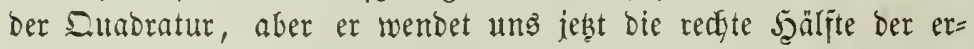

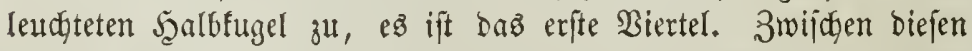
weriffiebenen Ricftgeftalten, ben Suabraturen und Eysygien, ericheint unz ber Mont als Eityel. Der Aufgang des Miondes hängt na= türlidy mit biejen Bejtalten zujammen. Der Meumond geht mit ber Sonne zugleidy auf uno unter, ber Sollmono medjelt mit ifgr feine

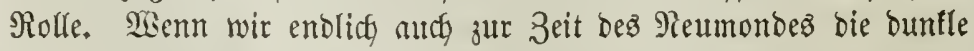
Mondicteibe von einem blafien, ajagrauen sidfte erleuchtet jefhen,

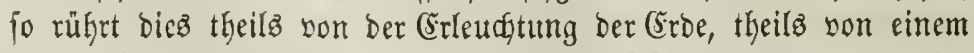
eignen sichte bes Mondes her, wie ichon frither angebentet wurbe. 


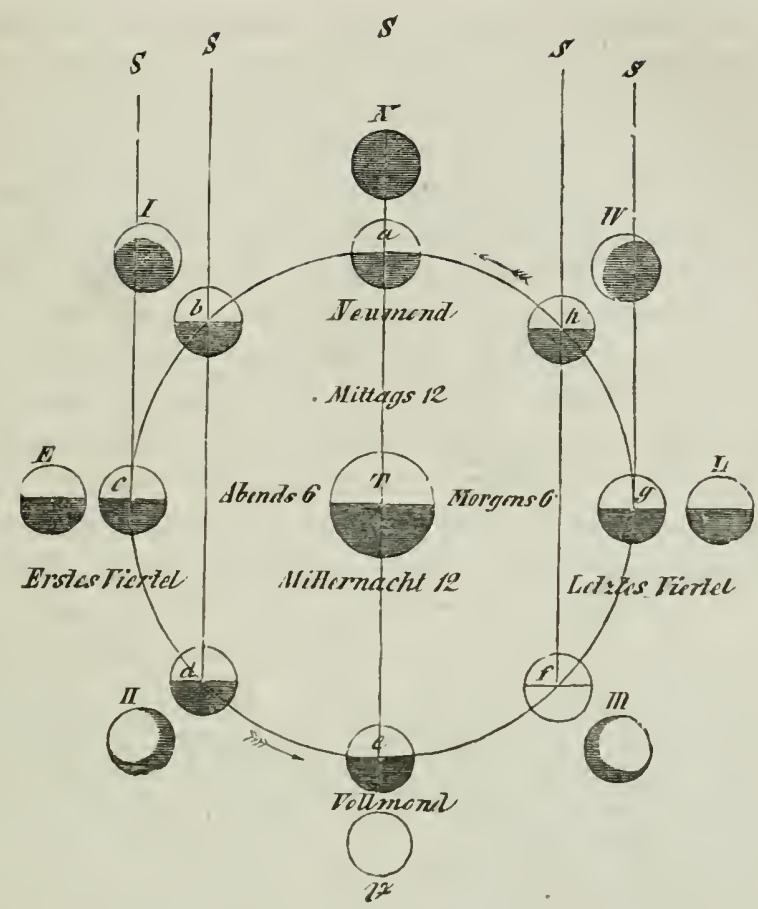

Die beiftehende Figur veranjajaulidgt die Ridjtgeítalten bez Mondez während eines einmaligen MmIaufez. Die mit $\mathrm{S}$ bejeid neten fenfredften Sinien jeflen bie bei ber weiten (Entjernung als parallel zu benfenden Ridyungen deş Sonnenlidytz Dar; bie mit a, b 2c. bezeidyneten Edfeiben ben von ber Eomre beleudjeten Mrono, unt bie änkeren Edfeiben bie Beftalten, in benent er bem

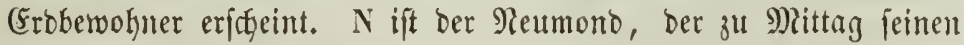
Gödfiten Stand am Şimmel erreidgt ober culminirt, wäfrend V, ber

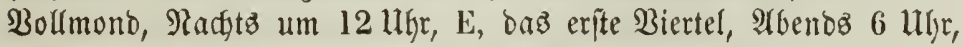

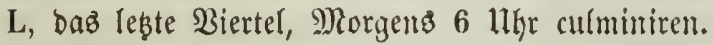

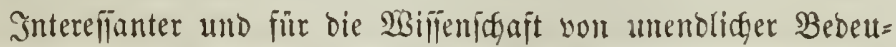
tung find bie burdy ben Miondauf bemirften Berfinjterungen. \$la=

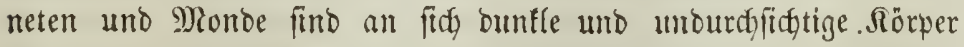
und werjen als foldje, wenn fie von ifreem (Eentralförper erleudjtet merben, einen Sdyattent in ber Piidgtung bez verlängerten Ridftiftrafls 


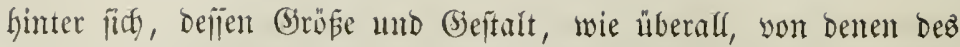

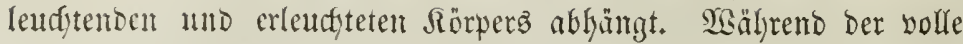
Edyatten ober Rermjoatten aller Beleudinng beraubt ijt, enthält

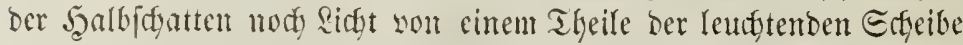

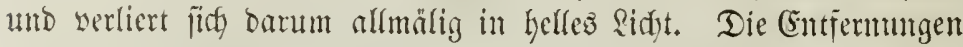
unb Sröpen ber \&laneten fund aber fo bejdaffen, dap nolle Sdyat= ten nie von einem Szauptplaneten anf ben andern, fonbern mur auf feine Monde und yon ben Mionden auf ifren Saauptplaneten

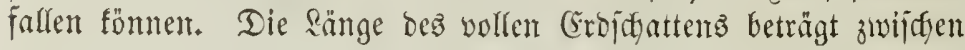
188,640 und 182,408 Meilen, die bez nollen Meumonojdattenz zwifden 51,033 und 49,376 Micilen. Der Edatten ber Groe libertrifft dafer den RGitand Des Mondes yon ber (Erbe um melyr als bas Dreifadye, fo baj er Dent Miond nidst allein treffen, fondern fogar über zmei Etumben lamizg ganz Kederfen fam. Der Momb Dagegen famn jeimen wollen Edyatten mur in frimer geringern (Ent= fermung anf bie (sroe werian, und immer wirb ber verfinfterte Theil

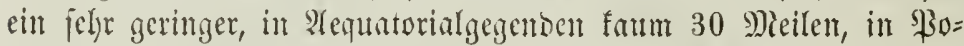
largegenden böchifenz 200 Sieilest im Durdymefier jein. Wentr

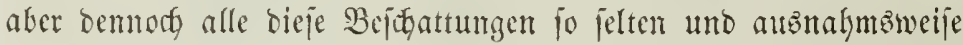
eintreten, fo liegt ber (Siruts Darin, baß́ bie Ebenen ber 9) Tonbbalnt unb ber (Erobahn might zujammenfallen, fondern umter einem 2 Sinfel won $5^{0} 9^{\prime}$ gegeneinander geneigt fint. Der Sollmomb wirb baker

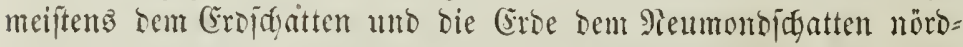

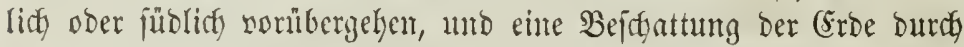
Den Miond, eine Eomnenfiniternifi, fo wie des Miondes burch bie (Froe, eiute 9)ondinfternifi, wiro nur baun eintreten, wenn ber )iond an 3eit feiner (Sonjunction ober Dppopition mit ber Some

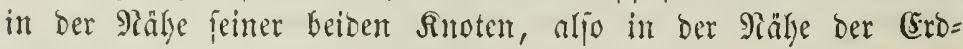
balin ift.

Die Connenfinfterniffe find entweder totale, oder ringförmige, ober partiale. Tie totale Eomenfurfternis ift immer nur son fur= zer Dauer, weil wegen ber Berwegung Der (Erbe nady wenigen Mi= muten wieber andre Erborte in ben Edyatten treten. Der Gang ber totalen Fimfternif bilset baljer eine frumme Rinie auf ber Fro= oberfläbe, beren ?lnfang on ift, wo zu gleidjer Beit die Eonne un= tergeryt, und beren (Ende nach 4-5 Stumben an eirtem vom erften um $100^{\circ}-120^{\circ}$ entlegnen Sorte ift, wo bie Eomne eben aufgeht. 
3u beiben Ceiten bicjer Sinie ift bie Finfternis partial, benn bieje

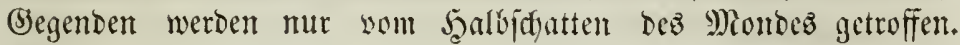
Waähreno einer wirflidy totalen Berinjtentung tritt eine eigenthüm= lidfe Dunfelleit ein, bie meder völlige Padyt nod, Dämmerumg ift; Der Şimmel ericteint grau, und bie helleren Eterne werben fitdstbar; bie figwarze Miondifjeibe ift won einter lebhaft glänzenton, fitber=

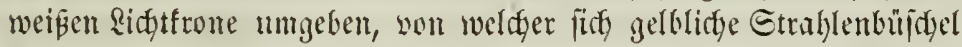
verbreiten, bie fid alfmälig inz 2 Beipe verlieren. WBie cin- zeuerrind

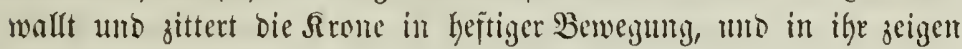
fidf) jene rofeurothen flammen ober $\mathfrak{B}$ olfen, bic wir idgon frillyer in Berbinburg mit ben Eommenfaufeln bradtent. Reider bietet fidg jo jelten bie Gelegenleit Dar, bieje munterbare (Erifdeinumg zu be= obadgten. Die mahridgeinlide (Erflärung Derfelten ift befantlidy in einer ungebeutent Somnentmofphäre gejuctyt worden, weldye mur nidgt ftarf gentug glänze, um neben ber lentgtenoen Eoume walyrge= nommen zu werben. -

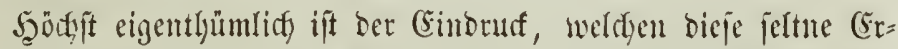
idjeinung aij bic Thierwelt madjt, befonders auf freien (Gbenen, wo man ben Exyutten des Mondes beutlidy Germutommen und über

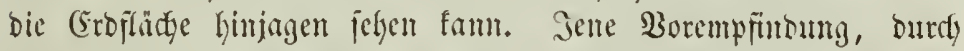
weldje fich fonft bie Thiere bei sitterungasucränderungen fo fidger leiten lailen, ît ihmen hier werjagt. Eie gerathen in bie grö́pte

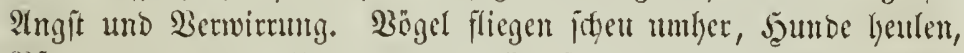
Fiferde mo anbre Thiere bringen fids fejt aneinander, ober werben

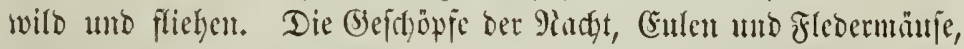

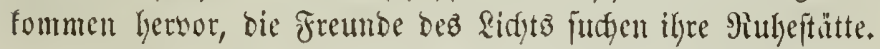

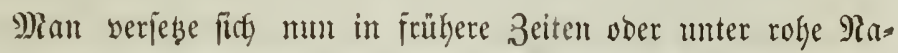
turvöffer unt füge zu alfen biejen angitwollen Geenten nod eint abergläubiges Bolf, baz lieer händeringend und in dumpfer Der=

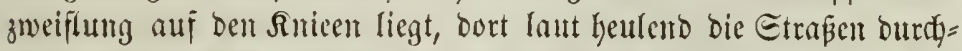
tobt uno bie Brumren bebeft, um bas vom Şimmel fallente Bsift abjuljalten: unt man Gat ein Bild, wie eş mut ber Didjter von

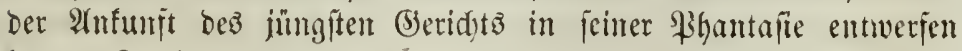
fann. 3n jenem nod) in imjern Giegenden bisweilen gangbaren

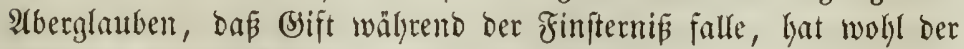

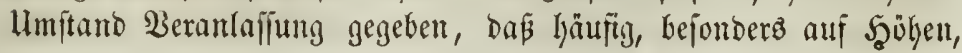


Thau zu fallen beginnt, wegen Deż fđjnellen Eintenz der Temperatur oft um mehrere Brabe.

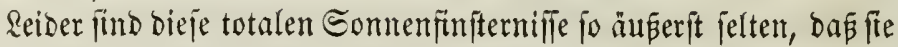
für Denfelben Drt Durctidjnittlict erit nady $150-200$ Sahren und Dann immer mur in einer Dauter bon wenigen Minuten wiederfefren. So lyatte im gegemwärtigen Sahrhunbert Sübbeutiafland mur ein Mal, am

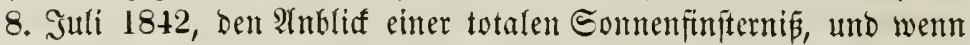

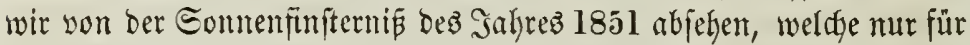

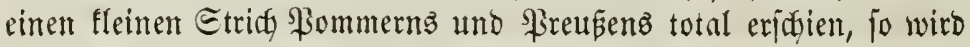
Dem nörolicfen Deutidfland bicjer $\mathfrak{A}$ tnbliff erft am 19. 2Auguft 1887 zu Theil werbent. Midgt minber felten fint aler audf bie ringförmigen Connenfinfternifife, in weldye jente bann übergehen, wenn ber jateinbare Montoburdimejer ffeiner als ber ber Conne ift. Heberbies bauert bie Erijteimung dez flammenten Ridtringes ber Eonne um bie Dunfle Miondideibe nur wenige Minuten, er zerreis̄t bald wieber

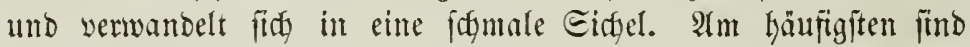
bie partialen Eommenfinfterniffe, weldye nidgt mur bei allen totalen und ringförnigen für bie Srte nördlidy und jüblidy von ber Sinie,

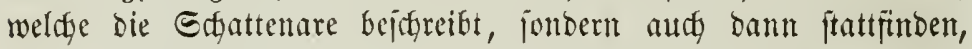
wenn Der Ectjattenfegel an ber Erroe vorïbergeht. -

Die Mondfinjternifie fömen mur total voer partial jein, nie

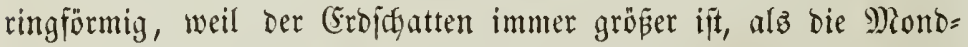
iageibe. Eie fömen gegen vier Etunben bauen, totale menigitens

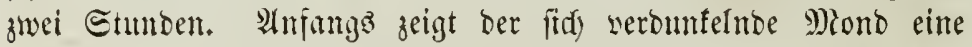
graue Farbe, uno jeine flecten werjdwinden. Im Fernoobr zeigt

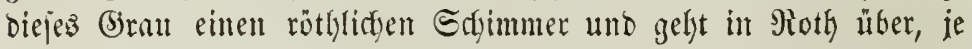

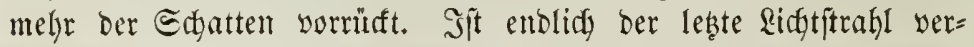

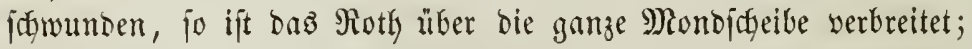
alfe Fleden, audy bie fleinften, zeigen fith wieber in zarter, rojenfars Gener Beleuctutung; mur um ben Mittelpunft bes Edtattenz, ben Rernidjatten, lagert fid bunfle Yiadyt, in Der man Mälye hat nody etwaz zu erfennen; biz endida an ber Dfffeite ber erfite Sidutiftrafl wieber herworbridst. $2(m$ jonderbarften ift jeme rothe Färbung ber werfiniterten Mondidgeibe, bie bei bewö́ftem Şimmel bie mannig=

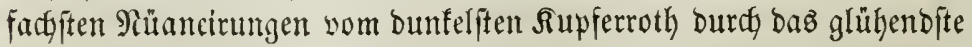

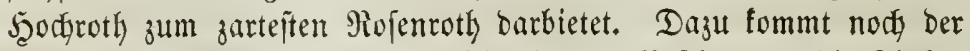

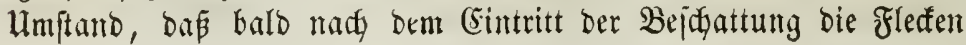


bes Monbes verfdwinden und fpäter bei tieferer Dunfelfyeit wieder

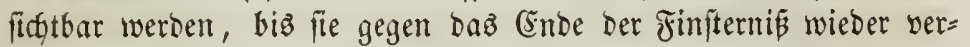
fdyminden. Die sidftbredyung in Der Erbatmojphäre, bie allerbings wohl einen Santheil an bem \$hänomen hat, fdeint affein nidyt zur

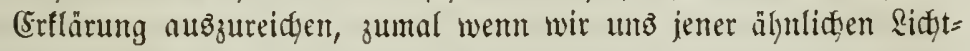

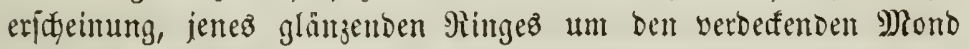

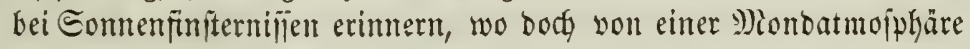

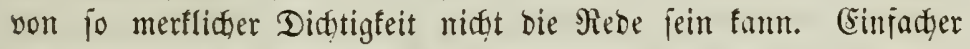
möhte wohl jene atmahme jein, bie beiden (Grideimungen genügt,

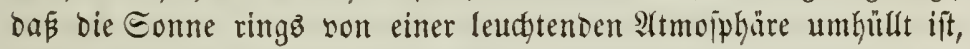
beren Rifft mur fidftbar wirb, wenn baz jtraflendere \&idyt ber Son= menideibe jehlt.

Die bisher betradteten Berwegungen ber (5roe, Des Miondes und ber Sterne haben yon jeher Das Mañ fïr bie Gimtheiluty Der Zeit, für bie Zeitredyuntg gegeben. In ihnen hatten Die Bölfer Der granen Borgeit, jelbit bie philopophifden Siriedsen und bie in

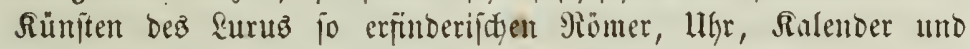

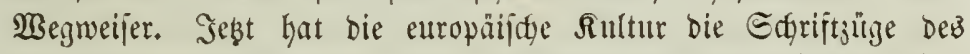
Şimmelö verbunfelt; vor aller Biloung umb Gelefriamfeit jiebt man bie Ratur nidyt melyr. Der cinfältige Şirt bei feiner uädyt=

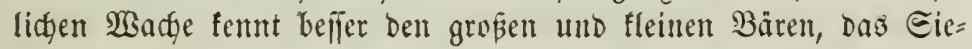
bengeptirn und ben Drion, Die ifm wege und Zeiten bejeidfnent,

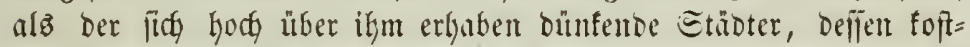

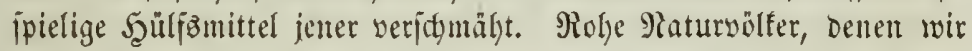
oft faft die Menjdennatur abjpredyen mödten, jeken uns blinde (Suropäer oft in Erftaunen Durd) bie Eidgerlyeit ifyer Drt = und

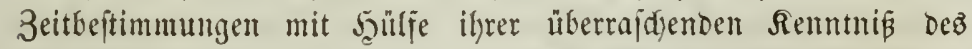

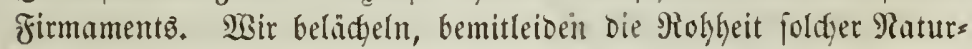
Finber. Für wenige Brojdgen faufen wir unjern fialender, für we= nige Thaler umje Mhr und fragen nidts nad Eternen, Eonne und

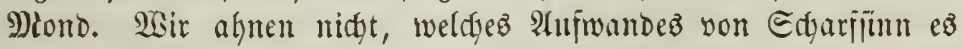
beburite, ehe Tage, Monate und Jahre fo georomet unb feftgeftellt wurben, daßj mau unz eigner Beobadjung überlyeben fonte. (Sin Bliá aư bie Berjudje ber Borzeit wirb genugen, uns eine $\mathfrak{B o r}=$ ftellung bason zu idfaffen.

Bon jeher waren eb ber Lauf ber Soune ober richtiger ber

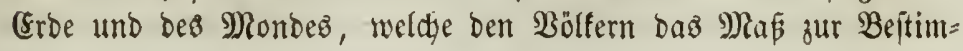


mung ber Zeitperioben gaben. Die Rotation Der (Erbe erfolgt nact)

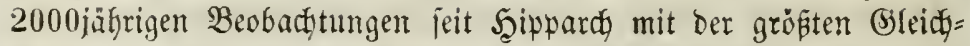
mäpigfeit unto gieft baher mit ber größsten Bienautigfeit bie Dauer bez Tagez alt. Ather je nadjoem bie volle Dauter einer Rotation auf bie Conne oder einen Firitern bezogen wirb, erfalten wir einen

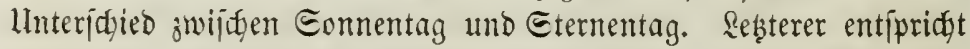
genau ber vollen Miotationzbauer, ba ber Firftern wegen feiner un= enolidfen (Entfernung unberilght vout Der fortfdreitenden Babnbetwe= gung bleibt. Die Sonne aber fommt befamtlich in Bezutg auf

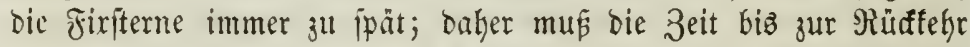

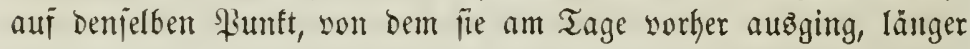
jein als ein Eterntag, und Dieje Dauer ijt ber Eonnentag. Theilt man ifh in 24 Etunden, jo fommen allj Den Eternentag 23 Etun= Den 56', aljo $4^{\prime}$ weniger alš auf ben Eonnentag. WBăre aud bie

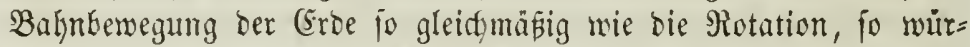
ben alle Eomentage gleidy jein. Heer bie (Erbe läuft bald jedneller, bald langiamer und überbie in ber Efliptit, nidgt im Afequator, und fo wiro auds bie Range des Eommentagez veränderlict. Dies

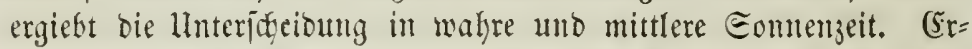
fitere ift jene ungleidförmige, in weldser ein $\mathfrak{T}$ ag 30 Eecunden über ober unter 24 Etumben baben fann, unto wiro burdy eine ridutige Eonnenufgr genan angegeben. Der mittfere Eonnentag ift bie burch=

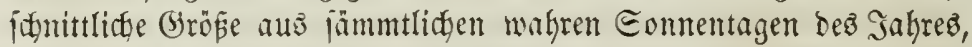
baher find alle bieje Tage volltommen gleidy lang. (Sine ridtige

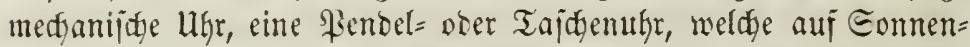
zeit geftefft iff, zeigt ben mittleren Somnentag an und wirb in $\mathfrak{B}_{e}=$ ziefung auf ben wafren Eomnentag, aljo auth auj eine Eonnenuhr, bald yors, bald nadygehen, aber nady Serlauif eines Sahres fids

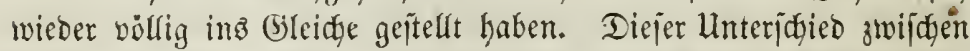
ber wahren unb mittleren Єonnenzeit, ober eben jenez $\mathfrak{B}$ or $=$ und

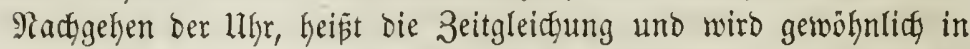
ben Ralendern zur Etellung ber Hhren angegeben. Eie fan im Februar und Rovember bis über 16 Minuten betragen. Der $\mathfrak{A n}$. fangspumft ber 24 Etunden bes Tagez ift nidgt son jeher uno liberall gleidy genommen morben. Die alten Bölfer lię̧en ihn mit bem llutergang ber Enme zujammenfalfen; denn, fo fagten fie, Mittag und Mritternatht fint burd tein bejtimmtes MRoment Kervor= 
geboben; und ben Aufgang ber Sonne taun aud ber Fleipigifte leidgt werfajlafen. Aaber bie Ungentmigfeit bes bald frülyeren, Gald ppäteren Eonnemunterganges führte allmälig jur Mitternactyt als

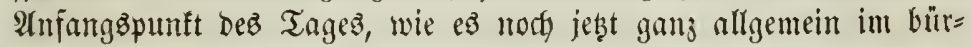
gerlichen Reben gilt, feit aud ber leste Mejt jener alten Beitein= theilung, ber fich nod in Stafien bis in bie nenere Zeit unter bem

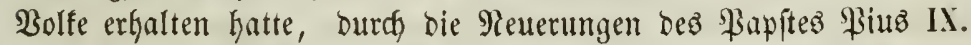

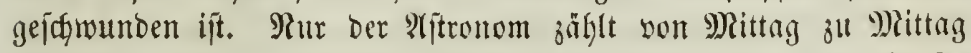

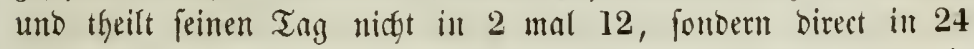
Stunden ein. Shym gilt ja bie sadyt als am widgtigiten, als bie Zeit feiner Thätigfeit, und fie mag er nidft auf zwei verjdiebene Salendertage vertheilent.

Die älteite Zeitrecthunng geidgah alleim nady Monaten, weldye unmittelbar aus ber Beobadtung bes Miondaufs genonmen wur= Den. Die Arater fannten fein Iahr; ber Adferbau forberte fie nods

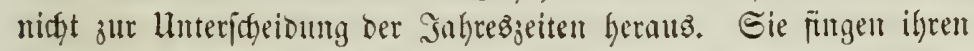
Ronat genau nit bem Gintritt bes Reumondos an uno redfuten

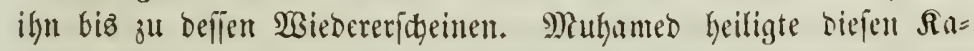
lenber, und bie Türten und alle bie zafllofen Bölfer, zll bentn ber

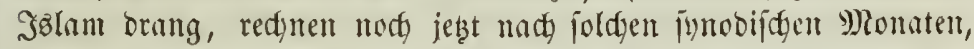

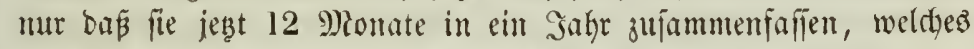
aljo gentu 354 Tage, 8 Etunden $48^{\prime} 34^{\prime \prime}, 8$ betriagt. Die Suben waren feine affronomen; aber fie wurben bennod) gewahr, daß ber Peumond immer bald nady 29, balo nady 30 Tagen jurüffellyte,

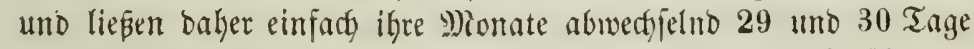
bauern. Daburdy erljelt ihr Sagh genau 354 Tage, aljo itber 11 Tage weniger, als daż Eomrenjahr, weldes 365 Tage 5 Enmben

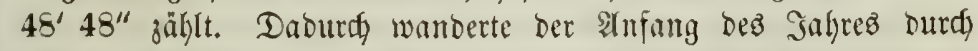
alle Jahreş̧eiten, was fïr bie Beptimmung ber Fefte uno bas

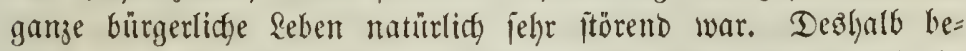

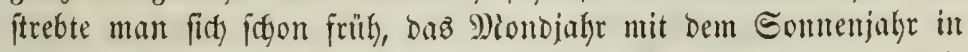
Uebereinitimmung zu bringen, uno behalf fidf ju diefem 3uvefe mit (Einifgaltung von Tageit ober Monaten. Edjon ner Atthener Mie=

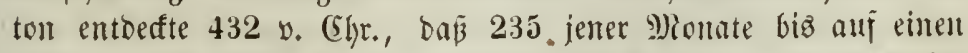
geringen Unterfodjed 19 Eomenjahren entiprectien. Da aber 19

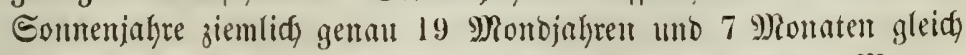
fommen, fo fiel Meton barauj, imnergalb 19 Sagren 7 Monate 
einzuifalten, to Dás 12 bason ju 12 Monaten, 7 zu 13 Monaten gerectinet wurben. Der Fehler betrug erift nadt zwei Jahyrhunberten einen $\mathfrak{T}$ ag. Aehntlidy ift bie Edyaltmethode ber Suben. Auth fie haben in 19 Sahren 12 Edjaltjafye jut 13 Monaten, uno ber Unteridjied von mangelbaften uno überzähligen Jahren, bie um einen $\mathfrak{T a g}$ fürz̧er ober länger finno als - bie regelmäß̈igen, rührt mur

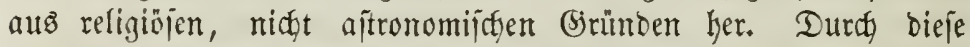
Metonifate \$eriobe fommt allerbirgs eine genifife Dronumg in bie 3eitredjung, aber es bleibt body immer jehr unbequem, nad fo

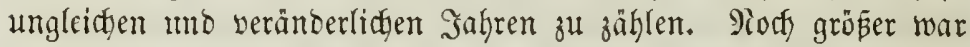
aber biejer Mebelitand bei ben \$erjern und 2 egyptern, welde nach Connenjafrent rechneten, bieje aber з̆ 365 Tagen annahmen. Die vernadyäfïtigten jecţ̧ Etunten betrugen in ungefähr 120 Jahren 30 Tage unt wurben bann burdy einer Edjaltmonat aużgeglidjen.

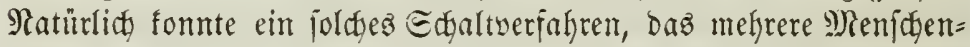

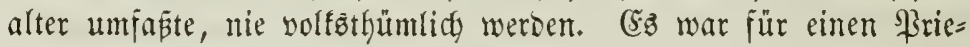

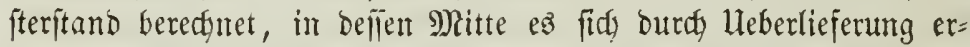
bielt, und mit befijen Bernidtumg $e^{3}$ vergefijen wurbe. Bei ber Rünitlictfeit aller biejer Eyjteme fam bafjer audh inberall bie 3eit= redfnung in bie Şänte ber \$riefter, uno wenn fich biefe, wie ez in Nom häufig geidah, mit Den Madsthabern veritänigten, um fie lälger im 2 tmte zu erhalten, ober einen neuen früber eintreten zu la lien, fo wurben baburdy bie Sagre balo länger, bald fürzer.

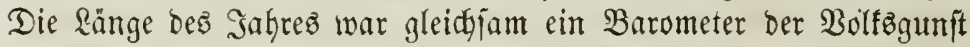
oder vielmehr ßriejtergumit für bie $\mathfrak{S e r r i d j e r . ~}$

Diejer llnorbunung madte Sulius Căjar ein Ende; er be= ftimmte bas Jahr nidyt melyr nady dem Raufe bes Mionbes, jonbern ber Conne, unb feste es auf 365 Tage 6 Etumben fejt. Tach bem Juliaurifaen Ralender bat baher baz gemeine Jahle 365 Tage, je= Dez vierte Dangegen 366 Tage, indem nadh Dem 23. Februar ein Tag eingeidgaltet wirb. Alber auch fjer beträgt ber Feffler in 128 Jahren nod einen Tag und war zur Zeit tes \$apiftez (Sregor XIII.

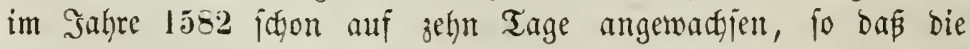

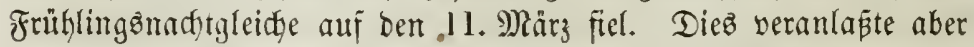
bedeutende Etörungen in ber Beredgnung Des Dfterfejtez. Die

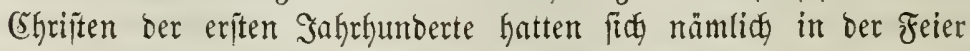

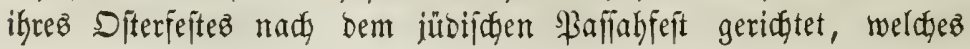


am 14ten Tage bes Mionats Rifan, beflen Bollmonb auf ben Tng Der Radytgleidge ober zunädyit banady fiel, gefeiert wurbe. Daburd fielen aber bisweilen beide Fejte Jijammen. Daz Ricenijate Con=

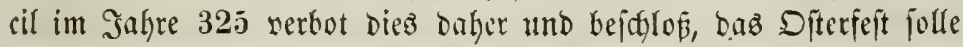
an bem Sonntage gefeiert werben, welcher bem eriten Bollmonde nady bem Frühlingsanquinoctium folgt, unb bies folle inmer auf ben 21. Mănz fallen. llm aber bie Bollmonde voraus zu lieredy=

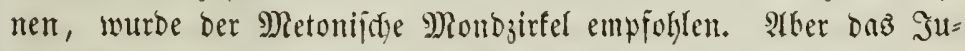

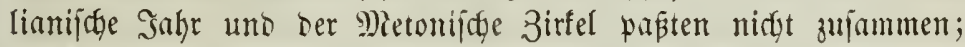
jenes war ja um 11 Minnten $12^{\prime \prime}$ ju lang, uno fo muste die

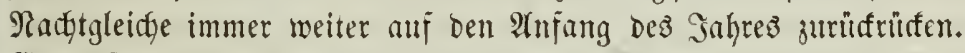
(5ż entitano Berwirrung, uno von allen Geiten erboben fids $\mathfrak{R l a}=$ gen, wurben Boridulïge ju Berbefierungen gematht. Da veroromete ßapjt Giregor nach dem \$llane dez Aloys Eili burch cin Breve,

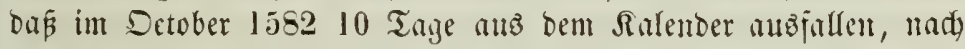

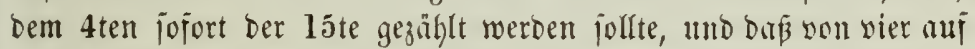
einander folgenden Eäenlarjuhren brei (jemeinjahre, nur bag vierte ein Edyaltjafy fein follten. Daburdy wird ber Febler in ber 3eitred)=

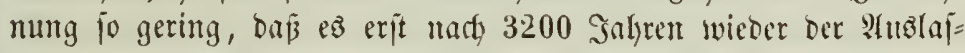
jung eines ๔analtages bebari. Diejer verbefferte Sulender beipt ber Gregorianifde ober ber neue Etyl, im Siegenjabe zum Jullimijotsen oder alten Gryl. Er warb son ber ganzen fattyolijden Egrijtenteit angenommen, uno nur bie protejtantijogen Staaten weigerten fich

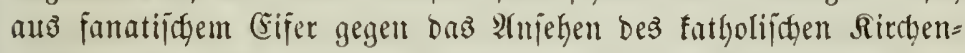
oberfauptez. Cinte furdhtbare Berwirnung, felbit 2fufftände, wie in

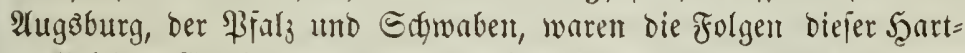
näafigfeit. (5ndich muste man diejem Ralenderfrieg ein Ende ma= chen. Die grope llnbequemlidyteit Des Bebrautbes non zwei Ralen= Dern bei Slaubenżgenofien, bie unter einanber wohnten und mit einanber verfehrten, und befonbers der alutrieb bes großjen seibnit

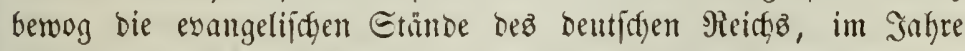
1700 ben yerbefferten Ralender eimjufübren, indem fie auf ben 18. Februar biejes Sahres jogleidy Den 1. Mär folgen ließen. Mur in ber Diterberedynung blieb nody ein lunteriftied juifdyen \$roteftanten uno Ratholifen. Die \$roteftanten wollten nidft bie allertings feh $=$

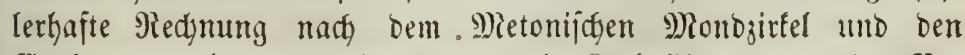
Epatten annehmen, auf ber bod bie Ratholifen wegen bez $\mathfrak{B}_{e}=$ 


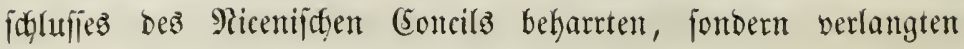

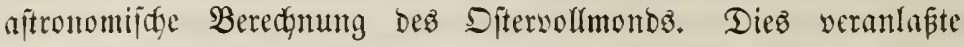
wieber Etörungen unt Berwirrungen, bis fith bie enangeliichen

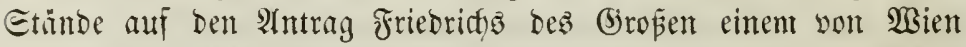

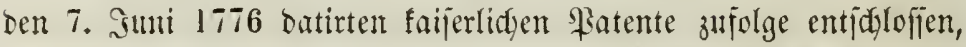
Dem neuen Etyl unter Dem Miamen eintez allgemeinen Mieidgafalen=

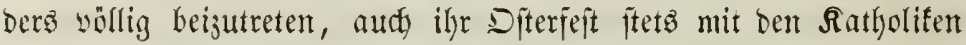
jutgleidg zu feiern. Da Englano feffon 1752 uno Ecfottland 1753 Den verbefïerten Satenter angenommen hatten, Dänemart und Scthes =

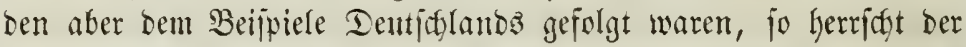

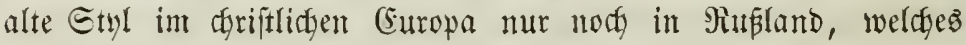

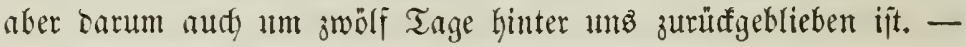

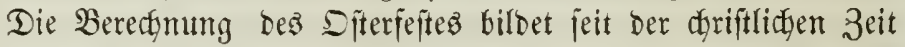
Den Bremtumft ber ganzen Ralenderrectyung und verbient baher

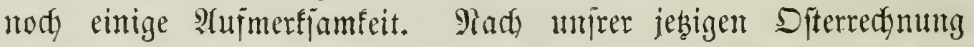
fint Die Ditergrenzen Der 22. MRarz und ber 25. 2(pril. Der 2\%.

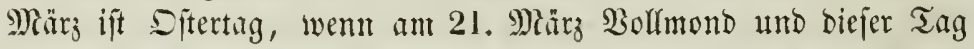

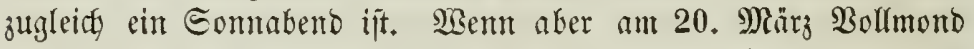

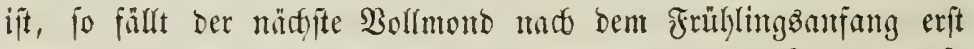
wieber auf ben 18. Afpril, unt ift Dies zugleidy ein Conntag, jo

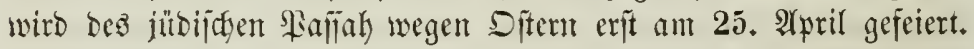

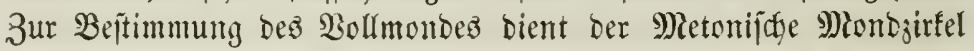

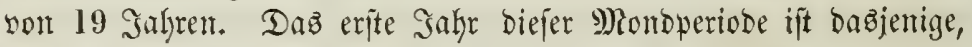
in bem ber Meumtond auf ben 1. Samuar fällt, und bie Zahl, weldye bezcidynet, Das wievieljte Safre bez Birfelz daz laufente ift, heifft bie golonte Zahl, weil bie (j)riecten, alş fie ihnen Mieton bei

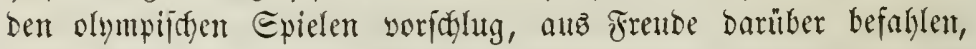
fie int Gold eingutragen. Sm Sahre l v. (Ehr. war bie goldone Zahl

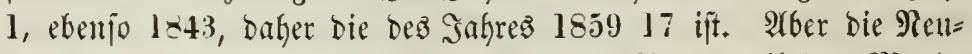
monbe fallen nidjt alle Saghe auf biejelben Tage, weil baz Mond= jahr um 11 Tage fürzer ift als bas birrgerlidye, ber Reumonto io= mit jährlich um 11 Tage rủdfwärts fällt. Fiel baher 1843 ber erifte Reumond anf ben 1 . Sanuar, fo muste ber leşte 11 Tage wor Endoe bez Gahrez, auf Den 20. December fallen. Ifm 1. Ia= muar 1844 warest alio 11 Tage jeit dem leşten Reumond verflof= fen. Daz jülo die Gpatten. Die Epatte für 1845 ift baher 22, Die für 185926 . Nady Der Epafte wiro ber Siferwollmono beftimmt. 
Mrit berjelben golonen 3afhl fehren natürlich biefelfen (Epaften wie= Der, alfo aud) biefelben Mionatştage für bie Bollmonbe, aker fei=

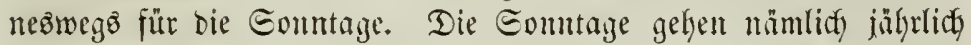

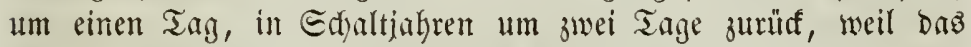

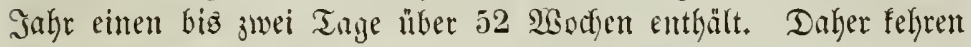

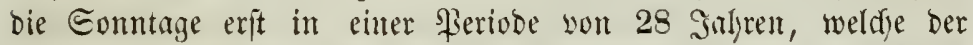
Sonnenjirfel heiêt, mieber auj biefelthen Monatżtage zurüf. 9

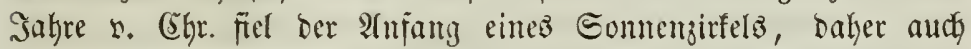
1840 wieber bas erfte in einem joldyen unb 1859 bas 20 jte bej= jelben ift. Die freben $\mathfrak{B}$ odjentage bezeiffyet man mun mit ben Bucdjtaben A biz G, jo baj der Sieujahrstang inmer A erhält. Der Budfitabe, weldyer auj ben erftent Somntag, aljo auf alle

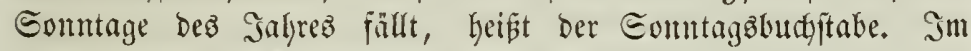

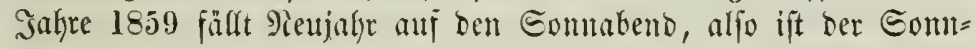

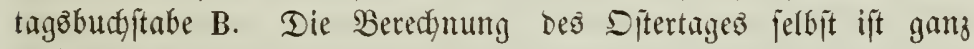
cinfad. Fus den (Epaften beredynet man ben Djtersollmono. Fün

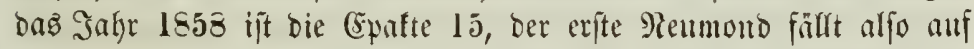
Den 15. Jamuar, Der folgenbe auf ben 13. Jebruar, Dam auf ben

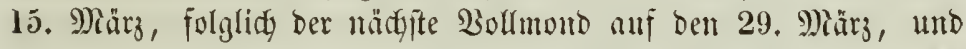

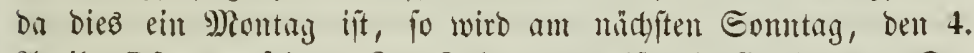
2ppril, Ditern gefeiert. Im Safre 1859 ift bie Čpafte 26. Der eríte 9eumond fällt baher auj ben 4. Inutar, bann auj ben 2. Jebruar, ben 4. Măr子, Den 3. April, aljo der Diftervollmono auf ben 17. 2fpril, und Da diefer ein Eonutag iit, jo wird Ditern erit am folgenoen Eountug, ben 24. Ifpril gefeiert. Sndem idy ben

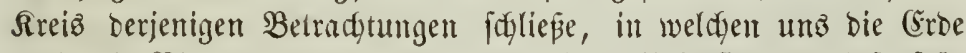
nod) als \$llanet galt, gebe idy eine furze Lleberfidgt ber Diterfejte für bå̉ nädyjte Decennium:

\begin{tabular}{|c|c|c|c|c|c|c|c|}
\hline & abre & $18 j$ & & iten & $\mathfrak{a u}$ & & 24. $\mathfrak{I}_{\mathrm{p}}$ \\
\hline & - & 1860 & $=$ & $=$ & $=$ & $=$ & 8. 2ipril. \\
\hline & $=$ & 1861 & $=$ & $=$ & $=$ & 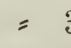 & 31. Må̃ \\
\hline & $=$ & 1862 & $=$ & $=$ & $=$ & $=:$ & 20. Ifpril, \\
\hline & $=$ & 1863 & $=$ & $=$ & $=$ & $=$ & 5. 2 fpril. \\
\hline & $=$ & 1864 & $=$ & $=$ & $=$ & $=$ & 27. )ไårซ. \\
\hline & $=$ & 1865 & $=$ & $=$ & $=$ & $=$ & 16. 2) 2pril. \\
\hline & $=$ & 1866 & $=$ & 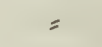 & $=$ & $=$ & 1. Ifpril. \\
\hline & $=$ & $186 \pi$ & $=$ & $=$ & $=$ & $=$ & 21, April, \\
\hline
\end{tabular}

11 
Jm Saf̧re 1868 füllt Difterı auf Den 12. April.

$=\quad=1869=\quad=\quad=31 \cdot$ Maing.
$=\quad=1870=\quad=\quad=17 \cdot$ April.

2) Die Eroe unter bem (Finjlufie fos mifder Siräte. Şir haben bisher unire (5rbe mur aub bem allgemeinften be=

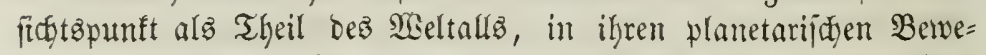

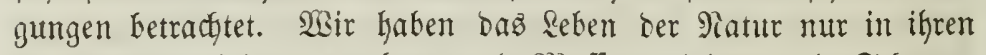

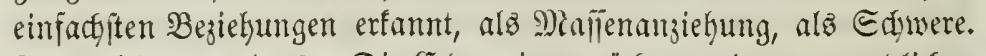

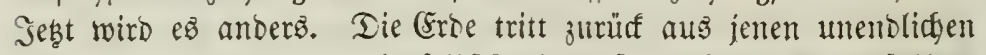

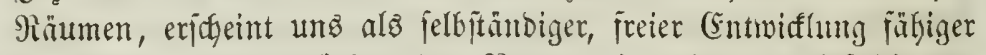

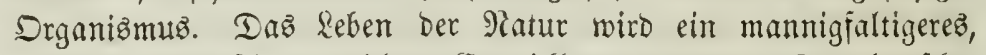
tritt uns in fräftigerer, eblerer Entwwifflung entrgegen. Dort herridjte

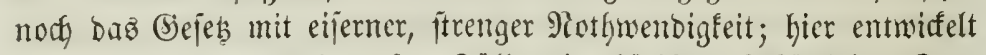
jith bie Freitheit in buntejter Fülle, in hödjiter Edjönfeit. Dort Gerrichte Unendlidfeit und ftetes Beharren Der Form, Beränderung

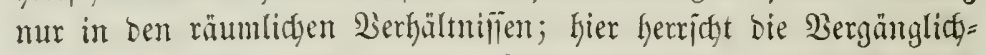

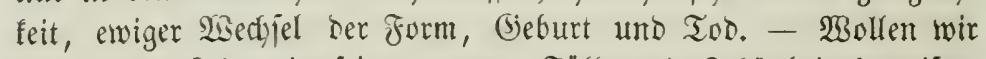
aber biejez seben in jeiner ganzen frille uno Edjönheit begreifen,

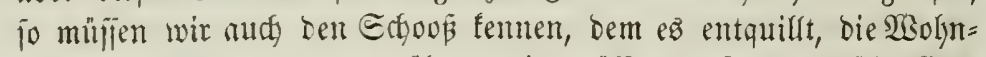

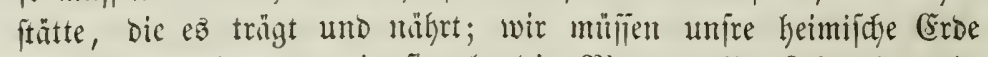
audf fennen lernen, wie fie als bie Miutter alfes Lebenbigen in

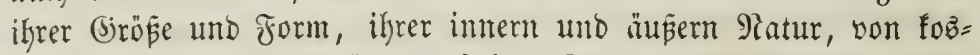

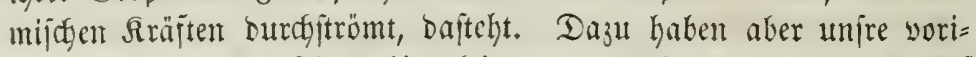
gen Betract)tumgen fobon hingeteitet; Denn bie Riräfte, weldje auf (Erben wirfen, und bie Art ifrer Thätigfeit fönnen feine andern jein, als bie, weldye wir in ben fosmifden Erideinungen bes wiseltalls, in ben Bemegungen unjres Blanetenjyitems entoccen.

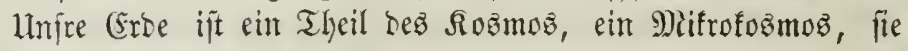
ijt ein \$lanet und Eentralförper, fie freifi um eine Eonne und wirb son Planteten angesogen, fie freift um fich felbft uno ziefgt ifre eignen Theile an. Die Erbe fteft unter bem (Ginflufje ber alfgemeinen (Gravitation, werm wir mit biejem Pamen die fog = mijhe $\mathfrak{R}$ raft in ifrer llnmittelbarfeit begeidnnen. Wir wollen bie

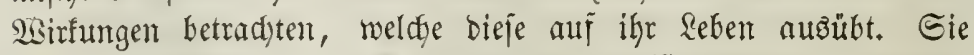

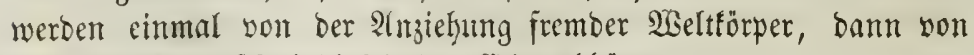
Der Notationşgefdywinbigfeit ber (Srbe abgängen. 
Bäre bie (Erbe eine flüfifige Manje oder ifre Dherfläbe gleith= förmig von einem Meere bebefft, fo fömute fie während ilyer tïg= lidgen und jäfrlidgen Bewegung nidgt in Mitthe bleiben. Diejelben Errijgeinungen, bie wir ifyon bei Den Störungen bez Mondes in jeiner Bafn fennen lernten, würben fid and hier wieberlyolen. Der Mont mürbe bie iffm jugewandte Eeite ber Erbe fitarfer anjiehen, als bie abgemante, who bas Mieer zn einer $\mathfrak{W e l l e}$ in bie Şöhe ziehert. atber auch ber Mittelpuntt ber (Erbe mürbe ftätfer angejo= gen werben, alz bie abgewande Eeite, bie Entfermung belïelben vermebrt, feine Ânjiefungsłanjt vermintert werben, und barum and

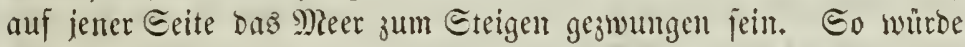

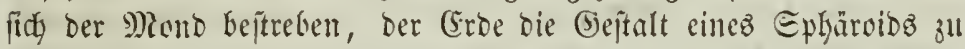

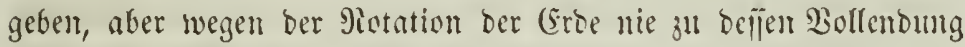
gelangen, fonoern mur cine fortifdreitende breite Waelle erjentgent.

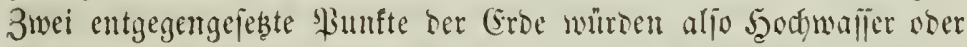
Fluth, alle \$untte Des gleidıweit von ifynen abjtehenten llmtreifez tiefes Meer oder (566e haben. Mit dem Sumpe dez 9)iondes müroe

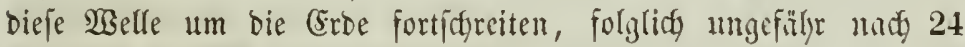
Stunden 50 Minuten mit ber (5nImination bes Miondes an ben= felben \$unft zurinffehren. Innerhalb biefer 3eit milßte jeder Drt zweimal Fluth und zweimal (s6be nadh je 6 Etumben 12 Misuten

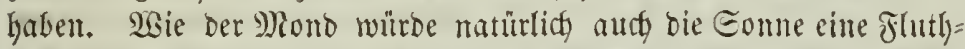
welle erzengen, bie aber wegen ber grö̈ern Entfernung Der Eomne

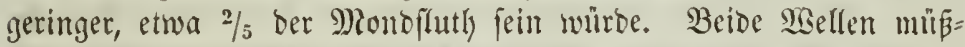

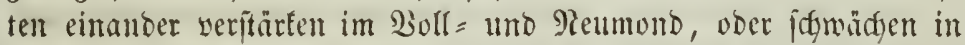
Den Suabraturen, ein Marimum, Die Epringi(utl), unt ein Mini= mum, Die Rippfluth, erjengen. Die hödjiten Fluthen unt tieffiten

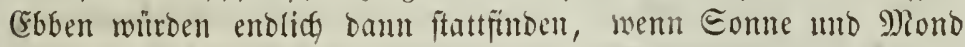

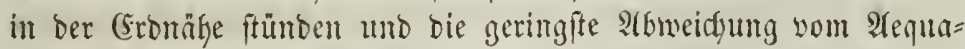

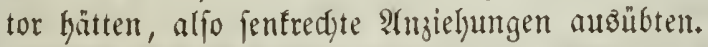

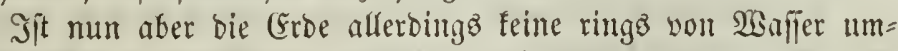
flofiene Singel, fo ift fie bod) fait zu $3 / 4$ bom Mlicere bebeft unto

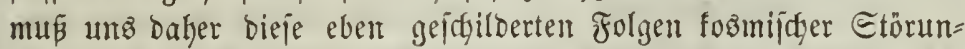
gen, wenn audh mannigiady mobificirt, jehen lailen. In ber That find fie bas, was wir (Ébe und Fluth nenten. Mur bie \&änber=

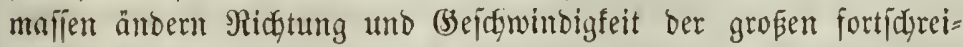
tenden Welle. Säüten unb Meerbujent lenfen fie ab, Untiefen und 
Snjeln verzögern fie. Tage fann ez währen, elje die gef̧emmte Fluth cintritt; und ftatt ber in einer gewifient Beit nach ber (5ul=

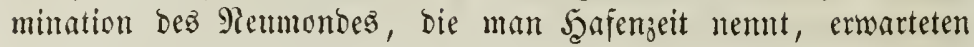
Epringfluth erideint oft eine ältere abgelenfte Fluthwetle. Fludy

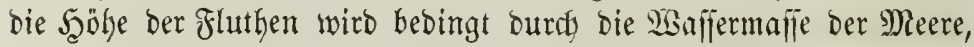

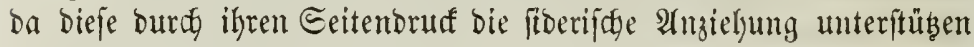

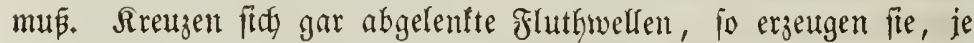
nachbem Fluth und Fluth ober Fluth) und (sbbe zujanmentreffen, eine

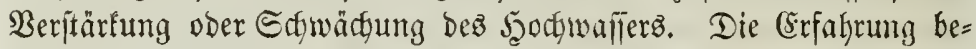

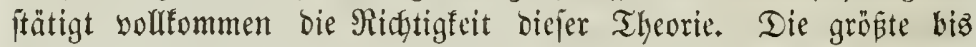

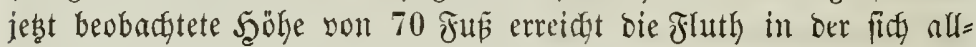

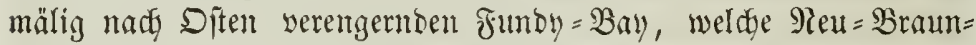

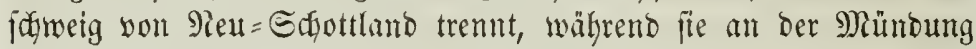

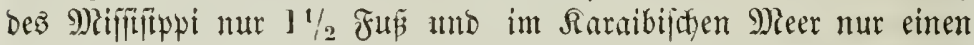

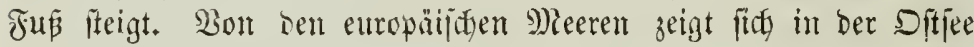

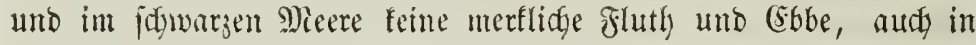
Dem mittellantoijden Mieere ift fie faum waljentelybar unto erreidgt nur an wentigen Srten, bejonters im abriatijaen Meere, bie Şölye

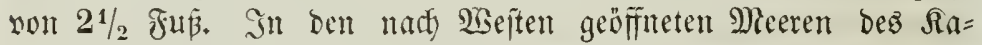
nala uno bes Bujenz von Briftol erreicht bie Epringfluth bagegen

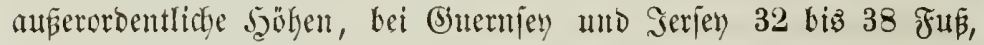
bei Et. Malo 46 Fur, an ber Mündung der Eavent 45 ₹uñ.

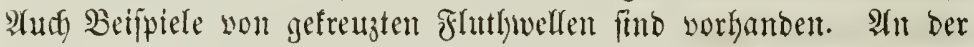

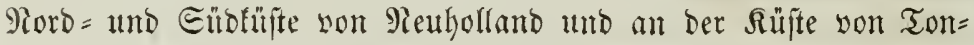

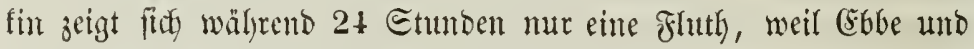

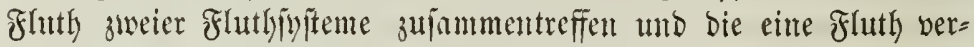

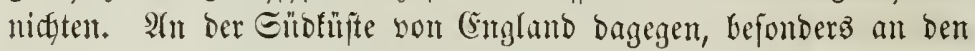

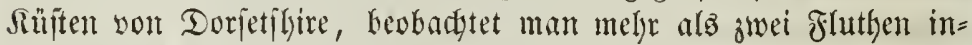
nerfyalb 24 Etunten, weil bie abgelenften Flutfwellent einanter jolgen, nidft freuzen.

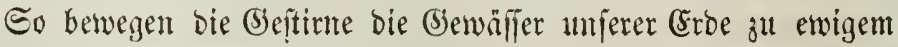
Epiel und ewiger llnuthe. Eie führent bie \$itere in hohen $23 e l=$

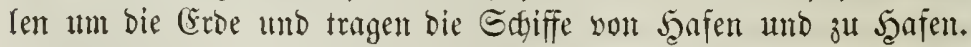

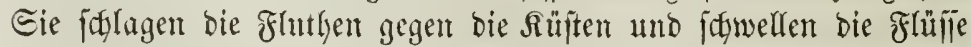
meilentweit in ifgr Bett binanf ober thürmen fie aut ifren \$lündun=

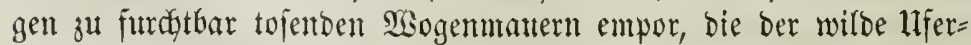
bewohner dez 2 mazonenjtromz \$ororoca, daz fradjenbe Meer, 


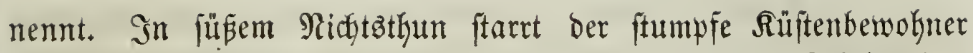
auf zur glïhenden Sonne ober trảumt beim bleidgen Şyeine bez ) Mondez; aber er ahut nidyt in ifnen bie Führer jenter unkeilwolfen Fluthen, bie joeben jeine Sghtte zertrimmerten, uno benen or feine Sabe entreisen fonnte, wenn er Die \$rophezeifungen ber Şifien= fdy aft bemust hätte. Dod er giebt Darin jemen Bebildoten nidyta nach, welde in 9Rond und Sonne wohl nady ben Urhebern von Bitterung uno $\mathfrak{R}$ rantheiten pähen, aber nichtż bavon wij̄en wol=

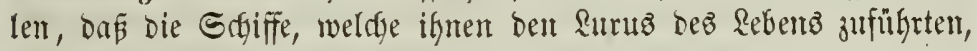

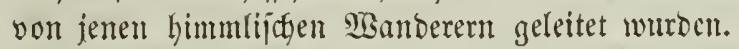

Unter bem Ginflufie der fiderifyen Pnjiebung und ber Gro= rotation erfalten uatürlich die gefammten Siewäfịer bes Dceanz nady ben Gejetzen der Träglyeit cine eigne Beweghng von Diten mady $\mathfrak{B e j t e n . ~ ( S i n e ~ g l e i đ j e i t i g e ~ F o l g e ~ w i r b ~ a b e r ~ a u d ~ b i e ~ E t r o ̈ = ~}$

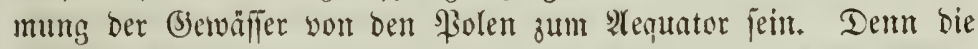

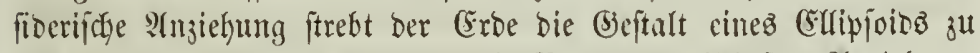

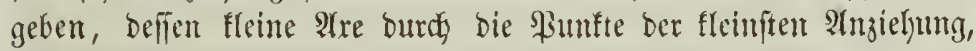
alfo bie \$ole, beftimmt wirb. Daker ftrömt bas Mleer yon ben Polen bent argezogenen ßunften au, um bort bie fortfdreitenbe Flutfyelfe zll bilden. Berftärtt wirb biefe \$olarjtrömung burd)

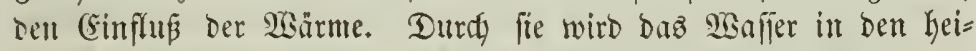
Een Aequatorialgegenben burdy bie liberwiegente Berbunfung be= ftänbig verminbert, in ben falten Folargonen bagegen burdy bie

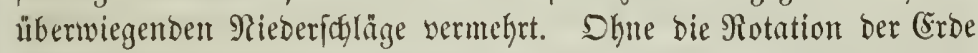
würben fidc aljo ein Etrom finlteren 2Baffers in ber Tiefe yon ben

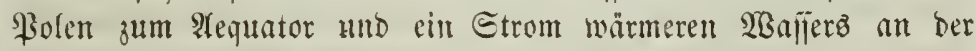

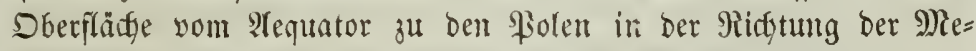
ribiane ergießen. Durdy bie Rotation Der (5rbe aber und ifgre von den ßolen zum 2lequator zunehmende Gefdumbigfeit bleiben bie von Den \$olen herabjtrömenden Shemäjier mit ifrer geringeren (Se=

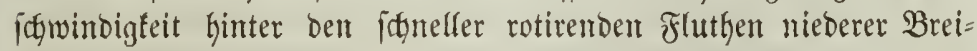
ten zurüf und erhalten barum itgeinbar eine wejtlide arblentung fo wie umgefehrt alle vom 2requator abfliefenton Etröme in ben langjamer rotirenden Breiten nady Diten abgelenft werben. Eo

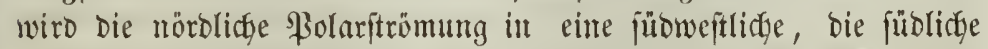
in eine norbweftlidge umgemandelt, uno beibe vereinigen fich in ber Rähe Dez Aequators in einen weftlidgen, mit einer Befdymindigfeit 
von 1 bis 8 Jup in einer Eecunde die Keipen 3onen ber Erbe umfliependen Etrom. Da aber bie \$olarjtröme bas falte und bidyte

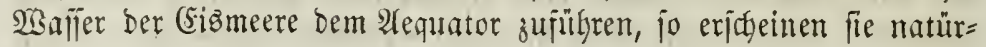

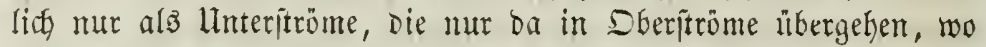
ber jobädgere Ealjgehalt fie über bie jowwereren, jalzreidyen tropi= idgen Meere erfyebt. Als joldye fennen wir bie arftipte Etrömung,

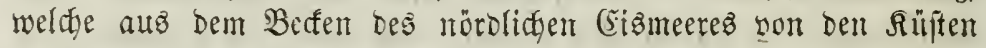
Exibbergenz uno Norwegents, wie aus ber Bafinzbai gewaltige Mallen yon Treibeis bis in bie mittleren Breiten Der $\mathfrak{A}$ zoren herab= fühnt und bie Siewäjer, welde fie ourdjptromt, um $7^{0}$ unter ber herridgenden \&uftemperatut erfältet. Durdy Sgumbolbt wourbe eime

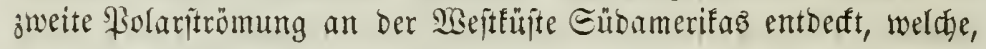
aนz Dem jïblichen Cismeer ftammeno, erfit bei ben (jallopagozinjeln in bie allgemeine $3 e j t i t r o ̈ m n g$ überigeht unb anf ifrem gangen

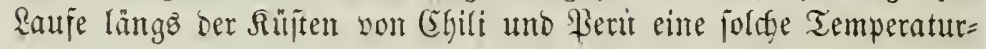

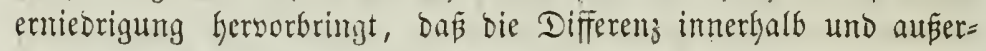
Galb ber Etrömung auj $10^{\circ}$ pteigen fann.

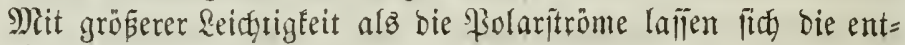
gegengejebten, oceanijøen Fliijen gleid)enten Etrỏmungen nactwei=

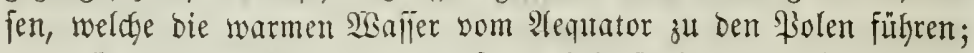

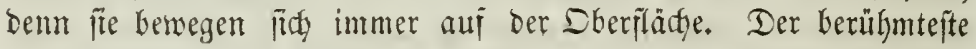
unter ifnen ift ber Golijtrom, welcher, aus den vereinigten Strö= mungen dez Mericanifdyen (5oliz umb Der Meerenge bon Mucatan

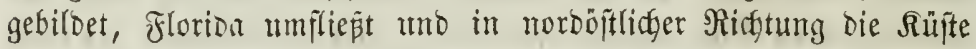
Der Bereinigten Etaaten begleitet, um fid endich, abgelenft burch Den falten Bolarjtrom, ju verjweigen und theils findidy gegen bie Azoren Gin abjuflefen, theils die Moromejthijten Csuropas und bis= weilen jelbit Eibiriens eifïge (Siejtabe zu bejpülen. Bei jeinem $\mathfrak{u} r=$ fprung ein idmmaler Etrom, 8 bis 10 geograptijace Meilen breit, belynt er fich allmälig bis ju einer Breite von 60 bis 70 Meilen aus, serliert aber eben jo viel yon jeiner Beictwindigfeit, bie bei Floriba $8 \tilde{J} u \tilde{B}$, bei den $\mathfrak{2}$ zoren noch einen $\mathfrak{F} u \tilde{B}$ in einer Eecumbe beträgt. Eeine Temperatur teträgt 2 njanģ $25^{0}-26^{0}$ und über $=$

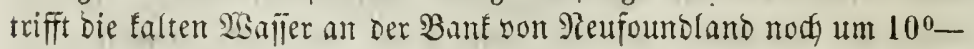
110. Eo trägt ex jeine Temperatur an bie Răuten bes atlantifhen

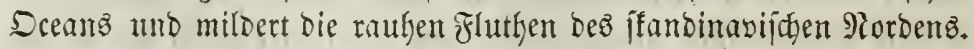
Styon lange yor ber Entoefung 2 merifas brachte ber (Solf= 
ftrom Boten ber neuen $\mathfrak{B e l t}$ an bie Ufer Cruropas: Thilfie, (jiefledbte, fünitlich bearbeitete Stücfden S2olz. (Solumbus felbit eriuly bon einem Bewohner der Izaren, Daß man wunderbare Boote, "bie midgt finfen founten," mit freitgefidgtigen, feltia =

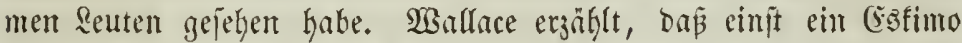
in jeinem Boote in ber $\Re$ ähe ber Drfney $=$ Smjeln erfdyienen jei. Zur 3eit Dez fiebenjäfrigen Sirieges brachte ber Bolfitrom bent Şampt= majt eines vor Єt. Domingo geftrandeten Єdiffes nady Edyottland herüber. (Ein ander Mal warf er SBalmöltommen an bie (Seftribe Englandz, bie man alz lleberbleibjel eines am Eap Lopez in 21frifa geftranbeten Єchiffes erfamnte. Dieje lebeten beisen Thatjaden fünn= ten einander zu wideripredsen jatinen, unt boch find fie in Dem

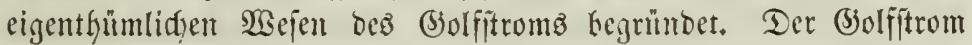
ift ein ganzes Eyftem, ein Rreislauf ocentifuer Etrömungen. Der

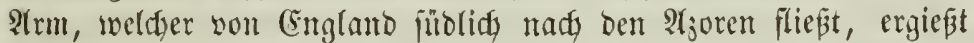
fich mämlidy in ben grofen 2tequatorialftrom, ber son ber afrifant=

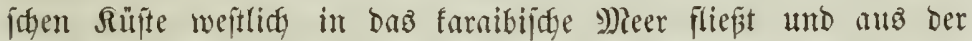
9)teerenge son florida als (5jolfitrom wieder gervortritt. Die rufige

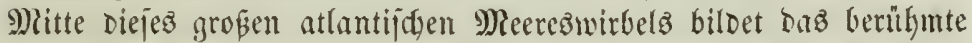

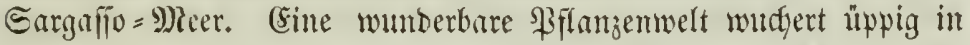

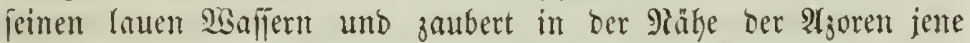

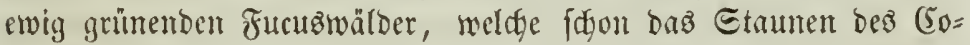
lumbuz erregten.

Der mericanijdye Solf bildet gleidjam einen Dient, bejlen Bärme, Durdy Den Golfiftrom in ungekeure Fernen geleitet, Den Rorbmeften Suropas zu eintem Treibhatje madt. Tropifde

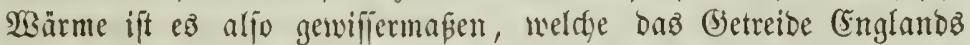
reift uno bie Trauben Epantiens uno zrantreiçz rötlyet. Fuf Der

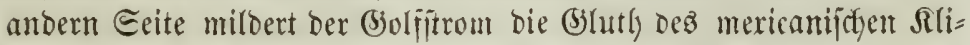

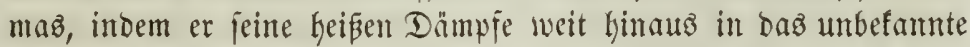
arftijche Baffin trägt. Bonl Dort Ger felynt er, ftatt mit (B) futhen,

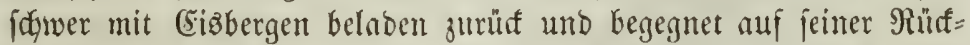
felyr ber Geiben Fluth in ber Räbe Der Meufoumsland=Bant. In biejer Begegnung brängt er Den uriprünglidjen (S)ofjitrom jurürf uno bilbet fo eine hufeifenförmige Srümmung bon mehreren Scunbert Duabratmeilen Flädge, gleidyjam einen $\mathfrak{F a f e n , ~ i n ~ w e l c h e n ~ b i e ~ C i z ̇ = ~}$ berge zu ifrer enblidgen $\mathfrak{A}$ uflöung cinlaufen. 
Dogleid) der (Golfiftrom bereitz im 16. Sahrhumbert von Eir Shumphrey (Silbert entberft ward, fuhren boct bie Eeejahrer nod

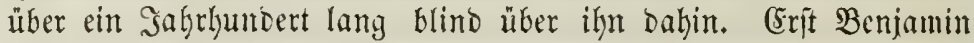
Franflin legrte jeine Bebeutung jür bie Edjiffjafint fennen. Im

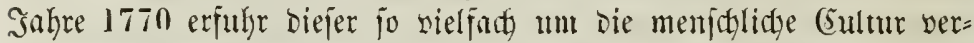

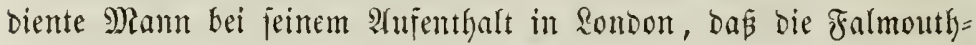
Boftidfiffe nady Bofton gemónhlich 14 Tange länger unterwegz jeien,

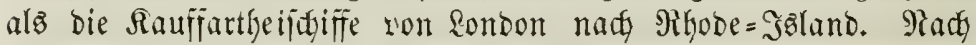

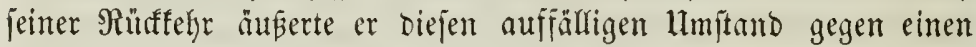

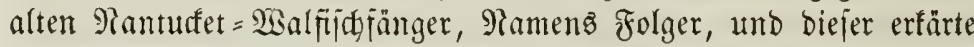

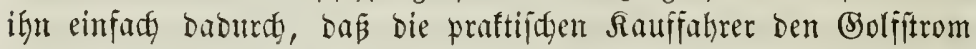
benuąten. Folger zeidunete auj Franflinz Berlangen den Bolffitrom auj eine Eeefarte, uno bieje Zeidgntming war fo getrau, báp fie noch

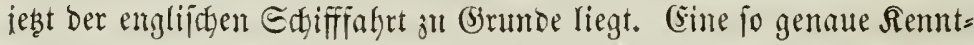

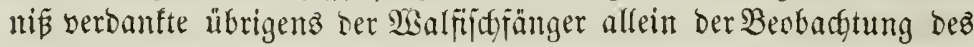
Walfifides, ber niemalz in ben bjolfftrom lineingeht, wohl aber gern fich an ben lifern beffeltben auffält, wo er bie reichfte Pahrung findet.

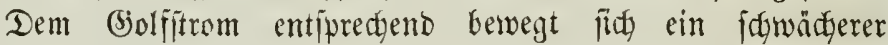
Strom in füdliḑen Beffen bes atlantifiden Meerez längz ber

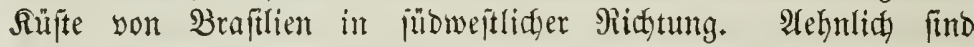
bie Bewegungen im Stillen Dcean. Sin norböftlicher Strom, Der aus ber Meerenge von Malacca Gernortritt, bejpült Gier bie

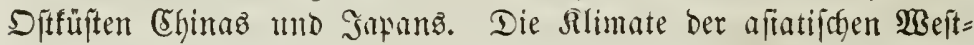
füften entipredgen Dafer ganz Denen Der amerifanijhen Diftüiften.

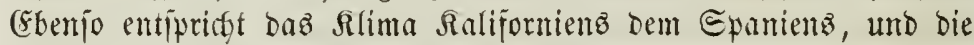
janbigen, regentojen Şbenen Unterfaliforniens erimern an 2(frifa.

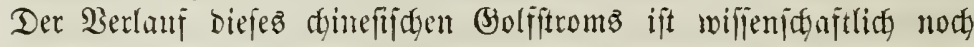
nidgt hinreidgeno erfundet. Man weiß nur, baß er füblich von ben

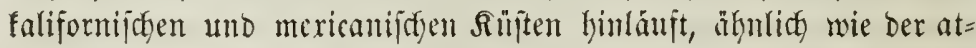

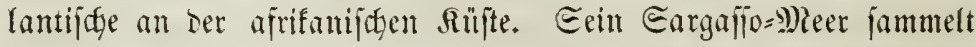

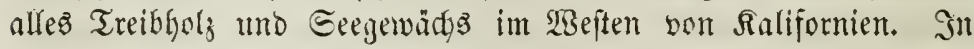

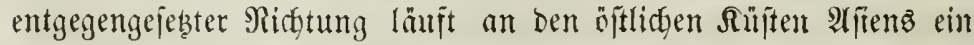
falter Strom Gin, ähnlidy Dem falten Ctrome zwifden bem Bolf= from uno ber Rüfte Pienfoundands. (Gr liefert Den Bhinefen gerabe jo ifren Peictuthum an Fiiden, wie betanntlidy jener atlan=

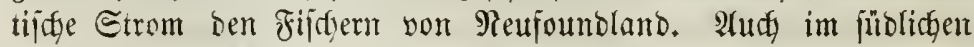
Thyeile bes Stillen Dceans tritt eine golfiftromähnticte Strömung 


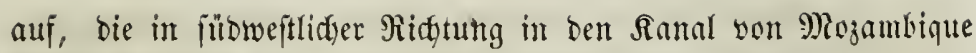

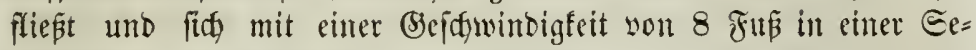

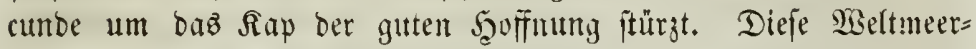
ftrömungen find $\mathfrak{e B}$, weldye fehritraß̧en ber Continente über ben Dcean augbreitem. Sie be= günftigen ober verljindern ben Berfely bez einen Rantez nit bem anbern; fie ritfen weit entfernte Slläge eintanter nahe utmo trennen,

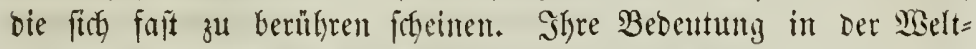

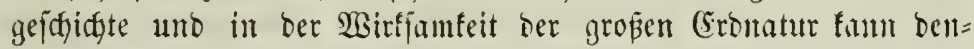
fenben Beiftern midgt entgethen.

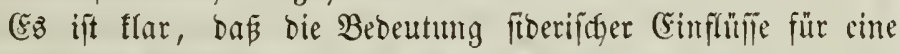

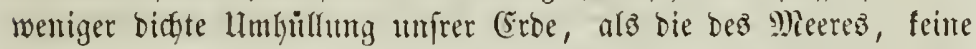

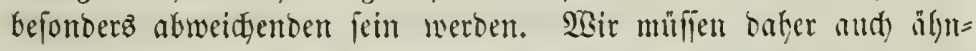

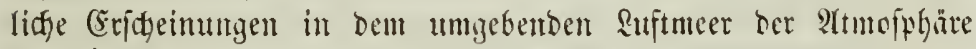

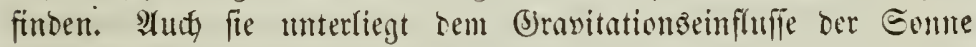

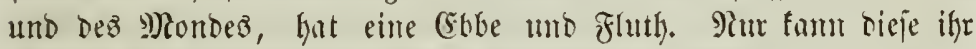

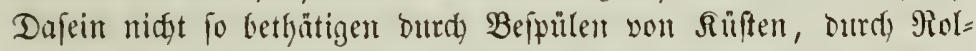

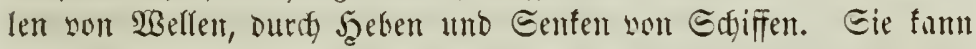
fid alfein bemertbar madyen burdy bie yon ifgerjeugten Edymans fungen im Ruftorut, bie in ben Differenzen Der Barometeriftüne fitdetbar werben. Begreiffidjer 2 Beife find bieje aber fo fleine Briòs Ben, báp fie faum Durds bie Beobadtumg nadygewiefert werben fön=

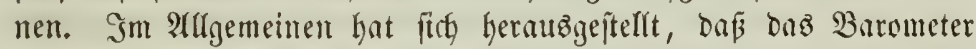

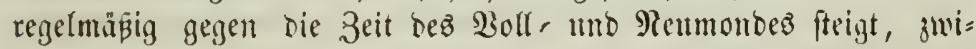

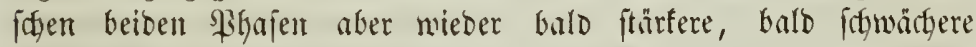
Edimanfungen erleibet, fo baß ber hödfte Barometerftanto gemöbn= liđ in bem leģtent Biertel, ber niebrigite nady bem eriften Biertel eintritt. EGhenfo erreidgt baz Barometer einen hödffent Etant in Der (Eroferne, cinen tiefitten in her Eronäbe bes Mondes. Den Barometerftänden entfpredfen zugleid, nach Theorie und Erfalyung, alferbitgż, wie bir fehen werben, in einer gewieifen Beidtrüufutrg, bie Regenmengen, fo Dap in ?IIfemeinen mit bem Eteigen bez

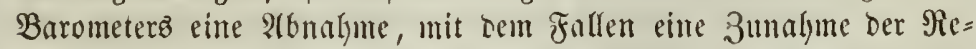
genmenge verbunben ift. So fümtent wir aljo, ofjne fürchtell zut inü|jen, ber Räderlidfeit antheimzujaflen, bie Beflauptung wagen,

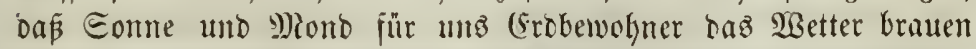

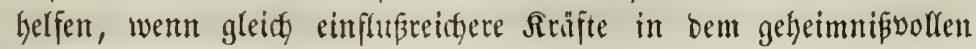


Epiel ber $\mathfrak{A}$ tmojphäre bie Şerrichaft führent. Diefe geringen $\mathfrak{B} \mathfrak{a}=$ rometerifjwanfungen, welche im Mittel mur $0,6+$ bis 1,16 sinien betaracn, entipredjen in ber That bem Begriffe einer atmojphä=

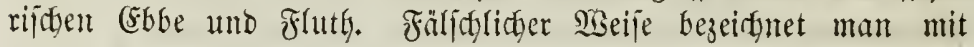
biejem Pamen häufig eine gamz anbere Eriddeimung täglidyer Baro= meteriffwantungen, welde weder vom Mionde, utod yon ber MaF=

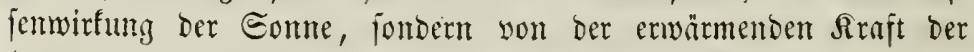

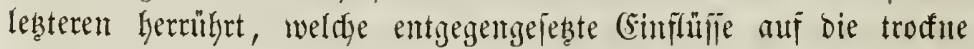

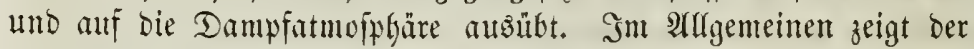

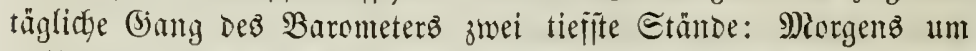
$3 \mathfrak{W h r} 45^{\prime}$, Abentoz um $4 \mathfrak{u h r} 5^{\prime}$, und zwei Göchfte Stände: Mor=

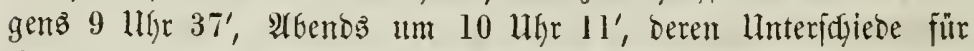
Saalle im Mittel mur 0,2 Sinien betragen, am Aequator Dagegen eine Sinie erreidfent. -

SBidftiger aber alo alle bieje Bewegungen fïto bie Strönun= gen, weldye aud) in ber Ruft burdy bie Rotation ber (Frbe in Ber= bintoung mit ber ungleidgen (Erwürmung Der Ruficfictent hervor= genufen werben. WBie bie (jemǟjer, fo ftrömen and bie Ruftmafien

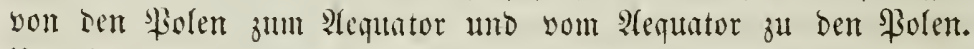

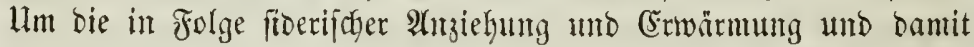
verbuntoner Berbünnumg entftandene Reere bez äquatorinfen \&uftgür=

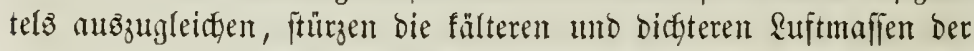

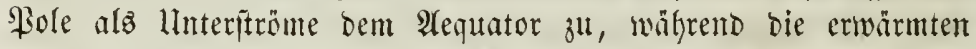

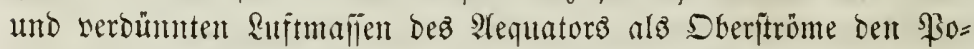
len juflięent. Beide gelangen in Breiten, beren Miotationtögejdyin= Digfeit vout ber ifrigen abweidt, bort zu=, hier abuimmt, unb blei=

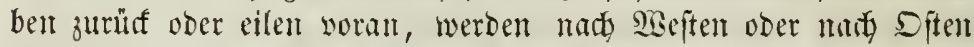
afgelenft. So entifteken Süboit = und Norboitftrömungen in ber Tiefe, Suldowejt = und Mordweittrömungen in ber Şöke, beftändige Winde, die unter Dem Mamen ber bireften umb zurühffehrenden Baffate befunnt finto. 3wifden den 2 sendefreifen begegnen bie bi= reften \&alifate cinturber uno gehen in Sitwinbe üher, währent bie

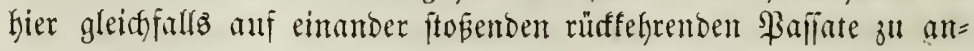

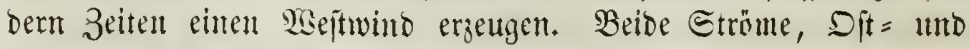
Beftninte, treten in biejer Region, weldse man bie ber Sinlmen

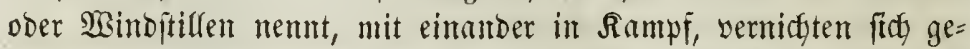
genfeitig uno erzeugen $\mathfrak{B}$ indojtillen, ober erregen furdftbare $\mathfrak{B}$ irbel= 
winde und Drfane. Auth im 2lorben werben ben \$allaten ifre (Srenzen gefteft, inbem bie rüffefremben Baffate in Folge bes Crs= faltens zum Meeresniven herabjinten uno im Sampfe mit ben

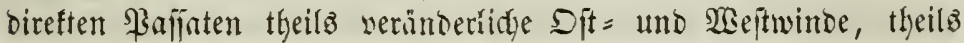
den tropifdyen äfnlidbe Etürme erzengen.

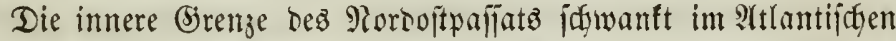
Deen zwifden $5^{0} 4 j^{\prime}$ uns $13^{0}$ mörol. Breite, im gropen Deean zwifden $2^{0}$ uno $8^{0}$ Meere jwifden $28^{\circ}$ und $32^{\circ} \mathrm{n}$. Br., im gropen Deean jwijthen

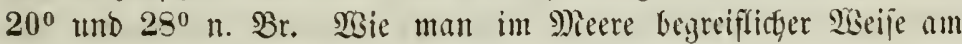
leidteften bie Sberitrome twafhrnimmt, jo madyen fidt in ber 9 (tmo-

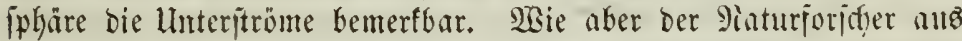

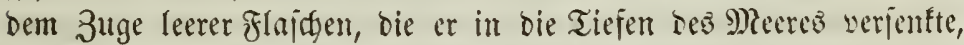

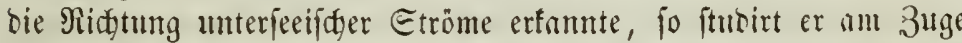

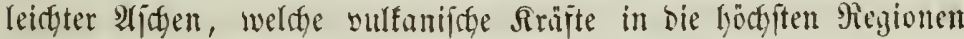
fdleutorn, ben Etrom, ber lodd über feinem Saumte Sahingeht. So wirb es ifm möglid, bie mamngfaltigen Erjdeinungen in bem

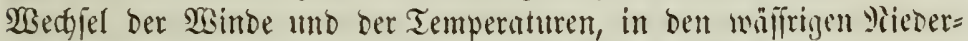

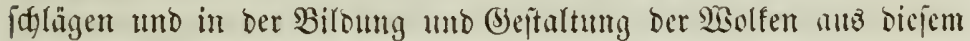
Rampfe nuf = und abjteigenter Euftifröme zu begreifen. Denn trobs

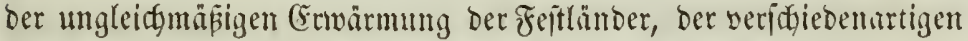

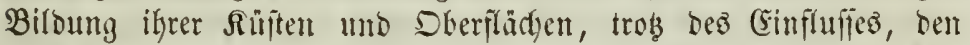

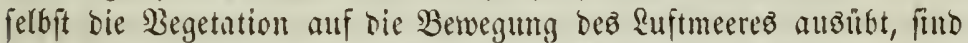
bieje Strömungen es body, weltbe im शllyemeinen an allen Srten bie herridyenben 2 Binbridutungen bebingen, mögen fie felbjt aud oft gemug in ifrer llmgeitaltumg faum nody fenntlidy fein.

Echon in ber Durch Beftänbigfeit ausggejeidgneten Aequntorial=

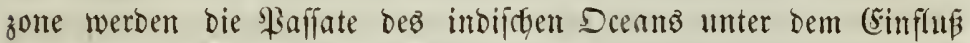

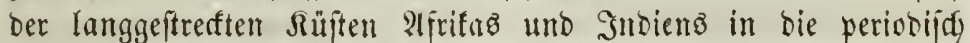

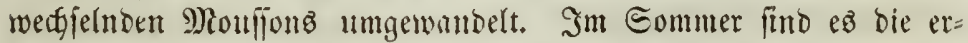
Giksten Flädyen von Defan, ju benten von ben fübleren Meeren cin

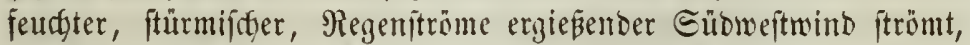

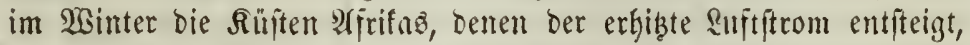
um burch bie tübleren Rüfte von Norboft her wehender, fanfer Binde erjegt ju werden.

Regellofer find nntürlidy bie WBindwerkältnifie der Feftlänoer, bejonberz ber gemäp̈igten 3onen. Bald herricten ßaffatwinbe, bald 
Iofale; Gald biefer in ber F̧öge, jenter in ber Tiefe; bald wito bie

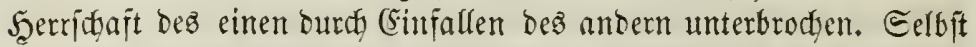
in biejer ipridgmörtlidy geworbnen $\mathfrak{B}$ ern̈nderlidffeit und Sepeslofigfeit

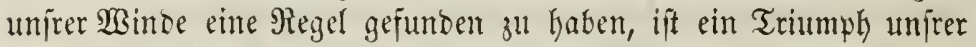

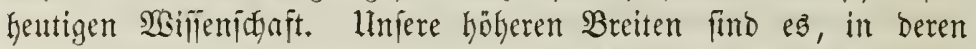
unteren Euftididiten ber berabfintenbe Aequatorialiftrom mit ben

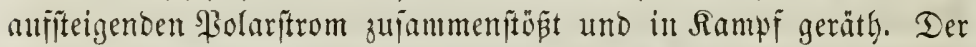
eine verbrängt ben andern, weidyt ifm nad oben und nad) unten und zur Eeite aus, fo bá beioe Etröme über= und unter= und

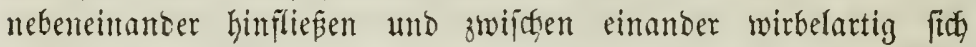

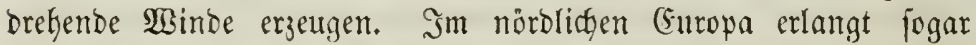
ber rilffegrembe ober SW.-Fiafiat ein Hebergewidft über ben No.-

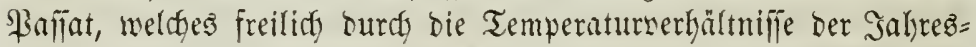
zeitent geänbert wirb. Im Eommer walten bie reinen $\mathfrak{B}$ Beftwinde

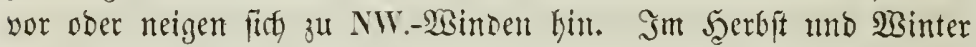

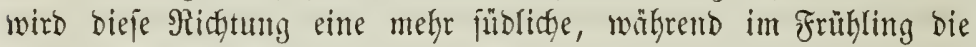
Ditminde an Gäufigiten auftretert. Die Wectjet uno llebergänge werden burdf) jene erwähnten $\mathfrak{B i r b e l}$ erflärt, meldje bie ganze ge=

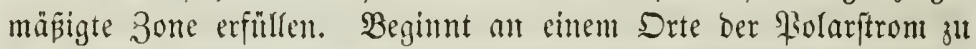

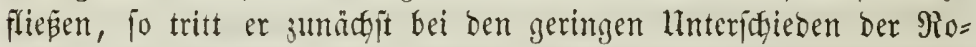

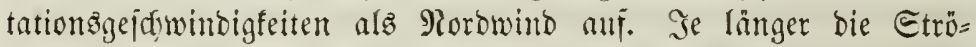
mung anfält, Defto meiter fließst bie Ruft son Morben Ker, befto

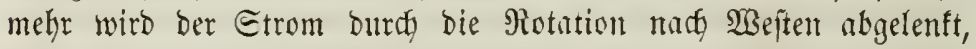

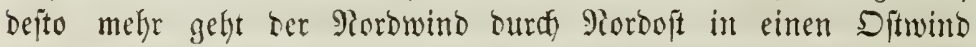
über. Tritt mun eine Alequatorialftrömung ein, bie fid gleidyfaflz anfangs als reiner Eutbmind zeigt, io wandelt fie bent Dftwino in einen Euldofitrinto um ober verorängt ifyn ganz und herrifot als Eüowino. Bei längerer Dauer treffen bie entfernteren Ruftmafjen aus niederen Breiten ein, weldae burch bie abnehmente Rotations=

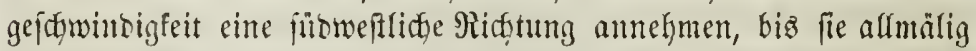
in Meftwinde übergefen. (Fin neuer \$olarftrom wirb endide ben

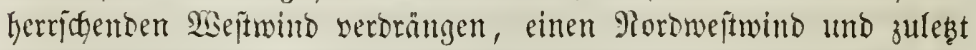
wieberum einen Rorbmino erzengen. So burdfläuft der $\mathfrak{B}$ sind im

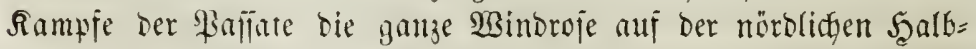

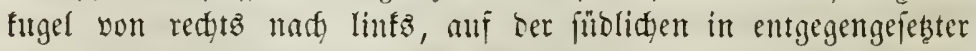

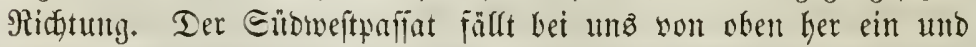

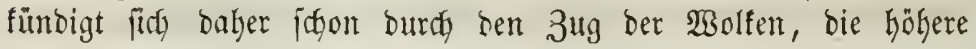




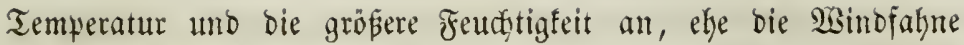
jein Dajein erfäbrt. Der Mordofimind bagegen brängt von unten her jeinen Begner zurhtef und erlaubt oft nod) lange nad jeinem

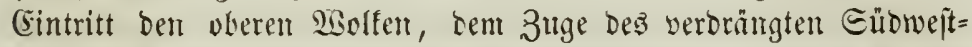
winbes zu jolgen. Barometer und Thermometer nefmen imnigen Antheil an ben $\mathfrak{B e c h j e l n ~ D e r ~ W i n d r o j e . ~ D i e ~ B e r a ̈ n d e r u n g e n ~ a u f ~}$ Der 2 efteite ber Winbrofe fitto mit Den Bewegungen bes Bard = meterz gleiçzeitig, wäkrend bei ben Beränberungen ber Ditfeite bie Anjeigen bez Barumeterz ben eintretenden 9Rieberjalägen voran= gehen. 9)it Eintritt bes \$olaritroms fällt baz Thermumeter, jteigt bas Sarometer, umgefęrt bei eimfallenden Afequatorialïtrömen. Der vom (Fis]neer her welyente fulte und jawere Porboftwind wird in

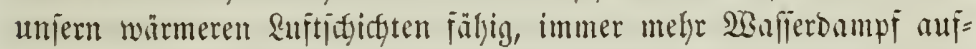
junehmen; er loft barum imje 2 Solfen auf umb bringt heitres Wetter, Rălte im Winter, Bärme und Truftenteit im Eommer, Der aus ben Tropen fommente warme und feudyte Ellomejtwind bagegen wirb burif bie Temperaturverminterum gezmungen, fids jeines Dunitgehaltes Durd, Miederjolag zu entlebigen; er bringt berwölften Scimmel, im Winter mildere $2 B$ itterung und Edthee ober Thauwetter, im Commer Regen แmb fühle Witterung bei lange bedeftem Şimmel oder brüffende Şize mit Sewittern und Etürmen.

Befanntlid) gilt im Aftgemeinen bas $B$ arometer als ber eigent= liche Betterprophet, uno eв burrte wenig Saaushaltungen geben, in Denen ein Wetterglaz mit feinter feften şetterffala fellte. Wie wenig Bebeutung aber joldgen Wetterifalen jufommt, geft fison aus Dem Borbergefagten herbor, namentlich aber aus bem limitande, ba

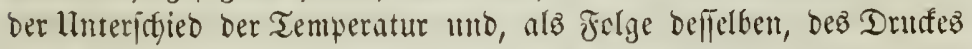
ber beiben entgegengejebsten \&uftftröme im Binter viel größ̈er ift als im Eommer. Wie aljo bie Bewegungen reş Burometers liber= haupt im Winter viel gröper fint als im Eommer, fo müpte audy Der Mapitab, welder ber Efala ju Srunde gelegt ift, im Winter we= nigitenz boppelt to groß jein als im Eommer. Witterungäregeln

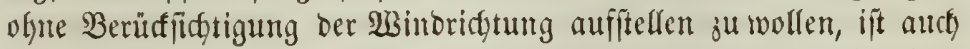
fifyon beşalb ein bergeblidjes Bemülen, weil ja auj ber Bejtjeite Der Winbroje bas Barometer bei Rieberjdäagen jteigt, auj Der Dit= jeite fält. Daju fommt, Daß die Erjdyeimungen der einen Eeite oft in bie ber anbern libergelyen, ofye dak in ber Form bes gie= 
beridglage eine Alenterung ober Unterbredyung eintritt. Wenn es

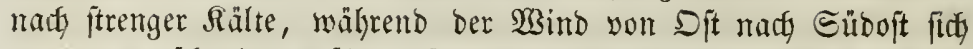
wendet, ju jofmeien anjüngt, fo mildort fid allerbinga bie Temperas tur mit fallendem Bacometer, ohne aber über Den (Sefrierpunft ftei=

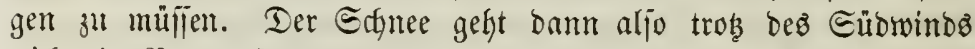
nidyt in Miegen liber uno Dauert jelbjt ununterbrodgen fort, wenn

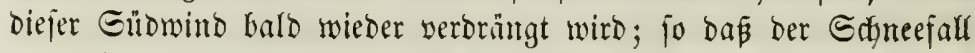
Dann in Der That aus zmei verffiebenen Bildungen bejteht, Deren

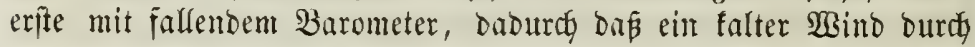
einen warmen verorängt wirb, erfolgte, währento bie zweite mit ftel= genbem Barometer, wem ber warme Wind bem falten wiederum widh, eintrat. Die befmunte 2istterregel: "neuter Ectuee, neute

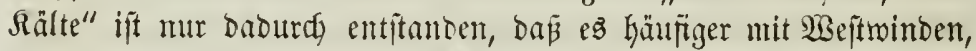

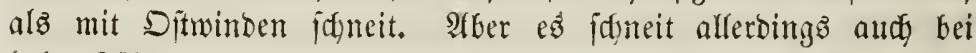
hoher $\mathfrak{R}$ ălte, nur nicht in Floden, fondern in Form feiner Eiżnabeln, bie fid beim Jeerabfalfen aus ber obern marmen und feudeten \&uft in ber untern trof́nen nidft vergrößern fünten. Diejez eine Beipiel wirb finreichen ju überzeugen, wie wenig innere Wabrheit alle unje ăf einjeitige Beobactung gegrübeten Sistterregeln befiţen. Die Simbe fund unje beiten Betterpropheten, wenn bas Barometer namentlich ifre 2tus̃jagen controlirt; aber ifre Strömungen und Bedjpel in Burauts beftimmen zu wollen, ijt ein eben jo großes

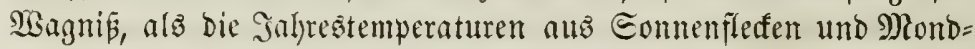
wedjeln oder aus $\mathfrak{2}(\mathfrak{b}=$ und 3unalyme des Solareifez zu errathen. Rody fernen wir bie Bejetze nidst, nad) welchen bie neben einander fliependen 2tequatorial = uno Polarjtröme jich lagenn uno balo bem

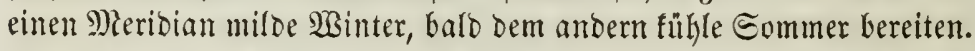

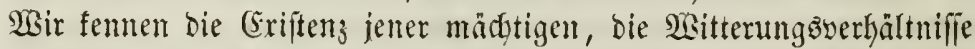

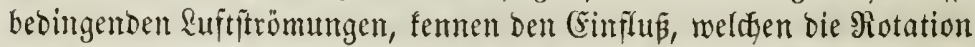
Der Eroe auf fie ausinbt, und ahnen jum Theil wenigitents bie Csin= wirfungen ber (jravitation Der Sonne unb bez \$) Mondez, welthe in ifren Folgen vielfeidyt bebeutenter find, als fie uns in ben faft unmertli=

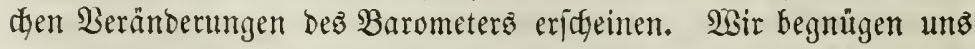
lyier mit bem einfadyen Mefultat, daß Meer und Rufthülle unfrer

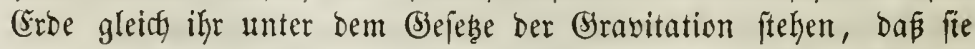
Durd toomifose Sraft in ewiger Berwegung uno emigem Sampfe erbalten werden. 


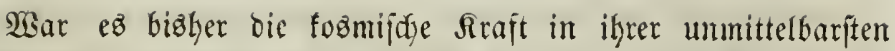
(Einfactheit alo Mafjenanziehung uno Miotation, beren Baalten wir in ben Umbüllungen ber Eroe betradfeten, fo werben wir jeşt bieje

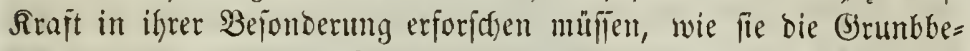
bingung Der irbiicten Rebenzentwifflung wirs. Der Edfoop ber

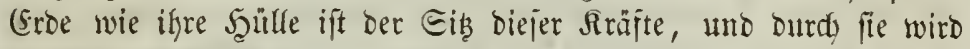

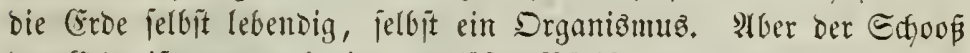

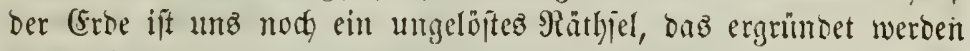

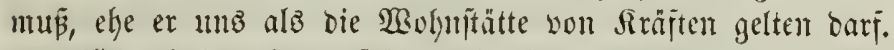

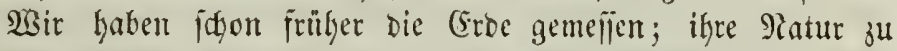

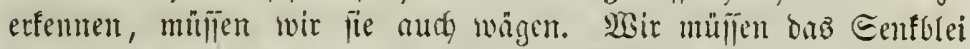
in bie ungejegenen Tiejen jenoen, um bie Didftigfeiten Der verbor= genen Malien zu eripäfen. Diejez Senfblei ift wieber bna \$iendel.

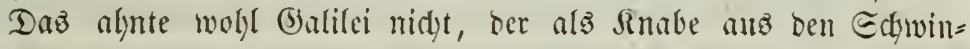

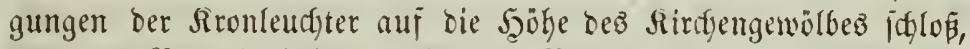

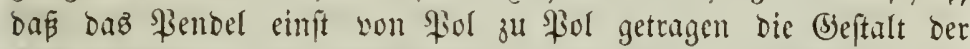
Eroe bejtimmen, bie Didjtigfeit ber Erojofidden, Jeöblungen im

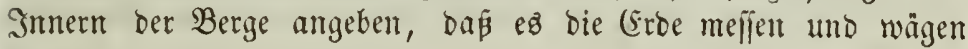
werbe.

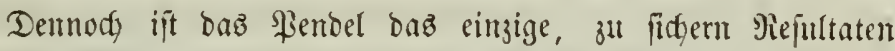
jührenbe Mittel. Indę hat man veriđiebne $\mathfrak{B}$ Bege eingeidlagen,

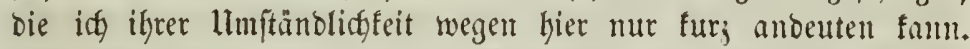
Der eine gründet fïd aulj bie Plblenfung Dez Bleilothz von ser Bertifalen in Der Mähe eines Bergez. Durdy aftronomiidde Mittel

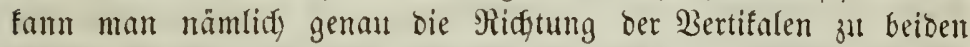

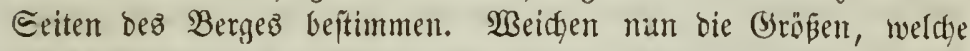
Die Beobactunt bes Rothez bafür ergiebt, von jenter ab, fo fann

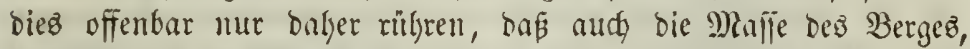

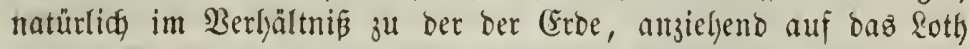

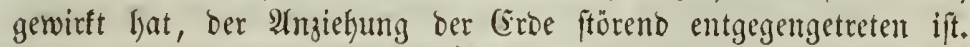
Rennt man min bie Malje bes Bergez, fo famm man nady bem

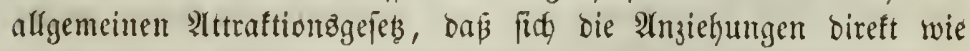
bie Maffen, umgefehrt wie bie Suabrate Der Entfernumgen verlyalten, bei ber befaurten (bröße ber (Eroe burdy Bergleidfung ifrer $2(1)=$ ziefyung mit ber bez Bergez bie Dicftigfeit ber ganjen (Erbe be= rectinent.

Edyon Bouguer hatte barauf aufmerfjam gemactst, baßj groß̧e 
Bergmallen, wie ber (5himborazo, burch) iłre Anziehung Das Bleiloth

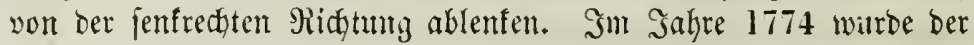

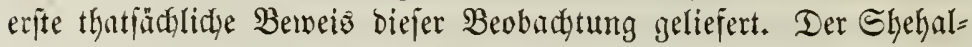

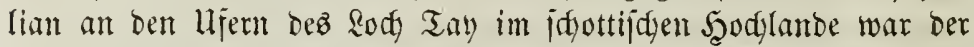

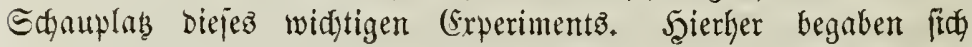

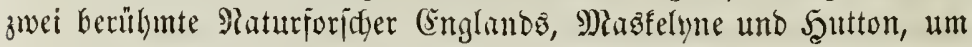

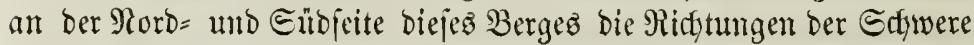
zll beobacten. Eie ridfteten an ben beiben Etationen $\mathrm{N}$ und $\mathrm{S}$

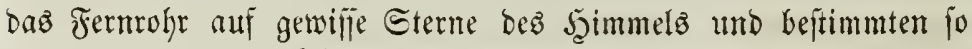
Den Unteridgied Der $\mathfrak{W}$ Binfel, weldye bieje Micftungen mit bem Bleiloth an beiben Drten madtent. Daburdy erhielten fie natürlidy audf bie Reigung ber beiben Bleilothe zu eimanber uno fonnten bieje num mit berjenigent vergleidyen, weldye fie ohne ben Berg, nady Der (Ent= fermung Der beiden Stationen yon einanber, haben mupten. Die

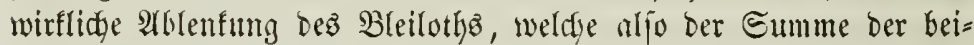

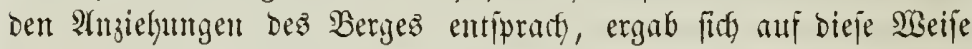
зи 12 Єectnden. Durdy eine genaute Bermejīnng Des Bergeż war man im Stande, anth eine amuähernoe Edäkumg Der Mafife bes Berges zu erlangen. Madyte mant mun ferner bie Boratsjeţung, Daß̉ bie Didjtigfeit Der (Eroe Der Didjtigfeit biejeş Bergez gleidy jei,

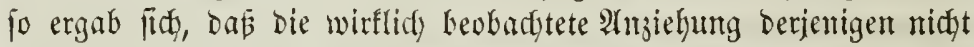

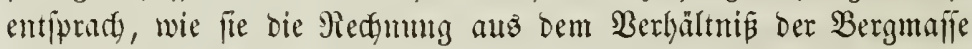

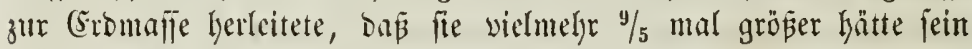

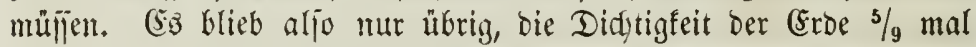
grö́per anzunefymen, alz die jentes Berges, bie man auj etwa $23 / 4$

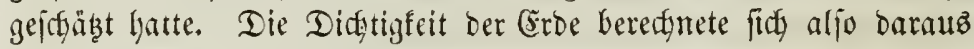

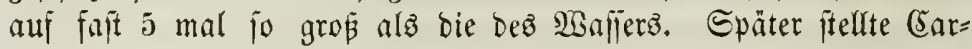

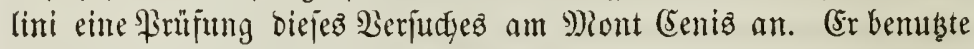

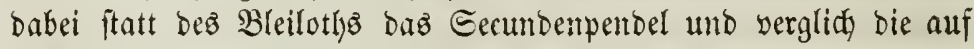
Dem BSipfel deż Bergez beobadytete Ränge Defifellen mit Derjenigen,

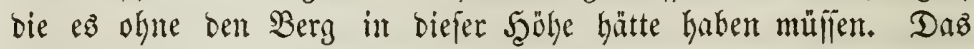
Rejultat feiner Beobadytung war eine Didjtigfeit ber Erobe, welcte $42 \%$ mal bie bez $\mathfrak{3 a f f e r z z ~ u ̈ b e r t r a f . ~}$

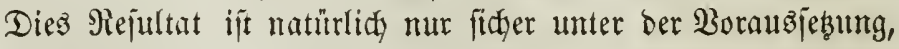

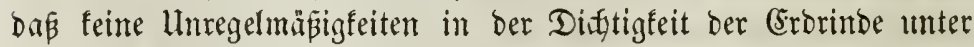

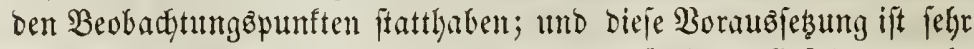
3meifelfaft. Daher giebt bie Drefwwage untrüglictere (Erfolge, umab= 
natủrlid aud fein Edfyingen beş ßendelä erjolgen. Bringt man aber bie Drefwage zwichen zwei grofe uno iffwere Maffen, fo wirb eine horizontale Penbelidjmingung entîtehen, weil jente Maljen in Folge ber Afrzilefung bie fleinten Rutgeln beftänbig in ifre ur=

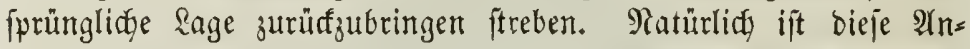
ziekung nur gering, uno bie Edjwingungen fint äuserft langáam,

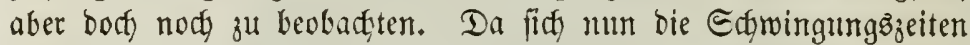
umgefehrt wie bie Suabrate Der Fallhöhen ober \$enbellängen ver= halten, fo fann man aus jenen bie Rănge eines Cecunbenpenbels für bie anziegenden Malien beftimmen. Da nun bie Ränge bes gegen bie (Erbe gravititenten Eecundenpendels befannt ijt, fo erbält

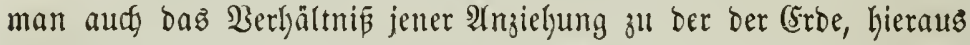
entlidy unt aus ber Entjermung ber angiefenden Mafien, aus ifrer Brrōene und Didytigteit bie Didytigfeit ber (srbe.

Daz Enbrejultat ber Berjudye, wildye mit F̧illfe biejer mit

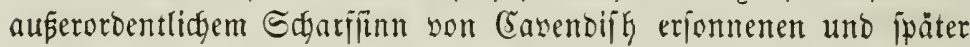
yon Francis Bailey serbeflerten 2hpparate auşgeführt murben, ift,

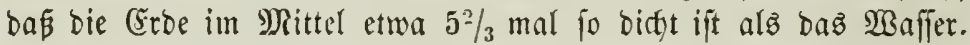
aber alle bie Erroberfläde bildenten Edjidyten find nur halb jo

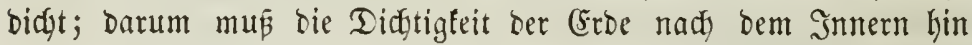
bebeutento zuntelymen; gejeflojienen Tieje ruhen, um oen pids unje ftein= uno eroartigen Mafjen gelagert haken. $\mathfrak{\text { Waz }}$ ijt aber bie Maturbefdyaffentheit biefes (Eroinnern? Sit ez eill Metallfern, eime glügende, gefctgmolzene, mur. burdf gewaltigen Druff zujammengelyaltente Maffe? Wisir wifien ez nidyt; wir fennen ja faum bie Minbe unfrer Eroe, faum bie bünne

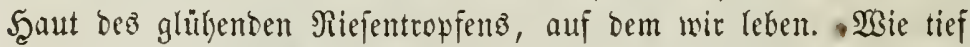
ift benn ber Menich in bie (Erbe gebrungen? Wenn ifn alld bie

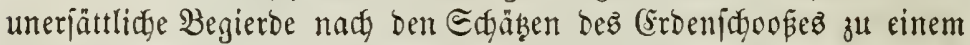
Sourme erniebrigt hat, Der lieber in bie Tiefe wühlt, alz nad) oben ftrebt, fich lieber in gardyt vergräbt, alż bem Ridjte entgegenbaut: faum 2000 Fun tief hat er jeine (Sruben unter den Epiegel beż Meerez getrieben, faum den 10000 ften Theil bez Erobalbmeffers; ; und tiefer reidgen jelsit faum bie tieffiten Bohrlödher unjerer arteft=

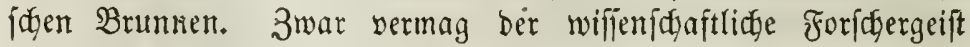
tiefer in baz verborgne Smmere ber Crrbe zu bringen. $200 h$ t $60 \mathrm{mal}$

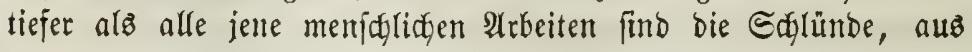


melafen die Bultane igre glühenben Maffen emporwerfen; und auds oa, wo Steinfohlenichidgten fid muloenformig einjenfen uno wieber aufiteigen, erjøliept find bem Beolugen eine geheimnifpolle Tiefe.

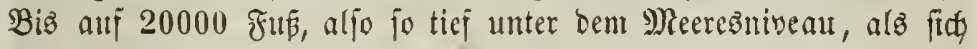
ber Chimborajo über ifm erhebt, vermag er mit dem Althe bes (5eiftes ifre Rrümmungen ou verfolgen. Dod, fügt er audy ju biefen Tiefen nod bie höchiten Theile ber gehubenen Erorinde, bie höchiter Sipfel des Şimalaya, fo min̈t ber ganje Raum, ber ifm

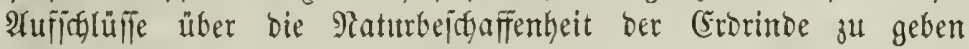

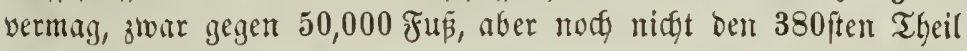

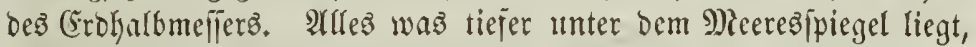
tiefer ala ber vom Sentblei erreidbte Meeresignumb, bleibt uns jo unbefanut, alв bas Sunere ber andern ßlaneten unjers Eomnen= [yitems.

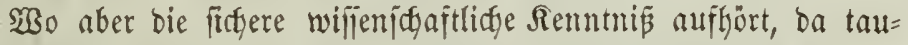
den wieber, wie bei ben fernen, unire Gonme umtreijenden Welten, wie in jenten geheimnipbollen Rebelregionen, buntle Rlynutgen, phantafitifge Bermuthungen auf. Man meinte, ber Druf, welden bie ïber einamber gelagerten Edidgten ber Croe auf cinamber aus= ¡̈ben, mülie bod, nady bem Mittelpuntte junehmen; man berednete, in welder Tieje flüfitge, ja jelbft luftörmige Etoffe ourd sen eig= nen Druf ihrer Schidten bie Didgtigfeit bez \$latins übertreffen mürben, und man fano für ben Rern der (Frbe eine Didgtigfeit,

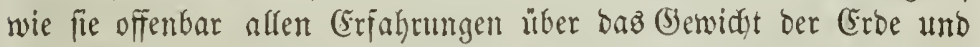
ifre Abplattung wiberjprady. Ilm (sintlang in bieje Wiberjprüdse 3u bringen, hatte fabon ber berühmte Salley bie (5rok aus̈gehöhlt unb burch einen in jener Interwelt frei rotirenden ungefeuren

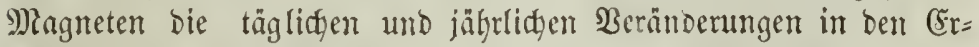

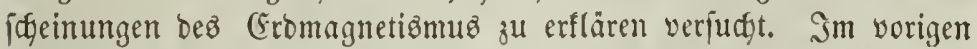
Jahrhunbert ging man weiter; man verlor fiç atto jenen fofon fehr gewagten und willfürliden Bermutfungen in nod phantafiereidere Träunte. Man bebölferte jente Soblfugel, in ber eine immer fidy gleidjbleibente Wärme herridte, mit Fiflanzen uno Thieren, uno

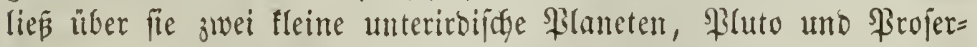
pina, ifh milbes Ridgt ergiểen. Nahe am Roropol, da, wo bas Bolarlidyt ausfrömt, war bie \$forte ju jener Interwelt. Dieje conberbare Träumerei ift gar niçt fo alt, als man gern glauben 
mödyte. Rod Alerander v. Şumbolot uno Scumphry Dawy wurben offentlich uno wieberbolt won einem gewifien Rapitän Eymmes zu

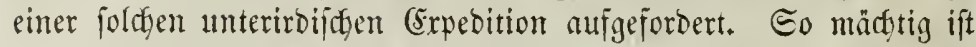
jene Reigung bes Menicten, unbefunmert um bas wiberipred 3engní woblbegründeter Thatjacten und alfgemein anerfannter

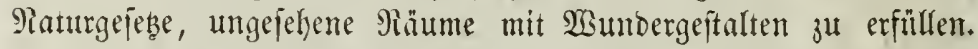
Dod nidyt franthaft mödte idy jene Reigung nennen; fie ift nur

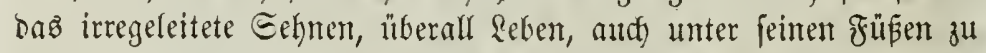
finden. (5̧ find heitre fiftionen, bie man nur nidgt mit lang= weiligem Ernft in ein willenjogaftlidges Bemand zu fleiden ver= fudben barf.

Rods find jene 3meifel nicht gelöit, nods ift jenem Drufe, weldyer ben Rern unjer (Grde fo unbegreiflid) zu verbidaten firebt, Ridyts entgegengejeţt. Co veriutyen wir es benn, ifm ons Reben

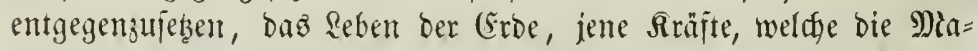
terie erfalten unb beleben, jene fosmijhen Sräfte, Durch weldye alle Welten mit einanber in imnigem Berfelyr ftehen. Die Edwere, Der Drute Der Majlen gehört Der tooten Materie an. Aber bie Materie ift nidgt toot, fie ijt jelbit lebendige Sraft. C5z giebt feine todte Natur, benn atı bem Tubten fam nimmer eil Reben er= waden. Dem Feljen entipriest bie Riflanze, Dem Sagfertropfen daz Thier, die ganze regungsloje Materie wirb jeden Mugenblia rebendig.

MBas ift Reben? Die Siflanze entfeimt ben zarten Samenforn,

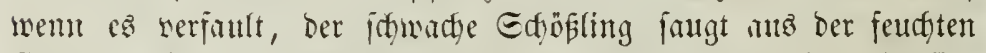
Grbe und Ruft feine Rafrung und jekst aus ben geraubten Gtoffen

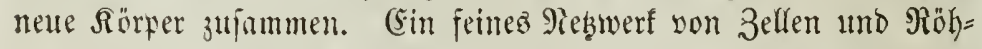

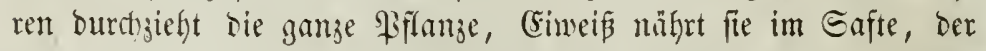
in ben (bängen auf= und nieberfteigt, Farbeftoff färbt ihre Blätter, uno Etïrfemelyl fammelt fith in ihren Samen zur Pafhrung für

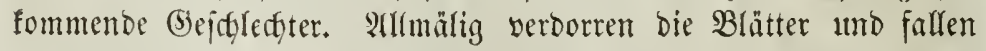
$a \mathfrak{b}$, mady uno nady verwanbeln fie fith in eine bunfle, pulverförmige Maffe, Den Scumus, und im Raufe ber 3eit verfdumbet aud biefe

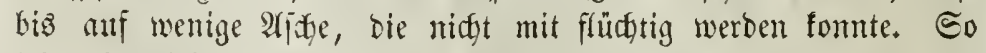
lebt, fo fitrbt bie Fifanze. Lnb was ift bas Rebent in biejem Badjen uno Eterben ber Filanze? Soll ez Der Baumeifter feim,

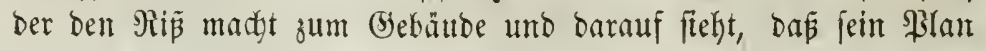


genau bejolgt werbe? Der Ban felbjt würbe dann willenlos yon

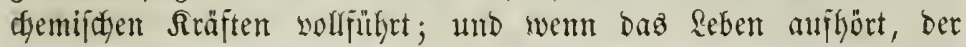
Bau verfäallt, dann fämen fie, bie Todtengräber der Miatur, bie ber Erde wiebergeben, was you ifr genommen war? Itber wer als wir bringt benn jene tobten, willenlojen Sräfte in bie Matur, wer

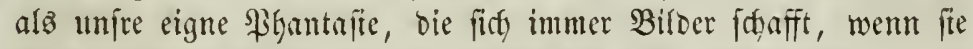
fidf) bie geheimen Urijadyen ber verwiffelten Rebenzeridgeinumgen ver=

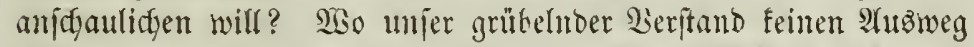
mehr findet, ba ift er fognell mit einer Siraft bercit, ber er alles Unertlärlicte, Unbegreifilidge zuidjieben mödste. Daz fimb freilids nidgt bie Rraffe, bie in Smnern ber Siatur walten; ez giebt

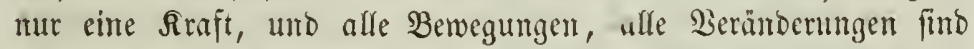
nur wedfelnde (Eridycinungen biejer eimen Saft bez Sebenz. Dic Materie ift jelbft Rraft, felbjt Reber. Sidft won aupent fommen in fie jente Sräfte, bie fie bewegen mo verwanbeln, bie einen હtoff zum andern ziehen, bie jie fidh behnen mo madjent lajien, die ihr liebliche Töne uno ftrahlendes sidjt entloden, bie ihr die Siflange entteimen Kafien unb aus ihrem Edgoobe bna frohe Reben bes Thie=

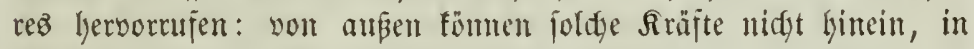
ifrem Innern foflummert verborgene Sebengfraft, wou innen ent= fpriefit ifre bes Rebenz bunte Füllle.

Das Biel dicfes Rebenz, daz in der Mraterie fajhmmert, daz

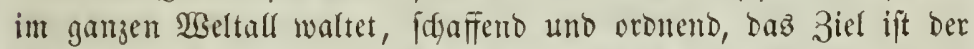

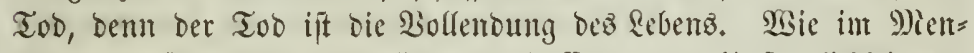

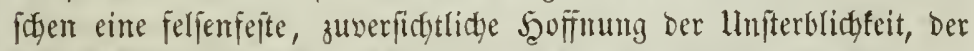

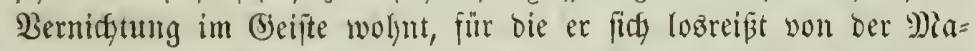
terie, für bie er bie Siatur, feine eigne Siatur opfert, fo regt fict in ber gausen Matur ein Eelynen nady jener Bernidjumg; nady Berflärung, ein Eehnen, weldes alle Rräfte herwornuft zu ewigem

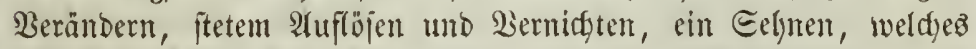

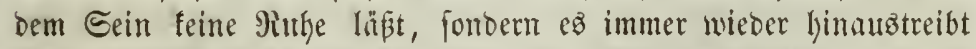
in ben wogenden Etrom dez $\mathfrak{W e r b e n z}$. AGer biejez Eefnnen bleibt ein hofjnungslofes, benn bas 3iel tum mur erreidyt werben burch

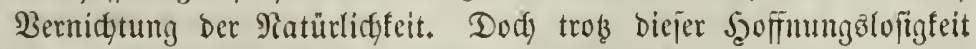
verbweifelt bie Matur midght; immer verjudyt fie ez wieber, jentem Biele nadjzujagen; und fo oft fie audh in biejem Rampfe gegen ihre eigne Endolidgteit unterliegen muşte, immer erlyob fie fich won 
Menem, unt mandyen Edyritt hat fie bereitB ihrer Bodfendung ent=

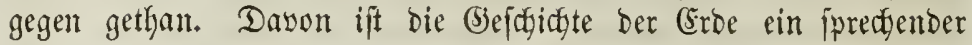
3euge.

Wie aber äunern fich jene Berjudye, worin offenbart fich unz bie Thätigfeit ihres Rebenos? Sch foumte antworten: eben in jenen

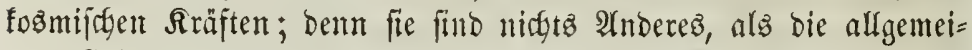

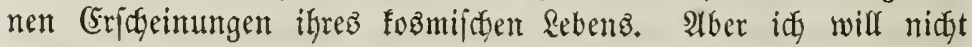
vorgreifen. Alus bem Reben jelbjt müfien uns jene Siräfte erwady= fen. Die Edyranfen Der Endlidffeit, weldfe bie Matur in ihrem Sampfe 孔u hibermindent hat, fino Bielfeit uno Trenmeng ber Gin= zelnbinge, Stoff = und Formweridiebenfeit. Denn ber Beift ift uns theilbare Eintheit. Wie aber gelangt bie Patur zu biejer Einkeit? Durdy Bernidyten alfer ltnteridjiebe, burdy Beridgmel $I_{3}$ en Der Etoffe, Berflüctigen ber Formen; uno in biejer Eridgeinung memen wir

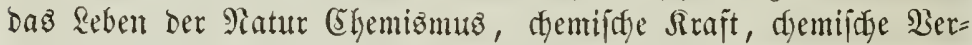

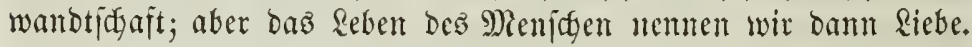

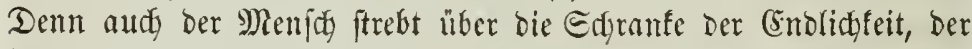

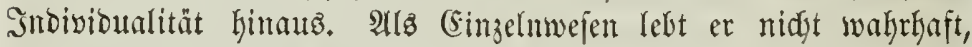
nur in anto mit bem atmbern will er leben. Darum verjenft er fruch

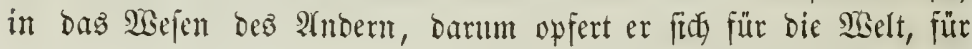
Familie, für Baterland. Eeime Brujt ift weit, vermag viel in fids

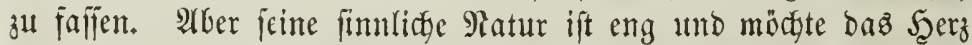

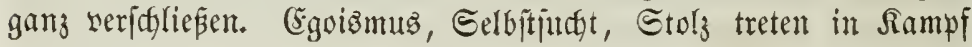

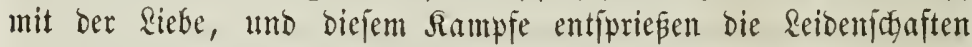
unt Triebe.

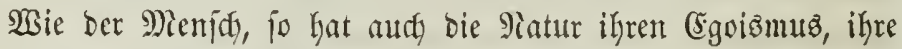
Eelbitjuctt. Auth bie Minterie wiberftrebt ben mädtigent Miegungen

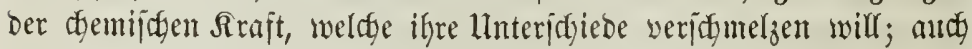
bie Materie will finf jetbjt erbalten in ifrer Miulge, ihrer Bejonder=

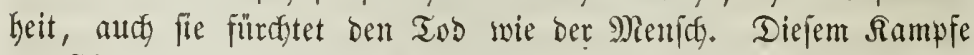

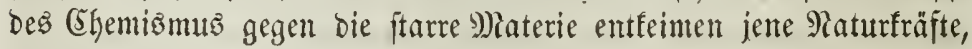
bie wir fosmijafe nannten, bie Reibemidgaften ber Natur. Bier

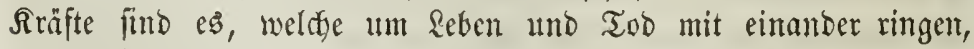

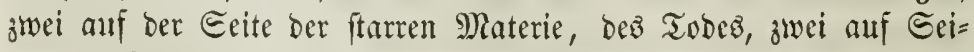

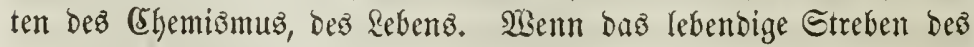
(5hemismme bie Etoffe ergreift, zu einander zieft und in einander

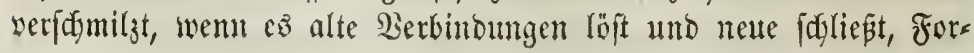


men umwandelt und newe (sigenifhaften herworruft, bann erwadt

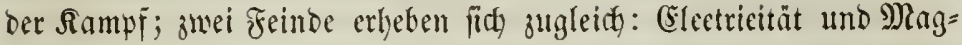
netismus. Sene ftrebt Der Minterie ifjer Freiljeit зu geben, unter= ftübt Den (Shentizunts, vernid)tet bie linteridiebe: Darum vermag fie felbjt Berbinsungen uno Trenmungen zu berwirfen, ju ber fid bie Raturfraft an fid nidyt zu erbeben vermag. Afber ber Miagnetiö= mus will bie S) Raterie retten, er niderftrebt jenem Triebe nach Bernichtung, erbält bie Materie in ifrem Beftchen, in ihrer Rufbe. 3wijgen Beiden idwantt ber Eieg, bald erkebt fith bie eine, bald bie andre Sraft, feime unterliegt je ganz. Darum fömen wir aud in unfern fümftlidgen Experimenten uie eine einzelne Sraft allein herworrujen, wir fömen fie wohl in ifren Cridgeimungen fondern, aber immer find fie beibe ba, went audy oft ummerflid). Darum

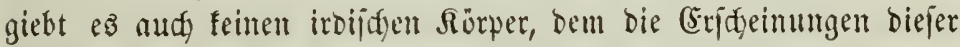

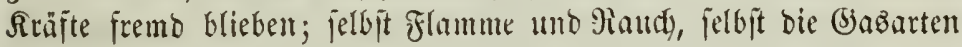

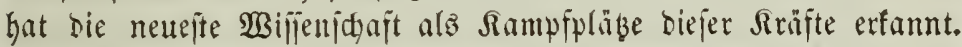
(Erlyebt fich aber jenes Eebnen ber Mlaterie nad ifyer Berlläung,

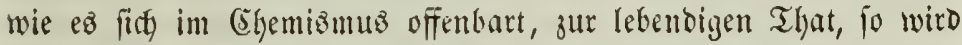

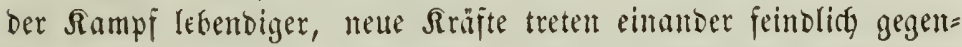
über, daz Ridgt auf ber Eeite bez Rebens, bie şärme auf ber ber Materie. Sener Funfe, den bie (Slectricitüt in ber Mlaterie erwedte,

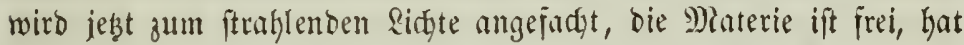
ifre feffernoe Sdywere übermunden, und leidgt entflielyt fie als sidyt

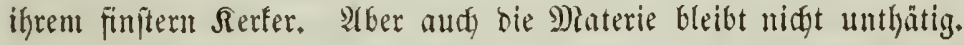

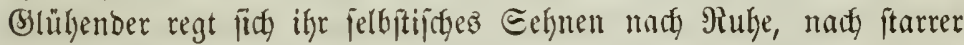

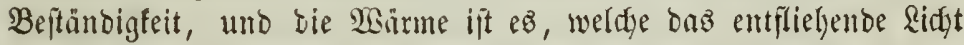

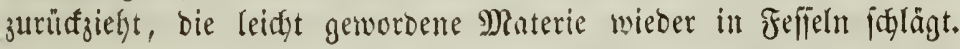
So find audg sidst und Miaterie eng mit eimunder verbunden, und nur fünjtlidge Mittel bermögen ifre Erifbeimungen zu trennen. In alle vier $\Re$ räjte find imnig mit einander veridgmoljen, ergeugen fin inedjeljeitig und gehen in einanoer über. Das ift nidgt

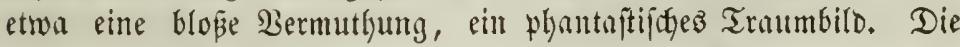

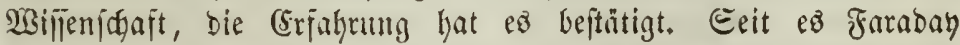
gelungen ift, jene glänzende Entbedung zu madjen, baß nudy

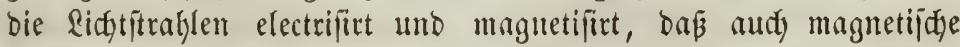
Etröme leudgtend gemadgt merden fömen, daß Wärme audg ben Magnetismuz der (3)ชaarte̊n erböht und vermindert, bürfen an bem 
gemeinamen Llphrunge, an Der innigen Berbindung jener Rriffte nidgt länger jweifeln.

Fudy unje (Erbe itelyt unter bem Ginfuñe jenter Sräfte, hem

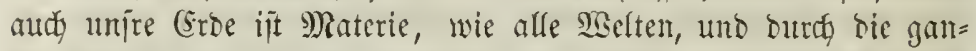

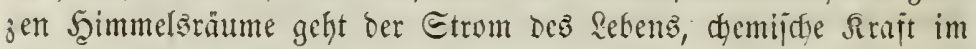
meiteften Einne. Wrelten werben von $\mathfrak{B e l t e n}$ gezogen, Flancten

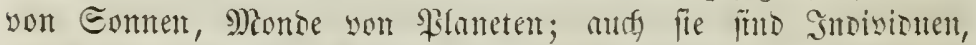

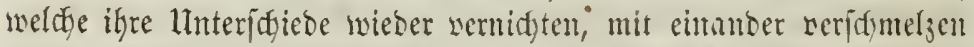
mödten. Darum gebiert fids aud bie Eroe jene feindidfen Brüber:

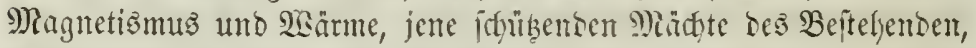
Electricität und 尺iđt, bie Sorkämpjer ber Jreifeit. Sente, welche für ftarre Suhe fämpien, haften barum auch fejt on Der Materie, mohmen im Innem ber (Erbe, bieje bic Feimse Ser Shaterie, flieljen fie und wolmen in Den jreieren Regionen Der Atmojplyire.

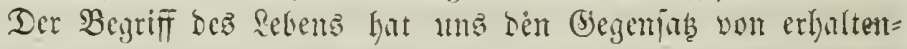
Den und von sernidfenden Siäften ergeben, bie wir bei mirer Erde

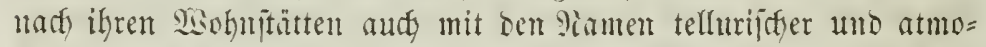

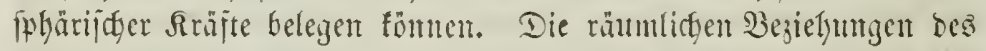

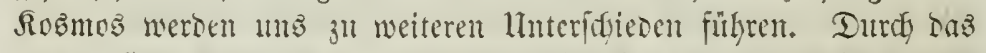

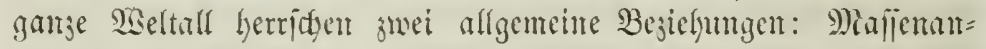
jiebung und Piotation. Iie cine nothigt uns, Sentrum und $\mathfrak{P}_{\mathfrak{e}}=$

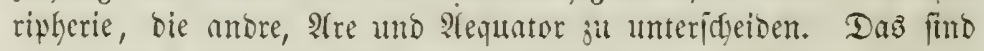
fosmijase Begrif̈e, fosmijtye Bejielyungen, Deren Bebcutjamfeit nidyt genug hervorgelyoben werben fann. Wisir begegnten ifyen im ganjen Reicte bes Rebens, wo Srifite, wo Bewegungen herrithent: Denn fie fint bie (Elemente bes Rebens. Wir findent fie in Der Anoromung

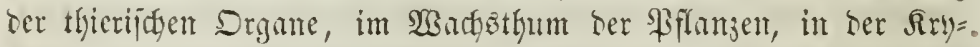
ftalfifation ber Ealje und Metalle. Wir finden fie in bem gropen Beltban, in Den Berbältnifien fosmiffyer Materie und nemen fie

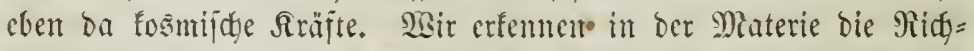
tung auf bas Eentrum und auf bie Reripheric, und wir nennen

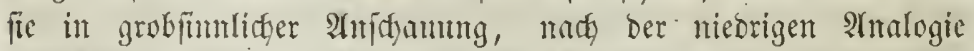

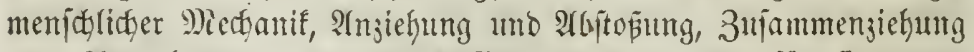

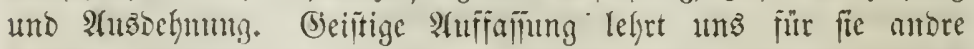

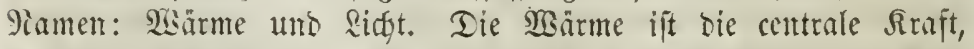
weldye bie Materie jujammentält, ım Den Mittelpunft sersicbtet, welde bie geformte Naterie ju sernidyten ftrebt, indem fie fie in 


\section{3}

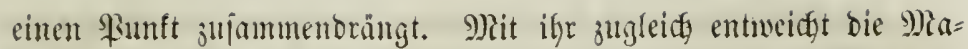

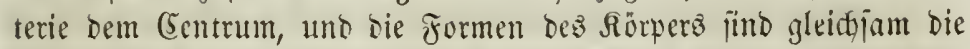
Edyanfen, innerlyalb beren Der jtrenge Rerfermeifter Der gejangenen Materie freien Epiefrum genährt. Dos Ridyt ijt bie peripherijde Srafit, weldye bie Materie verflüdtigt, ben (5entrum entloft, weldse Die Materie ju sernichten ftrelt, inven fie bie Formen ins llnent=

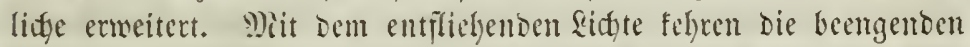

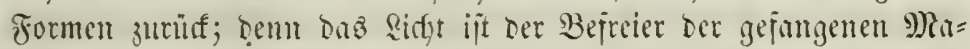
terie, welder bic Banden lejit. Eo wohnt bie fejielnde 23 ärme in

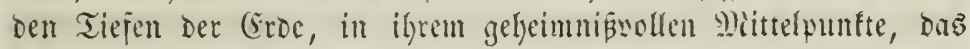

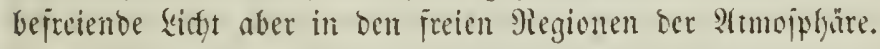

Dic polaren Bejichungent ter Materic ergeten uns juei anore

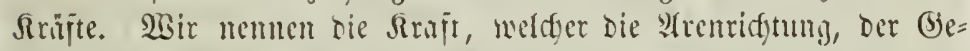
genjaţ von Folen zufommt, Mingnetismus. (5s ijt bas Etreben Der Materie nad) Ruthe uno Befgartlidffeit, bas Etreben, bem ewig

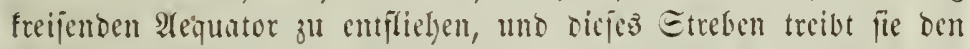

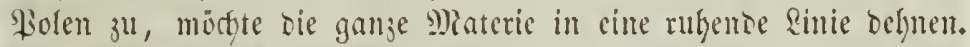

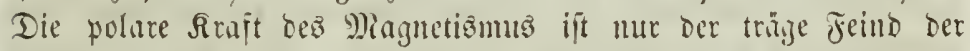
felbfttbätigen Bewegung, aber Darum aud) Deš Sebens; $\mathrm{cr}$ will bie

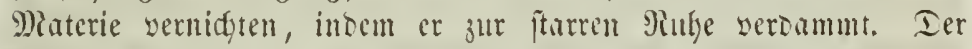
fräftige (Erreger Deş bemeegten Rebens ift bie äquatoriale Sraft her

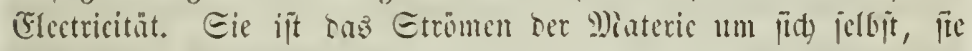

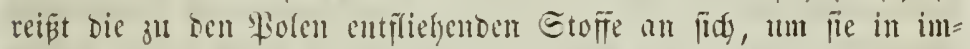

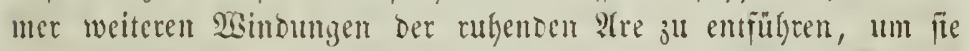
zll verflüdftigen in mnendlidyen Rreijen. Eie will bic Materie vernidten, inbem fie fie in Bemegung mflojt.

WBir merten ben polaren 9hagnetismus vorjugşweije an ben rufyenden Folen, bie Glectricität zwat überall an ber rotirenten Sberifläcte, aber am mädtigiten am Aequitor ber (Erbe mieberin=

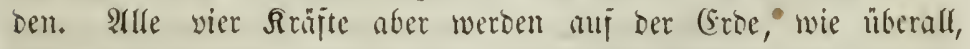

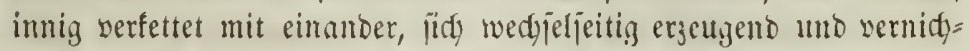
teno erideinen.

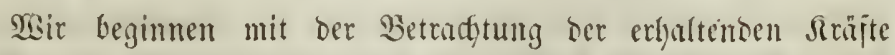
Der Miaterie und unter biejen mit Der Durdy bie (Ginjadgheit und

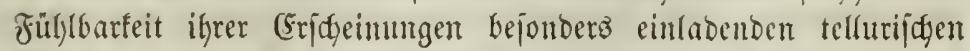
Warme. 
Die (Eroe bewegt fith im Weltraum, umgeben von einer zahl= lofen Mienge ungleids entfernter Beptitime, weldge Bärme gegen fie

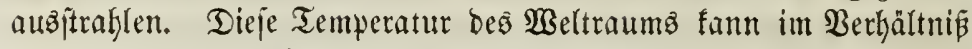

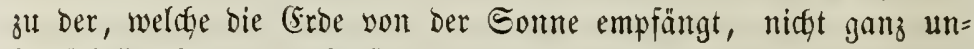
beträdftlich fein, weil jonjt bie Şöhe ber Sonme über bem Şorizont einen weit größerenl Unteridgied ber Temperatur Kervorbringen müpte,

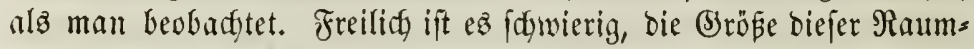

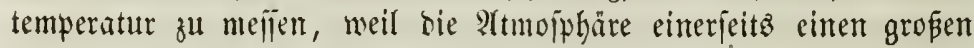

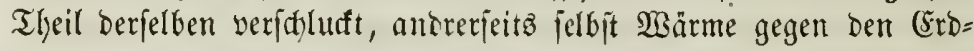
boben maştraflt. Defiemungendjtet ift ez den eifrigen Bemühungen

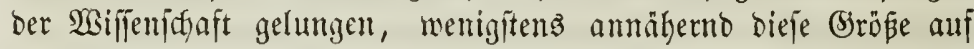
- $142^{\circ} \mathrm{C}$ zu beftimmer. Die gejammte 2 ärmemenge, welde ber

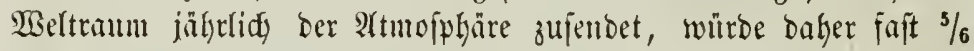
Der jährliden Eonnemuarme betragen und in Etande fein, eine

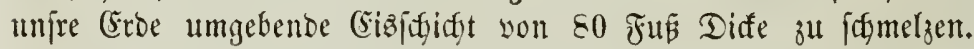
Eo jehr ein joldjes Rejultat unjerer gewölynliden Borftelfung von

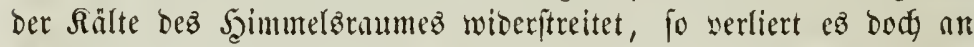
Auffälligfeit, menn man bie geringe brö̉ée ber Somnenjideibe am

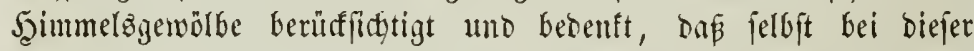
Innalyme bie Eonne nody immer genöthigt ift, bie mittlere $\mathfrak{T} e m=$ peratur bez Bodenz unter bem Aequator um $116^{\circ}$, bie mittlere ber Iftmojplyäre fogar um $139^{\circ} \mathrm{C}$ zu erhöhen. Die äupere Errmaffe whirbe allerbingz längit bie niebrige Temperatur bes Weltraums angenommen und biefe felbft in bas Innere fortgepflangt haben, wenn nidgt biejer fortwährente Bärmezuflup yon ber Eoune her fitattfämbe. CSin großer Theil biejer $\mathfrak{B a ̈ r m e ~ g e f t ~ a b e r ~ w i e b e r ~ b u r c h ~}$ 3urilffwerjung uno Etrathlung für bie Erove verloren, unb ba bieje fehr ungleidjmäsig find, fo bewegt fid bie Temperatur an jebem Orte zwiiften gewiffen Brenzen. Die Stelfung ber Errbe zur Sonne bebingt eben io eine ungleidge und jtetz wedjelnto Bertheilung ber Wärme auf Der Erooberflädge. Notations = uno Bahnbeinegung ber (Srbe führen bald ben einen, Gals ben andern Drt balo ictie= fer, bald fentredgter einfallenben Etraflen ber Sonne entgegen. Bald nähert fich bie (Erbe der Eonne, uno bie Sntenfität ber $\mathfrak{B a ̈ r m e}$ wädyjt, balb entfernt fie fidy, und bie Intenfität nimmt ab. Eo ift bie (Grwärmung cines \$inttes ber Sberflähe abhängig von jeiner

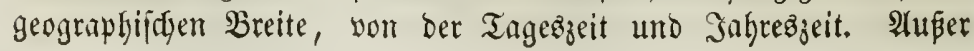




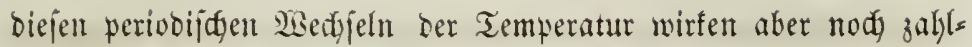

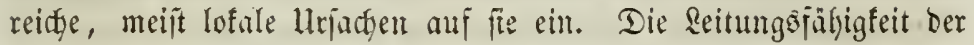
atmoiphärifdent Edfidten, ihr Dampfgehalt, ihre Bemegung ftören jortwährend Daz Bjeidygewidgt Der Temperntur. Tie Ratur ber Eroflätje jelbjt bedingt endid) wejentlid) Den (Einflü ber Sonnen=

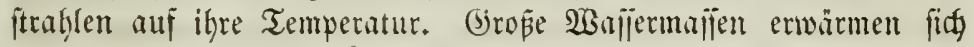

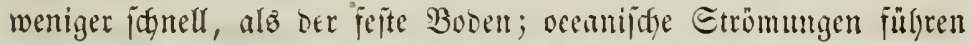
erwärmte Bewä̈lier in tältere Zonen und milbern igre Temperatur; Şähen und Biebirge theilen aud bem fejten Boben bie nicberen Temperaturen ber oberen Piegionen mit und erzethen flimatijate

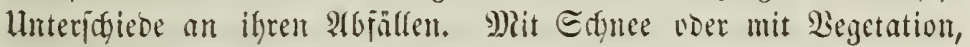
mit Sand ober Ferö, mit sisalo oder Grwas bebefter Boben wirb ganj veridgiebene Temperaturen jelbjt unter jonjt gleiden $\mathfrak{B e r}=$

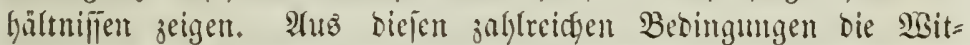
terungs = uno flimatijden Berbinltmifie im 3ujammenthange barzus ftelfen, zeigt Edywierigfeiten, bie nutr cine untermibete, Sngre uno Sahrfunderte umfallende Beobadytung Der Errideinumgen überminden fam. Dennod) haben bie flimatijden Berbältnilife jür baz Reben

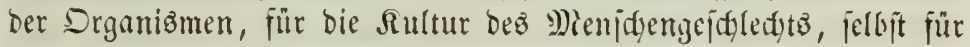
die Formen ber Maturanifamung fo mberedenbare wsidjtigfeit. Durd) bie Berbelierming ber thermometrijaen Snjtrumente feit ber

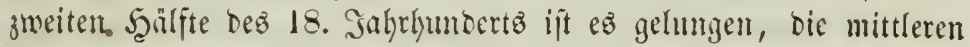
Gafreßstemperaturen zaflecidger Drte ber Erde femmen зu Iernen. Mlat hat baher Rarten entworfen, indem man die Drte gleidger

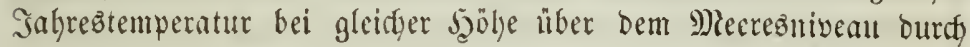
Sinien verband, weldge man Sjotherment nante. Jim Althemeinen

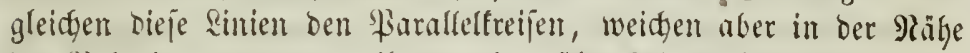
Der Fole bebeutend won ifgen ab. Sgier fteigen fie an ben $\mathfrak{B b e f t =}$

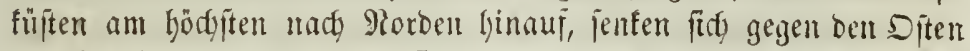
Der Sontinente und heben firth wieder von ben Dittuffen an. Eie

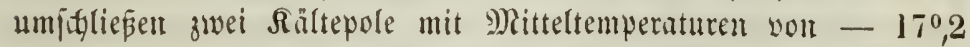
und - $19^{0}, \overline{\mathrm{C}} \mathrm{C}$, yon benen ber eine in Der Rifhe Der Renamin= Dung, ber anbere im Morben Der Barrowjtrape liegt.

Pody vor nidgt langer 3eit nafym man ben geograplijiden

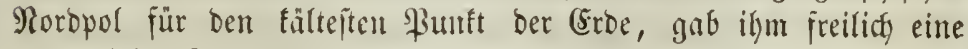

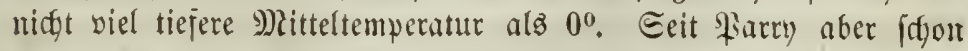
unter $75^{0}$ nörd, Br. auf ber Mriét Mefville eine Mitteltemperatur 
von - $17^{0} \mathrm{C}$ jand, gab man bieje Meinung auf, und bie neuere

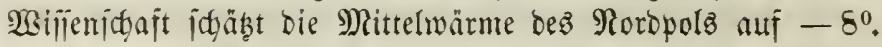

Die auffallenden Beugungen ber Şothermen bängen von $\mathfrak{l}_{0}=$

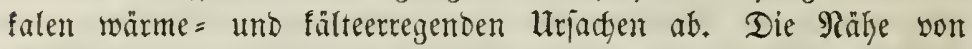
Wefttüpten, an weldyen in ber mörblicten Semifphäre Sübrweftwinde,

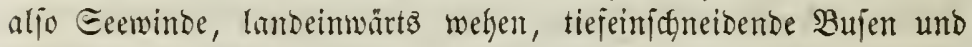

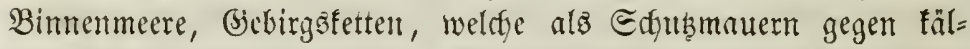
tere simbe Dienen, warme Neeres̄jtrömungen und heiß̄e, ̈̈ber bürre Eanditeppen Kerwehende Sinde erbähen bie Temperatur und orängen barum bie Siothermen an ben $\mathfrak{B e f t}=$ und Eibtüften (5u= rowas nach Morben. Die Rähe eifinger Polarmeere, bie mallenthafte

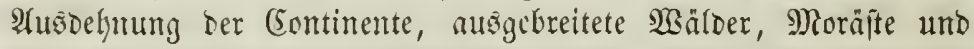
Eimpie, weldye burdy Edgattentühle, Serbumitung und Etrahlung die Črtwärmung bes Bobens verkintern, erniebrigen bie Tempera= tur und brüftent Daher bie Sjothermen bez öjtlidyen Europas und

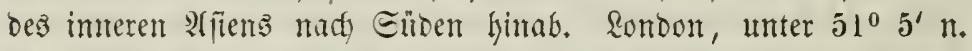
Br., liegt Daker in Derjelben Sjotherme von 90,8 C mittlerer Jahres= wärme, wie Franfiurt a. $\mathfrak{X}_{3}$. unter $50^{\prime \prime}, 1$, wie bie Rrim unter $45^{0}$ Ino Befing unter $40^{\circ} \mathrm{n}$. Br. Sine auffallende Ericteinumg ift bas 3ujammentängen ber Sjothermen yon $18^{\circ}$ biz $8^{n}$, vejonberz in ber

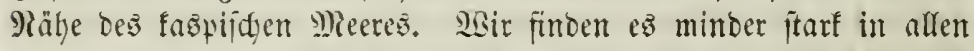
mittleren Breiten zwijden den Faralleten von $40^{\circ}$ und $45^{\circ}$ und förnest ben (Finflui nidgt werfenten, welden es auf Bifoung und Thätigkeit ber Bewolyner biejer 3one geübt hat. J̧ier orängen

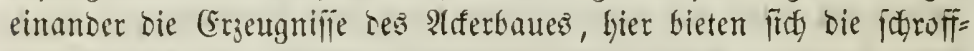
ften Rontrajte ber Segetation gegen bie Mactbarlänber bar. Darum blühten lier yout jeber Jandol, Afferbau und Bemerbe, wenn nidgt bie raulye Şand bes Menjojen bie Ränder in Mäften verwandelte.

Ilngleidy widgtiger für bas Sulturleben ber Bölter find bie mittleren Eommer $=$ und Sintertemperaturem. Derter Derjelben Sio $^{\circ}=$ therme fönnen in ihrer Eommer = und Winterwärme bie gröpten Ilnteridjiede zeigen. Der Gommer bes einen Srts tann eine mitt= lere 2 ärme you $15^{\circ} \mathrm{C}$, ber cines anbern in gleidger Siotherme eine 2 Bärnte yon $20^{\circ}$, Der $\mathfrak{B}$ inter bes einen bagegen eine mittlere

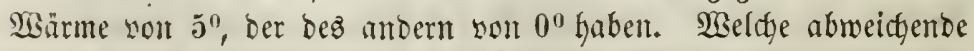
Bebingungen fütr Begetation uno Rultur! Befgien uno Edyottlanto haben mildere Winter als bie Rombarbei. Dublin und łejth ha= 
ben eine gleidge Sabresivärme you $7^{0}, 6$, wno bod fintt in Siepth bie mittlere Binterwärme auf $-2^{0}$ gerab, während fie in Dublin $3^{0}, 4$ bleibt, alio felbit bie SBinter von Probua umb 9)ailano an

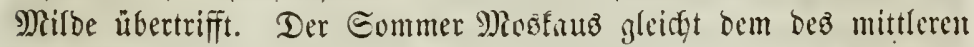
Frantreid, wälyrend fein winter um $12^{0}$ fälter ift. Ectroffer wer=

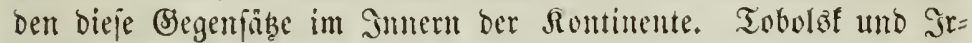
futbl haben ben Eommer Berlinz, aber einen \$inter, befien fïlte=

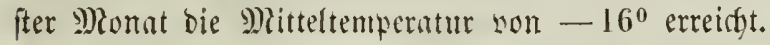

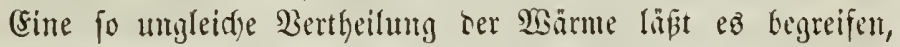
wenn 9)?yrthen und Drangen an Den Rüten Englando im Frien gebeifen, wo faum nody ber Apfel reīt uno bie frudt) ber Wein=

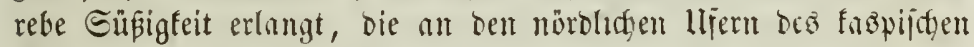
Seez troks ber rauken Winter nody bie herrlidffen secine liejert; fie läp̈t es begreifen, wemn bie Rartoffel felbit in ocn baumlojen

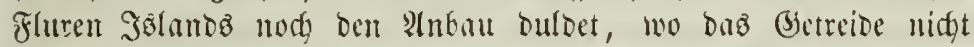
mehr fortzufommen vermag, wenn bie cifigen Berge 9 cowaja=

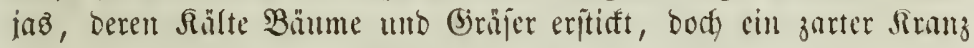

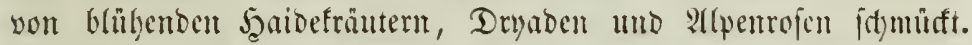
(5z ift biejelbe Erifbeimung, der wir begegnen, wenn wir som

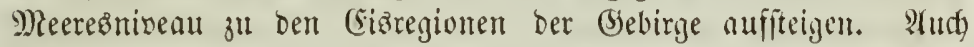
hier finben wir biejelben llnregelmäßigteiten in ber 2 ärmenbnal)me, bebingt Durch bic veridyiedene Etrahlungerähigfeit ber $\mathfrak{B}$ eryflädyen, wie

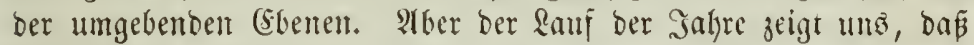
wir jelbjt an biejen Sjothermen feinen fejten Şalt gemimten. (68 wechjeln talte mit warmen Jabren. Bir lyaben im Sulbe 1801 bie mittlere Sahreâninme Sopenthagens nuf $10^{0}, 2 \mathrm{C}$ jteigen uno im

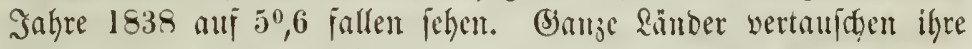
Temperaturen. Miloe 2 Binter in ßetergburg uno Edyweden, wie 1847, treffen mit falten Wintern in Stalien und Briectyentano zu= fammen, uno bie ungewölynliche Rälte, weldse im December 1829 in ganz Deutidyland herridyte, war bou Der milbeften 2 Bitterung in Sibirien und 2 merifa begleitet. Der $\mathfrak{W i n t e r}$ von $18 \frac{5}{5} \frac{1}{2}$ jeigte $แ$ เ eime ähnlidge (Erjdeinung. Bälyrend fich bei uns bie Temperatur im Samuar und Februar faum unter ben befricrpunft jenfte, $\mathfrak{c}=$

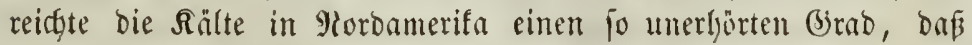
alle Etröme zufroren, viele Şäfen vom Eife veripert wurben und

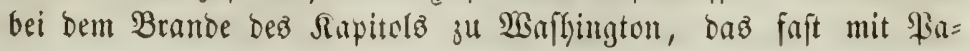




\section{8}

lermo in gleidfer Breite liegt, alle Brunnen eingefroren waren. Eine now auffallendere Ericheinung bot ber WBinter von $185 \frac{57}{8}$, wel= der jeine ganje Etrenge vorjugäweije jüblidje Ränder empfinten

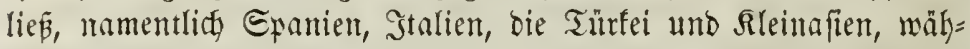
rento am Rorbtap eine fommerlidge Temperatur won $8-10^{\circ}$ über

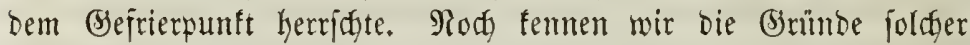
Eontrajte und Edfwanfungen nidht, aber weit verzweigte Beobadjun= gen werben uns einjt aud bie Utrjaden biejer fo widjtigen $\mathfrak{B i t =}$ terungsiftürungen algnen lailen.

BBenn gleidy für eine allgemeine lleberifdgt der flimatifden

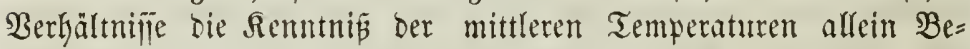

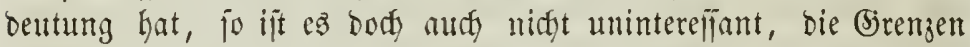

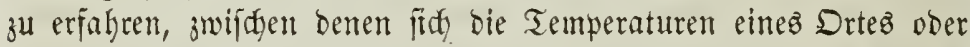
Randes bewergen. Măhrend ber Unteriffied alfer Mitteltemperaturen

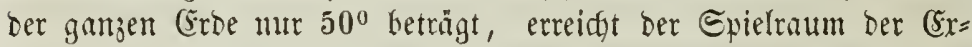
treme fofon im wejtlicfen MRittelentropa $60^{\circ}-62^{0}$, in Srfutzé jogar $73^{\circ}$ und in einjelnent Gahrent felbjt gegen $100^{\circ}$. Dieje Extreme Der Şibe uno Rălte wirfen gleidy zerfïrent auf bie Begetntion,

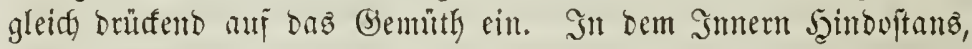
in Sberägypten, in Arabien, in ber Enfara erfält fith bie Tem=

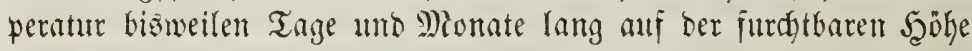
von $40^{\circ}, 47^{0}, 52^{\circ}$, in $\$$ Murzut jelfjt von $56^{\circ} \mathrm{C}$. (ober $45^{\circ} \mathrm{R}$.) im Edyatten. Tobtemifille begerridgt bie ganze Patur, fein Edyatten

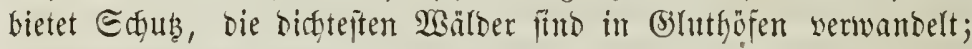

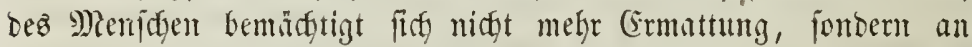
Wahnjin grenjende Berzweiflung. In ben \&olarregionen Rorb=

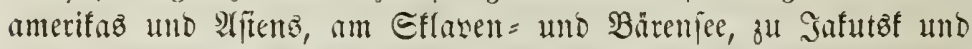

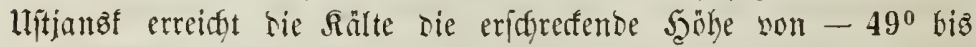
- 58 C. mo erfält fith jäfrlidy Mronate lang unter bem Befrier= punft bes Sueffiltbers. 2hatd) Dort biejelbe Tobtemitille ber Patur,

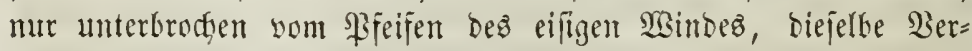

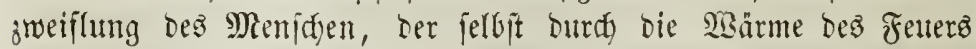

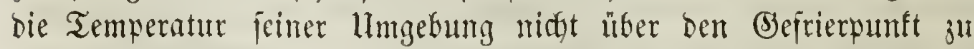
erhöhen sermag! Lho bod trokgt lier wie bort ber fühne Meníd

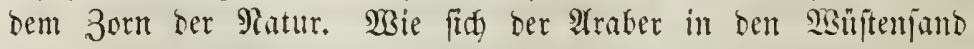

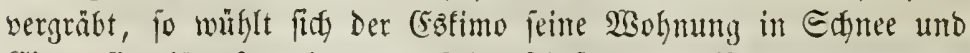

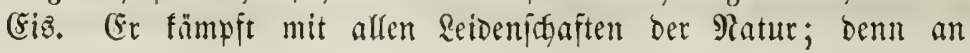


Denfelben Drten fteigt bie Temperatur Des Sommers oft zu Der tropi=

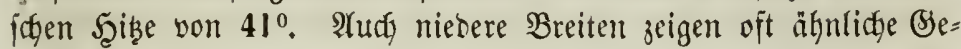
genjäbe ber Temperaturen. In Rlyima, unter ber Breite yon

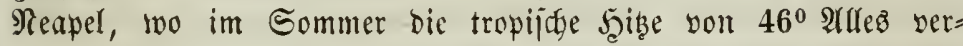
borrt und verjengt, ftieg im $\mathfrak{B i n t e r} 1540$ bie Rälte auf $-43^{0}, 7$

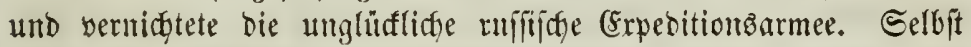
im Innern ber Gahara, in ber Seimatly der ßalmen, fïblid yon Murjuf, fintt bas Thermometer bismeilen auf $-3^{0}$, fo baß $\mathfrak{B}$ rum $=$

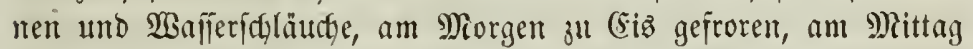
von glihtenter Saike aujgezegrt werben. Die hödyften und niebrig= ften bisher beobadbteten Temperaturgrabe into $60^{\circ}$ über und unter शull; Der llnteridied Der größsten (Ertreme beträgt aljo $120^{\circ}$.

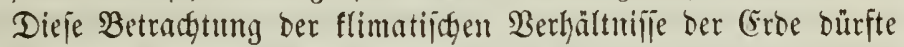
binreidyend fein, um die Einwirfung ber Somtenmärme auf Ero= oberflädbe uno Atmojphäre im Allgemeinen begreifen zu lafjen. Wir jehen fie in inniger Berbinbung mit Didgtigfeit und 9Raturbefdyaf= jenteit der Âtmojphäre uno beż Bobenz. Wir jehen fie in. Der Soöhe mit ber Materic, an bie fie gebunben ift, abmelymen, iefen

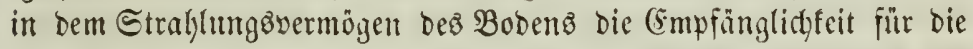

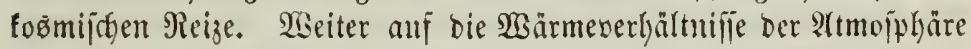
einzugehen, erjecint hier nidgt am Drte; es jei genug, bie Eonnen=

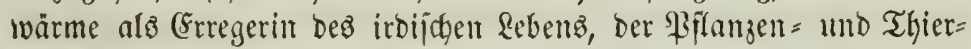
welt, als Bewegerin ber Bemäller uno \&üpte, als Ulrheberin ber Berbunftung und ber Rieberidyläge, Rebel und $\mathfrak{B o l f e n}$ zu femnen.

Sit aber alle jene Bärme, bie wir alli ber Dberflädye แ11 im Snnern unfrer Erbe beobacten, alfeinige folge ber Commen= ftrablen und ber Temperatur bes $\mathfrak{1}$ Beltraumb , ober rüfrt fie nody anderşwo her? Das ift einte Frage, bie jeit einem Jahrhundert bie

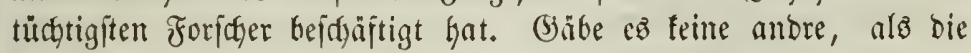
Sonnenwärme, fo müßte mant unter jeber Breite in einer gewiffen Tiefe eine Temperatur finben, bie bas Mittel von alfen benen wäre, bie an ber Sberflädye ber Zeit nach auf einamber folgen, und bie bis zut den gröpten Tiefen fich immer gleidg bleiben müste; benn bie Conmenwärme pflanzt fid) mur Iangjam im Smmern ber Erbe unb bis̄ zu geringen Tiefen fort, uno manther $\mathfrak{B} a u m$ findet in Winter feinen Too burdy ben $\mathfrak{B a ̈ r m e v e r l u f t ~ a n ~ f e i n e n ~} \mathfrak{B u r g e l n}$.

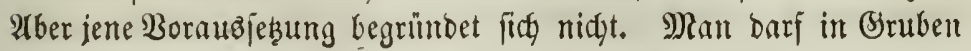


Ginabjeigen, um ben $\mathfrak{B e c h j e l}$ ber Temperatur, ber bod auf ber

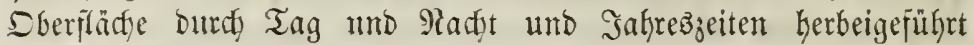

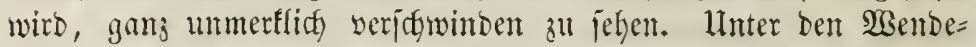
freijen Darf man mur einen Frté tiej graben, um cine bejtändig gleidge Temperatur zu erfalten. In umjern Rlimaten freilich, wo

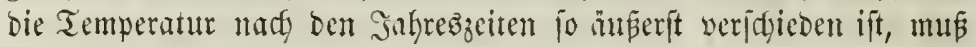
man tiejer, 55-60 Fū, in die Erde himabiteigen, um einte gleidförmige Temperatur zu finton, weldge mit der mittleren \&uf̣t= temperatur bes Srtez in gentauer Berbinoung fteft. 3u Safutŝf in Eibirien, wo Mitte Suni bas Thermometer bis $40^{\circ}$ und Darüber fteigt, wälyrend es Mitte December auj $41^{0}-45^{0}$ unter 0 fâllt, er= bâlt fich in einer Tieje von 50 Fus bas Sutedfilber ftets auf $-7_{2}^{10} \mathrm{C}$,

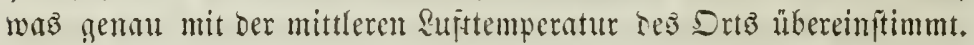
Grman war eş, Der bieje Beobadytung bei (Sielegentyeit eintes Bunn= nenbaues madyte, Den ein Dortiger Raufmann Edyergin unternahm,

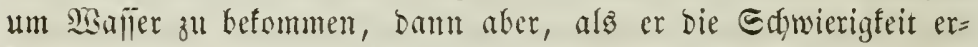
fannt hatte, in rein wijjenifgaftlidsem Snterefle fortiebte. Erit in

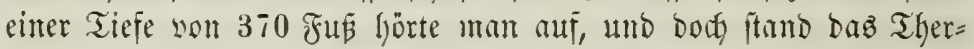
mometer nody $1 / 2^{0}$ unter 0. WBir feljen jaton ats biejem Berjudje,

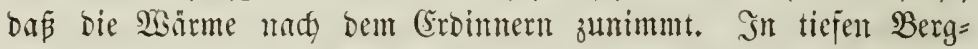

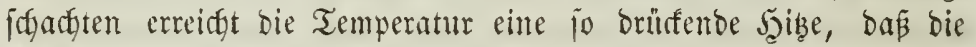
Arbeiter genöthigt werden, unbetleibet ou arbeiten. Nod) ergiebiger alsె Die Mefintugen Der Temperatur in Bergwerfen find bie llnter= fudyungen an Bofrlödern ron Ealgwerfen und artefijdyen Brumen; Denn hier famm man unmittelbar bie Temperatux bes ausfließ̄enden

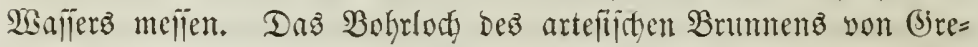
nelle bei Baris hat eime Tieje von 1683 Juß und Das ausfliépende Bajןer eine $\mathfrak{w a ̈ r m e}$ yon $2707 \mathrm{C}$, währent die mittlere Temperatur zน Baris mur $11^{0}, \bar{t}$ betringt.

Die tiefiten Bohrföder und wohl aud bie größten Tiefen,

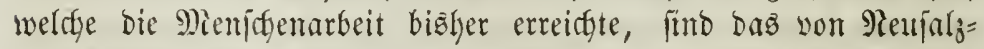

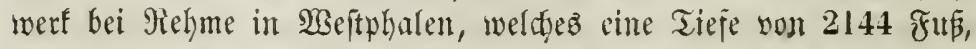

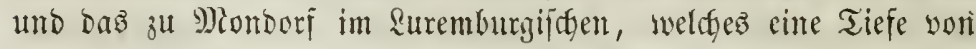

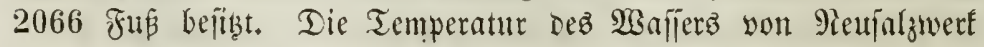
fteigt auf $32^{0}, 75 \mathrm{C}$. Gei einter mittleren Ruptemperatur non $10^{\circ}$, uno in ben nidft viel weniger tiefen Ectgadyten Der Bolominen yon $\oiint_{e}=$

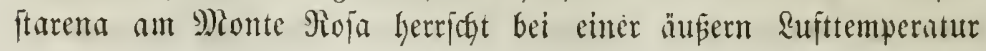


yon $3^{0}$ in ber Tieje von 2238 Fü eine hejtänoige Wärme von $16^{0}, 3 \mathrm{C}$. Das alfgemeine Rejultat afler biejer Beobactungen ift,

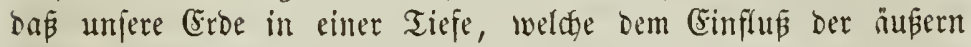
Sonnenermärmung entzogen ift, eine böbere Temperatur lyabe, als die Rinde jelbjt, und baj bieje Temperatur nađ Dem Snnern ju auf je $100-150$ ₹ü um $1^{0}$ C. 3unimmt. Für eine joldbe im

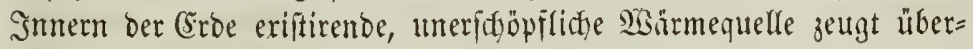

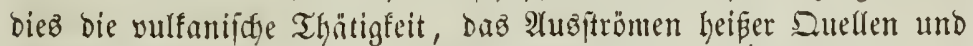
gejdmolzener Crromajien auz geöfuteten Epalten. Wisenn aber eine foldje (Stuth im Shoope Der Eroe herridt, warum bemerten wir nichtz an unjer Sberilädye? Soer hat vielleidft ber Eroboben frïher eine höhere Temperatur gehabt, als jest, wo er erfaftet ift? Biele Raturiorider, unter ignen Der berühmte Buffon, find wirf= lid) zu ber 2 nnfidft gelangt, baß unjre (srbe eine fleine Sonne fei, nur mit einer Yinbe liberjogen, weldge von oben und unten, yon ber äupern und imuern Eonne erwämt werbe. Die gause Mafje jei uriprünglich glühento gemejen, wie die der Eonme, habe fith aber Durdh iffere Bewegung im Raume linreidgend abgefülylt und jo eine äujere feite Rinbe gebildet. Dieje jejte Rinde aber majie von Sahrhundert zu Sabrfundert difer werden, und dic Errde, Die io nach uno nach erfalte, fei unviberruflich beftimmt, zulckst eine Sismajie zu werden, bie lebloz um eine Gonne rolle, beren $2 a ̈ r m e$ audy alfmälig abnehme und fich julebt ganj verlieren werde. 2fubre Seologen, unter ifnen Whifton, eröffneten uns nidyt minber ange=

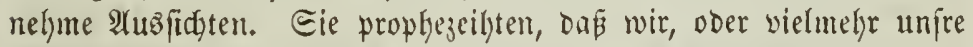
Radytommen, ₹łlülie, Ecen, Etröme, alle Meeri und jelbft ben Dcean allmälig veroampien jehen würoen, biz die aubigedörte Erobe an ber Sonne Fener fangte, und aus ifrer afdae eine neue Eroe ent= feime.

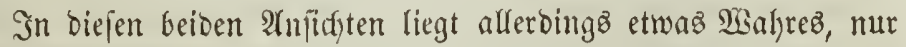
fino glüaflidgerweije ifre Bepürctungen burdyauz ungegrümoet uno werben ourdy Beredynung unb Beobadyung mij bas Eidjerjte wiber=

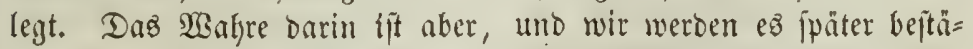

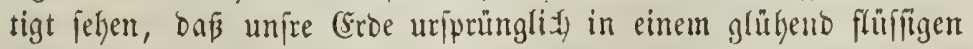
3uftande befindidy war, uno, wie alfe gefdmoljenen Mlajien an ifter Dberfläcbe burch Altø̈trahlung Wärme verlieren, alfmälig er= faltete und eritarrte. Raturlidy ging bieje Erfaltung von ber Dber= Ille, 23ettall. 3. 2luf. 


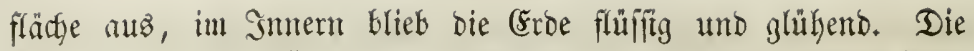

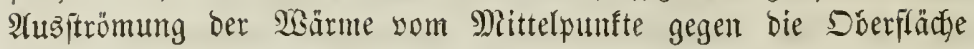
mup̈te aber mit zunefmender Eritarrung Der Errorinbe immer gerin= ger werden, weil bie erfalteten Edjicften berfelben immer mädg=

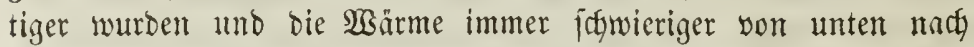
oben leiteten. Der $\mathfrak{B} e r l u j t$, den bie Centralwärme erteitot, ijt ba=

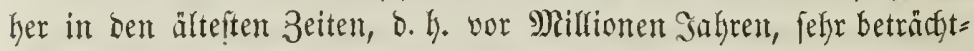

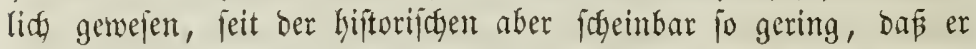

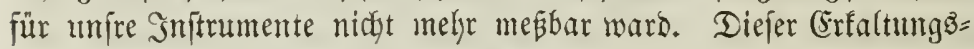

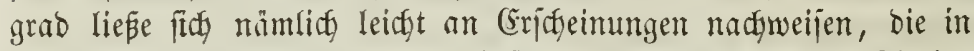

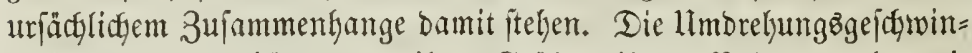

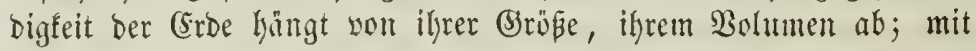
ber Berminderumg Der Temperatur if aber eine 3ujammenziefyung

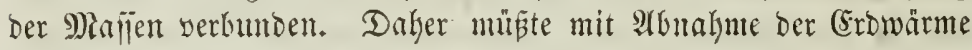

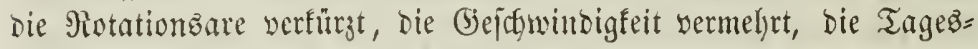
länge vermindert werden. AtGer bie Beobardutung ber Beweyungen

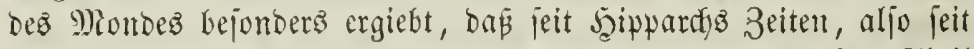

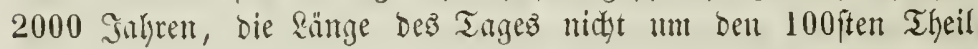
einer Eecunbe abgenommen hat, da

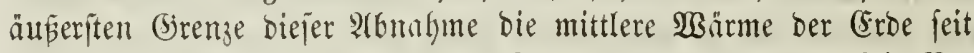
2000 Safjeel nidft um $1 / 170$ cines Grabes verringert hat. Die Be

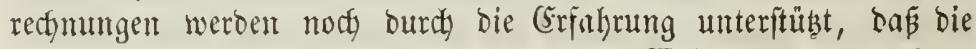

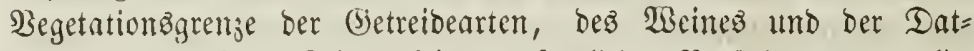
teln jeit hijtorijden 3eiten feine mejentliden Beränberungen erlit= ten fat.

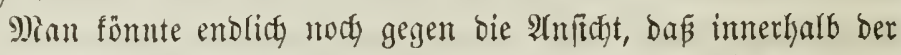

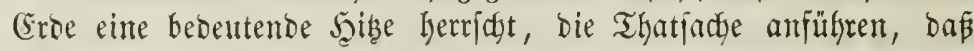
(iif) fajt überall, wo Thermometerbeobactungen im Scen uno in veriffiebenen Tiejen belfelben vorgenommen worden find, eine 2 (b) nabme ber SBärme bes Meerwafíters mit ber 3unahme ber Tiefe Des Meeres gezeigt hat. AlGer bieje Erricheinung bürfte eher ein Berweiz für, alz gegen bie mit ber Tiefe zunehmente Erowärme

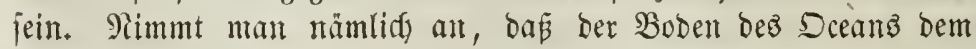

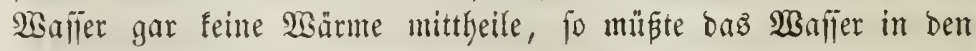

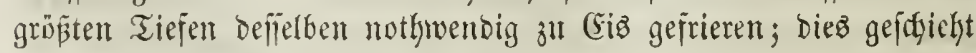

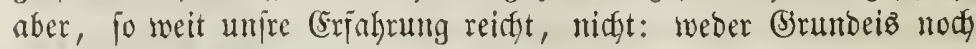

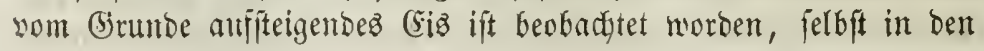




\section{3}

Bolarmeeren nidyt. Bielmelyr fintet man grabe in biejen Mieeren

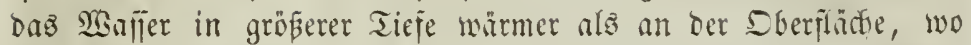

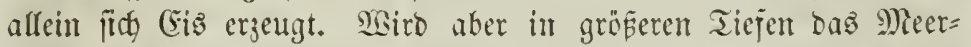

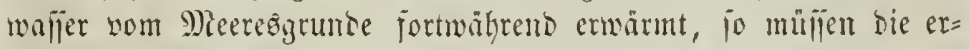
wärmten $\mathfrak{B a}$ aljertheile, als sie leiduteren, ftetz jofort nach Der Sber= flïdye aupiteigen, unt weroen burch fältere Ginabintente Theile er=

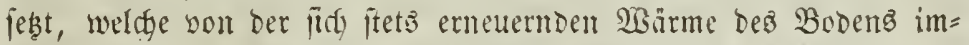
mer aufs 9eue linaufgetrieben werben müifen. Sitr baburdy iniro

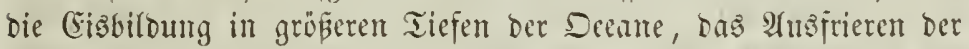

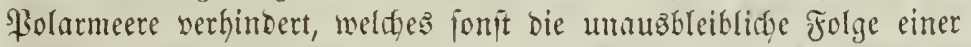
mit ber Tiefe zunehmenden Temperaturwerninderung, ober aud mir

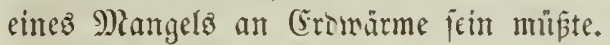

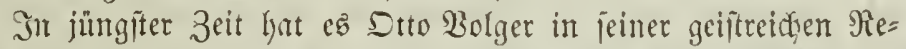
form Der geologijden sisillemidaft verjutd, bie alte Syypotheje von

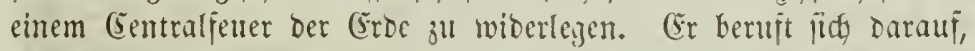

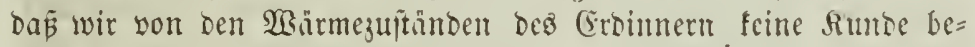
fižen, ba

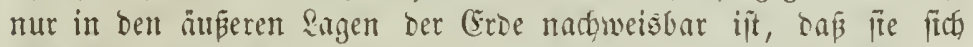
hier aber viel leiffter außz. bem junefmenden Drulfe ber auflagern= ben Edfidften, aus ber Berwegung tes in Die Tiefe bringenden

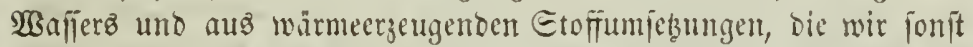

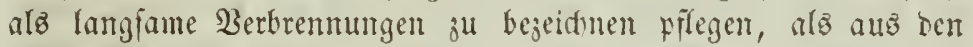

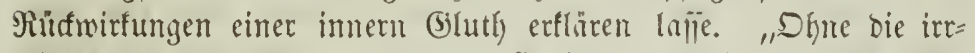

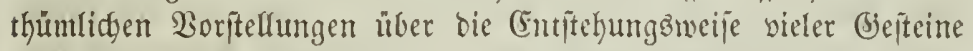
uno liker bie Erijdeinungen ber Fenterberige, meldye man jämmtlidy

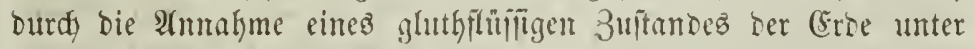

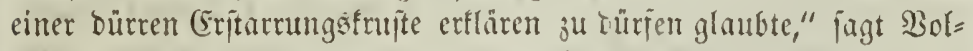
ger, "wuirbe man miemals llrjadje gelant haten, baz Inmere ber

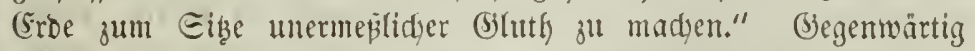
ift jogar, fälyet er fort, "Durdy himmelálundige Berectgnungen er=

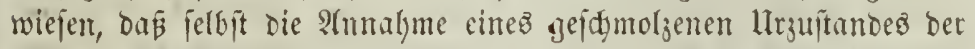
Erbe zur Erflärung der fenerberige mo der mit biefen in 3ujam=

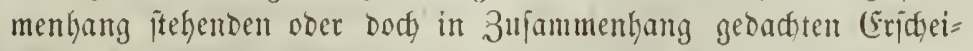
nungen unmöglich bienen fönnte, $D a$ gegenmärtig bie Crroe feinen=

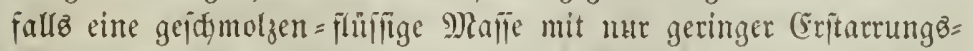

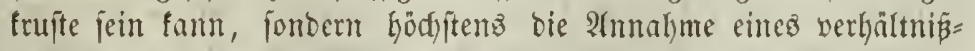

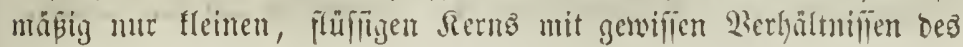




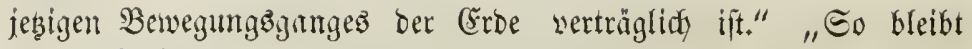

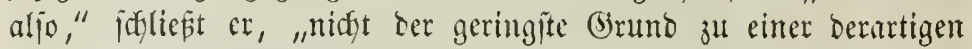

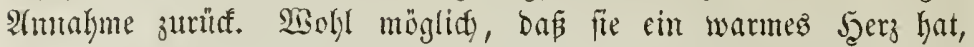

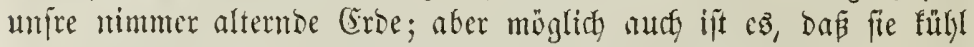

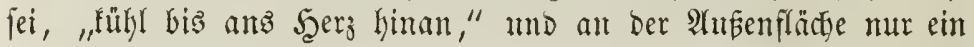
wenig menichenfreundlidy überwärmt." Sa er geht fo weit, bie

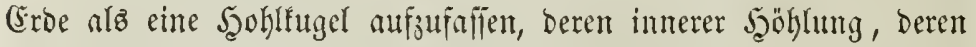
Unterwelt wa weber an Wajier nody \&uft mangele, und bie,

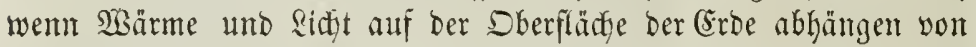

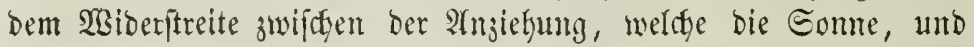
berjenigen, meldye bie Eroe auj Die Etoffe Der Dberfläche ausübt,

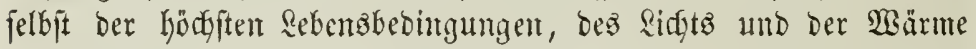
nidyt entbefrent mag. In wie weit ez Solger gelungen iit, bie alte Sant'idje und Raplace'iche Theorie yon ber innern (j)lut und ber Feuergeburt unirer (sroe ju eridyuttern, und in wie weit ifn

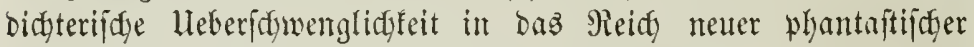
Saypotbejen veridglagen hat, Darïber werdent wir erít bei ber $\mathfrak{B} e=$

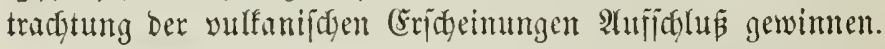

WSie Dem auth jei, nadf ber alten uno nod immer von ber

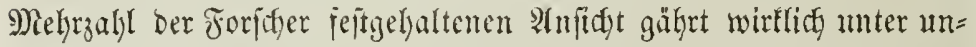

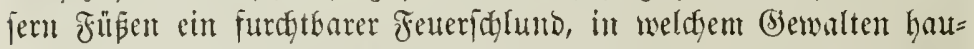
jen, bie felbit bas Feftefte und Etürffe, was wir im Gebiete irbi=

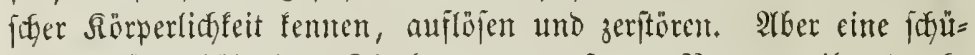

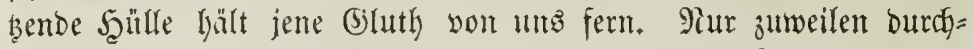
bredten die gefeffielten riejen aus lautbrüllemben Sdylünden ifre

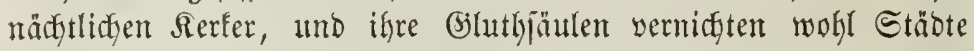

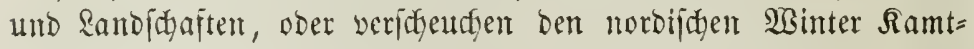

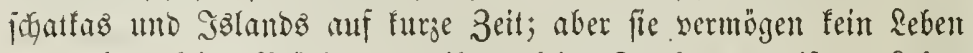
3n wecten, feinte Blüthe zut treiben, feine Frudgt zu reifen. Seben meft allein bie Eomrenmärme, weldje dic âtmofphäre Durchjtrafit

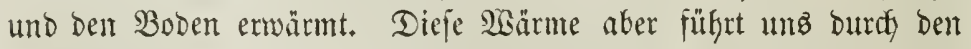
gefeimnifwollen Faben, Der alfe Refenserfffeimungen Der Ratur

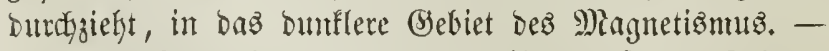

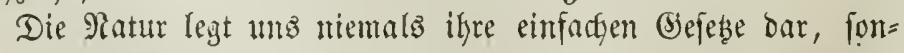
Dern mur bie Folgent berfelben - verwidfelte Errfteinungetr. TBenigen ift es vorbeffalten, biefé zu beuten, ben $\mathscr{W}$ entigen, weldye eine an= geborne Făbigfeit zun Hebergehen von bett Folgen aul bie Lriactgen 


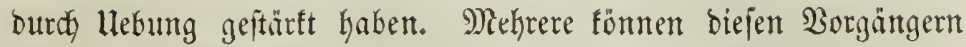
folgen, audy bie Deutung versolfítündigen; bie Meiften aber be= gnugen fid gern, bie Dentung nur fennen zut Ternen. Wiste all=

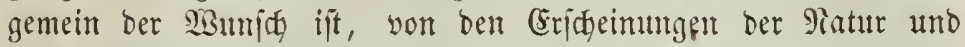

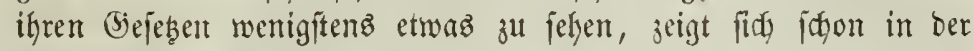
Theilnahme, welche gewöhnlidy die fogenamuten $\mathfrak{B}$ oriftellungen auz

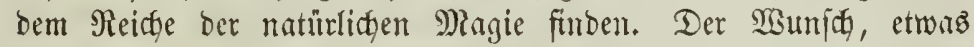

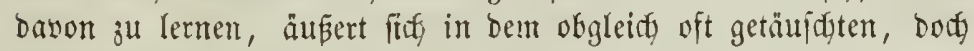
fortbauemben Berlangen nath Edyriften, weldye (Begenitänte ber Patur populär zu behambeln veripredyen, oft aber mur unbefrie= bigende Sberfläblidffeit zeigen. Die Befricoignng biefez Mism= fatez fordert aber eine Afrt Der Darjtellung, oer Berbintumg jwi=

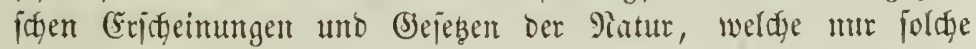

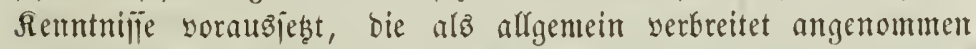

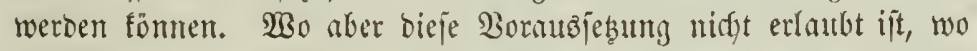
man mit 2 tuseinanderjeł̧ung idpwieriger Theorien, mit mathemati=

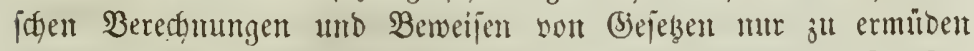
fürchten mur, ba hebt alle Bebenten bie Bebeutjamfeit biefez (S)e=

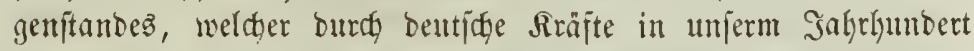
auf eine Şöbe gelangt ift, wo er fid bem allgemeinent Blife nidyt megr entgielgen fann noch barf.

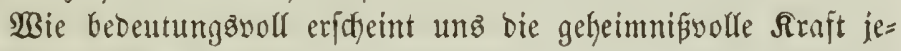
ner fleinen Mragnetmadel, welde ben Geefahrer burch unbefannte Meere fïhtht und burdf iffere Edjwntungen unz wie eine llyr bie Stunden dez Tages bejeidunet! 2Bemn Das Morblidgt, jene ferme Şimmelz̈gluth, weldhe purpurfarbent bem fiole Der (Eroe entfitömt,

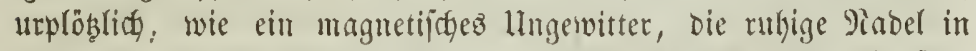
eine jitternbe Bewegunt verjegt, wenn biejes (Erzittern oft über Ränber und Meere auf Şunberte und Taujente von Meilen im

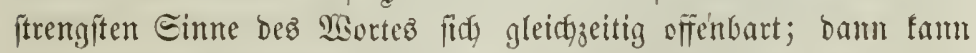
unz bie SHeidyzeitigteit biejer Eriforinumg befier alz zeuerfignale

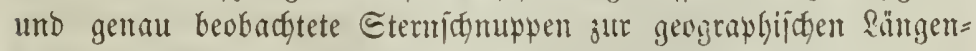
befítimnung bienten, und mit Bewunderung erferment wir, wie wir

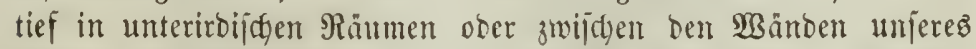
ftiffen Stubirftubdhenz an ben 3ufungen zweier fleiner \$)agnet= nabeln bie Entfermungen meffen fömen, weldhe fie you einnor tremen, bie Entfernungen, weldye Sajan von Berlin uno Berlin 
yon Mewyorf tremen. Wenn Tage lang bichte Mebelichleier ben

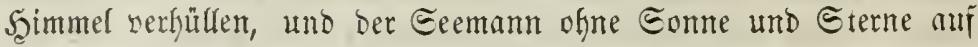
fremben Mieeren umberirrt, ohne Mrittel, 3eit ober Drt zu befitim=

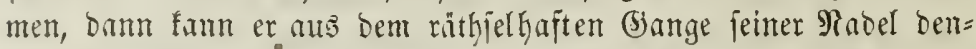
noch mit Eidferheit wiffen, ob er brokente Blippen vermeiden oter

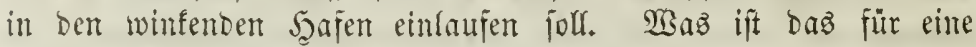
feltjame Sraft, bie fid in jener fleinen Sabel regt, bie faft mie ein

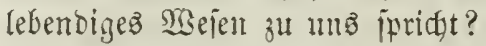

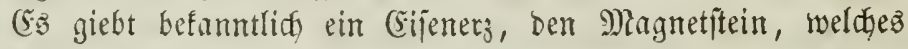

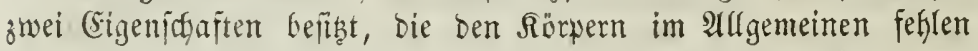

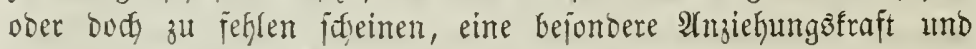

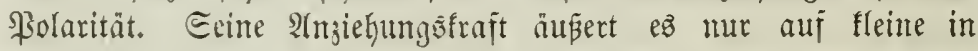
feiner 9rälye befindlictye Mafilen einiger Förper, unter Denten (Sijen ber am Gäufigiten vorfonmento ijt. Eeine Polarität bringt herbor,

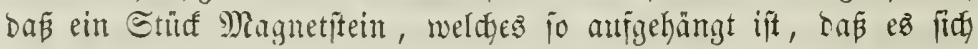
frei um jeinen edawerpunft brehen fann, mur in einer beffimmtent

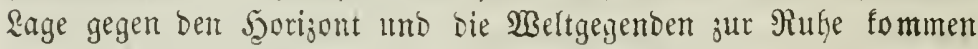

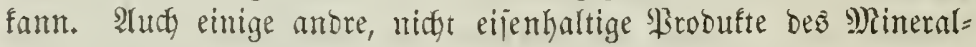
reichz zeigen biejelben Crigenidgaften, uno alle, weldje fie zeigen, werden unter ber Shejammtbentenumg Der magnetijdyen Rörper be

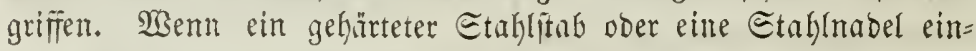
mal ooer öfter, ftets aber in gleider Ridftung, mit einem Magnet=

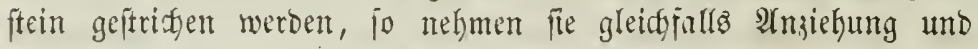
Polarität an, ober werben magnetifint, und bewafrem beide (Sigen= fofaften mehr ober weniger bleibent. Went eine foldje Magnet= nadel wagerectft iftwebeno aufgefängt wird, etwa an einem langen, eine Drehung meber serurfactendent noch verfindernoen Faben, fó

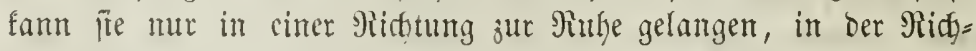
tung Des magnetijten Merisinns. WBiro bieje Midfunty an einem Punfte Der (Erbe aufgejutt), fo finbet fie fich meiftenz uäherungs = weije, an eimigen Funften genan, von Süben nadh Rorben gefend.

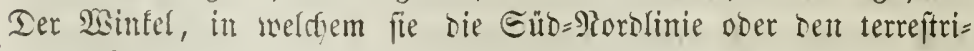

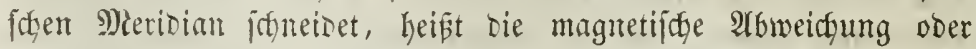

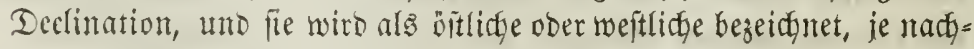

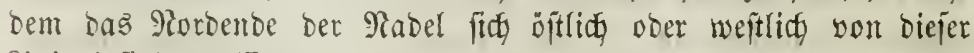

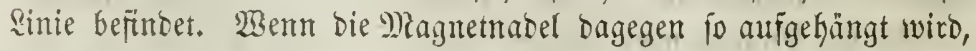

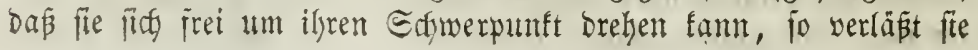


ihre wageredfte Rage unt neigt fü gegen ben Şorijont. Dież tritt herwor, wenn einer Rabel eine wageredgt liegente Are gegebent wird, um weldye fie vor ifger Mragnetifirung im Bifeidfigewidgt ift;

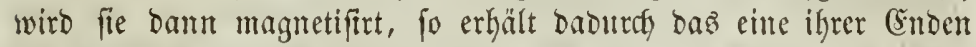

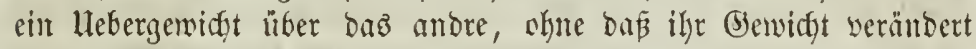

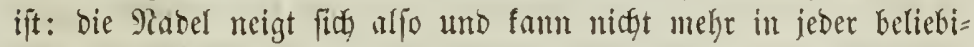
gen, fondern mur in einer befitimmten $\mathfrak{A}$ (bweidfung von ber wage

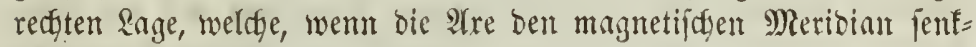
recfit burdficfneibet, bie Reigung ober Snclination genannt wiro, zur $\Re$ uhe gelargen.

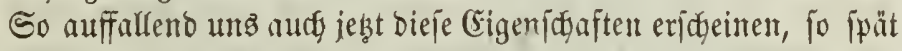

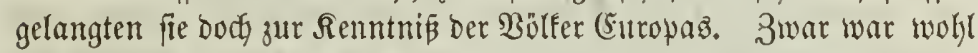
bie Ziehfraft bes Mragnets jofon in uralter Beit befammt, aber jeine Ristytfraft, feine Begief)ung zum Eromagnetizmms ift eine eigenthün=-

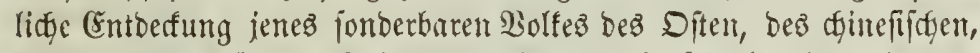

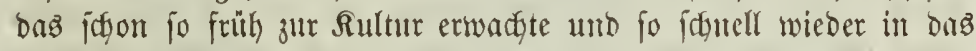

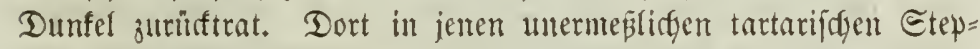

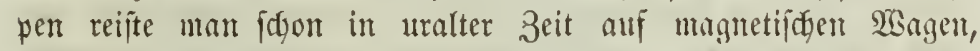

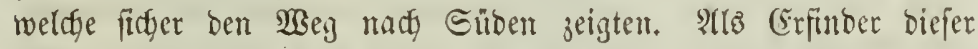
2Bagen, bie man Tifai=nant=fin naunte, wirb zmar ein fabelfafter

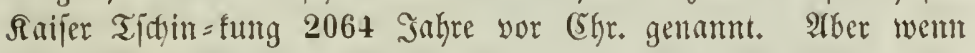
wir aud mit Reedft bie $\mathfrak{B a l y r h e i t}$ biejer Eage besweifeln, fo ift bod unbeftreitbar, bás bie (5hinejen bie Sübridgtung ber Magnetnabel

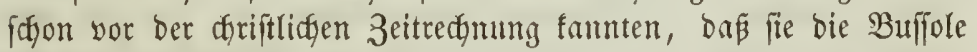
zur Eee menigftens unter ber Dynaftie ber $\mathfrak{T}$ fin im 3. Sahlfhun=

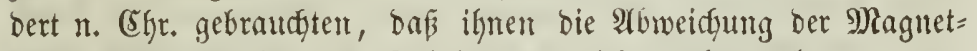
nabel päteftens im 12. Salyrbunbert nicht mekgr verborgen war. Der 2 Beften muß̈te von biefem veradteten Bolfe lernen. Denn

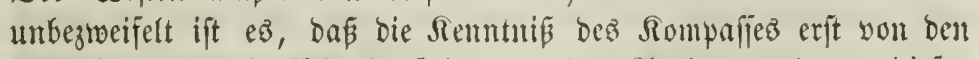

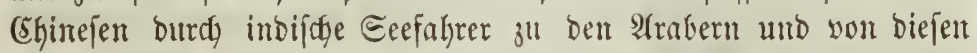
zu Den Epantern brang. Dapi ber magnetifoge Meribian aber we=

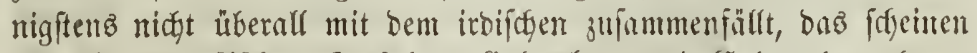
erft-bie europäifdaen Eecfagrer (Solumbus uno Eabot bemerft zu

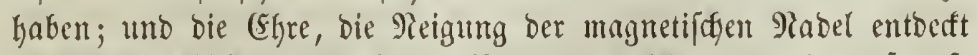

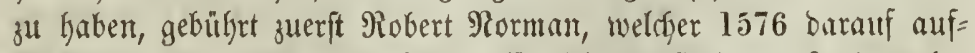

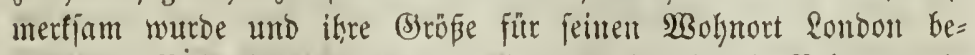

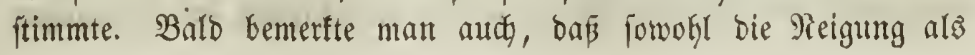


bie 2 bweidfung Der Magnetmabel weit entfernt finb, an allen Punf=

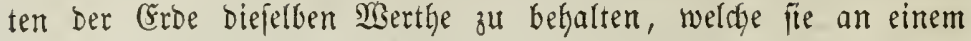
Punfte haben, mo bie Atrobefnung ber Seefahrten bis in bie amerifanifdyen und indijdyen Meere legte biez beutlich an ben Tag.

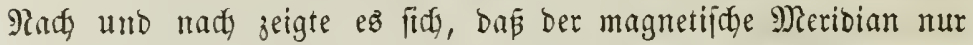
in bem ron ben folen entjernteren Theile ber Erboberflädse nähe= rungsmeije yon Süben nach ?orben geht, in ben bie Cropole um= gebenden Theilen aber jebe Ridtung in Bejiehung auf bie Süb= 9orolinie nefmen fann, jo Daß ez fogar \$unfte auf ber Erbe giebt, wo baflelbe Ende der Pabel, weldyes bei uns fait nach Porben geridytet ift, fith nady Süben wendet. Sie zeigte ferner, bas audh bie Reiguny ber Rabel Aenderungen unterworfen ift, weldye bis

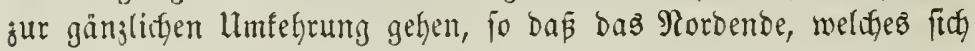
in umpern (Segenden ziemlich talse und an einem Sunte, in befien

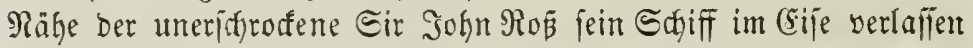
muste, unter $70^{0} 5^{\prime} 17^{\prime \prime}$ norol. Breite und $96^{\circ} 46^{\prime} 45^{\prime \prime}$ weftl. Ränge (yon (5reentwid), fich ganz uno fenfredyt bem Fuppunfte zu= wenbet, mit ber 2 nnäberung an ben (Erbåquator nad) und nad) jeine Reigung verliert und bann höher wirb als bas Eübende, weldeg bem હübpole ber Erbe ju immer tiefer herabgezogen wirb und enolid) an einem \$untte im jüblidyen \$olarfreife, bent im Sahre

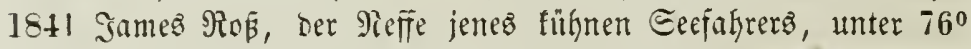

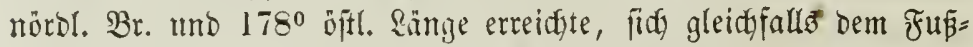

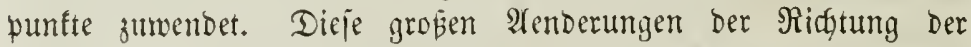
magnetificen Rraft anj Der sroe erregten bie 2 ufmerffamfeit Defto

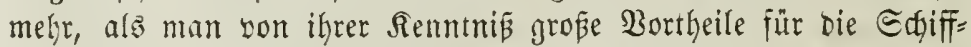
fahrt ermartete. Sidgt allein wirb bie Renntni bem Eeejahter nöthig, um banndy bie Ridgtung zu wäflen, in wel= der er jegeln muś, jontern burds fie fann auds eime befanntlids

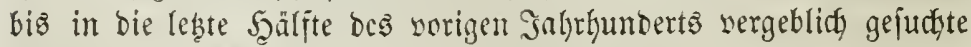

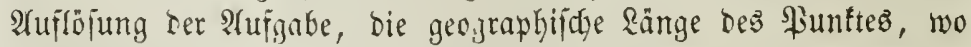
ein Extiff fith befindet, zu beftimmen, gefunden werben. Die Er: wartung diejes 2 tubens war es wohl bejonbers, weldse fatson ben gropen iffronomen Salley veranlap̄te, Sarten zu entwerfen, auf wel= d)en burch frumme Rintien angebeutet war, wie grof bie F(brweidyung an jebem ßunte Dez Meeres im Safre 1700 war, und fiergu ta= men bald ähnliche von Wilfe, weldye ben Zujtano ber Neigungen 


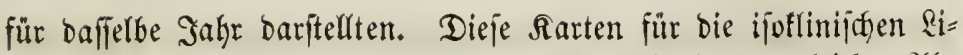
nien, wie man jene Sinten nennt, weldye bie Derter gleidjer $\mathfrak{P}(\mathfrak{b}=$ meidfung ober gleicter Mieigung ber Magnetnadel verbinden, haben

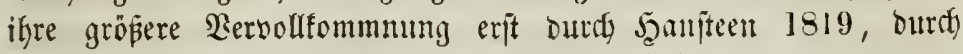
2. (Erman 1830 und durdy Barlow 1833 erbalten.

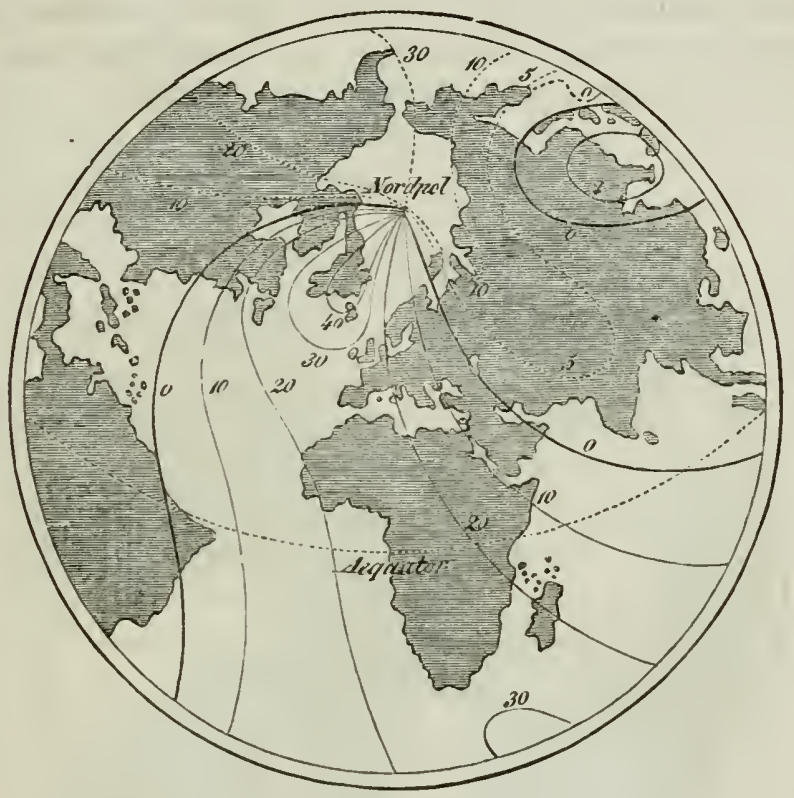

Sarte ber ifognifden Sinien.

Die beigefingten, nadi Barlow entworfenen Sarten veran=

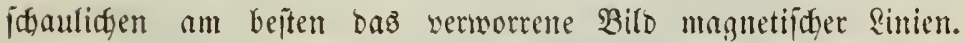
Die erifte, weldye bie ifogonifiden Sinien barfteflt, zeigt eine

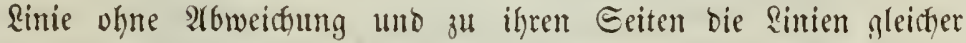

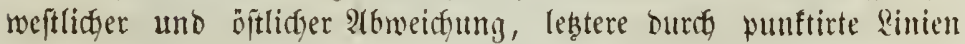
herborgefoben. Sie alfe laufen in zmei Situtten, bem aftro=

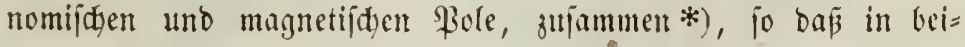

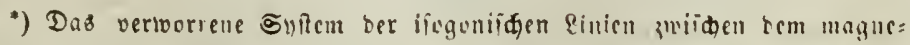

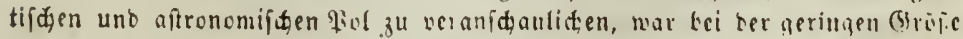

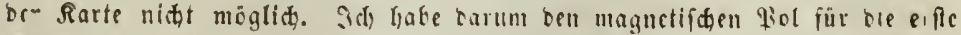
Sarte ganz unbeadtet gelafien, ia or auf ber zrositen un fo beutlidger bervor: 
ben bie Afbreidung ber Magnetnabel veridfwindet. In bem magnetijtyen fole giebt eş aber besmegen feine ober vielmehr

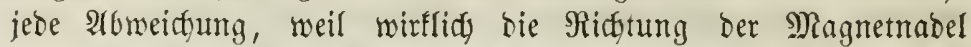
aufhört; in bem aitronomijofen- nur beshalb, weil ber Meribian, gegen welchen bie 2 fbweithung gezählt wird, feine Bebeutung verliert. Bejonders merfwhitrig erjoteint nod eine zweite in fith jelbit zujam= menlaujende einte ofne abweidyng im öjticten afien und bem dinejijden uno japanijden Meere.

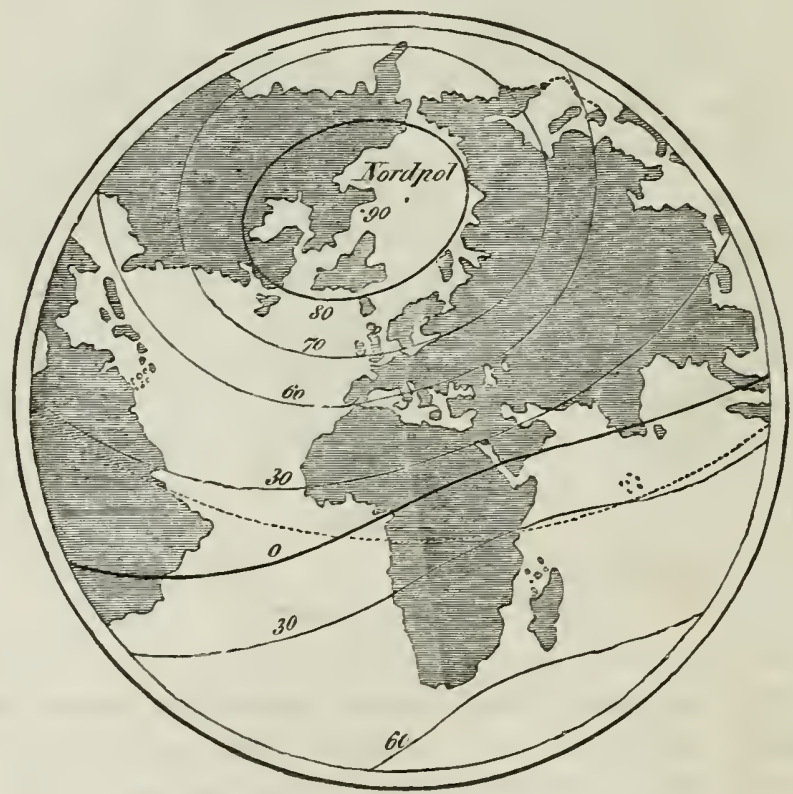

Rarte ter ifstlinificten Rinten.

Die auj ber zweiten Rarte Dargeftellten ifoflinifhen Rinien er= iøeinen gegen bie meribianartigen ifogonifden als \$aralfelfreife um

tritt. Ueberfaupt fönnen biele Rarten wegen ifrer Rleinfeit feinen SInfprud auj Stenanigfeit maden. Sie jollen ber Anidyaung nur ein Bilo vom \&auie Der magnetijen Rurven geben. BBer eine ffeciellere Renntnís bavon münít,

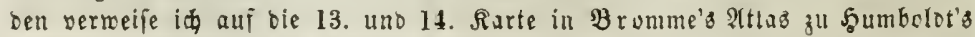

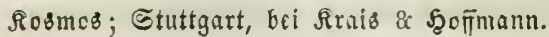


(5rbe mit einanoer serglidgen burdy ein Berfahren, weldez auf ber

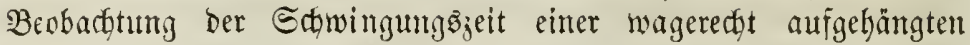
Magnetnadel Ferulyt. P(ut) bicje Sntenfität ftellte man burds frumme Rinien, weldge ijobynamijhe heipen, weil fie bie Srte glei= d)er Sntenfität verbinden, auf einer Rarte bar; fo baj aljo burdh bieje orei Rarten ber magnetijđge 3ujtand ber Eroe bolljtänbig ver= anjwaulidyt wirb.

Die umftehende Rate her ijobynamiften Rinien giebt bie

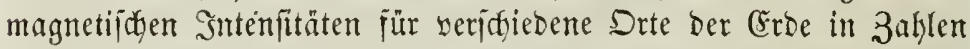
an, welchen bie für Ronbon berethnete Intenfität von 1372 als

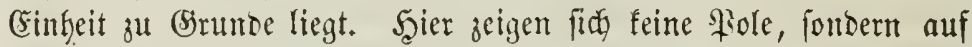
jeber Semijpläre jwei son biefen verjobiebene Marima ber Sntenft=

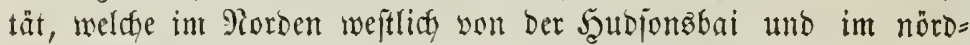
licken affien liegen.

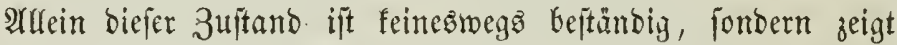
in ber 2 rt bes Serbortretens, wie auty in ben Urjadyen fehr ber= fulebene Beränderungen. (Sine berielben geht langlam vor fid), aber bafür während langer Zeit immer in bempelben Sinne, und erlangt saburdy eine foldye Bebeutumg, bas fie bie \&age uno $r i=$

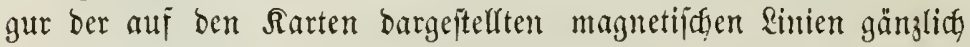
umgeftalten wirb. So find jebt swei sinien befannt, in weldyen bie Magnetnabel genau nath Morben zeigt. Die eine fommt auz

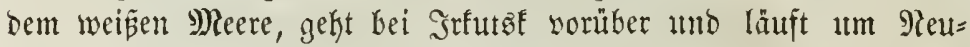
holland Surch ben Dcean bem Silbpole zu; bie andere geht nom Sübpol Durch bas atlantifge Meer uno burdafdneidet nörolich son Rio De Janteiro Den Rontiment von Amerifa. Die erftere von bei= ben ging aber nody 1657 burdy Ronbon, 1669 Durd Pariz, hat aljo in 150 Sabren $80^{\circ}$ burthlaufen. Die zmeite Sinte bewegt fin auts, aber langjamer, nath Diten. Cim periodiches Bejeb biejer Beränberung fennen wir noch nidft, wir wiffen mur, baß fie sor=

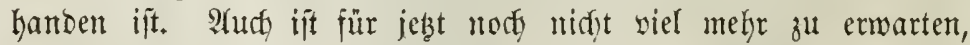
Da mebrere Salyrfumberte ber Beobadymig erit zut gegrünteten Fol= gerungen beredtigen. Sine zweite 2 rtt ber Beränberungen Deछ magnetipden 3uitnnbes ber (Eroe zeigt fid in einer tïglid) wieber= febrenben Edywantung beffelben, ift aber bis jebst nur in $\mathfrak{B}$ ezug auf bie Itbweidung anfaltent veriolgt worben. In unfern (be= genden zeigt bie Rabel am Morgen jebes Tagez am b̈flidyten, 
Nadymittags am wefflidyiten. Beobadytungen haben zugleidy ge=

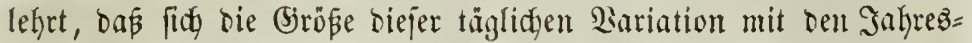
jeiten andert, bei ums im 2rpril am grö̈ten, im December am

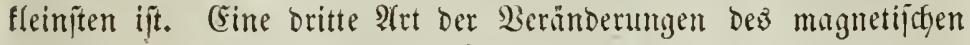
3ujtandes Ler (Erbe zeigt fich enolid) unabhängig sout Tages = unb Sahreszeit; fie tritt plöblict) ein unt vermehrt unb vermindert fids ebenjo plöblich. Dieje Berwegungen ber Siabel erjobeinen etwa fo, als whüben fie burdy bie Injiehung fleiner, in oer Mähe hefind =

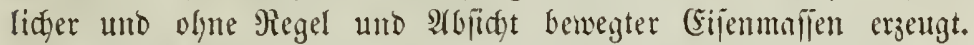

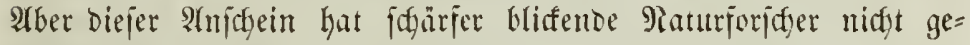

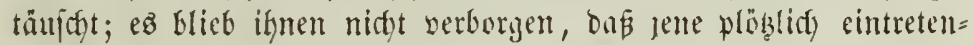

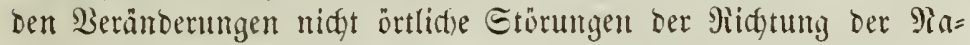

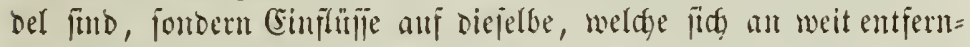
ten Siunften ber (5rbe gleidyzeitig zeigen. \$̧umbold murbe burd)

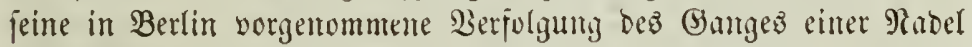
yon Lalber zu balber Etmoe und Durd) Die fich Darin zeigenden plöz̧lichen Etörungen içon 1806 uno 1807 veranlaṕt, von ander=

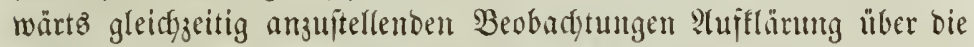
Ratur biejer Gtörungen jll erwarten. Allein jein Darauf jolgender

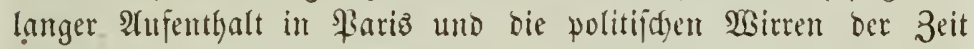
verbinderten bie Anorommig foldjer Bcobad)tungen, bis fie burct)

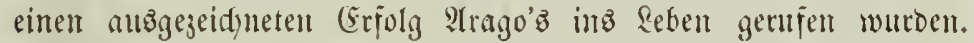

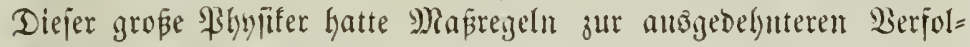
gung ber magnetijden Erjdyeimungen in Wariz in Birfjamteit ge=

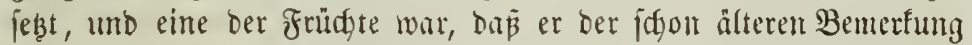

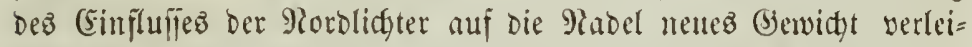
Gen und nadyeijen fonnte, Daß berjelbe nidft auj Begenden Der Groe, wo fie fidtbar find, bejorintt ift. Stbat exfolgten inmer zahl= reidjere, immer forgfältigere Beobadtuntaen in allen ?ändern ber Erbe. 2lber bieje Untermehmungen beourften noç immer größerer

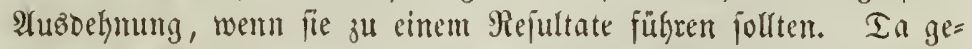

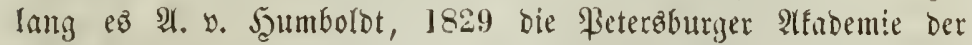

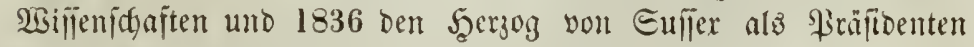
ber Ronooner Gocietät ber SBifienjanten ju betwegen, ifyen Ein= fluê fur (S)rintoung von bleibenden magnetifden Dbjerbatorien in

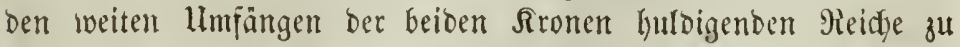
verwenden. Sezst erfolgten bie bortrefflidgften Beobadytungen in un= 


\section{4}

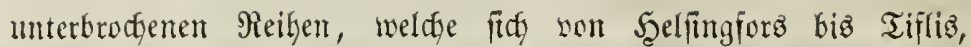
von Eitfa bis ßecting erjtreften. An Den entlegenjten Drten ber Eroe wutroen fejte magnetifje SBarten erridtet, in Sanaba, Sn= bien, Banbiemengland biz in jene eifigen Eilbpolarmeere hiuat,

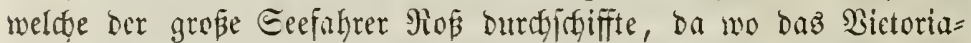

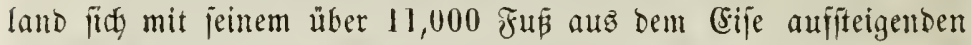

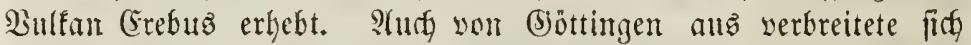

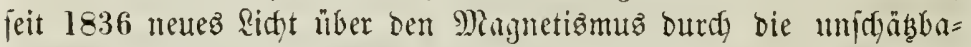

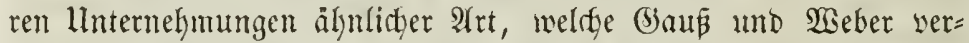
anlapten. Bon Sangr zu Jahr ift Der Sifer für bie Erjorjaung Deg Eromagnetismus gemadfon. Denn Cifer unt Fortidyritte ftefen in nothmendiger $\mathfrak{B e d f j e l b e j i e f u n g , ~ c i n e r ~ p o r m t ~ b e n ~ a n b e r n ~ a n . ~}$

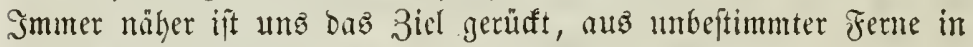

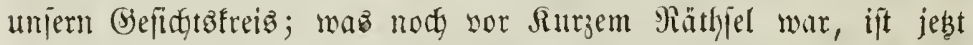

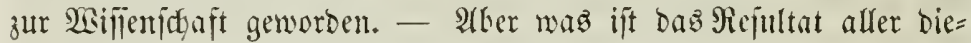
jer Forjhungen, haben wir eine Erflärung gemonnen?

SBir fömten freilidy fcinesmegs eine Antwort auf bie Frage er= marten, wartum bie Eroe Magnetismus befibt, wir bürfen ebenjo= wenig an eine Epeculation liber bie erite Urjadye ber magnetijtgen Rraft jelbjt Denfen, benn bieje wird uns ftetz verborgen bleiben: Die gewommene Errflärung fann nidgts 2nberez fein, als bie Ber= folgung bes 3ujammenhanges zmijuen den einfachften Aeuferun= gen Derjelben Rraft, weldye wir an ben Tag zu legen vermögen, und ben verwidelten, welthe ber (Srbförper uns jeigt. Sth glaube,

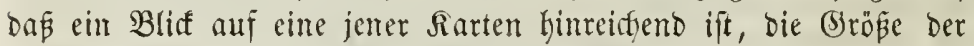

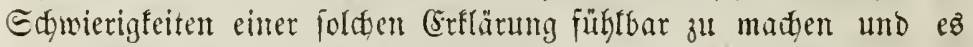
begreiflidy erjobinen ju la

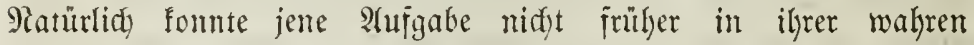
Form kervortreten, ehe nidft bie Beokadtung jo viel non ber (sr=

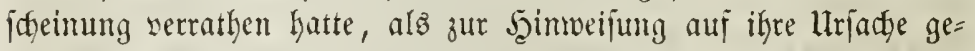
nilgte. Co lange war meniger eine 2lujgabe zu lojen, alsz eint

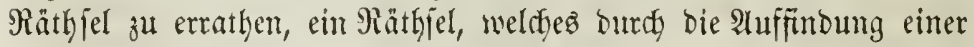
jelbit nicht weiter ju redfifertigenden einfadyen Ammahme erratfen wird, weldye bie veridicbenen Bevbadturgen im Zujammentange erjobinen läpt, cin Räthfé, meldges offenbar nur bam errathen

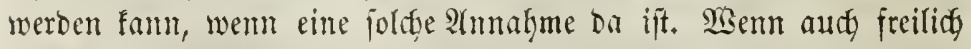

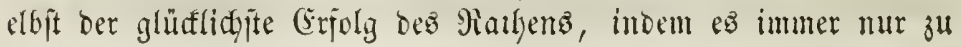


Darum murbe tein einjacter $\mathfrak{A}$ usobruf erlangt, weldfer bie Beobact)= tungen jelbfit wertreten uno in gedrängtejter Frorm angeben fonnte,

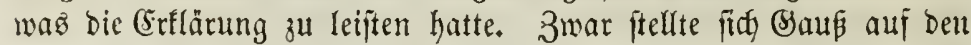

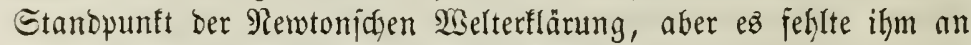

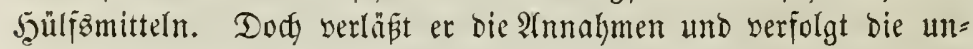
zweibeutigen Bedingungen, welden baz Seersortreten ber magneti=

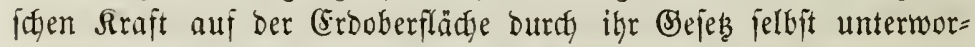
fen ifit. So find unz wenigitenz Andeutungen liber bie wahre Ratur bes Eromagnetismus gegeben.

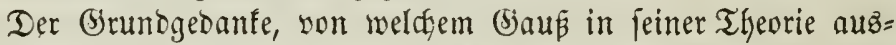

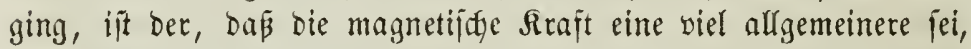
alż wofür fie bisher gegolten habe, baßj fie nidgt bloz im Gijen,

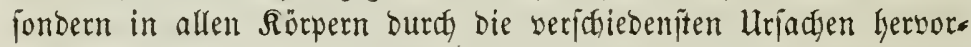

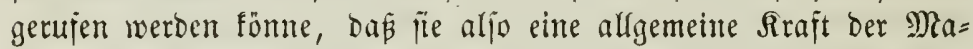
terie, eime fozmijale fei. Fajt über alle (Ermartung ift bieje 2 Anjicht

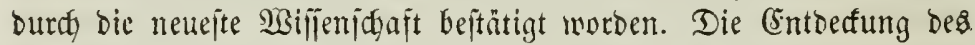

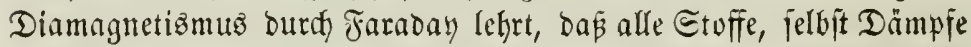

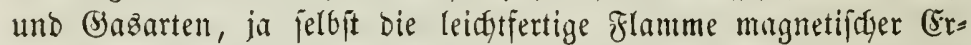
idjeinungen fähig fint, wenn wir mur Mrittel anwenton, weldue ber Zartheit biejer Etoffe angemejien find. Eo haben wir bie magne= tijade $\mathfrak{R}$ raft - wenn überhaupt von einer $\mathfrak{R}$ raft geiprodjen merben Dari; benn was wir $\mathfrak{R}$ raft nemnen, ift mur bie Form einer Bewe= gung - ja autd in unferer (Entmiđtung ber Raturfräfte fennen ge=

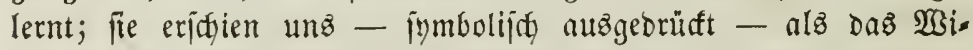
Deriftreben Dir Materie gegen bie verflübytigentoe, auflojende Mindyt Der (Eleetricität, als das jelbjtfüchtige ftarte Befarren ber aus iłrer

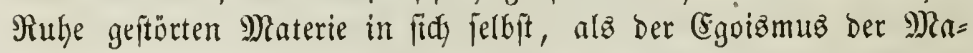

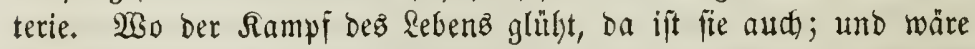
Die Materie zu melyr alz ätherijdyer Düntheit verflüdtigt, fie bliebe

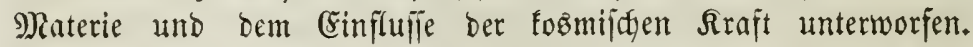

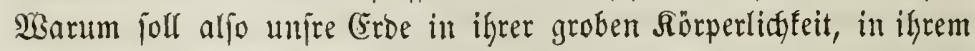
wilden (Entwifflungzfampfe nidft magnetijd) jein? Sene lebenbige Rraft ber Berwandifjaft - wir nannten fie eimmal eine dyemijaje - ,

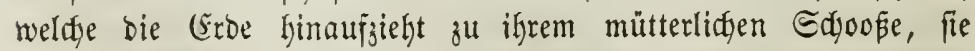
mit ber Come veridgmelzen will, wirft aber natïrrlid da am ftäré=

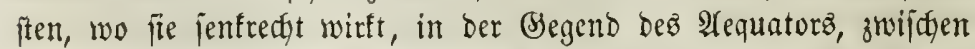
Den $\mathfrak{B e n d e f r e i j e r t . ~ D o r t ~ i f t ~ a u d , ~ w i e ~ w i r ~ j e f e n ~ w e r b e n , ~ b i e ~ a t m o = ~}$ 


\section{7}

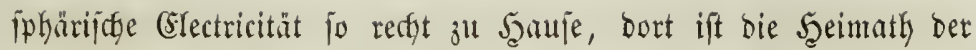
Salmen uno ber Tropenftitume, Dort erfojüttern täglidg furdytbare (Semitter, von beren erlatbener, grauenhafter Edjönheit wir uns feine Beyriffe madjen fömen, Dic Suftreyionen, bort bobrolyen jene

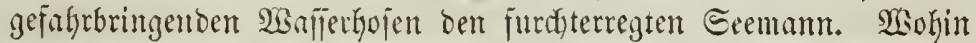
foll fich mult jente wiberftrebentoe, auf Eelbiferhaltung hebacte Sraft

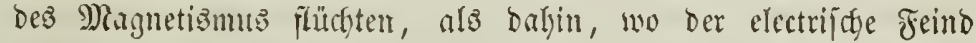
fdswäder ju twirfen verma, nady ben \$olarfreifen? Dort wohnt Darum bie ftürffite Finft Des צnagnetismms, bort rufen jene fo lange gejuctiten magnetijaten \$ole. Diejer innige 3ujanmenthang ber

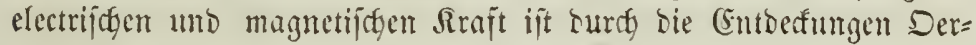

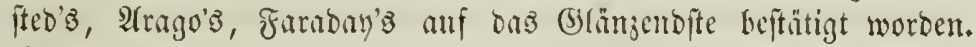

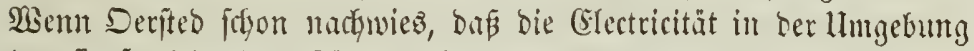
bes fie fortleitenten Rörpers Magnetismms erregt, fo hat Farabay mieber burdy ben freigeworbenten Magnetismus electrifige Єtrömun= gen herborgerufen. Freilich mïgen gar verifdiedenartige electrifdge

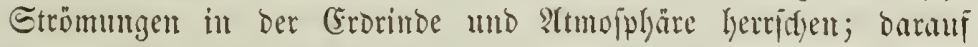

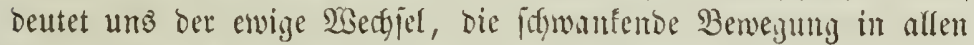

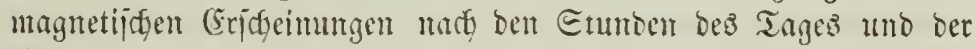
Padyt, nady ben Jahresjeiten uno dem Berlanfe gauzer Sullere hin.

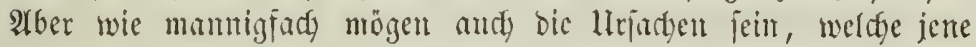
Ströme herbortufen? Demn nidgt eimmal in ber Sonme affein und in ifrer Fiolarität, autb) nicft in Der Motation ber (Erbe und

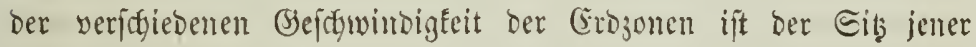

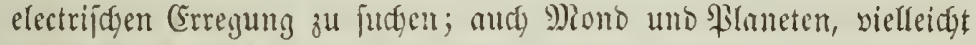

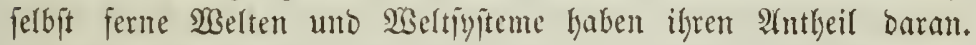

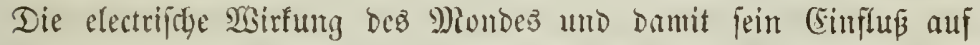

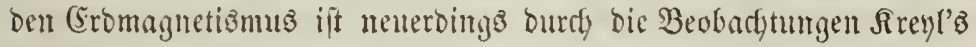

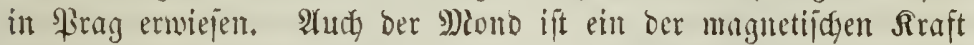

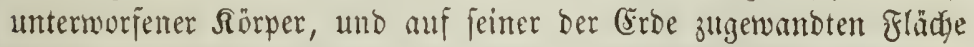
herridgt jenter Miagnetismus vor, weldjer ben Siliopol unirer Magnet=

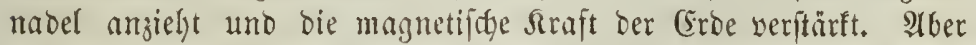
es fonmen nody antore Erreger electrilcher Єtröme in unfrer (Ero= rinbe linzan, und bamit aud) andre Dueflen bes (Eromagnetismus. Die 2 särme, ladben wir gejeken, ftelyt in eben fo imniger Sierbinoung mit ber Efectricität uno dem Magnetismmto, wie ja ein Band fith

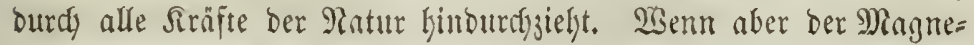

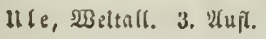




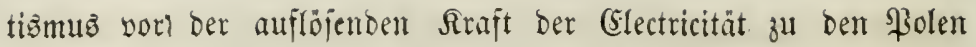
floh, fo flieft bie sisarme, als bie in Forment feffelnbe Madyt,

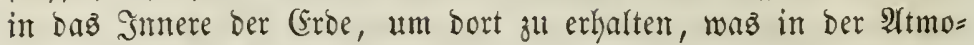
iphäre verflüctigt wird. Şier won inmen heraus wirft fie ourdy ungleithe Bertheilung auf bie electrijcyen Etrömungen ber Erbrinde, ftört ben rufigen Gang ber Magnetnabel. Şr fommt noct jente Wärme zu Şülfe, welche in bem Ruftfreije mit bem Sidfte um ben Eieg ringt; Denn dap autg bieje innig mit bem (5romagnetiomuz verfmipft ift, bafür fpricht jhon allein bas make 3ujammenfallent ber

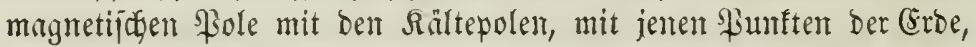
wo bie mittlere Temperatur die niebrigite ift. Soll aber bieje (5r= flärung bes Eromagntetismus in solltommentem Eintlang mit unirer

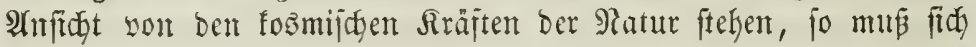
burch ben (Eromagnetismus aud) jene vierte Edyejterfraft, bas Sidgt, sfienbaren. Sonnte Jarabay jeine füntlidy erzeugten magne=

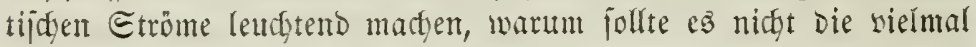

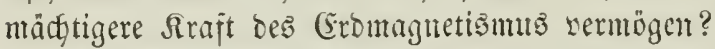

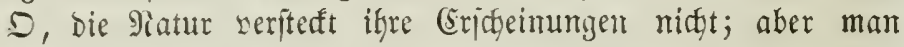

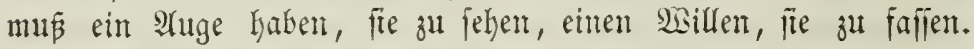
Eeft mur am jumarzen Binterhimmel jeme blutrothen flammen

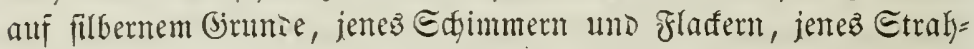

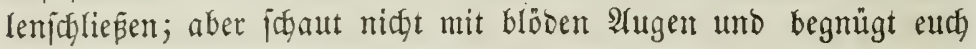

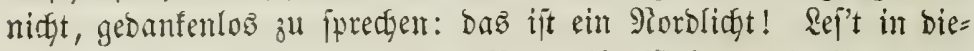
jer pradtwollen Sffentarung ber Patur ifr Seejen und ifre Tha= ten, loft ihr bie Gjekeimnijle ifrer Zauberfunit ab, zieht fie euch nake, wemt fie fern foeint. Demt micht immer ijt baz Ferne jo fern, unt was ify in ben Şimmelsaräumen flammen feht, entquifut

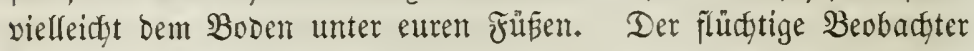
fieft in bem (5rolidgt, weil es in ben folargegenden am bäufigften

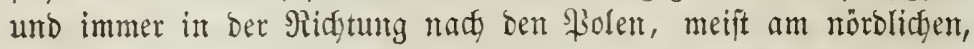
jeltner am jüblichen Scimmel gejehen wirb, cine Erjobeinung, beren Entitefung Diejen \$olarregionen angelyöt, und barum hat man ę audg Slorblidgt ober Wolarlidgt genannt. Daun aber fönnten \$o=

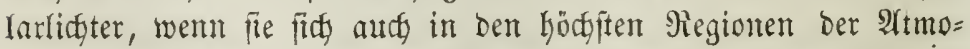
iphäre erzengten, niemals ben Bewohnern ber Tropengegend ficht= bar werben: eine 2 nfitgt, weldger vielfadge netere Beobactungen Durchaus wiberprecten; Denn Sumboldt hat bis in bie Tropenregionen, 


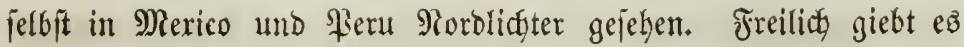
Bsegenden, bejonders im Rorben Amerifas am Bärenfee und an

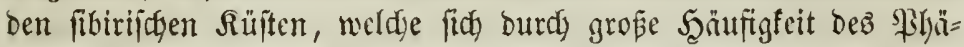
nomenz auszeidfnen, gleidjan bejontere Rorblictstifriche, in wel=

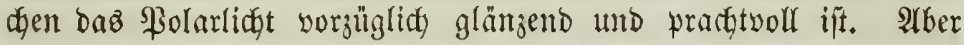
audh bort fajeint $\mathrm{ez}$ polarlidgtreidje und arme Sahre zu geben, wie eż ja auch getwitterreidje giebt, Ferioden, in benen bie \$olarlicts= ter bäufiger voer feltener ericheinen. Dertliche unt flimatipge (sin=

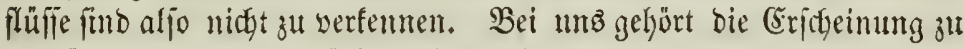
Den feltneren, unb ez bürfte balyer woly nicht gants jweefloz fein, went

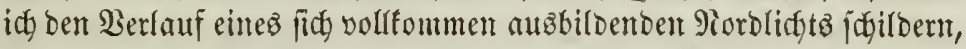
wie ez yon Rottin, $\mathfrak{A}$ rgelander, Saumboldt U. A. beobactetet murbe.

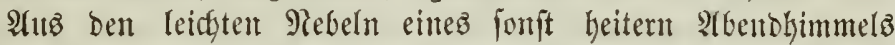

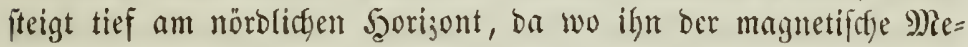
ribian burchjdyteibet, eine rautdgraue, balo ins Bramte, bald ins Biolette übergehente Miebelwand auf, ant weldyer bie Eterne wie Diamnanten auf einem Seidyentudche funfeln. Dald umfrängt fie ein glänzender Sidgtbogen von Glägelber Farbe, Der im foblen Morben

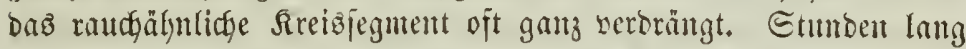

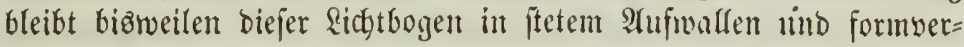
änderndem Edjwanten itehen; Damn eridjeinen idguarze Etreifen, welche ben lictiten Bogen tremnen, es billoen fith Etrablen, weldye fich balo idfnell, bald langlam verlängern und vertürsent, bald helf

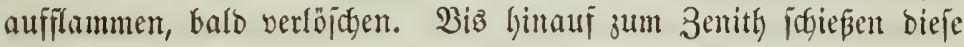
Strablen, aber inmer nade bent Sisuntte, auf welden bie Snclina= tionżnabel hingeridatet ift. Seßzt nimmt âtles eine zitternbe, wal= lenbe Bewegung an, Der ganze Bogen itwanft gleidy einer vom

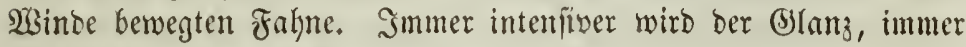
lebbafter fpielen bie Farben vom bunfeln Biofett uno bläulichen

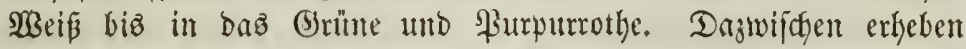
fid) fifwarje, biffem 9iaud ähnlidge Etrahlen; ber Bogen felbjt ent=

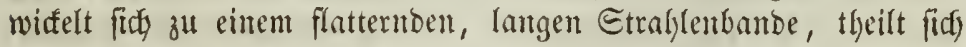
in ben graziöjeften 2 sindoutgen und vereinigt Dab Bantze in ein

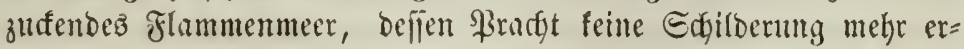
reidsen faum. Szody oben am Şimmel um ben magnetif(yen Zenitly

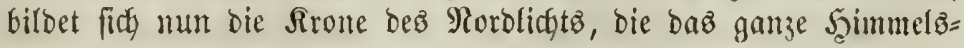
zelt nit einem milberen Blanze, einem rufigeren Edgimmer um= 


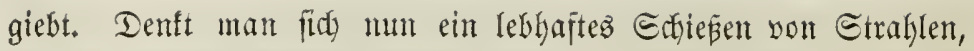

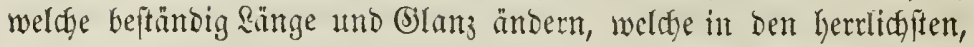
rotlen unb grünen Farbentőnen wellenartig einamber folgen, bentt man fich endidx bas ganze Feimmels̈gemölbe in cinte untgehenre,

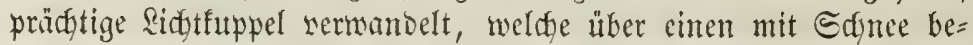
beften Boben ausgebreitet ift uno einen blendenden Ragmen für

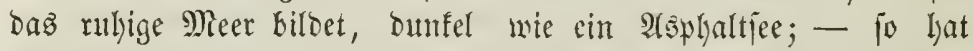
man cine fobwadje Borfitellung von bicfent wunberbaren Echau=

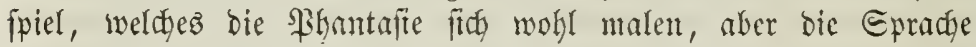

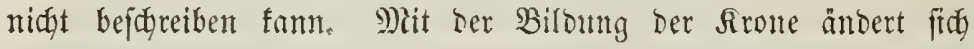
plöblich bie Richtintenfität Der Straklent, fie übertrifft bie ber Eteme

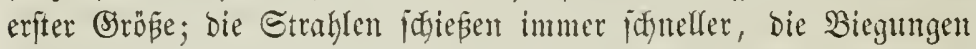

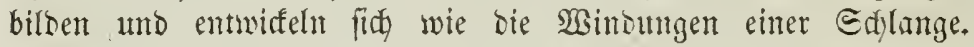

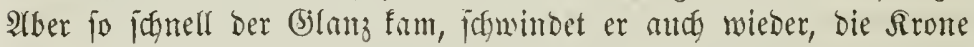

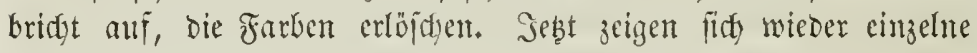

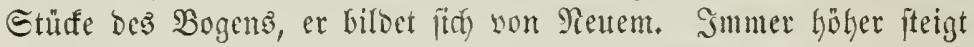
er zum 3enith aut, bic Etrahlen werbent fitrzer, bis fie nut noch cint breites rothes Band bilden, Durch weldges hintourdy man bie grüne Färbung Der obern Thoile erblifft. Seght ift bas ganje Sibrunomen auf Den fübliden Şimmel hinübergerinft unt bildot immer bläfiere Bogen, biz fie ganj veridymindert, ehe fie ben Szorizont erreichen. Bald freft man nur nody am gamjen Simmelaggewölbe zerftreut Glaffe, faft aictgrau leudtende, unkeiveglicte flecte, und and fie

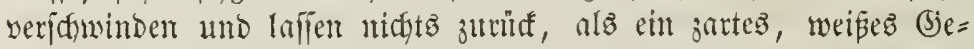

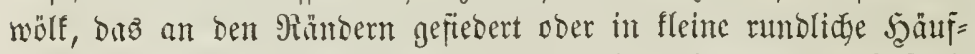
dyen, unjern Echäjuen ähntids, vertheilt ift. Dab ift bie Erridei=

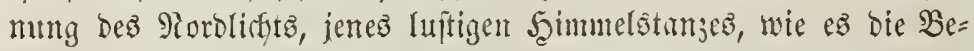
wolner Der Ehethantinjeln nomen, went es fids in feiner ganjen

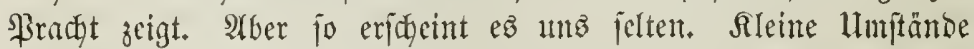
verciteln vft jeine Bofkentung, mögen fre mun in bem ungünftigen

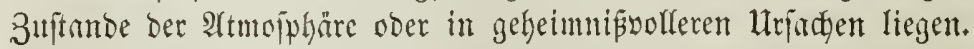

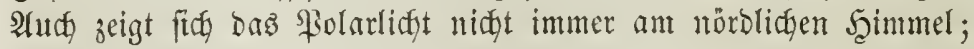
Siblichter hat man in Englanto, Morblidgter unter ben Tropen in \$eru uno Brafillen gefécen. Dies beutet auf eine yiel grö́pere Alfgemeingeit Der Hraadje hin, bie wir jut juchen baben.

In frülerer 3eit lat man oft gar wumberbare und abenteuer=

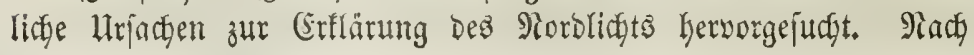




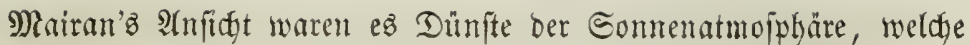

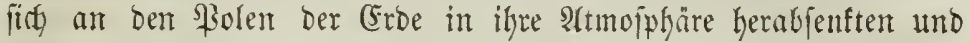
Daburd Das Rordidyt beranlapten. Fndere faben Darin nur eime optijate Erjotimung, Die, Dem Regenbogen ähnlich, von Dem Son= nen= und Wiond=Ridhte herrithre, weldes bie Edueemolfen und Eis=

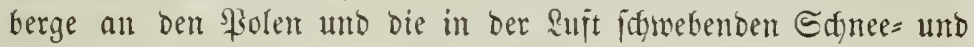
Sistheildgen reflectirten. Enolidy erflinte man bas Porblidgt audh für ein electriftes \$gänomen, bas in ber verbünnten \&uft ber obe=

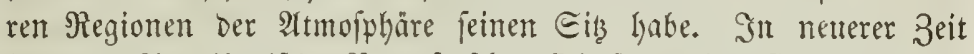

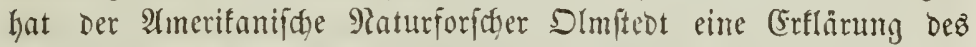

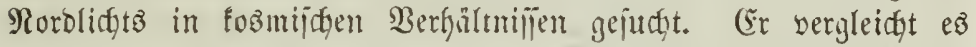
gerabeju mit bem 3odiafnllidyt und nimmt eine Porblidgtmaffe an, bie ex als einen lidten, nebligen, Galbourdfindtigen Etofi fafiloent, Der entzündich und magnetija) fei und Darum auf Der einen Eeite fith ju Meteorfteinen jufammenballe, auf Der andert Cinwirtungent auj bie Magnetuabel veranlafie.

Diejenige lirfache, weldye gegenmiatig am affgemeinften und

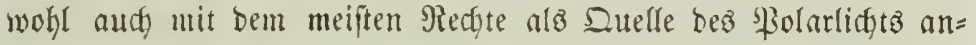
gejeken wirb, ift jeme, auj weldje uns fobon ber 3ujammenhang der Ericheimung mit bem magnetijaen Meribion und 3enith bindeutet, Der (Eromagnetiżmus. Dieje Bermutfung wirb nod beftätigt burdy

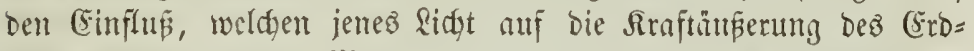
magnetismus in ber Magnetnabel aus̆übt. Die Magnetnabel ift

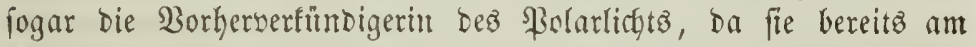

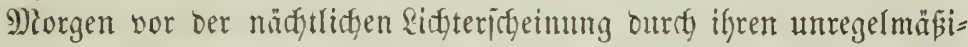

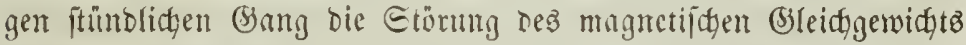
anzeigt. Bevor fid aljo bnz Solarlidgt nods bildet, ift baz magne=

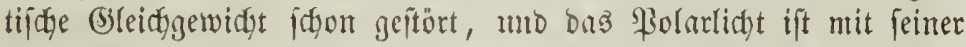
bon Richtentmidfung begleiteten Entlabung gernos bie Wieberher=

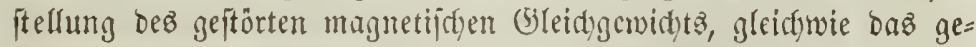

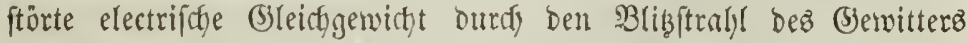

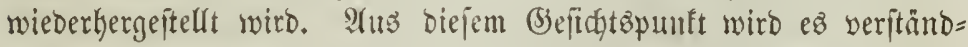
lid, menn Şumbold bas \$olarlidgt ein magnetifdes llngewitter mennt. Wenn aber beim electrijden Selvitter bie Entlabung unter heftigen Detonationen gejdieft, fo leudytet das \$olarlicyt als ein

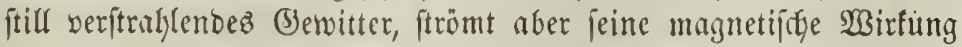

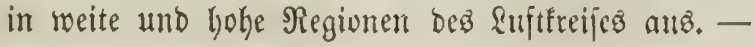


Benn das electrifche Ungewitter gewöknlich auf einen fleinen গiaunt keictränft ift, fo offenbart bagegen bas magnetifdye Unge= witter feine Sirtung auf Den Bang ber Rabel über groß̧e Theile Der Crob und beutet bamit anf eine weit verbreitete telluriftye $\mathfrak{T h a}=$ tigfeit. Frihter wollte ntan Das \$olarlicht gerabezu für eine WBir= fung Der Ruftelectricität erflinren. Sa man wollte fogar, gleich bem

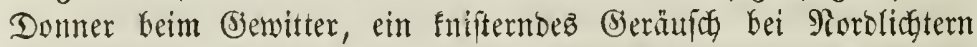

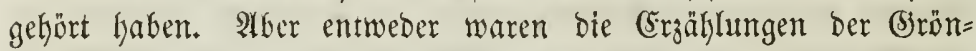
fanbfabrer und fibiriften Futbijäger, Denten man unbedingt (5ilau= ben beimaß́, mur erfunone Jagbgeidfidyten, ober bie Rorblidyter find jeb̧t fumeigfamer geworoen; Denn Den Stelehrten, bie fie belaufden, haben jie nictsts zu hören gegeben. Iluch ift wohl nicht im Bolfe jener (Slaube an das fnifternde (Sieräufd entifanden, fondern in ben Röpjen ber Belefyrten jelbit, melche um igrer Theorie willen hörten,

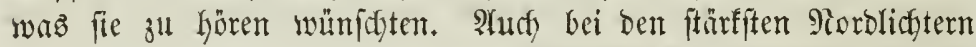
lyat bie genauefte Beobachtung feine Berinderung ber Euftelectricität gezeigt, wohl aber bes Eromagnetismus. Şödfit wahridteinlich ift eB Dalser, und Farabay's neuefte Entbefung einer Ridytentwicflung

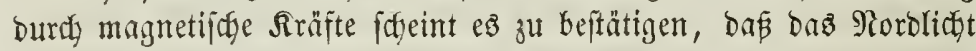
nur bas Ende eines magnetifoben Ungemitters ift, welches jeine Thätigfeit in ben Etörungen ber Magnetnadel anbeutet und fith bis zum leutbtenden Figänomen iteigert.

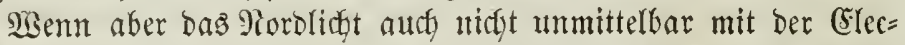
tricităt zufammenbängt, fo focint es boch eine innigere Berbinoung mit gemifien Borgängen in ber צtmojphäre zu haben. Darauf betutet namentlich jenter llebergang Der pradtyolfen Erfdectung zu Den zarten Cirrtsiwölfdyen ober Edanfdyen hin, wie ex fo oft in Amerifa yon Franflin, in Eibirien won $\mathfrak{B}$ rangel beobacbtet wurbe. WBent avir in biefer $\mathfrak{B}$ olfenform aud nicgt grabe wie frü= Ger bie Unjache des Rorblichts futfen wollen, fo föunen wir boch immer auf feine Theilnalme an einem meteorologif̧en \$rocefie, aut eine Eimvirfung bes (Eromagnetiômus auf Den Dutfttreis, auf bie Berbidytutng Der 2 aljerbimpje fduließen. In ber That zeigte fith grabe ban bas Plorblitht in feinem blendendfen Silanje, wenn jene $\mathfrak{B o b l f f y e n}$ in ben oberen \&uftregionen fofwebten, fo büm zrwar,

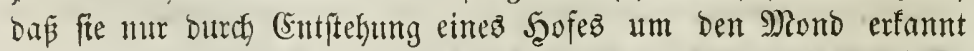
werben fonnten. Dft oroneten fich aud fidon bei Tage bieje $\mathfrak{W o z l}=$ 


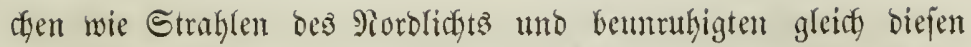
bie Magnetnabel. Dit waren and nact) grofen Morblidgtern nody

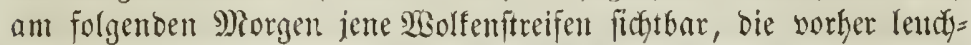
tento gewejen waren. Ia ber berühnte Eabine fah an eintem Berge ber joyottijgen Snjel Sfy ein (jewölf, weldyez währento ber Pacht anfialtent geleucbtet Gatte, und atz bem Etraflen gleich be=

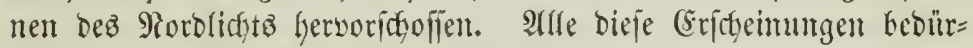

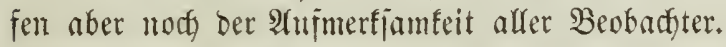

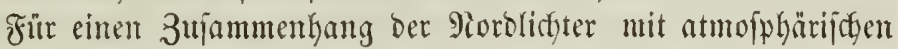

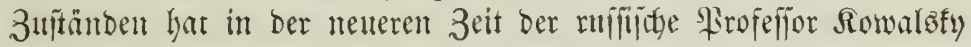
in Sajan aus einer mefringrigen Beobactutung von 9iorblichtern

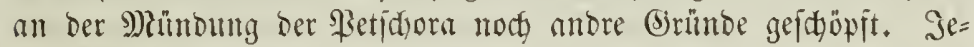

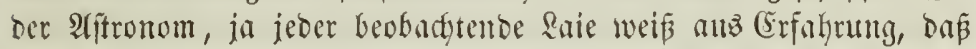
zur $\mathfrak{S B i n t e r}_{j}$ eit bie Eterne außerordentlid) ruthig uno in mildem

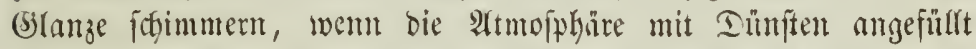
ifi, fo da

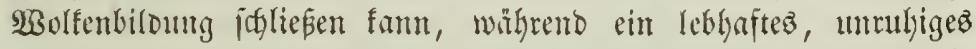
Funfeln ber Eteme ftetż auf fehr trodure \&uft hinbentet. Sowalafy

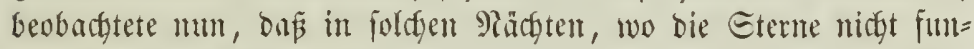

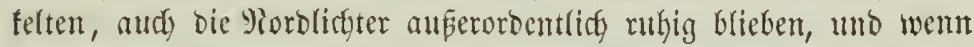

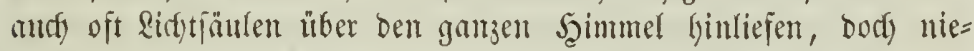

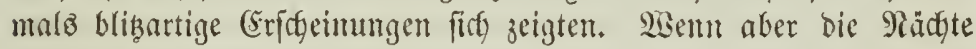
bejonderz falt unto baz zunfeln der Steme befonderz lebhaft war, jo zeigten fird auted bie 9iorbliçter won gamz anbrer Matur, nicfyt bló won bejonderem Blanze, fondern auch wedjeelvoller als jonft,

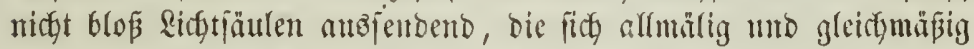
won bem Sidutbogen ans über ben Şimmel verbreiteten, fontorn an zerîtreuten Etellen hier und ba augentblifflich auffilamment,

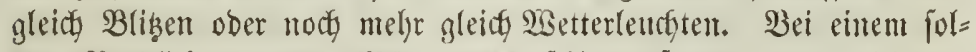

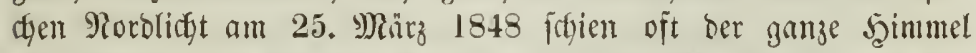

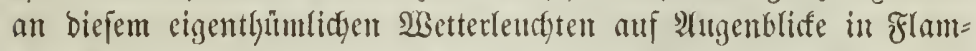

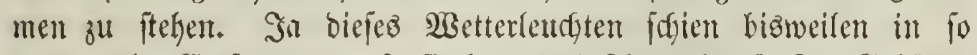

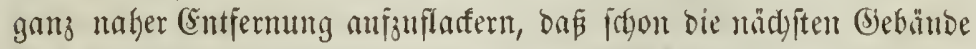
ifgm gleichjam einen Sejutergrumb bilbeten. Sownalöfy) glaubte au=

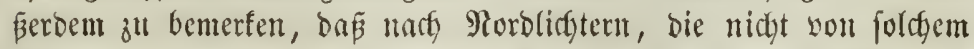

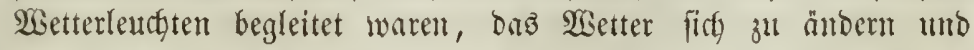

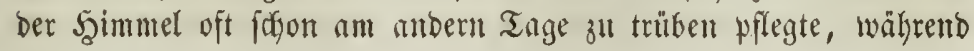




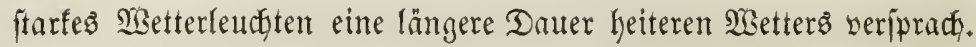
WBenn audf noch mandje Tämbdung bei biefen Benbadtutngen waht=

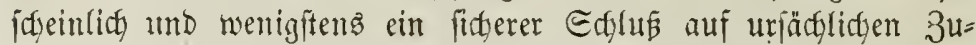
fammenfang nidgt möglid) ift, io bürfte jebenfauls eine grüblidere

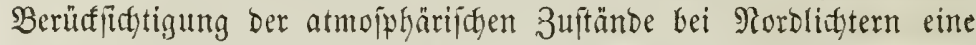
innigere Berbinoung beider Erjadeinumgen Darthum, alż man jeşt noch meiftentheils anzunelyment geneigt ift.

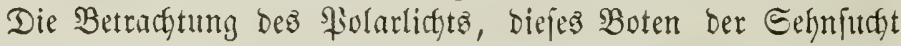

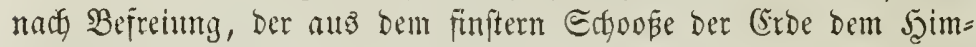
mel zufliegt, lyat uns foton in Das Biebiet jener Rräfte limüberge=

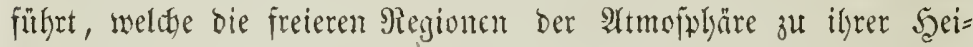

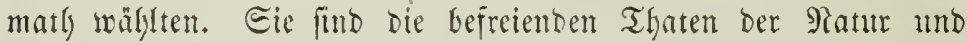

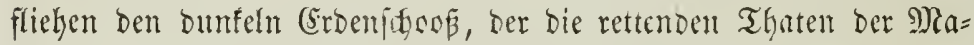

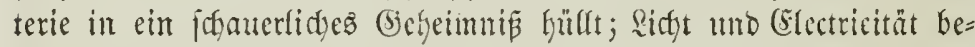
leben bie jtarten 3üge ber Matur, nefmen ihr bie Echauer bes

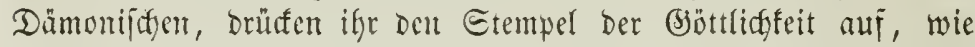

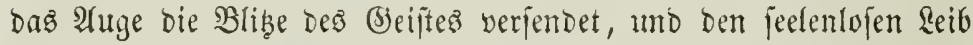
in ben firahlenden Tempel (5jottes verwandelt.

Das Ridyt, bie periplyerifuce Rraft im Begenfads zur centraten

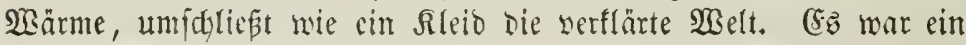

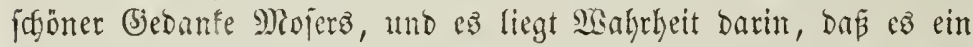

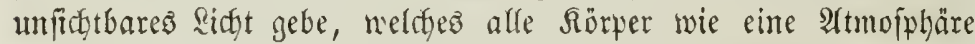
umbülle, nach allen Eeiten Etrafjlen meşende, gleich ben Rioft=

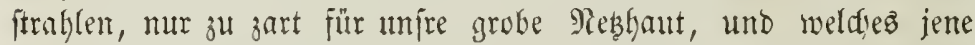
Bilder ans ber Ferne erzenge, in benen uns bie 2 Birflidfeit wie

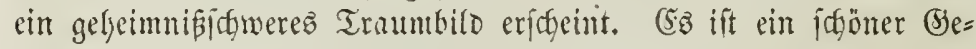
Danfe, nictyt blos ben ungeyeuren Majien geballter Materie, jon=

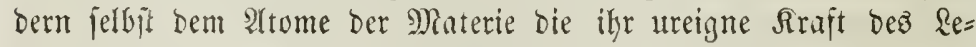
bens entfrablen on lafien, nidyt blos über bie biefammtweett, fon=

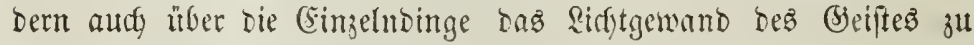
werfen. Miogen bie Miojer'idjen Bilder immerthin andere umb ein=

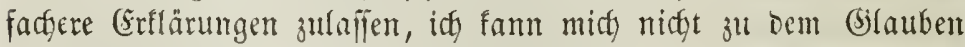

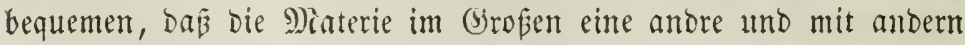
Srä̆ten begabte fein fönne, als fie im fteinften Stäubdgen uno

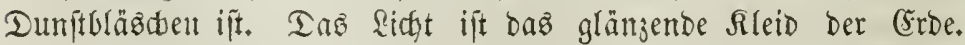
Das froke Reben Der Drganisment und ifyre bunte Farbenpradt,

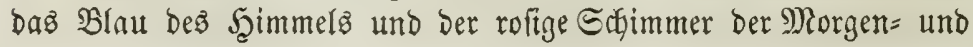




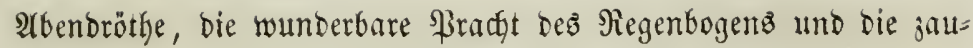

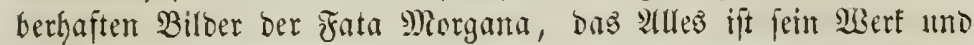

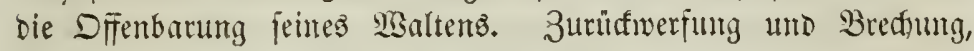
Beugung und \$olarifation, doz futb die einjad)en formen jeiner

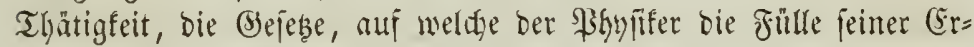
fobeinungen zurütfithrt.

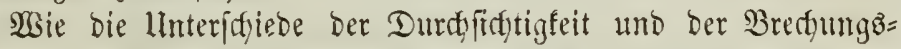

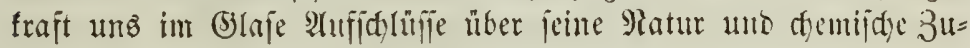
fommenfebuting geten, fo fint wir oft im Etande, ats ben Eidat=

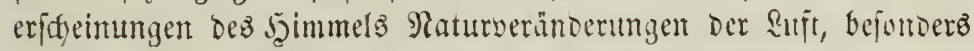

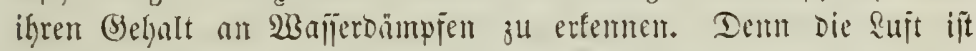

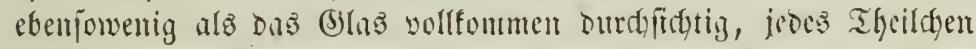

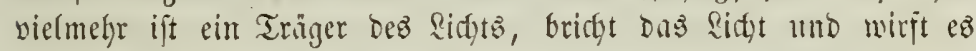

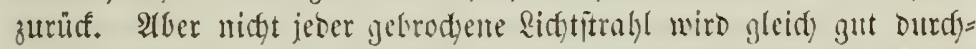

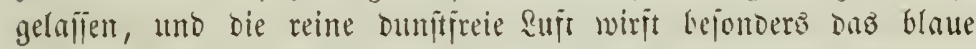

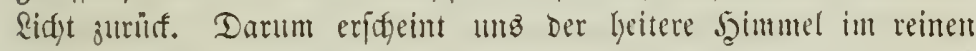
Blau Dututler im 3enith, alz gegen Den Seorizon, Duntler auf Şöhen, als in ber (Ebene, Dunfler in Den reinen Rüften Der Tro= pen, als it Den Dunjtatmojphären ber Folarlänoer. Iit wälirigen

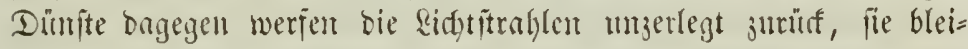
dent baher Das reine Blau bes Seimmels uno hiberziegen biefen mit

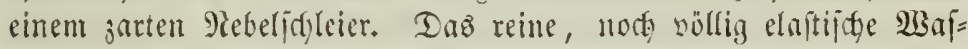

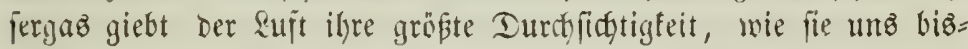
weilen nady hejtigem Siegen Der Szimmel jeigt. Beyiunt fid aber

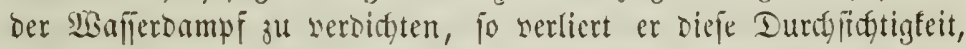
läát bie gelbent und rothen Etrahlen burdh uno erjengt die Erichei=

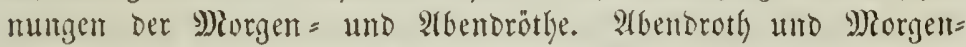
gran find ja mady uraltem (Slauben bie Borboten fujönen Wetterz. Damit Das Abendroth feine volfe Bradat entmiffle, muß bie \&uf Geiter und burjtfrei jein, Damit, wenn bie unteren Euftidyidgten ge=t gen Eommenumergang Durch Die Wämeftrahlung erfalten, Sistfer= gas vorbanoen fei, weldes fird) veroidten fömte. Eoll aber ber 9) Jorgenfinmel feine Fenergluthen jeigen, fo muß ons Entgegen= gejetste eintreten; Die Ruft mus fo ulberreidy an Feuthtigfeit jein, Daß̧ bie Eonne vergebenz ringt, bie nufiteigenden Dinnte ju jer=

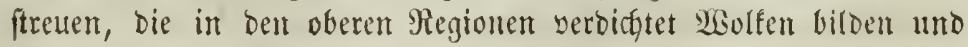
Regen bringen. So fündet bie Fairbe dez Şimmetz bie Borgänge 


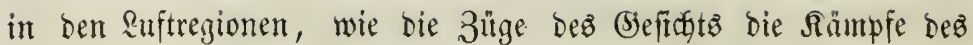

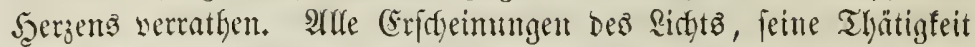
im Ban ber Welt, im Echmunf ber Erode, im Reben ber Thjere,

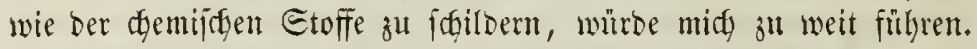

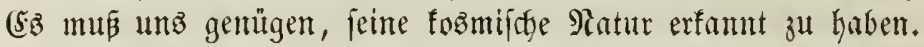

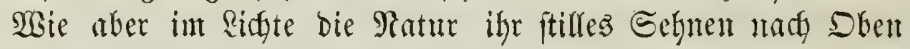

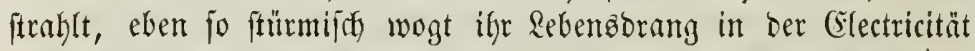

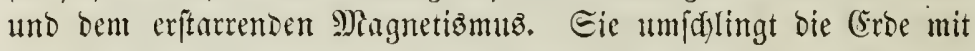
verlofenden 3auberfreijen, fite brobt bumpf grolfent ber trägen $\mathfrak{M a}^{2}=$ terie, fie triumphitt in blendendem Sidytglan, wenn fie bent Eieg errang. Die EFfectricität ift bie äqutatoriale Siraft ber Mlaterie, fie

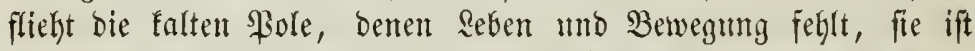

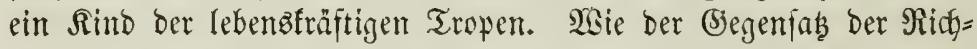

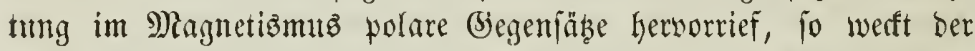

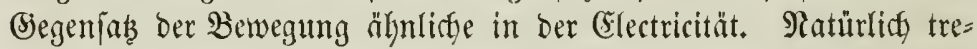

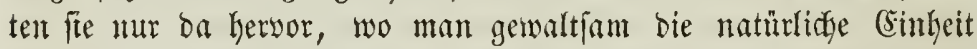
zerreifí, wo man ben Strom des Rebenz hemmt unb das Selnen

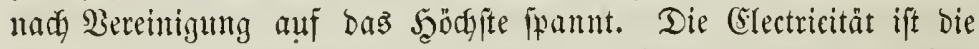
Ericheinung beż materieflen Unteridjiedez. 3wei ungleidyartige Mie=

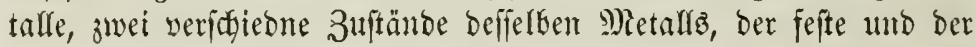

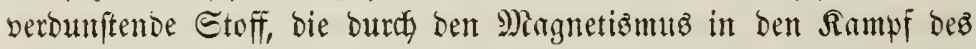
Starren mit bem Rebenbigen verjegete Materie bilden electriffe Ret=

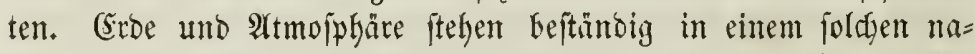

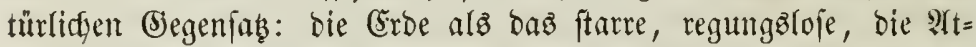

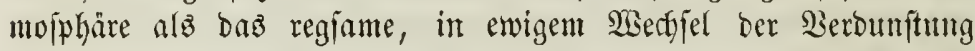
und Berbidftung begriffene Estement. Sie bilden eine natürlidge Sette, beren negativen \$ol bie (Erbe, beren pofitiven bie Âtmo=

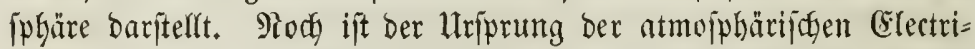

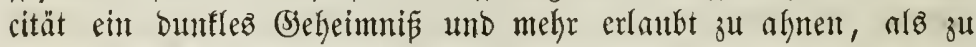

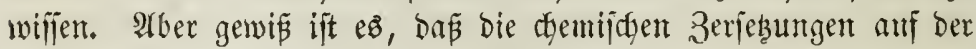

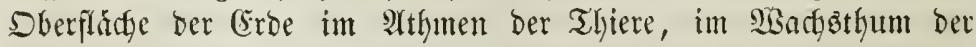
Bflamzen, und bie ftete Berbampfung bes 2 Saffers, verbumben mit

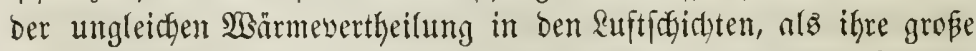
Şauptquelle zu betradsten iit, ba

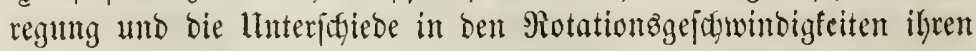
unbeftreitbaren $\mathfrak{A}$ (nttheil Daran haben.

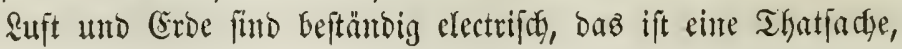




\section{7}

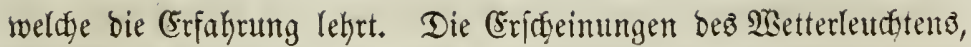
bie Et. Etmşfuer auf ben Epizen ber 9)afiten, auf Bäumen und Sefträudyen, bie leudgtenden Regentropfon mo Echneeflofen find

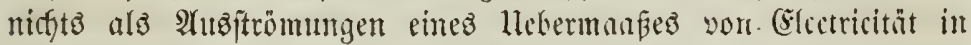

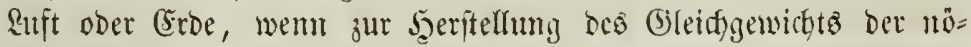

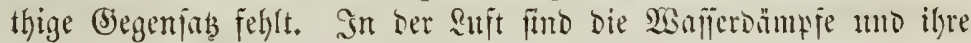

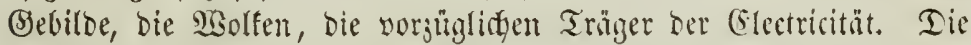

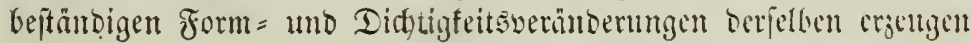
neue begenjäbe in ber electrijtyen Bertheilumg, bie ca in ber fo

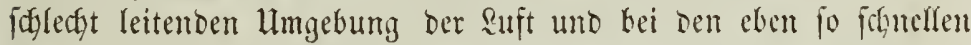
Beränderungen in ber Erbelectricität nie sul einem wirfliçen (bilcid)=

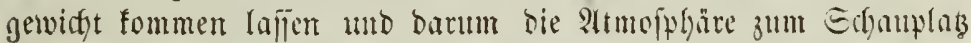
ber großßartigiten Piganomene madyen. Die electrijden Iämpje ver= einigen jidy in Den oberen Siegionen ju Bemitternulfen, "fit in

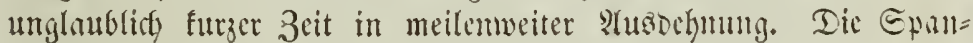
mung juifhen Şimmel und Eroe wädjt, und Donner und Blis vertinten ifre Siercinigung.

Die Seimath Der Siemitter find bie Tropen. Dort gicht is

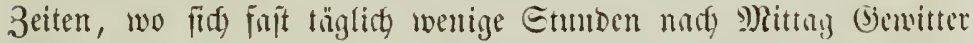
biloen, won beren furdytbater Sindt wir wergetlid) mad) Worjtellun= gen judyen. Das find bie 3citen jener croeridyüttermben Drfante,

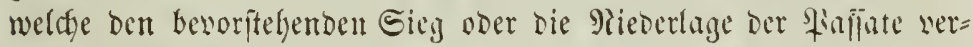
fünden uno bie Piegenjeit gegen bie trofne Jabresjeit abgrenzen. (E⿱ jenem glühenden Şimmel rem Micere entiteigt, bie bort 3 us cinter jo

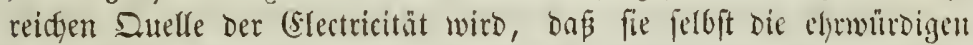

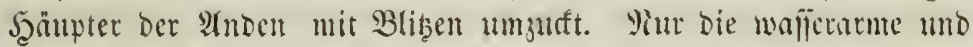

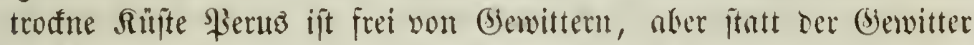

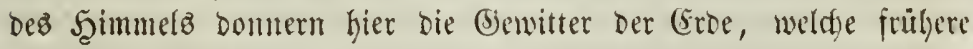

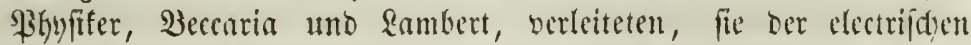

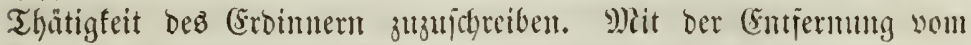
Aequator nimmt die Saünfigfeit Der Gewitter ab. Wälyreno in Deutidland nody 20 bewitter auf Dag Sahr foumen, hat Efan=

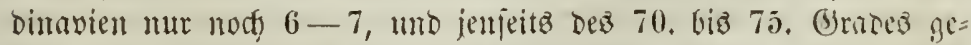
Gört ein (bewitter zll ben feltenften 9Raturerjdeinnngen. Daß bie Gewitter vorjugsిweife im Sommer und ilt wärmerell Rlima= ten aujtreten müjen, wo burdy bie Eonnenwärme die größte 


\section{8}

Menge $\mathfrak{B}$ affergas in ber $\mathscr{R} u f t$ aufgelöft wirb, iff einleudftend. (Es

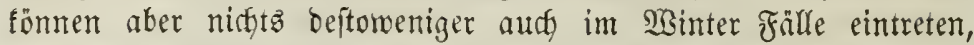
wo Durdf gelinbere $\mathfrak{B s i t t e r u n g}$ fo viel 2 ajīergas in ber suft auf=

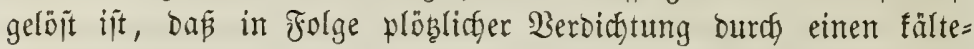
ren \&uftitrom bie electrijdye Epanmung fich bis zur Entlabung ftei= gern tann.

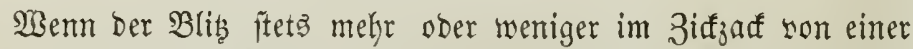

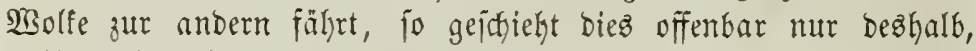

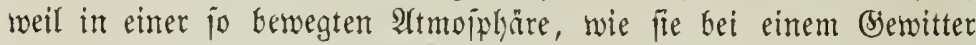

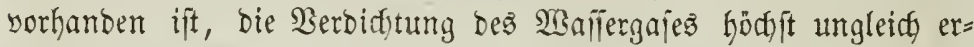
folgen mus bort fich anthäufen und burch bent Blits ausg gleidfen. Seben=

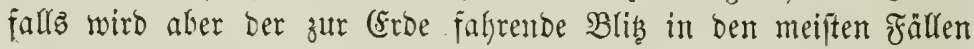

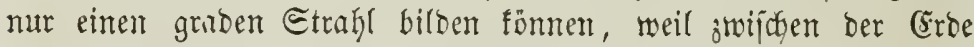

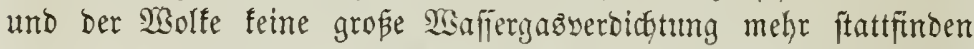

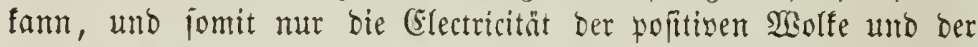
regativen (Erbe auftritt. Daraus folgt aber andd wieber, bá ber zur (Eroe fafrento Blib meift nur son eitrem einjigen keftigen Don= nerijhlage begleitet fein wirb, intom bie burds ben Blib hersor= gerufenen Edtallwelfen faft gleidyzeitig in unjer Dhr gelangen. Der

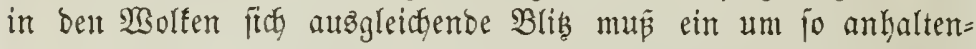
Deres Donnern bewirten, je gröp̃er bie Enttfernung zwifden bent unz zuntächit uno ben uns am entfernteften liegenden Theil ber Eufteridyitterung iit.

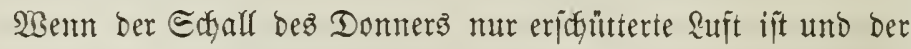

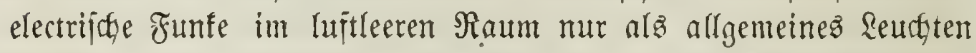

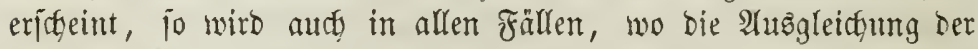

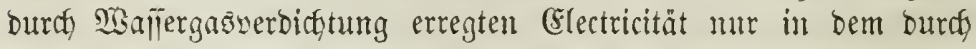

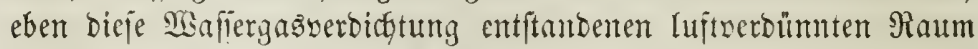
geidjefyt, ebenfalls mur ein seucten ohne Donner erfolgent fömnen, - ein $\mathfrak{B}$ etterleudften; - unt jeber $\mathfrak{B}$ (itigitrafl zeigt an jeinem Entijtefungspunfte bieje Erịdeimung. Durds bie fin immer von

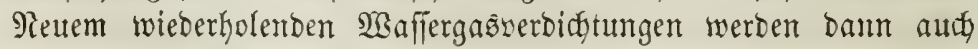
bie electrijgen Rabungen fith fo oft wieberholen, bis fich entritidy burch bie allgemeine Temperaturenniebrigung bie größte Menge bez

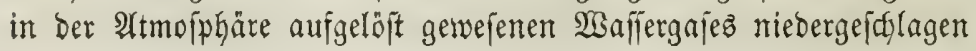


hat, und fomit bie erfite Urjacye jur Şervorrufung electrijoger Epan= nung aufgethoben ift.

Bemögnlich find mit Den Bewittem Stürme verbunden, wetde Folgen ber Durd Sisäruteentjiefung verbidteten \&uft, vorzüglid aber Der Damit yerbundenen Piteberifgläge ser nad) oben entweicfenden

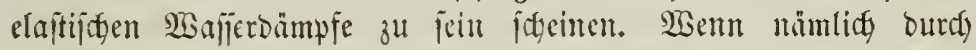
Das 3ujaumentref̃en cittes falten Suftîtroms nit einem warmen,

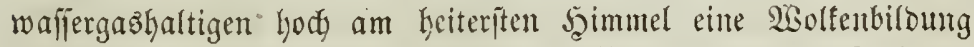

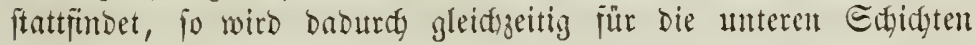
eine (Entziehung Der Eomentitrallen und ber Damit verbundenen Wärme berwirft. Die Ruft und Das barin auffelöjte Wajpergaz ziefent fich zแfinmen, Das Barometer zeigt ben verminderfen

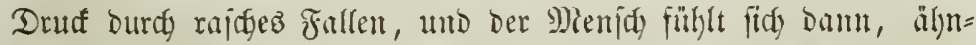
lidy einem aus fofwerem Eeewajier in leidftes fluninafier fommen=

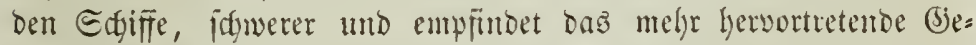

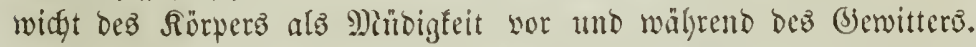

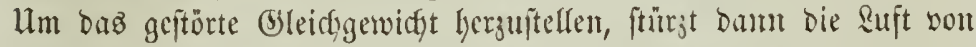
allen Eeiten mady unt erjengt fo bell bas Brewitter begleitenden Ettrm. Mamentlidg judft ber fojon in Berwegunty gewejente falte

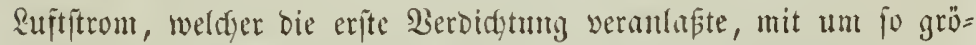

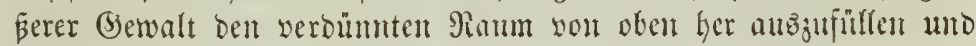

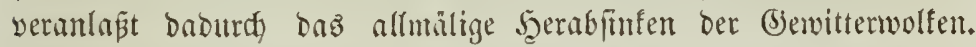
Ebenjo werben aber audy alle fleitreren $2 B o l f e n$, weldye fird in ber Sähe einter größerent Bewitterwolfe befinden, fowohl burdh bie elec=

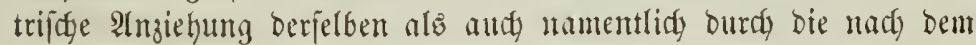

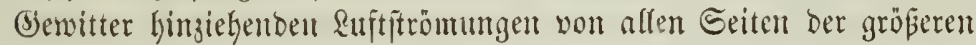

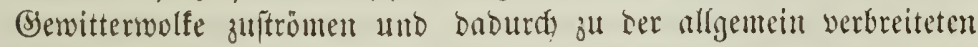

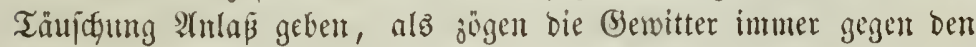
Wint.

Wenn ber bas ganje Bewwitter fortbemegente 2 sint unt bie

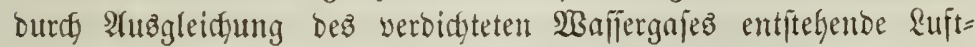
ftrömung, oder wern überlaupt zwei Euffftrömungen in entgegen=

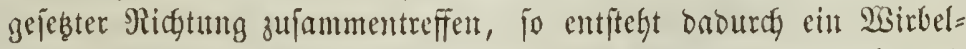

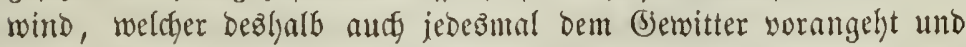
leidgte Bregenftände mit trïujelntor Bewnegung tridgterförmig in bie

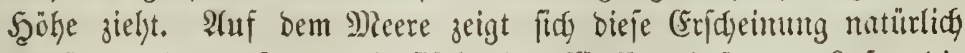

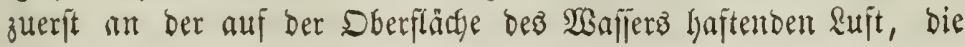




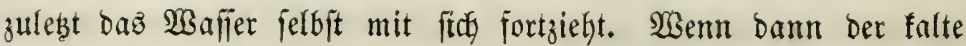

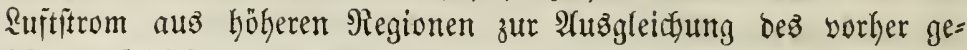

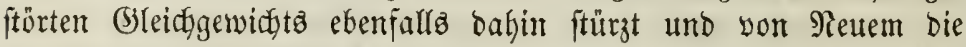

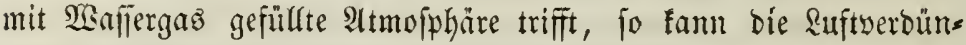

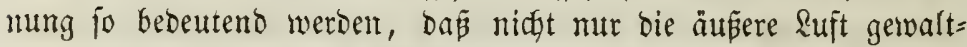

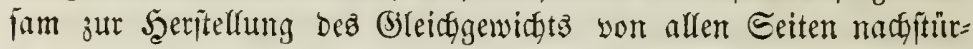

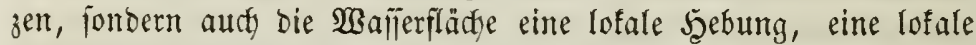

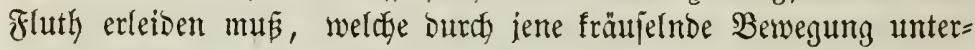

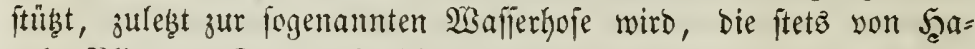
gel, Brith und Donner begleitet verheereno über weite Streffen ba= Gintobt.

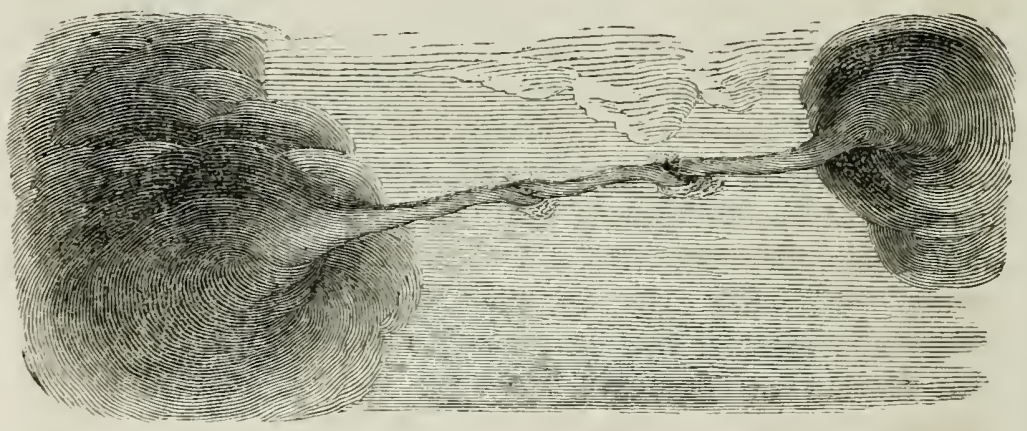

Dieje wirbelartigen wetterjäulen, $\mathfrak{B a j j e r t y o j e n ~ u n o ~ R a n t r o m = ~}$

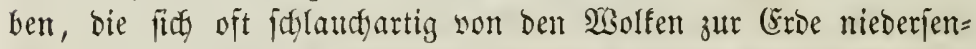
fen, gehören zu ben furchtbarften und jerfïtorenoften Raturericheimun=

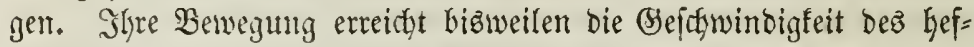

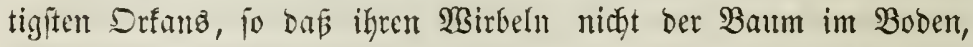

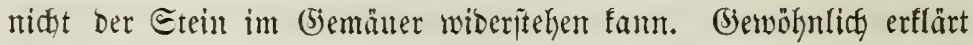

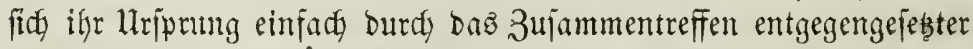
Ruftitröme in best oberen Negionen ber Ruft. Snbefien icteinen bock

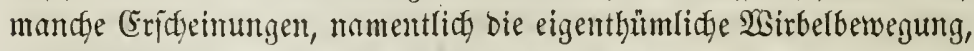
Der jonderbare Zñ ber Wanjertromben, weldyer dem Erzeugnifife

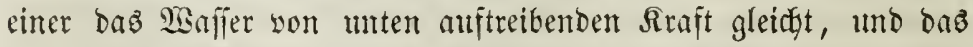

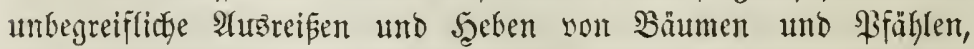
felbft yon gepflafterten Fußböben, twas ebenfo anf eine WSirfung

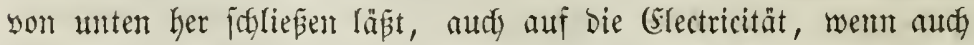
nidyt als alleinige Duelfe, fo body als thätige Miterregerin biejer 


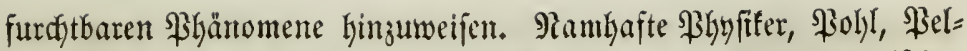
tier, Becquerel, haben baher feir Bebenfen getragen, in electrifden Brocefien bie Urjacte der Wetterjäulen ju jucten, mo eine von mix jelbit am 27. Datober 1849 gemadyte Beobadytung madyt mids geneigt, ifnen beizuftimmen. Iđ möbte ea mit ilynen einen elec=

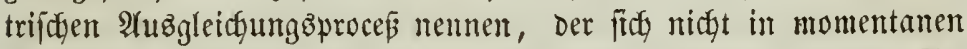
Explofitomen, fonbern in einer bejtündigen Etrömumg von ber $\mathfrak{A} t=$

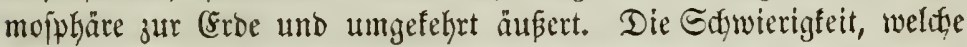
Biele befonberz barin finden, Daß̧ bie Electricititt aud im hödjiten (Srabe ber Gpanmung nidyt einen oft mit troffner \&uft erfüllten

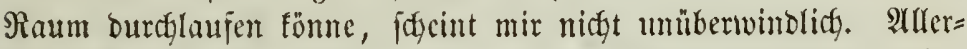

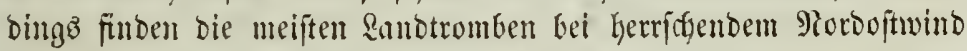
ftatt, ber fidy befauntlich Durdy feine Trofenbeit auszzeidyet. Alber meine eigne Beobachtumg und bie Bergleidung mit anberen bat mich auf einen bejonbern Uujtamb aujmerfiam gemadt. Smmer geken ber Erfigeimung von Ranbtromben warme Euftifrömungen

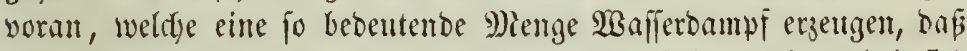

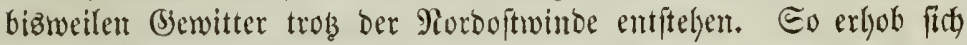
am 27. Detober 1849 bie Temperatur auj $11^{0} \mathrm{I}$., wälyrent fie mekrere Tage vorber auj $5^{0}$ gejunfen war. Der 3ug ber oberen 20olfen beutete auf füblidge Enftitrome hin; bie bäufigen Siegen= fdyauer aแళ fajt wolfenlojem Şimmel bemiefen bie lebhafte Thätig= feit ber 2 Baflerergengung. Wirtlids bildete fith im Siorboft cine Drolyente Siemitterwolfe, aber fie janbte nidyt Bliz nod) Domner, fonbern jene jeltiame Ranbtrombe und Keftige Sagelfdauer in ber

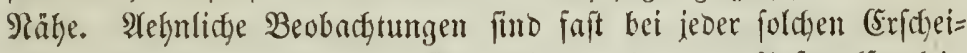
mung gemadyt worben, unb fie verbienen eine rege 2 Mfmerffamfeit, Damit aud) bieje Frage ber Tiatur mit Sidyerbeit gelöft werbe.

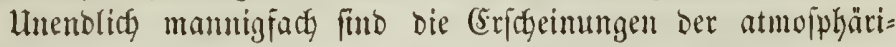

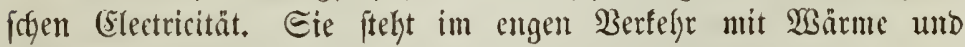

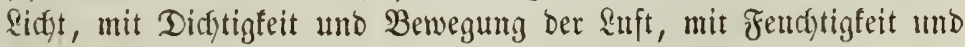

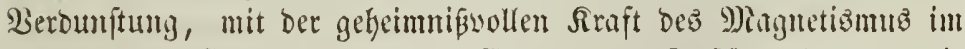
Edyoope Der Eroe. Sie ift ein Erreger und Berịtürer des organi= fiden Rebens, fie treibt Den Gaft burdh die Befäpe ber Hiflamze m

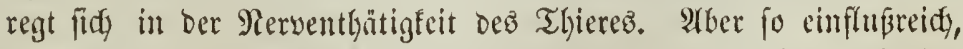
fo buntel ift fie audy. Slod viele Jahre werben vergelyen, elje ber

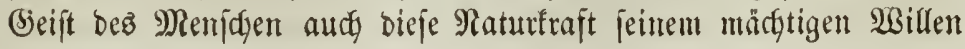




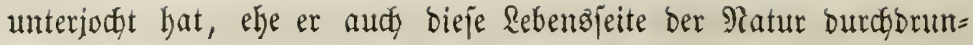

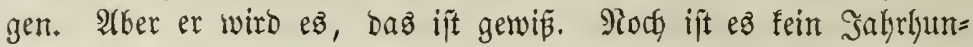

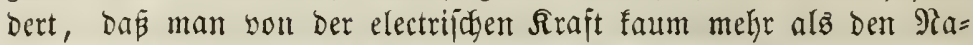

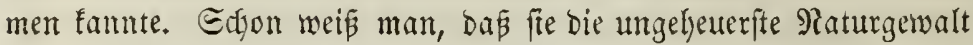
ift, bie an allen $\mathfrak{B}$ eränberungent ber Ratur, an alfen Procefjen bez

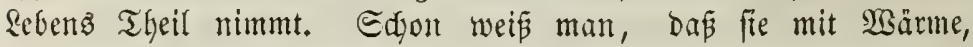
Sidyt und Miagnetismus von einer Mutter ftammt; fdon hat man

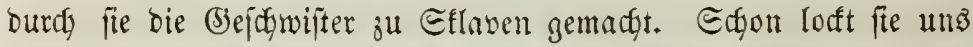

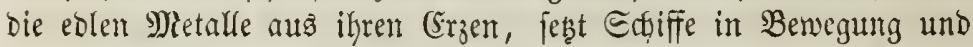

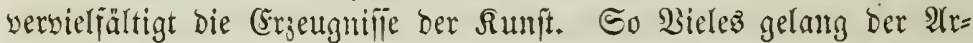
beit io meniger Sagre, unto Der untrmüblictye Menjogentgeift jollte nidft weiter bringen in baz Seeiliģtyum ber Patur? Die Afhmung

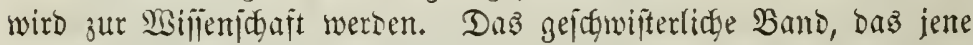
lebenerjeugenden $\mathfrak{i}$ räfte umichlingt, bie Einfeit ber bunten Erichei=

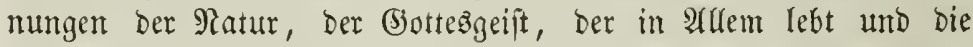
Monabe wie ben Eomtenball als Rimber einer Rraft umfapt, wirb

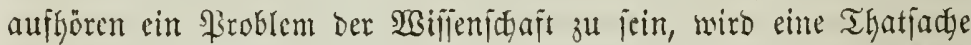

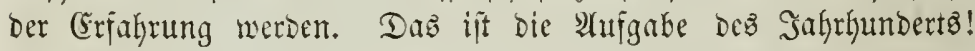

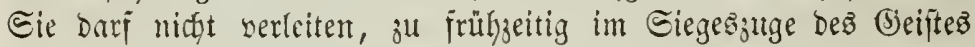

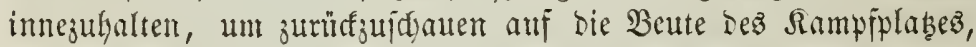

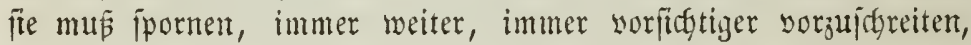
Sieg auf Sieg ju hăufen, um dez endrliden Bielez dejto gemififer zu werben.

Diejez Ziel aber wiro ein Gemäloe ber Ratur fein, ein Gee=

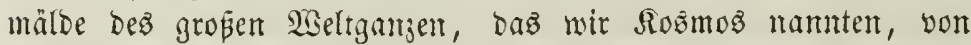
Meijterhand entworfen, treu in jeinen 3ügen, lebendig im $\mathfrak{A}$ uzz

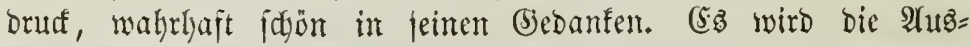

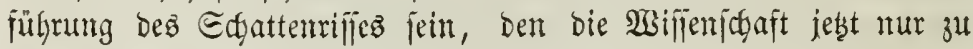
geben vermag. 


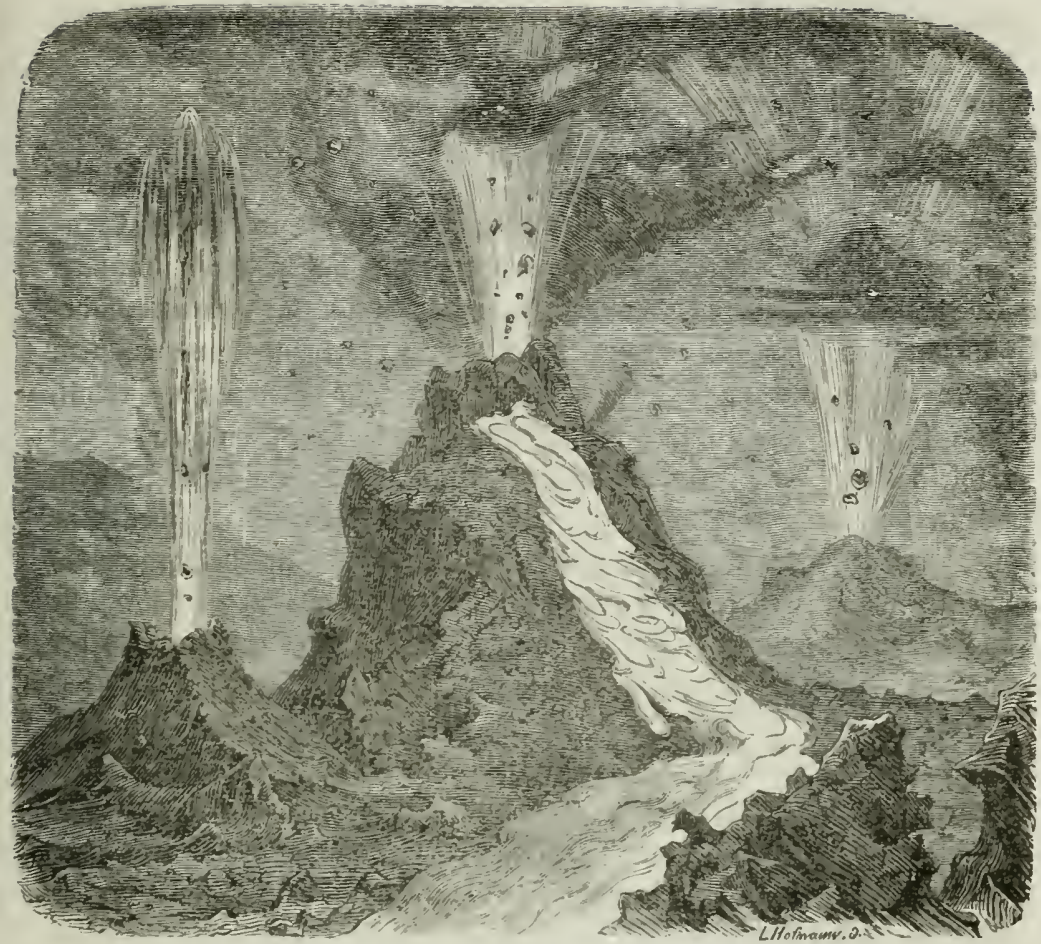

\section{Dritter 9(bidruitt.}

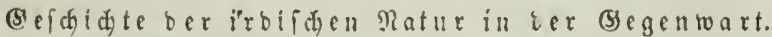

Die Erbe als felbitinbiger Erynnismub.

Nidgt blos ein 21tom im unendidget 2 Beltall, ein Blied in ber Sette ber Mejen, in Der Familie unieres Sonneniyftems ift ber Eroball, ben wir bemohnen; er hat fein eignes \&eben und peine

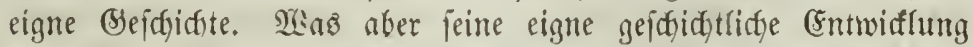
lyat, ift ein Drganišmus, ein Snbivioum. Die Sräfte beş Rebenz

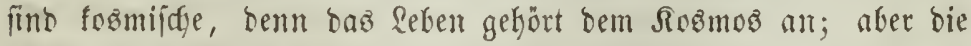
Frt ifrer Wirfung ift cine inbivibutelle, cine tellurijfye.

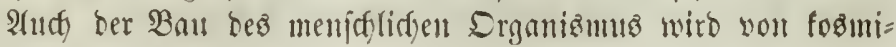
ulle, Weltall. 3. 2(ufr. 


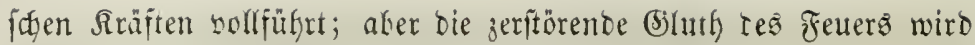

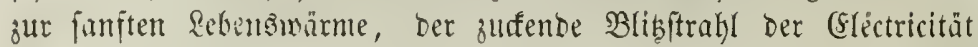

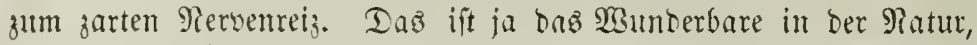

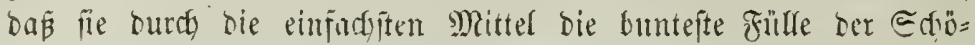
piungen ing Reben ju rujen meip.

SBir Guken Dirs Matten Der tosimif sen Sräfte im grofen Ban= fen ber irbifden Matur fennen gelernt, wir haben ifren immigen 3ujammenhang erfamt uno bie Sirofartigfeit ber Erideimungen be= wundert, bie fie in vereinter Madyt Gerborzurufen sermodten. Mefir noch, als wir jahen, ahnter wir ifre furdhtbare Bewalt, Denn je tiejer wir in ifre Erjheinungen einoringen molfen, iejto

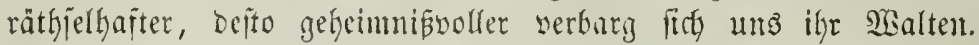
$\mathfrak{B e n n}$ fie aber yon Anbeginn trätig waren in unjer irbijden $\Re a=$ tur, welcte gewaltigen Beränberungen milfien fie hervorgerufen, wie furditbar jeritort und vernidftet haben? Dennody haben fie bas Seben auf unjer (Erre geftafien, entwiffelt, erfalten. arber ras ift eben bie Mizeibeit Der Natur mo bie Berblendung bes Nenichen, on

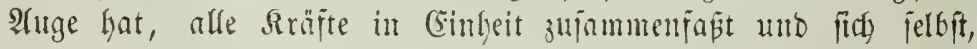
ber ewig jungen Rebensfaft, zu bienen zwingt, wo oer Menja nur

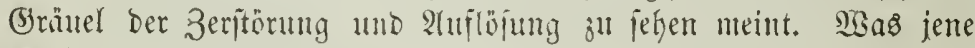

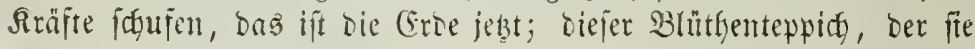

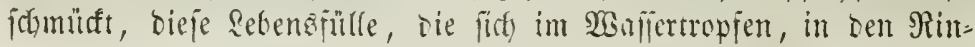

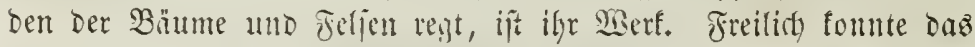

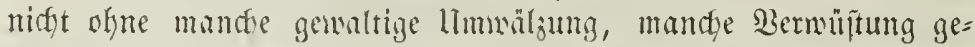

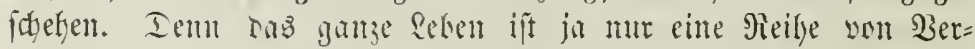
nichtungen, wno wo eeben, mo freifscit gebeifen follen, oa muв aud cintmal ber Too jein Sandmerf teeiben. WSir wollen jebt daz

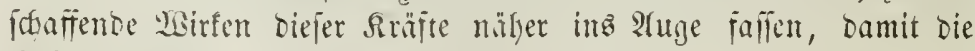

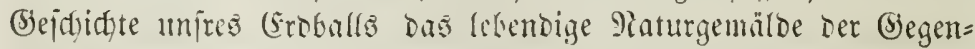
wart bor ums auprollte. Denn vlyne bie Bergangentheit fömen mir bie Siegenmant nidgt neritefen, wie ohne die Begenwart nidyt bie Bergangenbeit. Beide milijen in einmtoer greifen. Die Begen= wart mit ifren Werümberungen, ifren Billoungen, ifren 3erftörun=

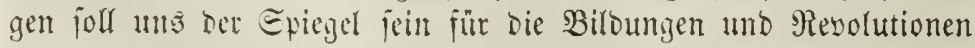
Der Sorgett; Die Bergangenteit aber foll mis der Echlüijel jein,

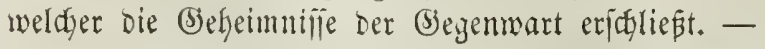




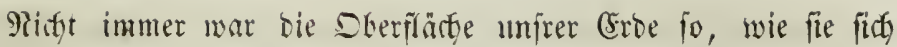
unz jekgt jeigt. Eie hat in ber bejtaltumg iffrer fejten uno flüF= fïgen Tleetle gar viele Beränderungen erlitten, bie endidch Gefarr=

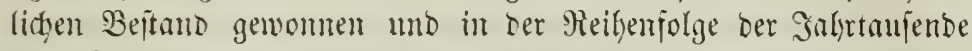

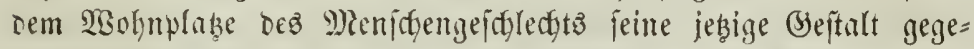

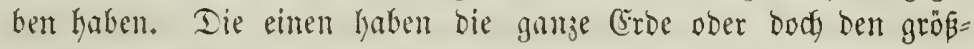
ten Theil berjelben betroffen, anbre blicben auf fleinere ober grör fere Etreffen bejdurältt; bie einen erfolgten felyr allmälig in langen

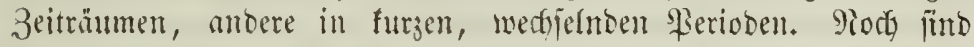

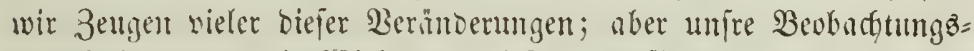

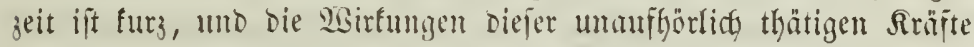

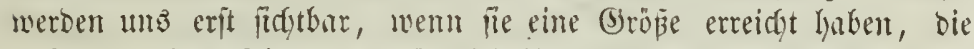
unjern groben Eimen jugn̈nglidy ijt. M)ögen auth vicle (Eridei= mungen midgt n̈ber bie Zeitgrenze hinalsgegen, wo unje Siontinente igre jeģige Bilrumg amtafmen, uno bie gegenuartige Drommg ber Dinge begant immer gefören fre einem Zeitranme in ber (jes=

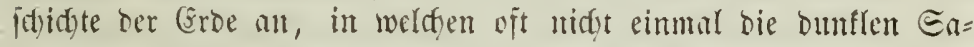

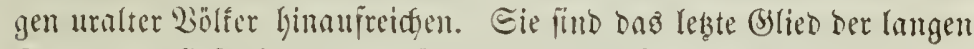

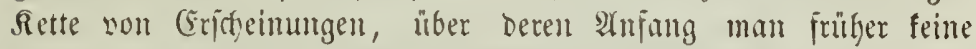

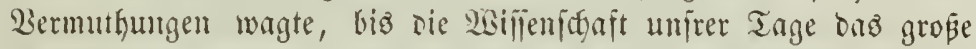
Raturgedidyt aus ben Edyriftügen ber Erobrinte verftehen lernte.

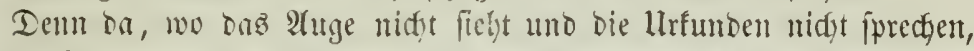

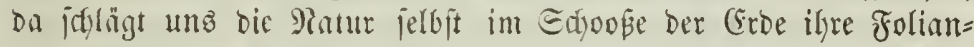

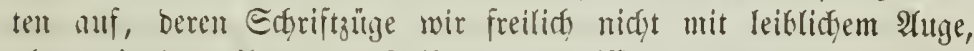

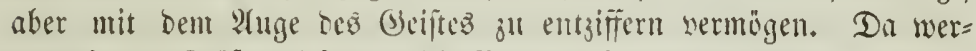
ben wir von Sräften lefen, tweldge Berge verfentten und Thäler erfyben, Meere in sonofeften uno sünter in Mleere verwandelten, welde

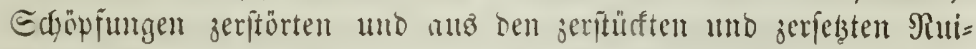
nen immer neue Bildungen eriffufen. Ulno wenn wir nod) jeģt äfnliçen wistungen begegnen, io merben mir in ilynen nidgt blog

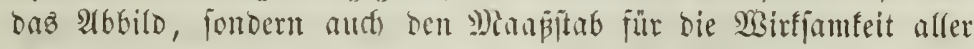
Raturfräfte ertennen, weldye in Dell früheren Bil(bungżperiobent der

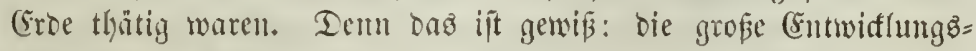

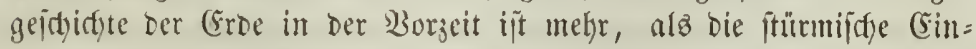

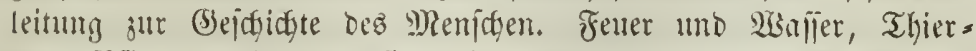

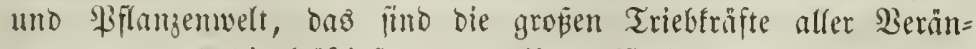
Derungen, uno bie fräftigiten unter ifnen $\mathfrak{W a f f e r ~ u n d ~ z e u e r : ~ j e n e s ~}$ 
Der ftetig und ununterbrocten, biejes ber periobija roirfende Faftor;

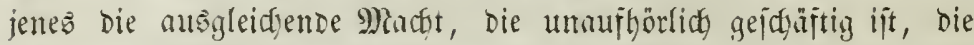

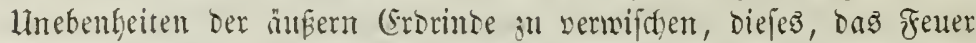
uno bie Gewalten ber Tieje, gleidh thätig, die Unebentyeiten wieberher= zuftelfen, indem fie neue Waijen aus Dem Snnen Der Erbe empor= treiben oder Sgebungen und Eenfungen auf ifrer Dberfläthe ver= unjacten. Bald wirfen beide auj ein 3iel hin, daš feinez allein fu erreicten vermag, balo befïmpfen und idmäden fie einander.

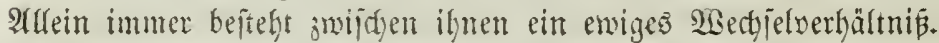

Edwieriger mird eร Iaber, Die Tharjad)en nad bem (Sin=

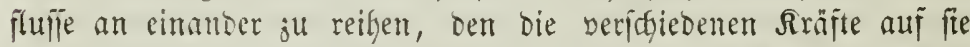
auggeübt Gaben. Int bie Eridgeinungen ber (Segenwart zu begrei=

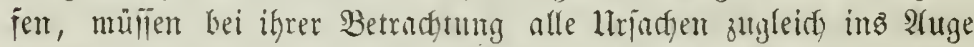

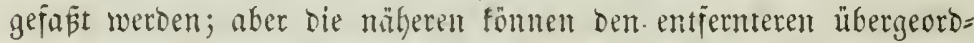
net werden. Desthalb wotfen wir nad einanoer biejemigen 2 Birfun= gen femen lernen, weldye bie beiden am mädytigiten idfaffenden

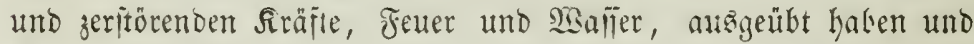

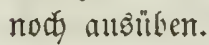

\section{A. Die Mirfungent Bex vulfanifden Sräfte.}

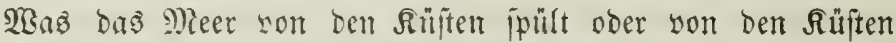
empfängt und mit ben Seidjen jeirner Bewolyner auf jeinem Srunde aus̄breitet, Die Baumerfe ber fleinen Thierwelt, Der Ṡnjujorien, Der

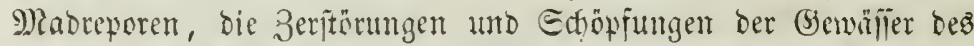

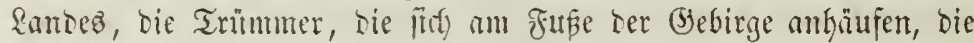

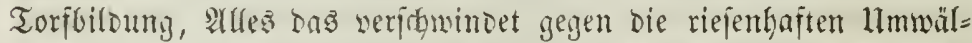
zungen uno Echopfungen ber sulfanildyen Thätigfeit ber Crobe, ge=

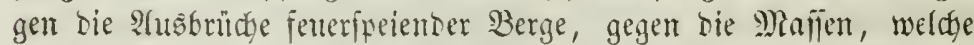
bei Grobeben in Die jerrifienen Echidgten von unten Geraujgetrieben werben, gegen bie vulfanijden Sinjeln, die plöglidy autz ber Tieje Des Meeres emprefiteigen, gegen bie allmäligen Setungen son \&ăn=

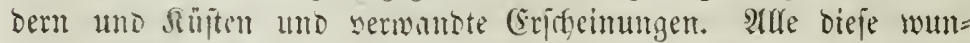

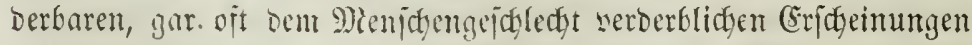
faffen wir zupammen unter bem Hament ber sulfanifden. Eie finto bie Wirfungen einer beftindigen Meaction bez Snnern ber (Froe ge=

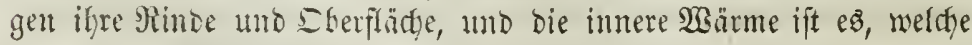
bie Reime biejer Rention erbült. 


\section{7}

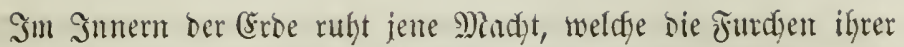
Oberfläde zieft, weldye fie wambelt unt in fteter Bewegunt erhält.

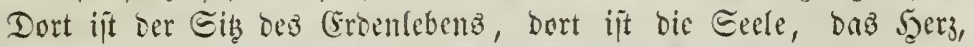

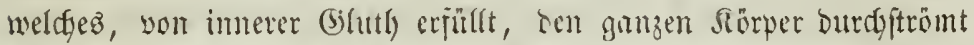
uno peine fejielmben Edyranten zu burdibrefjen trachtet. So ruft

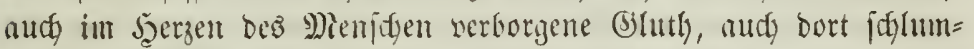
mert ein vulfanijajer Saeero, ein jeritörendes und ein erhaltendes

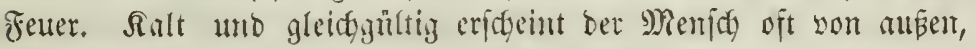

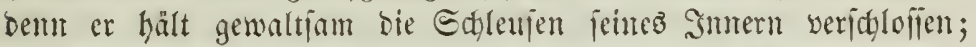

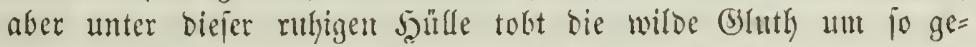
waltiger uno jerîtürender. Daun erfeft der Sörper won innerem

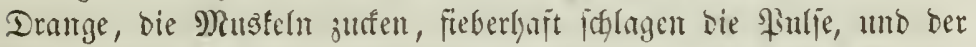

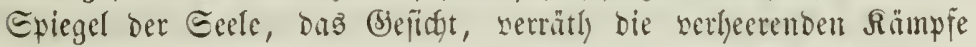

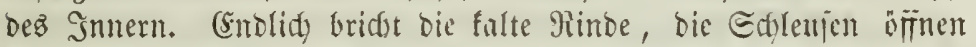

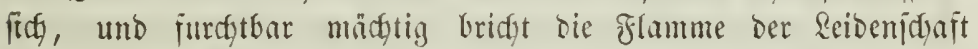
bernor. Berjelfectio greift ber Feueritrom um iid, ringz Zer= ftörumg und Flammen verbreiteno, Giz fich ber innere Drang be= jünftigt, und die mildernde Fluth ber Thränen fids über bic er=

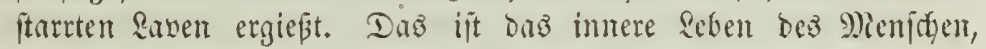
bas nidgt veridylofien Gleiben barf, jonbern in Worten uno Mienen

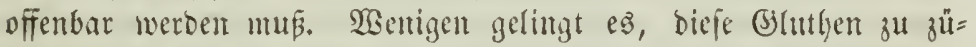

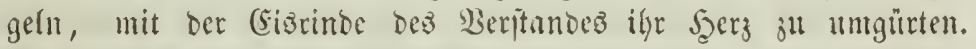

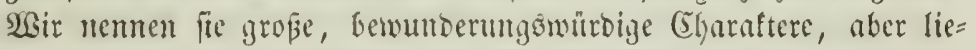
ben fünten wir tie nidgt; tenn bas Reben feght ifhnen, uno wie

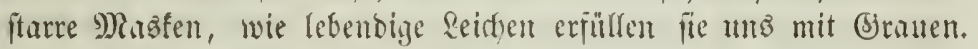

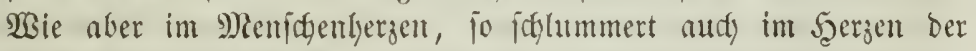

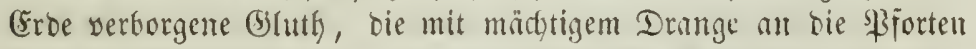

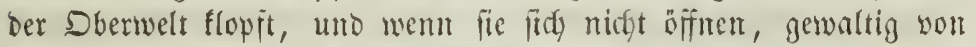
immen heranz ifre Seülle erichüttert, Ränder erbeben, ganze Bebirgs:

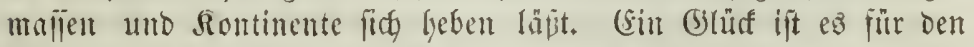

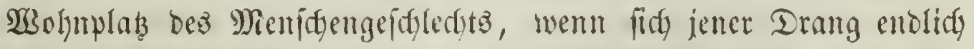
\&uft madyt, weme er bie Deffe fradjend. pprengt und aus feiner

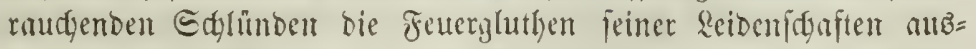

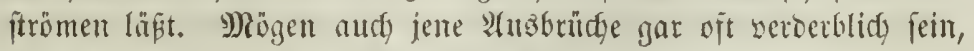
mit gejdynolzenen \&aven Etäbte uno Iörjer zerftören, mit iffrem 2lidjenregen blülende sanbidjaften, Gärten und Weinberge begra= ben: Die Thtäne bes Şimmeló quilat Gald hernieber und vermifat 
Die Spuren Der Berwütung; neues Reben erwadyt über ben Trüm=

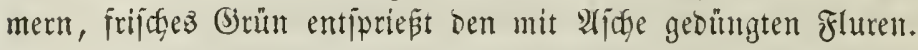

\section{1) Die Grobeben und ihre wirfungen.}

Wir wollen bie Siröpe uno Wradjt aller (Erjdeimungen ber wul=

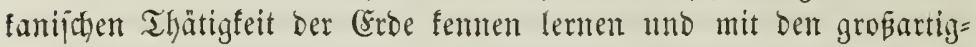
ften bejinnen, weldge am jurchtbariten bie Allgewalt ber im $\mathfrak{B}_{e r}=$

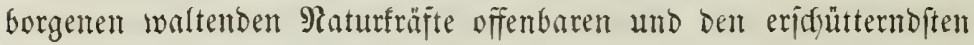

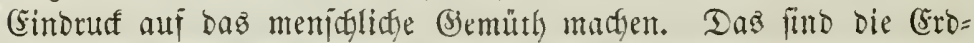
beben, jene von inmen heraus wirfenden Crichütterungen bes jeften

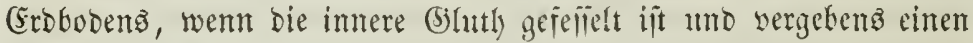
Atüweg burdh jene Foren ber Eroe, Die Bulfane, fuct.t.

Die Berwegungen, weldye ber Erobonen Durdh Erobeben erlei= oet, geben fich bald als jenfrectite, aufitopenoe, balo als borizon= tale ober wellenförmige, bald als wirbelnbe Ertwingungent zu er= fenten. Arber bieje orei veridfiedenten Bemegungen fommen felten einjeln für fids vor, uno bie beiben eriten, sie mifitopente uno

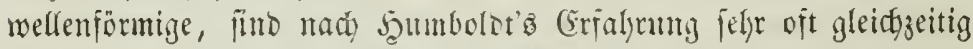
wahrgentommen worden. En jeltemiten, aber aud gejahrbringent = ften, zeigt fith bie milbelnde Benvegumg. Die furcftbaren (Ero= beben yon Jamaica am 7. Smi 1602, yon Riflabon am 1. 200 vember 1755, son (Ealabrien yom 5. Febrnar bis 28. M)ärz 1783, yon Riobamba bei Duito am 9. Jebruar 1797, von Garacas am 26. März lel2 bewiejen bie zeritörente Mirfung biejer Berwegung. Mauten wurden umgemand und einjelne Theile ron Sbelisfen

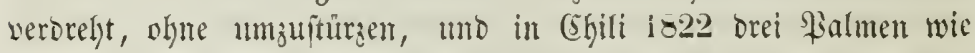
Weidenruthen un einamber gejalungen. In Calabrien twurbe im Berfen Der Etnot Sppioo, welcfe in einem natïrlidyen Amphitheater von Bergen ali angeidwenmutem Sinmbe liegt, ber Boben fo be= wegt, wie roent man ein weites Eandiás orehend jaüttelt und ju= gleid) burdy Etöse von unten her eriduttert. In Sitobamba hatte

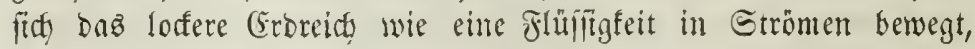
Aeffer umb Siärten waren seridgoben, Baumpflanzungen getrümmt

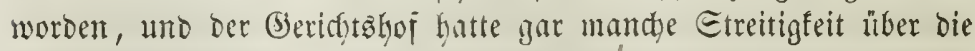
Berwirrungen, bie bas Erobeben im Eigenthumbered) angeridytet

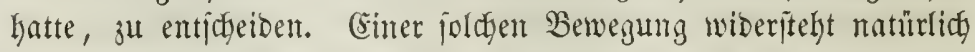

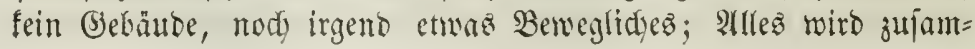


mengeidhüttelt und nivelliet, bie Trümmer merben umbergeidleubert, dá man den Plan der Etïde nidyt wiedererfenut. Die auF=

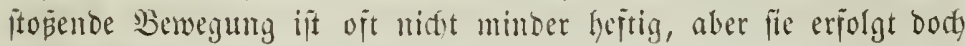
meift in cinjelnen furjen Etö̈en, Die freilid) Damn, wie bie (Ex=

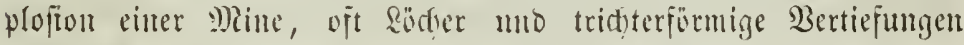
Ginterlajen. Eie erjenjen die jonberbariten Erideimungen. Eo

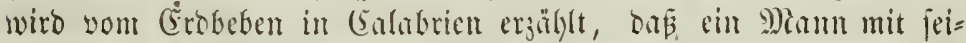
ner Frau uno eintm Ejel mit bem Boten, woranj fie gingen, auf=

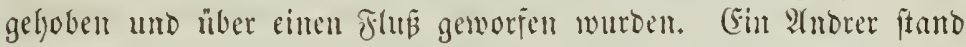
in ber fleinen Strot Eeminara Citronen pifütent auj eintm Baum

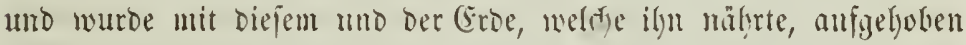

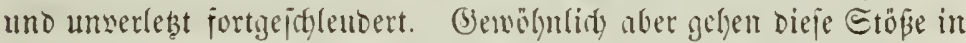
leidtere Ergittermigen luber, wie fie fith hei ben hänfigiten uno un=

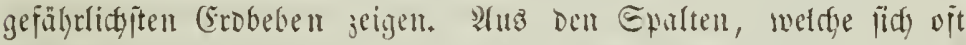
in Folge ber Bertrinmerung Des Eroboens bilden, fann man am

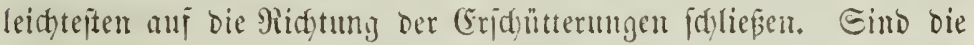
entîtandenen Epaltan bon gleidger \$idytung mib unter fid parallel, wie ite in ben meijten fintlen zu jein pflegen, jo weifen fie mi fleinere (srobeben mit Bellenbeweyung bin. Gehen bie Epalten aber itrafleniörmig bon cinem Mittclpunte aน8, jo wiro man แn= willfürlid an einen jenfredyten Etopi crimert, jo wie man an eine

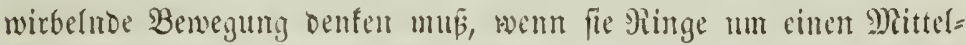
punft bilder. Durd ifere gamze siatur erimern fie auperoroentlidy an jene (bangipalten, in welden oer Bergmam bie (5rge abgela= gert fundet; fo Daß man in oor That anjuneímen gencigt ift, aud) die Epalten Der Erggänge feien ourd) pringere Erobeben gebildet worden.

Für bie Sejuldyte dec Erobitoung in Ier Borjeit fanm baker eine jorgfültige Beadfung Der Wirfungen von (Erobeben nicht gleid = gültig fein. Ramentlicf) gilt es zu exiafyen, ob eine bejtimmte

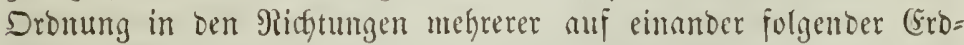

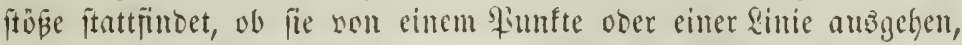
ober fich nad werjdiconen Pidtungen wertlgeilen. Bei Dem gropen Erobeben bon Enlabrien in Jabre 1 is3 gingen feine orci Saaupt= ftöße vom 5. Februar, 7. Febunar umb 2×. 9)ling von brei in gru= ber Sinie $j-6$ Mieilen von einnder entfernt liegenden funten

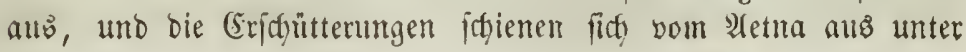




\section{0}

Dem Meere fortzujeben. Das ift allerbings eine auffaftente $(5 r=$

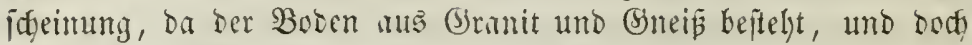

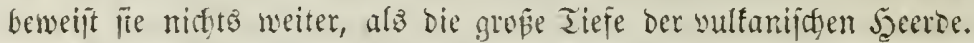

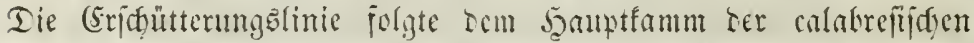

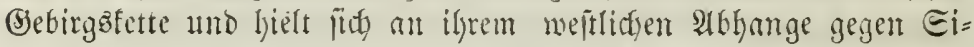
cilien fin. Datum wutrben bie wejtliden Segenden you Ealabrien

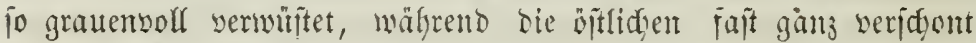

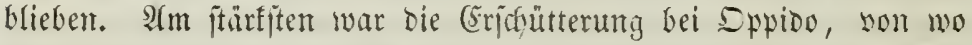
aus fie fith litber eime fläche sou so $\square$ Dieilen serbreitete, über 400

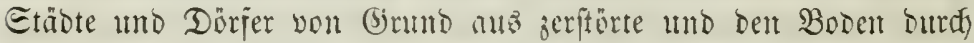

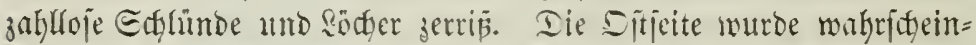

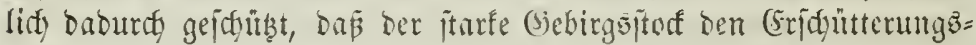
wellen nady biejer Eeite hin cinen Damm entgegenfegte uno fie

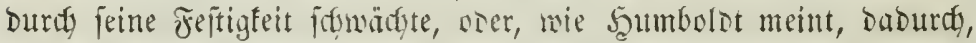

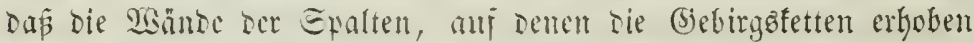

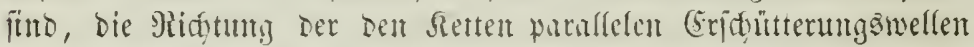

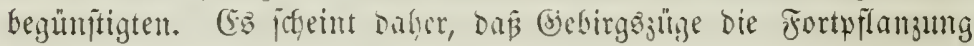

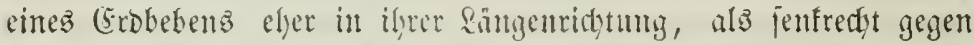

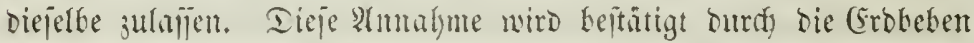

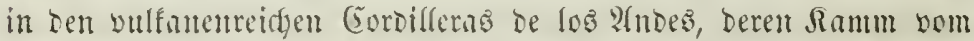

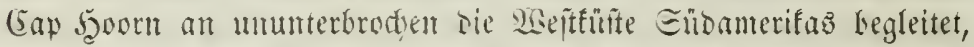

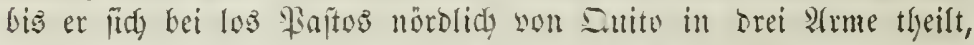
Deren bjtlidfiter unter bem Siamen ber Eierna de Barbang und

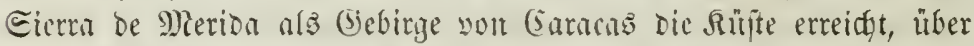

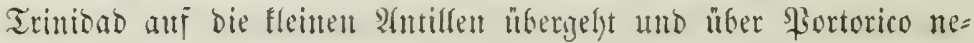

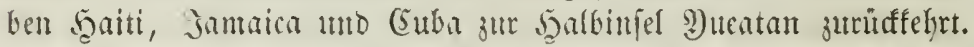
2lle groben und furchtharen Erobeben, welde biejen Theil ameri=

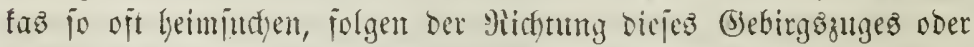

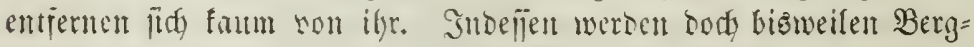
fetten von Grobeben jenfrecht burdjidntitten. Dies exeignet fid hüufig in Merico, wo Die Etoplinte nidyt Dem Sanuptgebirgåjuge,

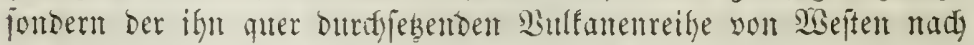
Siten folgt, weltte bie Fortpflanjung Der (Erbbeben in biejer Rid)= tung zat bedingen ideint. Fuffallenter ijt es, menn Erobeben bie

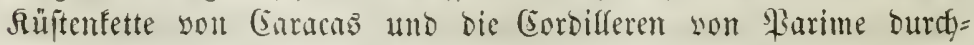
Gredyen, ober went fidf in 2Fien, wie an 22. Jamuar 1832, bie Cro=

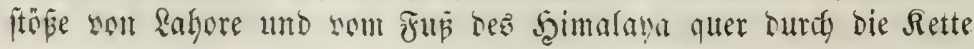




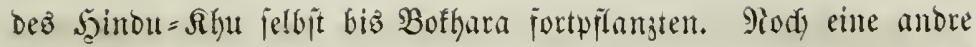

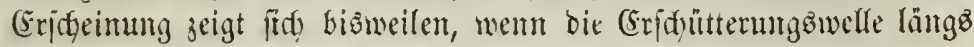

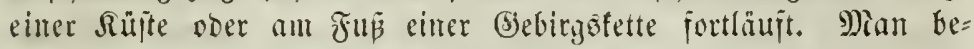

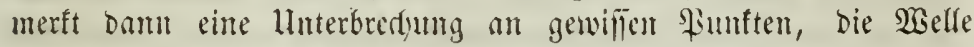
fidreitet mur in Der Tiefe fort, ohme fid) an Der Dberflädge fülylent

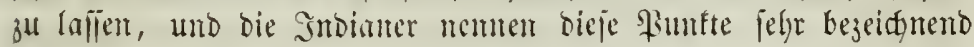
Brindert.

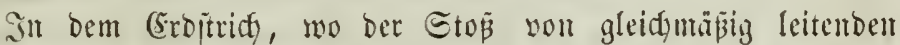
Edyitgten, wie von cirnem gemeinjamen Eantrum aub, fortgepflangt wirb, madgen Tid) Die Eajwingumgen nu fo meniger füblbar, ie weiter bie eingelnen Punfte son dem eigentlidgen Etoppunte ent= jernt fino. Den Bercidy Der Erjøütterungen neut mu Dam ben - Eridütterungäfreis. Sit hat fiet diejer ungemein grós gezeigt. Eo

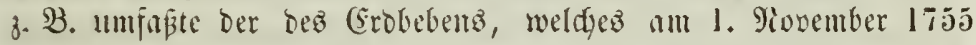
Eillabon zeritorte, cinen Maum, der an Brößje viermal bie Sher= flädge von Guropa ïbertraj. Diejer ungefente Siaum erbebte gleidgzeitig; Die Erjdütterungen muroen in Den शlpen, an ben itgwebijgen Riliten, auf ben antillifden Injeln, an ben gro= ben Eeen you Eamton, wie in Thüringen und in ten flei= nen Bintemmajern der battijath Gbene empfunden. Scaupt=

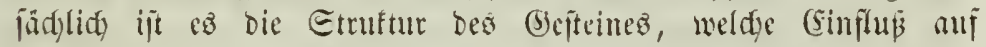
Die Berbreitung Der (Erobeben amblibt. Snbefien ergeben bie Er=

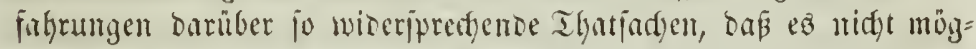

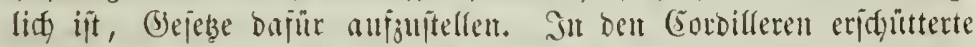

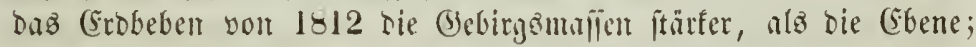
wägrend in Mejïn Dagegen die (Srjdütterungen in ben auj Granit= boden rubenden Etadtheilen bei weitem unbedentender waten, alz

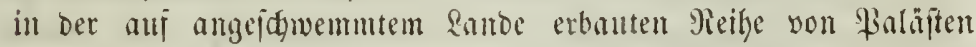
am 5ृafen. 2uj Jannica empjamb man die Bebungen am lejtig= iten auj Saltboden, ant jumäditen auj Sand= und Thonboden;

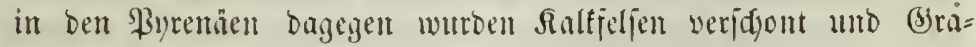
nite eridyüttert. Die Erobeben am Rieberrbein voun 17. December 1834 und 29. Suni 1845 bejdränten fids nid)t blos auj bas eigentlidge vulfanijde (sebiet, fonbern serbreiteten fids aud) luber

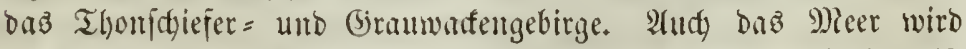
in bie allgemeine Bewegung der erjoütterten Croe mit hiteingerif $=$ jen, und in allen Räitengegenoen geben bie burch plöblidues Etei= 


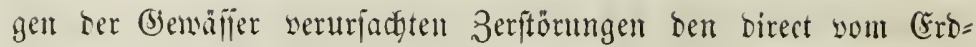
beben hervorgebradten wenig nath. Aruf offener See werben bie Erojtüse fo bemerft, als jei Das Extii auj einen Feljen aufgefah=

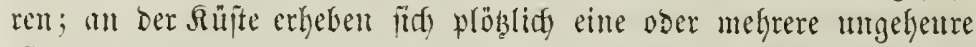
reflen, burdy weldte bie Edyiffe son don Anfern losgerifien und oft weit von ber Süpte in das sand hineingejdyleubert werben. Merfwurnoige, nod) nidht erflärte (Eridyeinungen bietet bie Berbrei= tung Der Grobeben in bie Tiẹ̣e Dar, bie man freilicy nur ba be= obadten fam, wo fidy Berywerfe befinden. Meiftens empfindet man bie Crojtöpe eben jo gut in Den Giruben, als an ber Sber=

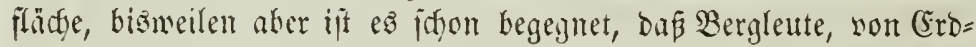

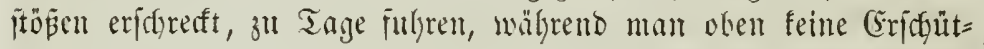
terung liemerft hatte, oder umgefelyrt, bẩ man unten nidbts yon ben

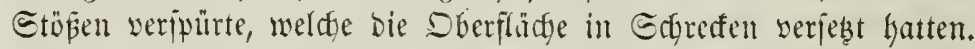
Bährend jener furdftbaren europuijdyen Sataitrophe, bie man das Erobecben son eiffabon nemt, fülylten Berglcute in ben verichie=

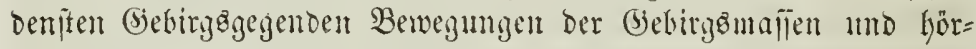
ten eimen Domer, oer olien jitwieg. Plter yon ben Etöpen, weldhe Sdyweden in Ronember $1 \$ 23$ erfugr, vernahm man in Den Tiefen

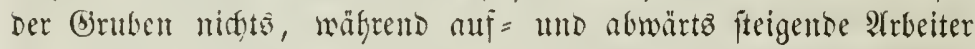
ifre Etürfe empianben.

Senip̈ Drïnt fing Sebem bie Frage auf, ob bieje verbeerenden

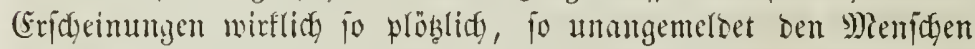

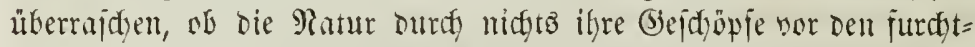

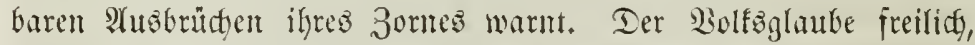

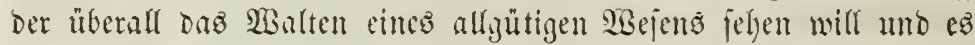
nidyt zu begrcifen vermag, wie ber alferbalter fo unvorbereitet, to idyonm Bolfsiglaube freilich meint foldte fidsere Borboten in gewiffen Wit=

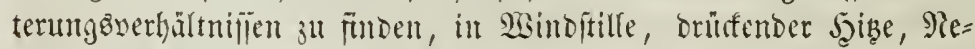
beln, verïnberter Euftelectricität. Diejer Bilaube aber ifit baltloz, gründet fitg mor auf zupällig, aber nidjt notlywenbig mit Erridunt= terungen zujammentängento Eridycinungen. Bei reinem, völlig

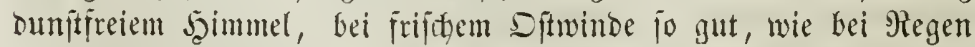
uno Donnerwetter hat man Eroftöe gepütrt. Freilidy fenten wir Den 3uammenthang zrifhen Iem, was in ben \&uftregionen un= frer 21tmojphäre unb in Sem Sumern umjer Erorinte sorgelyt, nod) 
zu wenig, als bak mir jeben 3ujammenthang weglengnen jolltent.

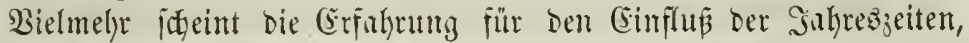

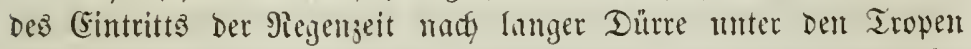

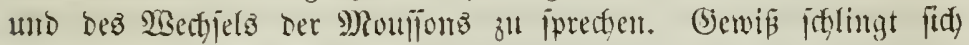

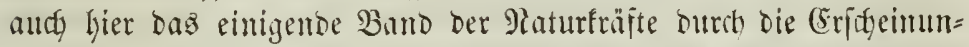
gen, und biejelbe Rarajt, weldye ben (Sroboden eriffüttert, wermag

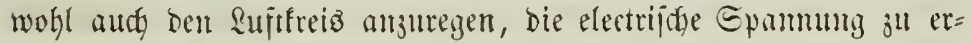

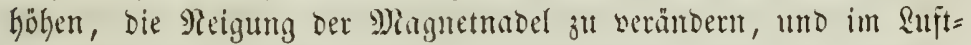

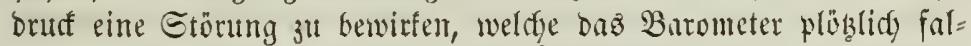
lent mact.t.

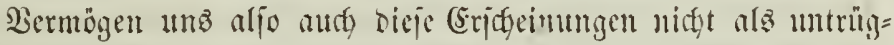
lidge Borboten vor bem brobenden Eturme unter unjern fü̈веn zu warnen, io giebt es nod) einen andern gewaltigeren Begleiter ser

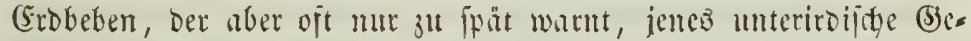

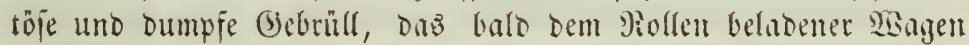
auf Eteinpflajter ober entjerntem Donner, bald dem Yianjicen Des

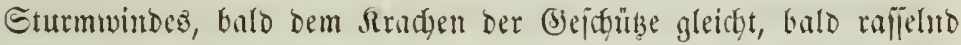
unt flirrento tönt, wie bewegte Retten, bald helfftingent, als wür= Den glajige Mafien in unterirbijđjen (Sewölben zerid)lagen. Balo geht dieß Getöje den Etüßen vorher, bald begleitet ez pie, buro fehlt

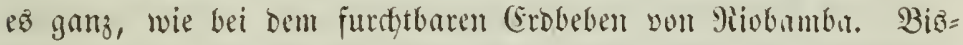

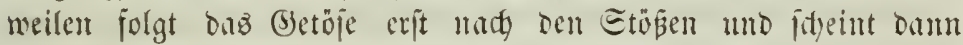

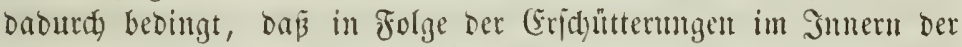

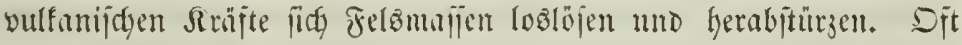
verbreitet fith ber unteriroifibe Domter aut ungeheure (Entfermuns

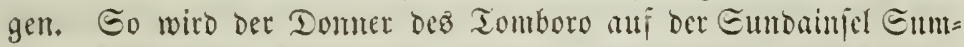
baba 400 Eeeftunden weit auj Eumatra vernommen. SIlö ber Bulfan von Et. Wincent in ben fleinen atntillen am 3". W(pril 1812 einen mäctitigen Savajtrom auß jeinem $\mathfrak{n}$ rater ergoßj, murbe jein ungehentes domterartiges (betöje 158 Meilen weit, über cime

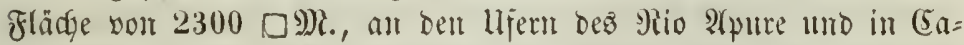

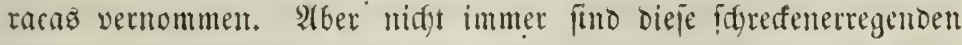
Domter mit ben Eridgütterungen, bie fie mit banger furtit) vornus=

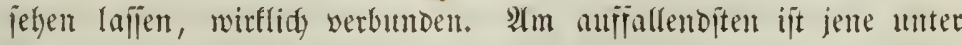

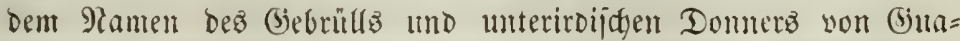
nantato befunnte (Erfdeinung, weldje bie Bewohner jener 6400 Juß

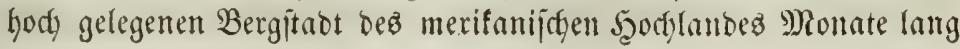


ohne irgento eine (Erifgütterung mit Ângit uno હctreefent erfüllte. Un Mitternadht Des 9. Januar $178+$ begaun bas (jetöje, uno un= unterbrodten rolfte Der Donner wie in idjweren Sicwitterwolfen un=

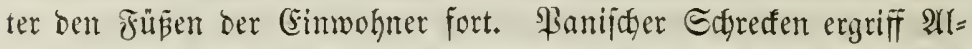
lez, man Flof aus ber bebrohten Etadt. Rur bie Sbrigfeit wollte ¿в befier willen; fie verbot bei jafweren Etrajen jebe Fludyt, da fie in ifrer siseisheit fogon erfemen werbe, wenn wirflidge (Sie= fahtr vorbanden; jeķt jeien mar \$iroceifitonen nöthig. Doch alles

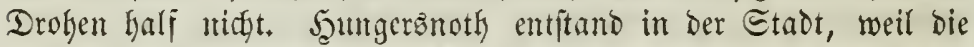

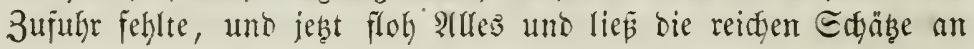

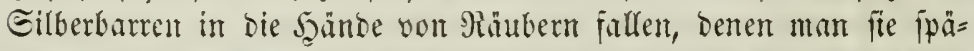

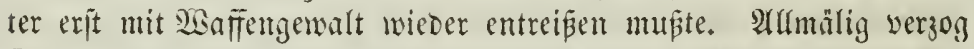

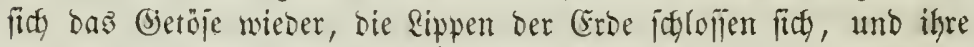
Drobende Etinme serbalfte.

SBie aber jene immere Gemalt umaufförlidy gegen iffere reffeltn ringt, fo giebt ez aud) mohl auf ber ganzen (Eroe feinten Miontat,

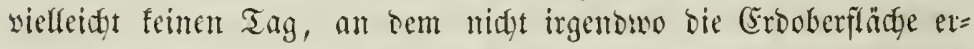
bebte. Miögen aud) einzelne Etö́pe nur menige Eecunten bauern

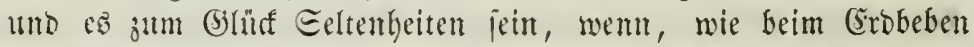

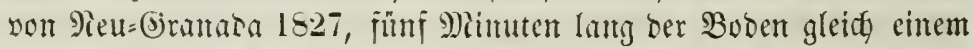

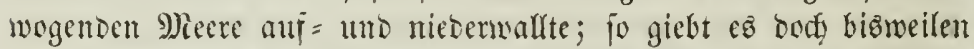

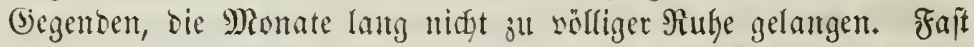

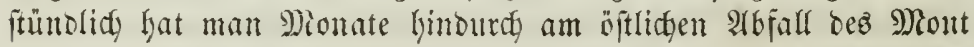
Senis, in ben Bereinigten Etaaten nörolid) non (Sincimnati unb

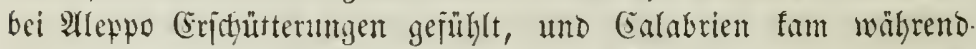

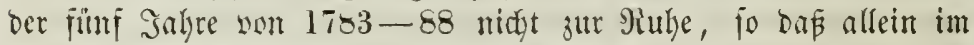
Sahre 1783949 Etöß̈e, Darumter 500 von houdjter હtärfe, wer= ipürt wurbent. Sn einzelnen Thällern ber Edymeiz, namentlidy im Sispthale, haben jeit mumehr 3 Safhren bie Erichüttenungen fajt nidjt

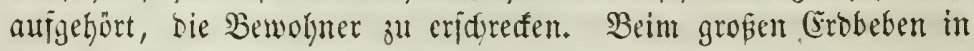
Peru zäblte man in ben eriten 24 Enmben 200 Eridütterungen und bei bem von $2 a$ alencia 1828 mefr als 300 , bie cinander mit Blizesidgnelle folgten. Bedentt man aber bie Edjwierigfeit, in jol=

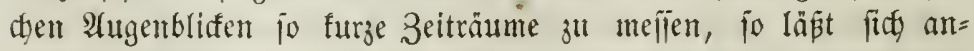
nefmen, dá̧ die meiften und werbeerenditen Etȫ̈e mur Eecunden uno \&ugenbliafe währtent.

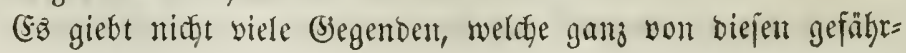


Iidfen Erifhüttenungen verifgont merben. Mag muth mantfyer Drt Gafrhumberte lang frei bleiben, antore Eroftridje werden bavon um

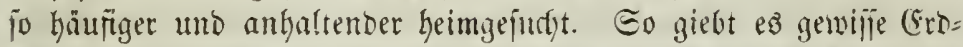
bebenzonen, meldye einer gemeinfamen Şeerd ifyer Erijdütterungen

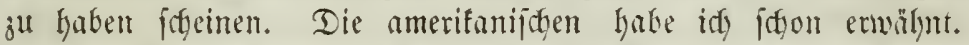

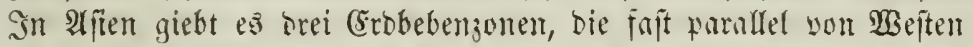

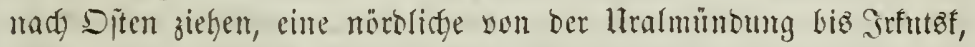
eine mittlere yom W(raljee bis nady Shina, eine fïblidye bunth bie Ränder am faimalaya. Daju fommt nod) jener mäcttige Bogen,

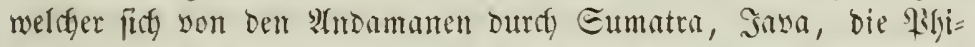
lippinen, Sapan, bie Rurilen, Ramidgatka uno bie झllenten zicht, wo fid biefe Zone an bie norbamerifanifhe ber Jaalbinjel Illiasta

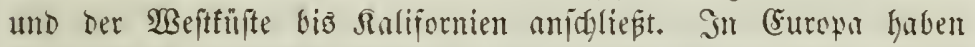
wir zmei oder brei (Erobebenjonen, weldye mir näher betrad)ten mol=

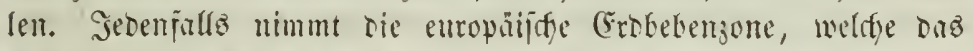

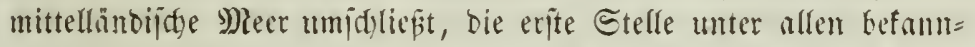
ten ein, nidft mur megen ifferes gropen lumfangs, ber gennueren

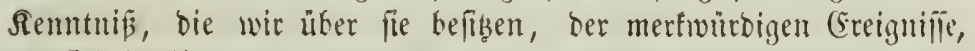

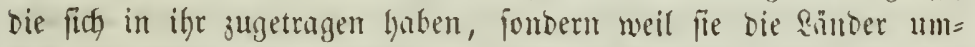

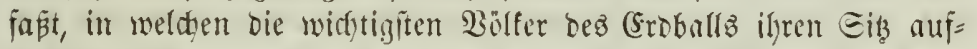

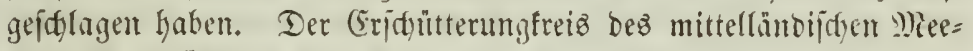

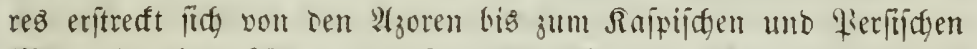
Meere in einer singe von fajt 11100 Meilen. Fuf ber Eilopeite

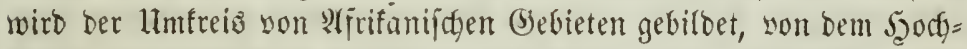
lande Der Berberei, Dem Lilatenu non Barfa umb Marmarifa. Die

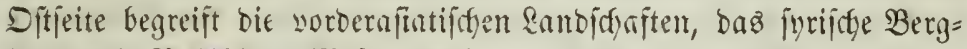
lano uno Palâitina, Mepopotamien uno Babulonien, ben meîtlidyen

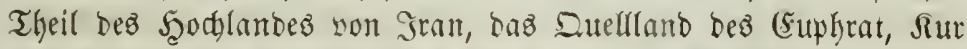

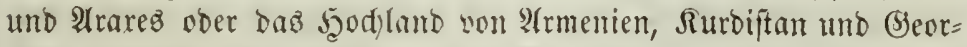

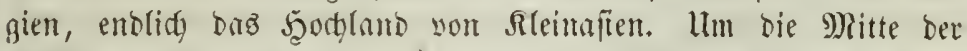
Erobebenjone lagert fidy im Rorben cin auz vielen Bjebirgagliebern beftefenter $\mathfrak{B o g e n}$, Der vom Safpiffen Mieere beginnt und ali ber

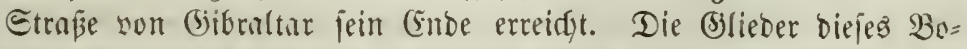

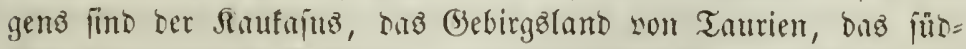

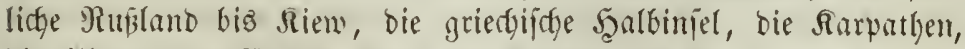

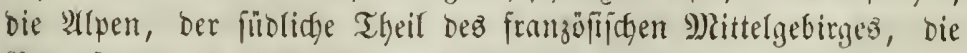

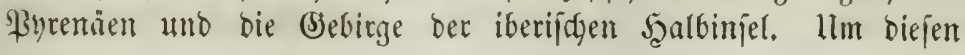




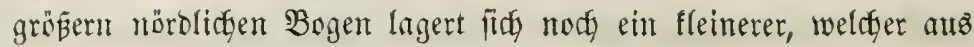
Dem beuticten Mittelgebirgşlande und aus bem mittleren und

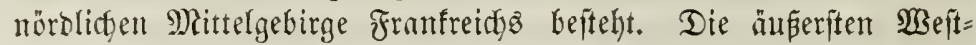
pumfte des Erobebentreijes bezeldnen bie Rjoren, Mabeira unto bie fanturifien Injeln.

Den eigentliden Seerd afler Erriffütterungen biefer Zone bil=

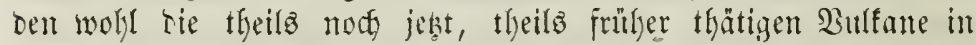
igrer Mitte; Dent bort fint auth bie Erobeben am häufigften, gans gewölynlidse, dem Boben eigenthünlidge Erjoeimungen. Den weft=

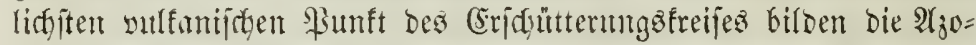
ren, eine Süllgruppe von einem Fläctenraum von $50 \square$ Meilen, Deren mulfonifhe Thätigkeit ifr Centrum im Bico auf ber Smjel gleidges Ramens ju haben idyeint umb fïh bald im Bilden von

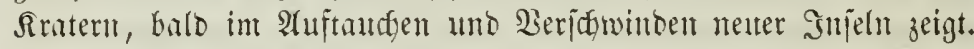

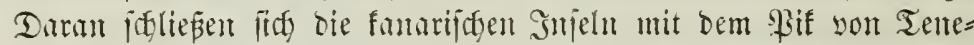
riffa. Ein zmeiter wufnifher Seerd ift die Snjel Sicilien mit ilyem 10,260 ซu民 fohen Aetna uno ocm Edylammvulfan Maca= luba bei (birgenti. Nörlid won Sicilien liegen bie ewig thätigen Fetterjhlüto der Eiparijaen Smjeln Bulcano, Sipari uno Etrom= boli mit oem Mlonte Edyicciola. In llnteritalien treffen wir ben merfwüroigen Sulfanbejirf von Peapel, Der fith yom Bejus ourth

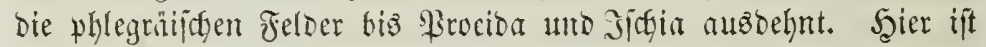

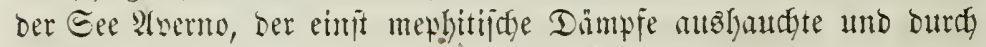
feinte verpejtete \&uft bie barüber binfliegendon Bögel töstete, jeb̧t son Der reinften und gejündeften 21 mojphäre ungeben; fier ift bie

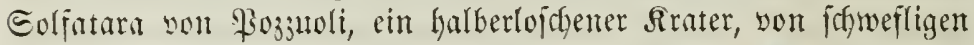

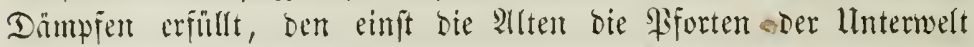
nauten. SBenden wir unz yon Stalien naty Diten, jo treffen wir

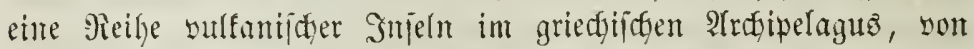
Aegina llfer die Salbinjel von Metlyone, Faros biş Eantorin mit

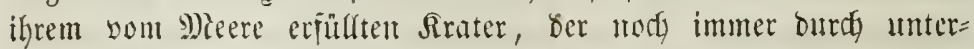

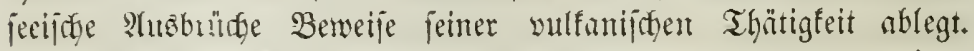
(b)hen wir nad) Aften linitber, fo begegnen wir jwar bort wentgen nod) thätigest Bulfanen, wohl aber Epuren ebemaliger meitwerbrei= teter Thätigfeit, Lie unvertilgfar Dem $B$ oden eingeprägt finto und fitf nod oit in ftarfen unt serberenden Erobeben äupern. In Rleimafien finden wir bie berildtigten fenerberge ber allen, bie 


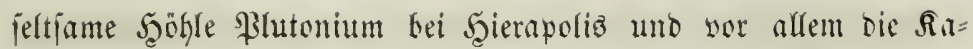
tafefaumene ober daz verbramte Biefilde wan Sybien, Das faton Dutrdy feinen Miamen, nod megr burdy bie afdenartige Eroc, einte

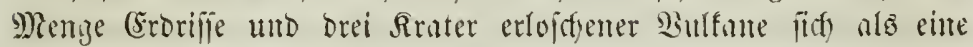

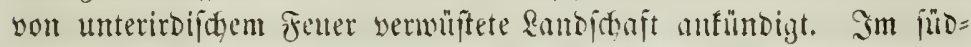

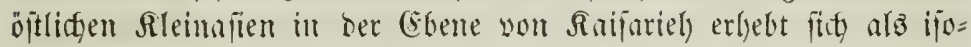

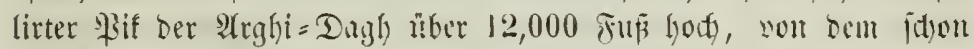

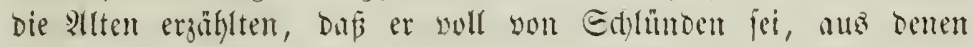

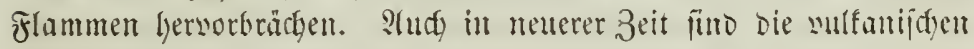
Eridjeimungen bort nidgt gant weridjumben. Ersbeben, marme Dueffen zengen son der fortburuernden Thätigfeit bes wulfanifcten

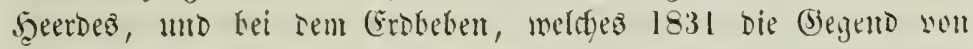

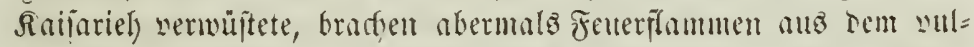

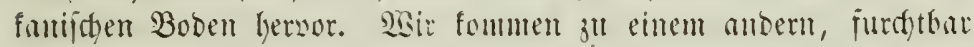

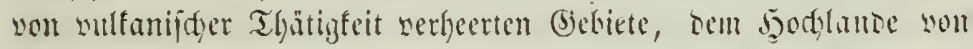

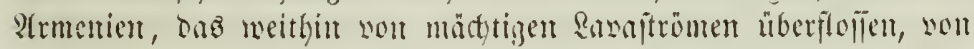
Ed)lafen und Bimfteinen überiduüttet ift. Der Mittelpunft aller

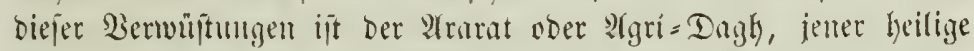

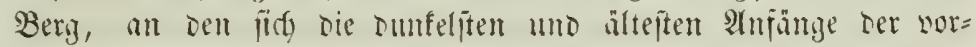

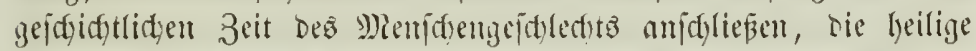

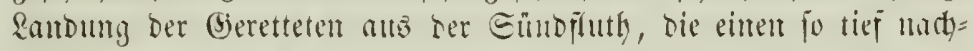

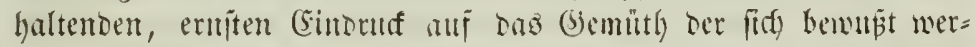

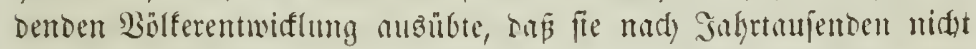

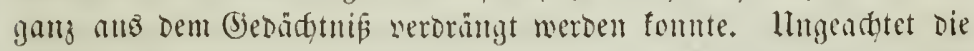

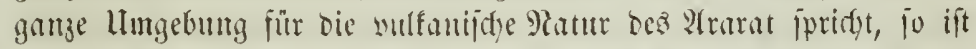

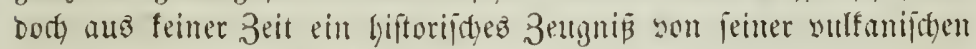
Thätigfeit aufbewalyt worben, und ferbft von (Erobeben blieb bie

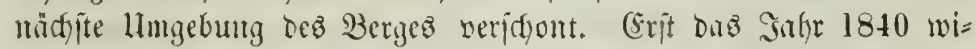
Derlegte Den fricolidfen (Elyarafter biefez Bergez unto judfe jene hohe Randidfaft mit einem jo furdytbren (Erobeben heim, dä mit cinem

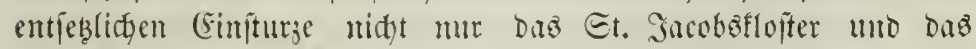
Dorf Alrghuri nut allen Bewolnern vernidtet, fonbern aud) weit=

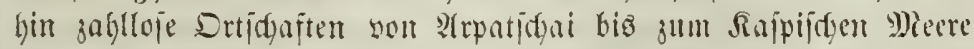
lin jertrummert murten, Taujente von Mienjichen bas Seben ver= loren, uno an viclen Etcllen bie Sberfïldje Dez Bodenz uno Der Rauj Der Bewaifier bie feltjamften Beränberungen erlitt. Senez Dorf 2 (rghturi, von weldyem fein lebendes 2 Bejen übrig blieb, lag 
in eituer ungeheuren Edludjt, von 6000-Fun hohen, fteilen Fels=

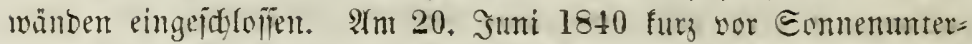

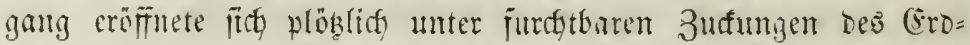
bodens uno Donnergleidem (jebrill, tas alle bewolner P(rmenteng

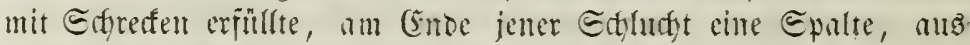
welder gewaltige Dampiwolfen hervorbraden und Edtlanm und

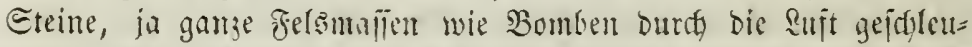

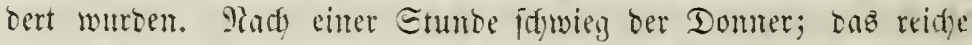
Dorf Arghuti, Das berühmte Rlojter, bie blühenten Felder uno jrudtbäume woren verjfywunden; zweitaujent frieblidfe Bewohner hatten ifre (5)rab unter ben aujgejefleuberten. Eteinmajen gejunden. In meitem llmtreife war jelbit die Eobne Ârmeniens furchtbar ver: Geert. Epalter batten firfy auty an ben MFern bes Arares und Saraju geöfinet und warjen Dämple, פBafjer und Exlamm empor.

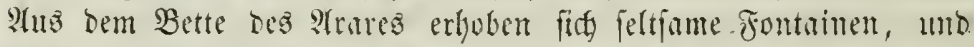

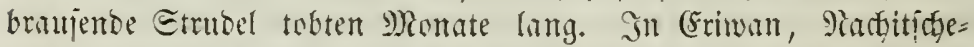

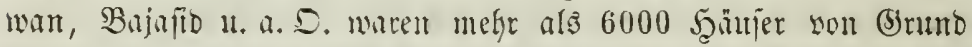
aus zeritört. Die Sullele bes Keiligen Gafob Gatte Uriprung und

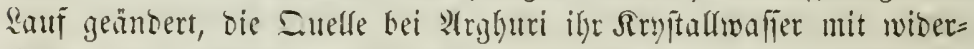

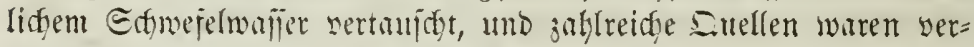

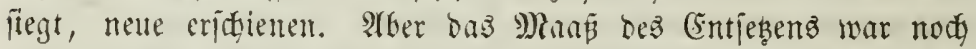
nidft criullt. Bier Tage nad bem 2(usbruch hegann ein mentes

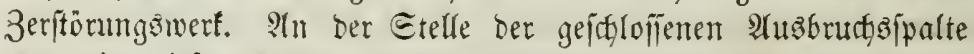
war ein tiejes Betfen jurliffgeblieben, bas son gejømolgentem

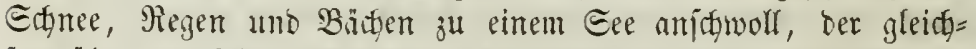
fam üther bem Thale fowebte. Der mädtige Damm, Den હdylamm= und Eteinmajien jeinem Druf entgegenjegsten, waro am 24. Juni

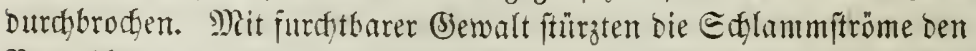
Bergabfang hinab, verbreiteten fith über bie (sbene und veritopften

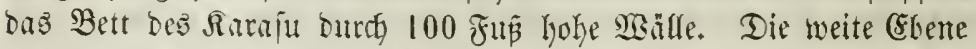
waro verwüftet, nit Bäumen, Felstrümmern und Reicfen bedefft. \&ange 3eit bitnete die ganze Sigento einen unjugänglichen Moraft. Erit als bie Ecilanmmajien troffneten, fonnte man belt gräplidgen

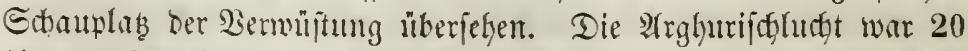

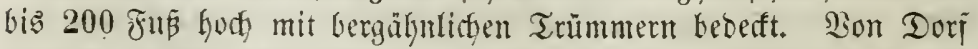
und Rlojter ift feine Epur zu finden; an ifrer Etelle erfyebt fids eine Reife fegelförmiger Bergfuppen aus $F^{2}$ 
Uleber einen Monat laug bauerten bie hejitigen Eriffütterungen fort, und nody im September waren Extyantungen mit fdywadem unter=

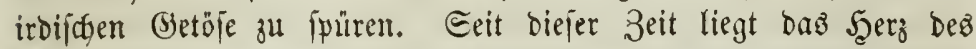

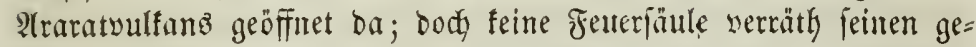
fährlidgen (Gharafter. - In bem ijtlidgen Gebiete unfrer Crobeben= zone, bem weitlidjen Perlien, wie in Dem wnlfanifden Syrien uno

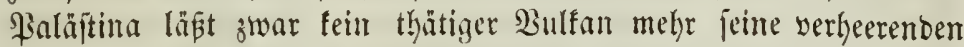

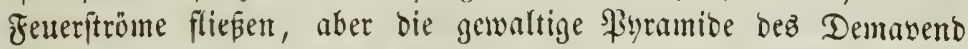
läp̧t Durd bie heipen Dimpre, die jeinem fratergleidfen (Sipjel ents

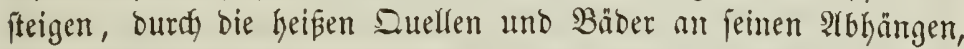
Durd) jeine weit utmler verbreitete (Erobebeniphäre, Durdy bie Echlafen uno Bimgfiteine, bie ringz um ifgn jeritreut fimb, feinen 3weifel mehr über bie SHluth, bie nody immer in jeinem Innern arbeitet, uno für weldhe bie Beit woht fommen fann, wo aud) fie eismal zum Reben geweeft wiro. Das leß̧te Bebiet ber Grobebenzone bes mittellänbifden Meeres betreten wir im Raufajuts, unb hier jehen

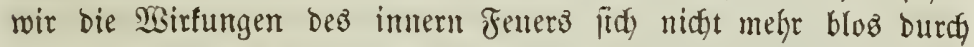

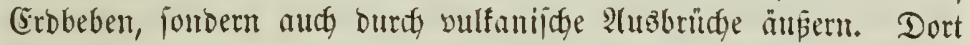

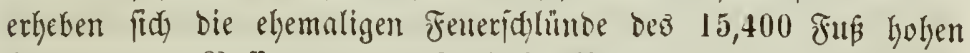
Elbruz, Dez Paffemtu, dez Sazbetf. Naphthaquelten, Sdjlamm= wultane uno daz heilige Feuer ber Subier, daz bem Boden yon Bafu entfitrömt, fint gewís hinreidfento Epuren yon ber ununter= brodfenen Thătigfeit einez vulfunifden Szeerbes.

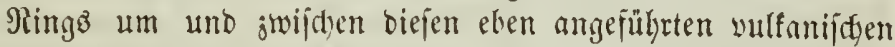
Eentralpunften liegen bie Sbegenden vertheilt, weldye am häufigften und zeritörenditen von (Erobeben beingefuntyt werben; uno and bie

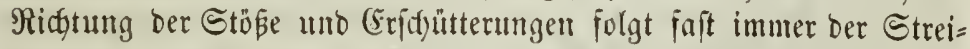
dungêlinie biejer 3one. Bon ber Thätigfeit ber Bultane hängt ge= wöhnlidy bie. Miube ber von ifmen beherridgten 3one ab. So lange bie Bulfane fdgweigen, toben bie Erokeben. Dafür ipridjt bejonders ber 3eitraum yom Saljee 1500 bis 1631 unto yon 1825 bis 1832. In ber erîten \$eriode rulte ber bejus, uno ber Aetna hatte unr

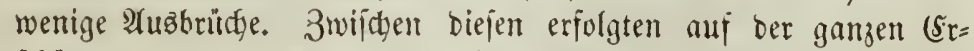

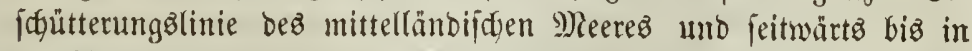
bie aflpen und Dejterreidy, Sonftantinopel uno Paläftina bie hef= tigften (Erobeben. In ben Gahren $1825-1832$ feierten wieber bie beiben groêen Bulfane unfer 3one, uno verbeerende Erobeben Ule, Beltall. 3. 2uff. 
waren bie Folge. 1827 wurden Meapel, Eicilien, Rleina|ien, Rifia

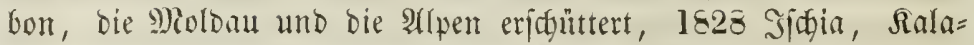
brien, Semua, Emyena, ber Rajpifde Eee. 1829 erfareften (Erdo= beben Miurcia, Die Türfei, Lnģarn, Eiebenthürgen und bas jüblidje

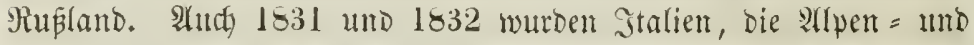
Sarapathentlanoer und Eyrien heimgejudgt, Giş endlidy SBejus und

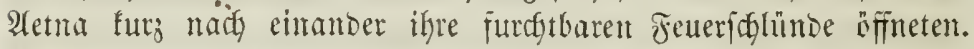
\{tber jeit einigen Gafren fint lie wieber in zeitweijen Edylummer

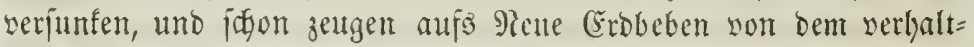
nen Brimme Der immern Bifuthen. 2(m 17. Decenter $185 \overline{7}$ murbe

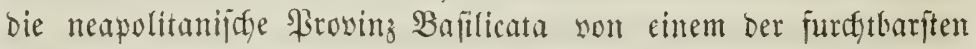
Erobeben Der ueuern Zeit heimgefudt, weldyes Szunderte von Dör= fern und Etäbten Dem (Eroboden gleidf) madgte und mefre als 30,000 Menichen utter ifrem Edyutte begrub.

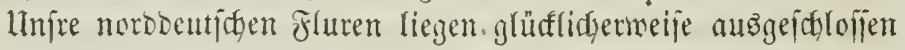
won Dem Bereich biejer furdttharen (Semalten, aber bennody er=

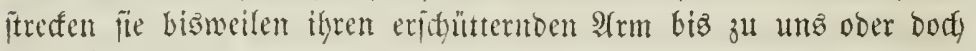

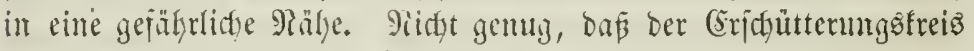

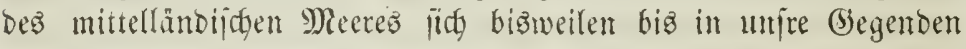

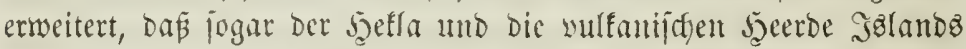

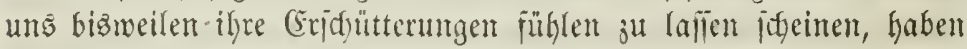

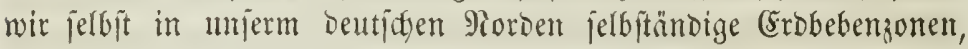
Deren Thätigfeit mur in neuerer Beit mehr eingeidlummert ift. $\mathfrak{B}_{e}=$

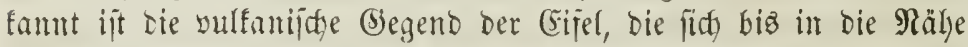
won (Soblens auf oem linfen Migeimufer hingielyt. Dort finten fich

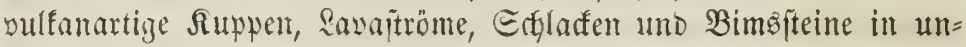

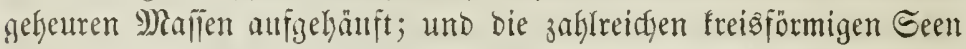
Hnd Teidfe, Miare gentamt, müfifen wohl als Rrater betractetet werben. Das größzte biejer Mianre ift ber \&aadjer See, rings yon

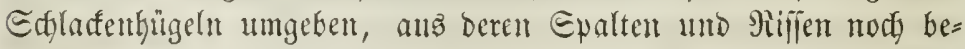

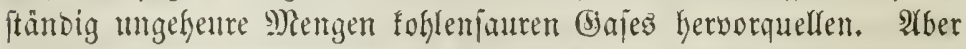

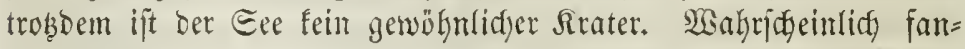
ben hier nur, wie noct) jeģt ans ben Buffanen der 2(noen,

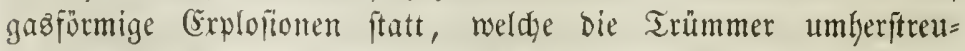

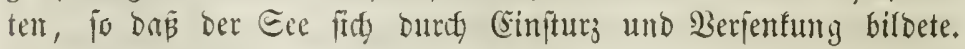
Biefleidjt warent fie mit Explofionen yon $\mathfrak{B a f f e r}$ verbunben, wie

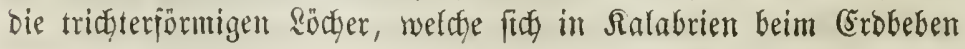




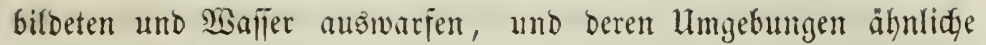

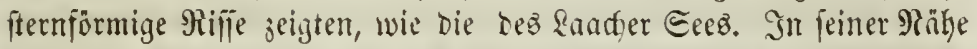

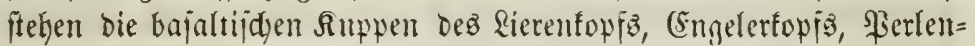
topf

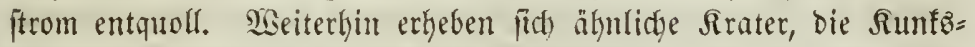
föpfe, Der Eteinterg, vor allem ber sadjümmer an ber Mette, beF=

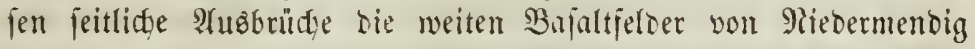
und Rottentgeim gebildet zu lyaben ideinten. Int Der obern Eifer

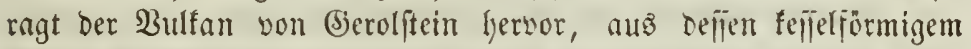
Sirater jidf ungeheure savaftröme in Das benad)barte Thal ergofien

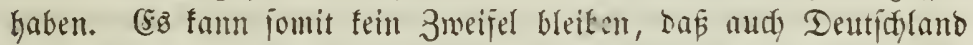
einft ber Eis gewaltiger pulfaniffoer Eridgeinungen war, weldhe jogar in ber jüngiten (Erobildoungzepodye ftattfanden, da ihre \$ro= bucte nody bie Braunfoblen burdybrodjen haben. Die Grobeben,

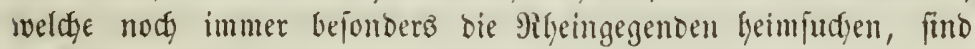

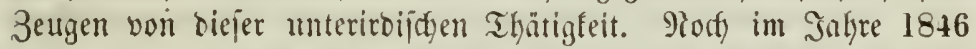
murbe jente Begend melymalz eridunttert, am leftigiten in ben Ifbenditunden dez 28. Iuli jenes Jahres. Der eigentliche Seero

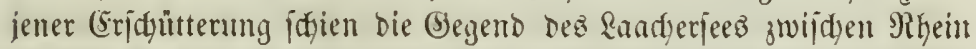

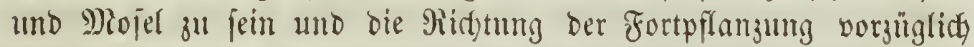
Dem Rauje Der Mofel aufwärtz, bem dez Mikeinez abmättz zu fol= gen. Darum jpürte man bie Eridunttermmgen nod) biz Rüttidy uno Brüffiel, biz Mlainz und Frantfurt, nads Diten Dagegen nur in geringerer Entfermung, weil bie asejergebirge uno ber Teutoburger

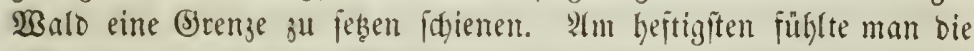

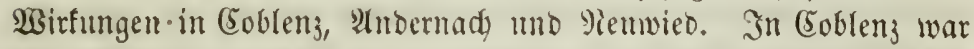

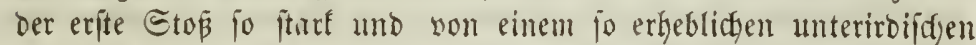

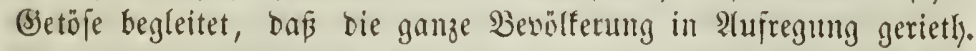
Mran afynte jo wenig ein (Frobeben, daß man allez 2(nore fid eler badgte. artes ftürzte auf bie Etraße ober fitefte ben Siopf zum Feniter binaus, unt fid) nady Der llrjadje zu erfundigen, bie man orauken fudfte, ftatt unter ben roüpen.

3u alfen neuen, ungewolgnten Edgrefuififen fommen gewöbn= lict) nodh unbegründete Befïrtstungen, wie ber Mienid immer im

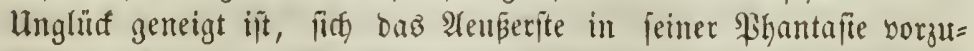
ftellen. Wer zum eriten Mlale bie Wirfungen beż (Erbbebents fühlt,

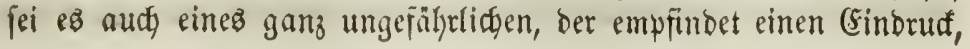


Den er nie vergiß̈t. In jeinen jejtefiten Heberzeugungen fielyt er finth erichüttert; Dent (Eroboden, Dent er jeit.nannte, fieht er wogen unto mallen wie die beweglidjent Flutben bes wanjers. (Gr afnt bie

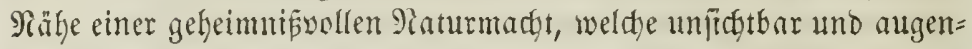
blifflidy bie Ruhe und Sromung Ler ganzen Matur jtört. Heberall glaubt er iffe mun zu begegnen, er traut jelbft bem Soben nidgt melgr, ben er betritt; benn es fömten find ja Edflunbe unter itym öரrnen uno $\mathfrak{B u l f a n e}$ biejem Şöllentioben entîteigen.

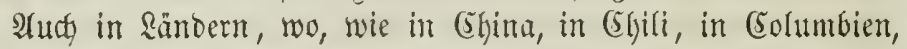
biefe Naturbegebenfeiten zu ben gewïhnliden (Eriffeinungen gehö= ren, wo brohende Esejahren, wilde Ecenen Des Edjrectents unt der Werwirrung з̆ Tagesgejprädfen werben, fintoet man bie (Entppin=

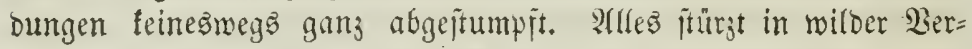

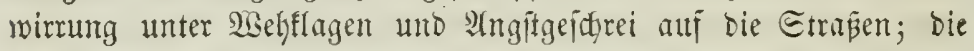

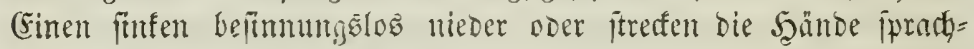

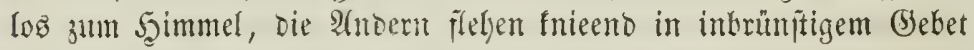
3u Den 5ुeilizen. Eelbit in Mierifo, wo bie Errfafrung ben fried= lidenen Sharafter ber cortigen Erobeben fentren gelefyet bat, ftürzt

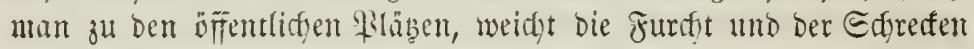

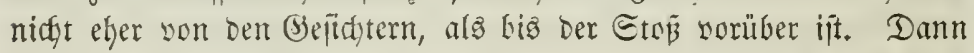

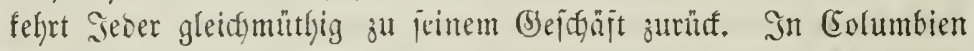

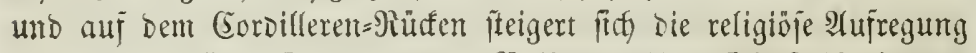
oft bis sum 2 sahnjinn, ber bas Bolf antreibt, iid jelbit in bas Grab 3u ftürzen. Sn Earacas fanden am 26. Mär 1812 gegen

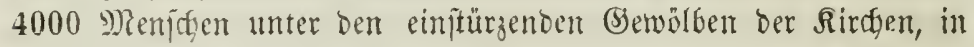

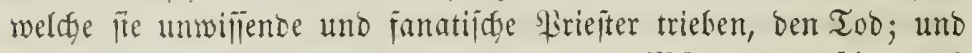

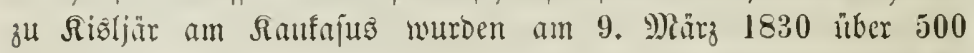
Menjeden yon bent Trümmenn des Tempels begraben, in ben fie

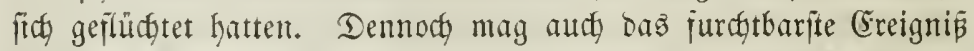
burch bie Dauer an Edyreffen verlieren, wenn nidjt ber Aberglaube

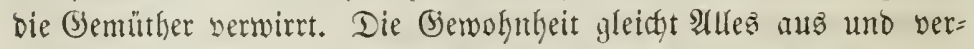

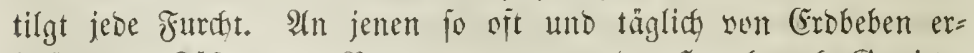

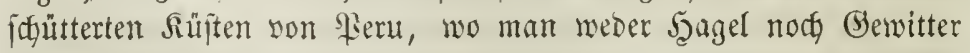

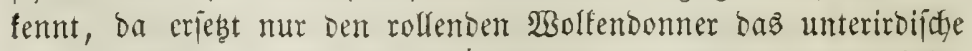

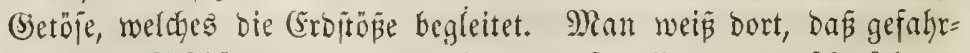

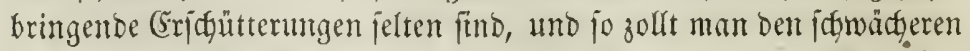

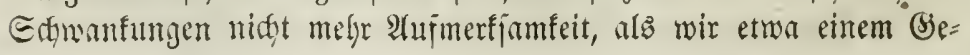


Gefanmten Girad Der Durdfiftytigfeit Der Ruft, worauf am 7. und 8. eime Göchit merfwürbige, burdauz nidyt nebel= ober höhen= raudjartige Trübung ber Ruft jolgte. Die Ruft war unbewegt,

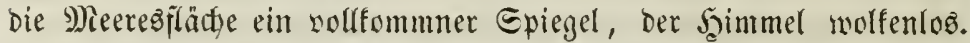

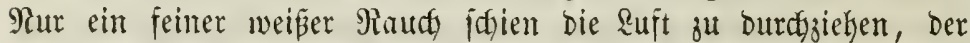

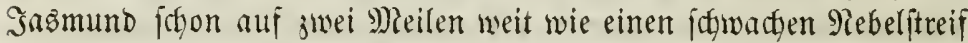
ericheinen liế, während es jonit $10-14$ Meilen weit vodfommen

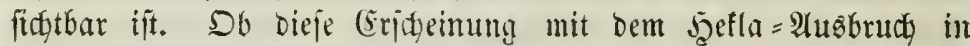
Berbindung ftand ober nidgt, lafien wir bafingeftellt. Deutlidg ge=

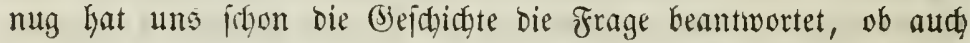
Der Bewohner Des Deuticten Fladylandes (Erobeben zu fürchten habe. Erobeben ịtnd unabgängig yon Der Patur Der Bebirgảarten, in Denen

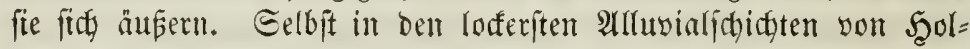
land, um Midoclburg und Bliefingen, find am 23. Februar 1828 Eroftổe empjutuden worden. A2m 7 . Suni 1857 wurben harmloje

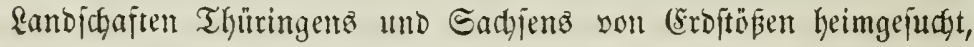
Ind im Samuar 1855 rinttelte wiederholt unterirbifder Donner bie Rarpathenlänoer aus dem Traume vermeintlidyer Eidyerheit. $\mathfrak{A m}$ 6. Mai 1857 wurde jogar au der ăußeriten Pordipize Sutrlands bei

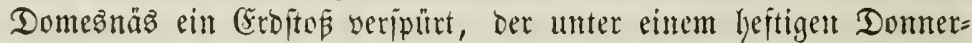
foglage erfolgte und einjelne Szänjer fo erjoütterte, Dap̃ die $\mathfrak{B e m o h}=$ ner Das Şerabitürsen der Deffen fürdteten. Sit einem Bauerntofe bradgen in ber That bie Däduer zujummen, in andern fielen Stuil= feln uno Telfer von ben Tifden, Epiegel von Den $\mathfrak{B a n d e n . ~}$

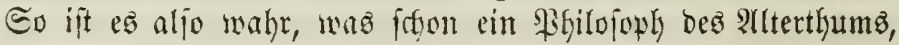
Ceneca, getrieben non einer ifm in's Seer gejoriebenten Afymung

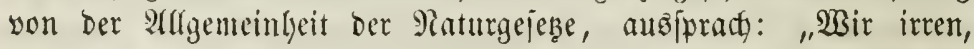
went wir irgeno einen Theil des (Erbbodens yon ber Befahr ber Erobeben ausgenommen glauben. Alle find bemifelben Befeg unter= worfen. Pidjts hat bie Matur fo gebildet, oa wảre: Das (sine fällt beute, das Anbre morgent. Uno gleidymie in

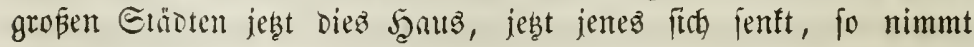
auf Dem (Erbitrije jebt Diejer Theil Edaden, jebst ein andrer." -

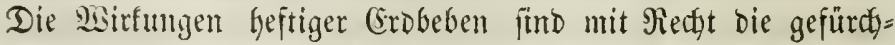

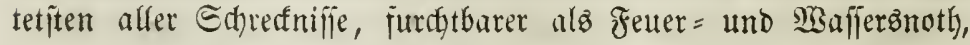

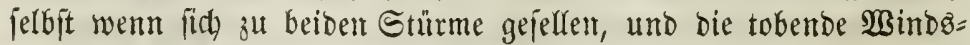
braut fidg ber Flammen bentädytigt oder Die Mafierfluthen über bie 
Cbene treibt. Den angebornen Bilauben an bie Siube uno Un=

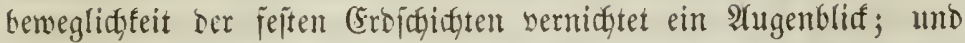
wem bie Eridteinung in ifrer Septigfeit begonmen hat, fo fann

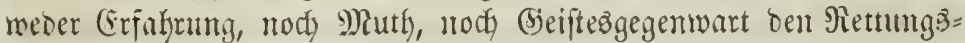

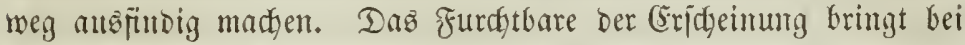
9) Menichen und Thieren biejelbe ängitliçe linruke herbor, unto jelbjt die Rrocodille bez Srinoco, wie Şumboldot jagt, jonjt frumm wie

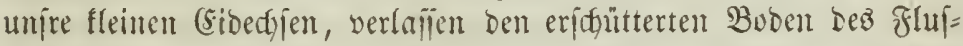

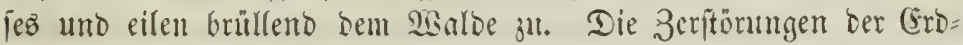

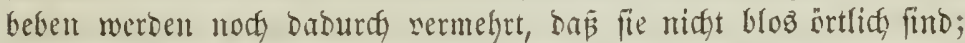

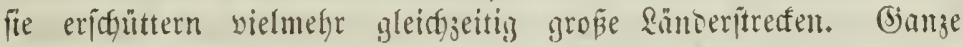
Etübte mit ifren Bennfuen merden in einem Plugenblide von ber Erde serjolmugen, bie feitejten Mautern jertrümmert; Berge ent= ftelgen ober fitirgen ein; jelbjt Das Rlima einiger (siegenoen, wie das non Suto, irleidet bedeutende uno oauernoe Seränderungen. Nod burdh feine Rrajt wurde in jo wenigen Etunten, ja Eefunden, eine

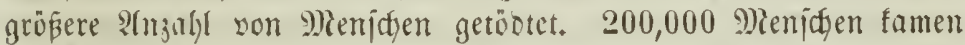
in Sleinafien und Eyrien im Gahre 526 ums Reben, 60,000 in Eicilien im Safre 1693; bei bem Erobeben yon Duito 179t jan= ben 40,000 Mienifgen ifren Tod, und eten fo viele bei bem von Miobamba 1797. In Dem fo oft yon biejen Edurefnifien heim=

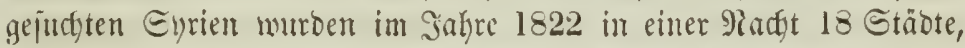
jedes einzelue Dorf, jede einjelne Sautte in Edfutthaufen verwan=

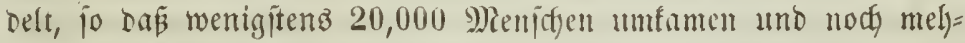
rere aufz Edyredfidyite veritümmelt wurben. Ins Eroheben, wel= đes im December Des Sabres 1857 dic neapolitaniidge \$rovin:

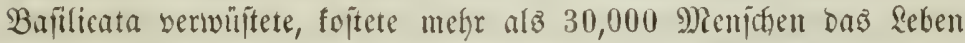

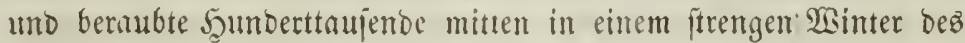
idüizenden Dboady.

Die ganze Raturoronung idgeint bei biejen Ereignifien auf längere ober fürgere Zeit nurnidtet. Bei bem Crobeben von \&ij̄a= bon wurben ferne Queflen in ifsem \&auj unterbrodten: Die Töpliker Thermen werifegten uno fefrten, alles überidwemment, von Eijen=

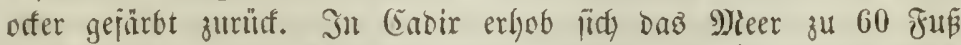

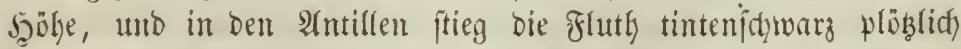

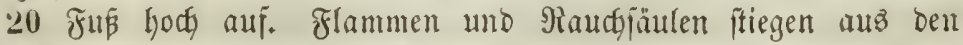
Epalten ber Felfen bon âlvioras bei ber Scauptifad auf. Bei 
Dem Erobeben son Cyili im Sahre 1835 widy das Meer unjern

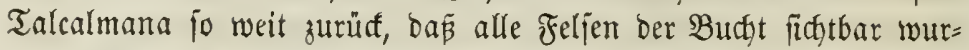

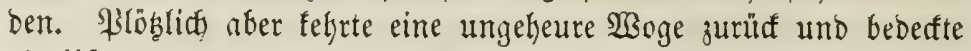
bie Hjer 28 Fuß̈ über bie Şöhe Der hötjten Epringfluth. Raum entgingen die Sinwohner bem Mellengrabe. Im Mifinitippitfale

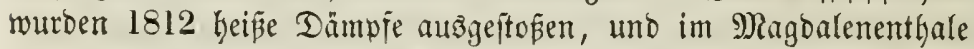
im Rovember 1827 burdy Fusbrïche von foglenjaurem Saje faft alle in Erohohlen lebenden Thiere erjtift und fogar bie weibenben Seerben bebeuteno bejøăbigt. Bei bem Erbbeben von Riobamba wurbe aus zabllojen Epalten, über meldyen fith fleine fortidnreitende Regel erfoben, ein jonbetbarer, zerjebter, jdylammartiger Tuff auż= geftopent, ber zugleid) Ricjelpanzer yon Snfujorien uno eine joldge Menge fein jertheilter Soble enthält, Daß̄ er unter bem Ramen Mona als Brenmmaterial bemut wirb. Dit erhalten fity bie Epal= ten, in weldye bie Feljendecfe zerreipt, Gallrtaujende lang. Befannt ift ber Feljen an ber Sillte von Gata, weldyer ber Eage nads im Tobesjabre EGrifti yon oben bis̄ unten geppalten murbe, uno ber

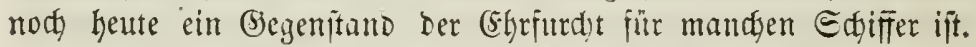

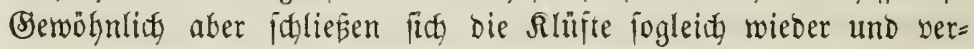
foblingen Thiere uno Menjden, Băume und Şäujer. In China tamen auj bieje weije 4000 Menidgen um. In Rifjabon ver=

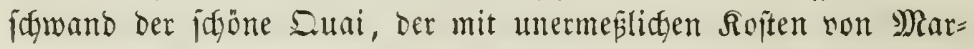
morblofent erbaut war, fammt allen Taujenden ber Bewohner, bie bier Eidjergeit gejudt batten, für immer und purtos in ben

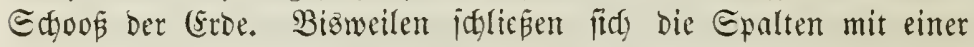
wahrhaft ichauderhajen Şeftigfeit, Die Allez in ihrem Bereidje jer= malmt; bisweilen offnen fie fids yon Reuem, um ben verfhlunge=

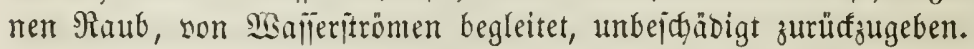

Das find bie furdytbaren Thaten Diejer Sraft, weldye Etäbte zertrümmert uno bie Bemolyer unter Trümmern begräbt, Şäfen

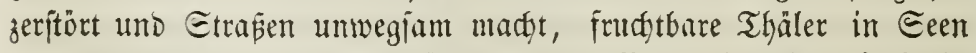
bermandelt ooer mit Den Trümmern Der Berge bedeft. Wohl ift

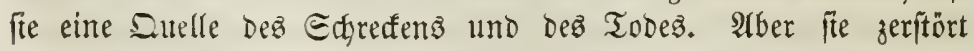

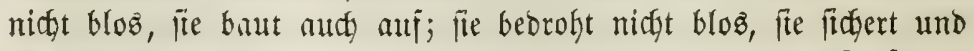

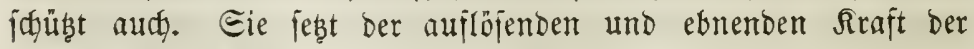
Serwäljer eine Sremze und fidyert Das Feftland vor bem Untergang. Wie genaltig und groparatig aber aud bie eben gefdyilderten 
Birfungen ber Erobeten jein mögen, für unz haben bier biejent= gen $\mathfrak{B e r a ̈ n} b e r u n g e n ~ d a z$ meifte Snterefïe, welche Durd) jue bie (5ro= oberflädge jelbft exleidet. 3war mögen in ocn früheren 3eitaltern,

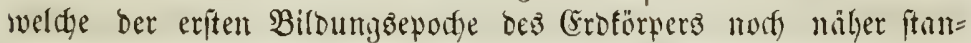
ben, jolche Berïnderungen groß̈artiger, gewalt famer, weiter verbrei= tet gewejen fein, als jebt; aber bie nod hente butrod hejtige Etöbe

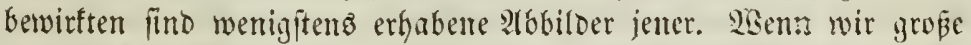

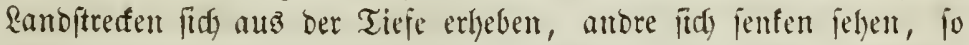

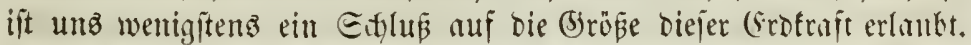

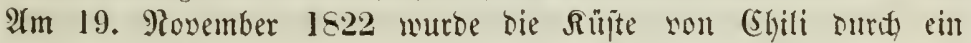
furctgtbares Erobeben in ber Rantge vor 1200 englifaten Meilent heimgejudgt und Et. Ingo uno Barparnijo gänjlidg jerjtïrt. 2An

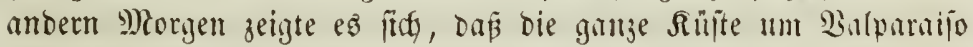

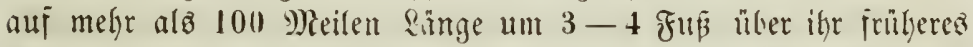
Rivean emporgehoben war. Esin Theil bes früheren Eeebettes bleb

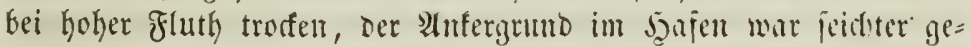
worben, uno ältere Etrandinien waren emporgetyoben und fomen

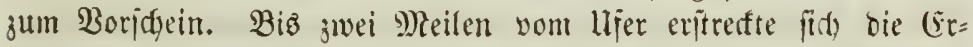

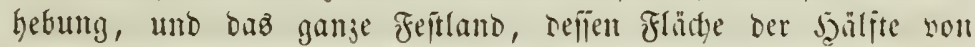

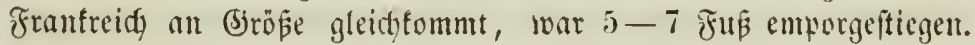
2m 20. Februar 1835 bezann mit hejtigen (Erofitǖen eine neue

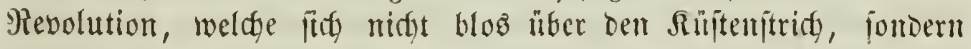
aud) über einen Theil ber Corbifferenfette autsochnte, won :ava =

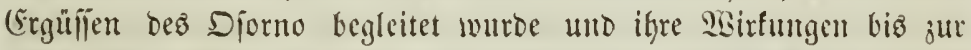
Injel Suan= Fernandes verbreitete. Wieber war eine Ertheburg Der

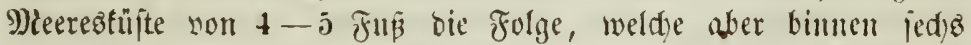

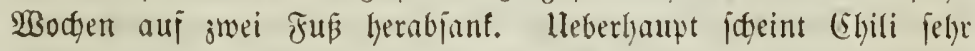
Gäufig jelbit in hiftorijder Zeit joldje 9iveauveränoerungen erlitten zu haben. Nady Danwin's llnterjutyungen zeigen find wenigitents

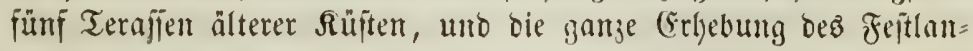
Des beträgt an mandjen Etellen $1000-1500$ Fußs, durtdjiffunitt=

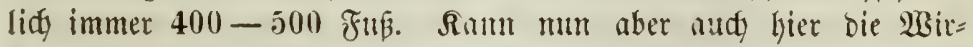
fung vulfanifder $\mathfrak{R}$ räfte nidgt in $\mathfrak{A b r e d e}$ gejtellt werden, fo hat man ez body bei einem ähnlidgen thänomen, Der langjamen unto noth

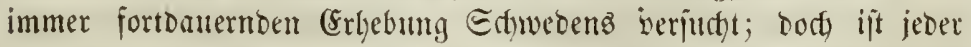
Berjuch einer antern, nidft auf bie vulfamijaje Reaftion des (ErD= intrem gegründeten Erfflärung bişger erfolglos geblieben. Demu 


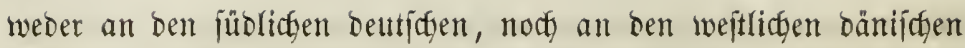

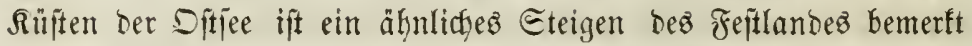
worben, weldyes bod nothwendig eintreten milste, wollte man bie Errbebung Edywedens als nur fheinbar anfehen und aus dem Sin= fen Des gejanmten Ditieepregelz berleiten. Sor faft 100 Sahren zuerit burch Celfuts auf bieje merfwitrbige Eridgeinutg Gingemiejen, fann man es mummehr für eine entiffiedene, burdh \&. v. Budg jeft= gejtellte Thatiadye amjehen, buß ber ganze Riljtenrand Efandina=

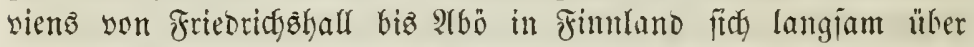
ben Meereşpiegel erhebt uno währeno ber hiftorifden Zeit wenig= fiten um 200 Fú geftiegen ift. Die Sebung nimmt fitftbar naty

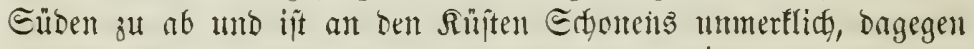
tritt fie nody beutlich bei Etouffolm und am ftänfften in Der (Begend von Tornea auf, wo innerfyalb 30 Safren gegen eine Meile breites

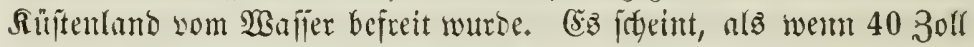
Eteigung bie Mittelyahl eine Sahrhunderts angiebt. Snoep fann

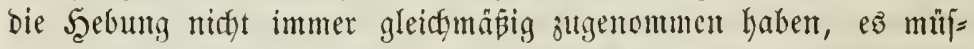
fen aud Eentungen wieber eingetreten feit, wie ansre Thatjadjen,

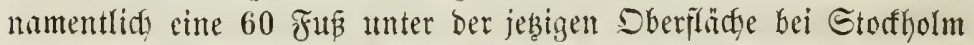
aufgejumbene Fifcherfhutte, weldge uriprünglidy am Meeregufer ftand, fo twie ber Scylojiefolm, auf weldyem 1473 bie Enot Sothaham er= baut wurbe, und Der jeb̧t fait im Epiegel des Mieeres liegt, be=

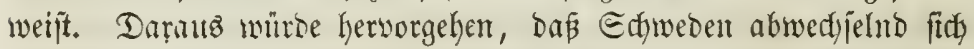
hebe und jente ober wenigitens auth frither eimmal fich gejentt habe; und biefe शmuahure wird ourchaus zulaffitg, da biefelbe jon= Derbare Erjheinuty an Der Rüftenftreffe ber Bai von Bajä bei \$ozjutoli, wo ber vielbejprodyene Eerapistempel ftefst, aufis Beftimm= tefte nactgewiejen iit. Der Fufboden diejes Tempelz nirb beim Göctiften Bafferitand einen Futi hody nom Meere bebeft. Drei marmorne Eäulen itehen nody aufredt, uno bieje haben bis zwölf

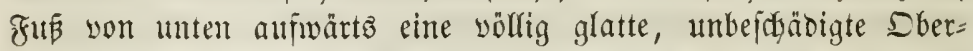

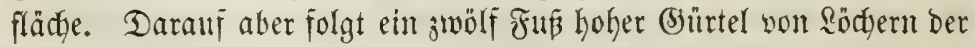
Bohrmujdyeln, weldye lange gearbeitet haben müjien, weil bie \&öcher

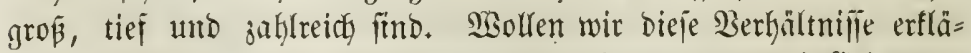
ren, fo minfen wir nothgebrutigen amtefmen, daß bei Erbauung

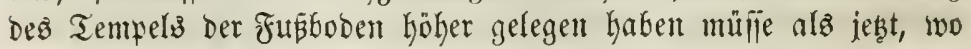
ifn ber hohe wafierfitand überiftwentmt, daß̄ er in einer fpätern 


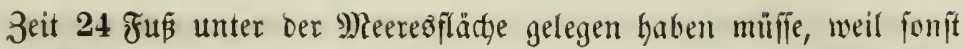

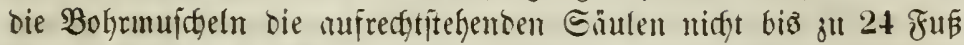

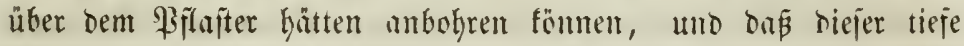
Stano lange genug geonuert haben mülïe, banit eine fo harte $\mathfrak{T} r=$

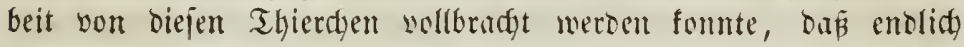

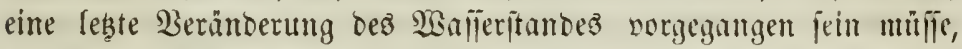
weldge bie গiuntere bez Tempels in bie Ringe bradgte, in meldyer

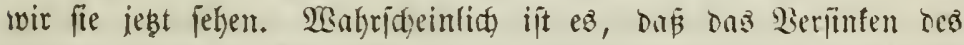

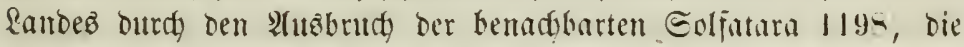

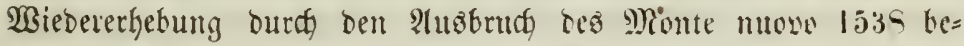
wirft murbe.

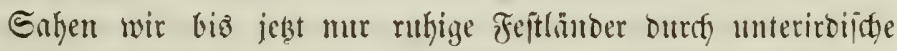
Ranafte emporgehoben, fo merocn mir mun fogar furdytbate bulfante bent geöffneten Edslintoen ber Eroe entifteigen jefen.

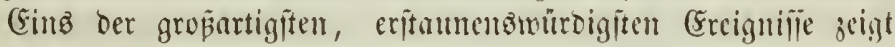

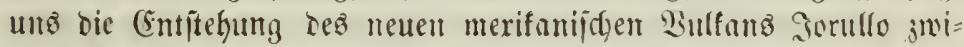

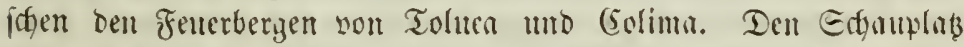
Diejer Erejdeimung bildete sinte von Bajaltbergen untgetente, reid)=

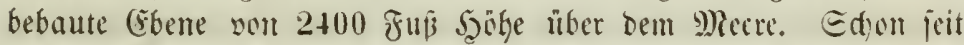
Dem 29. Stuni bes Salyes 1759 batte man bort ein jurdythates

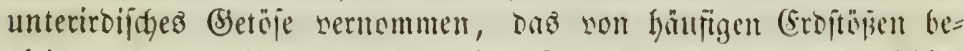
gleitet 50-60 Tage Danterte. Sim Eeptember war mieder völlige Muthe eingetreten. Da begann am 29. Eeptemler um 3 ulfr $\$$ mor= genz ber 2 (usbrud) bez neuen Bulfans. Da, wo heute fin finftrer

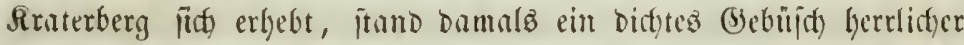

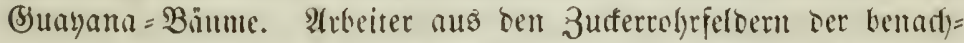

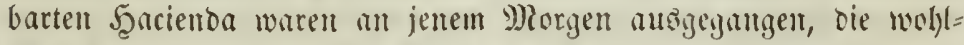

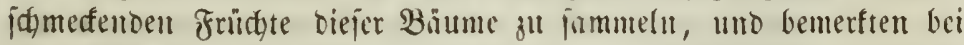

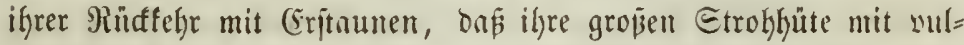

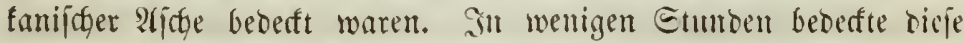

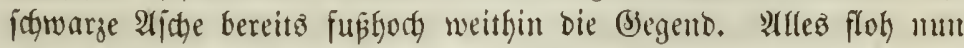
nady einem benadybarten Smbianerböridgen, Dns auf eiter Sfuböhe etrva 2260 zun über ber alten (Sbente von Jorullo lag. Bion bier

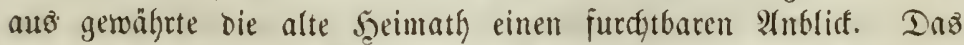
ganze Eand idgien in flammen zu ftehen und mitten zwifden ben

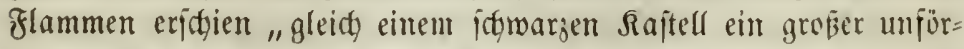
miger Rlumpen". Die ganje (Ebene, eine Flädge von mefjr alo 
$1 / 3$ geogr. $\square$ Meile, erhob fich gleich einem (Semölbe, am Ranoe 36, in ber Mitte gegen 500 Fuf hod. Nody jebst erfennt man in Den jerbrodenen Felsidficten bie Girenzen biejer Erhebung. Eine son

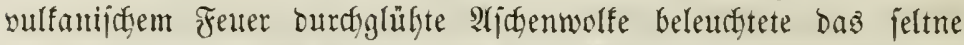
Ectyaupiel. Die ermeidste (Erbdecfe fitwolf an, mie ein fturmberweg= tez Meer; rings bradten Flanmen hervor, und glïhende Fels̈maj=

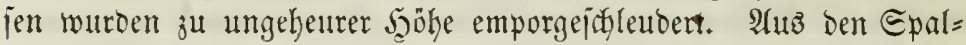

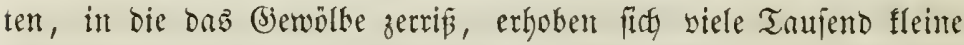
Regel von 6-10 Fuß Şühe, von ben Eingebormen Defen (J̧or= nitog) genannt. $\Im m^{\prime}$ Sahre 1780 fonnte man nod in einer Tiefe son wenigen 3olfen in biejen Sornitos Cigarren anzünden, und alsె Şumfolot bieje (segend im Sahre 1803 befucte, erhoben fits

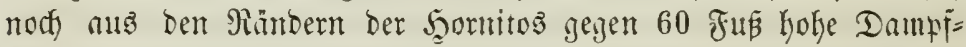
fŏulen, uno die Temperatur in ifren Epalten betrug nody $93-95^{\circ} \mathrm{C}$.

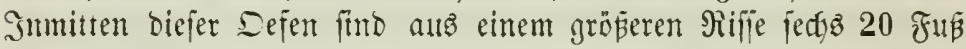
hohe Trummerhuten emporgeftiegen mo unter ifnen allf gleidjer Qinte ber Şauptrulfan Sorullo in einer Şöhe yon 1500 Fū. Die= fer ftant som 2 ugenblicf feiner (b)burt an bis jum Februar 1760 unaupgölids in Flanmen unb bebefte mit jeinen emporgejdyleuber=

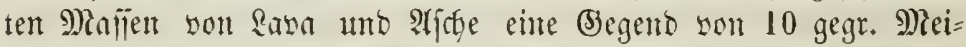

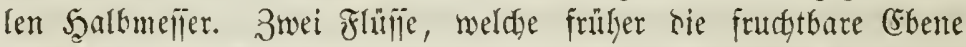

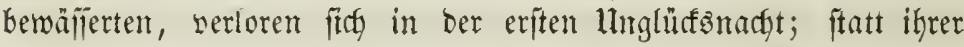
fieft man jebzt meiter gegen Weiten aus Den Epalten bes aufgetrie=

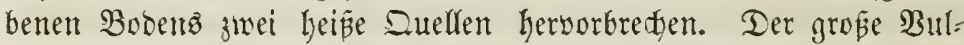
fan ijt jest erlojden, aber bas Rand ringsum if verwanbelt uno

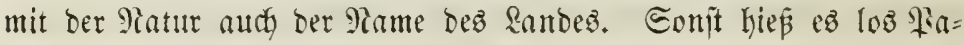
ftoz, bie Mciben, jekt Mulpays, daz böje Rand.

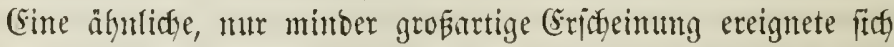

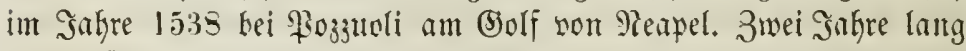
Gatten jđyon Erobeben bieje Giegento erjoüttert, alz am 28. Eeptem= ber zwijhen bem Eee Arerno, dem Monte Barbaro und der Eol= Fatara Flammen auz der Erbe Kerworbradjen; Epalten entfitanden

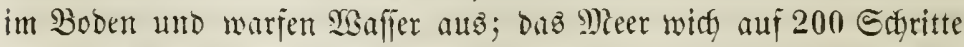

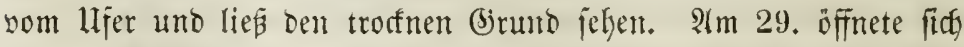

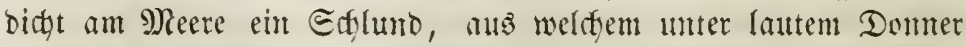
Raud, Flammen, Єdblamm und Felsmaffent aug̉geworfen wurben. Eo entitatto in iwei Tagen ein Berg son 413 FuF Seöhe uno 


\section{1}

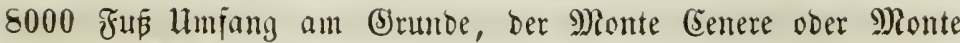

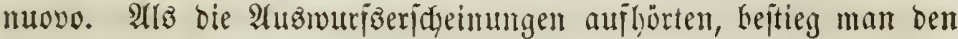
Berg uno fand auj jeiner Söbe cine tridyterförmige Definung, einen Srater. Go erjogeint er nod jebst.

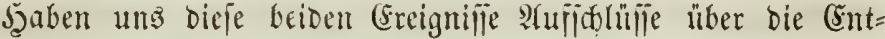

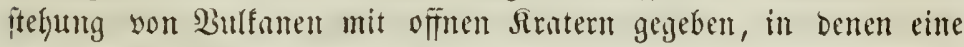

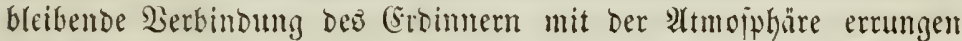
iit, jo vermögen Dody nidgt immer die empordringenden (Sewwalten Dieje Serbindung berjuftellen. Sit werben burds fie nur einjelne Theile unjer (Erorino zu ungeöfneten, Domf̈̈rmigen s)ialien em= porgehoben ober bie gehobenten Edgidte! Durtherodgen uno fo mad

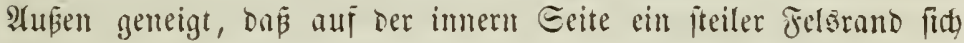

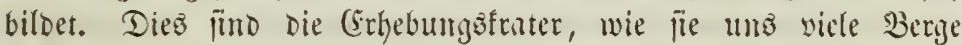
des Fejtlandes und vorjuggeweije viele Snjeln anjweijen. Unter Den

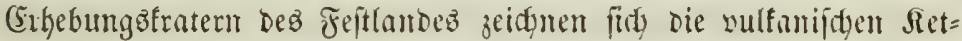

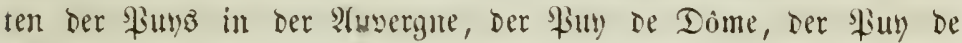

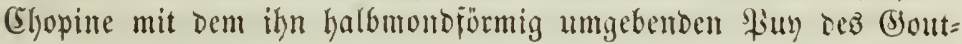

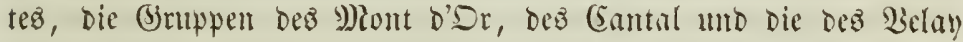
uno Bivarais nuв. Die ähntid) gebildeten Snjeln zeigen immer eine mebr oder minber wollfommene Reigelgejtalt, indem fie von Den

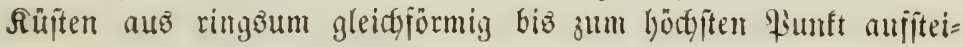
gen, aber immer in ber S) Sitte, wo man ben (Sipjel ermarten jollte, eine tiej eingreifende, feflelförmige Bertiejung seigen, an Deren bohen

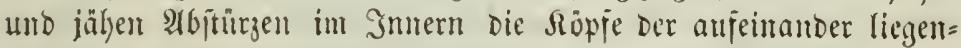

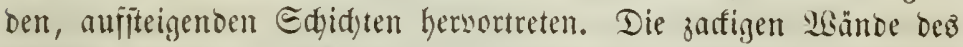
Siefielo, weldyen bie Epamier der cmarijden Imilln la Ealdera

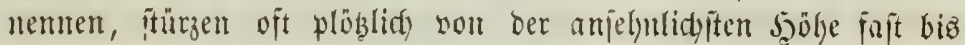

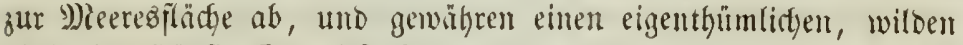

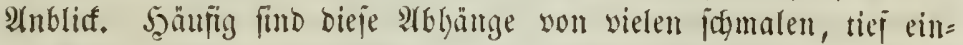
gerifienen Edyludsten, ben Barancoz Der Epanier, jeripalten, welde

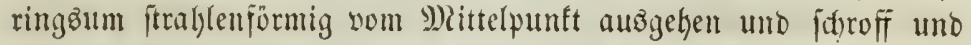
fteil abgerijien füto. Eelten jeflen die Barancos mit Dem Smmen ber Caldera in Berbindung, uno bei ben meiften smjeln Dringt

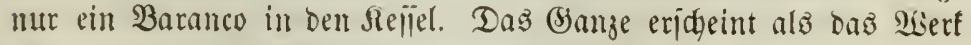
einer gewaltigen Rraftüüerung aus bem S̈mern Der (5rbe, bie grope Smjeln zu bebeutenden Şöhen erbeben taun uno erhoben hat.

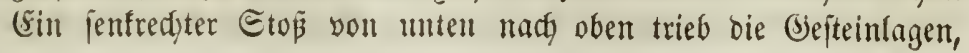


weltue ben yormaligen Meerezgnumb bilbeten, how empor. Dieje mupten beriten, wo bie $\mathfrak{R}$ rajt am heịtigiten wirfte, uno fidh wie

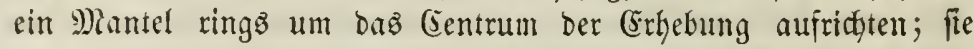
musten frahlenförmig som 9)ittelpunft auz aufgerifjen werben und Die Baranteoz erfalten, fie musten in ber Mitte Den Frater, bie Ealbera bilden. Wenige biejer Injeln mögen an Ectönteit und Deutlidfeit biejer Berfältmiffe mit Der eamarijoen Snjel ßalma zu vergleidyen jein, auj meldyer ber Boden Der Caldera 2000 Juß über bem Meere eine Meile im Durdymejier hat, uno beren furcht= bar zerrijiene 2 bände über igr eine fentrechte Säbe von $4-5000$ ₹ǘ erreidyen.

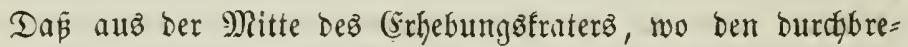

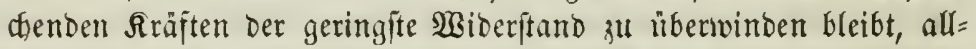

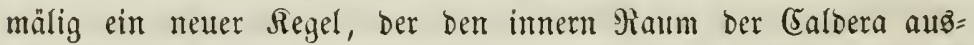
fïllt, emporiteigen und zum bauternben Bulfan werben fönue, ift eine (Erjahrung, welcte am bentlichiten und übergeugentiten ber

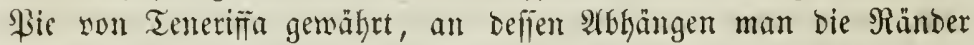
ber alten Ealdera als einen pradtyolfen jalbtreis non Felöwänben an ber Ellojeite mahrnimmt, ein atmphitheater bildend, won wo aus man ben lebten gropen Regel des \$if erjt in feiner bolfen

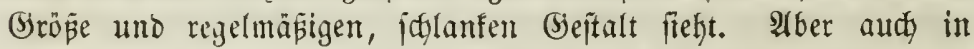
fijtorijder Zeit lyat man Dergleiden Erhebungberidyeinungen im Meere mit eignen Hugen amictauten, Injeln auftauchen uno oft wieber veridywinden jelyen fönnem. Im Jahre 1795 bemerfte man an einem vereingelt im s) Meere liegenden Felfen in ben Allenten, wejtlich von Unalajwfa, Dampi, welder biejen Feljen umbülute. Alङ im Sathre 1800 fich bie furdjtjamen Ginmolyner wieber in feine Päkge rwagten, janden fie fratt bes ilynen wohlbefannten Felien eine

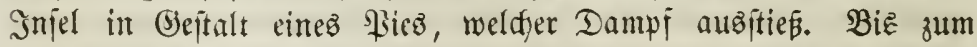

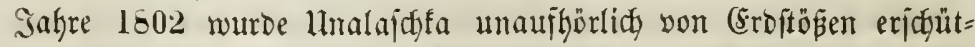
tert. Da lyörte plöblich daz Brennen des neuten Sulfans nuf, und urr Der Bulfan von Unalajbfa wüthete befto heftiger. Bald ba= rauj aber brannte biejer, ber Bulfan auf Der Snjel llmnaf uno Der neue Buffan abwectjelnd. Im Jafire 1806 hatte bie neue Эn= jel einen llmiang von vier geographijtsen Meilen und einige 1000

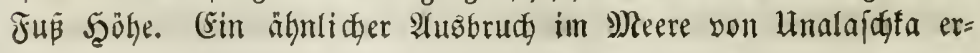


folgte im Safyre 1814, und abermals ftieg eine Smjel empor von

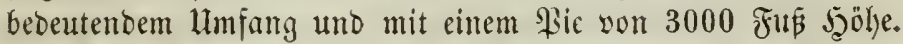

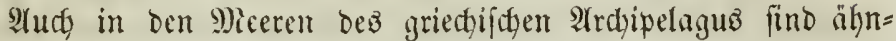
licge Injelerbebungen beobadytet worben. Edyon Dvid ergïlylt in

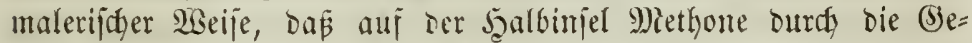
walt verjdlojiener Dämfje ein Berg wie eine Blaje erhoben worben

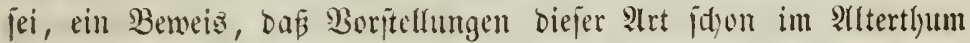

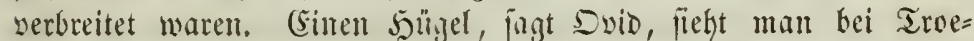
zene, jarofi und baumloz, eimit eine Gbene, jebt ein Berg. Die in fintere Jäblen eingeldjlojienen Dämpje judjen vergebenz eine

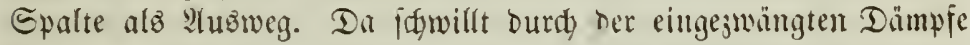
Sraft der fidy delynembe Boben wie eine lujtgejüllte B̉laje empor;

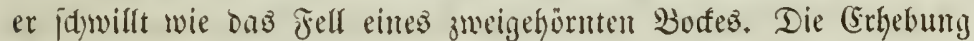
ift bem Srte geblieben, und der hod) emporragente Sailigel hat firdy im Rauje ber Zeit zu einer natten Jelsmajie erlyärtet.

$\mathfrak{A m}$ merfwürbigiten ift aber bie Snjel Gantoril, welde wie= berholt Der Edyauplas joldger Ereignifle gewejen ijt. Şalbmono= förmig umjaliept Eantorin mit jelyr fteil gegen bas Intuere abjal= lenden $\mathfrak{B a ̈ n d e n ~ f a j t ~ z w e i ~ D r i t t l e i l e ~ e i n e r ~ f r e i s j o ̈ r m i g e n ~ B u d y t , ~ b e r e n ~}$

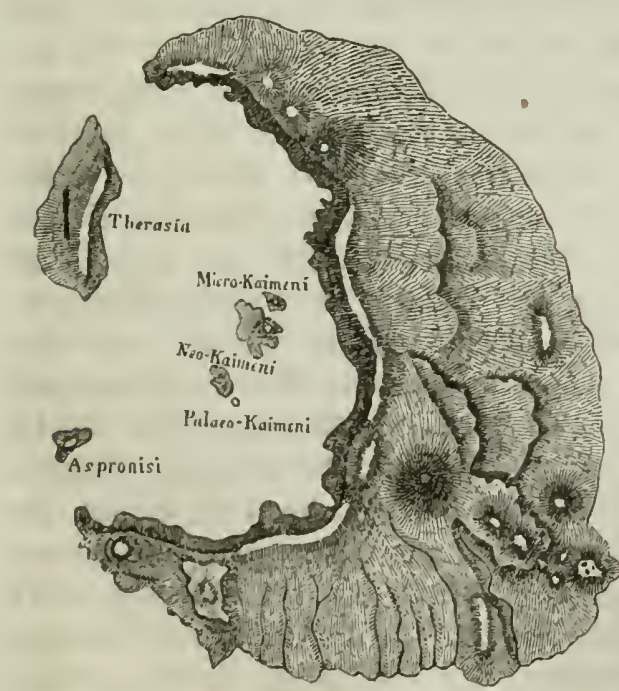

Die Injel Gantorin. nibriger Thyil ourd) bie langgeftreften fleineron Injelu Therafia u. Ilpro= nifi gejidslolien wird. Das Sanje gleicft Dent ring= fürmigen Llingebuntgen cincos alten unto mur an Drei Etellelt vom M)iere unterbrodenten Rrater

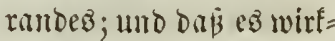
lich bafür angejetgen wer= Den muß̄, bajütr bürgen bie in feintem Imtern oft erfolgten Erifieinun= gen vulfanifater $)$ brüche und Das Daunit berbundene Emporftei= gen neuer Injeln. 


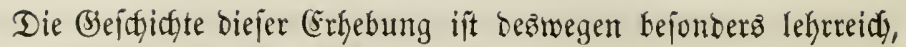

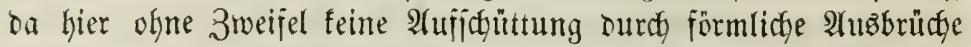

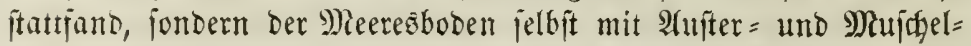
bänfen alfmälig in abwedyjelnten Ferioden ber Alufregung unb

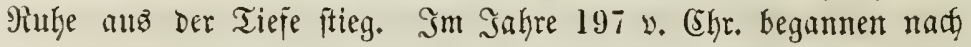

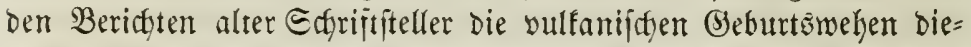

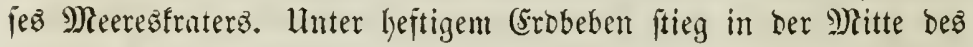

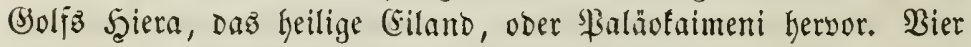
Tage lang entitrömten Flammen Dem Mieere und fochten und fie =

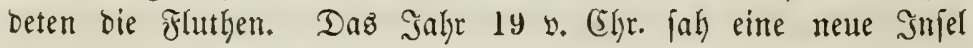
Thia ericheinen, mur 250 ๔chritte von ber eriften entfernt, mit ber

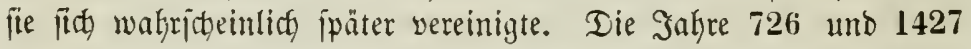

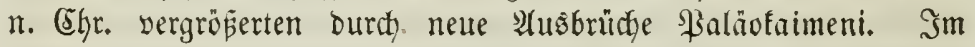
Jahre 1573 entitand mitten im Beffen Mifrofaimeni unter gewal=

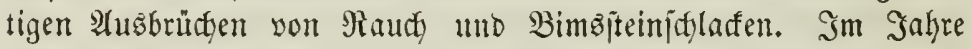
1650 ermente jith Der Berjuct der Snjelbildung, aber vergeblidf. 9iach) heftigem (Erobeben uno Donnerähnlidfen Entladungen erhob

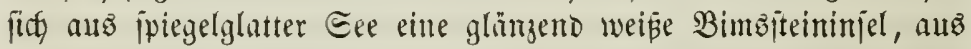
weldyer balo ein bidgter Rauth emporitieg, welchem monatelange furchtbare (Erichütterungen Desે Meeres und ber umliegenden İjeln

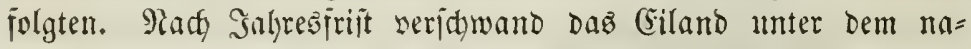
genden 3afn oer anjin̈rmenben şluthen. Mit erneuter $\mathfrak{R}$ raft, furcht= barer benn je, bridten die Miädste der Tiefe ein halbez Jahrhun= Dert päter hervor. Sie idjujen eine neue Injel Reofaiment int ben Sahren 1707-1711 unter einer merfwürbigen Folge son Erichei= mungen, an einer Etelle, bie vorher 400 F̌r

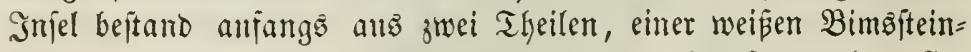

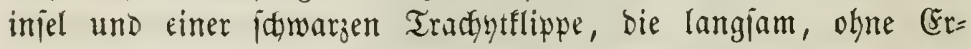
jđđütterung, Betöje voer Flammen, aนż bem Meere aufítiegen und

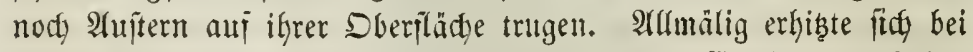
Bereinigung beiber Snjeln unter fortbauernber (Erhebung berfelben Daz $\mathfrak{B a f i j e r , ~ u n o ~ e n d l i c t ~ e n t r i t a n o ~ a u f ~ b e m ~ S ̧ u ̈ g e l ~ e i n ~ S i r a t e r , ~ d e r ~}$

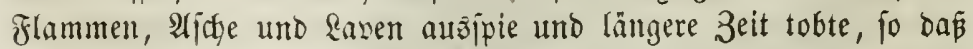
er jelbit mad feinem leb̧ten 2fus̈bruche am 14. September 1711

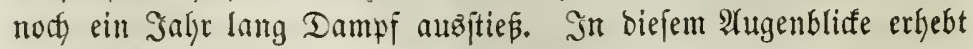

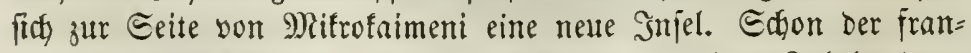

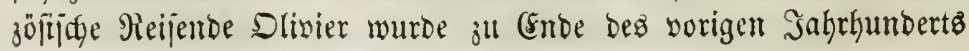


son Fiføern barmif minterfiam gemadyt, baß ber Eeeboben in ber

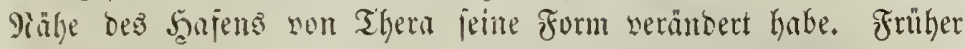

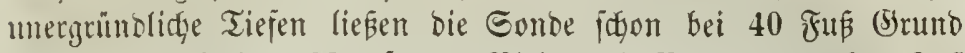
fïnen. Sm Gayre 1829 fanden Birlet unb Bory mur nody 9 Fuß Tiefe, uno der Romiral Ralande fand 1835 nur 4 Fup. CEs zeigte

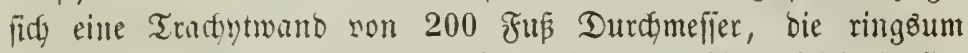
plöblich зu jüfer Tieje arfiel. So iteht jeben Âgenblif bie Er= itheinung cinter netten Smjel liber ber Meereșinădhe ju erwarten.

Bäfrend bie Crrbebung sou Eantorin offenbar ben uriprüng=

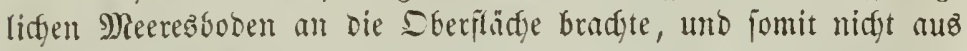
Pufichïtung um einen Srater herworgehen fonnte, fo find bagegon wieber ambere Erjđeimungen von sulfanijaen Snjeln in Meere

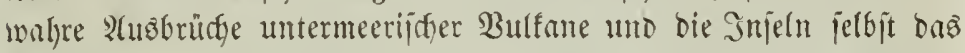

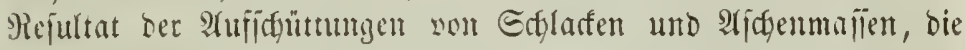
auch gewöhnlich balo wieber som Meere zerfïöt werben.

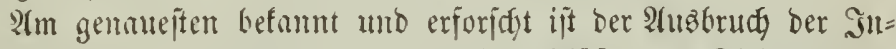
jel Ferbinantea oder Sulia an .Der Eilbweptuifte von Eicilien, zwi= fiten Eciaca unb oer Snjel Fantellaria, welder im Suli $1831 \mathrm{er}=$ folgte. Seeftige Cropitöße lyatten fün Tä Tane lang Eciacan und bie ganze

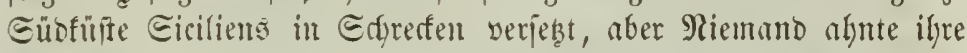
Bebeutung. Das Sieer wallte plöklidy auf unb braupte mit bon=

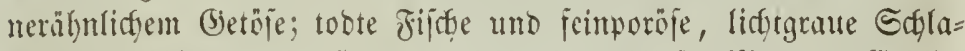
denjtitfe führten bie 2 sogen weithin in zabllojer 9)ienge. (5ndich entfrömten bem 9leere adyt Meilen won Eciacea leidfte, weipe Raudywolfen, bie allmälig bicfter und bicter murben und endich im Inmern eine mädtigye 2fictengarbe jeigten, bie bei Tage jogwarz, bei Sarfft leudftento war. Immer ftïtfer rollten bie Donner, immer

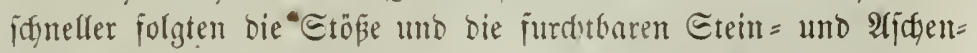

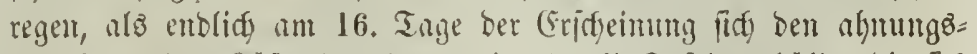

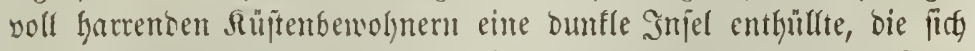

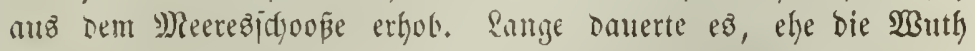
Der inteffelten (Elemente Den 3utritt ju biejem wumberbaren $8 \mathrm{sm}=$ fortömmling gefitutete. 3wei Monate nads jeiner (Seburt, am 25.

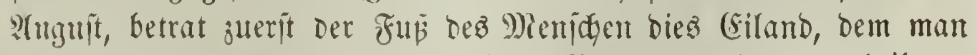

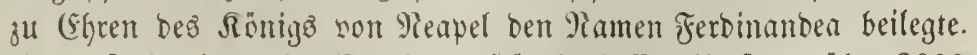
Man fand einen fegefförmigen Sgügel, dej̈en Umfang über 2000 Fuß ketrug, und Der ani Der nörblidyen Eeite 200, auf ber füb= 
306

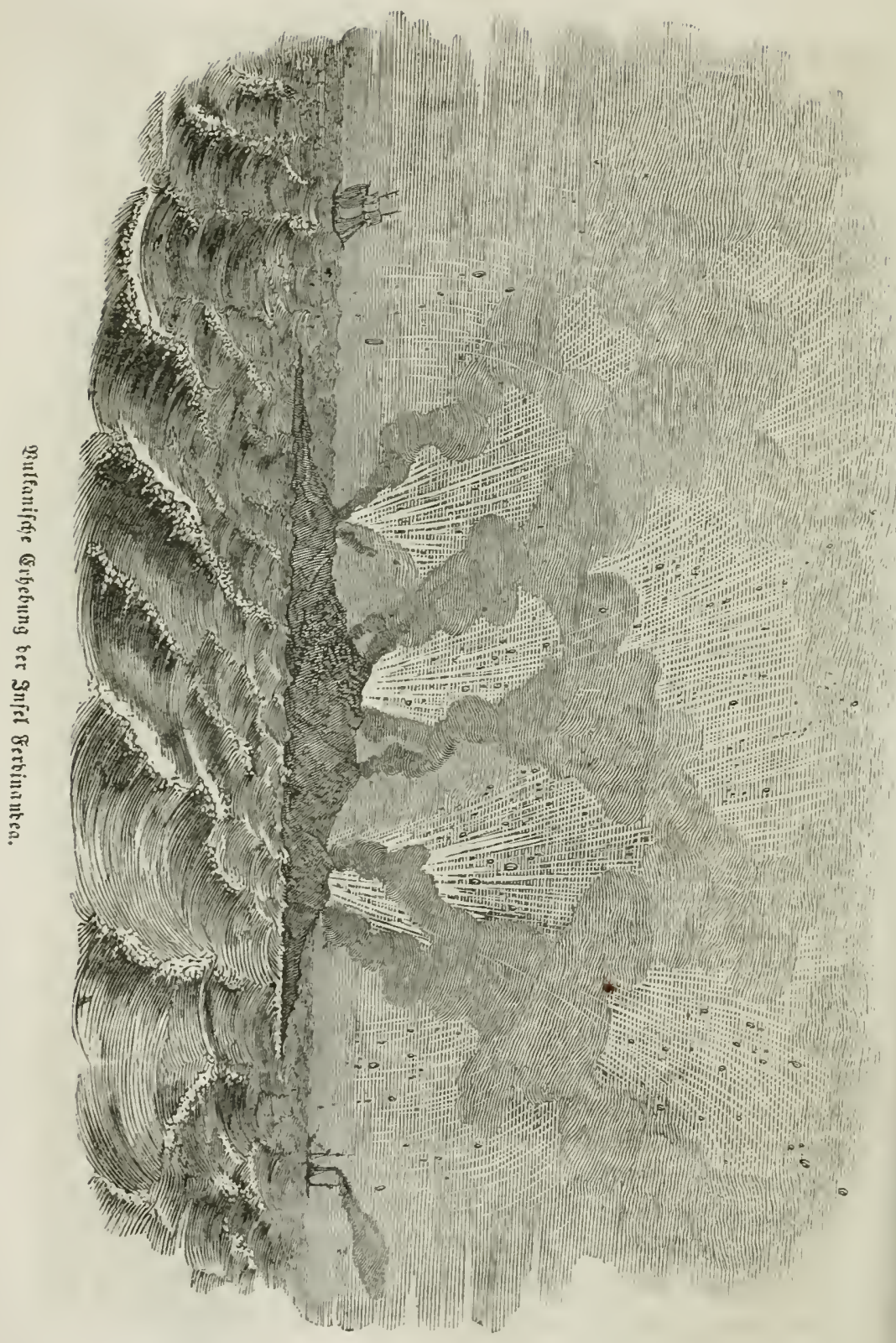




\section{7}

liajen 30-40 Juß fod) war. Sm Snnern jeigte fird cint Srater

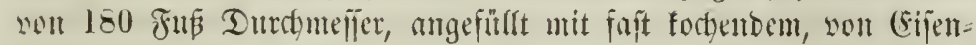

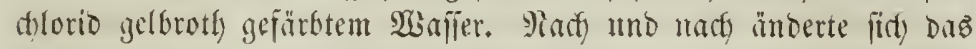

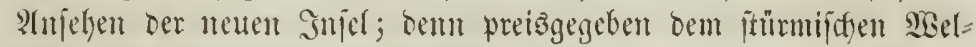

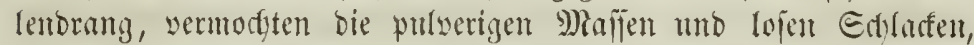

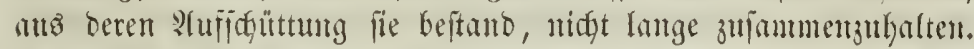

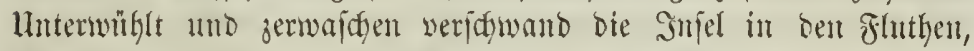
ehe ber Etreit über ifrem Beffis unter ben Boblfern entidjiesen war.

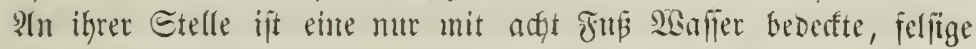
Intrieje jurügfgeblieben, Derent jactige Epizen Den Rorallen jum

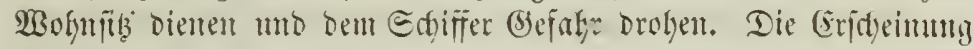
sicjer Injel hat eigenthümtidge uno nidft umwidtige Bejorgutifie für

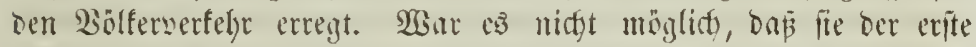
fist)tbar gewordente Pumft einer mädytigen, emporfteigenden Gebirgafette

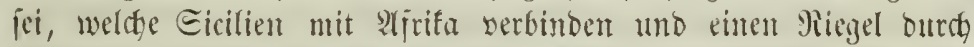
Die uralte Єtraß̧e Der $\mathfrak{B o u l f e r , ~ D a s ~ M i t t e l m e e r , ~ i d j i e b e n ~ f o u n t e ? ~}$ She lunterganty bat bie Futrdft jerftrent, aber nidyt grumbloz gemact)t.

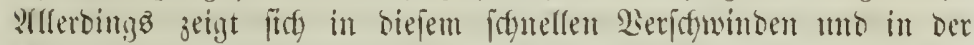

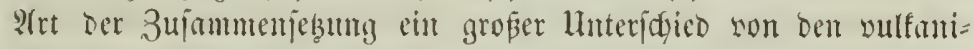
idfen Eentralfernen ber Smijelgruppe son Eantorin, bie eben io jeít nem Epiel ber woogen wiberitegen, alz alle undern gelzanten, weil

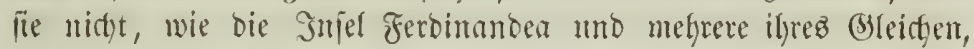

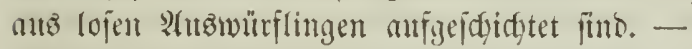

\section{3) Die bulfane und ifre (Entfehung.}

Sn breifudjer siseife zeigten fing uns die emporbrïngenden (be= walten bes Erointern witfan. Wir falyen fie eimmal in ben Eros= beben ben $\mathfrak{B}$ oden erfoüttern, basm ifh emporlyeben, plöblidy uno gerwaltfam, wie beim Jorulto und ter Rüfte son GGili, oder lang= fam und umunterbrodyen, wie bei Edyweden; endid, jahen wir Tie bie gelgobenten Edjidfent burdybredfen, wie bei ben Erfhebungä

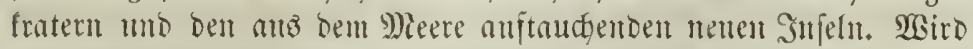

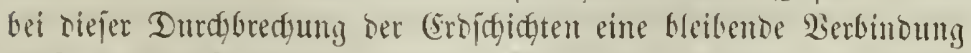

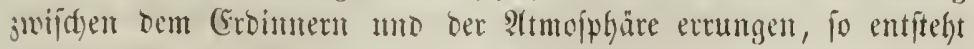

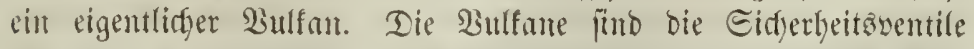

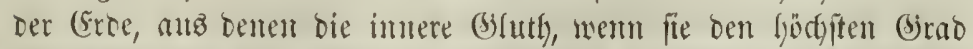
ifrer Epannutg erreidft hat, aubbredfen uno auztoben famt. Eino 


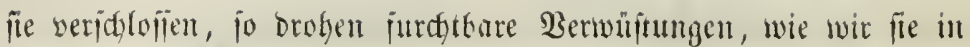
Ten Erobeben fennen Ternten, ben Rätoern. Heber bie ganje SGer=

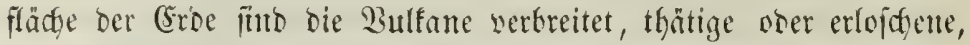
wenn wir einen folden Unterjdgieo maden wolfen, ber in ter $9 i a=$

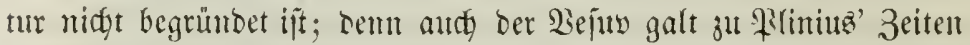

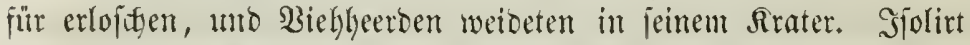

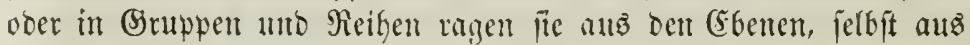
Dem Mleere Kervor; an liebiten aber folgen fie nuf bem Feftlanbe bem burch andre gröjere Bergreilyen vorigeseidfueten 3uge. In eini= gen Theilen ber Corbillerest und in ber Alusergne bilben fie fogar

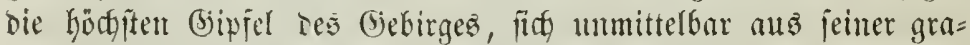

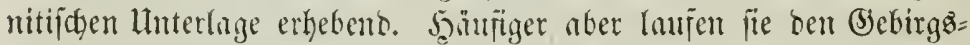

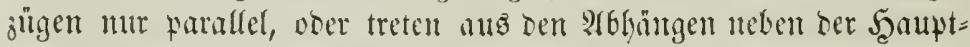
Fette herwor und folgen allen ifren Biegungen. Die mefrere Faun=

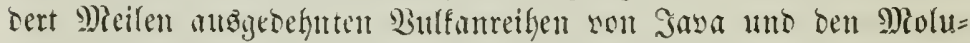

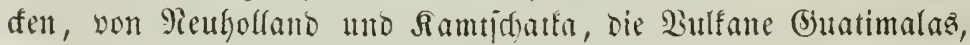

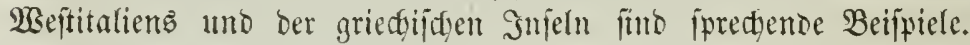

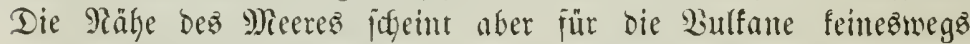
eine nothmentige Beoingung ifres Beptelyenz zu fein, wie mant

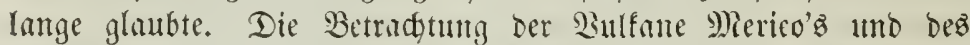

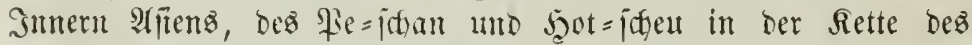

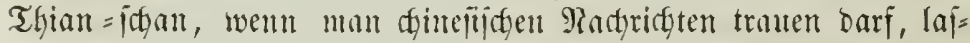
jen fie viefmefr als einen lhmitano ericheinen, ber einen andern

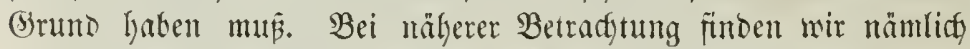

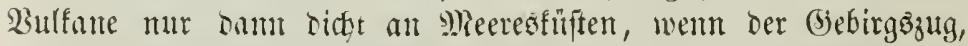

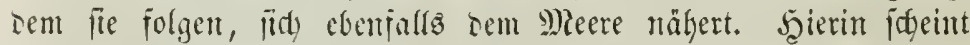

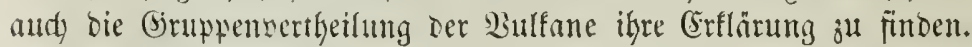

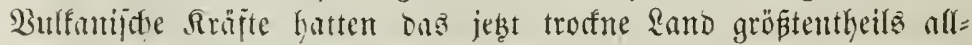
mälig gehoben; Dorum idweigt hier ifre Thätigfeit. Sie hatten aber and bie fejte (Erorinte zerrififen uno aus Epalten feuerflüfïge

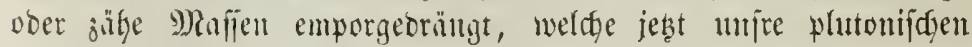
Bebirge bilton. In ber Midytung biejer Epalten fano baher bie

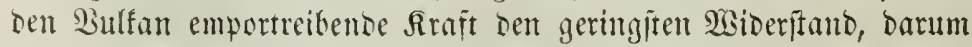

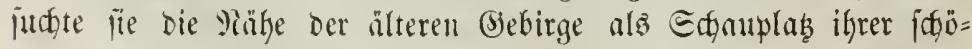

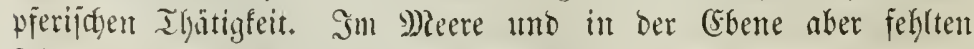

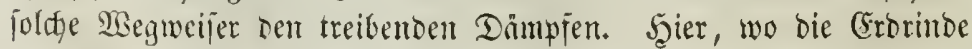
noch nidgt non frilferen Errhebungen gejpalten war, muste fie erfit 
Durdy Dämpje zerrifien werben, unb baher jtehen in ben ebenen voer hügeligen Begenden die Bulfane vereinjelt und vlyne Bezielyung zu ben mäbjten Bergfetten. Daß̄ aber and hier bie Buffane in

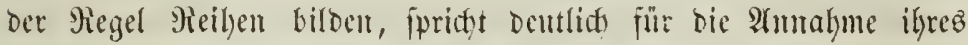
(smporiteigens aus linercen Epalten.

Wenn ber Drang ber unterirbijcten 9) Mädte mit furdtbarer Gewalt Tleile bes (Erobodens domfömig emportreibt, woer bie ge=

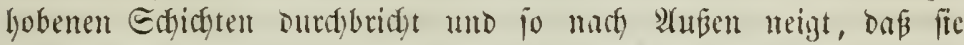

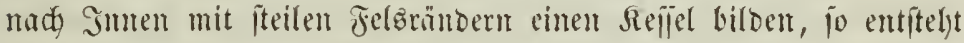
ein Erfhebungghtrater. CEine lange gefejlelte Rraft war thätig, aber fie hat fid burth bie gewaltige amptrengang erichoppt, bie gelyoberte

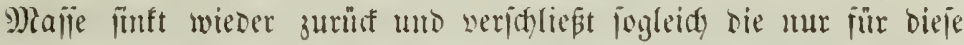

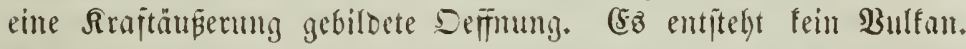

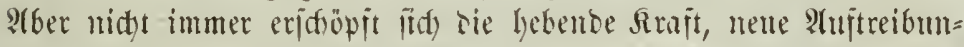

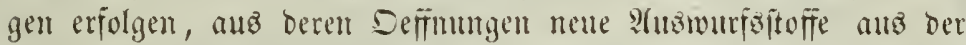

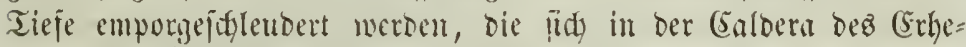

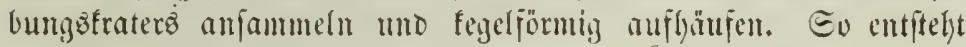

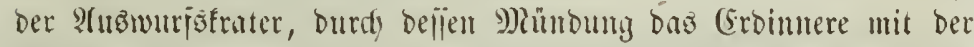
Atmojphäre communicirt. Biżveifen bleiben bic Zeugen des eriten

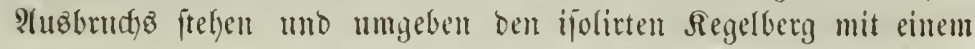
hohen Feljemmantel. Bis̆meilen iit von Diejem Rranze feine Epur mehr fidthar, uno ber Bulfun fteigt als Regel voer alz langge=

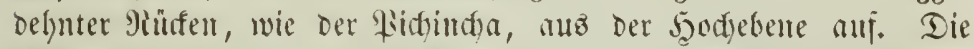

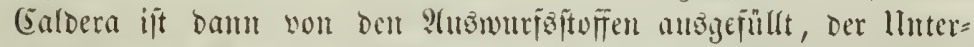

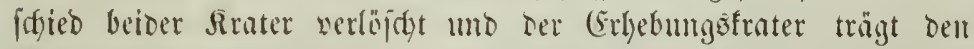

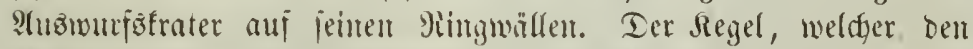

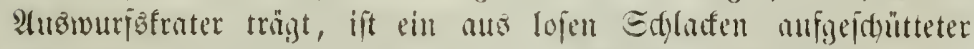

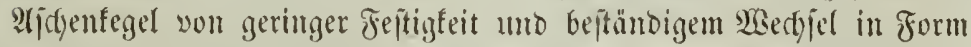

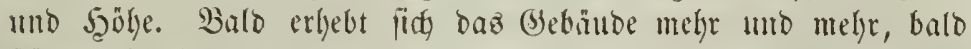
ftürzen betridytlidge Etüfe jujummen, bald wiro bie ganze Majle

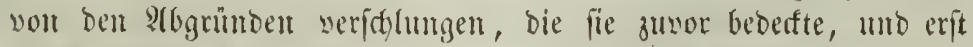

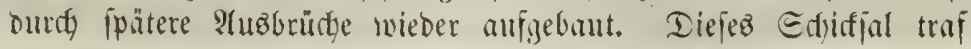

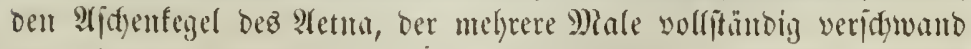

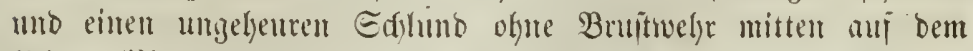

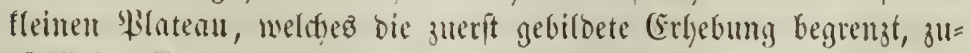

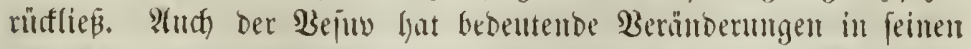

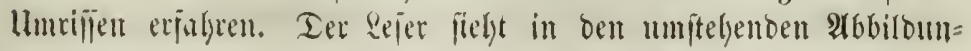


gen jeine Befitalt jur 3eit bes Etrabo und zur 3eit des 疋linims

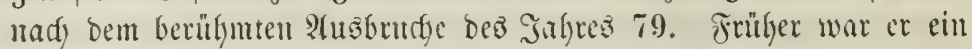

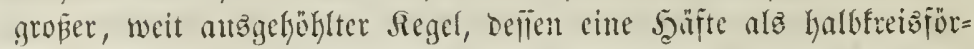

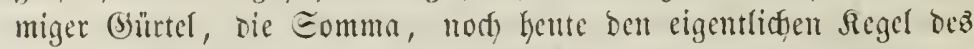

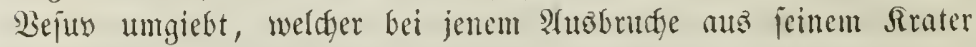
emporfitieg, währento die andre jölfte vielletcht zur jelfen 3ett in bie Tieje verfanf. Ecitom hat fidy die Beftalt bes Befun meniy

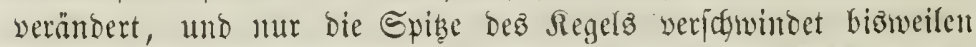

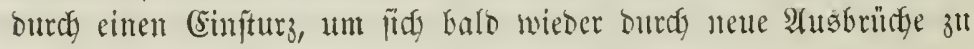
ergeber. -

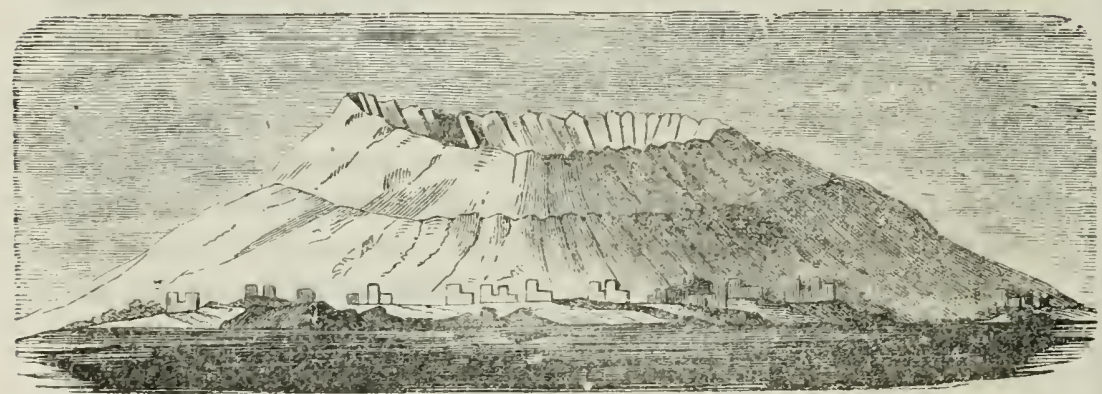

Der 23efuy zur 3eit Єtrabo's.

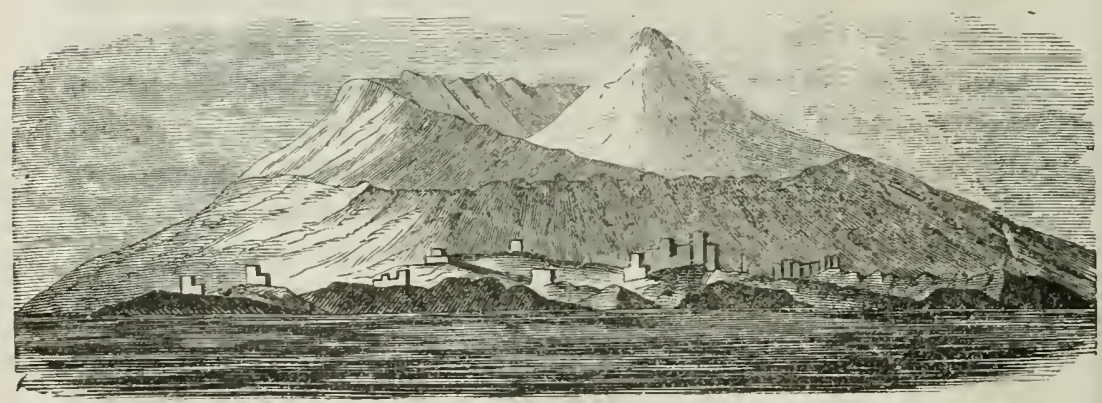

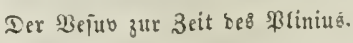

Der Brater, weldyer ftets ben Sipjel hes Bulfanz cimummt, bietet in feinem Smment oft wiser Erwarten nut wenig Snterejie

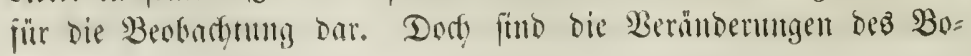




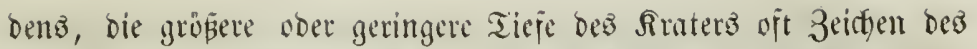
naken ober fernen Beworjtelyens cinez 2 (1ร)

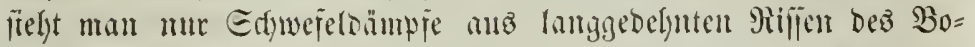

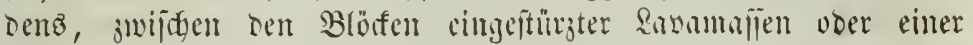

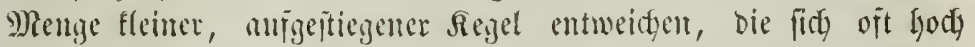

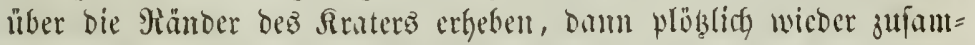

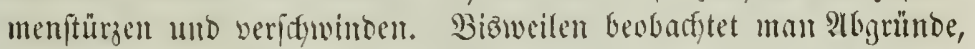
bie mit beftündig entweidenden Dinjten erfüllt fint mo in ber Tieje die glühende Eava jelyen lajlen, ober in benen Dumpfe Stille

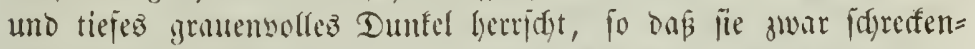
erregent find, aber meder zur 将, ntafie (pred)en, nod) ons geringite

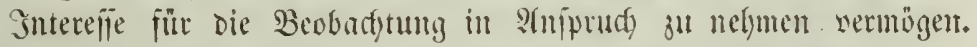

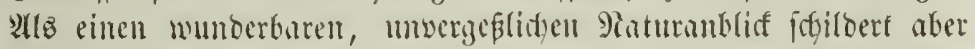
Alexander v. Sjumbolot den Blic, telt er in bie ungelyeuren, 15,000

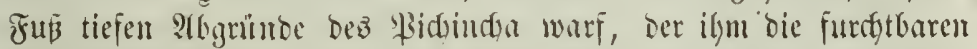

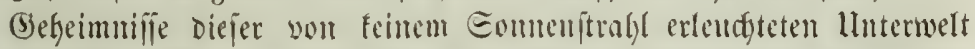
mit ifren Berggipfeln uno Feneritrömen in magifher Flammen= beleuđtung entlyülte. In langen šwijđenrüumen jwijden ben gro=

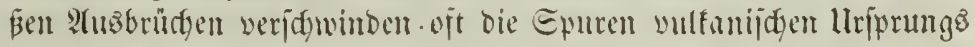

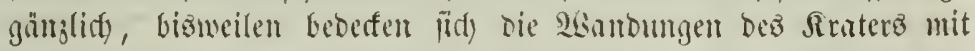

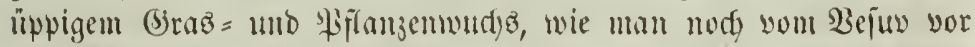

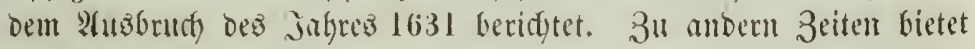
Der Rrater mar offene Epalten Dar, mo Edylaffenlyügel, benten man

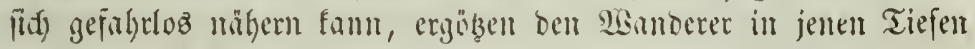

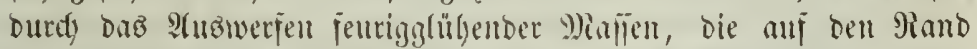

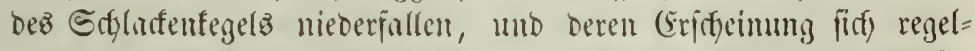

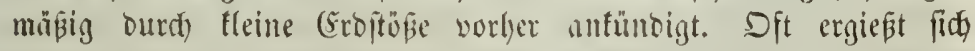
Rava aus offenen Epalten mo fleinen Ed)lünden in ben Sratev

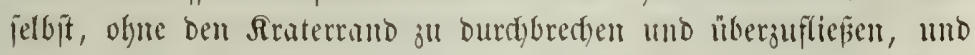

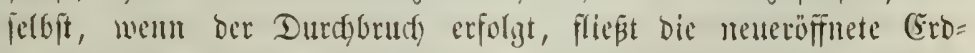
quelle jo rulgig und anj jo bejtimmten weigen, daßj jelbit in biejer

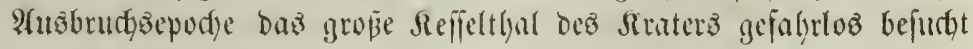
merben taun.

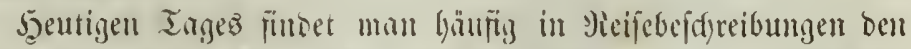

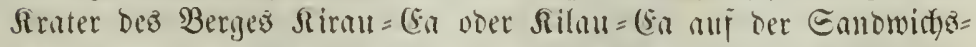

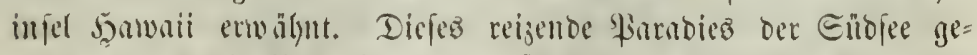
willgrt Dunt) die Bemeije bont ber funffytbaren Thätigfeit ber unter= 


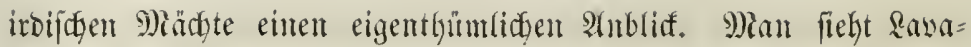

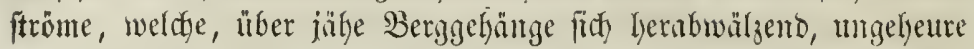
Etalaftifen vou wutberbarer Edjönlyeit bilbeten, riefige Sänten unto

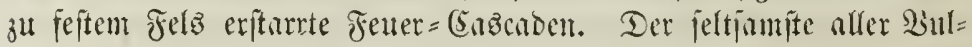

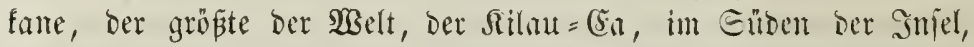

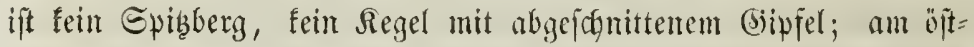

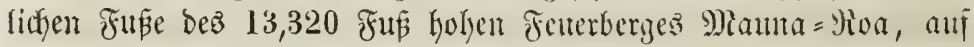

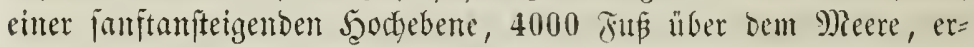

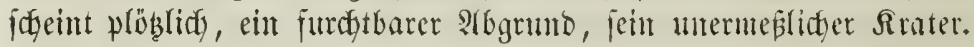

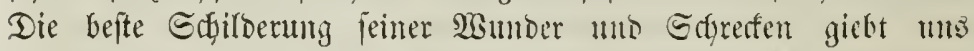
Steen Bifle in jeinem Beridjte über bie Bieife Der Rornette Uala= thea um bie 23 elt in Dent Gafren 1845 biz 1847. (Fr beldreilt

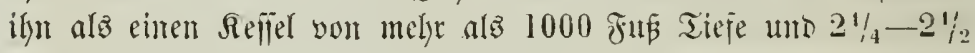
Dentiffent Meilen im Lmitange.

"Die Natur," jo erzälylt or, ,ift liet gropartig, aber buifter

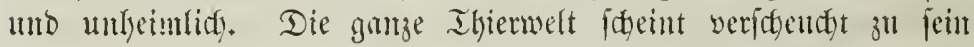

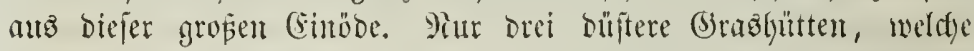

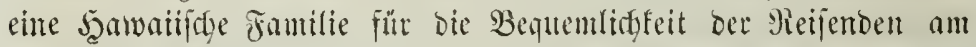
Nianbe bes Rraters erridgtet lyat, verratjent bie Gegemuart lebenter

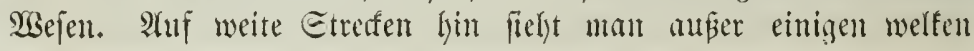

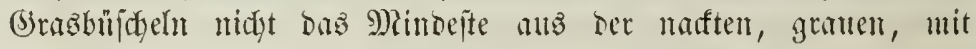
Bimbiteinen beftreuten (Erbe emporfeimen. Ningăm auf ber Ebene fteigen Edymejel = unto 2 Baflerbämpje auz ber Tiefe cmpor; unto mur bie fentegte llmgebung biejer Epalten ift mit einer nippigen Piflanzentwelt bewadjen; mutfernde Farren bringen fogar auf ben

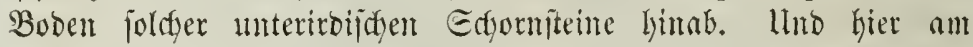
Rambe bez Rraterz auf dem Silante der fernen Sübjee begegnet

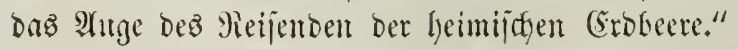

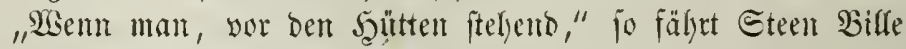
in feiner Edfilderming fort, "in Den Rrater idfaut, fieht man vor

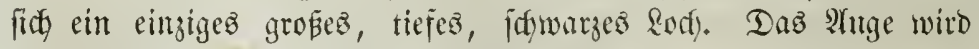

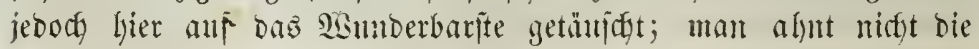

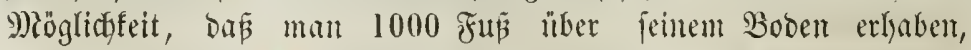
nod) weniger, ba

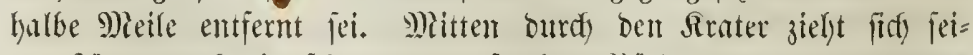

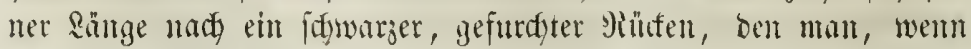

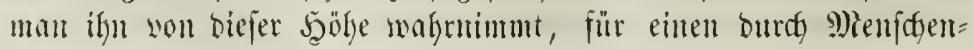




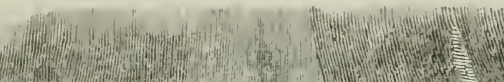

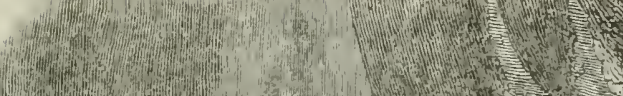
(6)

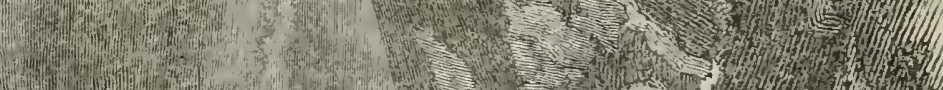
217. What 3.t.

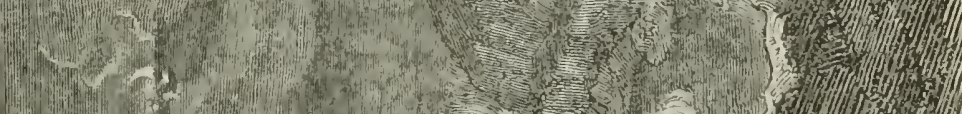

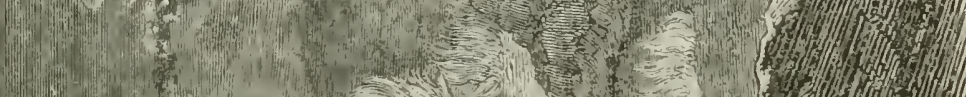
(2)

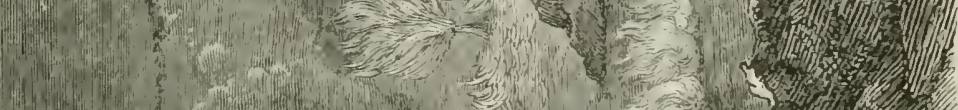

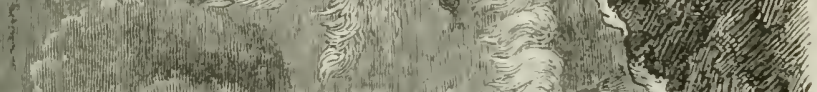

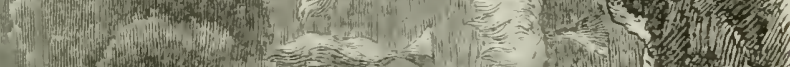

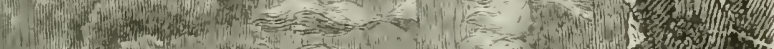
3.4. 1.14 * 12 (2) 4. 1 .

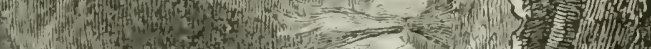




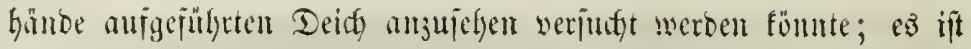

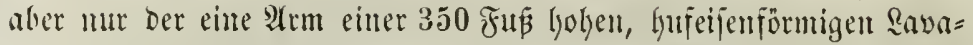

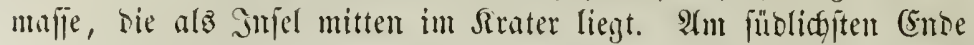

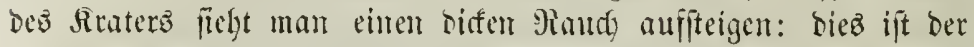

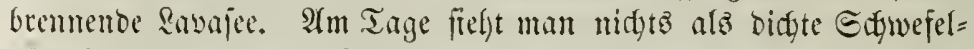

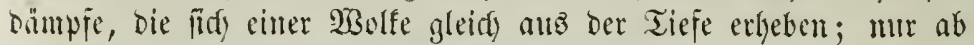

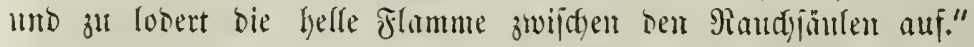

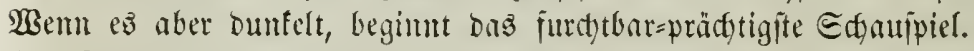

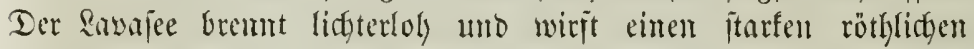
Edjein üler bie iffr ringb ungebenden, fintitem Feljen. Der Piei=

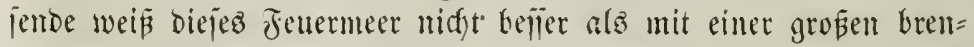

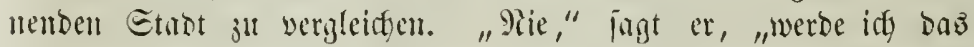

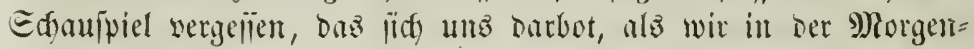

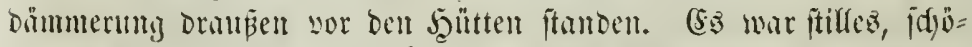

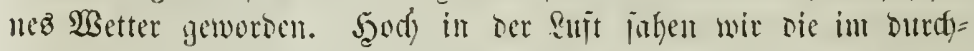

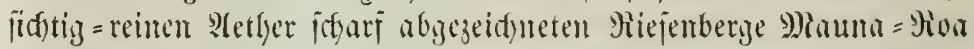

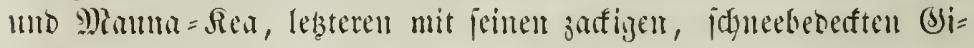
pieln, bie, bou ber anjzelfenton Eome belenditet, io meit hervor= fprangen, ats müpten wir fie mit don şänoen greifen fömten.

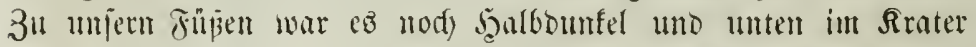

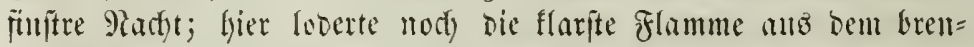

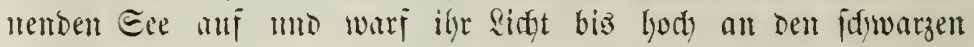

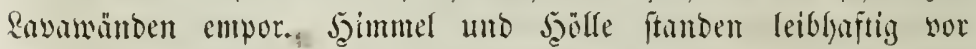
unz. Etumm war unje Bemumberung yor biejem gropartigen Maturgemälde, und jtunum entfällt mir jek̨t bie frajtloje Feder." Die Reijenden jitiegen jum Boden bez Ŝraterz himat. Eie mander=

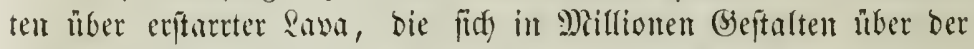
Tieje aujzeidjidytet hat, bals cine (steme bildent, bald fturmbenveg=

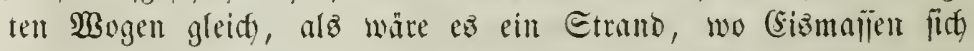

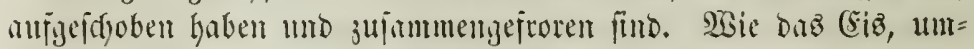

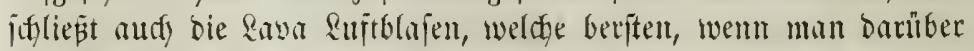
hingeht. Dem (siife gleich wiro fie gaudg allen Eeiten won unt=

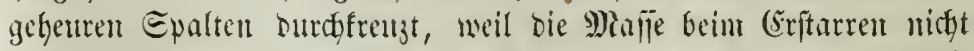
elafitidy gemug war, un ber an weridjiedenen Etellen unglei=

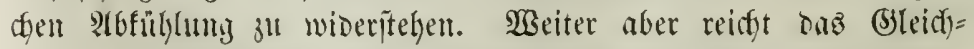

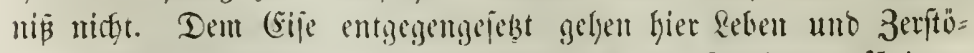

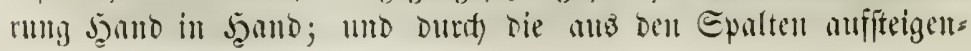




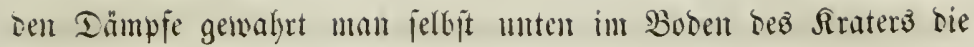

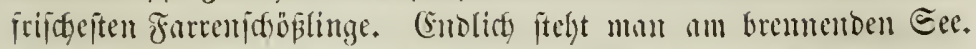

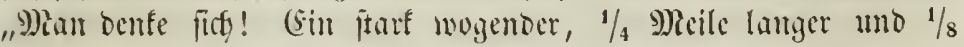
Meile breiter Eee, unb biejer Eee nidyt Majjer, fonbern Feuer! -

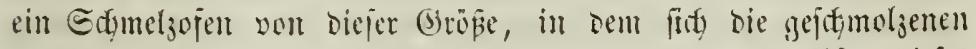
Metalle in flammenten Sagen mälzen! Hno am llfer biefes

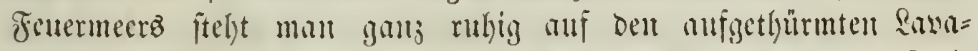
blöfen unb blift bie eben jo gropartige, wie grantenlyoite Eridgei=

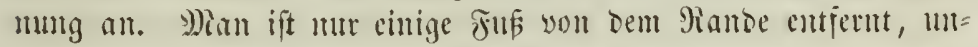

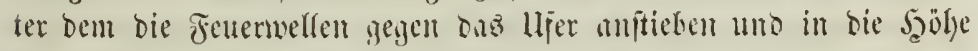
gemorjen werben, wie Ias Dieer, bas iid) gegen bic Eteine am Seftabe bricft; ein 9in, cinte cinjige 3uffuny in ber glühenten

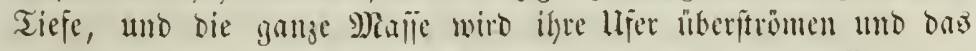

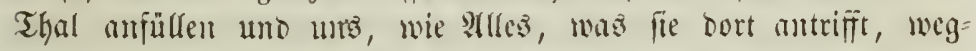

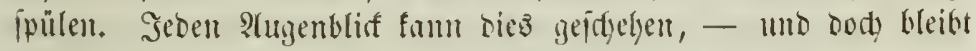

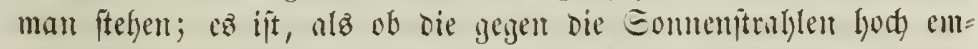
pormirthelubent Flanmen, in betten bie Prtmojphäre bent fturrenten

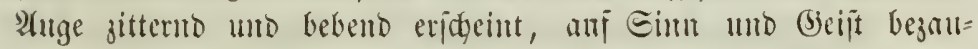
berno eimvirften. M) Mn ift an ben jofmarzen Etein, anf dem man fteht, wie jejtgebannt. S)lan fieht mit Entiegen - bejontors an den Ujent, wo der Rampi am gewaltiamiten ift - bie ungelgenren,

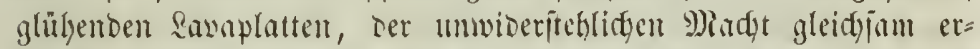

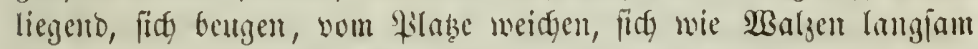
liber cinanber fojeben und in Die jeurige Tieje binnbgleiten, bie fie veridylingt, um fid) int näd)iten Etugenbliffe Ben. (Ë ijt mitten am Tage, und bod) ifi bie gejomolgene Rava

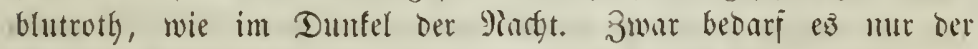

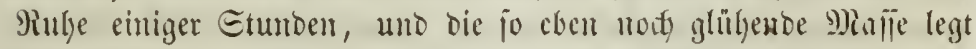

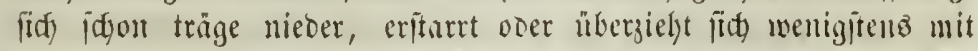
enter matten, granjdywargen Sinte. Allein bieje Miuhe ijt Tän= ígung. Daz Fenter erjtirbt lyier, um bort neแ aujulobern; bie Woge birfit nodymals, jprilht foner unto mirit savamajien empor,

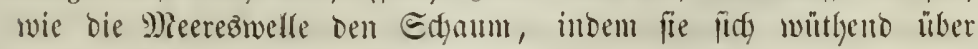

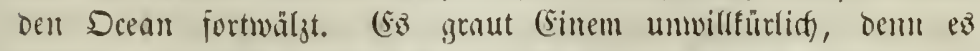
idyeint, alz müfie man unwermeiblidy wout ber Fenterbranbung ver=

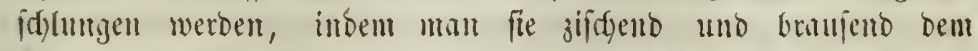

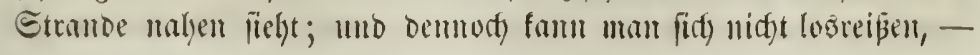




\section{6}

man fteft wie ber Bogel wor bem bezaubernden Blif Der Slapper= id)lange."

Die furchtbare (S)̈ttin Fiele, bie Seerricherin Der linterwelt, fa=

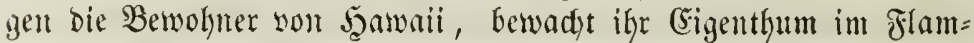
menmeer bes Rilan= (5a. Sbwohl fonft in-jeber Begiefung eifrige Ehriften, baten fie den Blauben an Bele biz alf ben bentigen Tag bod nicht abgelegt. Die Matur wirft lier ftänfer, als bie Relye ber s)iffitonäre. Siele ift anf Der Infel, jagen lie, fo lange Der Bulfan brennt; und dap (Ehriftug felbit nidht vermorbt hat, fie z" vertreiben, gilt ifnen alz ber idhlagendjte Beweiz ifyer Miact.t. Fer (Slantbe an Fele wirb nidyt fatwinden, elge nidyt ber brennende

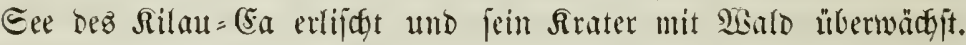
Bam aber bies gejdelyen wird, wermag fein Eterblidyer zu entidgeiben. Der furdtharjte Bulfan ber Welt bremnt unter biejer Injel, und wem der Rilau = Ea erlijht, werden antre Punfte der Edyauplab derjelben gewaltjumen Siaturjemen jeir. Daz haben

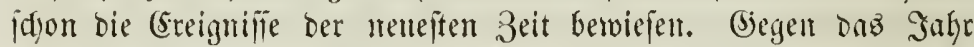

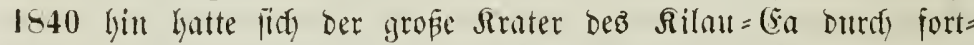

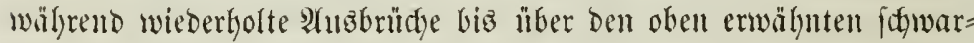
jen Damm altgefüllt. 3u Sube Des 9) 1840 verwandelte fich

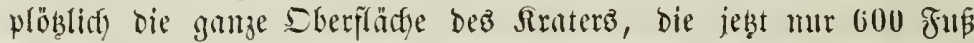
unter bem Sinto lag, in einen Fenerfee, defien rajende $\mathfrak{B g}$ gen, Dem fturmberwegten Meere gleid, jo entfeblid gegen bie Wand Des

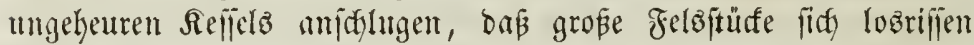

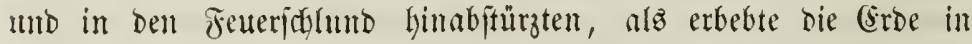

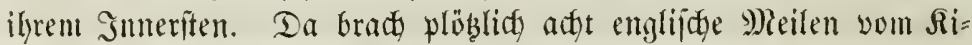
lau $=$ Ga mitten in einem $23 a l b e$ aus einem alter, bicht libermach= jenen Frater Der Ravaftroni hervor. Durdy eintll 1000 Fnz tief liegenden, unterirbifichen (5jang war die Rava lierlyer geflofien, tmb

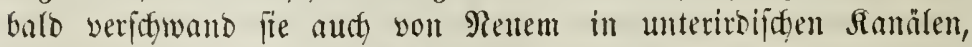

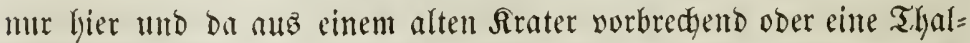

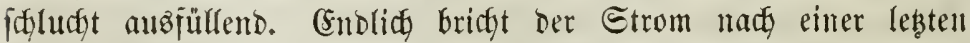
unterirbijfen Wandenutg herwor, gleid einem Fluffe, ber jeine

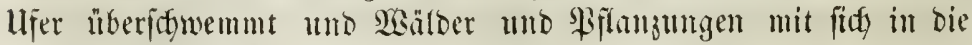

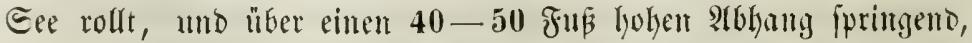

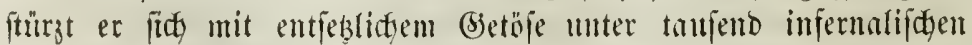
Tonen in bie Tieje ljinab. (Sin aแz gefdmolgenen M) Jineralien bes 
ftehenoer Flü, breit und tief wie Der 9lingarafall, son tumfeldut=

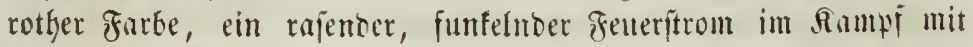

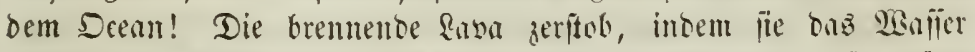
berührte, in Millionen non Ptomen und fiel, outh bie Ruit jurüt=

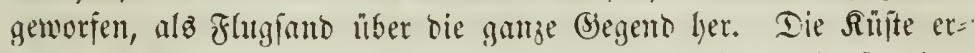

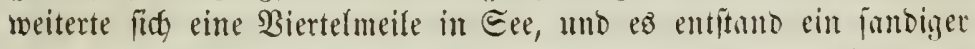

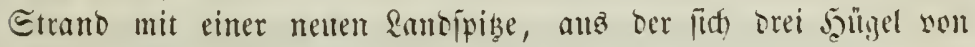

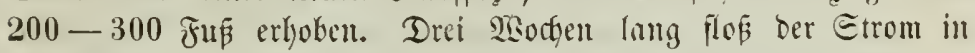
Daz Meer, an jeinem Eturge eine lalbe englijde Mreile, oberlyalb

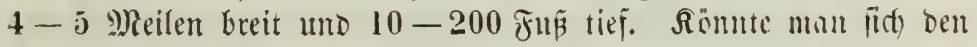

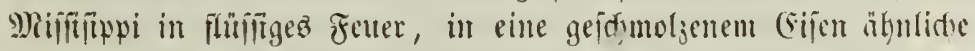

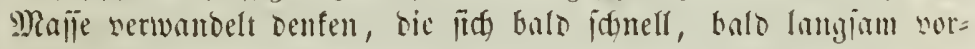
wärtz bewegte, balo zu eimem Eee ausoehnte, balo ourdy cinen

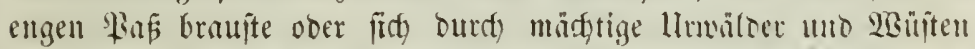

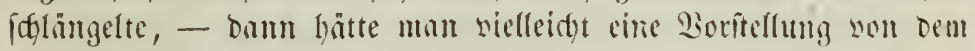

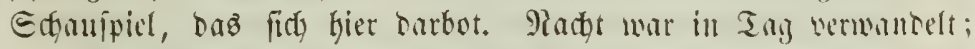
100 Meilen weit fah man tas Sidyt oor Snjel Şamaii, unt 40 Meilen weit las man um Mitternatft gernufte Edorift.

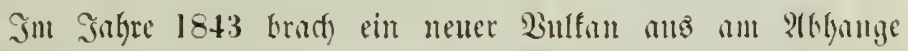

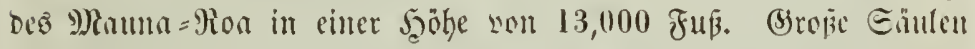
fliffigen Feuers wälgten find heroor unt rollten in eintem briten brentmenden Errom an den Eeiten des Bergez berab. Bald brad) auch anz tiejer liegenden Punften die Rava burct und crïlllte dic Thäler mit einem Fenerjet.

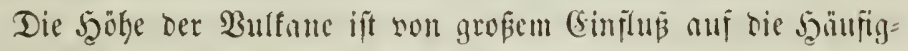

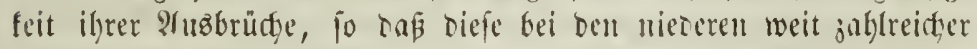

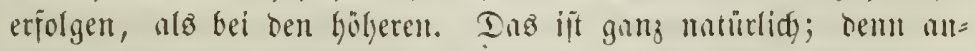
genommen, ber Şeerd sweier Bulfane, yon benen her eine viermal böher ift alв ber anoere, liege in gleidjer Tiefe, jo gehört eine grö:

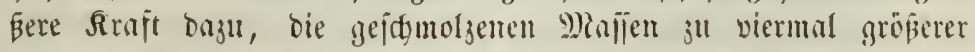
Şöhe su erbeben. Währento baher ber niebrige Etromboli, bellen

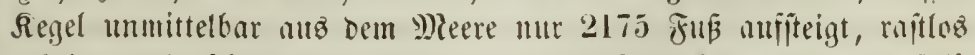

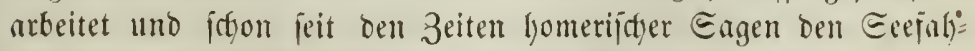

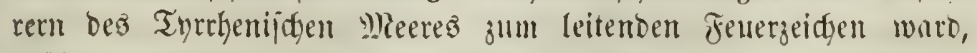
währeno ber 3637 Jus bohe Beju fojt fein Sathr ohne 2 (uabrïbe

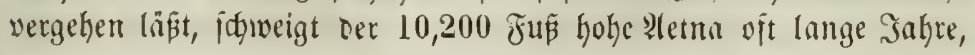


unt oer 17,890 Fü holge Bergriefe (5otopari fanm fith oft in Saht=

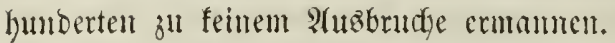

wasem aber bennody bismeilen, wie es idseint, gegen allez

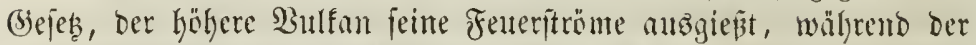

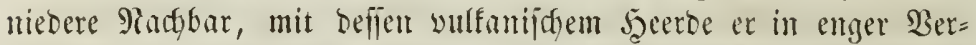
binoung fteft, unthätig ruht, fo milifen wir bebenfent, one in nic= origen Bulfanen jener Berbintoungafanal ojt eine 3eit lang Durds

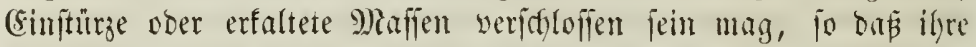

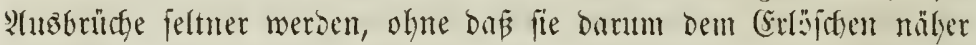
find. Y) ans bem Srater felbit, fondern meift aus Ecitenfpalten an Etcl=

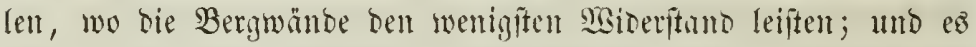

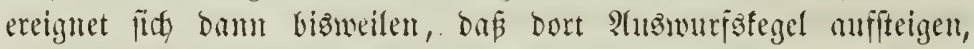

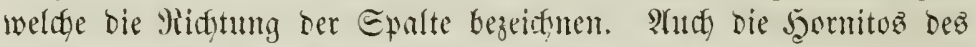

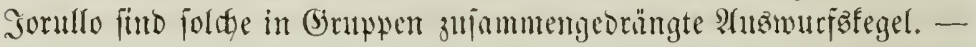

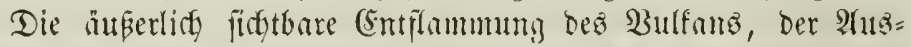
rnuch, gefört umitreitig zu Den großartigiten Edyaupielen ber $\Re a=$ tur, unto wieberfyolt fith Dody immer mit benfelben (Eriffeimungen, mur bald mit gräß̈erer, Gald geringerer bèeftigfeit. Im Allfgemei=

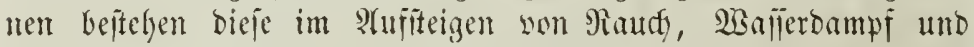

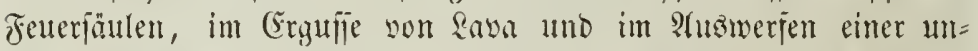
geheuren Menge won Ridge, mit fleinen uno grö̈ern Eteinen ge=

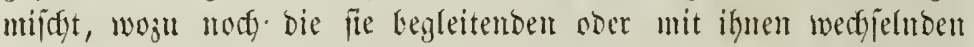

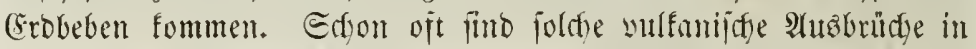

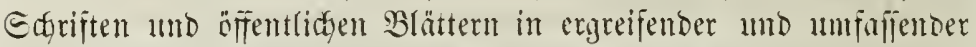

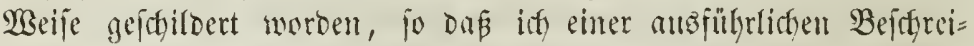
bung niberfoben bin.

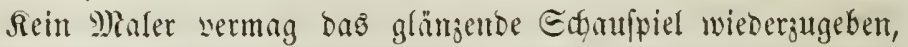
Daz die Matur im brementen Berge norïufrt. Der Rejer ermarte

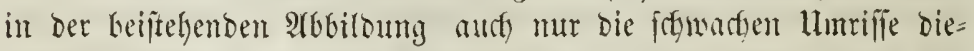
fer Eriffeimung. Eben jo wenig find 2 Borte im Etante, mur an= mäherno ben Cinbruf hersorzubringen, weldfen bic mumittelbare

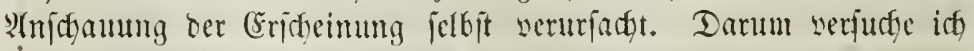
es mur, bie eimzeluten 3üge biejes großartigen Paturgemälde ber

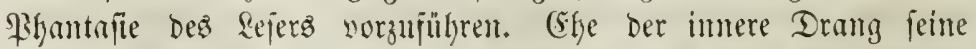
houdfite Epanmung erreid)t hat, ehe fich Die Sippen ber (Eroe affnen, vertünten mar fefwache Erriduhtterungen und häufiger bem Sirater 


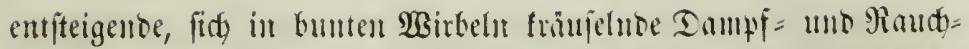

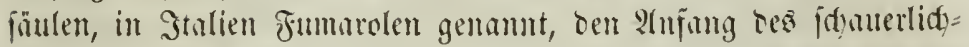

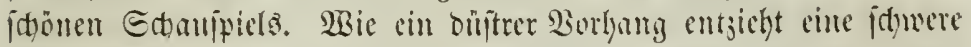

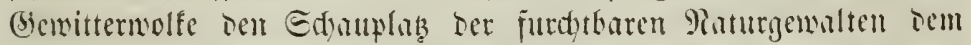

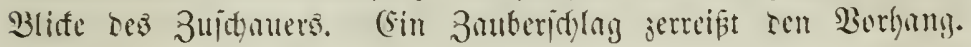

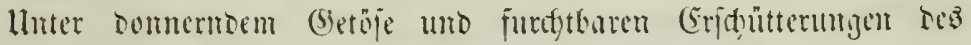

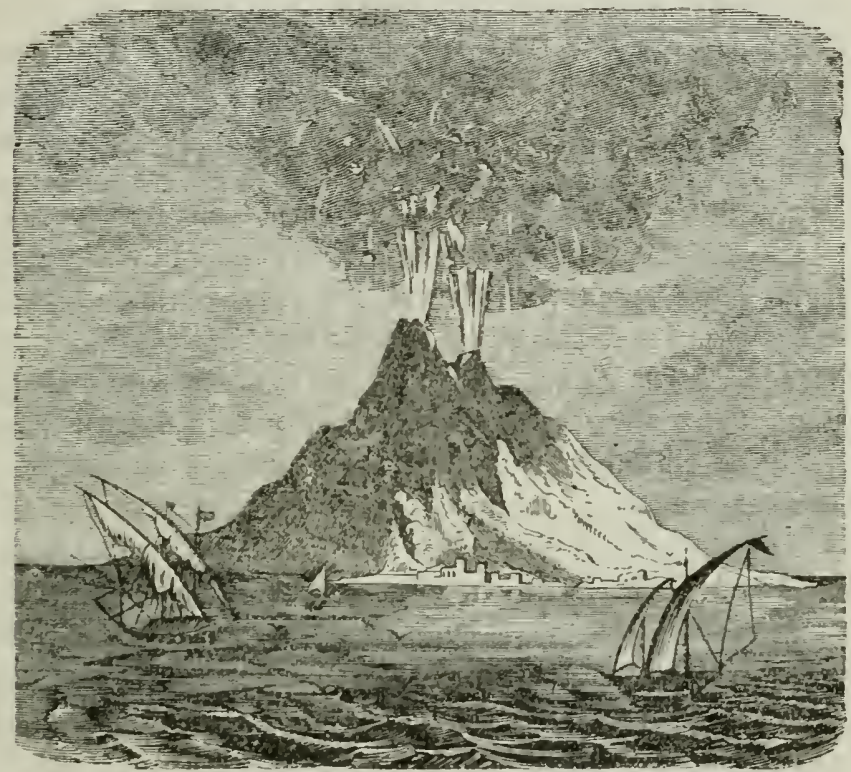

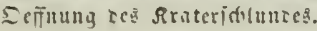

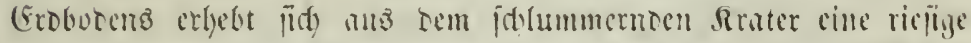
Dampfïule, ringz umipictt non wirbefnsen, weipen Dumptwäfstom,

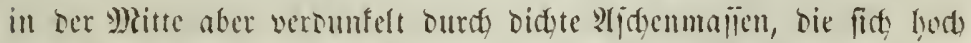

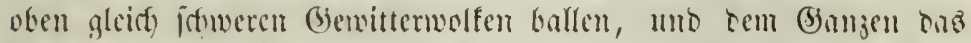

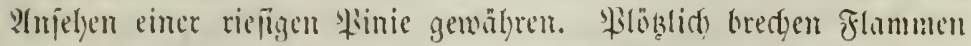

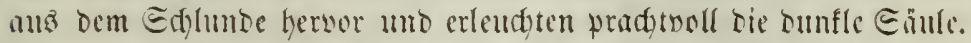
Whit Domergleidgem Rnall fteigen gliffende Etcinmalien rafetengleid in bie Rlifte, jerplaben jtrablenförmig und fallen in leidgten Bogen

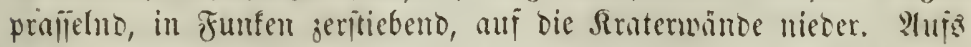
Neue eroröht ber eriduitterte Boden, Domer folgt auf Domer, prafielnd jteigen neue Fenterflumpen au; eg erfebt fid im Innern 


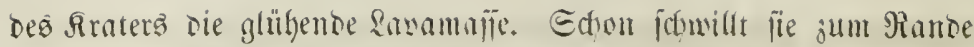

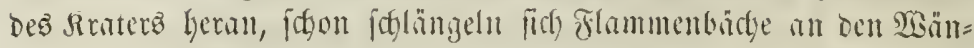

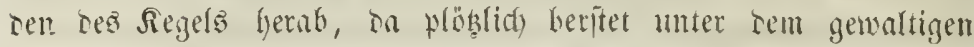

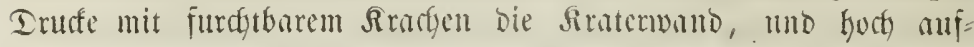

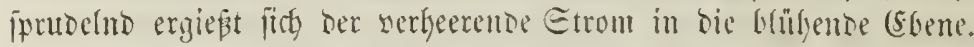

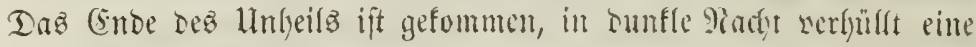

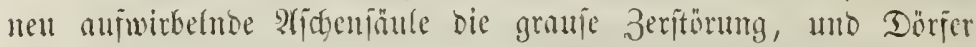

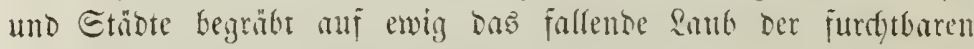
SHinie mer jeimer büftern Tramerdeafe.

\section{3) Die wulfanijuen 将odutte.}

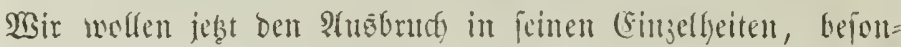

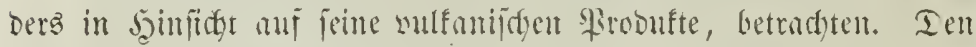

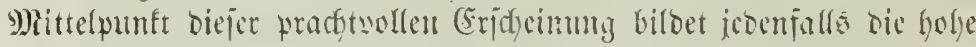

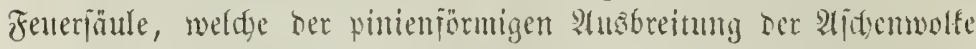

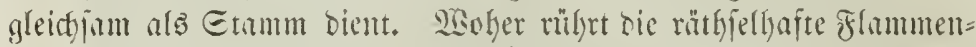
beleuctumig biejer felbit non Entumminden nictit benegten fener= garbe? Sit es cin bloper Eidytidtein, oder find es mirflich flam=

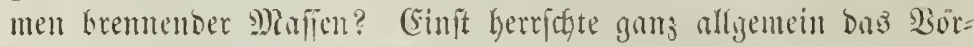

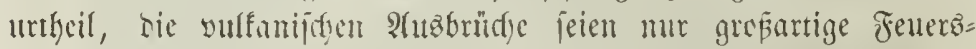

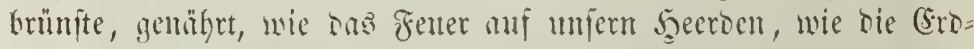
brämbe unjerer Eteinfohfenflïge, Durch unterirbijate Brennjtoffe. Balo war es (stopect), bald Echmefelfies, balo cin fentgtez Gemenge von

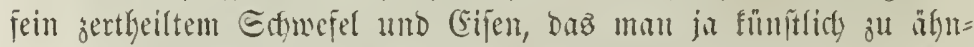
lichen Erjotinnngen bringen fonme, balo phosphorbaltige Mañen,

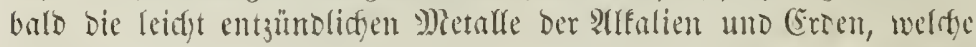
man, Durdy Eelbitentzundung ober Durdy ben eleftripchen Funfen

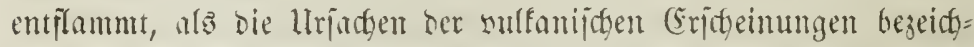

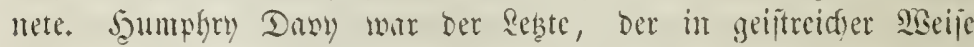

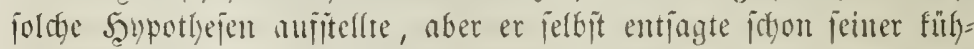

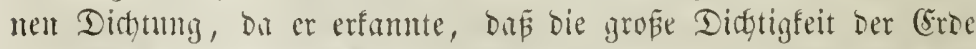
eine Malie fo leichter Rintrer, wie bic ber alfalijogen Metalle, im Snnern nitts julafie. Mlan juchte onfer cime antre Erflïrung, uno glaubte mu ben Bremftofi in bem sinfleritofigaje ju finton, wel=

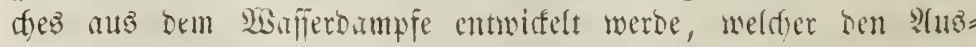
butbericheimungen vorangelyt orer fie begleitet, umb weldter, wenn er Durch bie fenerfiuifigen Majfen der :ava bimbutageht, angen= 


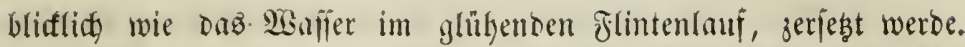

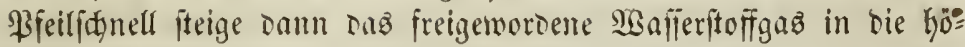
Geren Regionen empor, uno Da es Die zur Berbindung unit Dem

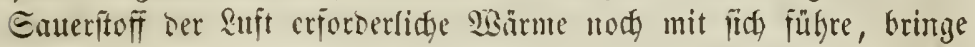

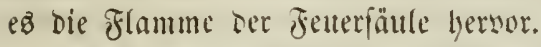

Eelbit Reopold won Buth fitimmt biejer Seypotheje bei, wonad

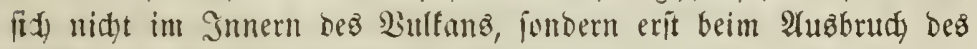

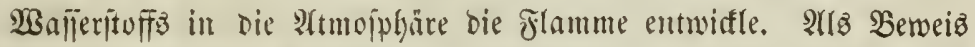
Dafür fülyst er bie jurftbaren Detonationen an, menn plöb̨lich bas felbit burch bie fluifige Rava entweidyente (5) fich bom Sauerfoff Der Atmojphäre auj allen Eeiten umgeben fieht, Den jtetz erneuts ten Donner, wenn die Semalt ber abjliependen \&ava auj Ägens

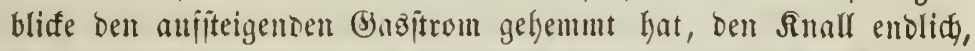
Der jebes Auriteigen greß̧er Flammen legleitet. Eelbit bis in bie Finftern Şöhlungen jutbt ber Eaueritoī feinen (Begner auf, feine mädgtige Siraft iprengt lie, und fïrchterlidy bört man bann ben Domner burdy das Innere bez Bergez wieberlyallen. Freilid foll

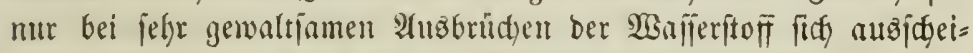
ben, wailgreno bie bei minberer Errjibung eriolgenden Erfalationen nur in Dampf nermanbeltes 2 afjer, tein zerjętez liejern. Unter= judyungen lyaben nod fein freies :Bafieritofigas gezeigt. Wenn fity

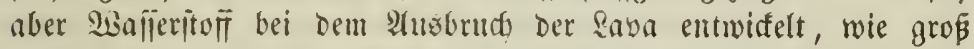

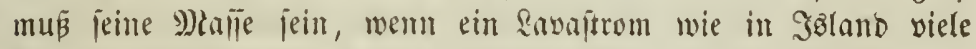

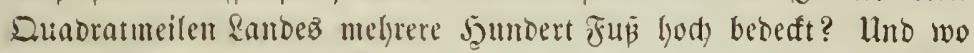
bleibt bann ber anore Theil ber atmophyärijden \&uit, ber Etidituff,

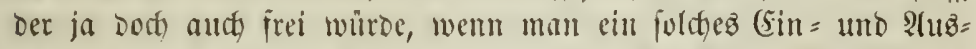
atlymen Des Croforpers annefymen wollte? Sewi fnum cine jo all= gemein und tiefmirfente, in io weite Fernen fid) fortpflangende Thätigfeit, wie bie ber Bulfane, nid)t in ber demiften Bermantst=

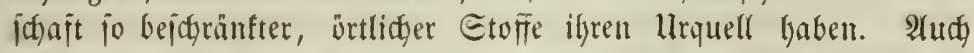
bürjen wir in jentr flummenoen Feneriäule nidyt bloz glühenbe Eteine uno Eano erbliffen, in jo Didter Menge gebrängt, bnj fre wie flammen leuthten. Denn unbegreiflich wäre $e^{8}$, wie jene glï=

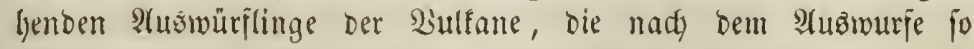
fitnell erfalten, und wenn fie auch mur einten fleinen $\mathfrak{B o g e n}$ in

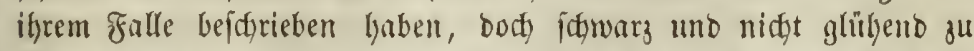
Boden finfell, bis in eine Soübe wou melyrere Tnufeno Fus einte Ilte, Weltalt, 3. *นศ. 


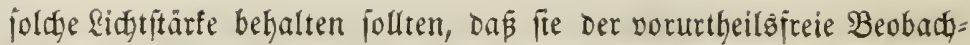
\$er mit einer Flamme vergleiḑen fönnte. Die einsige Errflärung,

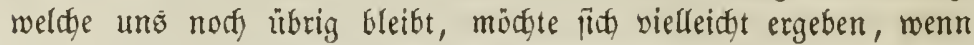
wir in jener ungebeugt Dem ftärfiten @utumwino trobenben Feuter=

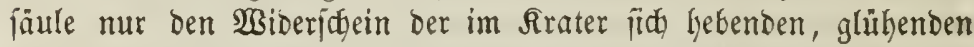
Rava erblifen. Damit ftimmt audf Die Beobactung überein, Daß

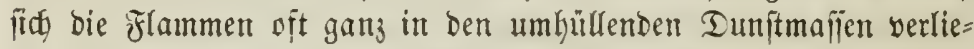

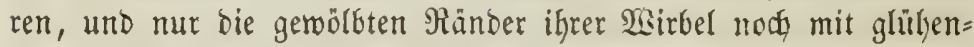
Dem Eaume gemalt merben. Sebe plaķende Dampiblaje jịteubert

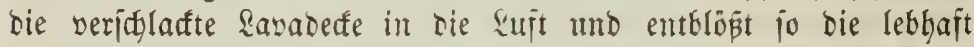
glügende Dberflädhe, Deren rothez Sidgt auf ben Dampinolfen uno

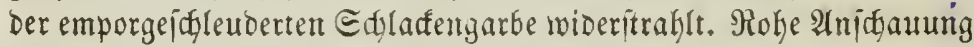
mur fonnte lobernde Flammen aus bem Bulfan emporiftiē̄en iehen, milienidgaftlidfe Beobadter jahen fie nidft. Freilid) hat man zmi=

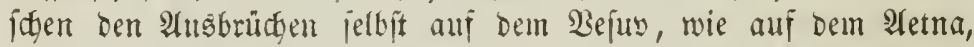

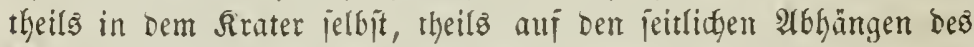

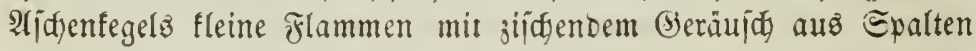

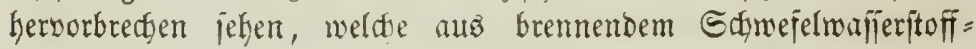

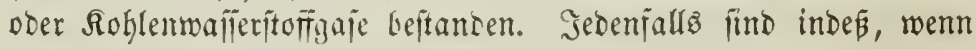

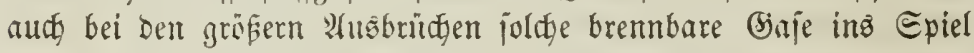
fommen jollten, biejelben body in zu unbedeutender Mienge vorhan=

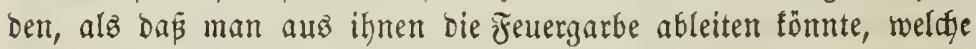

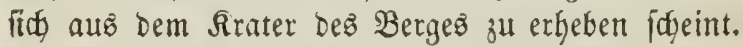

Benn aber audh jene Ridfteridgeinung vorzuggmeife auf bent

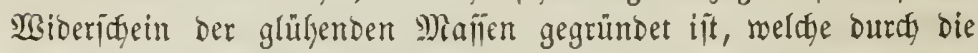
Explofion Der Wajîersämpje entblöpt werden, jo ift boch jene geballte

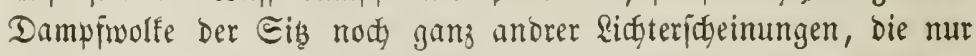

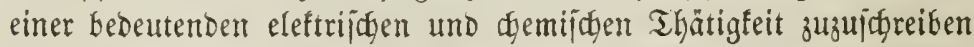

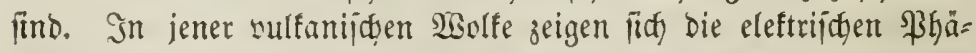
nomene in ebenjo großßartigem Maaßitabe entwiffelt, wie in ben

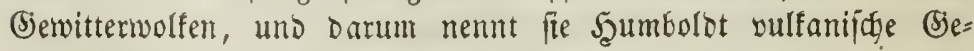
witter. Beitäntoige Bliţe uno immer rollender Donner finto von ben beftigften Berwitterregen begleitet, weldje molfenbrud)artig Gerabfür = zen und oft meit bebeutenderen Edyaden in Der Umgebung ber Rulfane anridsten, als bie von bem Berge ausgeipieenen 2liffen =

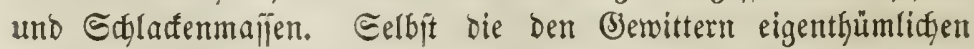

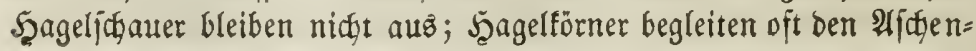


regen, beren Rern won fleinen Eteinen gebildet wirb. ATn ben $\mathfrak{A} b=$ hängen ber meijten Bulfane zeigen fïc) tiefe Rinnen uno (s)räben, weldye non diejen serkerenden Bewitterregen eingerifien wurben,

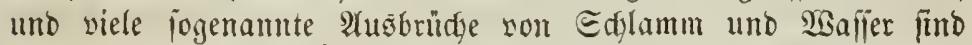

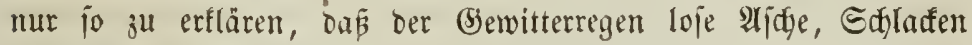

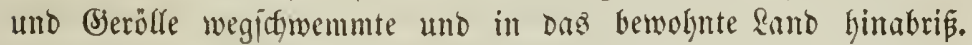
Die Crrflärung liegt nalje. Sebt wifien mir, baj ber einer Dampf= majchine entiptromende sifafferdampf ungemein grope eleftrifde Fun=

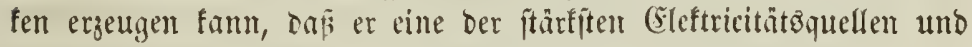
Darum oft die Ulradye de 3eripringens ber Dampffeffel ift. So

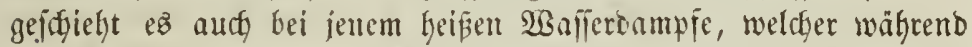

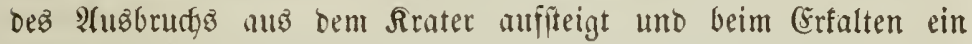
(Semölf bildet, von dem bie riefige slicben = und geueräule umge= ben ijt. Die plöblide Berdidtumg Diefer Dämpfe, bie Billoung

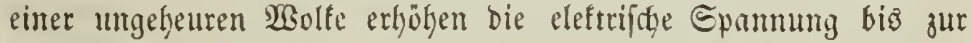
Entlabung. So wirten aud lier bie tosmijogen Sräfte im Berein: Wärme, Ridgt und Eleftricität, fie alle tragen bazu bei, bie grauen= Gafte Sirnctit diefes Echaupielz zu freigem.

Sene Sdylammptröme, bie ich erwaihnte, fino aber nidbt inmer Erzeugniffe Der (Bewvitterregen. Auf jenen hohen, mit ewvigem Sdanee

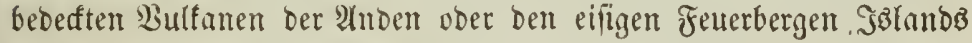

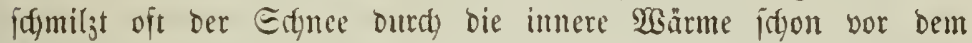

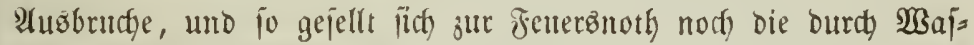
jer. Sidyt bloz (Erobeben, aud) Flutlyen deż gejomolzenen (Sijez

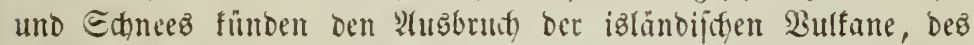

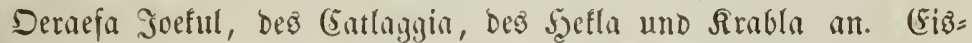

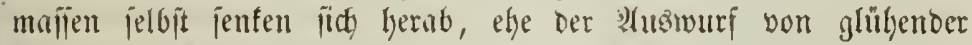
2tide uno Eteinen ben Syimmel Eange lang verountelt. Giegen bie

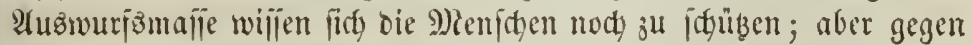
Daв fiebende $\mathfrak{B a f j e r}$ ift tein Edyzz zu finden, gar Mandfer wirb liberrajdyt und im eigentliden Eime gefotten. (Eine vier Meilen

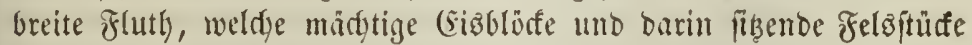
fortwälzt, bedecft oft onย Rano nom Berge bis zum Mcere bin In ben Anden werben aber dieje jurdtbaren lleberidyemm!ngen

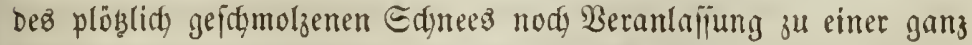

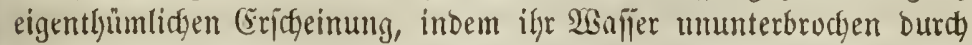
Die Epalten Des Tradytgefteins Durdfitert und Säblungen, bie 


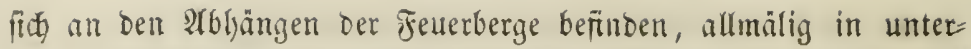

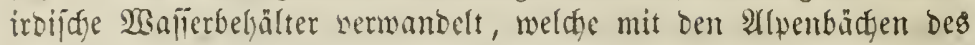
Sodylandes gon Euto vielfach communiciren. Durch mädytige (erd=

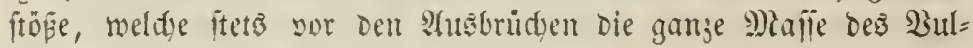

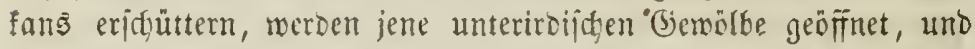

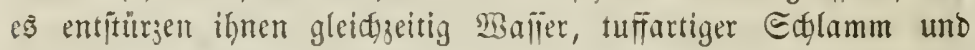
Fifite, Jisemadillas oder Fimeloden genannt, bie Das Dumfel jener Sëhlen fewohnen. Meilenweit werben oft bie Felder non biejen

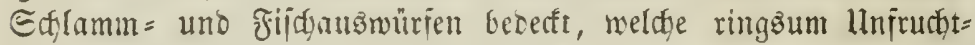
barfeit und Srantheiten berbreiten. $\mathscr{U}$ (m berildtigtiten find burd bieje (5rjarimungen Die Sulfane Imbabutu uno Eargunirajo, Deflen (S)ipjel im Sagre 1695 zujammenitürjte.

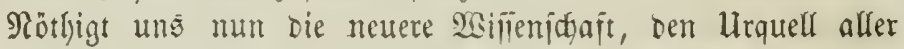

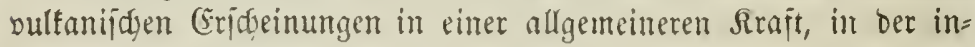

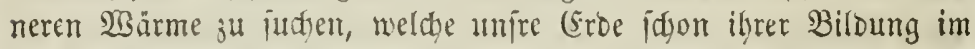
SWeltraume Durd 3ujammentaffen und Berbidten bunjtörmiger Stoffe seroanft, io finto wir wohl auds beredytigt, gleidjam vermöge

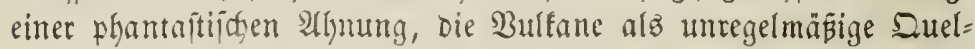

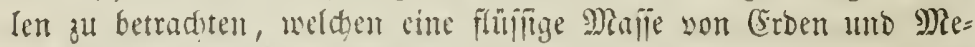
tallen janjt uno jitll entiliest, wenn fie burdy ben mïdtigen Druft Der Dämpe an bie Sherflädye geloben werben. Aber waz find nun Das für Etoர̃e, die aus biefen Sueflen herborftrömen? Wir wollen fie eingeln näher betradyten. Im Allgemeinen jefjen wir aus

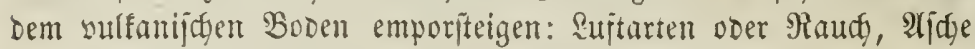
uno Eteine, und endidy glühend= flüfïge \&ava.

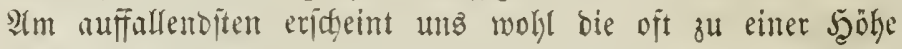
yon $10-12,000$ fus emporgeichleuberte $\Re a u d$ = und Dampfiäule,

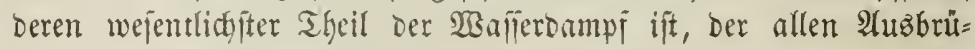
chen vorangegt, vielen Bulfanen aber aud bejtändig im 3ujtande

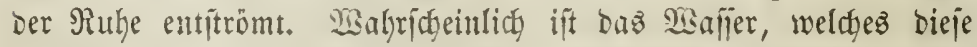
Dämple liejert, jum großen Theil atmojpharifdyen Uriprungs, wie

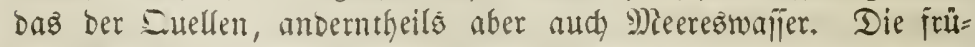

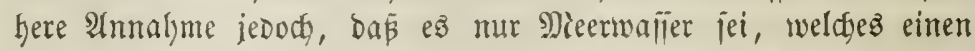
3ugang zu Dem sulfanifijen Seerde gejunden habe, wird burdy bie= jenigen thätigen Bulfaute miberlegt, weldye som Meere entfernt, im Jmmern Alitens jogar 200 Meilen von jeder Rĭhte liegen, fo daß bas Mecrmajןer unmöglidy zu ilynen gelangen funn. Eo lange ber 


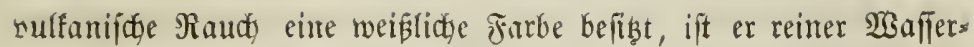
Dampi, wie er bei nieberer Erbitsung unb im Zuftanbe folummern.

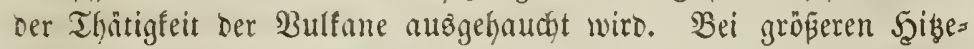
graden Dagegen, wo jelbjt iejtere Ctofie in Dampi nerwandelt wer= Den, enthalten bie Wonlersämpfe mody anbre (Saje, Wajierftof, Sok= lenfäure, mit Ecónejel= and Ealsäure gemijdyt, und Edywefel= bämpfe, welde fich aber leidyt uno făurll burdy ifyren eigenthümli=

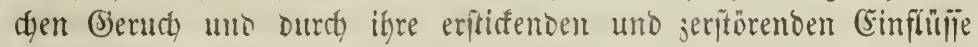
auf bie Begetntion verrathen. Dieje Äushandoungen von Dämpjen ober Inftatuellen jeigen anch ifre seränbernden Čimmirfungen auf

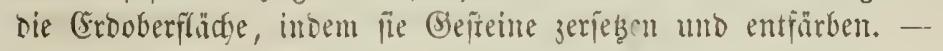

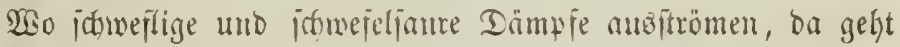

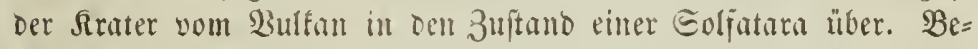

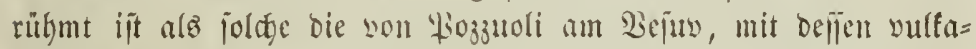
nifdem Seeerbe fie in unther Lerbindung fteht; Denn fo oft ber $B_{e}=$ juv in Thätigteit ift, ruht jene Solfatara, uno cin niederjteigender \&uftiftrom jitht burd) ifren Edylund hinab; ruht bagegen ber 2 ul = tan, io haucht die Eolfaturn Maud und Dämple ats. Seber Bulfan hat cigentlid) jeine Eolfotarn balo jerner, balo nälyer, oft

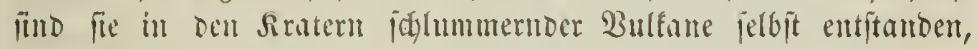

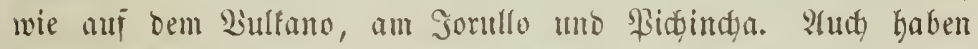

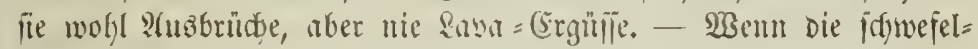
haltigen Dämpfe in bic \&uit mrätröment uno erfalten, jo seroidatet

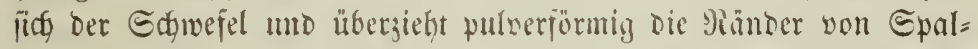
ten und Rijien, oder füllt jie aus mo bilset muernteplidy reidge

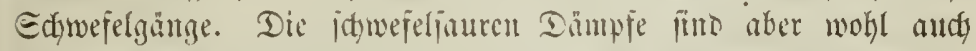
bie erjeugenden llrjadyen anorer Etorie, fie verwandeln ben Salt in Gups uno allabafter, bie Ijonerbe in Mlaumitein. -

Eefturer als jugweflige Dämpfe finto die falzanten, bie fich

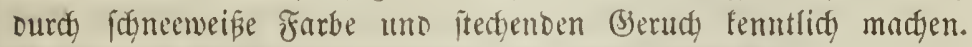

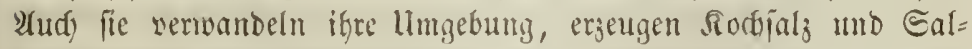
miaf oft in ungebeuren 9)ientgen. 2Am Befus wirb รaฮ sultanijac

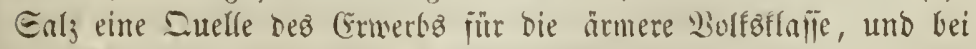

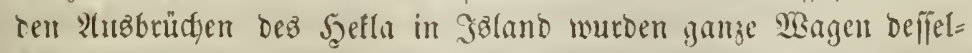

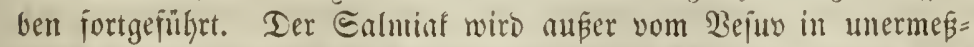
liđfer Menge non Den Bulfanen im Junern Rliens probucirt, über 


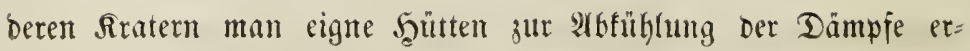
baut hat. -

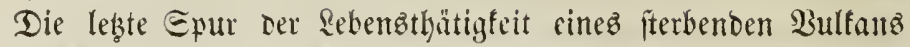
ift bas 2 tushauden wour Robleminure. Eie entiftömt oft noth $D r=$

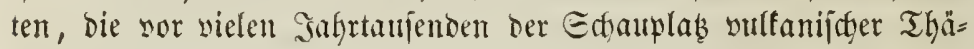

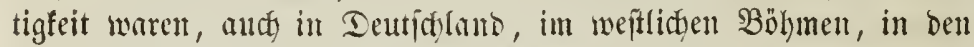

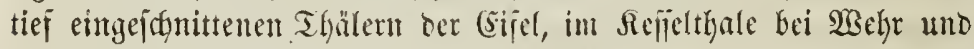

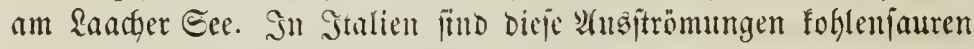
(Bajes bejonders hänfig, und man nemnt bort jolde Serter Mlojeten,

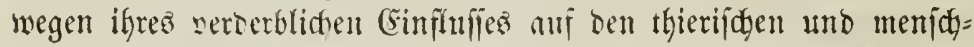

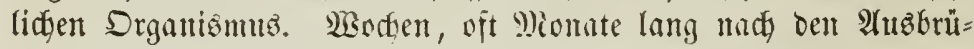
d)en bes Befun crideinen sie Miojeten im ganzen Umfreiz befielben,

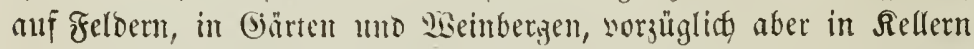
fteigen bieje feindidgen Eujtquelfen auj; und wenn lestere längere Zeit veridolofien maren, io ijt bie Mienge von Rohlenläure of̣t fo

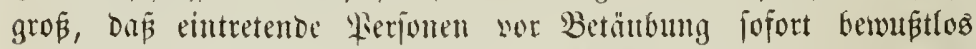

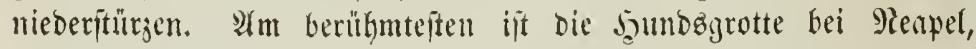
am berüd)tigriten aber uno jelbit ben (sintyekornen ein Biegenitano

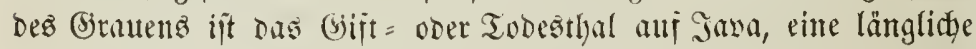

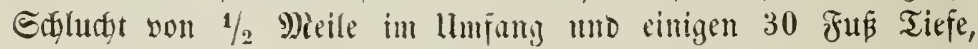
voulfig cben, ohne alle Wegetation an Boben, hoberall mit Sfeletten von Menidgen, Tigern, wilnen Thieren und $B_{0}$ getn aller $\mathfrak{A}$ rt be=

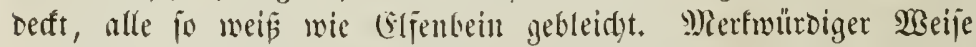

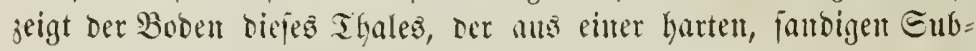

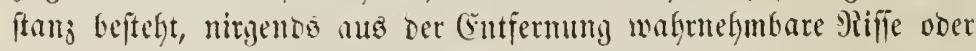
Epalten, benen sie surnerblidfen foflenfauren mo idgeffligiauren Dämpje entweiden fömuten.

Eoldse Derter finto die Branditütten ber Bormelt, bie unz nodt Die lebten Niegungen vulfanijater Thätigfeit offenbaren. Shnen ent=

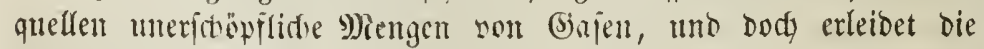
Attmofphäre, in sie fie übergehen, feine Seränberung. Freilid mö= gen einft bei höferer (Stomärme mädrtigere \$ircefife gemirft haben,

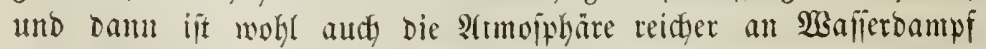
und Roblenjüure gewejent. Eind aber dieje baje, wie wir mifien, bie Rafrungsitoffe der Sijlanjenwelt, fo founte wohl aud in jener

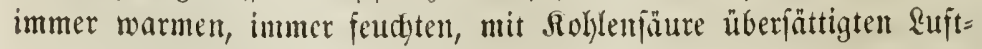

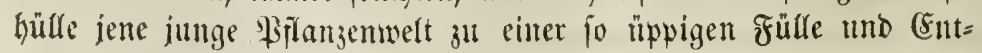


widlung ihrer Drgnne gelangen, baß nodh iffe Ueberrefte bie uner= idäpfiliden \&ager Der Eteinfohten bilben fornten. Sn Ënglant, Frantreidy, Belgien, am Riederthein uno in Sberiffleften find jente reiden Edyäke aufizeipeidyert, bie nod heut ben Mokliftano ber Bölfer hegrünten. In jenter $\|_{r} r_{3} e i t$ allgemein verbreiteter wulfani= ither Thantigfeit entquollen audy wohl bem Ectoofie ber (Eroe jene

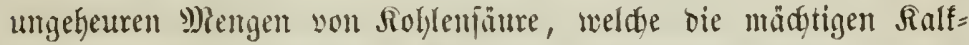

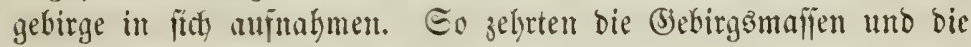
Begetation Der Borwelt in Berein an ber Sohlemfäuremenge dez Eufttreifes uno reinigten ifn fo, Das mur ser geringe (B)elyalt übrig blieb, weldfer ber jeşigen Drignifítion ber Thiermelt umidjäb= lich iit. -

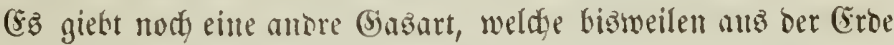

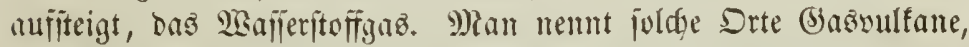

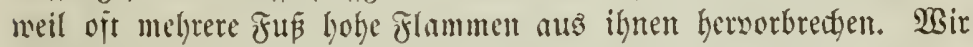
fenten bergleiden in Stalien bei Pietra mala, in Franfreidy untweit

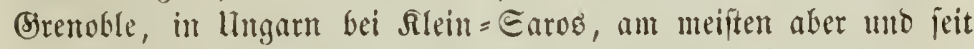
Den ältejten Zeiten befannt funo bic ewijen geuer auj ber Şalbinję Whidjeron bei Bafu. Dort ift bas Gremtbare Gas fo reidflyaltig rorhanten, Dur es anz jedem in bie Erobe gemadten \&odhe herbor= quillt, am büuffigiten aber auş cinem bürren, fteinigen $\mathfrak{s}$ altboden aupiteigt, wo einft ein alter Tempel ftuno, oer bon zmöl PBrieftern Der Feneranbetenten \$arjen bedicnt ward. 3wei $\square$ Mteilen beträgt

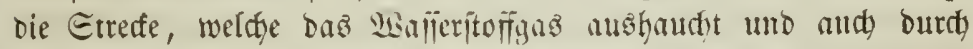

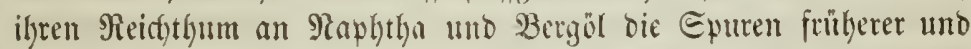
anjdeineno nody fortbauernder sulfauijder Shätigfeit ju erfenten

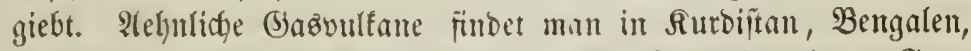

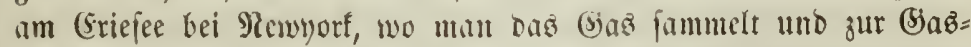

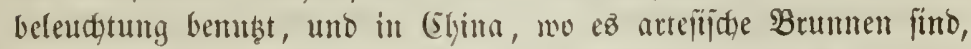
Feuerbrumten, wie man lie uenut, bie man oft 3000 Fur tief in

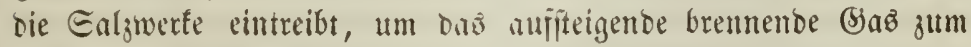

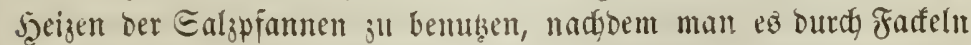
entjündet bat. - Räthjellyujter nod, alz bieje gener find biejeni= gen, weldye man jumeilen in Lngarn, Cumana, bejonders aber

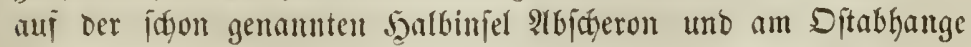
Dez Raufnjus beobadjtel; und ez ift noch gar nidft ausgemadyt, ob man audh fie zu ben vulfanifoten Eridteinungen zählen barf. Rad 


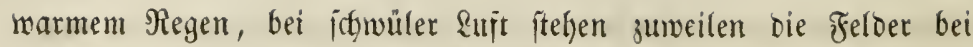
Bafu in volfen flammen, balo idfeint $e 8$, als rolle das feuer in

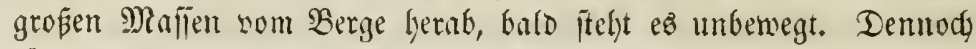

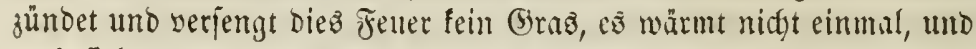

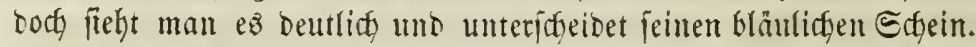

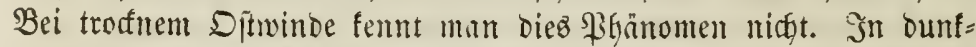
len und warmen Rădyten erhellt eż die (sbenten, aus benen bie

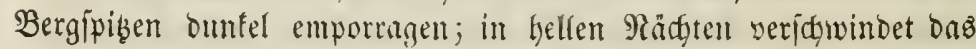

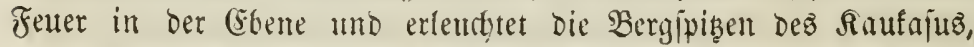
yor aflem ben Guglybutu, Den Berg des \$aradiejez. Die Zajiere Der Rarawanen filiefen erfafreft wor diejem unfeimlidfen zeuer, bie Meniden fintert in Bemunderung und 2rnbetumg nieber sor biejer heiligen ßrucht der 9atur. -

In eimigen Butfunen fimb in Dem 13 nijerbampje jo reidjlidge

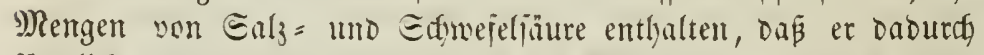

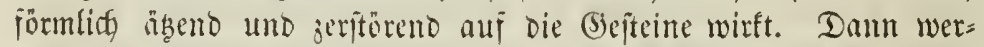

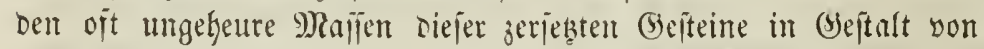

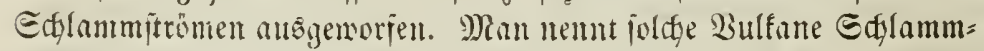
wulfane ober Saljen, weil Das wajijer gewöhnlich Rodjals entfält.

Die Ratur biejer Enljen ift afer eille jo veridjiedenartige, und fit

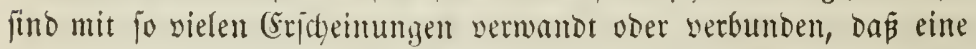

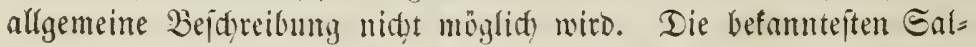
fen frun bie Eiciliens uno Stuliens. Şier jetigen aus fleinen Edjlammtegen ober @dylammteiffen von 3eit zu 3eit (5asblajen yon

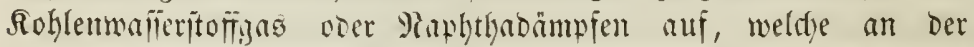

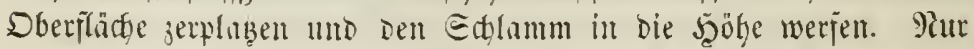

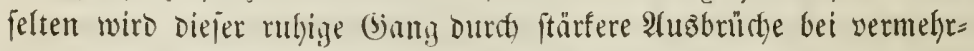
ter (B)asentmidflung unterbrod)en, Die von (Erobeben und unterirbi= itsem Donner argetinnoigr, von furtoftbarem Rradjen begleitet, ge= waltige Edflamm = mo Eteinmallen emporwerfen und Den Boben

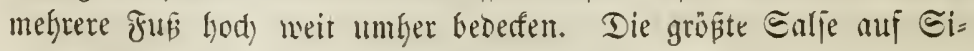
cilien ift bie won Miacaluba nördlid) yon Birgenti, eint flad ges mölbtes \&iatent von 100 Edyritt ins bevierte. Edyon hier jeigt fidf bie Berwandijtgajt Der Ealjen mit Den Maphthaqueflen unver=

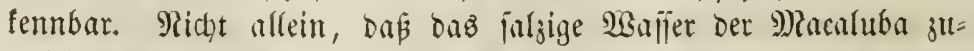

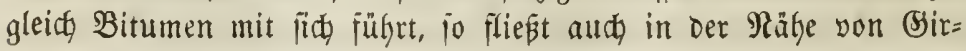


genti feit ältefter 3eit eine Paphthaquelle. Bidftiger nod erideinen bie Ealjen von Tozcana uno Mobena. Tie Enlje von Eajinto

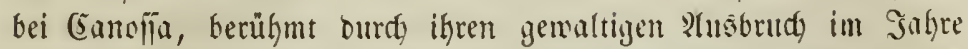

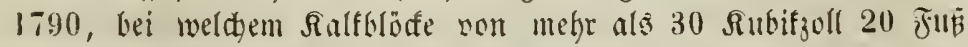
weit gejdeleubert wursen, hat ben Bosen in einem llmfange von

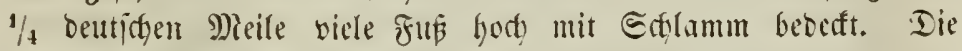

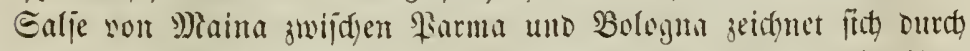

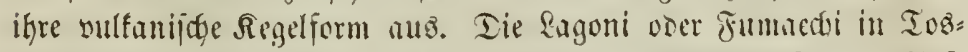

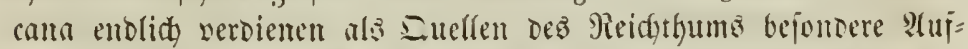

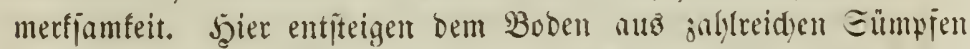

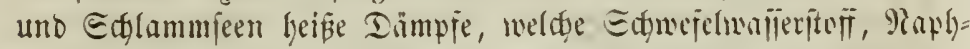
tha, vorzugbaveife aber Borfäure entfalten. (Simit war sicje bie=

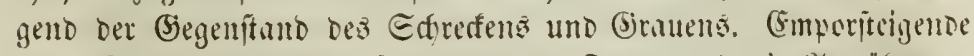

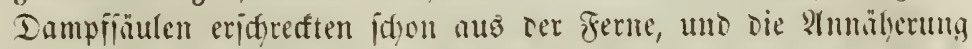

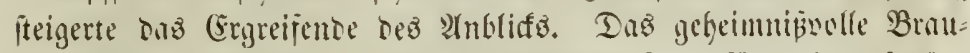

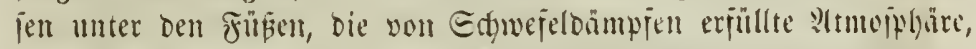

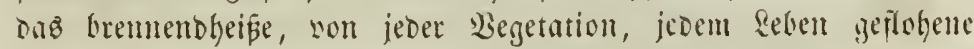

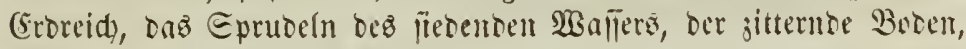

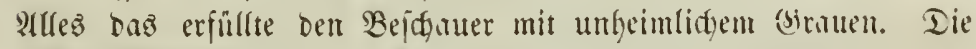

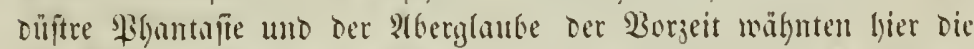

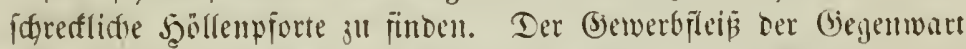

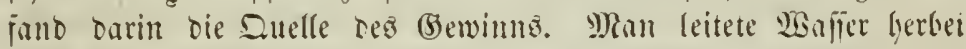

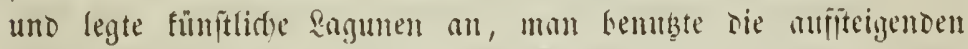

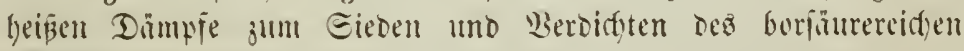

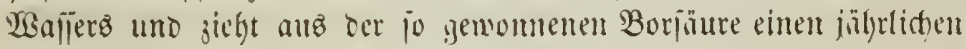
Berwinn won fajt ciner Million jranfen.

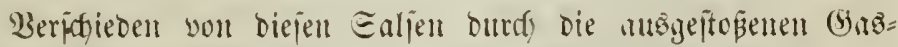

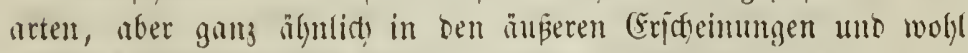

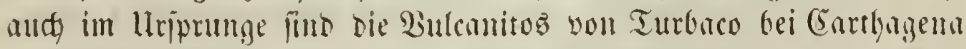
in Reu= Sirannon, welde bie umitehende Whoildung zeigt. Whath ther jeigen lith anf einem yon aller Begetation entblöften Buren

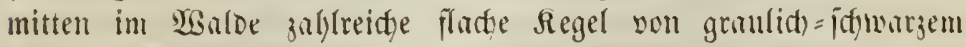

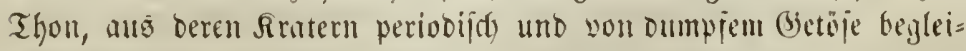

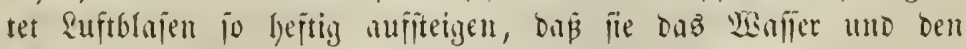

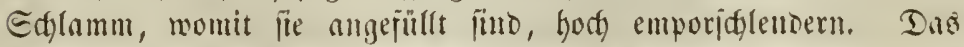

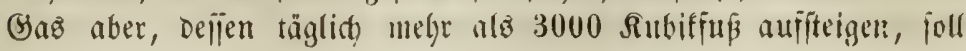




\section{0}

reinez Etifgas jein*). Die meiften Exthlammbulfane ftehen in

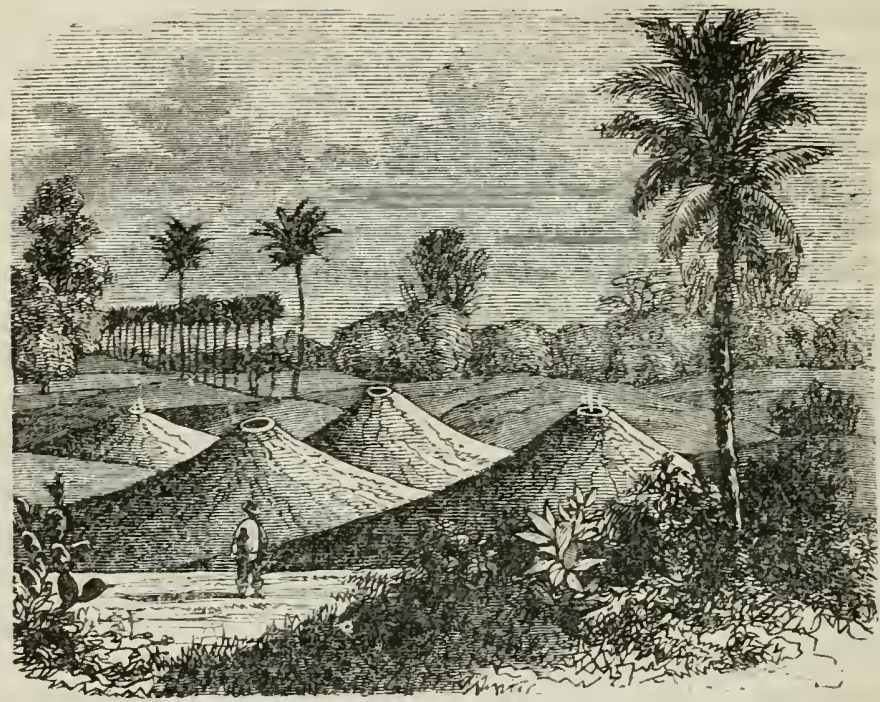

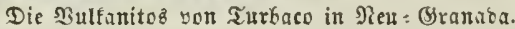

Berbintoung mit Gremtenben Gaşulfanen ober Raphtgaquelfen, wie ez faton die Ractbarichajt ber lebteren Gei ber Ealfe von Macaluba,

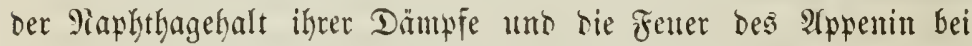
Bietramala und Barigaj30 in ber Pähe ser modenefififtent und to 8 = fanijeten Ealjen werrathen. Deutlider tritt bieje Bermandtifa aft auj ber burdf ifre ?aphaftlagumen beriffuten Injel Trinibas her=

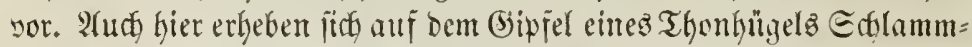
fegel, benen Edfmejefwailerfitoffigas unto alaumartiger Edilaum ent=

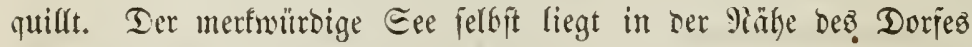

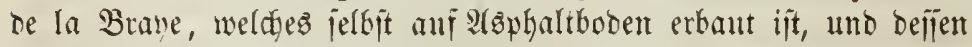

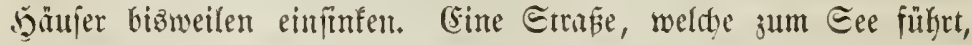

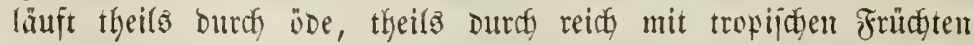

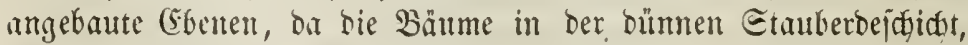

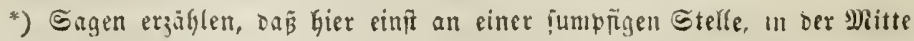
eimes Pralmentyainez, bas unterirbifde zeuer genütfact habe. Durd băuñge Befprengungen mit $2 B e i g$ wițer aber, io glauben tie kigutten firenlen, fei

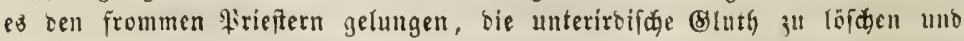
ren Feuersulfan in einen 2 is fîerbulfan zu verwanteln. 


\section{1}

welche Daz (Eropecty bebedt, jehr gut fortfommen. Wiso der Boben

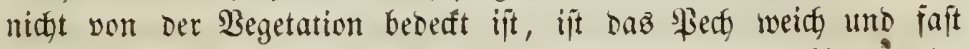
flujiig. Der Eee jelbft ift ofyne alfe Begetation, mur hie uno ba

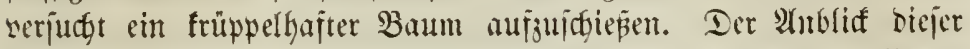

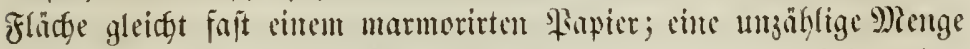

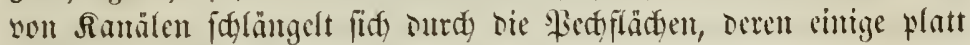

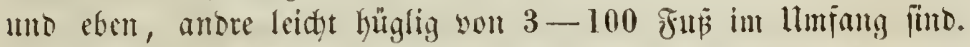

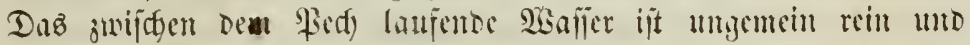

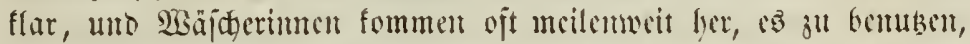

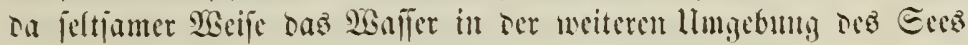

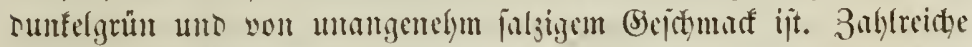

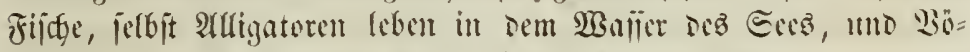

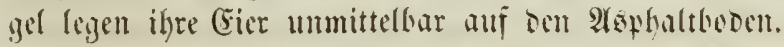

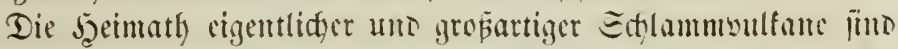

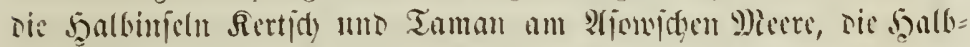

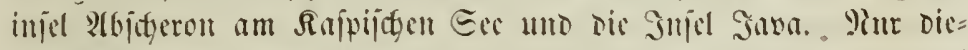

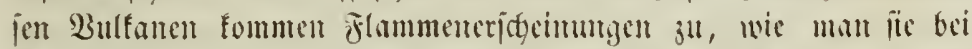

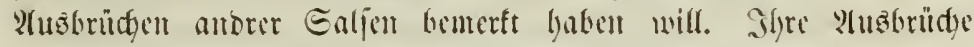

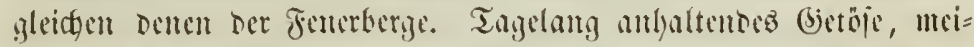

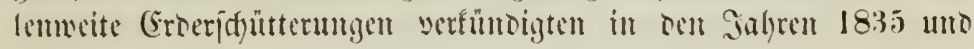

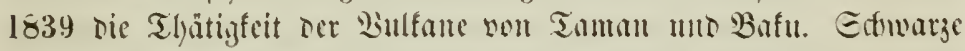

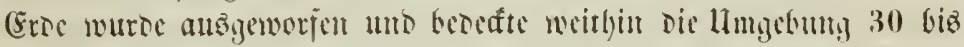

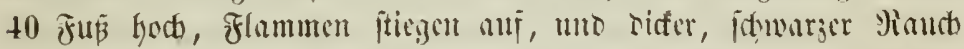

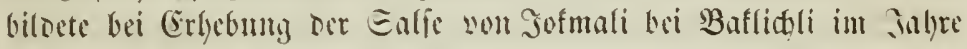

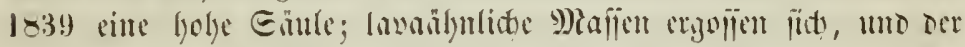

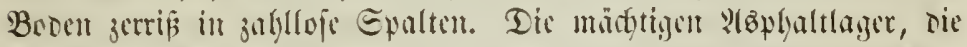

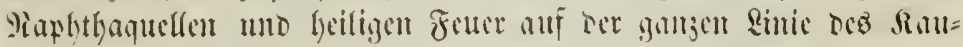

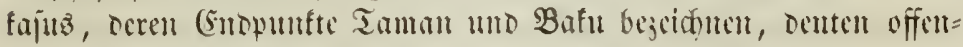

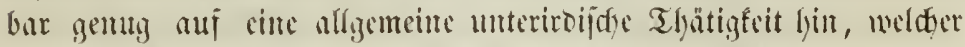

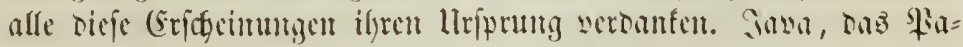

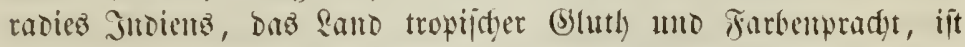

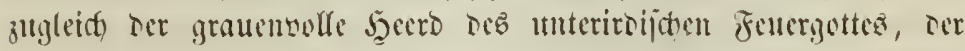

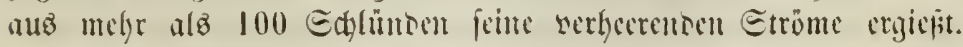

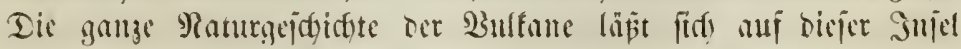

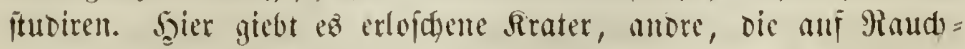

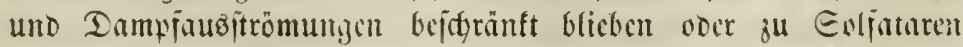

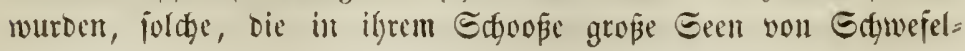


fäure haben, wie Der Tafctem oder Gnoienne mit feinem 1200 Fu位 langen Eee, anbre, welde in groß̈artiger Weije Edfwejelmajierftoff

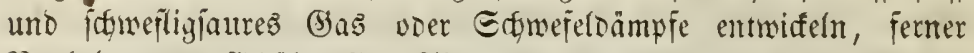
Maphtha = uno Erölquelfen, Thermen und Ealjen in groperer Menge. Endlidy aber giebt ez Gier Buffante, bie bis zur nenejten Zeit thätig bfieber. Unter bicjent verdiestent die meiłte 'Lujumerfamfeit bicjentigen,

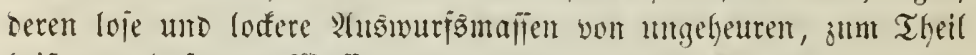

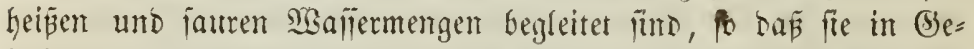

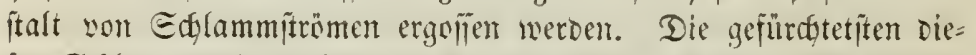
fer Edylammenlfane fint oer bjésé füblich von Batavia uno ber

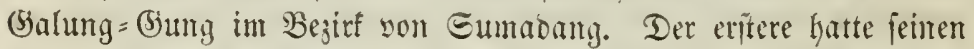

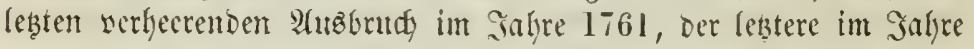

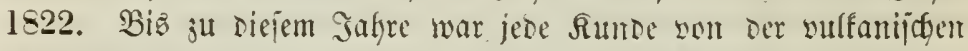

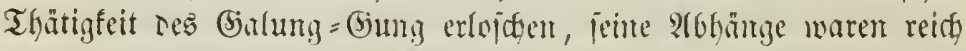
bebaut uns bevölfert. Im Enmmer biejes Gahtes mursen dic bie-

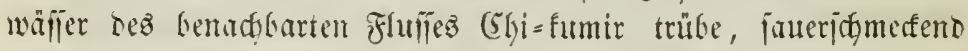

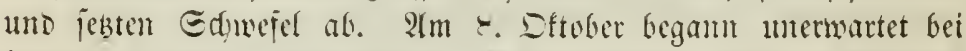

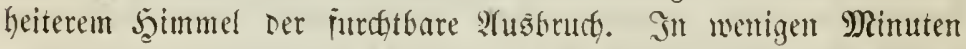

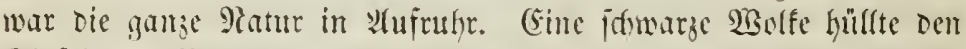

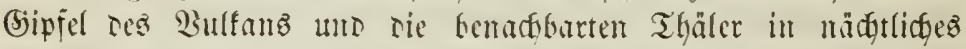

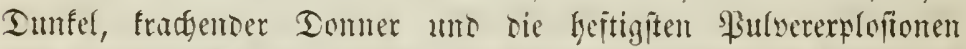

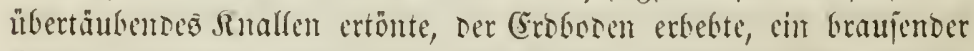

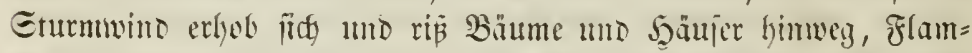

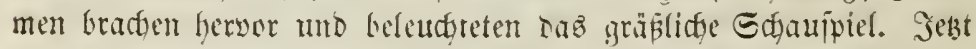

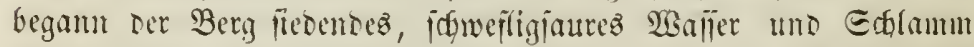

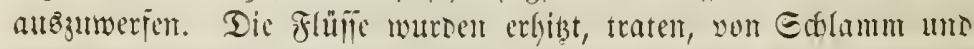

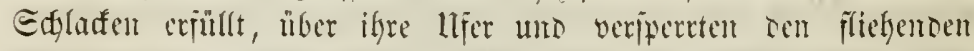

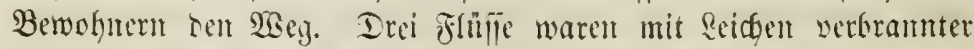

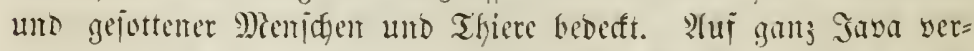

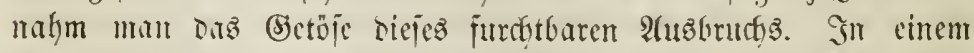

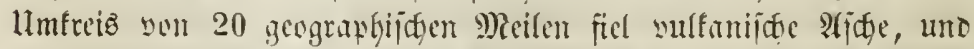
in ridft gerinturer Entfermung murden die Felser mit Edylamm beseft. $\mathscr{I}(\mathrm{m}$ 12. Sftober folgte cine nody hejtigere Esruption. Ein blühen= Des Rant war jur wilite umgenandelt. Heber zweitaujent men=

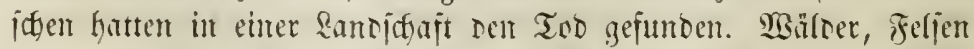

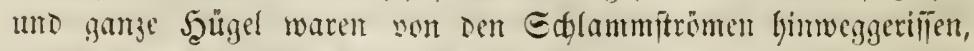
neue Berge an ifrer Etelle gebiloet. 


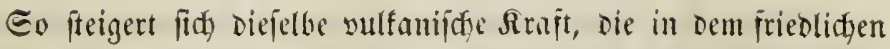
Spid der Rngoni bem gewimnindtigen Bemohner ein Eegen wird,

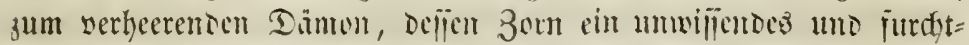
james Bolf Durdy Bebete uns Spfor zu bejünftigen judgt. Wir

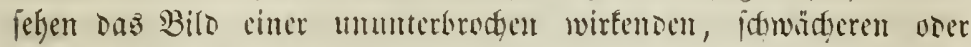

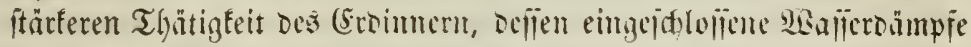

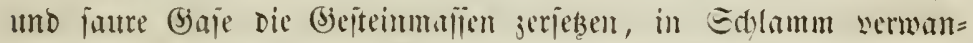

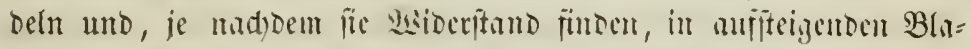

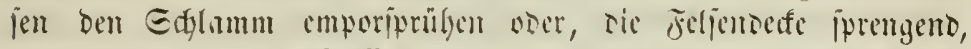

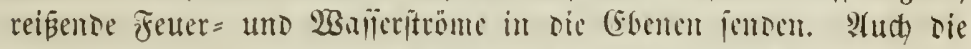

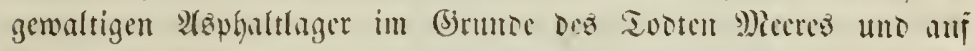

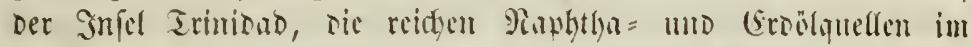

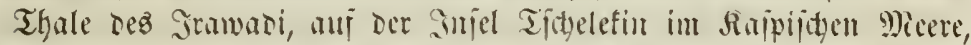

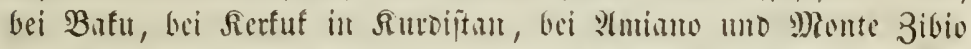

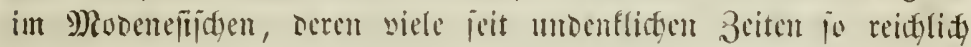

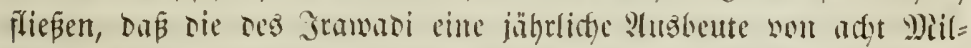

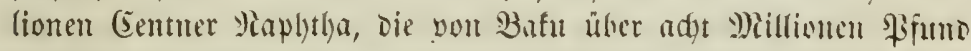

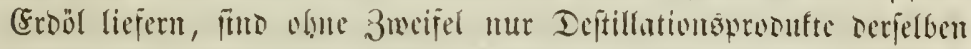

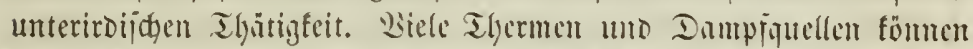

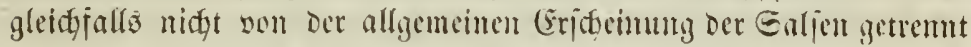

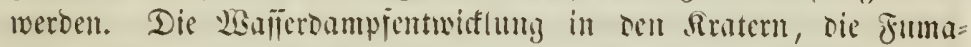
rolen, die als meipe Sielvel anz allen Epalten ihrez Budenz uno

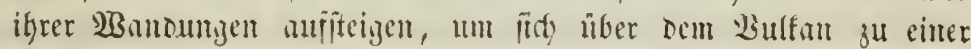

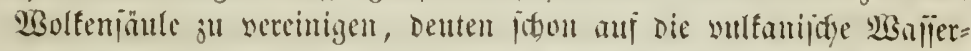
ergeugung hin. Die faljonänlidgen Dampiquellen in Der gräge ber

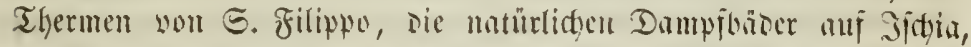

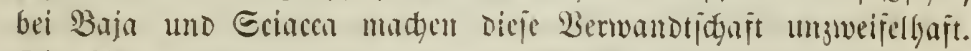

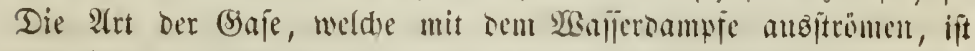

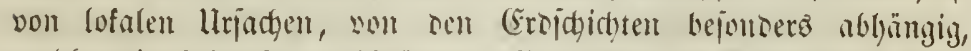
weldse die Dämpfe ourdyjtronment. Balo funo es Rolyleniüure, balo

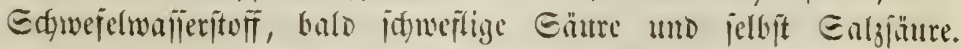

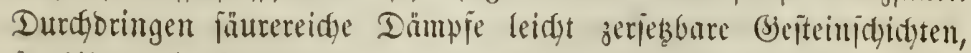
fo bilden fie Sdylamm und geben wabren Sdylammulfanen ifyren Uriprung; frömen aber füurearme Dämpfe burch (jejteine, weldfe jeber 3erjesung widerfelyen, jo erjdeinen Thermen und Dampiquellen. Ulleroings giebt es heíse Duellen, bie eine allgemeinere llrjadye baben unb baher von ben falten Dueflen nidgt getremut werben bürfen. 


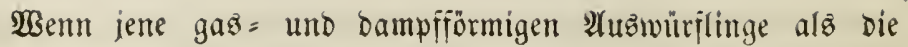
Erjeugnifie einer joblummernden ober hinjterbenden, wenigitenz einer

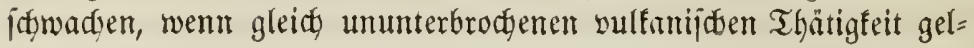
ten fornten, io legt ber Bulfan in ber 3eit jeintes frïfitigen Rebenz

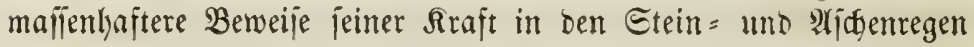
ab. Unter allen fejten 2 (uzburrigitoffen nimmt aber an Menge und

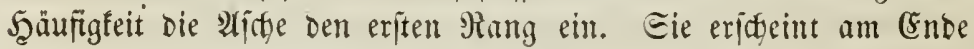
ber groß̈artigen Rataftrophe, wem 2 Hles weder in ben gemohnten

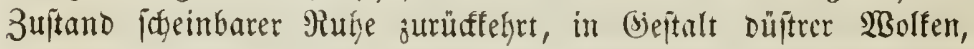

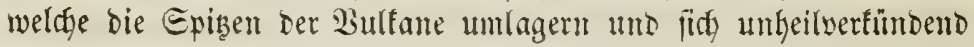

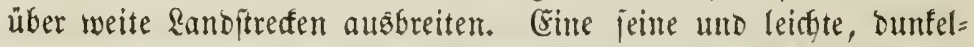

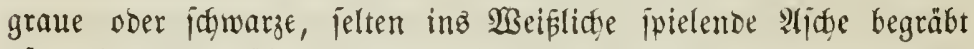
oft meilenweit blühenoe Randidaften und verbuntelt burd) iffe un= glaublidje Menge oft Tage lang nalye und jerne Begenden. In

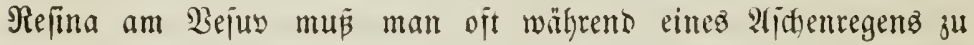
Mittag bie saternen anjünden, unb im Sahre $179+$ war jelbjt bis

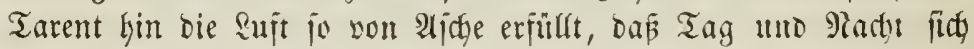

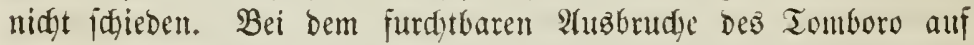
Sumbava im Sahre 1815 trat in ungęähr 50 Mieilen Entfermmg. zu Macajīar auf (Eelebez eine foldye Dunfelgeit ein, dá man am ufer bie Edsiffe nidft mehr enfemren fonnte, unt madt wenigen Stunben verbrängte vollfomme Finfterni Sava uno Mabura herridgte tiefe Madjt, jelbit bis Eumatra, in eine Entfermung, Der zwiffen Şamburg umb Dem Aetna gleidy,

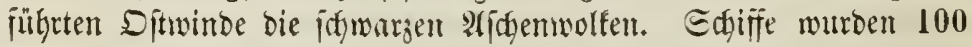

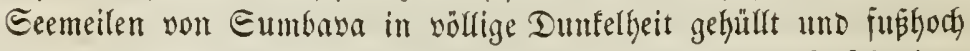

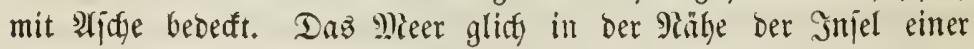
Sanbbant, idgwinmente Bimgiteine und alide, zerrifiene und halb=

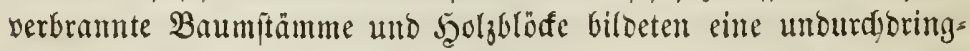

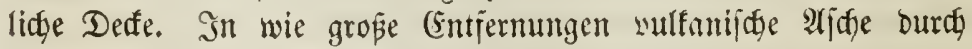
WBinde gefiutyt wird, davon liejern audf andre Bulfane Berweije.

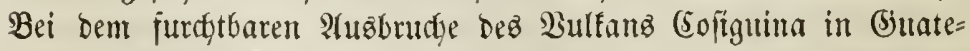

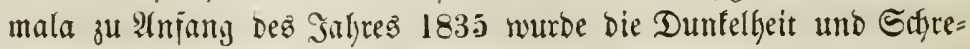

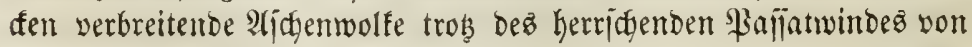
oberen \&uftitrömen 200 beutịte Meilen weit biz Ringiton auf $\mathfrak{a} a=$

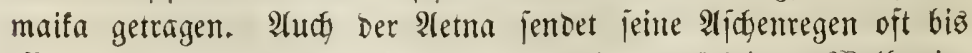

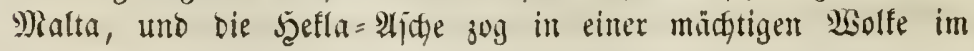


Jahre 1766 über 100 Stunnen weit uno now vor vier Sabren

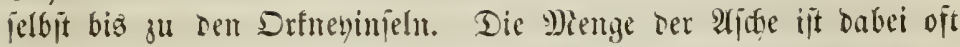

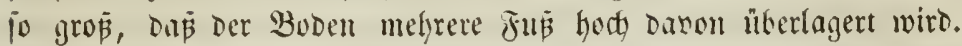

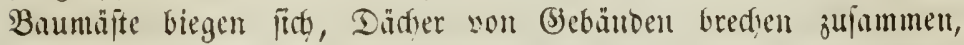
ganze Drtidgaften werben jeritirt, ihre Bemohner eritiff, ilyre Wiflan= zenderfe veryiftet. Drei Etride, Şerculamm, Fompeji mo Eta=

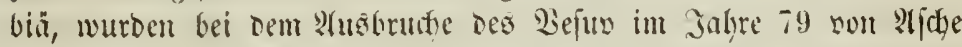
veridüttet. Der Raufajus liejert cinen nidt minoer auffaflenden

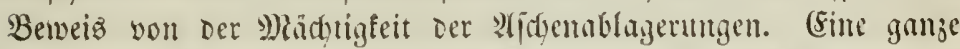
Etadt mit Rirchen uno Sänjern, Sellern und Brumnen wurbe un= fern Der Fejtung Der Rönigin Tlymar in erbürteter wulfanijd)er

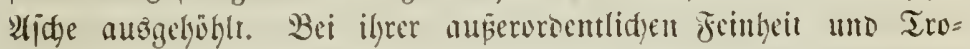

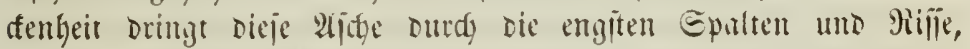
Durch bie bejtwerjdlolienen Fenjer uno Thüren uns nimmt bie jars tejten Sinbrinfe von Slegenjtänocn an, jo Daj man in Fompeji

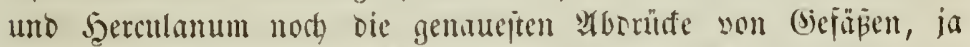
jelbît von Gefidtern mo Rlcibern verichütteter y)injityen findet.

Edywerer uno gröber als bieje sidue ijt oer wulfunijoe Gand,

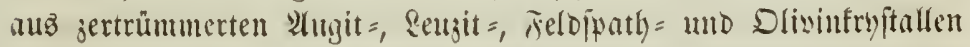
bejtehend, Der oft gleidzeitig mit ber aljoge emporgenorjen wiro und beim Miederjallen Blumen und Gras in weiter Minto seriengt und

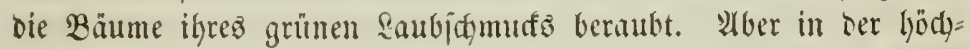

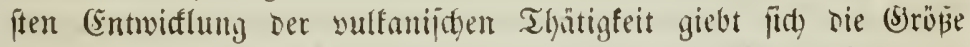

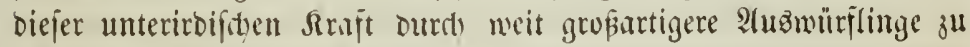

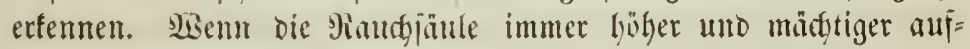
fteigt, immer gewaltjamer hervorbridyt anb ren jalfleidyer weroen=

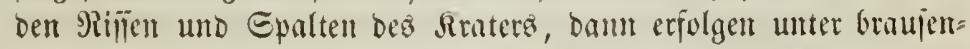

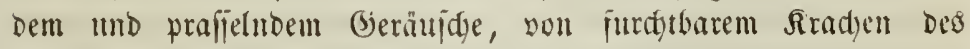

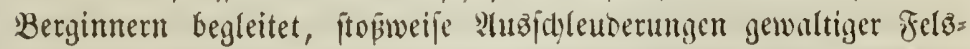

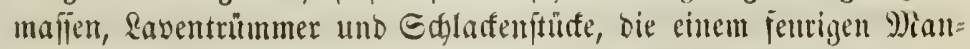
tel gleidy ben Bulfan überbefen. Eenfrectst fteigt die Trümmer=

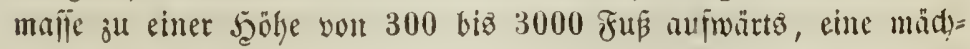
tige Siarbe bildeno, bie fidy Siafeten ähnlidy in ber \&uft zertbeilt. Balo ftürzen bie 9)afien in Den Srater zuniff, um mit ernenerter Wuth emporgejdleubert zu werben, balo fallen fie auj ben Sruter= rand und rollen am Berzgehänge binab. Die einen erfalten in ber \&uft und zerplaben praffelnd beim Rieberfallen, anore bleiben 


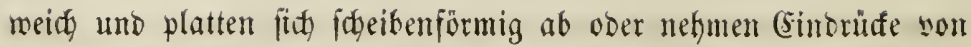

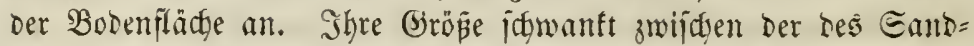
forns unt centneridfwerer Bläfe. Man unterideibet daher audt

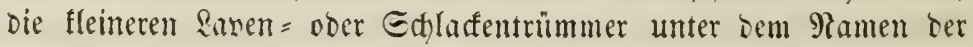

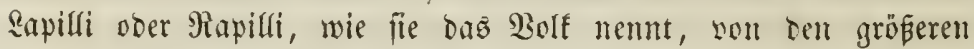

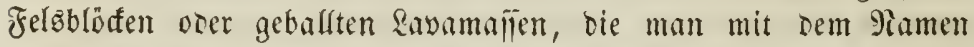
sulfanijtger Bomben bezeidgnet, und die Das Bolf won Meapel nad)

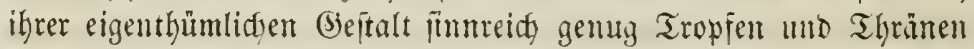

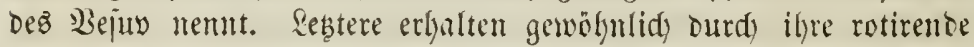
Bemegung in ber euft fuglige ober langgezogene, birnförmige Bes

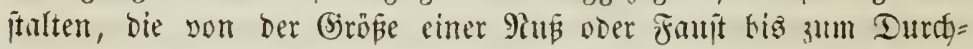

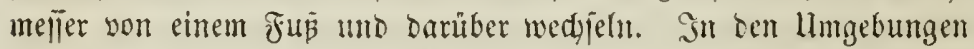

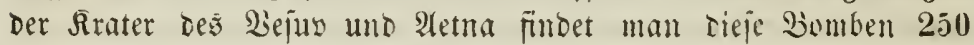

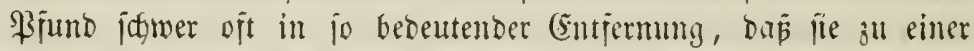

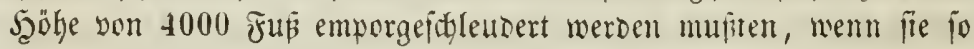
meit non ber Edjladfengarbe, der fie entitammten, neberfallen foum= ten. Bon anderen Bulfanen erzinglt man jogar nod aufiallendere

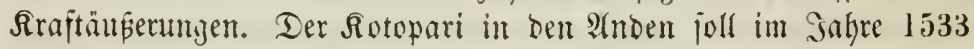

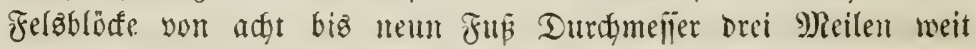

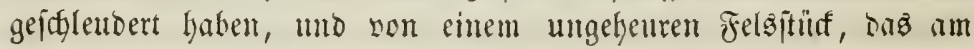

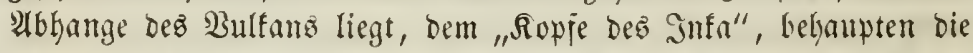

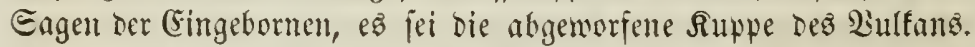

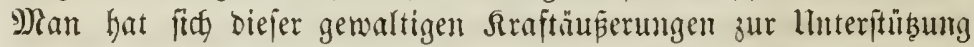
Der Syypotheje bedienten wollen, weldye bie Meteoriteine aus Dem

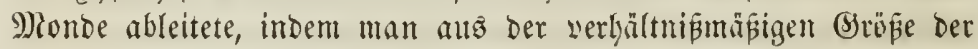
Sratergebirge im Monde aud auf eine weit größere fortithleubernde

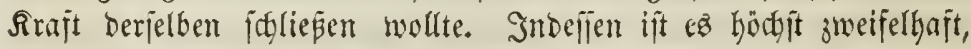
ob bie fraterförmigen Gebirge Des Mondes wirflid Bulfane wie

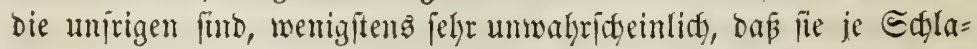

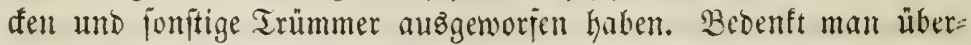

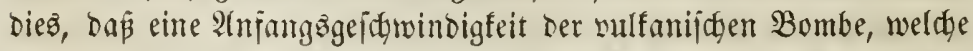

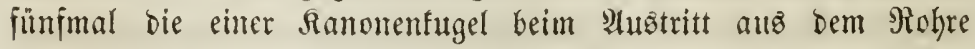

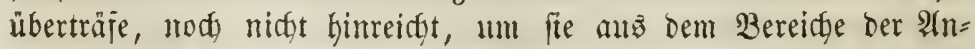
ziehung Des M)onbes zu fotlenbern, fo erfiteht man leidft, mie wenig ftidylyaltig biefe Soypotbeje ijt. -

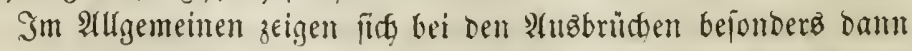

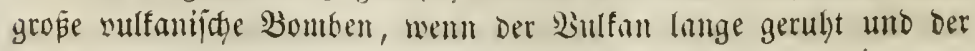




\section{7}

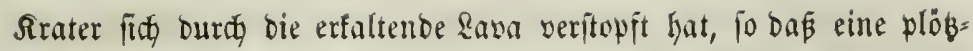
lidfe, jehr bebeutenbe Siraftentwifflung baju gehört, benjelben wies Der zu в̈ffnen. Der Bejux liefert einen Berweiz bazu in ben gros

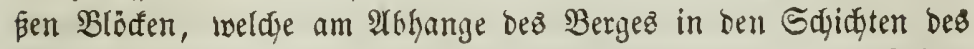
Bimbfteintuffez beyraben liegen. Dhme 3weifel find ez biefelben, meldye einft Den אrater beż Bejuv veridjlojien uno im Sahre 79

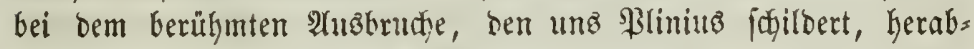

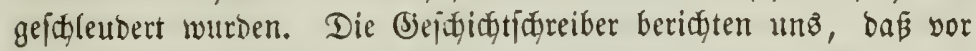
jenter 3eit ber אrater Deż Bejuy eime frudjtbare Ebene- biltete, in weld̦er Bäume grünten, Şeerden weiteten, und daz Sflavenheer

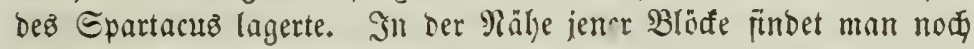
verfohlte Bäume von Bimbftein überlagert, trantige Zentgen eines Eriebenz, den ber 3orn ber 9?atur für immer veridgendfote.

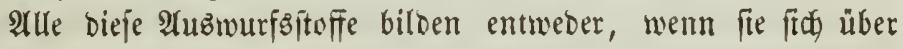
ber (Ebene ober auf bem Meerešboden ablagern und vom $\mathfrak{W}$ Baffer burdjorungen und vertittet werden, bidje (Erofdjidjten, bie man vuls fanifide Tuffe nennt, ooer fie häufen lith ain Pianbe dez Siraters

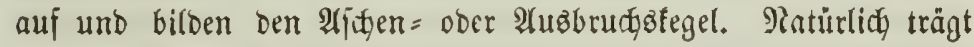

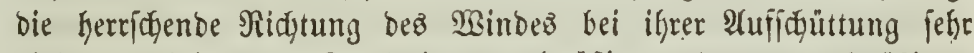

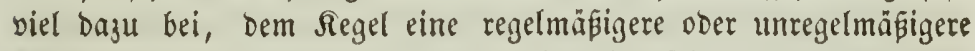
Form zu geben; jebenfalla i it er aber eine jehr unbeftänbige uno veränberlidge Eridgeinung, bie bald entitetyen, bald veridgwinden fann, wie es bie Erfahrung berviejen gat. - Heber ben gemeins

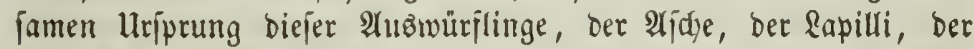
Sabladen auz Rava fam zwar fein 3iveifel mehr jein; benn jelbft

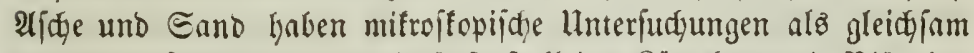

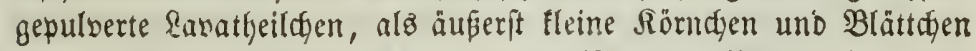

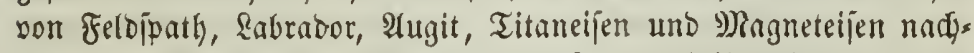

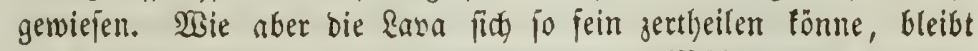

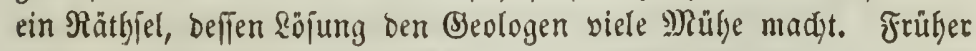
meinte man wohl aud, bie 2lidge werbe, wie bie Rapilli, burd bie

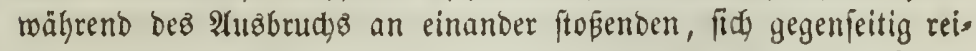
benden und zermalmenden Ravaftüfe erzeugt. Dem miberipridjt

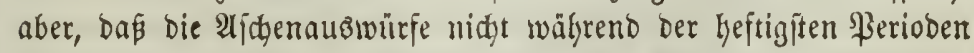
vulfaniffyer Thätigłeit, fondern erít gegen bas Enbe iłhe gröfte Etärte erreichen, uno daß ifre Mädstigteit oft bei weitem bie ber emporgefdyleuderten Steine übertrift. CEine eigenthümlidye ßeobadys 
tung füfycte zu einer neuen (Erflärug. Man fand nämlidy, Daß̧ Thon oder Salfmajien, weldye in einem ftarfen Feuer in eine id)ladenartige Majle verwanbelt waren, nach Dem Crritarren in eine innere Bewegung gerathen, fo Da blicfen in ein aịdgraues \$ulver zerfüllt. Darauf geftühst, hat man

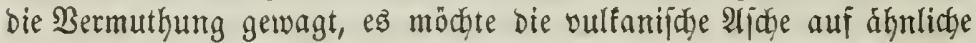
SBeije entitefyen. Da aber bie gröste Afduenmenge erít bann aus= geworjen wird, went icfon biele flüfitige Rava im Rrater vorkanden

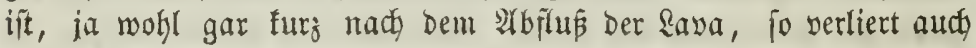
bieje $\mathfrak{A n n a h m e ~ a n ~ S a l t b a r f e i t . ~ M R a n ~ g l a u b t ~ v i e l m e h r , ~ b i e ~ f e i n e ~}$

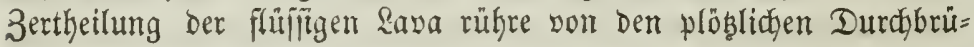
dyen Der entweidjenden Baje butrdy bie Rava her, indem bieje theils Daburd, theils Durdy Den Widerjtand Der euft fo unendid bertheilt

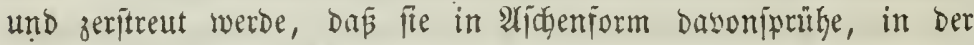
Ruf̣t erfalte und als 2riche juritufalle. -

Diefelbe gemaltige Iraft, welche Yjche, Lapilli, Shlafen und Eteine emporwirft, ift aud Urjacte von Der Şebung ber Rava, Des reiçlidjiten und zeritörenojten Srzeugnifies der Bulfane. Dieje geidymolgene Mialle im Smern Des Sraters hat eime unberfennbare

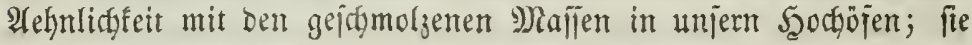

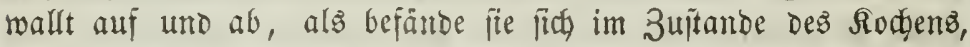

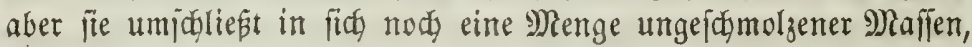
feite Befteine und Felsblöfe. CFin weiker Dampfballen pflegt nad, jedem Etope, welcher die Ravajăule hebt, emporzujteigen. Bon

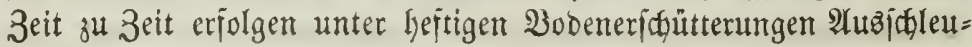

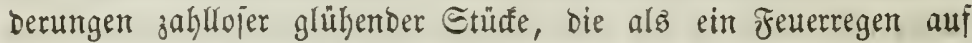
Die Ungebungen Des Srater nieberjtitrzen. Die Scebung ber \&aba

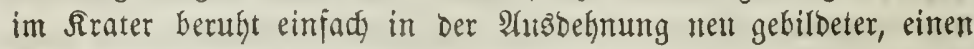

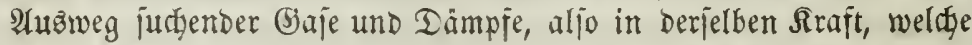

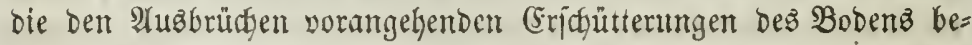
wirft. Da diejen (Sajen und Dämpfen die Derfe ba am erften

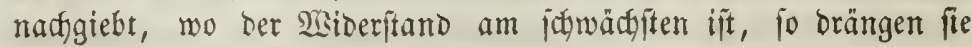

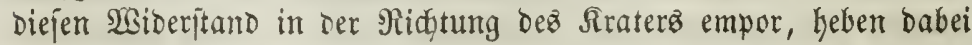

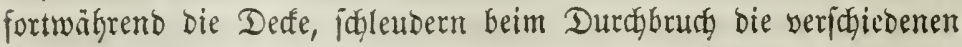

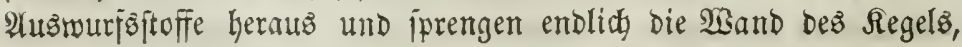

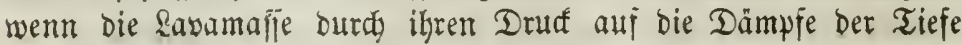
bieje nötgigt, burch die $\mathfrak{B a n d}$ felbit ifren 2 luzmeg zu nehmen. 


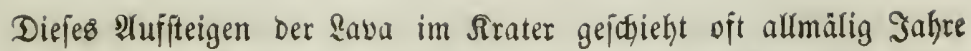

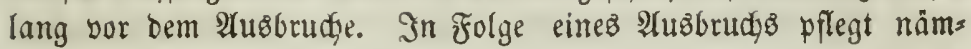

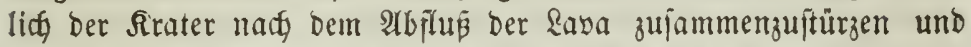
fid) zu einem tiefen Trichter zu geftalten, Defïen (5rund burch einen Samal mit bem Snmen in Berbindung fteht. Berfitopit fidf biejer

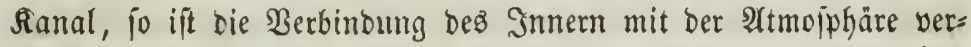
foblofien. So lange ber $\mathfrak{R}$ rater bieje trichterfürmige Bertiefung hat, ift ber Buffan ruhig; fängt aber ber $\mathfrak{B}$ oden an fich zu heben, swiro Der Tridjter fladjer, fo arbeitet ber Bulfan an einem neuen $\mathscr{2}(48$ s bruta; Denn jene Şebung Des Tridferbobens ift mur Folge Des

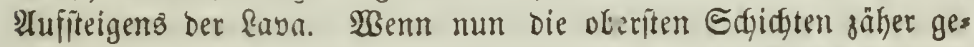

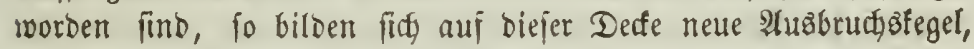
aus deren Eeiten oft glühende Eavafitröme hersorbredjen und ben Boben burch Ueberfließ̈en erhöhen, bis endida einer biejer Etröme lïh über Den Siraterrand ftürzt und eine Gtrefe am Berge finabs flięt. Sit ber Bulfan hod, io fint die Dämpfe oft niđjt fräftig genug, um die Sava bis zur Rratermünoung zu erheben, ober es

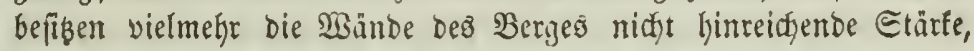
Dem Drufe Der genaltigen Ramajäule zu wiberitehen. Dann bilbet fíd eine Geitenfpalte, auz weldjer bie \&ava oft mit ber Şeftigfeit

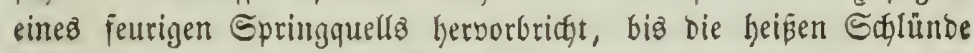

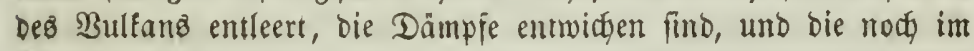
Srater fitlyenbe Saya ourdy feine empororängenden Bewalten mefri gehalten, ifher Edgwere gemäß wieder in bie Tieje himabjinft und Die Tridgtergejtalt Dez Rraters wieber heriftellt. $3 \mathfrak{u}$ ben jeltneren

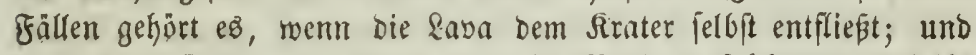
aud bann finto eż immer mur nicorige Bulfane, foldhe, beren Şöhe

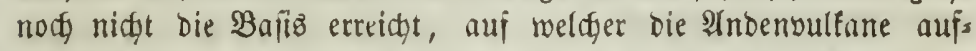

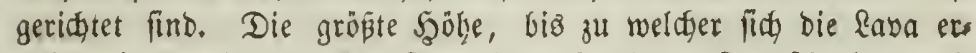
hoben hat, zeigt ber Ŝliutidjemôtaja = Eopfa in Siamtidłatfa, wels đgem im Eeptember 1829700 Fuß unterhalb dez Bipfelz, alfo in

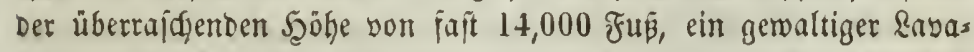

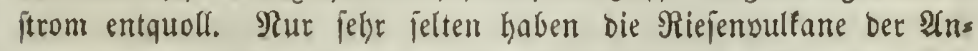

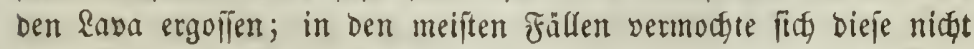

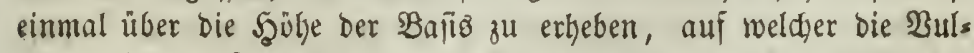
fane rufyen, alio audh nidjt bie Seitenipalten zu eröfrnen, auz bes nen fie an das Tageslidgt treten fonnte. WBabridgeinlids gewinnen 


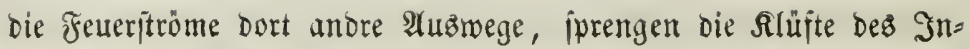
nern und erfüllen unterirbijate Epalten mit ifrem frembartigen Beftein.

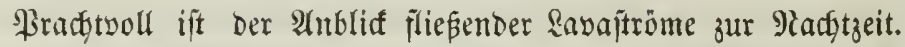

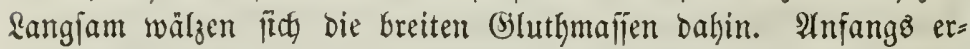
glänjt ein eingelner feurigrother ßunft, bald folgen ifym taujend an= bere, und blikfidnelf theilt fich Das Ridut wie ein laufendes Jeuer Dem langen Etreifen mit, ber hier einfach, Dort äftig, ober fidh freuzend, vom Frater und auz Epalten Dez âbhangez zum Berg=

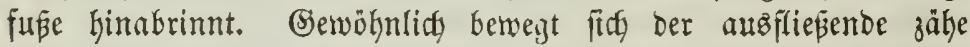
Savajtrom jefr langiam vorwärts, wenn er nidy etwa einen fiteilen श्Abhang hinabftürst, wo er vft jeurige Sagtaben von mebreren 100

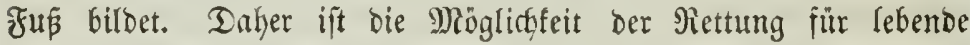
Wejen ziemliç leicht, jumal ba nan in vielen Făllen jogar über einen fliekenden Ravaftrom ohne Befahr hinïbergelangen fann, weil

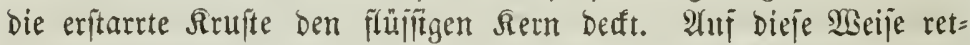
teten fith Die Nonnen eines Nlojters in Torre bell Amunciata über Die eritarte Deffe emes 50 Jup breiten Ravaftroms; und bei ber Berftörung von Torre Del Greco im Sabre 1794 trugen jogar

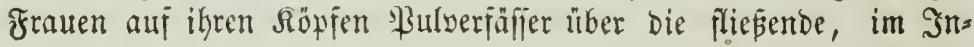
nern rothglïhende Rava hinmeg, Deren zahlreidge Epalten eritifende

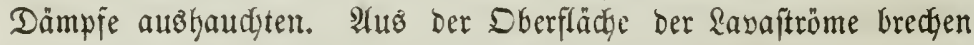
gewöhnlidy flammen herbor, weldye man ben unter ifnen brenten=

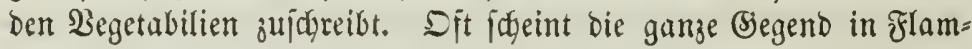
men zu jtehen, uno bie sujt jelbit entzundet ju jein, während un= aufhörlidy Blikge jelbft bis in grope Entjermungen zufen. Dbgleich die Slühbike Der Lana vielleidyt Dem Edymelzpunfte Des Supjer

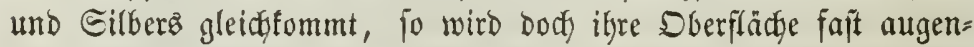
bliffidy feft, jobald fie bie Atmoiphäre beriblyt; aber bie erftarrte Sinde beritet aud wieber mady allen Pidytungen, uno aus ben Spalten fteigen Dämpfe herbor. Im Innern Des ?avajtroms aber concentrirt fids bie Şize und bleibt oft Sabre lang. Der englifde

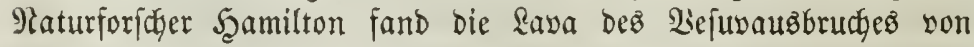

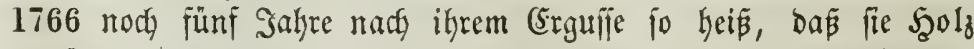
entzündete; und bie ungeheure, im Innern an einzelnen Steflen

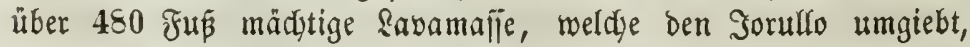

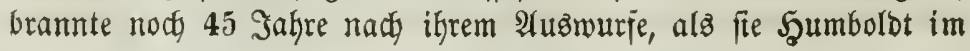


Jahre 1803 bejudte. Die Urjache biefer langfamen Abfüflung im Innern liegt wohl Darin, Dap bie erftarrte vbere Rinde ber Rava,

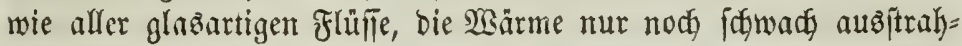
len läpt. Unter heftigem Sirađjen billoet fith biefe ftarre Edylaten= rinbe, welche bem fließenden Snnern zur Decte bient. Şin uno wieber wird fie emporgeboben, berftet, trennt fith in Stüffe, burdy fitets erneuten 3uflup georängt, uno finft entweder in Den (S)lutfs= flü hinab ober jeget fich ju beiben Eeiten bes Etromes feit. Eo geitaltet fid eine 2 rt bon Sanal, in weldgem bie Rava flieft, ber

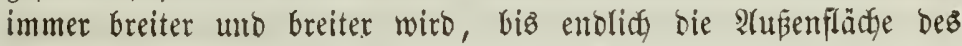
Stroms gang erfärtet und bie am Sirunde fließjende \&ava überbrüft. Daher tommt baz wujte unb wilde Amfehen ber meiften Lavajtröme,

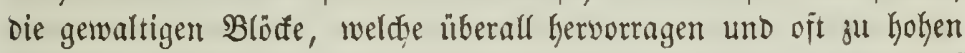
Bälfen aufgetlürtut funt, baher bie Röber uno Bertiefungen auf

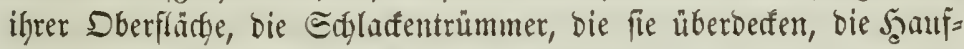

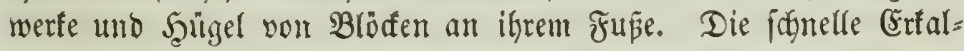
tung ber Savaftrome an ifrer Sberfläde ift auth Der Sirund, wes: halb bas Ergießen ber Rava in bas Meer ofme alle heftigen Ex= plofionell vor fid geht. 3war wirb 21nfangs eine Menge $\mathfrak{B a f f e r}$ zifdend in Dampf verwandelt; aber Das augenblifflidge Erritarren Der Sberflädje hindert jebe weitere Berübrung mit ber glïljenden Rava, und bie entftefenden Epalten maden burd bie augenblif=

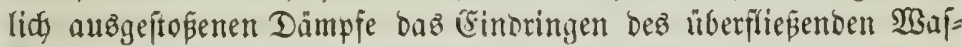

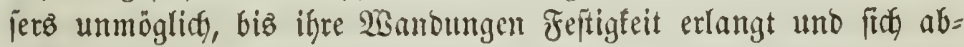
getühlt haben.

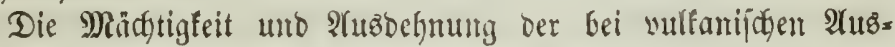

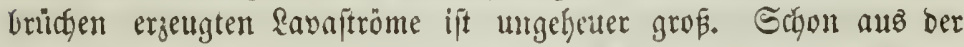
Ferne erfennt man fie in ber Ambichaft. Welfenförmig burdjiehen

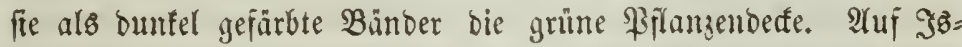
land fieht man ganze Thäler mit Rava erfüllt, gewaltige Jels̈maffen ragen in Den jeltjamften (Seftalten, sfit Ruinen alter Baumerfe gleidy, oruheno empor. 3mei Etröme des Efaptar= Mötul bom Jahre 1783 haben bei eitrer \&änge von jmanjig uno einer Breite

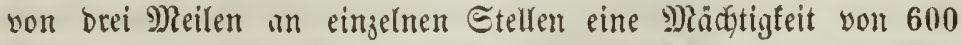

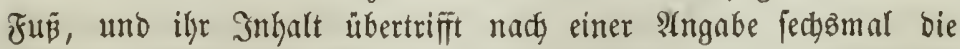

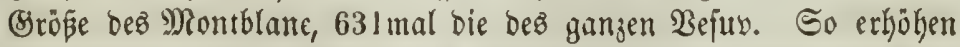
folche Ravamaffen ben Boben in ber Umgebung ber Bulfane aufer= 
orbentlity, und oft reidgen fie bis in unbefannte Tiefen unt meilen=

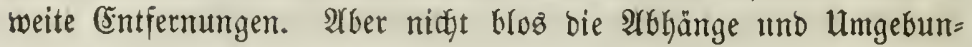
gen bes Bulfans ütertagett bie \&ava, jonbern fie bringt aud) yon unten in bie Silüfte unt Epalten bes angrenzenden Bobens ein,

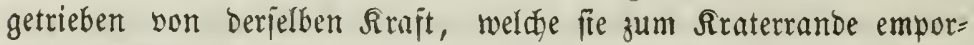
Gebt. So bilden fíd Bänge, bie mit Sefteinarten angefüullt finto, bie von betten ifrer lumgebung gans abiveidjen, und man findet folde nidyt blos in Der 9iähe ber Burfane, fonbern oft and in weit von aller bulfanifden Thätigfeit entFernten Begenden. -

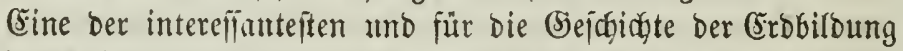

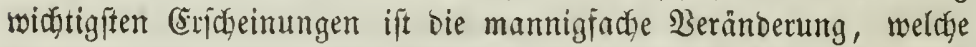
theils burd) unmittelbare Berührung mit ber feurig = flüfügen $\mathfrak{R} a \mathfrak{\text { a }}$,

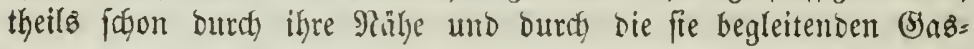
arten ambere Beffeinarten erleidert. Man fápt alle biefe Umwand=

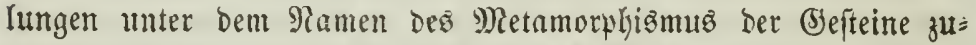

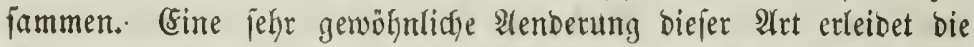
Farbe, indem burdy Die Şize ber Saya ber organijafe ober metals

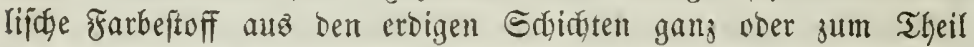
veriagt wiro. Die ictwarzen Thonjajiejer merden heller gefärbt, weil fidi bas Bitumen verfilütigt hat, andere Thonlager färben

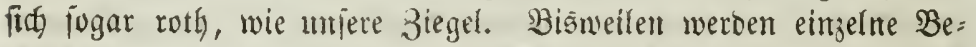

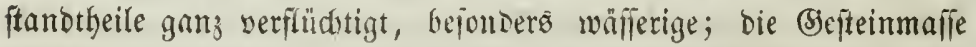

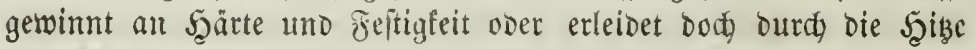

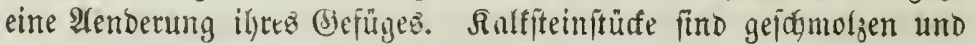

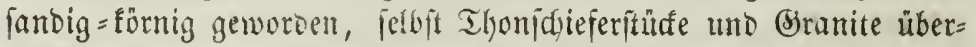
glait oder aufgebläht und zum Tleil veridgladt. Wair werben fpäz ter barauf jutiniftommen.

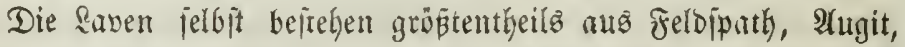
Seuzit, Titan = und Wragneteifen, unt man unteridyeioet fie butch bie yorherrichende Mlenge bes cinen voer bes andern biejer Mines

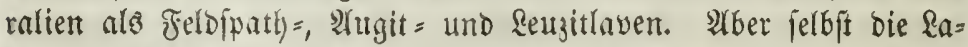
wen befielben Bulfans zeigen fo auffaltento Unterictiede und gehen

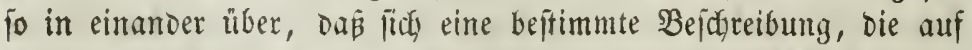

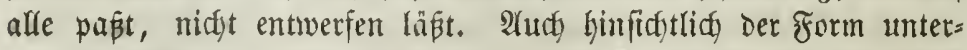
fópeibet man fie als eroige, Etein= uno Bjtağlaven. Die les̆teren entfalten bejonderz den Dbiibian, eine fajwarze, wie Brlas flin.

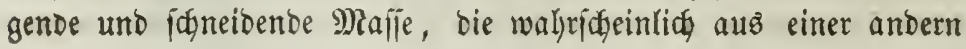




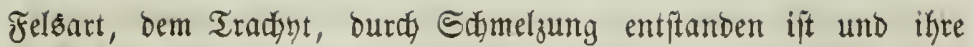
glabartige Natur einer fehr fognellen Arbfühlung verbanft; benn Berjucte haben gelehrt, Dn gefdymolzene Mlineralmafien, wie bie

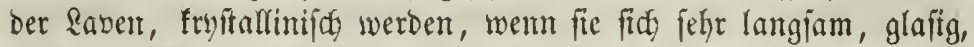

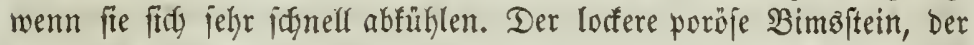

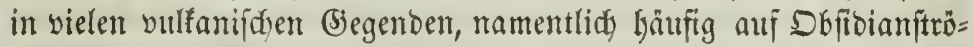
men gefundent miro, ift gleidger Ratur uno gleichen Utriprungs mit Dem Sbftion. Seine idjaumartige Bejdaffenheit ringt nur yon oen Kef́tigen Gasentwiflungen in ben glühenden Mafien her. Wenn bie Erfaltung ber fluififigen Mafie langfamer yor fidg geht, jo erhalten wir bie Steinlaven, weldye granitifje Keifen, wenn fie

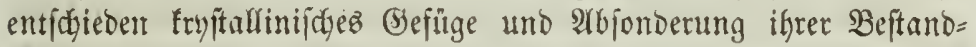
theile in grö̈en \$arthien jeigen, ober \$orphyrlaven, wenn mur

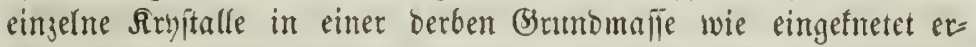

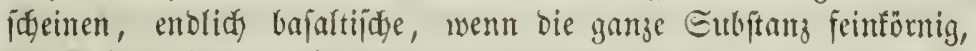
bie Bejtandtyeile innig uno gleicfmääig gemijogt finto. Bei ganz allmäliger Ertfaltung erhalten wir zuleę̧ bie eroigen faven, bie,

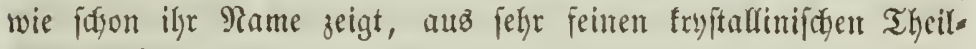
d)en beiteflen.

F(ud) alit bieje Fenterergeugnifffe ber Ratur habent Sumit uno

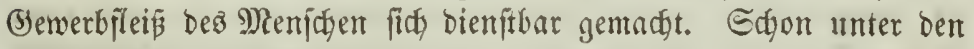
Urbenofnern Merifoz fpielte ber Sbfibian eine widftige Rolfe; er vertrat ifhen Gijen umb Fenterftein. Sifeilfpiben, Etreitäxte uno Dpfermefier wurben aus biefem \&avaglas gefertigt. Die Epanier

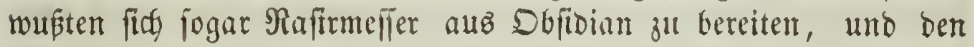
Römen lieferte er mady Sł'tiniug' Beridyt das $M$ Raterial zu pradjt= vollen Epirgeln, weldye aber midht bie (J)egentiannoe mit ilyren Far= ben, fortbern mur Deren Edyatten wiebergnten. 2titz bajaltifden

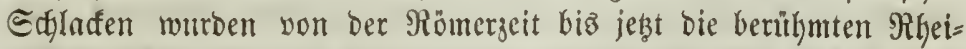

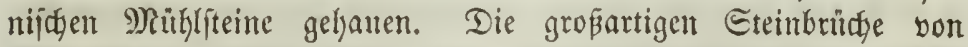

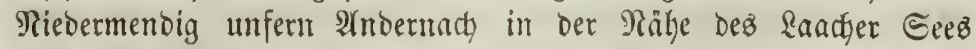

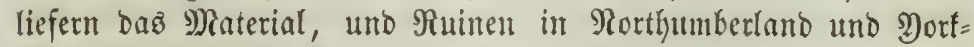

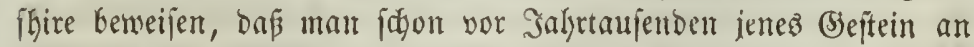
weitentlegenen Drten zu Genub̧en wuß̈te. F(udy vulfaniidge Tuffe werben zu Baufteinen, Brumneneinfajiungen und Irauffteinen be= arbeitet. Bejontoerz fint es wieber bie mäctstigen Trapablagerun= gen am Rieberthein, weldje bas Brohtthal und feine Umgebungen 
erfüllen, von benen der mannigfactite Sebrauch gemadth wirb. Bald mahlt man ben Trá̧ zu Pitulver uno bemukt ifhn, mit Salf verbunben, alz Nafilermörtel; bald ipaltet man ihn in Dunber für fefte Baumerfe, Fejtungen, Thürme und Ectlölier; bald bient er, wie Der berüfymte Beiberftein, zu ben feinften Bergierungen, 子u

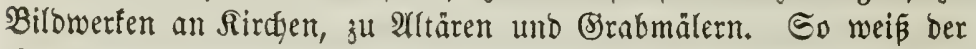
Renfich bie tobten Zeugen einer blinden und zeritörenden Raturs

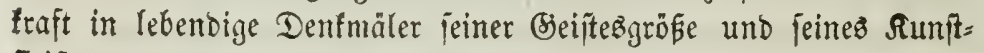
fleipes zu verwandeln.

\section{4) Die erlofdenen $\mathfrak{B}$ ultane.}

Rady biejer Betractumj Der jeşt herrjąenden vulfanijđen Thá tigfeit unferes Erbimnern uno ihrer Erseugnifje müfjen twir aud einen Blid auf bie erlofdyenen Bultane merjen, iene Zeugen einer rebensiregung, bon meldyer zwar jebe Heberlieferung fobweigt, bie aber bod einer Beriode anjugehoren fateinen, in weldaer unire Sontimente ifre jesige septalt ifon gröbtenthels erbalten baben modsten. Im .Allgemeinen fann man diejenigen Berge als erlo=

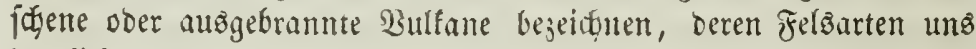
beutlich zu erfennen geben, ous fe früher in einem mefyr ooer min= Der. feurigen frnjle gemejen into, wie Bajalte, Dolerite uno Tra= dyte. Aud bieje Sejteine fino wie die Raven unter Mitwirfung

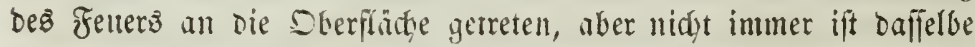

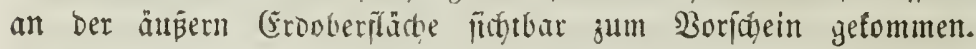
Ran fonnte baher, wolle man ifärier unterideiden, bie fo ent= ftandenen Berge von Ier 3 ahl Der eigentlids jogenanuten erfojdyenen und ausgeframnten Butfane ausichlieken; immer aber wirb man fte

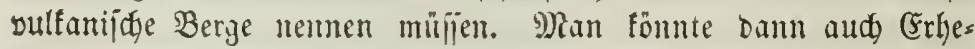
bungen, bie ifre Entitefung aurgejuntteten Etoffen versanfen, wie fie nody jebst aus ben sratern brennender Bulfane ausigemorfen

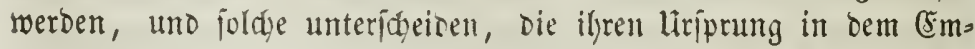

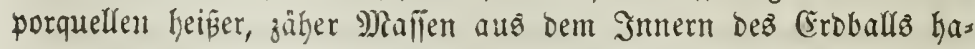
ben. Dergleiaen Berge bejtehen aub Bajalten mo Doleritem, bie überall, no fie bie liber ifynen befindlicke Crotrufte burdybradsen,

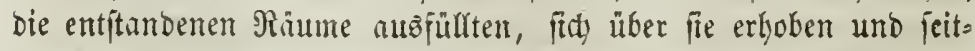
wärts abfließ̄end eimen Theil biejer Srufte überbecten. SBill man

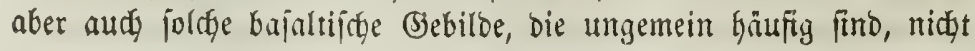


孔u Den erlofđenen $\mathfrak{B u f f a n e n ~ z a ̈ h l e n , ~ f o ~ w i r o ~ m a n ~ w e n i g f t e n s ~ b i e = ~}$ jenigen $\mathfrak{B}$ erge, bie nod Epuren früherer Sirater und felbft Raven aufweijen, bie bon ben bajaltijøen Seiteinen aber fकwer zu tren=

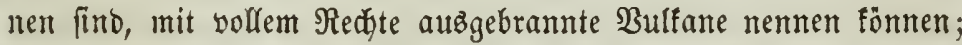
wiewohl bann wieder bie Edwierigfeit eintritt, zu beftimmen, welche

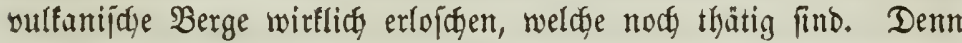
bie Entftehung nener Bulfane in Giftorifder 3eit an Drten, bie

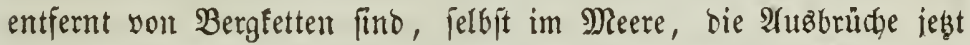

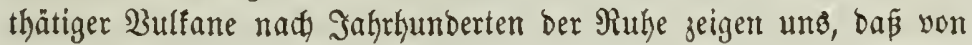
feiner Begend ber Groe berfidyert werben fann, fie fei von (B)= fahren ber vulfanif̧̧en Thätigleit frei, wie ja audg bie mit ben Bulfanen fo innig verwanden (Erobeben nidyt leidyt einen \$unft

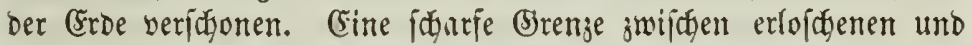

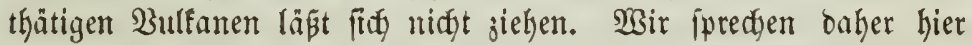
non vulfantijđ̆en Billoungen überbaupt. Die älteren vulfanijđen $\mathfrak{B i l}=$ bungen unterideiten fid von ben jüngeren, nod unter unjern $\mathfrak{A} u=$ gen vorgehenden bura bie Sröpe ifrer Berbältniffe und beuten baburdy vielleidyt auf eimitige gewaltigere Sirajtäuperungen bes $\mathfrak{B} u=$ faniżmıż, auj eine beftigere Reaftion bes Crbinmern gegett Die Sber= flädse, wenn tie ifren (Brumb nidyt in einer vormals bümeren (Ero= rinbe Gaben, welde ben emporbrängenden Bemalten geringeren Biberitand zu leiften vermodite.

Unter ben aubgezeidneten älteren vulfantiduen Rambitriđen er= wähnte id oben jogn bie niebertheinifaen Bebirge, befonders bie (Sifel mit ifren 9aaren, die franjörifen Randidaften Binarais und Belais und bie 2 (uvergue mit ifren 50 Edyladfentegeln, oen

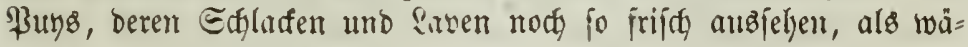
ren fie eben erit ausigeworfen.

Rirgends hat bie vulfanifue Borgeit die Epuren ihres Feuers auf einen engeren $\Re$ aum zujammengebrüngt, als am \&aadjer Ece.

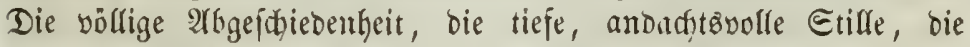
über feimer Flädge uno an feimen Ufern herridut, verjeģt ben $\mathfrak{B a n =}$

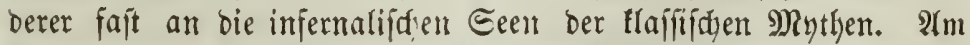
Ranbe eines jiemlid fteil abjallendent Refjel Bafferbecfen son fajt regelmäßiger Runbung. Ringo umzieljen ben Eee walbige 5̧öhen, bie fidh ojt bis an feinen Rano hinabjenfen, bismeilen einen idmalen Saum oben Uferjanbes voer fleiner $\Omega$ ar= 
toffeläđer frei lafler. Wisenige Bädje riefelt bort ben Bergen herab,

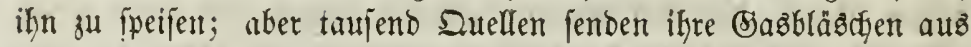

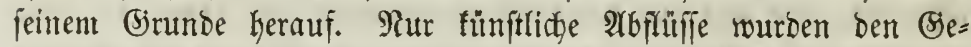

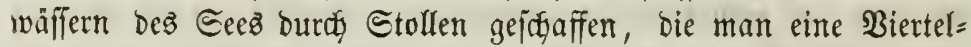
ftunbe weit burch bie Berge treiben muste, bamit nidjt ifre Meber= iftwemunungen bie Berwohner ber nakefiegenden 2tbtei gefährbeten.

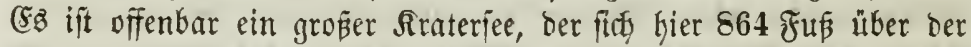

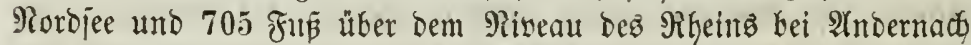
über eine Flädye von metr als 1000 Morgen unb bei einer Tiefe

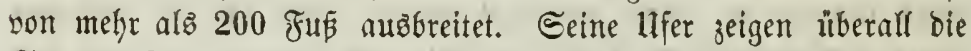
Epuren feiner ftürmijaten Seburt. Şier ift eine Sinube, beren Sohleniäureausftrömungen bie fleinen $\mathfrak{B o ̈ g e l}$ töbten, weldse barin ifr Futter fuofen; einte jener Mivfetten, wie fie fich in ben $\mathfrak{u t m}_{\mathrm{m}}=$ gebungen bez $\mathfrak{b e j u s ~ n a c h ~ j e b e m ~} 2$ uzbructe bilben. Dort treten bie

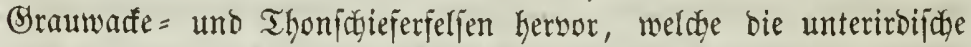
Gemalt einit Durdjbrach. Solojiale Bajaltblöfe fojauten brohend auf ben Banbrer nieber, unb Bimsiteine uno Yifden, bie mit

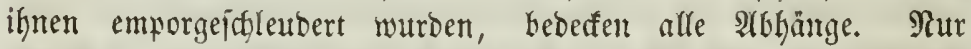
Ravaftrỏme entrifoilen bem Srater nicht. (Es war vielmegr bie furctitbare Semalt ber in Intmern ber (Groe gefpannten Dämpfe, melche bie felfige Ërorinbe in ber ungeheuern 2 tużbehnung bes Eeez emporfob und auz ifrem 3ufammenthange ríp, fo da fie nact bem Entweidfen ber Dämpfe uno afjefen wieber in fich zu= fammenbract, um den tiefen গefiel bez ๔eez mit feinen Epalten unto Slüften ju bilisen, in weldje bie Queltwafier fich jenfent fonn=

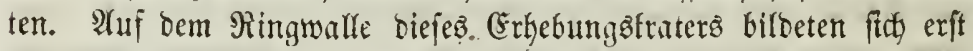
bie mirflidyen Siuffane, aus benten Sayaftröme fertorbraden. Der

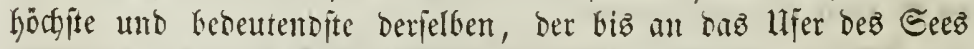
voripringt, ift ber אrufferofen mit feinem impojanten, 4000 žน langen Siraterfejiel, ber find una aupen burch eine jidjmale Edyludyt offrnet uno im Innern einen Teidy umidgliest, beffent Epiegel noth

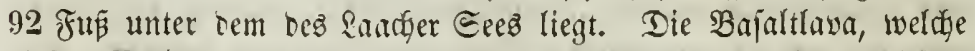

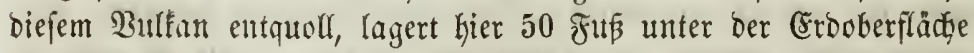
als eine 40 ₹ú mäntige, ojt in folofinale, vierertige Säulen ge= fpaltene Edyidgt über Dem Topferthon ber Braunfohlenformation,

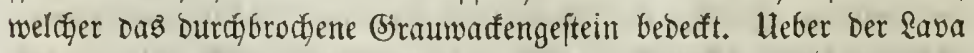

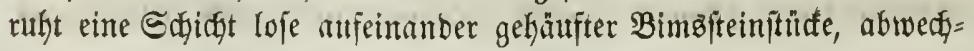


felnd mit Ragen einer lehm = und trapartigen, fum Theil von Damm =

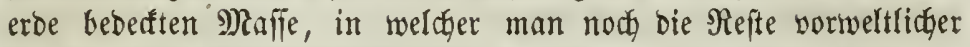

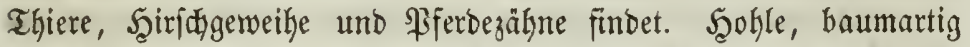

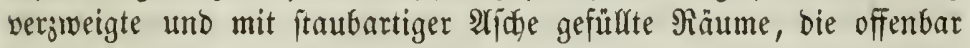
einer jerfitorten Begetation ifren Mriprung verbanfen, Durchgieben

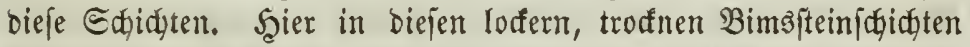

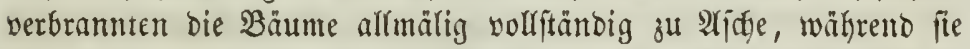

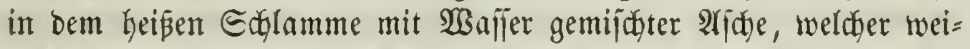
terhin die Tuffiteine und Traffe bes Brohlthals uno ber (5)egent son Riebermendig bilbete, nur verfohlen fornter.

Selbit mann bie Burfane ber Cifiel ioj gerftörendez Epiel trie= ben, wann igre Feuer brannten, igre Bjuthenftröme flofien und ifhe Aidjen = und Steinregen nieberfanfen, bentet ber Boden uns

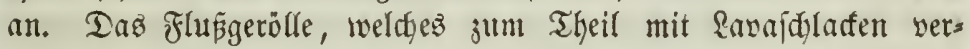

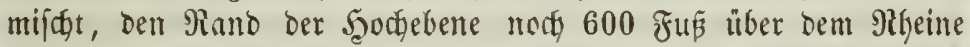

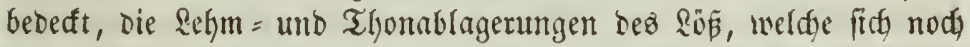

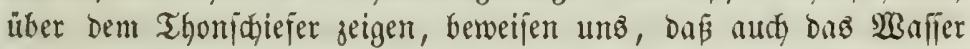

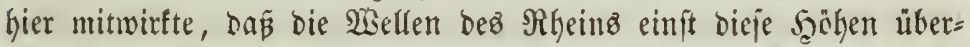

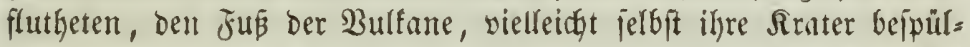
ten. Der Birloge bezeidhet jene 3eit, weldye ber gegentwärtigen

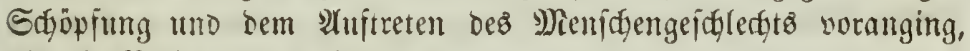
als bie \$erioce bez Dilustumb.

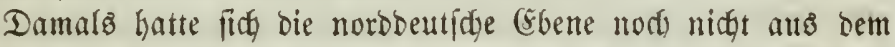
Meere erboben, und bie 230 gen eineß grofen Pordmeer\$ brantetent

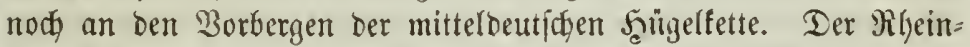
gau war ein weiter Binnenjce, beffen Waffier der Migein Durds einen engen Felienipalt bei Bonn unterlyalb des Eiebengebirgez in einen weiten Meerbujen aGfübrte. Glephanten, Tapire, PFerbe und Şir=

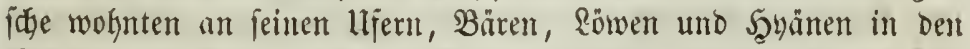

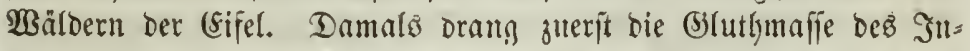
nern flüfifig ants dell Siratern ber (Erbe herbor, von Dämpien gelyos ben, Glafig aufgetrieben uno in bie Ruifte zerfitiebento. Biefleid, war es jene leb̧te gerwaltige Naraftanitrengung bei Errhebung ber

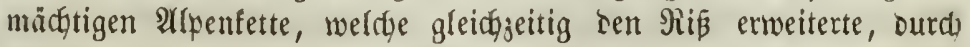

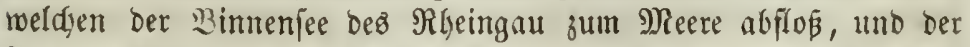

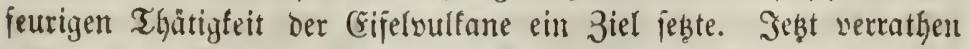

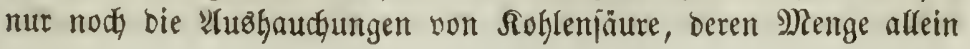




\section{8}

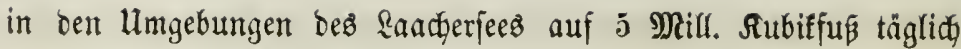
geiçägat wiro, bas früfere Reben.

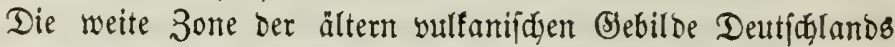
zieftr fich von ber Cifiel burdy bie rheinijden Bajaltgebirge in bie Trappe bes Eiebengebirges, den Beftermald, bas Bogelägebirge,

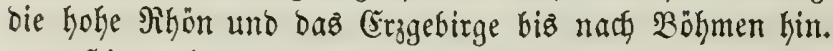

Şier erfebt fith mitten in Der meiten Ebene beż Egerlandes,

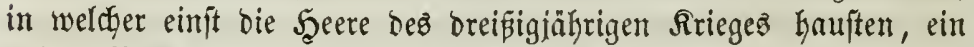
fleiner $\mathfrak{B u}$ ufan, eilt wohlerhaltenes Denfmal aus ber feurigen (Se=

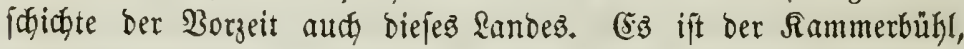
ein Şügel, Der faum 75 Fुน auffiteigt, welche bas Egerthal son bem Thale von Franzensibum ifeibet. Dem $\mathfrak{W}$ andorer, ber nidjt gebantenlos auf jeinem $\mathfrak{B}$ ege

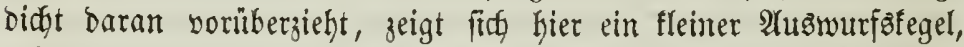

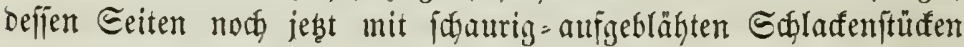
bebeft fint, bie an jeiner 2 Beffjeite namentlidy zaflreidje wageredute Sctidften bilden. Aluch hier fielyt man, wie in ber (rifel, jene

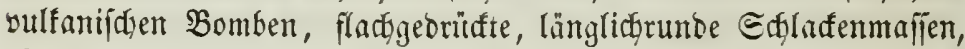
oft yon einem fü im Durdymefier, weldye eafige Duars= uno

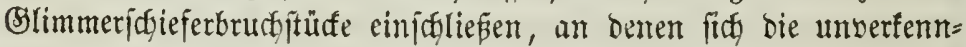
barjten Epuren fentiger Esinmirfungen jeigen. Bisweilen find fie io burch unto burds verglajt, gefdgmolzen ober mürbe gebrannt uno mit einer fo frifden હdyladfenrimbe bebeft, bur mast glauben mödte,

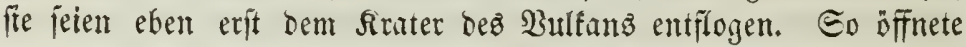

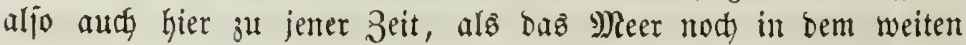

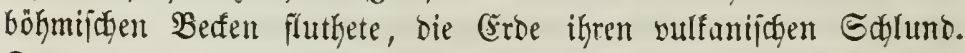
Tort wo ber Bajaltfeljen zu Tage jteht, quoll bie Rava hersor, uno

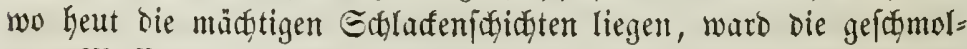
zene Mafie in Das Meer geiffleubert, erfaltete uno zerrís in viele Etürfe, bie vou ben Fluthen fortgefülyt, allmälig nieberjanten uno fich fófichtemweis auf bem Meereşovoen ablagerten.

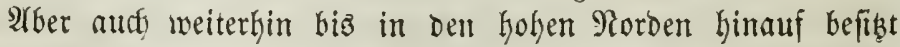

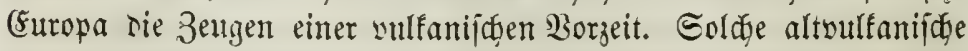

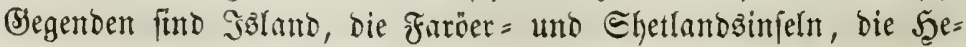

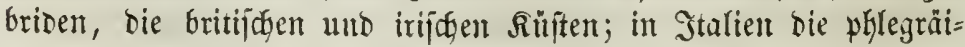

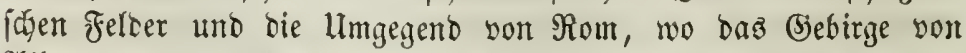
Altbano uno Der $\mathfrak{M}$. Cimini bei Biterbo (Eentralpunfte ber vulfas 


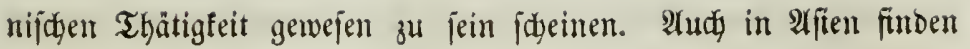
fid) viele erlojhene Bullane. Die Zerjtörung von Sodom unb

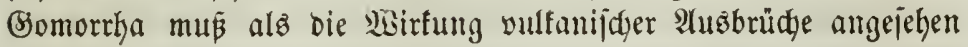
werben, und bie Grobeben in Eyrien bezetgen bie noch fortbauernbe Thätigfeit bez vulfanijđen Jecerbez ber Dortigen Fetterberge. Die Segend von Safia bei Sermillem ift gang vulfanifd, liberiäet mit Ravajtüfen und Bajalten, voll Spalten und Heiner Rrater. VIme= rifa ift yollends reidy an brennenden und erlojdenen Bulfanen,

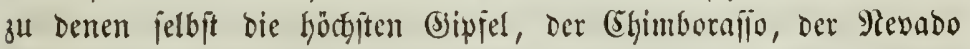
be Toluca uno andre geljören. Alud dieje altwulfanijoben \&aven, Die Dolerite, Bajalte und Tradyte hatten bei ifrem (Emporqueffen, wie bie heutigen, eine Mietamorphoje joldger Sejteine zur Folge, mit benen fie in Berühnung getommen fino, oder Denen fie fith genä= hert haben. Folgen Davon waren Aenderungen in Der Farbe, $3 \mathrm{u}=$ nahme an Didytigfeit, oder eill erlangtes tryptallinijtes Sejủge, Spuren von Edymelzungen und Derglajungen. Bajalt = und Dole=

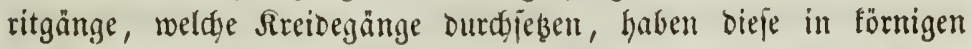
Marmor uno isländiften Doppelpath verwandelt, ober in (Syps

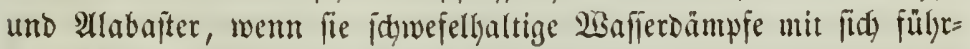

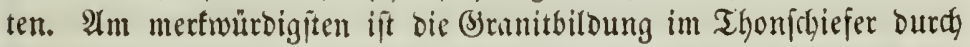
Berührung mit Bafalt und die (Ergetgung einer gropen Dienge felyr fơöner Rryjtalle, bez Bejupians und Alugits, weldse fith an ben

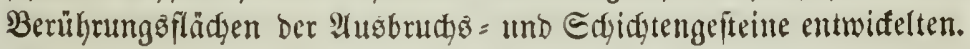

\section{j) Die Urjaden ber $\mathfrak{B}$ ulfane.}

Die gejammen vulfanijdyen Erjojeinungen find offenbar Fols gen gewaltiger Rraftäuperungen bes Smtern unjers \$laneten. Das rum irrte bie Borgeit, wenn fie biejelben, wie bie Erobrände ber Eteintoblenflöge ober (Eijentieje, von lofalen Urjacben und vom Dajein gewiffer feuernährenber Єtoffe abjängig madte. Wir tön= nen uns nidgt io unerméplidge Borräthe bon Steinfohlen benten, Daß bie Jahrtaujende bauernoe Thätigfeit vieler Feuerberge fie nidyt aujgezelyrt bätte. Eteintohlen fino ja Heberrefte der Hiflanzemvelt, jüngeren Beiten angebörig und Darum nicht in jo ungelgeuren Tie= fen gelagert, wie jie bem Szeerde von Bultanen zuertannt werden

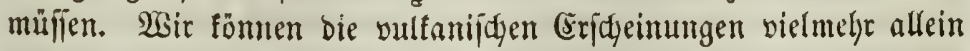
bon ber $\mathfrak{B a ̈ r m e ~ i m ~ I n n e r n ~ b e r ~ E r b e , ~ b i e j e r ~ a l f v e r b r e i t e t e n , ~ u ̈ b e r a ̆ ~}$ 
fich vertủndenden Madt herleiten. Shre unentbehrliden Diener

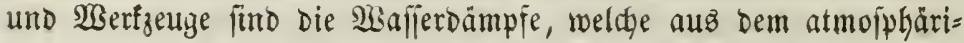

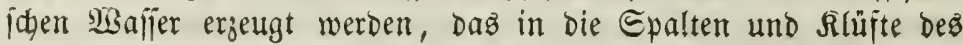
Bulfans einoringt, wobei natürlid das in bie (Eroe finfende Meer= majier bei am Mteere gelegenen Bulfanen, zu beren Şeero ez gelan=

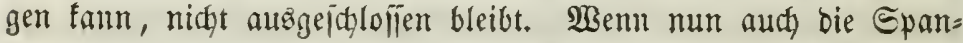
nung ber Wrallerbämpje bei einer Temperatur, bie ihnen ourd bie Echmelzhifize ber \&aven mitgetheilt wird, nidjt auşreiçen bürfte, um

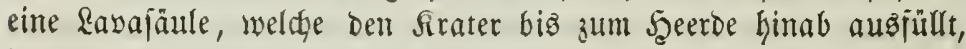

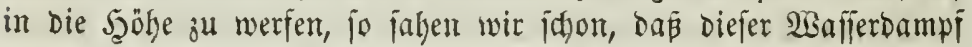
neben und ourdy bie gejdymolzene Sana aufiteigt uno beren obere

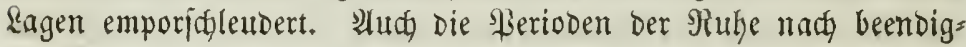

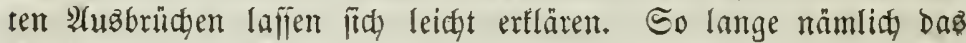

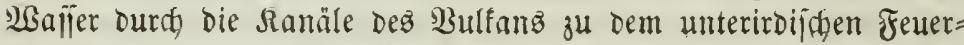

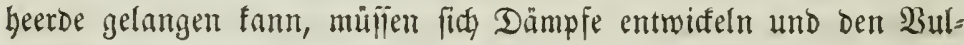

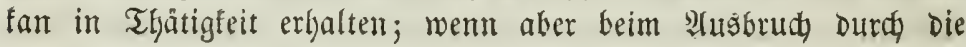

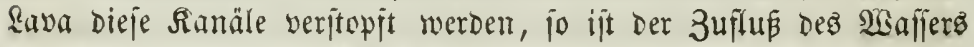

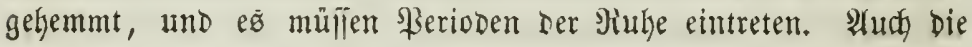

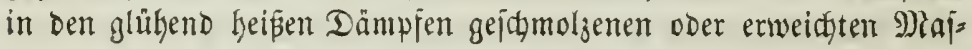
fen fönnen die siifje und Epalten in Berge verftopjen und Diejel= ben Folgen Gerbeifülren. Durdy die Dämpje merden aber niḑt

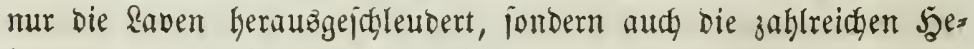
bungen und Die Errobeben bewirft.

Eime zufällige Erriçeinung im Rleinen gab, eine Beptätigung

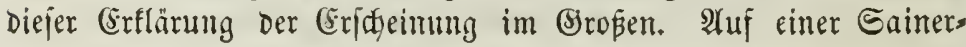

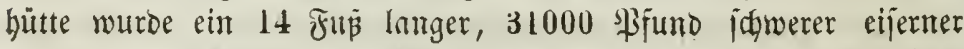

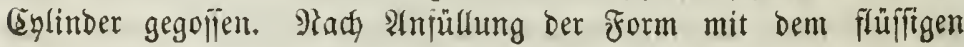

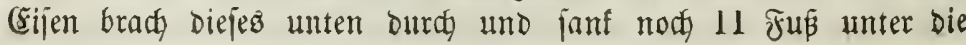
Form, alịo 25 ₹uk tief in den jandigen Boben. Bald darauf ers folgte eine erdbebenartige Erriøütterung von jolcher Şefitigfeit, oá

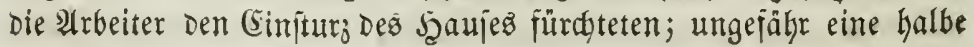
Etunde nadgher erjolgte eine zweite, mady 24 Etunden eine britte Erridüuttenung. Da nun ungejäh̆ in biejer Tiefe Sanäle lagen, meldye Das Regenwajier jammelten, jo wurbe burds bieje wahts fageinlid Waffer herbeigefüfrt, wofintr aud ummittelbar nad, bem Etope aus den Sanälen aufiteigende Dampfmolfen ipraḑen. Seidht

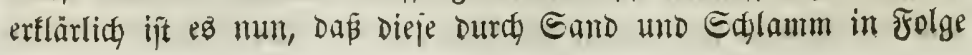


Der Erplofitonen für eine Zeitlang veritopft wurden, bis das $23 a$ jiler allmälig wieder zu bem hei bie Bafferdänpje uno andre (Sjaje, weldhe im Innern Der Crroe entwiffelt werden, Die Erridgutterungen Der (Erobeben erzeugen; und bedentt man Den imnigen 3ujammeng,ang Der vultanijđhen Thätig= feiten und Der Erobeben, jo fann man nidjt meljr zmeijeln, dá gleidge Urjactgen beibe herworbringen. Ulber ber seerd Diejer untheil= polfen bervegenden Sirajt liegt unjtreitig tiej unter Der Errorinde,

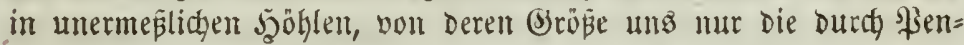

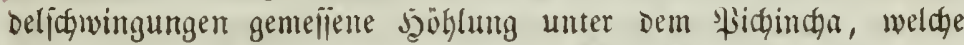

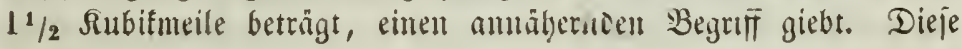
Şöhlen liegen aber nid̄t uur unter der C5jie Des Liulfanz, jondern

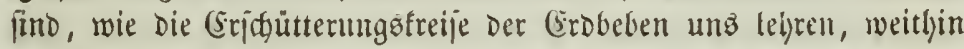

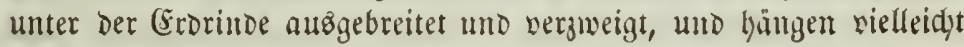
mit nod, grö̈eren in bedeutenderer Tieje zujammen. Wielleid)t ge=

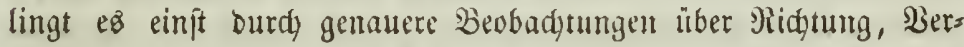

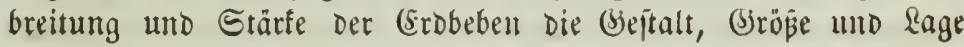

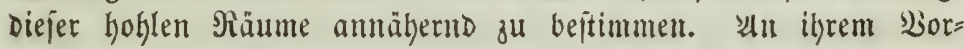
לandenjein bürfen wir midjt zweifeln. Dajür fpridyt der innere

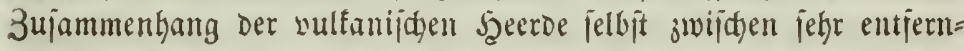

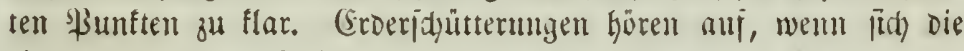

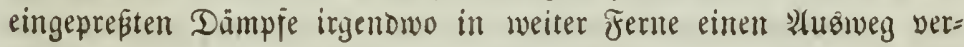

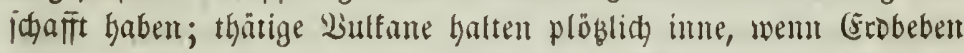
entfernte Begenden verwüjten, als ob Dort wor fint gehende Bers änderungen im vulfanijdyen Şeerde audt) im Bulfan bie gewolynte Thätigteit ftörten, Dem ofjnen Sdy/unde auj Beiten jeine Dampís majfen entzögen uno fie in ber Tiefe zurhidfielten. -

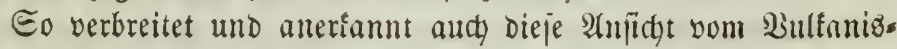
mus ber (Erbe unter ben Foridern Der Gegemivart ijt, fo haben Dodg in jüngfter 3eit Einzelne den Berjudy gemadit, 3u älteren

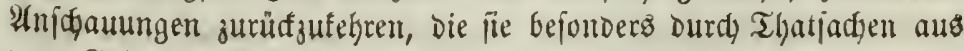

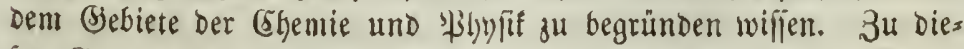

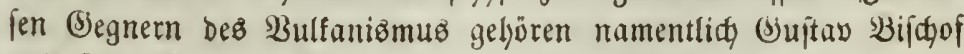
uno Dito Bolger. Eie lengnen die jeurige (s)luth) Des Eroimmern und efflären die Grobeben und Liulfane als $2 B$ irfungen unterirois idger Bergithinge in Berbindung mit demifden Berję̧ungen uno

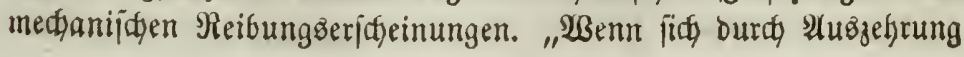


löslidferer Sđjidłten Şohlräume unter bem (S)runbe ber Thăler bil= Den, jagt Dtto Bolger, jo wiro baz überlagernoe Bebirge burch bie Epannung, mit weldjer ez auf bie zur Eeite dez unterfhöhlten bes

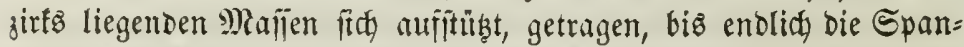

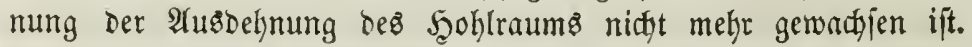
Rummefre erfolgt eine plöglidje Eenfung, entweder ein 3 ufammens rutijen bei mulbenförmiger \&agerung, ober ein itopíweifes Rieder= rüđenen ber unterböbltten Deffe. Dieje Bewegung bildet an ber

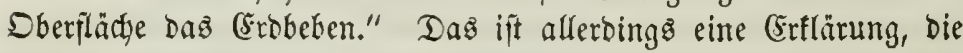

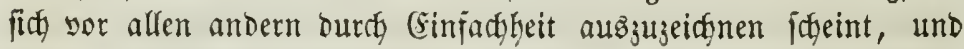

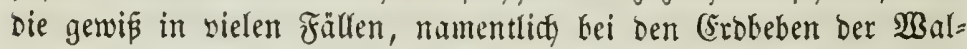

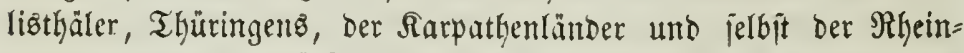

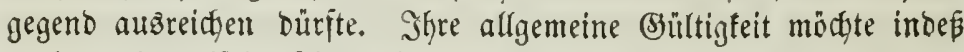
nod) зи bejweifeln jeir. Mam ift verjudyt von ihr zu jagen, was yon bem Heptunismus 2 Serners gejagt wurbe: jie ift auf zu be=

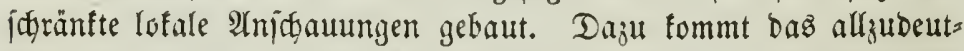

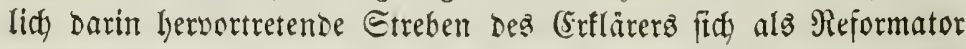

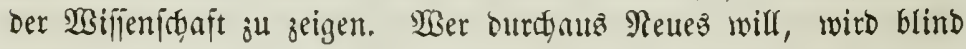

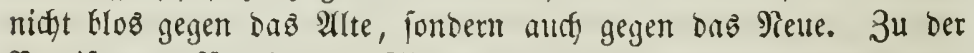
Begeijterung für die neue Theorie gejellt finch ber Fanatiomuz gegen bie alte; und man jeht in ihr niđht mehr das Ergebnis einer zur 3eit gegebenen Summe wilienjidaftlidjer Thatjachen, jondern eine

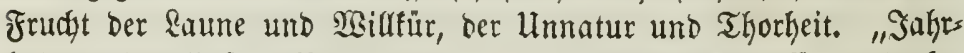
Guberte lang", jagt Bofger in ber Bitterteit jeines Şalfę, "bactete man aller Unnatur jum $\mathfrak{T}$ roţe mur an ben Sdywefel, bem man

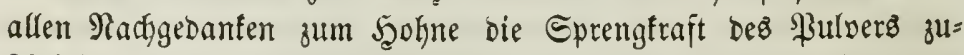
furreb. Eeit der Dampj Der Shöbe ber 3eit geworden, hat er es fein mülifen, weldyer bie (Erbleben erzeugt; - bods iffon broken

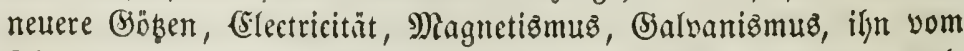
Throne zu ftö́en, unb fifon hat mandjer reblidje Sopf yon gal= vaimidjen 3urfungen Der Erobe geträumt. Der Dampj aber mußste

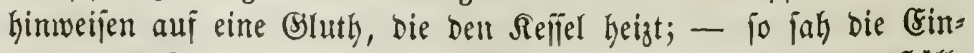
bildungafraft unter bem bebenden Boben bie Feuerftröme ber Şälle

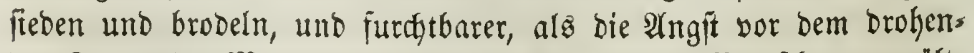
ben Sturze ber Mauern uno bem nieberrollenden Bergichutte, quälte Der Seedante an Das unter ben Sohlent wogende Fenermeer bie uns glüfticten Bewofgner Der von Erobeben heingejucteten Siegenden." 
BBürbigeren uno heiterernt Atridgaumngen nun will Bolger burdh jeine Anjidgt eine Etätte bereiten. "Damit Berge iallen," jagt

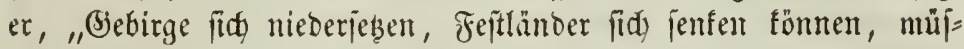

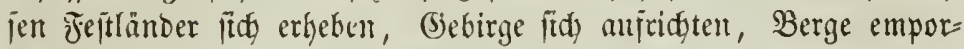
ftreben! Das Manfen Der Grojejte nerfündet unz nidgt ben $\mathfrak{U}_{n}=$

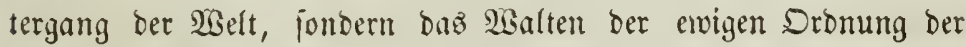

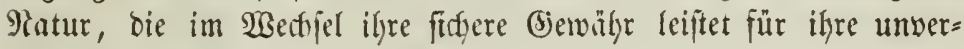
günglidse Treute!"

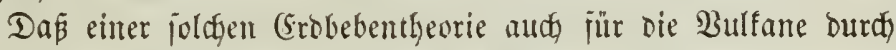
eine anbere alz bie bişher üGlidje Greflärung entfproden werben

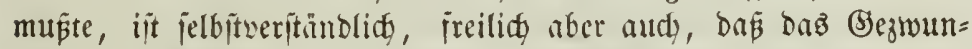
gene unto Rumitlde eimer jolden Theorie hier nods auffallender

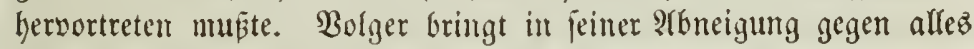

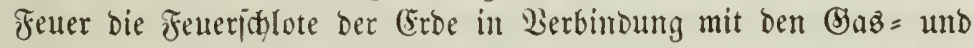

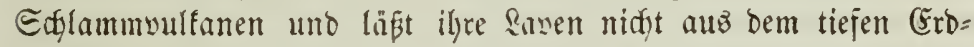
innern quelfen, jonbern aแ⿰ ähnlidy, wie bei ben jogenannten Faulbergen, aufigelöften uno ermeidten Bjefteinfichidten ber Sber=

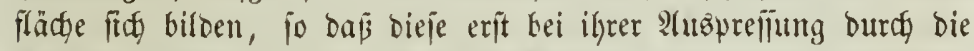

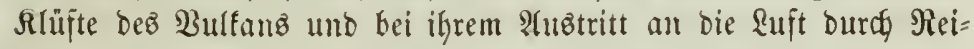
bung uno burdh Berbrestmung von (Bajent erglühen uno idfmelzen folten. "Wenn bie Gier wejentlicten Berhăltniīel", jagt Bolger, "in einter finfenten Bregend in Den Tiejen Dez Erobodenz ftattinden, wenn zu Faulbergen aujgelöfte 2 (ugit = und Felofpathgefteine gela= gert find über erweidften umb auzgelaugten, moderhaltigen, vollends

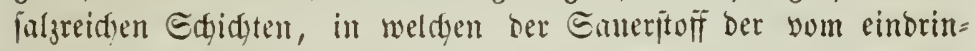

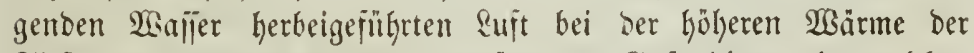
Tiefe zur Berbremmung ber ungep̈uruerten Baje bient, in weldfen

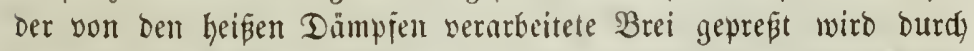
bie Rajt bes fintentden Bebirgez, wem das Sals mit ben Siejel=

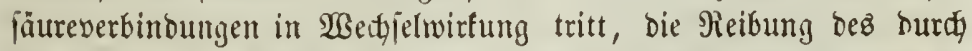

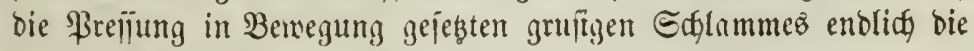

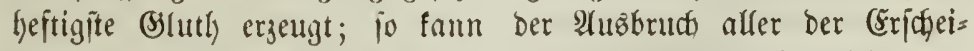

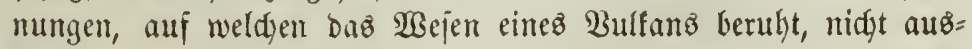
bleiben."

Beldyer biejer $\mathfrak{A n j u}$ idtent man mun audy den Borzug geben mag, Der ron einer Fenergefurt Der $\mathfrak{B}$ ulfane und einem (Emporbringen gefeljelter Dämpie, oder ber von zujammenftürzenden bebirgen unb IIle, weltull. 3. Auft. 


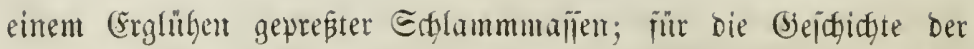
Groe bleift die Bebentumg des Bulfunizmms unverändert. atle Diefe bisher betracteten (Erif̧eimungen mo Edyöpungen ber wul=

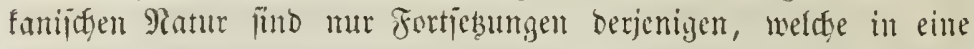

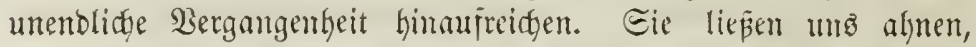

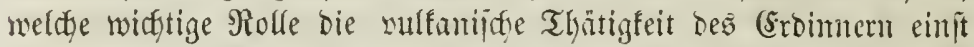
in bem grofen Drama jpielte, weldes unjer (Eroe ifre jetzige (be= ftalt und Bildung gab. Sier (bejteinarten waren es, weldye wir

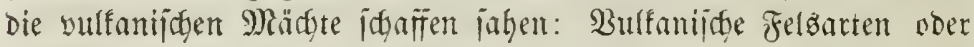
favagejteine, weldse im geidumolzenen 3uitanto kerborbradben, ge=

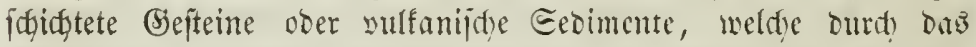

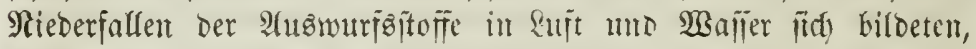
metamorphofitte ober umyenombelte (Seifteine, welde in ifrer in= nern Etmftur, Farbe mo Edjidtumy ourch Berührumy mit wulfa=

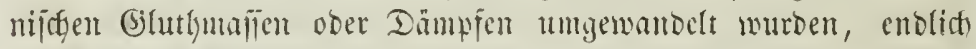
bie Fouglomerate oder Trummergejteine, ourd) Derfittung zertrüm= merter ungleidartiger felsanten entitumben. 9) lögen bieje $\mathfrak{B i l}=$

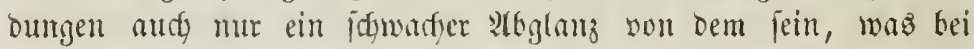
gefteigerter Thätigfeit oc Ěroentebeng in Dem chaotijđen 3ujtande Der Ilrwelt unter gümitigeren $\mathfrak{B}$ coingungen Des Drutfer und bor Wärme fowohl ber ganjen Crorinde, als bes mit Dämpjen gejüt=

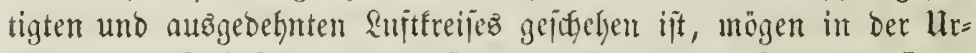
zeit weit riejenhaftere Fenergeifter gewaltet haben: fo warent fie es bennody nidyt allein, weldye unjer Erboberfiädye ifre Giejtalt gaben unb unire Erorinde erjüllten.

\section{B. Birfungen ber neptunijøen Siräfte.}

Der envig idgaffenden unb geiftaltenden, ong allte zertrümmern= Den, Reuez emportreibenben Rraft besె Feuers wirft eine andere Siraft entgegen, langfim und faum bemerft, aber mnarigejebt, weldge Prkes aubzugleidgen uno zu ebnen ftrebt, aber bemody in alfen ihren

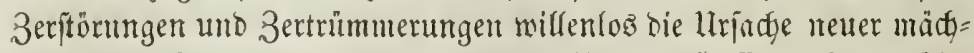

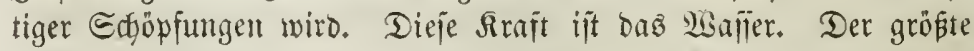
Theil ber Erorinde ift Das SBerf rufiger, langlamer Biloungen bes Waffers, wie wir fïe nodh heute ats Mieeren uno Eeen, flüflen und Duellen entitehen jeken; und bieje Bilbungen funo um jo wids=

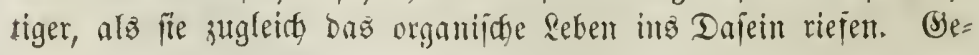


waltiam zeriprengten an weridiebenten Srten uno ju weridfiebenen Beiten die Bemalten Der Tieje bie nengebildeten Edfidten, hobent

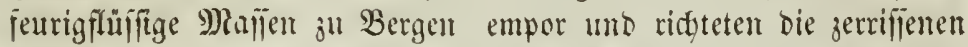

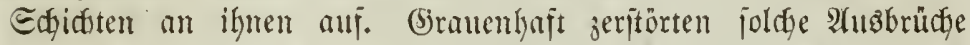

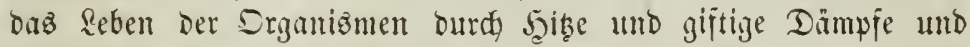

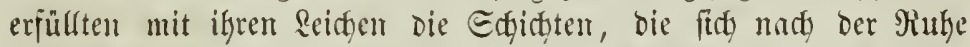

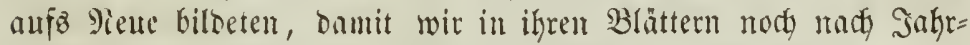
taujenden bie IIrgeidjidte unjerez (Sroförpers lejen fömen. Sente

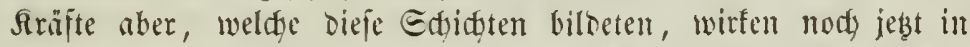

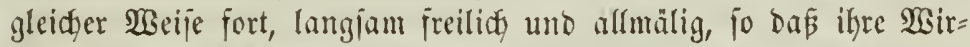
tungen unjeren Einnen erit nady einer Beige won Safurtaujenten jidstbar werben, in weldje jelbjt unjere ältejten Enigen uno $\Re_{(y)=}$

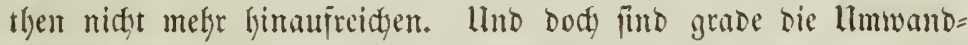

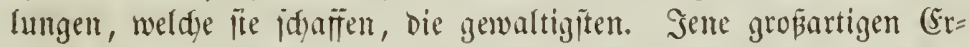
jajeimungen, weldye fie und ba plöblid mit ungemein in bie $\mathfrak{A} u=$ gen ipringenten 2 Birfungen lyervortreten, firt unbedentent im Ber=

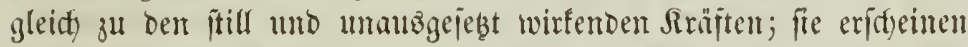

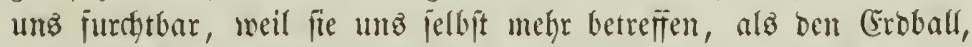

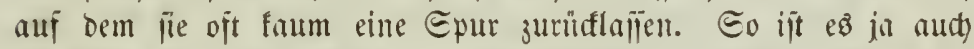
in Menjafenteben. Midjt bie angenbliffidjen, heftigen Regungen

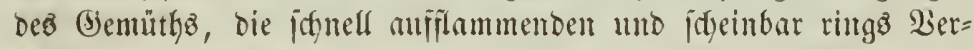
nidytung brohenden Reideniduften füto ez, welde bie Epuren Der

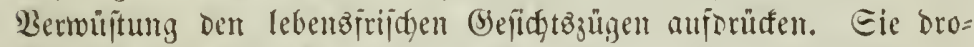
hen gewaltig, aber jie gelfen fidnell voriber. Die ftilfen seiben ber

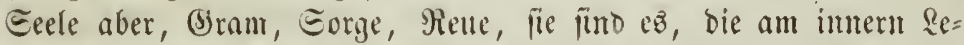
benżmarf nagen, bie unbemerft aber ficher bie Blitthe zerftören und

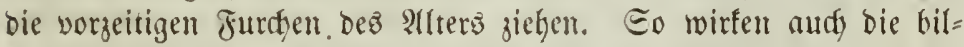

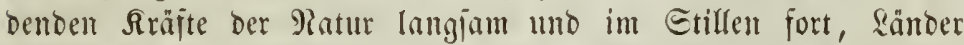

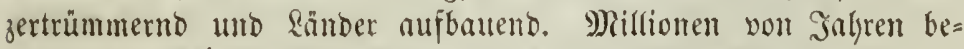

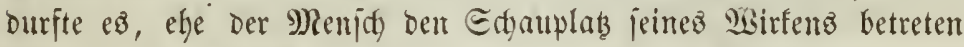
fonnte, ber vermejien gentig wohl glaubt, um jeinetwillen allein habe bie Edjöpungâfraft ber Matur gearbeitet, für ifn jeien un= natürlidje, gejebloje siejenfrajfte in Thätigfeit gemejen, um ihm eilento eitten Garten zu bereiten, in weldyem er thatentoz bie mü= fịgen Tage jeines Dajeint verträumen föınte.

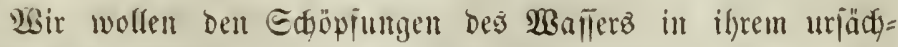
lidfen 3ulammenlyange und in ilger Bebeutjamfeit fïr bie (bes 


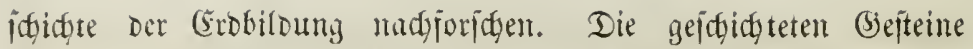
into Die Denfmäler ifgrer Zhätigfeit, weldge uns bie widtigiten uno

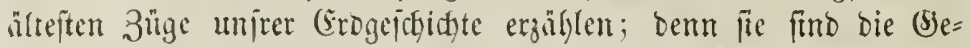
burtş = uno (Sirabitätten Der ganıen organijhen Welt, jener längit

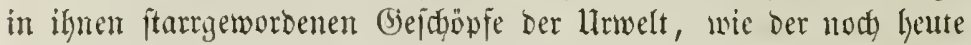

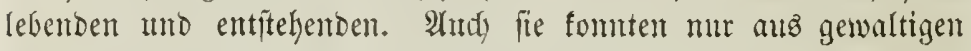
3eritörungen herborgehen; aber fie itammen nidyt aus ber llnter= welt, jonbern fint Trinmmer Der Geiteine ber Sberwelt, oft gerabe jener Majien, weldye die unteriroifichen (bewalten mit jo gropiem Rraftaupwand emporgeboben. Ier zerítörende jeind aber war baz

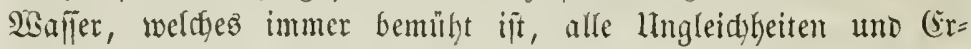

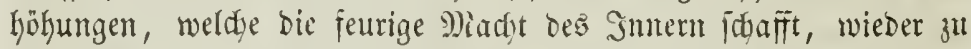

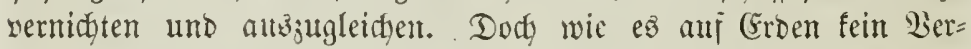
nicten, jonbern mur ein Berwandeln giebt, alles Zeritüren immer

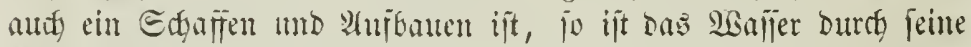
Auplöung uno Bertrïmmerung ber ieften (bejteine immer and zn= gleids Der Edöpjer newer Sebilde, newer Croblagen uno Felsmafien.

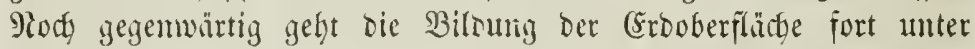

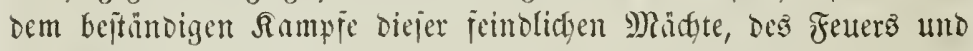

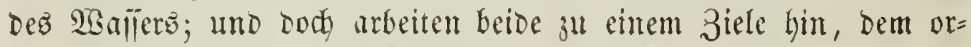

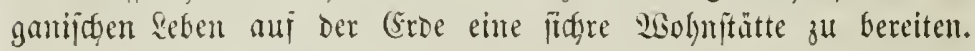

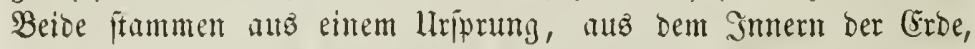
beide find Dudfen filüjïger Mlajien, bie son ben innern Gienalten

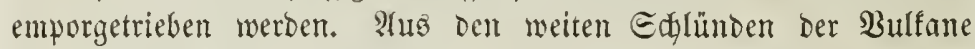
ftitrgen mit lauter Biemalt uno Donnerndem Biebrüll Feuerfluthen und glühende (Eroftröme herbor; aus Den fleinen Epalten Der (j)= fteine riejeln junjte 2isajierquellen, bie immer mädtiger anfdywellen, als wilde Giepbäche von Den Jeljen frürsen, in breiten Etrömen bie SEchen burdy3iehen uno überall langjam, aber fidjer, ben Boben

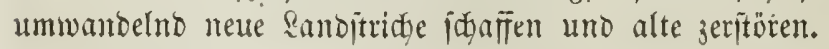

1) Die Duellen und ibre (5ntitehung.

Whie der Eaft in ber Hfflamae, daz Blut im Thiere überall in bem Rreislaui ourdy Den organijđen Rörper Reben und Bewe= gung, Gejundheit uno Brabsthum verbreiten, fo Durdyzieht ein be=

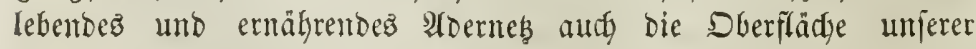

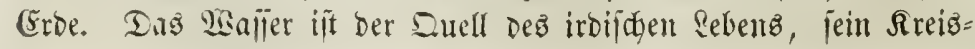


lauj von ber (Erbe jur Aftmojphäre uno non ber Atmoiphäre zur

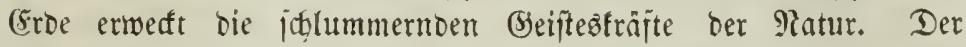
fturre Felien, benebzt non feudyten Pebeln, befleibet fidh mit einer jarten Mroosoede; Die verbrannten Fluren jumüfen fitch unter bem Thau bes Şimmels mit liebliçen Blumen; bem bürren Baum entloft ocr ftrömente Regen ein friftes (Brün. Wo ber Bacts

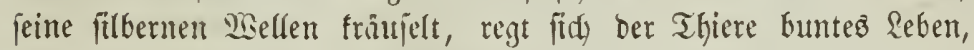

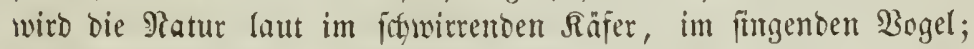

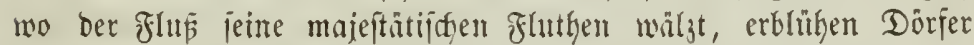
uno Etüote, Gärten und feloer an jeinen grïnenden lijern. Die

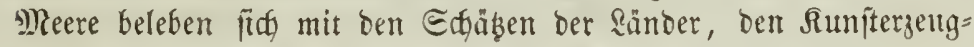
niffen ber Bölfer, fie werben bie Brüfen Deş S.unbelö uno ber Rultur, bie Träger bes Menjđengeiftes non Welttgeil ju Welttgeil. Bon Şimmel uno Eroe entquillt ber Eegen und tmipinnt bas ge= fammte \&eben mit einem ernährenden Peķe.

(E⿱ ijt eine befannte Thatjadye, baß̄ überall, nidgt nur in ber Rähe von glüifen uno Eeen, die Erboberfiñdbe jeudyt ijt. Dieje Feutftigteit wird theils burdy den Ricberifylag bes serbunjteten

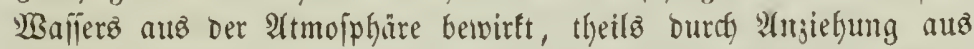

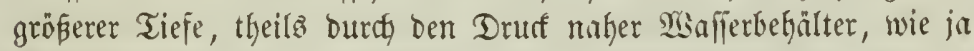

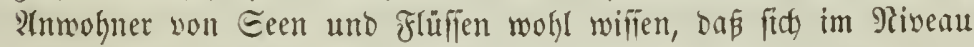
Derjelben ftets $23 a$ fifer finbet. Edyattige Orte, namentlicy ben Eon= nenjtrahlen unzugänglidge Edyludyter, belaubte ober mit Noos be= wadfjene Bergipizen freht man immer jeudft, jogar naßi, weil fie hauptiächlidy Den Thau und bie Rebel aufnehmen. Durch Eonnen= hibe und warme Winbe wird fortmälyend eine ftarfe berbunjtung ber Rieberifläge erzeugt. Die niebergefallenen Wailer fehren fum

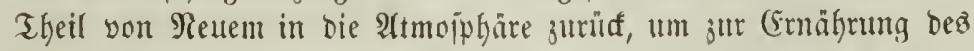

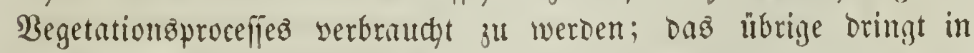
Den Boden ein, bis̄ eв burd, Thonlagen ober Felfen, bie ifm ben Durofjgang verjagen, aufgeljaltelt wiro, fith anjammelt und bann an geeigneten Etellen von jelbit wieber in Sullellen an bie Dber=

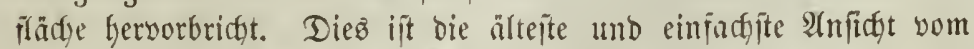

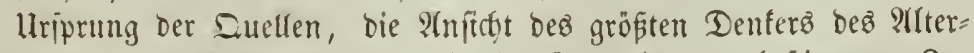

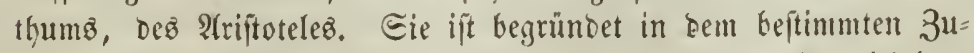
jammentange jtbijdyen ber Regenmenge und Dem Duelfenreidythum

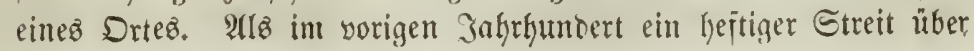


biejen (Segenitullo entitanden war, serfiel man. Darauf, eimen di=

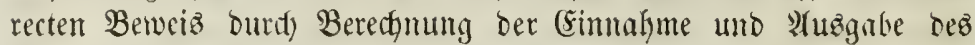

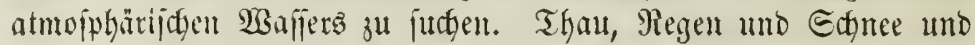
bie gropen Rebel = uno $\mathfrak{B o l f e n m a f i e n , ~ w e l c h e ~ f o r t w a ̈ h r e n o ~ b i e ~} \mathfrak{B e r g e}$ umlagent and ifr waffer an ifnen abjeben, find bie verifgiedenen Suellen, aแs denen bie Eimnafymen fließen, wägrend bie Fus̆gnbe

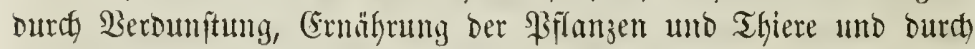

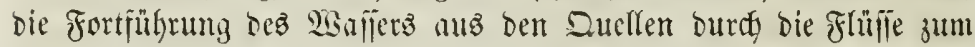
Meere gejdieft. Mariotte war ber Erite, weldyer zu berechnen fuctete, ob bic imnerbalb eines Stromgebietz gefallene Regenmenge hinreithent jei, um bie WBaffermafie ju liefern, welthe ber Strom

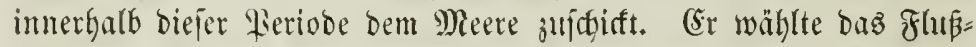

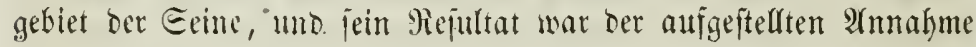

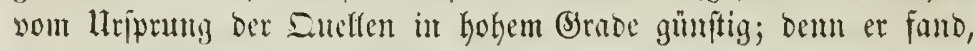

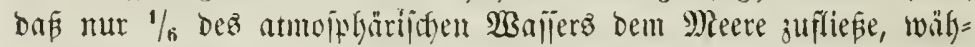
rend bie übrigen $5 / 6$ theils burth berountung, theils son \$3flanjen und Thieren verbraudt mürben. Afber ez zeigte pich hier bie Sdyteie=

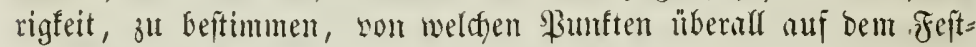
lande einem Flujle, Defien 3uflifie fith mit benen feiter Padbar= fröme rerwirren, 2Bafier jugefülgrt werbe, umb barum wählte 100 Safgre päater Dalton ein Snjelland, England, jum Siegemptand fei=

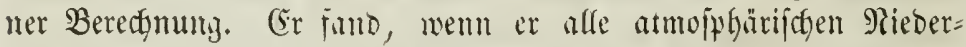
ichläge in Beftalt won Mègen, Edfmee und Thau in Betradyt zog

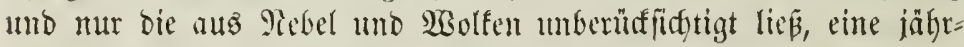
licthe $\mathfrak{B}$ alfermenge won $36 \%$ 3olf, welde auf bem ganzen Boben Englando vertheilt bie ungeheure Nienge son $4 \frac{1}{2}$ Sulifmeilen ergarb. Durch die Themje fliept aber mur $1 / 25$ Dowon ins Meer, und

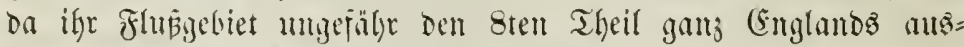

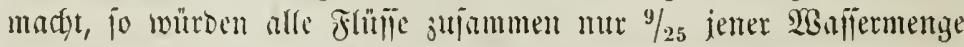
Dem Meere jufülyren. F(ber and) bie Berbunfungšmenge zou Dall=

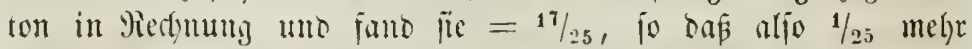

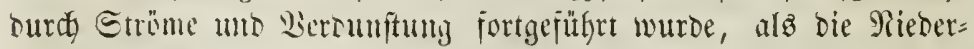

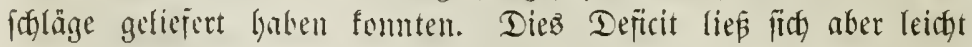
Deffen Durty Dic ans Den Wolfen und Mebeln auf Den Bergen ftatt=

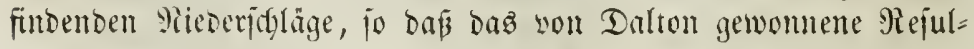
tat wohl als ein jiemlid genthgender Bemeiz für Den atmojphäri= føen llrprung ber Duellen gelten faum. Wenigitens baben alfe 
ähnlidfen Beredgnungen Die Thatjadye beftătigt, Daß taum $1 / 3$ Der

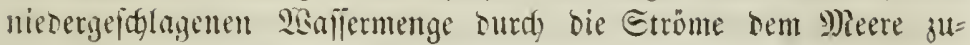
gejühat werbe.

Freilid idgeinen mandye Ereigntilie, bejonoers in (5ebirgøెgegen=

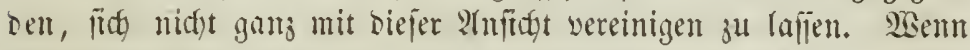

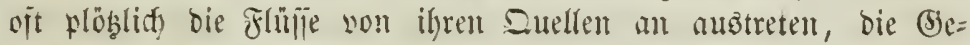
birgsthäler liberidwemmen, alle 3weige cines Etrominftems un=

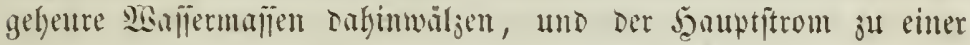
unerbörten jëble über feinen gewöhntiden 2 baflerftand anfdwill, uno wem ein joldyes (Ereignie fid) oft auj mely als ein Strom= gebiet gleidgeitig ausbefnt; Daun möbte man genteigt fein, bei bem

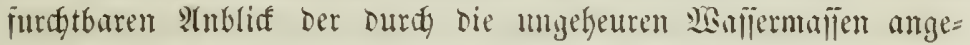
ridgteten Serkecrungen ju auzerorbentliden lirjaden ber plöblidgen

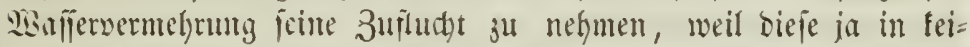

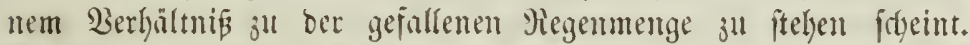

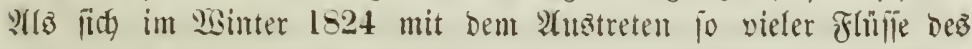
nördidfen und jüblidgen Deutidflandz eine ungewohnte Bewegung seigte, und gewaltige Eturmfintlyen an Den Rilften Der Rorbjee und bei Fietersburg unerböte Eingriffe in baz Sand macten, als in jenen Tagen im hohen (bebinge plöglid, wafferreidge Dutellen an Drten ausbradyen, wo ponjt feine Epur Dowon war; Da fduien eả sollentos unmöglids, die lleberifomemmungen b(o) von atmojphäri=

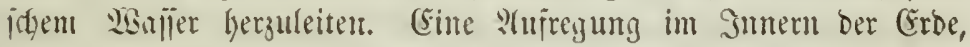
uveldge bie gewöhntidge Sronung ber Yintur werwirte unb ben $\mathfrak{W a f =}$

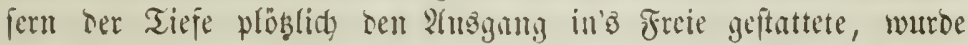

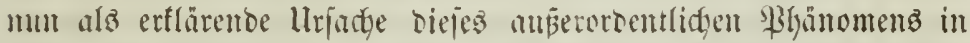

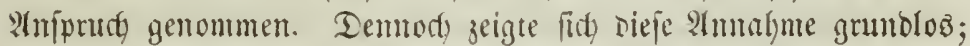
benn unjtreitig fomten bie angenommenen unterirbiftgen $\mathfrak{B a f i e r =}$

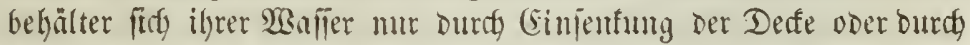
Erbefung ilyes Bobens entleeren. Aber von jolden Beränderun= gen ließ find nidgtz bemerken. Eie hätten mur surdy Grobeben be= soirt werben fönten, und wem aud in Derielben 3eit Groeridut= terungen in Der Edyweij und im Erbwarjwalde veriphint wurben, jo waren fie body nidyt son einer foltgen Bebutung, bap fie bie

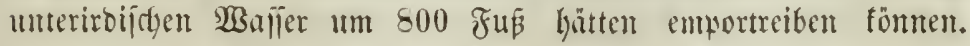
Eo gewaltige Erobeben hätten feinen Etein auf bem anbern ge=

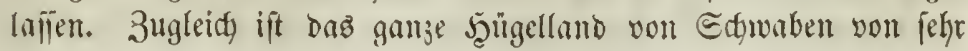




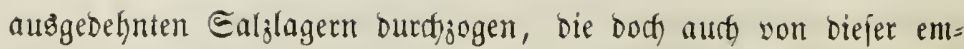
portreibenden Rraft midgt ganz unterüfrt bleiben fonnten; aber bie

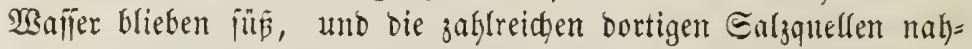
men feinen Theil an ber allgemeinen Bermefrung be\& Mañler=

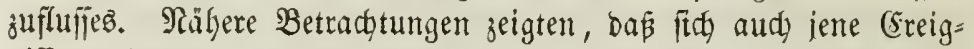
miffe mogl aus atmoipharijiden Urjadten ableiten liepen. Mactoem

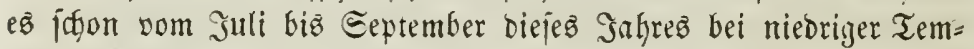
peratur, alio geringer Berdumitung, ungewöfnlid viel geregnet batte,

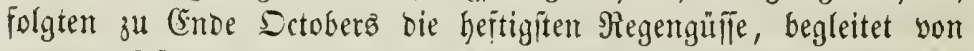
warmen ভübminden, weldhe ben frithgefallenen Sdynee bes ভdymarz= walds uno ber Tyroler uno Ectweizer Boralpen idmolzen. Der

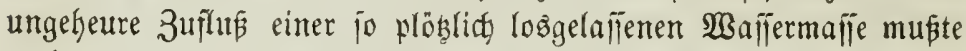
notgmendig, wie 10 Gahre iräter in ben Thälern bes Et. Botts häro, große Heberidywemmungen eräengen.

Bei joldfen Thatjacten fann man wobl nidgt mehr aum atmo=

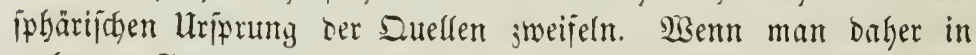

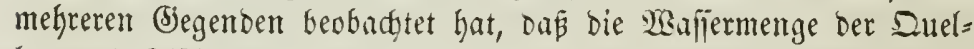
len und flüfie fich nermindert hat, fo iit biejer berluft meift auf

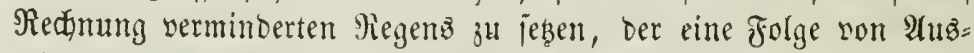

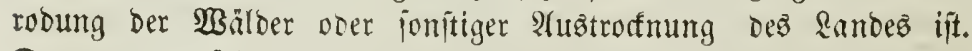
Denn wo es jelten regnet ober wenig thaut, da finto wenige ober

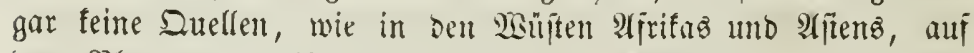
Dem Plateaut von Periten und an den Rüjten von \$eru. 2Bo

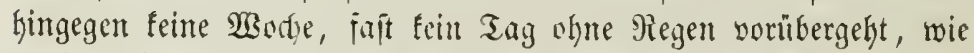

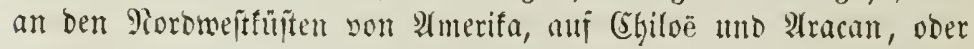
wo eirre beîtändig gejüttigte Dampfatmoiphäre daz Rand in feudje Rebel hüllt, wic in Den Folarläıben, da iit aud ber Dueffen=

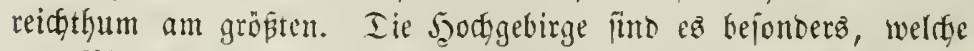

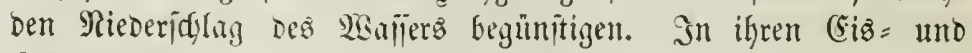
Edyneemailen haten ïe cin bejtündiges Rejervoir, bas gerabe bann

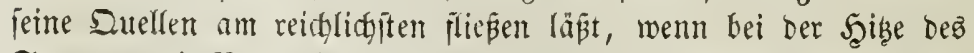
Eommers die Berbuminng unt ber Berbrauth an $\mathfrak{B a j p e r}$ burd bie

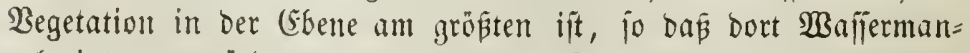
gel eintreten wïroe, memt nicht bas Edymelgen des હdynees und

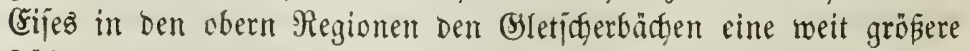
Fülle gäben, als fie in den fälteren Jahreszeiten beïzen. In nie= beren Elebirgen wirft eine andere Urjarfe wejentlich eir. Daz ijt 
Die Begetation bejonderz der Mrooje und farrn, welche bie Berg= Göhen überziehen uno bie Dünfte außerordentlidf ftarf verbidyten.

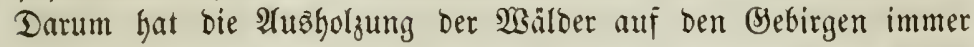
ben nadbtheiligiten Einflü auf bie waafierverhältuifīe Der Ebenen

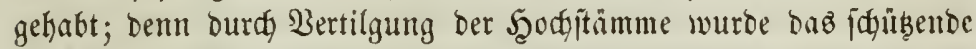
Dad) iveggenommen, unter weldeem bie Moobbere bem Boben bes

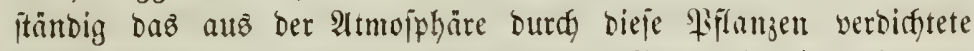
Baffer zuführte. Durd) Den Berlujt Der Moośbefe nber wiro der

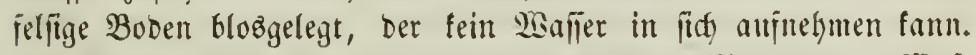

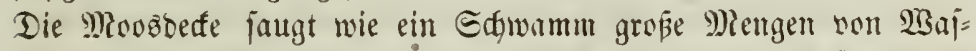

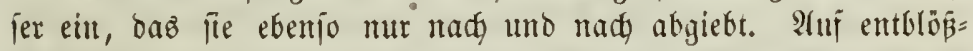

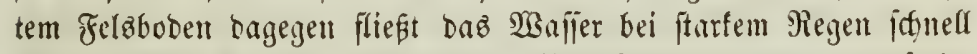

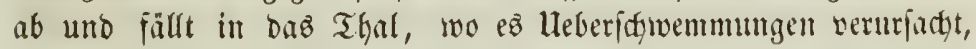
bie jomit um jo häufiger irerben minjen, je meftr bie strholzumg überfano nimmt. -

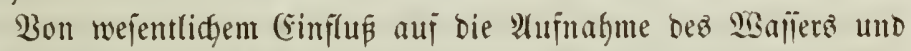

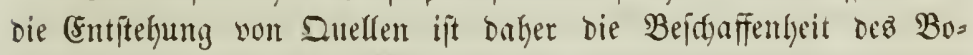

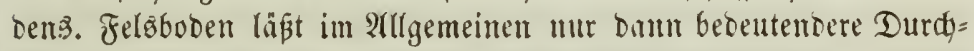

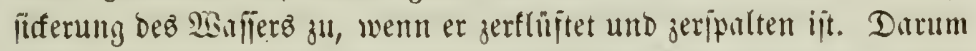

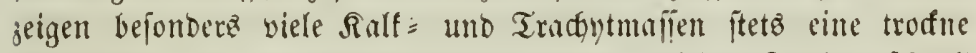

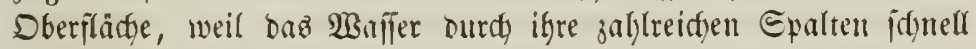

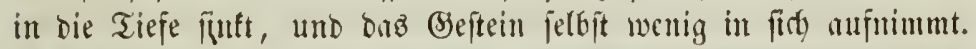

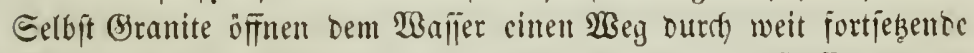
Rlüfte. Daher leiben aud bie tiefitent Gruben an Ligafierzubrang

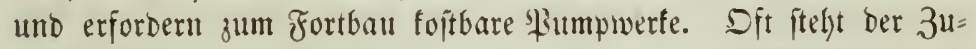
Drang bes Brubenwajiers im unverfennbariten 3ujammenhange mit oen Regenverbältnififen Der Deerflädge, fo Dor fitarfe Regen firde balo in Der Tieje Durdy bas fitäffere Sueffen Der Grubemwaj̄er ber merfbar madgen. Sandittine, zwar weniger jefflüftet, bieten burdy ihre poröje Etruftur gleidfjam natürlidje Filter bar, in weldeen bas Baaffer fehr langiant, aber gleidgmäig Durdfirfert, beren Majie

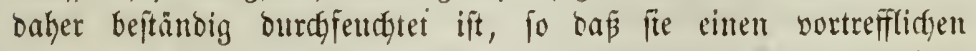
Bruno für bie Begetation bieten. In gemöbnlictye $\mathfrak{A}$ (fererbe bringt jelbjt ftarfer Regen jelten tiejer als $1 / 2$ \& 14 , menigitems nie über

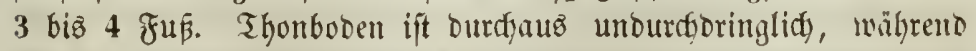
Eand und Bepdyiebe daz wajier biz in jebe Tieje burdfirfern laj= fen. Lluter ben veridjiebenen Bebirgsanten zeigen fid bejonbers bie 


\section{2}

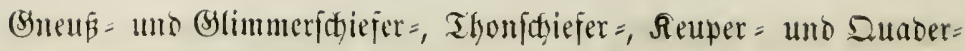
fantiteingetinge reitf an Sutllen. Der (Straumaden = Ralt entjen= bet mur dam Gäufig Duellen, wem er von 3mijkenlagen thoniger Binfe ourdyzogen ift. Meidft er jedody in große Tiefen, jo serjentt

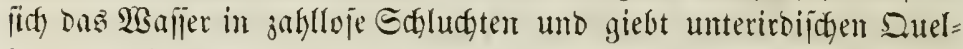

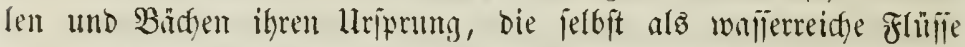
an bas Tageslicht treten. Muidfelfalf uno Surafalf fino bejonbers arm an Suelfen, weil ilgre Rlüpte daв 2 Bajper in größere Tieju füfren. Rreibeplatents fmo söllig bỉn und trofen, wenn nitbt

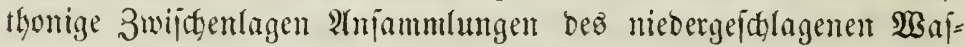

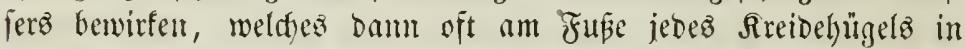
Suellen uno Bädjen herwortritt. Heberhaupt bieten bie $\mathfrak{T h o n}=$ und Miergellager bie natürlidfiten Ecteidemauern für Das Wafjer, jwi= ithen welden bie eimzelnen naf̈erfïhrenden Edyitgten fitd abgren= sen; แmo in bebirgen, weldye aus abmedbfelnoen Folgen falfiger und jandiger Sdfidten mit Thon = und Mergellagern beftelyen, wirt man ftets bie Suellen oberbalb biejer Thonlager hervorfrechen fehen.

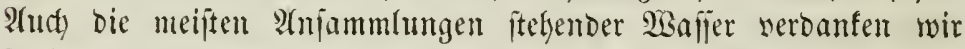
Foldyen Thonlagen, meldbe bas Gimpinfern ber Flüfïgfeit in bie Tiefe verfindern. Die Troftenlegung son Eümpfen, Eeen mo Torimonen ift oft mur Daburch möglidy gemorden, Dak man biefe

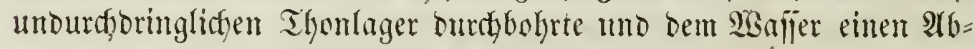
flup in bie Siefe veridyaffte. Fudy bie Frudtbarfeit ber Dajen in ben Ganowüjten beruft allein auf bem llmitande, Daß Thonlager,

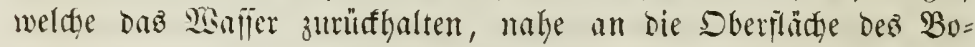
Dens fommen, währent he in Den übrigen Theilen Der waite mefyr

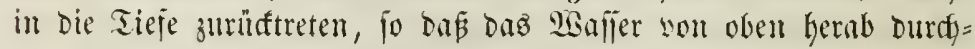
fitert uno Die obern Edyidgten troden läß̈t.

Da Das Majier aljo nur jo weit einfinten fann, bis es eine undurchoringlidge Ectidgt trifft, und audg nidyt jur Sberfiänge ju gelangen berming, wenn fith hlber ilym eine foldse Edyid)t finbet, fo

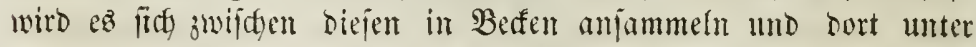
einem Druffe jtelyen, weldyer ber jälye entipridgt, bis zu weldyer

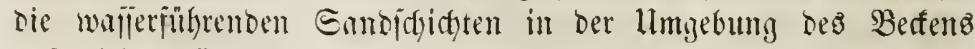
amjgeriffet find. Durdjbohnt man biefe obere mourdioringlidye

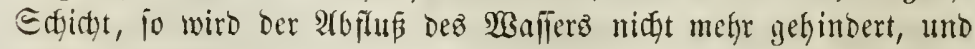

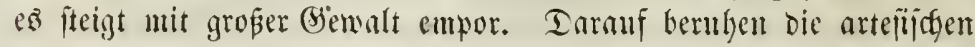




\section{3}

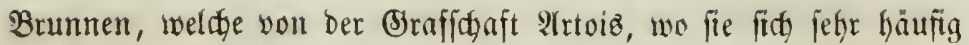
finten, ihren Ramen habes. Sie fönnen nur an foldgen Drten angelegt werben, nady benen fidh mergelige Eafidten himeigen;

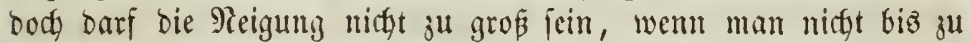

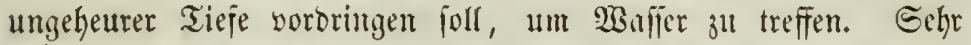
geeignet baju ift bie Biegent von $\mathfrak{B i e n ,}$ wo foton in einer Tiefe

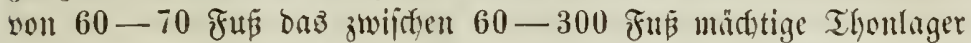
liegt, weldjes burdjongrt werben mus. Die Tiefe oer Brumnen ift

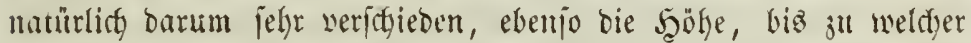

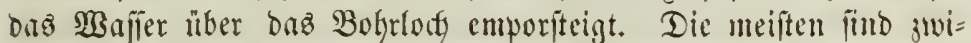

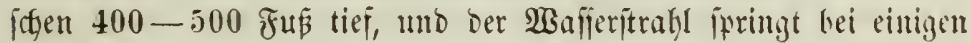

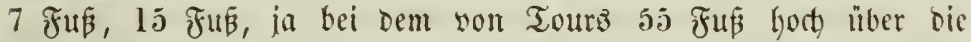
Bodenflathe empor. Die teffiten Brunten fint wohl ber son (5ire=

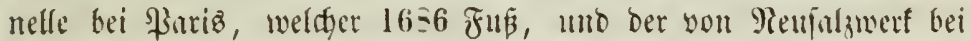

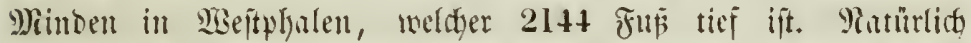

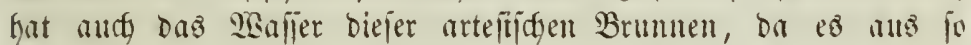
großer Tieje quillt, einte bebeutente Temperatur, bei bentekteren

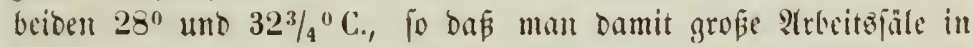

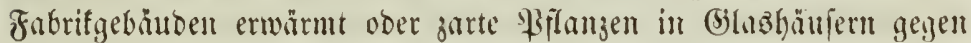

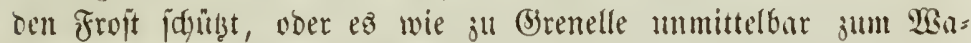
ideen gebrautst.

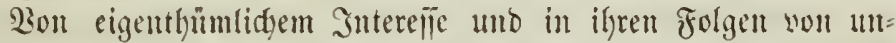
beredfentarer 23 idgtigfeit finto bie artepijgen Brumnen, weldye bic Franzojen vor wenigen Safren in ben Dajen ber ojtlisfen Eafjura

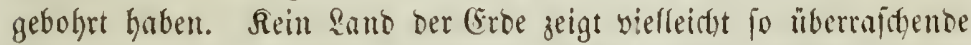

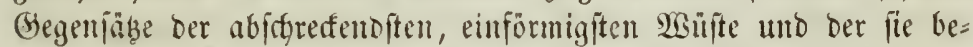
wältigenten Ruftur, alz bicje algeriffte Enthara. Des Menfiden

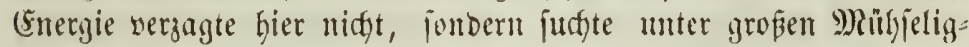
feiten auf ben in anjehnlidyer Tiefe unter bem Flugfanbe fïb anto breitenoen, feudgteren uno für ben $\mathfrak{A}$ nban empfänglicferen $B$ oben jul gelangen. Daburdy fam man z̆ ber lleberzengung, dä́ Derielbe

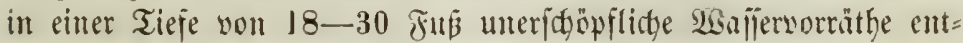

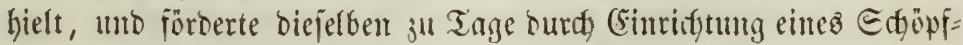

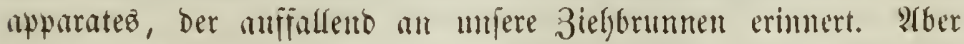

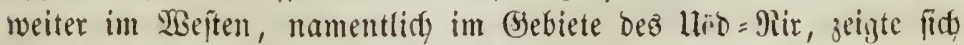
bieje (Einridytung nidft melyr märeidyent, unto hier begegnen wir einer Ted)nit, beren Uriprung wir faum in ben $\mathfrak{R}$ öpfen Der jeßzigen 
trägen Bewohner, ionben eher in Meberlieferungen aus ben Zeiten Der römijafen Seerrichajt fucten tönnen. (Gs ijt in ber That eine

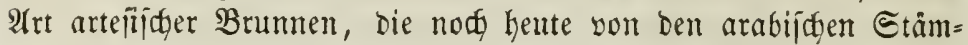
ment biejer (Segento, jreilid in ziemlid roter uno unvolfommmer Weije, angelegt werben. Fine Şandhacte, ein Siorb unb einige Balmenitämme zum Edyus gegen bas nadyallende (Eroreich fino

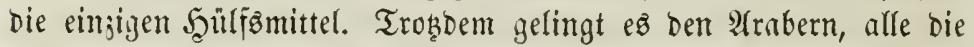

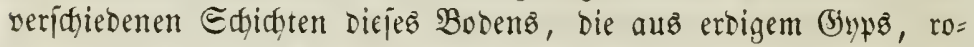
them Mrergel, gelfem Thon, röthlicfem farten Eanditein und end= lich bartem, fettem, grünlidg meipem Thon bejtehen, zu burdforin= gen, urm bem barunter liegenden wajierthaltigen Eand jeine Duelfen zu entlocten. Dit erreidten bieje Brumnen eine Tiefe yon $150-$

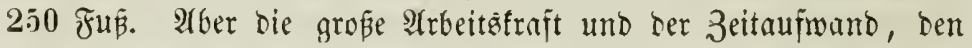
fie eriorbern, madjt fie. boch zu foitfpieligen und barum jeltenen Unternefymungen. Daju formmt nod, ba fie felten ifre uriprüng=

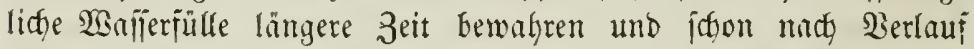

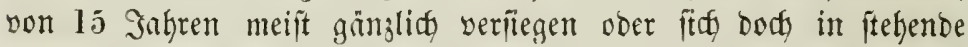
Brunnen vermandeln, oa bie Fäulni Die Berichủttung bes eigentliçen Bohrloch be herbeifühthrt.

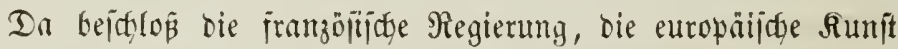
auj biejen Boden ju verpflanzen und burch bie 2 Bohfthat ber arte= iriften Brumen hier eine Eivilijation Gerbeizufülfren, weldhe bie Banfengewalt 12 Gathre lang vergeblid zu idfaffen verjucht hatte. Nm 1. Mai 1856 wurbe bei Tamerna ber erfte Erobohrer in $B_{e}=$

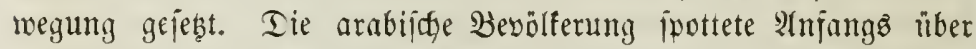

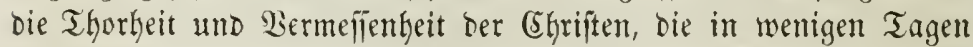

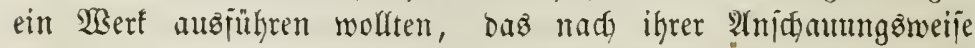
Jahre erforderte. Ecton glaubte der muhamedanijçe ganatiŝmus

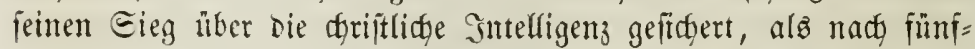

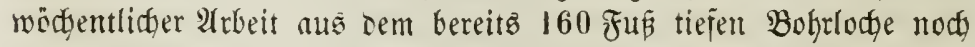
immer brafiges Saljer hernorquoll. Da ward am 9. Sunt mit

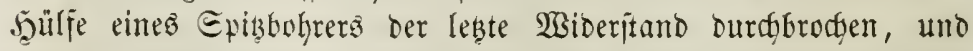

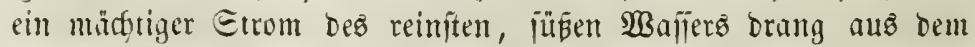

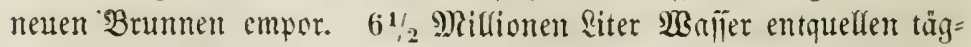

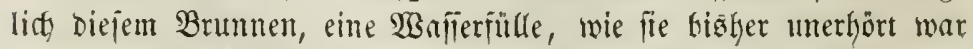
in ber buirren Eahara. 


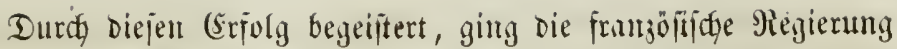

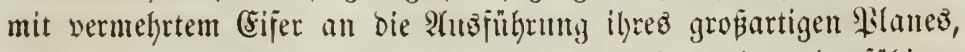
Durch artelifiche Brunnen Das dürre Eteppenland in culturfähigen

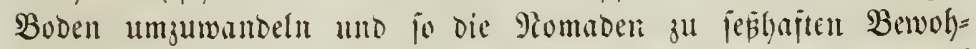

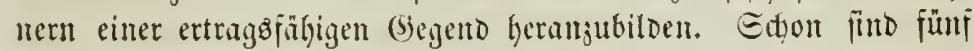
neue Epringquellen ben Tiefen Der WBüfenerde cuttuft; fifon um=

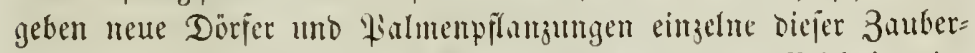

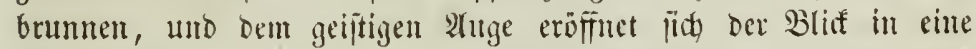

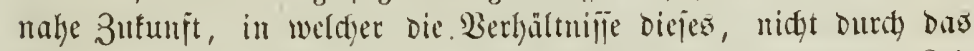
Echwert, fondernt Durdy bie (Enltur eroberten Randez für alle Zei=

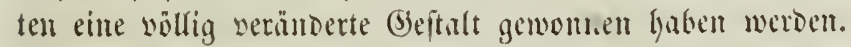

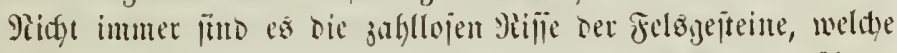

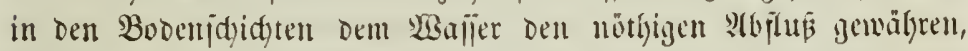

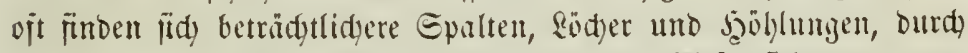

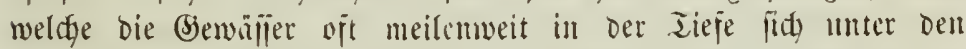
Edjiften ourctwinton, um jpäter irgenowo an einem tiejeren Sorte

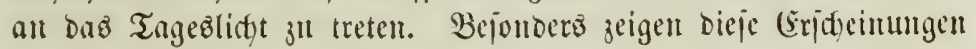
Die trofuen und quellenarmen $\Re$ alf $=$ und Dolomitgebirge Brieden=

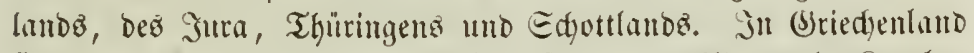

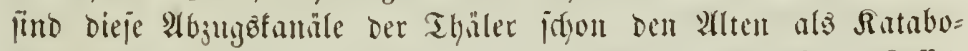
thra befannt. Mlorea bejteht aus einer Heibe gejdlojiener Rejlel=

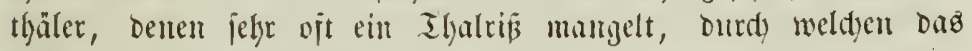

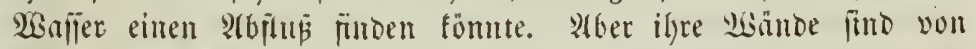

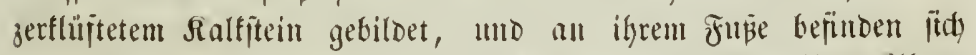

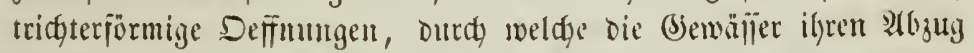

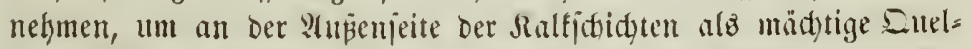

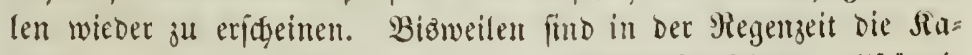
tabothra nidgt gerïumig genuy, um Dem warjer jeitent vollitündis

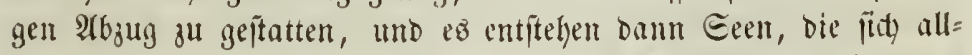

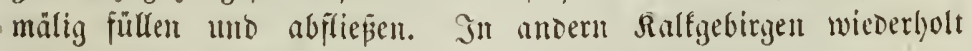
jich Diejelbe Erijgeinung, und bieje unterirbijgen Rantile beipen danı Ëntomnoirz im Sura oder Edhlotten in Thÿringen, Eeelödper

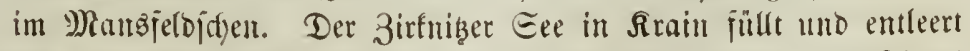

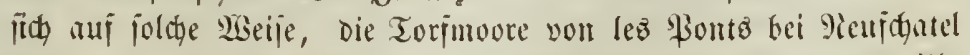

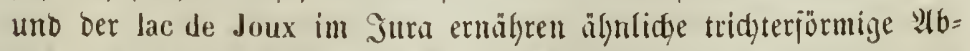

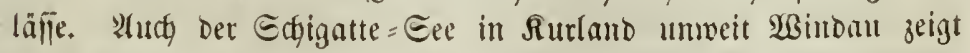

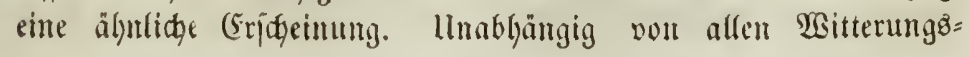




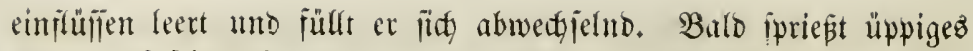
(braz auf peiner Fläche, umb das. Bieh weidet auf feimen Triften; Gald überifromt jeine sisajierfinulle bie lljer und ergiept fitd in bie ungebendent Edtludten und bie fleinen Dïnenjeen oder "BSigge"

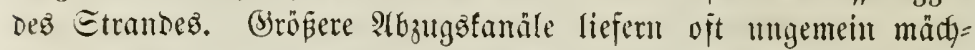
tige Duellen, dic jogleich als Bädje voer flüfife hervortreten. Die Eorgue bei Bautuje, der Mühlbady bei Biel, dic Eerrière bei

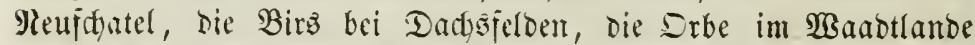

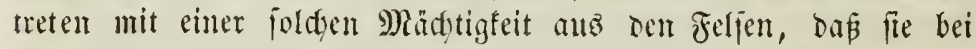

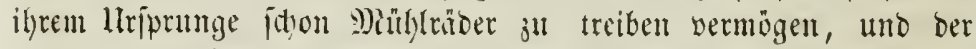
Eoiret trägt jogar Dampfidjifie bis an jeine Dutelle. Mädytige

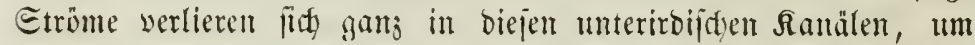
weiterhin in woller Etäffe wieber fyerworzubredyent. 2uf ber troffe=

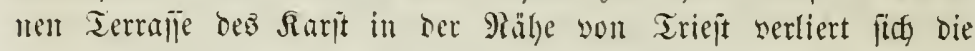

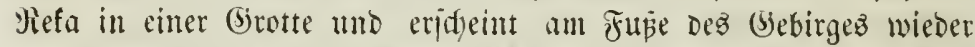

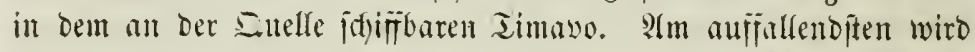

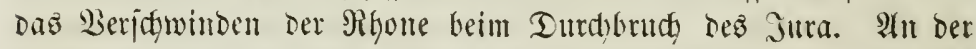
Perte du Rhone bringt biejer reipentofte Etrom Europas in eine oben fafi geidslojiene Epalte; 60 Edyritte weit ift er burdy Felb= blöfe ganlz beberft.

\{us allem Sorkergehenden geht deutlid) hervor, baßi der Mieid)= thum ber Suelten um jo größer ifit, je melgr Hegen orer wajijige

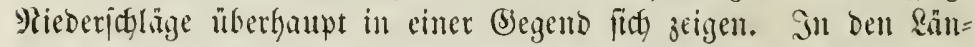

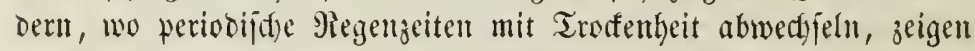

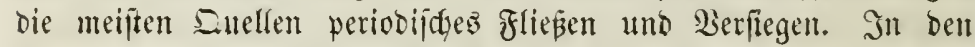

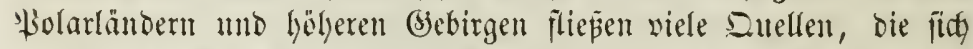

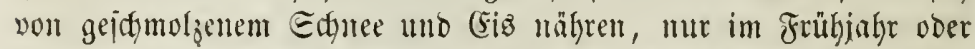
Eommer. In unjern Dentidgen Bebirgsländern fintoen jidy bie po:

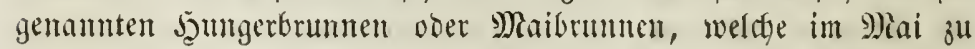

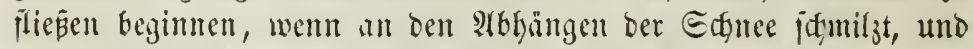

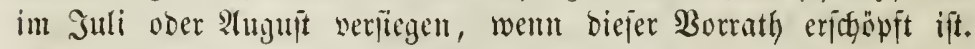

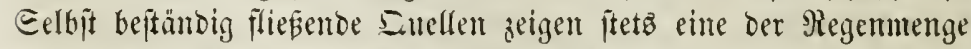

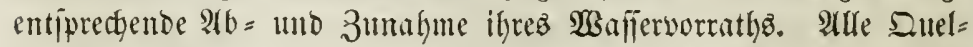

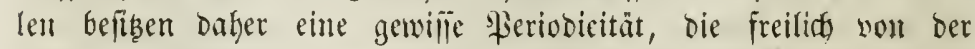

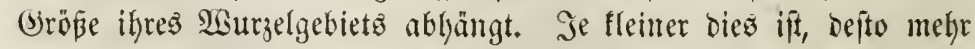
ift bie Enelle von lofalen limitünen abfingig. Seltit ungleidfer

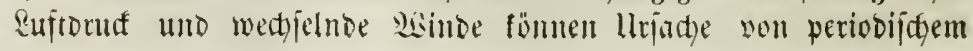




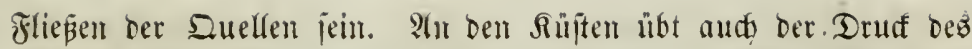

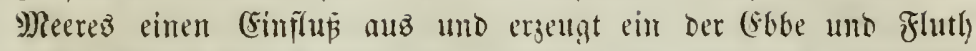

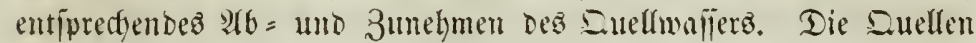
bei (Sadir, bei Brejt, (Salaiz umb auj Dent Frtilllen umb der arte-

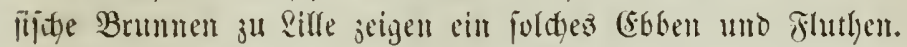

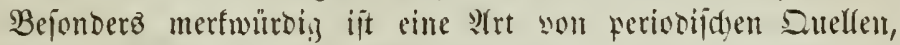

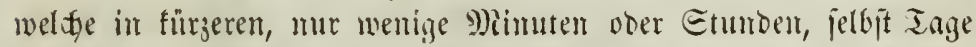

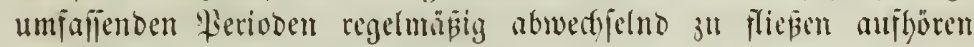

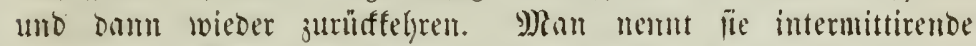

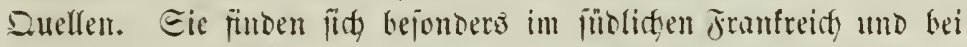

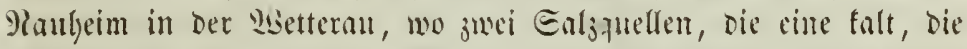

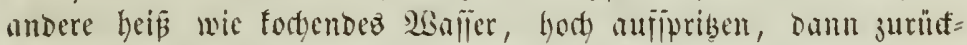

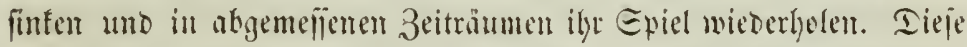

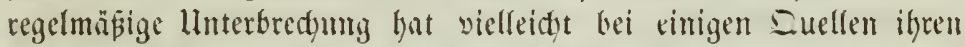
(Śnind in heverartig verbumbenen Siünmen, bei anderen in oer

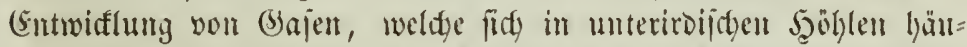
jen, bis iffe Epannfraft bie Edywere Des $23 a$ fifers ïbermiegt und biés int einem Etrabl emportreibt.

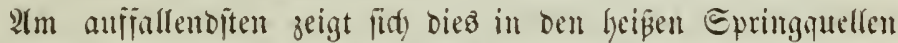

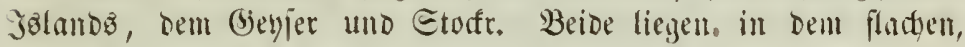

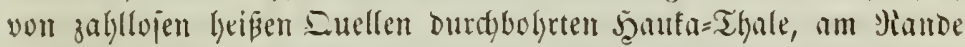

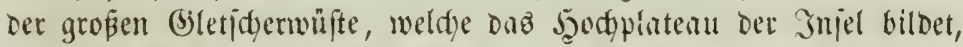

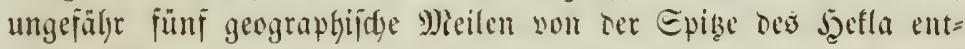

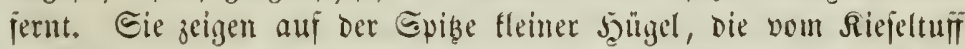
Der Duellen gebildet wurden, trid)terfürmige Beffen. Das Befen

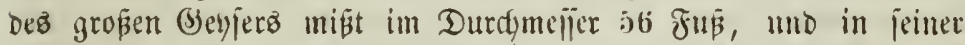

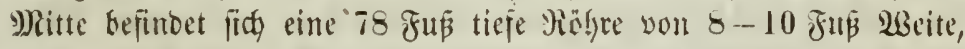

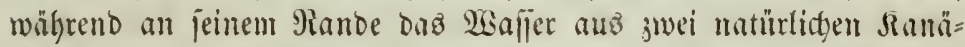

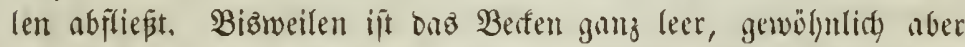

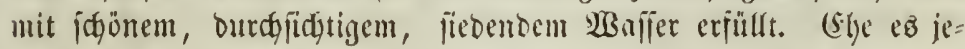
Dud) Den Mano erreidft, erjolgt gewölgnlid) ein unteriroijdjes, rol= lendez Betöje, gleidh entipernten Ranonenichüijen, daz den Bopen

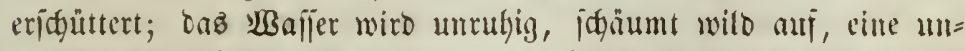
geljentre Dampfiwolfe fteigt empor und iftendert Das walier in bie

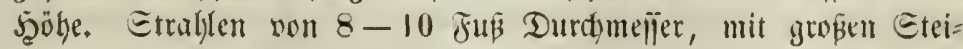
ren und Dantpi gemifdut, werben zu einer Şöhe your $80-120$ Fup und dariber fenfredst in bie enft gejdjleubert. MRit jebem 


\section{8}

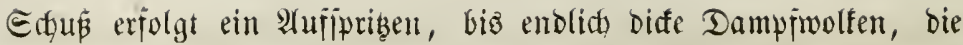

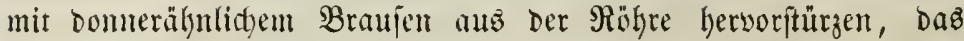

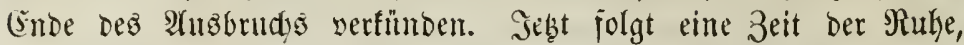

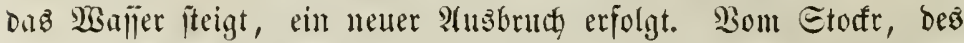

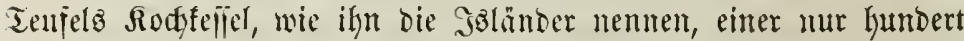
Ectritt vom (jeyjer entipenten Epringquelfe, bie unnuterbrodgen

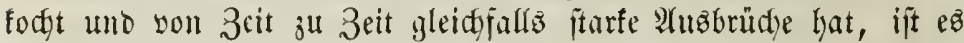
jogar befannt, baj er ju jolden (sridjeinungen aufgefordert werben fann. Steine, bie man in ben Srater wirft, weroen mit ungeheu=

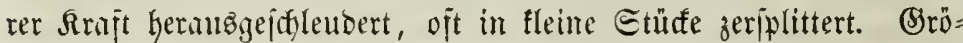
Bere Eteinmalien, burdy bie man bie Etoúfouelle veritopit, bringen

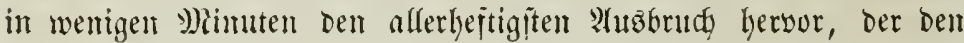

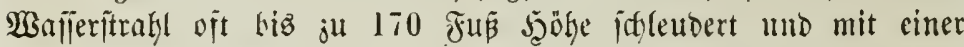
jtunbenlang anthaltenden, som betäubenditen (b)eränif begleiteten

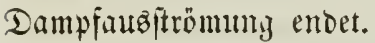

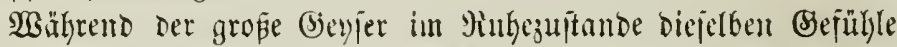
ermeft, mit Denen man an Den $\mathfrak{R}$ raterrand einez ifflummernoen

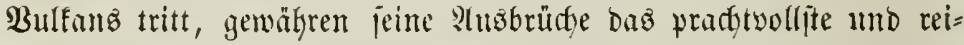
zendite Edamipiel. Injoweit cin Bild überbaut im Etande ift,

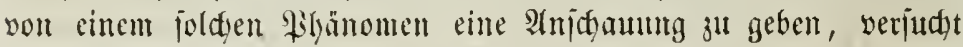

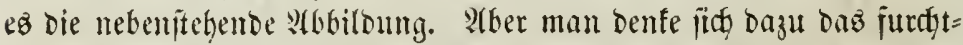
bare Brillen Der unterirbijकen Edjlünde, als wollte bie Erroe ber=

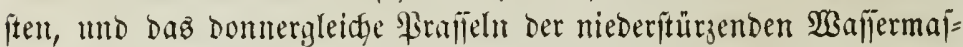

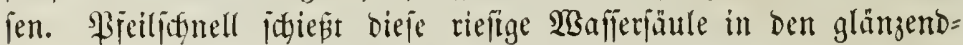
ften Farben, von reinften Edjaume gefleidet, empor. Hnermę̧lidge

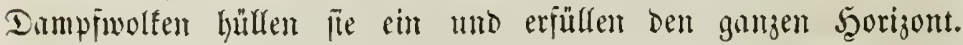
Die Eonme wird verbunfelt, mur bie Epizen des gewaltigen $\mathfrak{B a} a=$ jerfitrables glänzen in ben reizentoften Farben. WBie Boold = und Eilleritant jullen bie jein zeritiebten Tropjen nieber. Eange jtart

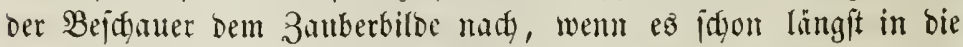
duntlen Tiefen werjant. Er hat einen (Sindrufe empfangen, ben er mit 2 sorten und \$injel nidft wiederzugeben vermag.

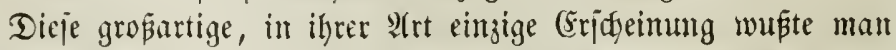

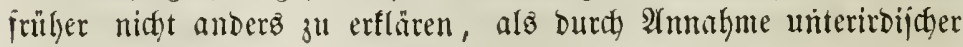
מ̧öhlungen, in weldye burd) Epalten yon oben her 2 Baffer eindrin=

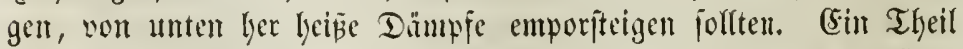

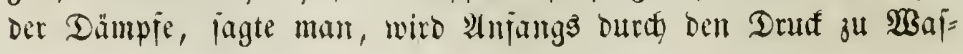




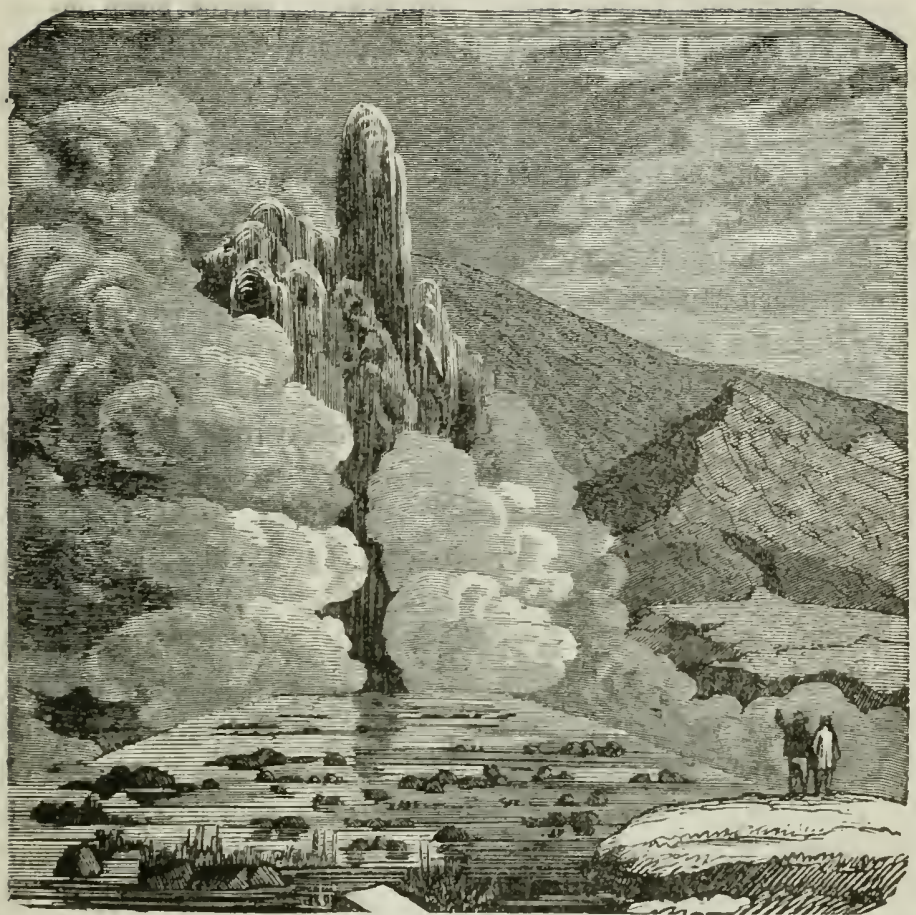

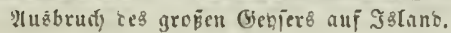

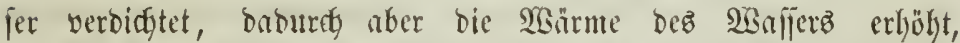
biz ber untere Theil ber Şöhlung mit fiebendem sonfler, ber obere

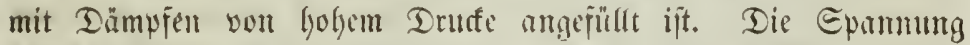

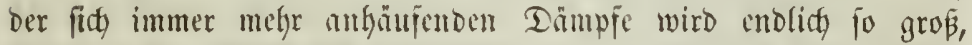

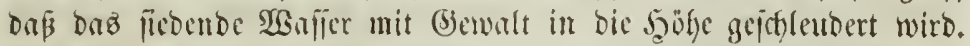
Daburch wiro ber Druf gemintert, utmo bie leidgten Dämpje ftei= gen nun mit groper Bejdymindigteit in bie Şohe. Dic Beritopfung

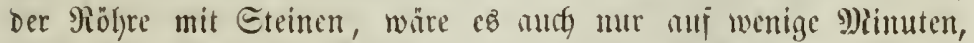
hat bann cine groß̈e Biermelyrung ber J̧ike jur Folge, weil ber

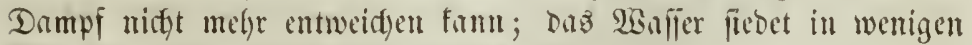

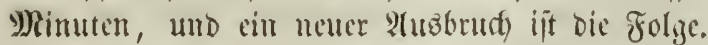

Bon ber Ungaltbarteit diejer Syypotbeje hat fid Frof. Bumpen

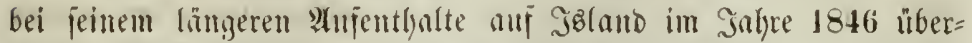

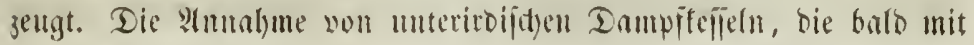


Wajier, Gald mit Dampi erfïlut jein follten, wurbe ourdy bie ein= factje Beobadtung wiberlegt, daß bie bei den Eruptionen über ben

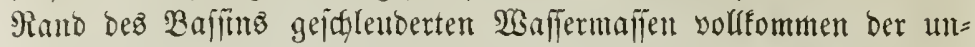
mittelbar barauf eimtretenden Miveauerniebrigung dez $\mathfrak{B a f f e r z ~ e n t = ~}$

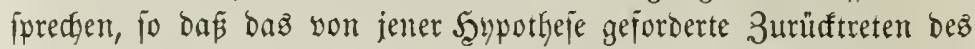
Waffers in ben unterirbiften Dampfeffel in wirflidsfeit gar nidyt ftattrindet. Dazu fommt, dape cine Beobachtung, welche während

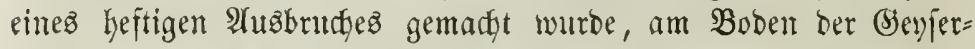
röhre eine um mefyr alz $9^{0}$ niebrigere Temperatur nactwiez, alz bem Rodfpunfte an biejer Etelle entipredgen muste; währent bods jene Şupotheje annimmt, dẩ bas an eimer tiejeren Etelfe fochende Wafjer, wenn es you unten in tas bievjerrohr geprest wiro, den Atubbruch bewirfe. Bunjen nimmt bafher jeine 3ufludft ju einer siel einfactgeren Grflärung. Wenn eime ourd wulfanilage Boden= wärme von unten jehr jtarf erfibze sajperjüule, welche urjprünglicy

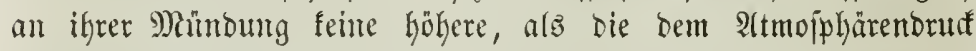
entiprectuende Temperatur befiłt, in eine enge röhre gebrängt wiro,

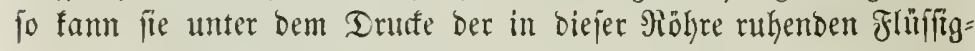
feit ant Boben derjelben eitue über $100^{\circ} \mathrm{C}$. fteigende Tempera=

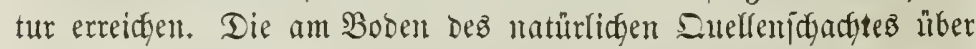
$100^{0}$ erhibste, aujiteigenbe, ftets son unten her enteuerte $\mathfrak{B a f f e r m a f j e}$

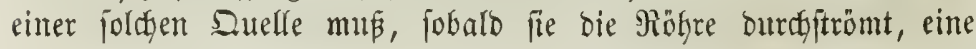
Dem verminberten Drute entipredyente Temperaturerniebrigung bis

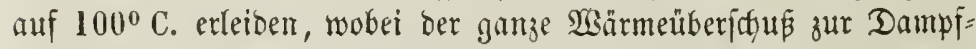
bilbung benust mird. Das Wajfer oringt Dann, burdh bie Expan= fivfrajt biejer entwiffelten Dämpfe gehoben, mit benfelben zu einem weisen Edyaume vermijat in einem contimuirlidyen Etrahle unter Braujen uld Bijhen aus ber Duellenmündung herwor. Şit bagegen Die ourdy Sncruftation gebilocte (jey)erröhre binlänglich weit, um

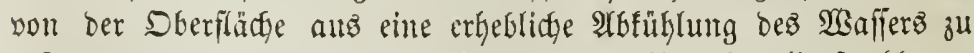
geftatten, und tritt ber weit l̈ber $100^{\circ}$ erfibte Duelfemitrafil mur

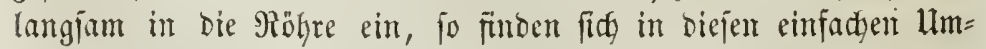
fïñon alle Erforbernifie vereinigt, um bie Dutelle zu einem Sievjer zu madyen, Der periodifi ourd plöblich entwifelte Dampifraft zum Aluzbruch fommt und unmittelbar Darauj mieber zu einer lämgeren

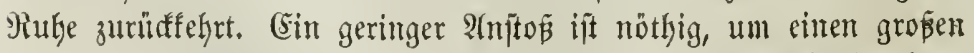

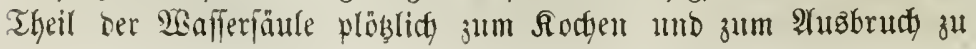




\section{1}

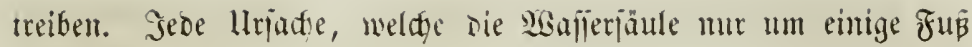
emporkebt, muk bieje \$istung zur Folge baben. Buträgt bie $\mathfrak{T} e=$

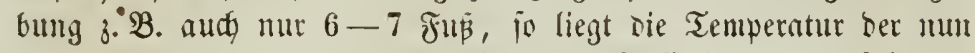

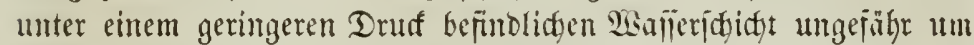

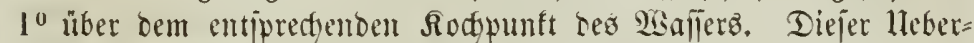
jđü von $1^{0}$ miro Daker ingleidg zur Dantpibildung verwendet und

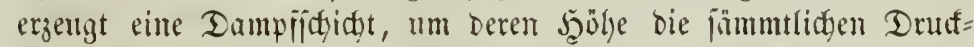
träfte abermalz verringert werden. Durdf bieje Drufyerminderm

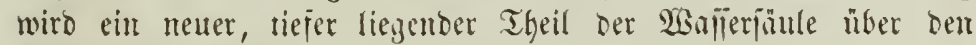
Rodypunt verjebt; es erjolgt tine nene Dampibiloung, bie aber= malв eine Berfürzung Der Drüfenden $\mathfrak{B a}$ alierididyten zur Folge bat,

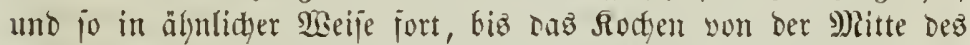

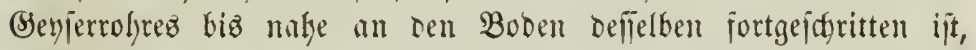

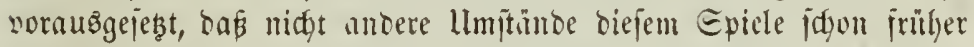
ein Ziel jeßten. Daßs bie bei biejem plöblia eintretenden Berbam=

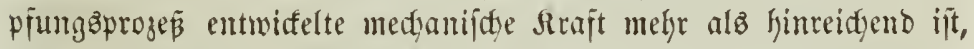

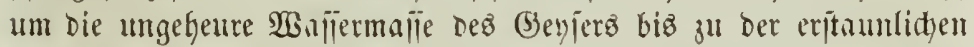

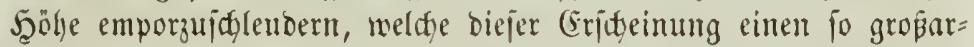

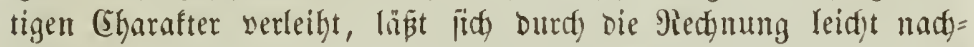

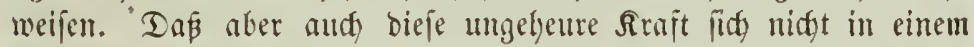

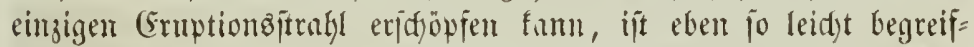

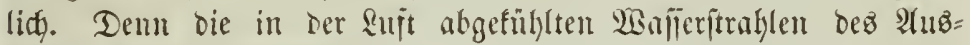

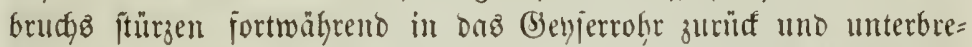
hen die Sraft ber emporbringenden Dampfiänle anf Augenblife

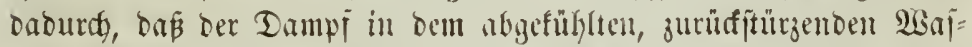

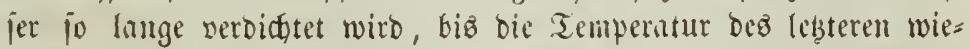

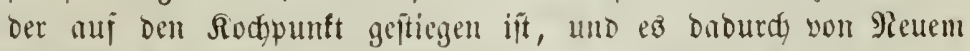
Die Fähigfeit erlangt, cmporgeidlendert zu werben. Eo erfolgt ein

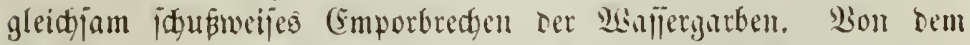

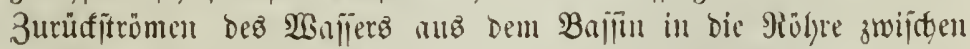
Den eingelnen emporiteigenden Etrallen kamn man fidg ourdh ten

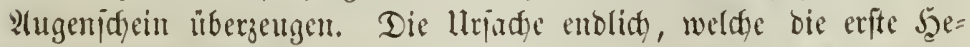

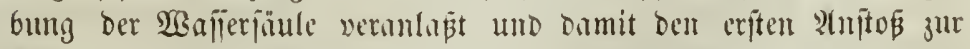

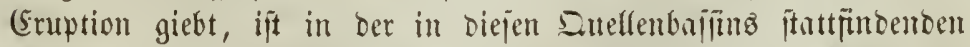
Biloung grofer Dampjblajen zu judhen, weldge bei bem 'Hufiteigen in eine obere filltere Edjidyt plöblidy wieder verbidtet werben. (58 entiftejt baburdy ftets eine fleine Detonation, Die non einer Sebung 


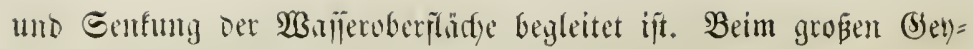

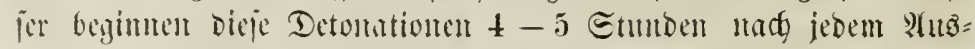

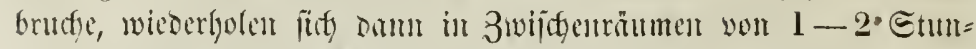

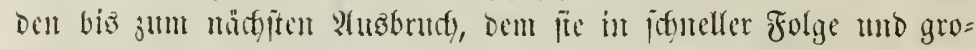

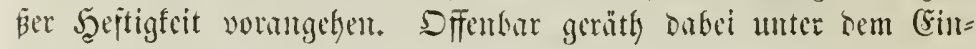

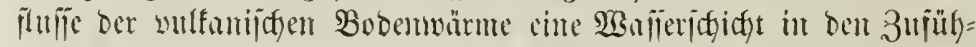

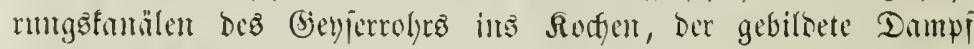
wiro beim 2 fujfteigen in bem fälteren Senflet werbidftet, uno bie Tem= peratur bicjer todgenden Ecfidyt Duth bie Dampibiloung wicour jo

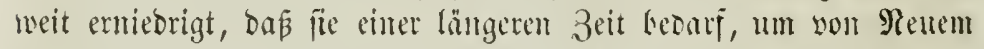

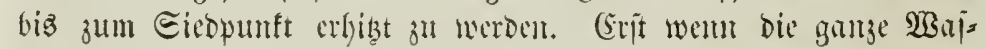
jermajie burdy allmälige Crhibung einc bähere Temperatur angenon=

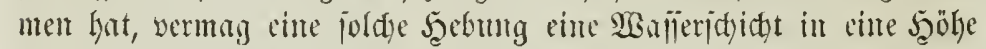
ju verjeben, wo fie Duth Drufferminterung ins Sivdyen gerathen

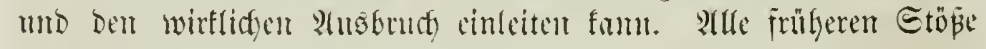

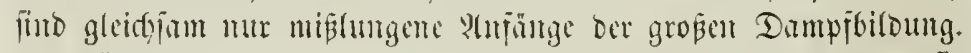

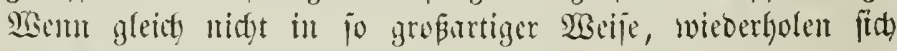

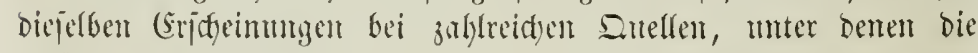
berühmtejten bie lings spring bei Bath in Eommerjetifire, la fon-

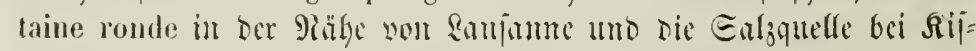

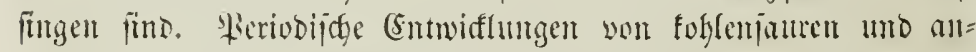
Dern Bajen, welde zum Theil surdy biejlbe Definung augbredsen, mögen sie einfactite Erflärung biejer Erideinungen geten.

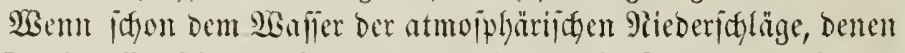

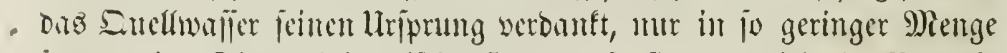
jumbartige Distge beigemijat jüb, Dẩ jie gar nidgt in Betradjt fommen fümen, fo zeigen die Duelfen jelbit gamz abweiffende Ber=

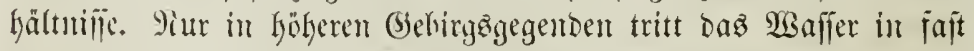

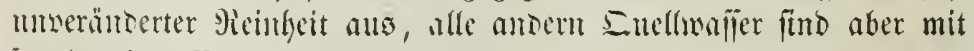

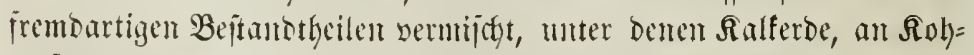

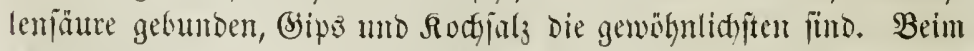

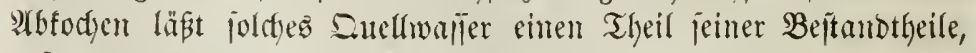
bejombers die fohleminure Ralferte fahren und jebt don jogenamten Bfanmentein der siancbejiel ab. Mandye Suellen, j. B. Die bei (Ehur, find jogar jo reith an Ralfende, da Bafferleitungen oft nach furzer 3eit mit eimer mehrere Sinien bicten

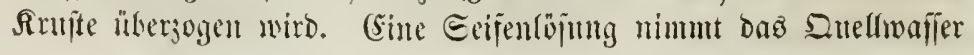




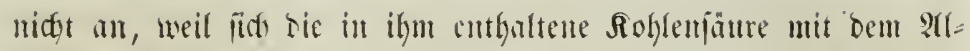
fali Der Eeife serbinset und oen fettigen Beptandtheil frei werden

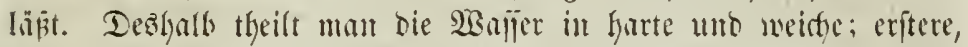

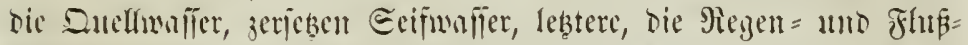

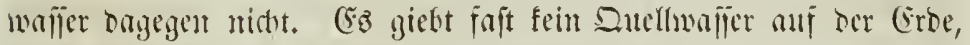

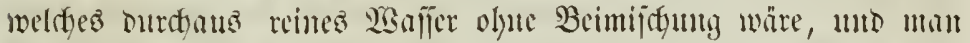

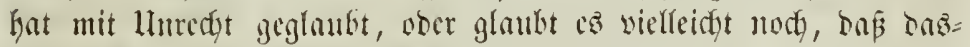

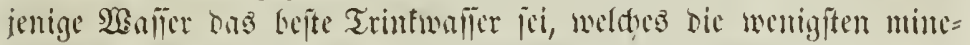

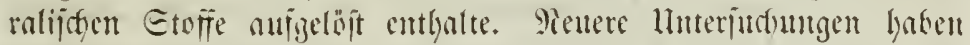

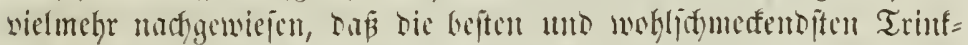

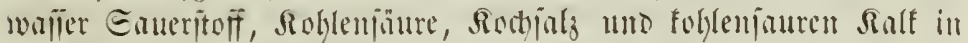

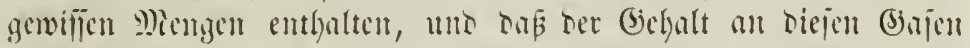

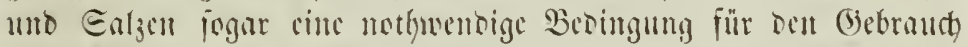

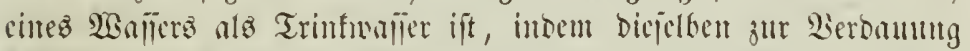
beitragen, und bic thicrijaten Srganismen eitten Theil Det ifun nöthigen Ealze, mamentlid orn jur Efcletthildumg möthigen Ralf,

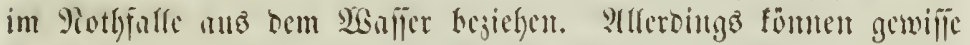

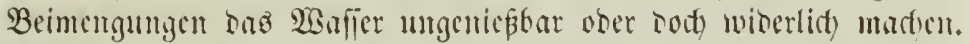
Euellen bejonders, welde in Fladylänom ans bebantem Boben

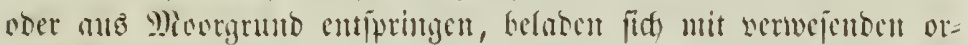

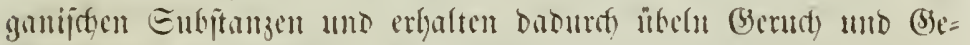

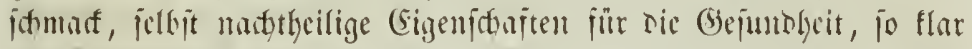

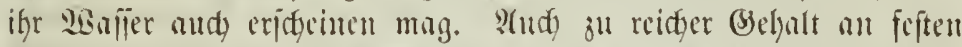
Etoffen, bejonbers an Ralfialzen, madyt Das wäler unugenthm,

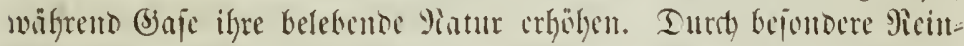

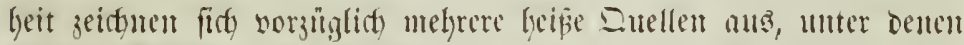

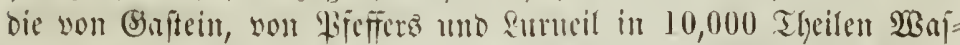

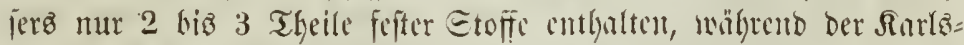

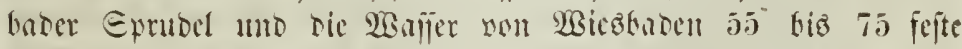

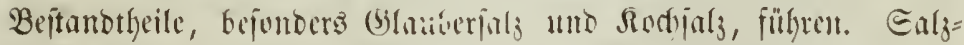
quellen fund bismeilen völig gefüttigt. Eo enthalten bie fünftid,

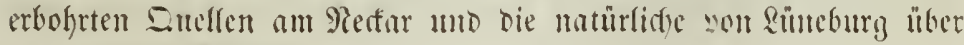
26 Firocent Siotbinls.

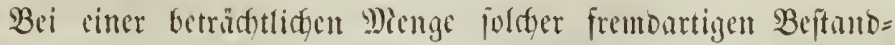
theile entiteben bie S)ineralqueffen ober Bejundorumnen. Afllerbings

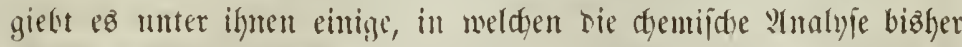
menig mirfjame Etoffe madzumeijen wermodte. Shre Secilfraft ift 
Defien ungeadytet feiner unbefannten 3auberfnft zuzujdreiben, jon= Dern mur auffallend. ourdy Die Eparjamteit in ben Mrtteln, weldse bie Ratur zu ifren fräftigften Mirfungen amwendet, gegenïber ben oft mailenhaften Trünfen und Biffen Der Seilfunit. Früher ftellte man bie Minernlwajier mur nady ifren (sinmirfungen auj ben thierijäen

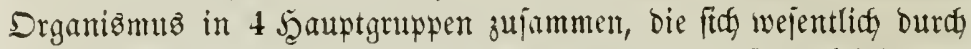

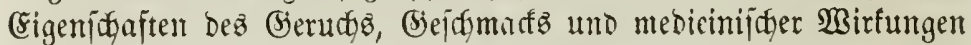
unterigheident. Shenan itehen bie Sauterbruntmen noer Säuerlinge,

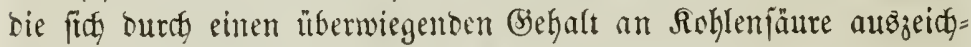
nen. Die reidfiten Eauerbrumen, bie wegen ber großen M)enge aufifeigender ?uftblajen ju freden iqjeinen, beipen Eprubelwafier, und bie meiften treten mit jenem polternoen Beräujd an bie Sber= fläche, weldtes immer bas Entweicten von Rohlenjüure begleitet.

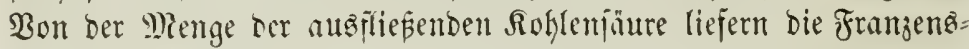
baber und Gifelintellen den bejten Beweiz, weldye in 24 Etumben

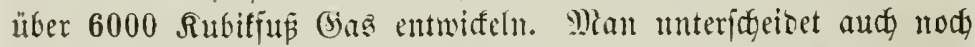
von ben ädten Eäuerlingen bic alfalifthen, weldse Durdh ifren be=

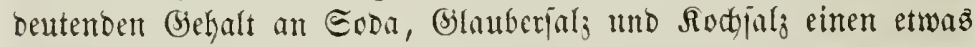
laugenhaften (Sejdmat haben. Tahin gehören bie Mimeralmaller

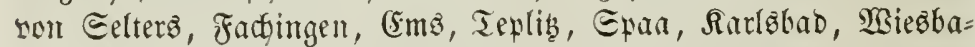
Ien, Baben = Baben urb Thanaŝ. Sie Cijenjüuerlinge ober Stubl= wajfer haben megen ifris (Segalte an fohlenjaurem Eijenorybul

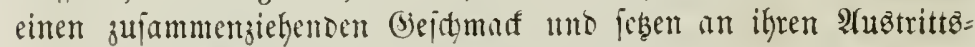
orten gelben Eijenofer ab, wie man 'b̄ bei ten \$yrmonter uno

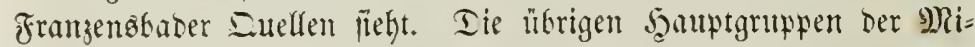
neralwafier biloen bie Ealsquelfen mit überwiegendem Behalt an Rodyjal, God uno Brom, die Bittermajier mit jawejeljaurer Bit=

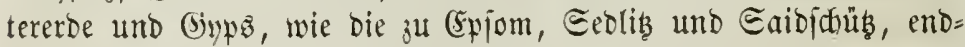

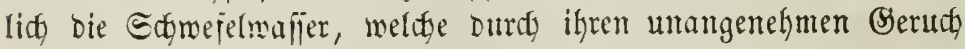
ifren Behalt an Edowefelwalleritofi verrathen, und bie entweder falte find, wie die in Wejtphalen, Bürtemterg uno Balizien, ober Geibe, wie die Saijerquelfe ju Andyen und bie von Burticheid, bie

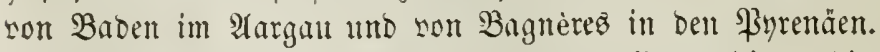

Ulnter Den itbrigen minerallyaltigen Dueffen verbienen bie meifte 2ujmerfjamfeit bie infrujtirenden ober verfteinernoen Duellen, weldye bie mit ifnen in Berührung fommenden $\mathfrak{R}$ örper mit einer fteinar= tigen $\Re$ rujte non fohlenfautrem $\Re$ alf ober Riejelerbe überziehen, weldhe 


\section{5}

man Tuffe und Einter nennt. $3 u$ Den jelmeren Eridheinungen bie= fer 2rt gehören bie Ablagerurgen von Riefelfinter, wie fie bie bei=

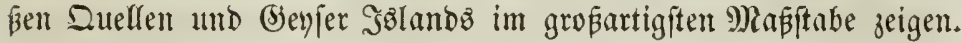
Der Tuff uno Rlingitein, aus welden bie Duellen ber Beyfer ftrömen, haben, jo meit biejer Dueflenbezint reicht, unter bem Ein= fluffe beş erfikgten $\mathfrak{W a j ן e r z ~ e i n e ~ Z e r j e ̨ ̧ u n g ~ e r l i t t e n , ~ f i n o ~ v o n ~ e i n e m ~}$

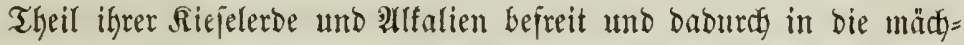
tigen Thonablagerungen verwandelt worden, weldhe jebet bie Bafiz Der Beyferquellen bilden. Die Riejelabjäbe des serbunftenden $\mathfrak{W a j}=$

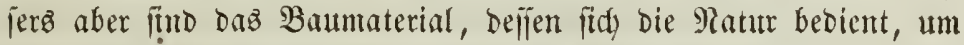

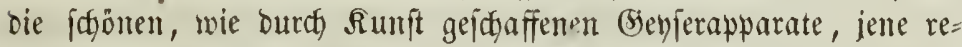

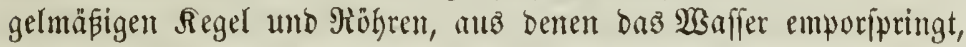
aujzujühren. Die תiefelfinter, weldge weithin ben Boben in ber Näbe ber Sievjer bebeden, gleidgen bort törnigen Şaufwerfen aus Eleinen Rutopfcten, fo fünflich georonet, Dap fie unjern Blumen= fohylföpfen ähnlidy werben. Anfangg fo zart, oa fie nicht unbes jđäbigt abyelöjt werben fann, erlangt bie Mafie mit ber Zeit eine

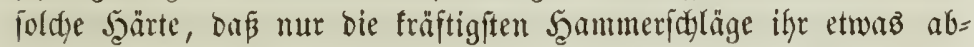
gewimnen töment. Die Mlädtigfeit ber das Beyjerbecfen umgeben= Dent Riefelfinter erreidyt ftelfenweije einte Şöhe von 12 Fuß und

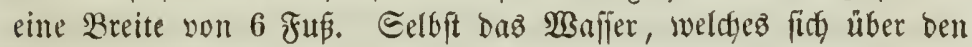

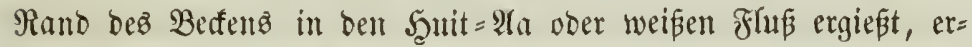
theilt biejem in weitem \&atfe veriteinernoe Sraft. In jeinen $\mathfrak{n}$ fern finbet man bie zarteften Meberfinterungen veridjiebener Bflanjentheile mit ifren feimften Fajern, Birten = und Beibenblätter, Binfen, Torfftilfe, Gebeine fleiner Ilyiere mit jo oitmer, fo zierlidyer Rie=

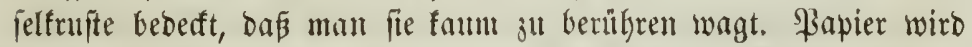

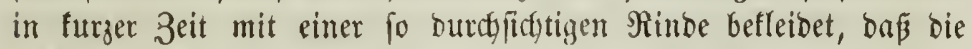

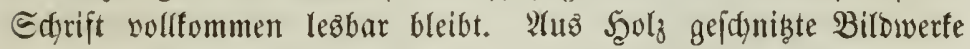
werben nadh lüngerer 3eit felbjt im Sutern von Riefeljubftan burds= brungen. Huth anbre (Segenten, bie 2(zorenimfel Et. Midjael uno einige Punte Porbamerifas und Deutfdylando bieten ähnlidae Riejelablagerungen bar; Die won Et. Midtat erreidyen jogar

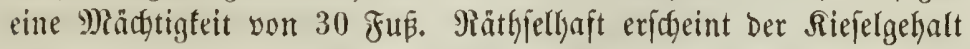

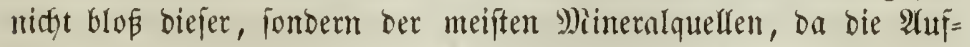

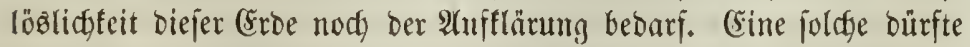
vielleidft ber Berjudy einez englifhen (Shemifers, Seffeey bieten, Dem 
eøิ gelaug, Durb heipe 2 alferoümpfe in eittem grofen Topferofen über 200 \&jumo Siejelerbe in Dampf auflejen und theilmeije fort= fübren zu lajien.

Minder auffallento fönnen uns bie auperorobentlich mïdtigen Ralfablagerungen anorer sueflen erideinen, da bie Auflözlidfeit Des boppeltfohlenjauren $\Re$ alfs, weldyen fie enthalten, bejonders in

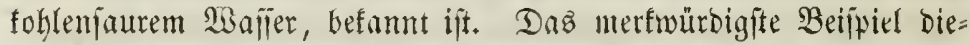

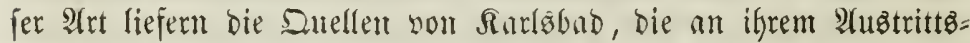
vrte eine ganje Deffe ron Sinter, bie jogenannte Eprubelichaale

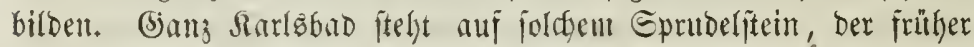
yon ben Duellen abgelagent wutroe und einjelne große Beffen heipen Suellwailers ïberdeft. Son 3eit ju 3eit gejdehen bei heftiger

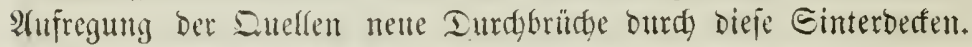

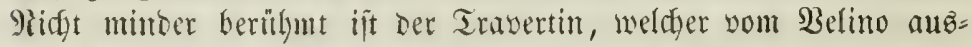
geictieden wird und an oen herrlidyen wanjerfällen vou Terni be= Dentente ablagenungen bildet. Fait in allen biegenden giebt ez folche falfbultige, veritcinernbe Euellen, weldye in ifrer Ulmgebung Ralfuffe und Elitwafierfalte bilden. Linweit Ergerum in Armenien

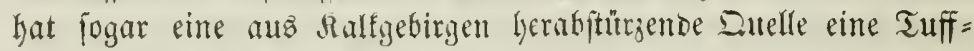
und Stalaftitenbrüte ïher ben Flü gebaut. Im \&aufe oer Zeit

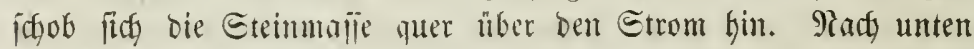
herabbängende Tropfitteine jenften fith immer tiefer, bis fie burdh ifr eignes (jemidt worn abbradyen uno jo bie (Sirundage zu bem gegenüberliegenden Brürfentopf bilbetell. Die Brücte, unter weldjer Der Etrom Dahintbraujt, ift mit Eroe unb Segetation bedect; fidger itberfyreitet man Das jeftjante Bauwerf, whne befien llriprung ju

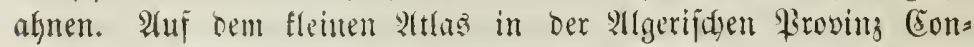

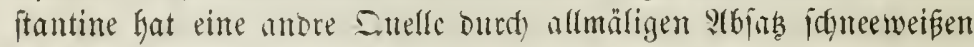

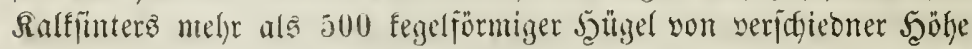
gebildet. Den maleriichiten 2Inbliff gewähren bie foloflalen Tropt= fteingebiloc des Bambuf Saleifi ober Baumwollentaftells einige

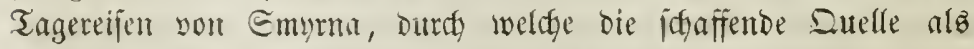
mäd)tiger Etrom wildidäumeno in bie Thaltiefe linabichieft.

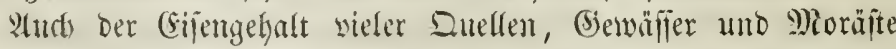

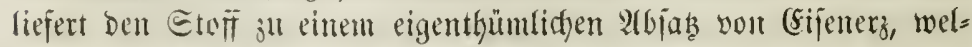
des unter bem Yirmen Rajents, Bohnerz, Rajencijenftein befannt ift. Radg längerer Zeit fönnen Diefe zu beträdgtlidgen \&agern von 


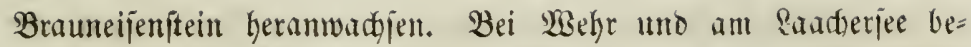

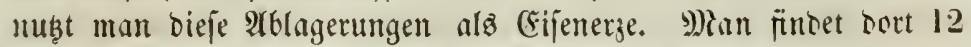

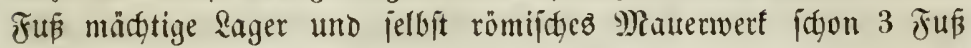
hod von Defer bedect. In 1011 Galyen witrben bie Quelfen bes

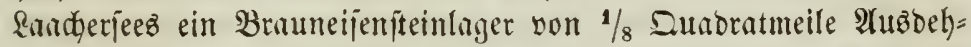

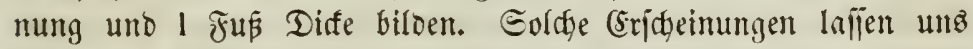
Daher autch auj bent Uriprung ähntidger älterer Bifoungen fodliebent,

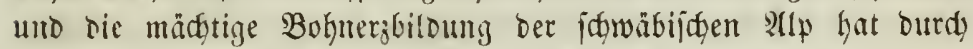

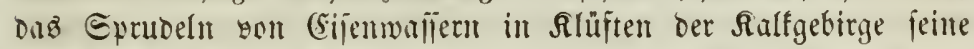

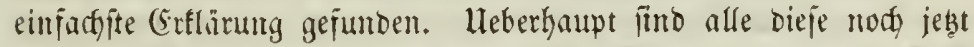

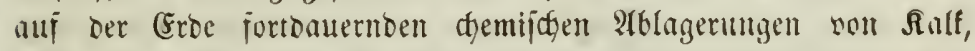
Riejel uns (sijen, weldye fïh aus ben jüpen Bemäffern nieser=

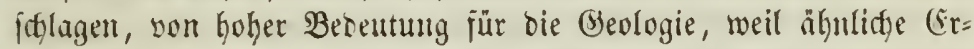

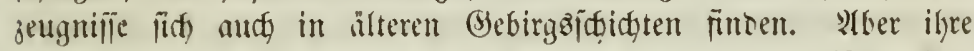

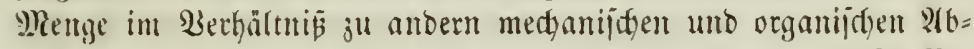
lagecungen iit nur jehr gering unt ihre Malje faum in biejer $\mathfrak{B}_{e}=$ ziehung in Betradjt ju ziehen. In älteren geologifden Formationen

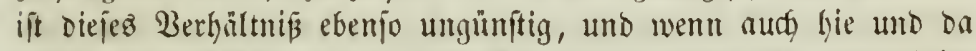

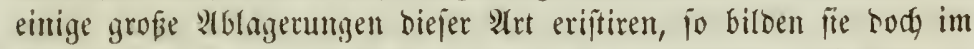

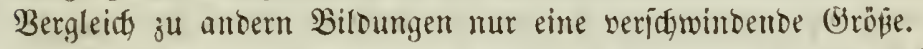

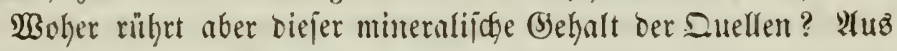

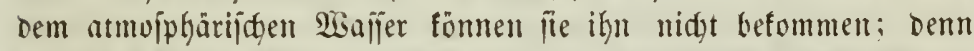
onz ift faft dyemijd rein. Plur in oer (Eroe jelbjt treffen fie bie Stoffe an, mit betten fine an ifren 2 (ustrittsorten zum Boridsein

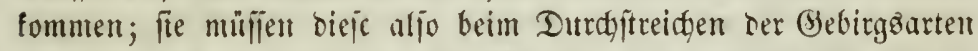

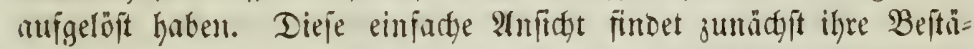
tigung in ben Ealzquellen, in weldent wir diejelben Beftandtheile aufgelöft antreffen, weldye aud bie Eteinjalzlager enthalten. Da

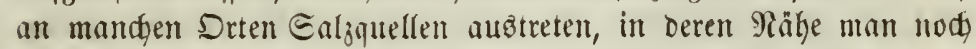
teine Steinjalzbinfe entoerft hat, entidgeidet nidfts gegenüber ber andern Thatjacte, nach weldyer an ben veridgienenften Deten uner= meßstiche Eteinjalzlager aufgejunten woroen fints, mo man frïher mur Enljioolen fanute. Yiod) vor wenigen Jahrjethnten gehörte

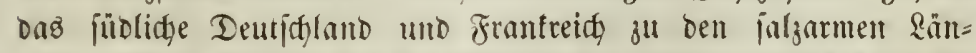
Dern, bis in bem einen ein (Erojall, im andern ein glüflidger $3 u=$

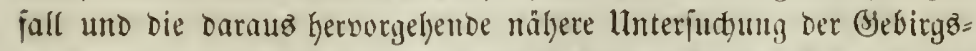

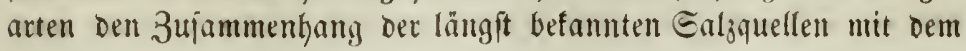


in ihrer Răhe befindlidgen, erit jo fpät entbecten Steinjalze fennen lehrte. 2(uch yon anderen Mineralquellen zeigen bie Beobactun=

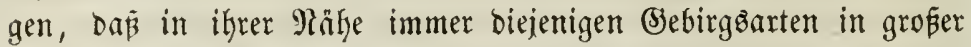
Berbreitung vorfommen, weldje an Beftantbeilen, bie in biejen Suellen bie vorwaltenden find, einen unerifappficten Borrath be=

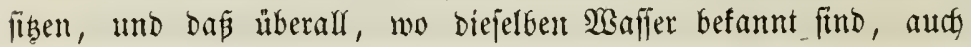
Diefelben (jejteine fidh mieber vorfinden. Diezs hat Struve auf's Seerrlidyjte beftätigt burdy feine (Erzengung fümiftlider Mineralwafier, weldye in ifren Wirfungen Den natürlidgen völfig gleidy fommen,

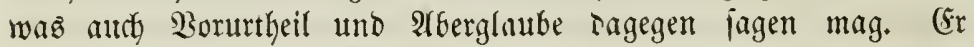

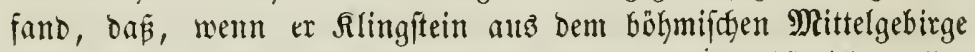

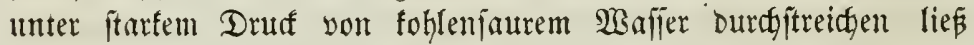
und nod freie Sohlenjäure 3uführte, ein $\mathfrak{B} a$ ffjer erzeugt wutroe,

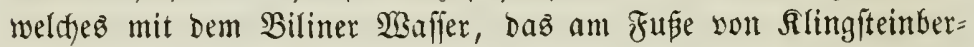
gen entipringt, in 3ujammenjeşung und phyifiagen (Eigenjadaften völlige Hebereinftimmung zeigte. Ebenjo gelang es ifm burdh $\mathfrak{B} e=$

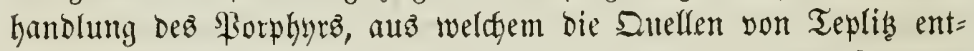

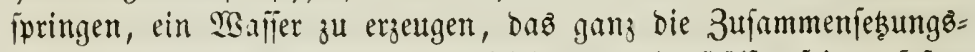
verhältnifje deż Tepliker, wenngleidy nut bie Şälfte feiner feften

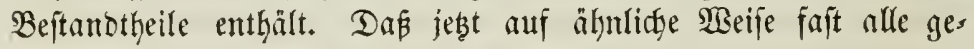
brä̀tdficţen Minteralwajier nadgebildot werben, ift befannt.

Eoldje (Erfahrungen mußten natürlid bie meiften Raturforidger

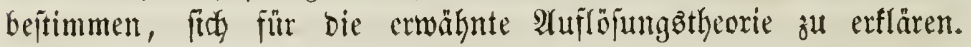
Eteffens freilidy unto andere Bjelegrte, benen unbegreiflidge, geheim=

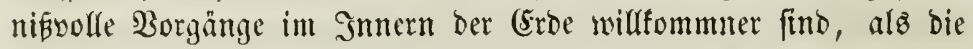

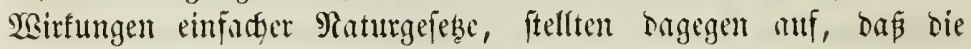
Erbe bod, nicft fo viele Beftandtheile hergeben fönte, als bie be= reitż feit vielen Suhrhunterten fließ̧enden Suellen gefiefert haben, uno beriejen fidy bubei anf bie ungeheuren Duantitäten fefter \$ro= Dufte mandfer Sultelen, unter Denen Der Eprudel bon Rarlz̈bad

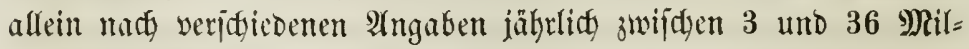

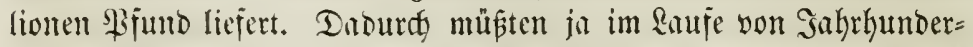
ten und Snhthtaujenden gewaltige hohfe Ränume im Snnern bes Berges entitehen, wedcte, wenn biefe Mlafien alle an einem einzel=

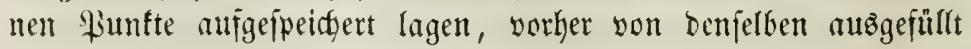
maren. Dennody finto biefe Räume nidgt fo ungeheuer, als man 
fie fich vorftellt. Zögen bie Rarls̈baber Duellen ifre fejten Etoffe

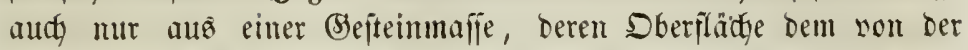

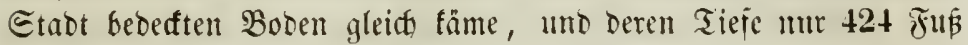
erreidyte, fo wäre fie bod hinteidgent, um währento eines Zeit=

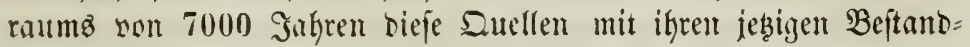

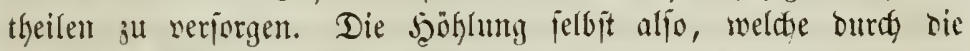
allmälige $\mathfrak{B}$ egrahme biejer Maje entiftamben märe, müfte verlält=

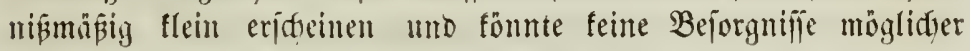
Eimftürze veranlaffen, Dar heise Dutellen ifren Şeerd tief im In= nern Der (sroe haben. 2lter bie Etoffe, weldye die Minterahwafier aแเซิ Dem Edyoo einem abgefonderten Enger beifammen, fortoern fie liegen überall im Berge vertheilt. Edyon ber $\mathfrak{B a} a$ ilerreidythum der meiften minerali=

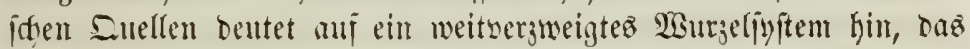

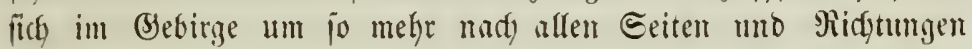

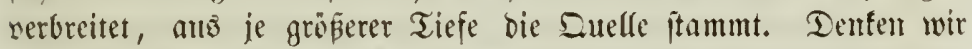

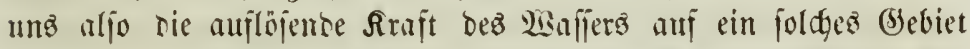

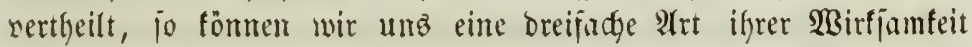

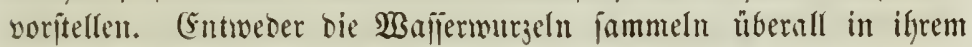

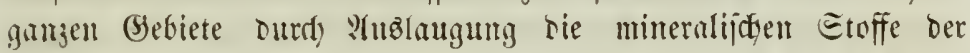
Duefle, Dam wiro ju einer merflityen Berminterung Der Bebirgas=

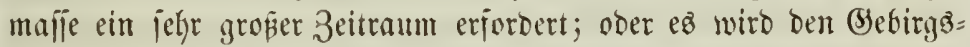
arten ein Theil igrer Beftanththeile alfmälig entzogen, jo Daß fie

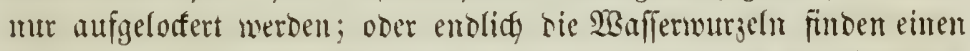

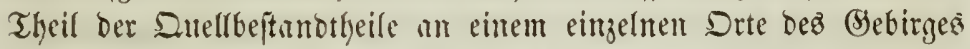

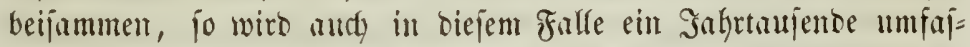
jender Zeitrutm erjorderlidy jein, um eine berettende Şöghlung im

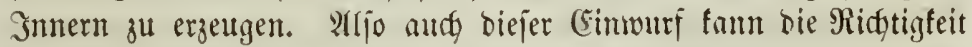
Der Theorie nidgt ftörent, nady weldger bie Mineralquelfen ifgre Єtoffe

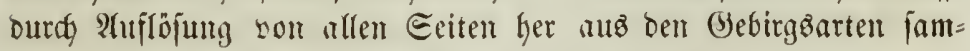

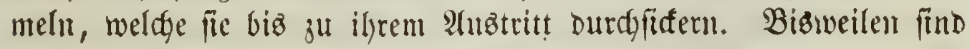

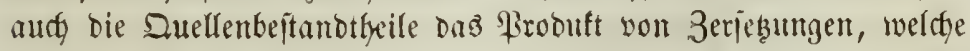

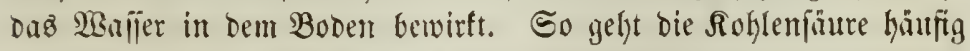

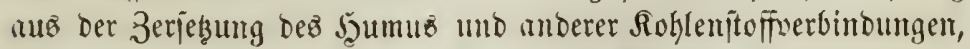

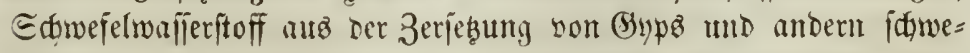

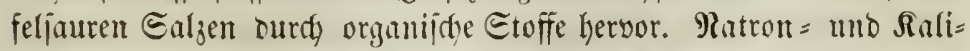

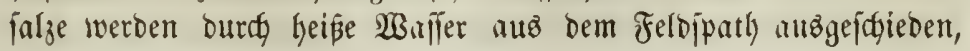


Bitterjals burch gegenjeitige Zerjeknung von (Sups uno Dolomit ergeugt.

Ieuperit widftig für ben Uriprung ber Quellen iff endfid bie Thatjacte, $D a \hat{p}$ find bie Säuerlinge bejonters mur in alt= ober nen=

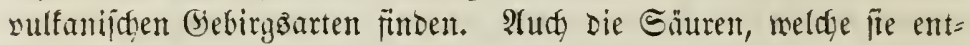
Golten, unt bie ihnen ihre auflöente Rraft ertheilen, Roblemfäure,

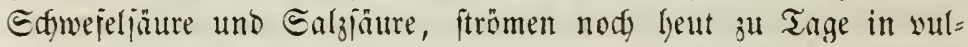
fanijichen Begenton ober Dod, Dort, wo alte Bulfane ifr sisejent trieben, in ungeheurer Menge aus. Mit Mecht erbficft man onger

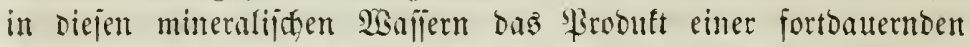

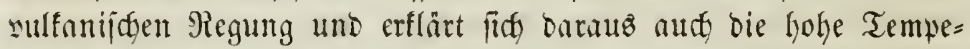
ratur berjelben, bie bei vielen jeit Эahttaujenden biejelbe geblieben

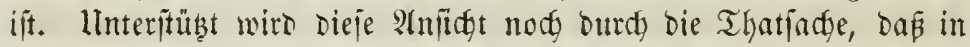
sulfanijden Eandiftidfen immer jahlreidge heipe Quellen gefunden

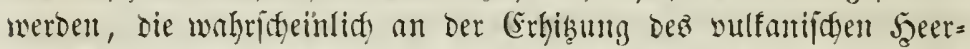

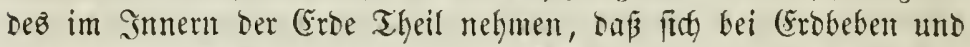

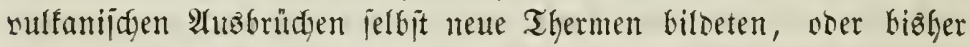
falte Sueflen in loeipe umgemanbelt wurben. WBent bagegen ber oft bereutente 2Bärmegrad anderer Suelfen, bie in begenden auz= treten, weldhe won thätigen ober erlojdenen $B$ ultanen fern liegent,

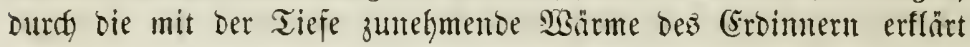
wird, fo bürje bieje (Srflärung wenig non ber erijten neridjienent fein, wenn man unter $\mathfrak{B u l f a n i s m u s ~ i m ~ m e i t e j t e n ~ E i n n e ~ b i e ~ \Re e a f = ~}$

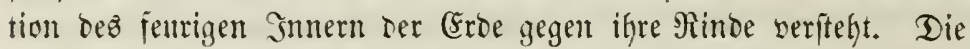
Errahrung Jebrt, Dañ bie Duelfen einen nieberen oder Göheren

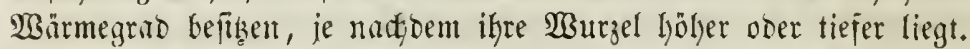
Sn Gebirzen ift indep ber şeerd, von meldyem bie Duellen ihre WBärme erbalten, nidft inmer fo jefgr tief, ju jogar büufiger über,

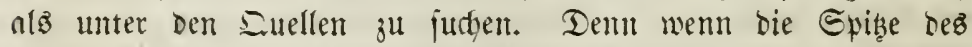
12,010 ₹un hoben Sotler cine Mitteltemperatur von - $10^{\circ}$ hat,

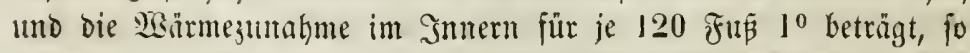
fiteigt bie innere Temperatur bei 6000 Fुu 5 fäbe noch auf $+40^{\circ}$, uno das Durdjiffernoe $\mathfrak{B a j l e r}$ hătte nod immer ein himreidjentes befülle, um in ber baghe von 4600 Fus bie Therme von Bormio zu bilden. Deshalb jelyt bie (sthebung über Der Meereşfläate in feiner nothwendigen Bez̧efung zu ber Temperatur ber Duelfent. In ber Nä̆he von Bulcano iprubelt eine heipe Suelle auts bem 
(5runde des Meetez hervor, whihrent bie von (5ajtein 3230 ₹uß

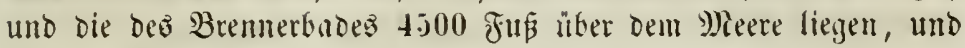

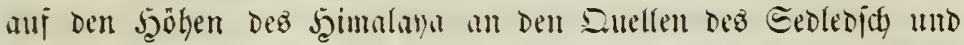

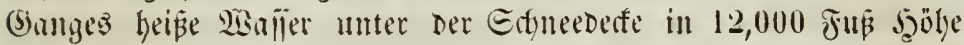
herworbedgen. In Siebirgen tecten fanter die meiften heipen Duel= len aแz bem (Strunde idguturtid) tiefer und wilder Edhludten ger=

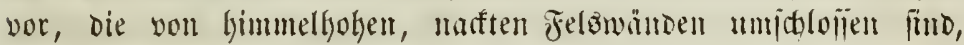
oder fie liegen in (sngpiijien, iu Duerourdgid nitt mäd)tiger Retten. Aud bas ift ein 3eidsen, dap biefelbe (Sewalt, weldye bie gewal= tigen M)afien bob, aud) ilyen ben llrjprung gab. Die leeipeiten Suel=

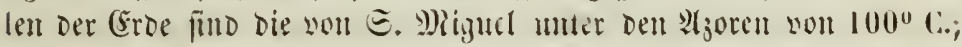
Die am Sin won $=2 "$, die son Butrifteit mit $7 \overline{7}$, Der Eprubel son

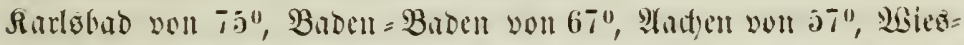
baben von 70", (5mb son 57", Tepliß̧ mit 49", Baren im *hargun unit $46^{\circ}$ und Bagneres in ben Siyrenten mit 50". Biele unter ifnen, bie Dueflen won Miont= Dore, won :lir, won Hifa unto

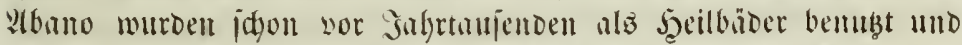

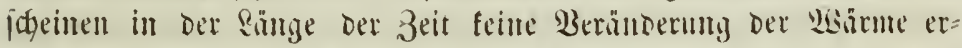
litten ju haben. Siur in vulfanijgen (jejenton mo unter Dem Eisflü von Erobeben finto Erhöhungen und Ernierrigungen ber Duellenwärme beobadbtet mordell.

2) Die Wirtungen der jllije un Me Mere.

Wie bebeutento and bie Jiolle jein mag, weltye die Duellen

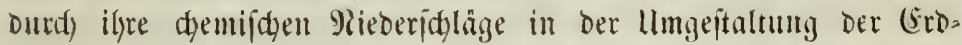
oberialäde fpielen, jo veridgminden fie bod) gegen bie Bedentianteit

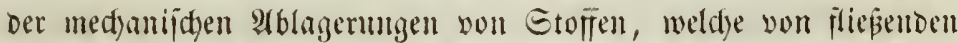

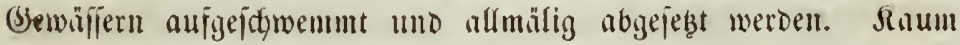

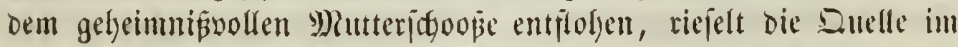
muntern Spiele von Rlippe z" Rlippe, bie verwanden Befälyrten z" fudsen. Mit ifnen vereinigt ftürst ber raujdende Bilobady in präd)=

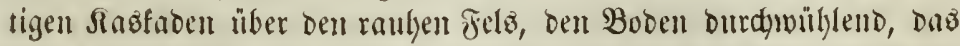
loje (Erbreidy son jeinen ljern reißend. Jmmer mäd)tiger idbwillt ex all, immer breiter behnt er fich auz, ber flü verläpt bie Berge, bie

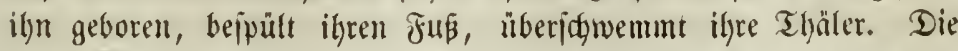
weite (Sbente nimmt ben Strom auf, Den ernjten und bejomenen 


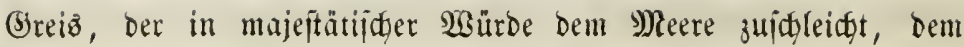
(jrake jeiner Mähen und Dem Edyooß̈e jeiner Berjüntuntg.

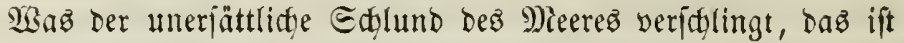
ein Ungeheures. Sđ̆ Dari mur an bie mädtigen Etröme P'merifa'z

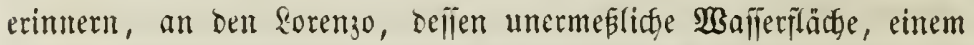
weit eritreeften Єee gleid), Den (Ëuropäer mit Etaunen erfüllt, an Den Srinofo, den $\mathfrak{A}$ mazonenjtrom, befien Rampi mit ber feindliden

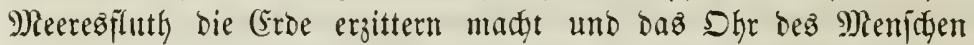

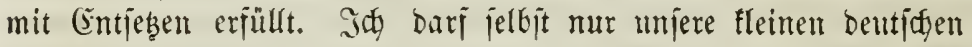

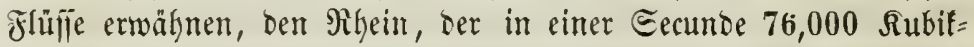

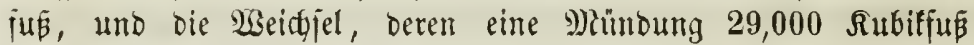
Waffier in einer Eecunde liefert. Träge wälzt ber Etrom bieje mädftigen Fluthen burdf bie (Svene Dahin, uno mur feinblidye Şem=

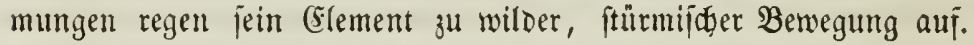
Feljen engen jein Bett wlöglid, ein, und in getwaltigen Etromidgnel=

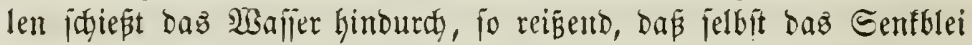

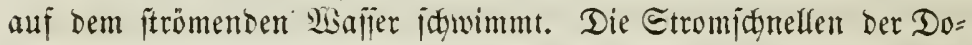

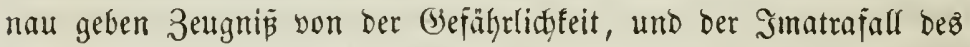

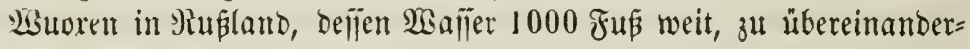

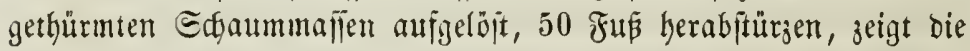

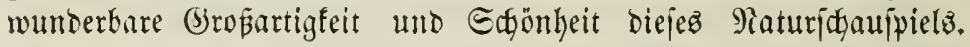
Ojt zroingen voripringende Felämajien ben Strom zu plöblicten WGendungen, ooer verborgene Rlippen werfen jeine Welllen zurüaf

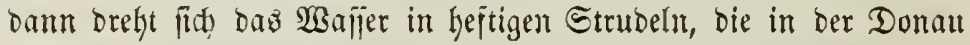

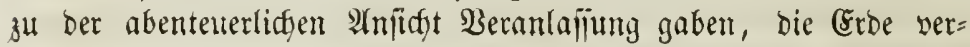

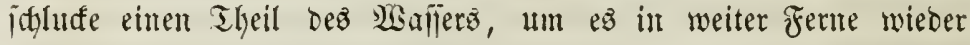
Gersorjugeben uno oen \$lattenjee zu bildon.

Furdtbar fämpft oer Etrom gegen Den 2 Biberijtano, ber jeinen

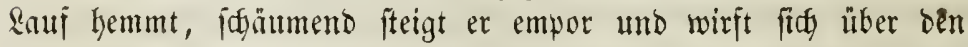
unerichütterlicfen Damm hinweg. Bald jpringt bas 2ajajer in rei=

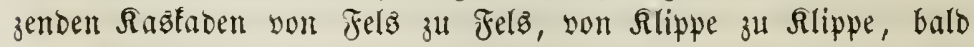

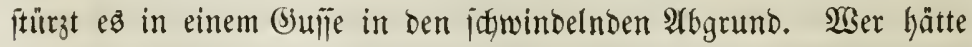

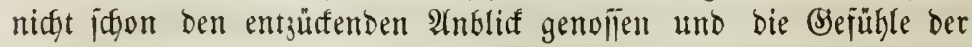

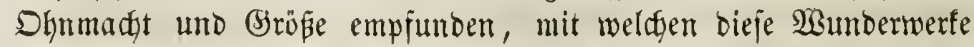
Der Ratur auds in Der Rleinheit ifres heimiften (Stgarntters bie

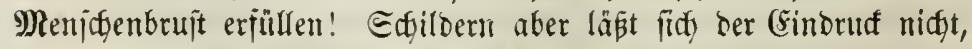
ben die gropartige Matur diejes Sdgaupiels in jerneren Rändern 


\section{3}

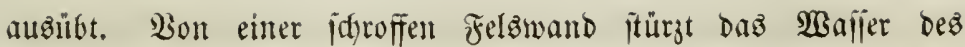

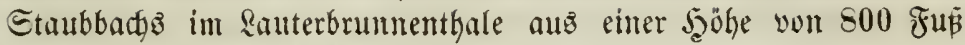
nieber. Im Falle jerjtiebt es zum jeinjten Etaubregen, ber blen= Dent weis in ben Ruffen ianebt uno Farbe und Formen in pradat= vollem Epiele wedjelt. In juei mädtigen Bogen non 1748 Fu户 uno 1068 Fuß Breite ftürst Der yiugara bie bem Sriejee entfliepen=

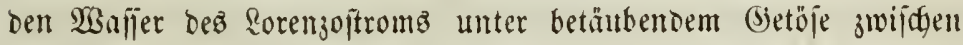
Feljenmauern in einen 138 biz 168 Fuß ticjen. Eđblund himab,

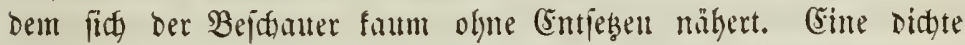
Ectaum = und Tebelwolfe, weldye Dem NGgrund entiteigt, werfin= Det ichon in einer (Entfermung non 10 Deutiden Mreilen biejen

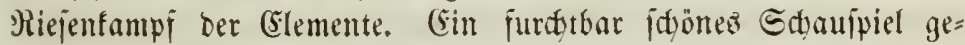
wähnt ber Tequentamajall in Reugramada. Sgier ftürjt fid ber

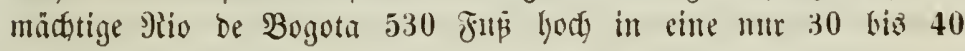
Juß breite Feljenfluft linab, weldye von Erbbeben eröfintu mard, won Der aber bie Enge erzählt, ein (S)ott habe bem flulje biejen

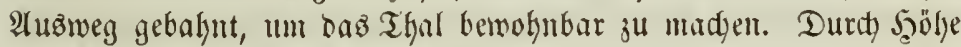

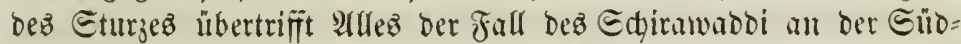

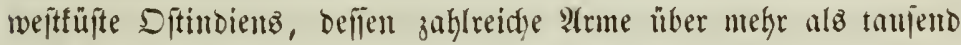

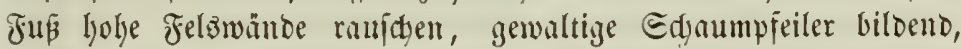
weldye zarte Dunitwolfen umiduweben. Dodh bie Szöhe beoingt nidst allein ben romantijgen (5harafter einte sibajerfallz. Daz bemeift Der ßarauta in Eñonmerifa Durd) jeinen furdtbaren Ratanaft yon (Suayra. Die ungeheure, 12,600 Fü breite Wajermaj̄e dieję Etromes wiro plöblich in einen 180 Jup breiten Ranal jufammen=

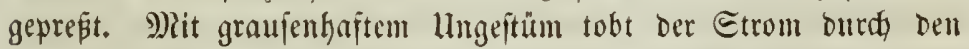
Engpaв, hod auf idlagen bie Bellen, die Feljen jeriplittern, und

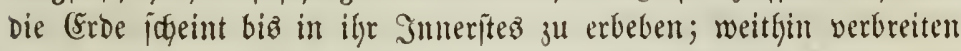
bie aufgeftiegenen Bafferdinfte einen ununterbrodenen Regen.

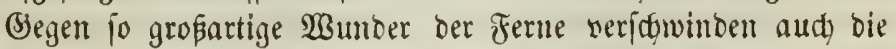

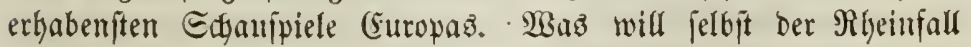
bei Edyaffiaujen mit jeinen 300 Fuß breiten und $45-60$ Fuß hoken Waflerbogen gegen einen Niagarajall bebeuten? Nber man afyt audy in Dem Sleinen bie Sröpe der Edyöpung und betet

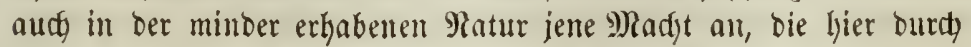
Wajieritürse bie Erbe erjøüttern, bort ourch Bölferjtönte Throne erbeben madyt! (Sinen eigenthümlidgen Reis gemähren bie Wafjer= 


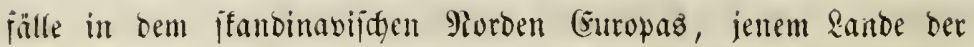
Thatfrajt uno des (Frntes in Matur mo Bewohnern. In Edyme=

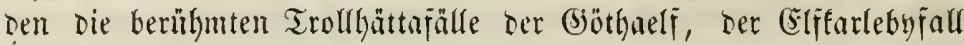

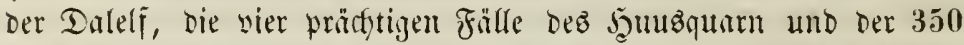

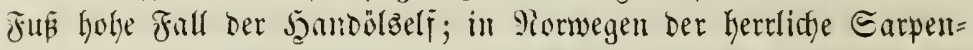

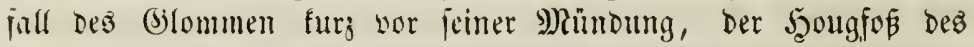

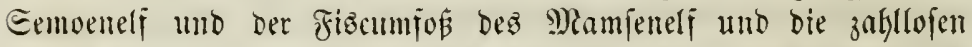

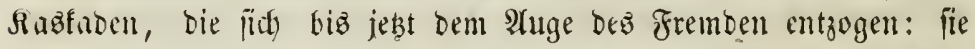

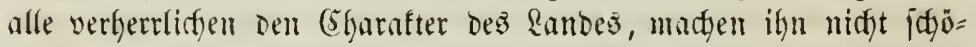
ner uno lieblicter, aber wild und romantifits. A(ter ber eifige

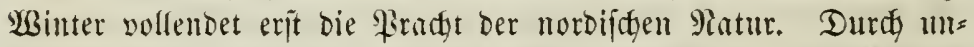

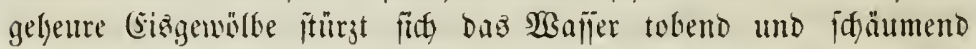

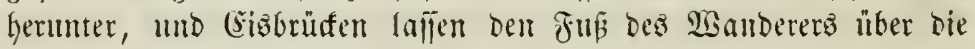
empörter isellen gleiter.

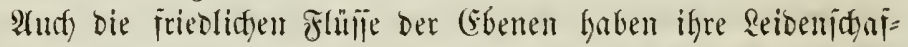

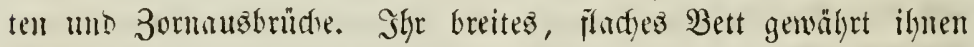

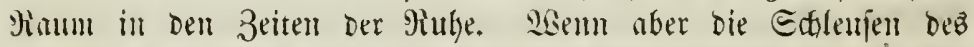

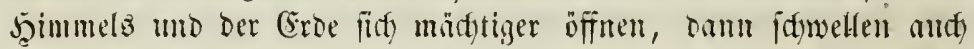

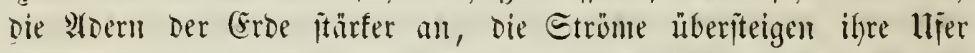
uno ergiepen lït) Eeen gleidy über unerméplidge (sbenten. In Den Qünoern periobifajer Miegenzeit jeigen aud bie Ueberidwemmungen Der Etrüme einen regelmäßigen ßerlauf. Der Srinofo fteigt vom Hpril biz Eeptember oft um mefr als 90 ₹ús und bietet bann

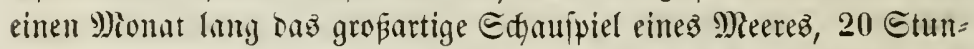
Den breit und über 200 Stunben weit, mit zahlreidgen 3 sirbeln und

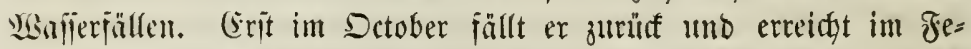

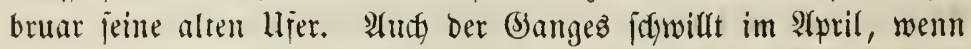

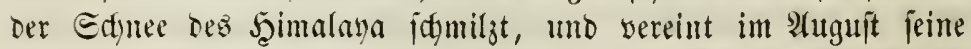
WBajler mit senen bes naken Buremputr zu einem unermépliden Eee, auz Dem mur einzelne Jăhgel und Dämme mit Etäbten uno Bewofnern gleich Snjeln hervorragen. Die Heberidjwemmungen

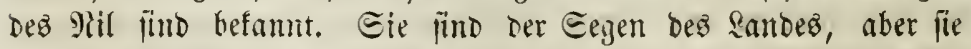

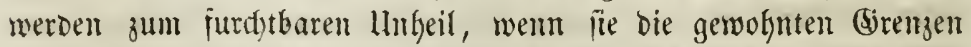

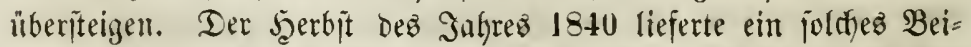

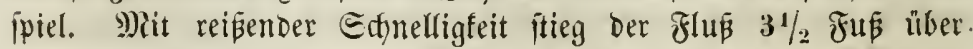
feinen erbabenften Etano uno Durdfbrad Dämme uno Mauern.

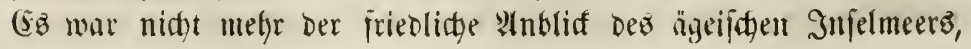




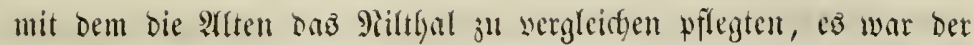
einer gräpliden Ënofluth, einer wilben Siarjermülte, uno bie glüf= lidgen Injeln Darin eine Beute uto ein Epiel ber 2 sogen. 150 Dörex murben hinweggeidfwemmt, uno nur fteinerne Bimänter wiberitanden bem gewaltigen Atnorang. Ealbit die friedidgen Etröme unjeres Baterlandes baben ifre, went audf anregelmäß̈:=

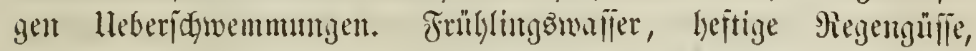

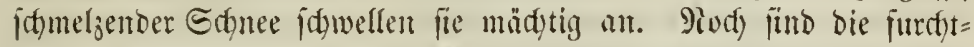

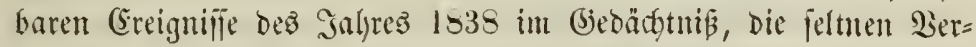
leerungen, weldye die Donau, die mit Eizmajןen bchaben 20 ruß

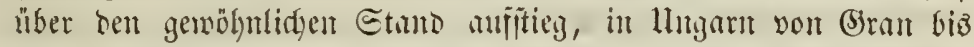

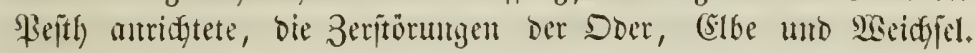
Sebes Sulgr bringt unz neue llnjälle, und mit Bangen fitht Der Bewwohner Deutidger Stromebenten hinter feinen fowadjen Dämmen ben brohenden Fluthen entigegen.

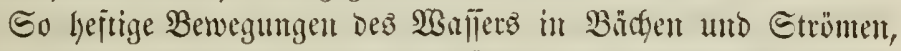
wie die eben geidilderten, rufen natiirlidy andy bedeutende Derin= Derungen in ber Matur ifher llmgebungen hervor. Die llfergefänge werben abgenagt und unterwaidsen, bie Betten tiefer anbgemühlt oder erbölyt. Siuhige Beffen nelymen bie aufgejdylämmten Trünmer, welde ifre wiloen 3uflüfe von ben lljers riffen, anf, und mädy=

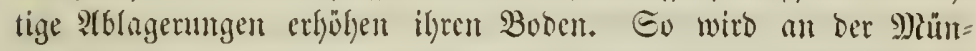

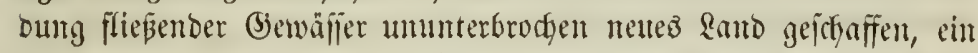
Telta gebildet. Edjon bie Millobandge zetigen bei ifjem Eturze in bie breiteren Thäler bieje Deltabilnung. Berberblity in ifrem obe=

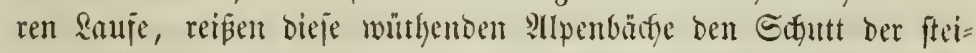

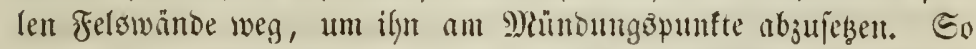
biloent fie einen feiliörmigen, oben abgeplatteten failgel, ber an bie

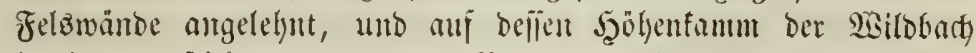
in immer feidter werdentem Bette dem Thale juitrömt. Den Strablent cinez Fäberz gleidh riejeln madh beiocn Eeiten fleinere

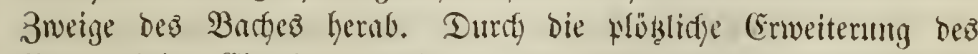

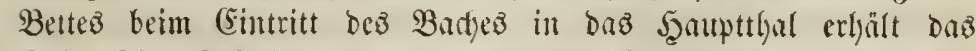
Delta feine Seftalt, und dicje erflärt bie furdjtbaren Berfeerumgen

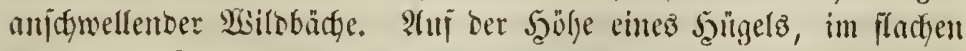
Bett verlaujeno, flutben fie mad) allen Eciten bin über, umb ber

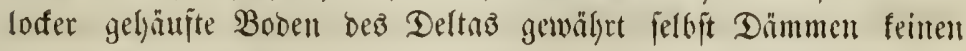
llte, weltall. 3. 2tuft. 
Fejten (5rundo. Der âtpenberwohner fasm oft mur Daburth bem

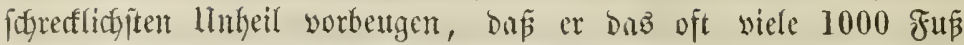
breite Delta it Der Entfermung mit Manern angiebt, weldye ben

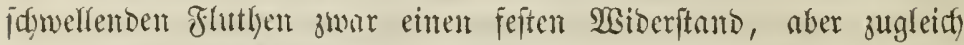
eine hinreidgende 2 ušbelyumg gewähren.

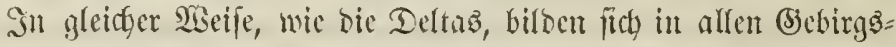
gegenden Edyutfegel und Edyuthalsen, wo fing eingeftuttene Edjludten in Thäler mümben. Mlögen fie aud oft mur bic Sair= fung vou Felsfturgen oder Eaminen feir, fo verbanten fie boch

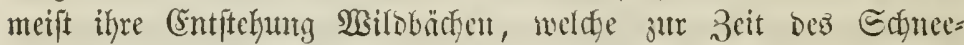

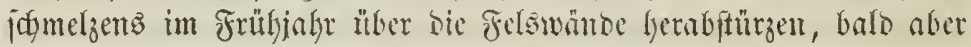

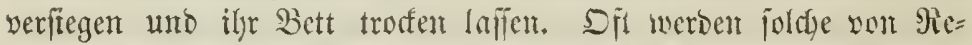

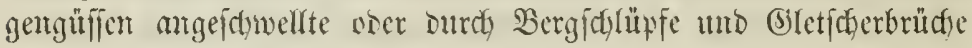
erzengte 2 Gillobäde ober Tobel, wie mant fie in oer Edyweiz nennt, fo gewaltig mit anfgefdwenmiten Maffen beladen, Dap fie als

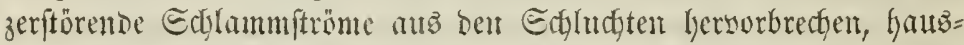
grope Feletritmmer vor fid Gertreibend. Seründerumgen in ber

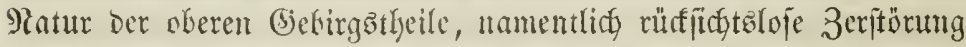
Der Gebirgäwäloer fömten mit Der Beit bie jeidfteften Bädge in foldye wnithende Tobel umwandeh. So war sie Siolla bei Thutfis

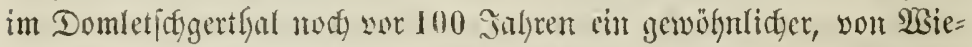
jen umlagerter (bebirgabad), ber mur bei (bewitterregen und zut 3eit

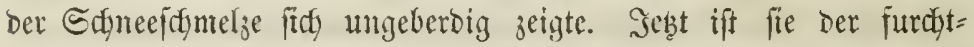
barjte alfer Tobel Der Exfyeiz. Die Berge, jwiftyen Dentent fie

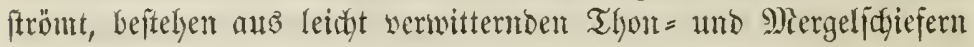
und jowwarzem, fojeferigem Ralfftein. Sdgutthalben fteigen im Şin=

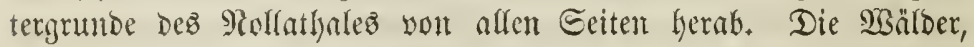
weldye fonft bie Eduttmajien befleibeten mb befeftigten, veridmant= Den in Enufe bes vorigen Sabrhunderts, bie Bierölle wurben be= weglidy, und Grofdylipfe traten ein. Sm November 1807 vollentete

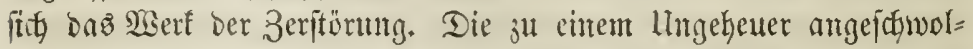
lente Roffa wälgte eitte Edgutt = und Bejobiebemajie von mebre alz

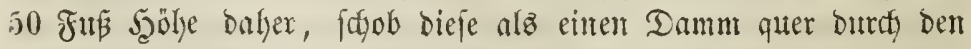

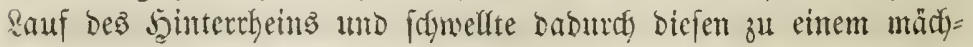
tigen See an. (j)lüaflidjerweife brads biejer See, ber bereitz 40

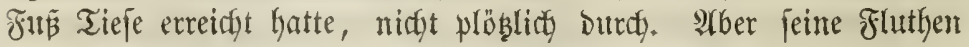

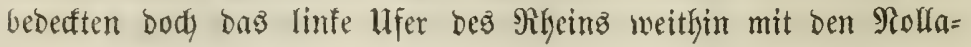




\section{7}

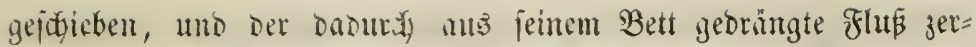

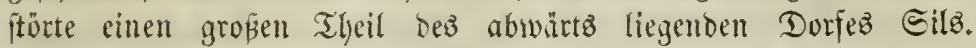
Seitbem liegt Das ganze Mollathal unb bas einft alB einz ber la =

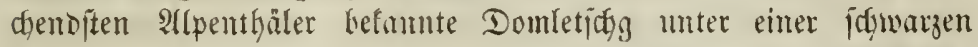

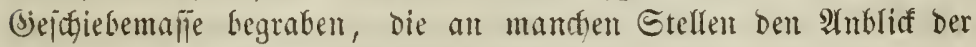
grauenvoliten siliftenci Darbietet.

Selbit bie getwaltigiten Edalammitröme vermögen aber nie bie ungelyenten Felobloffe, weldye fie in ben Berengertngen Lošreipen, Durd) eine Thalerweiterung limburdyüülyren, uns mur bie fleineren

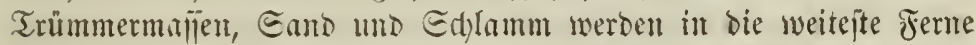

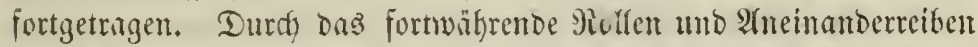
Diejer Brudjitulfe merden aber ifre idarfen (Efen und Ranten ab=

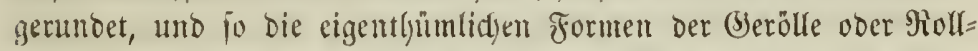
fteine herborgebradgt. Eelbit in gröperen fliljen verrathen fïb bieje

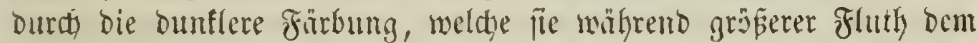
2Banfer ertbeilen. Im Dberrjeine hört man felbit beftintoig bas fni=

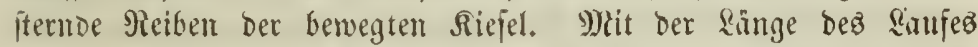

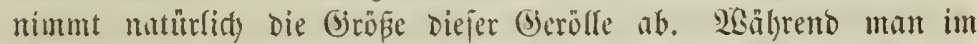

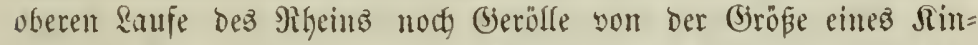

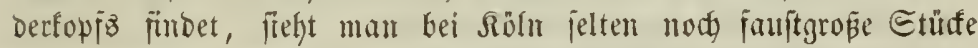
uno in Szolland mur jeinen Gand und Edylamn. Sime natủrlidje Folge biejer Fortbewegung Der Gerblle und jeinen Eanthetle ijt Deren \&bjeb̧ung an Drten, wo Der Rauj dez Flufiez lnngiamer

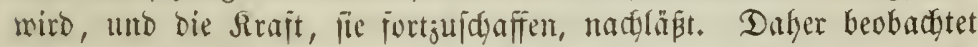
man in Fladjänoern cine jtete Serjundung ber Flupbetten, und wenn bieje tiej cingeidntitten fint, jo erfebt fids allmälig ber 2Bafjerjpiegal, und bei ftärteren Heberjofwemmungen werben bie lljer um fo leiçter überitrömt, je mefyr Daв Bett verjanbet ift. Soumt gar eine Geitigere Fluth, jo bridgt ber Flü ourd, gräbt fid ein neues Bett und lïpt bas alte als Rebentannal ober ganz trodten zurůf. In bewohnten Gbenen mußte man ouher fifgon von alten Zeiten lyer barauj Denfen, bie Ufer Diejer verjandenden Flu $\beta=$ betten einjuoñmmen, zu erlyöben, uno fo ber Möglichteit verheeren= Der lleberjdyemmungen entgegenzumirfen. So foumt ez denn, daß

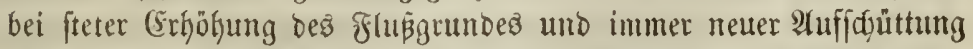
Der Dỉmme bie flupbetten fich aflmälig weit über bas 9liveau ber umliegenden (Siegenden erheben. Sin auffallendes Beipiel diefez 


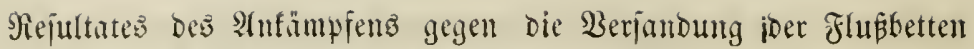

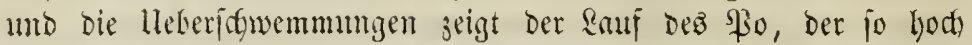

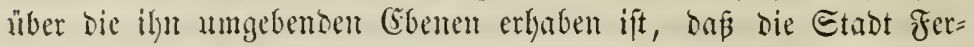

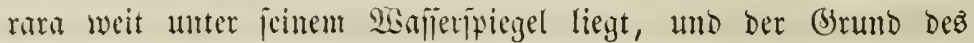
Flupbettes jellyt viele (Ellen höber ijt, als ber Boben ber Etadt.

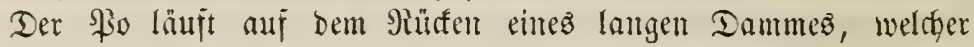
burdh eine grope Etrede ber lombardijdyen (s.bene fidh fingieht.

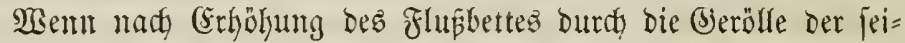

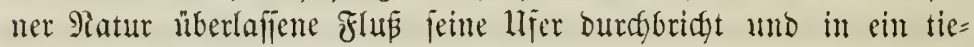
jeres Siveau hinabithis eime gabelförmige Thetlung Des vorber eimfictgen Raufez und bei

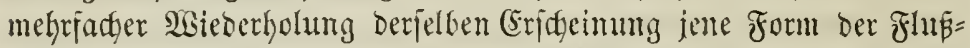
mimbungen, weldye man wegen iffer P(eb) lidfteit mit Dem griedi= fdgen Butfjitaben Delta genamnt bat. Die meiften biejer Delta's

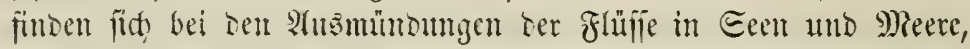
und man hat jebt ben anfangs mur auf bie Silmünoungen an=

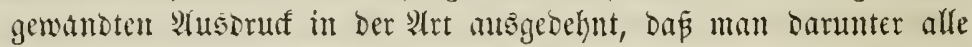

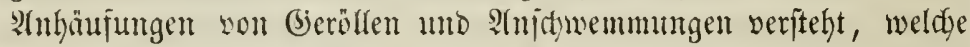

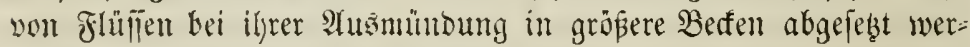
bell, wie anth ilfe form wedjicln möge.

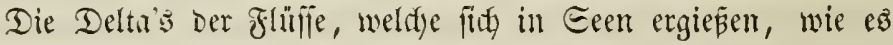
bie meijten flülie der Scodhalpen thun, bieten bie einfadyfen Ber= bältnifje bar, weil bieje $\mathfrak{W a j j e r b e c t e n ~ m e i j t ~ a l s ~ r u b i g ~ a n g e j e k e n ~ m e r = ~}$ Den fömen und nidyt Durch eigene Bewegung, wie das Meer burds Ëbbe und Fluth, itörend auf bie Eridgeinung eimwirfen. Das $D a=$ fein jolder Eeen ift Daher eine große Wohlthat für bie Bewolner Der Bebirgs̆länoer und ber Daran gränzenoen Ebenen. Denn bie

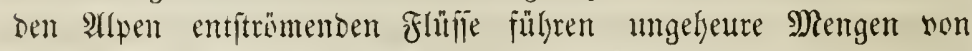
(jeröll mit fidh, bie bei igrem ftarten (jefälle uno Der biefdymindig= feit ifres Raufes bis weit in bie çbente hinaus gefülynt werden, bas Fluphett verjanden und die größ̈ten lleberidywemmungen bewirfen würben, wenn fidh nidgt die Eeeberten in ihrem \&auje fänden, in

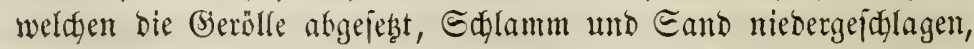
bie Єtröme geflärt und gereinigt wütroen. Alber biefe fleinen

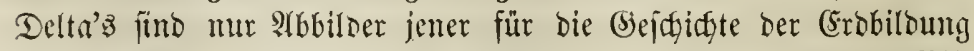

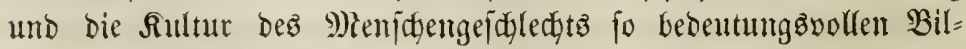
Dungen großer in bas Meer mintenter Etröme, die wir mit bem 
mur einzelme Sdyludten uno Thäler an ifren 2 byängen, bas Thal Der Berirrungen, Der Strom ohne $\mathfrak{W a f i e r}$ und bie Rette ber $\mathfrak{R} a=$ tromfeen jeigen, Daj fidt einjt Der Etrom burch fite einen $W_{3 e g}$ bract. Sebzt Durdfitrönt er in vielfadgen 3weigen eine weite Ebene, bie you ben beioen Sauptmünoungen bei Rofette und Damiette

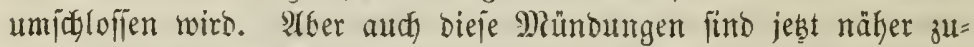
fammengerüat, bie Breite Des Delta's hat mit ber Erhöhung Des

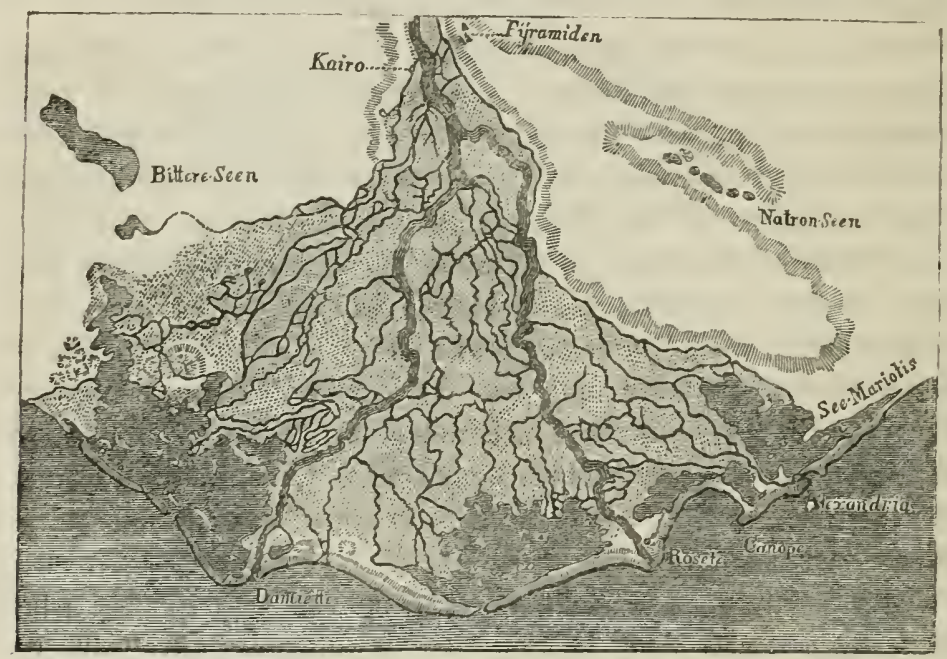

Då ఇițelta.

Bobens abgenommen; Denn Der Etrom fühnt bei jeinen alljährlidyen Uleberidyemmungen eine ungehenre Menge rothen Єiblammes und

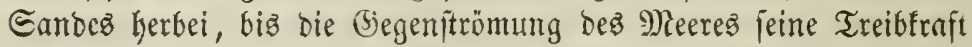
lähmt. Die eroigen Theile fulfen jebst nieber, werben aber von ben nadgfolgenten Wajfermajien auf bie Eeite gejđoben unb häufen fith Dammartig auf. (Segen biefen Danm ipülen bie 9)keerešwellen

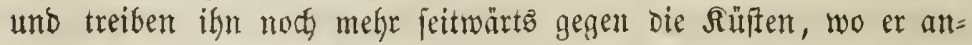
fangs Untiefen bilbet uno allmälig fidh zu einem mädtigen ufer= walle erhebt, ber bie Meubildungen Desె Fhtffez gegen bie zeritören= ben Sinfintle bes Meeris jhüht. Diejer Uferwall ift am erhaben= iten über bas ganze umliegende \&ano, uno jeine Dberftädye von Dünenjano bedect, feine $\mathfrak{B a f t s}$ aus feftem Ralfitein gebilbet. So

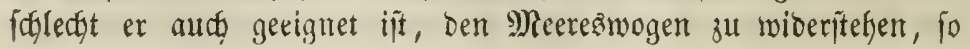




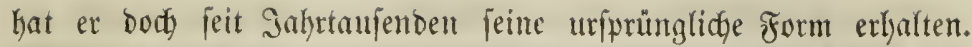
Daz wäre unbegreiflidy, wenn man fid nicht n̈berzeugt bätte, ba

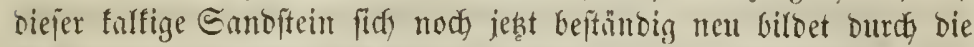
Banten fleiner mifruifopifiger Edyanfthiere, bie im Mferfanto leben.

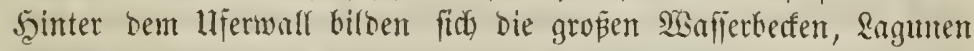
genantt, bie burch $T$ Mlütbungen mit bem Micere in Berbinbumg ftehen, aber mehr uno melyr your bem angefdwemunten Sdylamm erfüllft, altmälig ganz verifwwinden werben. 2fn zwei Etelfen, ben Miundungen von Mofette und Damiette, Kaben fich bie Arriftwem=

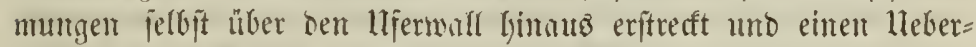

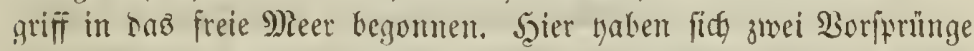

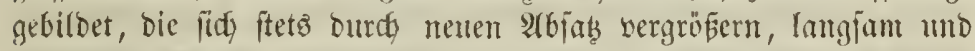
in ftetem Rampfe mit Den zertrïnmernden sisogen 万eళ Meeres. raic bedeuteno bie Bobenteryolyung nidjt mur ber Deltagegent, fon=

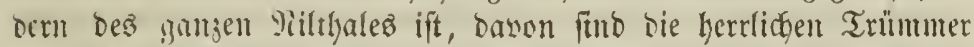
Der alten Sirndityebüune Thebenz bie beften Zengen. Damalb auf

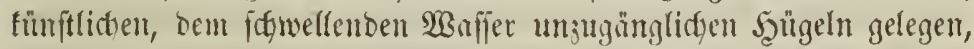
überragten iffe Eorfel Den Boden, der fie trïgt, in funftgered)ter

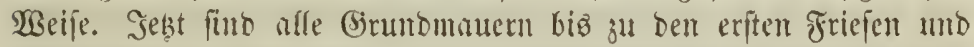
Sarmiesen in ibn nerfunfen, alle Etatuen n̈ber bie Sailfte som (Eroreid) bebecft. An ber fololifalent Miennonsftatue fanto man bei

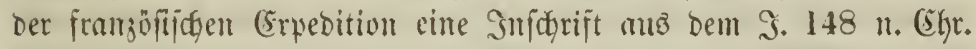

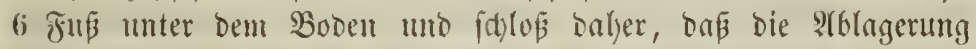
währent eincs Gahrhutnderts zwifchen 3 umb 4 3oll betrage. Da=

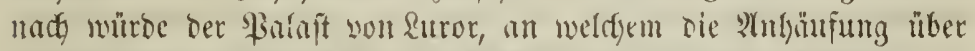

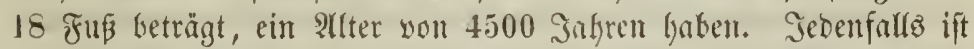

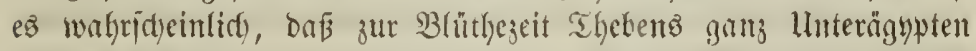

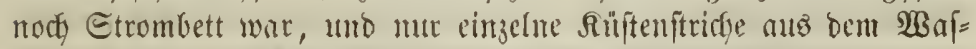

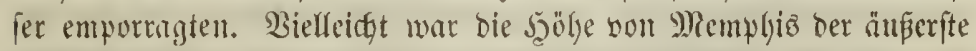
benohnbare Tlyeil, unt bier legte man barnm bie Rolonie an, welche ipäter burdy ifgre hequemere Berbintung mit bem Meere fich

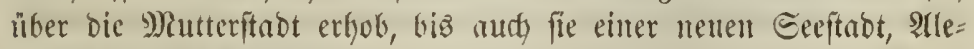
ranbrien, weidjen mufte.

Bie beim 9ii, fo zeigt fith bie Deftabildung and bei andern

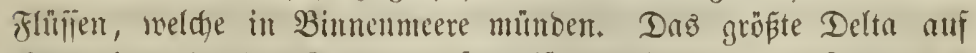

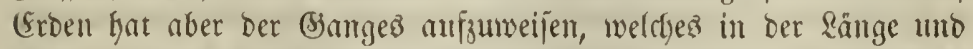

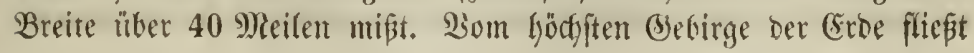




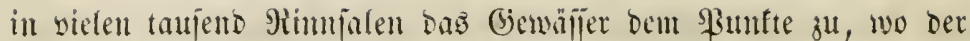

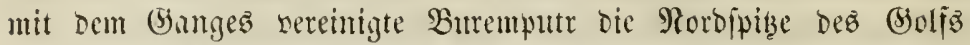
son $\mathfrak{B e n g a l e n}$ trifft. Dic unycheturen Mengen Edtammes, weldye bieje Etröme mit jïch jühren, und bie oft mehr als Den hunbertiten

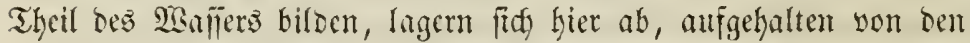
gegenifromenten Mecrsonngen, uno bilden cine weite Ebene, weldye ben Pamen bes Emberbundos führt und alto torfigen Moräiften, feifoten Exhlammjen und meiten Etrecten jumpingen ?antos befteht,

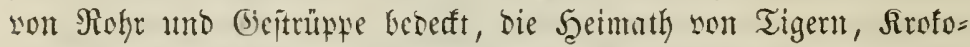
bilen und Edylungen. Ridot minter beseutent und nod ausigezeidy=

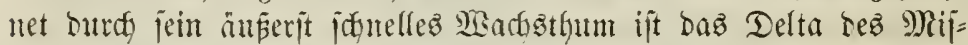
fitippi, weldyes cin fludes nicoriges Rano bilot, bas 9 Monate

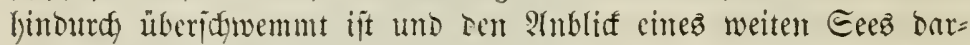

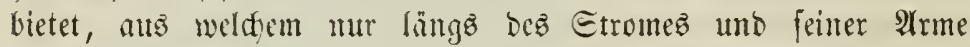
jomale Dämme herworichen. Ier Etrom jelbit nerjweigt fith in

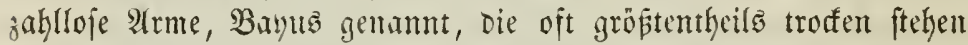
ober nur von den grofen Eanojeen gejperit wersen. Wenn fdyon bie Renge Des angejowemmten Edtamme ungeheuer ijt, fo fom= men bier nody die gemaltigen Flöße son Baumitämmen utno ganzen

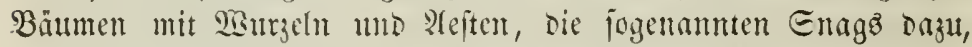

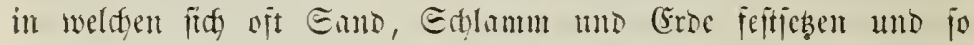
fafwimmente, mit reider Begetation befleisete Injelu biloen, bie fits mit bem feften emoe wereinigen und bies vergrößjern. Eo

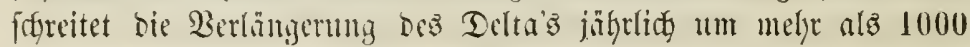
Fup nor.

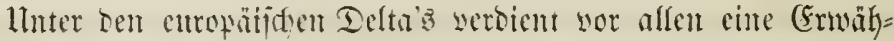

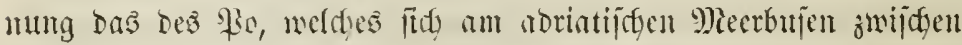
Rimini uns rem (josf son Trieft binjielyt uno in jeiner ganzen Ränge burct) cincm janjt gefrimmten llierwall begrenjt ift, Der in Der Măbe you Benediy Den Yamen Des Ribo trägt. Şinter biejem Sito jeigen fich bcjonders bei Sentedin und Somactfio bebeutente

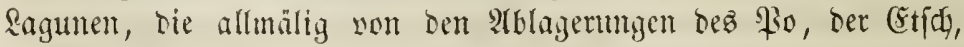

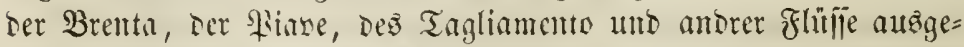

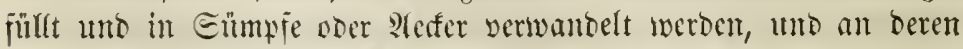
innerm lljer bie meijten Rujptenttiote liegen, jo Das fie immer mebr

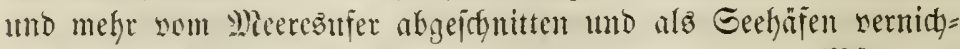
tet werben. Mody im Mittelalter lay Mavenna an oer Mủnoung 


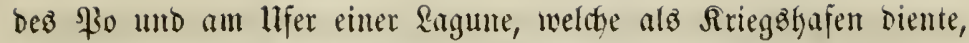
wäkreno es̉ Eeutigen Tagez eine Meile von Der Rüfte entfernt ift,

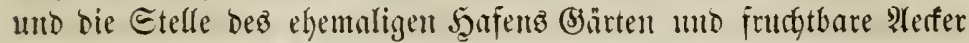

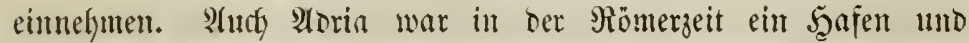
liegt jebzt $31 / 4$ Meilen som Meere entjernt, ba baz Delta in Folge Der Anjobemmungen fid über ben Mferwall Ginnts in bas Mer vorichob. Die sagumen non Benebig fint mur durth bedeutende Prbeiten bis jebst vor ber gärjlichen Berfantung bewahrt worben, und bodg theilt Bentedig vielleidft binnen Rurzent bas Edjiffal Man= rennas. P(ud) bie Einmolner yon (Somactbio fornten mur burd)

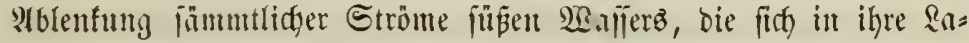
gumen ergoffen, bic Âtrïlung biejer fijdreiden Binnenjeen ver= finterit.

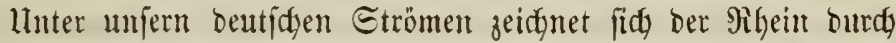

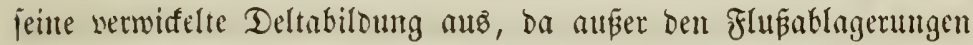
und ben sieeregbildungen lyier aud einte alfmälige Bodenfentung

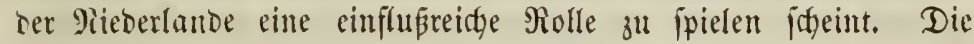

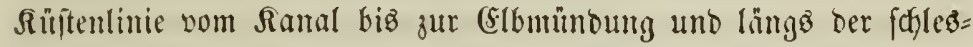

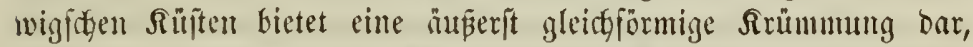

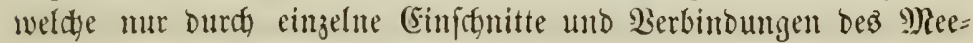
res mit ben zalylreidgen Bimesteen unterbrodjen ift, bie fich hinter Dem Lierwalle befinten. Die Infelrcilye, welthe fidh im Poroen bes

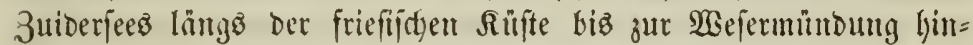
jielyt, zeigt bie lleberrefte biefes llferwalls, befien Zerfiturung burd bie Meeresivelfen fogar in hiftorifher 3eit bebeutent vorgefdritten ift. Bon ber norbdeutiden (sbene find bie Pieberlambe buth eimen

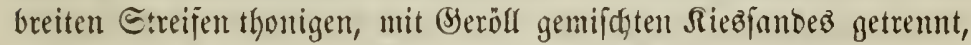

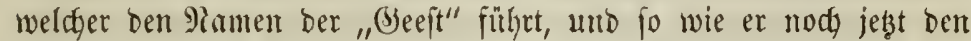
Boben Der weitphäliftyen Eteppen bildot, einft auth ben Booen bes

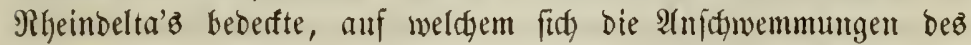
Rheinz, Der Edgelde und Maaz ablagerten. Durdy bie beftämbigen

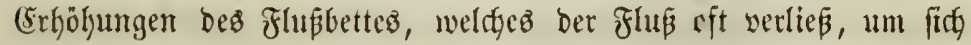
ein neues ju graben, uno burdy bie fleifigen $\mathfrak{B e m u ̈ l}$ )ungen ber $\mathfrak{A} n=$

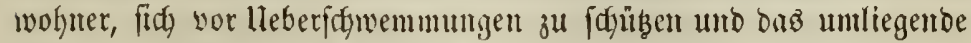
Rand bem Meere und Flufie zu entringen, haben bie Miundungen

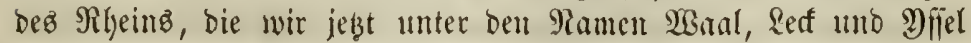
fennen, bef́tänbige Berändermugen erlitten. Die alten Bataver 


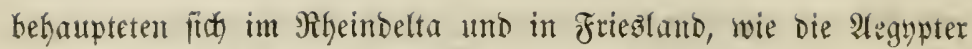
im Delta deş 9Ril. Eie erriffteten Saŭgel und Dämme als $3 \mathfrak{u}=$

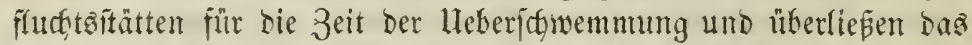
platse \&and Der periobifol wiedertefrenden Ffuth, weldye bie aufge=

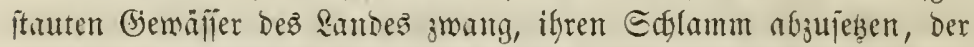
altmälig ben Boden über ben Bereich oer lleberictmemmungen er=

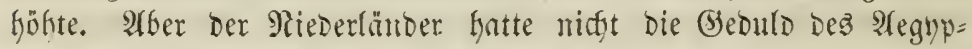
ters, er wollte Der Patutur abtroben, was bieje in langjamer Esut=

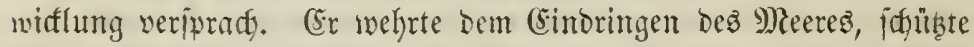

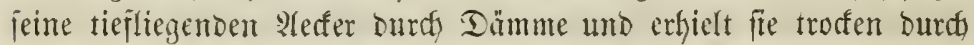

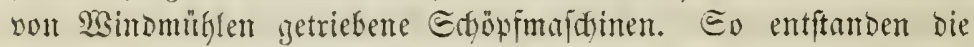

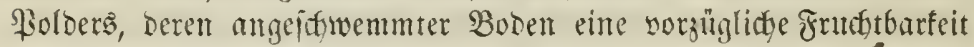

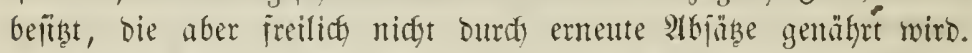

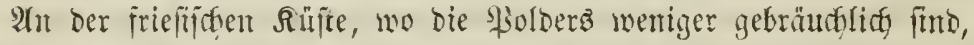

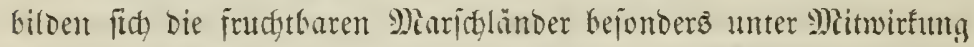
Der Begetntion, in Deren vielfadjem (Semirr bie Afnjdyenmungen zurüagefyalten werden, Die mun den Boden erföfen und das fandige

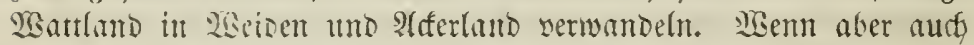

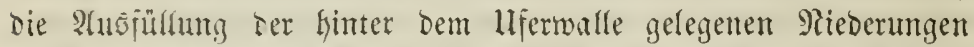

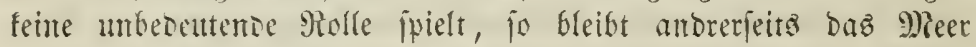
Durdbaus nicht unthätig. (Ë arbeitet diejen Bildungen mädtig

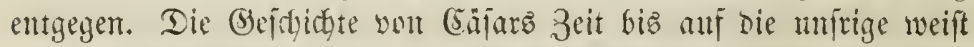

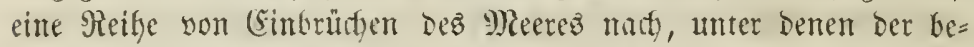
Deutendite Derjenige ift, weldyer im 13. Gahth. Den Zuideriee biloete,

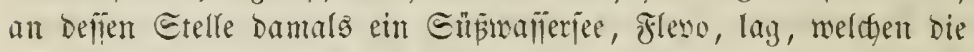

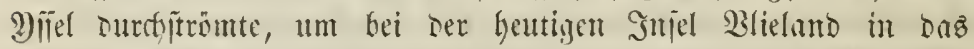

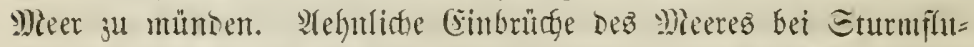
then gabent auth Dent Dollart unt Der Saljoe iffere Entriftefung, unto

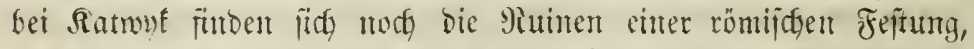
meldge Der Raijer Clautins in einer Entfentung von 600 Schritten

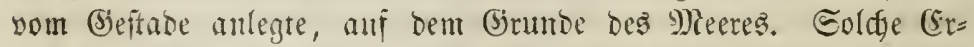

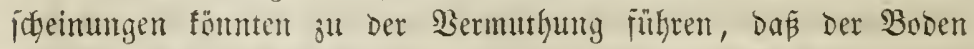
Der Pitederlande itho aflmålig fenft, unb baburch bie Dämme mit

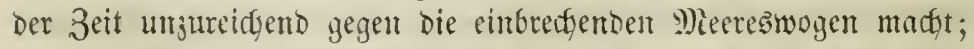

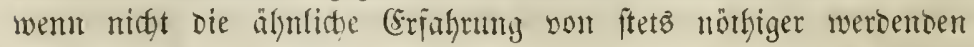
Errhöfungen Der Dämnte an andern flüijen, bejonders an siil,

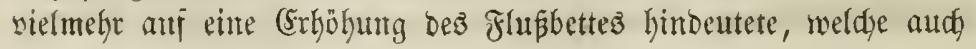




\section{5}

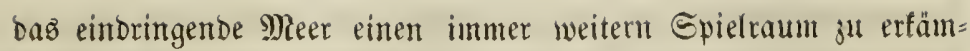
pfen zivingt.

Man ift oft aud geneigt gewejen, bie eigenthümlidgen Mitn= Dumgen unjerer Sitfeeflitje mit Deltabildungen zu vergleidyen, aber im eigentlitgen Sinne fann bier non foldhen nidgt bie Rebe fein. Allerbingz entipredgen bie ichmalen Ranbzungen ober Nefyungen, weldge biefelten gegen bas Meer fin abgrenjen, ben llferwäflen,

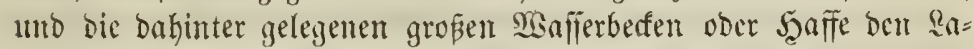
gunen; ater was gerade bie Deltabildungen am meiften dgante=

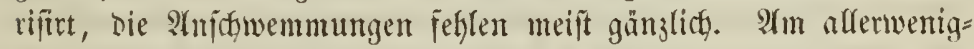
ften fönten wir bei ber Doer yon einem Delta fpredgen. Denn

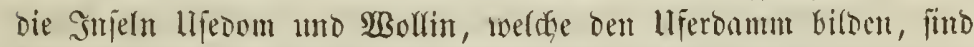

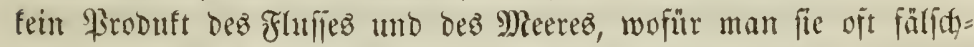

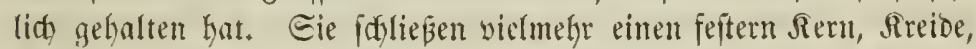

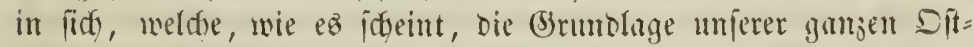

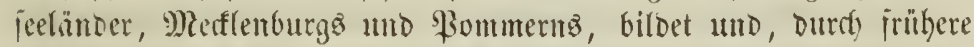

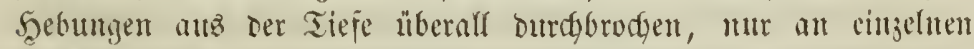

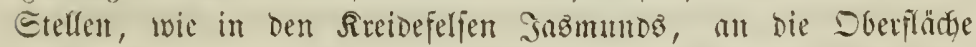
tritt. -

Da, wo feine llferwälle den (Fintritt deg Fluffes in bas Meer

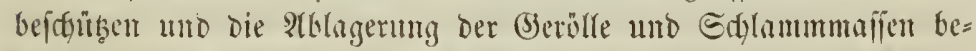

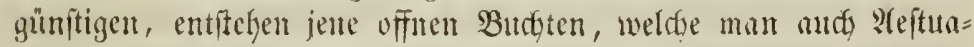
rien nennt, in Denen Daz MReer frei $n 118=$ und eintritt, uno 5 bbe

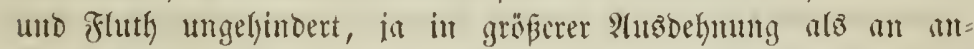

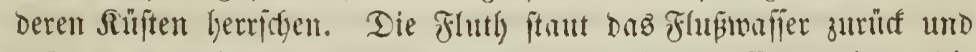

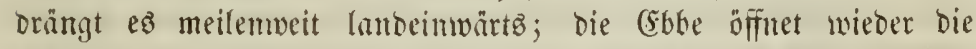

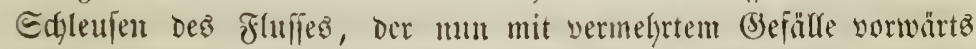
ftrömt und fein Sherülle meit in die See hinein fülyet, anj beren Srumbe er fie ablagert. Daz ïberzengentofte Beifpiel biefer $\mathfrak{A}$ rt liefert ber Maranlyon ober Antanonenfrom, ber grö̈te alfer fliifie, Der aus llrwälbern, unbebautem und angeidywemmtem \&anbe cine ungeheure 9)ienge vou Gdylamm, Sand und Treibholz in bas Meer fïlynt und bennody fein Delta gebildet hat, weil feine 9)eünoung Durdy feinen llferoamm gegen bie bort herrfbende Meeresftronmung

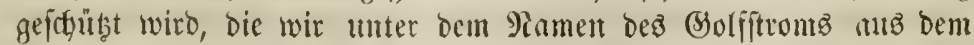
Mrexifanifden (Solf wieber herworbredfen jehen. Diejer Meereaffrom reift bie עom Antazonenftrom inz Meer gefülyrten Sand = uno 


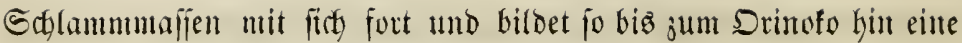

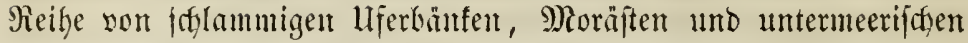

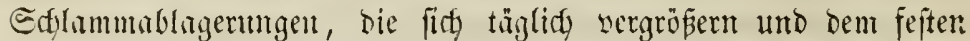

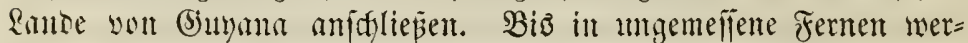
Den aber die feinterent Edflammtheile über bent gantjen Deean vers breitet unto lagenn jids auf jeinem Boben in Erfidgten ab, von be= ren Barlyandenfein Das EenfGlei mumittelbare Bemeije getiefert hat.

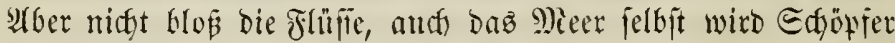

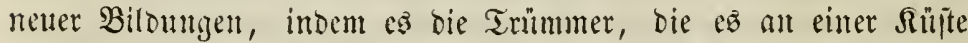

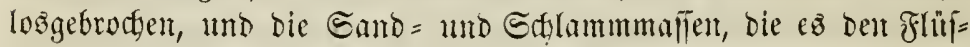
fen geraubt hat, an anderen säiften wieber ampült. Eo entifelyen

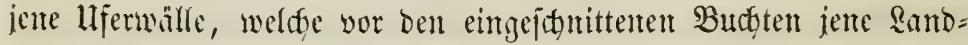
zuntgen und Relynungen bilseten, wodurdh bieje in Bintrenjeen und

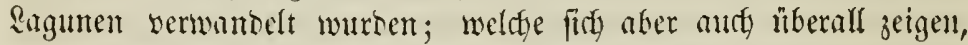

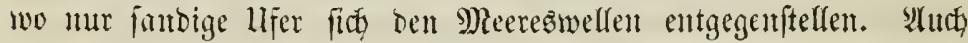
wo Flapimüntoungen biejen Llferwall Durdfbrodten lyaben, finbet fid oft nod) einte jeidstere, quer burdy bie Mlintoung gejogene Banf, bie

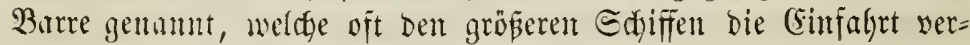

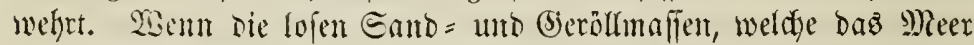
anjifimemunt, Durd) cin falfiges (Sement jufammengebaffen werbent,

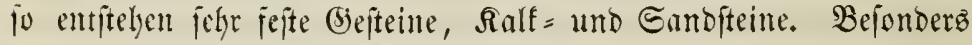
werben diefe Etrantbilsutugen burdy Den Recidtthum an falfigent Edralen son Eettjieren aller $\mathfrak{A}$ rt begimítigt, weldee, in ben $\mathfrak{B r a n =}$

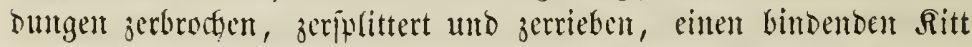
bilden, Der theils andere Ralfmaffen, theils ben llferjand zu Bies =

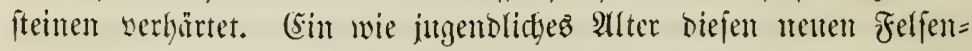
gebiloen zufommt, bas berweijen bie in ifnen cingepdlofienten orga=

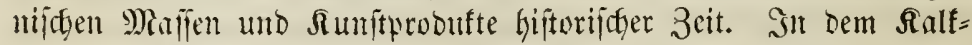
ftein von (Suadelonpe fant mant Edferben, fteinterme Beile, ganze Baumitämme unt Berippe von Meniffen; in Den Meuen Strand=

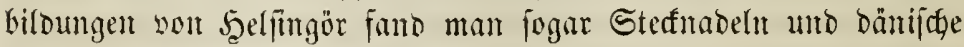
Mümzen aus ber 3eit (Shriftians IV., der Mitte Des 17. Jahrh).,

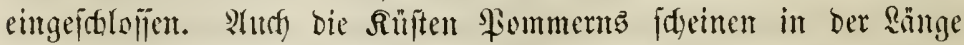

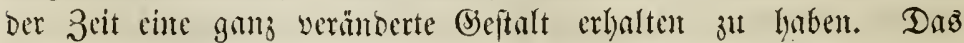

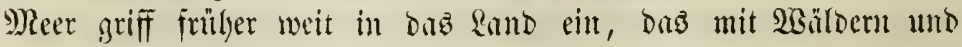
Sümpfen beneft war. In einem foldyen Moorgrumbe fant mant

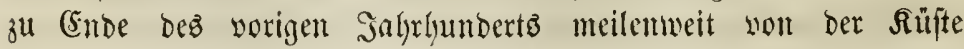




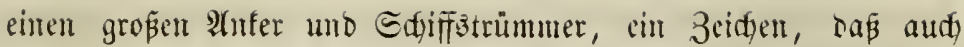

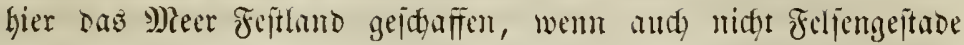

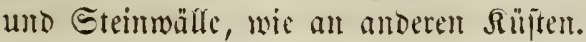

2So fein Bintomittel ben lojen Sant ju jejten Gejteinen wer=

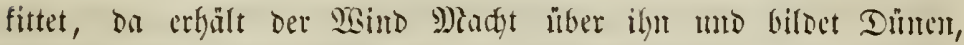

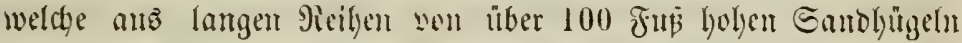

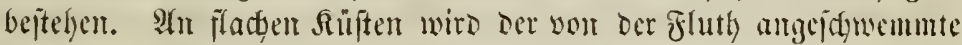

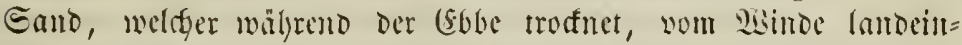

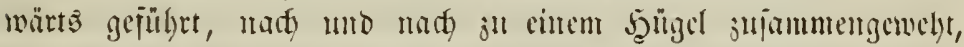

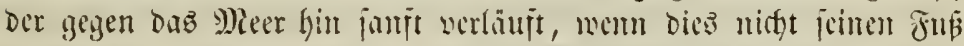

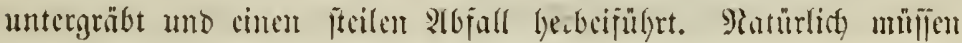

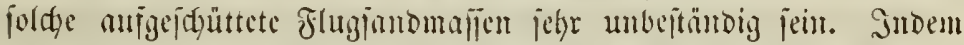

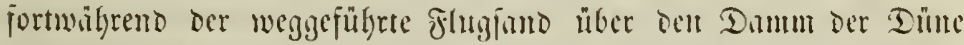

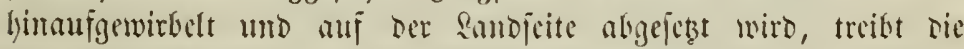

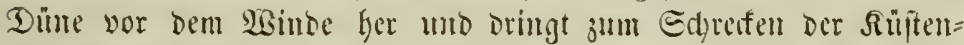

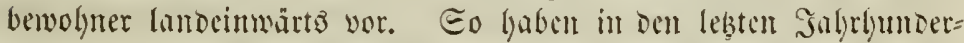
ten die Dünen an bon Räften der Bretngne und Der \&andes weite

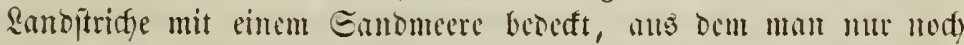

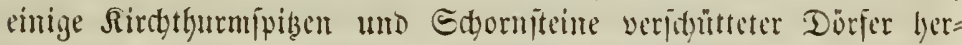

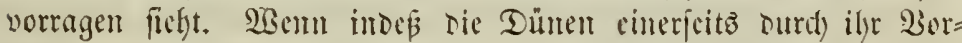

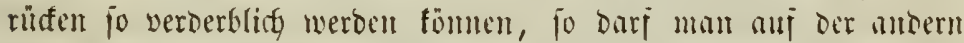

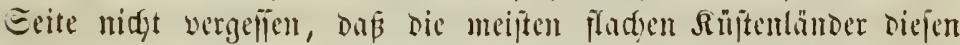

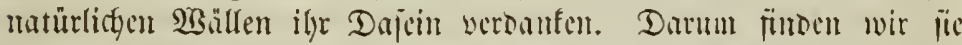

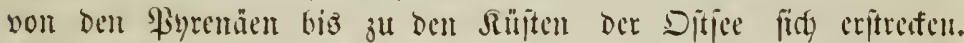

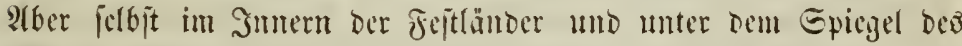
Meeres finden wir oft unverfentare Epuren iljers Dajents. Eo

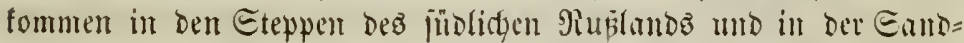

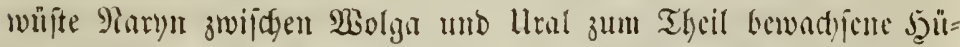
gegŭge vor, bie mant für bie alten Dunten des tajpijden und id)war= zen Meeres anjelyen mus; und and Das Eandftcintrif, weldyez über 200 Meilen meit bon bytlidgen Theil von Brafilient umbicht, will man als̈ eine vom Mieere überflutbete Dinte betrad)ten.

2) Dämme, ez madjt aud oft (rrobermigen auf Soften bez jeitent Rant= Dez, indem 6 T Theile bejielben zentagt uno verichtingt. Darin wiro

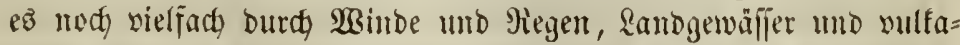

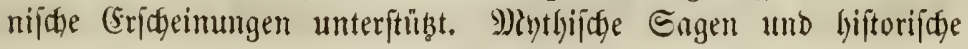


3cugnifie bieten uns reidye Belege biejer Thătigfeit bar. WBenn=

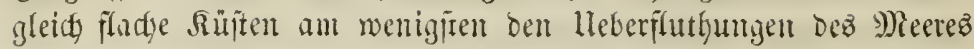
wiberitelen fömen, fo fint Dodh aud bie felfigen Eteilufer biejem

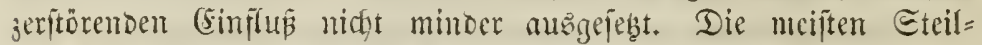
füften, weldye aus ben bärtefiten (Bejteinen beftehen, zeigen eine Minge son Epalten uno Rlüften, in weldhe Das Meer einoringt uno groß̉e Blöte ablọ̈t. 3war bilben dam allmälig bie losge= brodyenen Trümmer einen Damm, ber bie Fluth bridst und Das

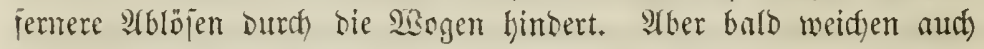

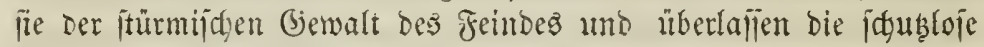
Sinjte feinem serfïntten (Sirimule.

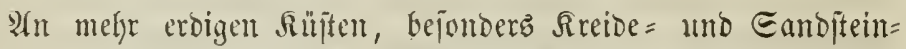

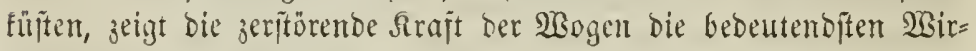
fungen; Denn Das Mlecr nugt an ber Sreioe, fpült einten Theil ifrer Mafie am (Srumbe jort und beraubt Den barïher hängenden Theil ober bie in ben weiden Malien eingeidglofienen Blöe fyärterer (5)e= Tteine ihrer Etübe, bie mut herunterîtürsen und vom Mieere ver=

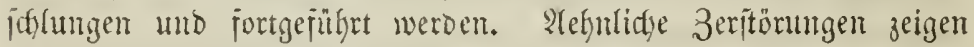

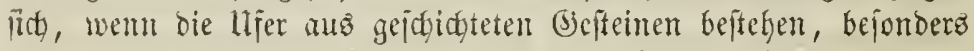

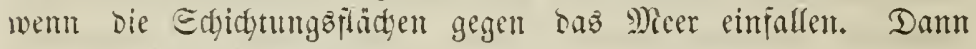

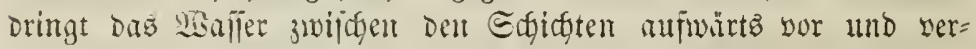

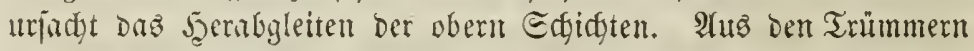

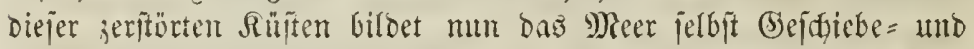
Entobänte, bejunders in Mieerengen und m kerworragenden ufer=

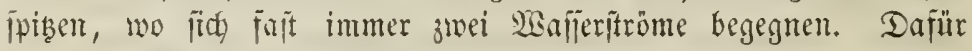

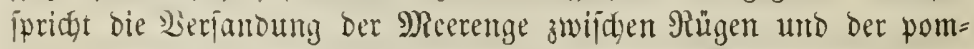

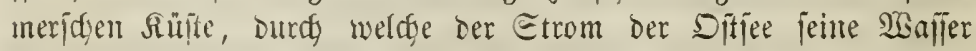

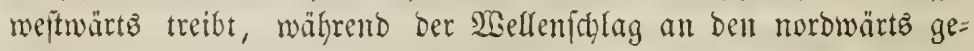
wendeten Dünentiliten Der Snjeln Dare und 3ingit fortwäljento Eand abjpult und oftwarts fortiülyt. $\bigodot_{0}$ wutro jogar bie Meer=

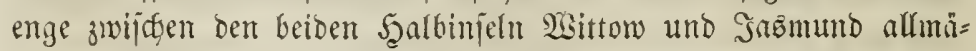

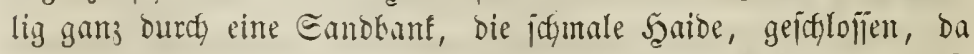

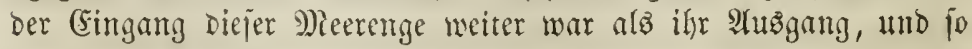

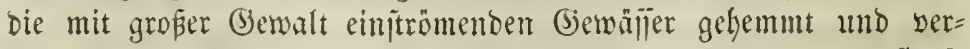

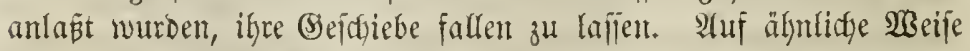
bemirft ber Bolfitrom da, wo er non Dem Etrom der Rocenzmün= 


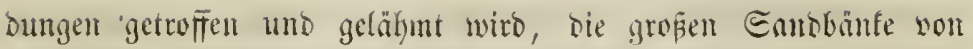
Reufoundand und Yieujdyottland.

Die Zeritönngen Deß \$leeres find aber wiel gewaltiger uno ihre Beifpiele jahllog. Die auszgezaftent Rilpten Der Bretingme, meldye Dodh aus lyartem (jiranit beftelen, jeigen nodg Deutlidje Epuren von ifyen bielfaden Beründerungen, Deren now alte Eagen gedenten.

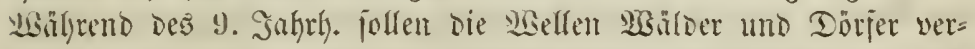

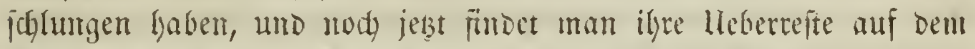

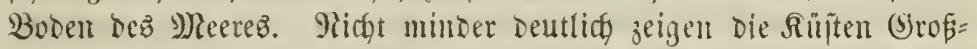

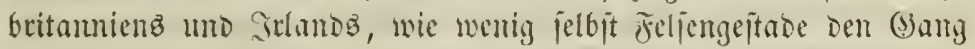
Des 2 Belmeers aljulyalten sermigen, wie irriz Der Glanbe an die Bejtändigfeit Der vorlyndenen Jeftlunder voer an Das llmer=

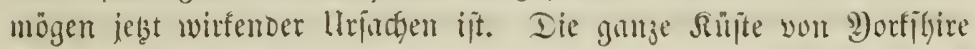

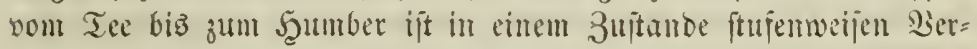

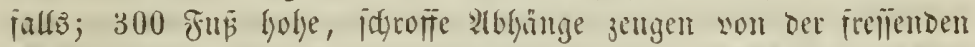

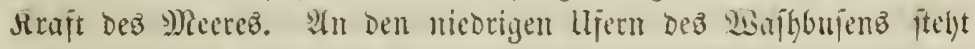

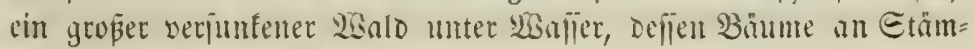
men, 2isurzeln und Aejten nody unverjefrt find, und Deren Sanr

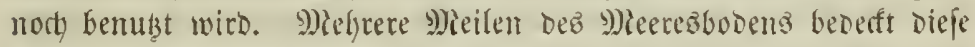
5̧oljablagerung, und wo jekt das s) Jeer fluthet, ftund eiujt bie Rirdge bes Durjez. Viod) an viclen andern Rüten Énglando

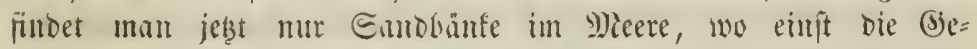

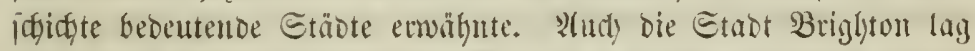

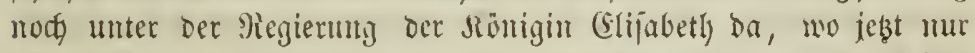
eine Meihe von Wịeilern fid) ims y)eer exptreft; won oer alten Etad ift feine Epur mefyr vorlyanden. Die Smiel Shepen am

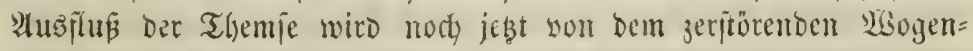
brange mit Dernidgtung bebrolgt, uno die Erfatgrungen Der nellejten

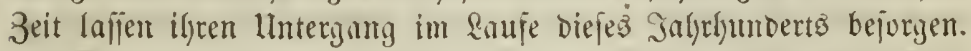
Die Sieculberfirdbe ftand nod) 3ur 3eit Jeeinridys VIII. eine Mieile

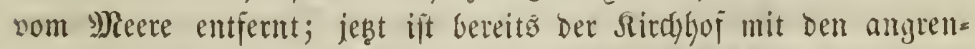

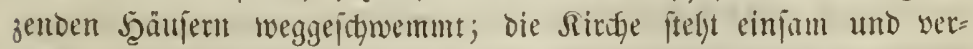

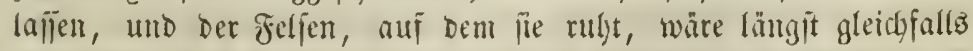
ein Raub Der Fluthen, wenn nidyt bie Sumpt Des s)ienifocn burdy

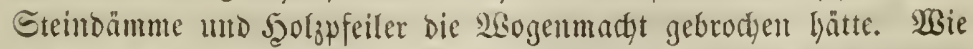

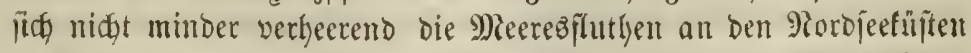

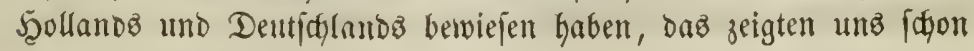




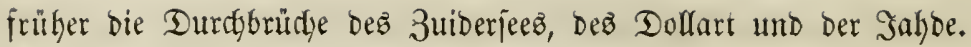

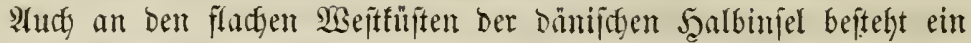
alter אampf zwiftgen \&anto uno Meer, ber eimft Sütlund zu eimer

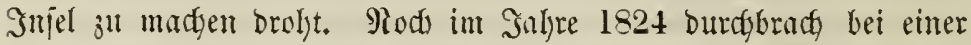

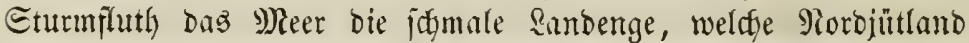
mit bem übrigen Theile ber Şalfinjel vereinigte, und bie $\mathfrak{B a f f e r}$

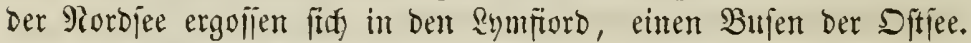

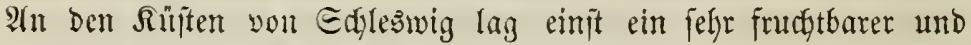

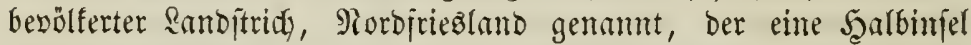
yon $9-11$ Meilen Rănge und 6-8 Meilen Breite bilbete. Sm Sabre 1240 mutrbe er vom Feftland abgerifien unb bis auf eine fleine

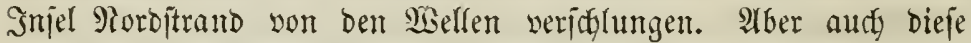

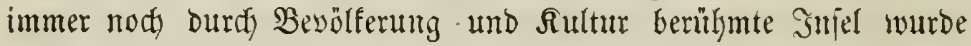
im Salfe 1638 von ben Flutfen zerrifien, unto jene idgrectlidje $\mathfrak{S a}=$

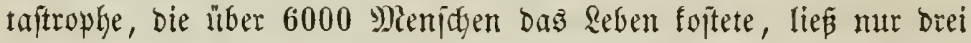
fleime, nowh inmer von gleidgem Edyiffále beorohte Infeln ïbrig, Piordjtrand, \$elworm und Rütjemoor. Futh die Ditfee hat an

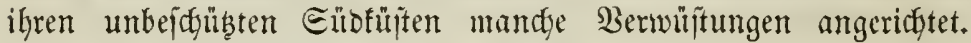

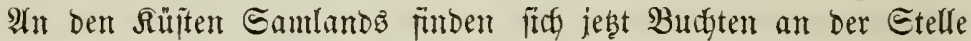

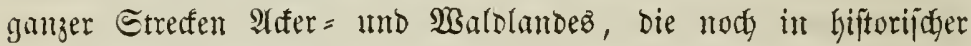

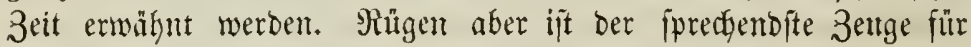

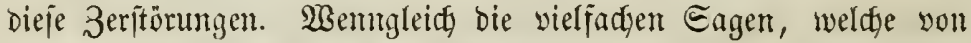

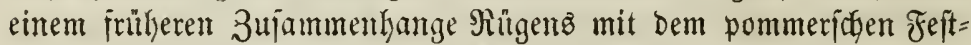
lambe einterjeits und mit Den SReibebänfen ber bänifdyen Snjeln andererfeitz, to wie von ber getwaltjamen Trenmung ber Sinjel Şib= Denfee von siligen burdh eine Eturmfluth in 14. Jabrgumbert er=

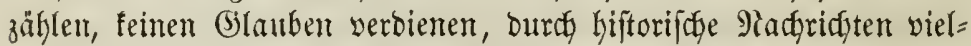

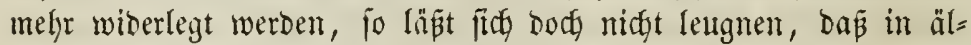
terer 3eit ein foldyer 3ujammentjang mehr alz wahridgeinlid ift. Die 3erftörungen, weldye bie Ditjee in neuteren Sahren anridftete, find ein redenter Zenge won ifren früheren Thaten. Die Stürme Dez Sahres 1837 wühlten bei Eminemünbe bie mäcthtigften Sranit=

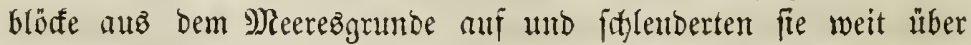

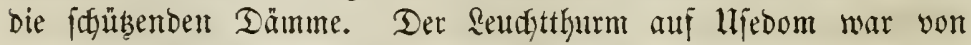
ben Wellent liberidfwemmt und bem Untergange nahe. Meerez̧ant, Muifdeln und Eeetang murben 50 biz 80 Jun hod über bie ftei= len $\mathcal{H}$ er bis tief in bie $\mathfrak{B g a ̈ l}$ ber hineingetriebent. 


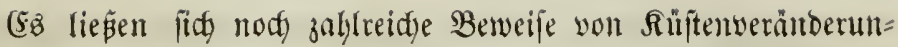
gen und Berwanblangen von Feftlänbern in Sujeln uno Meerez= gruno aujzäblen; buch bus afngefülyte genügt, um zu zeigen, baß

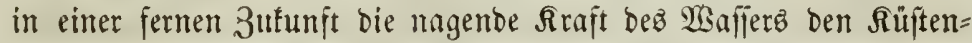
umrifjen ber Fefftänder uno Injefn eine gans andere Gejtalt geben

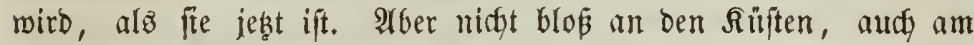
Meeregrgrunde ift bie Sraft Der oceanifjoen Fluthen in umunterbro= dyener Thätigfeit. Mtan hat Bewegungent bez Mieeres beobadgtet,

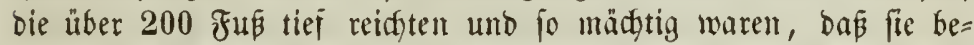
Deutende Ferzmajien in Etïlfe zeridglugen und als Trümmergeftein auf bie Siüte warjen. Alt ben Ehetlarbsinfeln fint joldge unge= heure $\mathfrak{B l o ̈ f e}$, bie oft melyrere 100 Fus weit weg geidsleubert wer= ben, eine gewölntidge (Eridgeinumg unto werben son ben Rendftthurm=

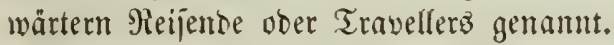

Sropartiger, als alle jene Beritörustgen von Rüften, find bie Duratgrnitche, weldge ats einem Meere it bas andere erfolgt fint, Erreignilife, bie früfen Épochent unjeres (Eroballz angehören. Saum Dunfle Eagen erwäfmen iffer, aber ber Boben felloft trägt bie ma= türlicten Denfmäler biejer (Ereignifife in fict. $3 \mathfrak{u}$ ben merfwitrbig= ften Begebenffeiten biefer $9 \mathfrak{n}$ gehört ber Durdjbrud) bez thracifden Bosporuళ ober ber Meerenge von Rouitantinopel. Bei alten Edyrift=

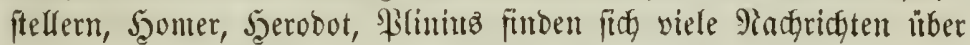

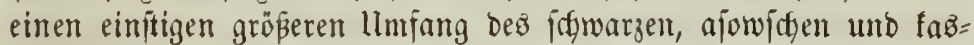
pijđjen Mreerez, bie aus einem bloß̈en Irrthume ober ber Damaligen

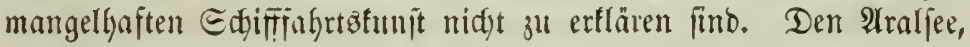

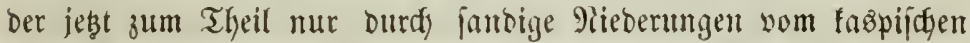
Meere geidieden ift, idgeint Şerodot nidgt gefarnt zu haben, mito fpätere Sisegrapkent lafien fogar ben Garartes uno Drus fich un=

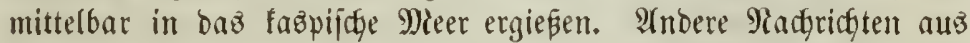
fpäterer 3eit fpreḑen von éfemaligen Seen im füblidgen Siußland,

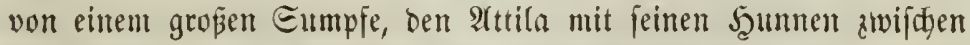

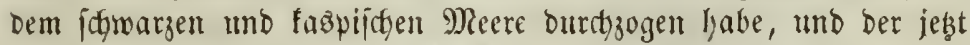

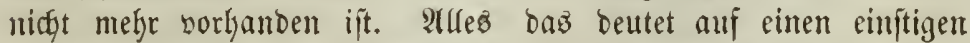
grö̈eren Ulmjang oiejer Meere, auj einen höherent WBajerritano ber= felben unt einen früheren 3 ufammenljang unter eimanber bin. Afber joldge Eagent uno Radgridgten fösuten gar feinen Betth für unz haben, weun nidgt neuere wifienjigaftlidge Unterjudjungen in jenen

IIte, weltall. 3. 24uศ. 
(5egenden iffre Angaben bejtätigten und unzweifelgaft jente Ränder als alten Meereşbodn ermicjen. 3n den Thatjachen, weldye bieje Sebauptung begrümben, gehüren bejonderz bie Eteppen, weldhe fid) nom weptliden lljer bes faspijden Miceres bis an bie Earpa, und

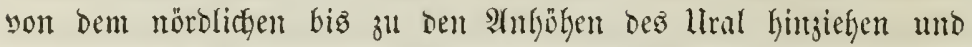
aus einem mit Ealamm verbumbenten, faljhaltigen Eante bejtelyen, über weldyen überall zahlreidge Enlzjeen verbreitet fint. Fud bie bort zeritreuten Sdyalen von Mufdyeln, bie den nody jeb̧t im fašpi=

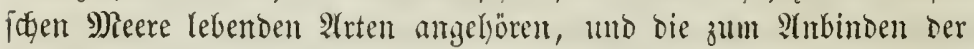

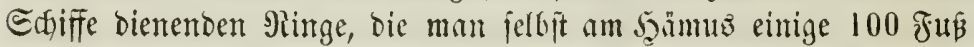
hod über bem Meere gefunden hat, geben ein 3eugnin für bie

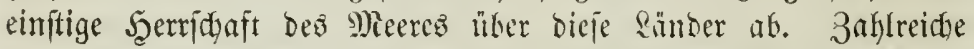
wifjemidgaftlidye Pieifen neuerer Zcit Gaben uns jelbit bie R̈liften=

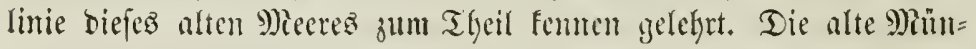
bung des Don mus einft da gemejen jein, wo jebt ber Doute in ifn mindet; und wirflid) fieht man bort zwijden Tijderfagf und

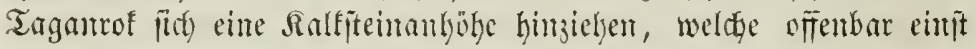
Das alte Eeeufer bildete. Fud meiter oitlidy findet man an ben Rorbräntern ber niebrigen Etewpen 200 Jup holke, fteil abfallente Ralf = und Eandlügel, malyhafte Dünten, Dic rings in einem Rranze

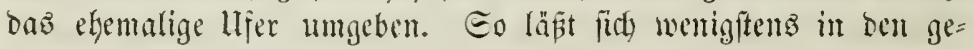
nau unteriudyten Theilen biejer Begento überall mit ziemlidyer Ei= dyerheit bie Brenze etgemaligan Meeres nadyeijen.

Diejes meite, frillyer gejdblöiene Meer empfing cine ungebeure

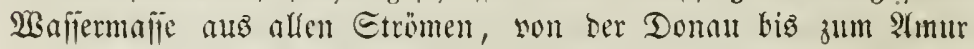
und Cir, Dem Druz unถ Sarartez ber Aftent. \$)it biefen mädtigen 3uftüfen fonnte fith wohl bie Berbunftung nidyt lange im (S)leids= gemidyt halten. Das Mivenu Deş Meeres erhob fid immer böber,

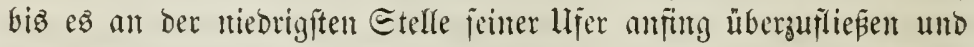
fid) ein Bett einjufteiden. Diefeg Bett wurbe immer tiefer, im=

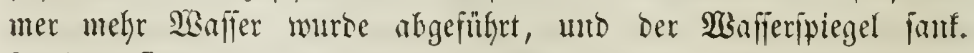
Fanden fid vielleidt im neuten Bette Ingen non minder fefter Eteinart, fo fonnte leidyt ber ungeheure, auf bie Etelle des 9 ab $=$

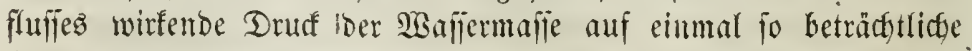

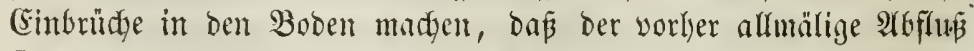
fich in cinen reisenten Durhbrung verwandelte uno eime lleber=

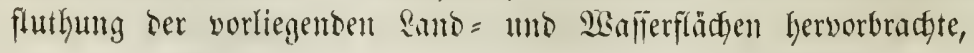


bie nidyt elger nadflaffen fonnte, als bis ber ganze Epiegel ber $\mathfrak{a} b=$

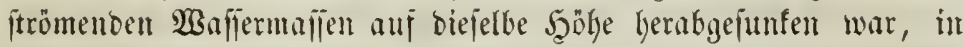
weldjer firt) Der Epiegel bez ägeifden Meeres unterhalb Dez Durdy=

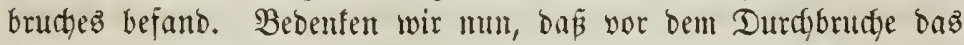

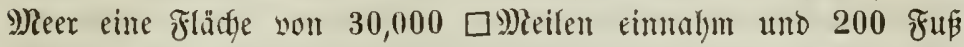

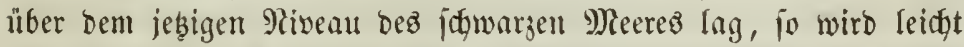

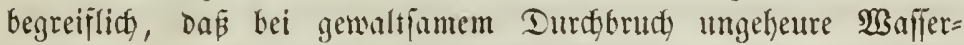

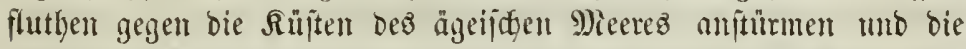
mieberen Ranbidgaften nerwüften ober bleibent unter ben Bellen be=

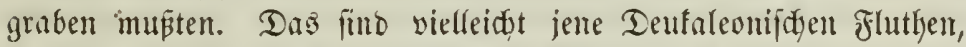
weldye nady ben alten griedijdent Engen eimft Thelfialien und ben

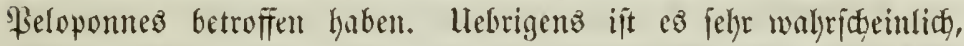

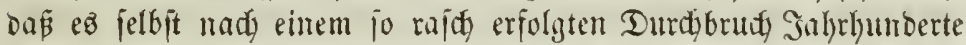

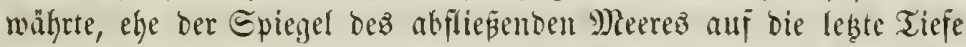

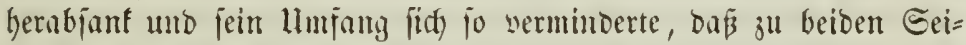

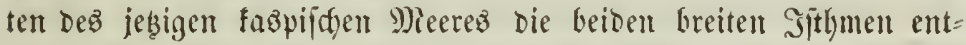
ftanben, burdy weldye Dns früfere Meer in brei gropée Eeen getrennt

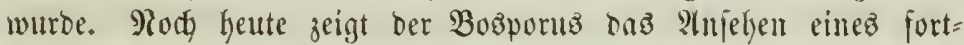
währenden ruffigen Etromez, welder nod) iumer feine llfer burds

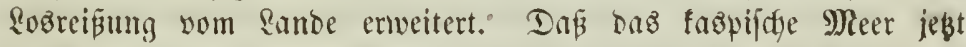

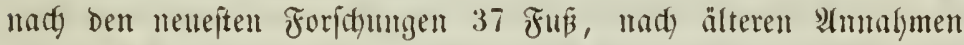

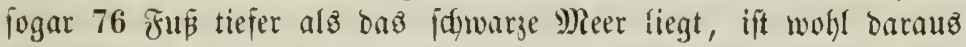

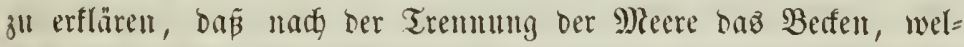

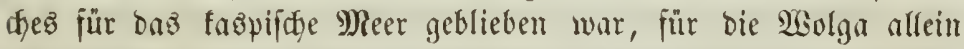

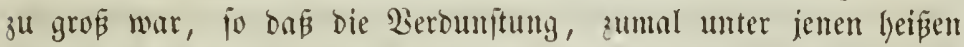

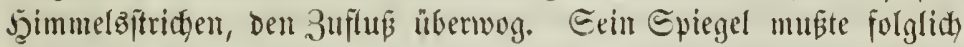

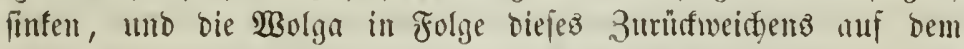

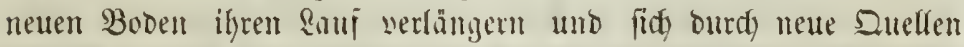
verftürfen, bis beibe wieber im (Sleid)gewidjt itanten. Fudy ber Atralfee zeigt beutlidye Epuren, Daßs er son jeinem elyemaligen Etande herabgefunfen jei; benn fajt bie Seălite befiellben bejtelyt anz En̈mpfen, zwijuen benen zaglloje Mrfeln liegen. (Er fonnte aber,

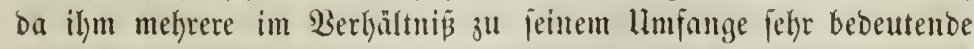

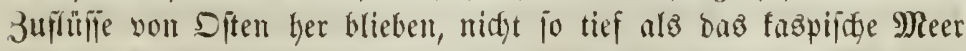
finfen. Pady neuerent Unteriudungen ftelyt er bolfer 71 Fun über Dem faspifajen, aljo jogar nody 34 fü über bem givean bes iळwarzen 9)eeres. 
(Sin zweiter nidft minder widftiger Meeresburdybrud gab ber Etrape yon Bibraltar ifren lliprumg. Alte unto nenere Edgrift= fteller haben ifhn wohl als eine Folge von jenem deż thracifdjen

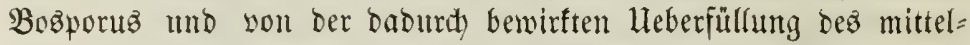
ländiîfen Meeres bariftellen wollen. Allfein ein joldher 3ujammen=

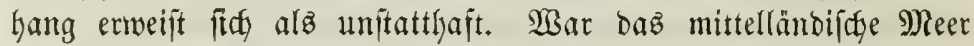

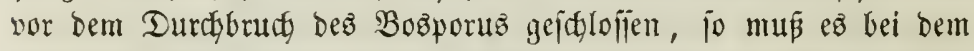

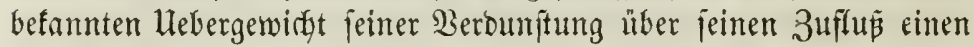

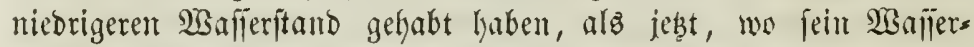

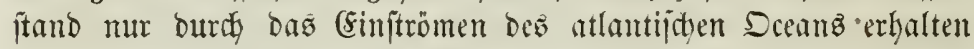
wirb. Demnady ijt nidft jul bezweifeln, da eine zelfenreitge zerrifien und jentz mädltige Thor gebildoet habe, baz

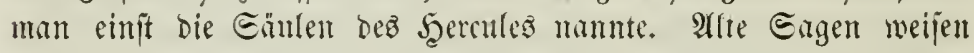

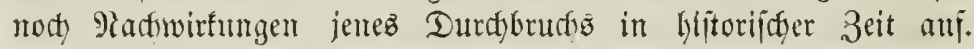
(simpt foll einer alten tartlyagifden Eage zufolge dus Meer in jenter Etraß̧e eine jo geringe Tiefe gefabt hahen, da je fie mur mit platten Edjiffen bejahren werben fonmte. Ándere Edjriftíteller errwähnen einer breiten Eanbbanf, bie jid querüber yon einem Routinent зum anbern eriftrefte, und bie man bie Edjweffe bes inneren Mee= reş nannte. Epäter jollen fich noch lintiefen uno mehrere Snjêtn in ber Mieerenge gefunden Gaben, bie ję̧t nidjt mehr vorbanden fïmb. Aflfe bieje Âtrgaben beuten unverfennbar auf ein fortwähren=

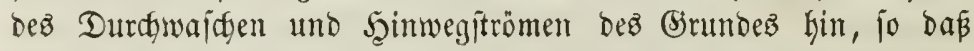
jene Smjeln uns lintiefen alż bie Ueberbleibjel ber ehemaligen, viel= leidgt in vorhifitoriifder Zeit zeritörten Rambenge zu betradten fintb. (Sine bis in unjere Beit fortbauernde Pactywirfung jenes Durds= brudfs ifit bie beobadtete allmälige Ermeiterung der Etraße, beren Breite nod 100 Jahre ע. Ehr. auf eine Meile angegebent wird, máhrent fie jeb̆t an Der engiten Etelfe über zmei Meilen beträgt. Für einen efematigen 3ufammentang zmiiden Eutropa und Afrifa

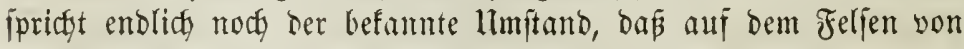

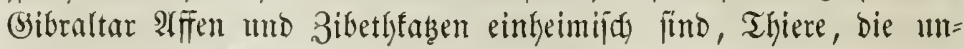
bejtritten nach âfrifa gebören, unt bie jonjt fein anberer Theil

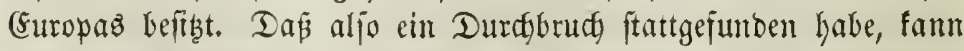
nicht meghr fraglidy fein, wohl aber, won weldjer Eeite er erfolgte. Şier fpredyen mum alfe Errifeinutrgen an \&ano uno Meer für einen Einbruch Dez Dceanz. Denn ber Epiegel des Mittelmeereż muste, 
fo lange ez geidylojën blieb, wegen der-überviegenden Berbuntung ftets finten, uno bie Bebirgsmafijen, weldye es som atlantijhen Drean trennten, hatten einem immer ftäfer werbenden, cinfeitigen

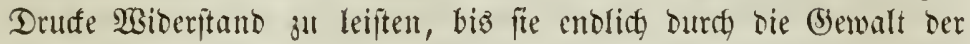

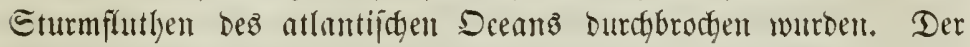
trichterförmige Borbof Der Etrape, deffen weitefte Deffmung vom (Eap Et. Wincent bis zum weipen Borgebirge in Marocco reidt, ift ofne 3meifel cine Bertiefung, Die fidy Der Decun in feine Dit= füjten gemith!t lyat. Die enge Defrnung Diejes Trichters befindet iing gerabe an Der Stelle, wo bie Blebirgsfette in einer ?inte von Europa nach Afrifa übergeht, wie nod) jebt bie gleidge Befirganant ter beiden voripringenden Jelşpipent betweift. Şutter biejer Berg= fette, Die vielleidft eime Bertiefung an Der Etelle Der jebigen Etraß̧e hatte oder Durch eine Ratajtrophe befam, lag Der grope Bimteriee tes bentigen Mittelmeeres, uno fo fonnte leid)t Der Deenn an ber Etelfe, wo ifm der fdymalfte Damm entgegenftand, Diejen Durd = brechen oder eine entitantoene Epalte Durchfluthen unb bei einumal exfolgter berbindung ber beiben 2 aljerbeden endidy biz jur Keutigen Breite ermeitern. Dies ift Der walyrjueinlicffte Bergang umo ju

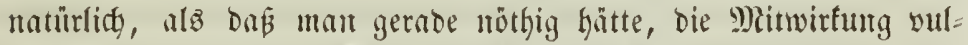

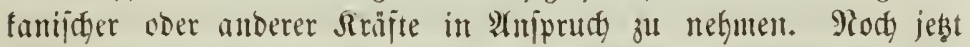

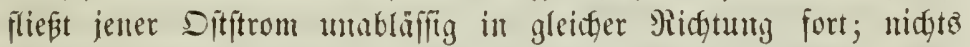
verändert ify ober hält ilyn ari, weder ber Ditwind noch bie Ebbe

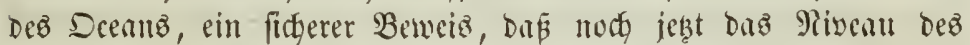
1)ittelmeerez miebriger fteht, alв baร bez Dceanz.

Piigt auj biftorijchen Piadfridgten, auth nidyt auj Engen, fon=

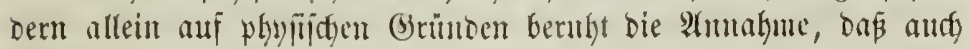
Englanto und Frantreich cinft cine santonge verbundest habe, bie

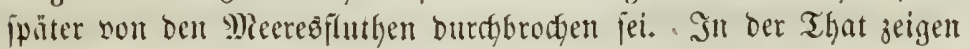

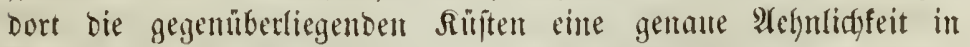
Mafie uno Frorm, uno gerade an Der idmaliten Etelle, Der jebigen

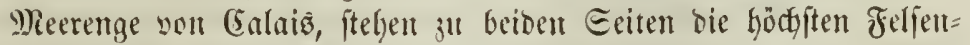

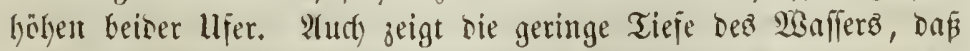
nodh jebt ber zadtige 1110 felfige Meeregboden bort cinen langgezo=

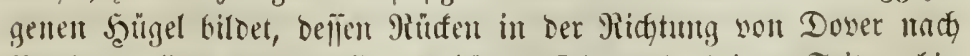
Boulogute liegt, und beffen \&bgänge fich madt beiden Eeiten hit

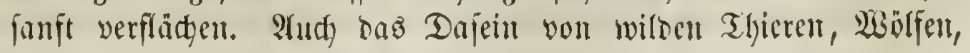


Bären 2 ., bie in älterer Bẹt in (Gnglano in Mienge gefunden wur= Den, fpridft für bent einftigen 3ujammentang ber Snjel mit bem Feftlande. Sedenfallä erfolgte aber bie Durchbrectung ber Randenge

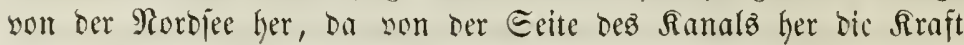
Des Scéans auj einem inmer feictiter werbenten Brntude jhon viel werlieren muste, mährend fie in Dem meiten Bujen Der Morbiee

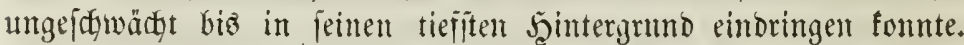
Erinnert man fith, Daß bie Fluthwellen bes atfantifften Dreans un Edyottland herum von Morden nady Eniben an Den Diffüjten won England vorbringen, uno bedenft man bie bebeutenden 3uflüfie,

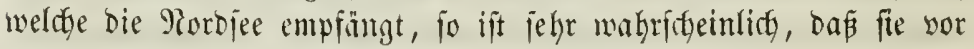

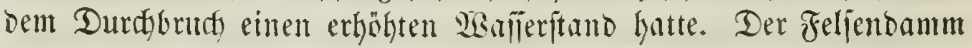
hatte alio cinen ftärfern Drứ yon Der Geite des Dentichen, als

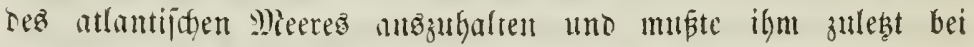
Eturmfluthen weidyen.

Ming man mun aud Den Eagen uno theilweife hiftorifden

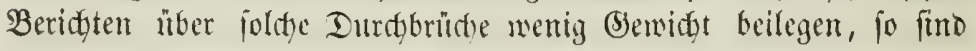

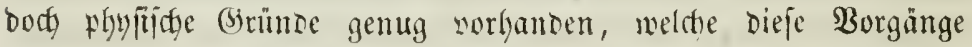

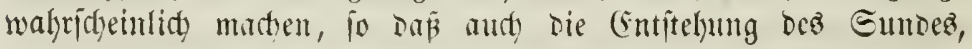

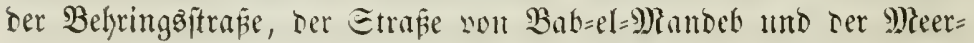
enge zwiidten ben Infelfetten Ditindiens, menn gleidy feime Sage

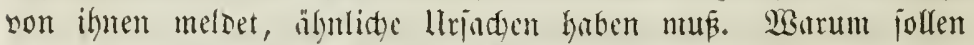
nidgt jene Urjadyen, welthe die Rültenumrifie ber sänder zu verän= Dern sermögen, bei vermelyrter Rrafit und in längeren Zeiträumen

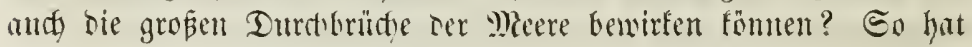

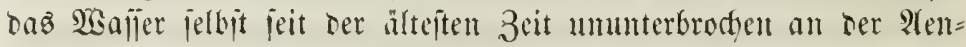
Derung und llmgettaltung ber gropen Meeresberfen unto ser Feft= länber und ifrer gegenjeitigen Berbältnifie gearbeitet unt, wie mir fehen, nidft olyne (Erjolg.

3) Wirfungen des atmofphärifden wajfers.

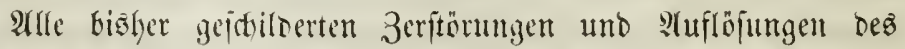
Baffers fünnen natürlict) mor ba eintreten, wo bie (semaifier wirf= lid) mit oen befteinen in Berülfrumg fommen. Da jeodd Meere,

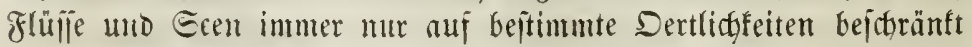

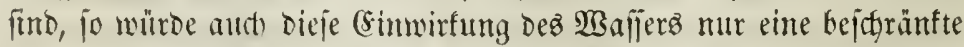

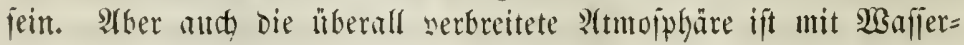




\section{7}

büniten angefïllt, weldhe, wenn gleidy langiamer, biejelten Zerfitö=

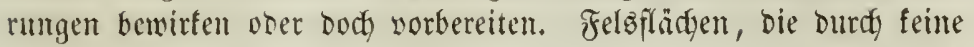

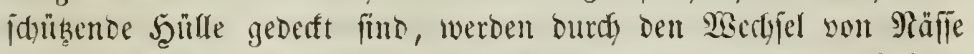
und Trodentheit, surdf Thgat und Meif, Den idgmelzenden Sdjnee

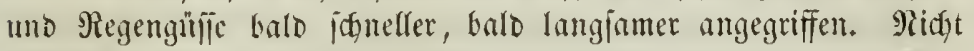

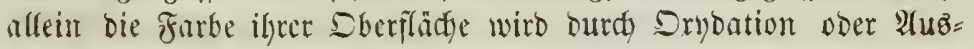
wajdunng Der färbenden Beptandtheile geäntert, die Bermitterumg

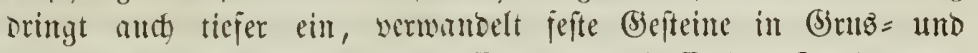

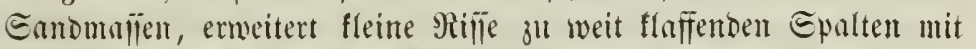
germideten (Erfen, wertifule Sliufte ju Engpäifien.

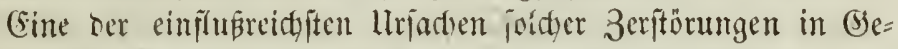

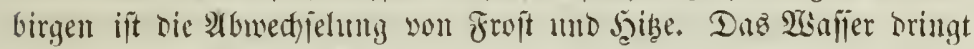
in Die Epalten uno Rlüfte Der Feljen ein, gefriert uno treibt bie

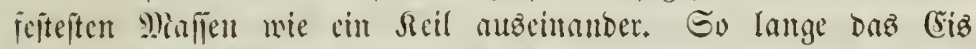

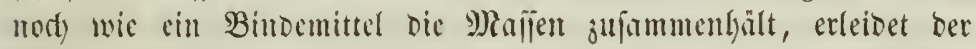
Felz feime berinderung, aber im Friughahr, wemn ez thaut, meidgen

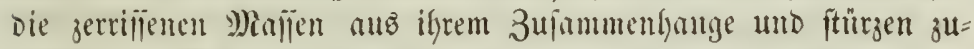
jammen. Ralffteine jerfallen in erfige Trümmer, Girantite und

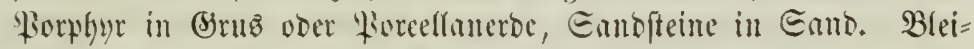
ben foldse vielfad jerflüftete gelfentrummer ftehen, fo bilden fie jene

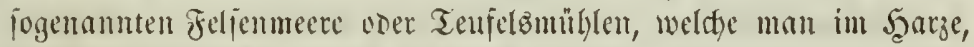
in Doen = unb Edywarjwaloe, suf nem Miejen = und Fidftelgebirge

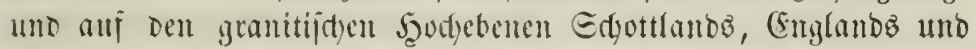
an anderen Drten antrifift, uno mit Deren bizarren (beftalten und

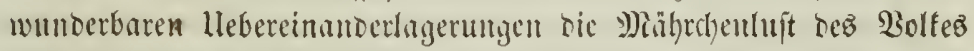

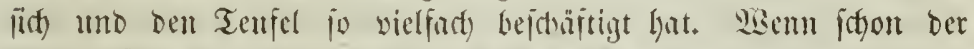

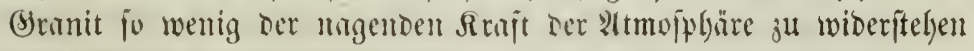
wermodth hat, io hat Der Empitcin natürtide weit großartigere Zer= ftörungen irlitten. Tie anffinlfenten Eäntenbiloungen ber 2rbers= barter fellen in Böhmen uno dez Biclergrumbes in der fädyfiffjen Edfweis geben Dafür bie beften Belege. Lleber 300 fup hod ftei= gent bie weisen Eanditeinpficiler uft in Den jeitfamifen Beffalten,

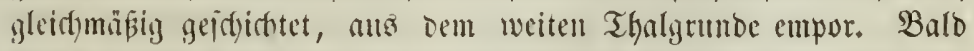
ftelyen iere vereinzelt noer burdy Eteimplatten brïtenartig verbunden,

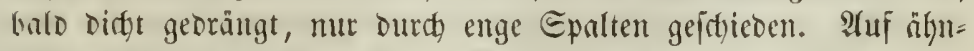
lithe Weife haben fint audy Die Rarrenfeloer ber Edjweis burdy ris= nenförmige Nubarajdungen in Saltfelfen gebildet, wie man fie bont 


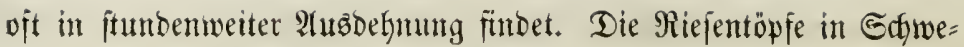
ben, auf bem Jaar; umb in Edyottlano Gaben oft feinen andern Ulrprung. Sie finto fejelelförmige Bertiefungen mit geldyliffenen

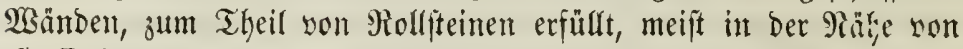
Wafleerfällen und Etromidgnellen, Denen fie ifren Utriprung rerban=

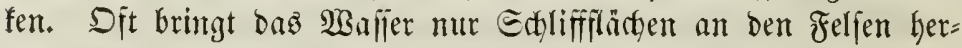

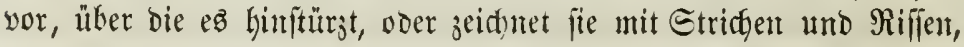
wenn bärtere Befteine feiner glättenden Biewalt wiberitteher.

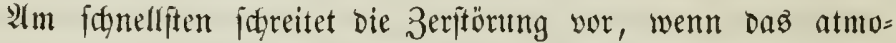

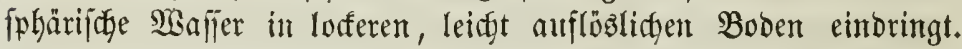
Dann löjen fich an jteilent behängen ganje Mafifen ab unt bilben Ero = und Bergidglüpfe, wie fie fid) in ben Alpen bejonberb ereig= nen, wem bei lauen Sübminden anj Den mit Sdjnee bebeften

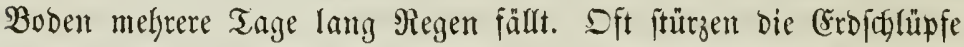

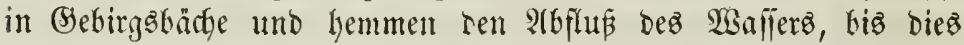
mit Sewalt ben hinoernden Damm dutrdybridjt, ifh mit alfem, was

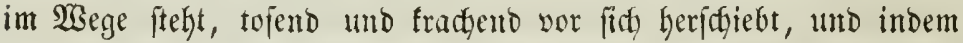

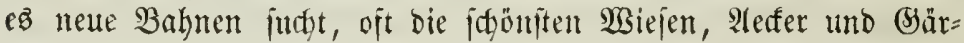
ten für immer unter feinem Edfutte begräbt. Soldfe Sdglamm= ftröme neunt man in ber Edyweis Rüfenten. Mian erfennt ihre

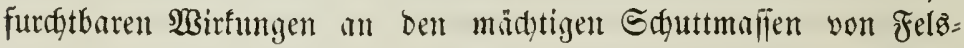

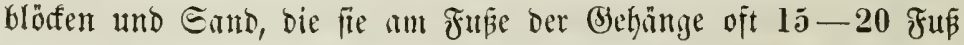
hody aufthürment. Eelbit ber weränderte Stromlauf eirez Thalbadyz

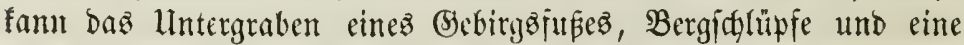

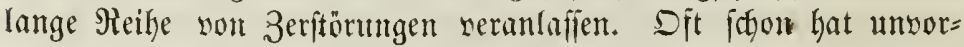
firftiges Edflagen von 2 Gäloern in ben Allpen und anderen Biegent= ben für große und fructstbare Thäler bie idyerflicffte Beröbung her=

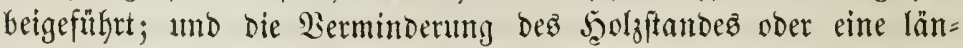
gere Folge ungünfitiger Safre fönnen für ganze Bebirgsịnfteme, bie

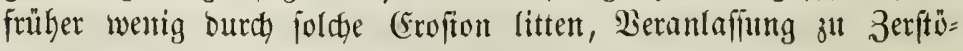
rungent werben, Deren Enoe nidft vornuşutleken ifit.

Ermägt man ben (Simflupi, ben fo bebeutende Erofionen auf bie Geftalten bes Biebirges anşüben müfien, fo gewinnt man Yeidyt

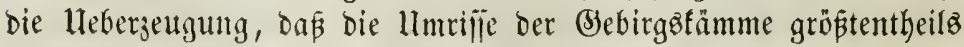

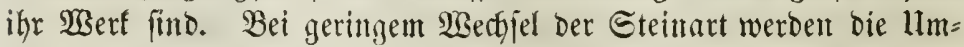
riffe einförmig, gerablinti̧, wie am Sura und mehreeren Alpentetten; wo aber fejte Ssejteine mit leidgt zeritörbaren wedfjedn, entitefyen 


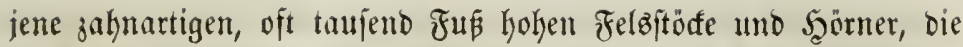
burdh tieje (Sinjdynitte getrentut werben. Die nody immer fortidurei=

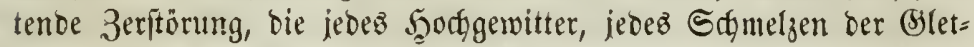
idjer in bem heutigen Boben ber Allpen hernorbrimgt, bie zerrifienen Styludyten, bie wilden Trĭmmerhalden, bie niederitürzenden Bipfel, beren Donner nody immer bas obe Edfweigen oer sllpennatur un= terbricht, Âtes daz brängt зu ber leberzeugung, baß po, wie heut, bie Erofinon jeit undenfbaren Zciten an Der Befeftaltung unjerer (Be= birge gearbeitet haben miljie. Die jettjamen Beftalten bes \$faffen=

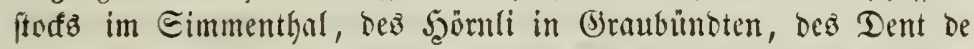

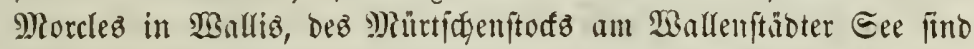

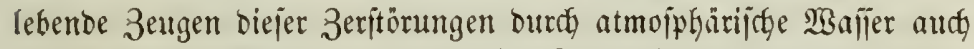
in ber grauen $\mathfrak{B o r}_{j}$ eit. Der rauke, felfïge Sharatter eimez Befeir=

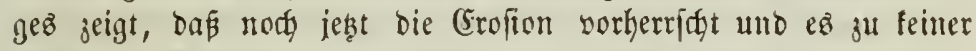
bleibenden Hlblngerung ron Dammerde fommen räpt; benn wo bie Piulle eingetreten ift, ba ftellt fith aud bie Begetation wieber ein, Daz Wurzelgeflectht bejeftigt bie Dammeroe, und bie 3eritürumgz=

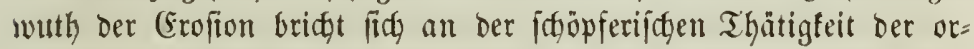
ganiicten Rebenzfrait.

Unter allen biejen Beränderungent ift cine ber widftigften bie

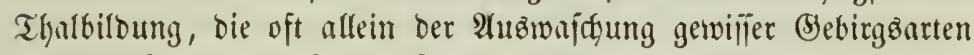

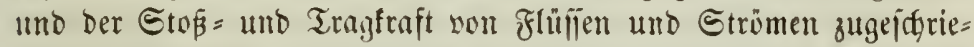

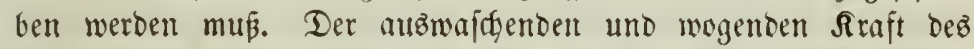
Waliferz, bie wir jo ethen fennen lernten, erliegt zwar loferer $\mathfrak{V}_{0}=$ Den am leidjteften, aber audf Felfengrund wird nom rinnenten $\mathfrak{B a} a=$ jer cingeifgnitten, wenn aud oft nad langen 3eiträımen. Mandhe WBajlerfälle ber Edymeiz baben feit 50-100 Sahren ifhe Beftalt uno igr zelabett nidyt wejentlid, veränbert, obgleid, fie mit groß̈er

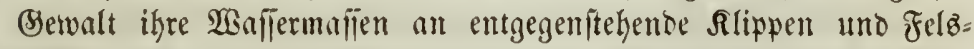

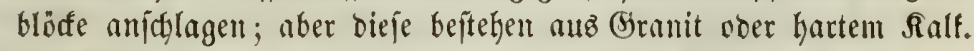

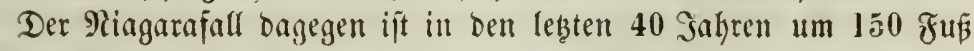

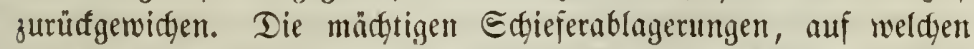
bie 40 Fuß bifen, Garten Ralfiteinbänfe feinez Abjurzes , ruben, weroen yon bett mit Eturmez̈genalt auż der Tieje emporiprizenden und bagegen getriebenen $\mathfrak{B a f j e r m a j i e n ~ f o r t w a ̈ h r e n t o ~ a b g e l o ̈ f t ~ u n o ~}$

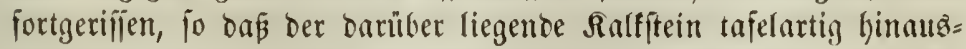
ragt unto jeiner Etüb̨e beraubt in bie Tieje hinabitürtyt. Die ab= 
gejdwemmten Theile, Felstrinmmer, Siejel und Gand, wolfführen mun die grofite wie die feinjte Arbeit hes Eteinthanters, runbent und glätten bie Ranten umb (Erfen ber Feläarten $a b$, graben flacbe uno tieje, inmen abgerunbete uns ber Etrömung folgende Furdien und

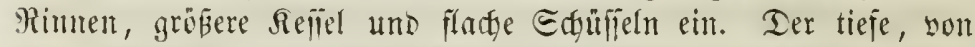

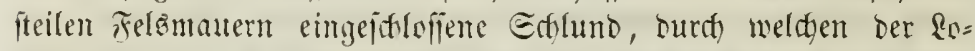

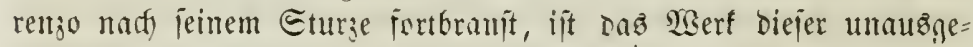

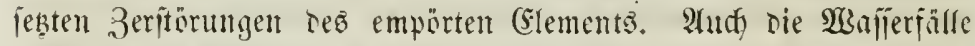
Pieflanos, CFithlanoz mo Ingermannlands geben einten Beweis you

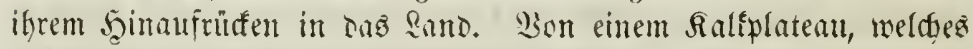
auf Eanoftein ruht, ftürzen bier alle aus Dem Smmern bes Sanoes fommenoen Flüfie gegen oen finnijden Meerbujen bin in Wanjer=

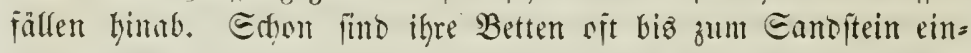
gejchnitten, uno bieje meithe lluterlage wirb jo hejtig angegriffen, Duf bie sberen Edhidten mehr mo mehr zufammenbreden. Sinzelne Fälle find bereits jeit Menjoengerenfen melyrere Meilen zurïfge=

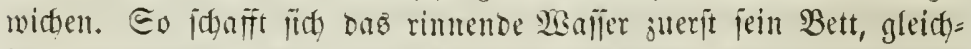

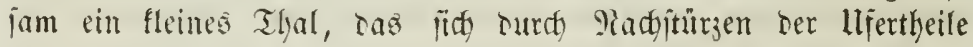

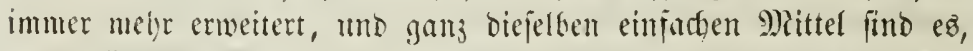
reren fith die Siatur bei Der Bildung ber meiften größeren Thäler bedient bat.

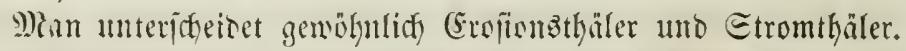

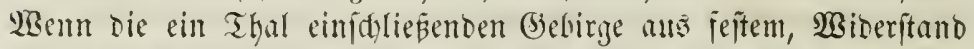
leiftentem (jejtein bejtefon, wïhrent eine leidft jerfiörbare Forma= tion sen Shalboren und bie tiejeren Theile der Thalwände bilder,

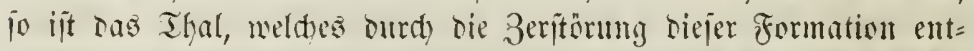
fteht, cin Erofionsthal. Die Eettenthüler bes Wallia, daz Eim= menthal in ben Bersteralpen unto die meiften Thäter bes Sura tra= gen now die unwerfentharen Epuren ifres llriprunga in ben glei=

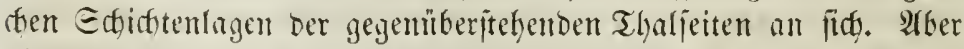
nidt immer lä̈t fith bie Siejtaltumg ber Thäler ourth bie allmä=

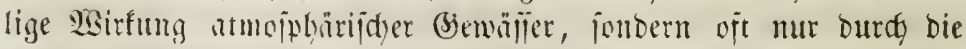

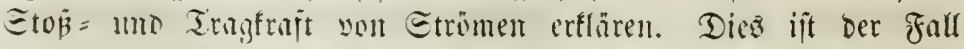
hei Den logenamten Etromthälern, weldye fidh meijt in betrïdthidger

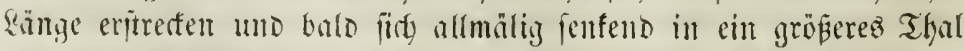
roer eine Ebene muntuen, bald nuch beiben Eeiten geöfinnet das Berbinoungø̈glied zweier größerer $\mathfrak{B e i t u n g e n ~ b i l d e n . ~ S f t ~ j e i g t ~ o e r ~}$ 
fid) an Drte rerjebt, wo bie feintiche 2 utth bes Erobebens ober die funnreidye Zeritörungęfunft bes Menidyen gewaltet; fo wild uno zerrifien ift ber 2 hnlliff biejer zeriprengten Blöfe uno übereinanoer= geftürzten Trümmer. Salyre vergehen, ehe fith wieber Strautgwert

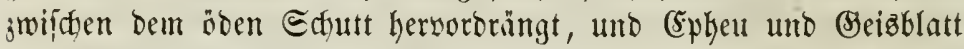

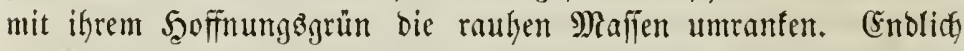
iprofien auch wieber Sras uno Bald auj Den Sthutthalden und verhüllen mit ifrem üppigen Exleier die Epuren frủherer 3 er= ftöruttg.

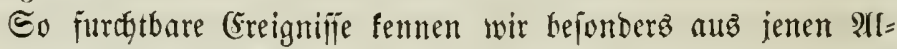
pengetirgen, beren zacfige Bripfel in bie emige Sibregion hinauf=

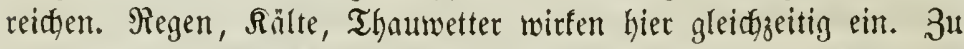
Sahrhunderte alten Epalten gefellen fich täglid neue. Slïfte er=

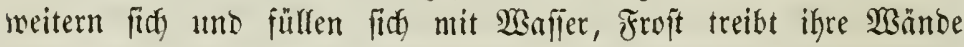

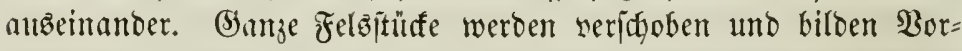

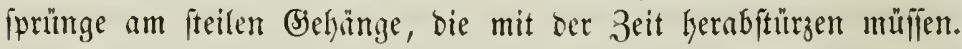
Im Şimalaya find bieje Erjotinungen wahrhajt graujenerregent.

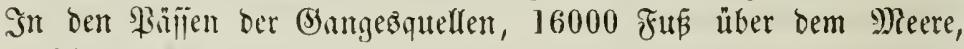
zwijhen fimmelanfrebenden. Bergen, iprengt ber Froft unablällig gemaltige Felobblöfe los,, beren Trümmer ben Boben ber \$äjle be= Decten. Bergitrỏme burdytränfen oft bie weidyeren Befteinlagen uno majotyen fie hinmen; bie getrennten $\mathfrak{B l o ̈ f e}$ ftüren bann mit unauf=

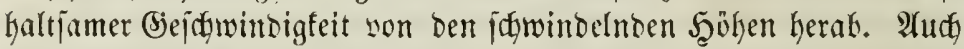

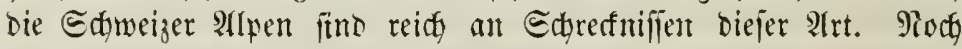

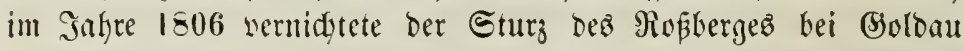

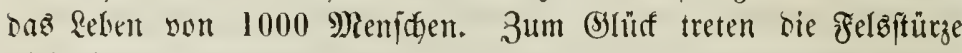
nicht immer ganj unerwartet und plöblich ein; benn bie Revolu= tionen Der Matur Gaben io gut wie bie ber Bölfer ifre Borboten, uno wehe Dem, Der bie eimen ober bie andern berfennt ober ver= leugnet! 3unchmentez Gieröll, Deffnen der Epalten, Eenfungen

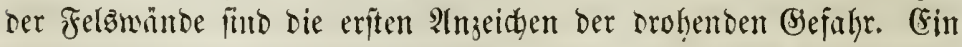

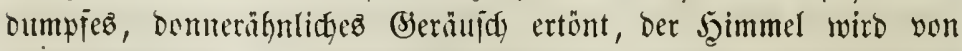

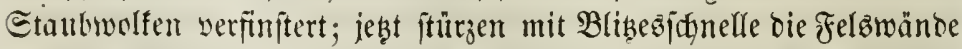

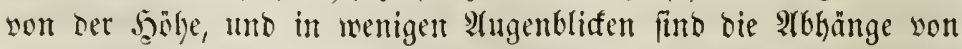

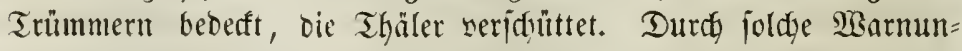

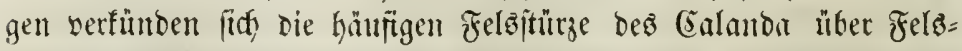
berg. Die Anwohnenten entrgehen ber Bernidutung, die über ifre 


\section{3}

Bohnungen hereinbridgt. Sn älteren Zeiten fïno oịt ganı̧e Stäote

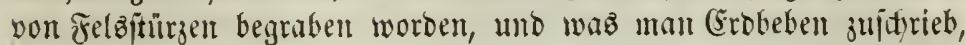

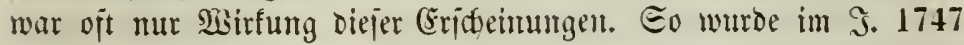

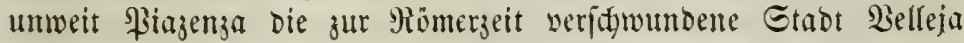

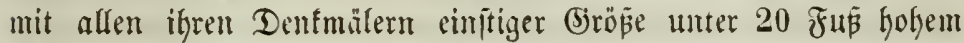
Edyutt wiederholter Bergfälle hervorgegrabent.

Die meiften Bsipfel oer Schmeijer artpen erfielten burdy foldte Etürze ifgr zerrifīents Anjegen. 3weimal bradgen in vergangenten

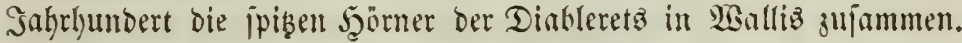
Tage lang währte ber Etur, 2 Stunden weit flogen bie Bruts=

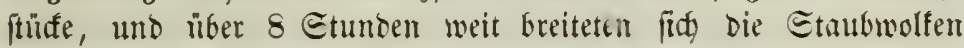

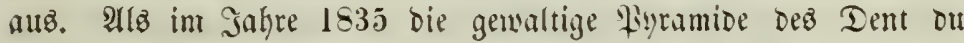

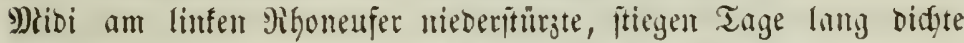
Etaubwolfen zu grojen sjagen empor. Bletider waren in bie Edjludten geidlendert und hatten die Trummer in einten zähen

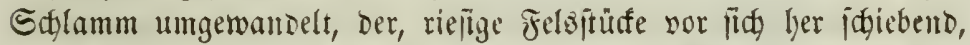
eirrem Berge gleidh im Thalgrunde vorrüfte. Wäloer wurben um=

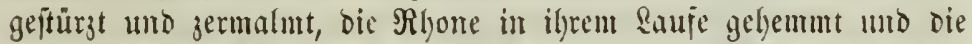

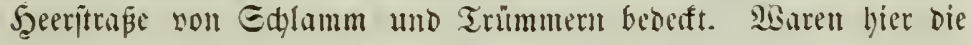

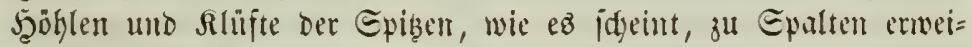
tert, von Waijer erjüllt und auseinanter gefprengt worden, jo Daß

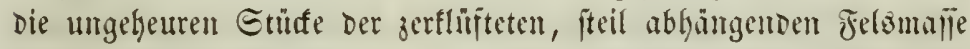

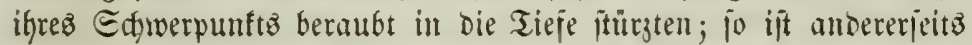

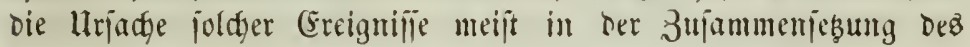

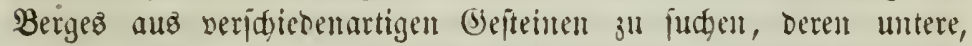

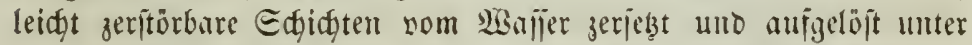

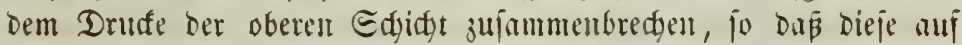
iljnen abwärtz gleitet, im fignellen \&ante bie gleitenden Theife zer= trümment und in jähem Falle bie nüdjiten Tiefen mit Trünmern

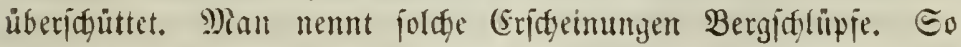

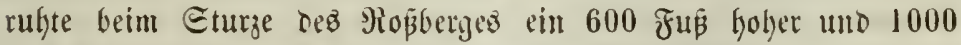

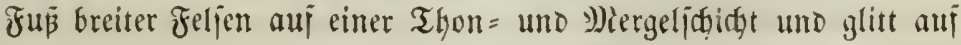

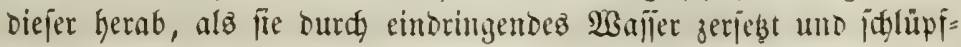
rig getwordent war. Banze Misilber ftürzen oft mit oen Bergen, bie fie bedeften, herunter, wie es nody in Gahre 1847 mit einem Theile bes über Altorf gelegenen Banmwaldes gejdgat. 
Sine viel allgeneinere Berbreitung alş bieje Ericheimungen baben die (Srofälle, bei welffen der Boden jelbjt jenfredgt in bie Tiefe Der (Erbe verïntt. Sn vielen Făllen fund burdy unterirbifde Aturmajdung entitandene Şöhlungen, Deren Deffen bie auf ilynen lajtensen 9) Rajןen nidgt melyr zu tragen vermögen, bie Urjacte von

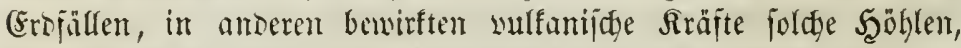
oder Bergmerfe untergruben den $\mathfrak{B}$ oden und veranlapten jein $\mathfrak{B e r}=$ junten. Bei felfigem Boden entitehen burdy Den Csimitur; idgadgtälyn= licte Rödger, bei lodferem Dagegen triçter = oder feflelförmige arbjen= fungen. Sewöhnlid jammelt fid in foldfer Bertiefungen 2 afjer, uno mandhe Teidse, von benen bie Sage geht, baj fie verjunfene

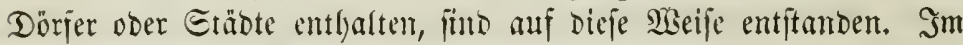
Rleinell find joldbe Cimjenfungen niḑt jelten, bejonders wo ber Boden aแร Sreide beftegt, wie es ju in einem gropen Theile unje= res nörblidyen Dentidylande ber Fall ijt. In Sütland fommen ba=

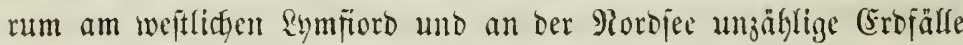

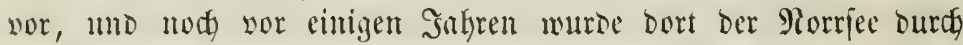

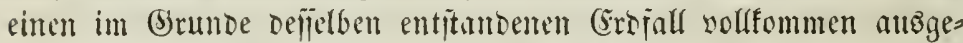

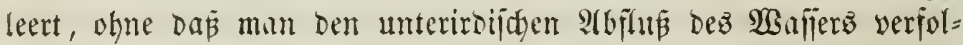

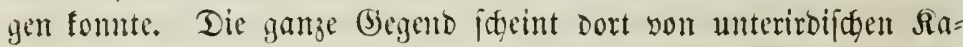

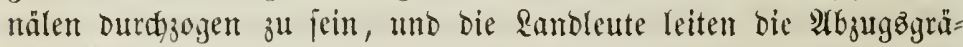
ben ihrer feloer in bie tridterförmigen Bertiefungen ber Grofülle,

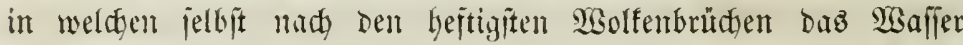

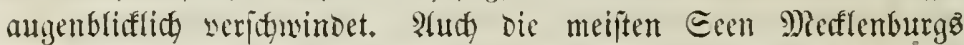
und Fiommerns, Der Serthajee auj Rilgen, die tiefen Eeen Der märfijden Edyrei; bei Bufow und ganz augemideinlid aud bie

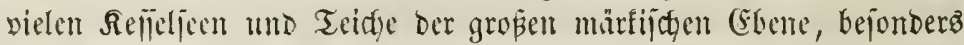
Der Şöhenjinge länge Der Doer, verbanten ifyren lurprumg foldgen Erofällen. In vielen diefer Eecn will man noch bie Trn̈mmer

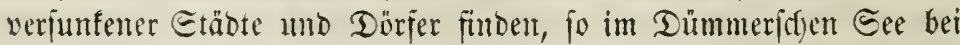
Edwerin, im sabentar Eee uno im Siolizice.

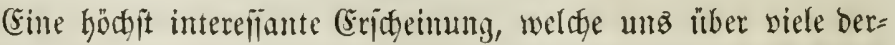

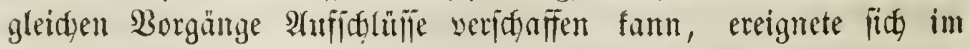
Jalyre 1844 bei Frenpifa Jjolland umveit Elbing. Dort wurbe ein artefijder Brumen gegraben und war fajt vollentot, alż man in einer Tiefe yon $11+$ Juв aแ eimen yroßen Etein ftié, imeldyer mit Dem Meipel jerjdlagen werden müte. Währeno hieran gear= 


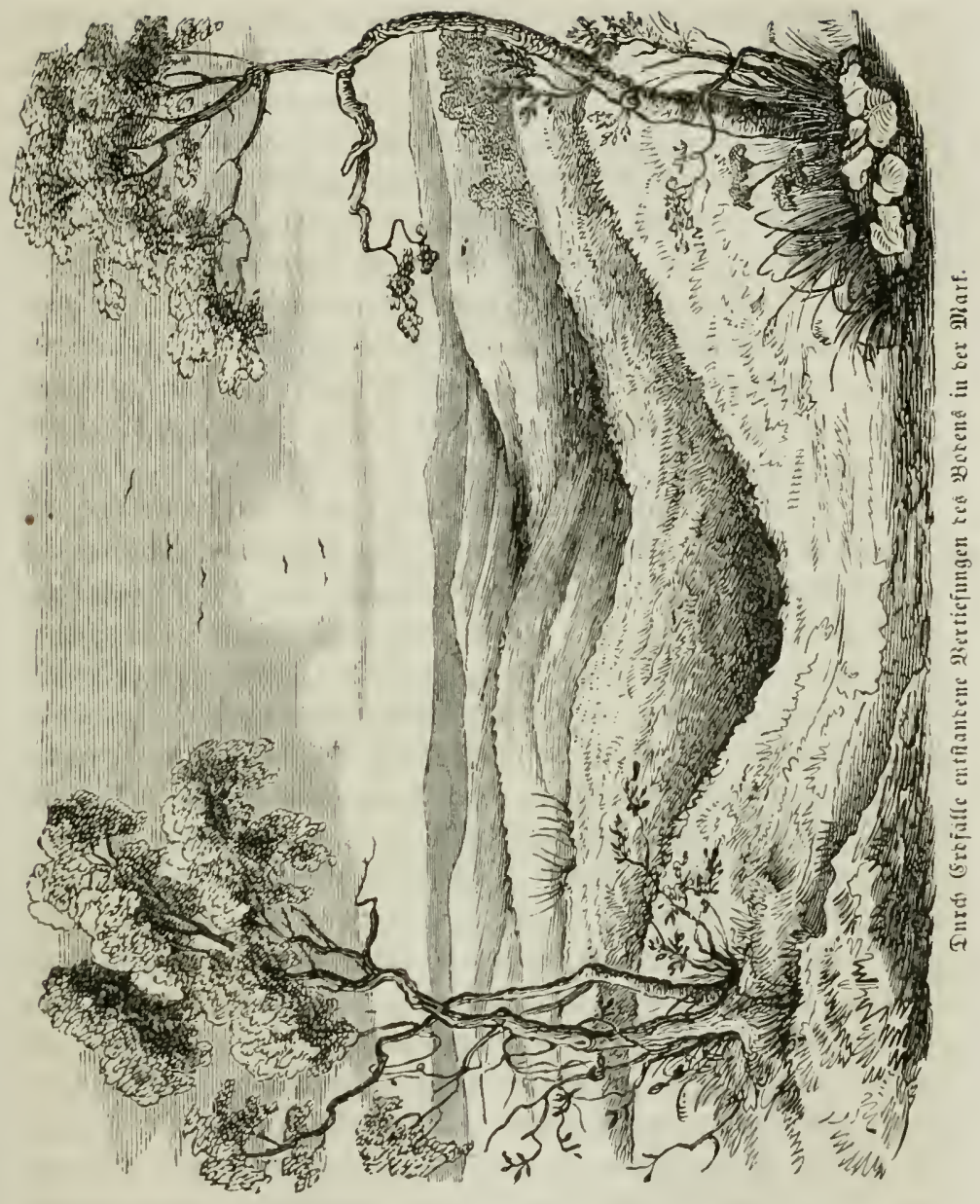

beitet wurbe, gewalyte man ben gemaltigen Durdforthd ciner gro=

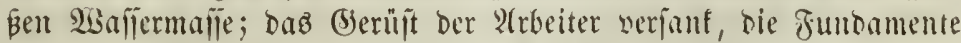

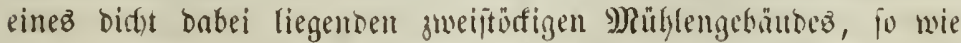
die Bohlentwerfe und Mafjen von (Grbe Ginter demjelben ftürgten

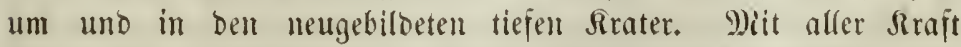
wurbe mun gearbeitet, eine S) Jenge von Eanbfäfen wurben ver= fenft; Dod wurbe banit nur ber Sauptfrömung eine anberc Sidd= 
ung gegeben, ohne im Wejentliđten etwas zu befiern. Das Stür= zen ber Funbamente unb weiter liegenden Sromaijen belynte fith.

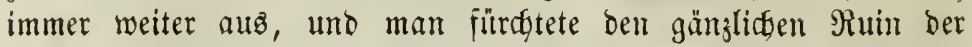

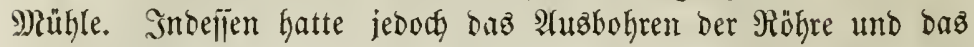
Meípeln bes Eteingeröls jeinen Fortgang genommen, uno endlich

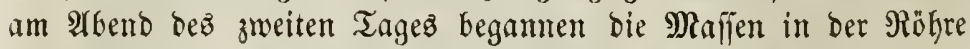

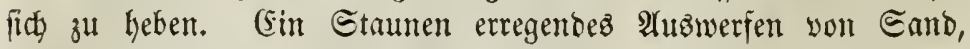
Thon uno Steinen erjolyte auz bemjelben umb füllte ben furz vor=

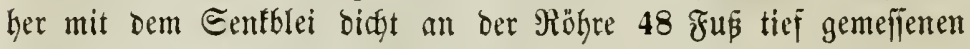
Rrater in 3eit von $1 / 4$ Etunbe 10, baj alle nah und fern gejehenen

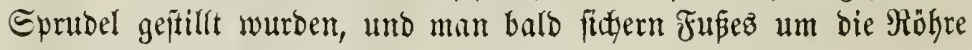
herumgehen fonnte.

Eoldge tleinere Grfdjeinungen milffen mun jur Grtlärung für die groß̈artigeren bienen, welden ein Fehr.allgemeiner Gimflü auf

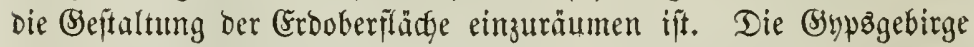
Thüringens find bejonders reidy an joldgen Sinjtürsen. Die Edylot= ten, weldfe fich unter bem Boben hinjielgen, haben gropen Rejleln ifren Ilriprung gegeben, weldge oft Durdgmejier von 250 Juß errei= dhen. अfud bie oft über 100 Fü tiefen Eeelöder jener Begend, Die fid nodh bejtänbig bilden, find poldye Sinftürze im syps mit fteilen $\mathfrak{B a ̈ n d e n . ~ D a z ~ h o ̈ h l e n r e i d g e ~ \Re a l f g e b i r g e ~ v o n ~ S a r a i n , ~ S l l y r i e n , ~}$ Dalmatien unb Sriedsenland weift zaflreidje Sefjel und Tridgter

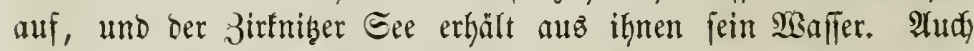
bie Sbruini bei Soefia am idmarzen Meere find (Simftïrze bes von Queflen unterwaidenen Steppenbodens. Şier werben oft burch

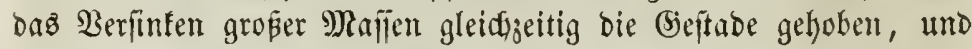
Durch ben gewaltigen Druff Der verbrängten Edslanmmafien felbft Injeln im Meere emporgetrieben. Aber jelbjt in ber Bejtaltung Der Sebirge ift bie BBirfung von Erofällen unvertennbar. Wie fol man fich anbers bie fonberbare (Jejtalt bes M)ont (Servin erflären,

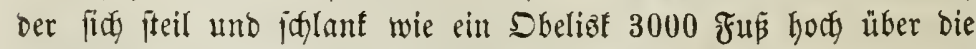
weiten Edyeefeloer erhebt, bie ringz um ifn bie hohen Bebirg fämme ber Alpen bebecten? Cine Grofion, bie alfe angremzenden Majien zeritöt unb wegführt und mur biejen feimesimegs aus fejte= ren Steinarten bejtehenben 3ahn übrig gelafien bätte, ijt unmöglich anzunehmen. Die Gebirggformen bes benadbarten Sieflelz von Breuil Deuten Dagegen auj eimen Sinftur; Demn hier finden fith 
nod) bie abgeriffenen Edidgten berjelfen Etemant, welde bie oberfte

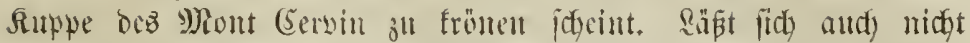

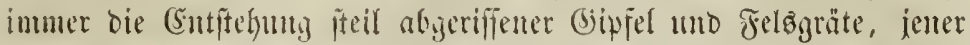

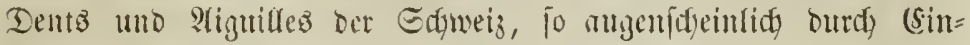

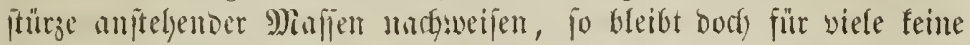

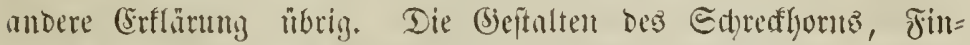

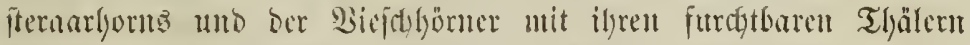
fönnen unmöglid) Werfe jerförenoer Gtröme fein. Miögen audh

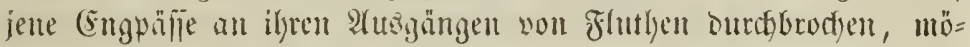

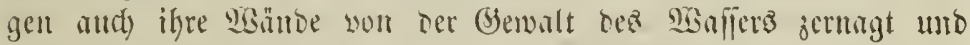
zerrifien fein; bie weiten Siefiel in ilgrem Sgintergrunde fund allein Durd) (Einfturs zut exflären. (Sinen guts anbern Eharafter bieten

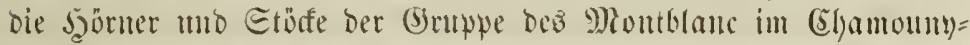
thale bar. Sfier fielyt min, bak bie Crofiun gemint hat, baß biefe

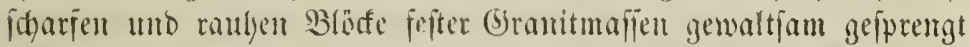
wutroen unt noch zerrifien werben. Die mutherbare Siabel ber

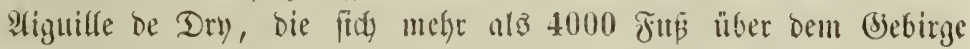

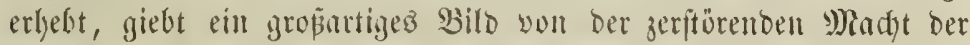
Pintur.

Bon nidgt minderem Einfü mi Den malerifden Eharafter

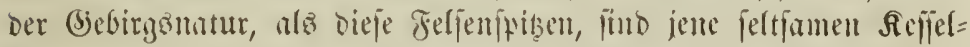

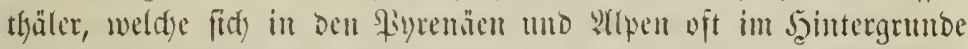
ber bie Gjebirgatetten onrdyichneibenden Duertyäler finden. Eie wur=

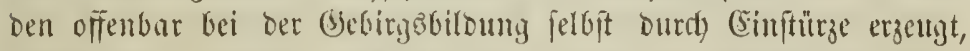

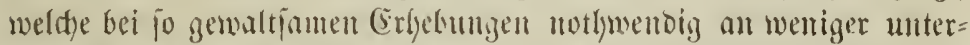

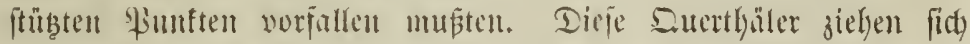

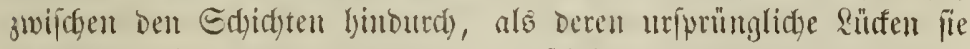

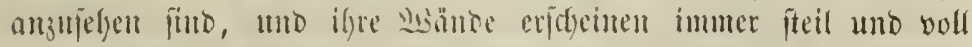

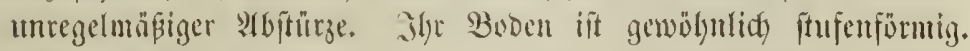
Die Flinfie idbleidgen haljer oft eine lingere Etreffe in ifnen fo fanft und unficher fort, dẩ fie Durd) Dänme in iljen Betten gehalten

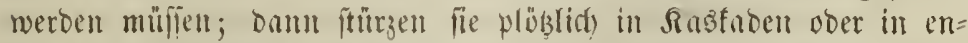

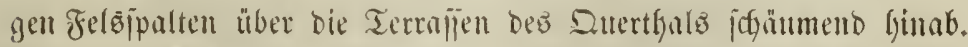

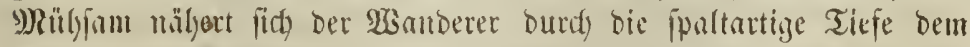

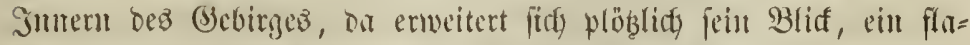
dyer weibebooen liegt vor ilym, Walferfälfe ftürzen liber bie hoben

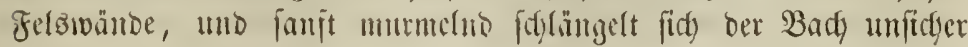

Ule, wettull. 3. Uuft. 


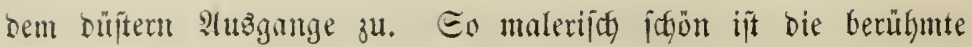
Sule be Bavarnie in Thale von Barègez und der Cirque de Trou= mouje im Thale son Seéas am Yorbablyange Der \$yrenäen. Piei= zento futo die 2lpentlyäler von Breuil an 9)ont (Eervin uno von Macugnaga am Fuße bes Monte Sioja, welde Reijente mit wul=

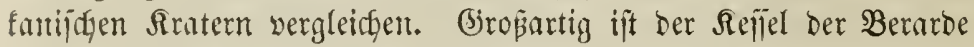

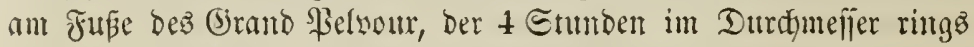

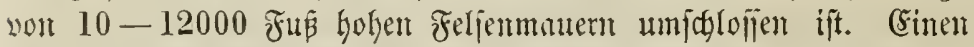

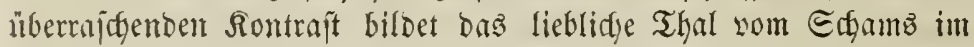

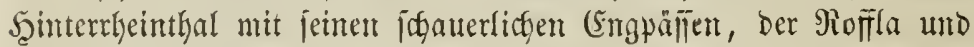
Bia mala, burch weldye fidy eimit auf der eimen Eeite der Eee des Rheinwarbthals in ben Refiel non Edunts entleerte, auf ber an= Dern ber neue Eee jeinen Attoweg brnd). Denn bieje fejplfürntigen Weitungen waren ohne 3 weifel uriprunglidy großße Eeebeden; und nod) jeBt finset man auj ifrem Boben bie abgelagerten Edaidaten

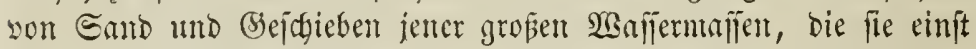
erfülften, nod) jeb̨t frelgt man an ifren Eeitenwändent oft bie beut=

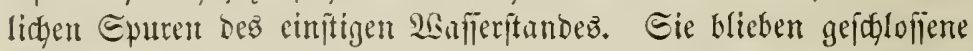

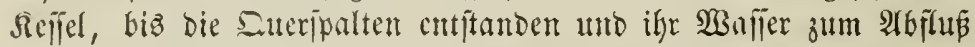

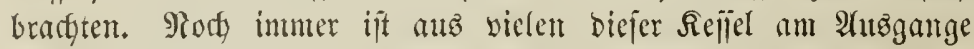

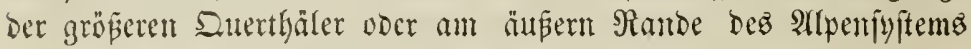
Das SEajier uicht ganz abgelaufen; uno jo entitefen jente Geen, bie fo siel zur Serichönerung Des Alfenlandes beitragen. Ştre große Ticje, Das jteile Abfallen ber fie eimithliepenten Giebirge, das aud

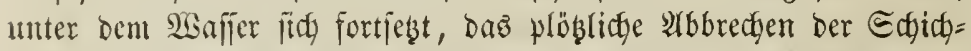
ten an biejen \&bitürzen entfernt jeben (5iebanten an Aušwajchung. Hber wie entitanden jente gropen Weitungen, twie bie verbindenden Epalten? Waren jene Weitungen eimft Eeebeffen, jo tönnent bie

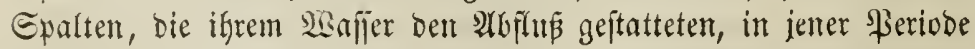
nody nidjt bagemejen jein ober bod) nidyt ifre jetzige Tieje gehabt ljaben.

Die Sieljeltyäler find aljo ältere Bildungen, uno ba fie gerabezu

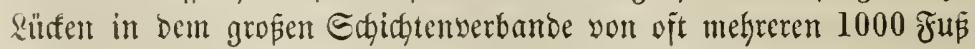
Tiefe futb, jo fonnen fie mur bei ber Bobirggabildung jelbjt burch (Sinjtürzen wentiger gut unterftübter Theile berjelben hervorgegangen,

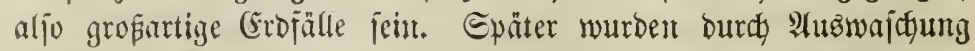

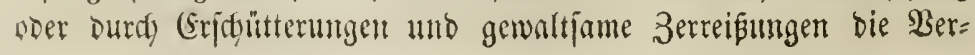


binbungsipalten gebiloet, und wahrideinlidy hat biejer Borgang in

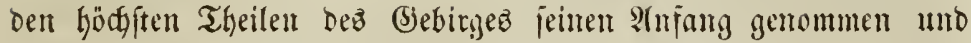

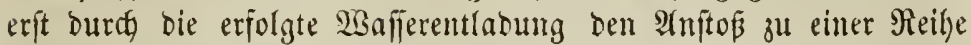
analoger (sreignilfe gegeben. WBie gewaltiy die Berwüjuntugen

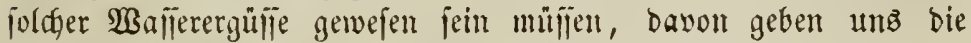
Ueberidyemmungen unjerer Etröme faum eine idwwadbe 2 hmung. Man bente fidy mur, Dá Der Bobenjee, befien Tieje biz auj 1800

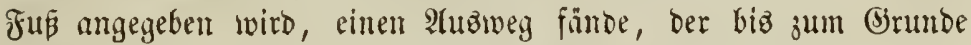
reidgte, unb mun mit feinem $\mathfrak{W a j f e r}$ fich in baz Sigeinthal ergöffe; wie mütroen Bajel, Etrajpburg, nody melyr aber bie Etäbte bes Rheingaues verwiljtet werben, weil die Etromenge von Bingen

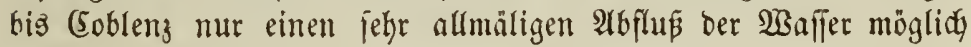
madyte!

Um Den llmijung joldyer Berwijitungen mur einigermaßen an= fdgaulidy zu madgen unb zugleid bie Möglidgfeit von wirflidgen Thalburdbrüchen zu begründen, jei ez mir erlaubt, bier noch ein (Ereignifis der neueften Beit ju erwähnen, welches das Bagnethal

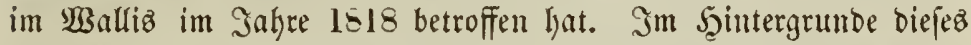
Thales jebste fid in einer Thalenge burdy häufig von einem bohen

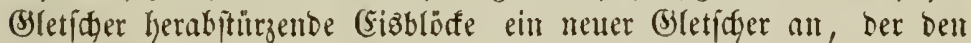

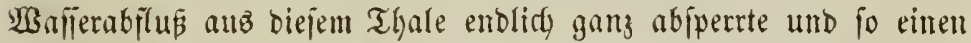
Eee bildete, welder bei mehr alz 200 Fuß Tieje eine $\mathfrak{B a f f e r m a f f e}$ von über 130 Millionen $\Re u b i f f u \beta$ entljielt. Eo nahte ber Som= mer heran, bie erhöhte 2 Barme lofferte bie Jugen auf, uno plöblich Durdbbads bie Waffermafje ben Bletidyer, frïrzte mit verbeerender Wuth burd baz 8 Etunden lange Thal humas in baz Şauptthal von $\mathfrak{B a l l i z}$, wo fie fich bei Mhartinady mit ber Mhone vereinigte und burdh bieje einen Theil ber mitgeidwemmten Trümmer Dem Benjer Eee zuflutfete. Dieje słluth glids nidyt einem WBafferjtrome, fonbern einem jurdtbaren, in withender Bervegung begriffenen

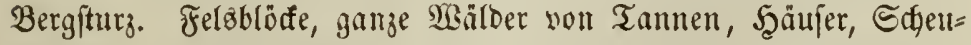
nen uno beren Bructitüfe rollten übereinander bin, unb bie $\mathfrak{B a f f e r}=$ majie war fo bamit überlanben, Dás man baz 23affer nidgt fah,

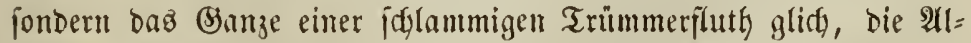
lez mit fith fortrí, waz ihr entgegen ober zur Eeite ftand. In ber untern Sẳifte beż engen Thalz hatte fie viele 100 ungeheure Sranit= blöfe, bie am Fuse bes Bebirges theil(z frei, theils in alten Edyut= 
Galden wergraben Iagen, melyere 1000 Fuß weit mit fids weggefülyrt;

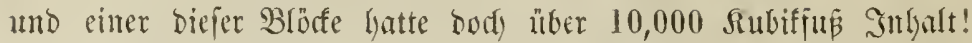
In ber ganjent offenen (begent von Martinad Iagen Edutt,

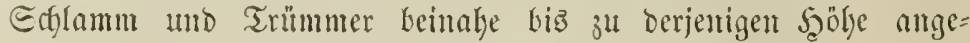
häuft, weldye bie fluth Gier erreidyte.

Eoldyer und alfnlicher Ereigntifie mögen in frülgeren fierioben unjerer Crobe noch viele umb gropartigere vorgetommen fein, berent

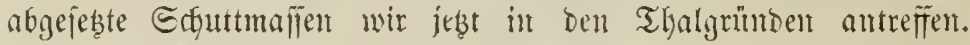

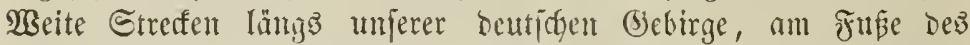
Edywarzwaldez, Ler Allpen, Des Jura find mit einter meilentreiten

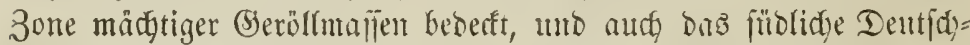

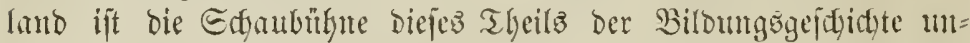

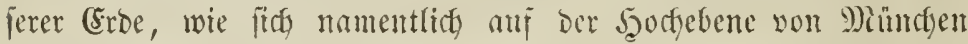

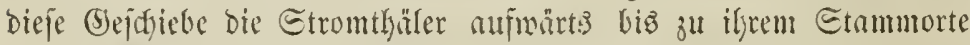
in ben ?llpen weriolgen lafjen.

Go arbeitet die Eroe nnch beftündig ant Der beftaltung igrer

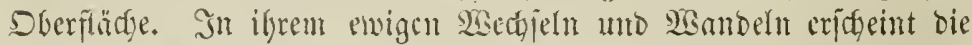
Fattur bem fleinen Mentiden gropartig und furdytbar, wentm er fie nidyt

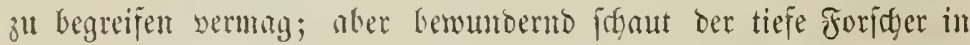

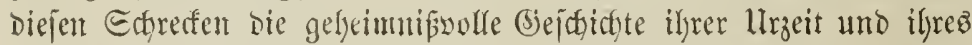

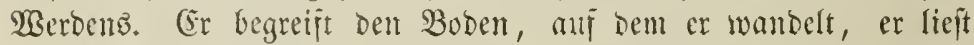
in inm, wie in feinem Butbe, Thaten แmo $\mathfrak{S}$ Gutber. Er burdeilt nidyt Thal mo Gebinge mit Dem Eimne bes Touriften, ber mur nady 9 tbenteuern Gajot ober in Träumen ber Fhantafe fotwelgt, wo bie Sintur Sieize enthült, weldge fein Didyter zu fofaffen vermag.

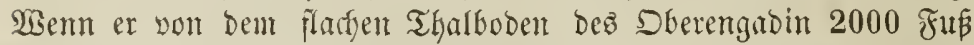
Gimabjteigt zu Den Etujen und Edyludjten Des lluterengabinz, Dam erzăblen ifym bic zerrifientent Felsెwänte won cinem mähtigen Sturze, weldger einjt bicjes lange Thal in bie Tiefe werjenfte. 95enn er zu bem bödjten alpenthale ber croe emporfteigt, zu bem $10-$

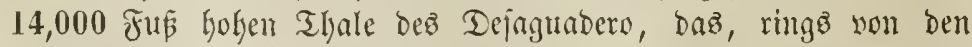

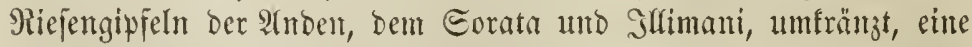

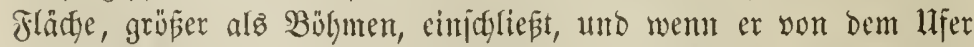

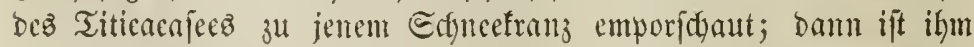

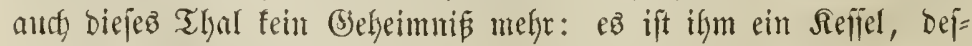

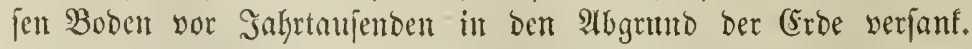

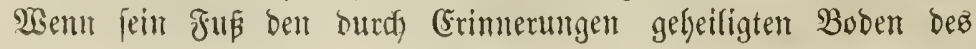


Sorbanthales betritt, uno fein Stuge über bie buifteren Fluthen des

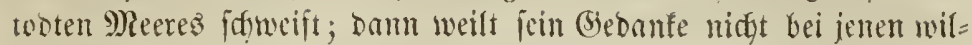
Denl lleberlicferungen, weldje biefen tieffiten Epalt ser (5roc auf den

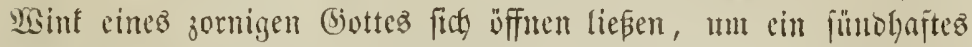

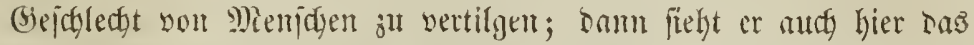

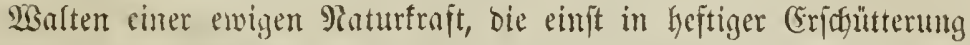

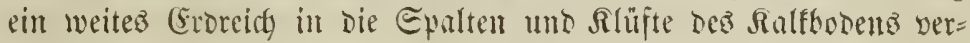

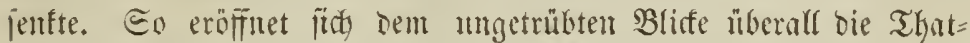

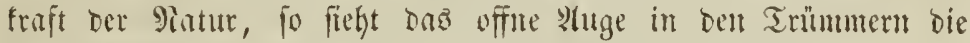

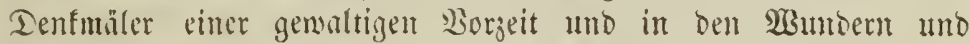
Edyreffen Der Biegenwart mur bie Epuren ber fortidgeitenden (b) $E=$ jojidyte bes iroijgen Piaturlebents.

Mamigfach unt grofintig fint die ltmgeftaltungen, weldye

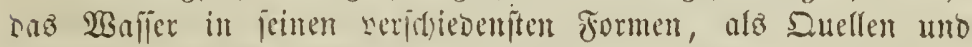

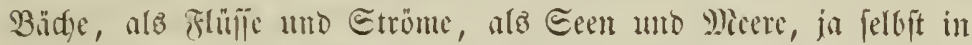

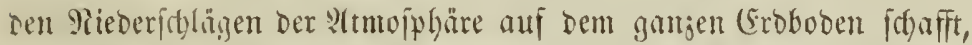
Ulmgeitaltungen, weldye jeit Gafyrtatfenden bie llmrifie der Mleere

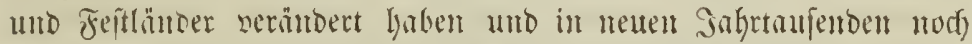
verïndern merben. Bädye und Etröme iffneiden yimen in ben

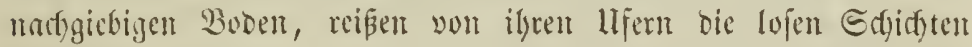

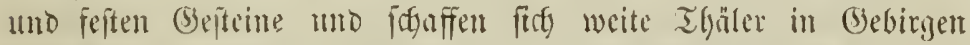
und (Ébenen. Thäler entfitten burd) atmofpgärifige Erofiton, burds

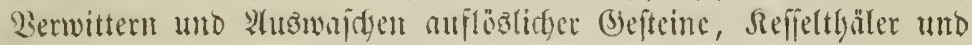

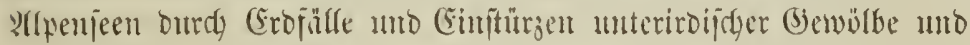
Şöblungen. Das Meer nagt beftändig an jeinen Hfern, unter=

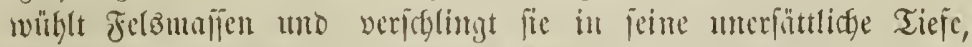

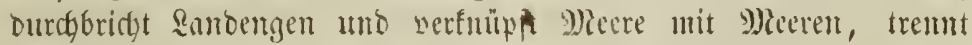

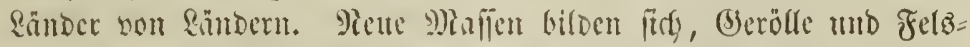

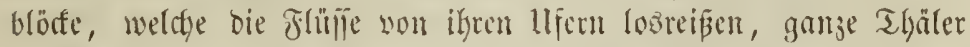

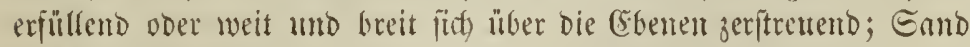
und Edblaummaifen, weldye von den Etrümen fortgeführt, ifgr

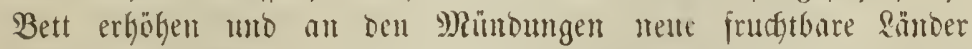
jofuffen. Daz Meer giebt jeme Bente wieder hernus, baut lifer=

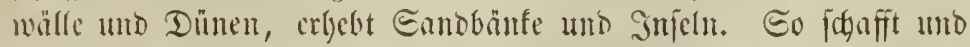
jeritürt bas $\mathfrak{B a}$ ajier atmutterbrodjen fort, uno wern autd) bie furze

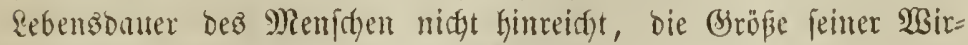

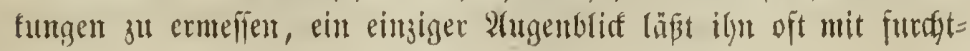


Garer Stemiflbeit bie Folgen empfinden, weldge gahrtaujenbe un= benterft yorbereitet lyaben.

\section{4) Die Birfungen des (siję.}

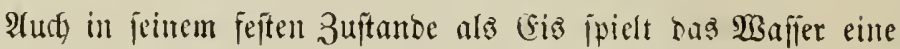

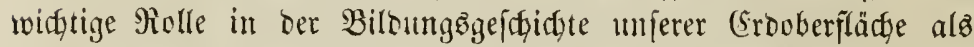

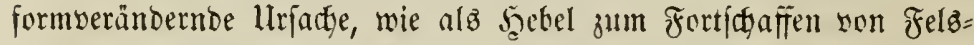
blöfen und Trümmern. Flud im filten, ftarren Eije Gegrinfen wir einen thätigen Mitarbeiter an ber Beftaltung unjerez Bodens.

Im Frithling und Eommer jofwindet unter dem Cinflup you

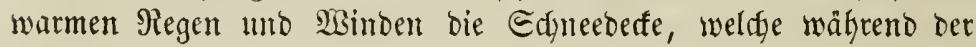
fälteren Saghreşacit eincn gropen Theil unjerez Grobobenz über= lagerte, uno mur auj hoben Bebirgen und in ber Mäbe ber \$ole eritaret bas Sefen ber Matur unter bem falten \$anzer. Blendent

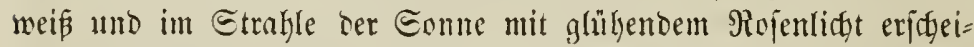
nend, bezeidjnen bieje Estmeefeloer ifgon in weiter Ferne ben eigen=

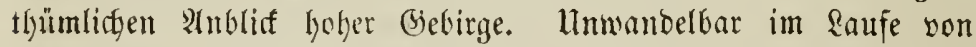
(5)enterationen, nidgt reunclyet burdh bie gewaltigen Sdjneefälfe ber

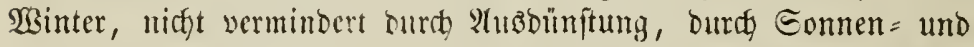
Bodenwärme, geben fie Das buiftre Bilo einer todten Ratur. Atber aud fie find mur fideinbar ons brab des Rebens, audy bie ftarren

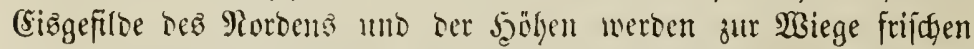
Rebenz, zum Tummelplab einter zaljlojen Thierwelt, zum Saaten für Millionen fleiner

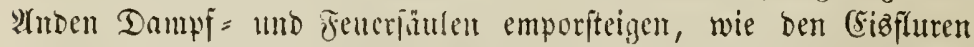
Dez Šimalana lyeipe Sutllen entitrömen, jo beleben Etäbctenpflan= zen und Snfujorien ben Edne der alpen, bie Eizfelder her \$olar= regionen, in blutrothen Etreifan bie blententweisen Befilde burth=

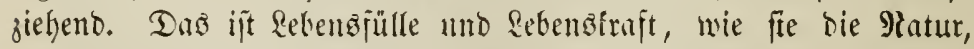

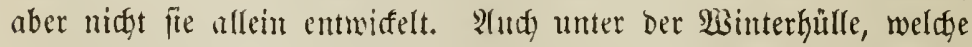
Bölfer bebefft, regt jich cin Reten, das jreilids nidjt mit groben

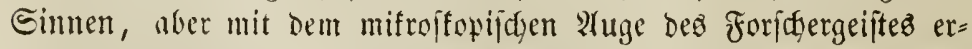

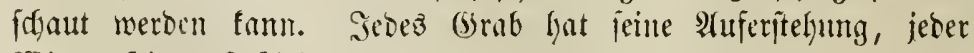
Binter feinen frithling!

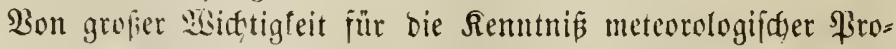

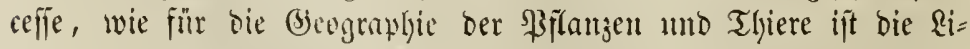
nie, welche die untere Brenje biejer niemala wegitgmelzenden 


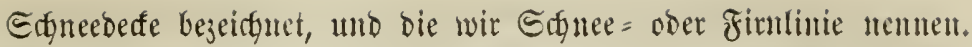

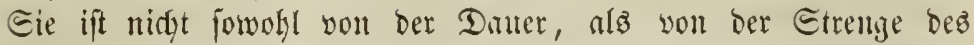
winters abjängig. So ift bas Smmere Eibiricnz der mittleren

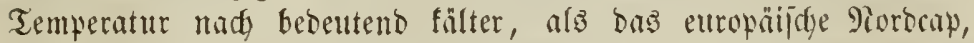
uno body liegt in Eibirien bie Edjneegränje um Bielez höher, weil feine Eommer warmer find. Daher ijt ez audy begreiflid, daj bie Tropentregion, in weldjer die Efyneegränje jwar im Afrgemeinen

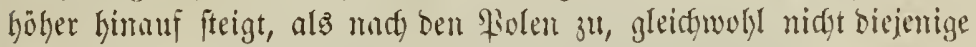

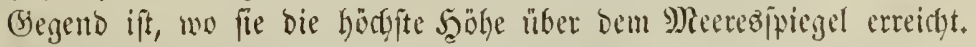

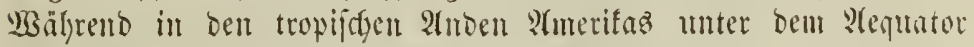

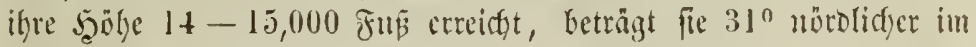

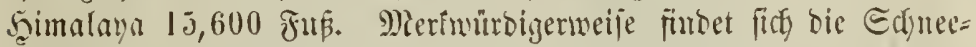
gränze an ber Eübjeite tez Şimalays üher 4000 Juß nicoriger,

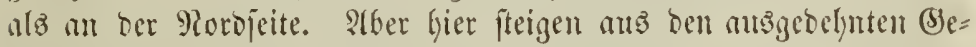

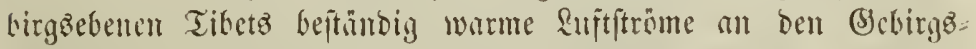

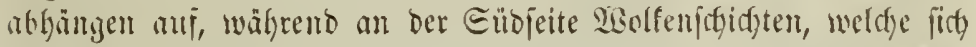

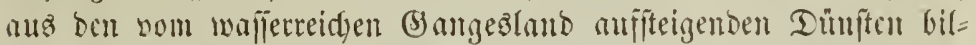

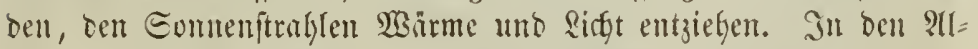

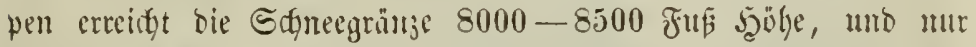

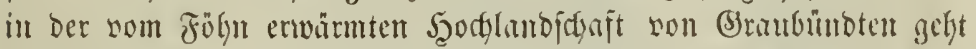

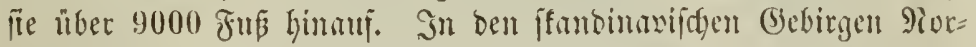

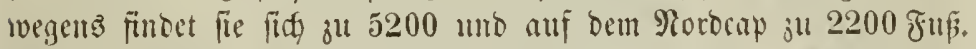

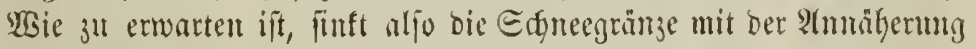
an bie \$ole abwirts, aber fie wiro audt, wie wir felen, burdy bie mannigfaltigften Mrjadyen verültoert. Die 2Särmeunterifjiebe ber

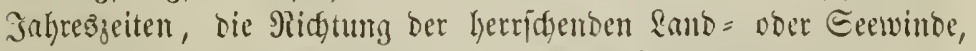
die Trofentheit ober Feudtigfeit ber oberen \&uftjdidgten üben cinen

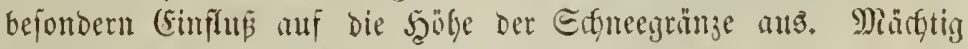
ungebäufte Edneemafien auf bem Bipfel bes bebirges voer auf benadjbarten Bergen brinfen bie Edjneelinie meit Germuter. Edyruff=

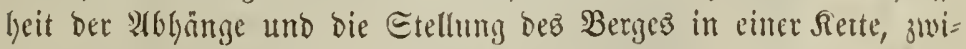
fden Edyneegipfeln ober in einer (Sbene wirfen wejentlid) ein. Afuct)

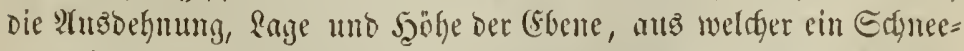

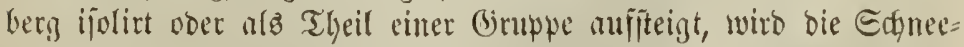
linie ergöhen voer erniebrigen, je nadjoem fie eime Eeefuife ober bas Immere eines (Sontinentz, bewalbet voer eine Brasflur, eine büre Eand = oder Feljentuafte ober ein jeudter 9)ioorboden ift. 


\section{4}

In Den \$olargegenden fommt zu Dem eiwigen Edynee ber Berge

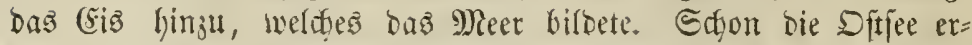

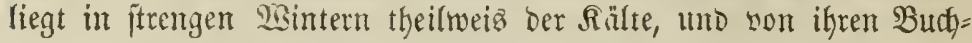
ten unb Wiern aus bildon fird weite Gisfeldor, über bie man im 23inter 1809 your Finnland nach Edweden mit Edylitten fubr, wie firch im Samuar 1655 anf Dem (Eije Des Belt Dänen und Edgweden

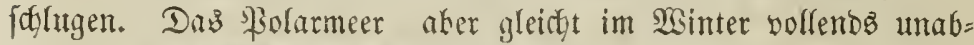

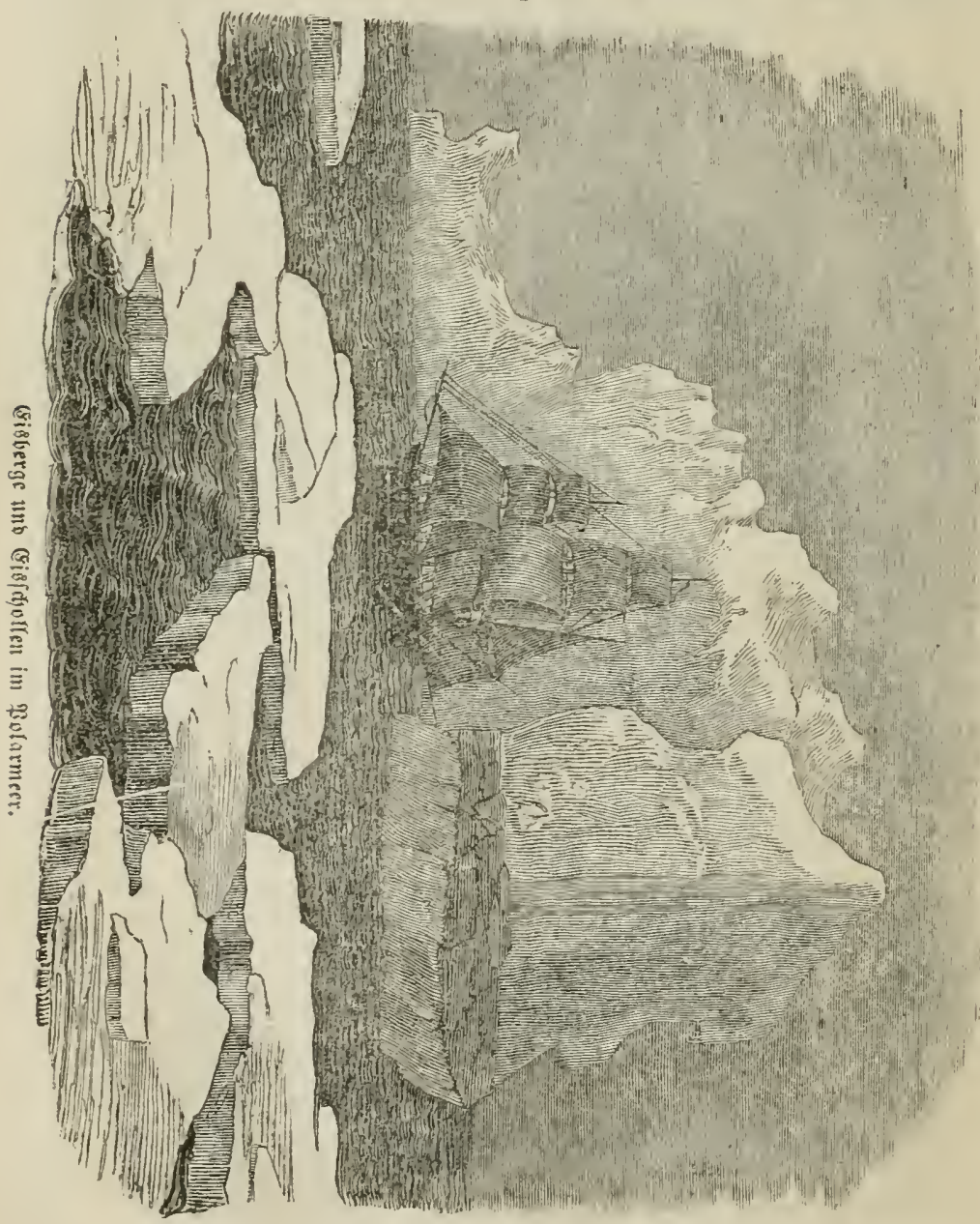


fehbaren Sdyneefteppen, mur unterbrodhen von bohen (Eizrnident und wellenförmigen Thälern. (Sigfelder von mefreren hundert Duabrat= meilen (sröß̈e erfüllen jente Mcere uno ragen of̣t +-6 Fuß hod

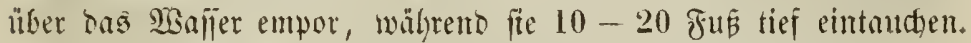
Dit werden fie von Den weellen jerbrodgen und von Simben und Strömungen in Benegung gcię̧t. Dam brolen fie Dem Schiffer

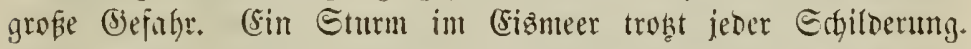

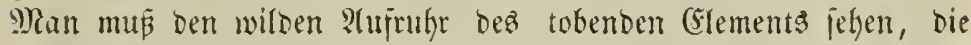

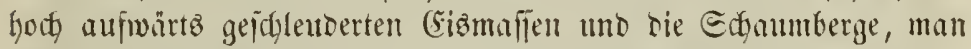

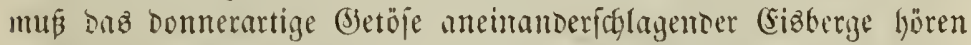

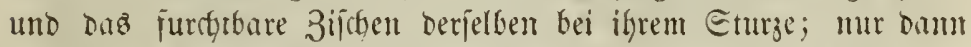
wiro man das Bito einto Polarfturmes begreifen. Edyon wem bie Etrönumg ein (Sisfeld gegen ein anderes unkemegtes oder

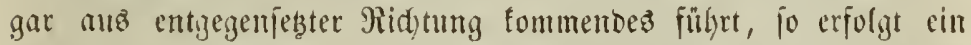

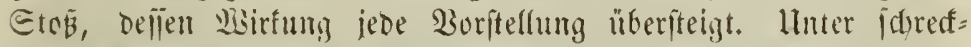

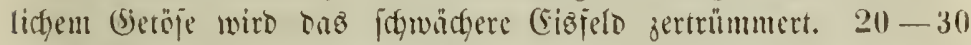

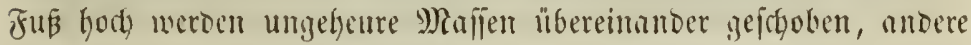

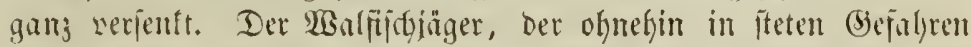

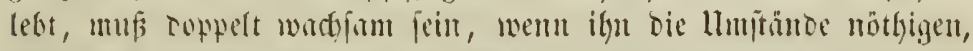

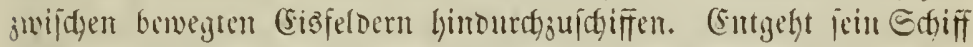

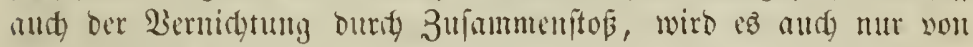

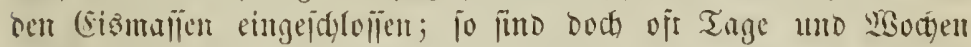

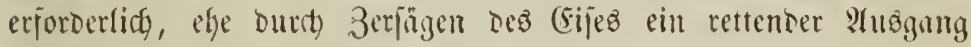
gewounen nirt.

(Jianj anderer Sattur, aber nidgt minder gefälyrlich uno groß̧-

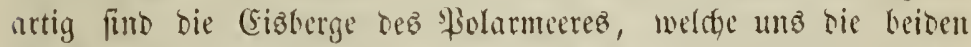

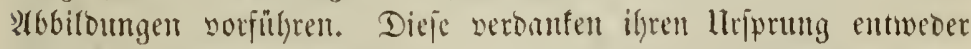
B) Tetiftern, weldye bejonderz an Den Ditfuiten won Epizbergen uno

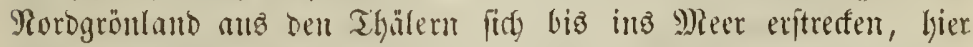

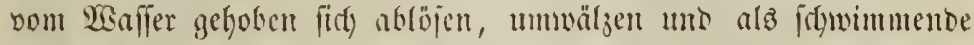
Eiaberge fortberwegen; ober fie werben aud in Budften, ferbft im

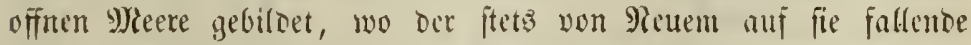

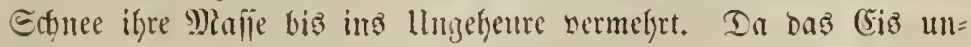

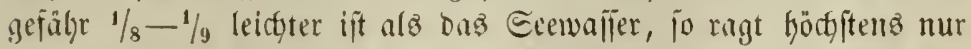
Der adyte Theil Der Majie auz dem $2 B$ nffer hersor, uno man fam baher aus ber Sähte eines (Eisberges auf leine Tiefe unter bom

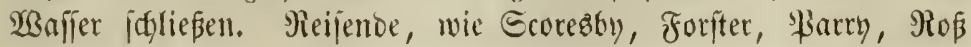




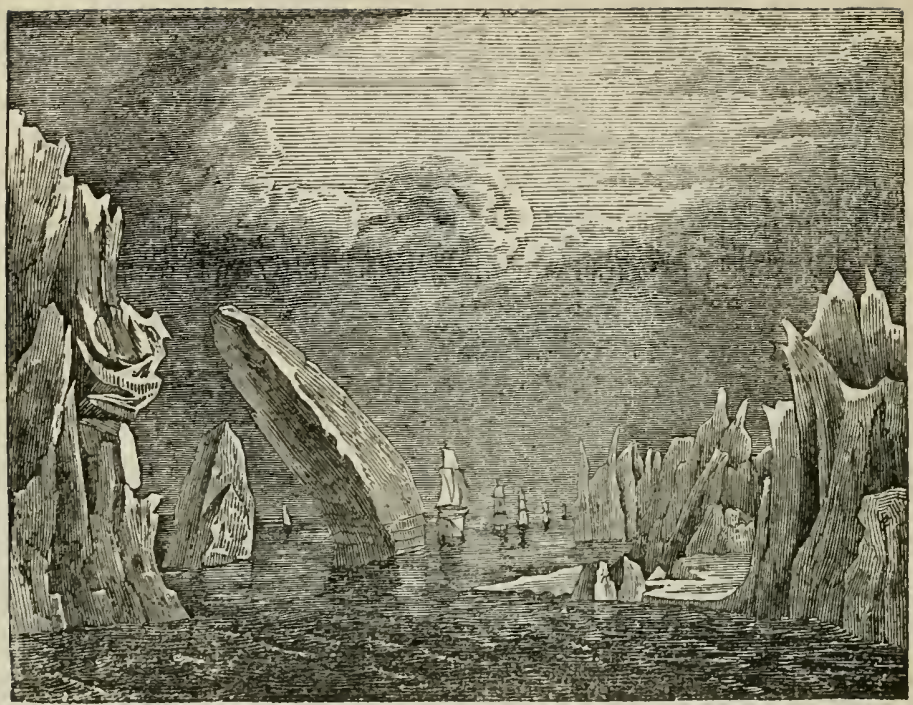

Gigfierbe in Bolarmeer.

haben aber (Giäbrge gejehen, welche bei ciner Flähe son $1 / 2$ unto mehreren Duabratmeilen eime Şähe von 150, ja jefbft 200 und

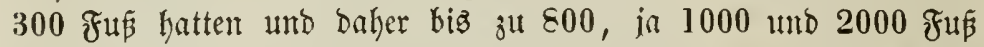
Tiefe in bas Meer eintaudjen muftert. Ectjon altz weiter Ferme

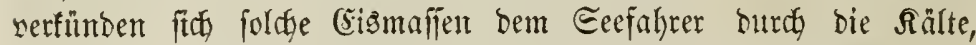

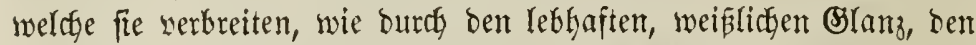

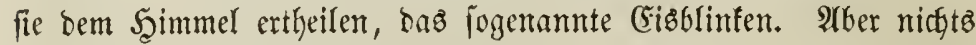
gleidft ber munberbaren Farbenpractyt, welche bie Cisiaberge int ber

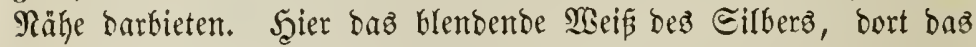
bunte zarbenfpiel Deż Regentrogenz, bie zadigen Epiben yon ber Eonne mit Broldglanz übergoifien, uno ber Şimmel barüber im fefönften (S)ün; Dału bie Eilferftröme, bie ant ben Epalten und Slüften hersorbrecten: das ift ein $\mathfrak{A n t b l i f f}$, wie er wohl mit ben

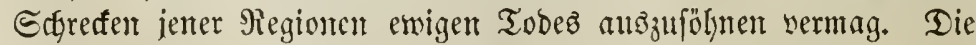

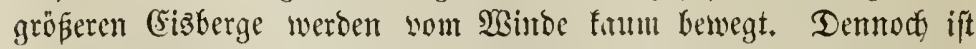

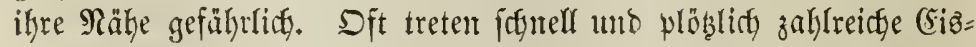
berge zujammen unb verperren ringz ben Ectiffen ben 2(uşweg ober füthren fie swillenloz mit fich in bie zerne; eitr Edfiffal, bns wieberholt bie tüfytent \$olarfahrer betroffen hat, weldge in ben leb= 


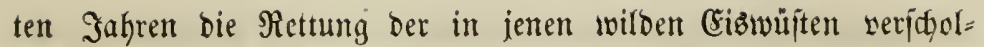
lenen Franflin'iøent Expesition verjudten. Dft änbert aud ein (5işberg Durdy Abidtmeljen in ber Tieje ploblity feinen Edywer=

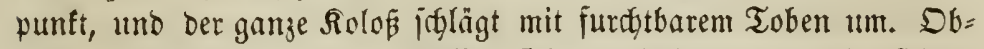

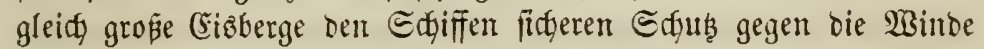
bieten, ift ez Dods biawcilen gefährlid, an ifnen vor 2infer zu ge= hen, weil bicje (sizmajien eine poldbe Epröbigfeit uno Brïdjigfeit

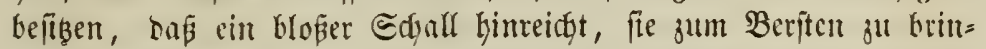
gen, und ein cinziger Ruberjalag iđon ben llutergung ganjer Mannidyaften berbeifübren fann. Demnot baben bie artiptyen Eee=

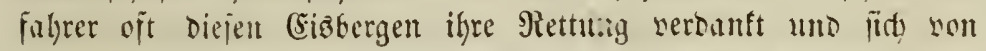
biejen weifinglingunden Edylepppferben mitten ourd cin ftumbermeg= teछ, von milo tobenton Echollen bebefteg Meer führen Lafien. -

Die Erenjen Des 'Holareifes reiden oft weit liter bie fiolar=

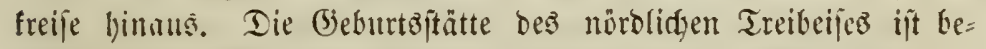
jonderz Dus Meer im Morden Epib̧bergenz und Brönlundz. Dort bilben lind in bell neun Mronate langen Wintern getwaltige Eizmmälen, weldge won Etrömungen naty Eiben getricben, won ben Etïrmen jerjofellt, won den Somnenftrahlen jernagt werben. Der Eecjalger begegnet diejen Eisbergen nod in ber Breite bes fïblidyen (5urowa, jelbjt biz zu $36^{\circ}$, aljo in ber Breite yon Gibrultar. Der Solfijtrom gält fie nidyt immer auj, weil er mur auf ber Dber=

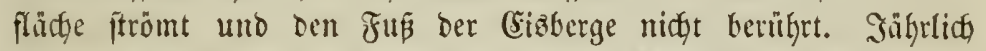
ftranben gewaltige, itber 100 Fuß hohe Cismaffen an ben Rüpten Reujounblants uno in her 9läke ber grofen Bant, in einter Breite

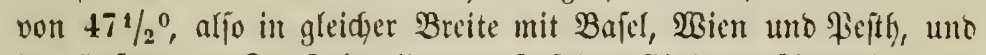

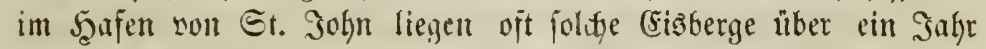

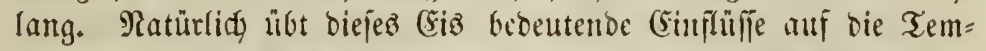
peratutr auz, uno b.rs Slima won \$zlnut wirb bejonters sutch bie

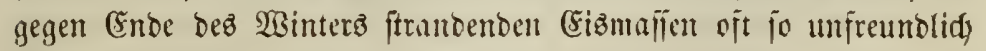
falt und feucht.

Die eigentlidte Srentze Deß Folareijez bildet cinte Sinie son ber

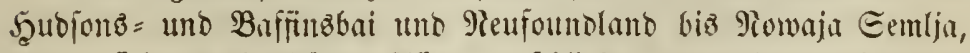

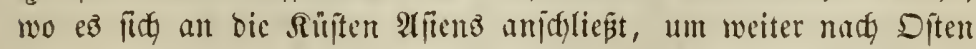
aud bie Beftabe 2Amerifoz ju umligers. Im gemaltigiten find dieje (Eizmajlen an ben Rifiten Eibirienz, wo fie cine miberiehbure, raufe Ebene bilden, Deren anfiteigende Dünte jene Trugbiloer lyer= 
borbringen, weldbe gleidy Der Fata Morgana Den Reijenden Rand

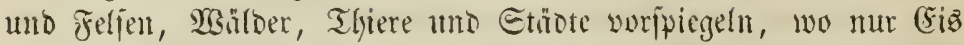

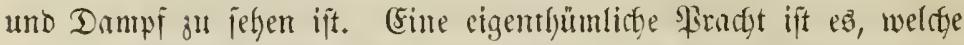

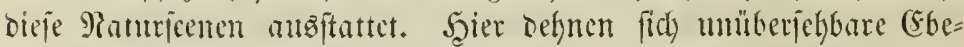
nen aus, son offnen Ranälen, Folinjen genannt, burchidgnitten, welde oft mehr als 100 Meilen weit dem Edfiffer, audy mitten im Binter, in jenten Regionen ewigen Froftes offites Fahrwaffer Dartieten. Dort fteigen rieftge Barge mit fteilen Gichängen yom

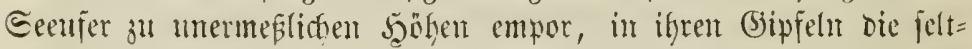

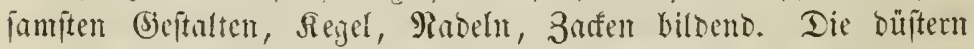

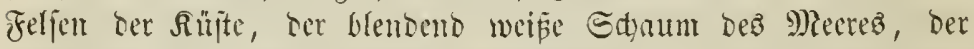
Dunfle Seimmel, bie wen Meteln crin̈llte Enft, Das füb bie Farben ju eitem Simälde ter Folamatur.

Man hat netterbings oft bie Behauptung anfgeftelt, dak bie

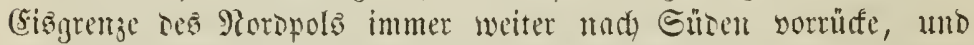
fit) Dabei auf cime Thatjadye an ben Diftüften (Srönlando berufen. Aher bieje Thatjathe beruht mur auf Eagen. (Gz ift hiftorifa, dap

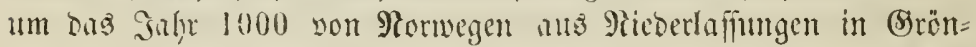

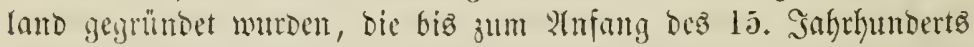
mit Dem \$Mutterlande in Derbinoung gellicben, jeitoem aber gäng= (idh seridgollen fint. Enäter jutte man sergeblich ifre Epuren

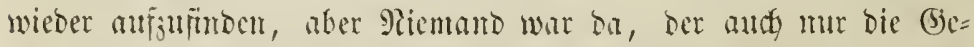

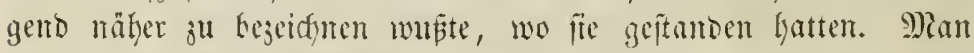

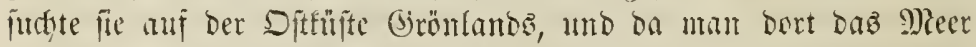

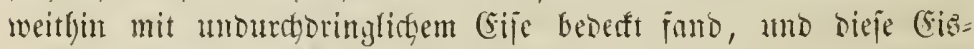
maffe im Emuje Der Drei jungiten Sabrhunderte nicht yon ber Etelle

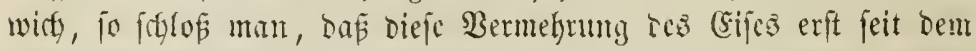
Ende des 14. Safrh. erfolgt jei, und daj baher dort ein wirflidy

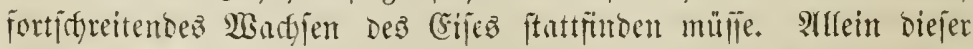
Sd)lup, fo nerbreitet ex auch fein mag, ift jehr gemagt. Dent eine foldye Sermefrung founte mur ganj alfmälig ftattfinten,

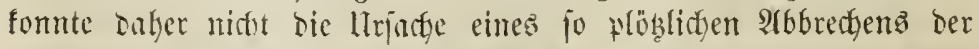

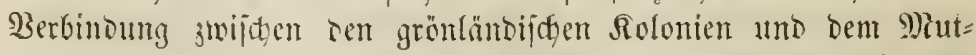
terlanto jein. Ier Ampalf eines mäctigen Feindes, eine Ecutge,

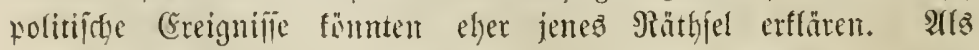
gegen Ende Des vorigen Sahrhunderts son ben Dänen neut Rie=

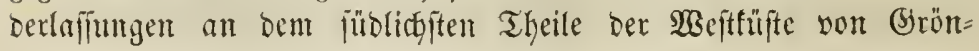


fanb angelegt wurben, fano man bort in ber That eine grope Menge non Trummen regelmäpig angelegter, grofer Bsebäuse, bie gar fei= nen 3weijel erlauben, Daj dies bie (Siegend fei, in weldyer eimft bie alten norwegifden Wffanzorte und die vielen Rirdyen ftanben, Deren bie alten Gngen gebenten. Frer won ben eljemaligen ento= priijden (sinwolynem hat mun feine Spur entoeft; mur Eafimos

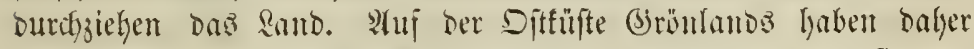

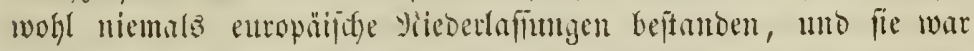
wohl in oen ältejten 3eiten ebenjo jelyr mit Eiz belegt alz jebt.

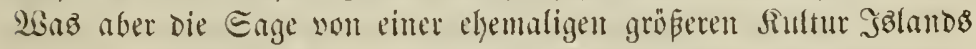
ergäflt, ift zweifelbajt, Into wem fie namentlid won ben vielen

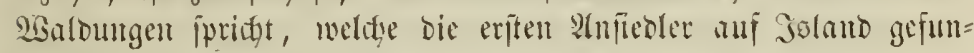
ben luaben jollen, jo ift me baran ju erimerse, Daß aud in ben

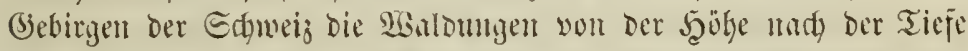

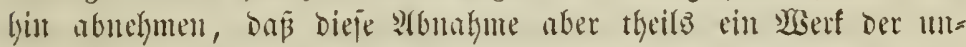

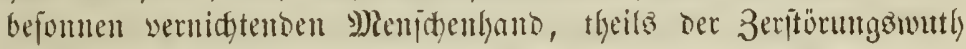

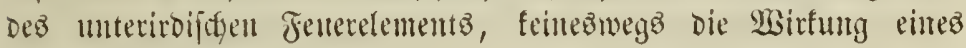
perïllberten Rlimas ift. -

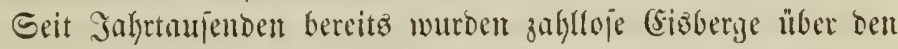

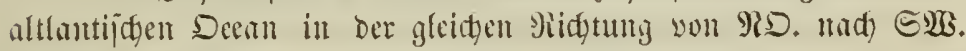
gefühyt. Bei ifyer auperordentlidsen (Sröße mü̈ten fie vit den y) Ceeresboden berübren und in ihrer fortgleitenden Bemegnng glät=

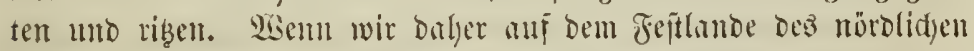

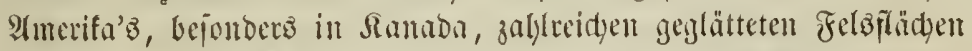
begegnen, Deren Sitzen unt Jurdyen eine gleidse Pidytung zeigen, jo finden wir wohl bie Bermutlung suel's getedtjertigt, Daf einft

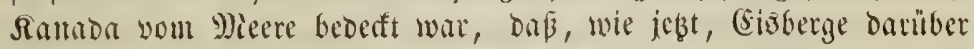
lintrieben und wie jebzt ben alten Eeegrund burds Sicibung glät= teten, biz fie an Den Rüjten Deş damaligen Fejtlandes, viefleidyt an Den ueifien Bergen frandeten. WGemn wir aber älnnlidjen (Er=

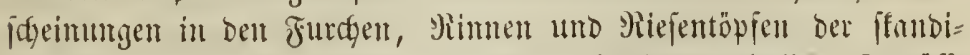

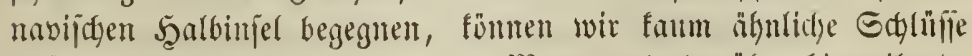
auf cine eimpige Bebectung vom Meere und Dartiber hintreibende Siôberge zurüctweijen.

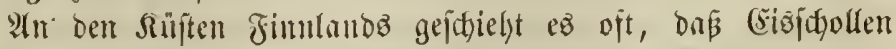

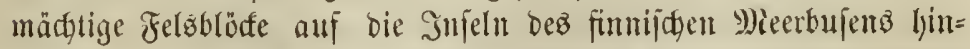
übertragen; uno mitten auf Der Snjel Sgodgland fiegt man nod 
einen gerwaltigen Branitblocf, ber auf biefe Weije im Sahze 1838

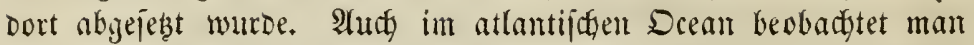

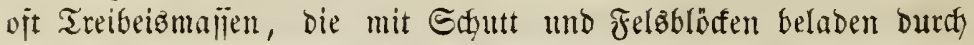
Etrömungen und 2 sinde in wärmere Giegenden getrieben merben unb bort aujthauend fid ilyeer Eteinbürbe entlebigen. Dieje Felz=

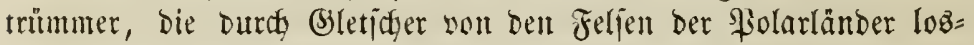

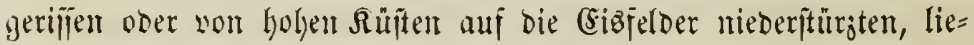
gen jeşt zeriłteut, jern, auj bem Boben bez Meerez ober an ben Riliften, an benen bie (sisberge ftrandeten, unb erzählen bem $\mathfrak{B}_{e}=$

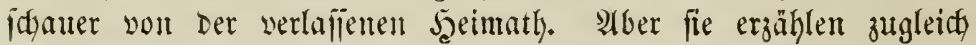

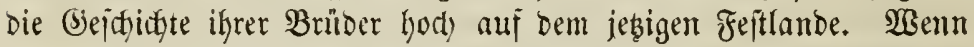
wir in Morbamerifa in weitem Bogen (Befteintrümmern begegnen, Die bem Boden fremb ifre Miutterfelien im holen Morben finten

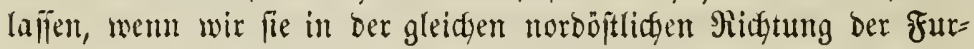

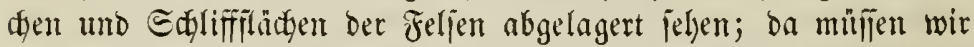
wieber an jenez Mleer Denten, das einft bie Ebenen Ranabas be= Deffe, uno an befien ufern wie heute Esizberge jtranbeten und ifre Enjen verjentten. Benn wir den Yiorden unjerez Baterlandes mit Trümmern von (S)raniten und Ralfitteiten bejüet finden, beren ganze

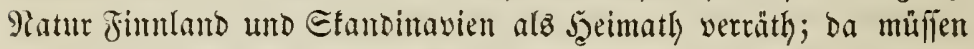
wir mieder auj ein äfrnliches Mleer im 9iorben des einítigen Europa

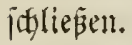

Bizweilen jeten wir endlidy in ben Treibeismajijen thierijahe Rörper eingejtlojien, bie anz uralter Borzeit jtanmen. Pallaz

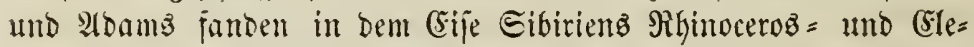

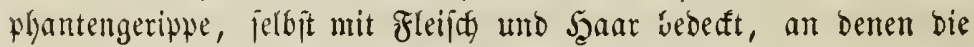
Eişăren und bie Şumbe ber Tungujen nagten, uno im September $18+6$ fand Mribbendorf einen joldhen bis auf ben 2 tugapfel wohk $=$ erhaltenert Elephauten Der Borzeit, ber jeģt im Mujeum von $\mathfrak{M o z}=$ fau aufbemahrt wird. Alber noch heute hüult bie Matur in gleicher

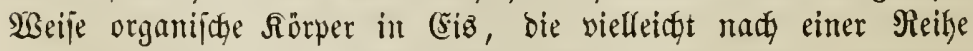

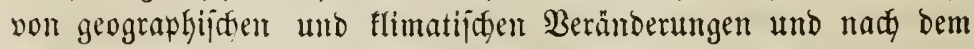
Erlöidjen Der begrabenten Sejejgledter in ferner Beit bem Beobadster

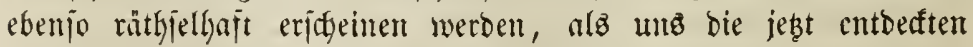

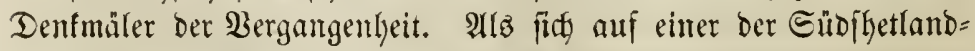

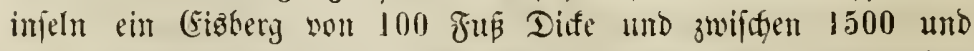
3000 Ju⿰ sünge von einer 800 fru⿰ hohen (Sisflippe ablöjte, zeigte 


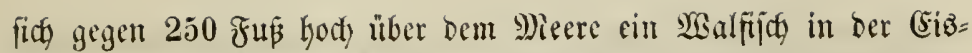

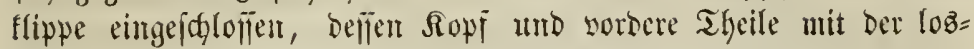
getöjten Miafie herabgefallen maren. H(und) anderwärto bat man

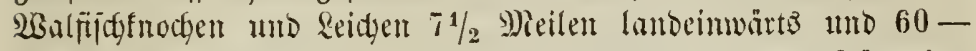

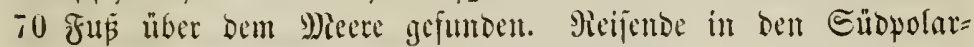

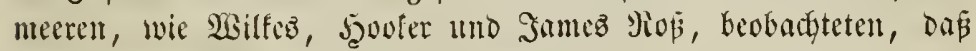

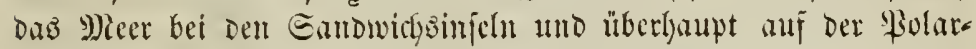
feite jeber antarftijaen Snjel oft gegen 100 Mneilen weit gefriert. Die (Eisjdjidyt ift ungebrodyen, hängt aber mit bem sanbe nidjt zu=

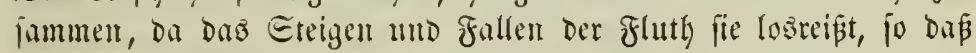

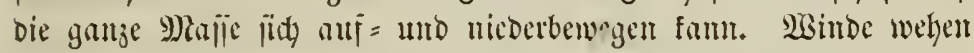

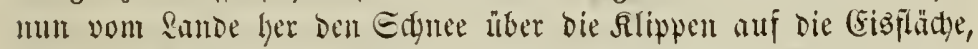

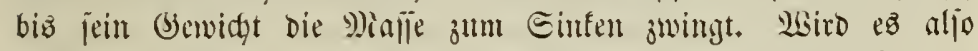

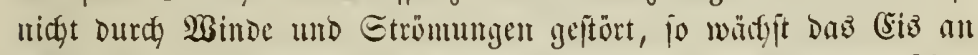
Diffe, bis es den Bober erreidyt. (Senvolynlidy aber fommt es iffon

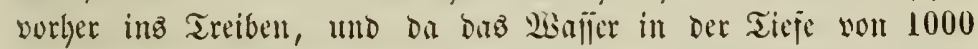

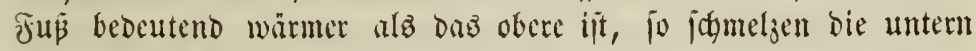

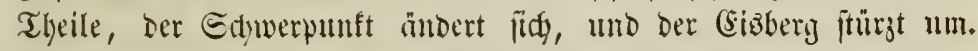

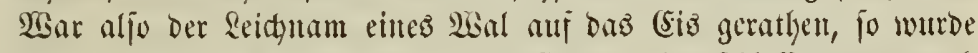

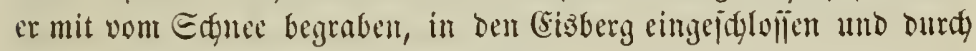
jein Umitinzen wieder jo hodh gergobent.

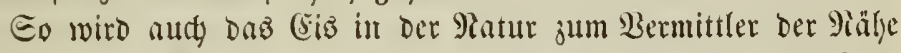

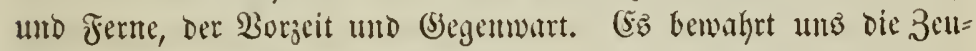

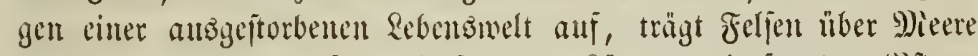
hinweg, ja bevöltert jogar Snjeln unt Einder mit fremben sijlan=

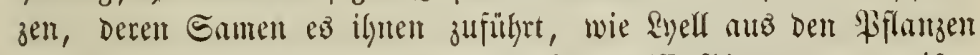

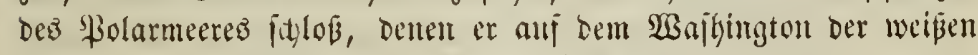
Berge uno bei Miontrenl in Sinnda begegnete.

Wenten wir uns jekzt von bent Cisjeldent ber Folarregionen

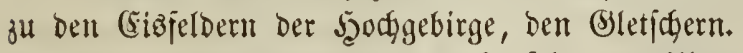

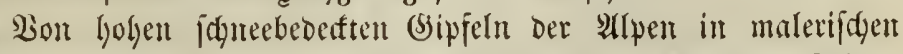
Forment umgeben, ergiepent fie fich aus weiten, von förnigem Edynee erjüllten Beffen burdy bie langgezoyemen Thäler ober your ben $\mathfrak{A b}=$

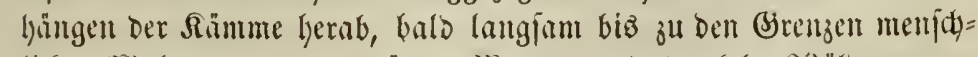

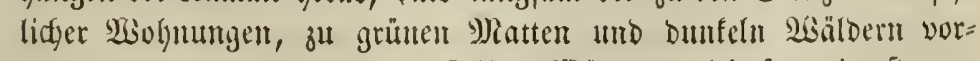

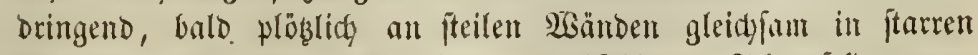

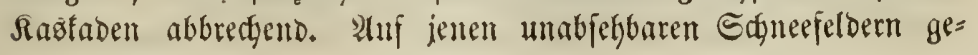


mahyt ber Wamberer nidfts you Der (Bropartigfeit unb malerijden

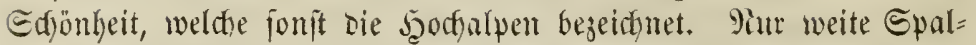
ten unterbreden mit ifrem wumberwollen Bau bieje Ginförmigfeit, riefigen Trummern gleidy, mit azurnen Bewölken, die ify milbeg Ridgt nod) aub oer Tiefe fenden, wemn Dem Simmels̈gemölbe ber eigentfümliche dunfle Blanj Diefer şöhen fehlt. Sft verhulllt mus eime fawnatge Decte lofen Extyees die flaffende Tiefe, weldye der

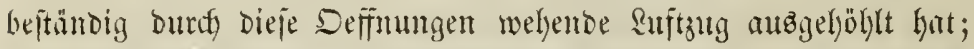
oft lyat Der Eturm den Edynee an Die Mänder ber Epalten gewelyt und fie brüfentrtig gejdlofien. Die Neifenten pflegen fid baher Durdy Etriffe mit eimander ju verbinden, Damit, went ber (Sine in eime verborgene Epalte einbridt, es ben STlnoern möglidy wirb, ihn mieder herausuziegen. Dieje meiten Eduneefelder find bie

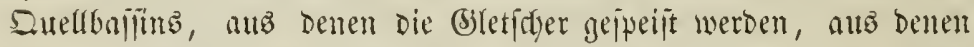

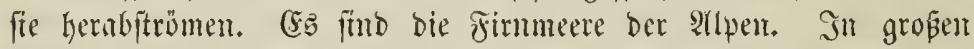

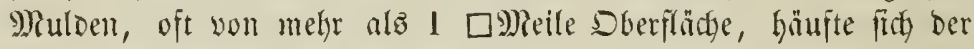
Edynce von vielen wintern an, mo erreidyte eine Diffe, bie felbit

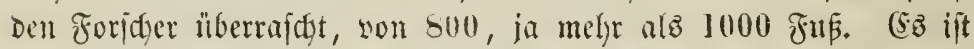
nidyt mehr Der mehlige, troufue Edynee mit feiner büntuen, hart= gefrornen Terfe, wie er pieb bet uns an jelyr falten, aber fomigen Mintertagen jeigt, und wie er unter Dem Mament des Sjönterfonnees bie böchiten Pllpengipfel bedeaft und, von furdterren Drfanen bis

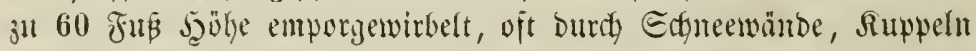

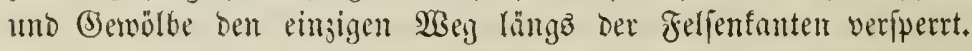

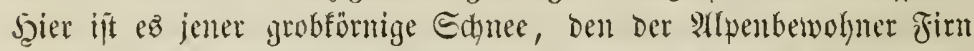

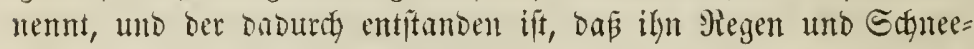
wajfer ourdafeutbteten, und fith bei folgentem Frofte um bie cimzeluten Mabeln und Florfen nette Echidyten anlegten, wie es auth oft in Den Ebenten geidfelyt, wenn ber Estnee lamge liegen bleibt.

alle biefe Edneemajlen find oft bis in bie Tiefen von $200-$

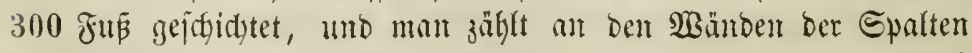
oft 20-30 bentidy getremte Ectidyten foldyen Firns, bie nads unten an Diffe abnebmen. Die oberen Edhidgten emtiprecten Den

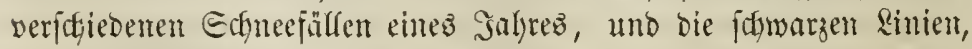
rüfren yon bem Staube her, weldyer bie Edhidten bebedte. Siad) unten verwijgen fich bieje feinewen 3miffenlinien, uno wir feljen mur nod die gröberen Mafien, weltge wälyrend bes Eommers fid 
auf Der Firnflädye anhäuften, bie jäbrfidyen Firmma fïen trennen. Unter bem Drufe ber barnuj laftenden Majien werben bieje unte= ren Sdyidfen mehr und mehr zujammengepreft, bas Edymelzwafier oringt in iłre 3wijđgenräume hinab, und fie bilden alfmälig, wie in einem Edureballe, cine juammentängende Majle. In ber

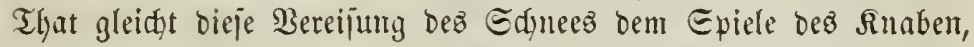
Der mit jeiner Şand ben vom $\mathfrak{B a j p e r}$ burdfrinftent Edynee in einen iteinfarten, eifigen Slumpen werwandelt. Die jejten Gepteine deş

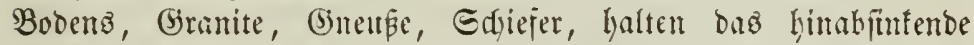

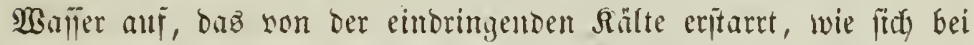
uns nady einem Echneejall in kalten Siädyten auf Etemen und

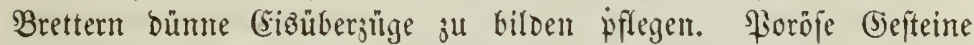

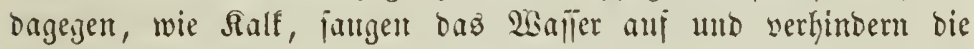
(S)letidarbilloung.

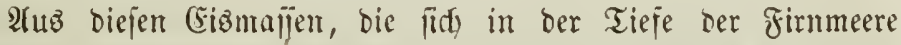
anjammeln, wadfjen bie Gletjher lyervor. Shr (Siz gleidyt freilidy nicht ben fpiegelglatten Winterbüllen umjerer flülie mmb Eeen;

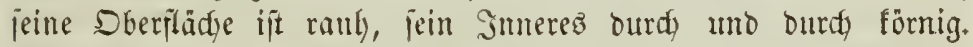
Dieje Biloung gleidyt einer Crifteinung, bie wir oft beobaditen tön=

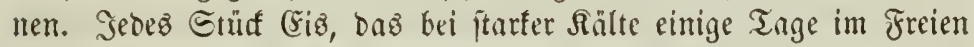
gelegen hat, zcigt fith balo, wemn es anfangz aud nod, fo glatt

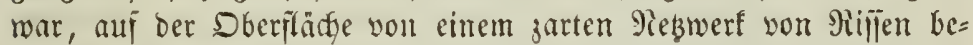
Decft. Die Mrjadbe biejer Miife ift bie ftarfe 3ujammenziefyung in

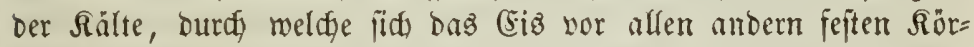
pern auṡzeidynet. Da bie Rälte in bie Tieje jebr langfam ein= bringt, und bas (siz fid) hier alfo meniger zujammenjieht, fo muß eż auj ber Dberflüche jerreifen, wie ber jendte ?elymboden, wenn

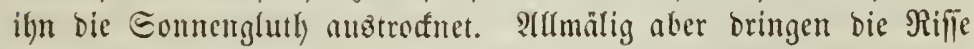
weiter in bas Sntere vor uno zerfällen, mit zahlreidyen \&uftblajen verbunden, bie ganze Majie in eimjelne fornige (5ruppen. Die frenge Sälte ber oberen Jiegionen erjeugt ein jeinerez Epaltennebs,

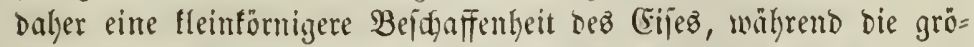

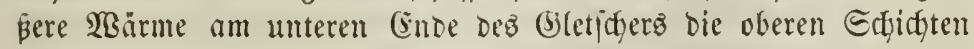
abjomilzt unb bie unteren grobförnigen bloslegt. Mur bie unterften

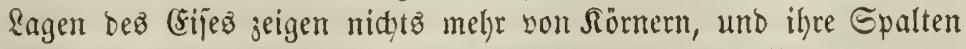
ruhgen mur von ber lluebenlycit bes Bodenz und ber Berwegung ber (sletidger her.

Ille, Beltall. 3. 2lufl. 
An Der Färbung Des GHIetidgerifes laben die \&ujtblajen einen

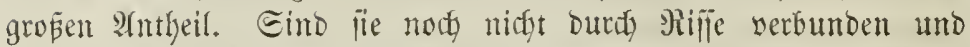

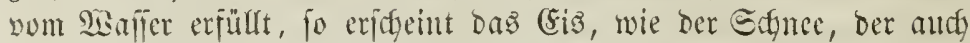

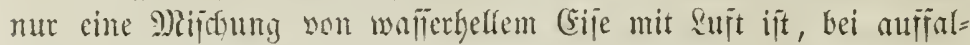
lendem \&idgte weif. Sit aber Das Edymelzwajler in bie Epalten uno Brästhen cingebrungen, jo wirb feine Farbe Durdfiffitig blau.

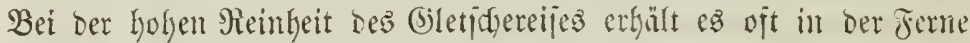

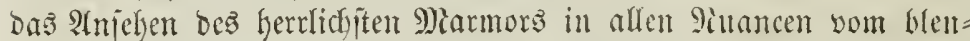
Denden $\mathfrak{W}$ eif zum ounfeln Blau ober Mleergrün. Dann gleidgen

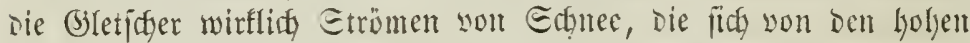
Bergfuppen in bie Thäler jtintzent.

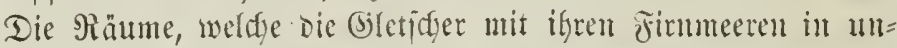
jern Sodyalpen eimefymen, find nidft unbedentent. Sn ben Edowei= zer Alpen som Shontblanc bis zur (Sirenje Tyrols zanglt mant ilyer

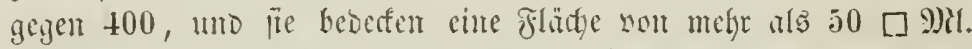

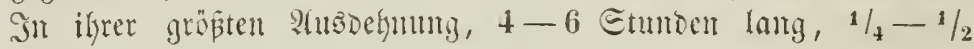
Etunde freit und zwifden 100 und fv0 Jns mädtig, finden fie ficts

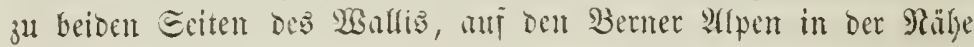

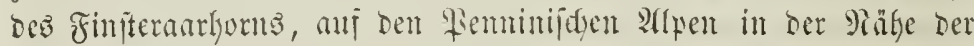
Dent-blanche. Eie umgeben im Weiten oen Miontblane, Mlonte Roja, die Grandes Ruusses und ben 9)iont Fiefrour, im Diten den Adula und Bernina. Sn Tyrol begennen wir Den Biletidyern Des Srtles und ber Degtfaler Giruppe, Den Etubbeier mo Plljeiner

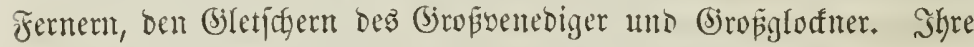
gröpte Entwidtung erreidyen aber bie Siletidyer in ben Folargegen= oen, bejonters im nördicten Morwegen, au Sslano, Brönlano

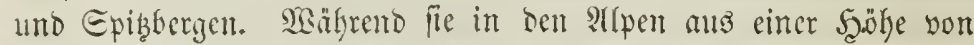
10000 Jup jelten in gröpere Ticjen, nIs 5-6000 Jup üher bem Meere Ginab gelgen, Dringen fie Dort ats Den Thälerm bis zum Meere, oft meilenweit hiber bie Riliten vor. Dit erreidjen fie eine sänge von 10 und eine Breite won 3 Mieilen unb bilden an ifren

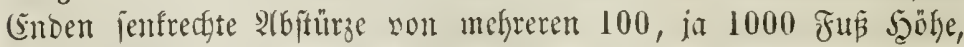
bie, vom Weffenidglage unterbohlt, oft in gemaltigen 9)affen abbre=

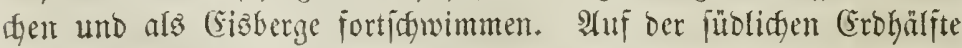

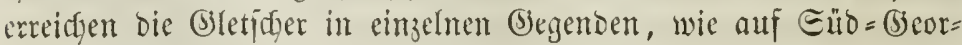

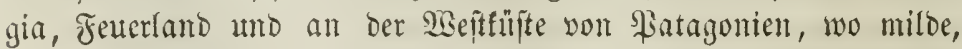
aber fendute sisinter, verbunden mit falten Eommern, ifre (Sntwiff= 
Iung bejonbers begủnitigen, bas Meer felbfit in Breiten, weldye ber Des jüblidjen (suglanbz, ja jogar unjer Alpen entprectent.

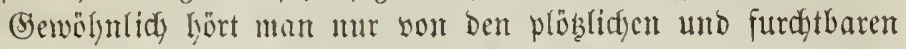
3erftörungen, weldye bic Edincemafien ber estpen antidten, wenn

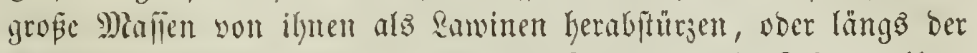

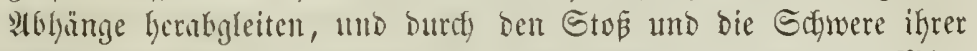

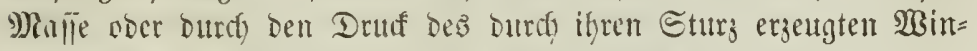
Des Bäume entwurzelt ooer zerfnift, ältere Edyutthaloen weggerif=

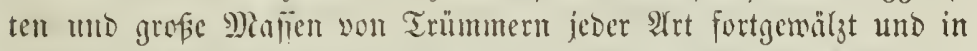
Der Tieje zu Edjuttegeln angegäujt werden. Bon ben Beritörun=

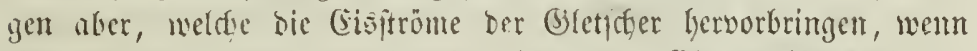
Tie aus on Syodgebirgen in bie Thäler mo Eebenen binaboringen, sernimut man wenty ooce nidits, weil fie fangiom uno unvernerft geidelyen; und Dodh fint fie niel gemattiger und Dauernber, weil fie Jalye für Jollyr jetig madjen.

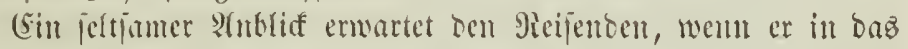

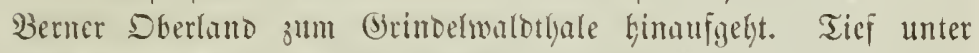

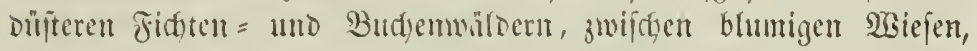

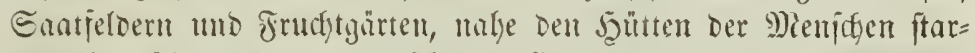
ren ifym idsunerlidye, unjerftärbare (Eiżyebiloe entgegen. Bie fam

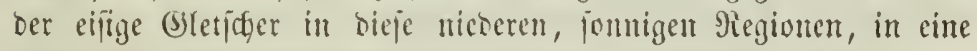

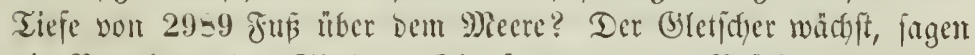
die Bewolyner des Thales. Gie fagen idern zeritärt wurben, wie zusijden Eitten uno Bex, wo Brubent= baute verbeft watrben, wie an Byoloberg in Tyrol, wo Bauernyäfe uno Birfenwäloer von ilynen serorängt ober fortgefdoben werben, wie in Morwegen. H(ber ber Biletjajer wädjit nidjt, er fleept viel= melyr wie cin હtrom.

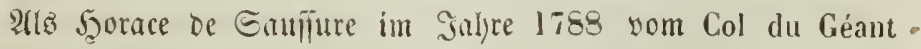

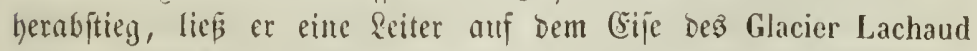
liegen. It Jafje fpaiter fand fie ber Miaturforjajer Forbes mieber auf, aber 12000 ซuß son iffem frütheren Etandorte entfernt. In

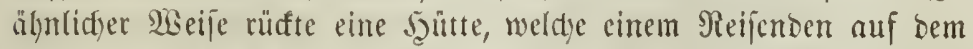
Anargleticter zum \$arfentlyalte gebient hatte, binnen 12 Jahren un

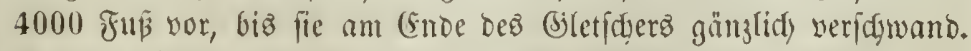
Soldje Eridteinungen brängtent ben Paturforidjern bie Heberzengumg

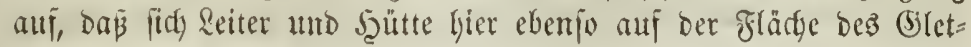




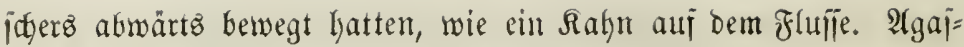

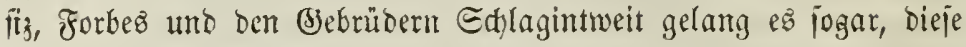

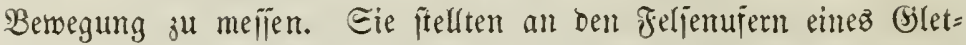

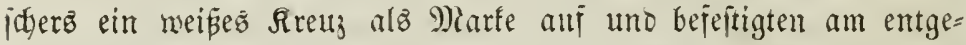
gengeję̧ten Mfer ein Ferntohr, Das̊ genau auf bie Marfe gerifftet war. In geraber Sinie zwiliden beiben wurbe in Der Mitte des

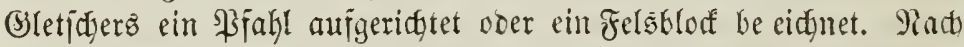

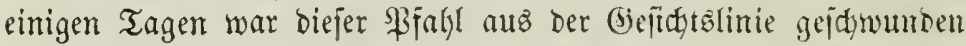
und nad) abwärtz entwidjen. (Fist neuer weiter aufwartz erridute=

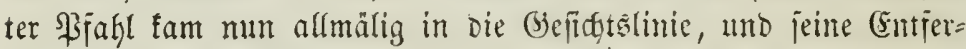

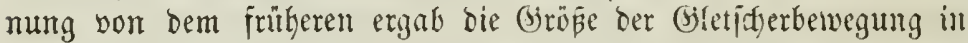

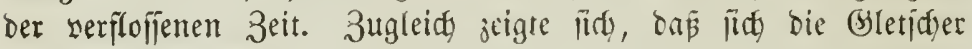
nifgt mur in Der Mitte ilyere Breite idjneller berwegen als an ben Ceitenränbern, gantz mie zläile, deren Bewegung burdy den Rei=

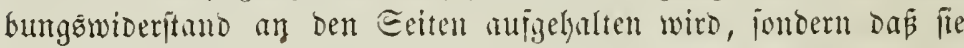

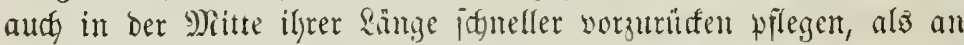

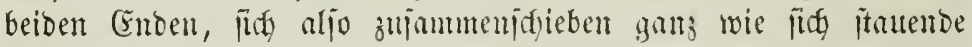

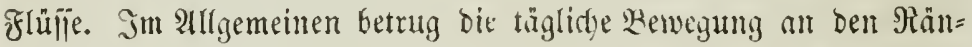

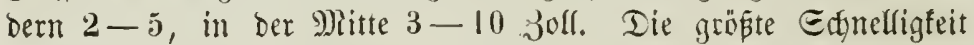
beobachtete Frorbez am Glacier des Bois; ile betritg 22 3oll täglidy, währento der $\mathfrak{A}$ argleticter faum einen 3oll täglidy sornisft.

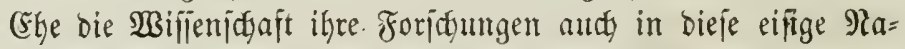
tur verjenft hatte, fonnte man woll an eine linwandelbarfeit ber

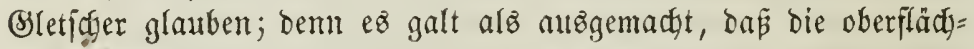

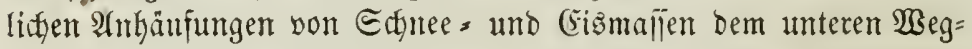

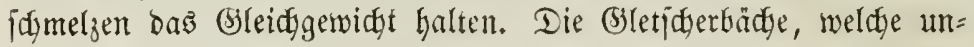
ter iffnen Gerworraujdten, galten als Beweiz; Denn man beacteté

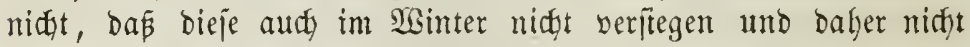
immer bem Edymelzmafier, fondern oft Sueflen ifren Wriprung ber=

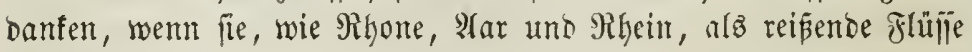
Gerwortreten.

Sn Der erften Zeit, als bie Bemegung der Bjletider befantt murbe, jucte man ifre Uriacte in einem Şerabgleiten bes (Sijeß auf ber geneigten Thalfialăche unter Mitmirfung des Drưfes ber

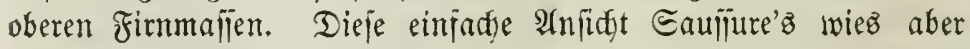

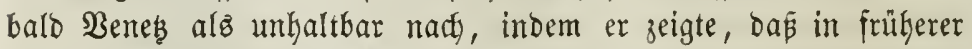

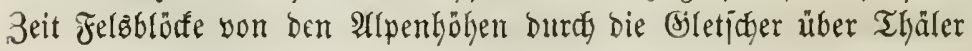




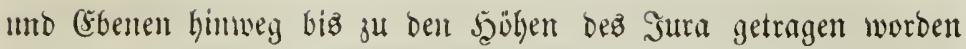

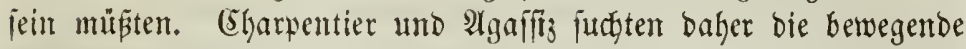

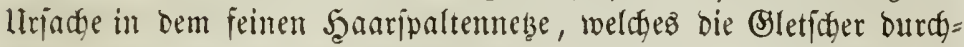

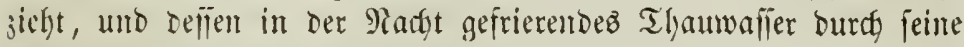

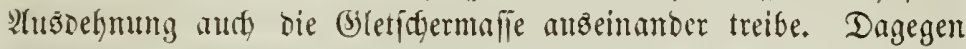

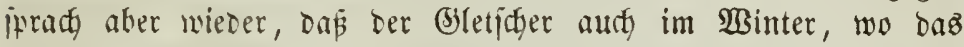

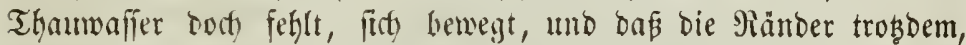

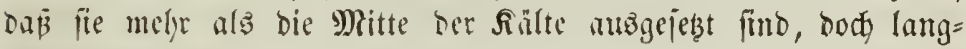
famer fortrindert.

Die nentere Foríd)ung läft bie Gletifderberwegung als ein wirf=

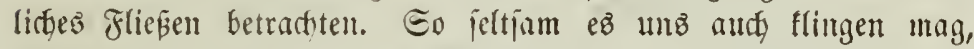

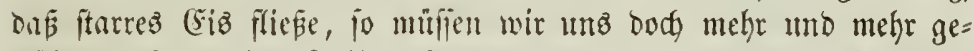
möhnen, joldye idgarfe Lnterichcioungen in ber Shatur aufugeben.

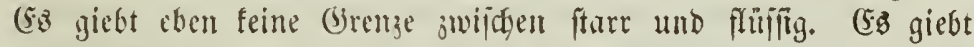

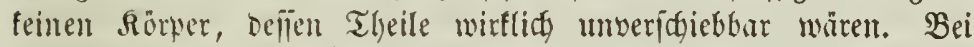
aller Eprobigfeit erleiben body bie Theile Des Eiję burdh Drưf

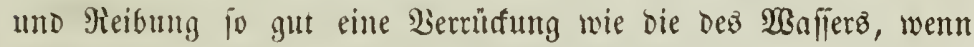
and eine langlamere unt unbebeutentere. SBent wir bie Bleticher= mafie alle Unebenfeiten bes Thalc8, alle Erweiterungen unt $\mathfrak{B} e r=$

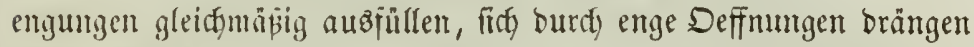
jehen, whne ju zeripalten, ba fömten wir eben mar von einem grles= Benl iprecten.

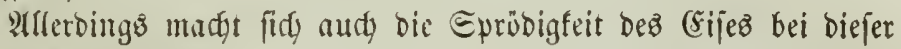
Fortberwegung gettend. Die ungleitye Epanuntmg ber Theile burch

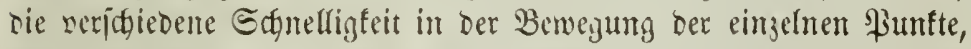
wie burd Den 3ug ber Edywere an ftirfer genteigten Etelfen, bewirft Rifíe und Epalten in Dem Gije. Dft jerflüften biefe ben Bletidger 10, Das fie ihn gonn unzugänglidy machen und ign felbjt in zahl=

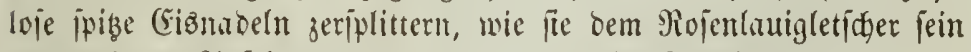

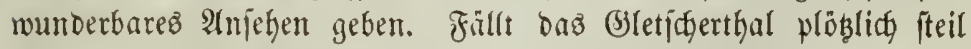

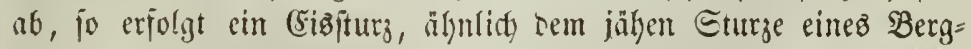

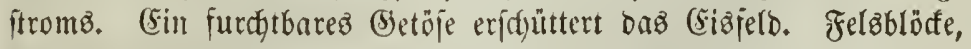
Die es bebeften, bewegen lidh und rollen ber Tiefe zu. Epalten

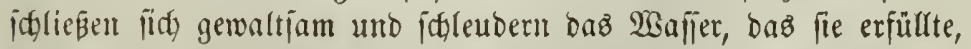
hoch in bie Rujt. Unrgeheure (siżmajen löjen fich fractent von ben weren Theilen ab uno ftür $r_{j}$ en praffeltno in gewaltigen Eprüngen in bie Tiefe. Dommerno offinen fing neue Epalten und Rlüfte, 


\section{8}

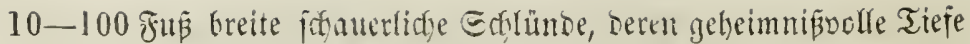

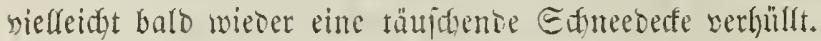

Die Epalten Des Siletifyers zeigen oft eine auberorbentlidse Regelmä́figfeit. Rängenpalten entitefyen, wenn Durdy ein Breiter=

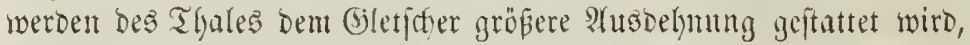

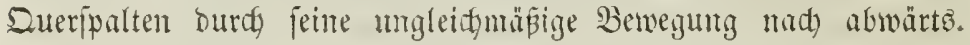

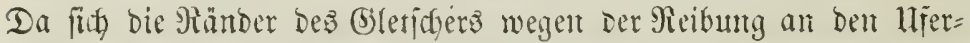
twänoen langlamer fortbenegen als bie Mitte, fo entiftehen an ifnent fortwährend Exaltent, bie fith im Borrilden orehen, bis fie jentredyt gegen bie Hjer fteben, aber aflmälig jich audy werengen unb enolidy

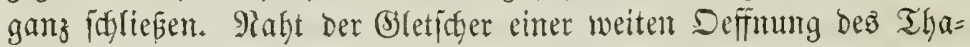
lez, jo zerreip̈t er in Dem Errebent, jie nady allen Seiten hin zu erfüllen, făcherartig in zablloje Epalten.

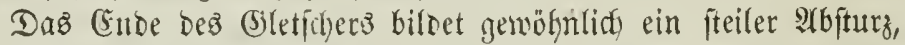
oft you $300-400$ ₹up Şöhe. Şier bridft aus einer Deffnung

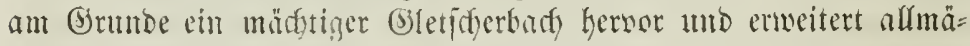
lig bie enge Sgofle zum pradtnoflen Gletiderthore, wie bie beifte=

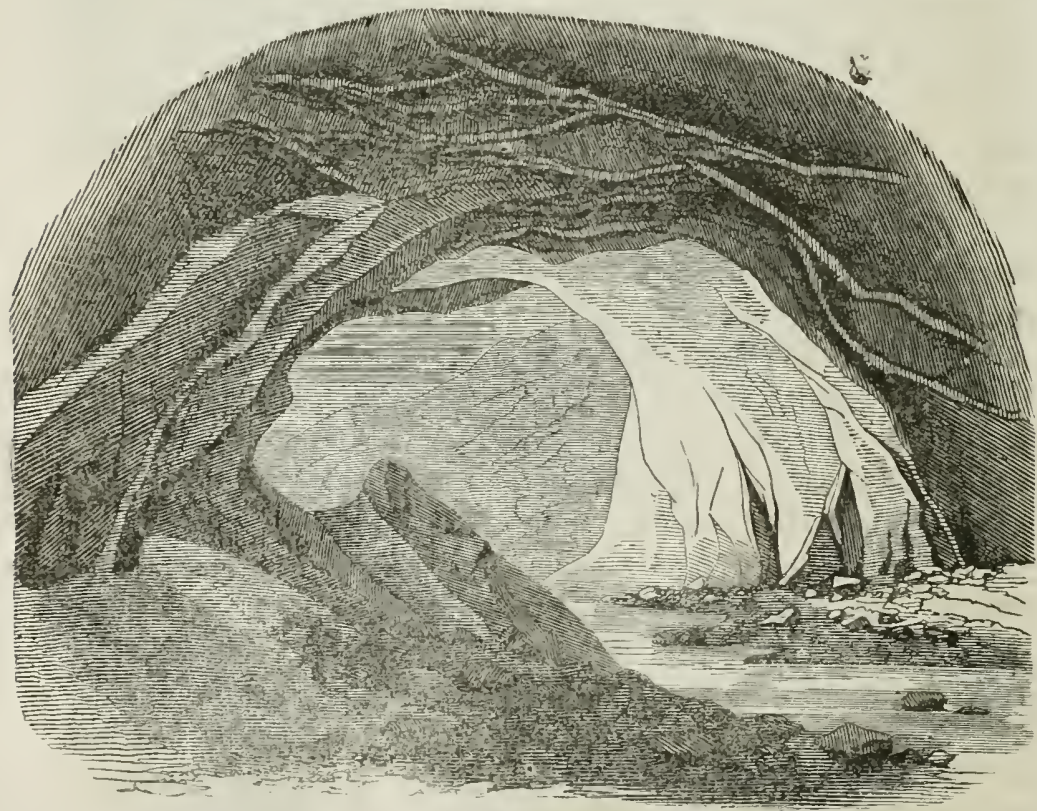

Eir Biletịţerthur. 


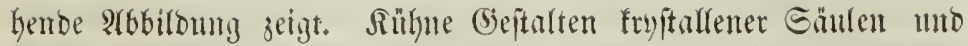
Sabeln, gewaltige Gigigrotten, feltfame Stalaftiten unb raufbende Rastaden wollenden bas Girnartige biefer wunderbaren Eisftrome

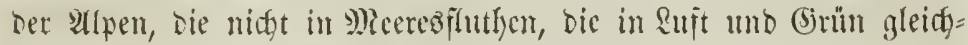
jam veridgummentio enten.

Wenn aber bie Sletjoter ber Alpenwelt ftarem Gtrömen glei= wen, fo bietet fith uns im Morben ber Polarwelt nod ein groparti=

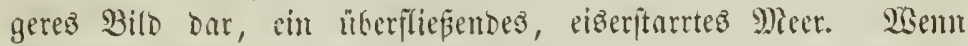
man liber ben gletpherrcityen Irlpenfanm hinats, welder nath in= nen abjallend bie gange Rïjte Brönlands umgiebt, burds einen jener jublreichen Fiorde, die oft $10-20$ Meilen tief in bas jeer;

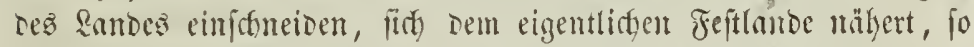

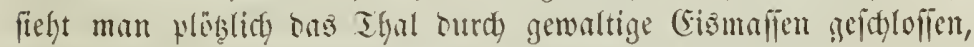
Die weiter im Şintergrumbe immer löber anfteigen und in eine eint=

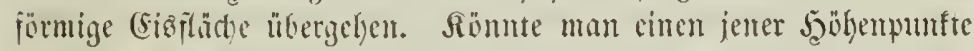
eriteigen, oie gleidy Smeln hicr und on über bic öbe Gisebene em= furragen, fo whinbe man biefe in endofer ferme ofme bie geringite Interbredung mit bem Serizonte werjomeljen feljen. Dieje gewal= tige (Eismafie, beren fteile şänte jiber das That uns bie umlie=

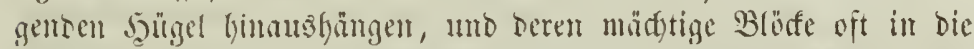

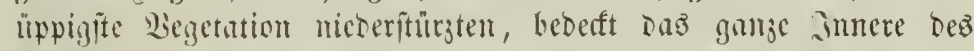

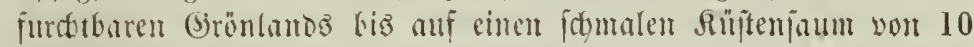

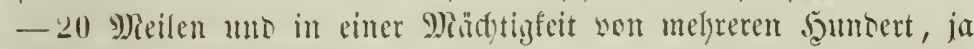
oft ein puar Taujend Fup. Eie hat alte jëken und Tiefen bes

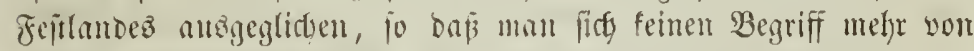
jeiner urprünglidgen form matben fam, uns mur Der Bliff auj

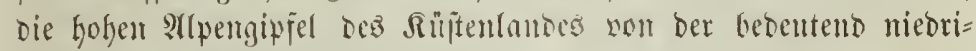
geren Rage biejes Smmerem ïbergengt.

Dieje (sisbildung ift mun feinesinegs eine eigentlid)e berglet= fayerung Des ganzen Feftlanoes uno bat nidgts zu thum mit jenen bis zum Miecre nieberifteigenton (Bletigern, wie man fie auf Epib=

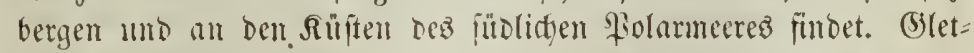
joce hibergieben gleidjam nur wie eine Sdyale bie Oberfläde ber Gebirige, und die llradye ifrer Bewegung ift eine ju Tane liegende, begrünet in Der form- uno Neigung bes Bobens, anf bem fie un= ter Der 2Birfung ber Edywere niedergleiten, fier mb ba in tricter= färmigen Thälent fitty anläufend unt von bort in bie wärmen 


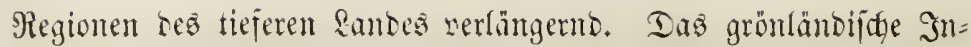

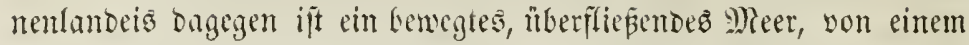

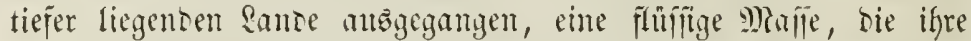

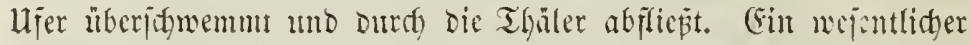
Antheil an ber Benegung biejes (Eijez idjeint ben zablreidjen, gros fent und fleinen Epalten und Rlüften juzutommen, weldye die weip=

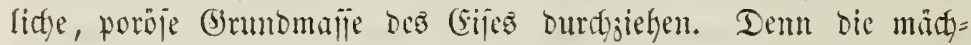
tigen (Singe laphirblanen, Durdjinttigen (sijes, welde begleitet von Riez= und Eteinjfididen ftetz in biejen Epalten auftreten, Deuten

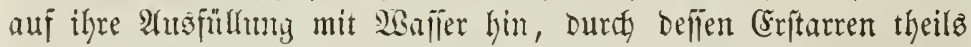

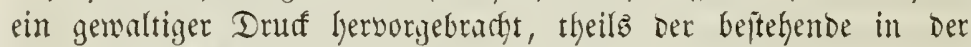

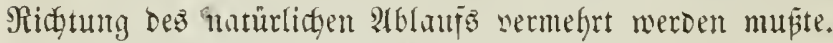

Sbwohl überall sorbanden, concentriet fith Dodh bie ganje be=

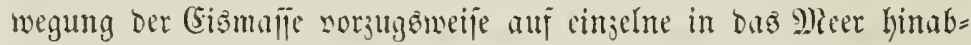

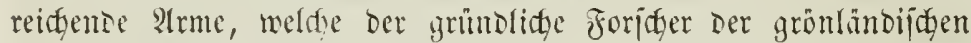

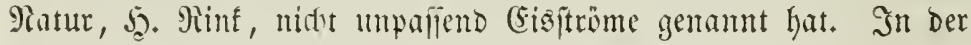

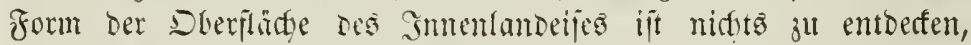

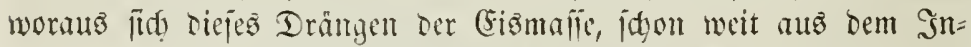

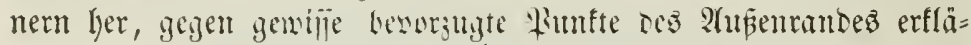

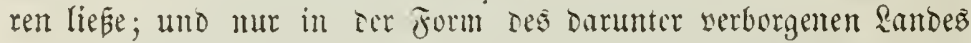

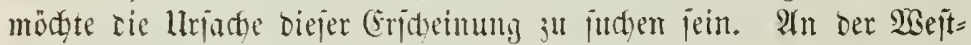

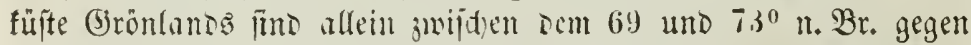

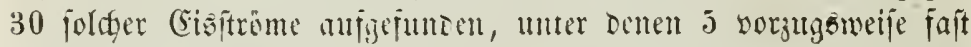

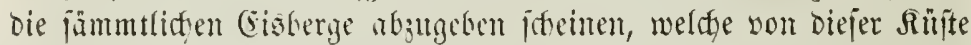

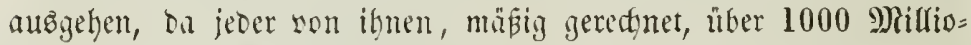

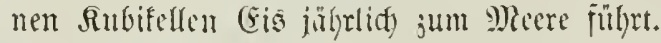

Denn bie Lisirfung einer jtrömenten Bewegung bicjer ftarren (Eis̄ma fien i it

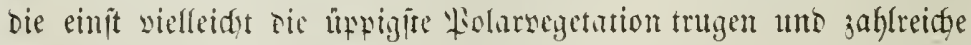

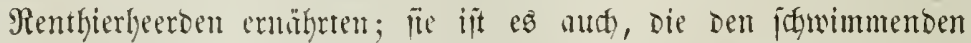

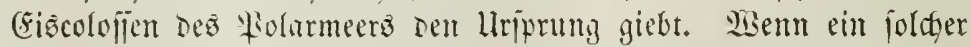

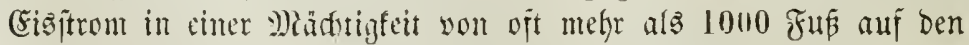

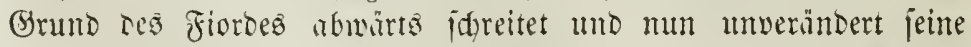

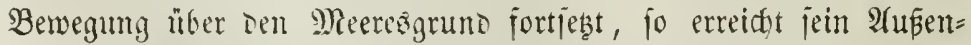
rano endlich eine Ticje, in weldfer das

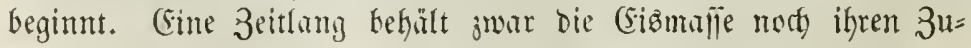
jammentang und rilft som Mleere getragen sor, bis irgend ein 
3ujall biejen 3ujanmentang aufbebt. (Ein furdtbarer Donner

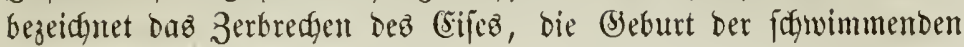

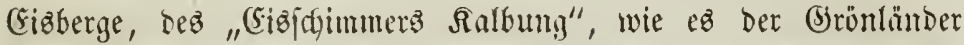

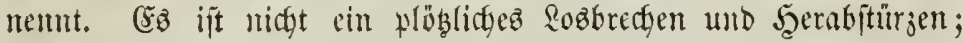

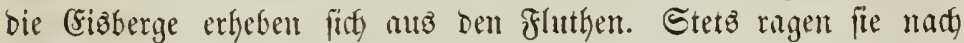

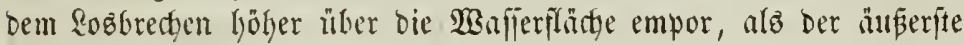
Rand dez Ranteijez, bun dem fie lyerrillyren, und der burct den

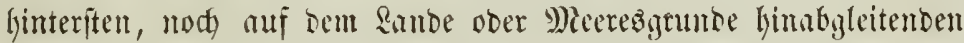
Theile nieberigeorilut ju weroen icteint. Bis in Den Eommer lyin=

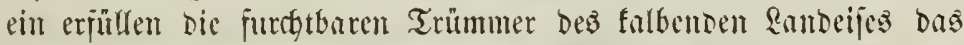

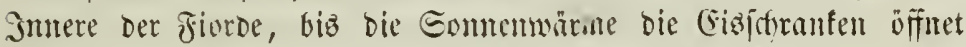

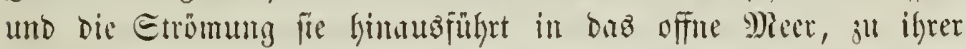
Bamberumy mady Euben.

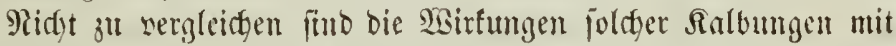

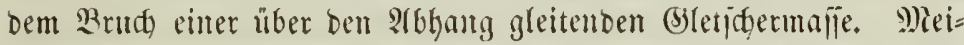
lemveit wiro Durch bie Bewegung Des Meeres allez (Eiz gefnift, und bie Gercitz in Fiorbe angefammelten (Sizherge begimen neue Ratbungen. Die feiften Gizwände erbeben, zeriplittern unter gewals

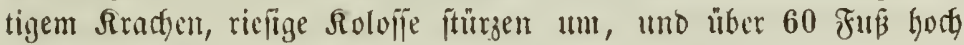
thürmen pid die Trümmer und Edgoflen übereinnmber.

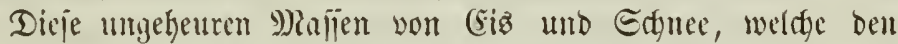
(sisbergen uno (Sisitrömen iften Uriprung geben, und unter weldyen

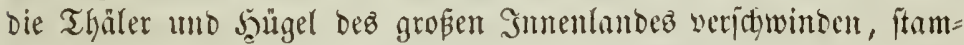

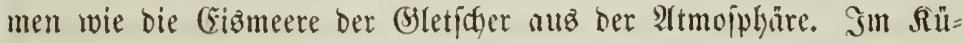

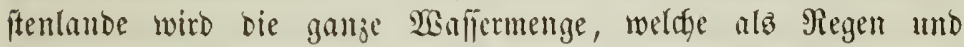
Edynee jährlidg nieberfällt, im fließ̈enden Zujtande wieber finmeg=

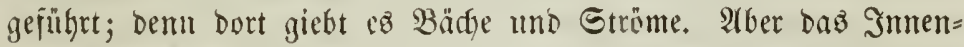
lanto femt feine Etronme; bie Thäller, in Denen fie einft vielleidyt

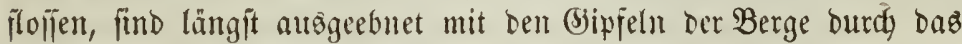

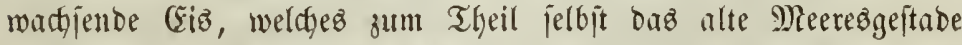
verbirgt. Der $\mathfrak{2}$ (nblif Der (Eisitröme und bie gewaltige Menge dez

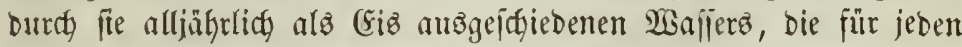

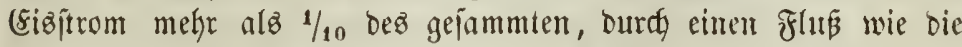

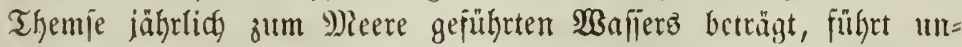

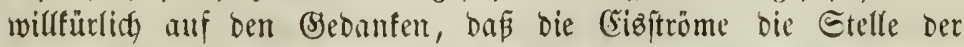

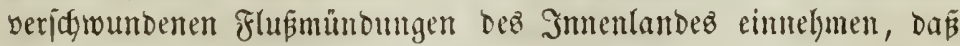
fie in ber That Gjer fino uno leiften, was jonft ben glüffen zufommt, 
Dá fie Der meiteren Heberithwemmung hes Rantes eine Brenze jesten.

Eo baten wir im Gohen Porben Grönlando eine Gefitaltung

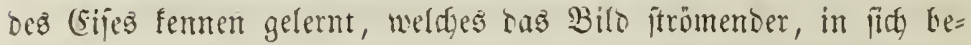
weglider Majlen nollemtet. Der non ben Af(pentgähen hermieber=

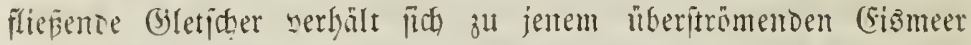

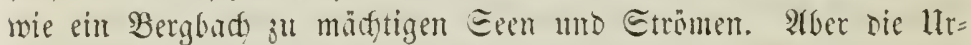
fadje riejer Bonegung ift burdh jente grofartige Eriddeimung nur um to tiberjengenter Dargethan.

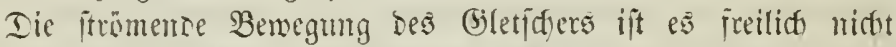

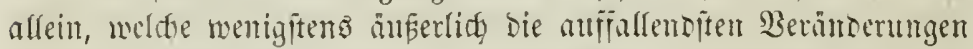

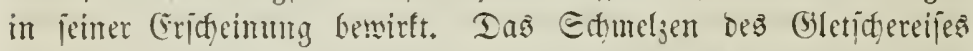

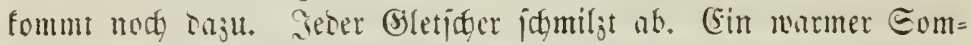

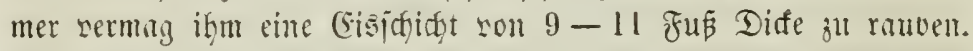
Samm aljo sie matrulfende Gletijermalle biejen Berlujt midt er=

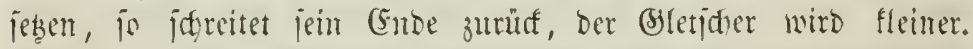

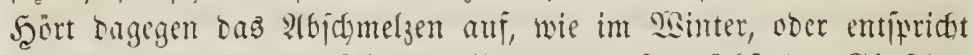

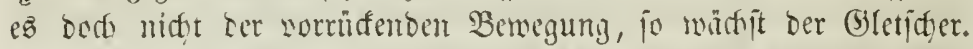

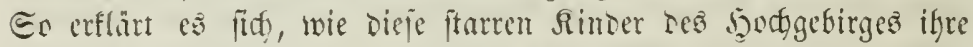

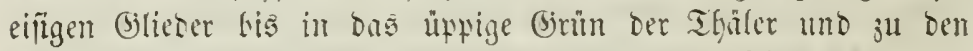

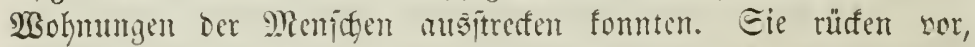

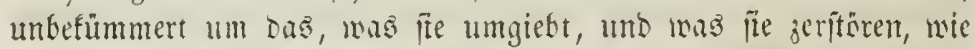

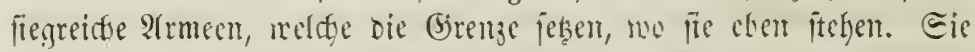

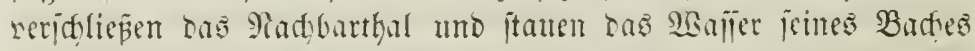

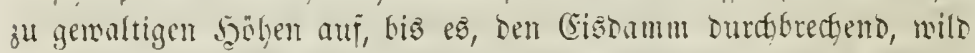

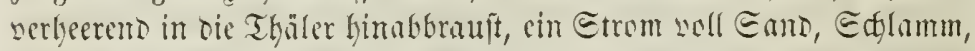

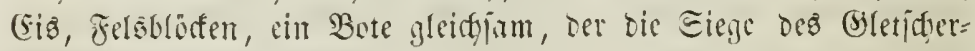
riejen ber zerne sorfüntet.

Einen eigenthümlidyen (Sinflú anf Das Ectyelzen Dez Glet=

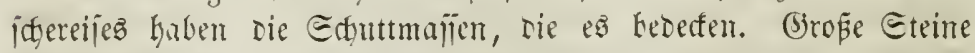

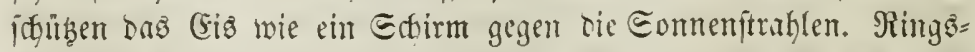

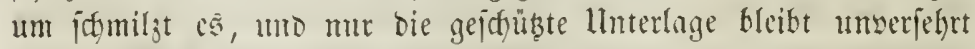
wie ein Fiedejtal ftefyen, Das bie Eteinplatte trïgt. Bjetichertifde nennt man in Den Alpen rieje Erifteimurgen. Piegen und Eon= nemidein zernagen endlid biejen Etiel, er lvidft jujammen, und

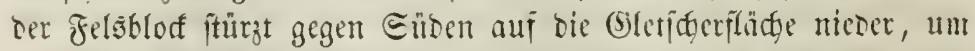

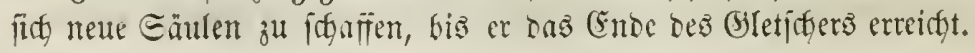




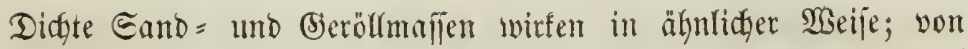
ifnen geidübt bildet fidy unter ihnen ein (Sizhügel, biz er zu fteil wird, sie lofen Trunmmer zu tragen. Sie ftürzen baun auf bas Eiv nicber und zerftrenten fidy auf jeiner Flädye. Sebzt aber wirfen fie entgegengejetzt. Die fleinen Eteinden, Eandföndfen, Etaub= theilden, Blätter und Snfeftenlcifyen werden ftärfer yon bet Eonme

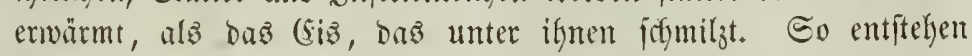
Röder, in bie fie simfinfen, biz fie burd) Das Gis ben Sonnen=

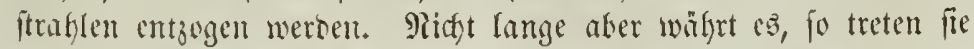

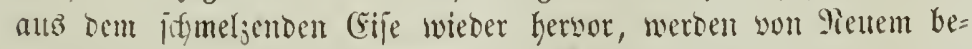
ftrahlt und futen you 9enem ein, biz fic in wedjelmoem Epiele

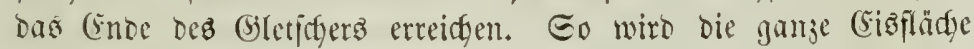
uneben, ourdylöhert, und gröpere Eandmafjen biloen felbjt tiefe,

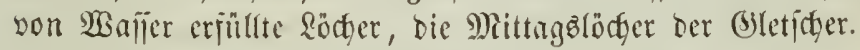

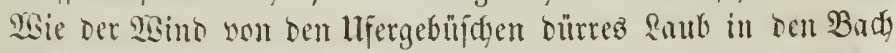

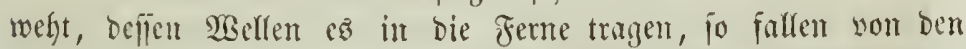

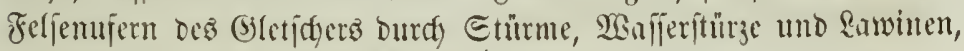
ober surdf jeinen eiynen Anorang gegen bie llfer felsblörfe mo Eteintrümmer auj jeine fläto nieter mo werben auf ille fortge=

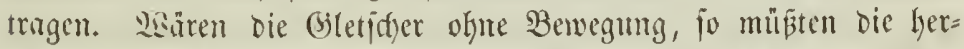
abgefullenen Etcine an Derjellon Etelfe liejen Heiben und Dem Dariberbängenten Sejtein gleidgartig fein; nber man fintet an jei= nem untern (snoe die bejteine feines obern vermijot mit den eben

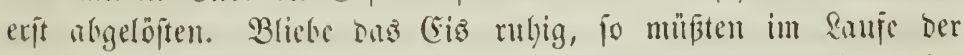

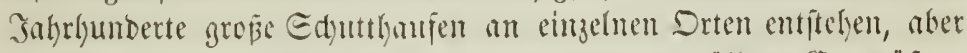
es bilden fid) gleidfïrnig fortlaufende Edutrwälle. Es müsten bieje Etcine mur an Den Siäntern Des̄ Sletidyers liegen, nidjt aber

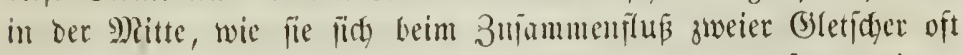
mehrete 100 , ja 1000 Fuß von ben Felomannden entfernt zeigen.

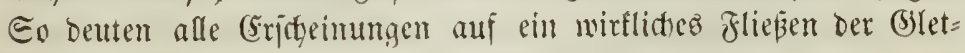
facer bin.

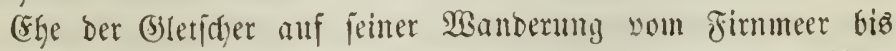
an jein unterez (snbe gelangt, fitürjen zwar einjelne Der mitgefüll)r= ten $\mathfrak{B l o ̈ h}$ bei plöbsliden Eentumgen ober an tief eingeíchnittenen Eeitenthälern wieber herab, aber burch bie größere Mafle ber hin= zufommenden Trümmer wädbft ber Eteimwall immer mädbtiger all. So bilden fid bie Eeitenmorïmen voer Sandefen, wie ber Sdyweizer 


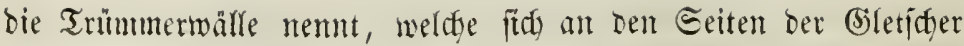

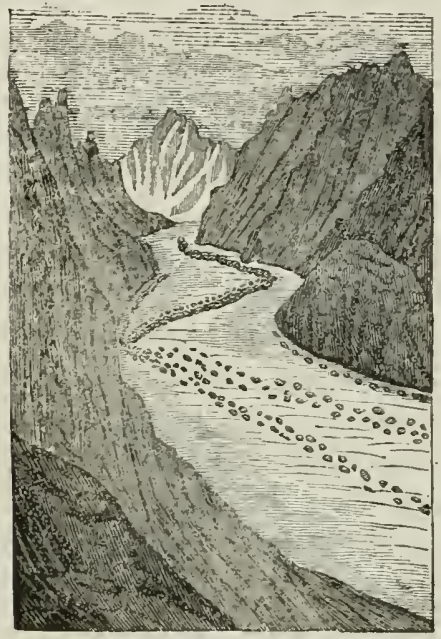

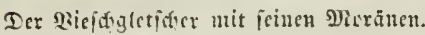
hingielyen. Die beiftehenoe 2 (b) bilbung bes Riejtyletjaters am Ahtyange Dez Finfternarfyorn jeigt fie bem eejer.

Tretell alts Den Eeitenthä= lern neme 3ufintile ju Dem Silet= jofer, jo vereistigen bie neuen (B)leticter aut) ifyre Eteinmialle mit benten bes alten. Sebt flie= fen juei anfeitumber treffente Geitemmorinten in cinanber tmo billsen eimen nenen Mall, der in Der Mitte Des ermeiterten (biletichers fith forthenegt. Co entitelen bie Dlittelmoränen oder binferlinien, beten 3ahl

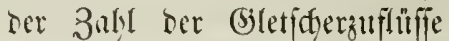

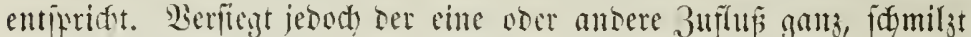
er ab, weil er zu flein war, mährent bic mädbtigere CEismafje tod

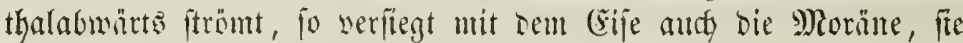
wereinigt ïd wieser mit Der bemadbarten Mlittel = ober Eeitemmo= räne. Die Bilsulty einer Meittelmorinte fielyt ber Pejer in ber ne=

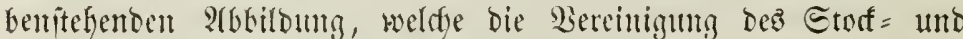
Mnarcelfgletictyers im Dejthale onritellt.

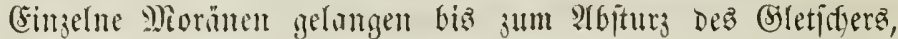
und ifye Edfutt = uno Eteinmafien thürmen fith Dort jum mädti= gen Etirnwalle anf, wie man gemöhnlich die Rand = ober End = morïne bezeichntet. Der (sileticher jelbit milhlt an feincm untern

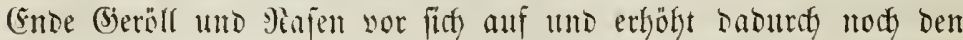

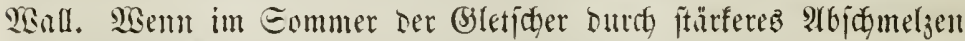

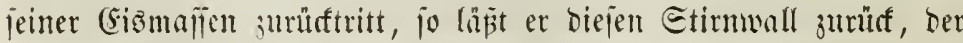

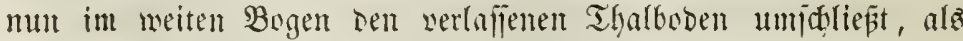

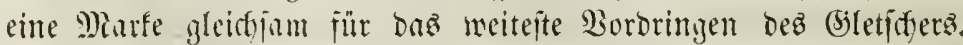
(Sejoticht biez 3urthfweiden alfmälig und gleidfmäpig, fo wiro ber

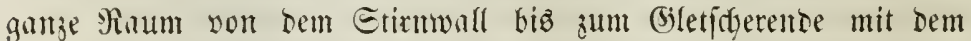

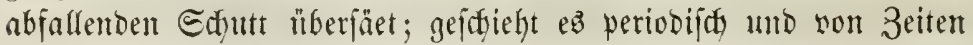




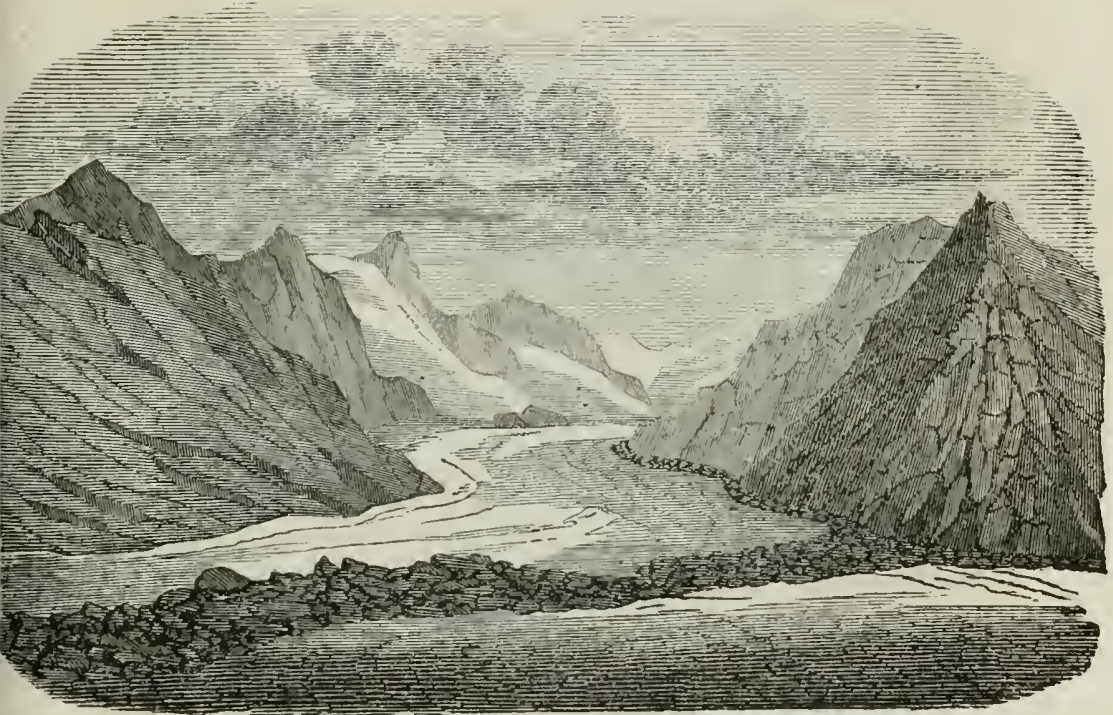

Stof : und Miarcell = STetidier im Sezthate.

Der Singe unterbrodsen, jo bilden jïh mehrere Etimmäle hinter

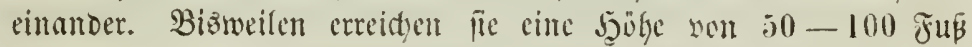

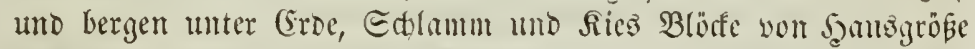

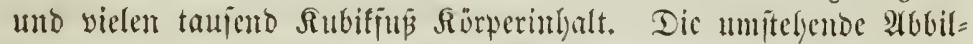

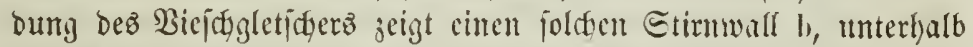

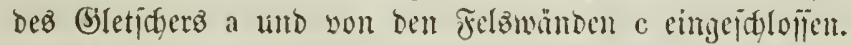

Diejelben Felablöre uno Echuttwälle fint ez aud, Denen wir an

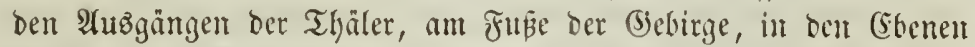
und an ben Abhängen ber umgebenden Berge begegnten, utb bie (idd) in weiten Bogen mehr alz 3000 Juß über bie Şöhen des Sura burdh die Bagejen und ben Edfwarjwalo

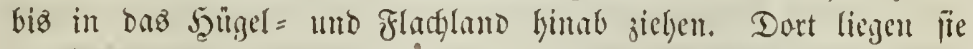

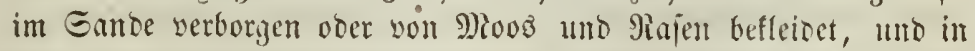
den Erapen der Etïbte und Dörjer, auj Jeldern und Weigen, in

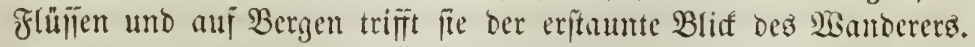

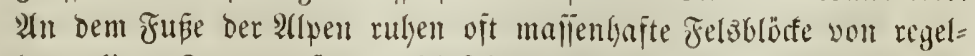
loz erfiger Form auf ben Sipipln fegelfürmiger Fupigeitclle, oder

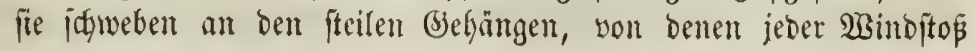




\section{6}

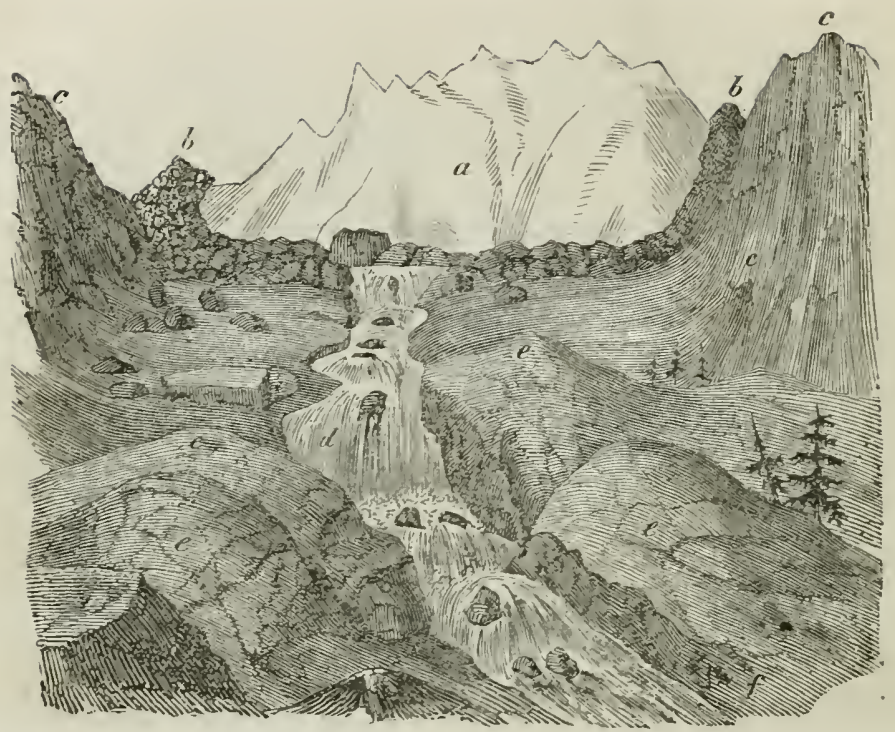

Ier Etirritwall bez Biejdygletianers.

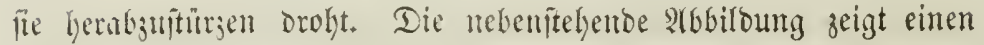

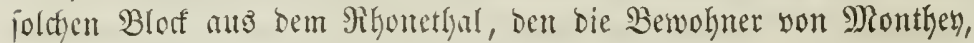
in befien Siäfe er liegt, Pierre à Dzo nemtent.

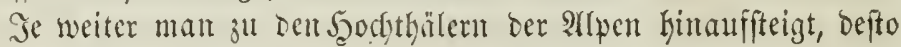

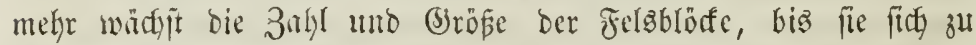

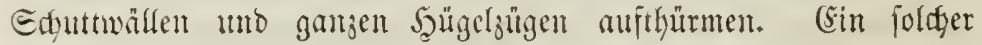

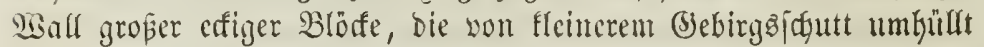

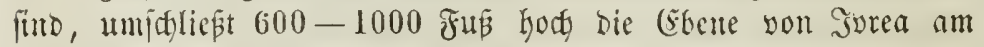

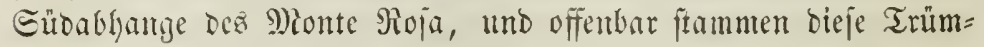

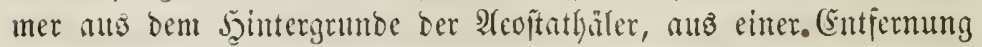

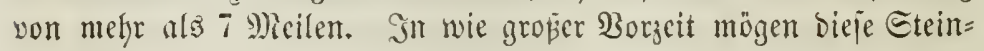

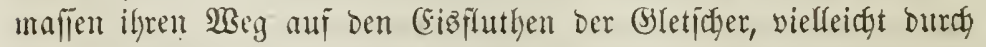

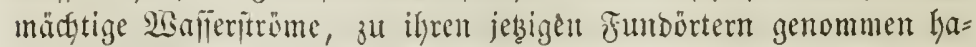
ben! Die (Erimnenumg ore astpenbewolnner reidyt nidgt fo weit, uno

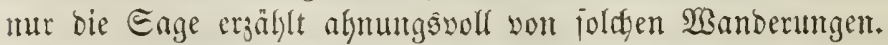

Ded uno naf́t erjgeitren nody bie regetlojen Edyuttlyaufen an

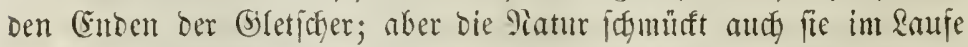

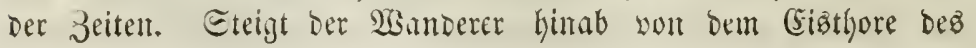




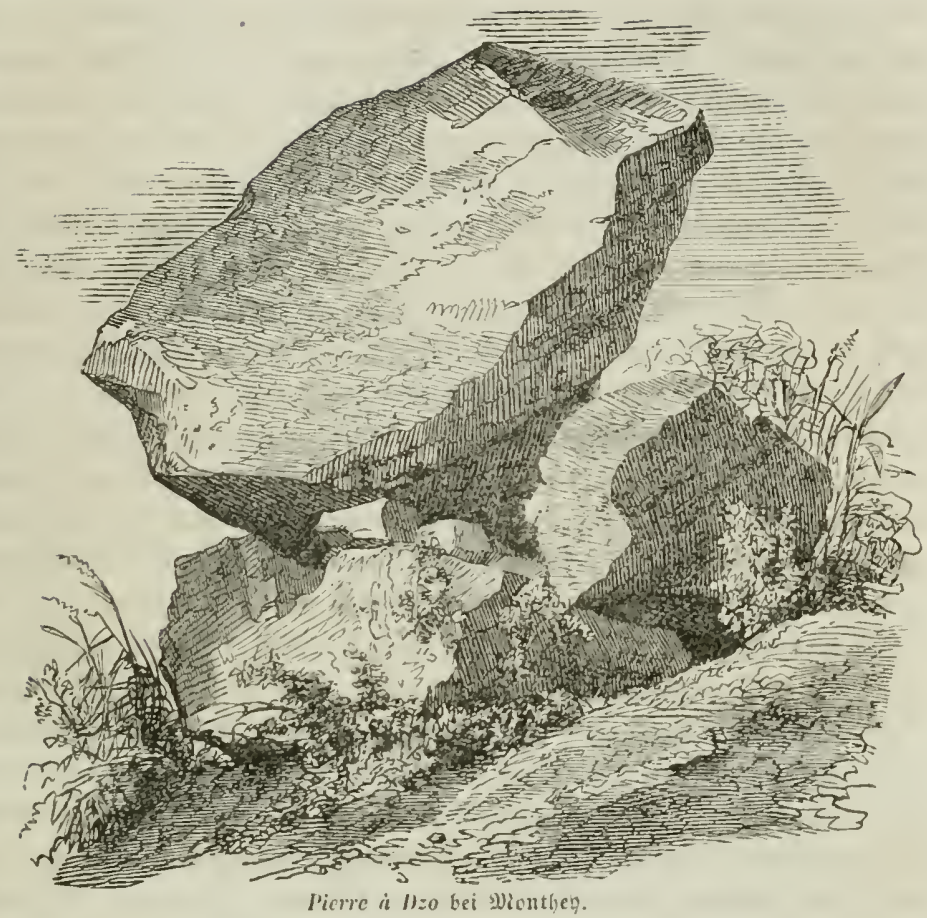

(5letfders zu ben älteren Marfiteinen feiner Beweyum, fo fielt er

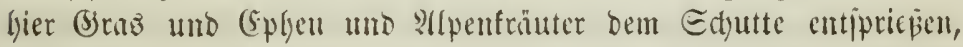

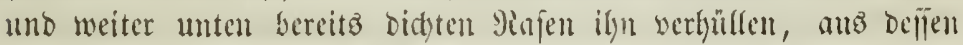
grüner Deffe mtr nody bie Santen grö̈erer Blöfe berborragen.

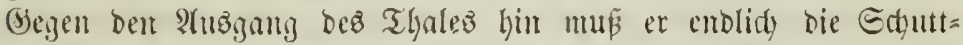
wälle in ben Säldorn oder felbit in mo unter ben Dörfern fudten;

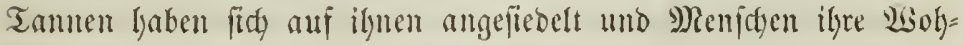
mungen erbaut; Dent fie fanben Edyus anj ifgren Erböbungen ge= gen bie lleberidnemmungen ber Gebirgabäche. Sit er mun an ben

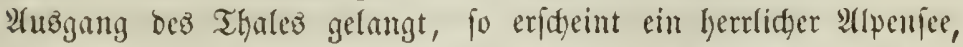
Den gegen bie (Ebone bin mur ein mädtiger Eteinmall abgrengt.

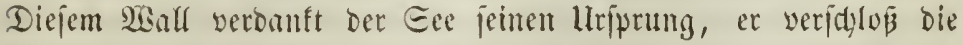
Thalmünoung und ftaute bie (bevälifer Ginter feinen Manern auj. Shre Patur verräth zwar bie Blöce biejer Trummerwälle, wie

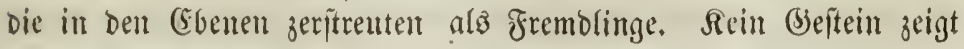




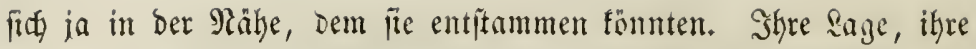

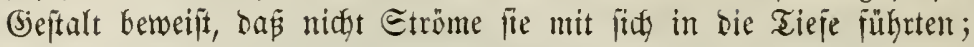
bern fie liegen oft gerabe auf ber Epize und jeigen idgarfe Sam= ten, die im Rollen hätten abgerumbet werben müijen. Demtods würde ez jojwer werben, bei jo mädtigen Trümmermerfent an eine frïlyere Bewegung berjefteen ju Denten, went nicht bie Spuren ihres Begez zu finten wiren. WBie Etröure ifjr Bett furchen und tief

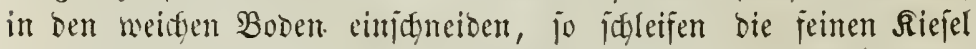
und Enndförner, weldye die Bjetidyermajie unter ifrem ungefeuren Druffe jortleewegt, bie Sberfiadfe aller Felien ab, über bie fie hin= gleiten. Ptlles Beneglide mirb jermalmt, und ber feitejte Boden geglättet vier won grö́̈erent eingefrorenent Eteinen wie sont Feilent

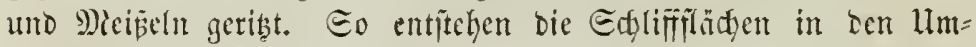
gebungen Der (j)letidfer, dic parallelen Furchen und Miundhöafer,

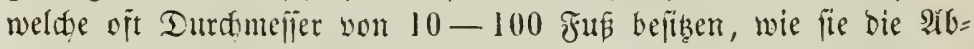

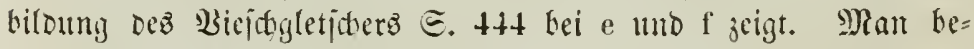
gegnet biejen (Ërigeinumgen tiej unten in ben Thälent neben alten Miorinnen, wie hodg über bem jestigen Etande ber (j)letifter, j00

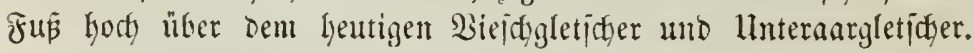

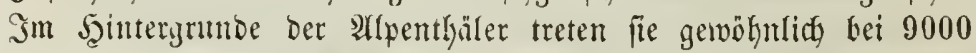

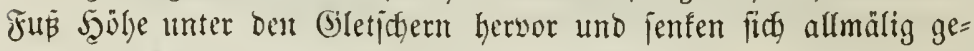
gen ben $\mathfrak{A}$ tuggung Der Thäler hitr, an Deren Mhünoung fie nod eine 5 gähe von $5-6000$ Fus imrehalter. SBie wir aber auz ben

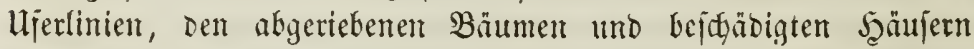
Die Jäble erfenturn, zu welder eint angeidswollener Etrom einjt ge=

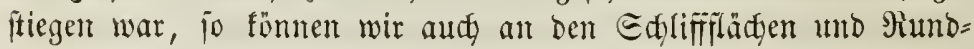

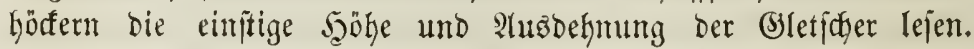

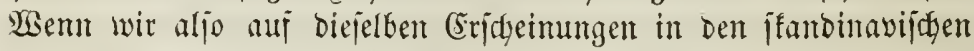

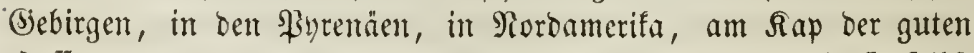

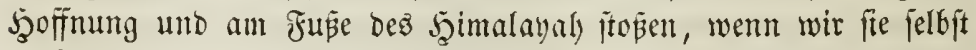
in Rändern autreffen, Die jern von bent jeşigen Bjletichergebirgen ourch) Ffladfländer, Mieere uno Mittelgebirgsländer getrennt find, im Sura, in bett Bogejen, Dem Edywarzwald, in Edyottlano uno Fimuland: jo mililen wir ofientar auf biejelbe llrjadge, wie bort in

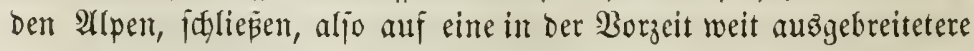

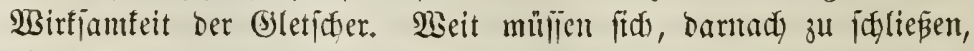

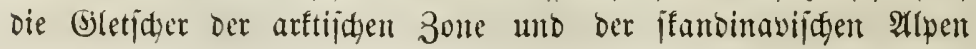




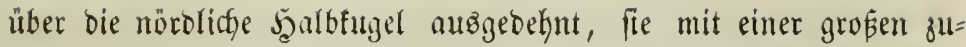
fammentängentent (Eisfrujte bebeft haben. Bejtano aber auch in

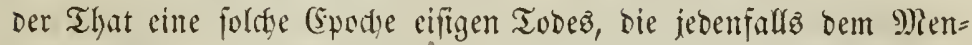

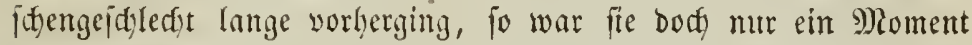
in jener Pieife won Docillationem, burds weldye bie (Sroe von ifyrem glübent beifen 3utranoe zu ifrer gegenwärtigen Temperatur ge= langt iit.

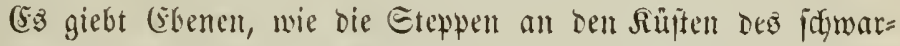
zen Mieeres und im Sntren ?fitens, in Denen meilenweit fein Stein

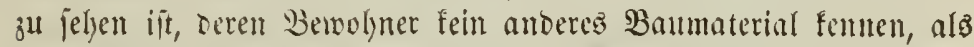

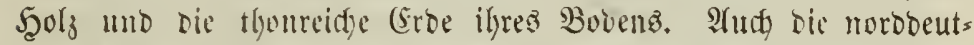

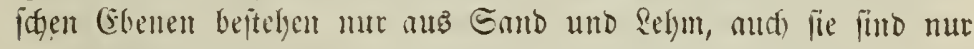

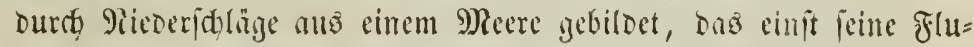

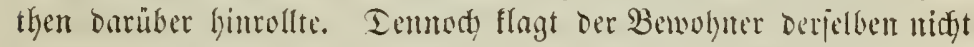
über Mangel an Eteinen. Bismeilen formte Der Reijende, wenn er ein märfiidfes Dori betritt, find völlig in eine Bebirgägegeno ver=

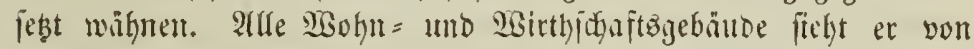
Felofteinen aufgebaut, überall um Bisten Roppeli, felbft an

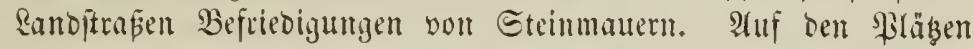

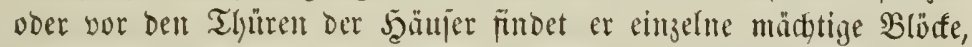
auj benten bie Aften ruhen ooer bie Rinber ipieten. Dranken anf

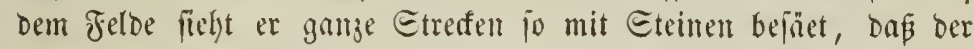
Ranomann fie nidgt bejtellen fomme; ani anderen 2Refern finto bie Steine in lyolye badofenjörmige Janufen jujammengetragen ober in (S)ruben verjentt. Ante (Ehauficen, alle Etrapent der Stäote funo mit Felditeinen gepflaftert, viele Rirct)en unt Thürme davon ge= baut; uno verwunbert jangt man fid, woher biejer verifdwenderifthe Reidythum fomme. Edjon umpere seutffien Sorfalyen verwendeten

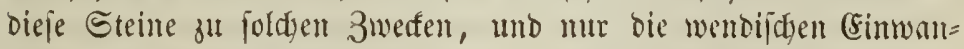
Derer, weldye in ifrem beimathlidgen Eteppen an Ralf umb Reghm= bauten gewölynt waren, wupsten fïe lange nidjt zu bemuzer. Sioct findent wir atz jenter 3eit Epuren einer rofent Eftrlptur, ein=

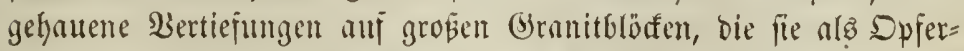
fteine oder Brabmäler bejeidfnen. Ev liegen bei grantfurt a. D.D. auf einem bewaldeten J̧ügel brei foldyer Eteine, weldje regelmäßige

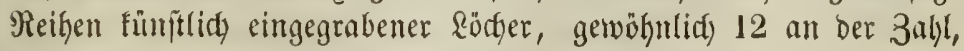
zeigen; unb bie \$bantafie ber Bepdyauer hat fidf idjon lange mit แe, şeltall 3. भup. 


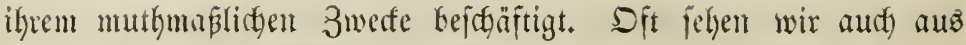
joldfen übereinambergehäutfen $\mathfrak{B}$ (öftent wumberbare Eteinpforten und

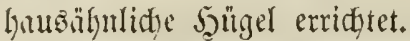

Wem alfo trotz ber fteigenden Siultur, weldye bieje Eteine zu

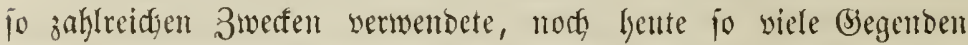

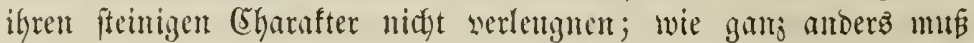

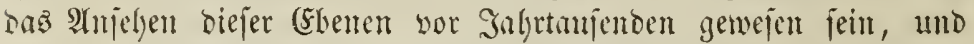

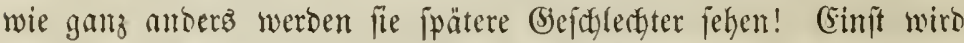
man bieje $\mathfrak{B}$ löde vielleicht mur nodh anz $\mathfrak{B u ̈ h}$ ern femten ober unter Dem Edyutte der Miuinen jucher.

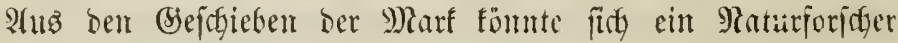

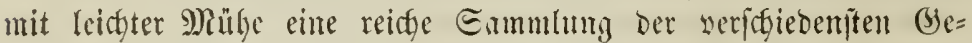

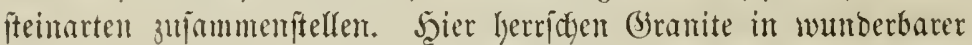

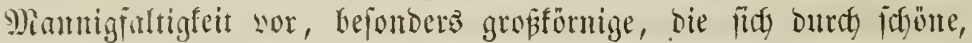

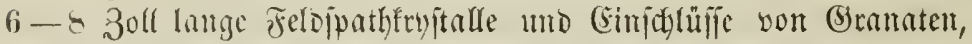

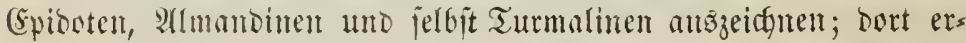

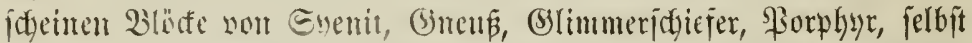
Bajalte mo Edhinten. Sn nnoeren Biegendent treten Ralffiteine, reidf an weriteinterten Sireticn und Edfneden, bejonders Trilobiten

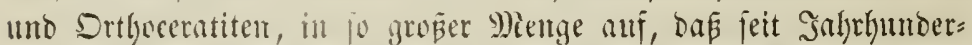

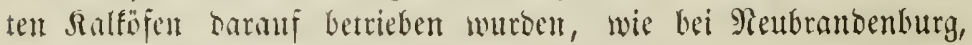
anj Miedom uno bei Sorat.

Wiser in Etcinen nidłtż weiter als Baumaterial fieht, bem föntuten bie fleinen zerftreuten Steine Der (Sbenten wohl entgehent.

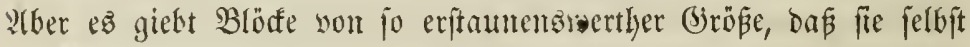

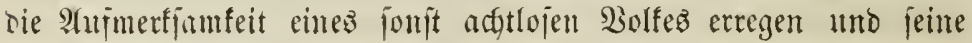
Eagenpoefie bejuantigen mupten. Bei 2 suffow in Meaflenbury

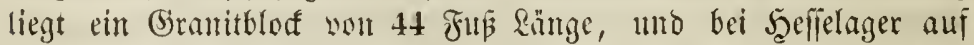

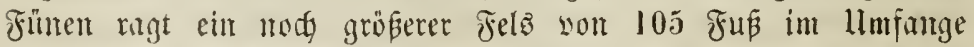

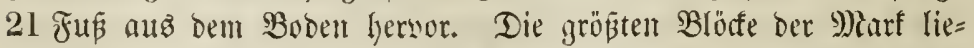

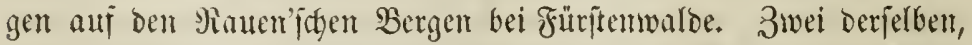

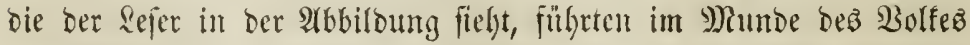
Dell Pamen ber Marfarafenfteine, uno von Dem größten, Der 95

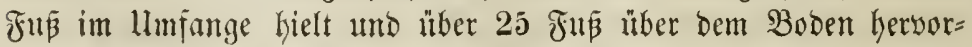

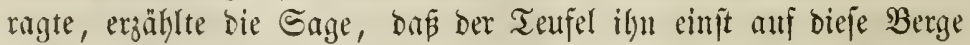
geidjleppt und eine Söniggtodser barin veridlofien habe, beren

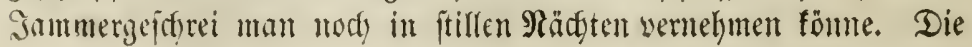




\section{1}

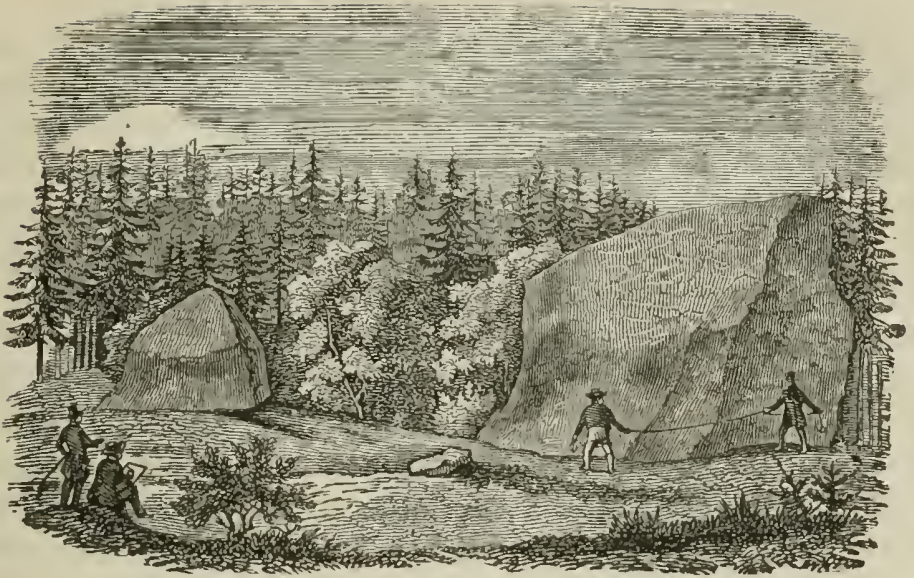

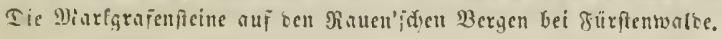

Sunjt lyat ben 3auber gebrodsen. Cie werwandelte ben Etein in

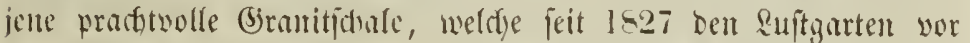

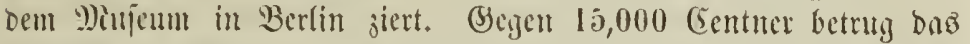
(Sewitht des Bloctes. Mian meífelte Daber an Drt uno Etelle Die Edfale aus rem (Broben mo bradte die noth immer niber 2000 (Eentuter jownere Etemunafi anf ciner Boblenbahn an dab Epree=

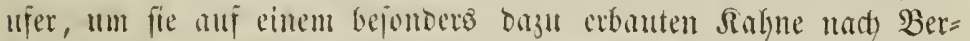

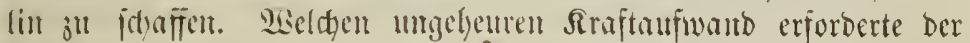

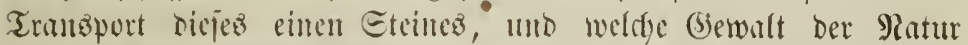

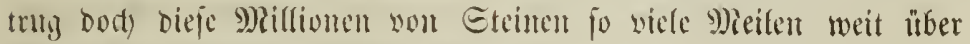
Meere mo Ebouten auj Dicje Berge!

Die Szeimath Der Blüre fund bie Ränder, in benten fie jebt liejen, nidt. Der felym= mito Eambloden, auf bem fie rulgen, ge=

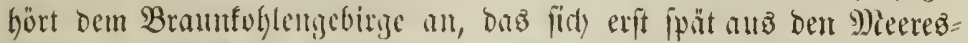
flutben abliggerte, uno fcin jeites bejtein liegt unter ifgm verborgen, bon Dem fie losigebrodien feil fömuten. (Erjt in weiter Ferne, in Den Biebirgen Efantinavients und Finnlantoz begegnet der Beologe Felछmalien, oern Siatur mit biejen Trünment übereinjtinmt. Die

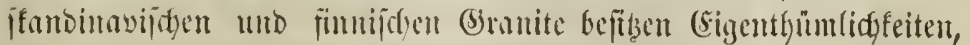
namentidy in ilyen gropen geldipathfryftallen uno ben bejondenen cinyejolofienen Dimerntion, wie fie fein anderes Sranitgeftein wie= oer jeigt, Lleberbies fommen mit biejen Beidjeben Mruidgeln und 
Edfnedfen nor, bie nodh heute bie norbiiten Meere berwohnen; uno Moofe find auf ben Blöfen entbeat worden, bie mur bas jfandi= naviíche (S)ebirge trägt. F(ther audh bie Berbreitntng biejer Steine, bie man eben als Fremblinge an ifren jeşigen sageritätten erratijoge

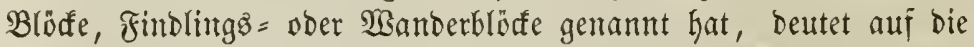

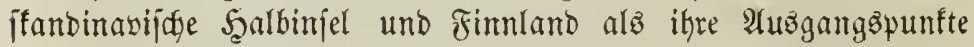
hin. Brutuppentweife umbiefyen fie in weitem Bogen biefe alte Şei= math, und ifre äuferite (jrenze läuft von (S)öningen in Saolland burd, Weftphalen und Seannover am 9iorbrande Deß Şarzez ljint, Durdf Eactjen, Edsleften und Polen ither Reipzig, Breslau und

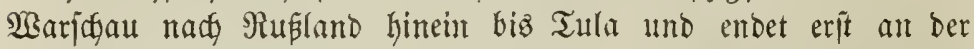

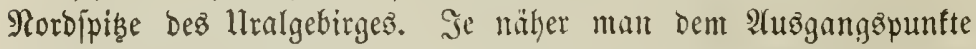
fommt, bejto gröper werden bie Blüfe. Sm jüblidfen Edgweben

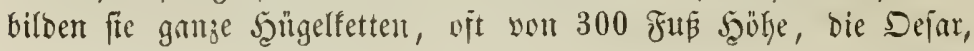

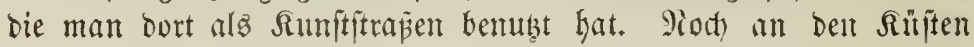

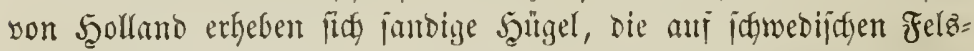

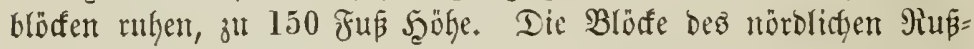

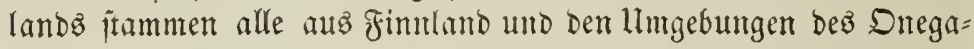

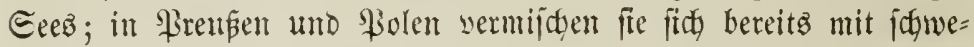

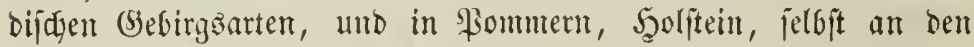

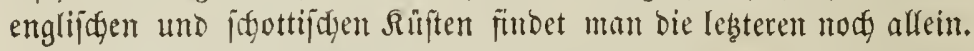

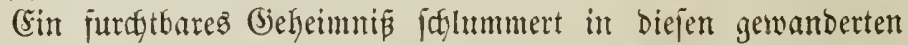

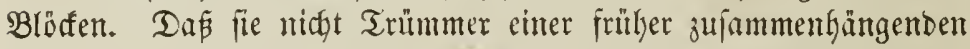
und aus der Tiefe ber (srbe bervorragenten Siebirgsmafle feien,

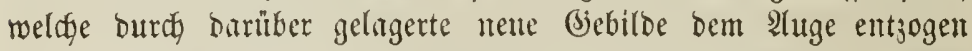
mutrbe, Davou jeugt die ganje Ratur diejer Eridjeinungen. Rtber weldye $\mathcal{S}$ raft rif fie won iflerem litrgeftein los, jwang fie ben weiten

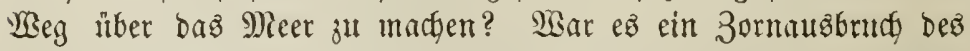
jeurigen (Eroinnern, woer einte gervaltige Flutl), welche dieje Blöte in jo weite Fernen, jelbft anj Berge fidleuberte? WBar es eine cinzige furdtbare, aber fajnell noritbergelyende Siataftrophe ober eine lange Rette von Ereigniffen, weld)e bieje Fremblinge über bie (Ebe= nen zerftreute? Das fint Fragen, weldhe Den Maturforifher feit jenen Tagen bes vorigen Snhrhutndertè bejdäftigten, wo zuerft ber

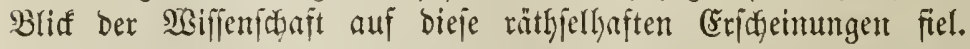

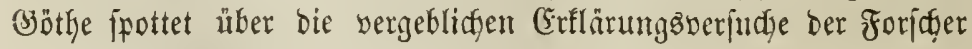
Dem Bolfzglauben gegenüber in feinem Fraft: 
2loch piart bas Rano von fremben Eentnermafien;

Ber giebt (Erflïrung folder Shleuberfraft?

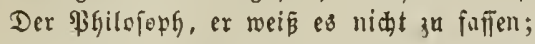

Da liegt ber Fels, man mús ifn liegen lafien,

3u $\Xi$ banten baken wir uns fidon gebad.t. -

Das treu=gemeine Bolf allein begreift

Uno lisit fids im Begriff nidyt frören;

Shm if bie 2Beibheit langft gereift:

Ein 5 Bunber ift's, ber Eatan fommt zu Egren.

Micin 3 Bubrer linft an feimer Blaubensfrüfe

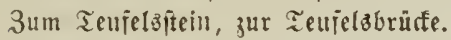

In ber That ift bie Enge idneller mit biejem \$hänomen fer= tig geworben, als bie Wiijenjifat, wor allem bie norbifhe Menthe

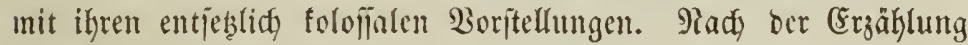

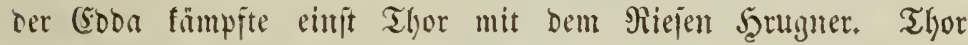

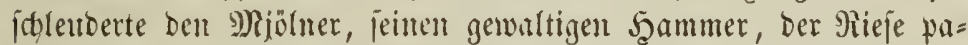
rinte ihn mit feiner gewaltigen fteinernen Reule. Die Reule zer=

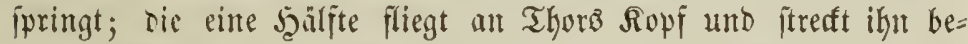
tüubt zu Boben, bie anore zeriplittert, und bie zerftreuten Stüfe

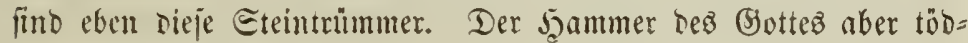
tete den Sanuguer.

Der erite :Hubliaf ber regelloz ourtheinander geworjenen Blöde ließ ite gleidgiom atz eitte won oben Gerabgeftrute Gaat eridgeinen, utto wirflid) fandent fids Sinturforifger, wie (Elyabrier und Rod, veranlapt, in ifyten Refte ciutes zeriturten Erotrabanten zu erbliden.

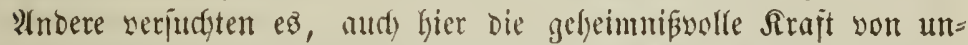
ten emporbrängender Bewalten eine Bivlle frielen zul lajien. Rods in meuerer 3eit fal Boll in Meubrantenbury in ben Trinmer= gefteinen ber bultifhen Ebene bie Wirfungen einer gewaltjamen Sataftrophe, weldye fith naty alblagenung unjer tertiären Bilbun= gen, aber gleichzeitig mit rem Dillvium ereignete. In jener 3eit ber Beburtgmefyen des ffandinavifacn Bebirges branthten, wie er meint, bie plutonifgen 9) laffen von unten empor und fudften bie

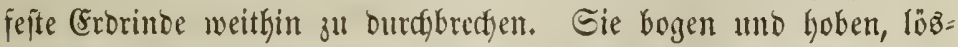
ten und zerbradjen ober iprengten burdy Stöpe bie fie liberbedenden Fetalngen. Minenartige Explofitonen idgleuberten viele Mleilen hod ibre Bomben empor, bie in weitem $\mathfrak{\Omega}$ reije über bie umliegenten

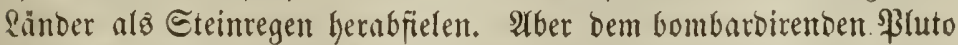
mus̄te গieptun in jeiner Arbeit helfen. Fuf gewaltigen Fluthen trug 
er bie son flutonifder Sraft jerprengten und jerriebenen Trtumer

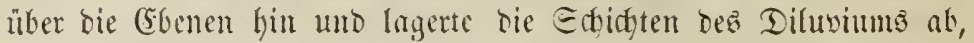
in weldsen bie immer mädtiger gefthlenderten Bomben begrafien

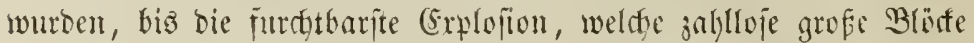

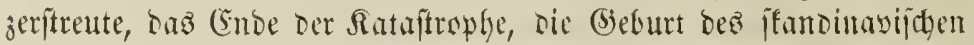
Bebirges verfündete. Dieje friegerifte Sylyotheje auds anf bie er=

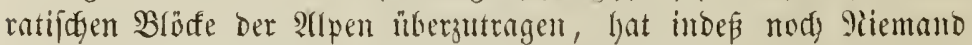
verfudgt. WBaffer fobien hier bie einjige 9 raft ju fein, welde man

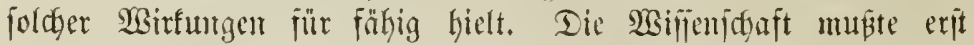
zablloje Thatjudjen anfifuchen mo in llebereinfimmung bringen,

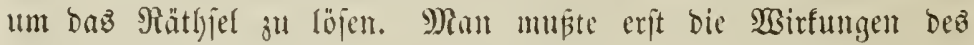

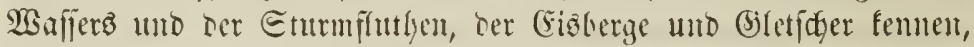

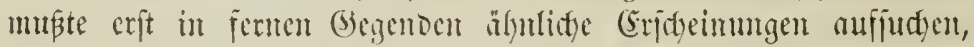

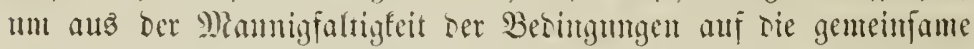

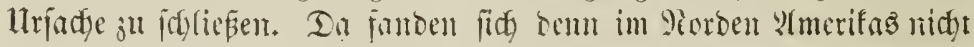
minber mäbtige Eteintüfe, bie, ehen fo fremo ifrem Boben, fith

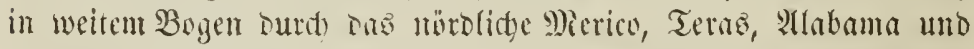
(B)orgien eritreften; und im Ellden Der (Grbe fand Darwin in

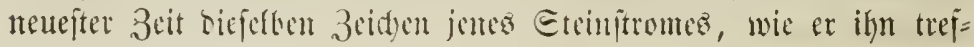
jento begeidfuncte.

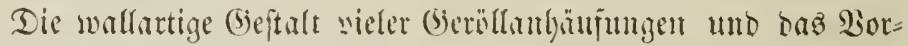
fommen von Blöfen aü leiftem Eamo = unt Wlferboten, in wel=

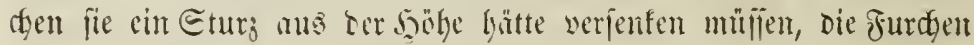

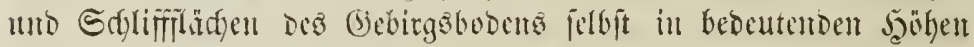

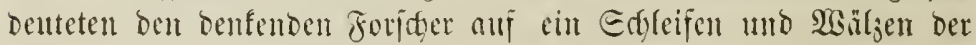

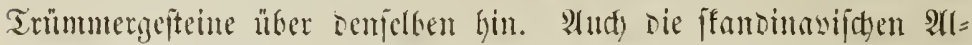

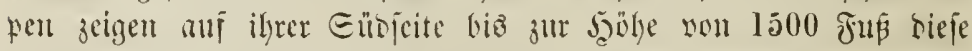

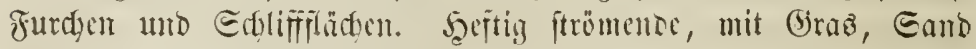
und Blörfen belasent Fluthen Gaben stjenthar an Der Rorspeite sie

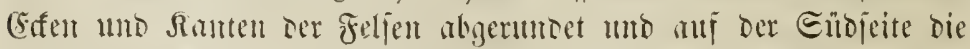

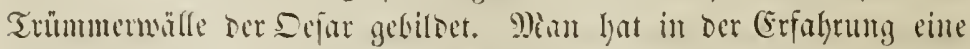

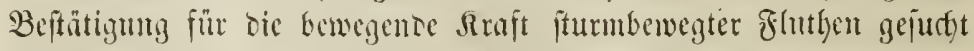
uno gefumben. Fn ben Rïjten fimlands wurden nody in biejem

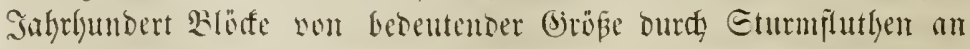
ifren jesign Ent getragen. Die Eage vent einter cimbrijden f(nth),

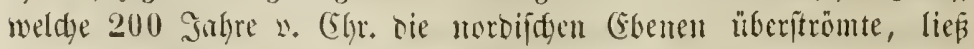

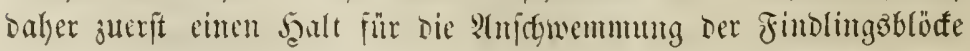


finden; unt wem man and feine Beweije für ein fo jungeb (Ereig= nis jant, Meere bedeften gewie in grauer Borzeit bie heimathlidjen Fluren. Snjelgleidr ragten bie Retten Der Rarpathen, Des Riejen= gevirgez, Der Thüringermnto und bara aus dem Deean hersor,

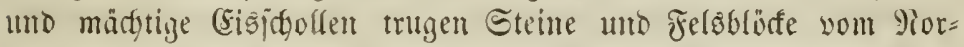
Den her, liepen fie am Etrande und auj bem sisege fallen, unto

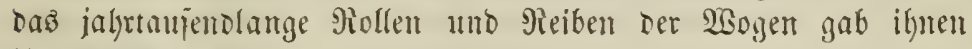
iḩre jeşige Bejettalt.

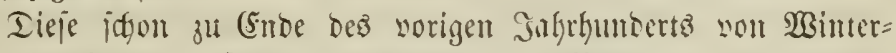

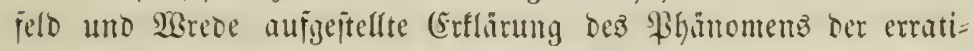

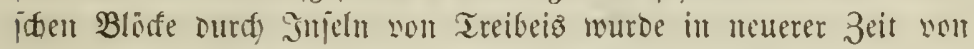
Enell unto de la Bedje nods meiter ausigeführt unto son bent bal=

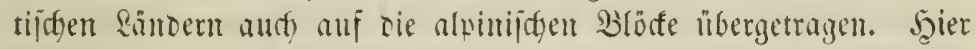

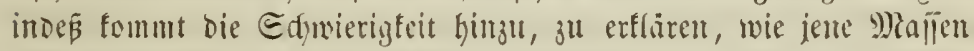

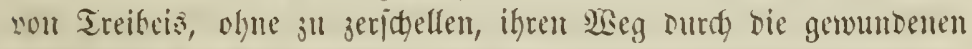
Thäler in Die seffente Edyweiz fanten, uno wie, trob Der veränter=

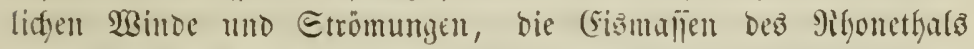

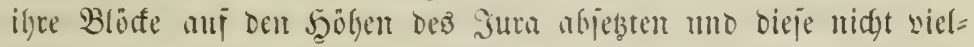
melg tiej mad Deutidgland veridglagen wurben.

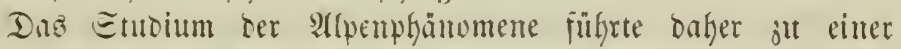

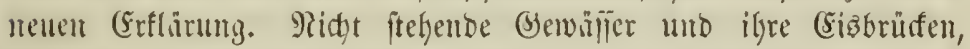
jonsern gemsiltige Etromflutthen jolten jene Trummer von ifren Etammelien herabgejdelendert habent. Seopelo y. Buch war ber Grintber biejer Theorie. Err erfannte juerjt die ganke Gröjje biejer

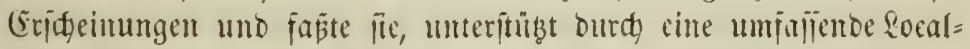

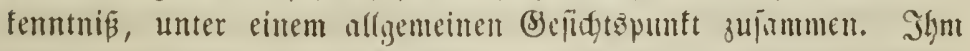

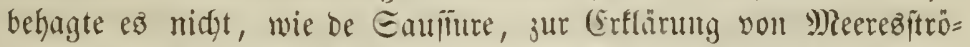

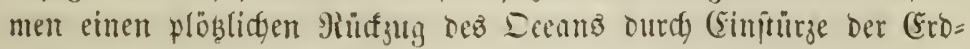

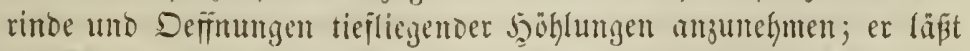

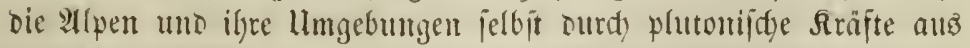

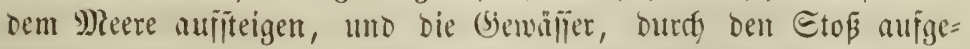
worjen, in ungeheuter fluth son den Gipieln zur Ebente herab=

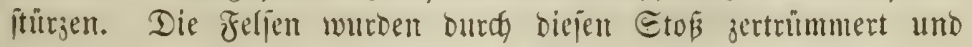

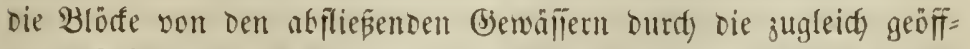
neten Eeitenthäter fortgeriffent. Daher Finbe man aud Blöde, meinte

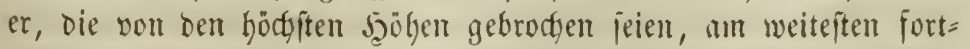

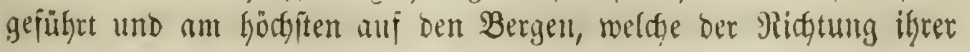


Beivegung entgegenftanden; Maffen bagegen, weldye fith yon tiejer liegenten Felien loğgerifien, feien idgon von weniger foben, fid ent= gegenitellenden Seligeln aufgehalten worben, und nürben beşgalb

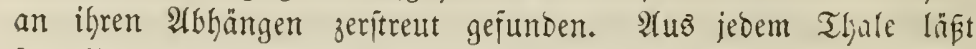
‥ v. Buch joldye Etröme gleidgseitig los̄brecten tho mit jo unbe=

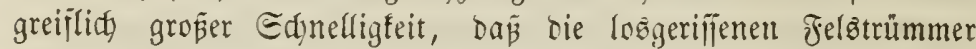

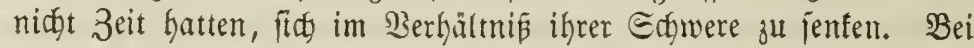

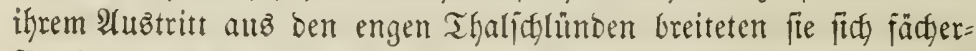
förmig in bie Estene aus und verloren Daburdy jeitlidy an ihrer (je)= fäminbigfeit, jo baj fid die Blöafe um jo tiefer jentten, je meiter fre yon ben Єeiten entjernt waren. bie Alpen und iffre llmgebung galt, wurbe mun audg auf ben Piorben (Europas ansgerelynt. (Fine nod) furdttbarere fluth, son ben norbijden \&ändern Gervorbredjent, fillte bie Trïmmer ber ftan,

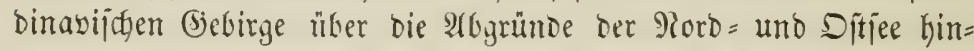

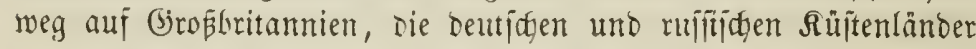

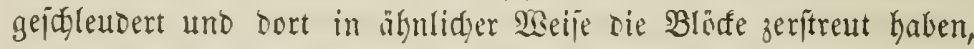
wie im Ltmfreije Der atpen. Iieje syupotheje bot ein jo barmoni= Fafees (Banje bar, alle Thatjaden idjemen Darin jo natürlidy be=

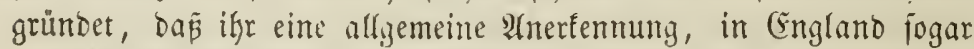
Daz Ánjehen einez Dogma zu Theil ward. Daju fam der längit

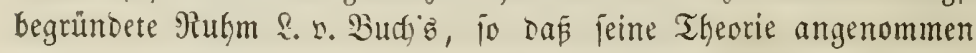

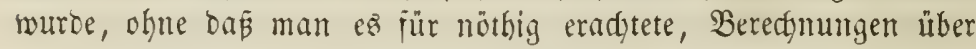

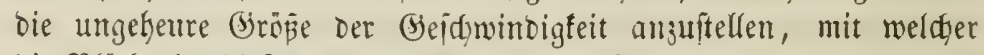
bie Blöfe in biejem fluthenitrome jortgejgleudert merben mußten,

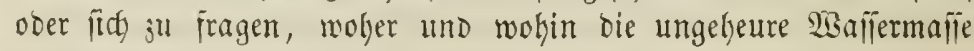
getommen jeit.

Diejer lange 3eit herridenden Theorie fteflen (Sharpentier uno

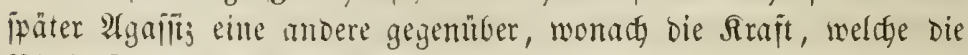

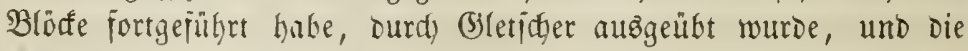

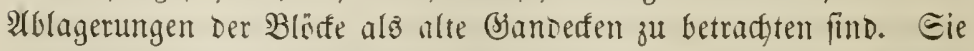

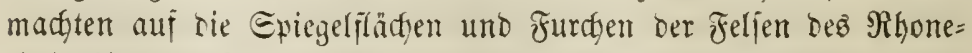

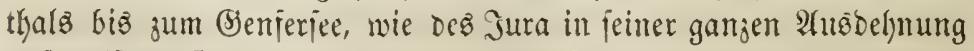

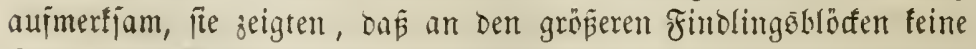
Epur von 26jtumpiung uno 3erreibung zu entbecten ift, wie Dodf immer. Den Geröllen Der Etröme zufommt; fie fint eefig uno

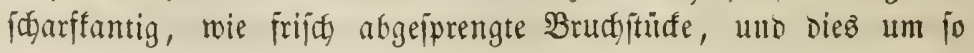


metr, je größer fie jint. Sie wiefen Darauf hin, wie die alfmälig

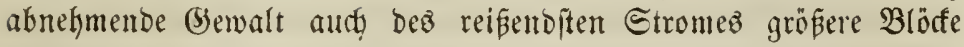
auf geringere, fleinere auf weitere Etrenfen mit finf fortreife, wie bei

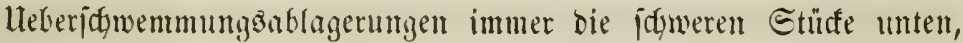

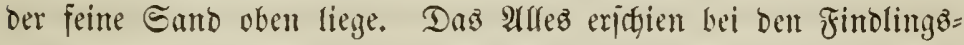
blöfen gan anders. Jaier liegen Felsftüfe son vielen taujend

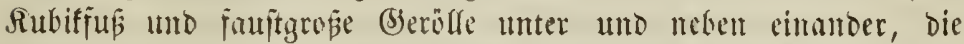
gropen oft oben, bie fleinen unten. Dft tretent bie :Hblagenungen

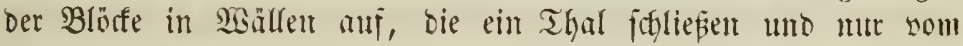
Thalgemäfer burdbrodgen find. Soldje Dämme aber bant tein Strom fidt fellojt in Den $\mathfrak{W e g}$, funtorn er reift die, welche er fin= bet, jort. Dit fino Blorfe nuj Das Eonberbarite aujgeridtet, wie auf Epizen ruheno; Etrome aber ridgtent midt nuf, fie merjen um.

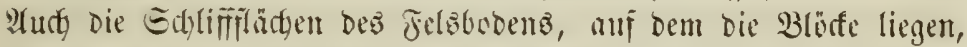

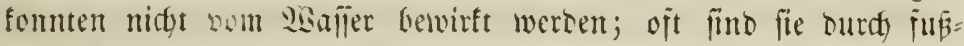

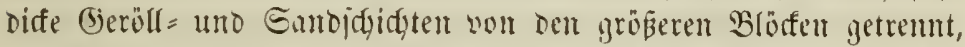

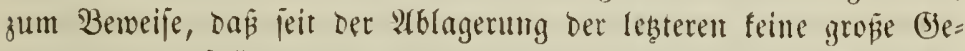
walt megr auf fie gewirtt haben fam, ba fie fonjt bent Eano mit

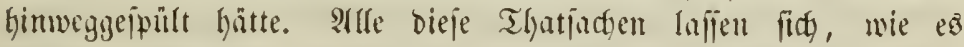

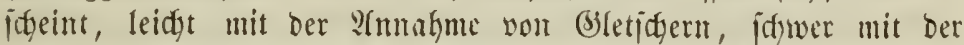

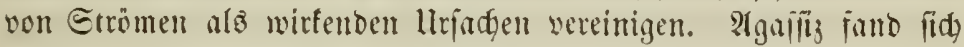

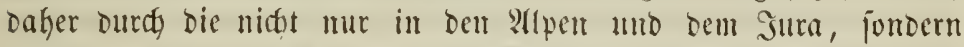
aud) im nörolidyen Europa und F(nerifa wahrgenommenten alten Gandeffen uno Edyliffilätben veranlä̆t, bex WGelt ein neitez Zeit= alter in ifren Ralcnder jll ictieben, indem er einen Beitpuntt all= gemeiner Bereijung Der Erbe behauptete. Die Erfaltung oer Ero=

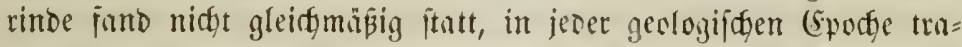
ten plößlidge Temperaturänderungen ein. Sime poldge Ratajtropthe war ez, welde nad) Erbebung bez Sura unje ganje Erovberfläde

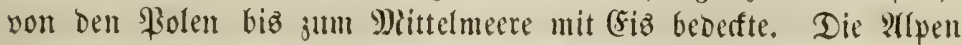
erhoben fich unter ber (siaberfe, die Eisfpiegel jentten fth, uno pfeiljonell glitten bie Felablöfe auf ilgnen zun Sura hinab. Lltter

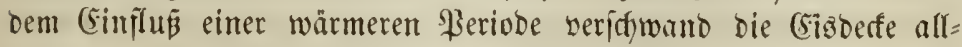
mälig wieber. Die Biebirgżüge, weldye Europa burtbtreuzen, wur= Den Scaltpunte ber Cismaffe, tmo balo bildeten fïd, wälyreno bie (5benten allmillig frei murben, ebenjo viele (s)letjdyeriyfteme, als Bergfetten vorbanden waren. Uuf biejen Sletjdern wurben bie 
Findlingablöfe von oben herah betwegt, uno man finbet fie beshalb ftetz in fternförmiger $\mathfrak{B} e r b r e i t u n g$ um bie Bebirge, von welchen fire Ftammen, gelagert. Flllmälig wurbent bie nieberen, bann auth bie höheren Bjebirgâfetten gant frei von B)letichern, uno endid, blieben mur nody als geringe Refte ber ehemaligen (Siżjeit bie (Jletifher ber Ntrent mo ber wenigen andern emigen Edymee tragenben Giebirge und ner 将olangegenden jurülf.

Dies ift bie Theorie von $\mathfrak{A g n i f i} 3$, bie immer mehr $\mathfrak{A}$ trbänger

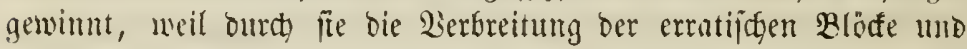
aller solei beobadteten Erideinungen am beften enflät wirb. Son= be

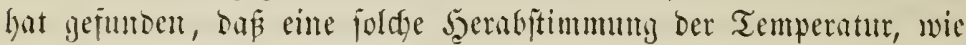
Fie zur (Srzengung io anşgebehnter (5)leticher nöthig war, in idreien=

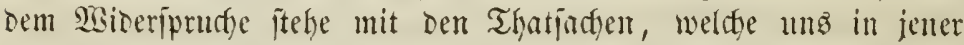
Reriode cin tropijates Rlima in ber Edyweiz uno jelbjt in unjerm

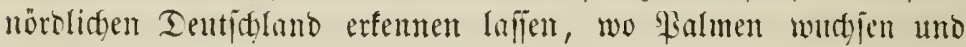

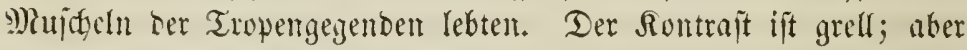

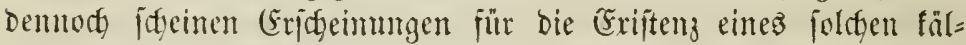

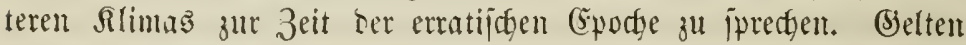

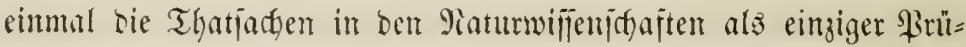

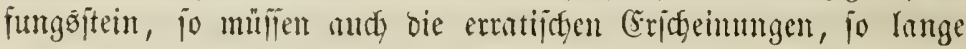
fie mur mit ben ję̧t an ben Bjletichem beobadteten Thatjacteen übereinftimmen, aus gleichen Urjaçen begrifien merben. Wisem man einit anbere Saräfte aufgejunden haben wird, welde ebenfalla

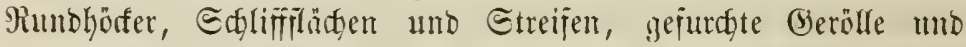

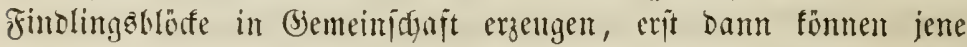

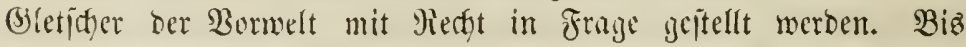

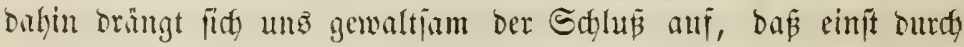

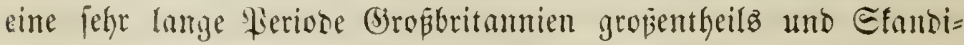

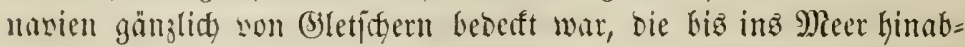

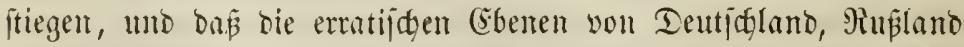
uno Eifirien bour einem Folarmeere bederft waren, aul befien

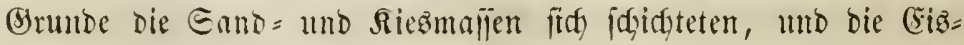
flöpe mit ifren Fintingen frandeten. Der Boden biejez alten SPolarmeeres hob jith allmälig empor, uno bon bem weiten Drean,

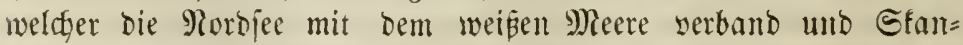

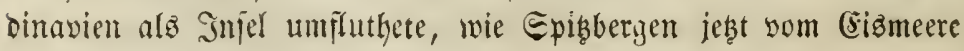




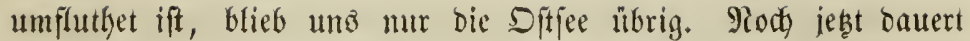
bieje allmälige Erkyebung bez Bobens in Eđfweden fort, wie mit

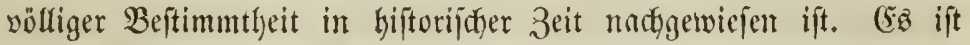
Die lebte Piegung jener Zeit, weldye bie Beburt ber Begentwart ein= leitete und in ifren Trümmern unţ bie Sropartigfeit ifyres Edyafs fens und Beritörens ahnen läß̄t.

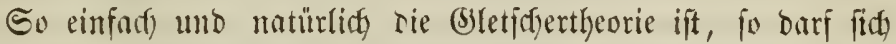

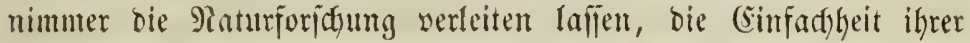
Roriteffungen uno Eallije auf bie bunte Mamtigfaltigfeit Der

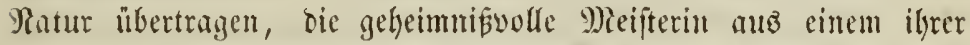
Seerte in iffer ganjen reiden Thätigfeit begreifon ju wollen. Daz

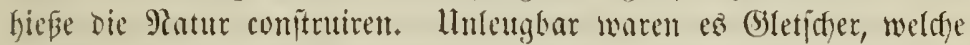
zabllojen Fimblingoblöfen ilyren Hriprung gaben; aber andere tragen

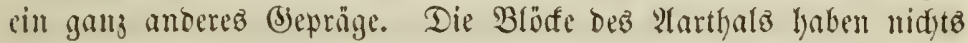
von ber eigenthümlidgen S)ioränenbiloung an fich, uno au zalylrei= den Drten finden fid abgerumbete, von gejdyidyteten Riermaffen umidblofiene Blöfe, weldye offenbar son Etrömen gerollt unb ab=

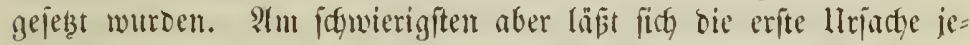

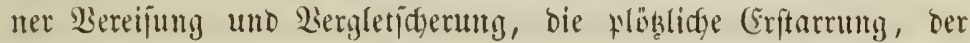
WBedjel von Wärme und Rälte, von Reben uno Tod ani Der (5ro= oberflädye begreifen. Der Eimfluß ber intern Sromärme ift ju un=

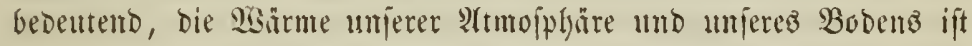

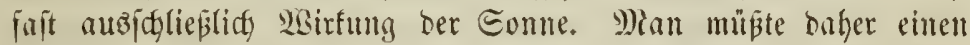

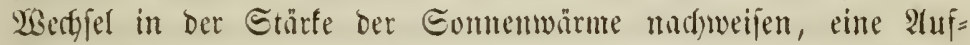
gabe, weldge bie größten 2ritronomen vergebent з uno jelbit bann nody whrtbe die plöbliche Bereijung, oer plöblidse llntergang ber ganjen organifden Viatur ein umgelöjtes släthfel bleibert.

Deflemungendytet haben älter mo nemere Forjder bie Tiejen

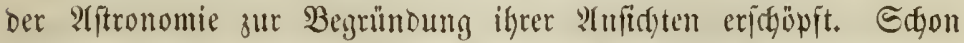
Wrede nahm in Sahre 1504 in Der Berlegentgeit, Dng nöthige

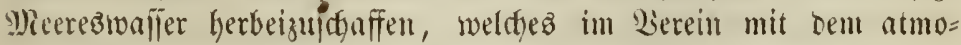
iflärifiden unjer Diluvium gebildet baben jollte, feine Zufludt) ju einem veränderlidgen, ercentrijagen Edywerpuntt ber Eroe. In neuerer

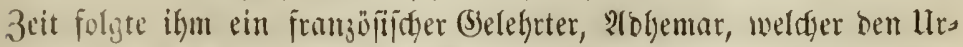
fprung jener Sirmaffen in urfüdylidyen.3ujammentyang mit ber lang= fan fortidgreitenden Drehung ber grö̧en Fre unjerer (Srobahn und 
Der baburdy bemirften Beränberung im Berbältniß unjerer Sahres= seiten bradte uno baraus jelbjt eine unteilvolle Zufunjt für bas Menidjengejdledyt prophezeifte. Der (5yclus jener Drehung beträgt 21,000 Эahre. Sn ber einen Şälfte verlängen fich bie beiben warmen Sahregzzeiten beftändig, während bie beiden fürzeren abneh=

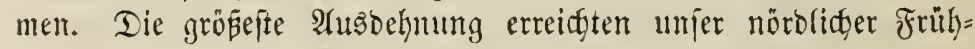
ling und Eommer im Sahre 1284 jur 3eit Friebridbs II., feitoem nefmen fie wieber ab. Dies geht fort bis zum Sngre 11,78t un= jerer 3eitrectumg, wo Şerbit und $\mathfrak{B}$ inter ihre gröfte Eänge er= reicht baben, wie fie diejelbe fugn 9252 Jabre v. Ehr. bejaken.

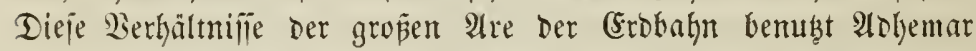
zur Erflinung jener ungeheuren Eisberfe, für beren einjtiges $D_{\mathfrak{a}}=$

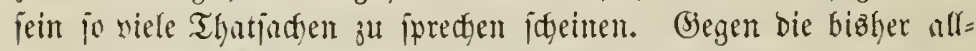

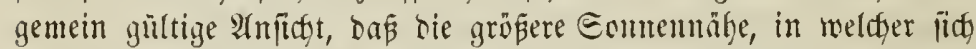
die (Froe waifrend Der überwiegend marmen Safreszeiten ber EitD= hemifphäre befindet, bie längere Dauer derjelben für ben Piorden ourch einen größ̄eren Wärmegrno aug̈gleiçen mülie, wendet 2robe=

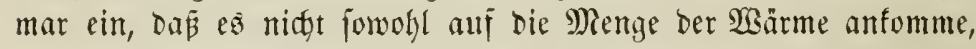
weldye hic Groe emplange, als allf bie, meldhe ifgr werbleibe. Die jüblidye Wolarjome ater hat, wie bie nöbdidye, während bes $2 B i n=$

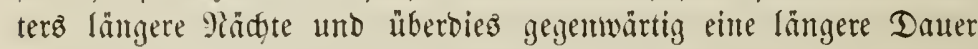

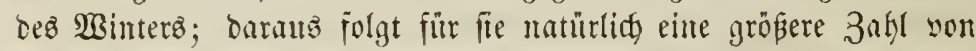
Radutitumben, alg̈ für bie mỏrblidge. Sene ftrahlt baher in ben län=

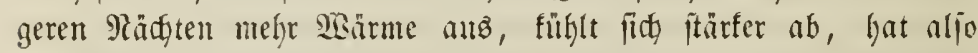
nothwendig cine niebrigere mittlere Temperatur, als bie nỏnoliche.

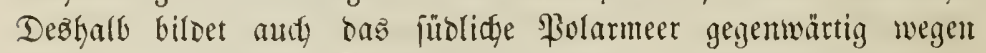

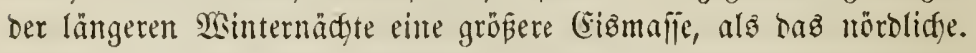

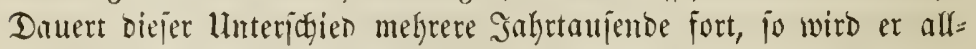
mählig jehr bebeutend werden. Sn ber That lehrt bie Beobactutug,

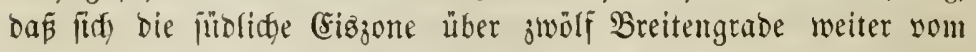
Sübpol eritreat, als bie nörblidse vom Rorbpol, uno baß̧ bas Eübpolareis niel sicfer ift, als baz Rorbpolareis. Sine fo be=

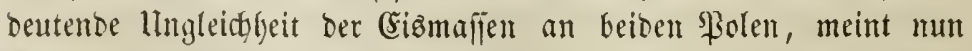

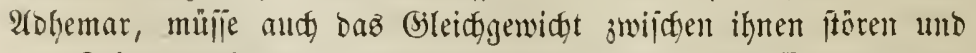
Dell Edwerpunft auz dem (Sentrum ber größeren Mafie nähern, fo

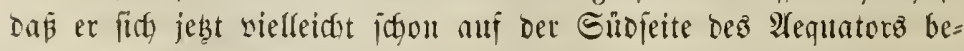

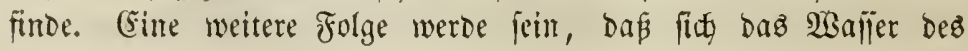


Sceans yon ber Eeite ber geringern (Eišmalle gegen bie ber grö=

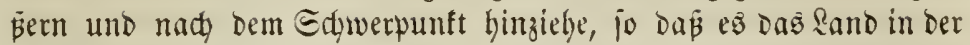

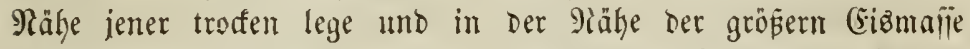

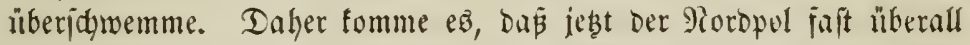

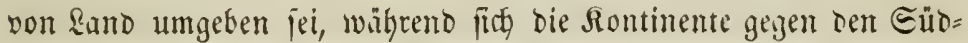
pol, wo Dag s) Jeer tiejer iit: pyramidal zupizen. Pady bem Salyre

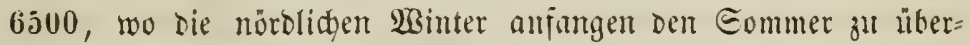

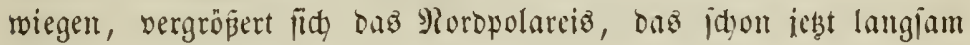
madjento junchmen joll, immer mehr, mithrend bas Ellopolareis

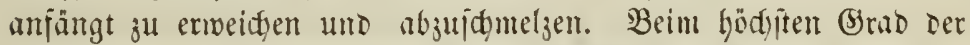

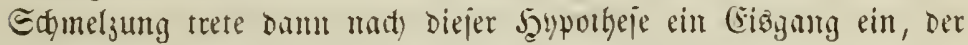

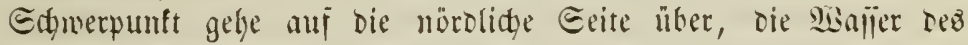

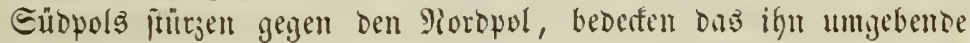
sand unter ibren Flutben and büllen bie som troftren Entre gegen

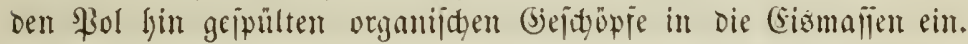
(5ine foldge fluth wird aljo jogon mad bem Jahre 6.500 eintreten,

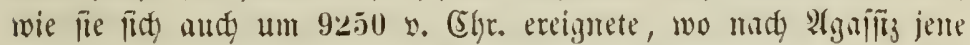
ungebeure Cistrutte die ganje nörolidge jăalbftugel bedectte.

Das ift bie jür bie tümpigen (bejchiffe oer Menjd)heit jo trojt=

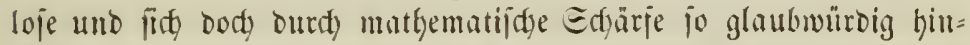

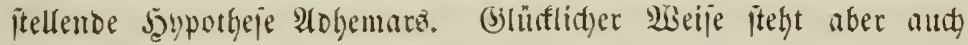
fie nidgt über geredte Zwveifel erbaben. Cin Ephäroid, wie unjere Sroe, verïndert nidgt jo leidgt jeine Arenftellung uno jeimen Edwer= punft. Eolle ein jo bebeutendes \$gantomen erjengt werben, jo

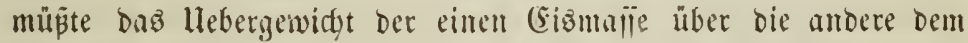
Berwidyte dez ganzen Şimalaya gleidgfommen. Heberdies fällt bie

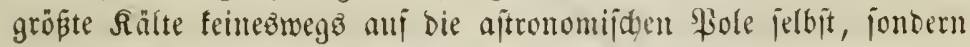

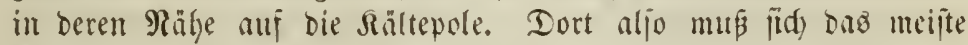

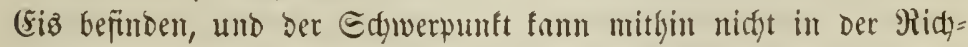
tung Der Cronre, fonbern nur in Der Der Răltepole serrïtt wer= Den. Daburd) aber wịtre eine Henderung Der Siotationsare forbei=

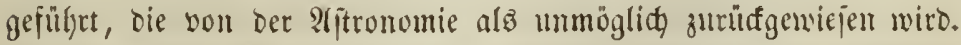

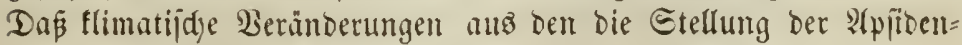
linie veränbernben Etönngen bervorgehen, fam nidbt gelemynet werben, aber jafwerlid joldge, weldye die mittlere wärme eines

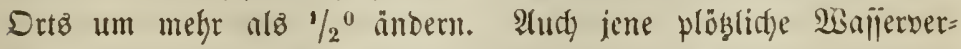
jebung von einen ßole zum anbern ift nur benfbar bei einem 


\section{2}

plöblid eintretenbent (Eiżgange, nidst aber bei cinem langjamen $\mathfrak{A} b=$

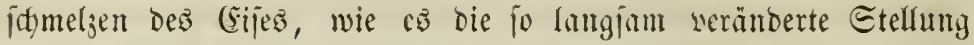

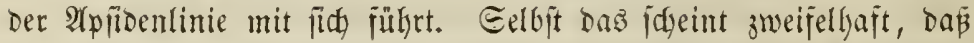

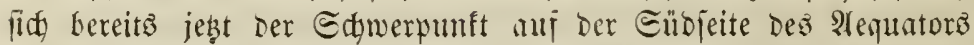

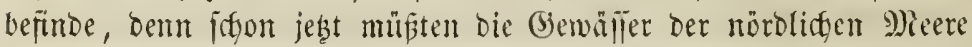
in einer Etrömung nady bem Eubpol begrifien fein, beren Epuren

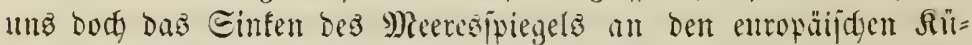

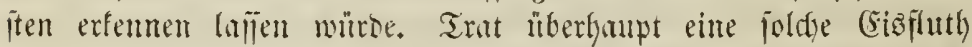
wor der jebigen (Epodbe ein, jo hätte jie nady diejer Saypotheje of =

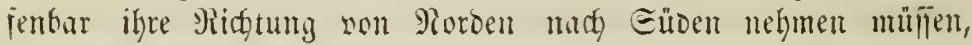

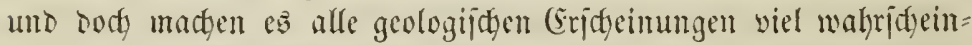

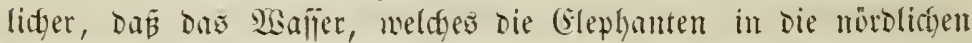

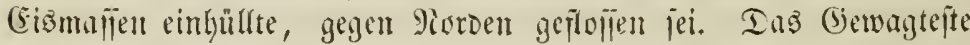

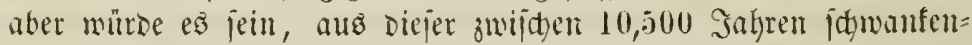

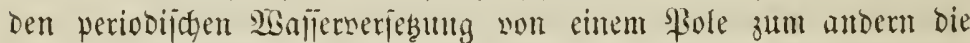

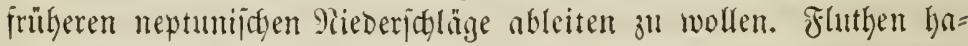

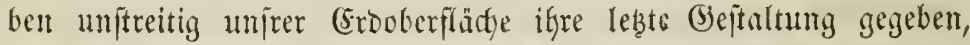

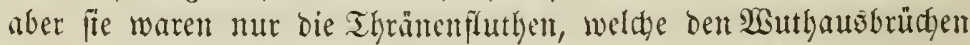

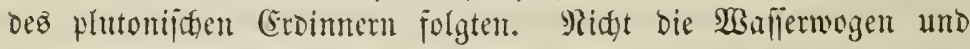

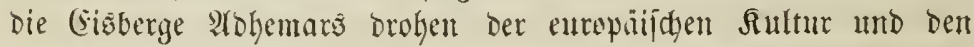

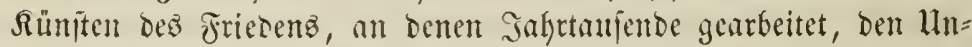
tergang; mur bie plutonifden biewalten ber Tieje grollen ber gegen= wärtigen Dromung der Dinge und mahnen ben in Träume Der Eidjerkeit gemiegten Erobemohner an bie Rebensfaft unter feinen

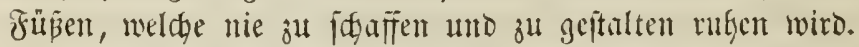

giods ift es nidgt getungen, bie rïthjelthafte Errideinung ber erratijdsen Blörfe, bie cime fo weit verbreitete ift, unter eimen allge=

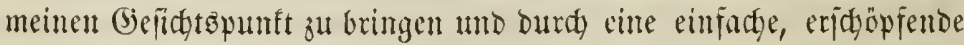

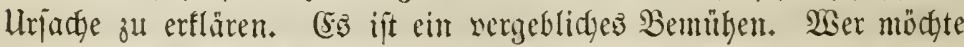

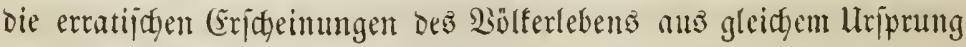

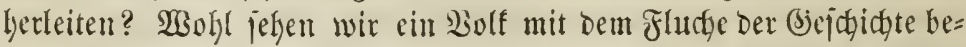

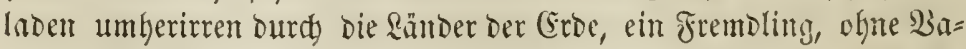
terland, obne J̧eimuth. (Sine jurdtbare Ratajtrophe jerifteute es in

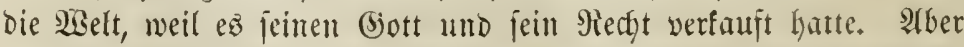
wir jehen auch ein anderes Bolf heimathlos in weite ferte zeritrent,

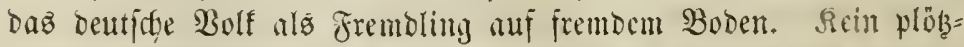
liches Etraigericht zerfiebte es in bie \$sinde; feine Eühte verzag= 


\section{3}

ten in Den Beiten ber Trübjal, fie judften cin Baterlant, weil fie

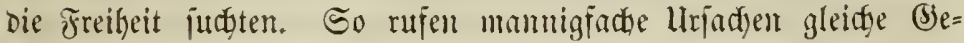

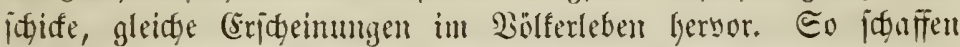

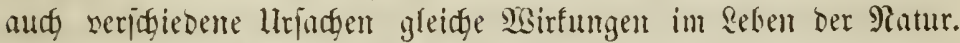

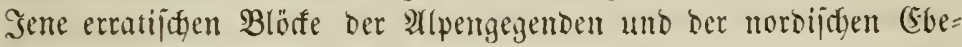

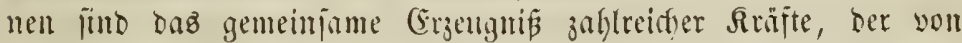
unten herauj bie jeite Erovinde zeriprengensen phatonifaen (bewal=

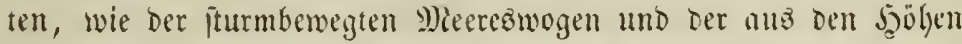

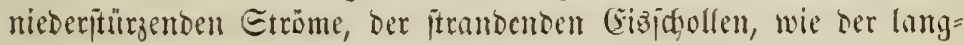
fam niebergleitenden (s)leticher.

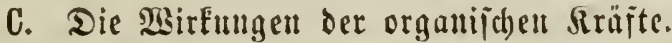

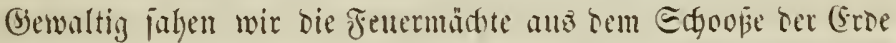

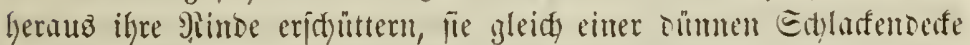
in Falten frümmen, blajig aujtreiben, Durdybereden unto mit ibren

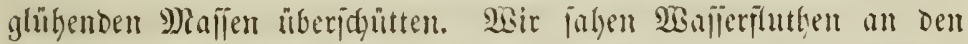

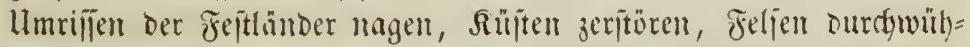
len, Jajeln und Berge verjdlingen, oder neue sänder bruen uno

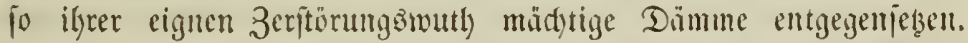

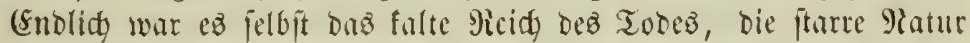

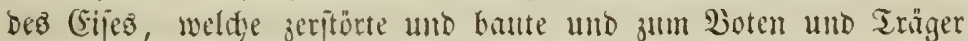

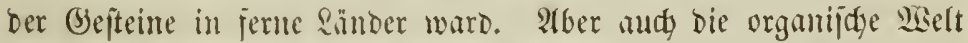
fitaart fith jum Bane bes Erobarls zujammen, uno bie Blitter der

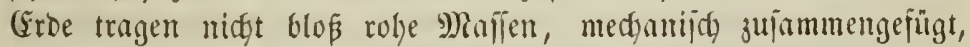

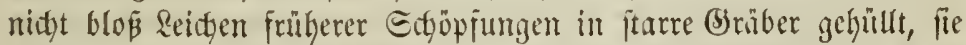
tragen auds lebendige Edyöpfer Der Begenwart, eine regjante 2 Sieft

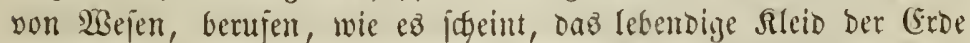

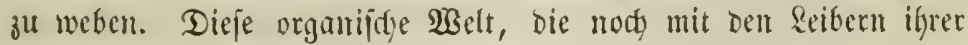
Dpfer in Der Bildungaproces Der Eroe wirfent eingreift, ift nom

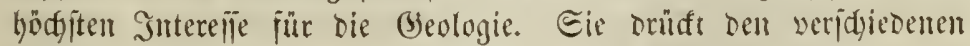
Edjöpfungsepoden cinen bejtimmten lofalen (Eharafter auj, oer um fo mebr lyerwortritt, je Mälyer bie geologiidge (Epodje an bie unjige heranteidgt.

1) Die Bauten Der fiflangenwelt.

Bflanjen uno Thjere geben ber (Erbe wieder, waz your ihr genommen wird. Die siflanzenwelt, biez eigentlicke Fint ber 
Erobe, ftreft aus bem mütterliden Boben empor in bie Rüfte bes Şimmels, als wollte jie aus ihnen die zarteren Etoffe berabholent, um bie Mutter zu Mähren. Wisie Fangarme frreft bie (Eroe bie ßiejenbäume dem Şimmel eutgegen, wie Ceufzer nad, Berflärung entiteigen ifg bie Blumen. In der \$iflanjenwelt verjüngt fids bie Erde, uno ifre todten Ueberrejte find die Duelfen neuen Rebens.

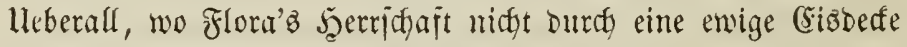

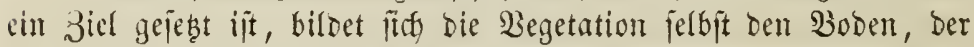

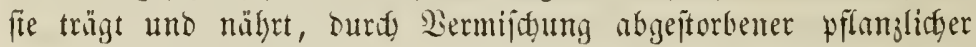

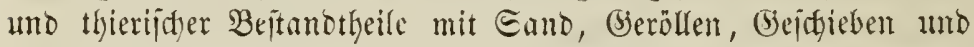
erdigen Thyeilen. Dieje Alfer = ooer Dammerbe hejteht baher aut

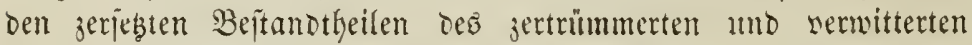

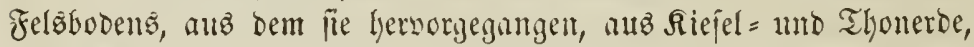

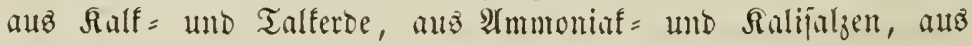

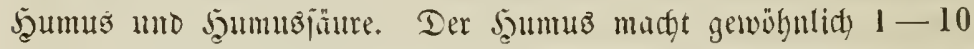
Procent ber frudftbaren Dammeroe aub uno biloet fid unter bem

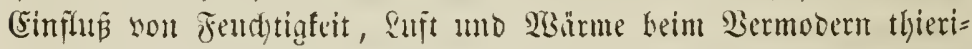
jager uno vegetabilijater Etofie. Dieje braune pulnerförmige Eub=

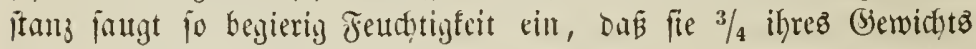

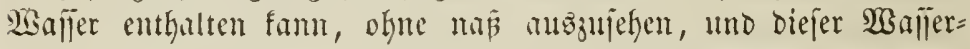
gehalt bient bejonders jur sojung ber Siahrungånittel, weldye bie

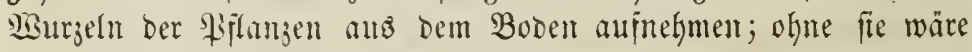
Der Roden mifructitar. Gand=, Regm=, Ratt, unt Thonboben

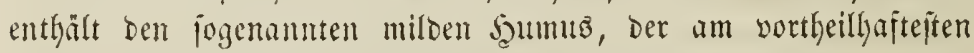

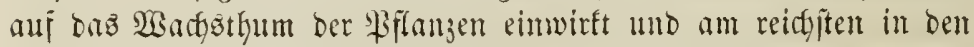
walo = und pflangenreideen Tropenländern norfoumt, wo or oft mehy=

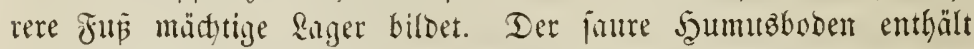

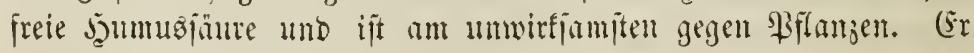

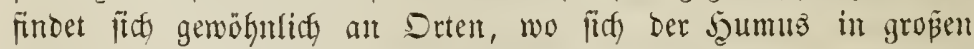
Mafien angebüuft hat, wie in Eümpfen mo Mlooren, und wo,

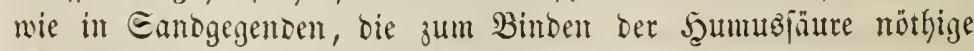
Ralf $=$ und Thonerde fehlt. STm weiteften verbreitet ift er im nörd $=$ lichen $\mathfrak{A}$ merifa und (suropa, und in der fibirifden Tiefebene, der Tunora, bebeft er Taujende yon Duabratmeilent. Stu ifn iftiept

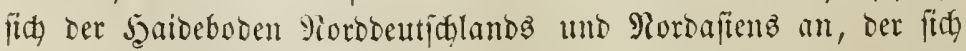
aus unferm Şaibetraut (Calluna vulgaris) bildet unt wie jener ireie Eăuren, yorherrideno aber siohle uno j̧arze enthält. Bese 
wöhnlidy ruht er auf granweí̧em Eanoe, Der in größerer Tiefe balo in gelben Eano ulbergegt, oft aber io ftarf eijenjdujijig ifit, Das er braunreth eridfeint. Dem norbseutidyen :anomann ift bieje

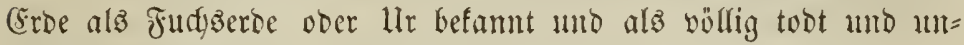
frutctuar werbajt.

Die Biloung ber Dammerbe geht umuterbrodyen, aber äuß̈er f́t

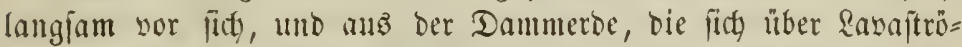

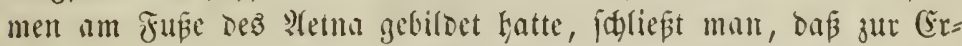

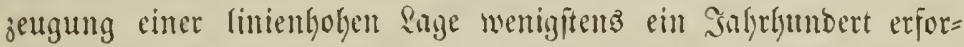
berlidf jei. Sludy Der tiejere llntergrmmo idjeint anj bie Bejdanfen= heit ber Beigetation einen (Sinflus bu haben, wiemohl eas won vielen Botanifern beftritten mird. Ier (Sharafter ber Floren idfeint midgt

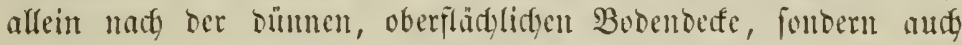

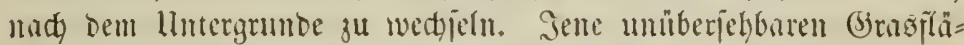
dent ber jübrujiuiden uno wejtakatijden Eteppen, jene einförmigen (5)razmere der amerifanifden Eavannen uno :lanoz idfeinen bie Einjörmigfeit ilfreß (Sharafterz meniger ben wed)jelnten oberen

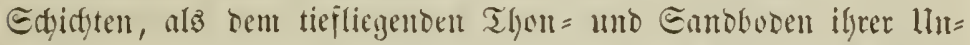
terlage zu verbanten. Dartum gehen bie Faumpas yon Buenoz

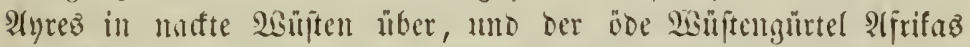

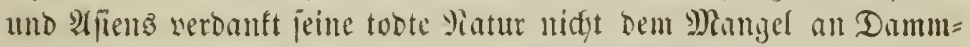
erbe, jonbern ber ltmmöglidfeit, foldye ju bilden.

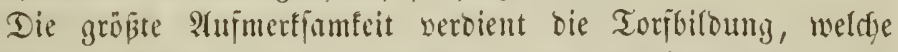
befonoers in Pieserungen, .in nulnen = unt feffelförmigen Bertic=

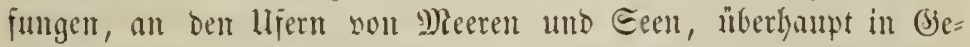
genden frattfindet, bie jährlidy lüngere 3eit unter itagnirentem $\mathfrak{W} a$ a $=$

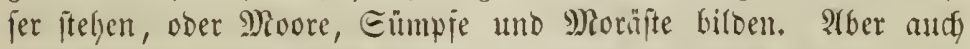

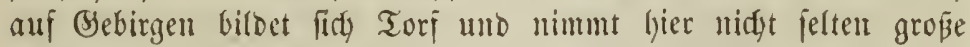

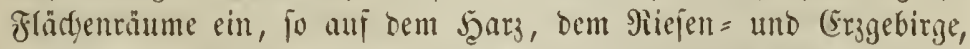

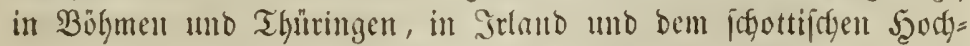
land. Dft bebefft er audy großje Eeen und Teidje voer bildet fogmimmente Snfelus. (Sine ber grö̈sten fidwimmenden Derfen trägt woht ber Reufiederejee in lingarm. Diefe, Dort Sambảig gentamt,

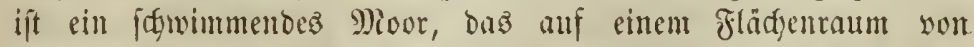
6 $\square$ M. mur 9iohr, Edjilf, Binjen, wertige Birfent uno Erren umb

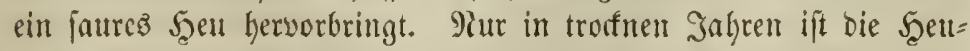

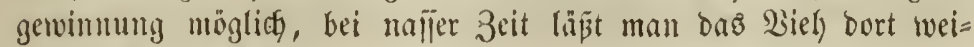


Den, Dasิ oft biż an ben halben seib in Ecblamm verinft. (Es

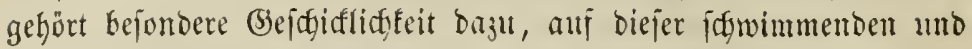
wie sisner wogenten Bodenderfe ju gehen, beren Diffe mur 2 4 Fuß betrïgt.

Aludy ber Tori verbanft feinen Ulyprung abgejtorbenen, yer= moberten und zerjegten Piflamjen, Deren Formen jid um fo weniger in Torfe erfennen lajjen, je weiter bie Bermejung vorgeidritten ift.

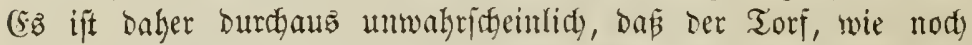
Mandge antefmen, eine eigenthümlidye Minteralfildung, uno bas

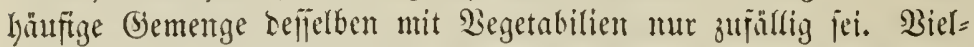
mebr giebt ifm eine burd Feudtigfeit bejdyränte uno aujgebaltente Berivejung und Berfohlmig verjdiebener Eumpipfianzen, bejonbers ber Torjmooje, SEollgräjer, Riebgräjer, Binfen u. a. m. jeine Ĕnt= ftehung, wie man es outd fintiflide Radbildumg bewiejen hat.

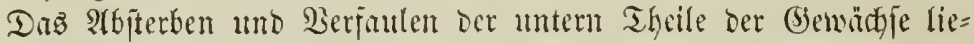
fert bie eingelnen Torfidgidten, auf benen eine neute Siflanjenterfe emporidiefst, bie im Berlaui ber Salyre fidy gleidfaflz in Torf um= wantelt. Die oberite Deafe Der Mrovere bilbet Der Majentorf ober Eticyturf, ber nody als cin verfilates Gemebe ber toribildenden Pfilan=

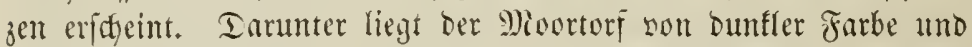
zut unterif Der Fedstori, ein jofwarzer, differ Edylamm, in oem fids) gar teine Prifanzenbeftandtheile melyr finden, bie ifre eigenthümlidse Etructur erhalten bätten, uno ber, werm er in Formen geprept

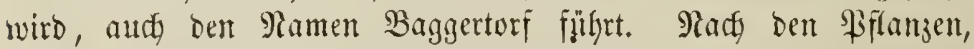
welde bon Torf bilden, unteridgeibet man vor allen ben Moożtorf, ivelder burdy bie eigentyümlidye Bejfaffentyeit dez Eumpfmoojez bie Beoingung feinter bejtänbigen WBiebcrergentyung in fich trägt, wälyento bie übrigen Torfarten, welde Durdy llmwandung von

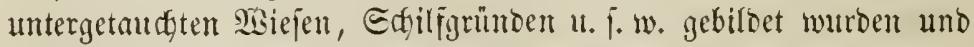
meiftens in alten Eeegründen ober trodengelegten blinden Fluß̧armen

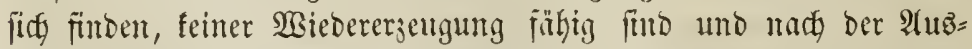
beutung fteril bleiben. Die Etreitigfeiten, welde fich offters über bie Wieberergeugung bez Torfes erhoben haben, beruhten lyaupt= füblich auf ber ungenauten lnteridgeibung ber veridfiebenten Torf $=$ arten, inbem bie Bertheibiger ber \$Biebererzengung fït auf Thatjudyen ftübzten, weldge ben Moostorfen entnommen waren, während ifgre Gegner bie Beweife für ifye Anfidyt in Wiejen = uno Eeetorfen 


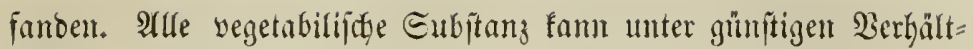
nifien bei geföriger Feudytigfeit แno Druf in Torf übergeben, bas partere Fortwucbern und Biebererzengen bes Torfes ijt aber mur in foldyen 2(blagerungen möglid, weldye aus 9) loostorf gebilloet find.

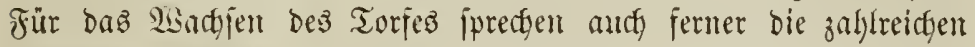

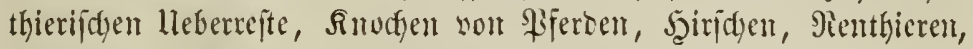
Debjen uno Afneroctien, bie man in Tormoorest funbet. Sn bem oftfriefifden Torfe fanto man jogar unter Bammitämmen einen wohl= erfaltenen menichlichen Eeidnam in ber umerjebrten Tradyt eines

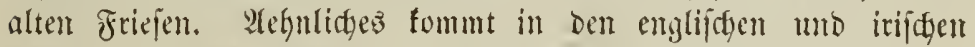
Mooren vor. Anth Werfe von Menidyengand hat man bäufig ge= funden. Eo entbecte man in ber lyollänbijtuen Sandida art Drentlye unter bem Torfe einen Etrußendamm, ber 4500 Edyritt weit wer= folgt wurbe, zum bentlicten Beweis ber oft weit eritrefften Boben= erbölyung ber Torimoore burd) Radmaden berielbert.

3um Brement wirb ber Torf auds in ben norbocutiden (Sbe=

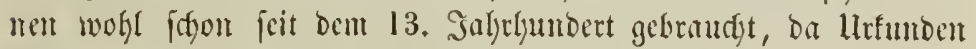
feinter erwillynen. Sine funitgemäpere Geminmung warb jeboch erft

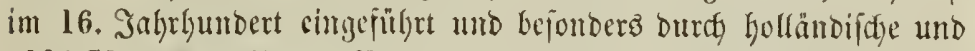
oitfriefiliche Roloniften gejörbert, weldse feim anderes Bremmaterial alż ben Torj fanmten unb unje Borfahren auf biejen Edgał ifrez Bobens aufmerffam madyten. Sn Srland mo auj ber baumlojen

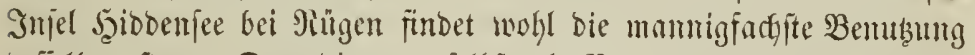
Deffelben ftatt. Dort bient er jelbjt als Baumaterial. Freilich fün= nen bieje Bauten feine \$alajte werden, wno bie armjeligite Alpen= hütte faun feinen traurigern 2 nblicf gewälyen alz bieje arcbitecto= nijđyen Etümpereien, Deren früppelfyafte Formen, mit ifren Dädtern bon Eeegrab, ifrem Semiutur von Torf ober Felofteinen, uno ilyren fleitren Bufflöbern, bie bin und wieber ants gebogenen Edyiffifen=

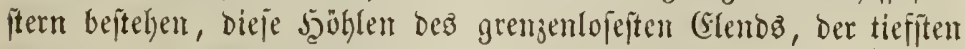

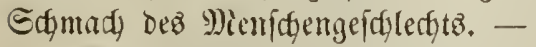

Ein gropartiger Bilbunģproeé burch bie Begetation geht in jenen tropijđen llrwälbern bor, wo nod) feimt $\mathfrak{R} u(t u r$ bas 2 Girfen Der Matur geitort lyat. Dort wirb Der Boben von einer untgeheuren Menge abgejtorbener Baumitämme, gebrodyener und gefnicter Aeîte bebert, Die Durdy wudyernde Edylingpflanjen und ylopje in eime fefte Edyidyt verwebt find, bie fint alfmillig in eine toriähnlidge Єub= 


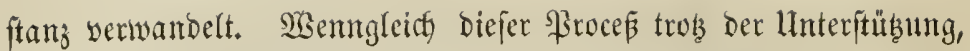
weldye er in ber movifgen Begetation Des Bodens fundet, mur lanty=

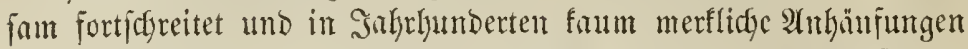
beninft, jo giebt ez body bejondere 3ufälle, weldye bie Edjopjungs=

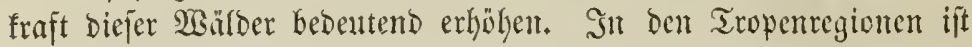

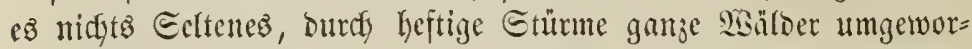

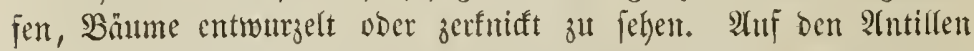

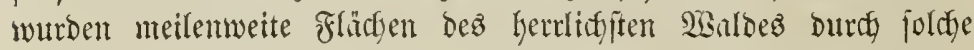

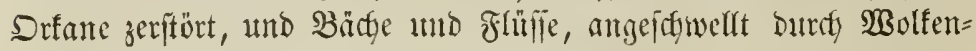

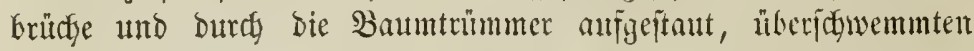

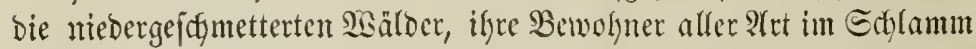
begraberto. Auf meilenweite Etrecten hin wurbe bas Mieer im

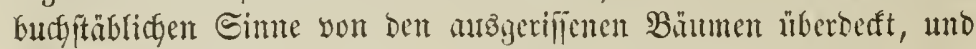

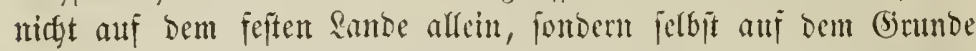

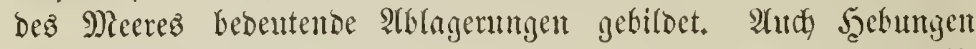
und Eentungen dis Bobenz haben an vielen Etelfen der utropäi=

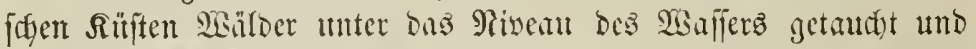

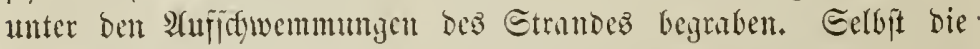

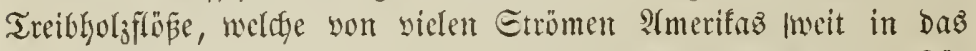

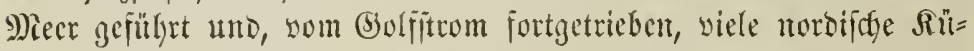

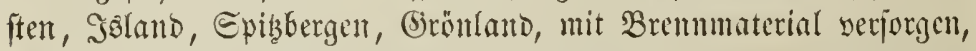

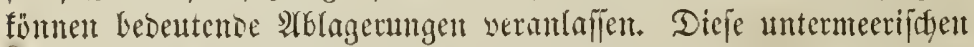
Waldungen zeigen gewöhntidy zujanmengeorürte, bald ftehende, bald

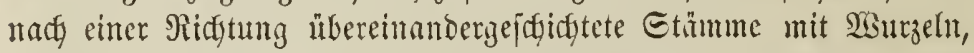

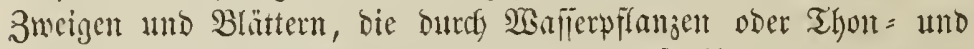
Eandidjidyten zulammengehralten werben. Dft bieten bie Eț̈mme

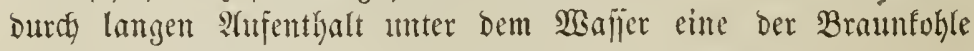

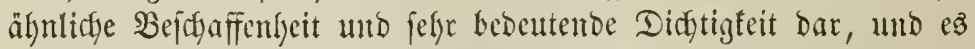
bedarf mur ber Şintweifurg auf bie 3ufammenjebutg unfrer Braun= fohlenlager aus übereinandergeworfenen, 3ujammengebrilften Baum=

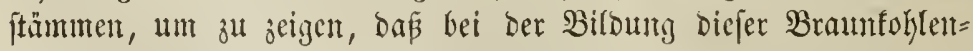
lager ähnlidje \$igunnmene im Epiele waren. Die gewaltigen Tan= nent = und Sicftenfitümme, weldye unter bom Boben ber baltifcten EGenen lagent, bie ganj verfiejelten Baumftümme, bie man neuer=

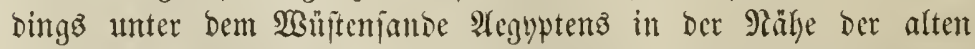
Fyramiden aufgejunden hat, bie Edyjuten Garziger Baumftämme, bie mit Eamb unt Eteinen auf ber eifigen Snfel Meu= Sibirien 
einen ganjen Berg zujammenjeben, fie alle fitto jpredtenbe 3cugen für bie Theilnahme biejer lebendigen Patur an ber (Sejdyidgte unf= rer Sorjeit.

Sin gans bejonderez Snterefle gewähren bie verjunfenen S⿱乛龰äl=

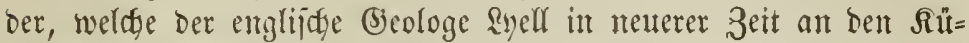

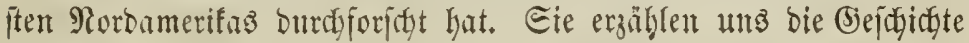

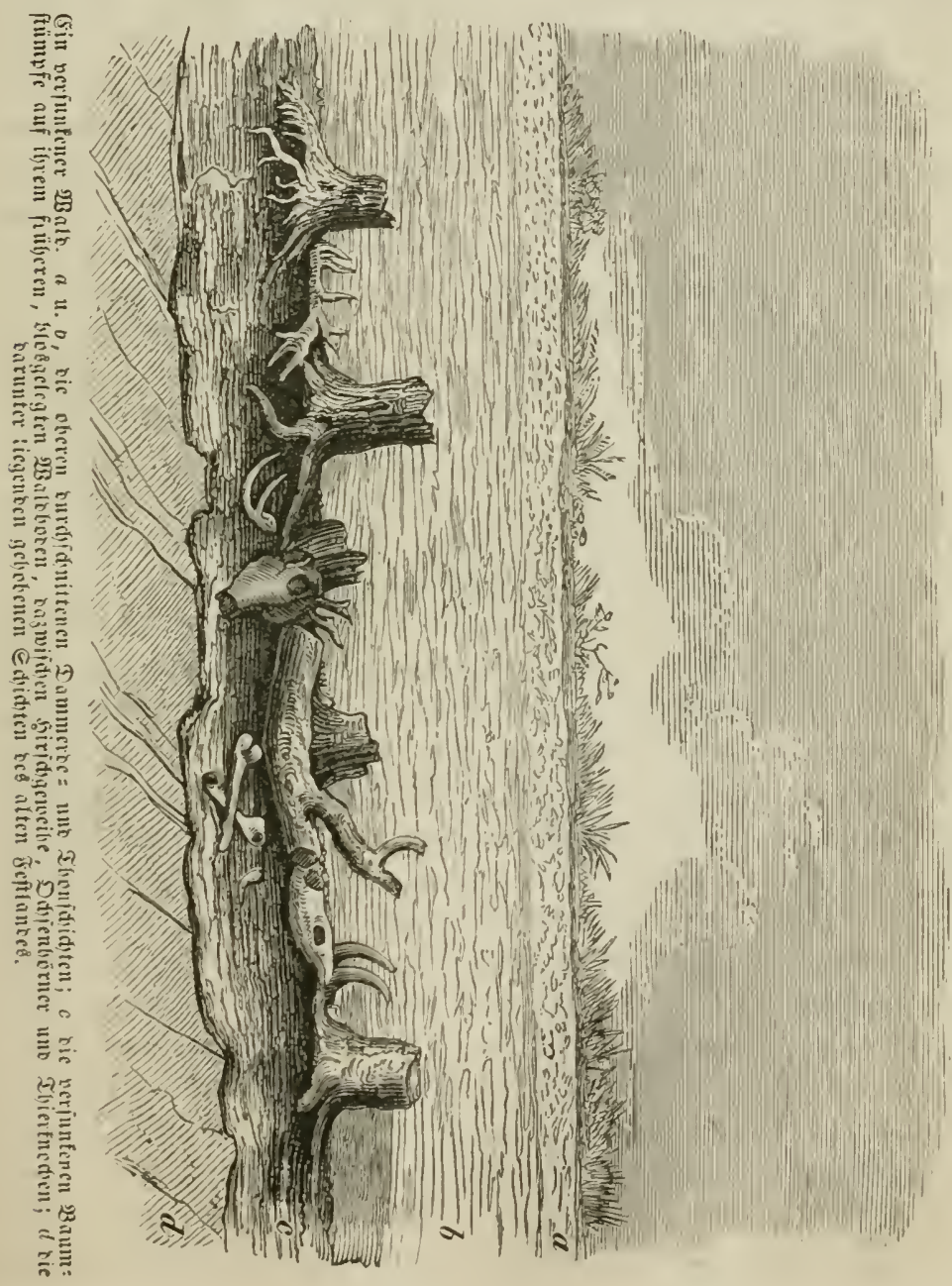


ifres Tobez, wie bes Bobens, auf bem fie einjt grünten. Sie er=

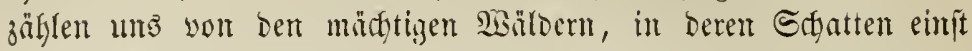
Die Riejentthiere ber Dorjeit, Das Megatherium, dns Maftobon,

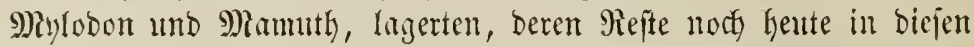
Marjajen liber ben Edjalen Der Gegenwart angehöriger Mufitel= thiere gefunden werben. Sn bem Fluffe Aflatamaha in Seorgien liegt unweit feiner \$Münoung die niebrige Snjel Buttler. In ben Ealzmariften biejer S̄nfel finto bie aufrectit jtelyenden Etümpfe und

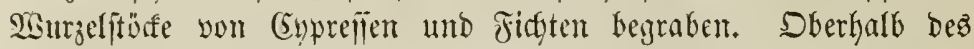
Braffwajlers jiefen fïf nodh jeß̧t weite Etreffen angejdmemunten

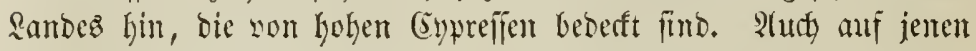

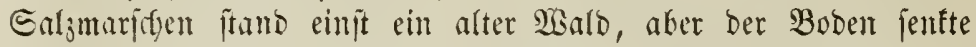

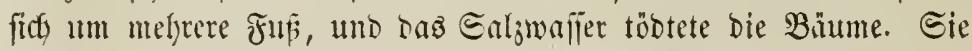

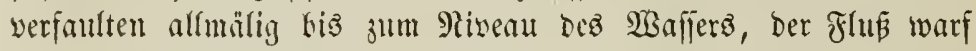
teue Ragent von Eand und Dammerise auf bie Ethimpfe und er=

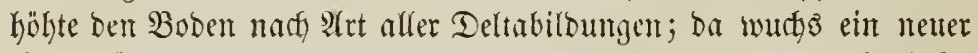

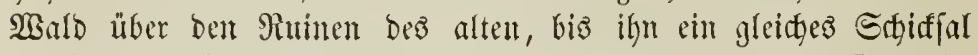

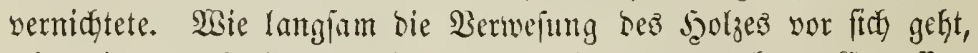
zeigt eine Beobadjumg, bie man in Sappetun madte. (Enprefien,

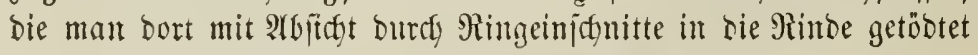
hatte, ftanden nod) mady 30 Safjen mifred)t.

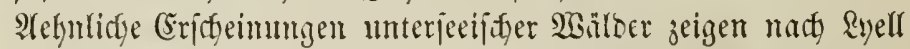
Die ganzen Diffüften 9ordamerifaz non Carofina, Bicorgien umb

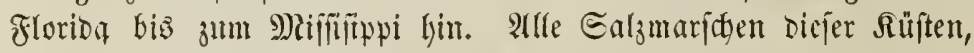

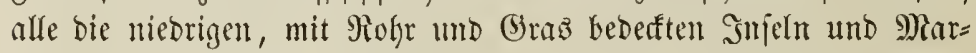

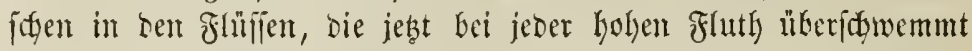

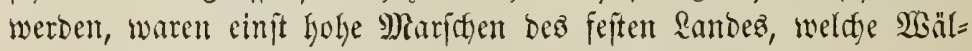
Der yon Cupresuss thyoides, Tupelo, Magnolia grandiflora, von

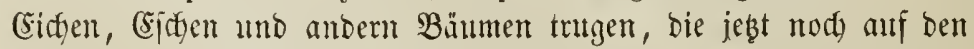

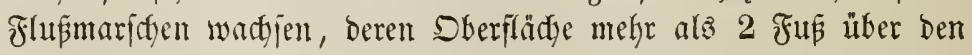
Epringfluthen liegt. Die Bfflamjer biefer Rülften wifien es jefhr

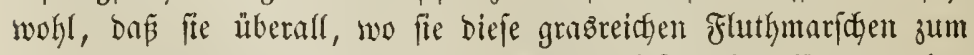
शrrbau eindämmen, nidgt n̈ber $3-+$ Fup tief graben fönten, ofne

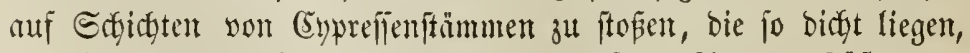

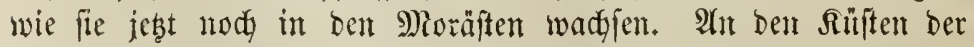
nörolidyen Etaaten, wo Das $\mathfrak{S}_{0}$ lz faton felten geworden ift, hat

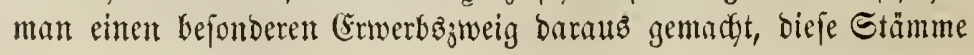




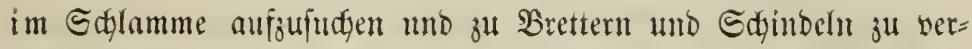
arbeiter.

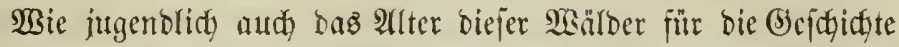
ber Cerbe fein mag, fïr bie bea Mienjhen ift eż immer ein fehr ljohez. Daz beweif́t bie ankerorbentlidye Tiefe, biz zu weldyer ber Boben ber (Eedermaridyen dez (5ap Mary ant ber Eübgremze von Rew = Serfety an Der Ditfüfte Der Defaware $=$ Bai mit Bäumen erfüllt ift. Mit ifren $\mathfrak{B} u r_{j} e_{n}$, wie fie gewadjen waren, ftefen Banm=

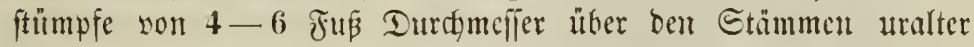
Sebern, bie in jeber möglidyen Eage, oft horizontal hibercintander

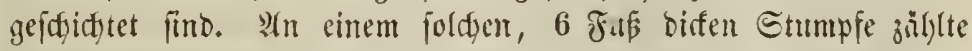
man 1050 Safrezringe. Darnuter aber lag eit umgeworfener Butum, ber über 500 Siljregringe bülylte tmb offenbar begraben war, elye ber obere frropite. Wiste siele anbre afer mögen mody in Der unbefannten Tiefe dea Mroorgrundea werborgen liegen! So er= hob fids eine Begetation nady ber anbern liber ben Bräbern, แnb

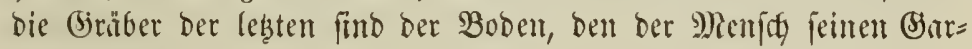
ten nennt!

\section{2) Die Bauten ber Thierwèlt.}

Wie bie \$iflumgenwelt, fo baut aud bie Thiermelt ifgre Sager und Berge auF. Bor allem erregen baz Snterefie bie grop̈artigen Bauten ber Rorallenpolypen, bie Siorallenriffe und M) Rabreporenimfelu.

Mitten auz bem Meere Der Tropen, faum von feiten burdy=

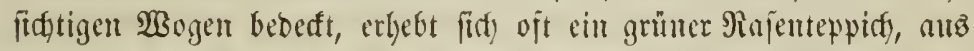
Dem an zierliden Eträudern Guntprangende Błumen bervorjdyim=

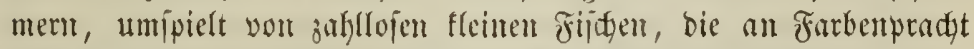

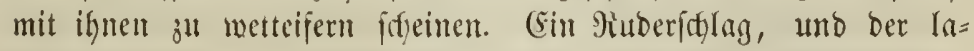
denbe 3auberyarten ift veriftwumben, bie ftrallenten Bhumen find verwandelt in bie raulyen 3aten cinez brolgenden Soralfentiffz. Die Rorallentfiere fint in ifrer Bauarbeit geftort.

Sn ber That lielt man in frillyerer Zeit bieje Thierdyen für Bflaujen mit Blïthen und Frïdyten, felbft für Eteine, und alz

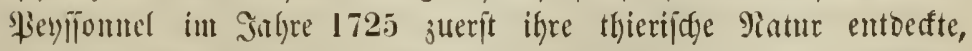
wagte er es nidyt, jeinen 9tamen zll memen, weil er ben Spott

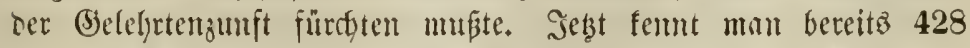
Arten joldger bautgätigen Thiere. Cine berjelben, bie Madrepora 
abrotanoides, zeigt bem eejer bie beiftefende Atbrildung, A it ua=

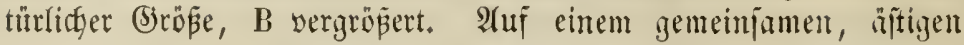

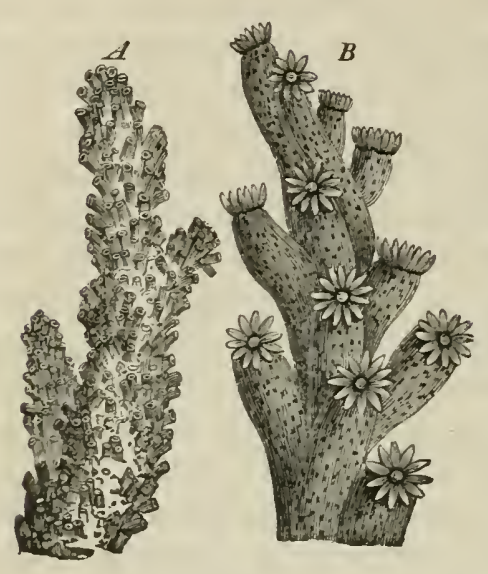

Madrepora abrotanoides.

Etocfe fieft man eine Mientige fleiner bedierförmiger, oft jtern= förmig eingejdnttener $\mathfrak{g}$ öhlen oder Bellen, aus benter im $23 a i=$ Fer Das lebende Rorallenthier, ber Polup, fine Fangarme kerwor= jtreft. Sebe biejer Bellen ent= Gält ein Thier, oft mir von mi= frojfopiifter Eidgtbarteit, und alle Dicje Thiere jtehen, wie fie anto gemeinjantem ltrjentug herwor= gingen, mit einander in Berbin= Dung, oft jelbit burch iffen Darm=

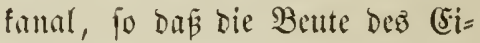
nen allen Althern bei ber $(\mathfrak{s}=$ แäfyung ju Gute fonmt.

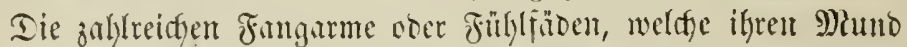

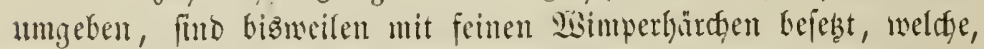
wenn Das Thier jeine Fangarme aubhreitet, in cine jonelle, wir=

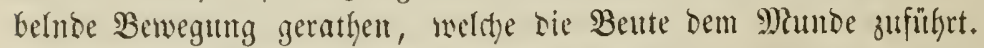
Bei manthen Arten entfalten fie nody furdtharere 2 Baffen, näm=

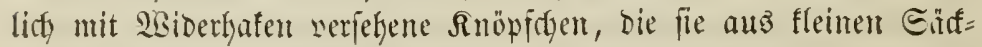
deen an langen, fpiraliy gewumonen fäben mit Bswalt herwor=

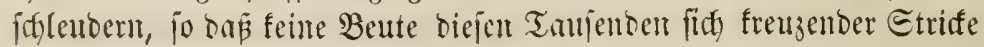
jll entfommen vermag. Bei Andern find fie endidy mit ipiben

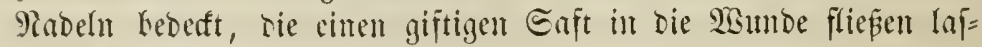
jen, ber einen frennenden Edfmer; beruriacht.

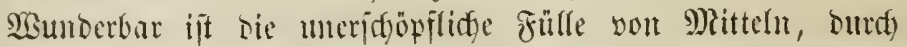
welche Die Ratur bie Gejdyledter bicjer Thiere ju vermehren weí, uno bie Eethelligfeit mo Eigenthümlicteteit biejer Fortpflanzung weijen lǟ̈t ums allein bie Edynelligteit ifyrer Bauten begreifon. Wir fehen hier bie gemöhnlidye gejoledttidge 3engung ourd) (Eier mit Dutterhaut, Dotter, Reimbläschen und Reimflect. SBir fehen Sunge gebären, bie anfangs jrei untheridwimmen, bis fie ficts fẹt= keftent unt bie Mütter netter Rolonien werben. Wir feken aber 
auth Sinospen ficty an ben ßolypen entwideln, bie, anfangz nidytz alz einte Erweitermy dez Darmfanalz, balo fich jur zellenförmigen

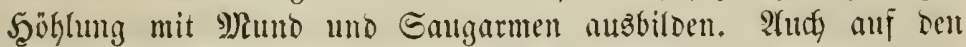

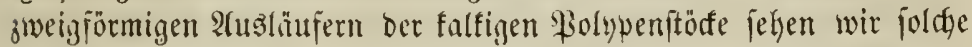
Snozpen entiteben, Die zu jelbitftünbigen Thieren mit eigenen Darm= fanälen werben. Sa, dieje Sitosipen fömen jelbft abfillen und (iid) getremt vom Mutterthiere im Meere entwirfeln. Wir jelyen

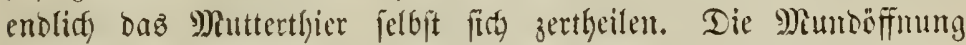
wirb Durdy eine Edyeibewand in jwei Deffimmgen geipalten, und Magen, Darm und Fangarme nelmen an biejer Epaltung Theil. Die jonberbarite Fortpflanjungżmeije jengen bie Folvpen in ber Bildung gewifler einflntidger Röperdyen, anz benen Thiere ent=

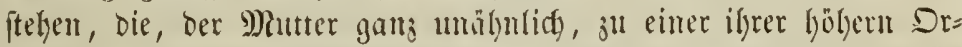
ganijation wegen gewölynlid ïber bie Folypen geftellten Thierflafie,

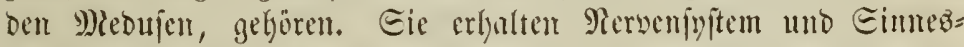

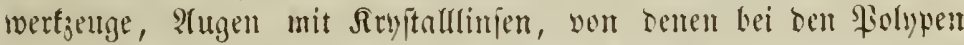

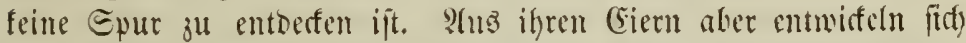
feine Mebujen wieber, fondern Fiolypen, gleidy bemen, ans welden fie herworgingen. Eo verjateden, wie die ?(rt und werife, jo groß ijt Die Sdjnelligfeit dicjer Bildungen. Bimmen 32 Etumben ent=

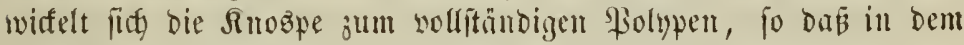
3eitraume einez Monntz die Bildung eimes Polypenftantes yon melyren Millionen Sndividuen mögridg wirs.

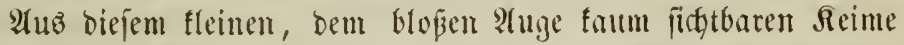

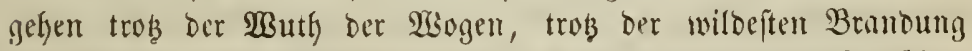

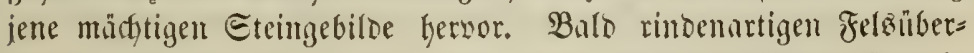
औigen gleidgent, wie Eschara und Astraea, bato äftigen, ftrauth)= artigen Gemäđgjen, wie Marlrepora, bald atz tugetige, tohltopf= ähnlicge Mafien, wie l'orites, ober in pilz = nuto bedferiafynlidyen

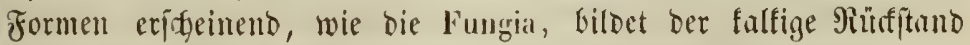

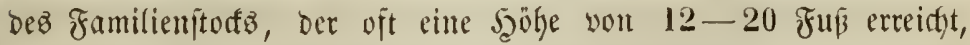

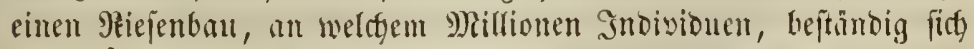
auzeinanber entmifelno, gebaut haben. Diefe fteinartige Eubjtanj

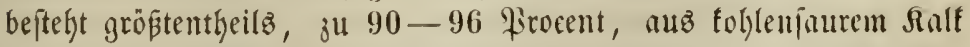
umb entbält außer den lleberreften ber organifdgen Berwebe mur nod) in geringer Menge Berbindungen von Fluor, Bhosplyoriäure umb Riefelfäure mit Ralf, Bittererbe und Thonerbe, Stoffe, bie 
jämmtlich im Meerwafier vorlyanben finto. Allerbings ift ber fohlen= faure Ralf, wie wir ihn fonft als Sreibe fennen, nur bann im

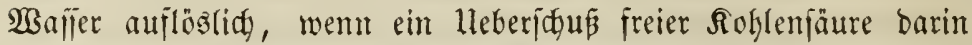
workanden ift. Man hat bie Suefle biejer im Meere nidjt abzu= leugnenden Rohlenfäure in jebr veridgiebenen Mmitänden gefutht,

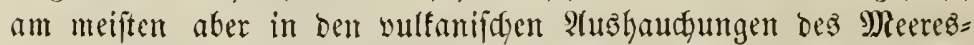

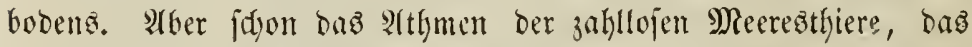
ja immer ben aufgenommenten Eauerito if in Rohlenjäure vermant=

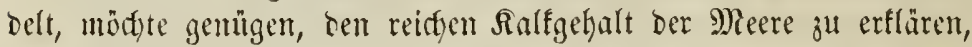
Der tropiiften Meeren oft jelbjt bie Eigenfdyaft zu infruffiren ser=

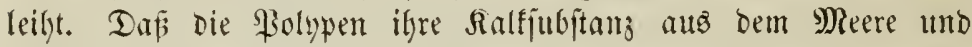
zwar burd igre Mahrung aujnefment, ift ungweifellyaft. WSie wir

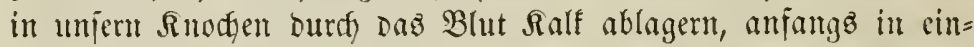

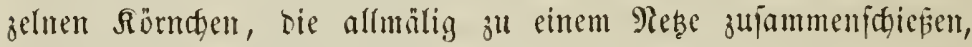
Defien Majiden immer bidfter werben und wadjen, fo lange nody

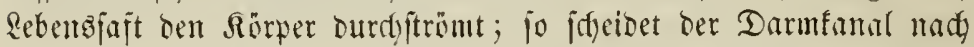

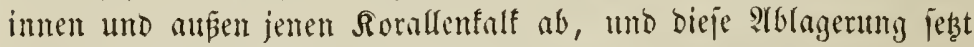

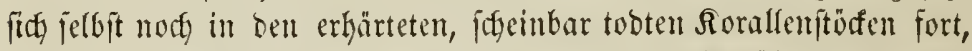
burdy beren zaflloje mit Dem Dorm verbundene Santile nodf immer

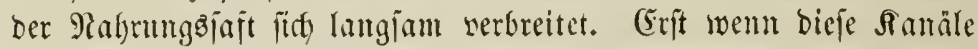
im fortiffereitenten $\mathfrak{B a d t g t h u m ~ v e r f t o p f t ~ w e r b e n , ~ f t i r b t ~ b i e ~ \Re o r a l l e ~}$ ab. Atber Reben uno Too grenzen hier aneinanter. CEin jungez

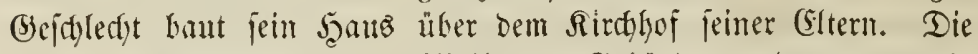

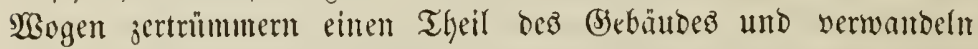
ifn in Etrutb, aber bie Sugend arbeitet raftlos vorwärto und fpot=

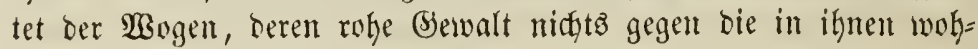
Hente Rebendfraft vermag.

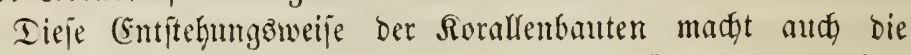

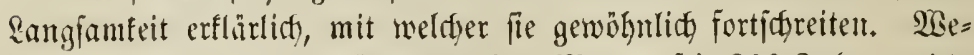

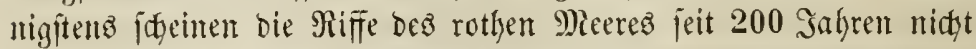
zugenommen zu haten, who bie Tiefe über Den Rorallenbunten yon Taiti ift gewiép jeit mehr als 70 Gahren unveränbert gebliebent. Rur in einjelnen Fällen tritt cime auß̧erorbentlidye Edynellighit beß Baute berbor. Eo wurbe auf her inbiften Injel Reeling ein fünft= ridger Simal in 10 Safreen burty bie Rorallen unifgiffbar, unt bie Bewolyner ber Maledinen muiffen beftäntig bie Rorallenftämme zer=

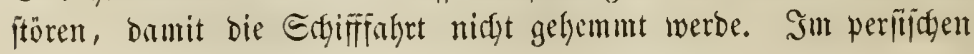




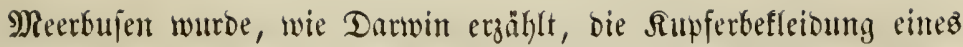
Edfiffes im Berlauf yon 20 Mronaten burd eine Roralfenlage won

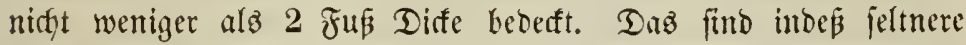

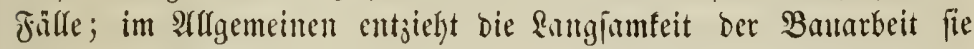
ber Beobactung.

Daju fommt, bas, wie jebes Reben, aud bas ber Polypen an

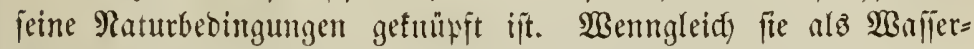
bewohner nur unter feter 2 Bafferbebeffung, wäre ca anty nur in Edyaume Der Branbung, leben fönnen, und auft und Eomengluth ihnen augentrfifficten Tod bereiten; io vermögen fie bods nidpt in jeder Tiefe auछ̉uthalter. PRidgt bloß ber mit ber Tiefe zunehmende

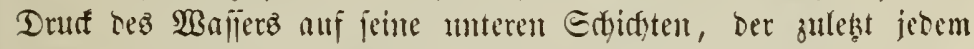
barten Seben eine Brenze lest, fortoern aud bie mit ber Tiefe ab=

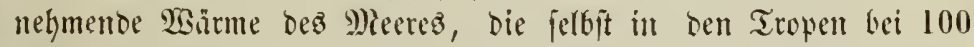

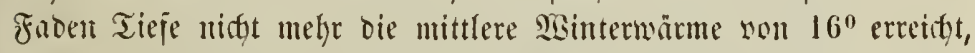

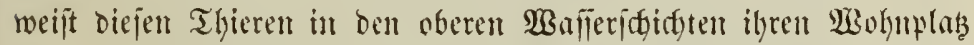
an. Die lebbaften Farben der meiften Solypen fpredgen itberdiez

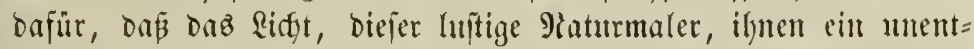
behrlidjer Rebensereis ift, den fie mar an der Dberflädye empfantgen

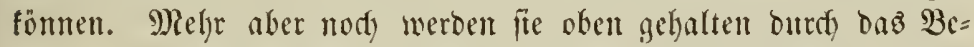

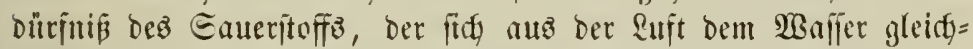

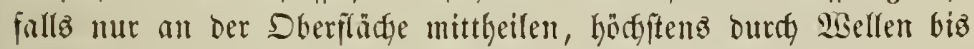
in eine Tiefe yon 30 Fraben зugefintyrt werben fann.

Die forallenbunenden Siblypen leben baker, wie ez and bie

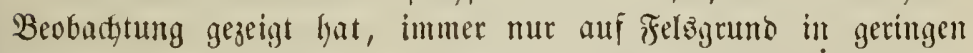
Tiejen, 6-9, jelten 20-25 Faben tier. Wentigftenz fano (5gren=

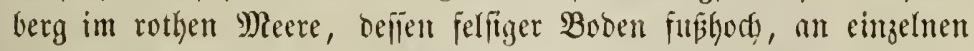
Stellen 9 Fuß biff von Soralfen überzogen ift, feime lebenden

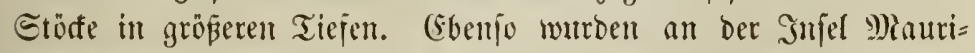
tiuz in einer Tiefe von 8-12 Faben nur nody bereinzelte unto unterbrodene Soralfemitsumme gefunden. SBent bagegen in neuterer

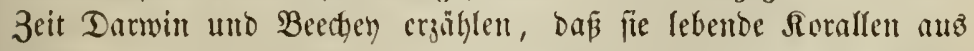
Tiefen non 160 uno 190 Fnoen herantholten, uno wenn Siós jelbft inuerhalb des fïtlicten Folarfreifez fie undy in einer Tiefe yon 270 Faben (1620 Fnßß) fanto; fo giebt bas mur einten Benveiz für

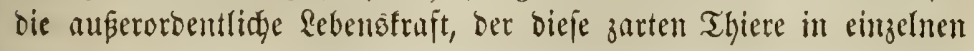




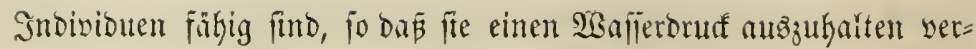
mögen, welcter ben unirer 9 (tmojphäre um Das 50 factje übertrifft.

Den fräftigften Beleg Dafür, boß́ bie Gauenden Forallen ilgrer

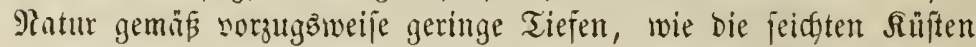
son Smjeln uno Continenten, jum Bauplat wällen, liefent bie

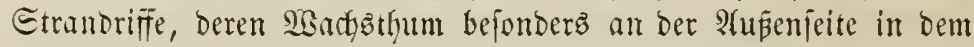
ftarf bewegten $\mathfrak{B}$ anjer ber Brandung friffig fortiftreitet. Da bie Sorallen mur flares 2 Baffer lieben, fo findert fid bieje Miffe ofjt in

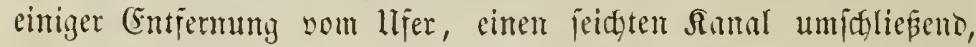

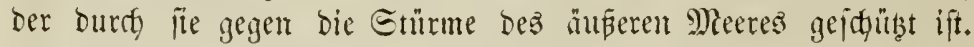
Mintoungen von Etrümen unt Bäden gegenüber fehen mir im=

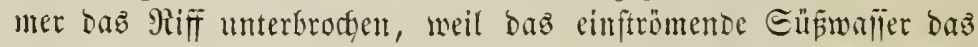
Reben ber Folypen beeintridstigt. Bald wenige Edjritte, bald meh= rere Eeenteilen breit, je nadfbem bie Büften fteiler ober flacter in

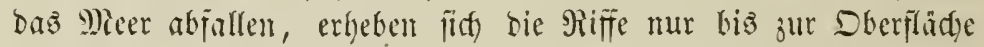

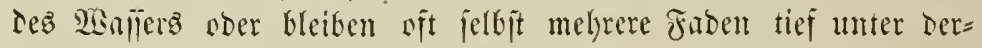

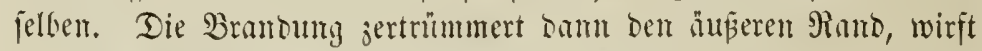

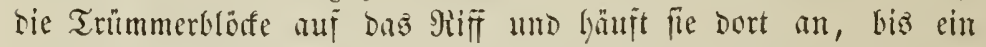

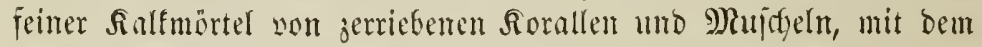

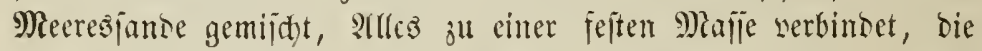

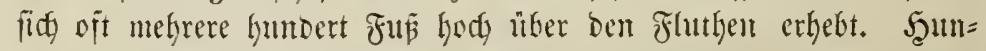
Derte son Eemeilen entlang umbiegen indfe Etranbriffe bie Snjel=

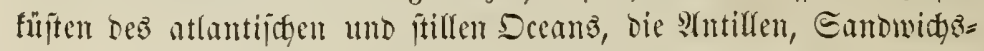

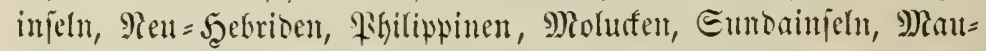
ritits uno Madagnafar. Im jeiđten perififfen Meerbujen verbrei= ten fie fïh jogar über meite frläden ber sffenen Gee unb bilden sereinzelte, muloenförmige Untiefen, jelbit rintgiörmige Someln, da ber Bau am Sande immer ifonefler voriffreitet, als im Snmern.

In Derifelfen Mieeren begegnen wir nodh anderen, wiel rüth= felhafteren unt mädtigeren Roralfenbanten, ben Dammriffen, bie

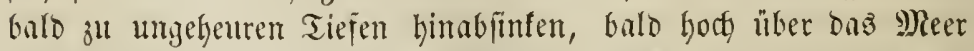
emporfteigen, Felammauen uno bebirgen gleid. Die netberiftehente

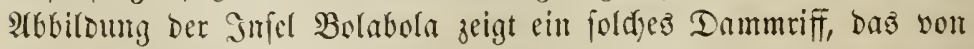
tem intern Felfenferne ber Injel ats wie ein weiter, flatter (S)İ =

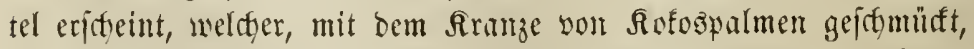
ben rubigen Raguntentanal von ber wogenten Eee fdeidet. Sft er=

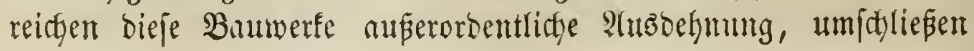




\section{7}

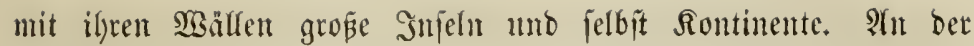

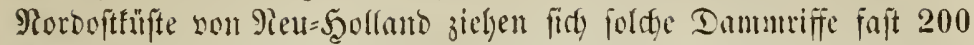
Eemeilen weit hin, mo aud an ber Süfte von Mieu= Ealcbonien

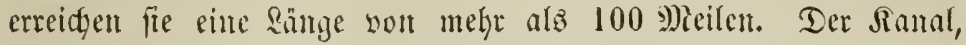
weldyer bieje Briffe von ber Siljte tremnt, zeigt oft einte Breite von 20-30, jelbit 70 Eiemeilen uno verengt fid felten anj wentiger

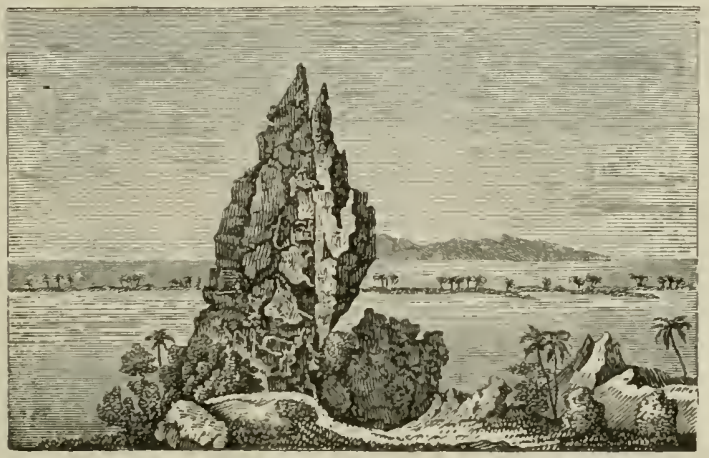

Tie Soralleninjel Bolabola im ftillen Decan.

alz 7-8 Eemeilen. Wie bei ben Etranbriffen, ift auth hier ber

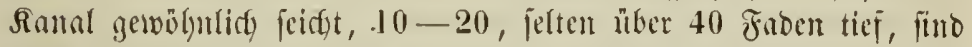
nutb bieje Miffe oft fuftief nom Miete bebeft ober in fladse Smpern

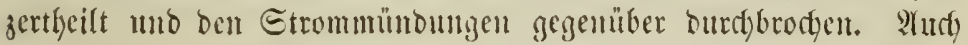

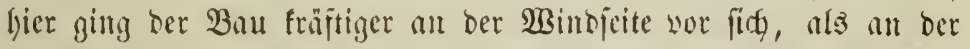

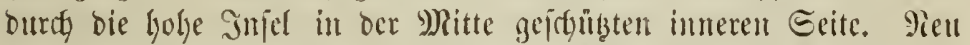

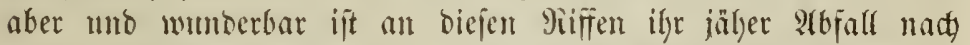

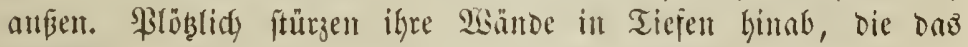

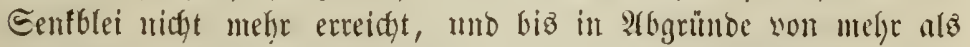
3000 Fuß befteht Daz ganje Siif bemody auz Sorallenfalf. Thiere vermodyten in foldgen Tiefen nidgt zul leben, nlfo aud) nidyt ju battell.

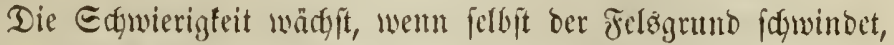
nuf bem bie Sorallen eine Barfitte fanden. Bei ben Dammriffen lies ifyn bie lobe Sufel, bie fie umgaben, noch errathen, und wenn

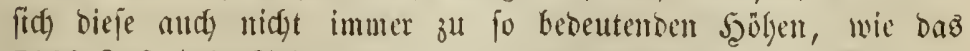
7000 ruß bohe Taiti oder aurd mur baz 800 Fuß bohe \$)inurua, exlyebt, fo taudgen bod wenigftenz, wie twir ez bei Bolabola faben, 


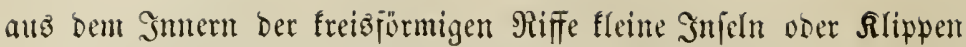

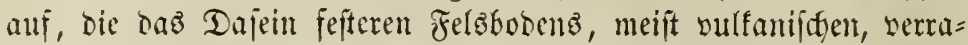
then. Atber mitten aus ber uttergrủndliđjen Ticfe bez Deeanz ftei= gen jene ringförmigen $\widehat{N o r a l l e n r i f f e ~ e m p o r, ~ b i e ~ m a n ~}$ Ptolle genannt

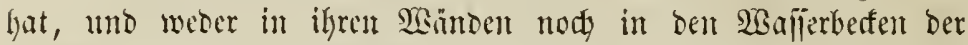

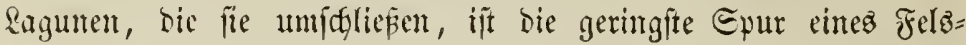
geiteins zu entoeffur. 3u vielen Taujenton fintoen wir bieje JMjeln in ben tropijfen Mieeren, weit won jeber Sinifte entfernt, und meift bilsen fie zahlreidge (bruppen, wie bie Micorigen Injelm, \&ord Mulgrave's Prrdtipel, bic Carrolinen, bie Racadiven, Malebiven uno

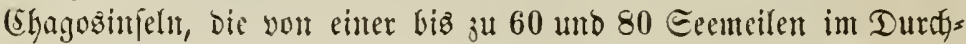
mejier inefien.

Sn ben Umrifien zeigen bieje nicorigen Soralfenimfeln eine mett= würbige Hebereinftimmung.

In ber Tropenjone deż groß̈en Deeans, bie unter bem Csin= fluife Der \$allatwinte liegt, find bie Difeiten der Rorallenriffe

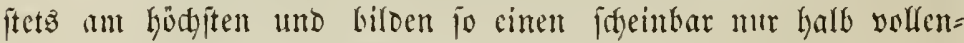

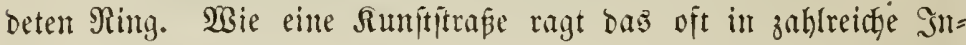

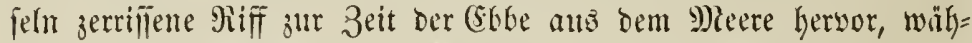

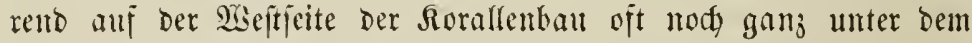
Bajijer verborgen beibt. Sit aber ber Bau weiter worgeidritten,

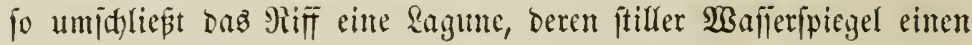

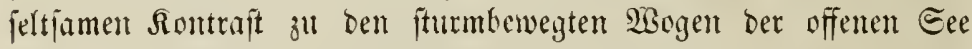

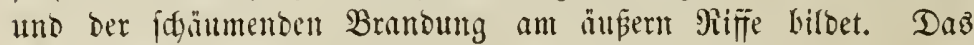

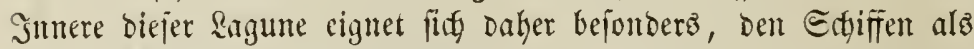

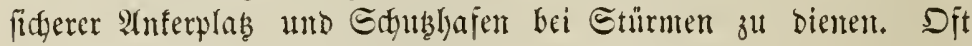
aber wiro bicjes immere Beffen burdy daz geidhäftige Fortbanen ber Sorallenthiere allmälig erfïllt; uno jo bildot fid) zullę̧t eine einzige

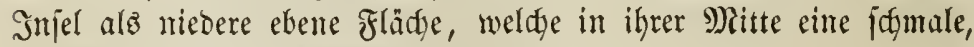

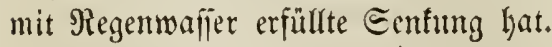

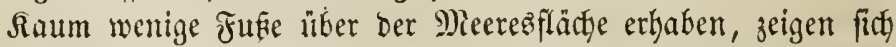
foldye 2 tolle oft fajt gans som $\mathfrak{W}$ ajier beberft, unt nur eine fijmale

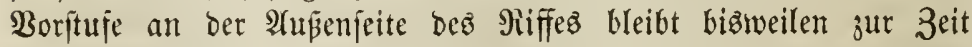
Der (Ebbe troffen. Aftrore werben wenigitens bei ftarfen $\mathfrak{B}$ inden

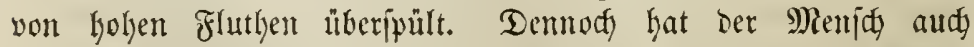

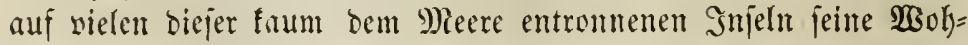
mung aufgeidslagen. Wienn ber Eomenftrahl bie Rorallenmaffen 
Durdyglïht und gefpalten, bie Brandung ifhe Trümmer auf einander gethürmt, unb falfiger Eand fie all einem feften Boben verfittet hat,

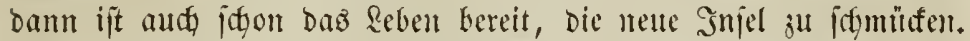

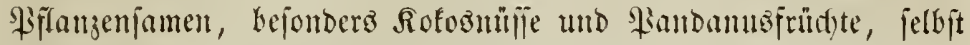
ganje, nod feimföhige Baumitumme werden burd bie $\mathfrak{B e f l e n}$ von

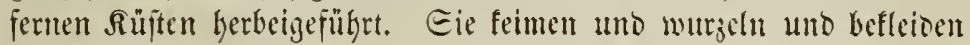
Den blendend weipen (Sirund mit fanfem (Sinü. Berirte Bögel miften bald in ben Bebuijden, und mit ben Baumitummen ent=

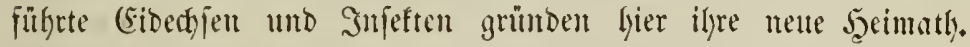
Endid fommt ber Mlenid, son fdnober (Bewvinnjud getrieben, bant

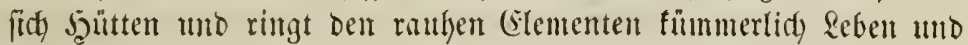
Ralyrung ab.

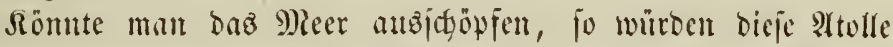
alż gewaltige Regelberge, bie Dammriffe alz rieftge fels̈manten

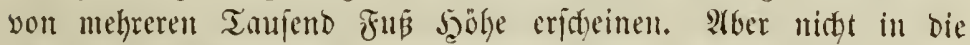

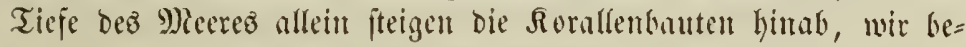
gegnen ibnen auf ben Injeln bor Elidie oft aud mitten auf bem

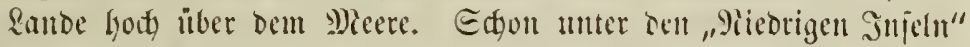

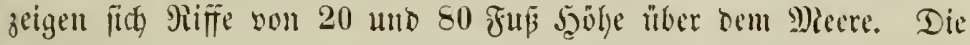

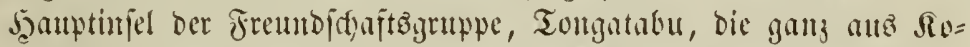

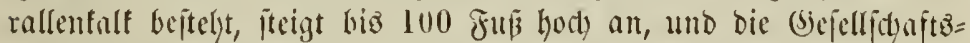

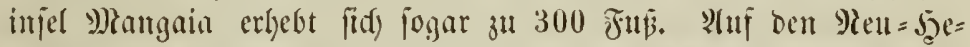

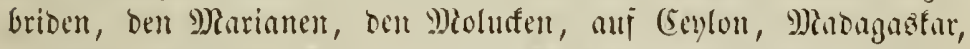

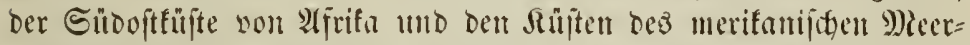
bujeng fintet man hod, über bem S)eere liegende Sorallenfelien, Den neueren Etranbriffen ganz älynlidy.

Eo lange man die Thätigteit ber Solypen nid)t aufmerfiam beobudbtet batte und mit flüdytigem $\mathfrak{B l i f f e}$ and nur auf igre $\mathfrak{B}$ au=

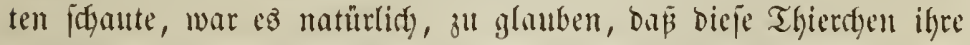

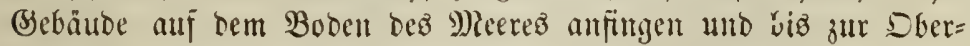

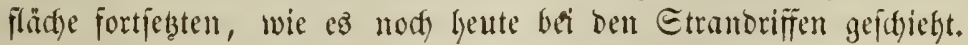
Den Wellen und bem 3ujall

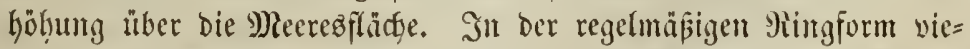

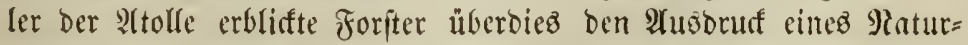

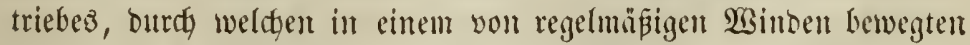
Meere die Rorallentfierdyen ifyre Befaujung vor ben Birfungen ber

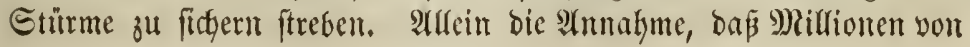


Thjerdfen, bie auf einer fo miebrigen Etufe ber Drganijation ftelyen, nadh einem gemeinjament, tiejeingreifenten Filane bauen, wutbe um

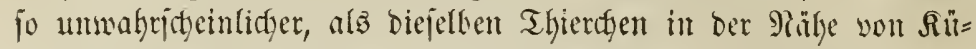
fent Miffe bauen, bei benten pie biejen Brumbjuts nidft befolgen.

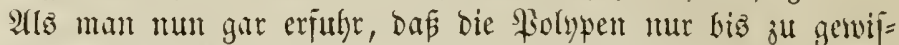

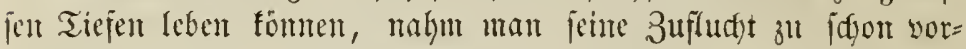
handenten Bergen und Bergrüffen des Mieeres, auf benten bieje Thiere ifren Bau beginnen fomten. Freilid) mußten bieje Berge

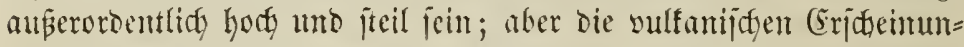
gen, benten man bei einzelnen âtollen begegnete, bie vulfantijgen Gefteine in ifrem Smmern ober Feuerberge in ifter Siähe, gewähr=

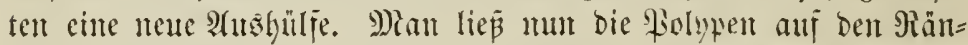
Dern auşgebranuter, unterjeeijager Bulffane ihre Bauten aufführen

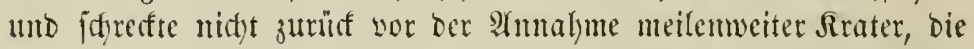

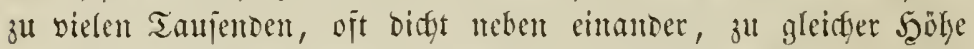
won etwa 20 Faben unter bem sisajer fid erfeben jollten.

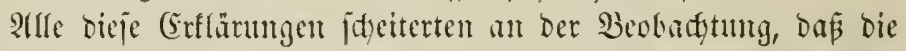
Soralfenbauten ofit zu ungefeuren Tiejen Des Mreeres linabgeten

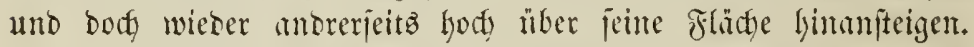

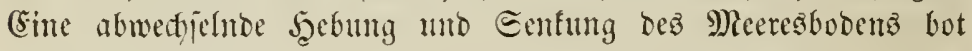

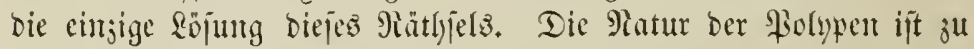

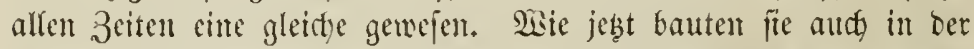
Borzeit unr Etrantoriffe au faujt unter Dıв Meer abjallenden

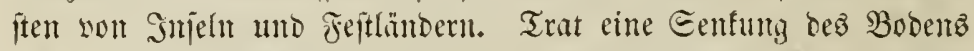
eint, fo ftieg Das Meer und beberte Santo und Miff. Pber bie \$o=

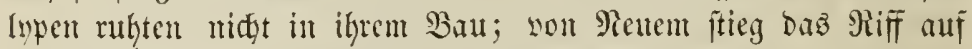
Den Trïmmern ber abgejtorbenen Rorallen zur Dberflüdye Des Mice= res empor. Se weiter bas CEmpinfen fortifyritt, defto mehr ent=

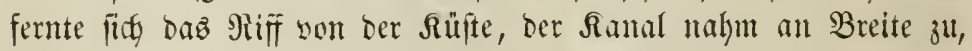
bas Rano veridgmant entlidy unter bent Ffluthen, unb ber Sinnal ward zur Ragune. Bejanten fith in ben uriprïngliden Strand= riffen, wie in ben beutigen, ben Etrommüntoungen gegenüber ofiene

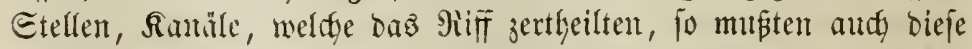
natürlidy mit bem Einfen bes Bobens immer breiter werben. STh=

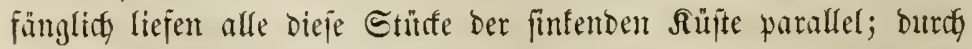
Den fetizen Fortbau ber \$olypen an ber Fupempeite aber frümuten

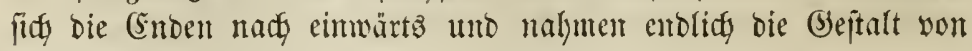


S马ufeifen an, wie wir fie nod, irbat bei den Malcoiven fehen, ober singen in geidtoflente nod) bie Epuren ifhrez frülyeren 3ufanmenthangez. Eie im Berein

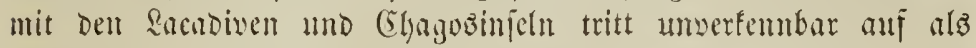
Das zerrifīen, 360 Meilen lange Erranoriff eincz verfunfenen füd=

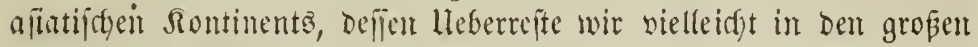

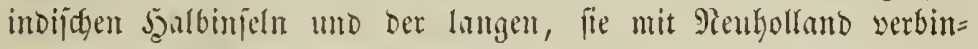
Dendert Sinjelfette zu jucten habert.

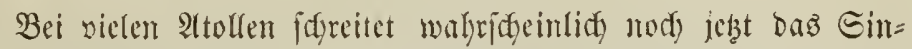
fen bes Bodenz jort, und Der umunterbrodjene Baufei der \$oly=

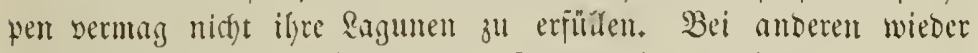
ift Dem Einfen eine Erebebung gefolgt, wie as bie Edyüijelform

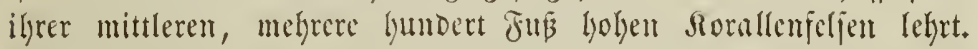
glidgt langiam aber, wie sie Eenfung, gewaltfan umo ftürmifd

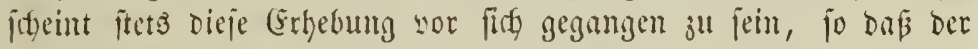
Sorallenflo jerrí, und feine Trümmer oft unter Rava unto al= Deren Felsmalien begraben wutroen.

Sisie geeignet aber aud bieje Şrbungen und Eenfungen bes

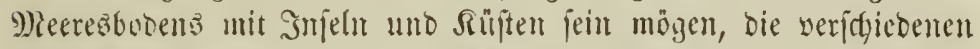
Formen und Eridgeinumgen der Sorallestbauten ju erflären, eş liegt

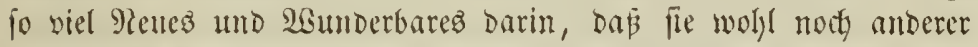
Thatiadyen zur Bejtätigung bebürjen. Eoldje aber bietet bie auf= merffam beobadytete (Begenmart in Minge. Mody heute fichen wir ja Rändermaffen nicft allein plöblid) unter bem (Sinfluffé getwaltiger

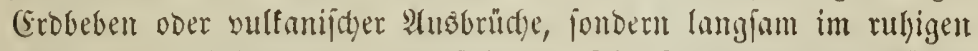

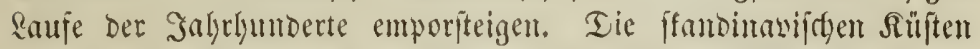
leben firth unlengbar in jedem Galirhumbert un 40 3oll über Den

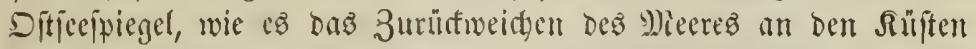
beweift. Hlber nuth Eenfumgen mus ein Theil berjelben erlitten

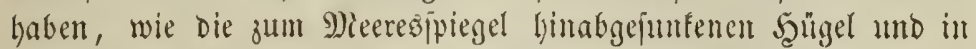

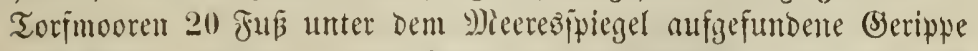
anzunefymen zumingen. Die Södfer ber Bofrmufdyel hod oben an Den En̆ulen Des Eerapistempels bei \$objuoli denten einten äln=

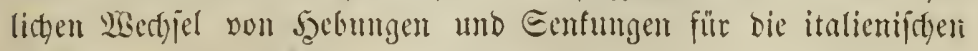

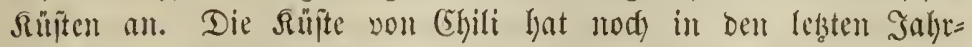
zelynten bei (Erobeben bebeutende $\mathfrak{S}$ äbertändermugen erfalyren, und

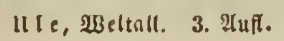


anf sielen jübaftatijten Injeln find ähnliche Erifheinungen beobs achtet worben.

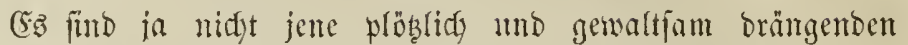
Sräfte bez Groimern allein, welde den Eroboben eriotüttern nold auftreiben, menn fid fein 2 (1)

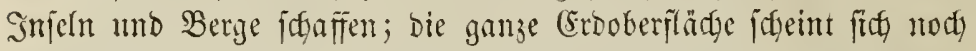
fortwährend in einem langjamen $\mathfrak{B o g e n}$ jt befinden, und bie in= nere, glithend fluffige Mafie fier burch Emporbehen auszougleidyen,

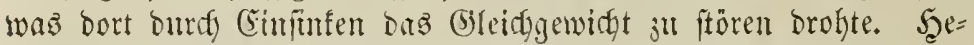
bung und Eenfung fint ftets miteinander verbunden. Sene Deente, Die wir als bie Sgeimath der Roralleninjeŕn fenten lernten, idgei= nen nus mehreren im Einfen begriffenen Berfen zu beftehen, deren

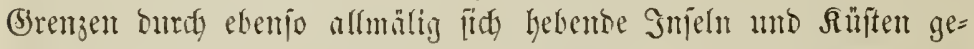
bildet werben. Die iseiffüte Eibamerifa's, bie Scebriben, dic Eundainjeln and bie oitafrifanijogen Rïften bifDen ben Biätel,

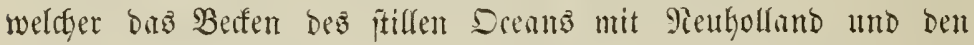

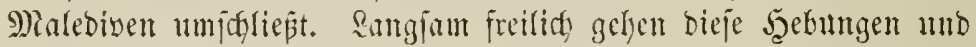

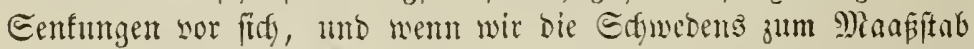

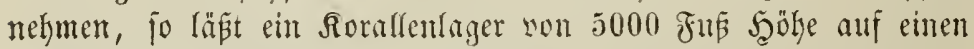

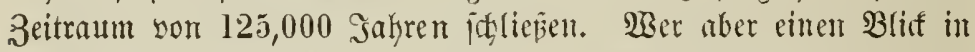

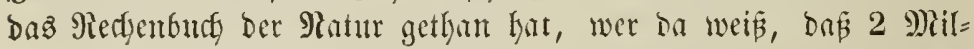
fionen Salye feit ber erften Bildung ber Etcinfoblen serftridgen,

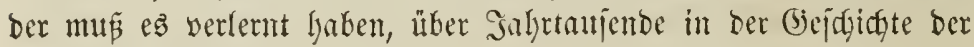
Crobe zu ftoumen.

Was uns in ber Ferne ber Eubojee in Berwumbenung jebste, bas fomte uns andy bie Rähe jeigen. Wir burften uns mur ju ben Ralfgebirgen Englands, Franfreiđgs, Staliens, Belgiens ober

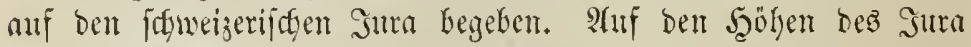
finden wir biejelben ringförmigen Aftolfe mit benjelben seriteinerten

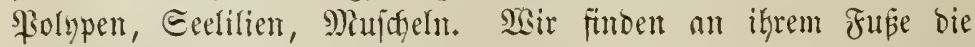
Trümmerbanjen zerbrobener Echalen, als Gätte eime heftige burn= bung fie Dort jeridgelft. Das Meer fintert Gier nidbt, mit bem

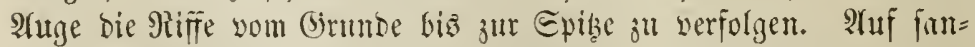
bigen Salfiteinen jefyen wir fie hier fids in abwedjelnden, feltent

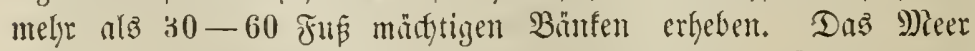
frömte aljo and hier eimft, und Sorallen bauten anf feinen Un= tiefen Riffe und Atofre, wie Gent in ber Sübjee. Sebungen utb 
Eenfungen folgten mudy lier mf einnonber und fofufen ben fleipigen Thieren immer mente bautpläbe. MRandfe Bänfe tautchte eime ge=

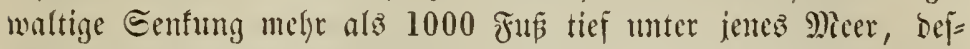

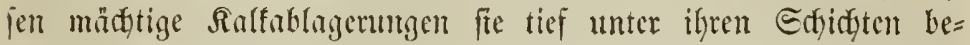
gruben. Sine alfyemeine Soebung iduf endlidy sie ganjent Sura= gebilde in ein gejtlano un unt trug bie Sorallemriffe mit fing auf bie

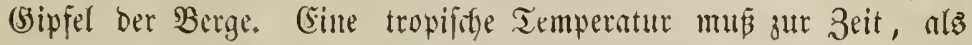

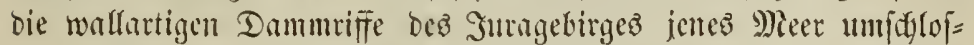

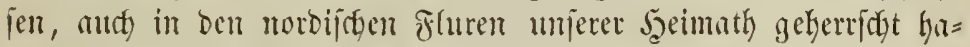

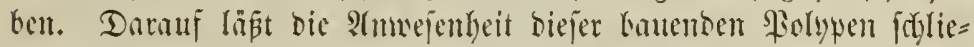

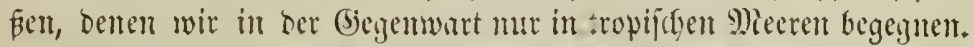
Das beftätigen uns andy bie baumartigen farn und armucarien= artigen Radelfölzer, weldye auf ben Fejtlätroen jenter Borseit itppig mudferten. Das beftätigen unz enblict) bie reidfen Enljlager, weldye auj eine ftarfe Beroumitumy des Meerwafiers lintseuten.

Co vecmigg der Blite in bic Tiepe bie todte (Eromaffe jum Epredjen jul bringent und Bifoer ocr Borjeit an's Ridjt ju zaubern.

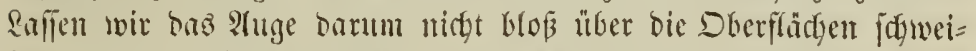
fen, ant ben 2Golfen haften! Das Smmere birgt immer Den Sein und bie Eeele bes ateuperen. Futd) in ben Eeelentiefer ruber ofit

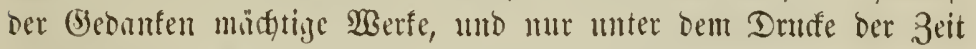
vermocteten fie nod nicty zum Reben emporätifeigen! -

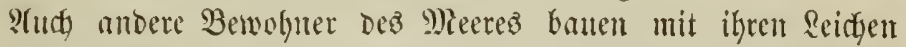
gewaltige Enger, bie bei grünblidferen Foridgungen bebeutungavoll für bie Beologie werben fömen, da fie älterer mo netterer Zeit mingefören. (Es finto die Miujgelbänte, weldye fid befonderz nuf ben naften zelsboben ber nörblidyen Mieere anfiebeln, wäbrento bie Sorallen bie jüblicten (jemäfier lieben. Die meiften Mieerez= bewohner bringen ige Reben fodswinmento an ber Sberflädje 3t, mer Fornpen und Minjdeln gegen in größere Tiefen, die Bradyupoden, befonders bie Tercbrateln finden finfy felbjt bis in einer Tiefe von

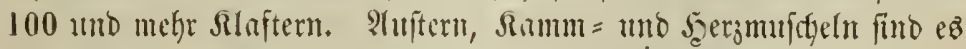
namentlids, weldfe bie Muldgelbänfe bauen, intem fie fid trupp=

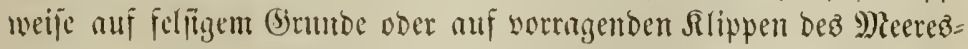
bodents anfiedeln. Mit einer Ectale an ben Boben geheftet, thür= men fird biefe Thiere reifjemveife itbereinnoer, ftören eintander

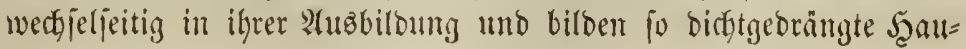


Fen, zwijgen benen eine Menge anberer, meift feinblidfer Meer=

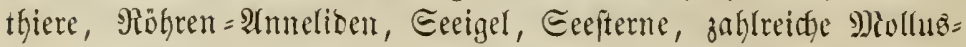

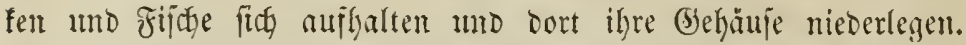

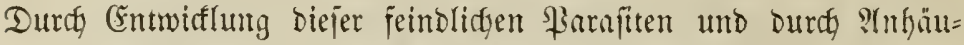

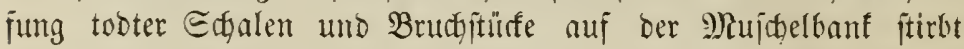
Dieje ans, oft mit iffen Berberbern zugleiđ, uno ihre Trinmmer bilden auf bem Meereagrumbe ben Boden für ben 2 tbją̧ neter Ecficften und ben Brund für bie 2trifiedlung netter Beffflecter.

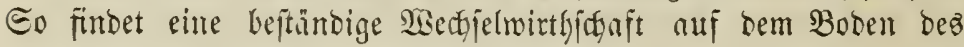
Meeres ftatt. Ectidyten medfjefn mit eitrander, bie burdh bie Ber= icfiebentfeit bes Materials, aus dem fie gebaut wurben, unto ber organifigen (sinjifliilie, bie fie enthalten, yon eben fo vielen Tobes=

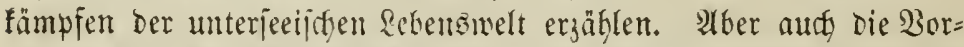

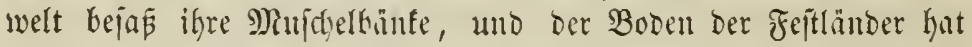

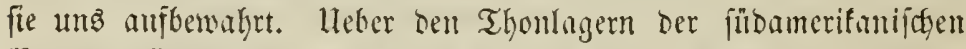

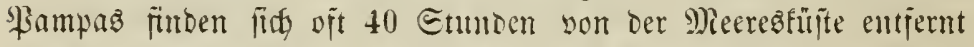

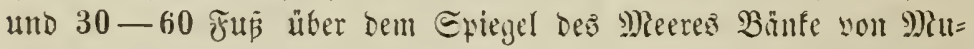

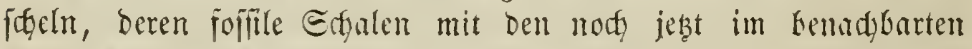

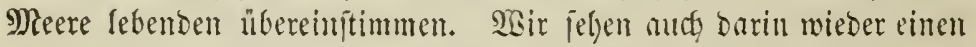
Bemeis, ba Dem Meere emporíteigt.

\section{3) Die Bauten ber mifroifopifden Rebensatt.}

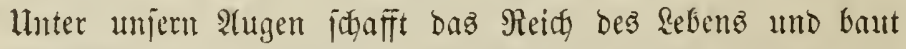

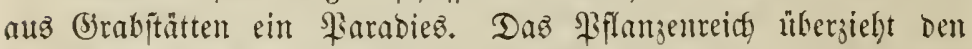

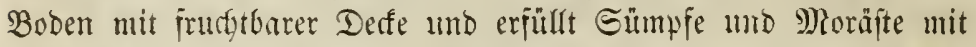
Torffagent; Das Thierreidy erfhebt zaflloje Snlfeln auf vulfoulifdent

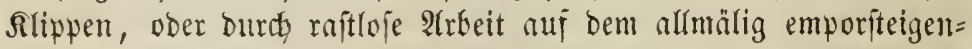
Den Mieereżgrunde, und eirre lippige Begetation wandelt fie zum

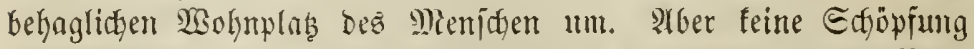

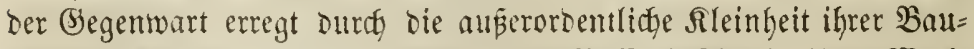
meifter und bie ungebeutre (Srö́pe und Majienfartigfeit ifrer $\mathfrak{B e r f e}$

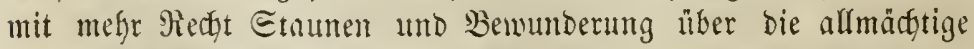

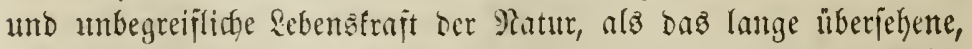

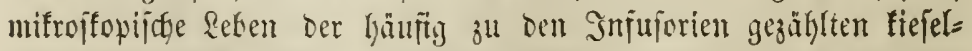
Fafaligen Etäbctenpflanzen, Der Bacillarien oder Diatomeen, weldaez Erd = und Steimididften geidyaffen und jeine rajtloje Thätigfeit von 
Den älteften Zeiten ber Erot biz auf umere Tage fortgejebt hat.

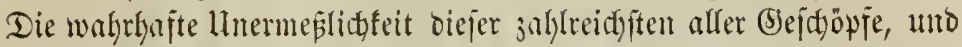

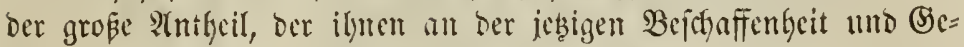
ftaltung ber Crobrinto jutommt, ift erift in ueuejter Beit, zuerit burch

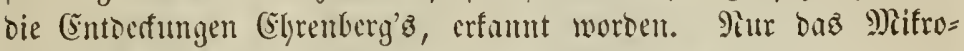

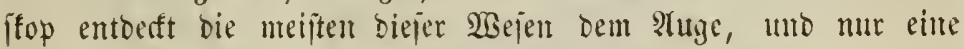

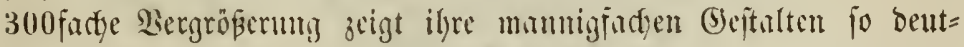
lids, wit fie in ben umpthenton stbbiloungen foldfer im Edylamme fich fintenten Diatomeen ju felyen fint.

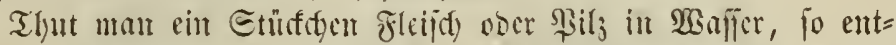
fitht eine s)ionade, eir fleines Thier, Das fith in wertigen Stun=

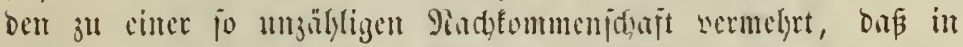
cinem einjigen Tropfen viele s)illionen entlyulten funt. Fajt liber=

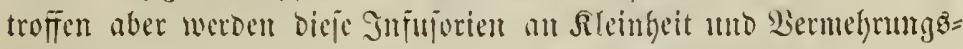

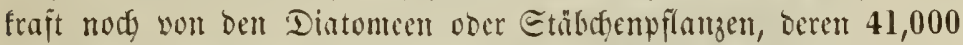
)illionen Эnbivibuen in cinem $\Re u b i f j o l l, 70$ Biflionen in einem $\Re u=$

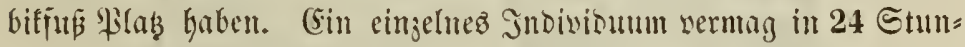
ben eine Padblommenichajt won 16 Millionen ju erzettgen, aljo in

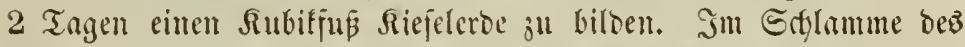

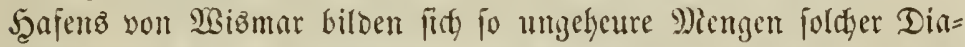

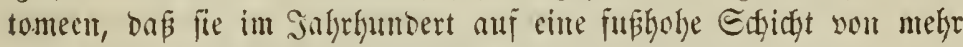

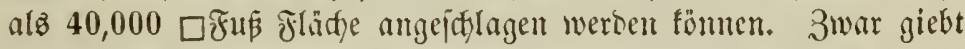

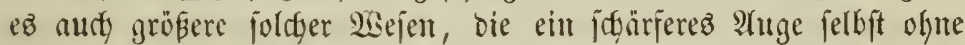
Bergröperumg walyrnimmt; aber warum folf ez nidyt audy in bicjer

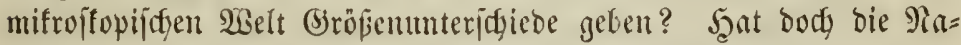
tur auch bie Maus uno den Elephanten, den Şäring แno bent

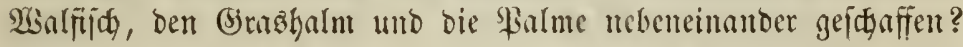

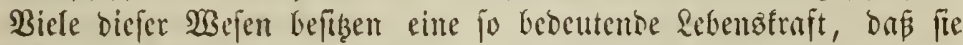
fich mefrere Salje im 3ujtande ber (Eritarrung und bes Eajein= tobes befinden formen, olyne barum wirflids tobt zu jein; denn wenn man ifnen bie Feudtigfeit fo weit entzicht, baj fie bolltom= men trofen erjedeinen uno nidht bie mindefte Bewegung megr äußern, fo fann man fie nadh Jabren burdy einen Tropfen Wajfer wicber

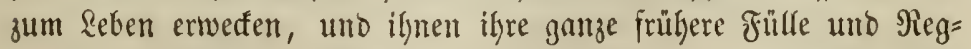
famteit zuriafgeben. Mandye ertragen aud citte beträcbtliche Şize und leben in heipen Duellen von $40^{\circ} \mathrm{K}$, fönnen fogar eine Zeits lang bie Eiebhike bez $26 a$ fïers aushalten. 2(nore bagegen ertragen 


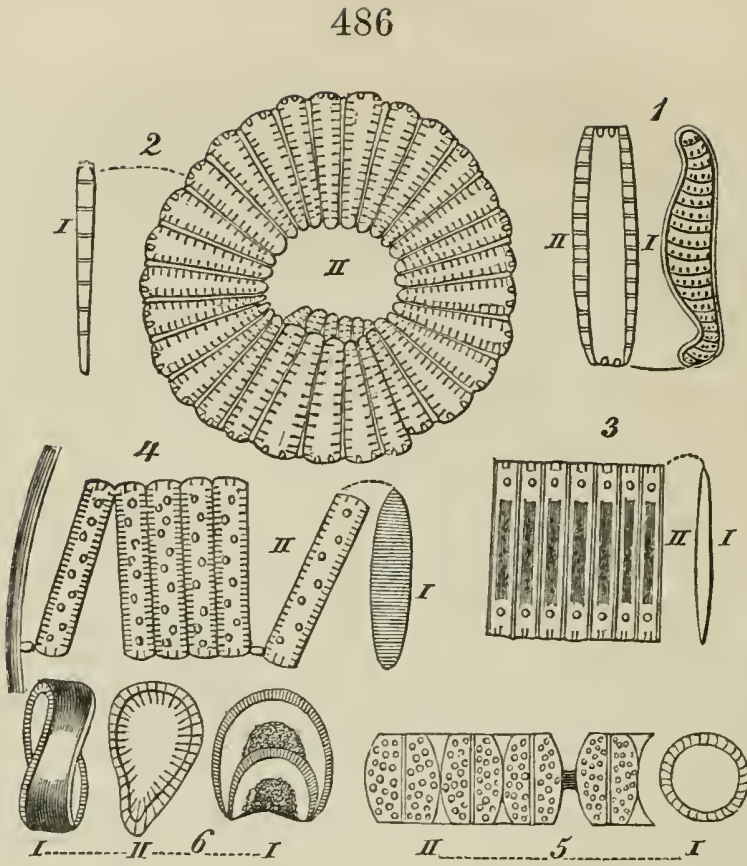

Diatomeen aus @

1. Epithemia librile; 2. Meridion circulare; 3. Fragilaria capucina; 4. Diatoma vulgare; 5. Melosira monilifornis; 6. Suri ella Campylodiscus.

$I$ bon ber Sante, II von ter Fläđje gejehen.

einte Rälte bis ju $20^{\circ}$ und frieren ein, ofne zu fterben. Darum vermongen fie aud in Tiefen ber croe ju exiftiren, wo mat faum bie Möglidgfeit organijapen Rebens erwarten jollte. Sulfanifate Niden und Bimsiteme, Forphyre und Forcelfaneroen find oft in

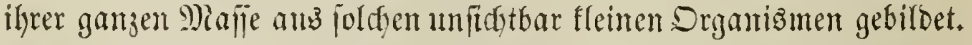

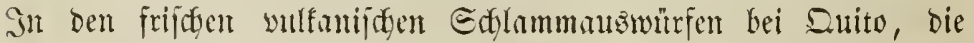
aus unbefamter, wie es jofien, jebr beträbtlicher Tieje famen, fand Şumbold vollfommen beutlidy enfentbare organifobe Bebilde, weldge zugleidh Beitanotheile berglyolger, wultanifd herworgetriebener Majpen waren, umb an bieje Thatpadyen baben fith neuerbings

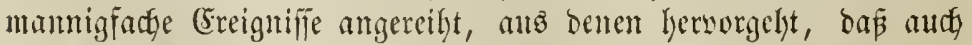
Da Rebentspputren fidt zeigen, wo man fie am iwenigften fu fin= Dell meint.

Siody wor wentigen Sulyren Kielten jelbit Raturforjher alle biefe unendidy fleinen sisejen für Thiere und faften fie unter bem $\Re$ in= 

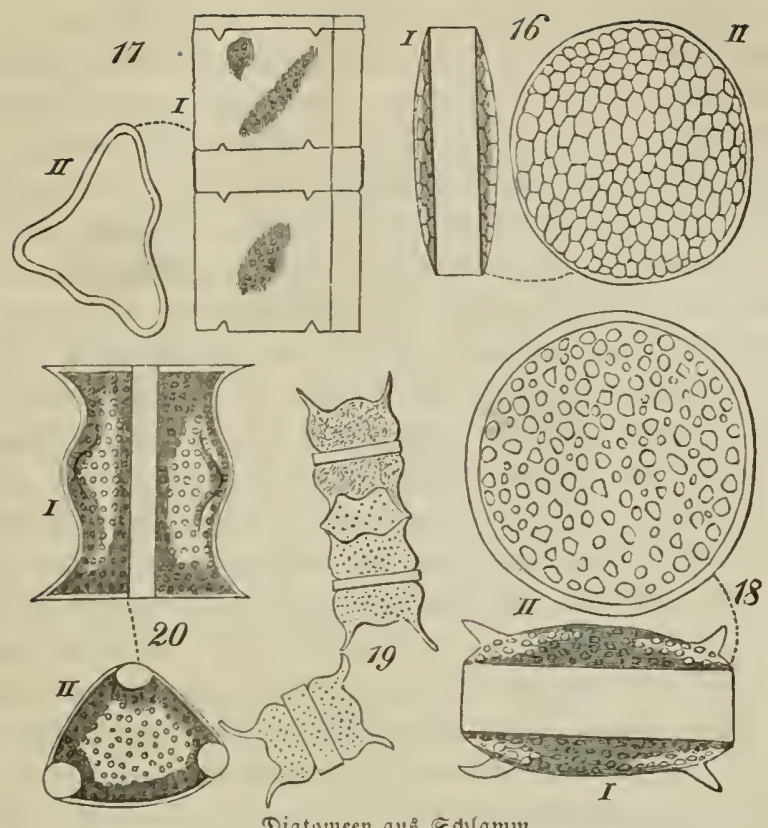

16. Coscinodiscus radiutus; 17. Silhodesmium undulatum; 19. Tripodiscus Argus; 19. Odontella aurila; 20. Triceralium slriolatum.

$I$ von ter Rante, II von ter ôlädie gejefyen.

ment ber Snjujorien jujammen. Erít Sem nerdä̈rfen Foridgernuge

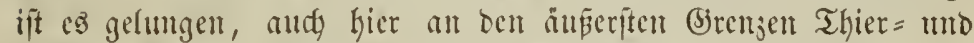

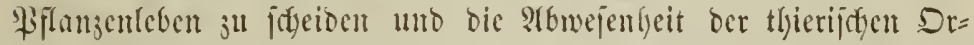
gane felbjt in Der einjadjen 3elle jum entiffeibenden s)ierfmal ju

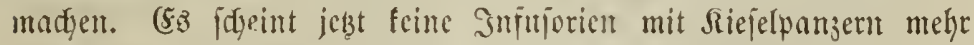
zu geben; man muß fie wohl als Siflangen fepthalten uno bat fie baher Etäbdenpifanjen genannt. In ben jeltampten Beftalten, ftïbden = uno tajelförmig, vieffantig und gefrinmm, bebeffen bieje

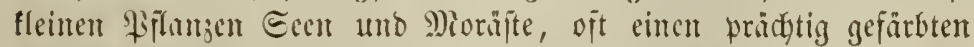
Edymm bildend, den man tas Blïlyen der Eeen nemt. Shr

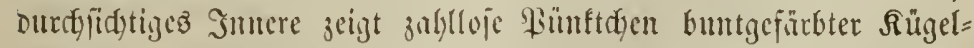
den, bie fids won 3eit ju 3eit lostremen, un nenen Pilanzen ify Dajein ju gebent.

Die Ricilifgulen bicjer Diatomen bilden hänfig den Boben= f.rk gemiffer Mineralwafler, ben Eijenterer, ben Riejelgutgr uno 
ägnlitge Mineralien. Shre Anfüufungen, befonderz in ben erît

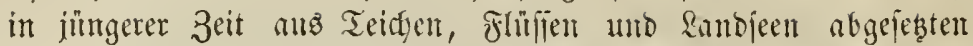

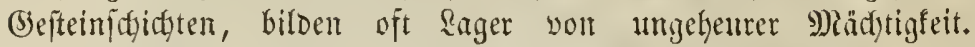

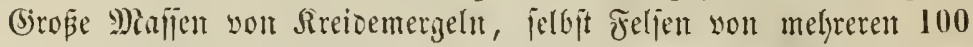

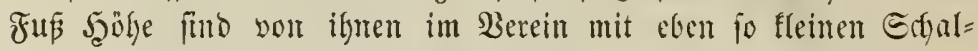
thieren geidsaffen. Die fnolligent Fenterfteine, weldye ofit in Der

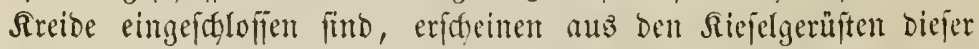
PFlanzen und den Ueberrejten der Eeejdyämme zujammengejebt. Die Tripelerde, das Bergmely non Bagnota in Togfinta, bie Spale

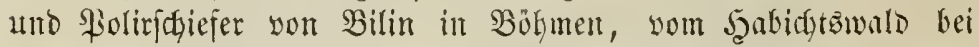

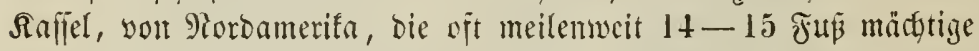
Rager bilden, fruro midfts weiter als bie Ucberrejte biejer abgeftor=

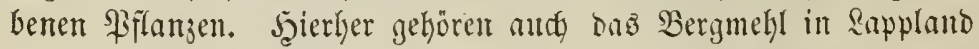

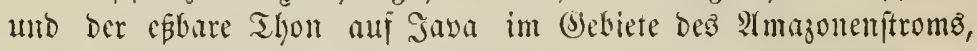

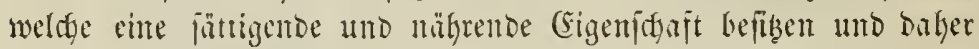
in Zeiten Des Miépmadjez unter Dem Srod verbafen werben. Dieje organifitent Erolager tretent bald als ganz lofere, methlige, bald als papierälyntidge ooer follentartige Miajen anf; anbere fino

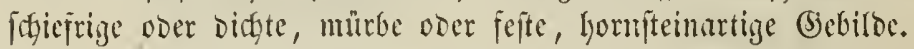

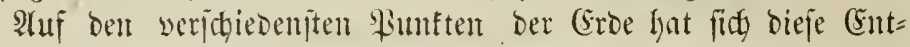

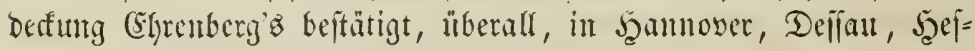

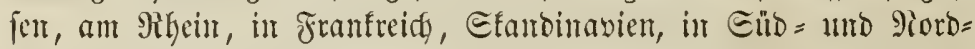
amerifa, auf ben \$igilippinen, auj Jasle be France uno Sale be Bourbont hat man sager bicjer \$iflanzenrefte gefunben. Das be=

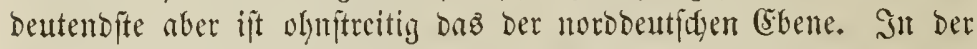

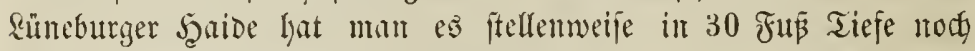

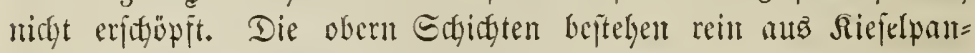
zern und bilden Sdjigten feinn, weipen Eandes. Die untern fino mit einer erftaunliden Mienge von Fidstenflintfyenitaub gemengt, ber ifnen eine gelbe Farbe leilyt. Dieje Riejelbante bejtelen oft po

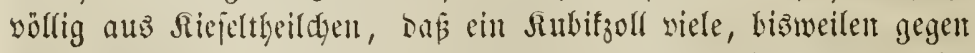
1000 ग)iffionent umfät; und ein jebez diejer Ricjeltfeildsent zeigt fidy bem bewaffneten 2 Huge alż baz ganze ober zerbrotgene ehemalige

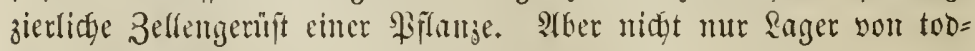
tent, and) wonl lebentont Etäbdienpflanjen futro gefunden worben.

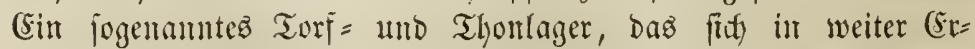
ftrefung längs ber Epree und unter einem Theile von Berlin jelbjt 
Ginjieht und bals mur wenige Fuß, bals gegen 100 Fuß mindtig

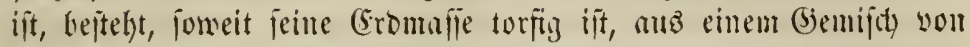
Siflanjenrejten und Riejelidjalem, oa wo fie fids als Thon Darfellt, fajt ganj ans Etäbdenpflanzen, bie riberbantpt fïr fid) allein wei=

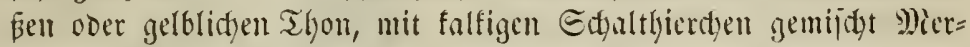
gel biloen und alo mäd)tige sanger mit reineren תalfiteinen ab= wedjeln. Die \$iflanzen dejes Rngers leben zun Theil in ber Epree uno andern Berliner 2 baflern, fund zun größ̈ten Theil aber folche, Die jebgt bei Berlin an Der Dberflädye nid)t gejunden worben fint. Dabei ijt merfmüroig, Duß rie ibnen entjpredtenten formen nidyt

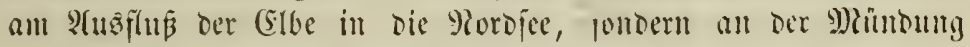
Der Soer in Die Deffie wiedergejunden werben, nljo nidyt in bem Flnipgebicte, meldyen bie Epree jebt anjebört, fontorn in einem, weldem fie friber angehert zu baben fodeint. Das M)ierimüroigite aber ift, Dá bie Berliner Rager organifityer lleberrefte Der Borgeit, bie Dody $10^{\prime}-15^{\prime}$ unter Selym uno Eano liegen, fidyllid) nody vicle lebende Formen enthalten, Deren edbensthätigfeit jeood bei ber Abiperruny von Ruft und Ridyt bedeuteno abgeftumpft ift.

Wir felgen aljo hier eine erbige Eubitanj, ein Gebiles won Drganizmen, bie nod) nidyt guns toot, aber bem Tobe und ber wöl= ligen 2ierifeiterung mabe find, mo weldbe bei ilyer $\mathfrak{B}$ anarbeit zu belauphen ber Beobadtunis gelungen ijt. Ev vermug die shatur

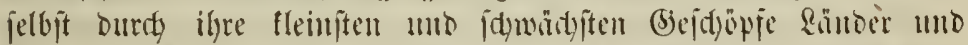

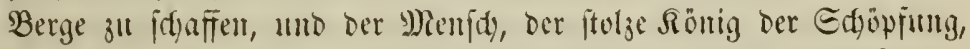
verzagt an Der Rojung feinter Rebenzujgate, welde nidjt Ränoer forffen, fondern geftalten foll zu cinem 260 hnitze des Beijtes mo Der Freilyeit! -

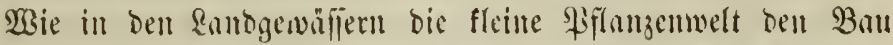

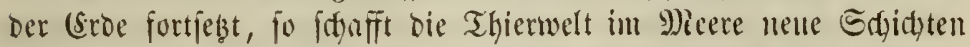

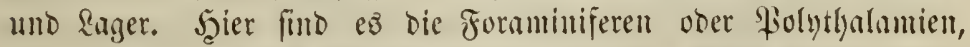

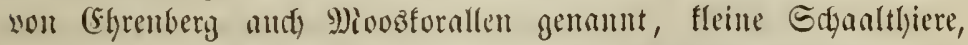
weldye, in galferturtige Etöde ober vielfammerige Bäumd)en won foblenfaurem Salf wereinigt, mit igren seicten ben Boocn erfühen,

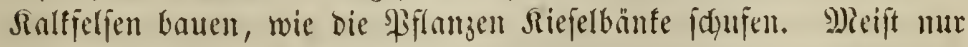
Dem bewaffneten 2luge fidytbar, felten größer alz $1 / 25$ Risic, oft faum $1 / 300$ Rinie großß, zeigt bie umftehende stbbildung einige von ihnen, Die in ber Sreibe vorfommen, in 300 fadter Dergrößerung. 


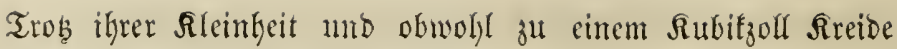
mehr als eine Million yon Indivibuen gefürt, bilden bie Fora= miniferen bods eine der bebcutenditen Formationen ber (Erbe, hier als : ger son unberedyentiarer Etïrfe be= reits unter anbern Echidgten beyra= ben, bort als Berge und Felien hoch emparragent. 3war bat man fie in ber Gegenwart nody nidgt, wie bie Diatomeen, bei ifren viel mäadtigeren Eteinbunten beobadten fömen. Ptber figon aus bem llmitande, dañ ber

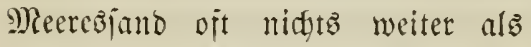

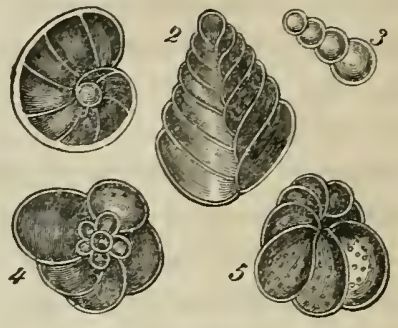

Foraminiferen ser Rreite.

1. Planulina turgila 2. Textularia aciculata. 3. T. globulosa. 4. Rotalia globulosa. 5. R. perforata.

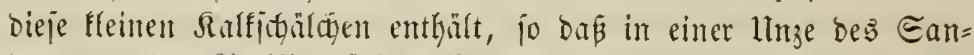

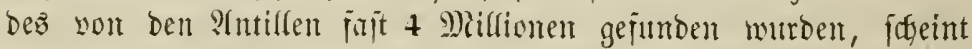

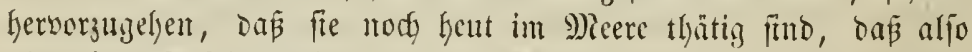

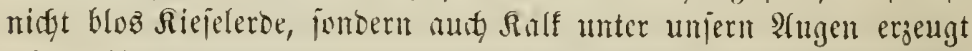

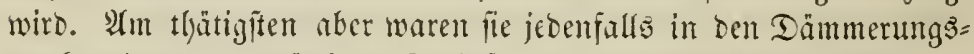
eporfen ber gegenwirtigen Edjörung. 3eugen bicier vormelttiften

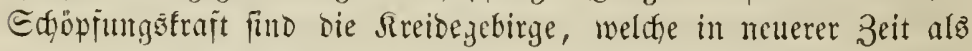
Grabjtätten ciner ungefeuren Menge biejer mitroifopijdyen Thjerdyen nadigewiejen füt, und benen bie jüngeren (Bebilbe bez parijer (brobs

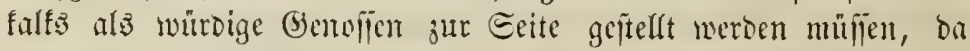

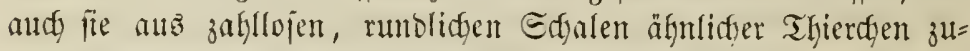
fammengejegt juno, sie man Witiolitfen genannt hat.

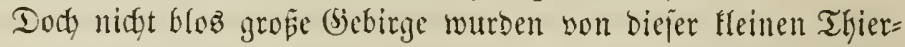

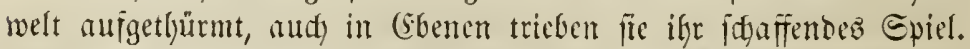
Range glaubte man, ber loje Eano jei nur aus 2tbjällen ber anjtefy=

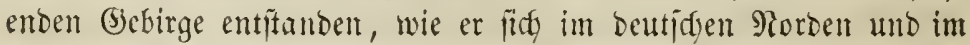
Berfen Der Ditjee bis zur Rewa wirflidy unter bem Miftrojtop alz

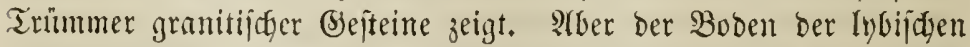

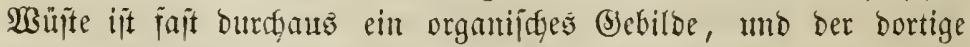

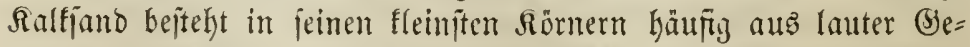

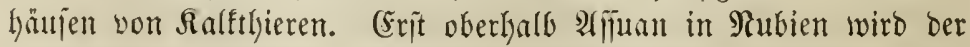
TGüftenjanto granitijd. WBie ein grober Theil ber \$yrentien yon einer foraminiferenart gebifoet mutroe, die man 9iummuliten genamnt

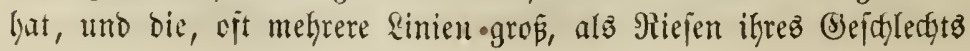


gelten fömen; fo fino aud bie jtolzen Piyraniben Aegyptenz, jene

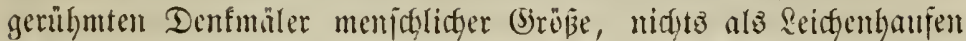

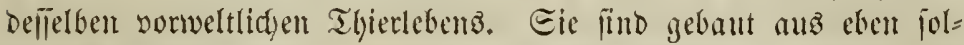

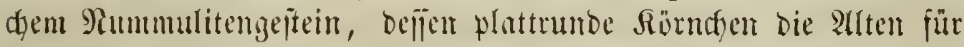

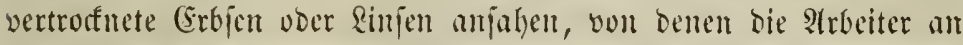

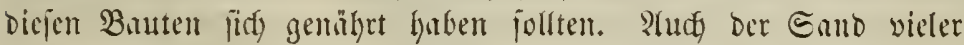

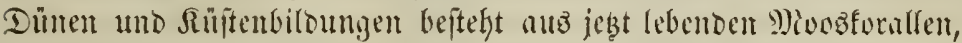
Deren jede ein Eantfurn worftellt. Bejonderz in Beefen bez mittel=

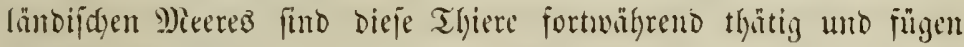
leije umo ummerflidy ber immer wadjenten (Erdrinbe cine Edjuppe nady ber andern zu. Daju fommen hier nod auperordentlids fleine Edgnerfen, bie ben Snjujorien alynlid) fïnd uno and) nidgt viel an

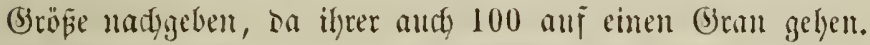

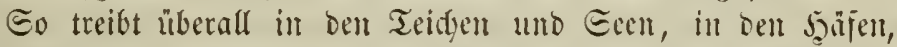

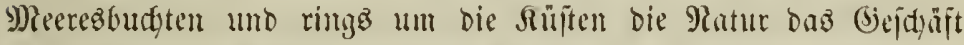
Der organifgent Etcinbilounty in Rleinen jurt. Durch bieje mäds= tigen Ranger wird unz erit vollends flar, waz lingiti fo viele andore Epuren verfundigten, ons nod in oer lekten Edjopfungäperiode

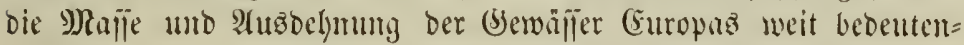
Der war, alz jeßzt. Wair glanbten bizlyer nur in ben fluthen die

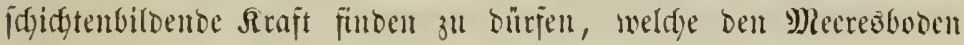

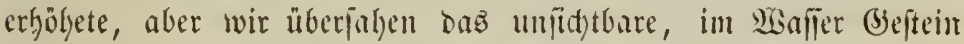

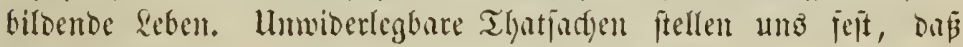

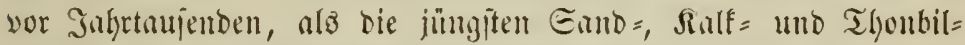

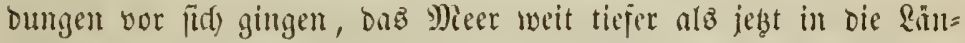
Der Europas cinjdynitt, und fids in Budyten und Bimtenjeen zers theilte. Dieje (sinjognitte wurben im Enufe Der großen Wieriode obme 3weifel von den Baumeiftern dez Ralfez vermanert, wälyrend sie

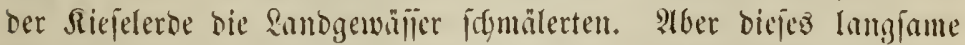

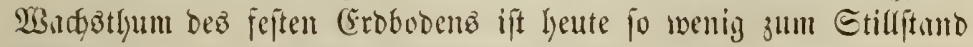
getommen, alı̉ baz̉ übrige Raturleben.

Tiefer eingebrungen in Die Werffitüte ber Matur, gewalyen

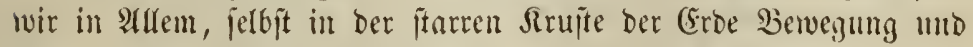

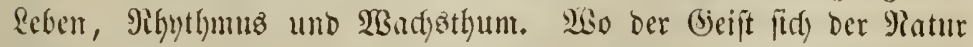
bemädytigt hat, lyärt audy das Etarre auj, ein jertiges Eein ju bleiben, uno wirb fortgerifien in ben Etrom bes $\mathfrak{W}$ serbenz und bes Rebens. Roch haben bie jofaffenten Bewalten igre rajtofe Thätig= 


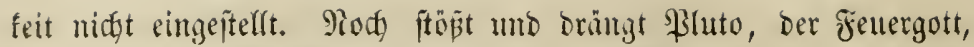

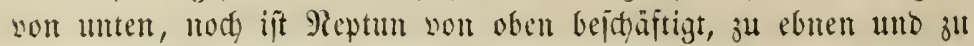

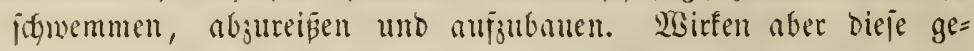

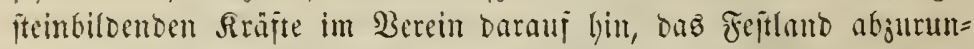

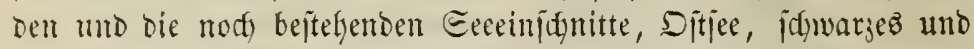

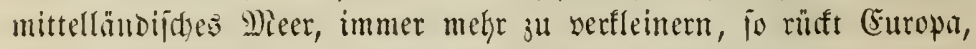
wemr aud langiam, boch mrsermeiblich ben Edjiffal feines plum=

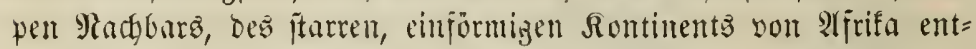

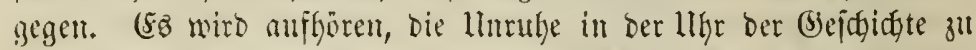

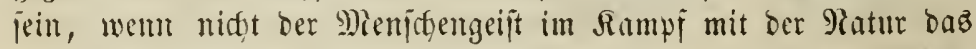
unvergänglidfe Eiegel feiner J̧errid)ujt ben todten Formen auforildt, wemn nidyt bas $20 ̈$ offerteben bem (Eritarren Der Materie entagegentritt.

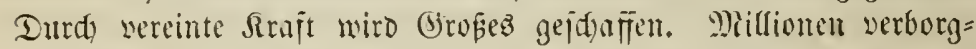
ner 2 sejen ridften Berge nuj, jeken Dämme den $\mathfrak{B}$ ogen entgegen,

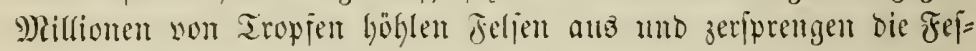
felu bes Scens. Eo nagt and verborgen ter wadjende beiff ber

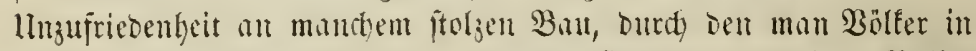

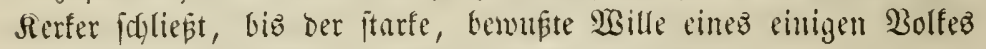
Das 2 sert or freilyeit in gewaltiger Eile vollenoet. 


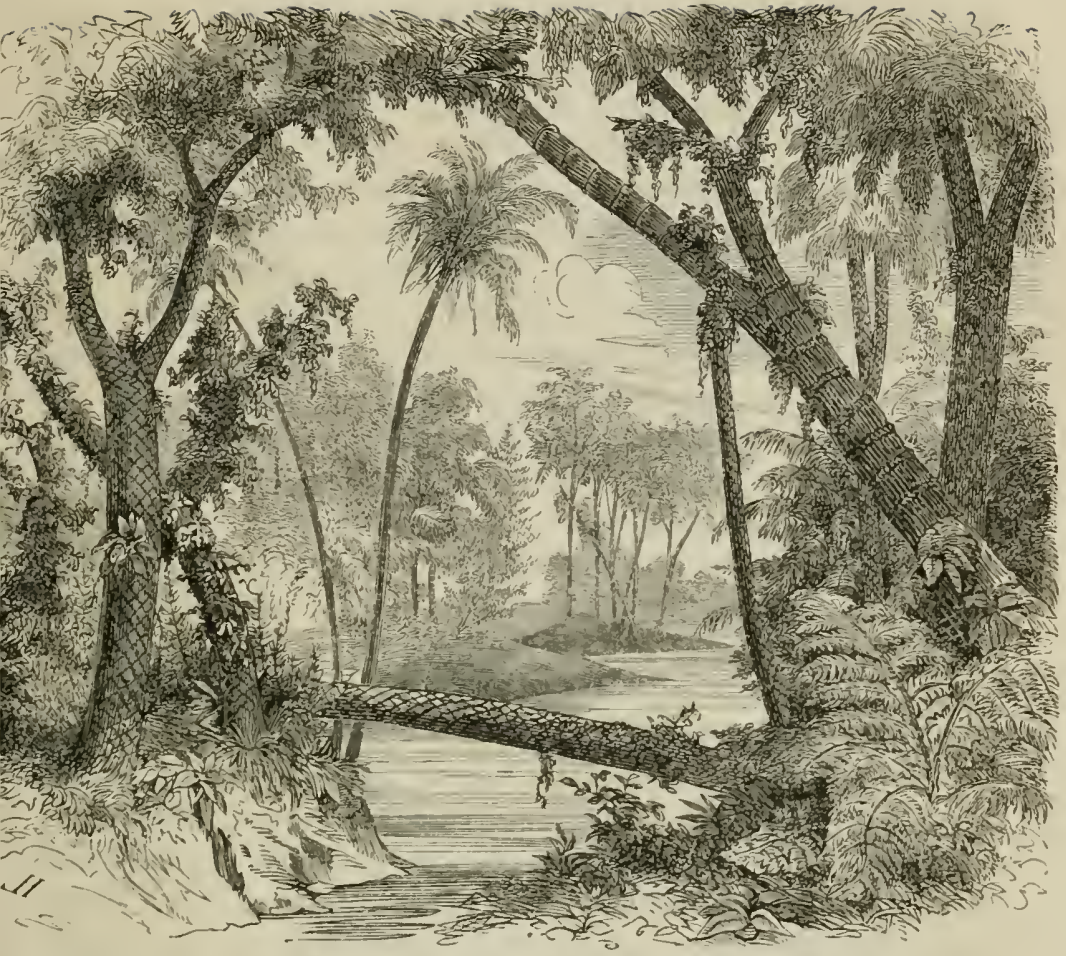

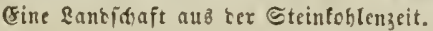

\section{SEicter 2 (bisfuitt.}

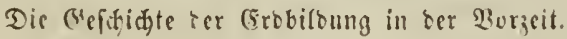

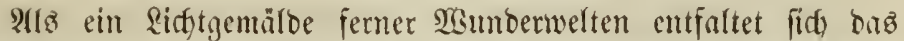

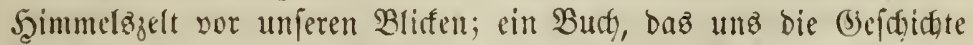
ilyrer Bergangenheit ergählt, fteht bie (Erbe ba. Aber nifbt eine todte Shronif ift es, bie wir in ifrem Edjooke anfidhlagen; wahres \&eben grünbet fíd belïere Denfmäler, alż bie vergillbenben Wergn=

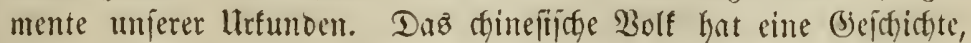

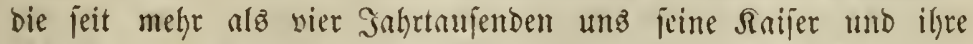
Echidfale und Thaten nufgegridgnet hat; aber bas ift feitte (Se= 
ichidfte, fo wenig wie bas dyinefitiche Bolf ein Bolf ift. Das bent=

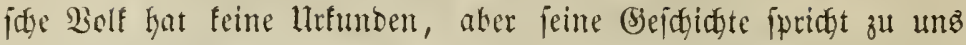
in lauten Tönen aus feinen Riesern unto Runjtwerfen, aus feinen

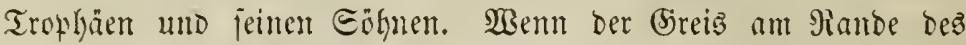

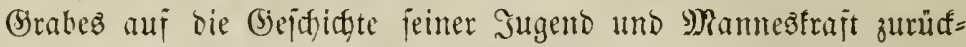
blift, Da taucten nur cinjelne (Erinnerungen, verblidyene Bilder jeines Sibens vor jeiner Eeele auf. Ather nicht dieje sit fojon

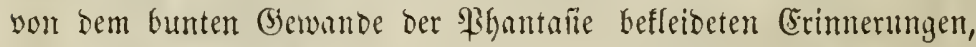
nicht bieje Mälrctent uno Sagen jeines Rebenz erzählen ify jeine

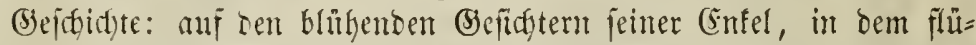

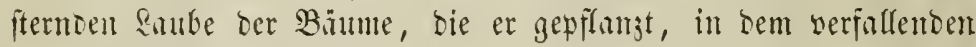
(Semäuer, ons er gefaut, liejt er in idjüneren 3ügen bie Thaten unt Echiffjale früberer Tage.

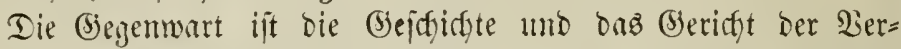
gangentfeit. Shre Edyopfungen reidfen in eine unendidfe Borseit

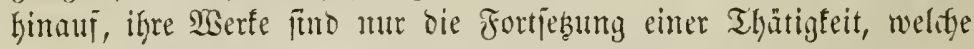

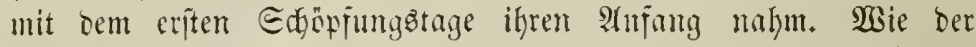

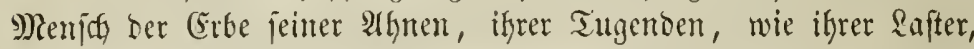

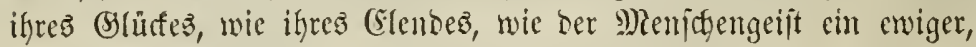
fort und fort dentender und iffaffender 2 (trbeiter an Der Berflärung

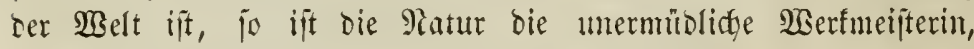

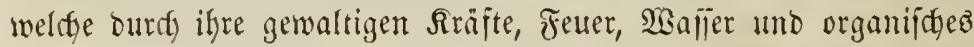

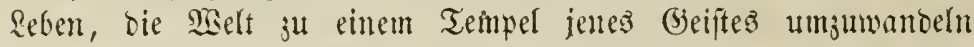
ftrebt. Die endoloje Rette biejer Edjopfungen zu verjolgen, bie

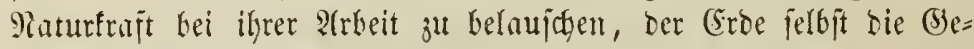
Geimurifie ifrer $\mathfrak{B o r}_{3}$ eit abjuringen, bus if́t bie erfjabemite umo an=

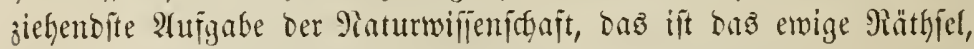

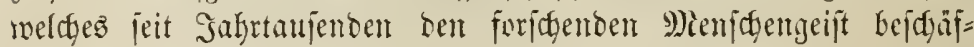
tigt bat.

Sisir bringen jo gern ein in bie bunfeln Tiejen ber Bejecticte

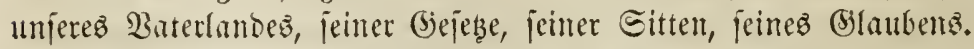

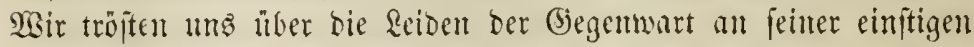

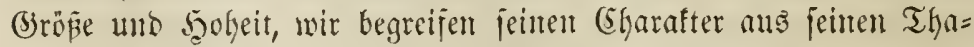

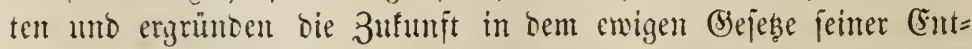
mifflung uno Fortbiloung. WBir lernen für unz jelbit aus ber $\mathfrak{B} o r=$

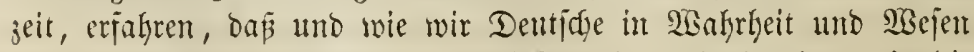
werben funnen und follen. So musfifen wir aud eindringen in bie 


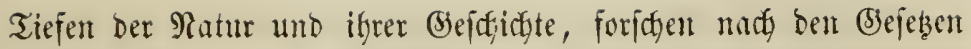
ifrer taujendjägrigen (Entwidfunty uno erfennen, ba turgejes nisgt auti 3eit, jonbern für ewige Dauter beftelyt. Dann werben wir ben Eharafter ber Siegenwart begreifen unt bie Gie= jididgete ber 3ufunft erratthen, werhen ben Beruf bes Memident in diejer gröen Sgeimath erfenten uno wifien, Dar und wie wir Men= idgen werben fömen und follen.

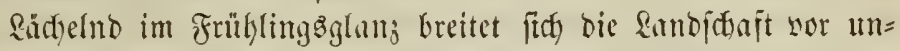
jern 2Hugen aus; zart entfeimt bie Eant bem winterlidyen Bohent, unto

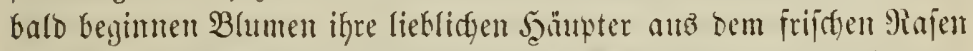

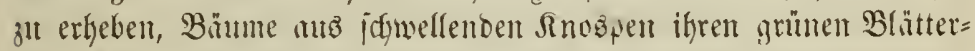

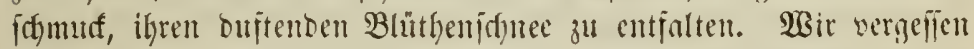
bie Etürme, weldse ḧber biefe glatren gebrant, bie Ffuthen, bie fie

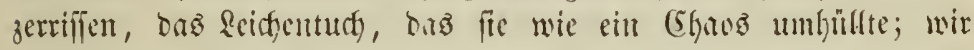

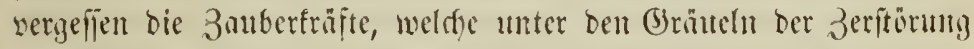

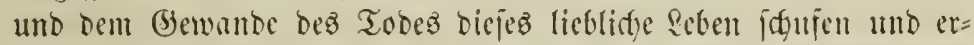
werten. Eo ijt bie Erroe, bieje Etittse ber \&ujt uno des Edtmer=

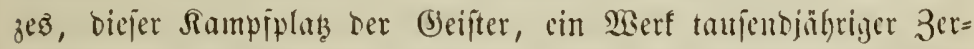

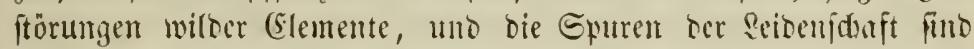

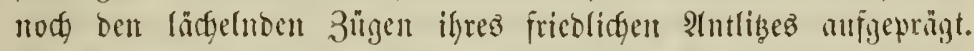
Die Begenwart ijt Dos (3)ab ber Bergangentheit, unto bie Etürme, weldge bald grö̈ere, balo fleinere Theile der (Eroe werwuijteten, balto

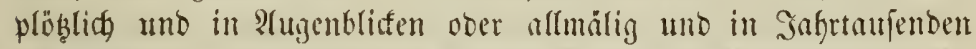

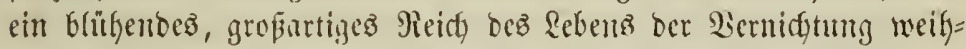
ten, fie haben bie Trümmer ber Bormelt zujanmengemedt zu cintem Altar, auf bem bie Besenemwart bie Dpfer nieberlegt, weldfe fie

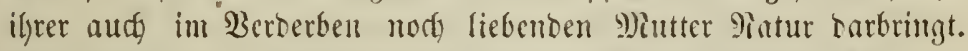

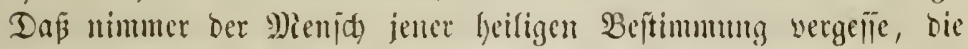

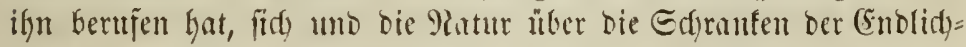
feit unt ber Miateric emporantyeben, fich und bie Ratur im Beifte

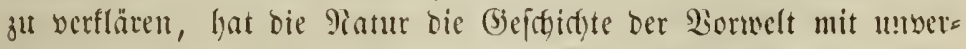

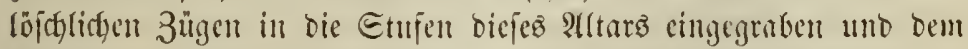

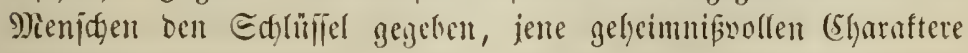
zut entziffern.

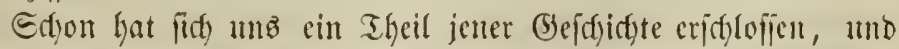
war es aude mur bic eines furrjert, menige Sabrtaufende umijajien=

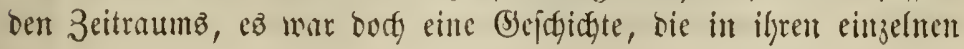


Bügen igfon ein Bildo ber früheren entfhulllt. Denn jene siäfte,

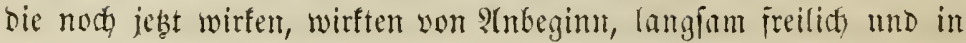
ungeheutren Beitrïumen, bie nidgt Taujente, fondern Millionen

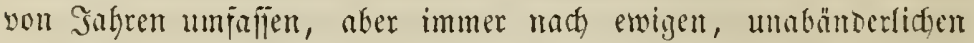
Beję̧er. Edyon mande unferer beutigen Edjopfungen gehörte einem Zeitraume an, in ben fanm bie bunflen Eagen uralter $2 i o ̈ l=$

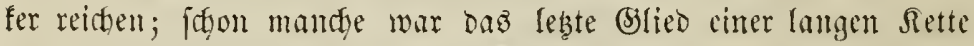
non Ericheimungen, über Deren 2 nfang man erjt Bernutthungin

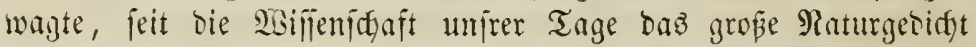
aus ien Ecfriftzïgen Der Errorinde verftefen lernte. Aud) in ber Borjeit mar ez uidfi etwa ein ungeheurer, mafjenthafter Sampi der

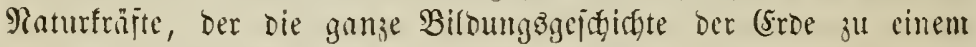
milDen, ungeitümen Drängen madte, um eilendos hen Sriboren jum (5arten, zun Edfauplng menjd)liden Wirfens ju oronen; fonsern

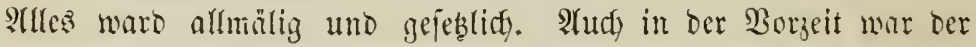
größ̄te Theil ber Errorinde bas Probuft rufiger, langíamer Bilsun=

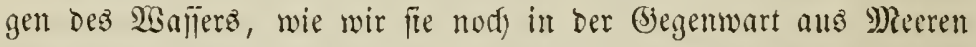
unb Een, Flüfien und Duelfen entiftelyen jefen, unt mit biejen Bilsungen zugleidy murte Dns organijase Reben ins Dajein gerufen.

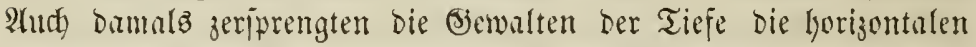
Edfidjten, hoben in jener bümen, vielfact) gejpaltenen Erorinde feurig =flüifige Maffen zu Bergen empor, ridfeten die zerrifienten

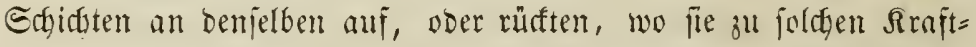
äukerungen ju fidwady waren, ganze Rantoftridye ju \$lateauz em=

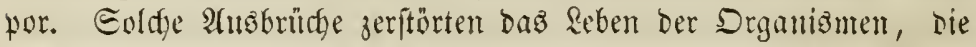

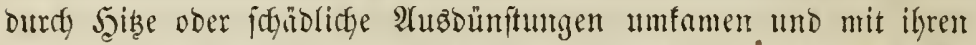

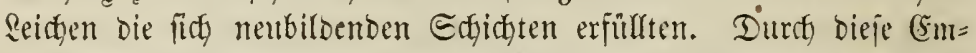
porbebungen wurben aber ber auflöfenden und nagentben Rraft Des

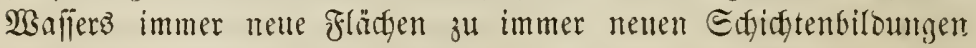
Dargeboten, und jugleidy erfielten bie Piflamben und Thjere, Deren

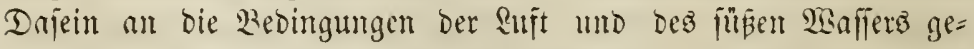
bunoen if́t, einen immer größ̈eren Epielrmm. Freilich mag wohl

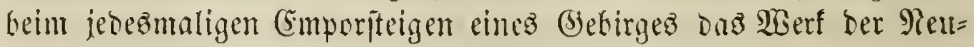

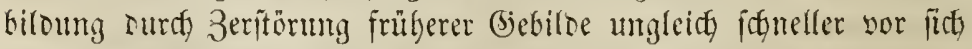

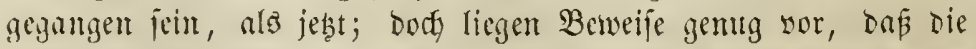
meiften (s)ieber aller Formationen, won ben alleptent bis zu ben jüngften, fich mur unter ähnliden Zeitserbältniffen gebirbet haben 
fönnen, wie bie Alllagerungen alif bem Boben ber Geutigen Mieere und Seen, bie wir bereitz fennen gelernt gaben.

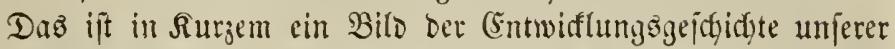
Eroe, gegrünbet alfein auf untrüglidye Thatjachen ber Matur, nidft

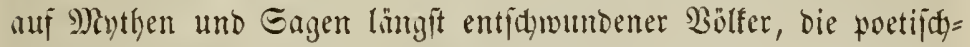

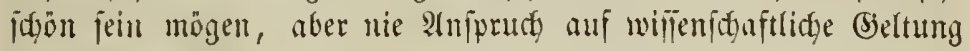

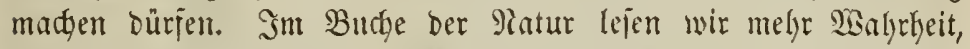

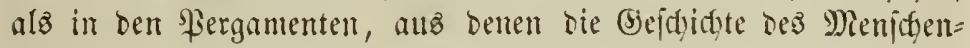

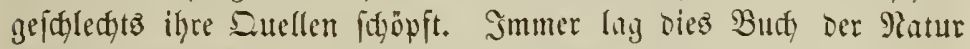
offen vor Den Á

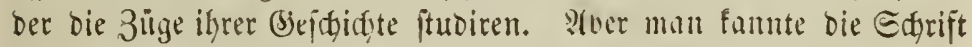
Des budjes nidgt, unt wer fie fannte uno lejen gelernt batte, ber burfte lie nifft lejen, weil mant ein anores Bud an peine Stefle

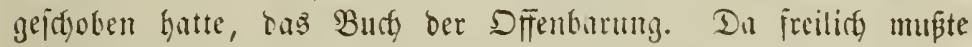
wohl die Beichicfte der Siatur io lange verborgen bleiben, jo lange

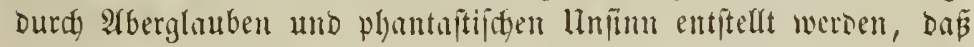

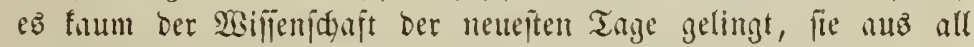

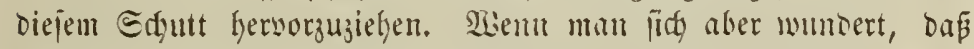

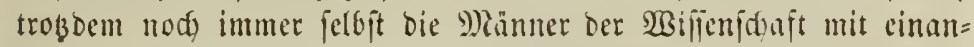

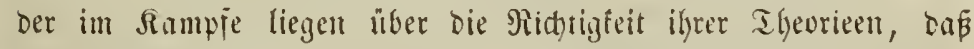
eine Theorie immer bie andre, eine $S_{2} y p o t h e f e$ bie andre verorängt;

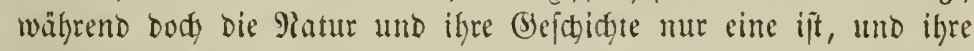
Thatjadyen 2(llen zu Bebote fitehen; Dann erimnere man fidt an bie

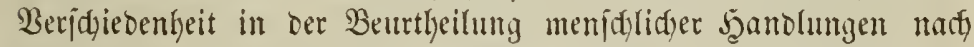
ifreen innern Beweggrinten. Baer vielfact) ein Ejegenftand der

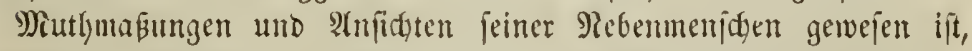

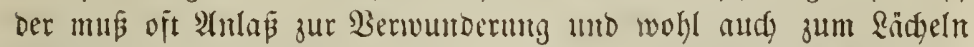

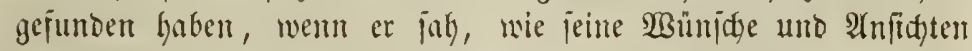
felbjt von feiner näbjten llmgebung fo ganj irthïmlidy gedeutet wurbent. Wenngleid) amb bemfelten Etoffe geformt, unter bem Einflü Der gleidjen Eel6ftjudyt ftehend, von ben nämlidgen Seiben=

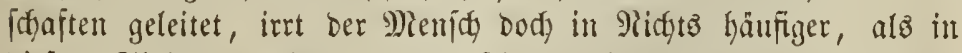

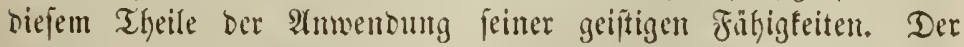

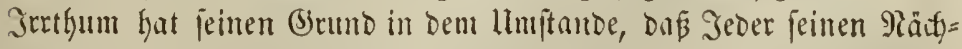
ften fiteng nad) fid felbft beurtlyeilt und beshalb meint, Hatrore

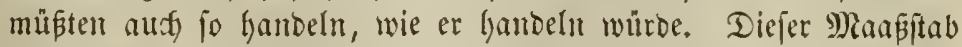
wäre alleroing to übel nictgt, fönnte man mur immer bie Bebủr

it 6e. Wettall, 3. 24 
nifie unb Triebe 2(nderer erpajen, bie mit ben unjrigen off eben=

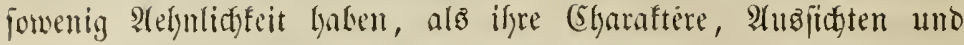

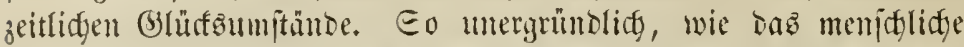

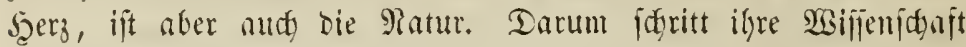

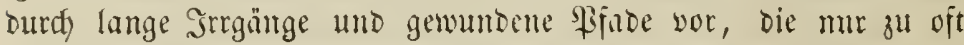

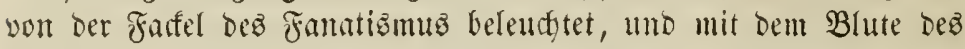

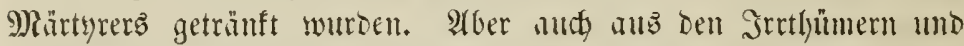
Rarrfeiten ber Borzeit müijen wir lemen; benn auch in ifynen ver=

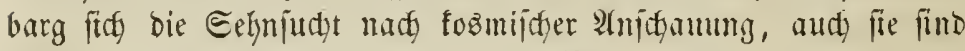

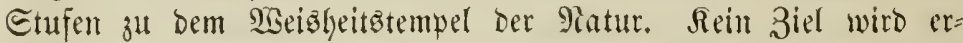

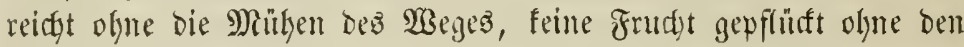

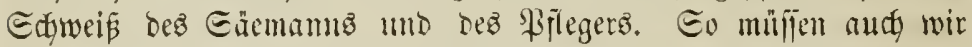

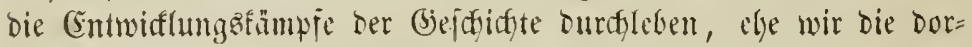

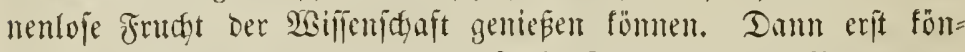
nen wir Den geläuterten Blif auf bie Denfmäler Der Bergangen=

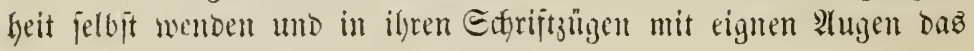
Werben der Erroe in Der llizeit lejen.

\section{A. Serjuche der Sorzeit über Die Gejhichte der Erop.}

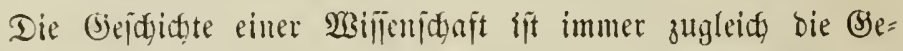

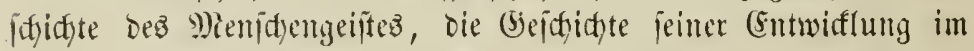
Etaat = uno Bölferleben, in אumit mo Bildung. Die beicfidste

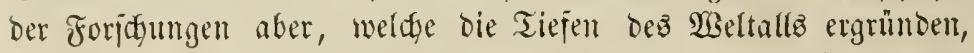

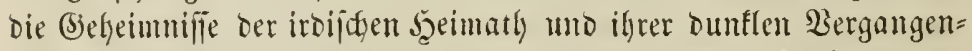
heit erbeffen folfen, greift am tiejiften in bie ganze Mienidsentatur

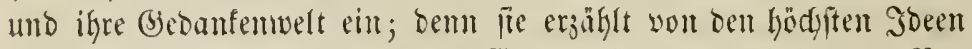

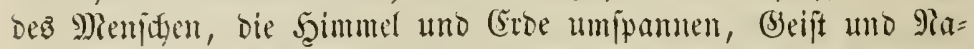
tur veriöhnen, Bott und $26 e l t, 3 e i t$ und Gwigfeit veridgmelzen

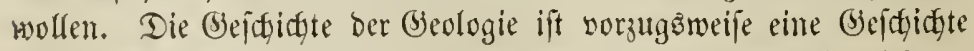
won Gebanfent unt Theorieen, on bie Thatjadten, uriprunglidy ge= ring, allmälig erjt hervortraten mo yon bem geifitigen Đebäube, Daz man barüber auffülute, oît erbrüft wutroen. WGo aber That= jadyen unb Beobadtungen feflen, ba vertritt bas Alymungžvermögen

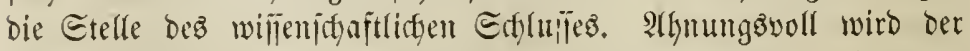
3ufammentyang you Patureriffeimungen ausgefprodfen, oft uner=

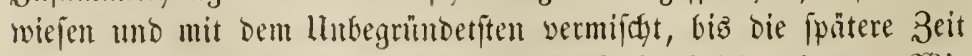

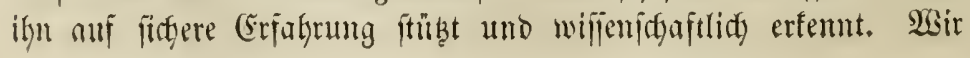


Dürfen bieje ahnente Flguntaje, bieje unnittelbare Thătigfeit bes (S) iftes nidut anflagen, die in Den größten Seiftern Der Borzeit

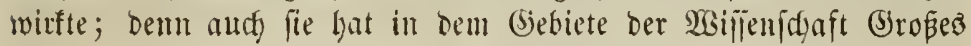
geifhaffen unt nidgt immer von ber (Ergrünoung oer Wirflidfeit ab=

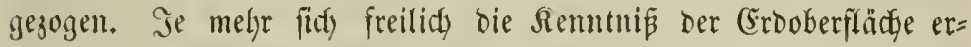
weiterte, je mehr man neue sunder entbecfte und ilyren Boben un= terfudte, je gentuer man zugleidy ben Geimifden Boben tennen

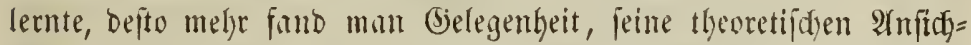
ten zu erweitem und zu beridytigen. Bon jeher war es ein Stre=

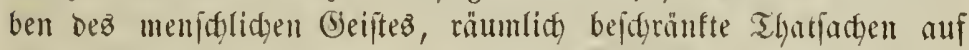

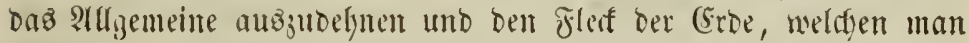
bemofnte, als baz typipde Ranto zu betridten, nad beffen Bor= bild bie ganze Dberfähtse der Eroe alammengejebt jei. Eo muk=

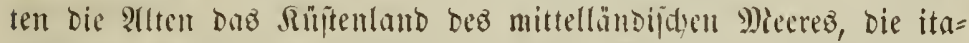

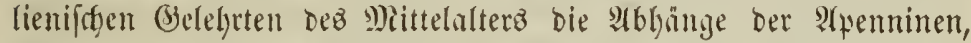
Werner daz fleine Eadyjen, Şutton Edjottlond als Typuz für bie Bildung der ganzen Eroe amplyen. Yiur bie Bergleidyung fonnte unteridgeiden lelyren, was allgemein gültigen Serbältniffen, uno nas lotulen Cigentlümlidyteiten angeböre, uno jo gelang ę ber nencren 3rit, Durd bie unendidye Servielfältigung Der (Erfahrungen an ben entlegenten Srten, an bie Etelle ber Bermuthungen beob=

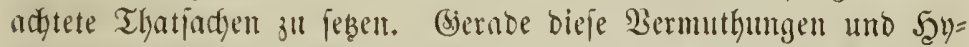
potbejen aber, bieje Trüumereien einer nad Erfemminiz büritenben 3eit, bilben in ber Sejojidyte ber (S)eologie cinz ber anjiehenditen Wiomente.

Bon jeher gab ez hervorragenbe Beijter, weldye aus menigen Eimjellyeiten baz (S) itheiden, bie allgemeinen Stejese zu ahnen, wo nidyt zu ertentment vermodyten. Eoldge 92änter gleidjen jenen Wiloen Piorbamerifaz,

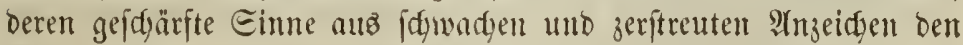

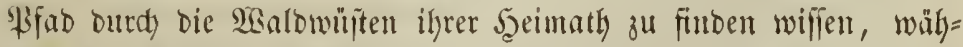
rello ber WGanderer Europaz ber Wegmeifer bebarf, um nidyt in ben heimijgen, reidjbebuten fluren irre zu gehen. Sie finto bie

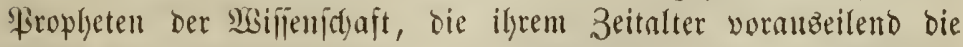
Balyn Der 3utumft bezeidhnen. Eo fdylummern oft, von ber Arlyung geboren, bie widytigiten WGabrlyeiten in Der WBiffenjdyaft, bis bie nüdterne Beobadjtung fie lervorzielyt unt ifnen meue Beltung ver= 


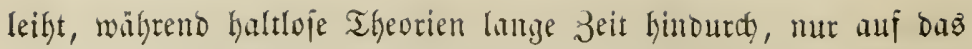

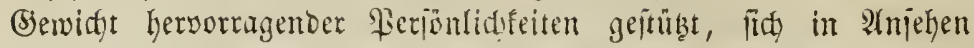

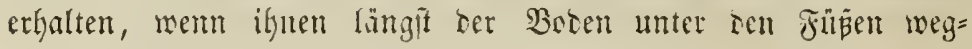
gezogen ift.

Die frilbejten, wern aud vit phantajtijhen Theoricen über Die Entiftefung Der (Eroe idjöpfen wir aus ben Pieligionent ber al=

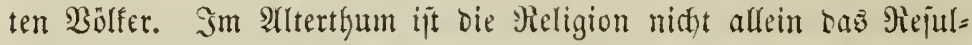

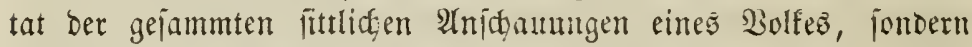

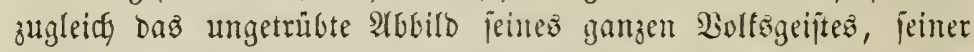

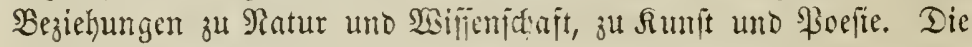

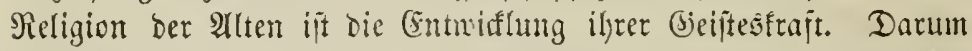
fuchte jie immer zuerft (jeifit mo Materie zu vermitteln, bie Edjö=

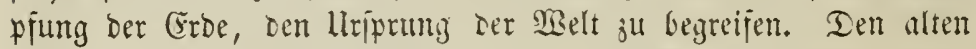

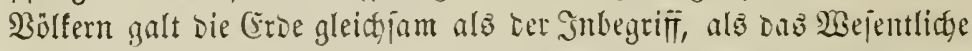

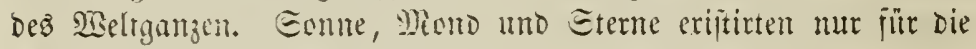
Erde, un auf igr zuleudyten, Tag und Madjt ju trennen, Das

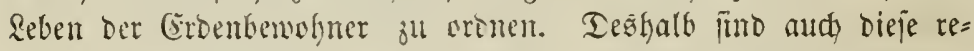

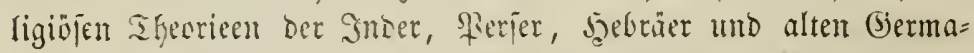

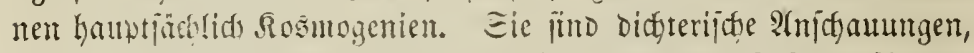

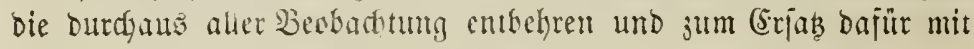

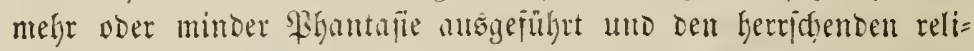
giöjen Soeen angepant mo untergeoronet fint. Senadfoem ber re=

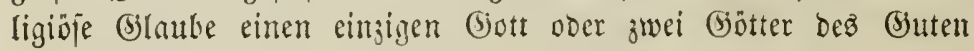

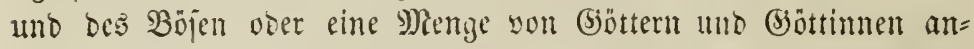

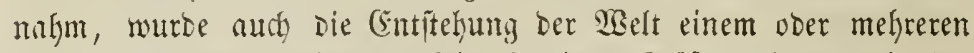

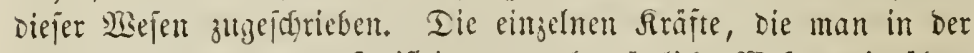
Patur jah, wurben perjonificirt uno als götlidge $\mathfrak{B s e j e n}$ mit über=

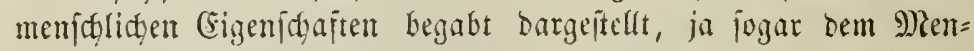

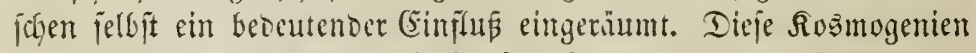
gefören nidgt ber Maturwifiemichaft, pontern ber Metythologie an,

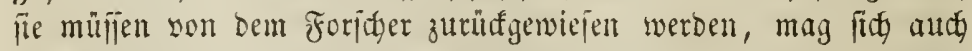

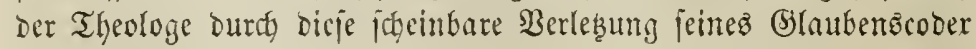
gefränft fühlen.

Die finjtern Maturreligionen ber jelavijeden Bölter bes Sîtenz

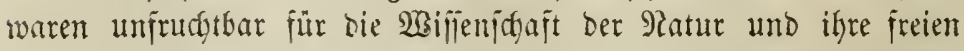
(bebanfent. (Erit in Briedyenland, Dem Tempel phypititer uno gei= frijer Freigeit und Edyongeit, wo ber Menjdy fids zuerfit jeiner 


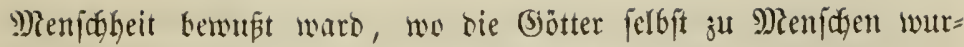

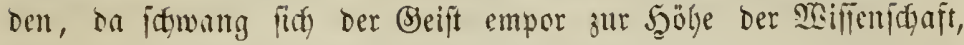
Die mit ber Freiffeit wutç8 uno blühte, bis fie mit ihr unterging. Dort galt bie Matur, waz fie Dem Menjáen war, bort adjtete man ifre (Ericheinungent, weil fie serfettet waren mit ber Entwidf=

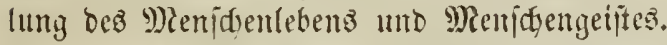

Die Briecten waren Zeugen ber grobartigen vulfanifden $\mathfrak{R} a$ tureriffeinutgen in iffer Seeimath, anf Dem Feftande und auf ben Snfeln; fie fanten Beriteinerungen in ifrem $\mathfrak{B o b e n t}$, bie $\mathfrak{2 n}$ ndjwem=

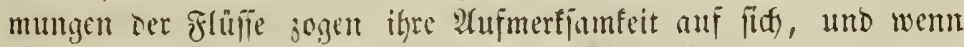

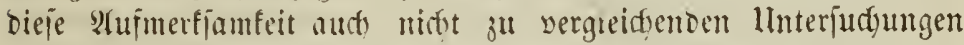

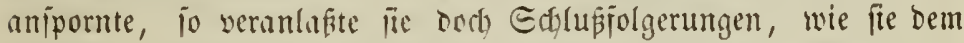

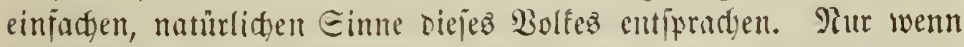
Die Alten ḧber bieje ummittelbaren Folgerungen anz Den Beobadt)= tungen zut allgemeinen Theorieen über bie Entiftefung Der Eroe n̈bergefen, verlieren fie fid, wie ifre Borgänger uno Madjfolger, in weitif(tweifige Träumereien ser buntejten $\mathfrak{A r t}$. Aber fogon bei

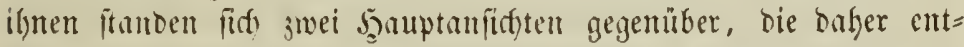

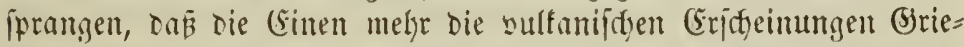

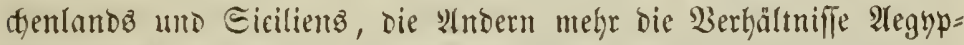

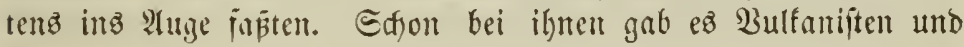
Meptuniftert.

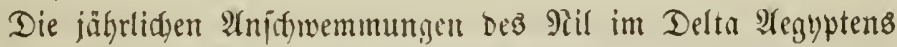

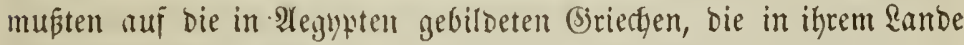
feine foldye Bcobadtungen anzuftellen im Stante waren, einten tie=

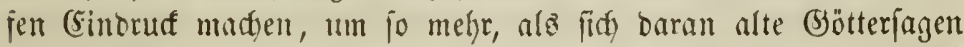
uno Mytgen fnủpyten, uno Hegypten währeno langer 3eit bas Eano ber Wifileniduaft, bie Jyodjidfule ber alten (Siriedtent war.

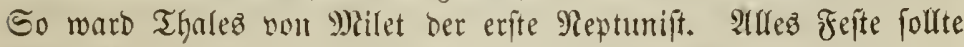

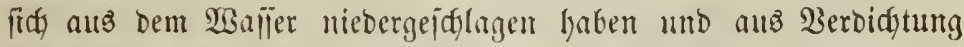
dez Edflammez hervorgegungen feir. Kenophanez, Futhagoraz,

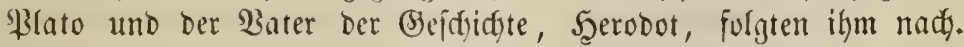
Diejer Edyule ter Meptunifiten ftellte fid bie ber Bulfaniften Zento und Empeodlez entgegen, nadh welden bas Fenter auz bem $\mathfrak{\Im} n=$ nern der (Eroe heraus Berge uno Ränder ertoben umb vielfạ) verän= bert haben jollte. Bei ber alfgenteinen Tentenz ber (S)riedyen, ben

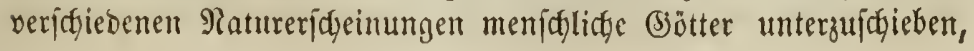




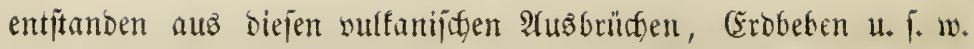
jene mannigfadgen Nythen yon Titanen und Biganten, weldye bie im Sntern ber Erbe reglamen wulfanijaten Sräfte reprïfentirten.

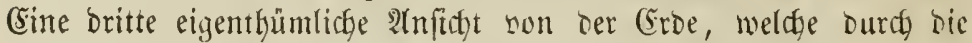
Raturphilofophie in unjer Zeit igren wejentlidgen Sirundzügen nadh wieber aufgettommen wurbe, ftelle Alriftotelez auf. Diejer Sđjö=

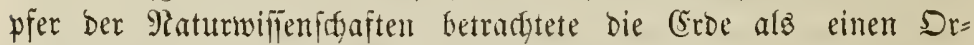
ganismus, Deffen inneres Reben Durd) Die Berïnderungen ber Dberfläcbe fith tund getbe, indem abwedjelno eimzelme Theile auts= trodneten, andere wajlerreidy withoen, abwectjento alterten uno

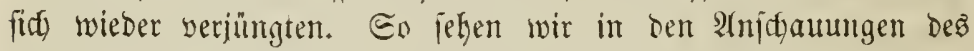
flaffifthen 2llterthums bereits alfe Reime umjer heutigen genlogifchen

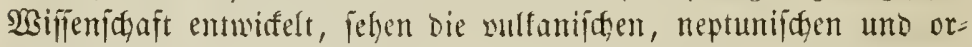

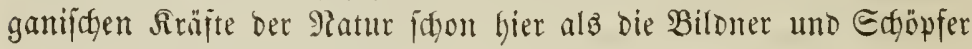
Der Erooberfläche anerfannt. -

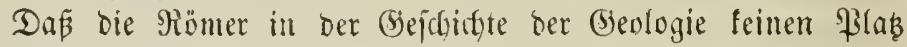

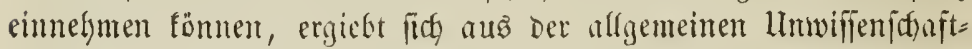
richfeit biejes Bolfes, bejpen runfer Bosen fïr bie zarte Wflange ber Raturwijenidaft unjudubar war. Die 3eit ward alt; ent= nervt und entartet fant fie in onz Grat, ons ilyrer lange harrte.

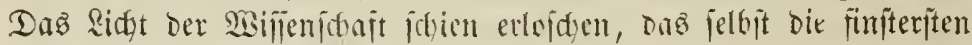

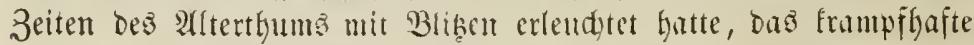

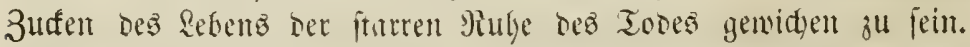

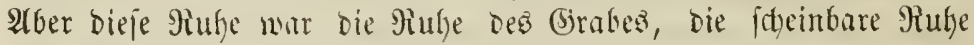
jenes geheimnifvolfen sirecefles, der aus dem Tode bus Reben, aus bem Eamentom Die junge 舛flmze entmifelt, es war bie Ruhe ber

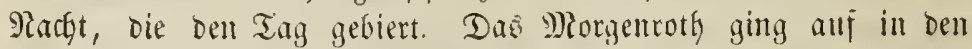

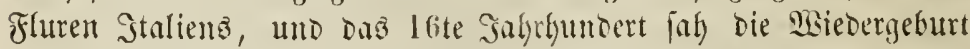

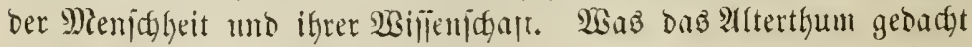
und errungen, war nidt serloren, fonoent mur ju göberer (Ent=

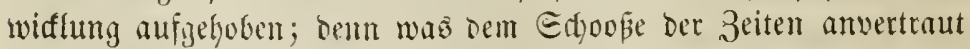

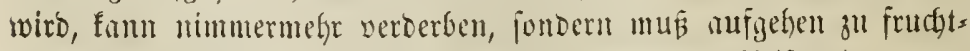
bringender Gaut. Der jeeres ocs âttertlumb , Priftoteles, war audg Der Bater ber nemen 3eit. Buf jeine Edyriften grünoete fids

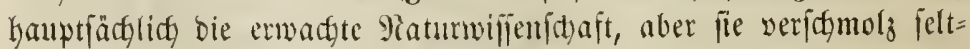
famerneife feine Regren mit ber Bibel mo ben herridgenden reli= giöjen Borftelfungen, über Deren Erbaltumg bie fatljolijche Rirtbe 


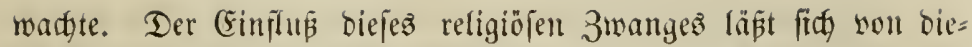

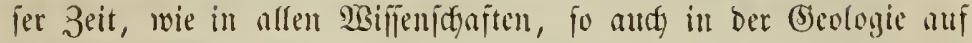
Das Deutlidjpte nattmeijen. Die Reķerei ber Selehrten, welthe auf Anfidgten geriethen, Die mit Der Bibel im Wiberipruth ftanden,

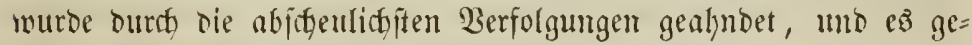
lörte Daljer feit geringer Mutl) baju, feine llebergeugung ohne

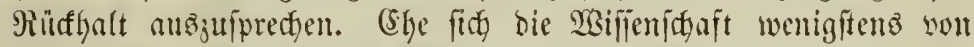
Den gröberen, finnlidgen Feffeln, weldge bie Rirdge un fie foblug, be= freite, bemulgten firt balger bie meiften Foridger, bie llebercinitim= mung ifrer 2tupidten mit Der Bibel nadyzumeijen. Eo famen vit bie bigarriten Anfitgten zu Tage, bie emsig biejer Tenben; ifren Ilriprung nerounten. Die sismberind und ber stberglaube hatten

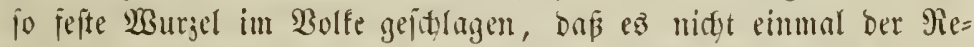
formation gelang, fie ganj ju berbrängen. An bie Stelfe Der in Miffredit gefommenen munderthätigen Seciligenbilocr traten bie Mineralauellen, beren Entbedung mit allgemeinem Subel und fird)= lidgen Danfigebeten nod im 17. unb 18. Galyrbundert gefeiert wurbe. Abenteurer burdsogen bie Ränber mo fudyten nad) eolen Metal= len, Eteintoblen uno Borcellanerde. Eoldge Betrïger wurben von Den Füriten geehrt und wou Den Sietiften zur Zeit Friebridy $\mathfrak{B i l}=$ lyelmto II., Den jogenamnten "Erwedten", bemubzt und in Schub ge= nonmen.

Den eríten 2) gen gaben bie Beriteinerungen, welthe man in Dell Gebilden ber

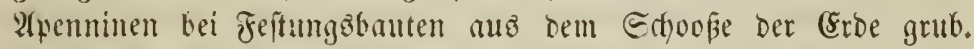

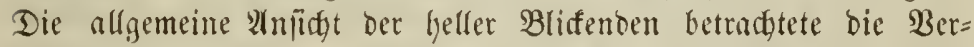

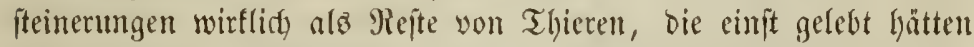
und burd) bie Eindfluth vernidytet mo an jente Drte ge(iradyt jeien, wo man fie jekst finbe. Prnoere Bjelebrte aber eridjopften ifre gange Whantafie, um wahrídgeinlid zu madyen, bap diefe Siejte nie lebenden 2 bejen angetjöt haben, fondern mur fogenamnte Ratur= ipiele feien, herborgebradft burdy eine munberbare plaftifase Rraft

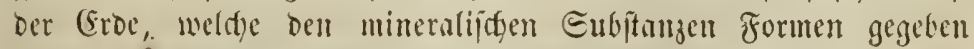
habe, die cintigermapen benen Der lebenden Thiere älntuln. In ifnen follte bie Matur den Berjudy gemadgt haben, of es ifge wohl gelingen werbe, nach uno naø, gleidfam ourd längeres unterir=

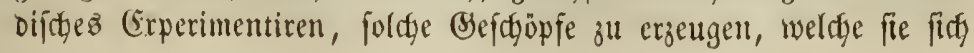




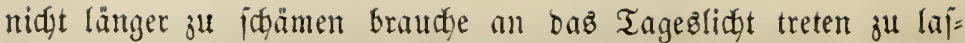
jen, und bie wirbig feien, ba if ifnen Der lebentige Doem einge=

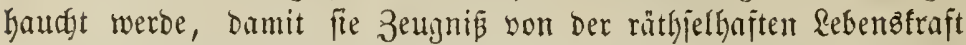

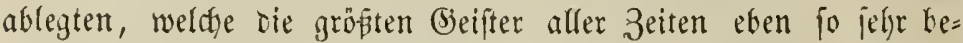

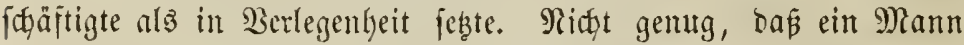
wie Rifter ben Gefteinen felbit biefe wunberbare Bildmerfraft zu= idfrieb uno die veriftiedenen Shantaftere der Berfteinerungen ver= fafiebner Formationen, sie jein idarfes 2ruge erfaunte, aus einer

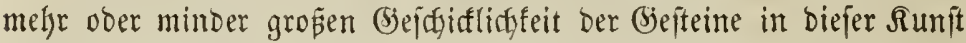
erflärte; audy (beijter juthte man inz Epiel zu bringen, Bergmänn=

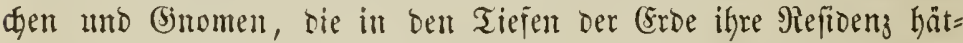
ten, felbjit Hianeten und Eterne jollten Dabei gearbeitet baben. Siurz, feine Theorie fonnte zu gejudst und phantaftich jein, als

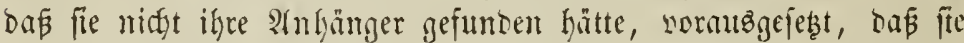
mit Boffâfagen zujammenfiel. Co weit fann fid ber gefunbe Menichenveritano verirren, westu er jetz nad) Dem $\mathfrak{B}$ underbaren hajoht, um bie einfadjpten Dinge ju enflaren! Sene Zeit ift norïber, wo joldge Maturanizaten (Eingang uno Bertheidigung finden fonn=

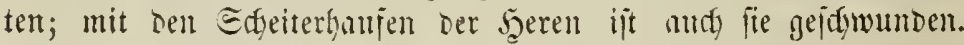

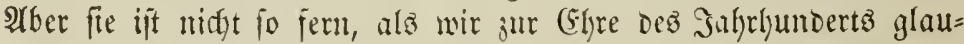

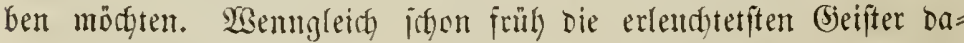
gegen antümpften, Sconaroo Da Binci, Jyoofe und Eteno, fo hat

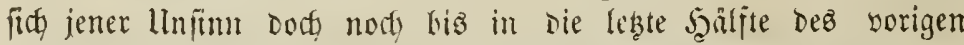

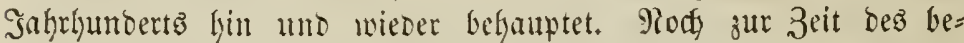
rưfuten (Shenifers Etabl glatbte man an jene wutnoerbare Ratur= fraft, welde fing in ber shaduiffung thierifder Bebilde in Etein

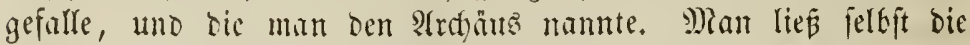

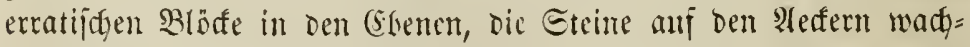
jen, wie Emijure jagt, gleid) Trinffeln in Der (Erde. $\mathfrak{A}$ uj einen bei

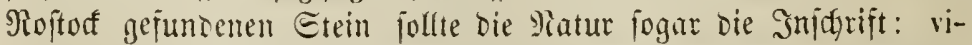
vant Gedanenses! geidfieten, aljo Den ulten Borfahren ein Rebehod)

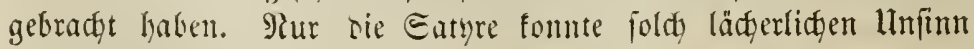
für immer vernicyten.

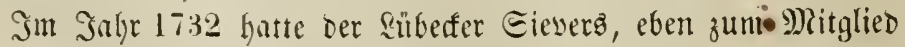

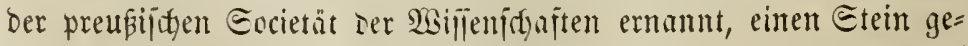
funben, alif weldfem er Proten entoefte, und son bem er fefhr siel 2uffeefens machte. Da trat ber berüfmmte Entyrifer Siscow, da= 


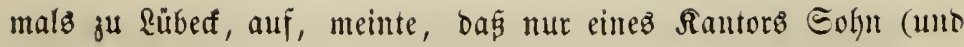
Der war Sieverz) im Stande fein fönne, ali einem Steine 9ioten ju lejen, und jarieb in Folge befien eine Sature, weldye ben Titel

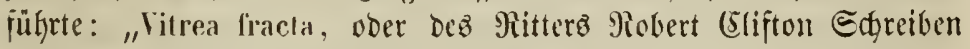
an einen gelegrten Samvjeben, betreffent bie nadjoenflidgen Figurest, meldye Derjelbe Den 13. Sanum 1732 auf eimer gefrornen Fenfter=

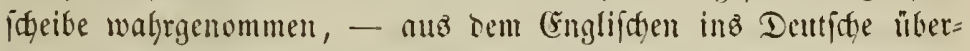

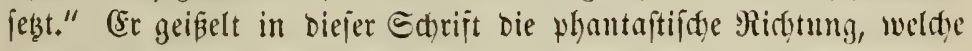
bie Belefriamfeit zu jenter 3eit genommen hatte, uno erflärt bie wunderlidben figuren auf einer gejrornen Fenfterdgeibe burd) ben Unhaudy ber (Sicdanfen einer gelebrten Gefellidajt, welde fid) in Dem 3immer mit ben verbängnipvollen Fenjterjdeiben verfammelt habe.

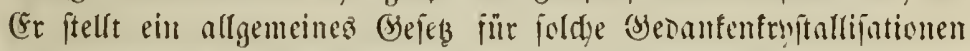
auj und preift Den Begierungen bieje jeine Entbertung mit folgenden Worten an: "Da bie Figuren nuf cimer gefrormen Fenfteridyeibe jo

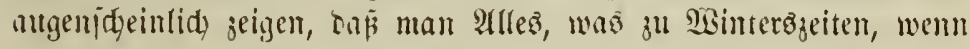
es ftarf friert, in eimem 3immer vorgegangen unb gerebet worben, aแ Den gejronen Fenitern lejen fam, fo bäudgt mid), wäre eg cine Geiljame Eadse, wern ez den Megierungen gefallen mollte, zu ver= orbnen, Daj ju foldgen 3eiten alle Morgen Die Fenfter in allen

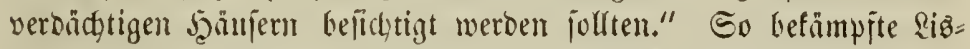

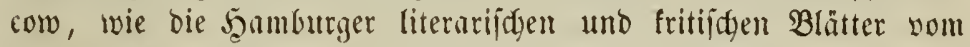
Gahre 184 erjählen, die 9arrbeit mit den gebübrenocn Waften,

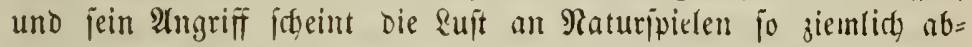

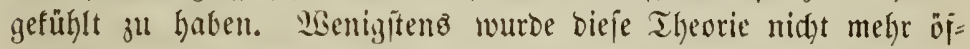
fentlid vertheisigt, went fie fith aud im bjebeimen nod lünger erfielt.

Radbem man zu ber lleberjeugung gefommen war, dap bie ßetrefacten nur Rejte orjanifjer WBefen jeien, war eg ganz natïr= (id), Daß̧ man die Tupen Derjelben zunn̈d)ît in ber lebenden $23 e l t$ judte. Dú man aber jo lange bei biejem Jrthum beharren fonnte,

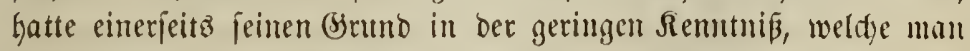

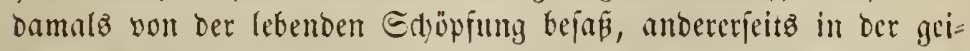

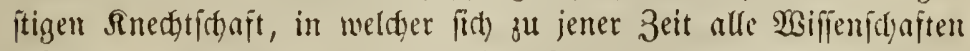
bejandent. Die Theologie n̈bte ohne Biderrede ben Supremat über alles anore WBifien aแż; mit Dem orthoboren Dogna burite feine

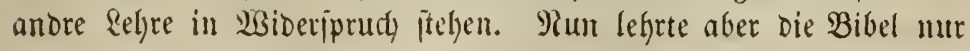




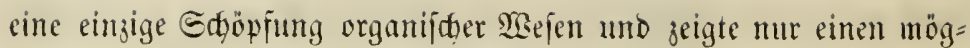

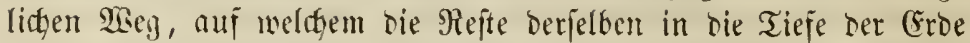
hatten gelangen fönnen. Sier alfo in ben \$etrefasten nidgt hätte Bemeife ber Eünoflutly jeften wollen, märe als Seberer betradgtet

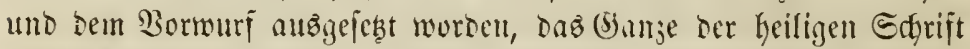
nidyt glauben zu wollen. Im Deutfigen Rorben fanden bie Beolo=

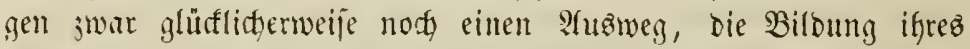
booens auf eine von oer allgemeinen Eimbflutlygtheorie unabgän= gige siseife meiter auğzubilder. Die Enge von der cimbriftgen Fluth, biefon Şirngepinnit jtaubiger Etudierituben, meldye fid in 2 ten

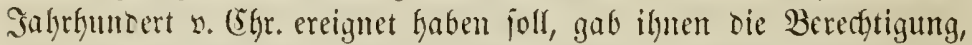

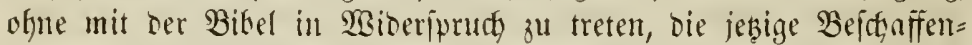

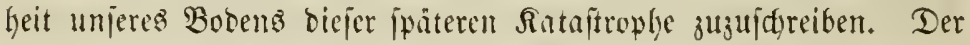

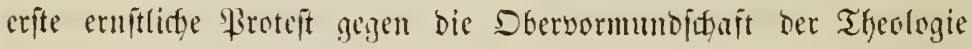

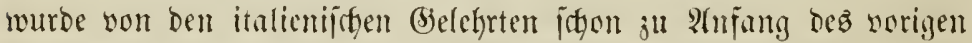

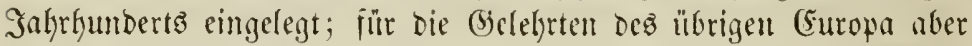

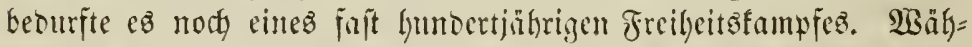
reno unter hefiligen, geiftigen uno politipden Sämpfen ber ganje

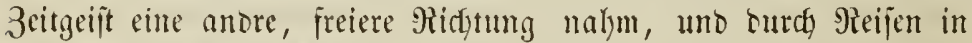

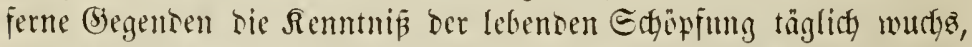
musten bie (beologen inmer melyr mo mehr bie llnmöglisffeit ein= fehen lernen, bie Tupen Ter Beriteitterungen in Der lebenten $\mathfrak{B e l t}$ aufuninden. (Es erlob fids mun cine Stimme nady ber anderen gegen bie Eünofluthotheorie, und am (snde bes vorigen Jahthun=

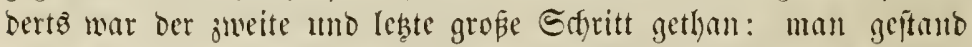
ein, Daß

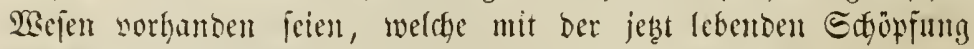
Pict) gemein hätten.

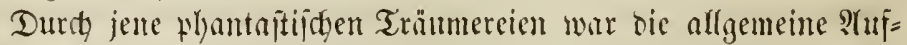
merfiamfait von den erniteren geologifden Etudien Der Edjicten unb iffer Ragerung abgelenft worben, uno mur Sinziche machten fid) burdy neuc Theorien bemerflidy. Etent, ein Däne son Gebutrt,

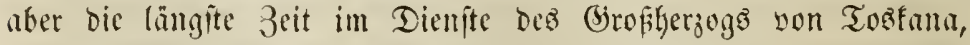
ftellte zu Ende des 17. Iahrhunderts cine Theorie auf, Deren finth

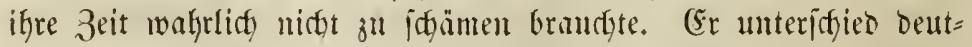

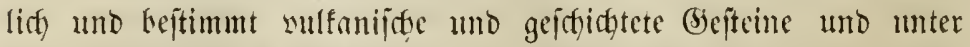
Diejen wieder bie verfeinerungalojen, älteren von ben jüngeren, $B e r=$ 
fteinerungen füfrenten. (Er unterffjied audf Formationen und er=

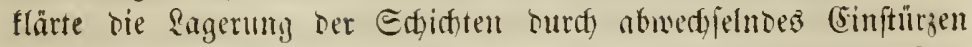

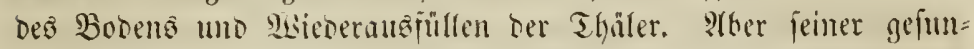
Den Midftung folgte man nidgt nad); man verlor firth wiener in un-

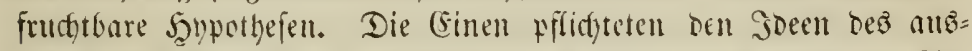

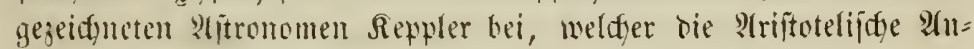

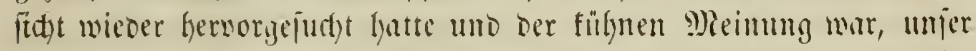

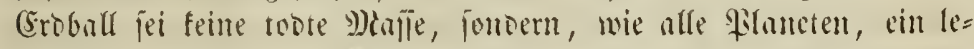

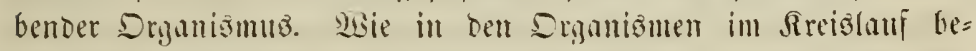

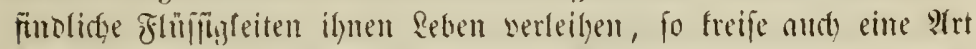
Aether um bie sigeltförper, uno bie tleinjten Theile ber Materie

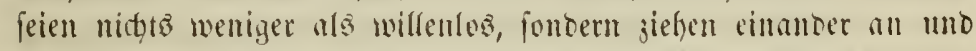

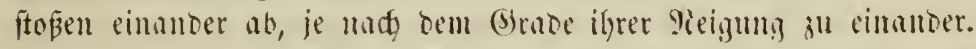

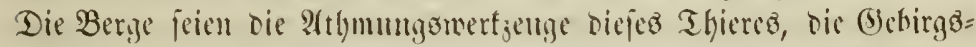

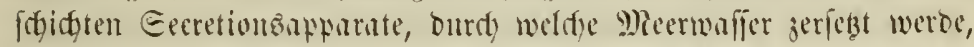

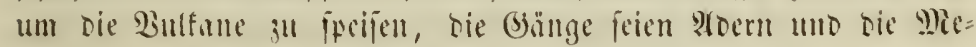

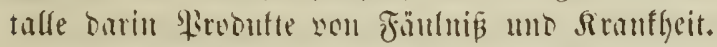

Die Englänter jolyten ifrerer religiôfen Tentenj, bic nody jeb̧t

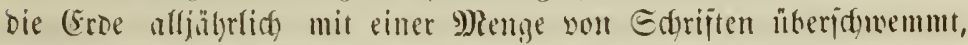
weldye bie lletereinftimmunty ber (beologie mit ter mofaiffen Edyä=

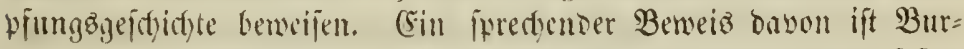

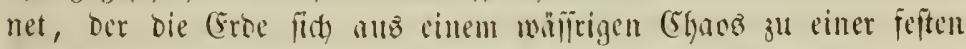

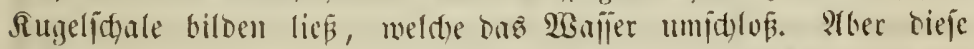

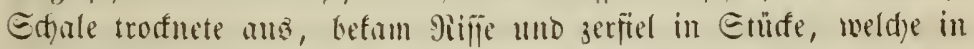

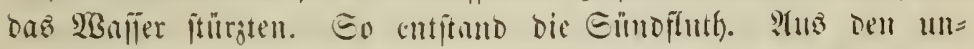

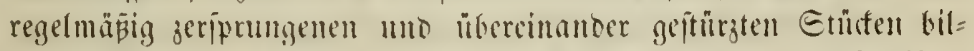

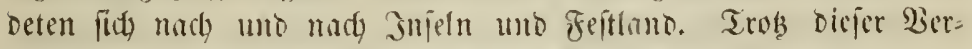
fuche, feine Theorie mit oer Bitel in Einflang ju bringen, wurbe Burnet bemnody oer Reberci tejduldoigt; aber nidts beftomeniger

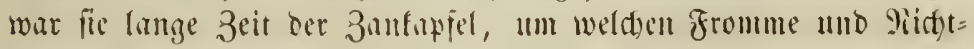
fromme fid fitritten. -

Reibnitg war Butlfanift uno efflätte bie broe für einen ur=

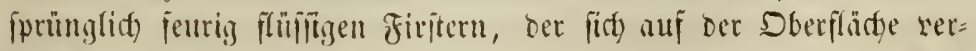

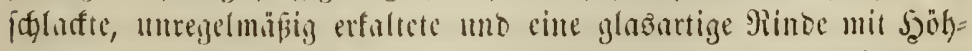

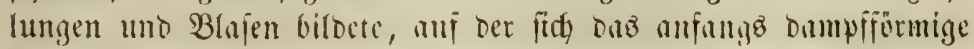

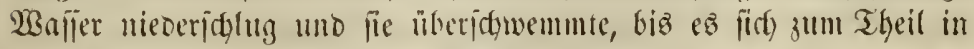

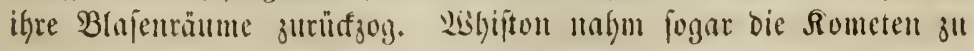


Şülfe. Slym war bie (Erde einft ein Romet, und ein Siomet fülfrte bie Eimbfiuthlyerbei, ala bie (Erce in feinen mit $\mathfrak{B a f f i e r}$ gefüllten Edyweif gerieth. Er berednete nidft alfein bie Stunbe biefez (Er=

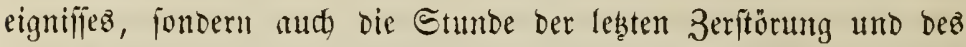
jüngiten Beridftz. Dent Bipfelpunft diejer phantriftifden Tenben; bildete endidy Buffon mit jeiner jo berithmten "Theorie ber Erod", welde 1793 erichien. Afuch ifjm war bie (Erbe ein uriprünglid)

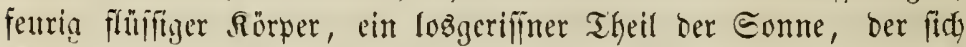
allmälig in ber viel zu flein angenommenes 3eit von 76,000 Iath $=$ ren alfinglte unto Durch) unregelmäpige 3ufammengiefyungen auf ber idflartigen Rrujte Berge uno Thäler bilbete. Daz in ber 2ttmo= ipgäre Dampifïrmig aufgelöfte $\mathfrak{B}$ anjer foblug lid auj ber erfalteten Erorinte nieber, löjte einen Theil ber Sdylafenmajife wieder auf

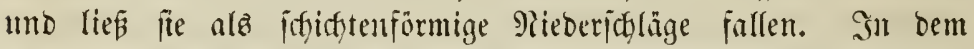
Mlecre lebten Thiere, auf bem feften Eanbe wudjern Fiflanzen. atber Durch bie fortoauternde Erfaltung fpaltete find bie Crorinte wieber, Das $2 \mathfrak{B a f j e r}$ brang biz auj Den glüfendent Sern ein, ver= wanbelte fids in Dampf und verurjacte mu ungeheure Sxplofito= nen, burdy weldhe bie Schithtent zerworfen, bas Mieer emporgefdflen=

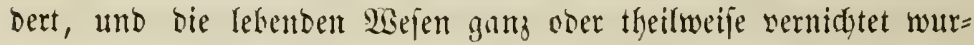

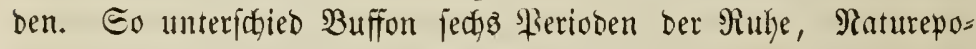
den, weldse burd) Resolutionen bon einanber getrent waren, uno währent beren bas organifaje Reben immer tiefer uno tiefer fant, weil bie Errfaltung Dez Groballz mehr uno megr zunafyn. Die

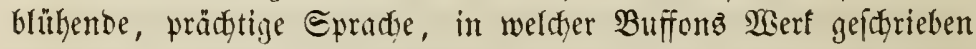
war, Die idseinbare Befräftigung feiner Theorie burds genautere

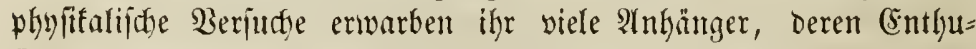
frasmus inter nidft lange anthalten fonnte, ba bie aus ber Beobady= tung gemonmenen Thatjacten allmälig bie unreifen theoretijden Epe= culationen verorängten.

San Raufe bez leten Sahrhumbertz entwiffelte fid nun jener philojophifine Efepticismus, ber auf bie Behandung ber Matur= geidsidfte ben wefentfidjten und heilfamiten (Sinflue ausinbte. Man fehrte son Den unfrucțtbaren Träumereien z̆ bent einfactsen Beobad)= tungen jurüf, und werm man früfer in bas (5xtreme ber Specula=

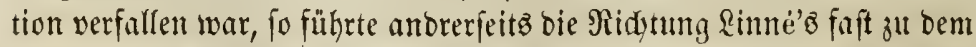

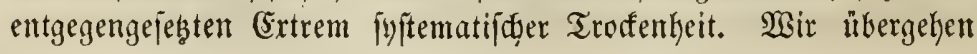




\section{9}

Daker biefe Zeit, in ber riliftig fortgearbeitet wurbe, befonders auf

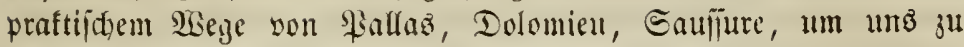

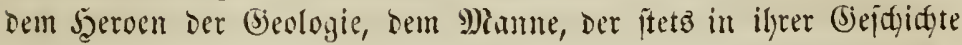

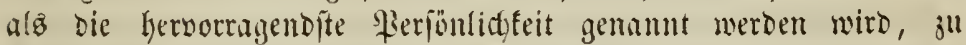

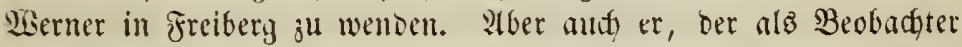

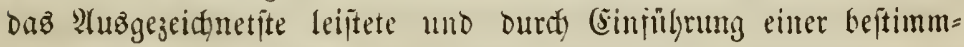

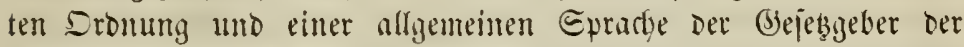
(B)ologie genannt fll werden verbient, ift als Theoretifer wieder Dem alten Jrtthum verfallen, ja hinter mandjem feiner Zeitgenofien

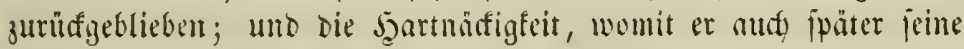

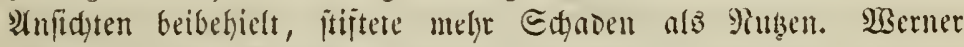
war volfenteter sieptunift. Der ganje Grobalf war ifym aus Dem Banfer Gervorgegangen, oas llrgebirge hatte fith zuerfit in fryptalli= niigher frorm niedergeidjlagen, uno um bies jejte Bjerippe hatten

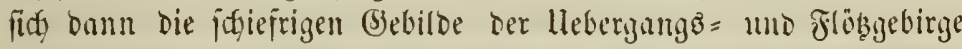

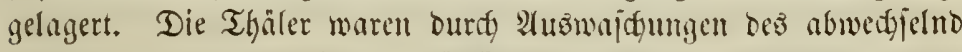
anidgneflenden und wieder zurüfïntenden 9 )eerez entitanden, mo= für freilidy bie Thalbildung Der fït)pijden Edyweis nuf Dns Deut= lidjite iprad. Der fduwade \$iunt bes siserneriden Eyjtems war

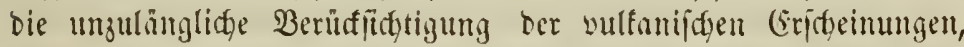
bie ifm nutr locale Sigänomene, Erobrämoe der obern Edjidten,

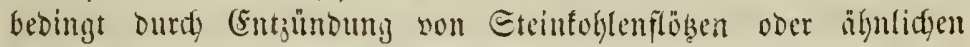

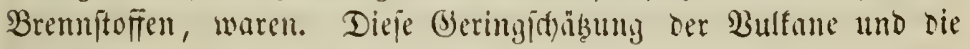
Berfemung Der ältern vulfanifiden Gebilde entiprang aus ber lhn=

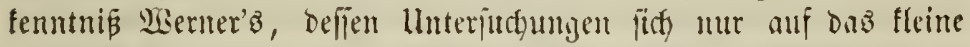

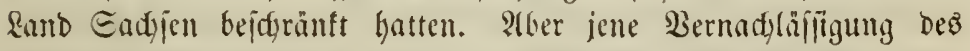

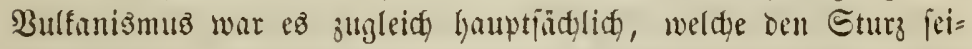

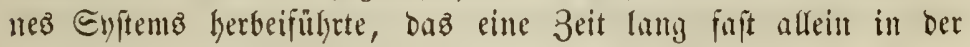
(S)eologie herrictite.

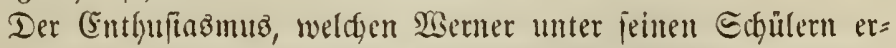

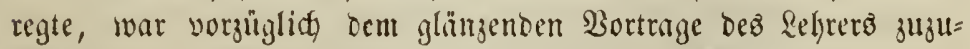

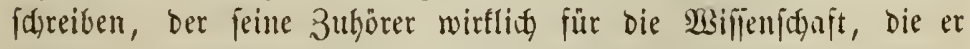

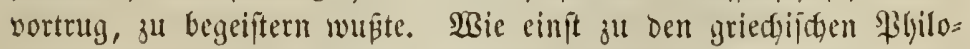

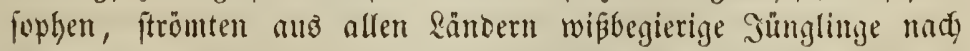

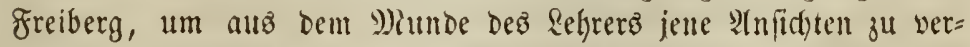
nelymen, bie ganz Europa erfüllten. Eo groß́ war bie Ébrjurdft, weldge bie Edjüler yor Dem Meifter hatten, deifenl liebenßnüroige 
Berfonlidfeit ignen thener und werth war, bas bie meiften berjel=

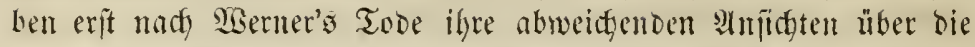

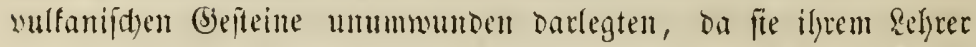

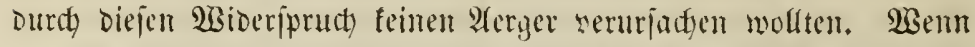

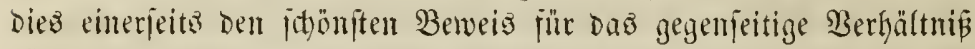
WGerner's und jeiner Edyüler liefert, jo mus man auf Der intoern Eeite

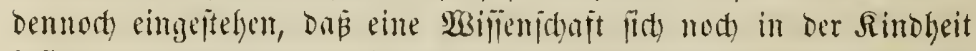

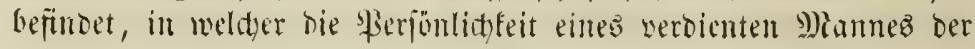
Etimme der walyrheit Edweigen gebieten fanm. Eobalo einmal Die Thatfad)en in einer 2 siffertifgaft fith fo gehäuft haben, Duß bie

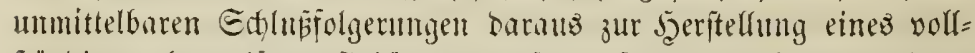

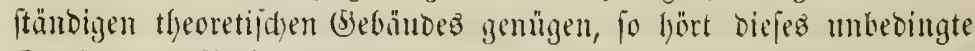

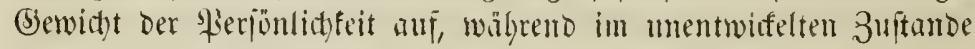

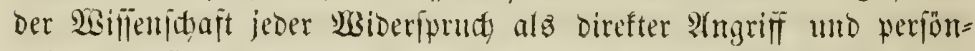

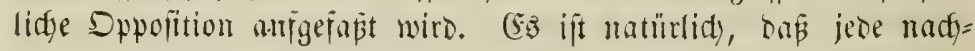

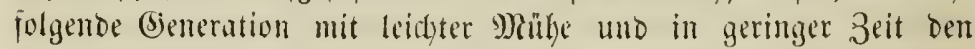

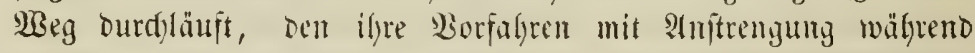
ifres ganzen sebens ebnen musten. Die Danfbarfeit, welde man gegen biefe Borgänger laben foll, bejtefyt aber nidft darin, baß man mur ber sou ifnen angebahnten Hishtung unbeoingt folgt uno

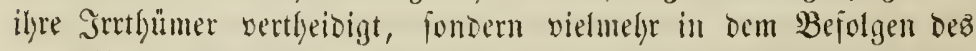

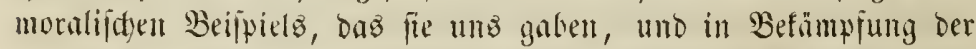

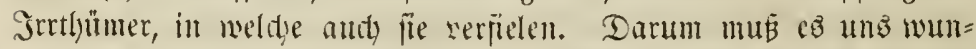

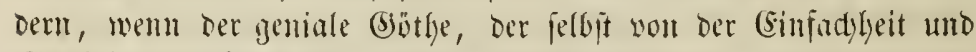
Rlarkeit Des siserner'iden Eyjtems befangen war, ein fo hartez

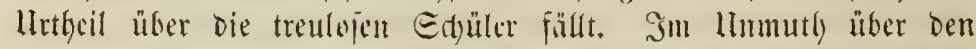

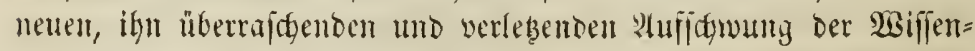
(id)ajt bridft or in bie 2 Borte aus:

\footnotetext{
Sum wendet ber esle Sacrner Den औürfen,

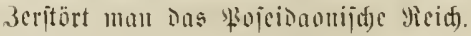

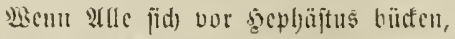

Id) fumu cs uidft joglcid) ;

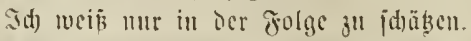

Єd)ou bab' id) mand)es Credo verpapt;

n?ir fins fie alle gleid) verbast,

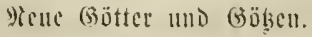

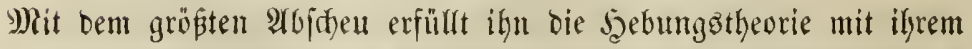

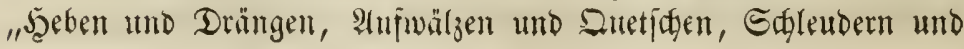




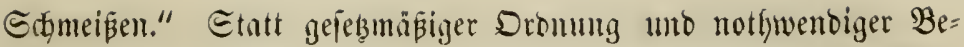

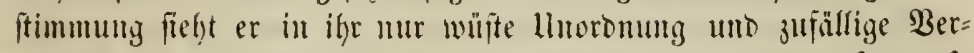

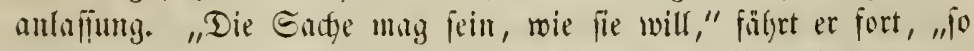

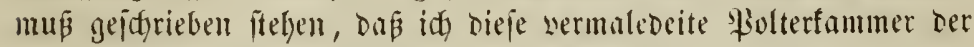

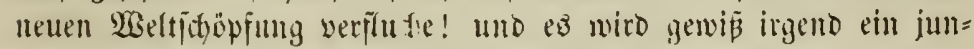

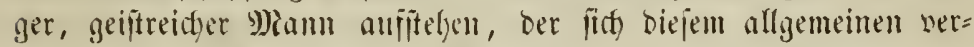

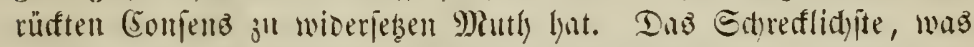
man lyören mus, ift bie wieserholte berfidjerung, die füumtlicten Maturjorjder feien hierin berjelben lleberjengung. WGer aber bie

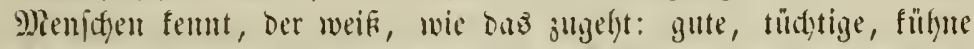

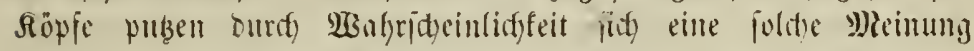

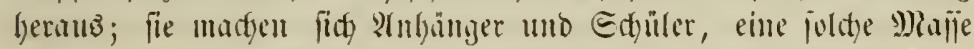

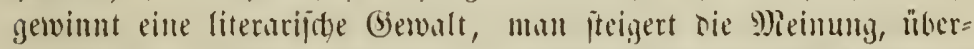

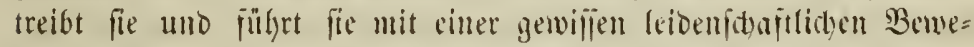
gung burd). Das hei ït man allgemeine llebereinftimmung Der For=

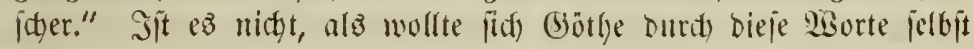

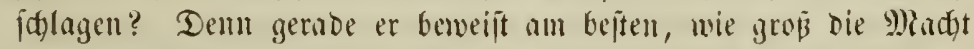

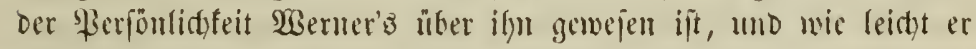

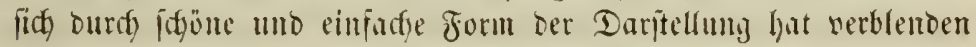

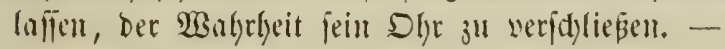

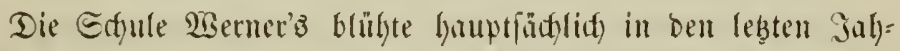

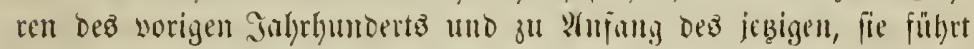
unz afjo unmittelbar jul Der 3eit, in weldyer wir jeßzt lebell. lleber

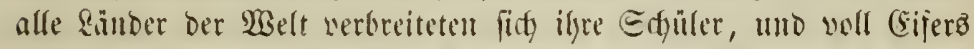
zogen fie alı, um bie ganze (Erbe son einem \$ole zum antorn in

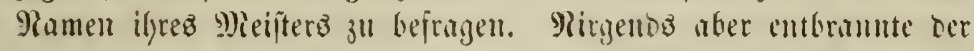
Rampi unter ifnen leftiger, nla in Dentidglanto, wo mun balo

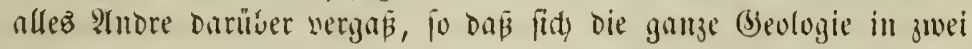
Sager theilte, Miepturijten uno Bilfaniften, bie fith mit wirflicter

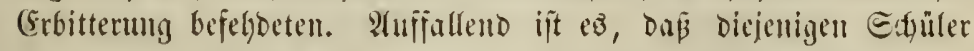
Berner's, bie entferntere begenton befucten, nady und mady bas

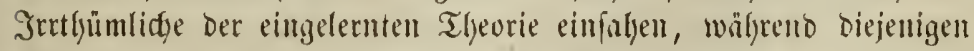
(B)ologen, Die auf Der heimifden Edgolle Ranbes fitzen blieben, den

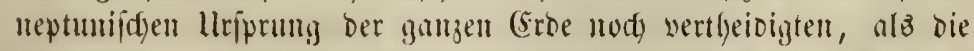

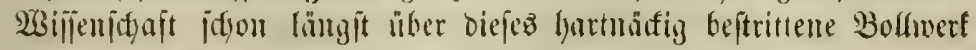
finaus zu ferteren Eroberuntyen geeilt war. 


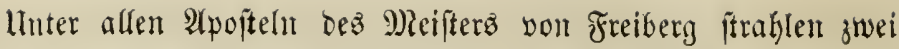
Forjcter herbor, bie auj bie (5iejtaltung ber Sbeologie ben wejent=

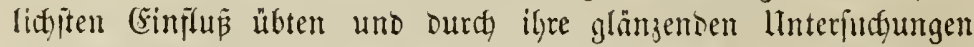
ftets eitl Borbild für fpätere SSeologen jein werden, wenngleidg Der

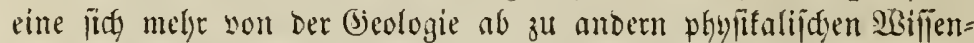

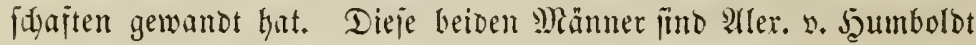
und Seop. n. Buch, ber einte nod beute in hohem alter bie Bierde

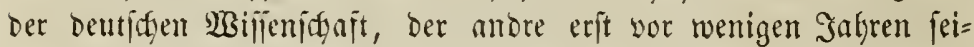
nem reifgen Sirfungg̈treife Durd Den Tod entrifien. Beibe einan= Der an Talent ähnlid, beide in unabhängiger Stellung und im Befitg bebeutender (jeldmittel, beioe ourd) innige, nie getrübte Freundidn vertmüpit, 〔eiteten gemeinjam Den heutigen Etand ber Sbeologie nidgt nur in Deutidfand, jonbern in oer ganzen mifjen=

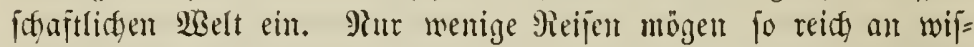
jenjofajtlichen Heplttaten gewejen jein, al: bie, weldye Szumbold

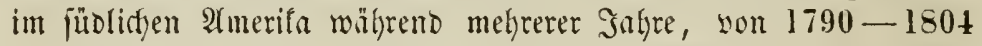
auşührte. Die Interjuctutg der ungehenren Buttane SüDamerifos, Der Dort io zahlreiden Erobeben und Die lidbtwollen allgemeinen lleberblife, welde ber grobe ßeijenbe aus jeinen Bcobadutungen jog, hibten auj bie Steologie einen mejentlidyen Gimflub. Aber ber eigentlidye Biejormatse diejer Brifienidajt ift Reop. v. Buct. Artre

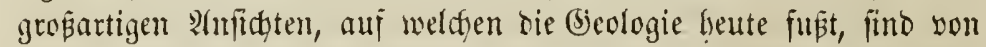
ify gejdaffen und in bie Sijlemifort eingejüfrt worben, und wenn

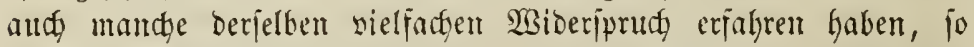
bleibt \&. v. Bud bod, bis heut ber erite aller Geologen und wirb

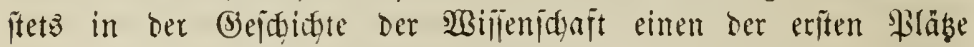
behaupten. (Sigent jeine Berbienjte erjoteinen bie Arbeiten jämmt=

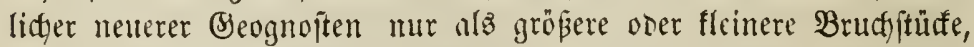
weldye fidy Den umjajienden Arbeiten biejes gewaltigen Mannez

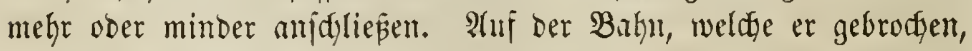
jureiten noch immer bie tübtigften Belelyrten aller Ränder fort.

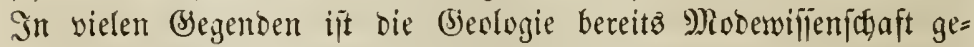
worden. In England bejonbers interefiftet fith bie Moblefie für bie= felbe, und wie überhaupt bas (5iebeihen aller mifjenjdyaftlidgen $\mathfrak{u n}_{n}=$ ternelymungen von ber Theilnabme der höheren Slaffen abhängt,

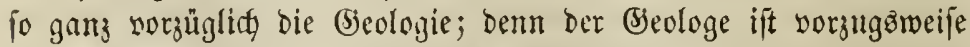
Darauf angewiejen, reijenter Raturforjher zu fein; er fann bie 


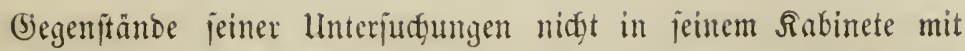
fich füfren. Darum ftehen bie Deutichen Foridger in Betreff grö=

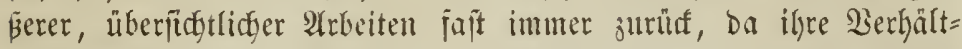

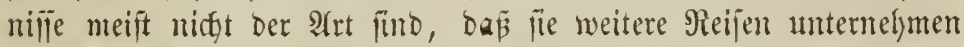

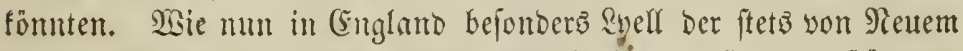

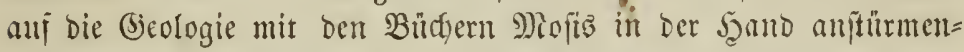
Den Theologie entgegentritt, fo ragen unter ben Mieiftern biejer

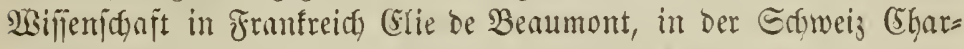
pentier, Af(gaiiiz uno Entuber hersor. Die Errjolge ber vereinigten Anjtengungen aller biejer großen Geifter werben wir am Bejten

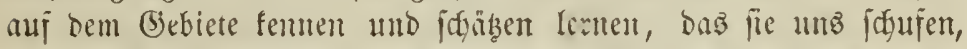

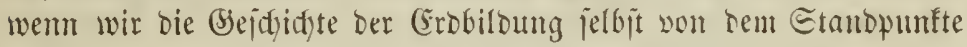

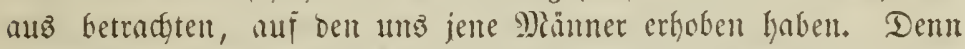

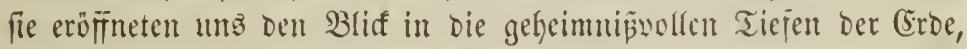

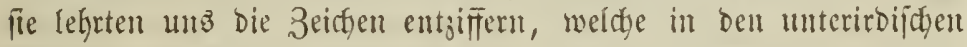
Blättern Dez Butches der Ratur eingegraben fund, fie gaben unz

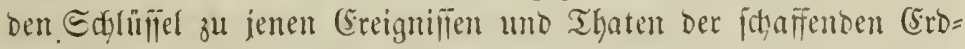
fraft, Deren Denfmäler unjer Fuß Getritt und unjer 21tige finnent mitsunt.

\section{B. Die llrfunden und Denfmäler der Crogeididte.}

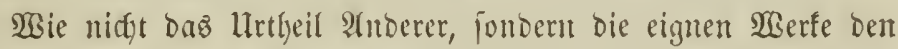

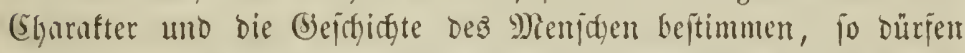

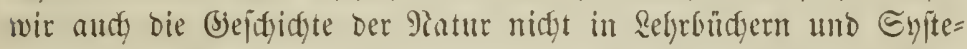
men, pondern in ben Dentunälen ihrer eignen $\mathfrak{T}$ haten judfen. Ber=

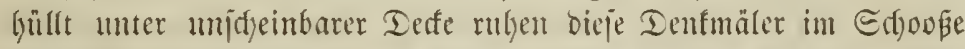

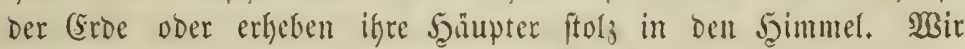
zielen bie Deffe ab, benu fie ift daz $\mathfrak{B e r f}$ gegentwärtigen Rebens, uno wie wir bie Thaten 2 (norer nad) unjern eignen beurtheilen, fo

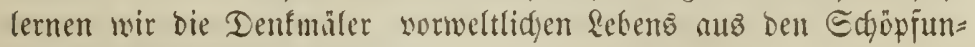
gen Der Biegemwart veriftehen.

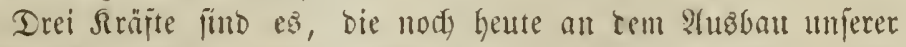

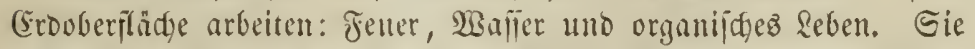

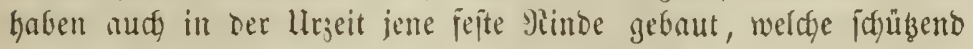
Den feurigen Siern unjerer (Eroe umídyliefit; die Befiteine, meldye ben Eroboden mit jeinen Errlegungen und Bertiejungen bilben, tragen

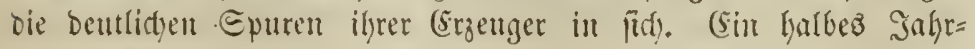
Ile, \$eltalt. 3. แup. 


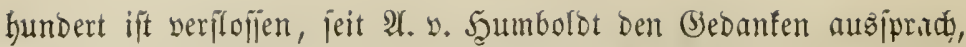
Der Eroball muifie einft eine höhere Temperatur beefijen haben.

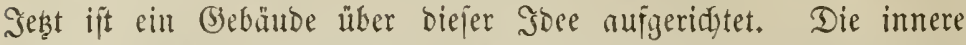

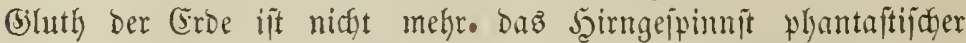

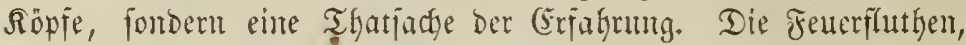
weldye nody heut aus ber Tieje quellen, Die Thermen, welde den

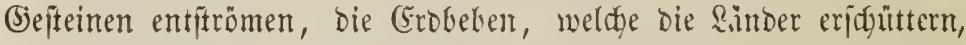
fino (Eridjeinungen, weldye zrweifellos die Mitwirkung Deş Jeuerz an

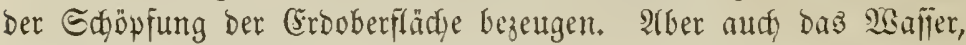

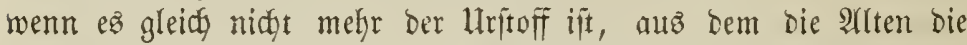
MBelt bilbeten, war ein thätiger Mitarbeiter an Der Beftaltung ber

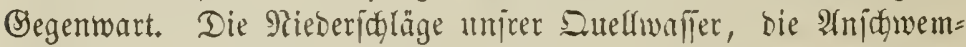
mungen uno 3eritörungen unjer Єtröme unt Mcere in Thälern

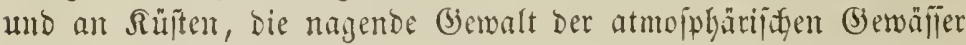
an unjern Bergyipfen lajien uns audy Daran nidt melyr zweifeln. Enolidy aber jeigen aud bie verfofilten uno verifteinerten lleberrefte Der Thier = unt \$fFlamzenwelt, begraben in ben Edjicten Der Errbe,

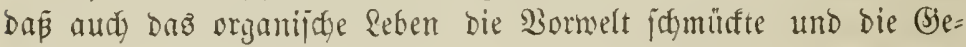

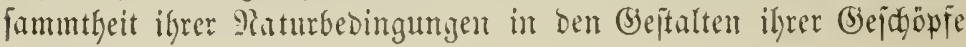
aนåprägte.

Die reidberwadjenen Berggelanange, bie moblgebauten (Ebenen

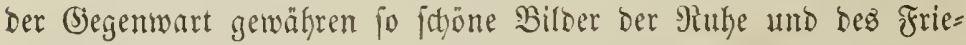

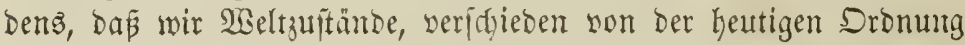

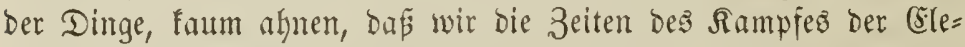
mente, bie munberbaren Ummandlungen, weldhe bie $\mathbf{S}$ sohnftätte bes Menifyen einjt erlitten, fajt in 3weifel fteflen mödyten. Dennody vermögen wir eben fo fiffer anz ben 2 Serfen ber Borzeit ben Bang z̆ enthülfen, welden die Ratur bei ilyen gropen Bauten nakm, als wir alls ben veridjütteten 9luinen von Seerculanum und \$3om=

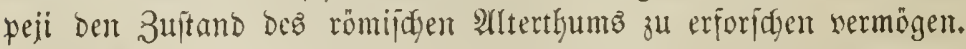

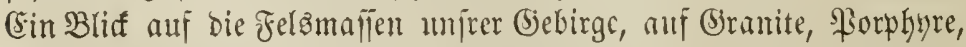

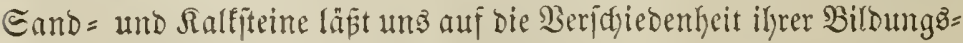

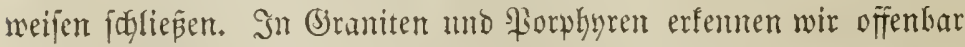

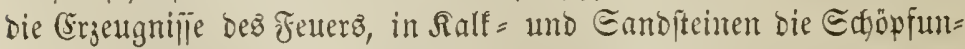

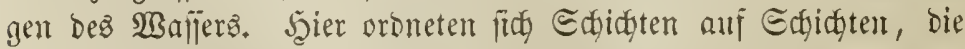
fict nach uno nady aus bem 2 sajfer abjekten, zu fanft gernubeten Şügeln umo Berger. Dort treten füfne Berggeftalten empor, nidjt 


\section{5}

nad) Edyidgten georbnet, fonbern majenhaft aus ber Tiefe empor= getrieben, geidfmolgen und gewaltian aufwärts gebrängt und ge=

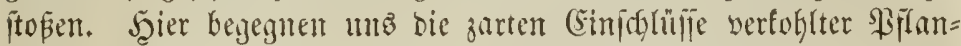
jen, beriteinerter Thiere, bort bie eingemengten Jryftalfe, bie bla =

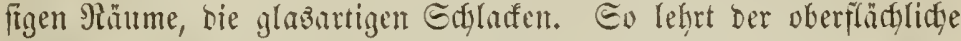

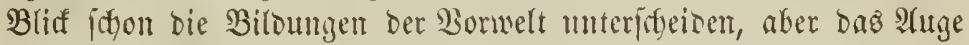
bez Foridyerz, bus tiejer bringt in bie Cinnetweide ber Frbe, lernt

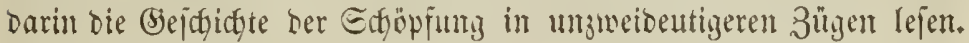

\section{Die Gefteine Der Ërdrinde als Dुentimäler Der $\mathcal{V}_{\text {orzeit. }}$}

थlB wir bie Beptaltumgen unjerer (Erboberflätye in ber Begen= wart betradyteten, waren eż vier Formen der Felzarten, welche wir

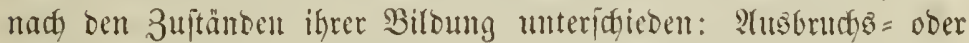
Eruptionsigefteine, geidjidjtete ober Eebimentgeiteine, metamor= phofirte ober umgewandelte befteine und Conglomerate ober Trün= mergefteine. Dieje bierfaden befteinbiloungen, welde wir nod, gegenwärtig fortidgreiten jehest burd) (Ergus vulfanifder Mafien als

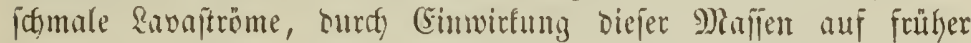

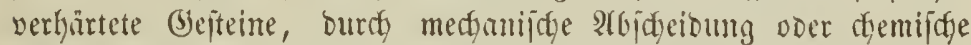

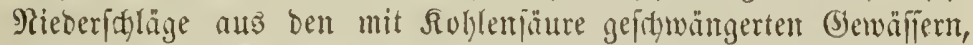
endidid Durds Berfittung zertrimmerter, oft ganj ungleidhartiger Felzarten; fie find ber fifwadye Haglans son Dem, was einft in Dem dyaotifdyen 3uttanbe ber llrwelt unter ganz andern Beoingun= gent bez Drutfes und einer ergöhten Temperatur, fowohl ber gan= zen Crorinde, als bez mit Dämpjen ӥberiüllten uno weit auछ̉ge= Dehnteren Ruftreijes, gejdgeken ift.

\section{1) Dic (Eruptionsgefteine.}

Aus ben Tiefen ber Croe, yon (3)tuth uno Dämpfen getrie= ben, ftiegen jene (bejteinmaffen empor, bie man mit bem Ramen oer Eruptiongagefteine ober ber enoogenen, mafïgen uno abnormen (Sefteine bezeidfnet. Eie bilden gleidjam bas ftarre Rnodjengerüft unjer Eroe, bas feine 3weige aus Dem inmern Edoope empor=

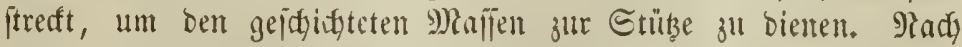
ifren dgarafterijtijgen (Sigenthümlichteiten unteridgeibet man fie

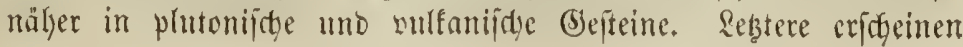




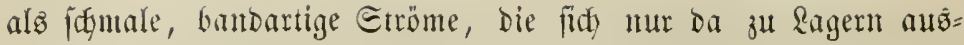
breiten, wo fith mefrere berjelben in cinem gemeinfdhaftlidgen Beffen vereinigt Guben. Benn bei ifnen Sañerbämpfe die mitwirfente

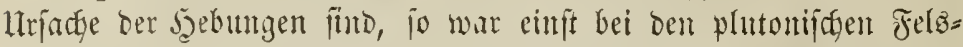

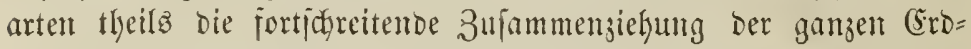
rimbe, theils ber Druff ber obern Edjidgten auf bie noch meidyen

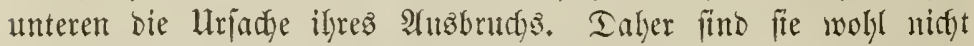
immer gejumolgen, fonbern ofit nur zäke und erweidgt hervorgetre= ten, แnd nidgt aus engen אliffen, fonbern aus weiten thalartigen Epalten und langgedehnten Sdhlünen theila entfifollen, theils her= vorgejdoben.

Ylber nidyt als mädtige Manien alfein, fonben, wie bie vul= fanifgen (seftcine, treten audy. Die plutonifden als (biefteingänge auf, indem fie anf bie fonberbarite art in bie Epalten mo Slüfte Der Edyidtenablagerungen eintoringen, fidg Darin veräfteln und burd)= freujen voer juifden fie linteinlagern und, wo bie Banguaffe ju

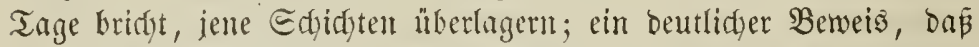

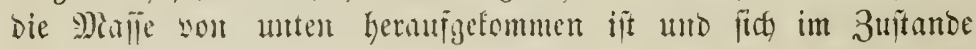

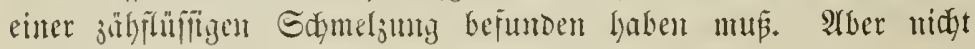
nur Eebimentgejteine, aut plutoniiche jelbit funto von plutonifden

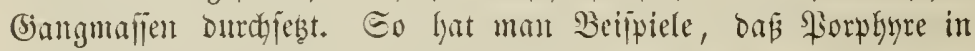
(Srantent voer jüngere Siranite fit in älteren veräftelten. Wemt man baljer frülger bieje Felsarten alb primitive ober llagebirge, ent=

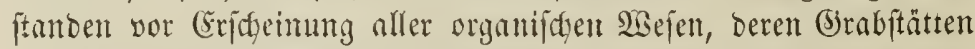
bie Edyidfformationten finto, betradtete, fo zeigen uns bie pluto=

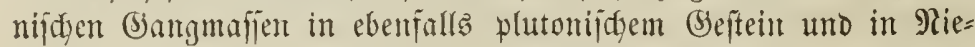

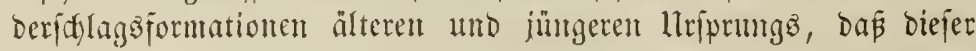
2H

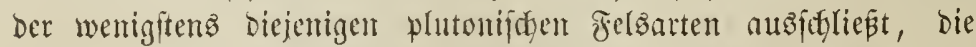
lange nach Dem Aluftreten ber organiffyen Echopplung zum $\mathfrak{B o r}=$ fdein gefonment fint. Ungebinge im ftrengen Sime des 2 Sorts fönnen nur biejenigen genannt werben, auj weldyen bas organijdge Reben im Edyoope Der Meere begonmen hat. Will man aber audy Den Begrff weiter aušbehnen, jo ergeben bie Beobadtumgen immer= Gin Alterḡveridjiedentheiten unter ben plutonifchen Felsaarten, wentn=

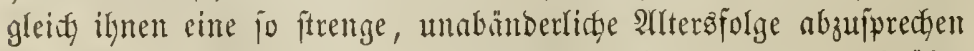
iit, wie wir fie bei ben Eebimentgefteinen finden werden. Früher 


\section{7}

ging man von Der :

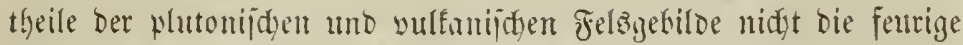

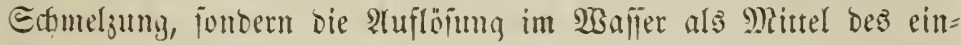

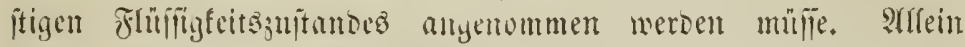

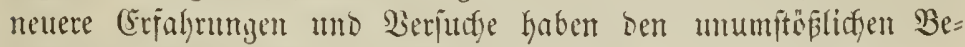

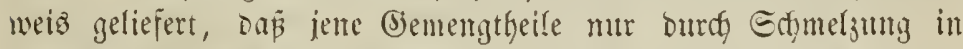
ben flüfigen 3uitano gefommen fino. Man hat jogar Felsipath= fryitalle, (5)timmer, Flugit uno jelfît Sularzfruftalle auf fourigem

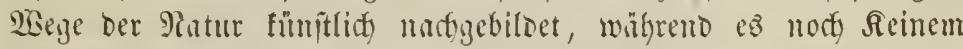

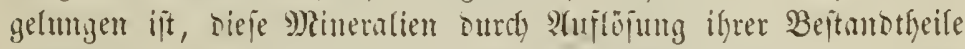

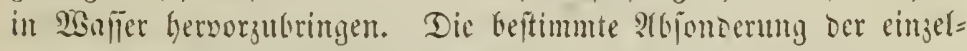

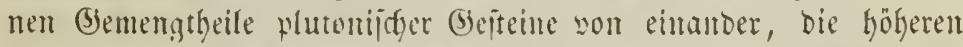

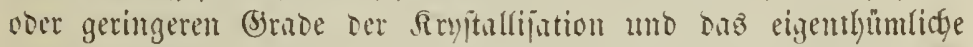
(S) fitige Derjelben muljen ralger madg allen bisher gematten Er= fabrungen als jolyes eines mebr oder minder langiamen Erjtar= rens aus dem gejomoljenen 3uftande gelten. Shrem \{ller und

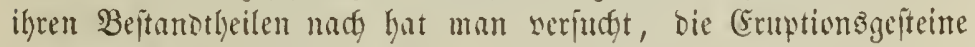
in Sritpen ju oronen.

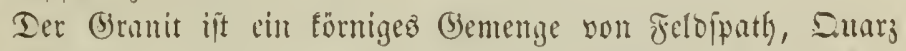

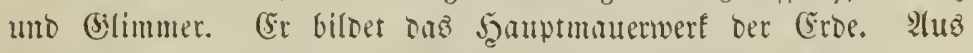
Thaltiefen iteigt er himan bis zu ben Bergrüfen, uno die er= babeniten Bipfel mperer Groe bejtehen aus jentem Gebilde der llrzeit. Sn der beimalamafette herrift er in Şöhen won 18,000

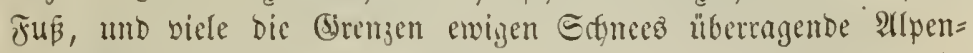
ipizen fund granitifd. Lleber 9000 Jü fteigen bie Sranite in Den Snlzburger âten empor und erreidyen in einzelten Bergen Şöhen von 12,000 Fur. Malerija Formen, Mannigfaltigfeit in

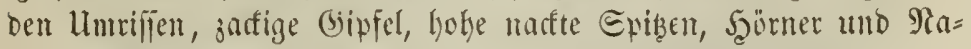

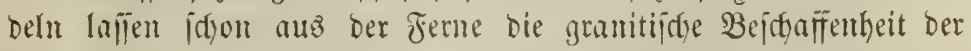
Şöhen mit Eidjertyeit errathen. Die fteilabjallenden Wänbe, baร

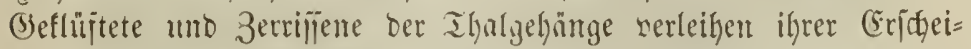
nung ein raulyez uno wilder Steprigge. Wer fennt nidgt bie wilde=

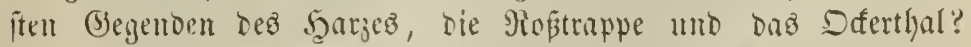
In alpinifder Erbabentheit entiteigen ber tiejen Edylucht, weldye

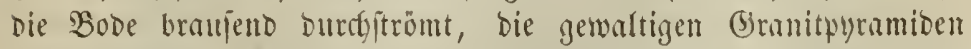

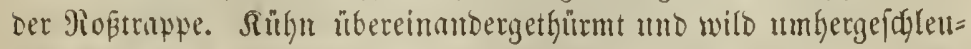
Dert jđanen bie wumberbaren Granitblöre brolgentb hervor aus bem 
Iieblidyen Thale Der Sofer. Einen wumberbaren Rontraft zu biejer rautgen Matur bér Branitgebirge bilden bie fanfteren lumriffe an=

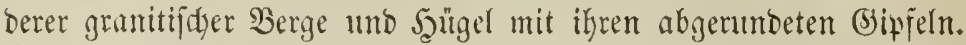

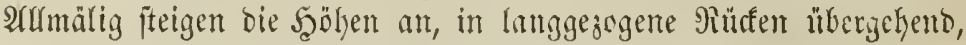
yon fladyen und weiten Thälen burdjidytitten.

$3 u$ biejen Ungleidffeiten ber Formen fommt bie Beridjieben=

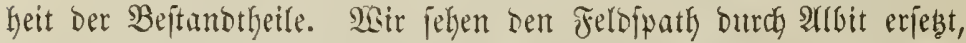
finden frembartige Beimengunnen, Turmaline, (3ranate und \$i

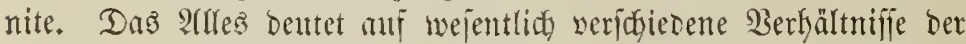

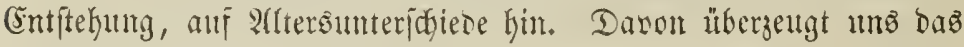
gangartige Sujtreten won Graniten, bie wir neuere nemen müjïen, Da fie gleidy Bweigen eines gewaltigen Baumes nidgt nut in über= liegende אalf = tno Edjieferisefteine, wie in Den Brampianbergen

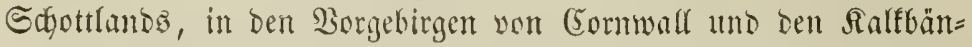
fen yon Rorwegen, fonsern felbit in ältere Grante einbringen und

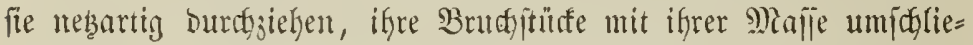

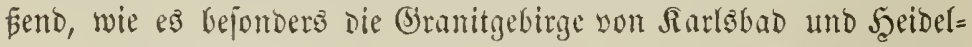
berg bemeijen. Die beifthende stbbildung giebt bawon eime $\mathfrak{A n}=$

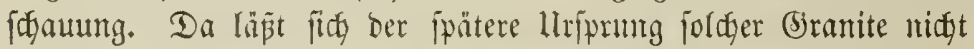

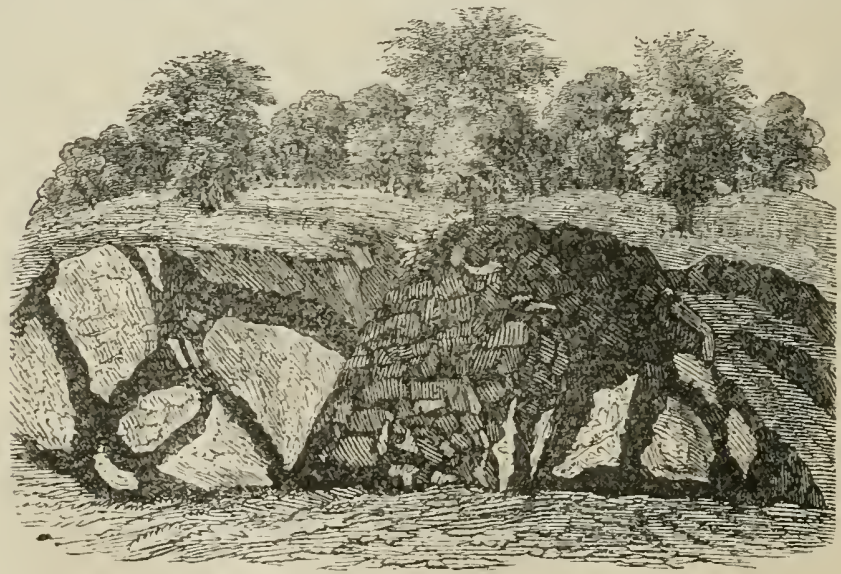

(5ranityänge im (J)rnit bei 5ुeirelberg.

megr begweifeln; feurig = flüijitg ftiegen fie aus Den Erotiefen herauf

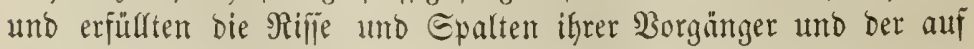
ihnen lagernden $\mathfrak{R}$ alfe und Edjefer. Dit erfhobent fidy fogar bie 
aufitteigentoen (Sranite fäulenförmig über bem Boben, Dent fie burdf =

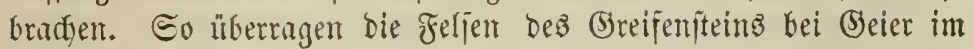

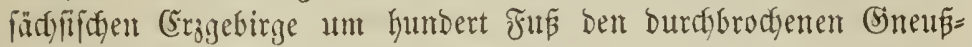

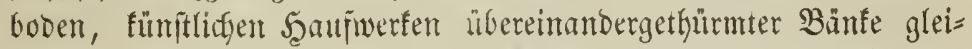
dend. Rod jeltiamer eridjeinen oft bie gewaltigen Felfentrimmer,

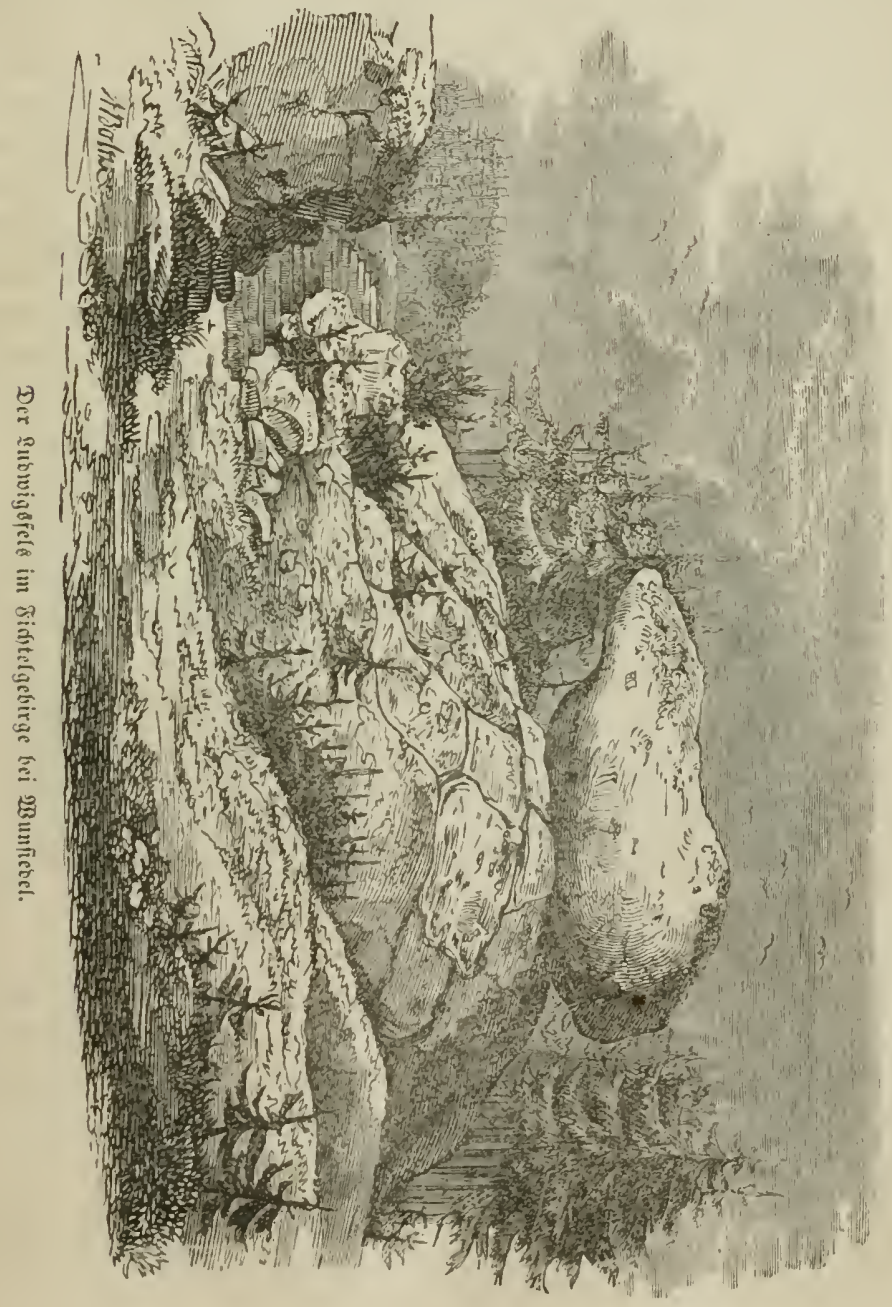




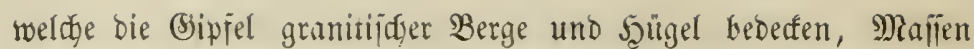
bon grotesfer Form, aus ungeheuten, viele fundert (Sentner iffwe=

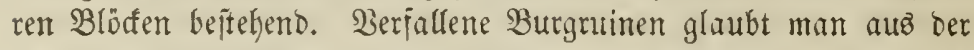
Ferne jut überbliffen, fo mild nerworren, fo fülgn finto bie Bolöfe aufeinander getfürmt. Şier jefiweben einjelne Blöfe, brofent im

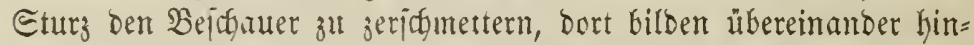

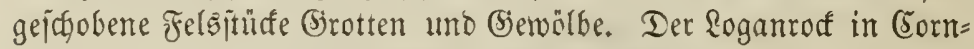
wall uno bie zaffreicten Blöfe der Euijenturg im Baireuthijaten,

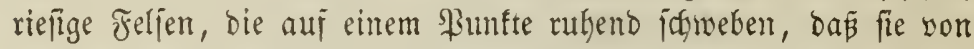

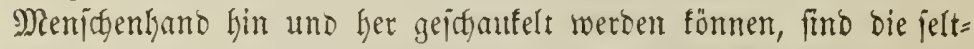

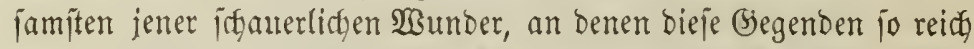
finto. "Sluthen uno $\mathfrak{B o l f e n t r u ̈ d}$ e, Etröme uno Erobeben, $\mathfrak{B u l}=$ fane, unb was jonft bie Ratur gewaltjam aufregen fann, rief man

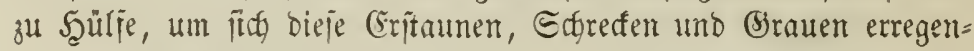
Den djaotijagen 3ujtände ju erflären." lino bod) liegt bie (Erflärung

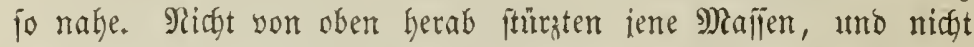
am Tagezlidft wurben iie zeritüft, iondern bon unten brangen fie Kerbor alz Trïmmerhaujen, von Dämpjen Der Tiefe Keraufgejtó̈en, unt lagerten firth über Den Epalten, Deren Deffnungen fie verifsló=

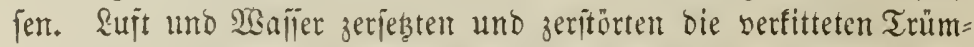

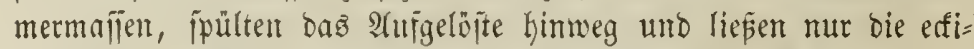

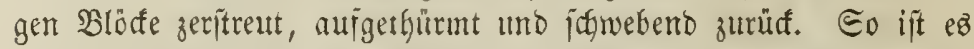
feinem Zweifel melgr unterworfen, bie Granite find Feuergeburten,

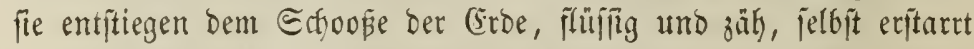
uno zertrümmert, wie bie wilden Gieftalten ber neueren Branite berveijen.

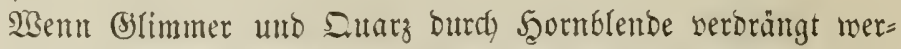
Den, io geht ber jüngere (S)ranit in Eyenit über, ein Beftein, Das jeinen SRamen yon der alten ägyptijgen Etnot Eyene führt, in be=

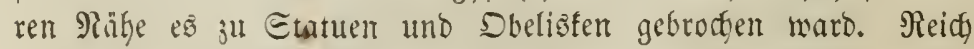

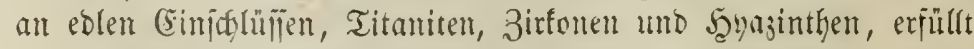

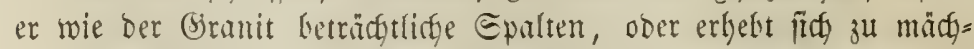
tigen Bebirgen. Bon Rlüften und Epaltent zerriflen, zerfällt er oft in genviltige Blöfe, Deren Trümmerfyaufen 2ibfänge und Thal= tiefen bederfen, mur son einzelnen Ferfent, wie Rlippen in Meere,

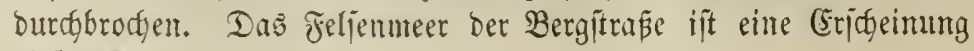
biejer $\mathfrak{A t t}$. 


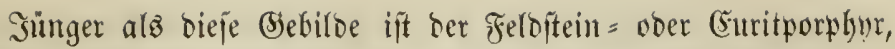
ein Tei] Didften Felojpathez, in weldfem Rörner, Blättḑen uno

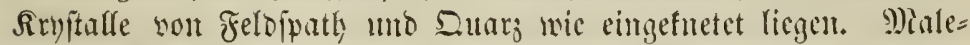

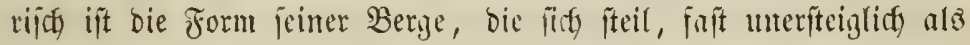
Regel erheben, rercinjelt uno ohne fitdefbareż Banto, mit jafarfen,

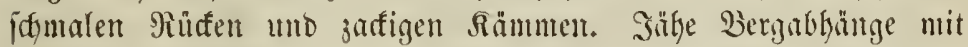

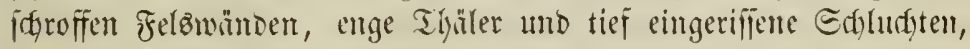

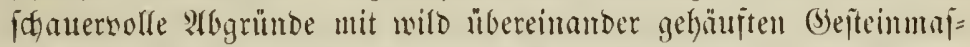

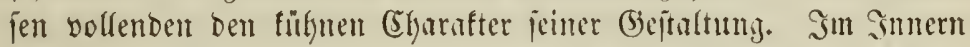
zeigt ber \$orphye oft fettiane Formen te" 3erflififung unt 21bjon=

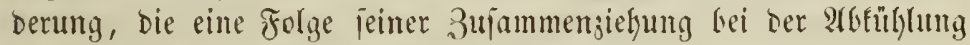

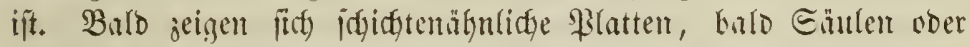

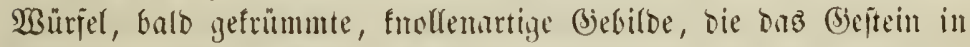

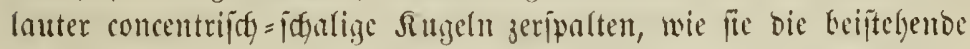
erbbildung zeigt. Sn bicjer Zerflüftung bilsen bie Trimmernerfe,

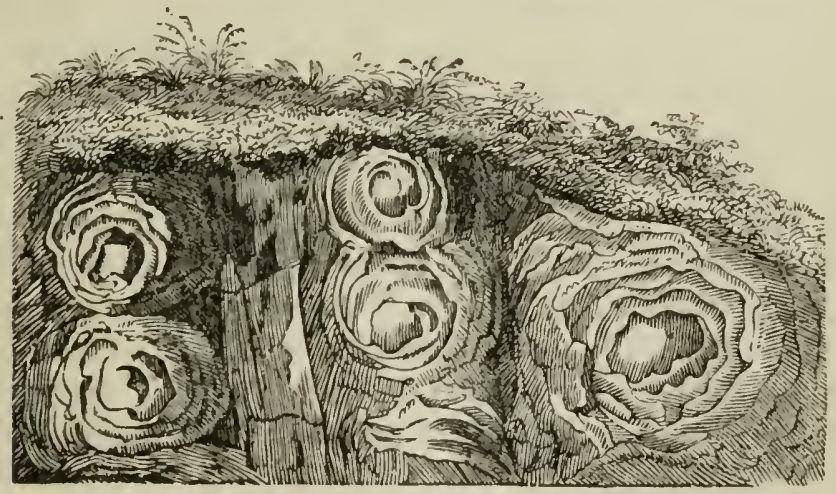

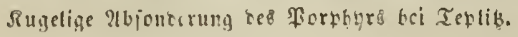

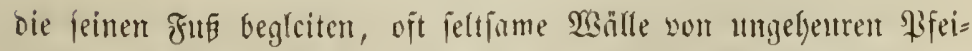
lern uno Eäulen. Futh er fitien cinft burff) ältere unt nettere For=

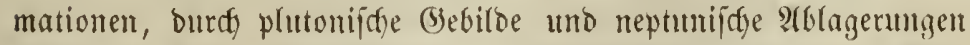
empor; aud er eriüllte Epalten in Edfiefern uno (bange in (S)ra= niten. Die Allpent Der Edfweis und Efanbinasiens fint 3eugen jeines Şerbortretenz, ganje Bebirge, wie der Domterzbers, find peine Erzettgnifie.

Dem \$orpfynr verwanot ift ber Brünftein ooer Diorit, ein 


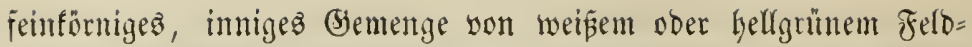
ppath und ounfelgrinter Scornblente, ber, wenn lestere in ftrahligen,

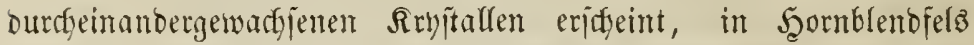
"ibergegt. Bald ragen jeine aufgethürmten Feljenmauern auz ben leichter zerjötorbaren Siejteinen feiner llmgebung Gervor, balo erbebt er iidy in ijolirten fegelf̈̈rmigen Bergen, teren Feljen burdy und Durth zerfliffet, oft nur Şaufwerfe runter Manfen und an ifren

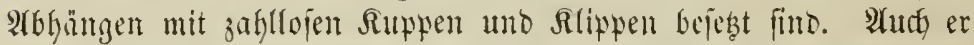

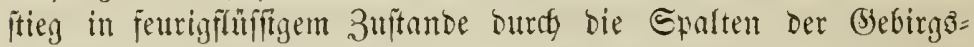
idjicten entpor, beren Sinume er eriüllte. Die genalijum zeritorten Edjidytenlagen, bie losigerifienen uno von feiner \$inlle umfülften Brutfiftufe, bie Durbbranuten Gefteine jeiner llmgebungen Iajien

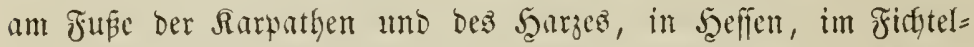

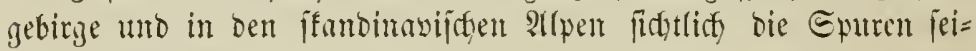
neş Şerbortretenz ertemen.

Eine ber verbreitetifen (Befteinarten endidy ift bor Eerpentin, fidyon in alten Zeiten berithmt alo Material berrlidger Rumptwerte,

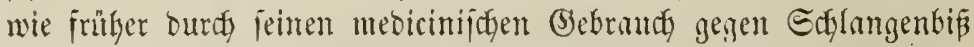

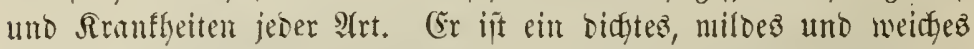
(5ejtein, wejentlidy aus Iabrabor und Diallage, Tem Felofpath uno

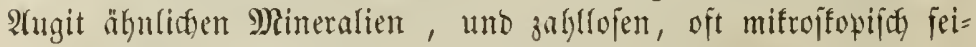
nen Rryftallen non Magneteijen bejtelyend, bie ifm bisueilen jelbit magnetijhe Cigenidyaften ertheilen. Eng mit ifm serbunden er= fotheint ber förnige (Sabbro, in meltgem Der Rabrabor burdy Felo= ppath, bie Dialfage burch Brongit surtreten ift. Die Spalten unt Rlüfte beş Eerpentins find häufig von einem ber jonberbarften und

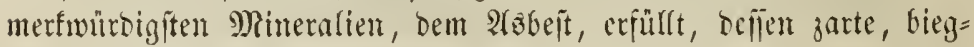
jame Fajern janon zu Plinius' Zeit gleids Flads verarbeitet und ou unverbremtlidyer Reimmand verwebt wurben.

Uber audy in newefter 3eit hat ein (5)anggejtein oes Eerpen= tin, der Chrnjopras, Berüfmtheit erlangt. SEeniger ourch jeine

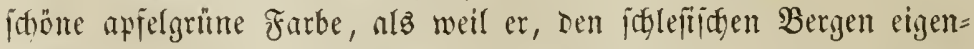

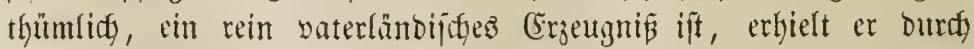

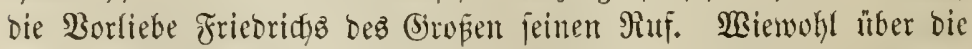
ganje Crobe serbreitet, tritt ber Eerpentin boch nirgendz in großer 2tuabefnung auf uno bildet felten erbabene Berge, fondern mekx

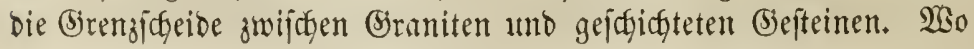




\section{3}

er aber, wie in (5raubünoten, nicht mur alz bie Gronnolnge bez

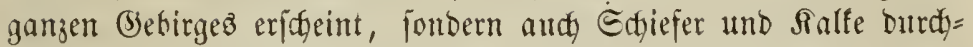
bredyend als Spalten Gerworitieg, da ift ein Servorqueffen jeiner

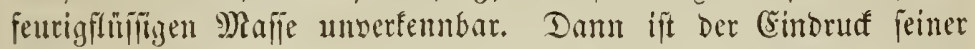
Patur ein büfterer und wilder. Die jerboritenen Beftalten peiner Felätämme, bie buuffeln Trümmer und Edyollen, weldhe burdy Ber= witterung cin loferez (Eroreid sildom, Das jeben siaffertropfen be= gierig einjangt, dieje rauthe (Sinöbe, weldye allez organiijdse Sebent,

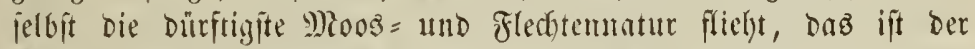

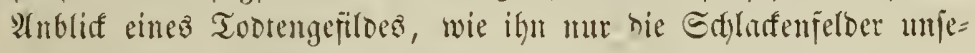
rer heutigen Bulfane gemähren.

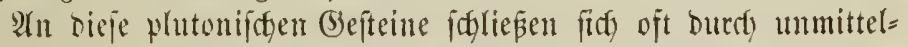
baren llebergang bie vulfanifgen bebiloe älterer umo neuerer Zeit

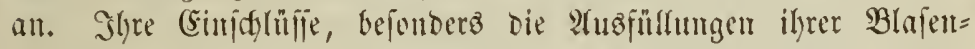

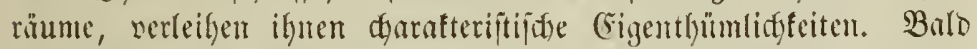

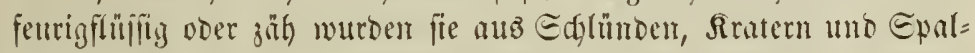
tert ergofien ooer autsgeidglendert uno erfalteten allmälig; bald in jeftem 3uitunde, verbrumut, zertrümmert, jerrieben, orangen fie, von Den Maüdten Der Tieje gejpgoben, heratif.

Die Bajalte, lange ein Begenftand dea 3weifela und

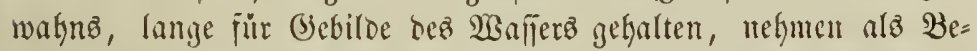

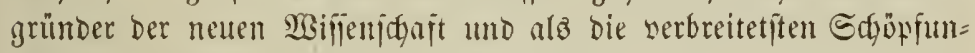
gen dez jüngeren Fentergottes mit volfem Mect)te bie irffe Etelle cin. Sie fiellen eine butfle bidjte Majfe fo imnig mit einander

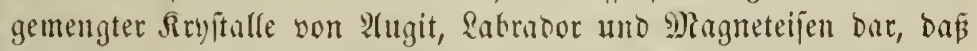

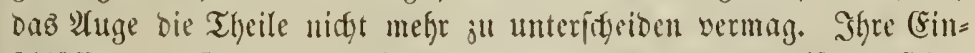

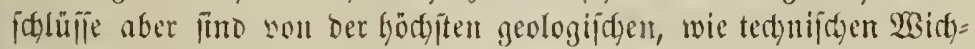
tigfeit. Der Slivin, Der ftete Beyleiter aller Bajalte, dgarafterifirt

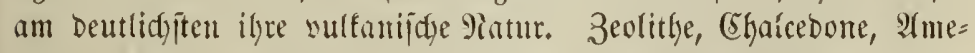

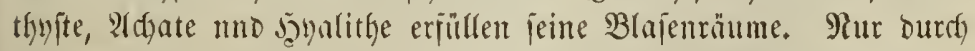

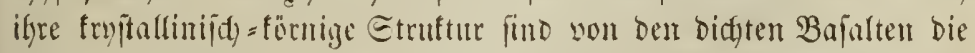
Dolerite beridjeden, Deren weientlidgen CGgarnfter bie eingeidglofienen

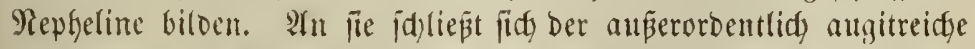

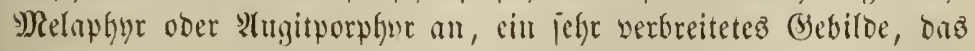
bald, unter der Sgüllle wilo zerrifienter Bebirge berborgen, fie viele Taujend Fuß

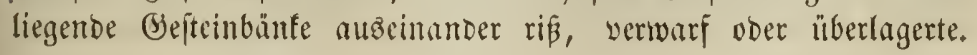




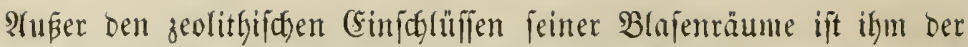
Epioot eigentfümlich, ber burdy fein Borfommen in vielen plutoni= faten Gejteinen Beranlajiutg gegeben hat, biejer aud) burdy jein

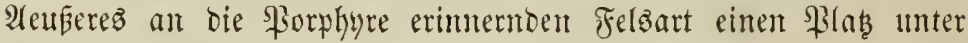
ifner anjumeifen.

In nuther Begiefung zu ben Bafalten fteht ber Slingitein oder Bhonolith, ein imniges (Semenge von gelofpaty unt 3eolithen, bef= fen gangartige Epalten von Mejotyen auşgefüllt weroen. Daz

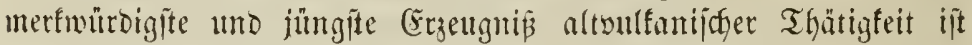

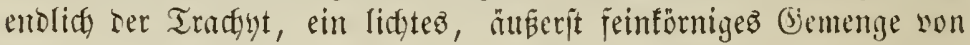

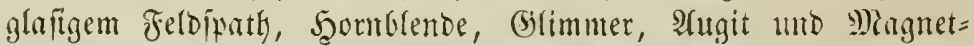
eifen, Durdh jeine eigenthümlidyen Eimjchlitile, bie Dpale, autgegeidy=

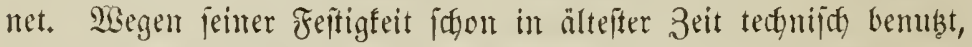
bilot er bas Raumaterial bez grösten Deutichen Baumerfes, bez Rölner Dontes, und nur bie Dherfäatye jemer Scöhen jeigt bie Epuren der Berwitterung Durd) atmophärifche (Simflüje. Die

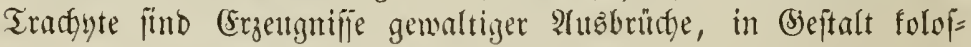
faler Dome unto glodenartiger Siewölbe ans ben Deffmungen oer Sroe herworgeftiegen. Bald erjdeinen fie als mächtige, gewaltam aus ifrem urfprängliden 3njammentyange gerifiene tuo empor=

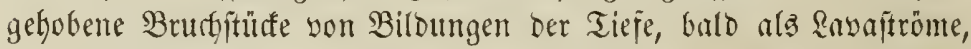

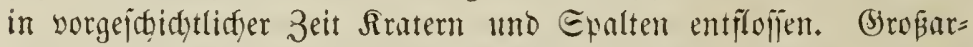

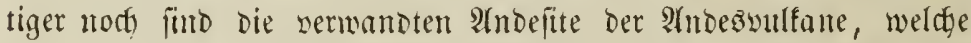
einft, biefes riefige bebinge Durdbredgend und in eritartem $3^{u}=$ fitube jenfredft aupiteigend, jene hödyten aller Feutberge liber utermeß̈liçen Sä̈hlungen der Tiefe bildeten.

Sm imnigiten 3ujammenhange mit ber 2 seife ifrer Emporhes

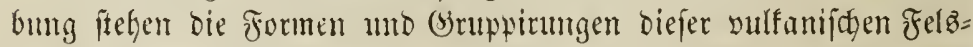
gebilde; Denn bald wurben die Mafien in weichem 3uftande auf=

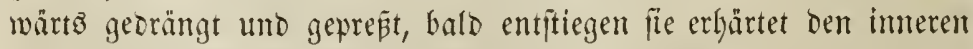
Tiefen. Die Brialte bilden gewaihnlidy einzelne, theils gerumbete over abgeitumpite Regel, theils find fie fdrofi bis zur Epibe hinan. Die 2 bhänge ifrer Berge find mit zafllojen, balo regellos ectigen,

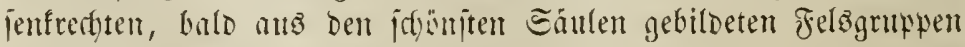

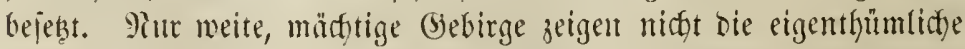
Regelform. Dem hier quoll die glühende, zähfiüfifge Mafle Etrö= men gleidy aus ungegeuren Epalten thber bie Dberflidge ourdybro= 


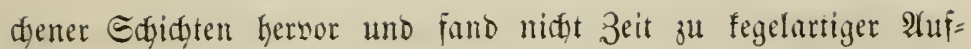
thürmung. Biele Bajaltberge umidgliefen nody frateribntidye Deff= nungen, aนs denen einft mähtige Ravajtröme floilen, Die als bunfle

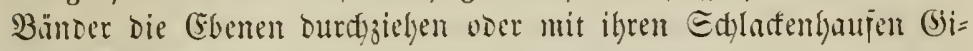

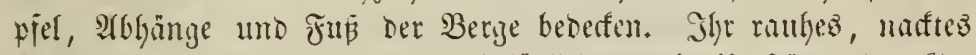

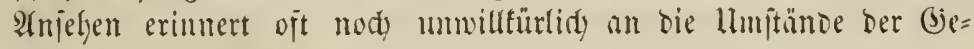

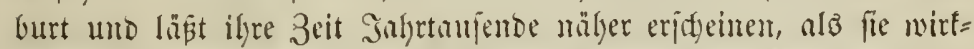
lide ift. Die Alusergne und die (sifel funo bejonders reidy an jol= den Erideinungen; aber über gans Deutjolant fint jie zerftrent und in allen Theilen Der Groe zu finden, wie itgon früher bei $\mathfrak{B}_{e}=$ tradytumg ber vulfaniiden Thätigfeit unjerer (Eroe gejeigt murbe.

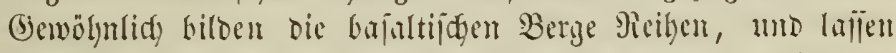

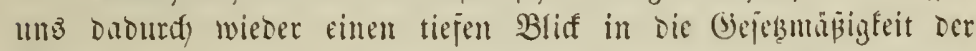

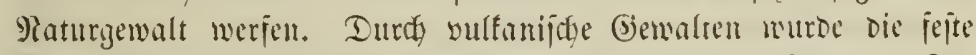

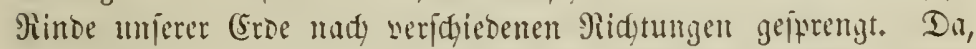

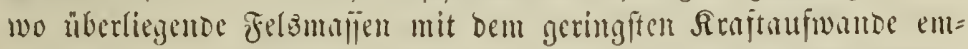
porgelgoben, veridyben, zerrifien ober burdibroden werben fomten,

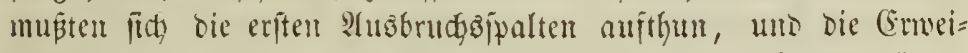

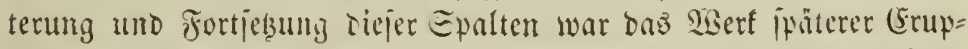

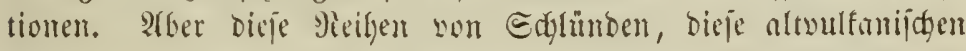
Reget unto Donte, Dieje lantggeitreftem Gajaltijden Bergrilden treten

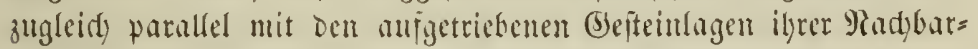

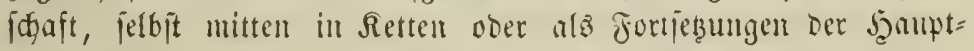
gebirge anj. Erobeben uno heipe Dueffen folgen Demjellen 3uge.

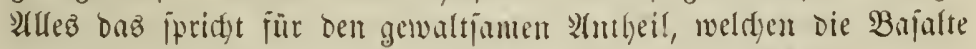

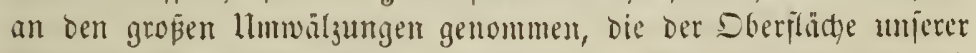

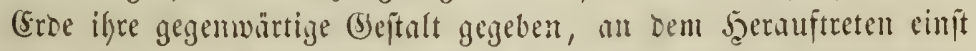
tiefer gelegener Felöma jen, an ben (Emportreibungen oer $\mathfrak{B}$ ergfetten uno Eimjentungen ber Thäler. WBir werben immer wieber gemahnt an bie Ulevereinjtimmung ber Borzeit mit ber Begenwart und ifren

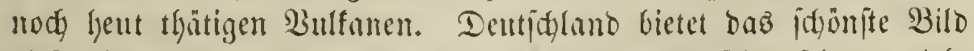
Diejer Mevolutionen Der Sorgeit. Mitten burdy feine Fhuren ziefte

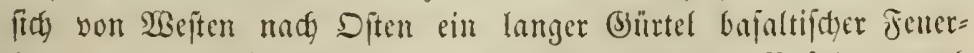
berge, in Der (Eifel begimemo, ourd bie rheinifigen Bajalte, ourd)

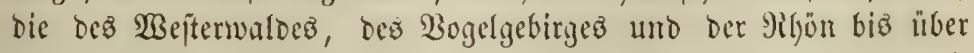

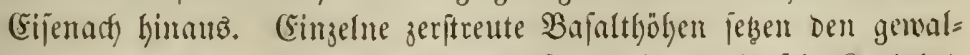

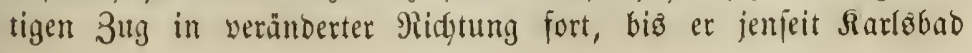


im Mittelgebirge Böhmens in gropartiger Weije hervortritt und

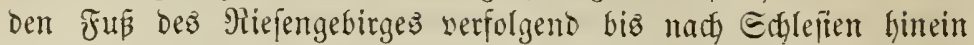
vorbringt. Eo zerrí eine gewaltige Rlujt Das beutidje Rand, aber

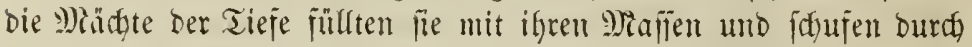
bie reigenden Gebirgelandidyaften ein Band, nicht bie Bölfer zu tren= nen, jonbern zu binden.

Minder ansgezeictuet, wiewohl grofantiger in ifrer (5ridteimung, find bie Siejtalten phonditlifder jooben. Sin fübnen, ifflanfen Formen, bald Regeln, bald bloten gleidy, fteigen fie oft zu be= Deutenden Şöhen an, sie Durdhbrodyenten Retten beherridgend, und macten in ihrer vereinzelten Etelfung und Durdy ifre fteil abjtin=

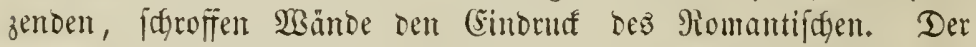

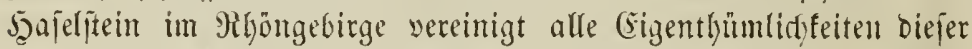
Bergnatur. $\mathfrak{A}$ uch die Tradytberge fteigen häufig ijolirt aus ben

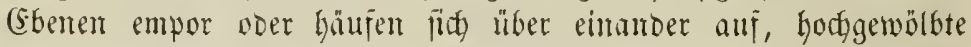

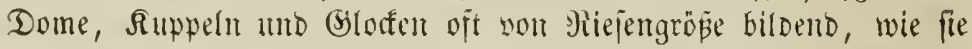
felbit Das Eiebengebirge auj daz Şerrlidyjte aušneijt.

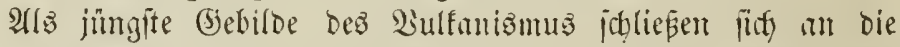
cbon betradteten die (5rjeugnilie unjerer nod) thätigen Bulfane, die

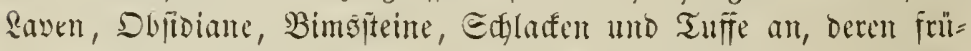

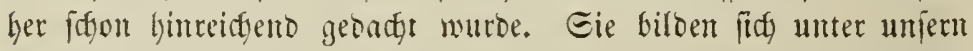

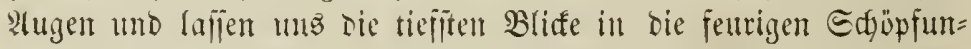
gen ber Borzeit thun uno aus Der Plelynlidfeit ber Formen, ber

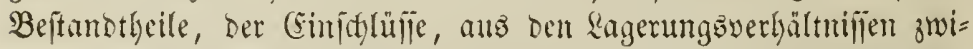

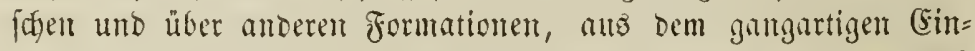

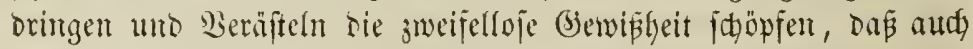
bie plutomijoen felsarten einft aus ben Erotiefen in flüifigem ober ermeidytem 3uftande zu Tage braden. Sebenfallz weifen uns bie Reibungseriheinungen auf ein gleides Repultat Giu. Sn Sebir=

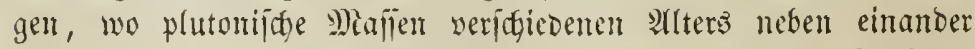
ober zwifdyen geidjifteten (5iejteinen auftreten, zeigen fids oft glatte, mit grablinigen Etreifen oder furdgen verfehente Flädgen, weldje

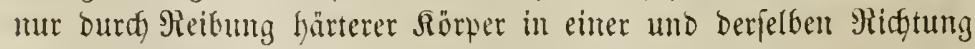
entitanben fein fömen. Eie find bie augenidseinliden Folgen auf=

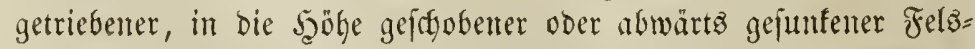
majien, Deren Richtung unitreitig Durch die Etreifen und Furcben bezeidgnet wird. Durdy Dieje Erhebung und Eenfung wurbe audh 
eine Bertrümmerung bebingt, weldye Feibungsiconglomerate erzeugte.

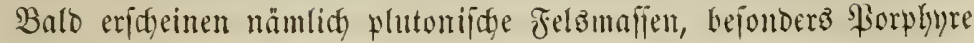
uno Bajalte, umgeber son eigenthümlidfen. Şüllen zujammengefit=

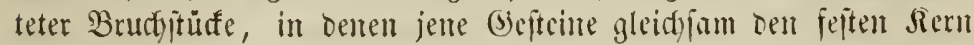
ausmadyen. Sn anbern Füllen fitoben bie nuв ter Tiepe empor=

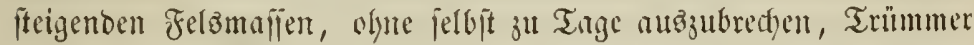

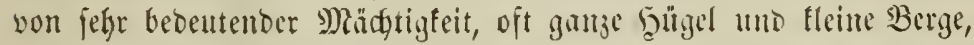
bie auz joldyen (Eonglomernten bejtehen, vor fidd) her. Der Şarz,

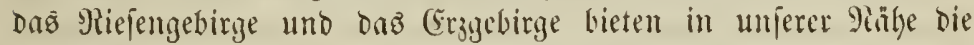
Dentlidjiten SBeweije. Dieje (Songlomerate foument oft in meiten Etreden, burdh bie ganje Ränge von bergen hin, wor unt plegent die brenze anzugeben, weldje zwijgen friller und fpäter leervor=

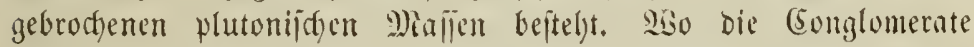

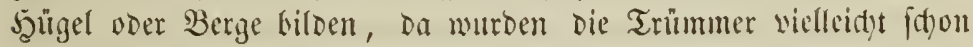

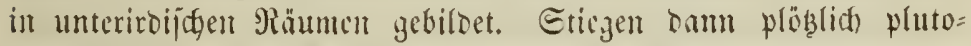

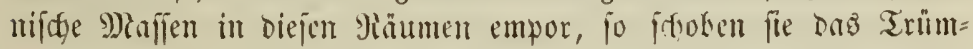

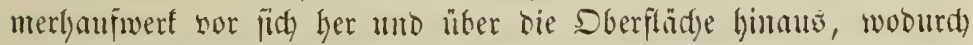

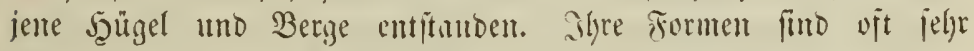

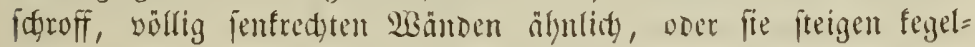

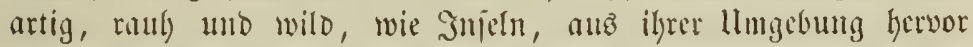

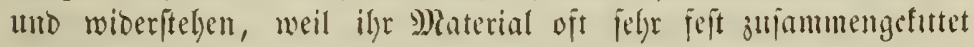

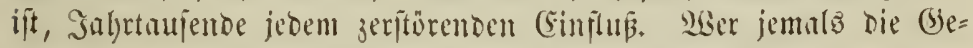

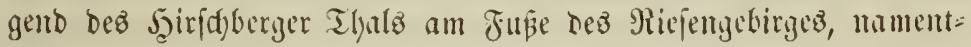

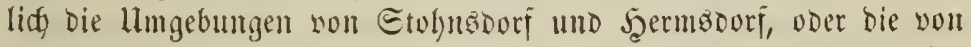
Fifdbach bejudyt hat, bom werden bie wunderlaren Trümmerlyafen Des झrubelbergez oder oie gewaltigen, wie son Geifterbant aufge= thürmten Blöfe Der Falfenberge gewiß urvergeß̈lid) jein.

\section{2) Die Eebimentgefteitre.}

Da, wo \$luto, Der Bott ber Ulnterwelt, nidgt mit jeinem ge= waltigen :Frme bie Feffelut zeriprengt unt peine slithenten Mafien

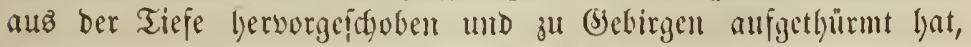

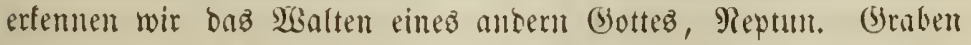
wir in unfern Ebenen tief in ben Eroboden, fo tief, alz es nur Menidentyand vermag, fo fopen wir übcrall auj Biloungen, die

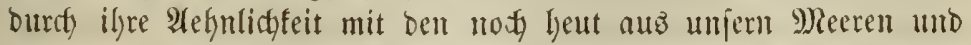
slüfifen fidy ablagernben Sieberichlägen offenbar igren neptuniidsen, 
wäjrigen llrjprung nernathen. Dieje gejdidyteten, von Beriteine=

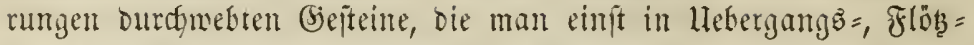
und Tertiärformationen fonderte, jeb̧t unter Dem Giejammtnamen Der neptunijoen ober Eedimentgejteine unjapt, baben im Rauje Der Jahrtaujente unjerer Erooberfläue ifhe gegemmärtige \$ignjogno= mie gezeber. Sătte aber \$luto niđt bejtändig son Smen gefoo= bu und Den ganjen (Srofreis erjahttert, jo würoe unz unjere (5ro= vberfläde nur Ias traurig einförmige Bilo oer jübamerifanifden

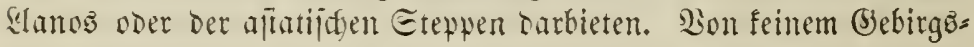
zug Durthbrodyen, mur hic und Da Durdy augigewajdene Thäler ge=

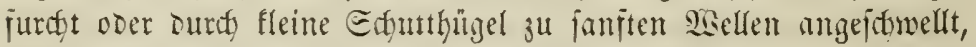

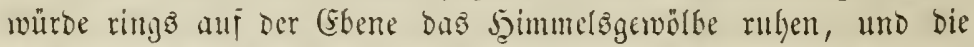

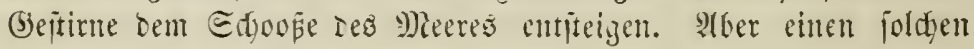

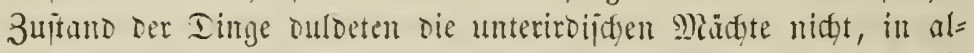
len Eporfen Der Borwelt befintūten fie bieje SeröDung uno jtreb= ten immer bunter, immer mannigialtiger zu geitalten. -

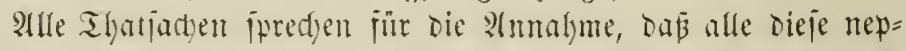
tunijtfen (bejteinbiloungen in oer Borgeit auj feine andere siseije

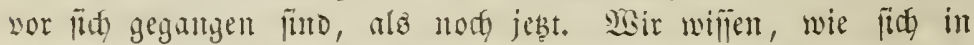

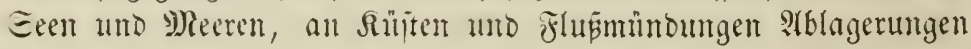
son Eund, Thon nnd Gerollen bilden, die in jeinjter Bertheilung

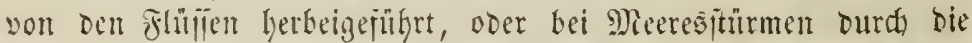
brandenden Wogen erbohen, ooer ourdy Winde non Eandwhiten liber oas Mieer gemeht uno von Etromungen in weite Entjermun=

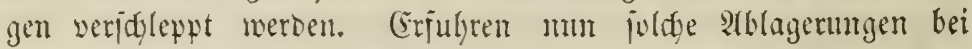

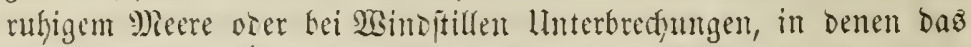
fidh biloente Eediment unter oem Drufte des salfers fids verbids= tete, jo emptand Edjidutun], Etratification, und es ijt natürlich, Dá jolde Interbredyungen unb Mblagerungen oftmals mit einander abwedjẹn fomnct. Die vom sisajer herbeigejührten Etoffe biejer Cedimente bejtehen in Der Jiegel auכ Thon, fohlenjaurem Sialf und

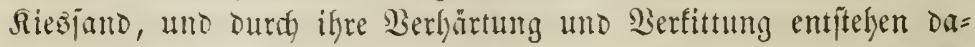
her weit perbreitete Eagerjolgen non Thon, Thonjhiejer und Ralf= itriuten, Mergel und Eanditeinen.

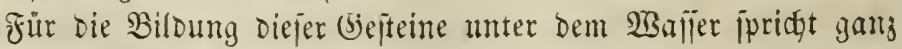
bejonders die Thatjacte, Daj man an vielen Srten in Tiefen von

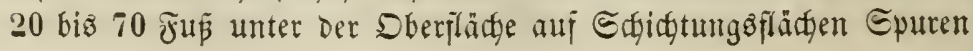


von Thierfüben, bejonters zon Echifbfröten und Eturmng̈geln ent= Defft bat. Difenbar mustent bie Edfidften, als fie biefe Eindrinfe

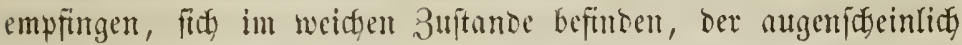

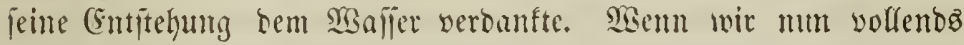
in Den Edyidten bes Eesimentreiteins sie bentfich erfennbaren

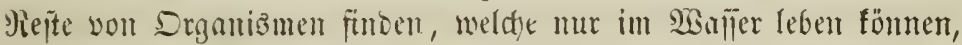
alfo aud) cinfit leben musten, fo ift uns bamit felbit bie Migglidy=

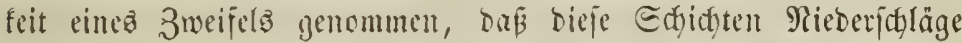

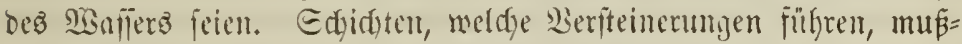
ton zur 3eit, als fie jente organifcten giefte in fich aufuabmen, im 3ujtantoe ser Beidygeit fein; benn in fejte bejteine bütten niemarz Thiere uno 秘antzen gelangen fünnen, an beren lleberrejten wir jo=

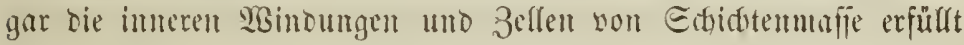

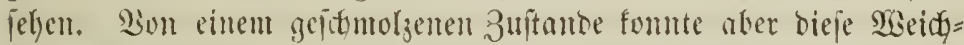
heit nidjt hernilyen, weil thierifde ober pflanglide Siejte, wemn fie in

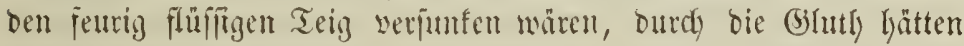

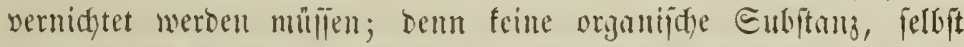

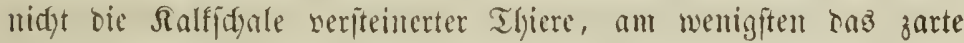
Siflanzengeweve, ift jeuerbeftündig ober sermag iffer form bei hö= beren Şizegraden aud) mur einigermajen getrell ju bewalgren. Siur wälirige Nicberidgläge maten alio geeignet, jolde lleberrejte in fids auf=

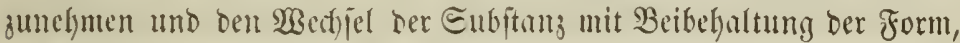

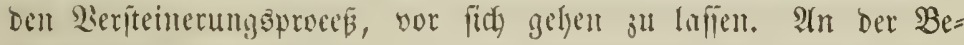
idfaffenteit ber Drganizmen, weld)e in oen Edjidjen begraben liegen, wiro man mu jogar erfermen muifien, of fie aus Randgewä́fiern

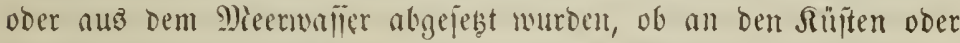

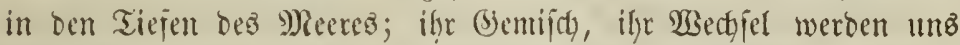

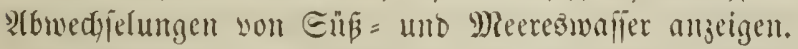

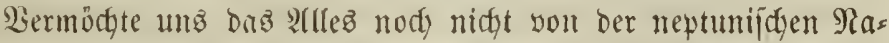
tur biejer Edfidfen ju üterjeugen, fo müpte ez ein Blid anf bie

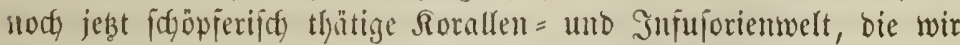
in lentigen Meeren Eand = und Ralffteine unter unferen 2tugen

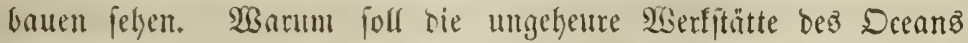
bieje midjt audy in früleren 3etten unjerz Eroballz beherbergt ha= ben? Warum follen fie bei igeer zabllofen Bermelyung wälyeno turzer Rebenöbauer uno bei ifyer gleidfförmigen Bertheilung burd)

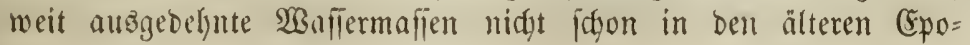
Ille, weltaft. 3. 2tuศt. 
dyent ber Edgäping gernoe wie kente uno madh gleidfer Bauregel

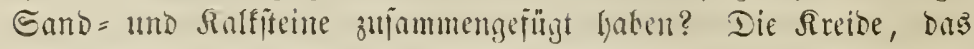

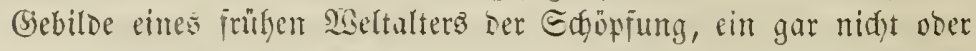

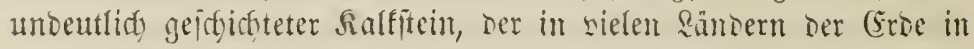

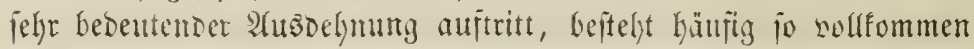

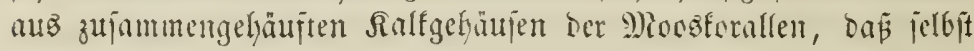

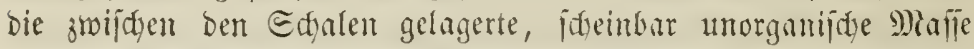

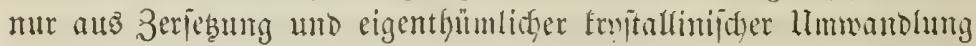
Des Drgnniffen entfifanden ifit. Iieje Thatjadje gilt nidgt allein

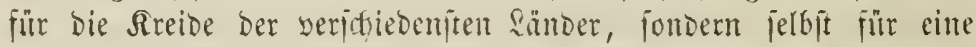
Mentge Der Sreise naleftehenter, afer weber weiser nod abfürben= Der Ralfgebirge, Die bisfer mur zmeifelfajt Der Rreidejormation bei= gejäflt wurbent. Sognar im Surnfalf, dor wie die Rreise cine weite Berbreitung bat, aber alter ijt alos bicje, hat man meterlich Deutlidje

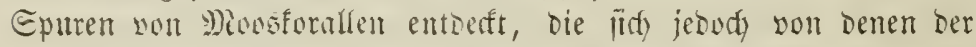
Rreide unterjdeiden. Ev reidt bie Morgendämmerung ber mit uns lebentent giatur viel tiefer in bie Gejejichue der (Erde, nIs man biager glaubte. Eimit gelingt es vielfeid)t, Diejer fleiniten Thier=

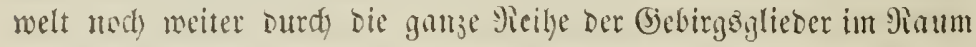

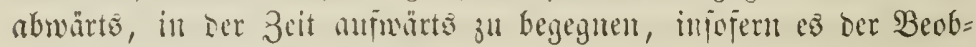
ad)tung überlyaupt möglid) ift.

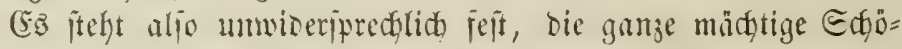
pfung oer neptumiften (jejteine ift aus sem $\mathfrak{W}$ afïer hervorgegnu= gen, gebildet Durdy Mieberichläge uno Den Ban Der Drganiamen. \$3o wir im Snnern ber Eontinente foldye Enger uno Edyiduten mieberfinten, Da fint wir zu Dem Edjlujie. Geredtigt, bus irgentowo, ntaly ober fern, Giebirge, yon Dentr Die Etofife abgelöit murben, flię̧endo sisafier, meldye fie fortiüfrten, Eeen unto Meere bejtanden haben, an Deren lljern oder (Srund jene Etofie abgejeght murben.

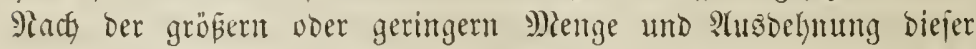

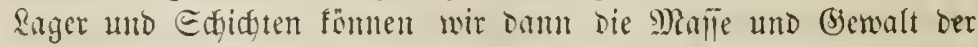

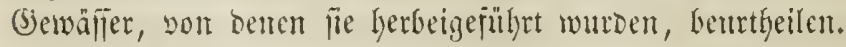

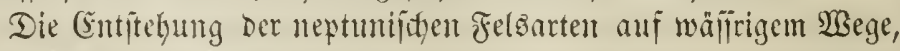

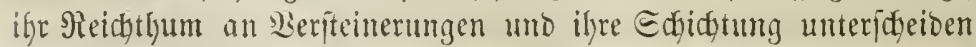
fie auj bas Beftimmtejte von Den plutonifden Bejteinen.

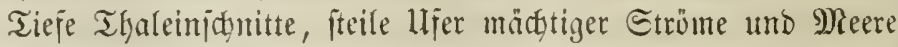
fafien bie Eigentfümlidfteiten biejer Edjidtgefteine am günfigiten 


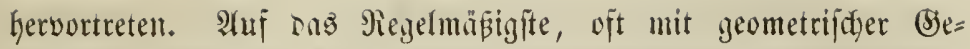
naugfeit fieft man bis zu bedentenden Szöhen die Bejammtmaijen jolcher Felägebildo in Ragen abgetbeilt. 2SGie bie Blätter einez $\mathfrak{B} u=$ des liegen fie litbereinander, Das unterfte bem oberfen in jeber

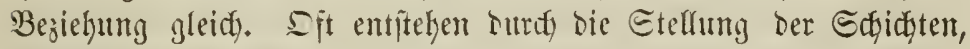
Durdy Sonderbarfeiten ifrees Banes die b̈berrajdyenditen Ecenen in

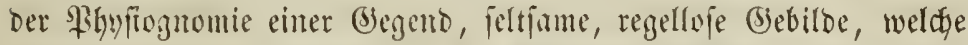
utralte Eagen zแ Rumptwerfen ber Bigguten madjen. Dft tritt zu

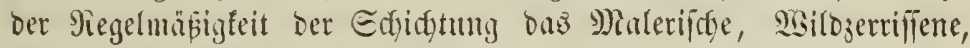
gewaltfan Berfiturte mädytiger Bergtheile; benu nicht immer zeigen Diefe Edjidten, flöge unt Sager, wie fie genannt werden, cine horijontale Rage, wie cine regetmäpige und ungettörte 2ablagenung fie

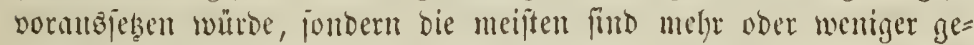

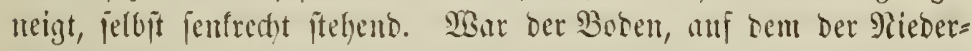

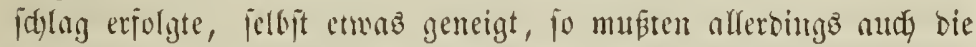
Edjifyten eine geneigte Rage amnelymen, und jwar mit nady unten

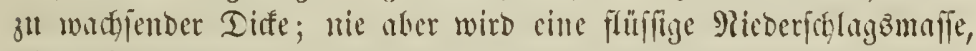
allen Siaturgejęenen entigegen, einte fiturf genteigte ober gar jenfredte

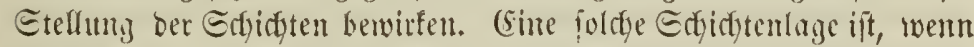

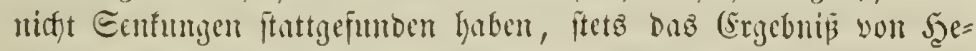
bungen, son Stufridjtumgen, bie zu verfdjiebenen Beiten eintraten uno wohl Den meiften Edjidgten ifye von ber uriprüngliden Rage abmeictende Eteflung gegeben baben. Bei foldsen 5ebungen forute

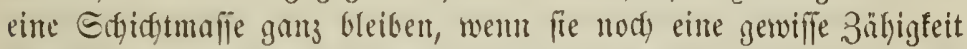

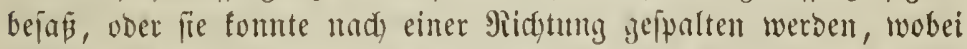

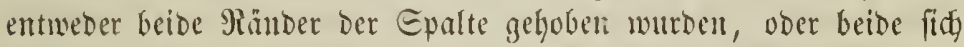
fenfter, ober ber eine Fiand jid hob, ber anbere fich jentte. Da= Ger fonment ${ }^{8}$, Daß wir oft zmei Formationen übereinander gelagert

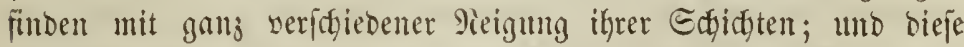
ungleidyförmigen sagenungeverhältmiñe finto won ber alferhöchften

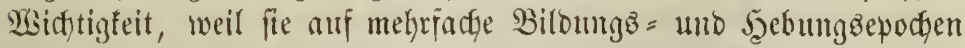

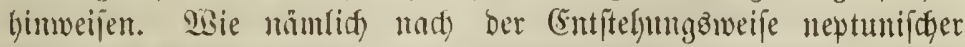

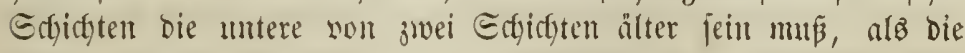
obere, eben jo iift andis bie untere von zwei ungleidförmigen 2 bb= lagerungen ätter als bie obere. Ftuth fömen beibe nidft auf bie=

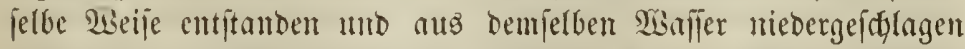
fein, weil fie fonft mit einander paralfel liegen müsten. Die ho= 


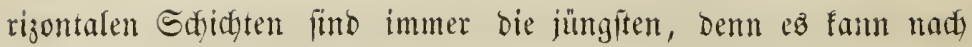
ifyer Billoung feine Saebung metre erfolgt jeint; wir finden fie fo, wie fie firfy unter bem 2 Gajier abgefert baben.

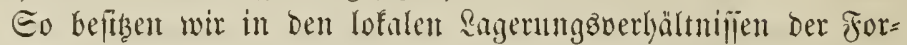
mationen zu einunber ein ficteres MNittel jur Befitimumung ihres res=

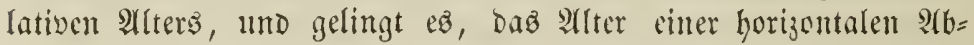
lagerung ju befitimmen, jo haben wir audg eine relatio befizinmte Epodje ber Rataftrophe, weldje bie Fufridtung Der (jirundrage be=

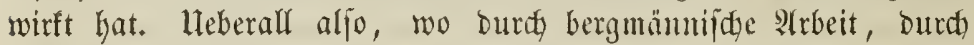
tieje Thaleimidnitte oder an dent Feljengętaden Des Meerez daz (b)ebirge entblöst ift, wiro es müglids, die Reifenfolge ber Forma=

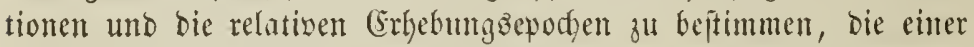

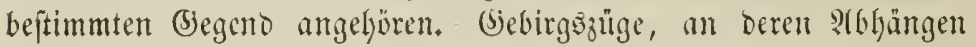
gar feine gefgobenen neptuniijen Edyidten gefunten werben, find offenbar älter als biejenigen bebirge, in Denen wir aus ifgrer ur= fpünglidjen borizontalen Rage emporgerinfte Edjidften antreffen; und

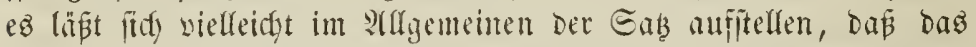

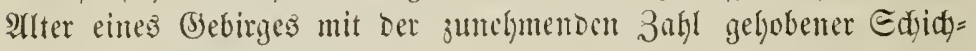

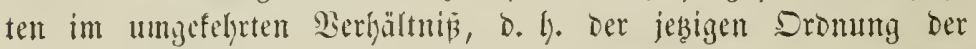

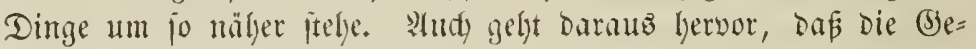
birgsfetten nidyt gleidyzeitig, jonbern nadh umb nadh herworgetreten, und bie jebigen Rontinente erft im Raufe von Safrtaujenten ju iffrer jez̧igen 2 tusbohnung zufammengerügt jeicn.

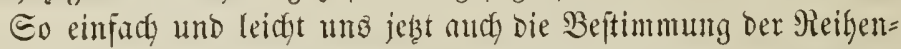

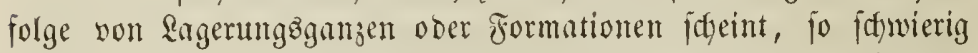
wird fie, wenn bie Beobadytung nidft auf eine und biejelbe Begent bejdyränft bleibt, jondern auj geographija) getrennte (jegenden auz= gedehnt werben folf. Demn wem man bie früferen 3uftände ber

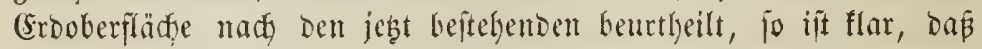
eine llebereinftimmung afler Sblieber ber veridjiedenen Meififenfolgen nicht zu erwarten ftelft, indem früfer, wie jebst, an ben einen Etel= len bie Eedimentbiloung rajd) fortiddreiten, an andern gar nidft ftattfinden, an nody andern ältere Eedimente fortwährend weggeppuilt uno gejdjwädft werden fomnten, fo base, wenn audf in ben zu ver= gleidjensen formationsfolgen einzelne BSlieder als übereinftimment erfannt werben follten, Demtod) bie übrigen we lentlid) von einanber

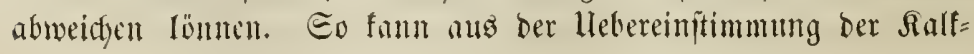


fteine bei Solothurn uno im Apennin feintesmegz audy die ber Darauf gelagerten jüngern $\Re$ alffifteine gefolgert werben. Daju foumt, Dap jelbit gleidjeitige Formationen in ifrer Eteinart uno Berbrei=

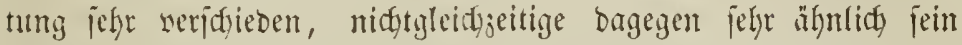
fönnen, fo wie and gegenwärtig in reridgiesenen Begenden bie ungleidyartigiten Eebimentbitoungen, Átblagerungen yon Edylamm in Mieren, yon Eano mo Ricieln burd Flüije, von Trabertin

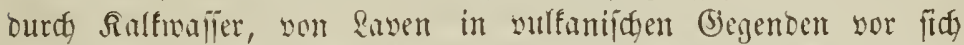

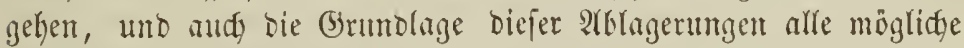

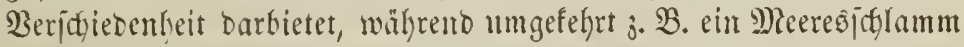

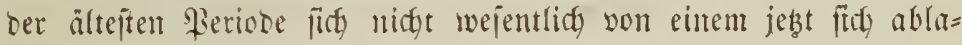
gernben unterideiden mödte. WBo wir aber weber ause ben $2 a g e=$

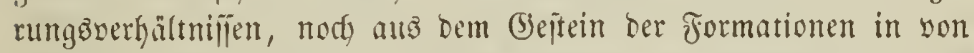
einunber getrennten Rändern sie Sennzeidfen jur Beftinmung ihreß

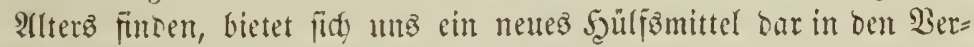

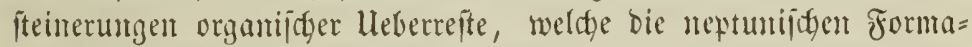

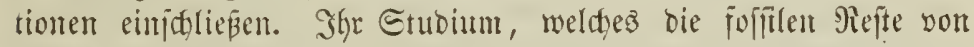

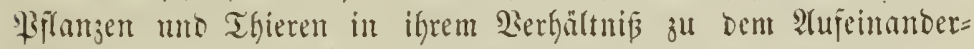
liegen und relativen 2 ilter ber Sebimentformationen betradjet, ift in neuerer 3eit jajt ber widstigite Theil ber Bengnofie geworben.

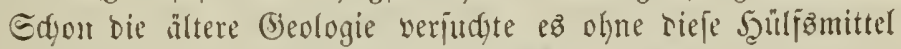

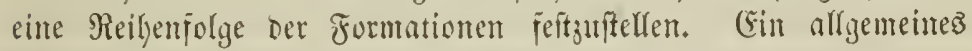
Meer, aus weldyem fid bie Echidften ablagerten, follte zu Zeiten jeine Bejøaffentleit unt jomit bie feincr âblagerungen verändert baben; gleictjeitig folften gleidjartige Biloungen entitanden jein, zu

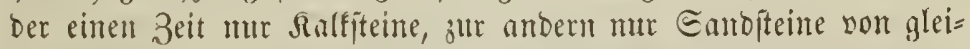

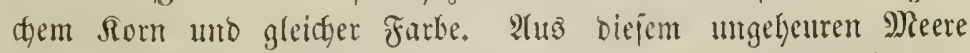

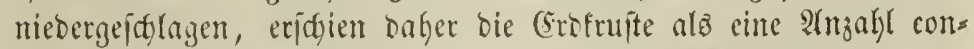
centrijder Edjalen, beren jebe in firth gleidgartig, aber vout jeber

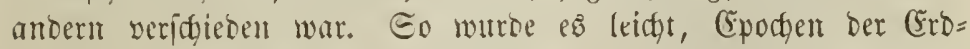

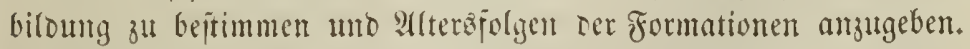

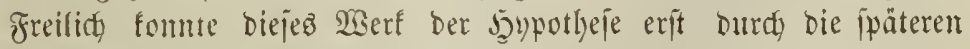
Forjdyungen über bie Sebensanelt Der Borzeit jeine Bef́tätigung und

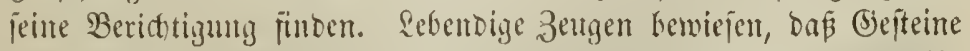

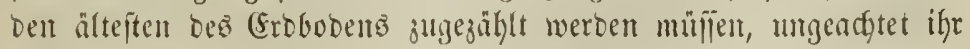

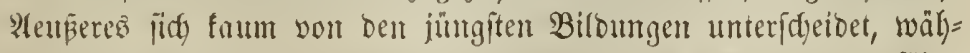

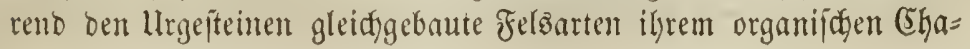




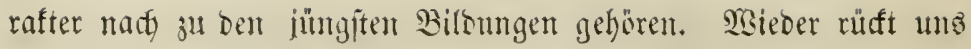
bie Patur baburdg näger, wieter gerwimen mir bie lleberzengung von

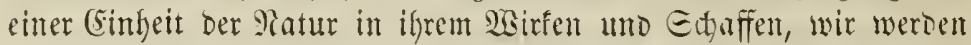
Keimathlidy in ben fremoen Regionen oer Borjeit, in tericn wir feine andre Eteinbilounty gewahren, alb nod hente unter milem Augen vorgeft. Wohl mögen zu verictiebenen Zeiten Cinflinje ge= waltet Kaben, welcge Eigenthümlichfeiten im Sharafter ber Forma= tionen bebingten, aber bieje Cinflitfle waren natïrlidge und gejebs= licke. Die Feftitellung biefer Birengen, innerhalb beren wir allein

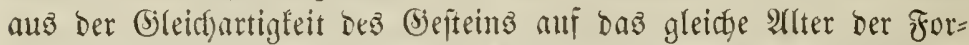

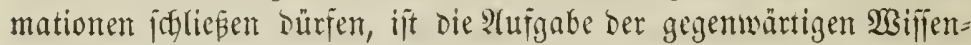
fdyaft ber (5roc. Ierjelbe Cifer, mit meldem man bisher ben va= terlänbif̧en Booen erforichte, wiro hinausggetragen werben in ferne

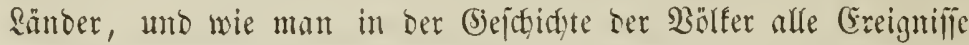

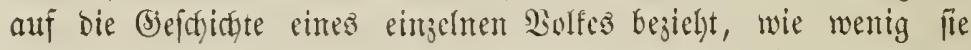
audy mit biefer zujammenhängen, fo wirb man fith über bie Epo= dyen geologifuer (Ereigniffe orientiren, inoem man fie auf bie gleidh=

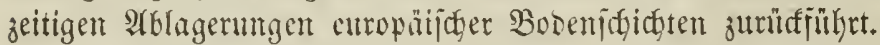

Die beiftehende 2tbbiloung foll $1 \mathrm{~m}$ seit ideales Bild von bent innern Bau ber feften Grorinde gewähren, wenn diejelbe irgentwo

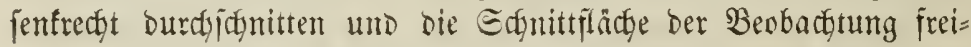

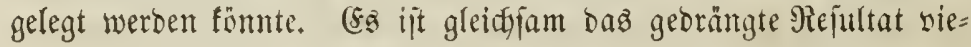

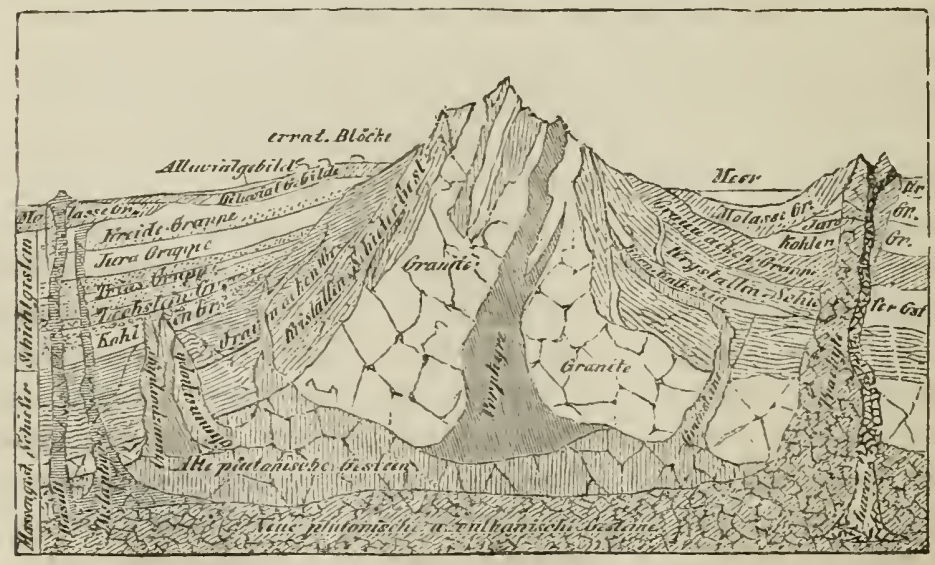

Scenter Suerfonitt ber Errinte. 


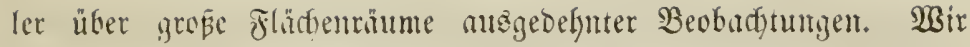
Fehen Darin bie Edfidgtgeteine bon ben (Eruptionsegêteinen gejtört

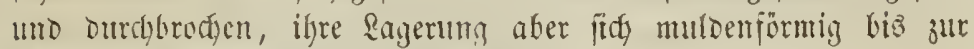
Sterfiăbe uno jum Meere fortietsen.

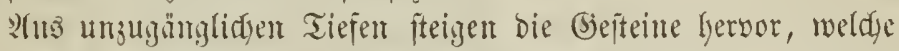

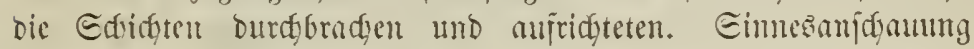
giebt Dort feine (Erfenntnís mehr, nur bie Bergleidfung Der That=

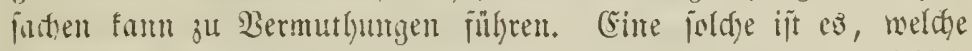

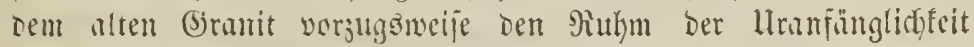

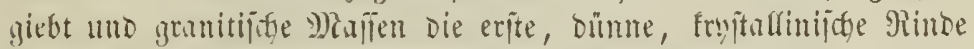
unjerer (Frie bilden läpt, auj weldher fich einjt die ältejten Mieere

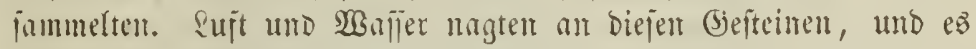
waren die criten Thaten Der Meptumifaden (S)ewalten, weldye ben älteiten Thonidgiejer uno bie fryjtallinifden Edjiejer erjeugten, De=

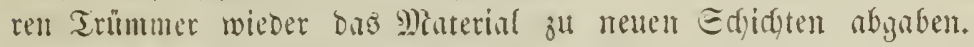
Dutrd plutonijage Rräfte wurben bie crften Betten meptunijader

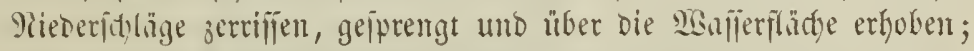

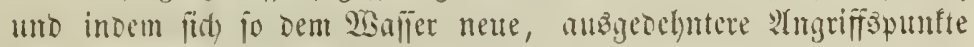
Der 3eritörung sarfotem, führten beioe faftoren im Sanfe Der Sagre=

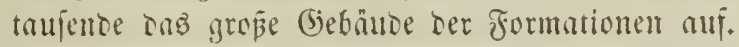

Eine anbere bildlide Darffellung jeige unz mut bie idente Meibenforge Der hibereinantorliegenten Formationen, wie fie burds cin Zulanmentigiefen ber an vielen einjelnen Drten Geobaditeten Meihenfolgen geronnen ijt. Eie biene Dem Jolgenden zur Ěrflärung uno Bernmidgaulidyung.

Die unteriten und ältejten Ectidjtenlager beftehen anz Bseftei=

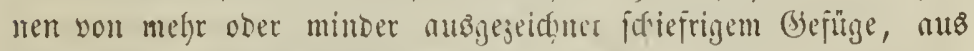
glänzenDem, Dunfel gefürbtem llrthonjthiejer, einem innigen Be=

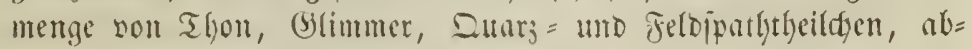

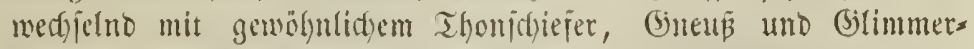

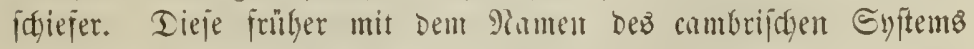
bezeidynete, über 311,000 Fur mädytige Formation ift arm an orga=

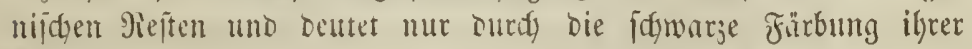
Edvidoten auj Das Dajein verfoglter vrganijager Enbitanjen him. Bald in Tajel= und Dadjidjefer, balo in Alamichiejer ungewan=

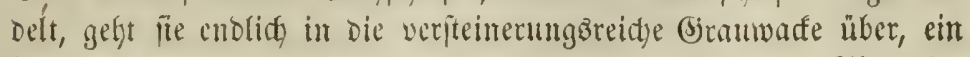
inniges (Songlomerat feiner unto grober Duarztörner, in Thonerbe, 
iteale Reithenpolge for Formatiunen.

Erratiijae Blöcfe.

Diluvium.

Bliveen.

Miscen.

socen.

Freise.
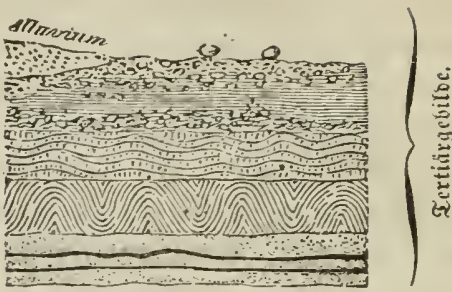

Suaberjanditein.

Neocomient.

riealoen.

sura.

โุ่เซิ.

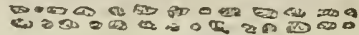

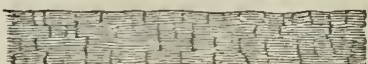

L

$\frac{6}{3}$

$-3-3,-3$

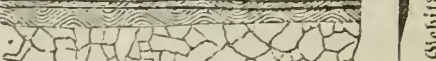
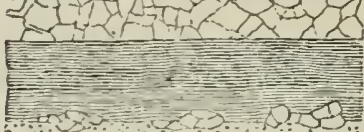

Setuper.

9)ouiduelfulf.

Bunter Єandítein.

3edyitein.

Rothliegendes.

Rohlenformation.

Rolgenfalfitein.

Sbere Sraunatáe.

Mittlere (Sraumaffe.

Untere (Sraumaffe.
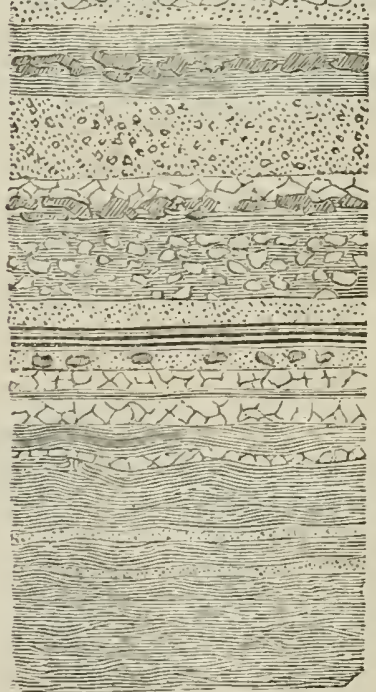

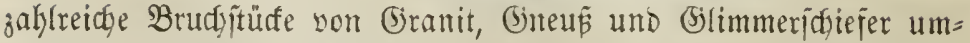

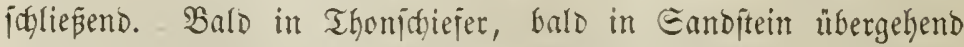
und bon hartem, Dunfelgefïrbtem llebergnnģtalfitein liberlagert, bildet bieje jomit als filurilades Enjtem befannte Formation am Fupe umperer beutichen Sebinge, im Riejengebirge, Şarz, Thüringer= 


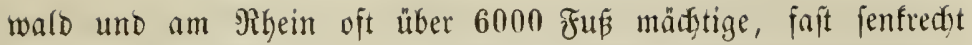

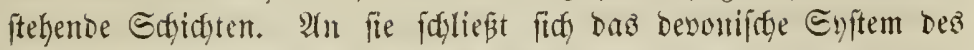
alten rothen Sanditeins an, cine Sieihe von $\mathfrak{R}$ alf = und Eamb=

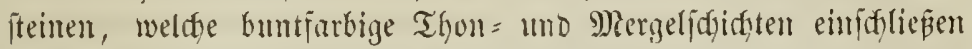
uno in Den (Srampianbergen Englanto eine 9lädbtigfeit son 13,000 Fuß erreiden, wägrend fie in rem Continent (5uropas faft ber= janwinden. 2llle bieje oft farm von eimanber zu unteridgeidenten Formationen fonte man früher unter dem Ramen ber llebergangż= gebilde juiammen, wälyrento man fie jest mit oen beiben mächiffol= genden als primäre ober paläozoijac Sruppe bezeidnet. Sie er=

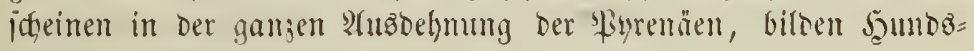

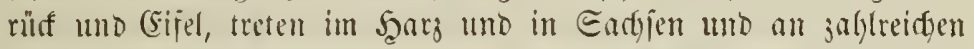
Bunften Deutitalanos, Sfandinaviens und Englands hernot.

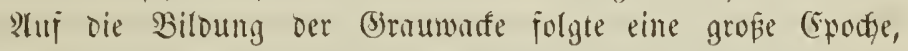

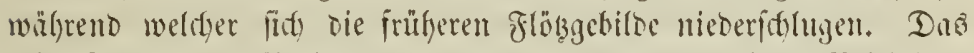

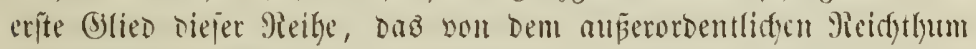

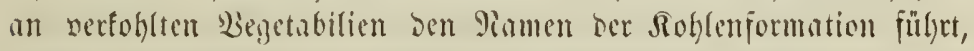

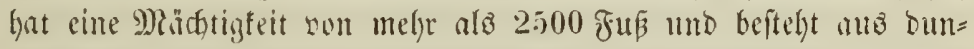

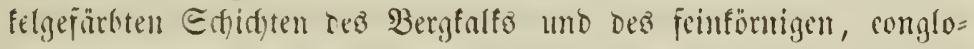
meratijden Soblempanditus, weldyen die non wenigen Zolfen bis ¡ 60 Fuв mädtigen Eteinfoblenflöze folgen. Eie bilden den Reichthum Englands uno Belgiens, in Denen fie ben 20. bis 24.

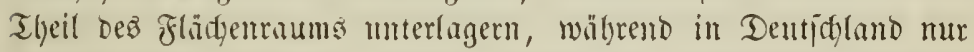

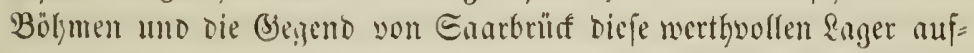

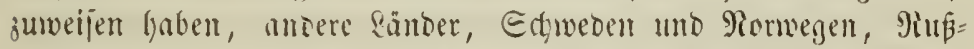
land, Stalien und (siriedjenland ifrer fajt ganz entbehren. 2tuf

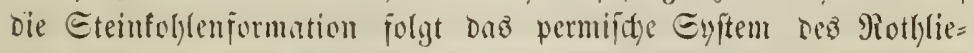
genden uno Des Zedyjteinz. (Erfter ijt ein grobförniger, Durch ro= then Thon gebunbentr Eanbitein, Der in inniger Beziefynng ju bem

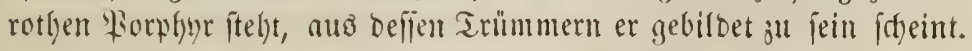
Durch Den mergligen mo liberaus $\mathrm{arg}_{3}=$ แnd verfteinermggereidgen

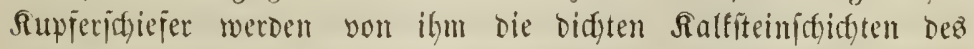

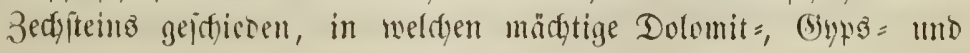
Eteinfaljager anftreten.

Der 3edfitein bejeidfnet die brenze zivifden ben s̈lteren und

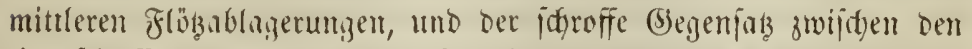

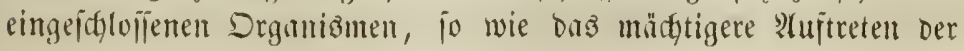


Salferoe an Stelle Der bis̆ger Gerridgenden Thoneroe liepen in ber Biffenjchaft hier ben Anfang einer meuen (Erobilloungsepoche be= grinndet erideinen, bie mit bem Mamen ber fefuntären bezeidfnet

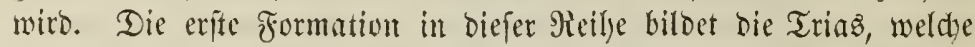
Den bunten Eanditein, Mufchelfalf uno Reuper in einer mittleren

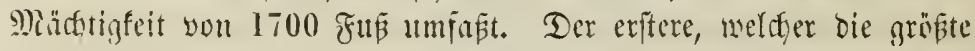
Insobefmung erlangt, ift quarzig, feinförnig uno burch fein thoni= ges Bintomittel gewöhnlith roth, jeltner grinnlid, und weis gefärbt.

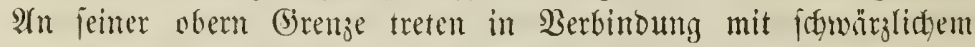

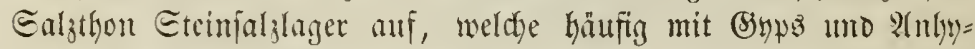

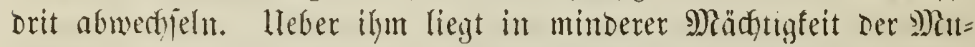

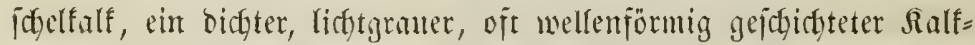

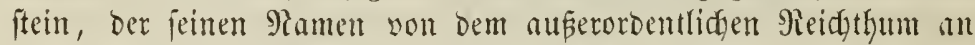

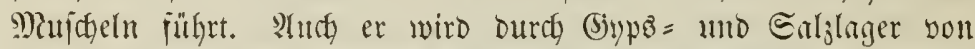

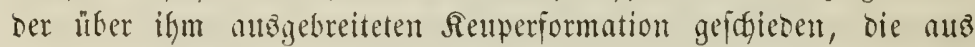

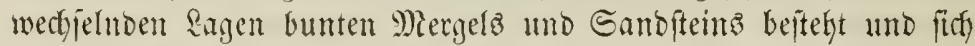
yon bem ägnliden bunten Eanditein burdy bie graue, bon $\Re$ ohle

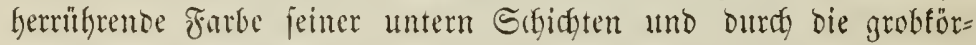
nige, fajt conglomeratifde Bejdaffenfeit jeiner obern Ectichten un= tericheibet. Dieje bedeutento Formation breitet fid über bą ganze

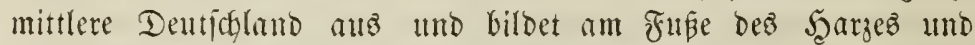
Thüringerwaldes meilenmeite, wellenfürmige Saitgelreilhen. 3war fefflt Der Mijchelfalf Dem Boden Englando and zranfreidfo, nber Der אeuper tritt bort um fo mädtiger auf, uno ganz Mitteleuropa serdanft biejen (Sebildest ben wejentlichjen atgeil jeiner Dberfläche.

lleber biejer formation nimmt cine andere nidgt minter be=

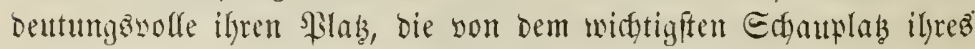
Anjtreteng, bem idqweijerifden uno beutiden Sura, ben Pamen ber Surnformation erfhalten hat, in Englano aber bie Dolithgrnppe genum wirb. Eic befteft wejentlich aus abrwedjelnden \&agen von

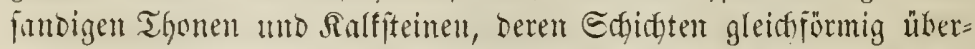

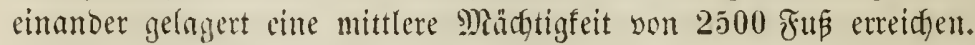

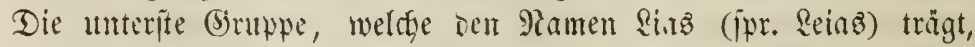
ift ein grauer ober Gäulficher, werfteinerungöreider Ralfftein, ber in Edjeffer überigeft amb von gelblidjem Salffanditein bedeft ift. Darauf folgen zum Theil Edyidten blauen Thons unt tyonigen Sanbiteins

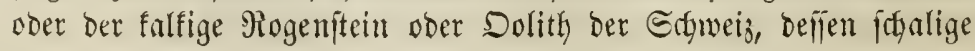


Ralffteinförner Trümmer yon Muifteln ober Sanbfömer umidfic=

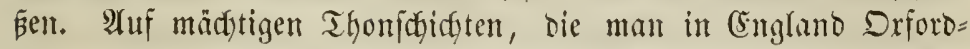
thon nent, ruht entolid ber Roralfenfels Englands, ein gelblidser

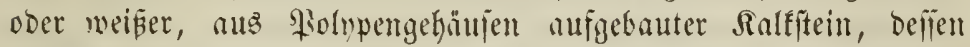
idsiefrige Ectictsten den io widytigen lithograptijgen Etein liefern. Reue Merigel = uno Thonlager und eine Edfidft hellent und biffen Ralfiteines, ber als \$ortlandifein Daz Material zu ben \$radjt=

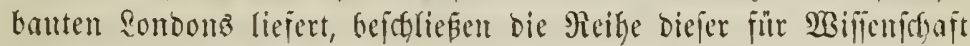
uno Reben gleidg widftigen Formationen. In jufammenfüngenter

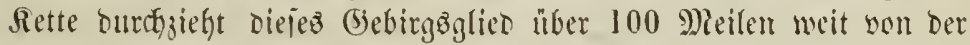
Ryone bis jum Main daż mittlere (Guropa. Bon gigone und Rhein burdfbrodjen bildet es nad) Güben bin bas Bjenggebirge

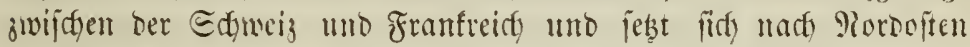
hin bis zur Donau uno Sinat uno in verindoerter Siddumg faft

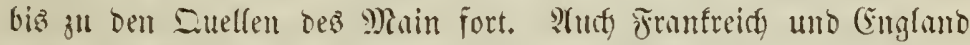

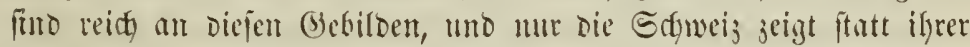
umigemandelte formen ron Marmor, (Branmate uno Bslimmer= ichiejer.

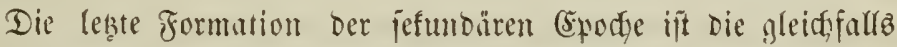

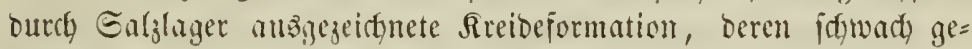

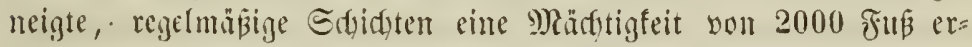
reidfen. Das unterfte bified in biejer Reifge bilden theits in ber Stimeiz, Frantreid, Deutidgland und Polen die ats Peocomien be= jeidfneten \&ager von Mlergeln uno gerblicfen, groben Salfifteinen,

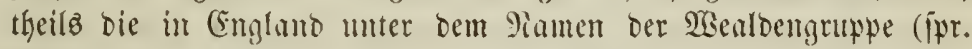
Bielden) zujammengejaßten, mit eijenifüuffigen Sano = und Thon=

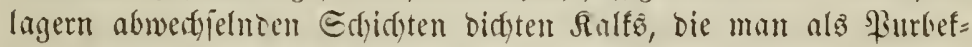

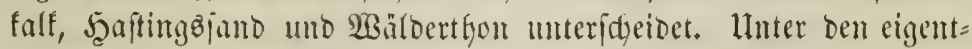

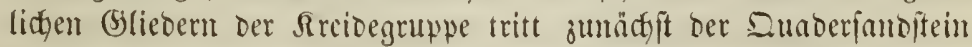
hervor, ein balo umberfittetess, balo ourdh thonige uno falfige Bintoe= mittel zujammengefaltenez Souglomerat feiner Sunrzinofönter, ber

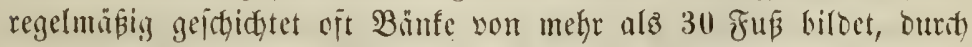
beren 3erflifiun! uno Berwitterung würfelige Blörfe oder Suabern

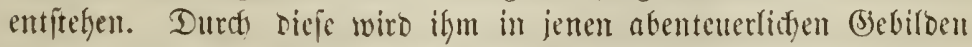

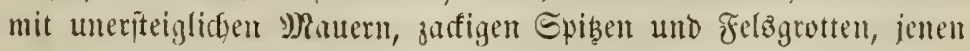
abgeítukten, bon hohen Edjuttwällen umgebenen Regelbergen, wie

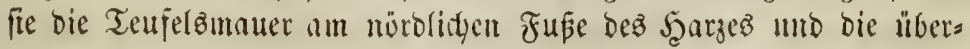




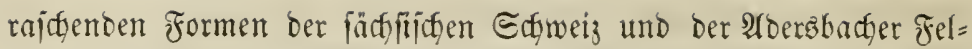
jent Darbieten, ein merfwüroigez, jäulen = uno obelisfenartigez $2(n=$

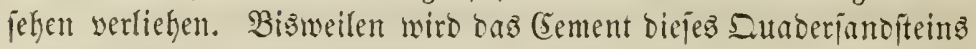
ein (Semiify son Thon uno Ralf mit erbigem $\mathfrak{T a l f}$, befien grüne

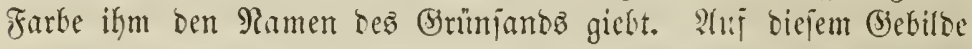
ruhbt oft ein in jeinen untern Edfidfen zaflecidfe grüne Sörner

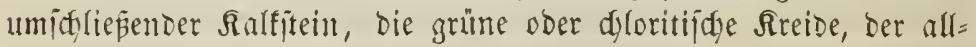
mälig in ben thonigen und fantigen \$slänerfaff und entolid in bie reine, bidfte Rreire itbergeht, beren obere Edjidgt bizmeilen bor weiche, lictgelbe Sreidetuif rettritt. WBit haben fhon früher bie Rreibe mit ifren eingeifloilenent Fenterfteinfnoffen und Sreidemer=

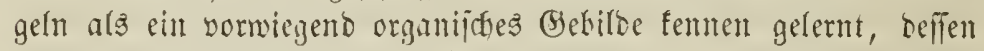

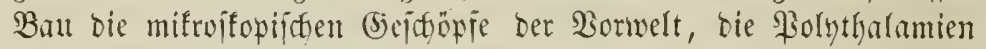
und Riejelpilanjen anffïifren. WBir erftaunen aber über bie gemal=

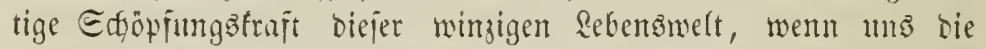
ungeheure Auasbefnumg biejer Rreioegebilbe entgegentritt. Englund uno Frantreich, Belgien uno Deutichland finto zun größ̈ten Theile von biejen formationen übertagert, uno nidgt mur bie 2 bbhänge ber (Bebirge, fondern jelbft bie Grbenen uno ber Meereaboden zeigen

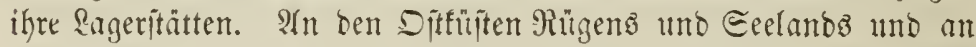

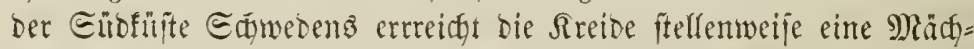

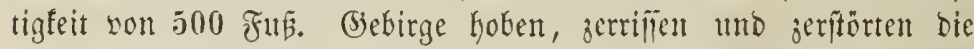
weit verbreiteten Rieberiđdäge dę einjitigen Sreibemeeres, jüngere Bildungen ükerlagerten fie in ben grö̈en Teefebenen (Furołaz.

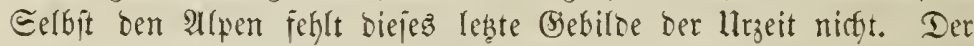

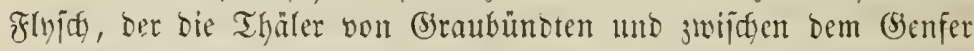

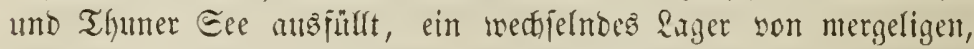

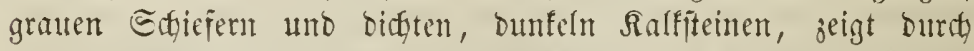
Die eigenthümlidge Ragerung jeiner Edfidgten auj älteren Ralfgebir=

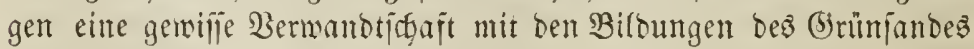
uno 23 äloertfonez.

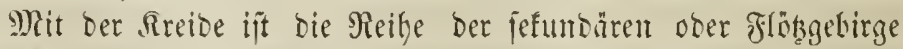
geidfloilen. Ein mener Eharatter tritt in ber Erobildung hervor. Die tertiären Echidften treten mur in abgejonderten, einjelnen Grup=

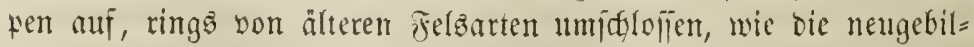

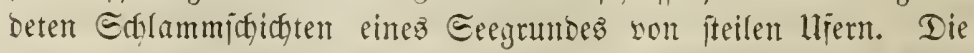

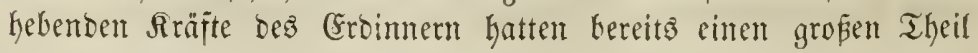


Der Evibrinde trofen gelegt und ausigedefhnte Feftlänber gebildet, jwi= iden Denen nur Eeen, Budten und Bimtenmeere Der gejteinbilden=

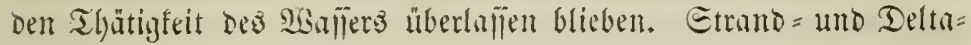
bitoungen treten herwor, lofale (Sigenthuntidffeiten bejeidgnen bie Biloungent in getrennten Beffen. Sin geringer 3ujanmenlyalt und eine bunte s)ijtung Der Bejtandheile beweijen Den geringen Druf, unter Dem bie Edjidten entitanden, und die lange Zeitouner iljert

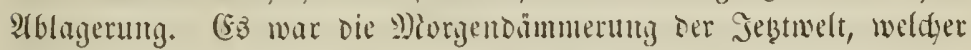
dieje (bebilde angebören, aber eine Z3eit, won der bie (bejtyidte bes

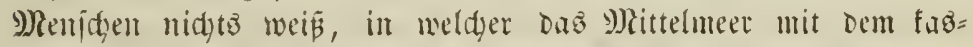

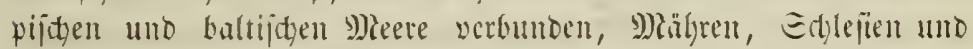

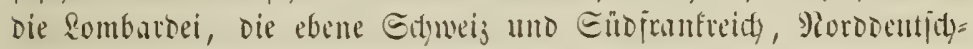
lano mo Eüdengland nody Meeresbeten maten.

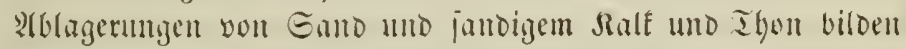
Die Gejammtmalen der mannigjaltigen Tertiärgebilde. Die unter= ften Edyidten, Die Den Yimmen Der (Evcenformation führen, bejtelgen aus Eand = uno Thonlagen, weldye mit Brauntohlcnîlizen uno

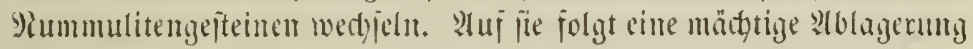
bräunlidgen, balo feiten mid lyarten, balo loceren unt crigen $\Omega$ alf=

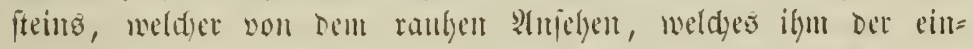

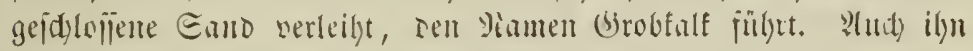
baben wir idyon als organijases bebilde femen geternt, als Das

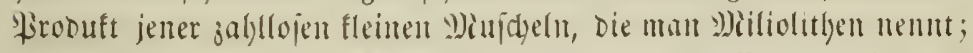

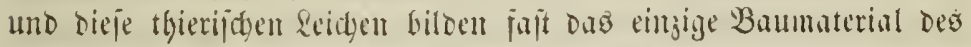
ftolgen Saris, Das aแs unteriroijdyen Brudjitätten, ans jenen jurdyt= baren Ratatomben, Der menjolidye Rututfleiß llber Den Eroboden

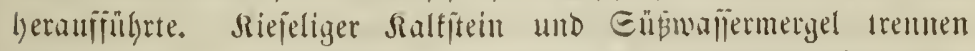
Dieje untere Tertiärormation vou Der jüngeren, ber D) Ualaje, meldge

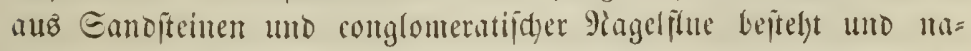
mentlidy bie stlpen auf ifyer nörolidgen Eeite in ilyrer gunzen (Er= jtrectung begleitet und zwijdyen 2llpen und Sura eine ankerortent=

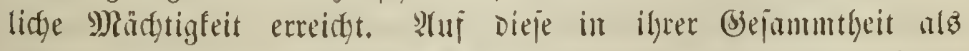
9)iocenformation bezeidneten \&lblagerungen folgt Dus jünsjte (3)lied

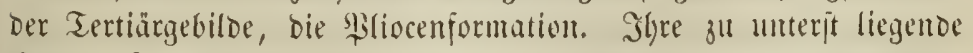
Sruppe fint man genölgnlid unter Dem Pamen Der Eubapenninen= formation zujammen, weil jie bem fupe diejes (S)biriges ju beioen Geiten jolgt. Meeres = und Einfwajperablagemngen, gelbe Eand= 
jojidgten uno bläulidye Miergel wed)jeln mit einanoer in biejen (S)e= biloen, weldye burch die Branbung Des Mieeres und bie Ströme ber

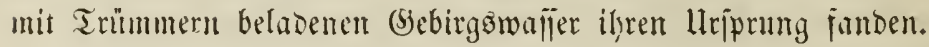

3)it Diejen Formationen, Deren mittlere Mädthtigfeit man auf

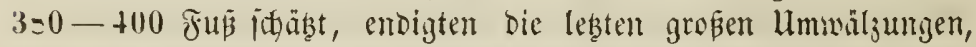

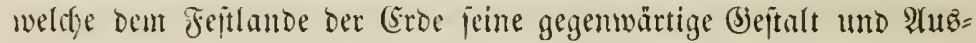
Dehmung gaben. Sine gewaltige f(utl), weldye den grö̈ten Theil Des Flaneten bedecfte und die Rebenzwelt der Borzeit jum Keb̧en

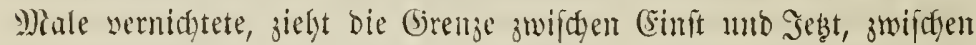

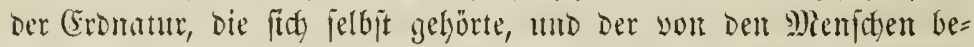
herriffen Erbe. S)an bezeiffnet Daher aud Dieje jüngften (Sebilde,

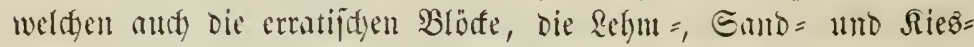
ablagerungen bes nördidyen Dentid)landz angebören, mit bem $\mathfrak{R a}=$ men ber Diluvialgebilde. Sods beute idfreitet ifre Geftaltung fort in Fliffen und Eümpen, in Eeen und 9heren. Fluthen frönten

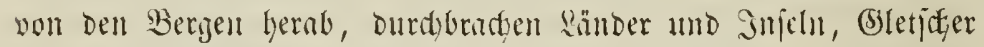
trugen Die Trümmer ber Feljen in Ihäler und Ebenen, \$flangen und Thiere bauten ben Boben, auf welthem jeb̧t ber Mienfid feine

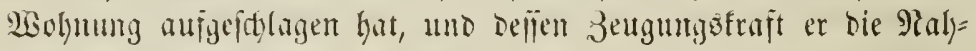

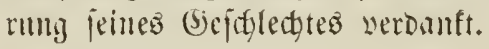

\section{3) Dic metamorphofinten (s) fiteine.}

Den auj feurigem Werge erzengten plutonifaen uno vulfani= inen (sruptionsmaffen laben wir nisht mur bie ju veridfiebenen

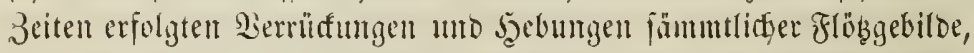
wie jebe fidtbare llnoronung uno Etörning auj Der Corooberflädye, Deren Epuren man in unenolidger 2 (njagh wahrnimmt, jüujoreiben,

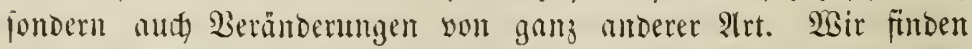
in unjerer (Srorinse eime Menge son Bejteinen, die offenbar nicht won worn herein in ilfrer jekigen Bejtalt gebildet wutrben, fondern vielmelyr fpäteren llmmandungen unterworfen waren, weldye mäd = tig genug waren, Den Aggregatzuftand ilyrer Malje zu änbern,

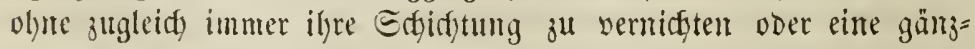
line Samelzung ju bewerfitelligen. Dies find Die ntetamorphofir= ten (Sipiteine. Eie ftehen in Der innigiten Beziehung zu ben un=

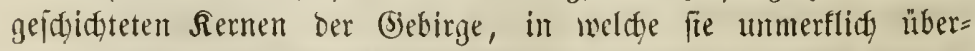

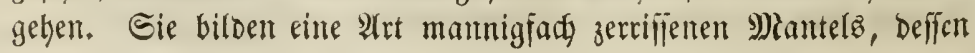




\section{3}

Sdjidjen idgalenartig um ben mittleten Rern getagert fïno. Se näher man biejem Serne fonmt, dejto auffallender wiro die fry=

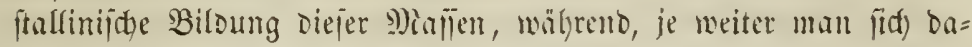

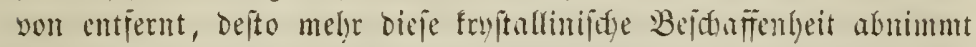

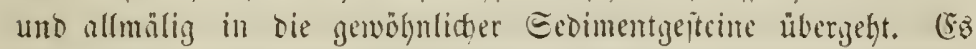

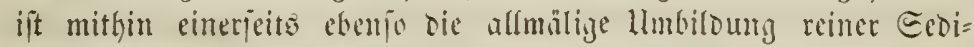

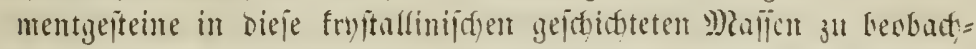

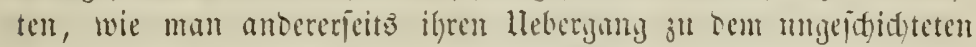

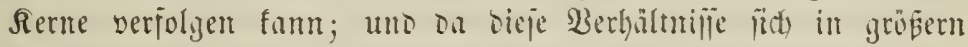

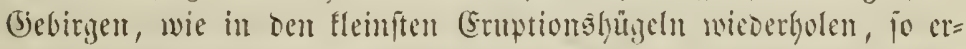

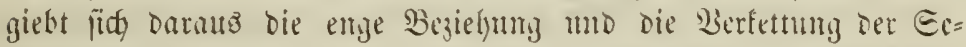
Dimentgeiteine mit oen ungeidjicteten vermittelit Der geidjidteten fryjtallimiagen Minilen.

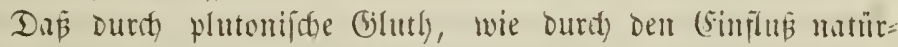

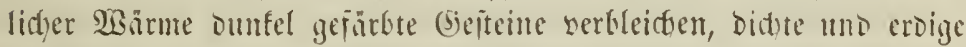

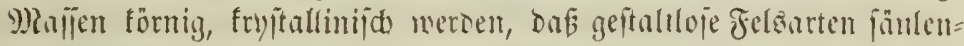
artige forment ammehmen, ja Doß jelbft Renoerungen im demijden

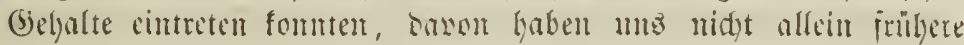

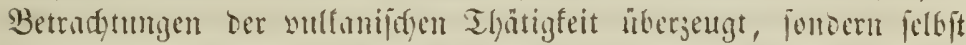

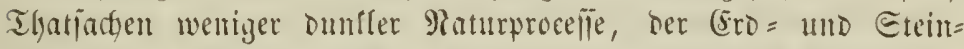

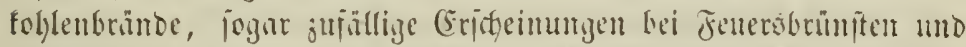

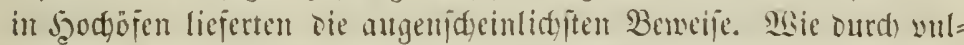
fanijge fener wursen and burd Eteintohlenbrinde bie thonizen und jojiefrigen 9)injen, die Eano = mo Ralfiteine der limgebung

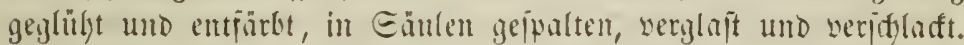
Die (5oafz, in meldye Eteinfublen burch joibe bermandelt wersen, zeigen nidft jelten jene fäuligen Afojonderungen, weldje ben Boblen im maturtliden 3ultande nie cigen pint. Die Thonidjejer einer

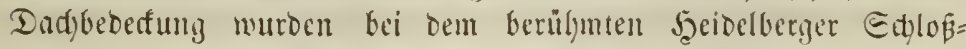

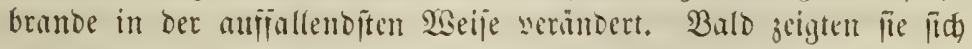

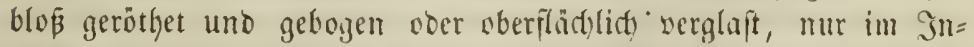
nern nod) von beutlityem (Sepüge; bald waren fie fo volffommen zu

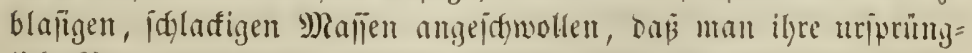
lidge Matur faum nod erratthen fornte. Tie verylaften Buryen bes

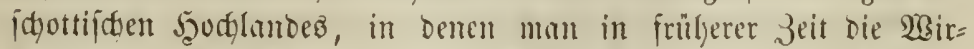

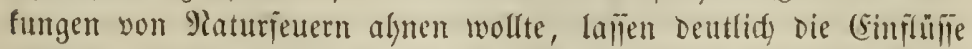

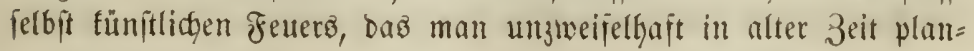


mäp̄ig zur Gidyerung jener Feiten vermandte, auf Sranit = und (3neusitücfe, auf Trümmer von Forphyr und rotlyem Eanditein, meldye dieje $\mathfrak{B a ̈ l l e ~ z u j u m m e n j e s ̧ e n , ~ e r f e n t e n . ~ B a l d ~ e n t f a ̈ r b t ~ u n o ~}$

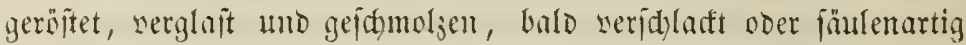

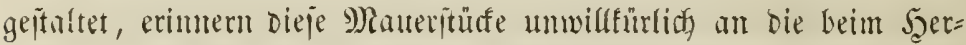

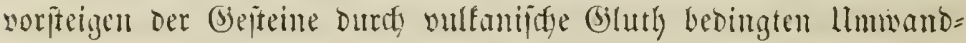

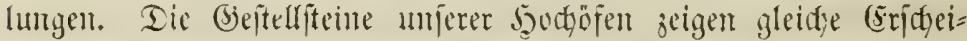
mungen. Wemgleids die Thätigfeit fumplidyer Fener nidyt ganz im Bereide natürlider (Erifyeinungen liegt, fo find es bod bie= jelben Sräjte, weldhe hier wie bort wirfen, Sräte, weldye antz ber Shatur entipringen und anf bie Matur bejogen werben bitrfen. Sur Die Mittel fmo flein, welthe wir ammenden, mo bie 3eit unjerer Beobadyungen verjawintet gegen bie Golytaujente, in banen bie Satur arbeitet.

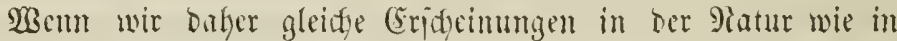

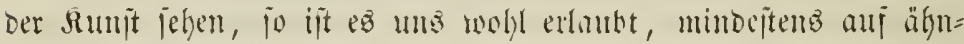

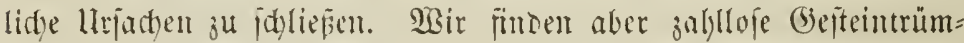

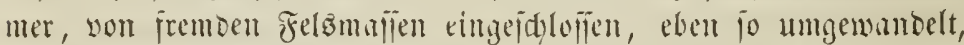

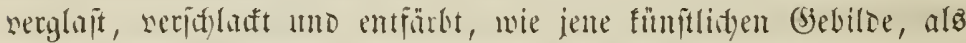

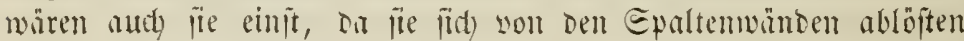
unt in bie Tiefe fielen, yon cintem fentrigjlüfingen Teige umbüllt morden. Eandjeintrünmex, yon bajaltifden (bebilden unjd)lojen, eridteinen in bie zierlidyten Eäulen abgejontort, thlo in grojartiger

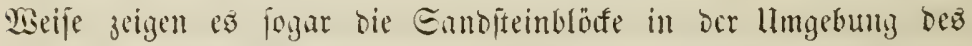

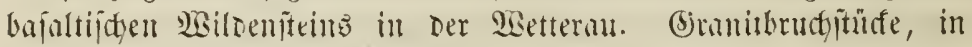
Burplynte unto Bajalte eingehnllt, zeigen fid mit jumelgartigen Hinden ooer Edylufenfruiten boduft, als mären fie in Sier. geme=

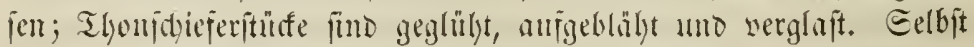
Da, wo neptunijde (Sebilde mit emporiteigenden plutonifden Beftei= nen mur in Berüfrung famen, an Epaltenvinten uno in $\mathfrak{B e}=$ tungen, erfulyen fie limwandlungen, weldye ifre urperinglidfe $\mathfrak{R a}=$

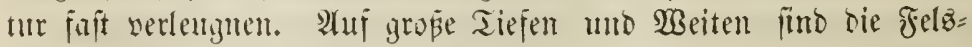
arten Durctbrumt, gebleidyt, in Eäulen gejondert, biffte und eroige

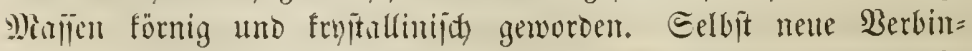

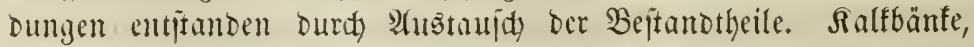
welche Durds Sranit = voer \$orplyntmaflen emporgelyoben uno auj= geridtet wurben, fint von Riejelerbe Durdborungen, bie jenen ent= 


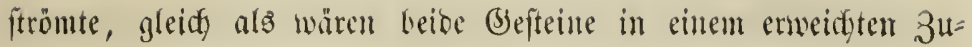
ftante gewejen unt in cinnomber verffoffer. Şier baben fdjwefel=

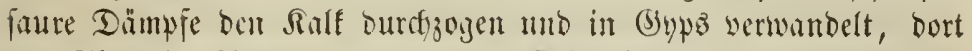

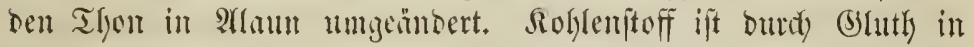

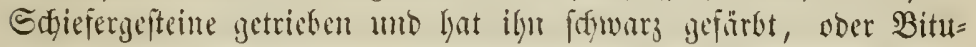

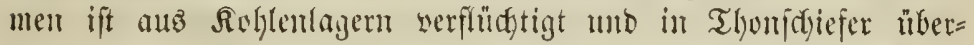
geführt worben. Eellejt Metalle fffeinen auts bem gewniltigen beeerde

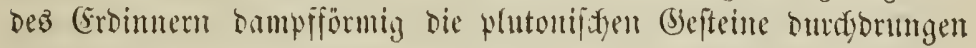
uno ben bariberliegenden angeflogen, in ifre Epalten und sifife Ginmigeftiegen ju jein.

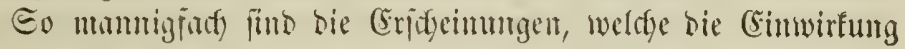
Der plutonifden Gefteine auf meptunifde Edfidgten bervorbradfte;

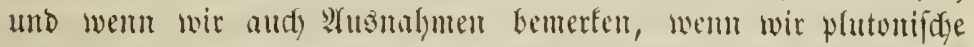

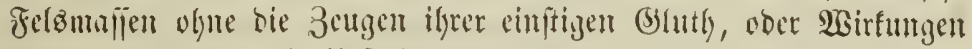

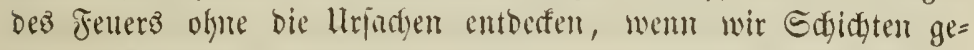
ftört, gebogen, emporyeridtet ferfen, beren sise fen feine fitgtbare

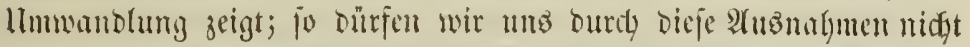

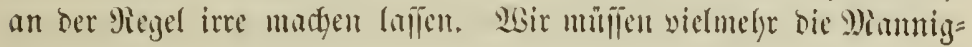
faltigfeit ber llmitände unto Beringungen bedenten, unter benen bie

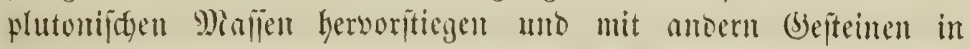
Berbintung traten. Die 2Seitungen, Durd) weldye plutonifde

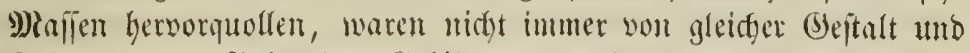
(brö̈̈e; bie auffiteigenten Befilde waren bald methe, bald weniger

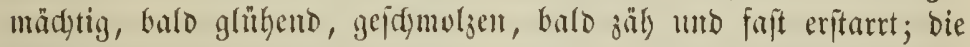
Edjidten, nui beldye bie (blutl) simvirfte, warent längft fejt ober nod) fidlommantig uno flitifits.

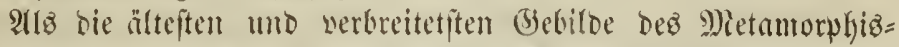
muв betrad)tet man bie fryftallinifden Ed)iefer, unter weldyem $\Re a=$

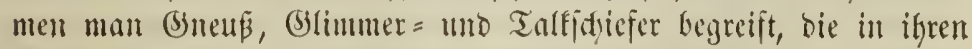

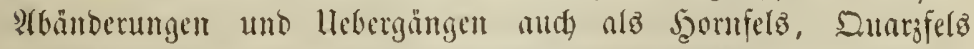
und Ehbloritjdiefer autreten. 2tuf ber cinen Eeite verläuft ber

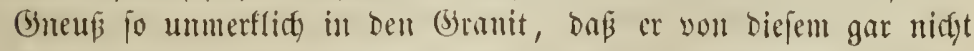

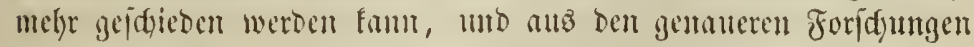

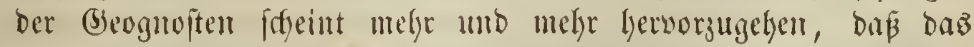
gauze allpengetirge fajt gar keinen ungejefid)teten (Branit entbält,

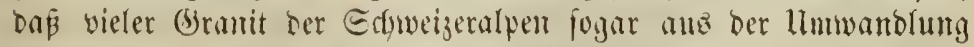

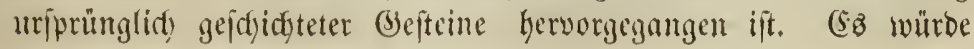

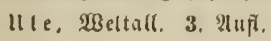




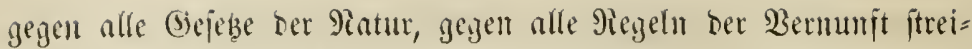

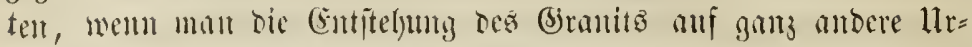

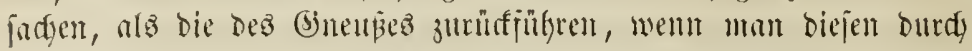
Metamorthoje aus neptutifgen (befteinen hervorgelyen, jenen aus ben Tiefen des Eroimtent anfijteigen lafien wollte. Die lleber=

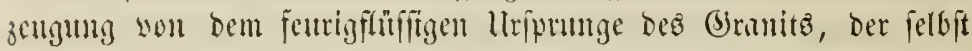

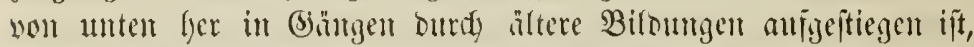
liez

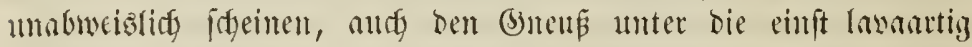

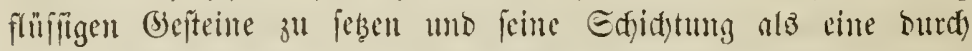

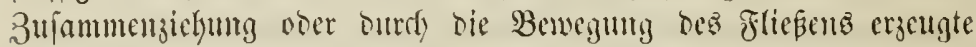
Echiefermug ober Tafelifruftur ju betractent. Diefe Forberung

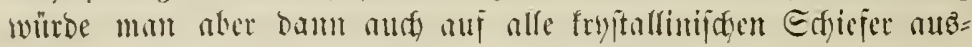

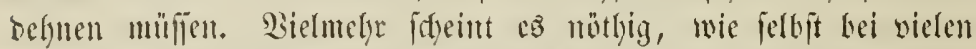

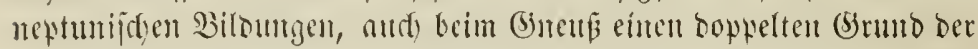

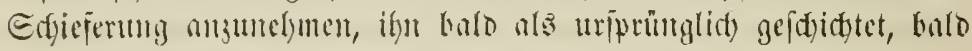

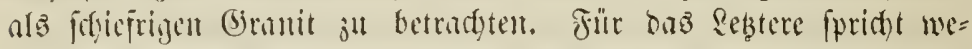
nigftens bie Eagerunty ber Edfidfen, meld)e oft nußer allem 3ufam=

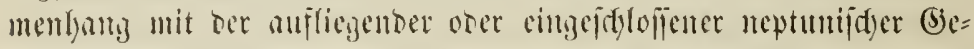

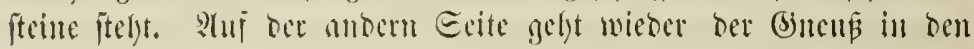

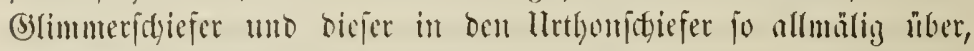
ba

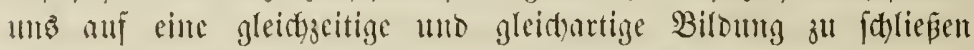
zwingt. ager ber lltrthonidgiefer verlauft wieser fanft in ben ver=

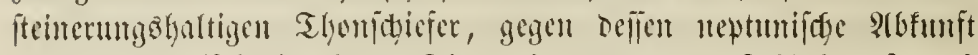
gar fein 3weifel obwaltet. Dies oringt uns ben Edgln auf, Dá

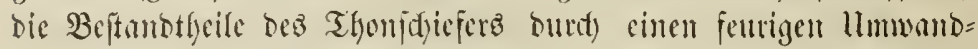

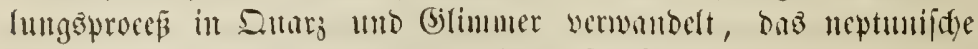

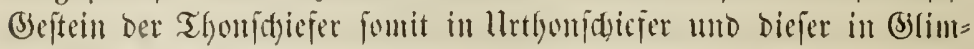

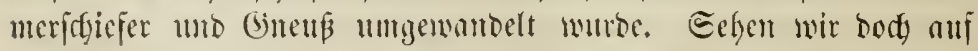

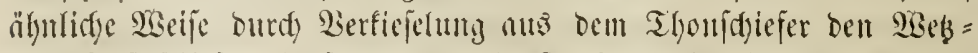

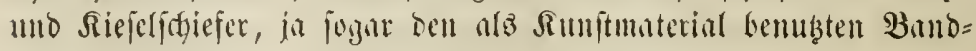
¡aвpiz hervorgetyen!

Diefe merfwüroigen Befteinarten, gegen beren Metamorphiš = mus man gar mandfectei gat eimoenden molfen, bildent vielfeidgt

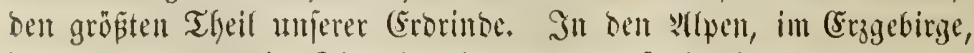
im Böfmerwald, in Efandinavien mo worgh̆glidy in Brafilien bit= 


\section{7}

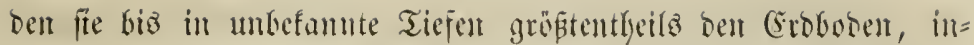

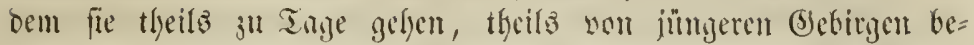

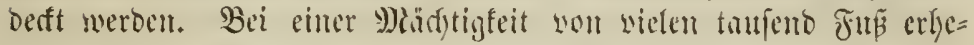

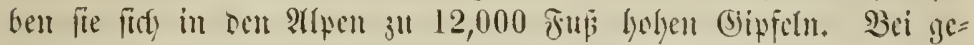

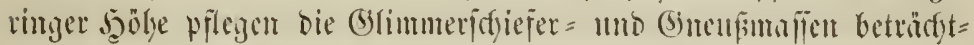

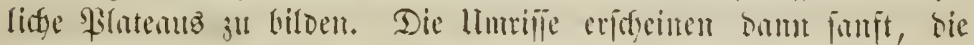

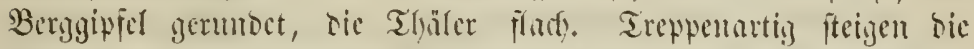

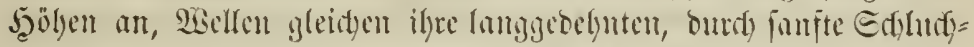

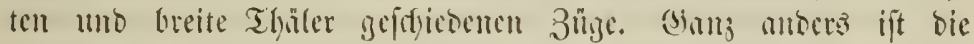

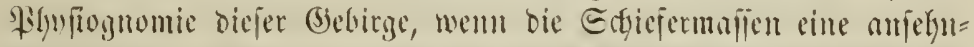

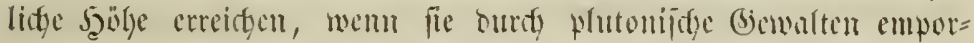

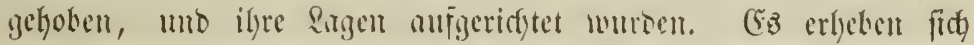

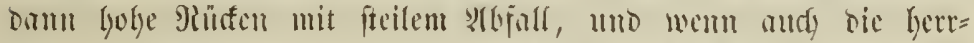

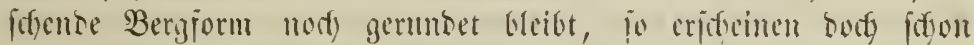
idgärere Rämme uno tiefeingeidnittene Thäler. Epraften, weldge

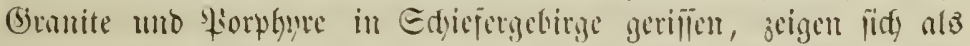

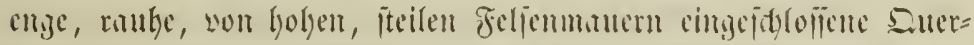

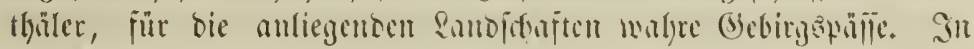

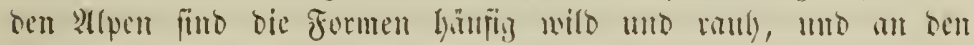

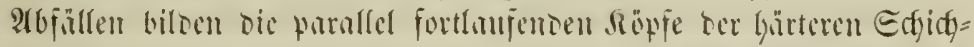

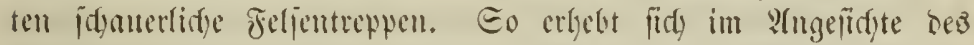

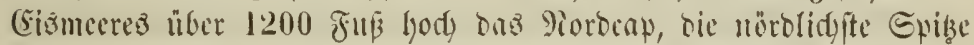

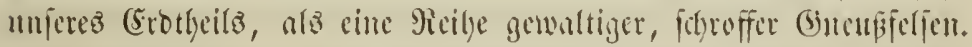

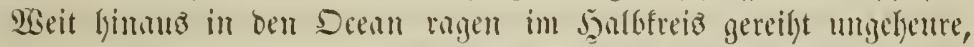

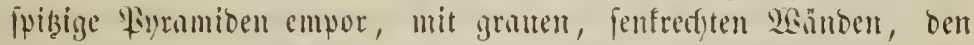
wilo autürntenoen Mierräwogen Trok zu Sieten.

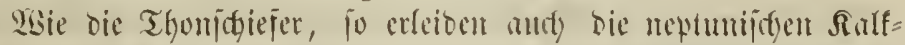

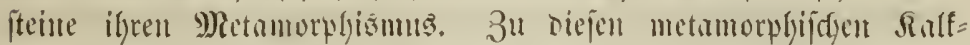
fteinen gehört vorjugsubeife unto unbefrtitten ber förnige ober fali=

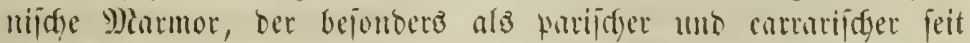

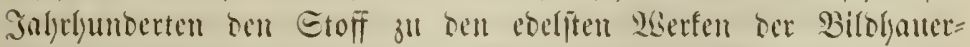
funft geliefert bat. Ier foünje Minrmor ift eine llmusuthung bez

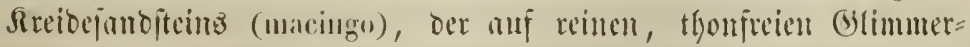

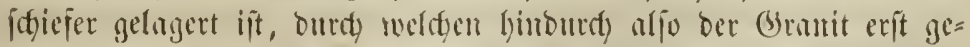

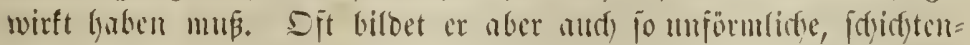

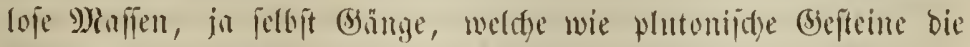

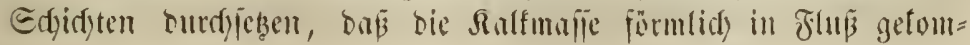




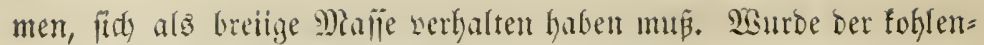

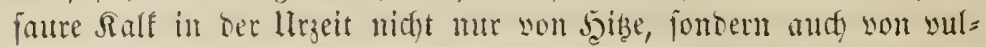

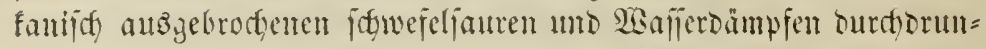
gen, fo erweidften fie ifhn, wertrictent bie Soblemïure und erjebten

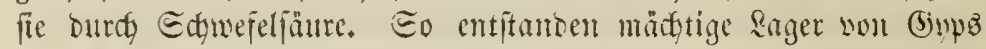
unto Antyprit.

Die merfwüroigite lintwantung bes Ralffeints bieten aber bie Io=

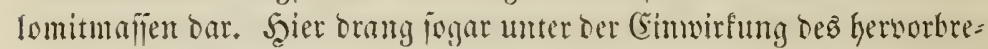

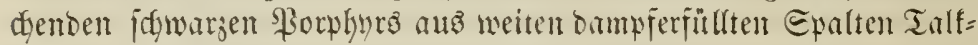

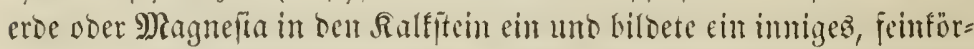

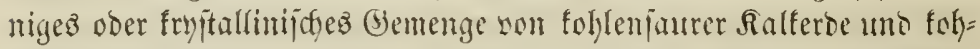
lenfaurer Talferbe. Die in groper 3 aly neben cimanter ftehenten,

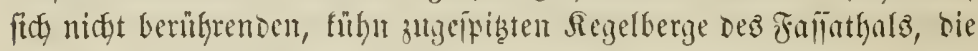
anterwårts bomattig anf̧getriebenen Miafien bes Dolomits, bie mert=

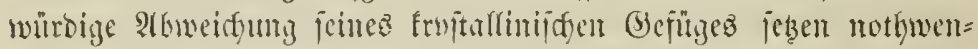
dig buld helende plutonifge whallen, Gald heike Dämpfe voraus, weldye fidf burdf bie neptuniaden Edyidten einen sieg Gaijnten uno fie in cine poröje, aufgeblähte Miafie vermantelten. SBgäre es

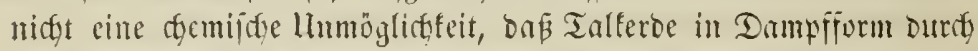

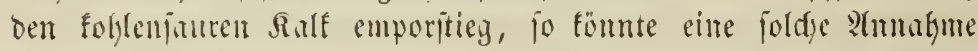

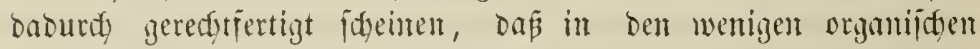
lleberrejten, Denen man in biejen metamorphofitten Ralfiteinen be=

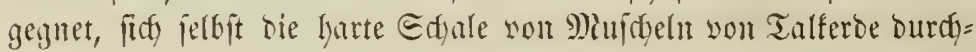
brungen furbet; bemn nod fenten wir feine orgmijaen siejen,

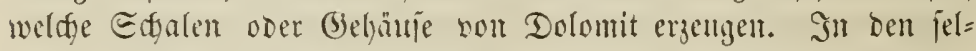
tenen Setrejaften Des Iolomits if aber bie Edyale ber Mujctel

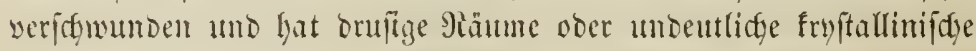
Eteinfente hinterlajien, weldye ben fonit in ätteren Ralfíteinen vor= fourmenoen Frten angegioren. Dieje Thatfache ipridgt für ons päa= tere Şinjutreten Der Talferbe zur uriprïnglidgen Ralff̈teinbildung. Der reidge (behalt Darumterliegenter Miaflen an Soghle uno Bitu=

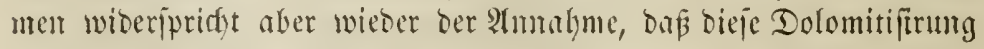
mit eimer foben, won unten wirfenten Temperatur wertumben gene= fen jei; und bie Berillyrung mit jeurigillifiligen, talferbereiden (be= fteinen ideint fogar eine llmwandlung des Dolomits in förnigen

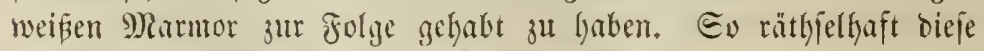

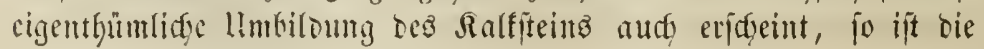


Ratur body feime Zauberin, bie mit anderen, als eimjadyen uno na= tïrlid)en Mitteln arbeitcte; mux mjer 2(uge reidgt nidft tief genug,

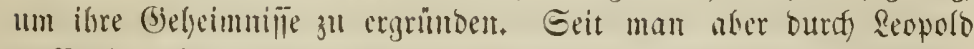

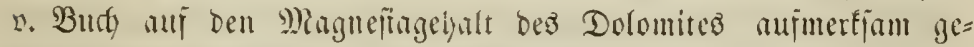
madyt ift, hat bic foridyuty nidgt gernht, Das Dumfel biefer Ers

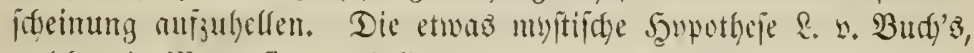

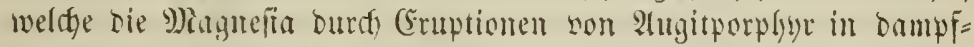

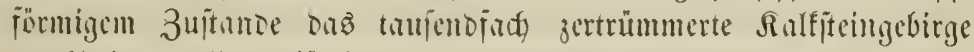

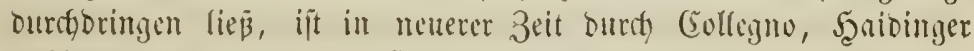
14. 2f. In Mnturyemï̈erer Beife serïloert worden. Die befamnte 3ujammenlingerung oes Dolomits mit (Syps jührte ju ber Dermu=

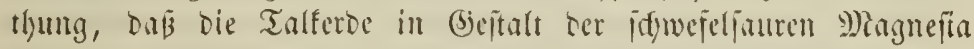

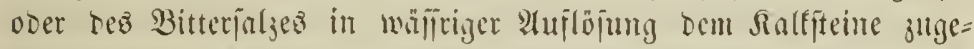
fïbrt wurbe und biejen unter Dem Eimflus tellurifder Bärme uno

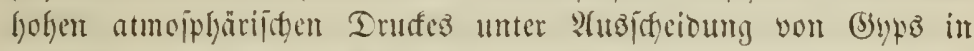
Dolomit verwandelte. Berjudye, bie bejonders won Miorelot antge= ftellt murben, focinen bieje 2fmathme zu bejtïtigen. WBie bic Ber=

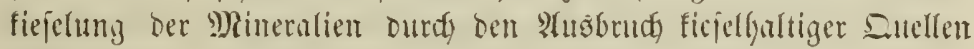

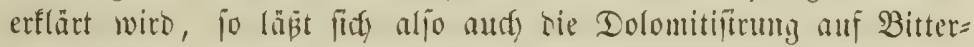

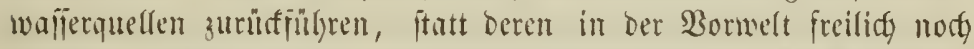
häufiger bie Meeresfluthen gewirft haben mögen, beren Gebalt an

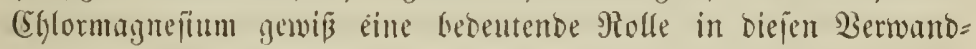
lungen der Ratur geipielt hat.

Die Biloung aller diejer metamorphifath Sefteine, beren nidjt eimmal alle erwifgnt werben fömnen, wirb allyemein alö $2 B i r f u n g$

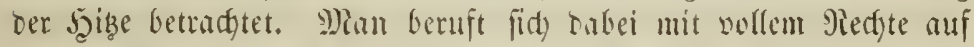
Die obenangedeuteten Eridgeinungen, weldge man an ben Befleidun=

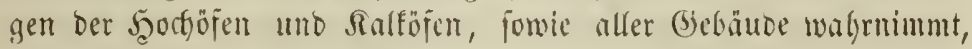
in melden man längere 3eit bindurd) einen gewaltigen Şizegrad unterbält. Şier zeigen fïd bie meiften biejer Erjdeimungen. Sand= fteit wirb in Dutrs, Didter Ralf in förnigen umigemandelt, Felojpath=

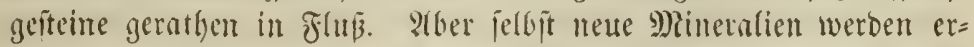
jeugt, Deren Bejtandtheile in Den zum Bau verwentoten Pinernlien firf) Finder. Felopatheryitalle, Silinumer, Siranate wurben Durds Rumft uno 3ujall in Şütten gebiloet, zum beutlicten Betweife, daß Die meiften ber in ben metamorplyijtyen Befteinen eingeiprengten Mineralien äbulidger $\mathfrak{B i r f u n g}$ igren Ilrperung serbanten mögen. 


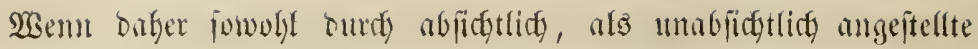

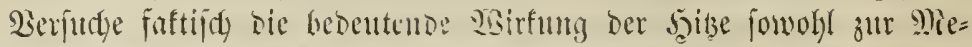

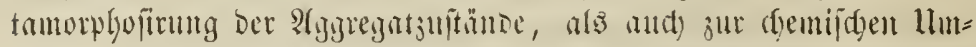

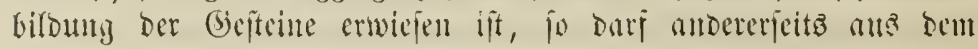
Fehlidjlagen vider joldyer Berfudye nidjt gejolgert werben, Dã

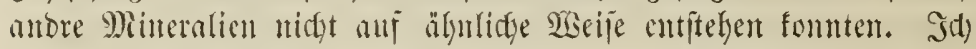

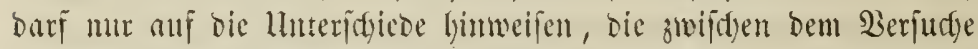
umb bent in Der Miatur wirfenden Sräftent bejtegen. Dort ginty bie

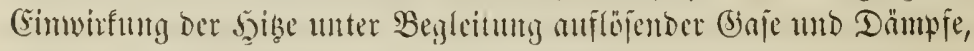

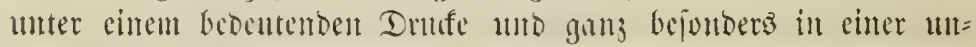

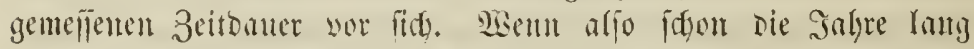

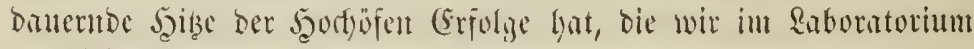
vergeblidy ergielen, jo liegen alle geologifden \$ghantwomene hinjidgtlids

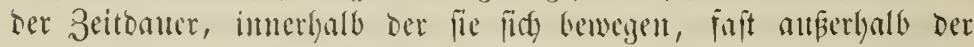

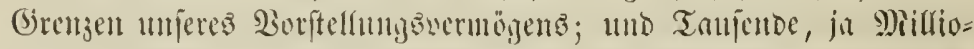

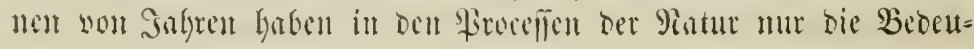

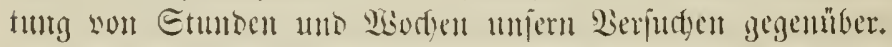

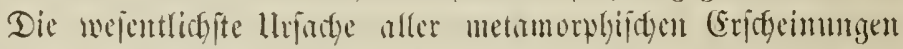

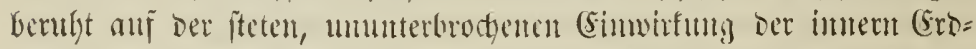

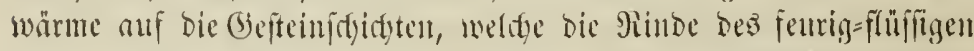

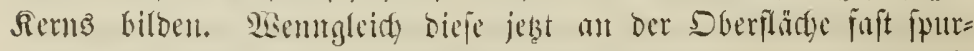

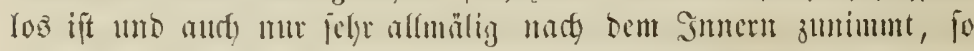

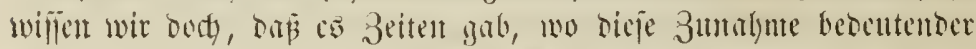
war und fidgon in geringer Siefe cine Temperatur leerfote, bie

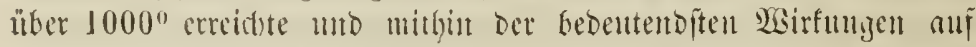

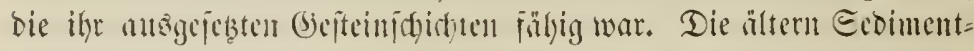

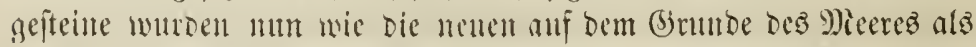

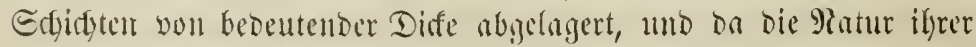

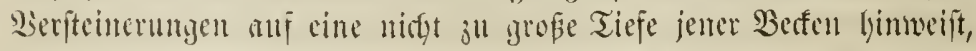

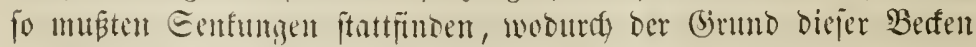

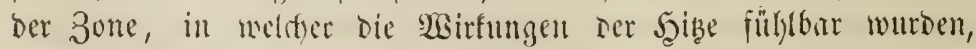
näfer gebradgt wuroe. Dału fommt now cin anderer Umítant. Dic Meere werbalten fich botomntlid) anters zur $2 B$ ärme, als bie feften befteine, weldge cine regyelmäfige 3unalyme der Temperatur nad) imnen geftatten. Sn ifmen fimbet cine beitänoige Etrömung

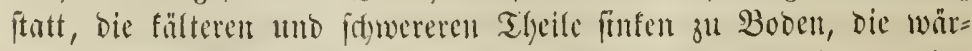

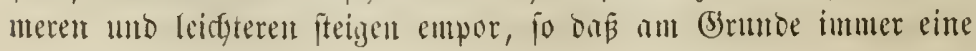




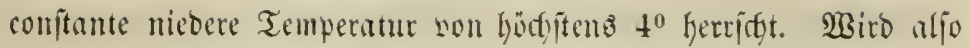

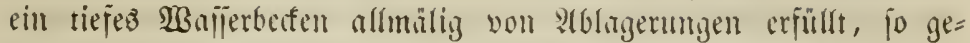
rathen bieje nadf uto mady in Den Bereidy Der innern (Sromitme,

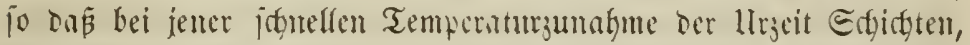

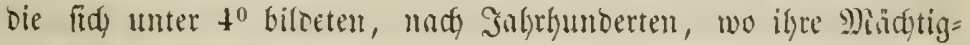
feit sielleidt 1000 Fuß erreidgt latte, fdon eine bem jeurigen flufïe nabe Temperntur betommen musten.

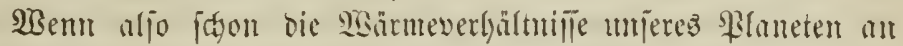

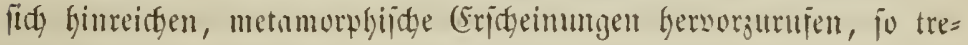

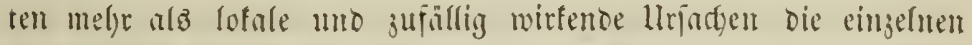

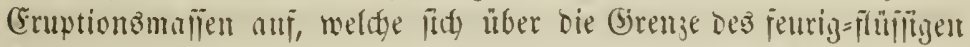
Eroferns erboben mD, dic Eerimentgeiteine Durtybredyend, cinen

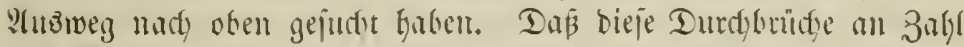

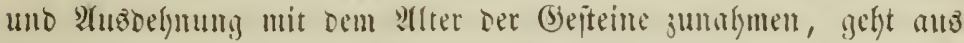
Der geringeren Diffe Der Erorinde in frifleren 3eiten kervor. Da =

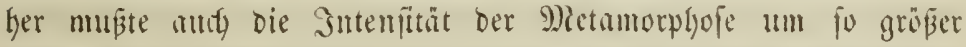

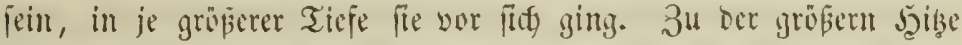
gejellte fidt) bier nudy die lüngere Zeitbauer, ba in gröjerer Tiefe,

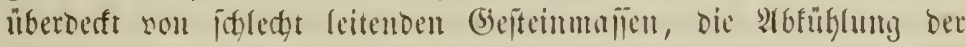

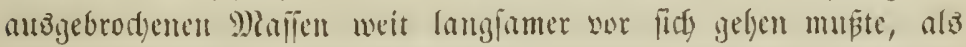

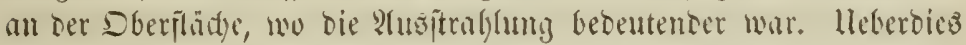

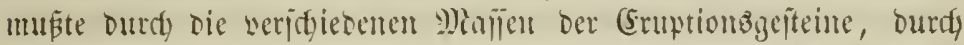
bie Jjibegrade, unter welden fie bald mur in breiiger Eejtalt, balo

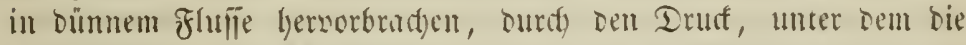

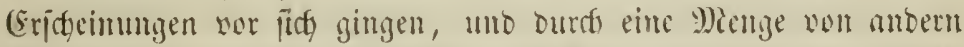
Berhälnilien die metamorphofirende (Simmirfung Der Erntionbz=

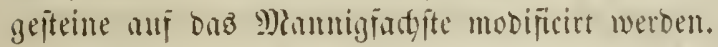

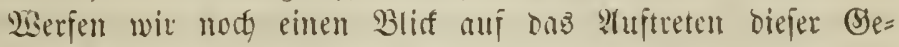

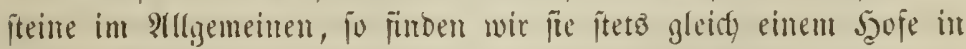
weitem llmfreije bic (5ruptionşgefteine umgeben. Siid) immer tritt Daв (jejtein wirflidy herwor, Dem mun bie llmwandung feiner llut= gebung zujderiffen fömte. Dit ift ez in ber Tieje berborgen, oft

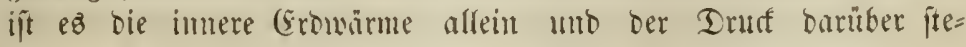
henter (5ro = unt Wallermalien, welder bie Bernandumg ber

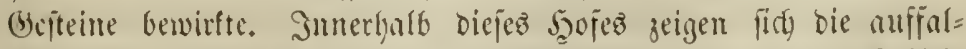
lenditen lleberiturjungen uno Durdeinumberwerpungen der Edjidy=

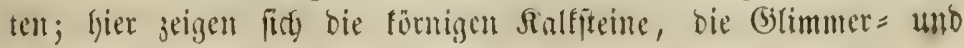




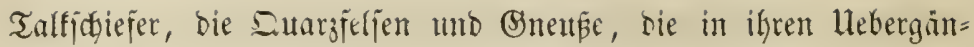
gen bie compacten Edfictyten ier äufern llmffeirungen bez flutomi=

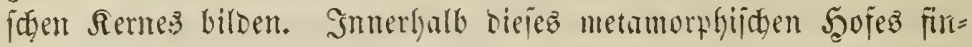

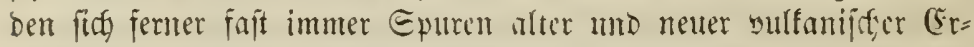

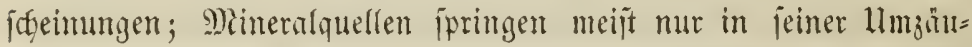

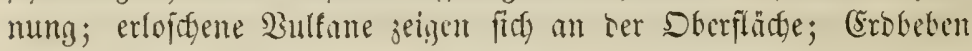
find zaffreidfer und bejtiger, als suf bem übrigen platten sambe;

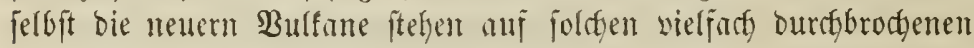

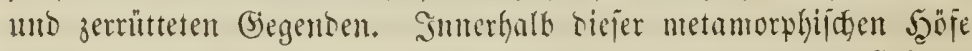

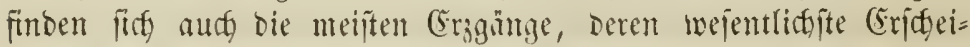

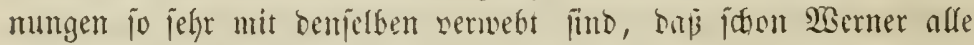

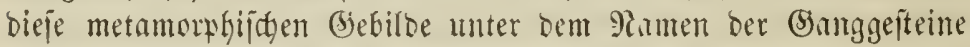
begrifit.

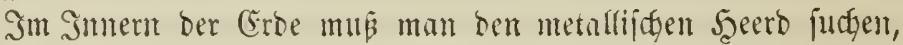

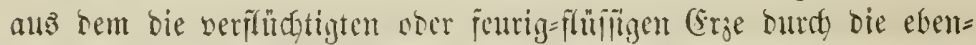

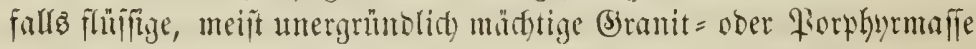

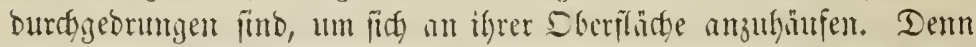
eine tiefere Metallmalle, aus meldyer bie (Erstheile ber Bänge auf= geftiegen jein fönnten, ift gewöbnlidy nidyt fidgtbar. Die reidfiten

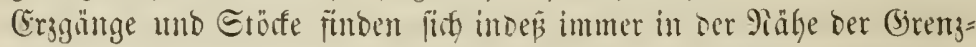

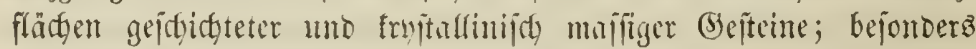

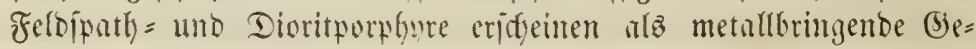

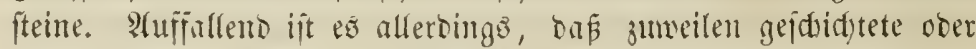

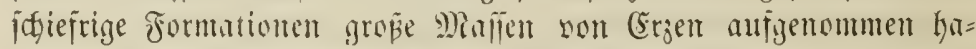

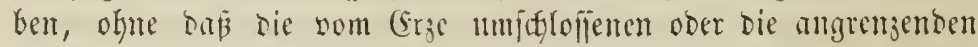

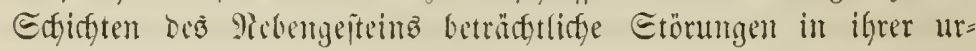

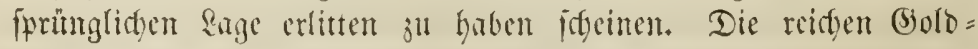
und Silbererge llngurns und Eirkenbürgenz fommen fajt ăuż

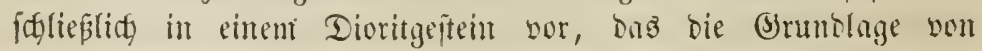
S)limmer = unto Talfidiefer vour aufliegenten Tradtyt idfeidet. Im

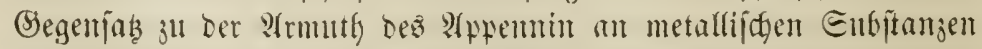

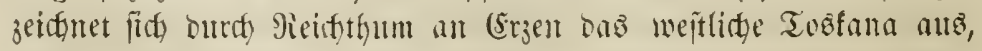

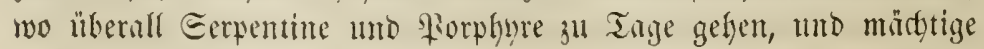

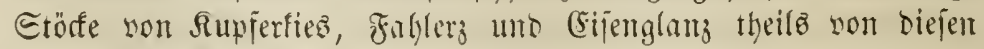
phutonifgen Geifteinen jelbjt, theilz bon ben in ifrer siăhe auj= liegenben, fpäteren Edficttbildungen umidtofien fint. Bei H(rentoal uno folium in Edfweben burdfidwirmt das snagneteifen ben 


\section{3}

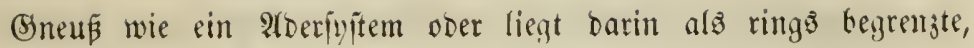
ftodfürmige Manje, Deren (Sifengeffalt weit in Das Mebengeftein wer=

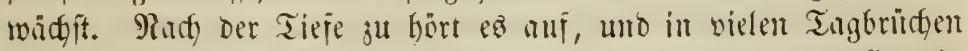

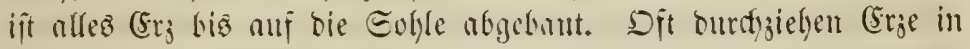
rereinzelten Etrcifen ober in feinen fiunftden tingemengt ganje

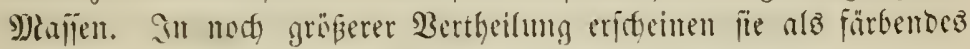

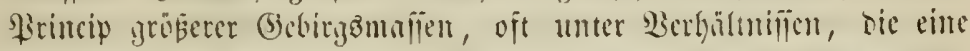

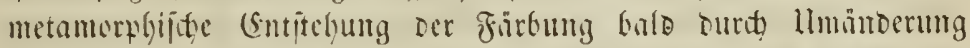

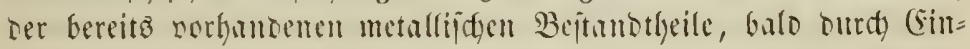

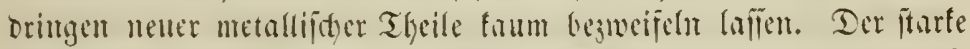
Eifengehalt vieler rothen Eantofteme und Eonglomerate ideeint oft

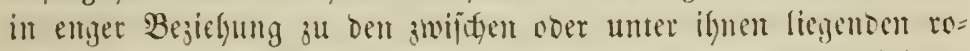

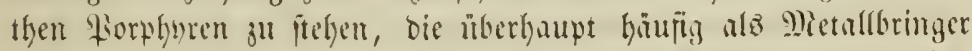

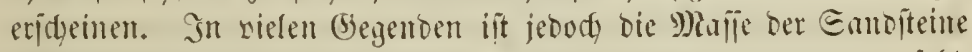

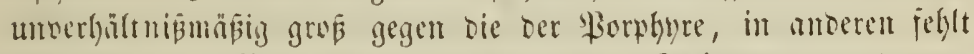
jeor Epur won fiorphys oocr entipredgenden Etcinarten, und man

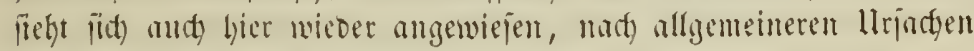

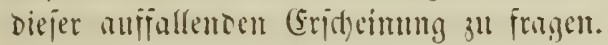

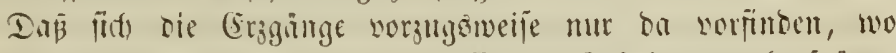

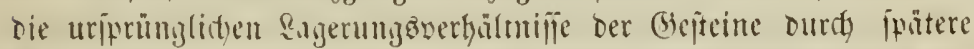
(Emportreibumgen geitört und cimit tiefer liegende giegionen an bie

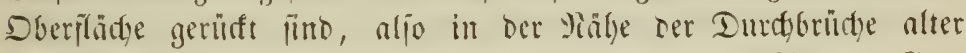
Eruptingejteine, das iit eine für den Bergmann wie für oen Gico= logent gleidy midtytige errjulyrung.

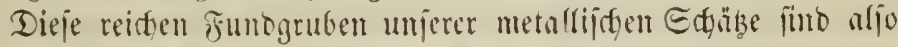

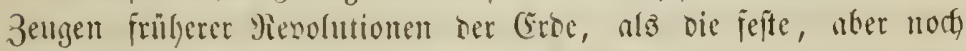

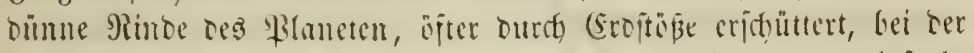
3ujammenzietung im Evfalten zerllüftet und jerpalten, megriandse

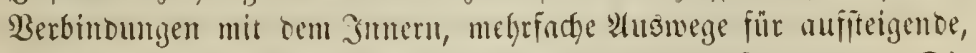
mit (Ero = uno Metrllfteffen geidjwängerte Dämpie barbot. Die Den Epalten purallele, lagenweije Hurorommtg Der Thcile, nie regel= mä̈ïge WBiederlyolung gleidgartiger \&agen jull beioen Eeiten, bie bru=

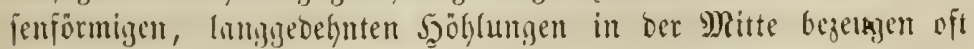

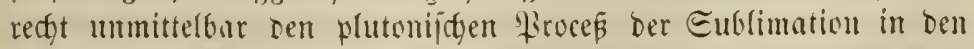

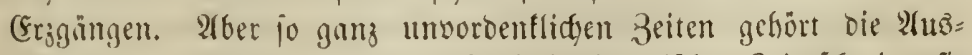

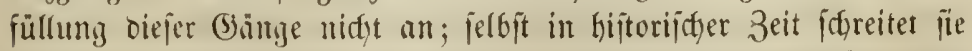

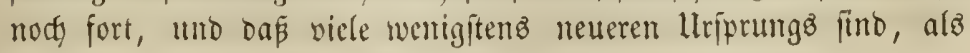


Die Erfidutgejteine, Inavon giebt unz bas midgrigite und reidyfte

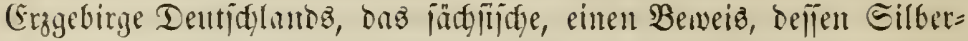
noern Den Forktyr burdjjęzen und Daher zum wenigiten jünger

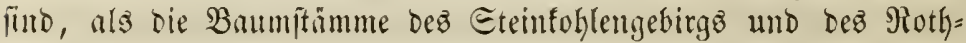
liegenton.

Im Alfgemeinen aber findet man bie Sebirģmafien um fo

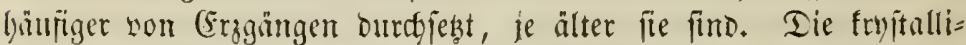
mij̄ten Edyiejergeitcine, Die Grauwafenbiloungen uno bic ältejten Eruptingefteine zeiduten fich baburd) aus; ärmer fimb bie mittle= ren Flobjarmationen und bie jüngeren Eruptiogejteine, am ärmiten

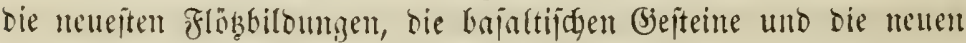

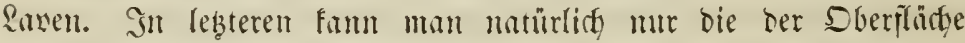

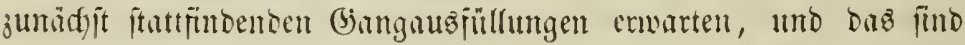

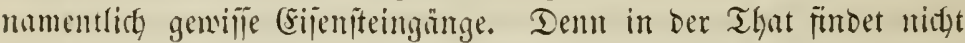

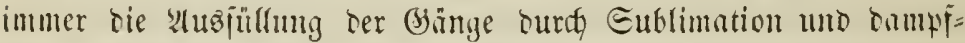
förmiges (sinjtrỏmen son unten her ftatt. SSewiể wurben viele

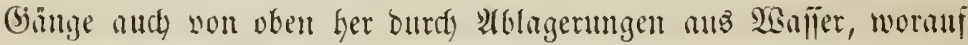
bejonders mantye anger uno Etöfe Ginbenten, antre won ben

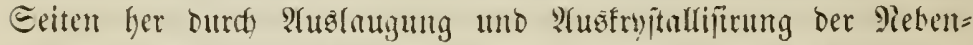

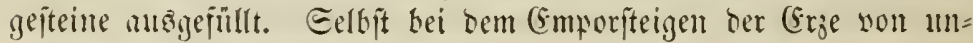
ten jueint bas $23 a f j e r$ oft cime Rolle gefpielt zu haben. Die mei= fiten Erzgünge, weldge, wie bie Freiberger, vorguygiweije ats Suturz, Ralfipath, Edwweripath, Flup̈path nuto Etgwejelmetallen beitehen,

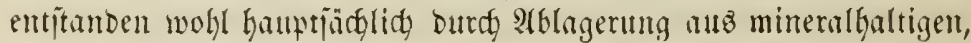

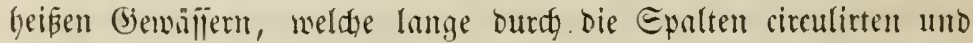
fids ontei in ber Tiefe fortmigrend mit neuen Mimeraljubitungen jøwängerten. In meldyer Weije bieje Metalle in ben Tiejen ses (5rointern nupgeipeidyett liegen, bariber vermag nod) fein Beologe

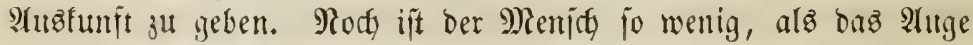

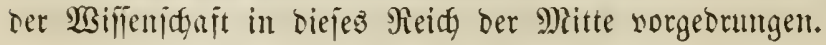

\section{4) Die songlomerate.}

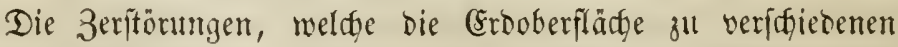
3eiten erlitten, und bie Berfitung ber zertrimmerten Bcifeine ga=

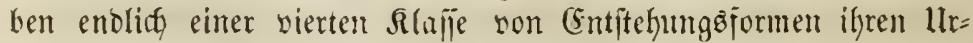
iprung, oen Trummergefteinen, Conglomeraten ober Breccien. Die

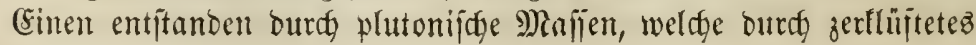


(Beptein emporbrangen, und beren Brutfytüfe ju Conglometaten आ

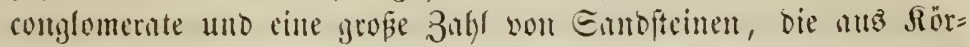

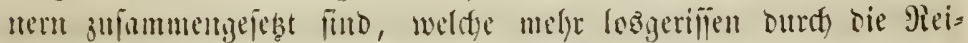

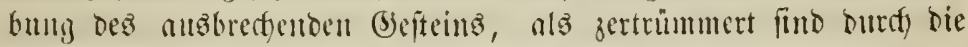

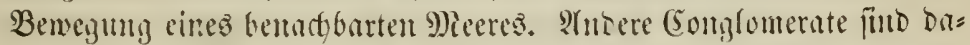

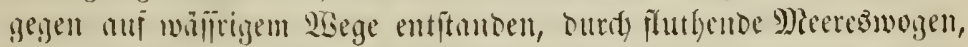

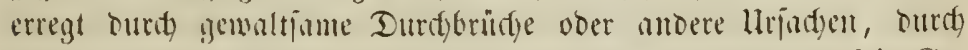
bemegte Ellimafier, wie eş nod) hent ju Tage gejdielyt. Die be= fteintrümmer untoen nad) entlegenen Fernen gcjührt, fielen zu $20=$

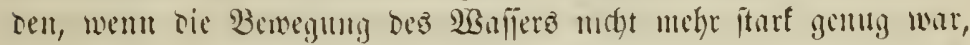

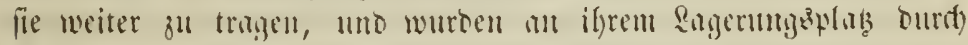

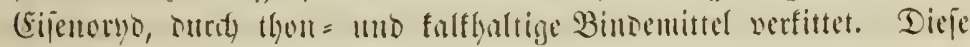

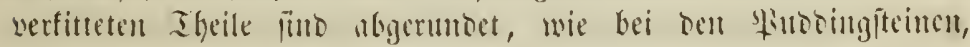

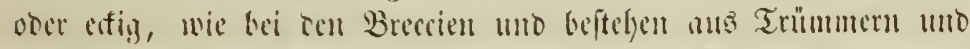

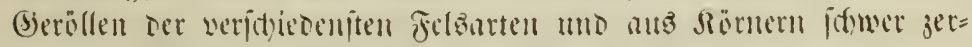

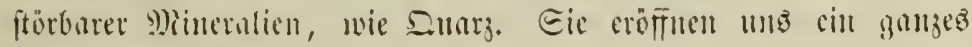
Miluenm Der Bormelt.

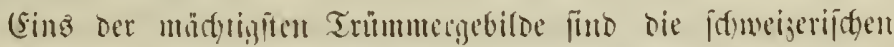

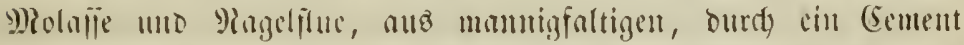

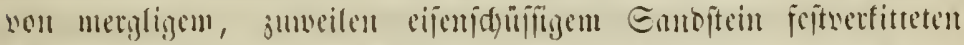

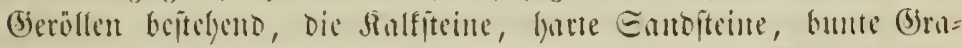

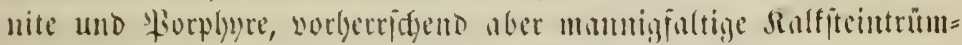

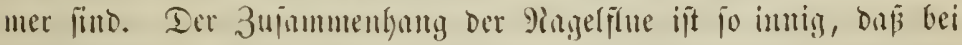

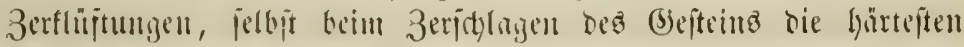

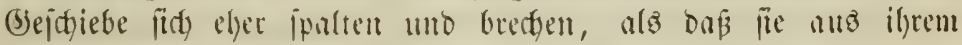

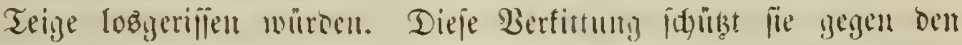

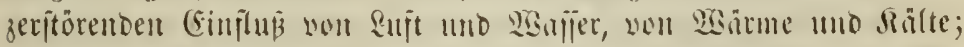

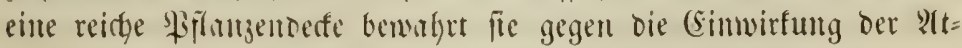

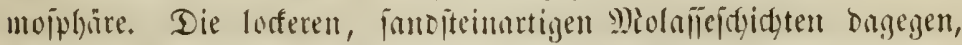
weldye oft mit ilgnen wedjich, verwittern leichter, werben buth

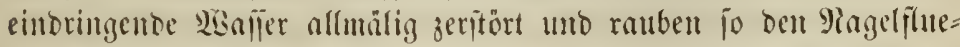
binfent midyt jelten ilyre Unterlage, fo don gewaltige Maflet in ftumbenweiter (Erjtreftung jufammentretben und mit boumerartigem (betoje rie Ifäler in ibrem Eturge begraben. Settemartig folyt bie

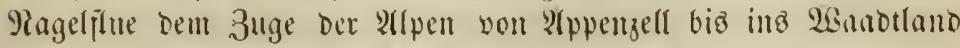

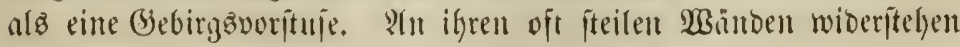


bie härteren Gerölle älterer Sejteine Der Witterung mehr, alsె Das fie verbintende (Sement, uno ragen Deshalb gleids $\mathfrak{R} u g e l n$ und

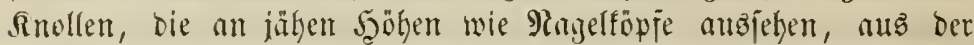

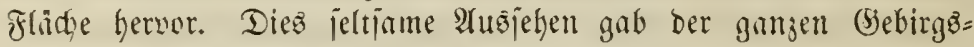

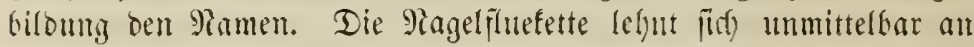
bie iteilen nörolidgen Ralfalpen an. Eteft man auj Der äukeriten

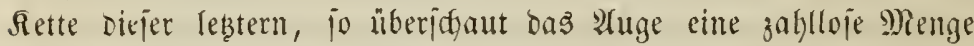
grüner Berge und Bergreiken, bie fith über 4000 Jup hod) erheten,

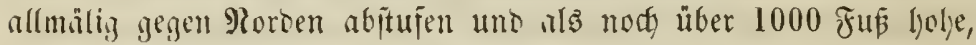
fidroffe 28 änse bie Eeeufer umfringent. Dit erbeben fidt) aud jrei=

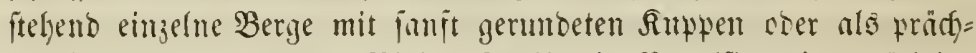

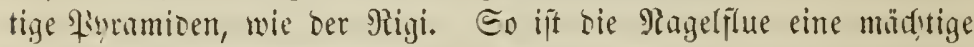

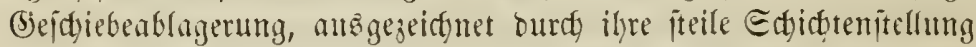
uno Durdh ifre Unabhängigfeit ron Thalbiloungen heutiger Zeit.

\section{Das organifitge fében als lithumden ore Dormalt.}

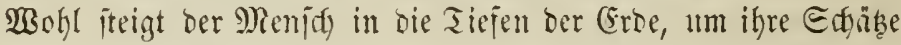

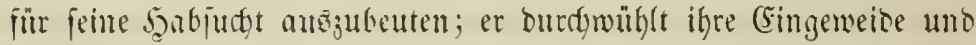
exjorjdt bie Ragerjtitten ber Metalle; er crgrünet bie Beheimnifie

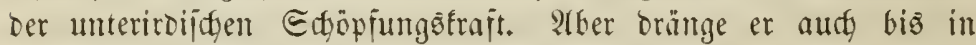
Die Mitte ber Erte mit jeinen Gruben unb Edfadten, bie (5ese=

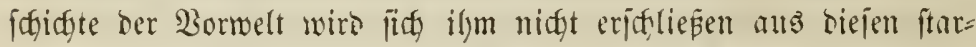
ren, iteinernen Dentmälern roher Raturfnajt. Wer bie Siejobicte ber Erobildung, die âlterģolge ber Şüllen fennen lernen will,

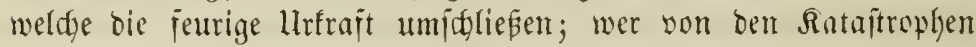
lejen will, weldse ben $\mathfrak{B o h n p l a b ~ b e z ~ M e n i d y e n ~ e i n j t ~ e r i ́ c y u t t e r t e n ; ~}$ wer ein Bilo jener 3ujtänoe joauen will, weldyes einft in ben Epo=

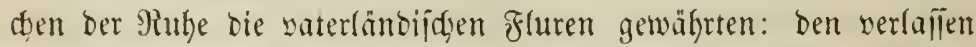
hie bisher angewandten Mittel, er porjdt nady neuen mito fintet fie in bem Reben Der Erbe, bem Reben Der Srganijation.

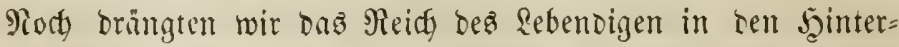
grund jurnit, meil wir jeiner nidgt beburften. Sebt, wo wir bie

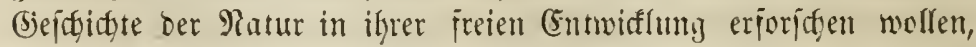
fönnen wir es ter Betradtung nidyt länger entzietgen; benn mur

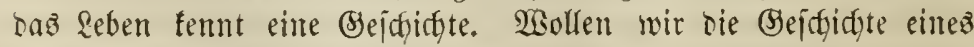
Bolfes ftudiren, jo werben wir zwar iffe rohen llmrifie fajon aus 


\section{7}

Den Epuren erfennen, welde bie medtanidden Rräfte Des Bolfes

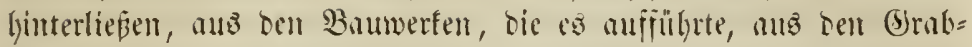

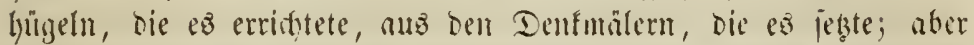

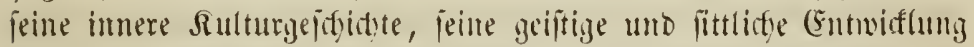

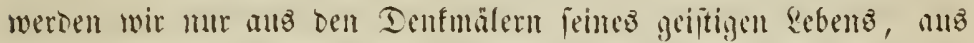

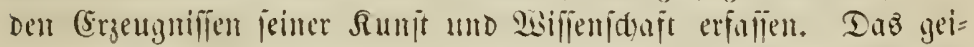
jtige Reben in ber 9latur wiro ater repräjentirt Durd bie Srgani=

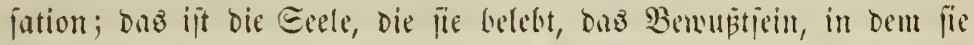

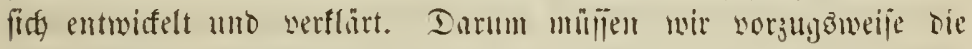
Drignifation ber Borwelt letendyten, wenn unz ein lebendiger

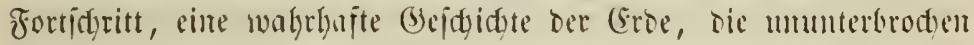

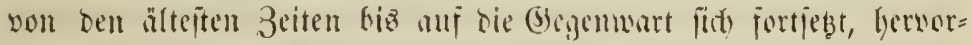
gelyen jou. Daßs wir biez aber vermögen, Daju bat bie batur

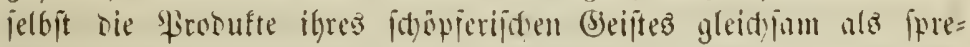

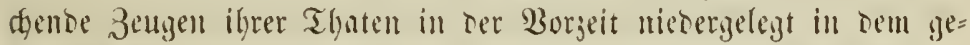

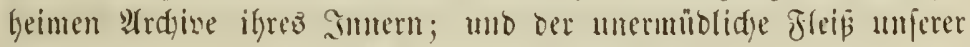

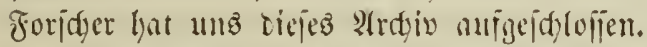

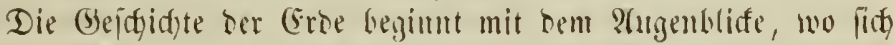

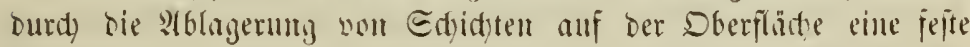
Sinde bildete, in Deren Blättern wie in Lttunten alle Erlelmiffe

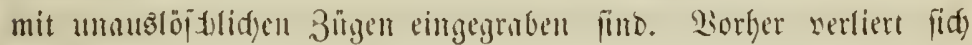

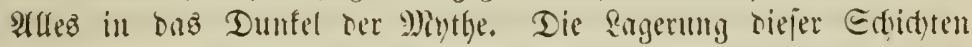

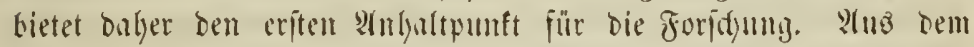
Waffer niebergejhlazen, lagerten fids alle Edjidten urpprünglid) horizontal ab, uno es fann baber als allgemeines (Sejes gelten, Daß̄ bie tiejerliegende Edyint die ältere, die Darnuf gelagerte bie

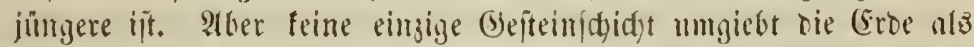
zujammentyängende Edbule; Seebungen uno Eentungen bradten Theile des (Erobodens zu ter eimen Beit in ben Bereid) bes lanto=

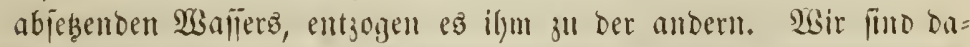

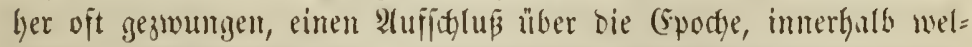
dyer bie Edjidtenlagerungen burdh cin bejonberes Ereigniß gejtört uno veränoert wurden, in Den bemadbarten formationen einer

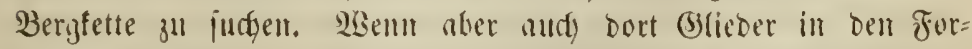

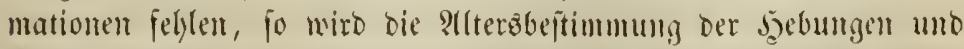
atblayernmgen immer fofwanfenter. (58 fann eine Sebung unmit= telbar mady bem 2lbjake ber lekzten aujgeridyteten Edjejer unb eime 
Eenfung unter bas Riveau bes Mieeres wor Afflagerumg ter hori= zentalen Edficften jtattgefunden haben; is fanm aber aud bie feh=

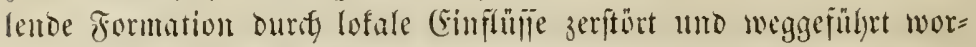

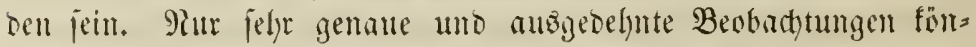
nen Damn zu einer wirfliden 3eitfeftimmung ber hebenden uno zer=

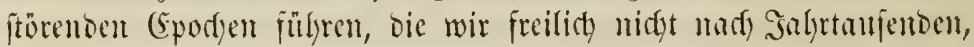

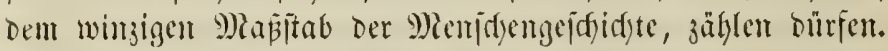

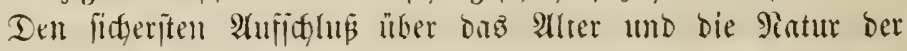
Edjidten gewilgren bumn bie cingeidglüienten Srganizmen, bie man oft felbjt an folden Suten, wo bie einjefnen formationen horizon=

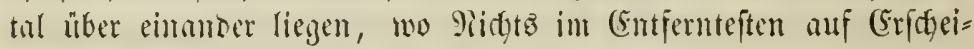

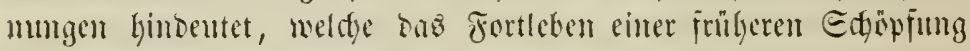

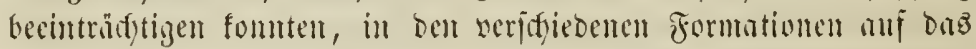

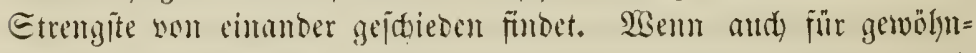

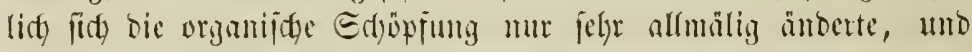

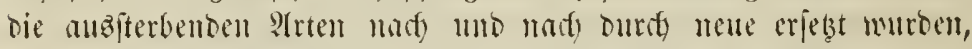
wem aljo ser פEedjel ber 3eiten, die Beränderumgen ber Tem= peratur, der Euft und des Bodenz ben Typus ber Esltem in den Yadfommen meift mur itujenneife ummontelten, fo murbe bods

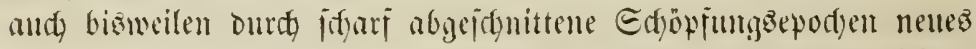

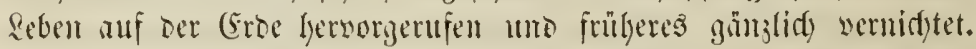

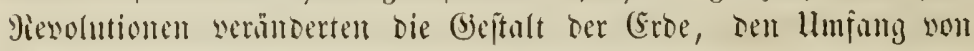

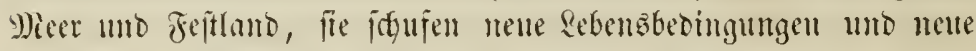

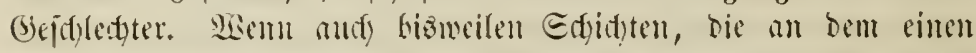

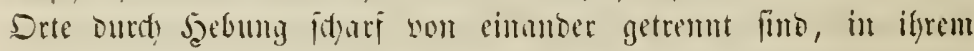

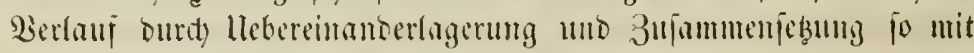

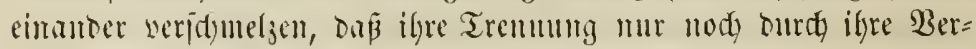

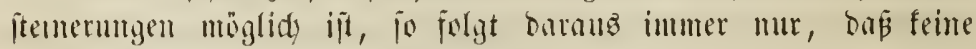

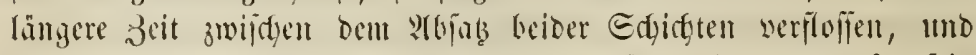

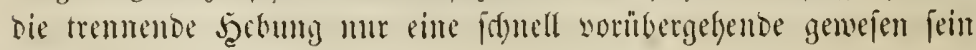
founte.

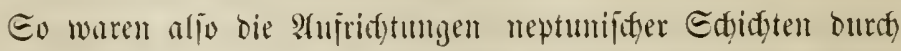

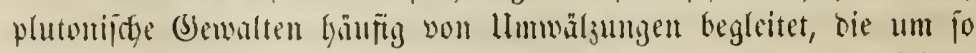
größere Etörumgen in Der rufigen Bevolferumg Der Erde bewirften,

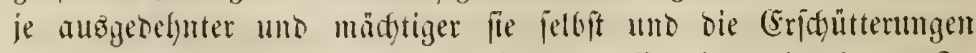

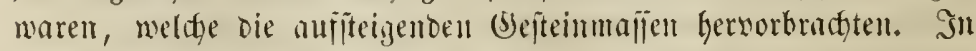
ben Perioden ber Miuke fonnte fidg organifdes Reben in Meeren 
und auf Fejtländern entfalten, Defifen Rejte von ben reptunifden Sabiten bulo fparjam, bals in ungelyeuren Mengen umpjloffen murner. Bald wernidyteten in Folge plöblidger Erlgebungen hejtize Rataftroplyen bie gejammte Dranuifution, bald leitete ein allmä= liger llebergang auz einer fieriode in bie andere binulber, und wirbellofe, wie sirbelthiere zichen fidy ourd cine Meilye won for=

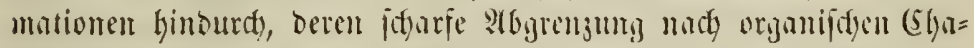

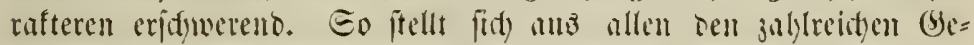

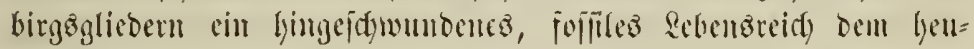
tigen Reben gejemïber.

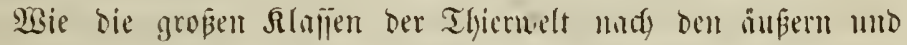

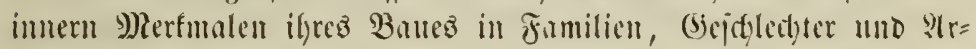
ten anseinnondyegen, fo bilben bie (Sefteine won ber härtejten, fein=

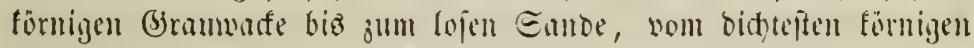

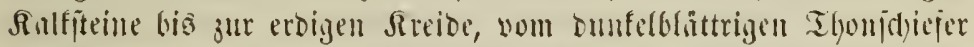

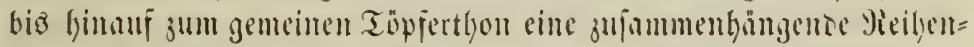

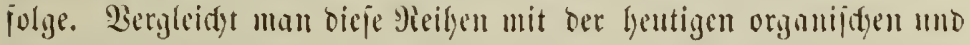

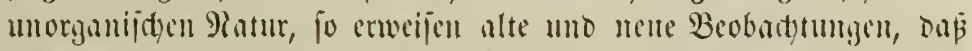

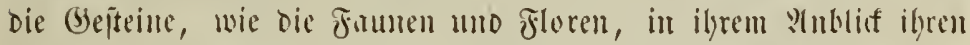
gentigen Berwanden un jo unilynlider find, je äleren Epothen

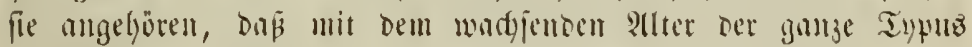
Der Bildmy fremoartiger, abueidentoer wird sou bemjenigen, land) weldem die Patur lyeut ju Tage baut mo jeugt. Siur niebrige

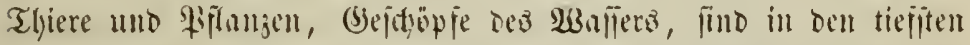

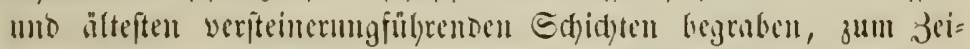
dyen, bas einjt bie Erbe rings mit Whajer hedecft gewejen, anz

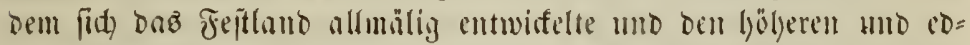
leren Befdopten llriprung mo Eeben gemilgrte. Demn ijt gleids

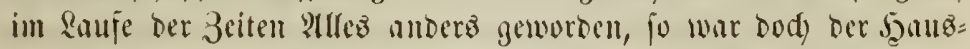
halt ber Matur im Broken uno 2Bejentlidgen yon jeber berjelbe, und

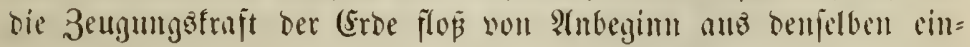

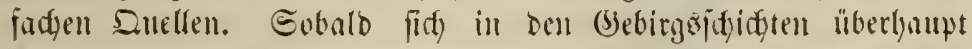
Epuren vorweltidgen Rebenz zeigen, fint and) bie wGurgelpormen aller thierifden Bilomn, die Etrablthiere, 2Leidytliere, (silieber= thiere und Birbelthiere jugleidy vorbanden, unnbhälngig neben bem Fiflangenleben, das fidh nidgt vor dem Thierleben nuf ber jungen

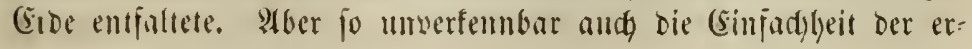




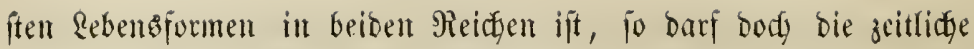
Entwifflung Des Thier = unt Bflunzenteicfes von nieorigeren, ein=

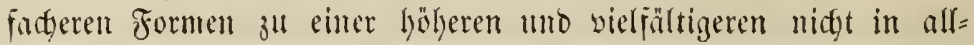
genteinem unb unbejdranftem Einne feitgebalten werben. Siur in Der böheren (Sruppe Der Wirbelthiere treten in fitrengiter Micifyen= folge mady einnonoer Fiff, Reptil, Boger und Eälngethier, aljo bie

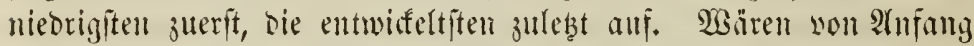
alfe Bebingungen dez Drjeins für alle Rebenşorment dagewejen, fo

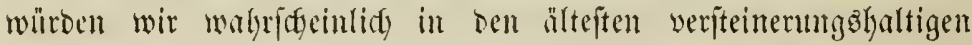

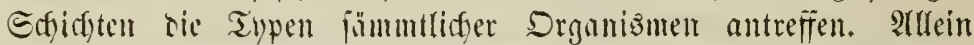
gemifie Rebenzberingungen, Fefthro und Enißwajier, Berghöhen uno Eünufe, fonnten erft im Bicrlaufe ser Erorindenbildung nach und mad) eintreten, mo jo musten aud gemifife Driganifationen cine Entwifflumb in ber Zeit Gaben. Fiiche und Reptilien entitan= den unto verifguntoen unter zafllwien Fornt'n, Gesor Eängetfier

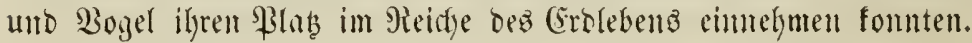

Bergleidyen mir salger bie antife, foffite Rebenswelt mit ber

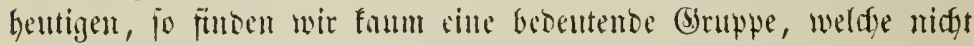
in irgent einer Periode ber Borwelt ilye fojitilen Bjegentildoer Gätte.

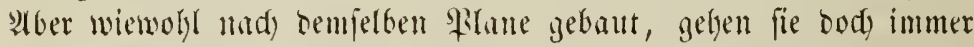
in ben Eimzelntyeiten Der Etruftur mit ifren lebenden Berwanoten wejentlid) anseinander.

Co zeigt fid uns allerbings in ber Drganifation ber 2ionwelt

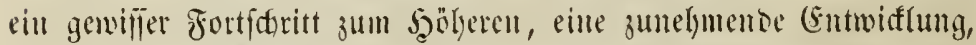

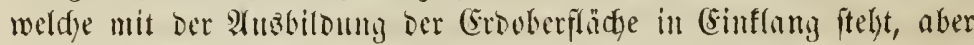

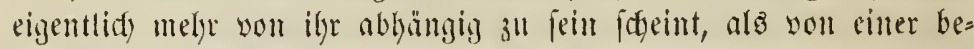

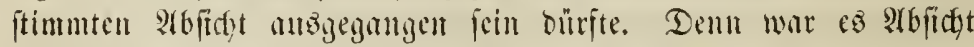
Der gistur, jeocsmal mur grabe biefe unoolffommene Edjöfung zu

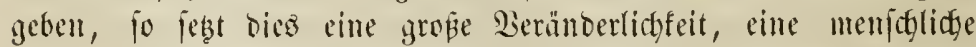

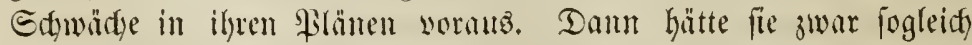
Dus Bolfendete iduffen fümnen, aber es nidjt gewollt, fonbern

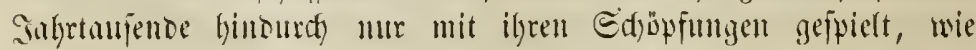

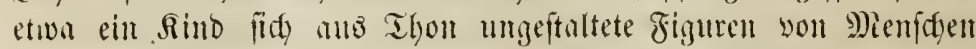
formt, wiewohl igm Das litrbilo wor 2rugen idjwebt. $3 u$ foldgen

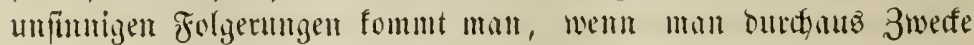
in ber Patur juct. Die Eroe founte mur Drganizmen erzengen, 


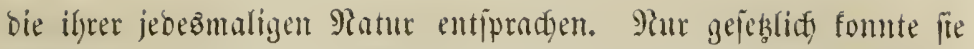

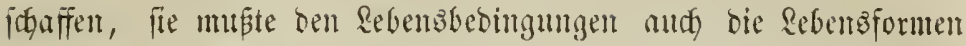
majiller.

Eben fo wentg Dürfon wir biejen Fortidyritt in ber Emwiffumy Der Drganifation gar leugnen wollen unt etwa in ben riefigen Formen Der Borwelt bent Beweis einer vollfommmeren, parribiefififen

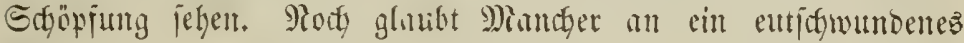
Waradiez, an einent Fall Der Edyöfmin, Den der Eündenfall dez

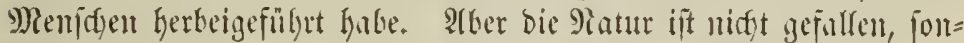
Dern unauflyaltam sem ewigen Biele ifrer Entwifflung entgegen=

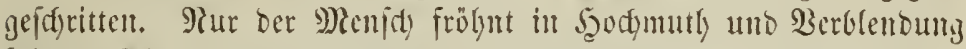

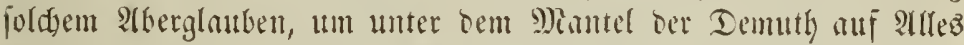

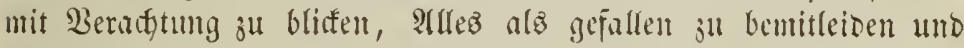

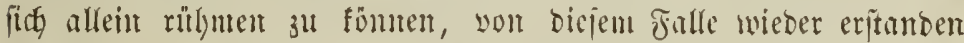
зи jein. Llm menjiflidjer Eünde wiflen warb feine Ratur ver=

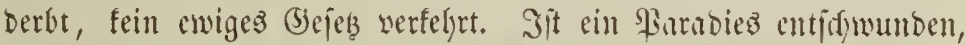

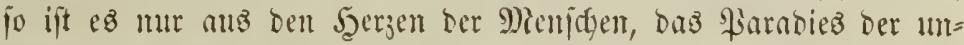
bejangenen Cinffeit mit ber Natur, ber frentigen Riebe zul bent

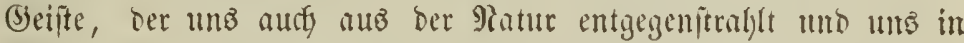

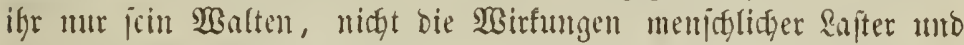
Reidenidgaften erfemen lelyrt.

Sine parabiefijde Edjöfing war mie vorlynden. Sie hat ez yröpere Thliere auj ber Črbe gegeben, als es nody jeşt giebt; nur bie (Siruppen, in bentent fie auftreten, finto andre geworben, und Darin liegt bas lleberrajdende igrer Eridyeinung. 3war mögen bie ältêften Edyadytellarnte Riejen gegen bie Kentigen jein, aber größ̈er als heutige Echilfrobritengel, alz Bambuffe ober Bufferanten waren

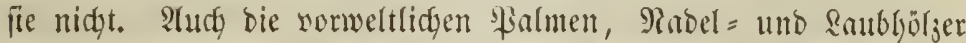
überfdritten weder im Ganzen noch im (Sinzelnen bie Grö̈Benver=

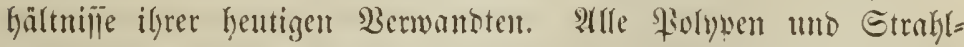

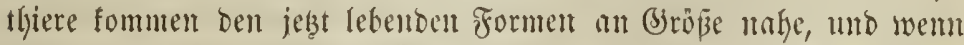

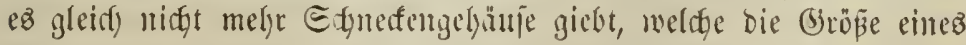
WEagentrabez erreidgen, fo fennen wir bagegen Mhuffeln you midgt geringerem Uminange. Eelbit bie Jijate, bie bevorzugten sisejen ber Borwelt, bewegen fids mur imnerlyalb der leutigen Brö̈enterbält=

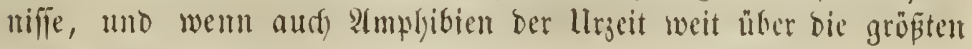




\section{2}

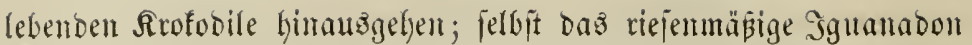
Imo bie furchtbaren (Seftaltent Der Enaliojaurier bleiben binter bem

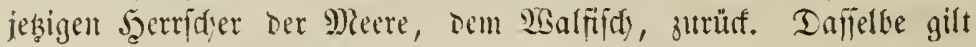

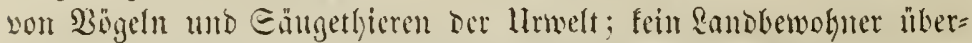

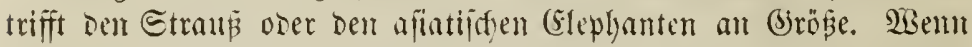

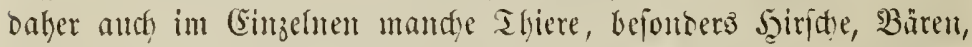
Syyänen uno Fautthiere mebr llmfany hatten, als ifge heutigen

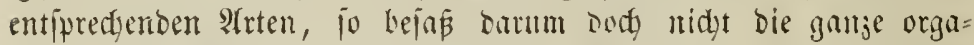
mijobe Ectoppfung einen riejenmäßigeren (Sharafter. Lleberbies wiro Die gröpere Mafje einzcher Wejen Der Morwelt burd) dic gröfere

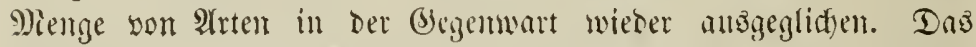
Weltalf war zut allen Zeiten Dajilbe Bermuntreid. Etets herrid = ten im Bropen wie im Rleinen ewige bejebe, weldye ber 2Beltför. per in jeinen Babnen unb bic lebuloige Piatur in iften 3engun= gen nie überidgriten iari.

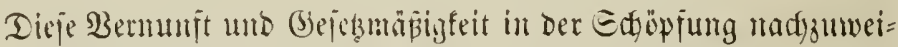

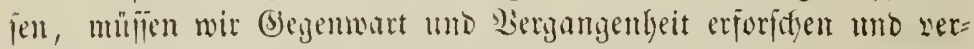

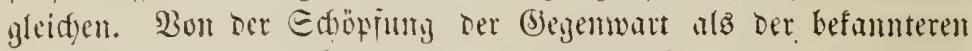

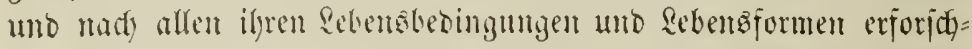

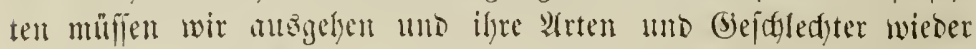

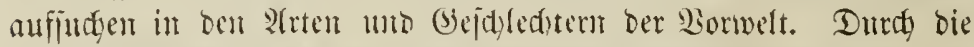

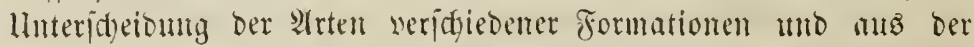
Etellung, die fie in Der Etujonleiter Der (sntwifflung einntehmen,

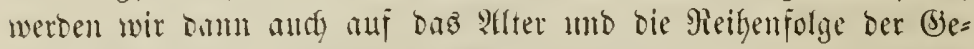

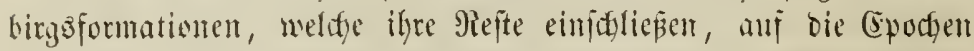

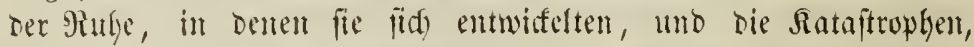

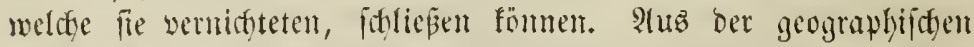

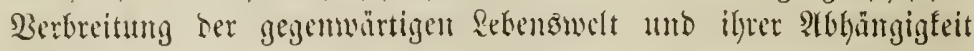
wan Boben und Sllma werben wir aud auf bie Rebensbebingun= gen ber analogen (befdüpje ber Borwelt futiejen fümnen uno ein

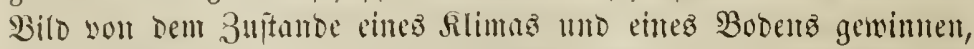

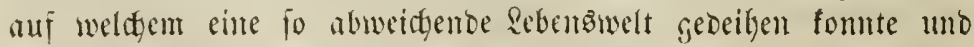

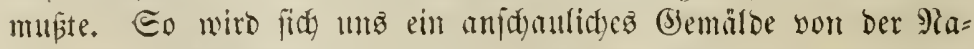
tur unferes Croföpers von feinter erfen Entwidfung, vom erften Rebengfeime ourdy alle Biloungen uno Berftorungen hindurdy bis auj Den gegenmirtigen 3uftumo enthüllen. 


\section{1) Der atrtbegrifi in Der Rebenzwelt.}

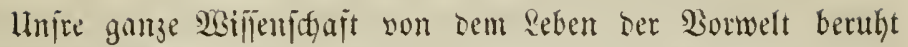

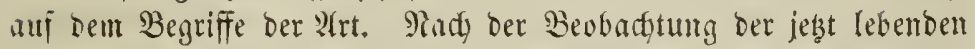
Siatur - uno mur burdh fie fam Der Begriff ridtig erfakit wer= den - geljören zu einer und berfelten 2rt alfe Sndiviouen, weldye bon gleidfen (Sltern abjtammen, und Die Den Etummeltern wieder

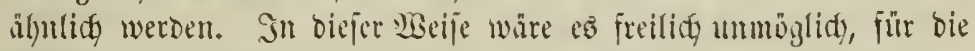

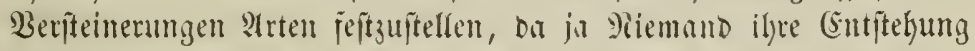
beobadaten fomte. 2her felbit in Der lebenten Edjopjung suingen umberwinblidge Edtwierigfeiten Der Beobarftung ju anberen (Sha= rafteren jeine 3ufhut ju nehmen, um bic 2leten zu unteríbeiden.

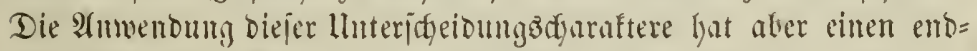
lojen Etreit der Maturjoridger über Don engen voer weitern Begriff

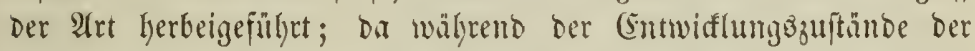

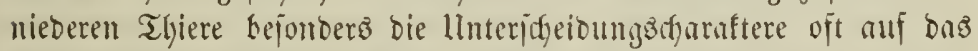

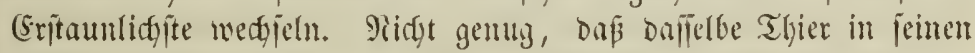
veriduiconen febenzepodgen vĭt bie jeltjamiten Bermandungen er=

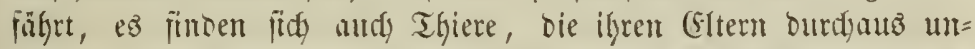

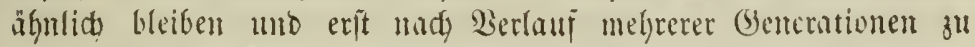

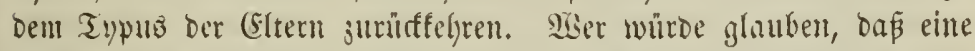
Raupe und ein Edymetterling ein uno ballelbe Sndivioum find, menn man nidyt beren allmälige Berwandfung beobact)tet bätte?

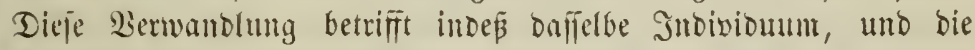

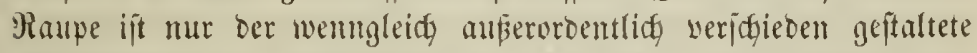

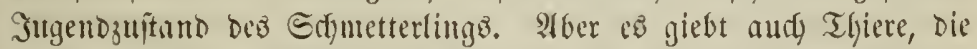

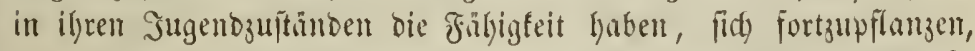

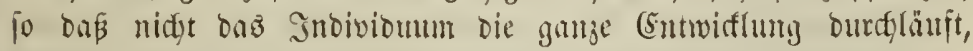
jonbern bas Thier erît Durdy verifjiebene Sienerationen hinburds ju

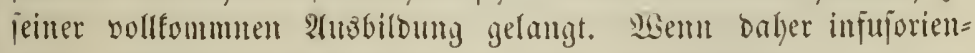
artige Thiertyen ilgre Bimpern verlieren, fids jejteken, Fangarme entwifeln und Folypen werben, weldye fids burd) Eproilen und

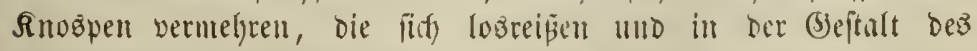
1)iutterthieres bavoniffwimmen; wenn fid biefe Bolypen bann in die eänge befnen, ringförmig eimiduñen, furdyen uno gliebern; menn fid) bicje (blieber enslid) abtrennen und alo jelbitftänoige,

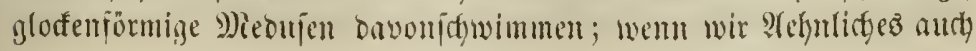


bei höheren Thieren f̈nden, aus den Csiern wurmïrmiger Şolo= thurien, bie zur Familie ber Etralylthiere gefören, wie Joljannes

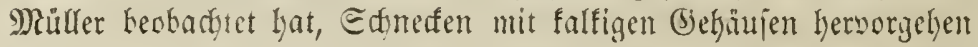
fehen: wie foll min bei jolden Creignijen, welde bie heutige

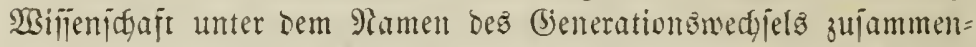

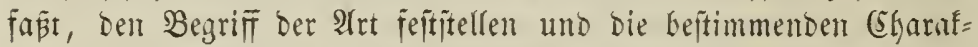
tere abgrenjen, menn man nidyt fortlaufente Beobadgtungen über

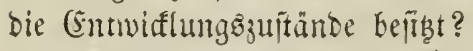

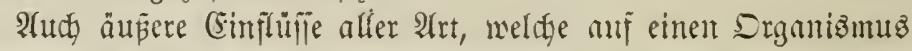

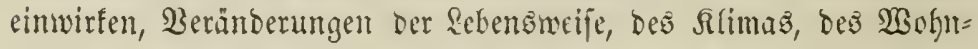

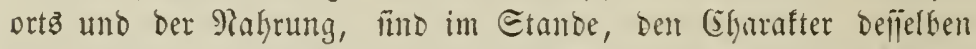
zu veränbern, obgleich bieje Beränerungen nie jo bebenteno fmo,

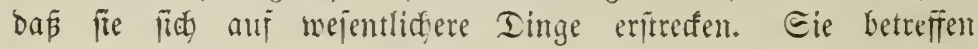

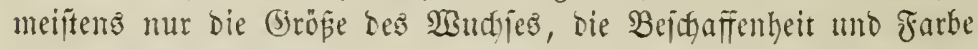

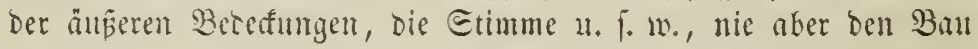

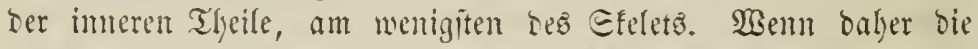

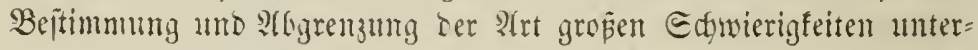
liegt, io ît es weniger beabalb, weil bie Arten burdh äupern Cin=

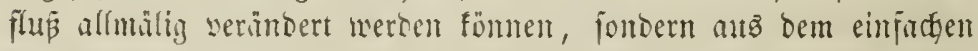
Gruntoe, weil wir in vielen (S)rupen Dez Thierreitgz n̈ber die Ent=

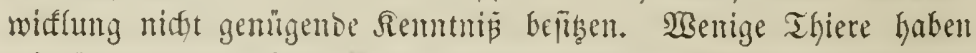
wir ftets unter unjern 2 ugen, bei Den meiften müljen wir mur aus

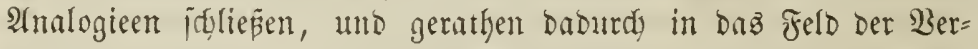
muthungen, Das nie Eiderheit gewähren faun. Dies ijt bejonbers Der Fall bei ben niebern Iljieren, bie erit jeit wenigen Sabren in Den Bereid) ber Beobawung gezogen find. Sgier fellen alle (B)rundligen zur gentueren Bepitimmung Der $\mathfrak{A}$ rten; leitende Prin= cipien fönnen nod) gar nidgt auigejtellt werden, anto berjenige, wel= der audy mur bie geringite Berictiebentheit zwijten zwei beriteiner= ten Edbalen entbeaten fam, ift ebemio beredytigt, bieje beiben @dya=

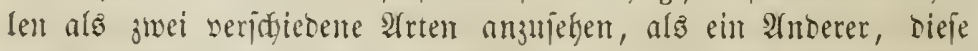
Berictiedenteit für unbebeutend ju erflüren tmo beide Edyalen un= ter berjelben $\mathfrak{A}$ rt zujammenzufäfen.

llnter bem Eimflüle gemijier theologifder anfïten fat man

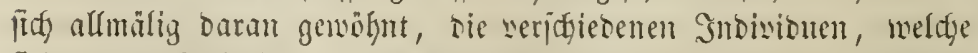

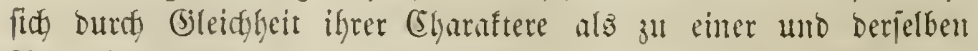

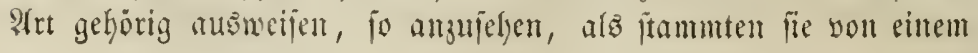


eimjigen Csttermanace ab; mb man bat jogar ben Begriff ber art Dahin befinit, dap fie ber Inbegriff von Sndividuen jei, weldje von

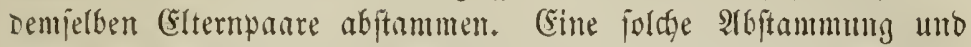
alfmälige $\mathfrak{B e r b r e i t u n g}$ ber Padytommen eines eimzelnen Saares ift

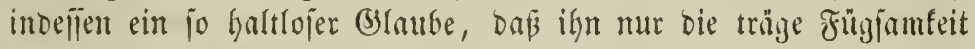
Des menfolicken Beiftes unter Den Druf eingelebter SDeen exflär= bar madyt. 2Am leidteften läßt fidy die llnmöglidfeit einer foldyen

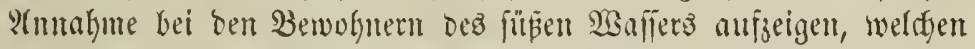
surch bie Begrenzung oer Flupberfen beftimmte 260 hmpläßze ange= wiejen fint. Der Jectjt ber Doer läß̈t ïd) nidgt unteridgeiden von

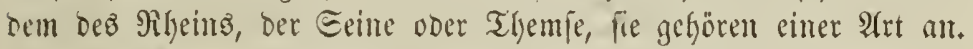
Gine $23 a n d e r u n g$ biejer Fijøe aแz einem Flüberfen in bas anbere oder eine llebertrayung Des saidgs ift zu jeber Zeit eine völige Ulnmöglicteit gewejen. Die saedte oer veridbiebenten Flusgebiete fönnen oalger nidgt von eirrem Eltermpaare abftammen, fie milfen an ben Sorten entitanden feit, wo fie nody jebst leben. Ftud bei

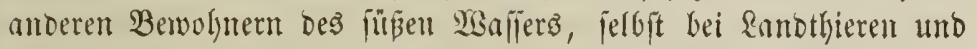
Meerbewohnern laffen fid) Srünoe füt biefe Anfitft finden. Die

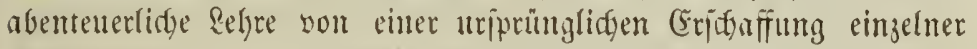

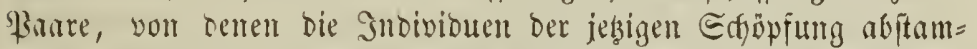
men, verdanft ihren verwirrenden Sinflutí felbft auf bie Söpfe vie= ler Maturioridger ber biblijden Trabition wou ber Prdye Moabs. Whan bente fith aber nur eimen ?hugenblif, fagt Bumeifter, bie

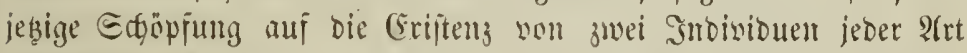
beiffränt. Eolfen die reipenden Thiere syunger leiben auz zarter Edyonung gegen bie idywädere Ed)öfung? Soll Der Pmeifenbär,

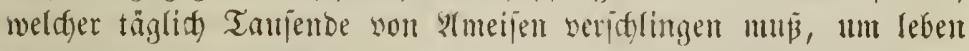

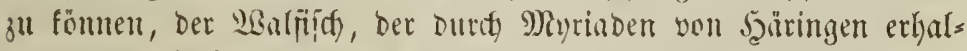
ten wiro, mit jeirrer Sleburt erit warten, bis dieje $\Re$ ahrumg iljm in hinreictgenter $\mathfrak{A} 11$ aht bereitet ift? Bäroe niçt ein cinziges \$aar

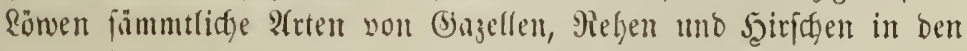
erftell Wodten ber Edjöfung vertilgen? Zu jo lädertidyen Wider=

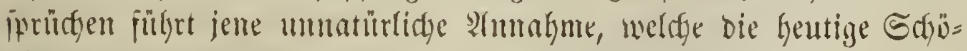
ffung in anderer Weife und in andern Bergälnifien ber Menge und ber Saturneigungen entfteben lafien will, alz fie nods jebst jeigt. Einfam lebente Thiere miljen einfam gejdaffen, in Sdywär= men uno in Sefellidaften lebende aud in Edywärmen gejdaffen 
worben jein. Sebes Thjer bat jeine eigenthümlidfe Rebensameije, bie зu jeiner Drganipation in fo bejtimunter Begiefung fitegt, bá fie nidgt geändert werden fann, ohne bieje zuyleidg zu ändern. (Sin gejelliges Thier fann mut in Bejeflligfeit leten, Edtanren und Edymärme von Thieren muf̣ten alı Edjaaren uno Edymärme ge= idjaffen werten.

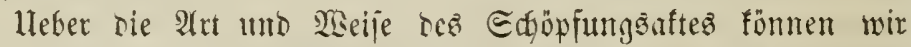

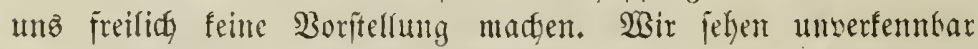
einen allmäligen Fortidyritt in Boflentung Der Drganijation, ber

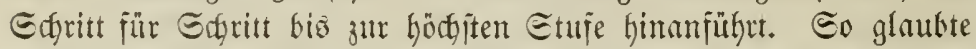
man lange 3eit, Das Thierreidy ftefle mur eine einzige Etufenteiter

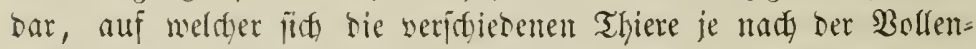

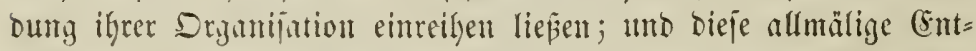
widflung zu eintem vollentseteren Bau judjte man audy anf bie (Ent=

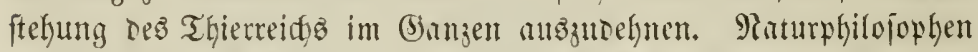

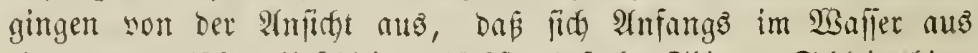
eimem organiident Mridgleime hödjit einfadfe Thiere, Sdbleimthiere

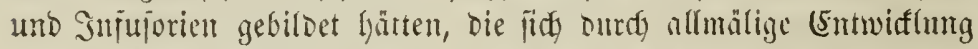

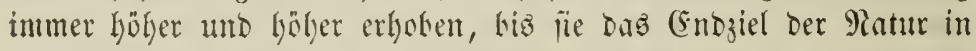

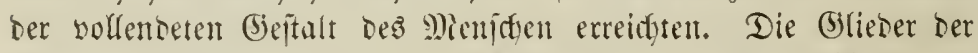
Keutigen Edgöfung feicn nur Albfinmlinge analoger Frten Der Borwelt, bie fidf int Emtje for geologiften Epodfen yom miederen

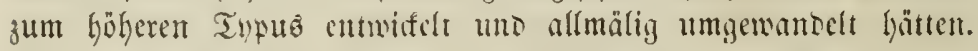

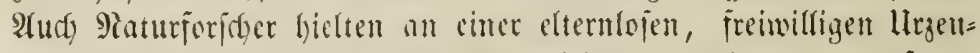
gung nieberer thierijder uns fiflanglidyer Drganisment atts form=

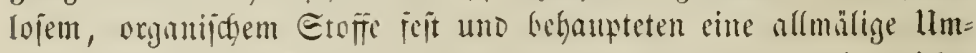

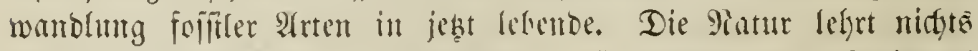

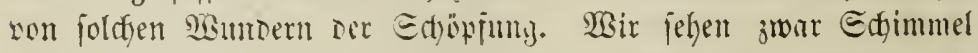

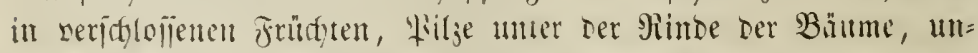

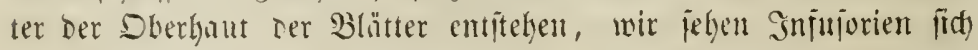

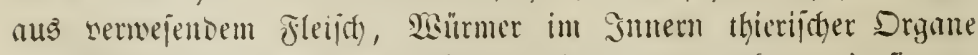

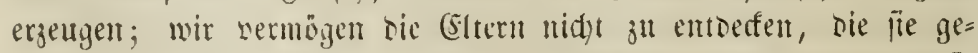
boren, wir mülyen uns vergebens, die Sicime ju finden, benten fie

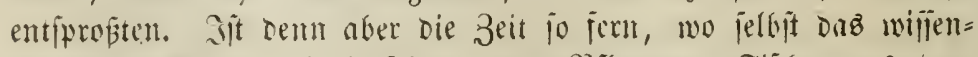

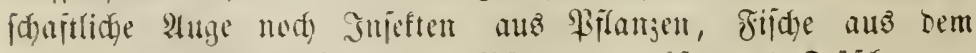

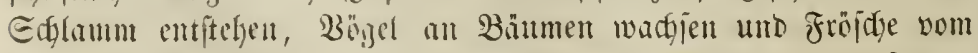

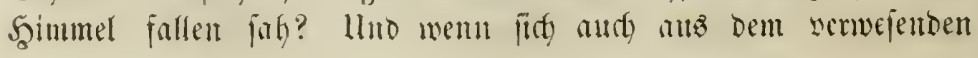


Belfgemebe der Biflanze die einfindje Belfe der Etäbdenpflanje, aแล ner

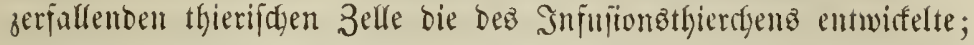
meldye Thatfadye ber Ratur beredjtigt unz, all bie Ulmwandlung

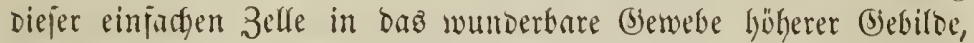
an eine foldge unfeimlidje Eeelemwanberung ju glouben? giods umfüllt Duntel ben erften Tag ber Edyopfuntg. WSohl mag fid

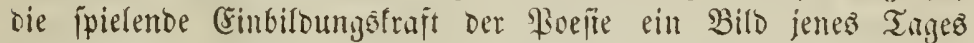
malen, wohl mögen Rationen glüubig an ben leeiliggeprodsenen

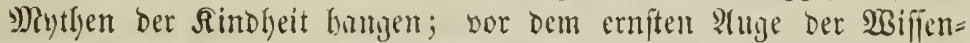
idyaft, nor bem mur gilt, waz wirflidy ift, mus bie ?Rebelgeitalt

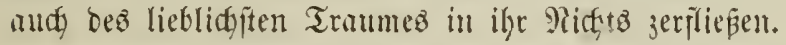

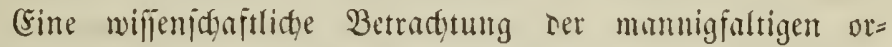
gunifden lleberrefte, meldie die Edjicften ber (Eroe umidglie=

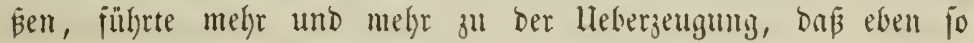
viele getrente Edjöpfungsiepoden exiftiten, alò wir getremute Formationen unteriffeiben. Darin fitimmen im Effgemeinen bie

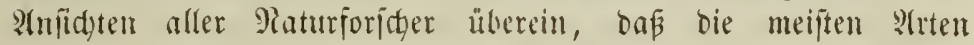
getrennter formationen aud) wirflid) von einanber veridgieben

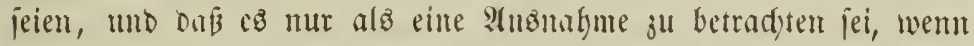
eine und diejelbe $\mathfrak{A}$ it aud in veriffiedenen formutionen vorfomme.

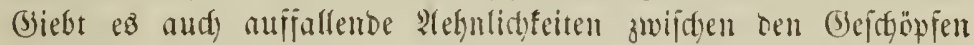

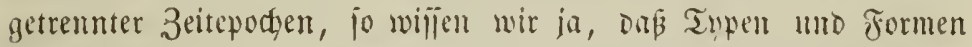

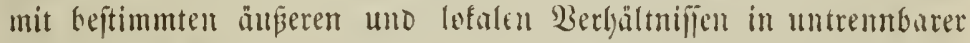

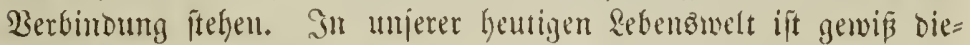
jelbe 2 rt an veridgiebenten Drten entftanden, weldye gerabe bie zu

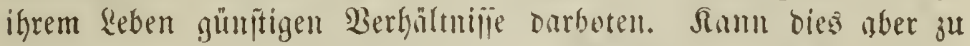

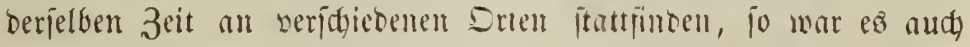

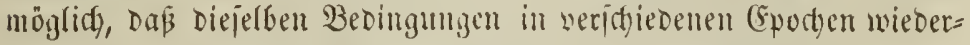
fehrten und biejen Beoingungen entipredento and bie gleidjen Typen

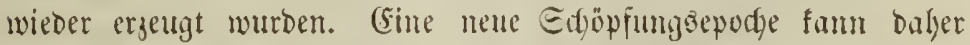
wejen Gerborbringen, weldye senten Der worigen mur beżlalb äln=

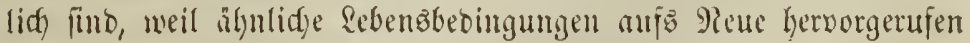

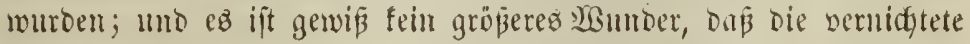

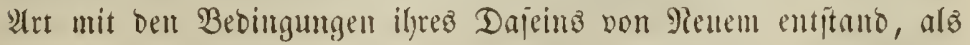

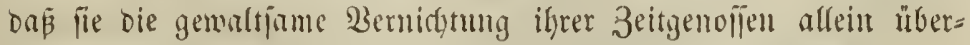
ftano uno alfein in bie neue 3eit ber Edyöpintg linüberlebte. 
Die Bettgeilung ber Beritteinermaen in Den Sdfidten ber

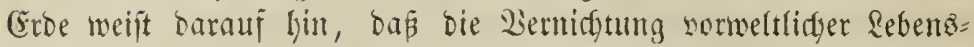

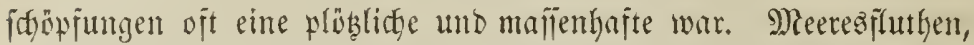
Durctbrüche und zeritörente (Baje, Serjantung und Beriajüttung

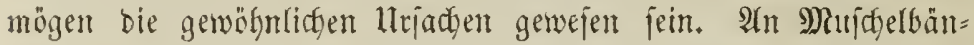

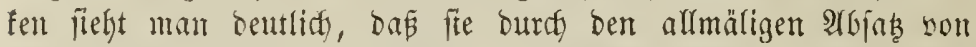
Befiteinmafien, bie fie umbüllten, ju Girunbe gingen. Thiere hin= gegen, bie ifren 2 Sofhnort werändern fömten, umb Deren Berfei=

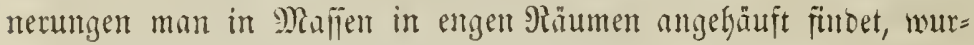

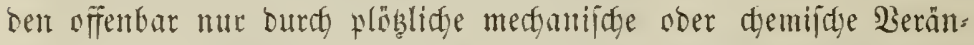

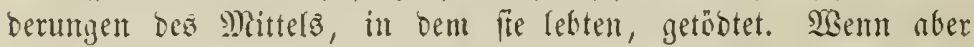

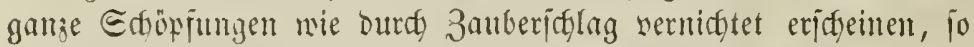

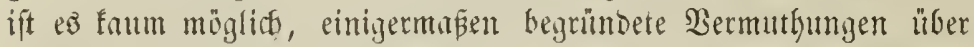

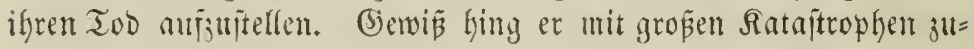

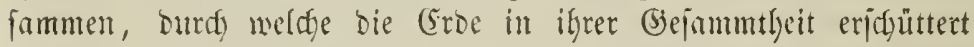

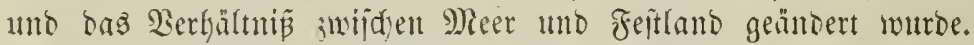
So es aber autde ebent to viele foldter Ratuftroplyen gab, als ge= trennte Formationen erifititen, wo jebe jolthe Ratajtrophe bie ganze

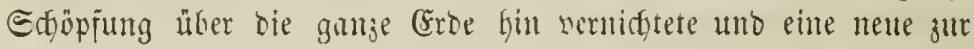
Folge hatte, oder sb bie llebergünge bismeilen, oder fogar für ge= wöhnllich langiam unt frieblidy erjolgten, wolfen wir bafingejtellt

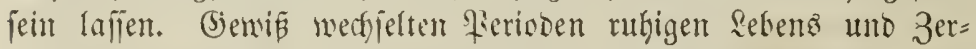
ftörungen, gants wie in ber Entwirflumb ber Bepteine Epocten ruhi= gent $\mathfrak{A b j a k e z ~ u n d ~ S ̧ e b u n g e n ~ g a n z e r ~ B e f b i r g e . ~}$

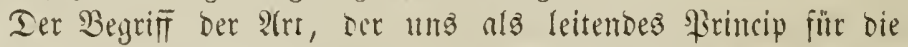

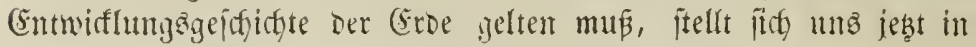
Thier = uno Pifranjenwelt ala ber umveränderlidge Tupuş ber $D r=$ ganijation bar, ber emifelyen mo vernicftet, aber nidgt verwandelt

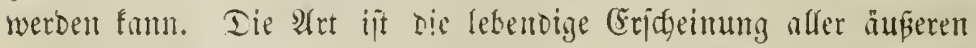

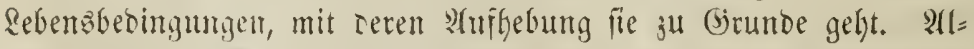

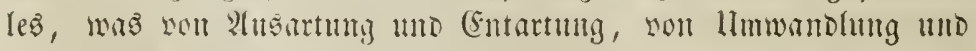

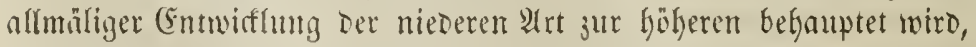

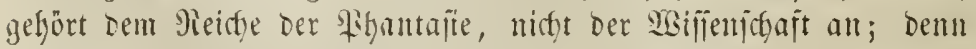

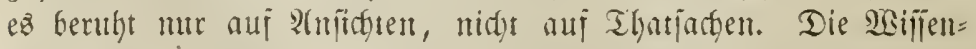

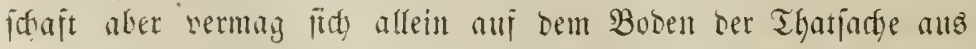

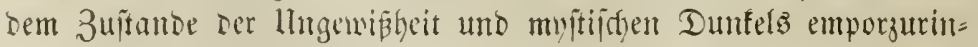

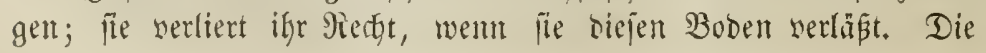




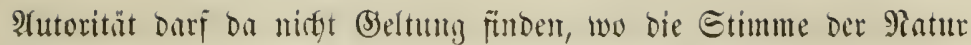

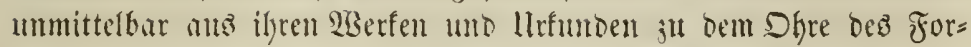

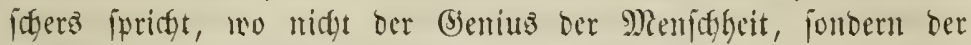

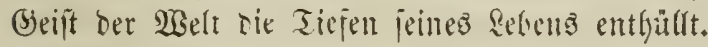

2) Die Rebonsuelt der (B) egentart.

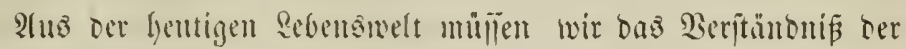

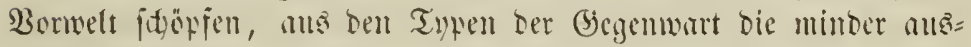

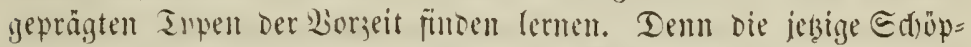

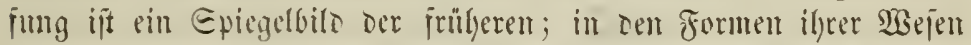

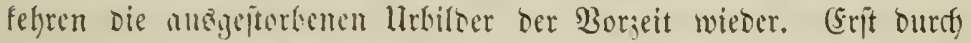

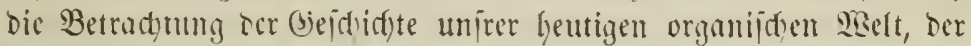

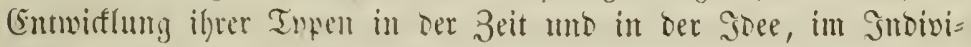

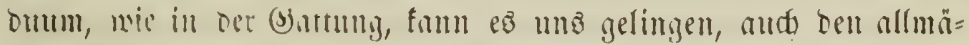

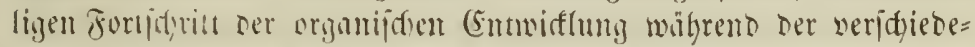

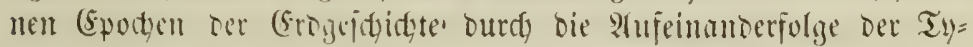

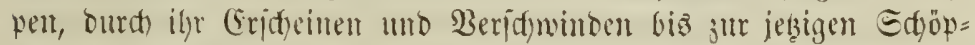
fung nadjinesijen.

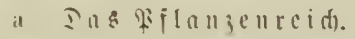

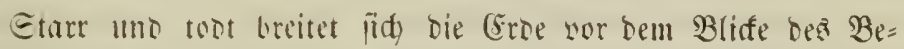

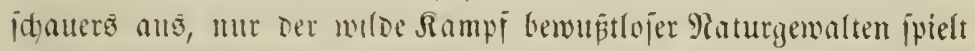

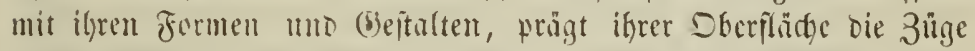

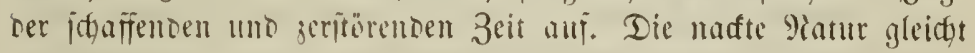

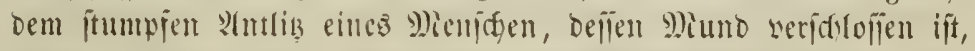

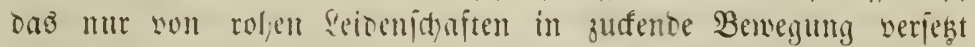

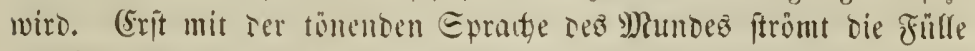

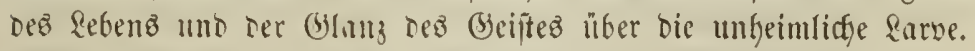

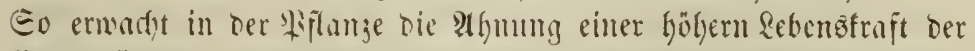

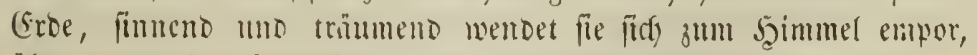

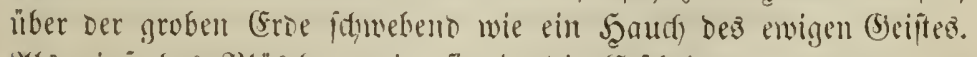

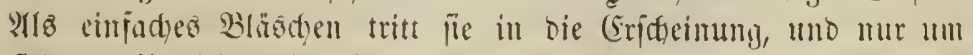

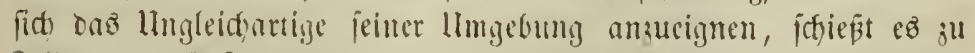

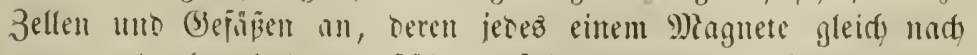

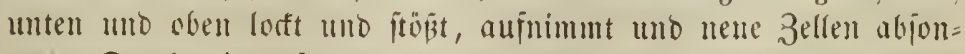

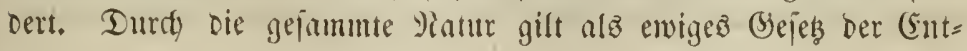




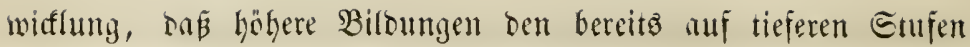
Gerridenten Typuళ mieberfolen, umb nicbere ben ber höheren voraus verfinden. Eo crimnert bie Pffanje nod in bem Bau und in ber

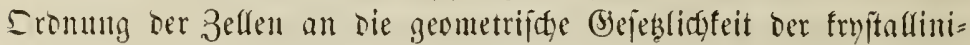

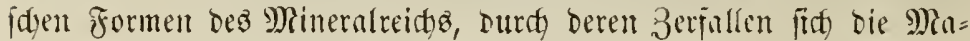

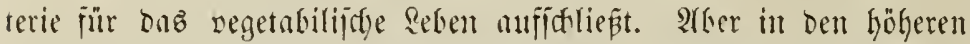

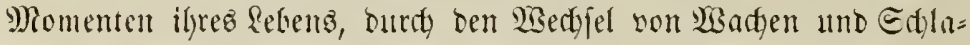
fen, Durty Die zarte Sieijbarfeit ifrer eden Drgane, Durdy bie (snt= faltumig einter Mannigfaltigleit bon Mitteln zur Crreichung ibres

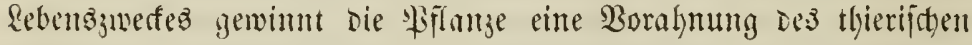
Dofeins, ein Semeingefühl, dem Beltbemubtfein bes Thierez ent= iprectient.

23ic jenes Qeben, burdhlanft and bie Piflanje Perioden der Ent= widflung. Bon Der (Srre geboren, ftreft fie zuerjt ourch) Entwidfung Des jelligen und foljerigen Etorfes in ber Rängentidgtung nad) oben.

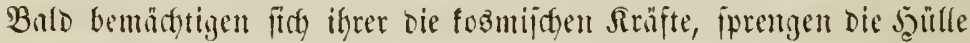
oes Etammes, entfalten fie ju jeitlicten Gebilden uno Defnen bie

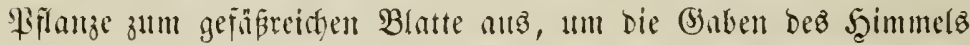
und Der (Erbe ju emplangent. Eine ftete linullye bemäcfitigt fith ber

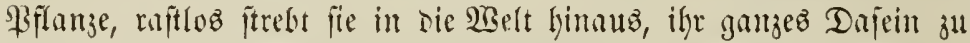

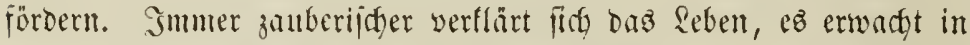

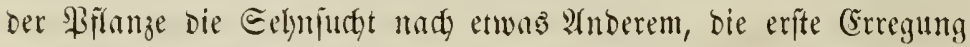
alles Beiftigen in Der Patur, Da ez die Edüpfung eines identen Wejens ihrer eignen Matur, Die Möglichteit ifyrez Fortbeftandez gilt.

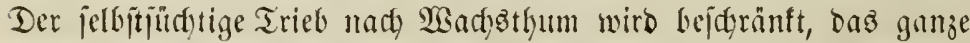
Sinnen Der Biflume gilt Der Blüthenbiloung, zu Deren Bollenoung eine wunderbare Bermandunt alle Sorgane ergreift, bis oft nact jafrelanger Borbcreitung Der farbige Blüthenfram wlöblidy alz neuez (Sebiloce in volfendeter Edyongeit herborjpringt. Dnz Blatt wiro ju Reld, Rrune, Etaubgefäв̈en unb Etempeln verflärt uno labet burds bunte Fradyt unt mumberbare F̧armonie in Siröß̄e, Form uno Fär = bung Einn mo Beijt ju Senuß uno Deutung ein. Daş Enoziel aller Thätigfeit errectyt Die \$ffhnge in ifrer Wiedergeburt burdy bie

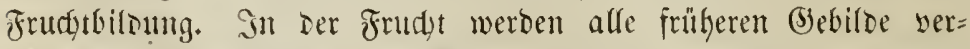

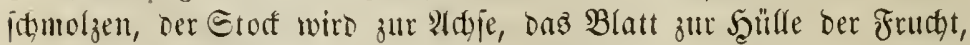
ric Blüthe zum Gamen. Die sou ber (S)burt ant in jteter 2 an=

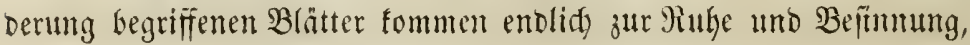




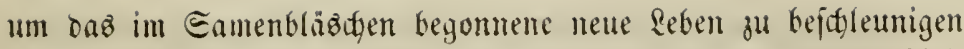
uno zu foghtben. Die im fruthtfnoten nodh getremten Blattîtiele verwadjen ftunmartig mit ibren Bändern, uno bie einjigen wafren Blattgebilte, Sriffel und Rarbe, fullen ab, fobald fie ifre Bejtim= mung erfüut. Die Farbenpradyt Der Bhume jomindet, daz Eajt= grün Des Blattez gelyt über in (belb, Noth uno Blau, und ber

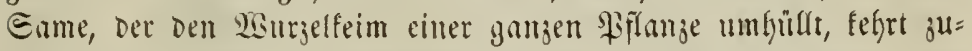

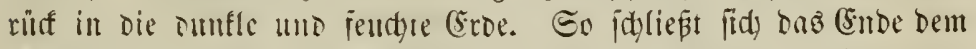

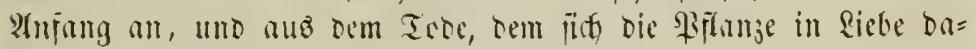
lyingiebt, erblül)t ein נenes, jugendithes seben.

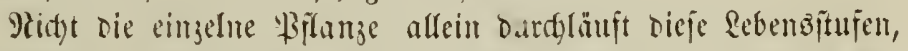

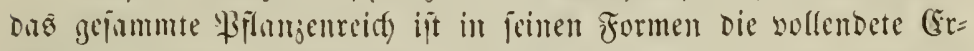
jheimung riejer aupiteigenden Entwiffungaphajen. Sere Brmple jeigt unв Die Dumbjïl)rung einer Rebensperiode. Die eime erfĭllt

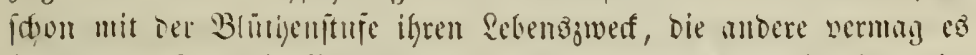
felbjt nid) liber vie Blattbildung lyinaus zu bringen; aber jede nie= Dere weijt nuf sic goblere hin, ofme fit at erreidgen. So jeben wir

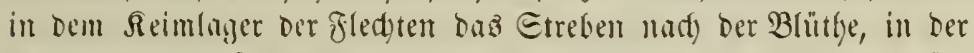

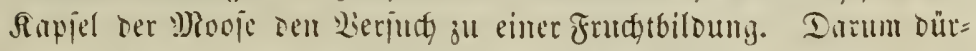

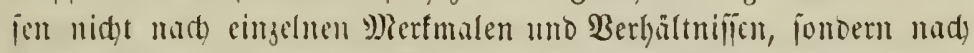

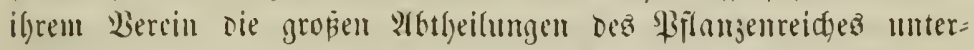
fdicden merden; Imo menn aud) Der Mangel Deutlidfer Bhäthen=

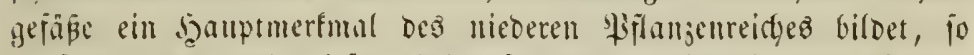
Darj uns bod) nidgt diejer allein, fondern jugleid) bie ganje (Figen= thümlidyfeit in oer Reimumy, in Der Blattfellumy, in Der Dertheilung

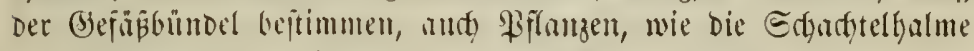
uno Bärlappe ifm eimjuteigen. Der Eame allein, als Das leb̧te

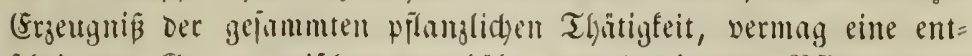

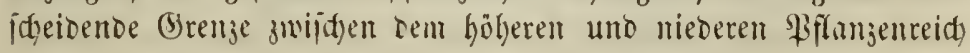

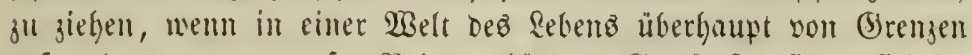

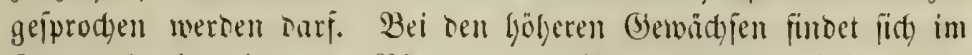

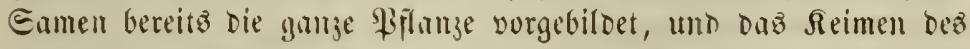

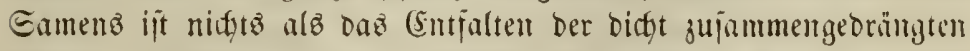

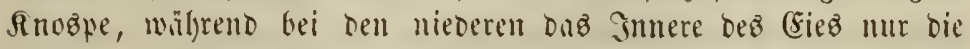

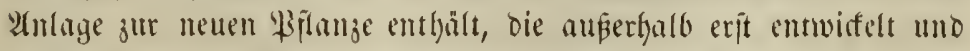

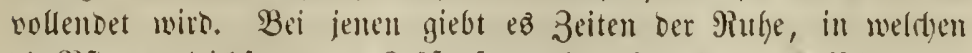

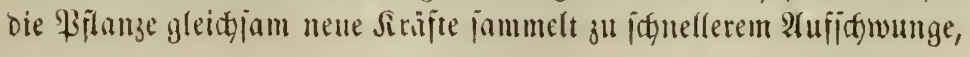




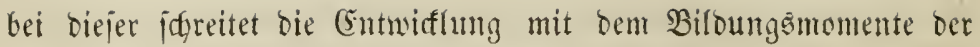
erifen Zelle murafibaltian uno ununterbrodyen fort.

Daz tiejite febent ber Brilanje beginnt mit ber cinfadjen Belle

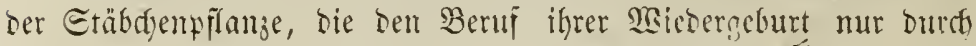
Biloung nener 3ellen im Smrern ber alten Mutterzelle érfüllt. SBir

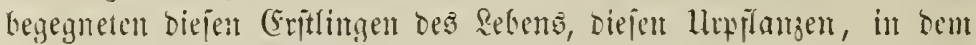

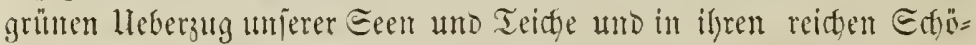
fintugen in Dem Bobent miferer Tieflander wie in ben Edjidten ter

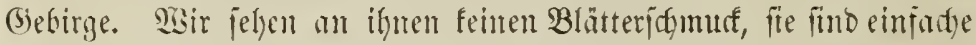

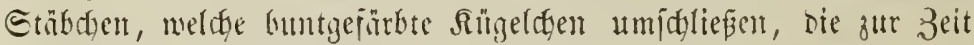

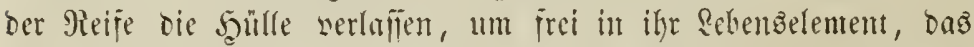

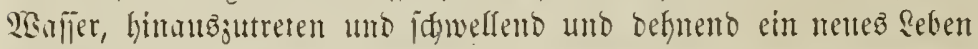
3t begimen.

Ranm erbeht firt bie \$iflanze von biejer tiejen Etuje mifrojfo=

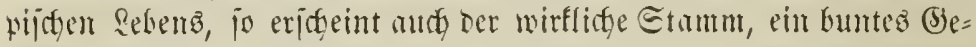

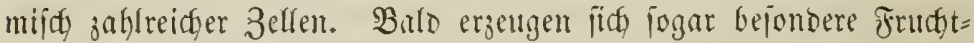
zellen, bic zuterft als Edylüuthe hervorbreden uno fith entweser ju

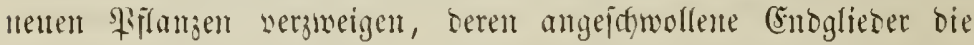

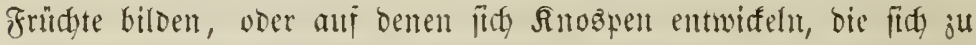

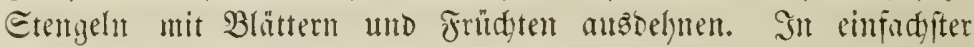

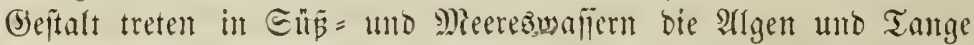
als zarte Fäbent ober mädftige, mefreere fundert (Ellen lange Etämme

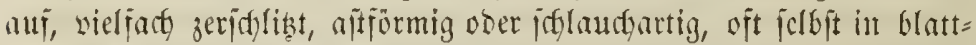
artige Sebiloc aแB̊zedefynt, auj benen bie fugelförmigen Samen=

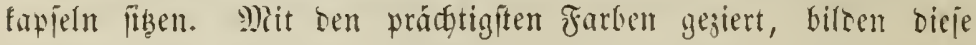

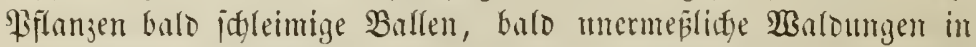

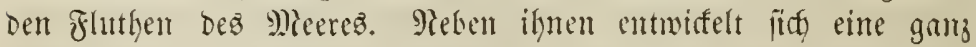

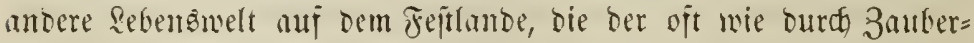
idjlag ber Eroe entfeimenten \$ilje uno Edtwämme. Etatt ber

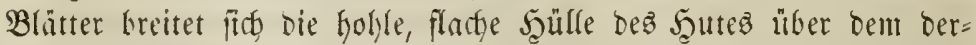

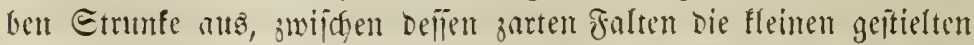

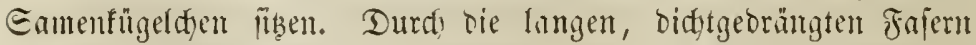

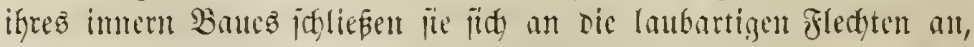

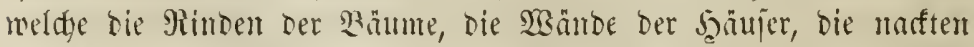

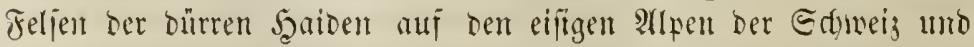

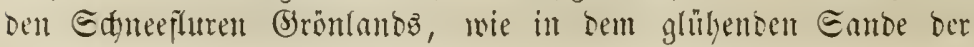


Eahara und bell f̧hren unjerer beimatl) mit grüner unb butter

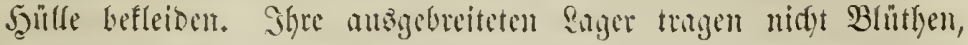

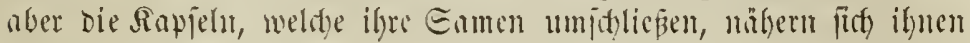

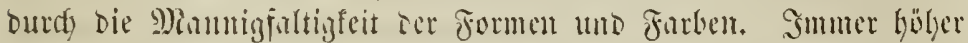

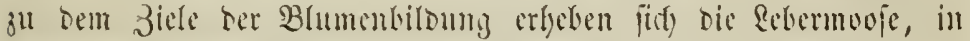

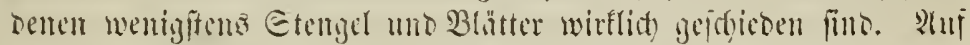
jarten, wafferbellen Etidden erbet jith bie Eamenfapjel, bic an=

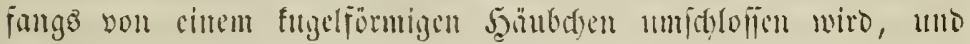

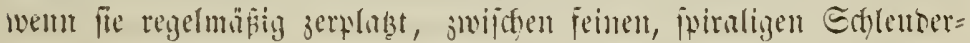

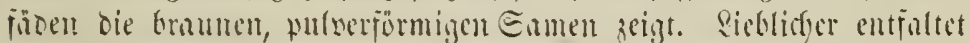

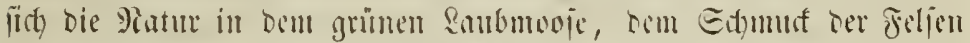

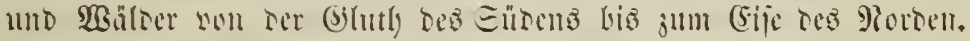

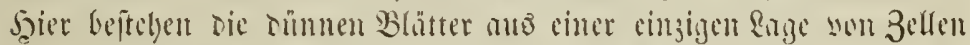
IIID Itmgeben moblgeorbuet ringz Den Etengel, oft bie frutht in

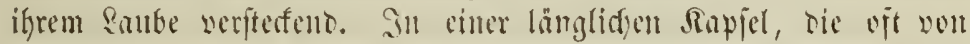

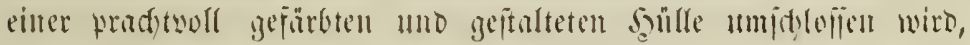
liegen bie Enmen um eims mittlere Eäule gelagert, won jelligen Enaffden ungeben.

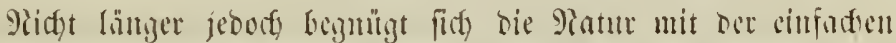

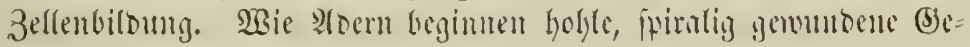
fäje bie Pflange zu Durd)jichen. Dicher llitergang von Der Zellen=

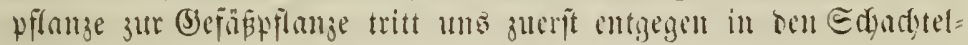
halmen, jeltfamen, jwergartigen (Bejtalten unfer Szeimatly, bie weter

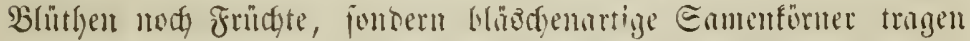
uno jelbit nidyt Bläter zu erjengen vermögen. Shr Etengel ift viel=

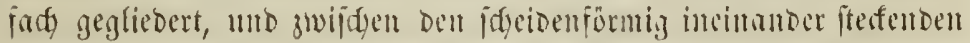

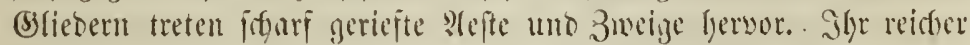
(S) galt an Riejelerbe gab ifnen auty in ber Borzeit eime lamge Daner

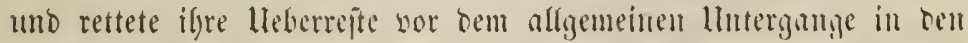

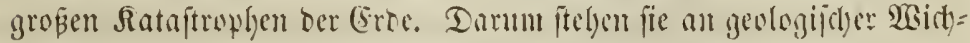

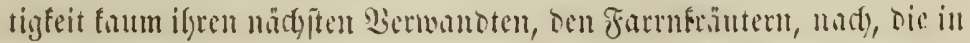
ungeheurer Menge und (Sropartigfeit Die Fhuren ber Borzeit bedeffen.

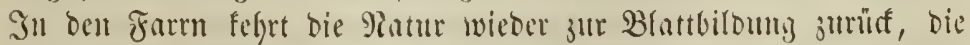

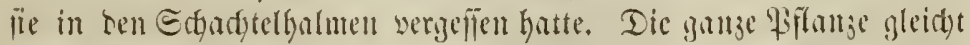
einem einzigen Blate, Das vielfad) zertleilt und zeridhlibt oft bie

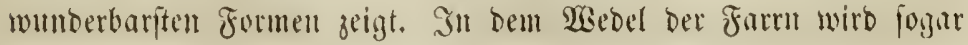




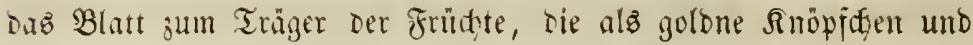
Bedjer in langen Etreijen uno bidften $50 a ̈ u f d e n$ fird auf jeinem viüten fingielyen.

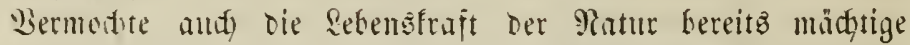

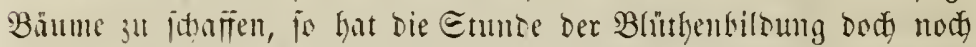

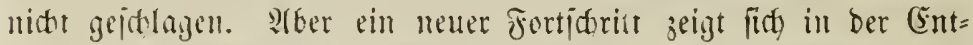
miftung tes Eamens. Bildete lith Gisher Der nelte Etamm erït,

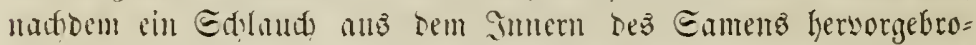

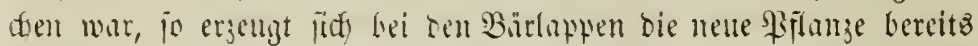

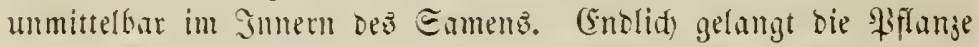

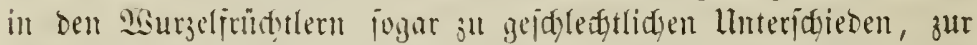
Befrudtung Des (Giezs surt) Den Eamen. Afber nod) wolynen beide

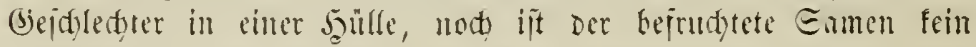
jelbititandiger Erganismus, sejien Reim noffendet, freier Entwiflung

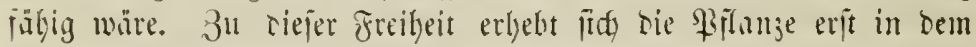

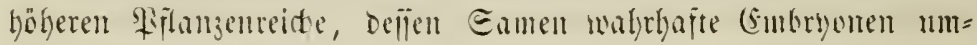

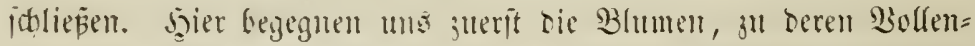

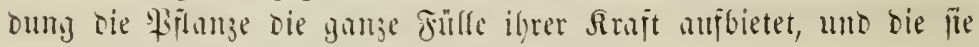

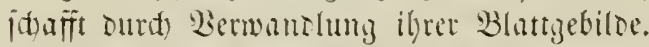

Eieje bölere Entwiaflung nes

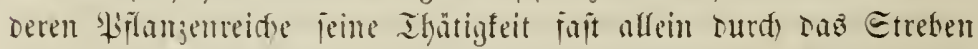
mad) leiblider Gejtaltuny offenbarte, ohne volliftändige biebiloe einer

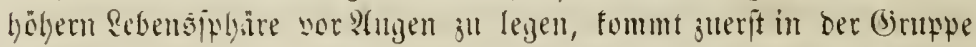

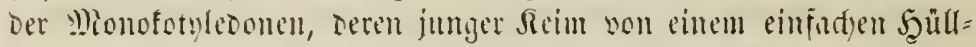

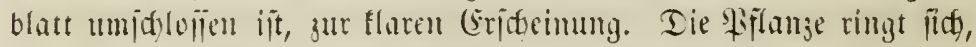

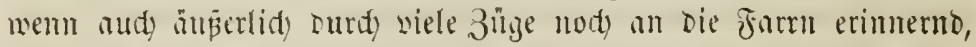

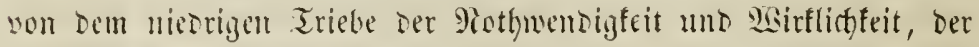

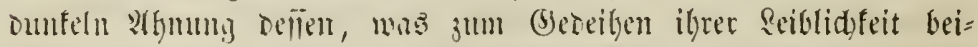

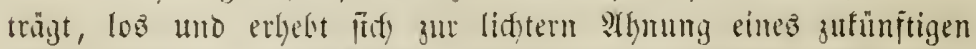
Iajeins, Das burts Die Bildung won beutlidjen Blütlyentreifen mög=

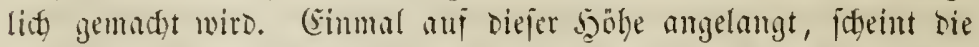

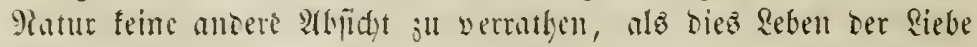
zur Daritellumy einer allgemeinen Soee, wornus allein ein geiftiger Snbalt zu uns ipridgt, in Dem manniginaltigiten Epiel äukerer For=

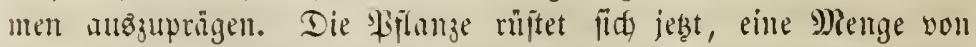

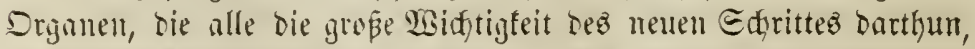

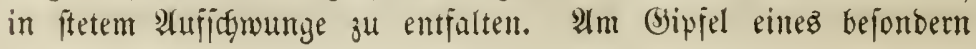




\section{5}

Etiela entwifelt fïh, wemn ihre Blätter eben am idjönjten grïnen,

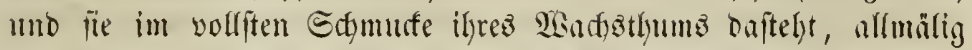

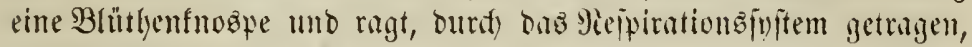
am Gödjiten in bie 2itmojphäre. Stm Etrahl der Eome beginmt

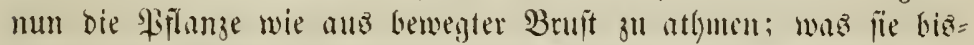
her getgeimmiswoll verbarg, tritt als Sild oner Blume, mit berem

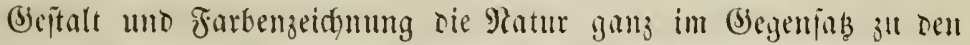
fajt überall gleidgbleibenden Blätern auj eine elvenjo merföbyflidge Weife fpielt, wie mit ber beftalt unt Farbenzeidumung ber Jnjeften,

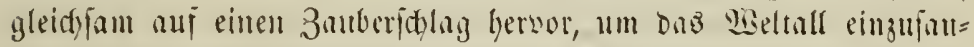

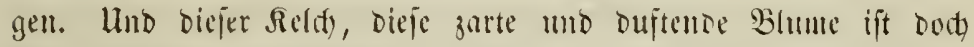

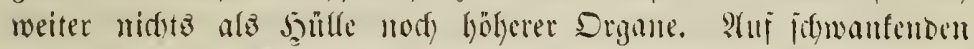

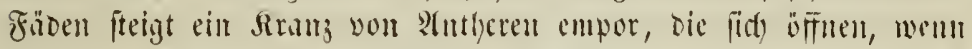

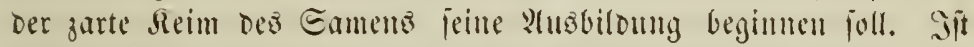

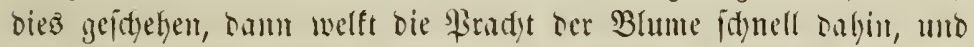

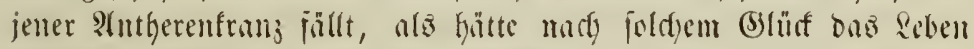
mun feine Bebeutung verloren, glcictywic ber Edymetterling, madyocm

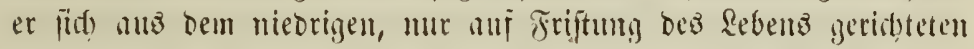

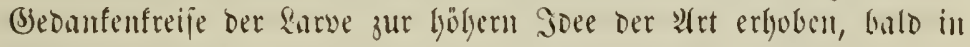
vollem Edymufe bem Tode entgegenteilt. Dody hat bic Matur, alo

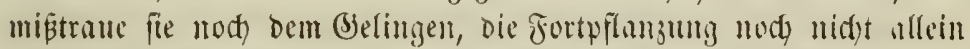

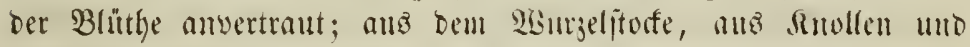
vorzüglid) 3roiebeln fprofien nethe Sifhnzenintiviouen hervor. Bei

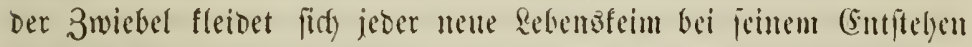
in cine Şülfe ein, bie ifm in peiner zarteften Sugend zum Ed)utze,

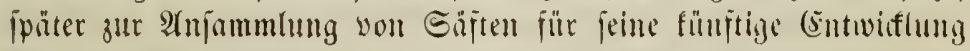

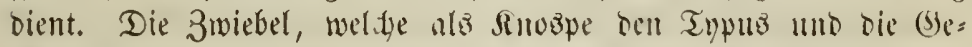

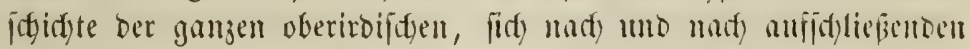

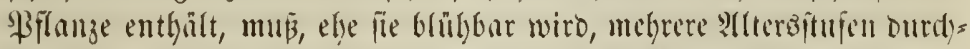

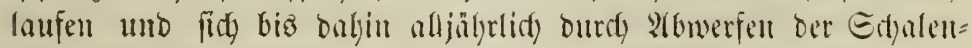
häute theilmeife verjüngen. Das erimnert an den Rarvenzultano uno bie Berwanblung ber Injeften, infofern fidg lier wie bort bie innerm Theile auf Roiten ber äußern vervollfommuen.

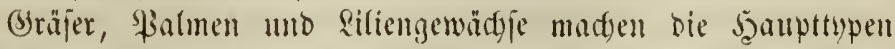
biefer gropen, gegemvärtig ber Tropenzone in ifgren meiften und

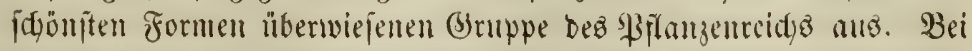
Den Bräjern erjdeint bie Bhtume anj ibrer unterften Enfuje, obne 


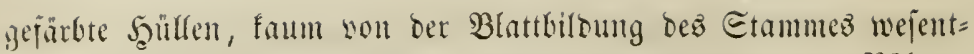

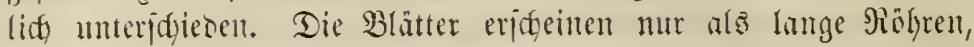

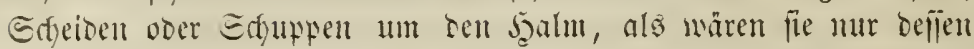

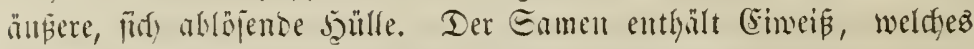

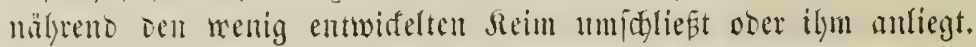

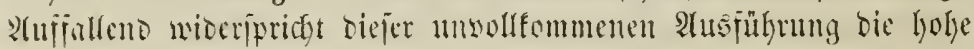

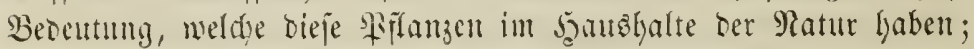

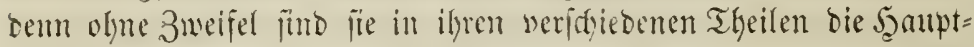

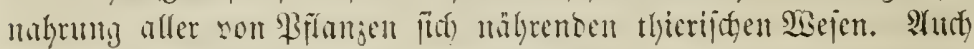

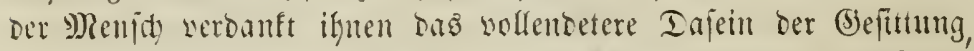

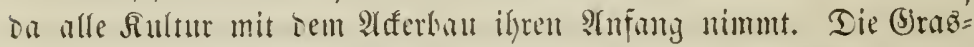

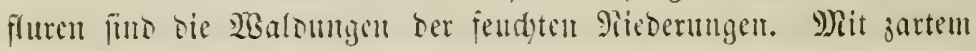

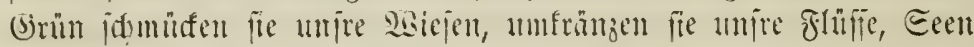

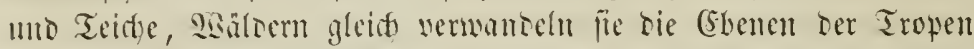
ill unburdyoringlitge Bilonifie. Şier ein jutrter, forwantentor Şalm, Den bie Etrablen Der Eoume nerjengen, crlyebt fid) Dort Das (Sins in Dem rifigen Bambus, tem jdylaten Pifang, ber mädtigen Prun=

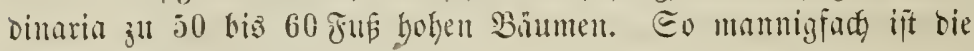
Natur in ifgren Edjopingen!

Durd) Dii jurten Blumen Ier Binjen werben wir himberge=

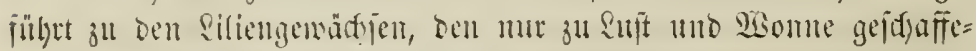

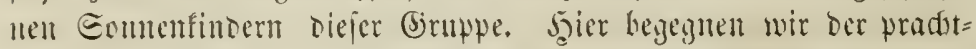

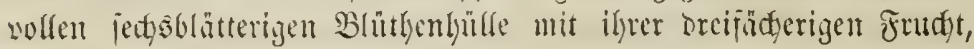

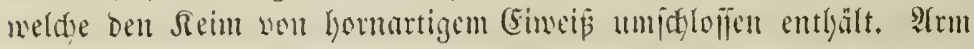

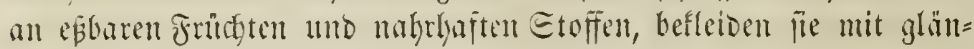

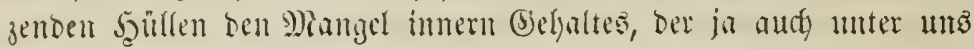

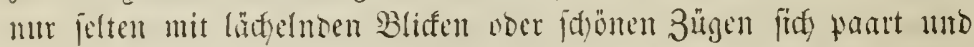

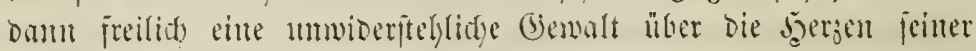

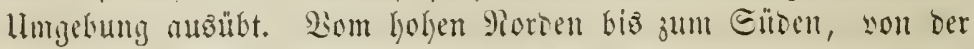

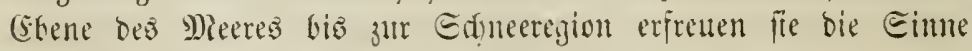

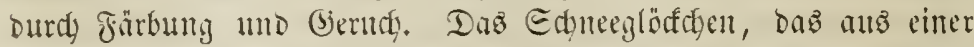
ciiigen Defé, bie Rroftubarten, bie unmittelthar ans bem rauhen Edyoofe Der Erbe lerworklilyen, bie :utanas mit ber fofflidyen Frudyt,

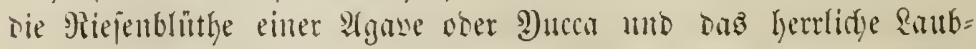
werf ber Bananen mit jeinem fojimmerntoen uno glänjenden (S)rn̈, Das non Der gewaltigen Şöhe Der Etämme herabuallt; weld ein Rontraft in biejer bunten Rebens?welt, Die nady Fülle ber Formen 


\section{7}

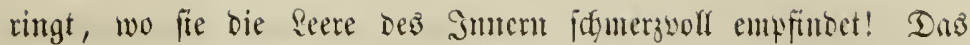

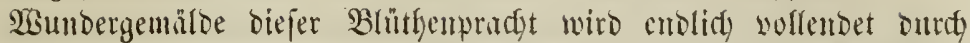

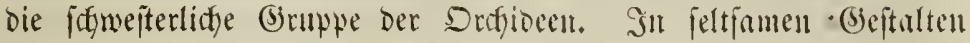

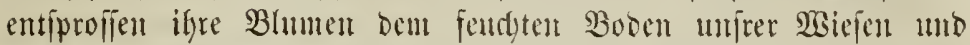

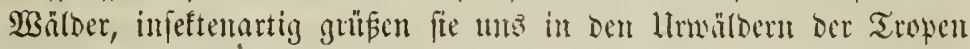

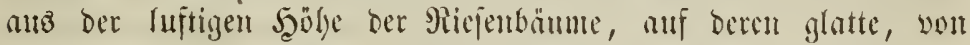

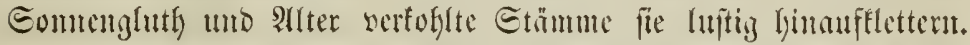

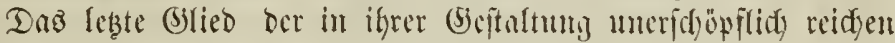

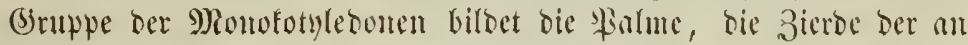

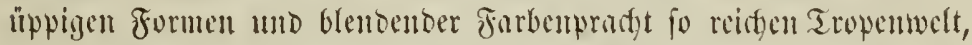

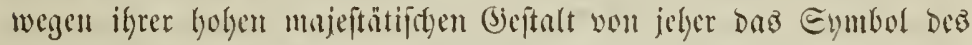

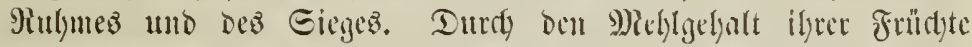

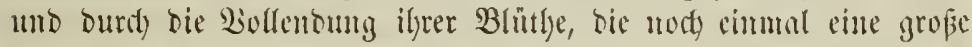

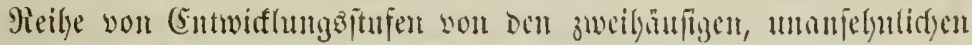

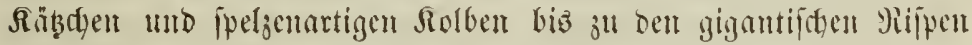

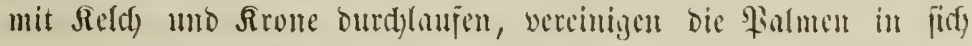

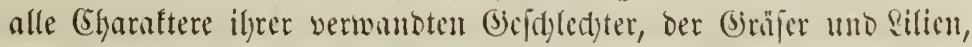

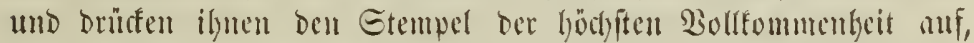
Die auf biejer Etufe crreidjt werben tomute. Bald erbeten fie firs

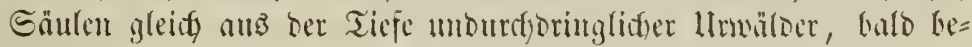

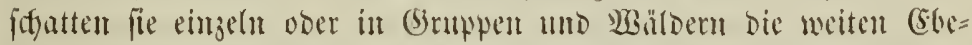

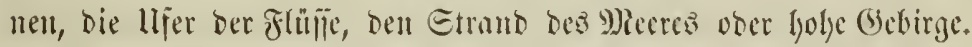

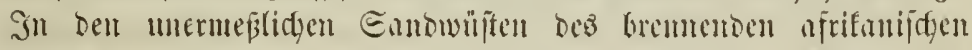

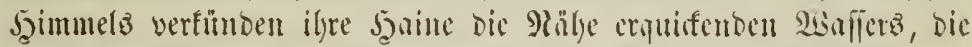

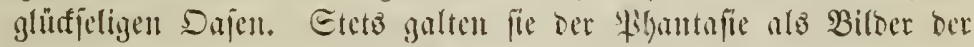

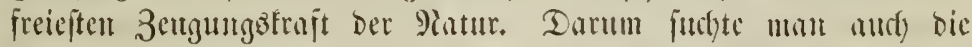

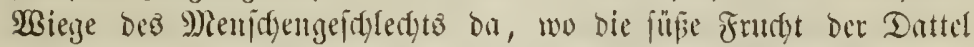

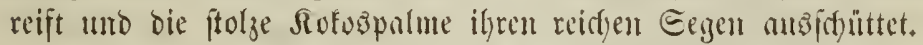

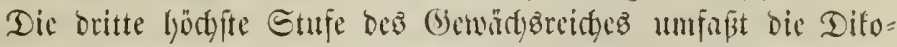
tyledonen, beren Reime von zwei Eamenlappen umithlofien fund. Sie zeigt firf in allen Theilen geregelter anyelegt, in ber Berjweigming

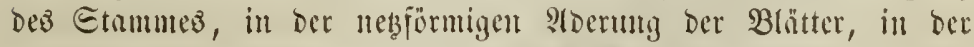

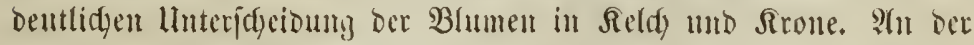

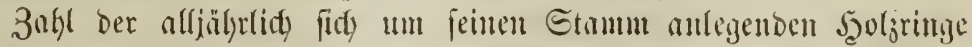

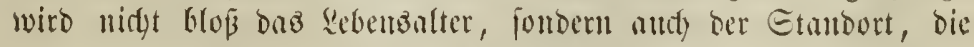

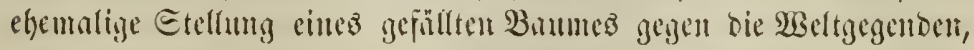

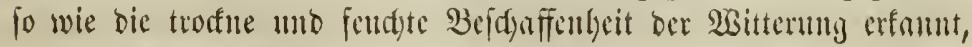
II 6 , 23itmll. 3. 2tแp. 


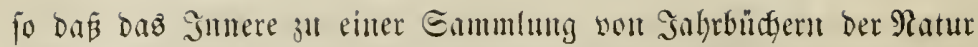

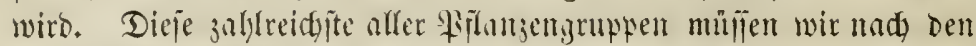
brei dyarafteriftijdyen llnterjdyicden ifjer $\mathfrak{B}$ hument nod weiter zerfällen. Sn ber unteriten $\Re$ lafie jelylt nod) bie innere gefürbte Blumen=

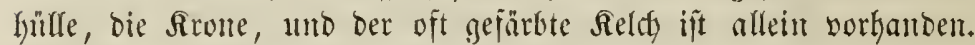

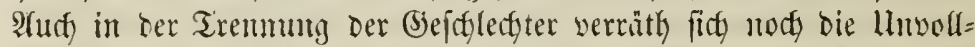
fommentyeit Der Blüthe. Die widytigyten familien biefer abtheilung

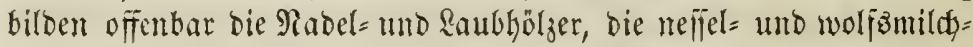

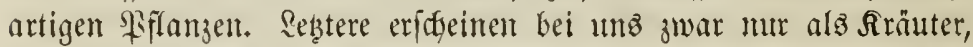
in Der Tropenzone aber alB Bäume, นnto Mandtem mödte bings fitwer fallen, in ber Feige und Den ) Maulberbanm Berwande

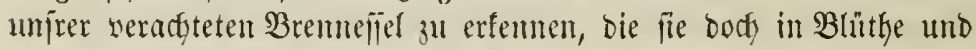

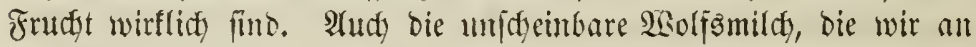
Den 2 Segen zertreten, hat im Eliben ilyre mädytigen Berwanten.

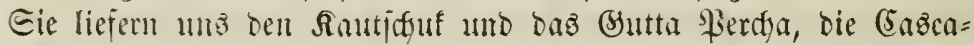
rille, Das Groton= nefmen bieje bummartigen Cruphorbien auf ben canarifaen Snfeln an. TEenn ifre Dunfelgrinten, söllig blattlopen Zweige, alfe aus ciner Sisuzcl entipringent, fids im Salbfeis n̈ter ben Boben hin=

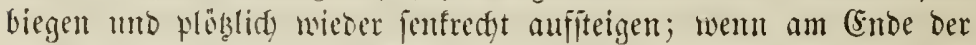
biffen, erfigen, fleifidigen : Yejte idarlid)rothe Blïthen bersorbredgen, bie in Der Ferne glittenden $\mathfrak{R}$ ohlen gleidjen: bann gewinnt ber Baum

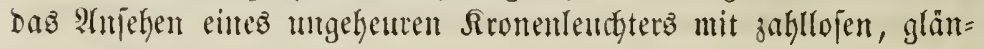
jenten Ridftern.

Widytiger und verbreiteter find ohne 3weifel bie Rabel = und Snubböljer mit ifren japfen = und fäbdgenförmigen $B$ lüthen uno

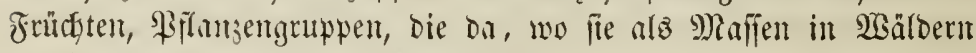
gerriden und burch ihr bulitres ober lactendes (Srün bas (S)mütly Deš Bejđnters ergreifen, Den Sharnfter der Begetation, ja bie ganze Shyprognomie ber Matur beftimunen. Die Pabelgölzer, bieje \$al=

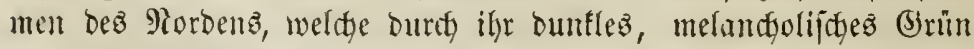
Gommer und 3 inter hindurch bie oft oben Ranbjaffen beleben

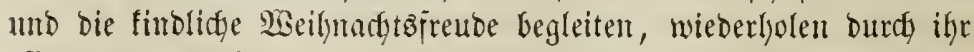
offenez, nidyt geidglofienez Frudtulatt uno bie einfachen, nabelförmi= gen Blätter bie nieberen Formen Dir Farn. Wenige \$fiflanjengrup= pen fömen fid) in ifrer Bedentung für Den Mienjiden mit ben $2 a=$

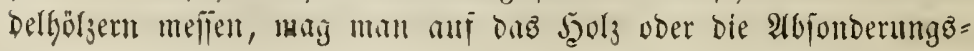




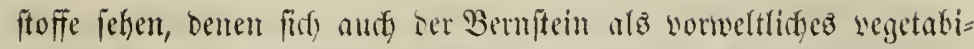

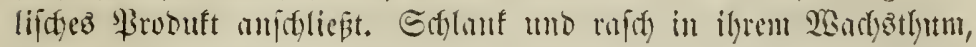

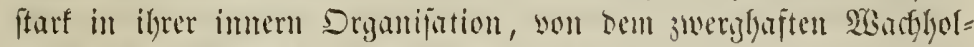

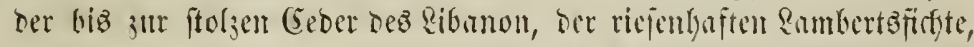

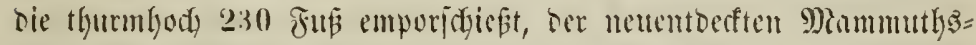
fiefer (Washingtonia gigantea), Dereu futhelfajte 5 g̈hlye man anj 300 -

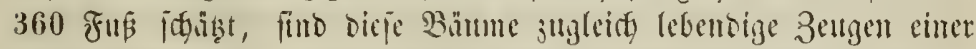

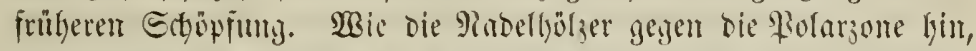

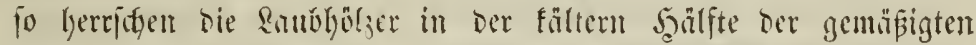
3onen vor, als sanbwäloer won der manmigjaltigften (Seftalt uno

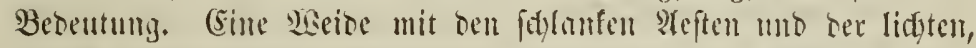

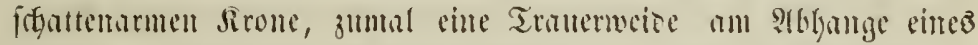

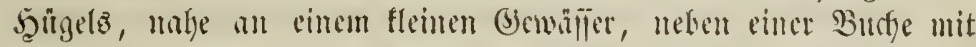

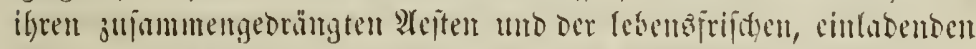

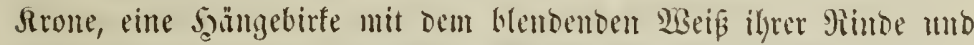

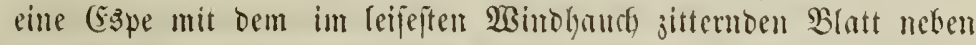
Der elyrwüroigen (Fidge mit Dem feierlitgen smube, bieten bem santo=

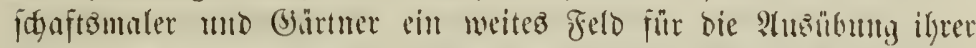

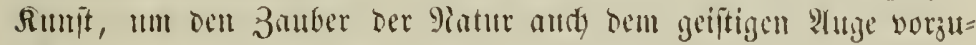
füllyertr.

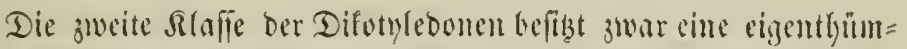

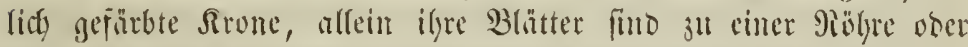

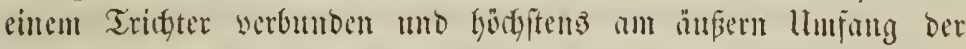

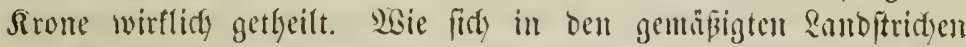
Das Blatt alljührlich ernentert, raftloz thätig, um mïfreno jeines

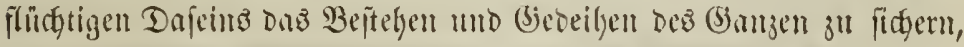
wie

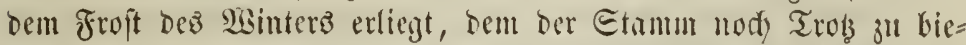
ten verming, fo fommen mo gelyen bie Bewädfe biefer Sllafie, bie

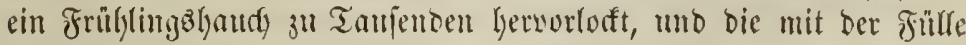
und Pradjt ifres erquiffenden Grints bie Eroe weit und breit

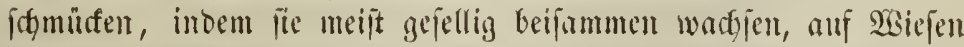
wie ant troffuen Drten, wohl hint unb wieber bebulfdy, aber fetten Wä̈ldoer bildent. Diefe felige Minienzeit, bie mit ber (Entwiffung

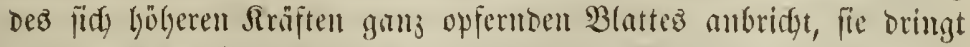

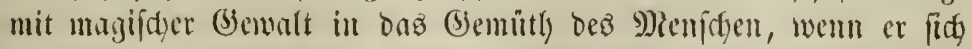

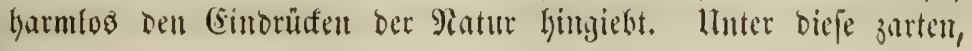




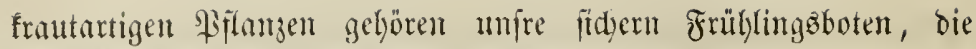

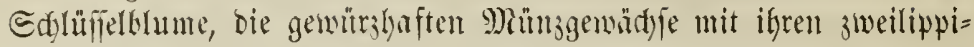
gen Bhumen, bie lieflidyen Bergi bie duftenden Sinprifolien, ber Sleander mit feinen fdjönen Blütthen,

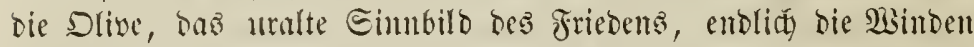

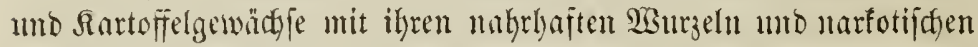

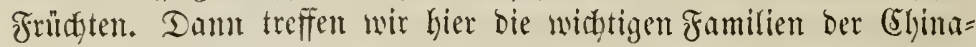
büume, bes Sinfeebaums, bes Baldrians unt die umfangreidjte aller Familien, bie der Syngeneififten, meldfe im Röwenzalun, ber Samilfe, Der Sornblume, Der Difitl, Dem Ealat unto Der Sidforie auth bei uns fo zaffreidy und nüblylidy vertreten ift. Die R̂ürbis=

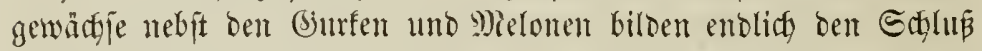

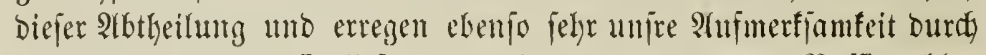

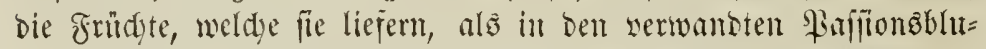

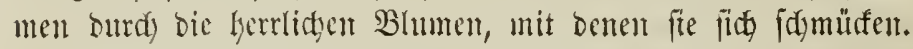

Die britte umo lebzte Slafie ber Difotyledonen endidy unter=

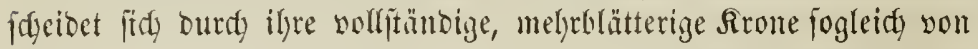
ber worigen. Die zalyleidjyte von allen Piflanzengruppen, waz bie formelfe Mannigfaltigkeit ifres Snlhaltz betrifft, eridgeint fie fayon

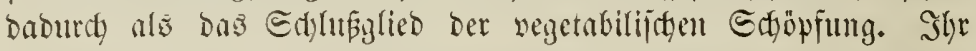
Formenreidfthum aber nötfight unb, auth fie nodfunals in swei fleinere (Sinuppen ju föndern Mad) Der Stellung ilyrer Rronenblätter, weldge entweber voum Seld getragen werben ober an ber Itefje fizen. Sn Der einen iwerben wir bie loöffite (Entfaltung ber Blume, in ber an=

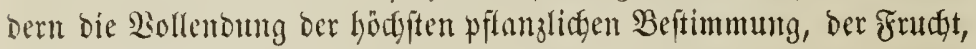
erreidgt jelyen.

Die Frittlingafeier ber mit unverfiegbarer Sugendfrifdje wieber

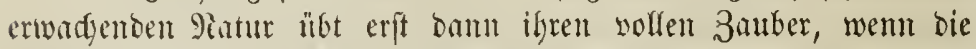

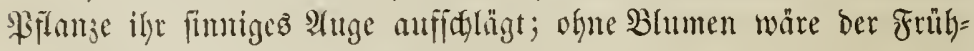
ling ein Şimmel ofyne Stente.

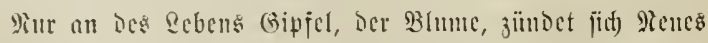

In Der organijden Gielt, in der empfintiemben an.

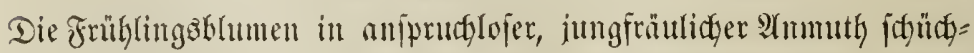

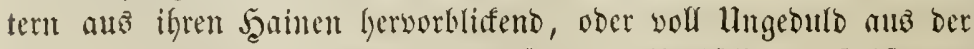

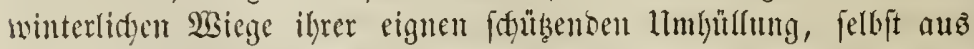

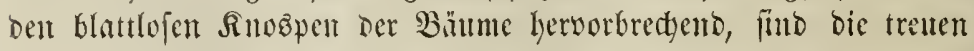
33orboten biefer 
in ifrem Brautifhuntf jeigt. Sinte munoertar wedfjelnoe Formen= fülle, von flatternoen Ritbdyen uno huftigen Edymetterfingşblumen an biz ju vollfommuen Rojen, meldye in ganjen Baumgruppen wie

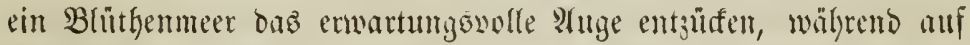

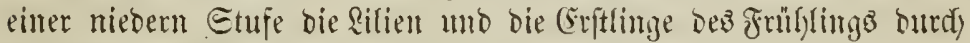

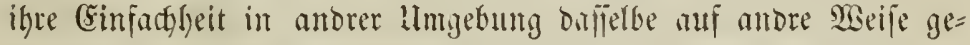
winnen; ein reidgez Farbarpiel, an bem bei vielen Fudyfien und (5acteen and ber Reld, ober bei Miyrthen und andern felbit bie Etanbgefäpe mo sermonote Sebilde Theil nefmen; entidy ein

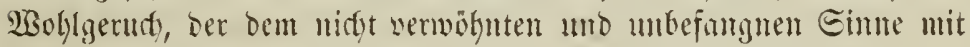
Rebenswärme entgegenntbmet, Den aber bie frilylingsblume noch veridmält, tum mit ifrem Şuniglaft bie jubelube Injeftenfdacar ju lorfen; - Rthez Daz verfilndet ben vollen Eommer Der Piflanjen= welt, ber in biejer Rlajle offenbar wirb.

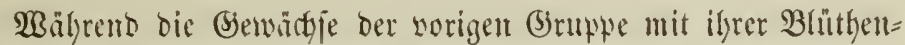
bilbung nod) auf balfem siege ftelgen bleiben, imbem fie wobl cint Doppelte Blïthenterfe ron Reld) und Blume, aber bie lebtere mur in Siö)ren= oder Bandform mit angewadjenen Stanbgefäpen ergen=

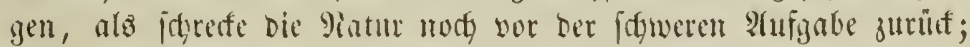

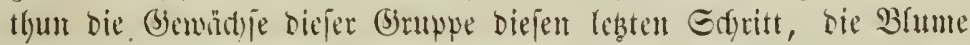
ala volftändiges (S)biloe mit freien Blättern bingujtellen. Da bie

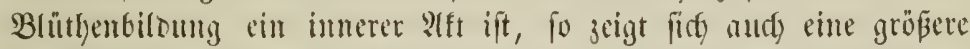

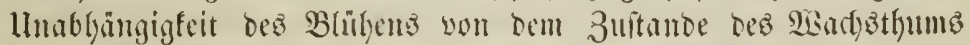
in ber Rrautbiloung, fo bas mand)e fiflangen fotsed)t wad)fon mo

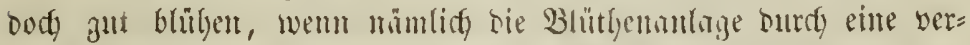
ebelte Pahrung anf Dem entipredgenten Boden aus dem Snbivibum cimmal gebiloet ift. Ridft uno ?uft Durdyoringen die Piflange berige=

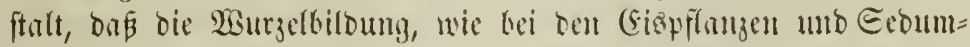
arten, ben Eteinbredgen uno Eacteen, gum jurïftritt ober faum ge= gen bie Blatt= แnd Bluthenbiloung in Betrad)t fommt, inbem bie Wurzel fajt feiner flüitigfeit bedarf, um bie Begetation zu unter= balten. Eelten wirt, worghiglidy an fofattenreidgen uno feudgten Tropenorten, bie Burzelung liberwiegent, wie beim Ephen unb ben Mangle = oder $2 B$ urgelbäumen. Da Der norbijhe Eommer mit feinen lingeren Tagen ungleid) melgr lidyt fpendet, als ber fïblidge, fo fam

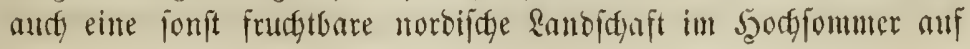




\section{2}

einmal eine reidgere und üppigere Bhumenausftelfung bieten, als manthe viel artentridgere (Sagenden bes Eübens. Daljer find be=

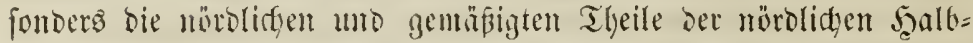

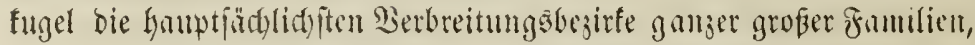
wie Der Edymetterlingsblumen, Der Dolden= und Jiojengemächje, die in ben Tropen gegen bie fleifdhigen, vielfadg fieberblïttrigen und öl=

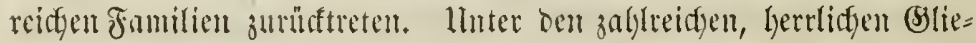

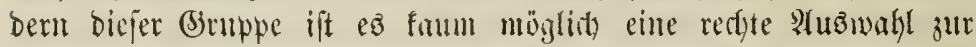

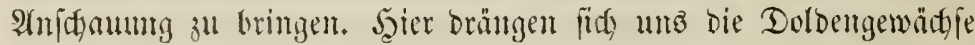
mit ifyen gewhishaften, atherijden Etuffen entgenen, Dort bie har

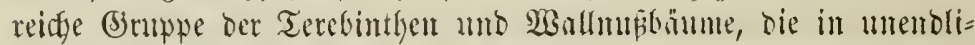

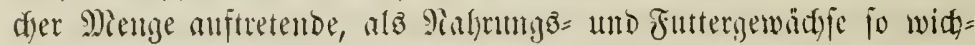

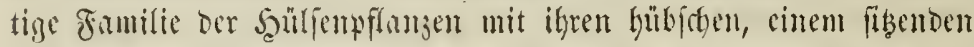

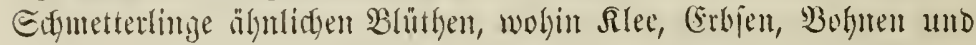

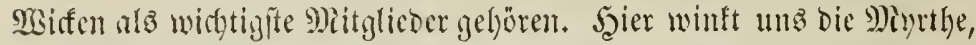

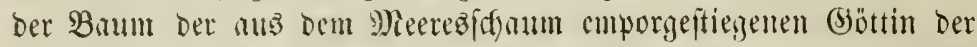

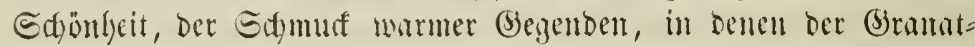
apfel, der foünjte ihrer Epröblinge, lyertict geoeilyt. Dort endich laben uns Dic jonberbaren, ifrer biffen, fleijd)igen Blätter wegen fo merfwübigen Eaftgemädje ein, meldye im (siegenją zu ifrem waffer= reidgen Inbalt bie trosfeniten Etmopunte lieben mo gernbe Durdy

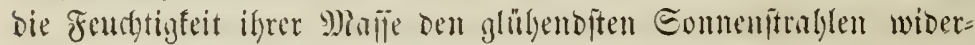
ftegen. Mianerpfeffer แnd Jomshub fund in unirer 3one bie burf=

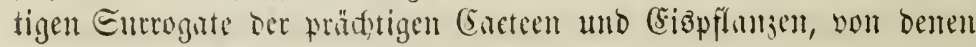

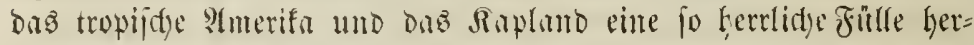

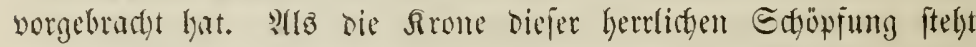
aber wohl bie lieblide (5iruppe Der Miofen ba, gleidy ausgezeidynet Dutry bie Blumen, wie surty bie frittfte, welde, wie Erobeeren,

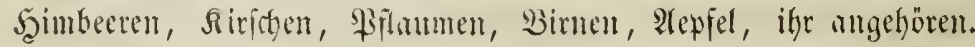

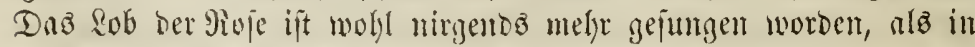

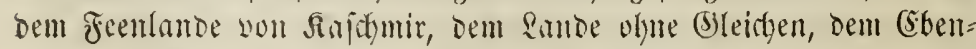

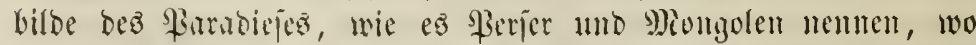

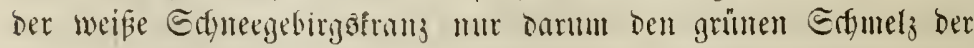
Boralpentyögen anngebe, Damit Die Srone Der fffimmermben Diaman= ten, mit grünen Emaragben bejęt, bie Rönigin ber Blumen am meiftent jiere. Die Siojenfeite, melde noch jebt gefeiert werden, wemn

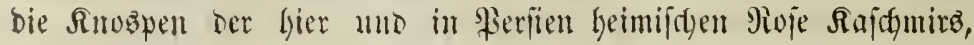


Der Eentifolie, anjoredsen, find burdy reizente Didfumgen weit unt breit im Drient, wie im Decibent verherrlicft.

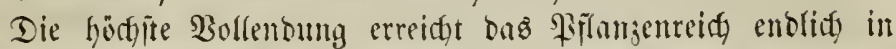
feiner leb̨ten Brnppe, ben Frudtuflanjen. SBent bie Blume in

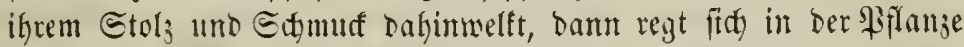

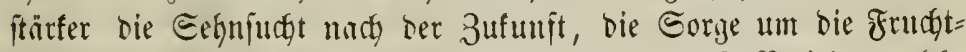

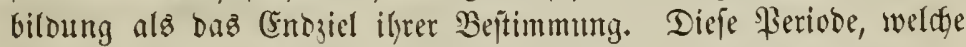

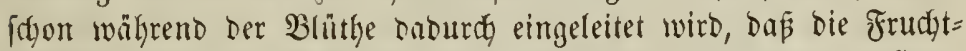
adje ben ron ber Reimung an g!eidjam in fortwährenter $\mathfrak{B a n}=$

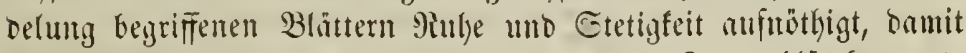
fie zur Bepunung fommen uno das fogon im Enmenblaşdent ent=

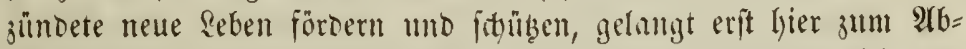

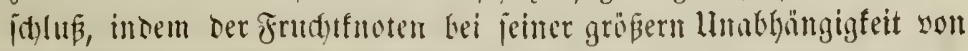
Den übrigen Blitthenferijen fith immer freier und sollfonmmer z̧山

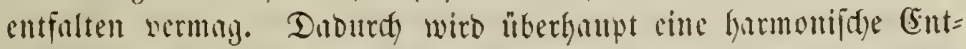

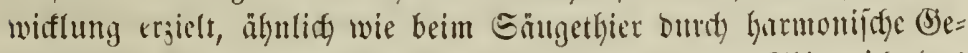
ftaltung ber Sryaneniyiteme unn, ber Einne Dem Thierreidy bos Siegel ser Bollendung aufgentüft wird. Şier veridgwintet bie Şerr=

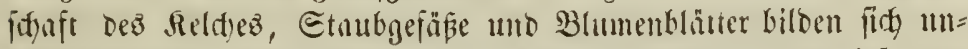
mittelbar ans Der Epintel des Fructitfnotenz hervor, umb biefe ent=

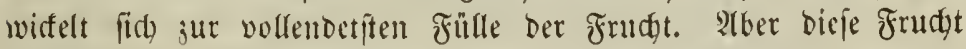

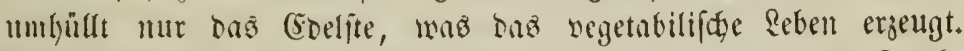

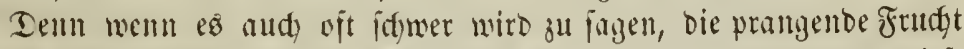
Der Srangen jei um der Serne willen Da, fo finto bod grabe biefe sie mejentlidse Bebingung jur (Entwifflung ber Frudft, und felbft ba, wo fid Frnüdte obne Eamen bilden, ift uriprïnglidy Dody ein Reim

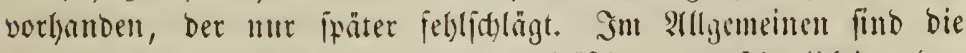

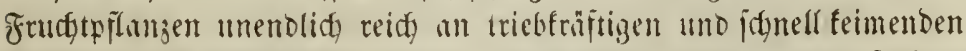
Eamen. Das Täjoelfrant foll in Englanto siermal bes Gahres reiden Eamen bringen, und jeber biejer jalylteichen und winsigen Eamen ift nom Şaudde Der Drganijation beherridjt, ein jeber ift

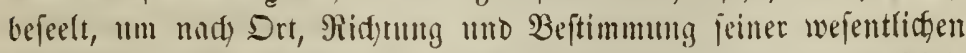

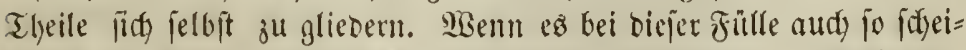
nen mag, nls braucte bic Matur nictit bon Berluft vieler Millionen ju zäblen, fo iff body fidter, mady ber rhythmifden Etcllung ber

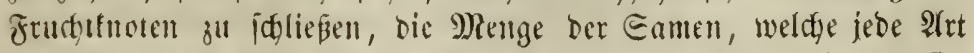
tme naturgemäpen 3uftunto zu reifen vermag, uno ber lyiernus fint 


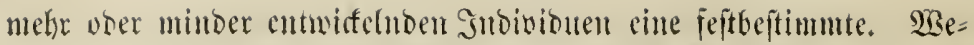

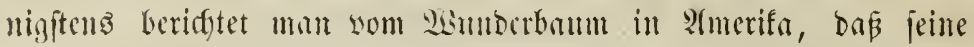
Früdyte mor eine gemifife 3ahl lebengfräftiger Eamen einfogliesen, bie

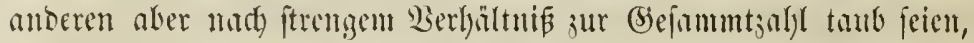
wie andf bie Braminen in Scintoftan bei ben Frnidgtent ber Mango

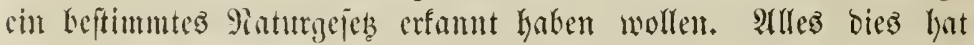

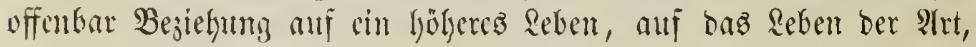

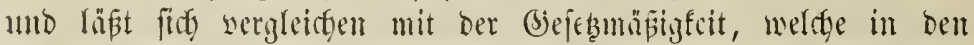
Geburto = unto Eterbesalyen ber Menidyen, io wie in bem Berhält=

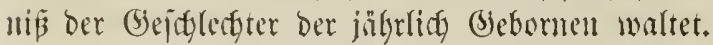

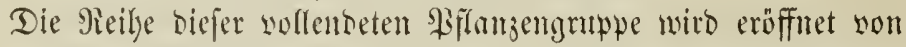
ben zierliden Mielfengemädjen unto ben unftheinbaren, aber bod jo

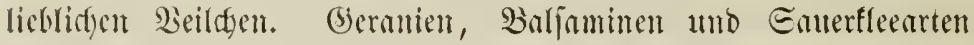

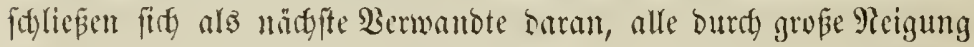

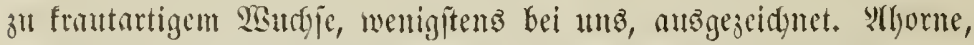
Saitanient uno Rimben folgen ifnen als baumartige, verwanbte For= men, uno zwifthen ihnen ftelgt bie Theeftante und bie Eamelfie

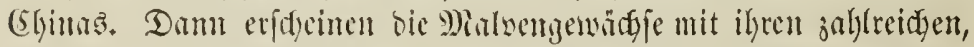

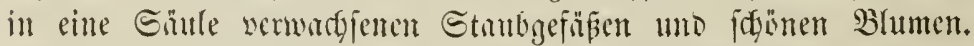

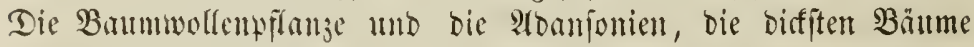

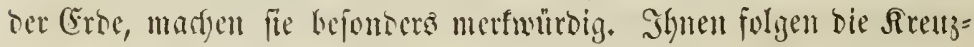
binmen uno Mobngenuädje, wegen ber jeltnen, in ihren Bhäthen= theilen herriffenden (jrumbingl Bier ebenjo merfwirdig, wie öfono=

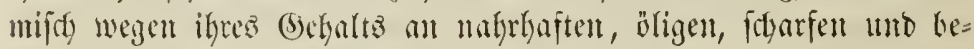
täubenton Etoffen. Rohl, Marps, Eenf, Mohn unt Dpinm daraf=

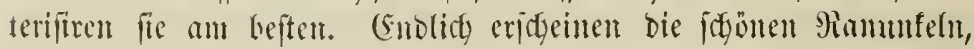

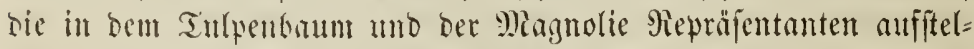

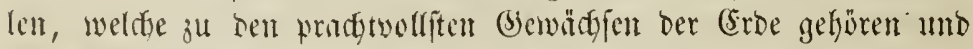

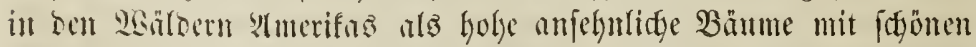

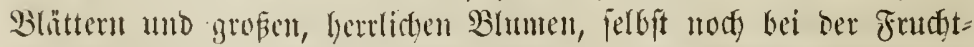

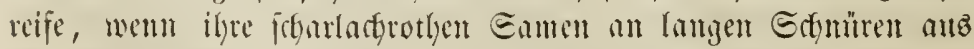

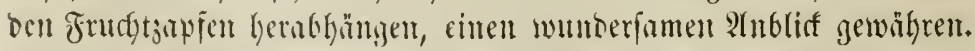

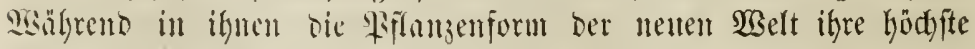

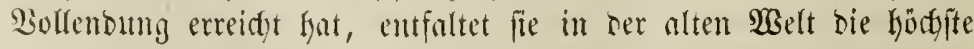

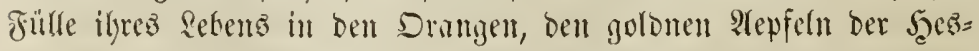

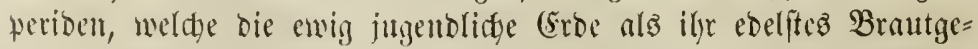

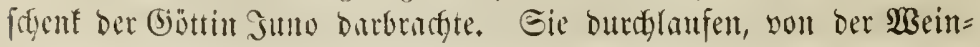




\section{5}

rebe beginnent, beren rantentes Ranb daż Giemäcbz zur Eonne

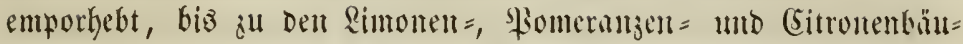
men mit ibren Gerrlidy buftenten Blüthen und erquiffenden Frühten

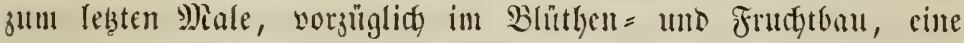
ganje Reige son Entwiflungajtujen in nimmer roftentem Fortjeftitt

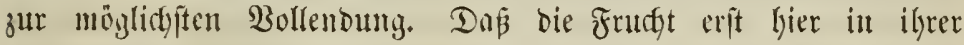
wahren Matur erjdeine, Kefrt bie Bergleidumg mit bem, was fie auf́ anderen Etufen eriftrebt. Denn wie viel Rob man andy aflen übrigen fpenden mag, alle find mit seingeln belyfutet, alle find

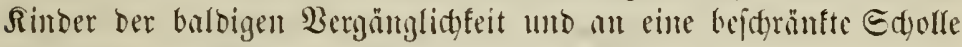
gebunden, unfïlig, Den Menjogen in entfernte 30nen zu begleiten.

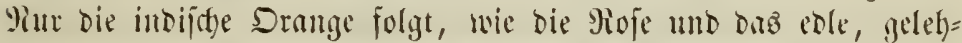

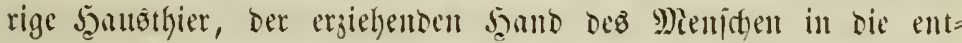

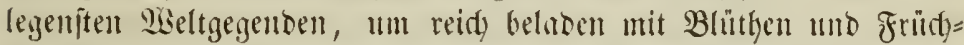

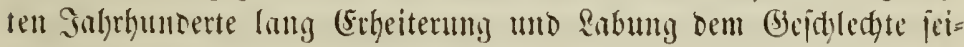
ner Pileger als Dpfer barmbringen.

\section{b. Das Thictrcid).}

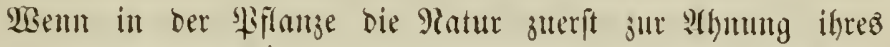
geiftigen Sebenz emadte, fo erbebt fie fits in Thiere zum $\mathfrak{B e}=$

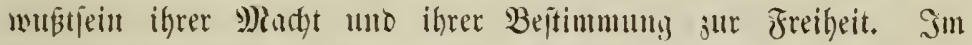
Thiere idgafft fide bie Sintur cimen Midjter über ibre Thaten, ei= nes Riuntler zur Berwirflidung, einen Didjter jur Berbers=

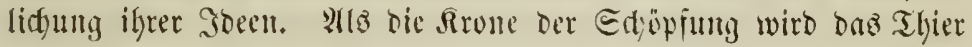

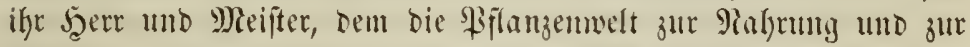

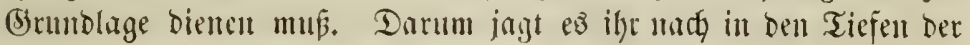

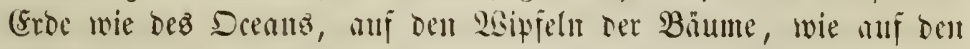
Edfuegipfeln der Berye, durth Wafiferfluthen uno burdy bie Rujte

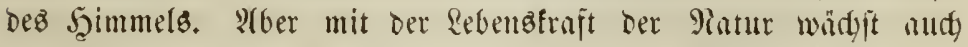

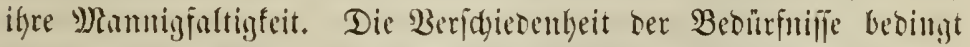
bie Beriftedentheiten bes thierijgen \&eibes. Şier fimben wir nidft mehr, wie in ber Piflanzenmelt, alle $\mathfrak{B e j e n ~ n a d ) ~ b e r j e l b e n ~ S o e e ~ g e = ~}$ baut; im Thierreidge begegnen wir orei wejentlidg getrennten (S)runt=

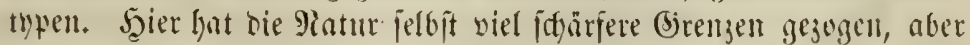
um fo fdwieriger wirb es bezhalb, bie Thiere unter fo allyemeinen (B) 
fonnte. Demn alfe Zmeige, alle Blätter, alle $\mathfrak{B l}$ lumen uno Früd)te bejtelen aus benjelben, immer nur in ihren Begiehungen zu einan= ber modificirten Beftundtheilen, uno nie feglt einer ganz, ber zut

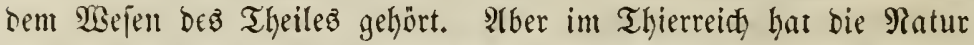

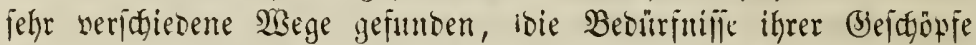
zu kepriesigen, bem einen Drgane juertheilt, bie sem andern ganz fehlen, utno jelbjt ba, wo mir bei Thieren Denjelben Drganen be=

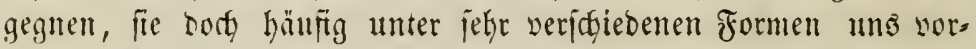
gelegt. Fuf ber andern Eeite hat fie wejentlida veridjiedene $\mathrm{D}=$

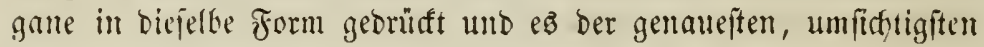

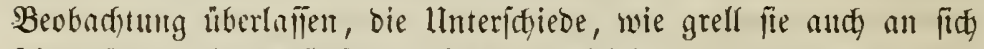

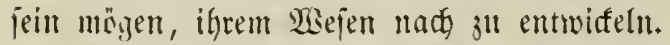

Ftud) Das Thier geht aus ber cinfaden 3elle hernor, deren

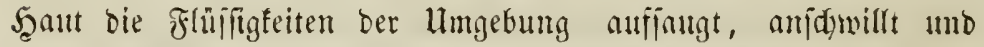

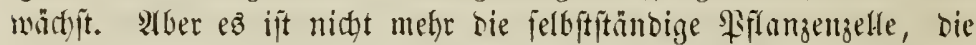

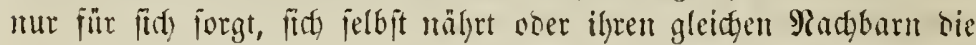

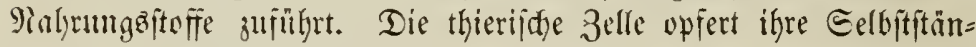

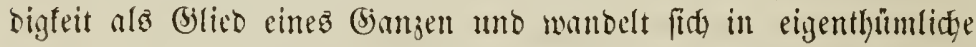
Drgane un, weldje den Bedurrfnififen dez Drganišmus bienen.

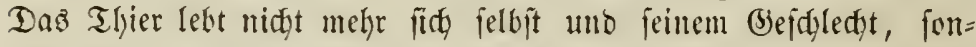

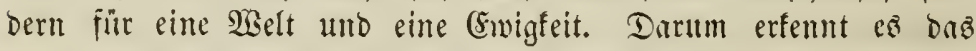
3iet jeines Etrebenz nidgt mekr in feiner 2 Biedergeburt, jonbern in feiner Empfindung, feinem Betwuftein yon ber 2husenwelt.

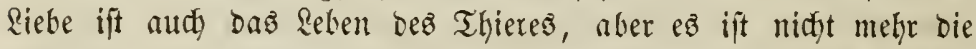
robe Riebe ber PFlanje, bie mur ben Stoff fudyt und in jeine $\mathfrak{R a}=$ tur verwandelt, fie gewinnt geifitigere Formen, beginnt bie Sintur

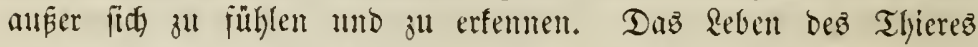
athmet Ereiheit, feime (sntwiaflung ift Das Etreben Danady. Das Thier wählt feine Rahrumg, jeine Sgeimath, jeine freunte. Pur auf ter niebrigiten Stufe jeines Dafeins beifhräntt fich feine zrei=

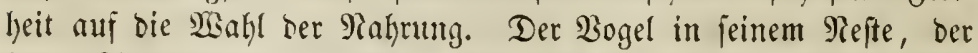
junge Qöme in feiner Şăhle, fie harren ber Epeife von ber Siefe

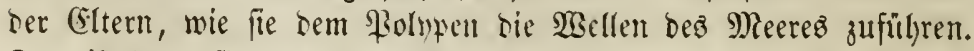

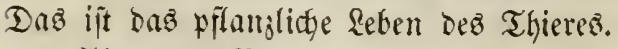

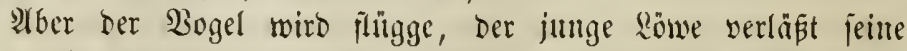
Sëhle; frei jagen fie ber Beute nach und futtenen fint bie eigne Wobnung, bauten bas eigene Meft; bie Mieduje reist fide von 
Dem Stiele loz, ber fie nody polypenturting an ben Boden des Mec=

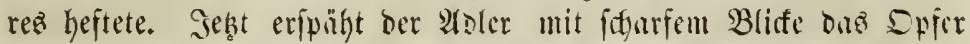
in ber Tieje, jebt laujdyt ber Söwe bem jernen Tritt bes Meniden;

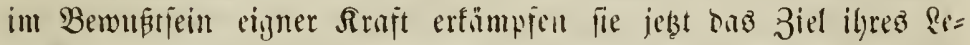
bens und wählen frei die (befübrtin ilger Tinge, welde ifye (be=

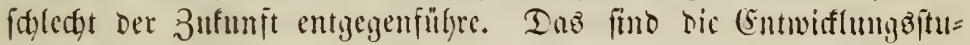
fen thierijoen fekens, weldses mir nicht in oem smbivioum alfein, fondern von bem gunjen Thieryeidyledt angeitrebt und vermirflid)t

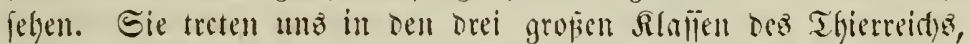

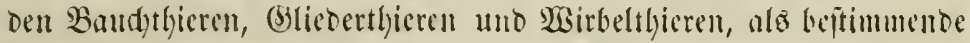

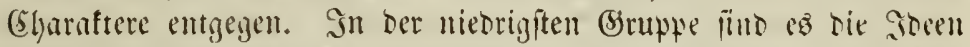
Der pflangliden Igätigfeit, Ermabrung und 3eugung, in ren böbe=

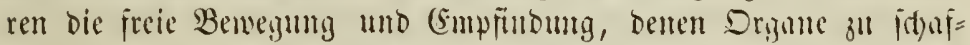

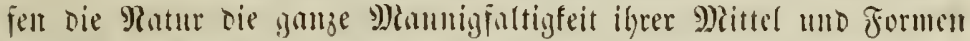

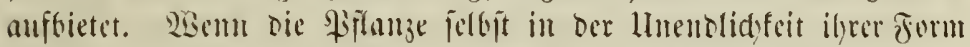
Daร alynende wejen blieb und es nur in ber Blüthe ju sinem ge=

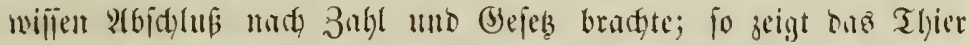

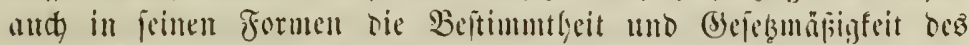
freien Wisejeng. Wenn and) auj Der niebrigiten Enme nod) pflanz= lidge linendidfeit und Gejeblofigfeit auftritt, menn bie siatur fidt)

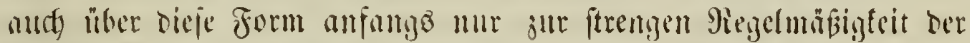
Blume erbebt, Der nollendete Typus dez ederin Thierez ift bie Eyn= metrie, weldye jeocm Sheile jeine eigenthümlidbe Beziel)ung zum an= Dern giebt, und nidjt blok cin Dben mo llnten, fondern audy ein

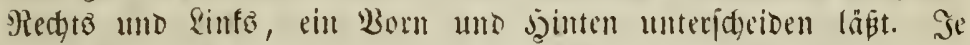
reiner bieje form hervortritt, ImI fo höher erbebt fith bie thierifde

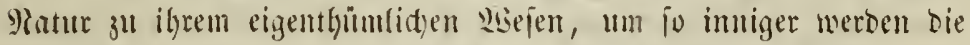
Begiehumigen tor Theile unter fich und zum (Sangen. Yhur umuoll= fommene Thiere, in Denen die Tremnung Der Drgane anz bem urant= fänglidgen (5haog nod) nisht cingetreten ift, laffen eine Pblöung ein=

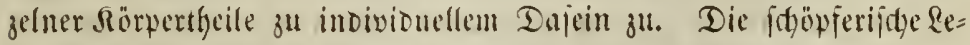

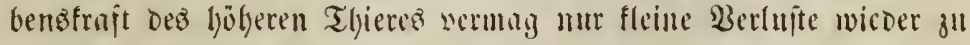

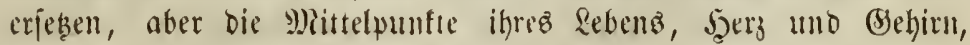

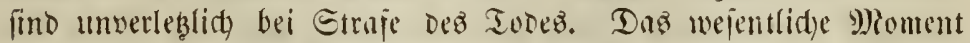
zur weitern Snoinionalifirmng ber thierifden formen liegt in ber

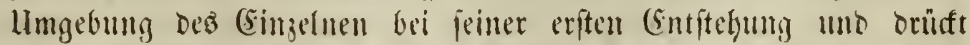
feiner allgemeinen Soee Den Egarafter Der Beptimmtheit auf. Slima, 


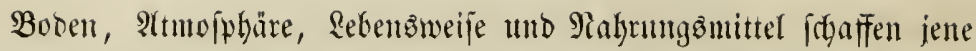
bunte Mannigfaltigfeit ber Formen, mit welcher unz ber einfadge

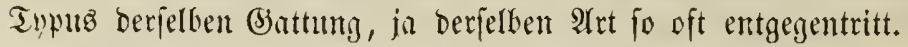

Bieber ift

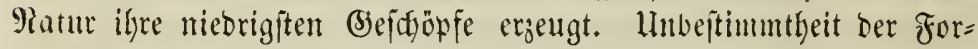
men, Mangel an Bewegungz = unb Einnesorganen, bollendetere Ftusbiloung ber zut (Erthaltung nöthigen Beroaumgaorgane bezeid)= nen ifren mejentlichen Shgaratter uno veridgaffen ihnen mit Rerft

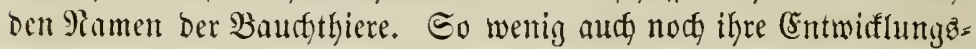

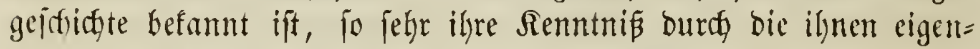

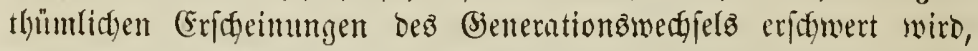
bie uns daffelbe Thier in bent veridgicbenften Formen unb ben man= nigfaltigiten Rebensweifen zu verfolgen zwingen, fo ift body in ber

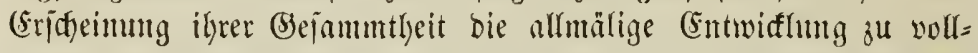
fommuterer Drganifation unverfembar. Die unregelmäjige Bsejtalt

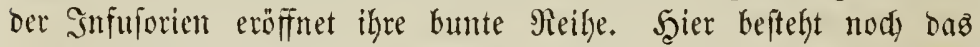
ganze Thier oft aus einer einjigen Belle, welche im Snnern auz=

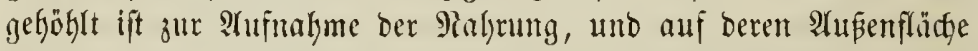
fich bewegende $\mathfrak{B}$ oritemwimpern finden. In ber Sugento ber höher

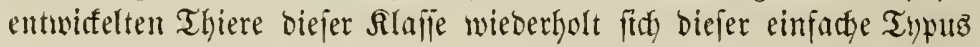

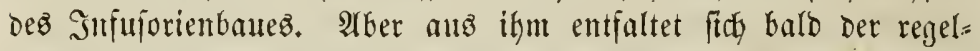
müsige, ftraflige Typuz, ber unz an bie Blüthen und Früdyte Dez Piflanjenteidgz erinnert. Die Sungen Der Medujen, bie autz Giern erzengten Sungen der Polypen, hödjit mahridgeinlidy audy bie ber Stadjelfäuter find in ber erften Periobe ihres Rebens infujorien=

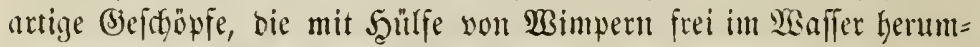

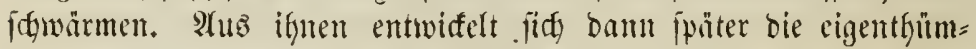
liche (beftalt ber Göheren Thiere ber Rlajie.

Die \&olvpen zeigen fojon einte gröfere Minntigfaltigfeit ber

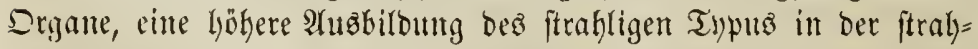

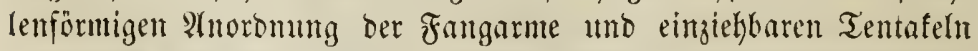

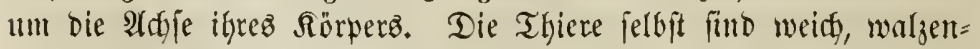
förnig, mit centralem Munde, ber in einen einfadyen, in ber 2acjje gelegenen Darm fühth. Bald entwirfeln frơ Sunge ans Eiern, Die aufauge infuforienartig, mittelitt ifyer 2 simpen frei untherjowim=

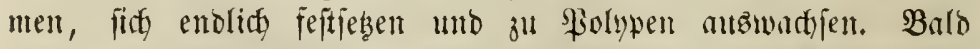
bilben fith Sinozpen und Eproffen, weldge nit bem Mutterthiere 
im 3ufammenlyange bleiben und fo arfmälig ganze Etöde bilben,

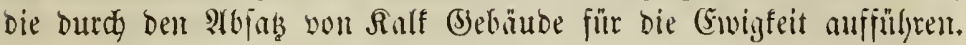
Die volffommente itralglige Srganifation zeigen bie eigentlidfen Etrablythere voer Etndelfhüuter, Deren falfigez bjerüit in feinem

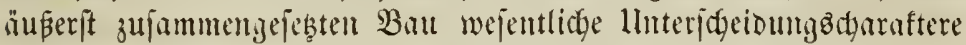
Darbietet. Man theilt fie Doher in Scanfiterne, Seefterne moto See= igel. Der אörper ber J̧ararferne liegt in einem bedyerartigen, in

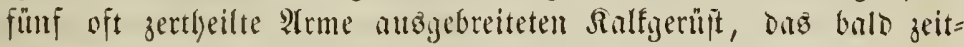
lebent, bald mur in ber Sthgento burdy eine falfige Gäule an ben Boden befejtigt ijt. Bei Den Eeejternen Dngegen ijt der siorper

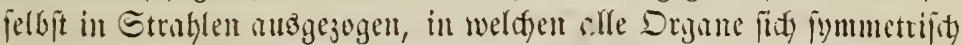

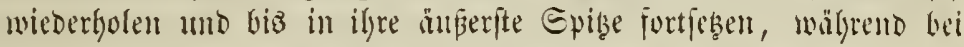

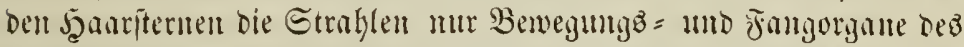
fdreibenfürmigen Rörperz fint. Die Eeeigel bieten fiton cinten ent= miffelteren Drganijationgtypus Dar. Sie belizen meift $\operatorname{Singel}=$ voer

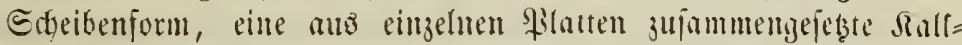

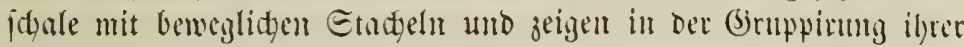

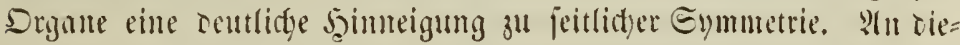

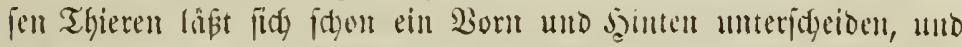

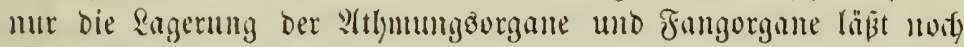

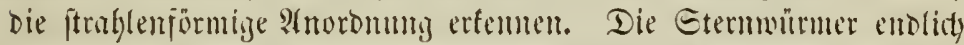

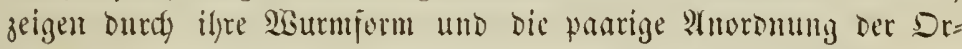
game nod) auffallenter Das Etreben der Miatur, bie Typent trob

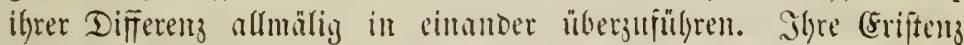

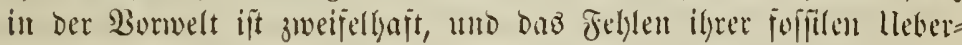

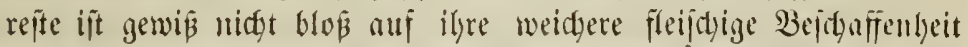

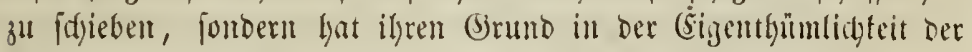

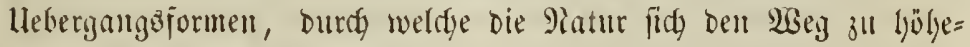
ren Entwifflungsiftujen bulynt.

Die hödjte (3)ruppe Der nieberen Thierwelt bildent bie Miullus=

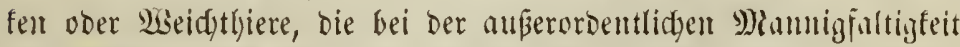

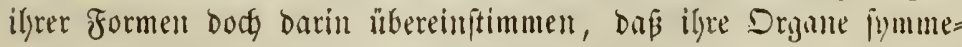

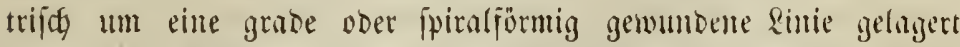

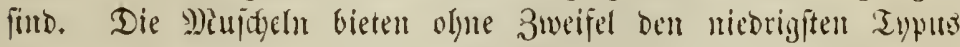
Derjenigen Bseidsthiere Dar, weldge für Die (Sejdjidte Der Bonvelt won Bedentung fint. athgemein befizen bicje Thiere zwei larte, falfige Edgalen, weldye oben burdy ein Edylós aneinander befeitigt 


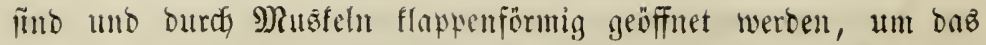

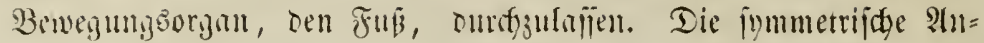

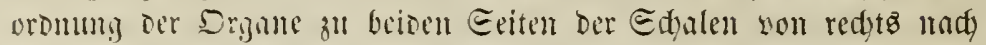

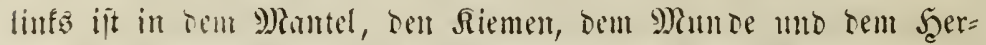
jen remlid erfembar. (Sime fonberbare Ameidung zeigt bie

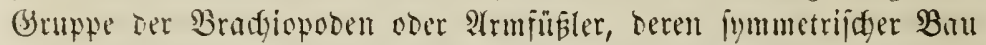
won oben mad) unten geft uno jitharfantig voripringente Eeitens ränder verurjatbt. Da wo iljre ungleidgen Edyalenbälften zujam.

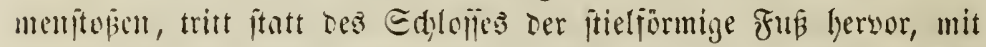

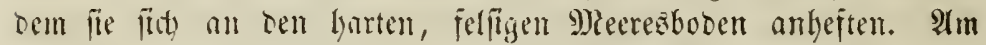

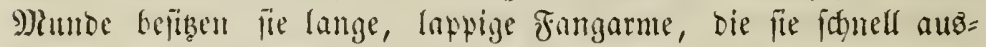
itrecfen uno einjieben, Dabura einen Etrubel im Wafjer erregent,

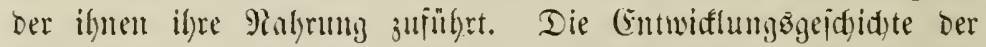

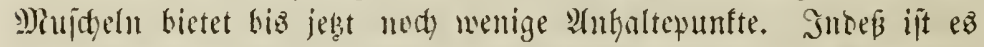
Dod) gelumgen, rie eigenthüm(id) geptalteten Sungen Der Malermu= idgel zu beobadten, Deren imere, ipiralig gemundene Srgane nod an bie Fanjarme ber Bradjipooen erimnern und deren untergeord= nete Drganijatonḡitupe andenten.

Bou grö̈erer Bcobutung fïr bie Begemwart wie für bie Bor=

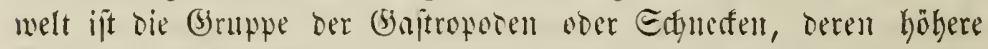

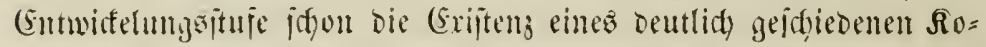

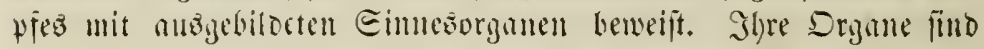

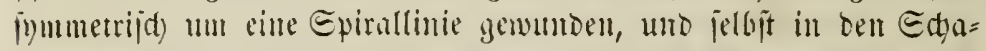

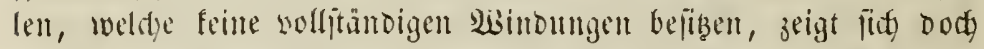

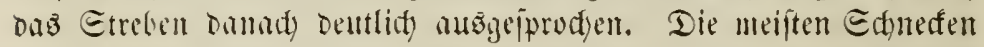
befiben eint falfige Edgnte, mur wenige fund maft, und and bieje

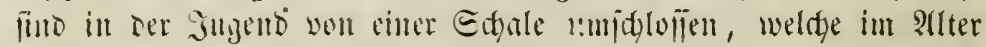
abgeworjen wird. Die biaberigen llnterjudumgen liber bie (snt=

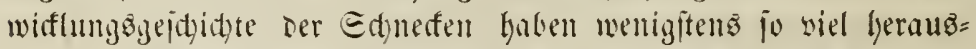
gejtellt, daßj riejenigen Familien, in wilden die Deffnung oer Edyale gunzrandig und beoutumo groj ijt, bei weldgen ber Fuß unentwiafelt ooer Durch bäntige Eegel erjegt ift, umb wo ein groker

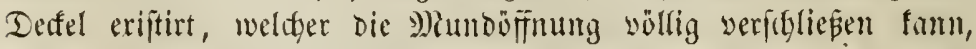
cinem niebeten Drganijationgtypus angehören. Den (Sipjelpunft

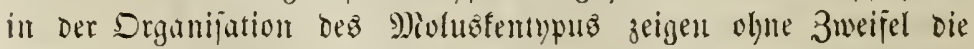
(Eephalopoden oder Ropfin̈ wie der Sautiluz, theils mit eimfadyen Platten, theils gans naat, 
aud) inlber Sugent, wie bie Dintenfilitye. Die Entwidfungägejdyidte

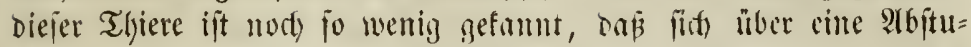
fung in igrer Sryanifation nod) weniy mit Bejtimmtlecit entidgei= Dell läpt.

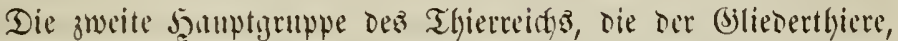

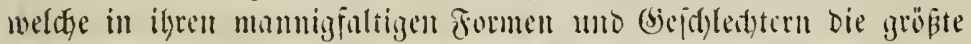

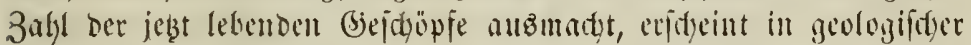

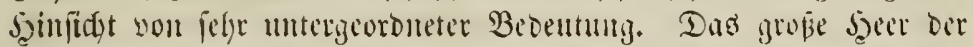

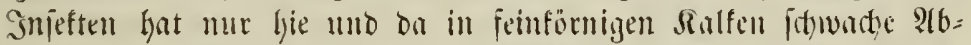

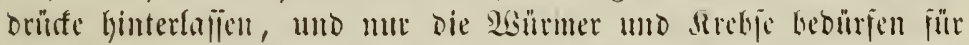
unjern Zwed eincr Belendtunig. Dns conjige allen gentinfane

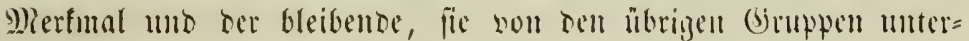
idpeidende Sharafter ijt eill langgeitrefter, in melyr vorr minder

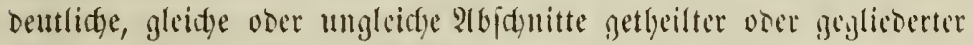
Sörper. Die Refonsineije bejonders morificirt ifge furmen mb be=

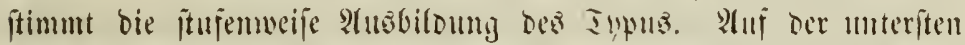

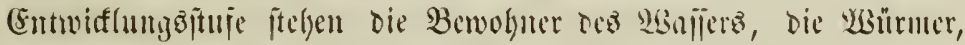

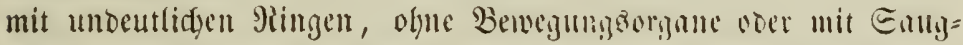
nitpjen und Borfen, bismeilen aber fqon ma bejonocrn Blntgefäben

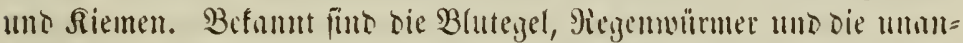

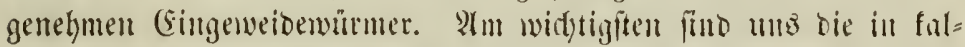

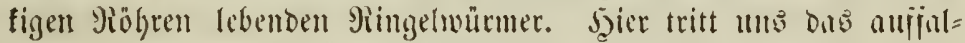
lende Beifpiel einer rüfidgritenten Mietumorplgoje entijegen. Daz

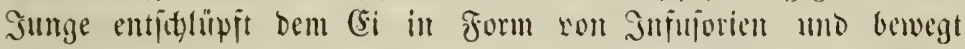

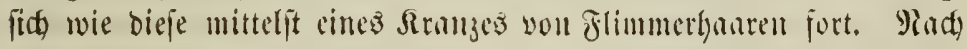
und nady befommt es (s)licoer, lebt einige 3eit mit entwicteltem

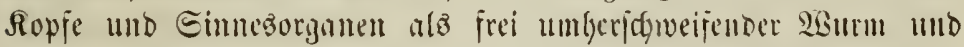

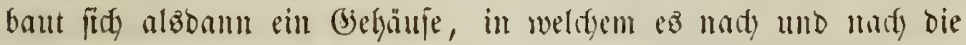

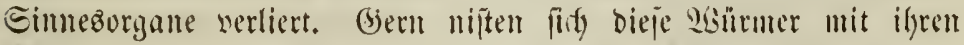

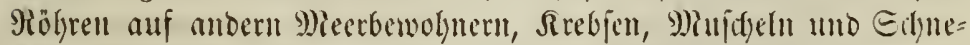
den an und fommen mit ilgnen and anz frühern Eroperioben ver= fiteitert vor.

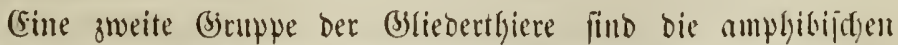
Rruftenthiere voer $\mathfrak{R}$ rebje, beren wejentlid) werictiebene formen bie

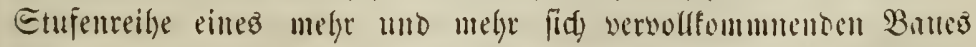
bilben. Şier wird es zuerit Bejteben der Matur, orei Jemuptab=

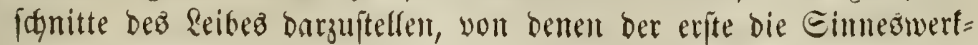


zeuge uno Den Nund trägt, Der zweite bie eigentlidten Bewegung = organe, ber britte bie Şauptmajle Der immern Dorgme an fidy jielyt. In ilyer Bolfendung Geipen bieje abjofnitte Ropf, Bruftajten und

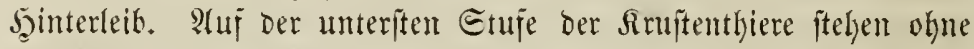

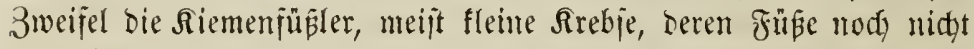
zum Sielgen bienen, fondern in blätriger form und ziemlidy zahl $=$ reidy all ber llnterffädye ber Brujt angebradyt, zum Echwimmert und

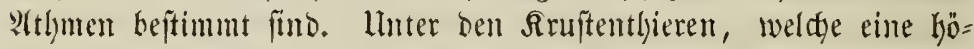
here Drganifationgitufe einnelymen, zeifgnen fich bie fonberbaren

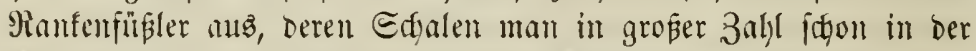

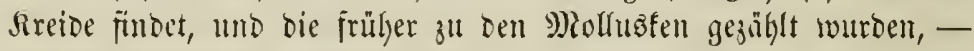
fo abweidgend ift bie Form uno Drgnnifation ber ältern Tlyiere von Dem gewöhnlidgen Bau Der Sruftenthiere. Sm entwiffeltan 3uftande

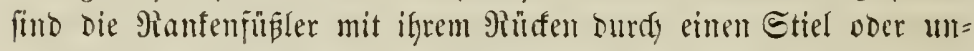

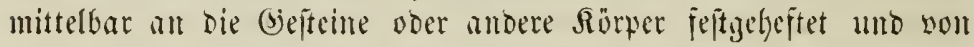

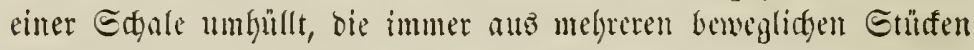
beftebt uno bald zweiflappliz ift, balo auds cincm oben offenen

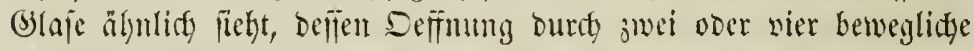
Slappen gefdlofien werden fam. Ticje Ramfenjübler baben bie vollitündigite rinffigreitende Metamorplyoje, welche wir in ganjen Thierreidy femten; Denn witsreno die Sungen zujammengejebste $2 \mathfrak{A}=$ gen, fühler an Dem Sopfe uno geglieberte Edgwimmfïp̈e befitzen, haben bie 2rlten Plugen uno fühler verloren, und ihre füpe find in lange, gervundente Panten verwandelt, weldge nidgt megh zur Srtšbewegung, fondern als Fungarme bienen. Eime ähnlidge rüt= id)reitende Metamotphoje erleiden and bie Edmanoberfrebje und Mäberthiere. Den bötyten Typus Der Entmiaflung zeigen bie De= fapoden oser jebnfüpigen Srebje, weldge unter affen Thieren bie größte Eymmetrie im Bau uno Das genauefte Fefthalten an gefebe

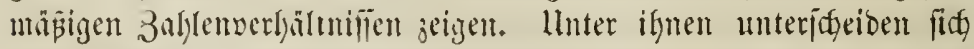

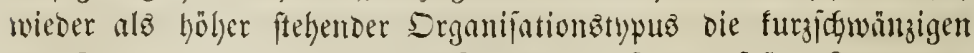
Rrebje, weldye mefre jum itufenthalte auf bem fejten ?ande be= fimmt find, uno ju benen bie Sinbben ober Tajdentrebje gebören,

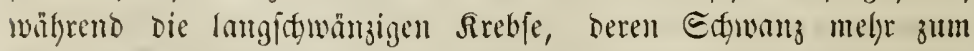
Sdfwimmen eingeridftet ift, und unter weldge bie gewöhnliden Jheftebje uno Soummern eingereift werben, eine niebere Drgani= jationsifupe behaupten. 
Afle

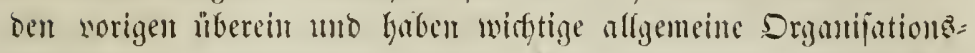

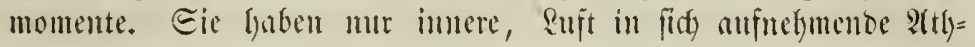
mungzorgane, einfache Brangfüpe, nie floficn, bismeilen and ju=

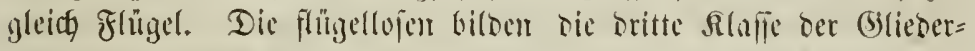
thiere, bie fpinnenartigen. Dir einen unter biefon unit zalf(reidfen

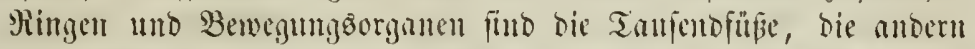

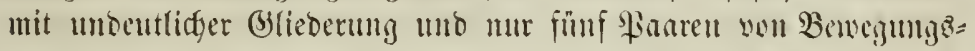
organen, bou benen nur vier wirflich zum (bieben bicnen, fimb bie

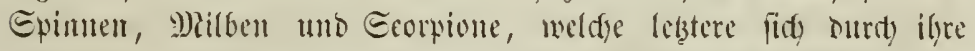

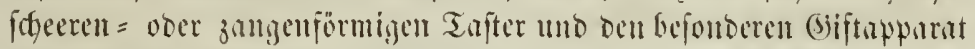

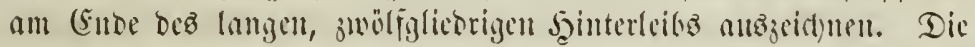

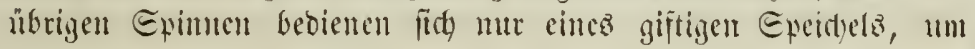
ihrent Fang iofort зu töoten.

Die lebste Rlaffe ber (s)liebertljiere bilben enthlich bie geffingelten Infefterr. Die glägel felyen hier feltent gantz, wentigjtenz nie ciner ganjen Bsruppe, fondern immer mur cinzelnen Familien, Bsattungen

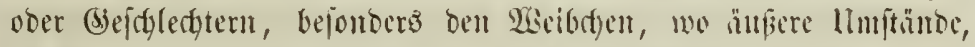
meift die parafitiface Rebensweife, igre Entwiffung bemmten. Die

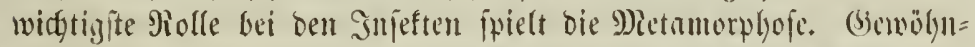

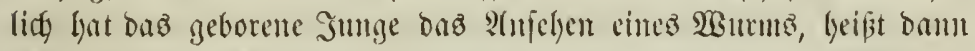
Minoe, Earve, Manupe ober Engerling, uno geht erit, nadoocm es

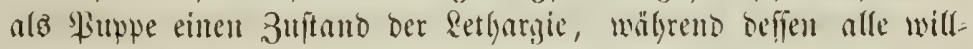
fürlidgen thierifogen Funftionen rulfen, Durdflebt bat, in bic fprittere Form bes reiferen Rebenżalterz n̈ber. Eo Durd)huten bie Infeften,

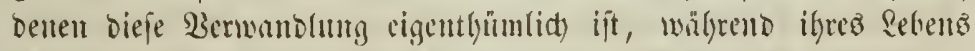

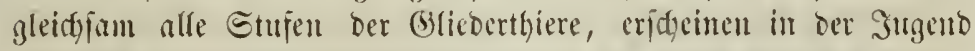

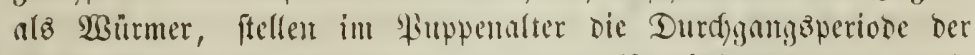

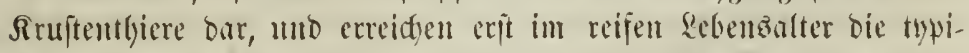

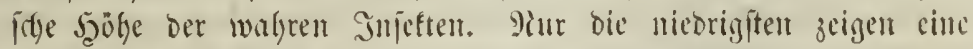
unvolfoumente Mietamorptgofe, ba ilyre Sumben fid mur burdy ifye

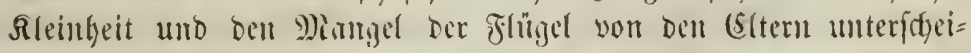

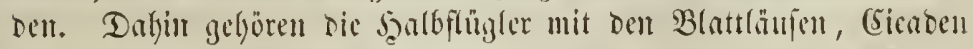

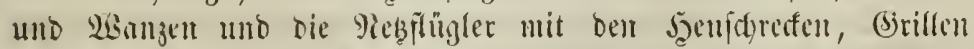

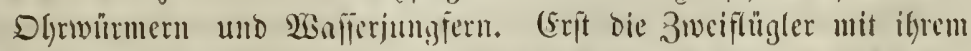

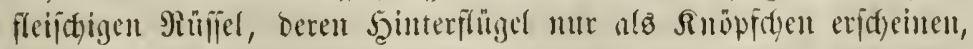

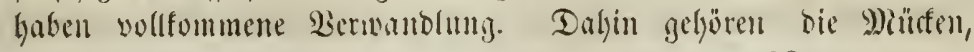

ll te, Meltitl, 3. "นf, 


\section{4}

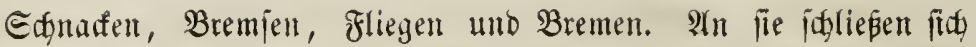
bie Smmen an mit fangenten Munthtyeilen, bie ound ihre gejellige

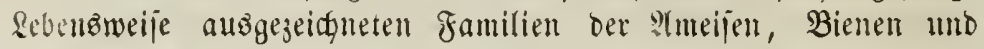
Weipen umfaffent. Dann fommen bie liebliden, buntfarbigen Edymetterlinge mit vier groß̧en, vou idunpenfürmigen 5̧aaren

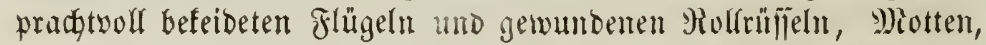
Epanner, Bulen uno Epimner, Titg = uno Atbenofalter. (Enolid) folgen bie $\mathfrak{R} a ̈$ fer, burdh freie, beisende Mundtheile, beweylidyen Bruftsaftenring und Gornige Sorberflüget aużgegeidnet, bie in ifren

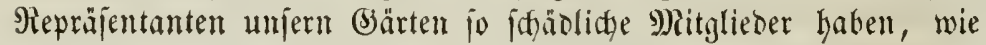
Die Borfenfäfer uno Miaifajer. -

Die britte Şauptabtheilung Dez Thierreidg bilden bie WBirbel= thiere, weldye einen ganj eigentfyumlicten Drganijationgtypus be= figen, ber mit Demjenigen ber vorkergefenden in burdyanz feiner

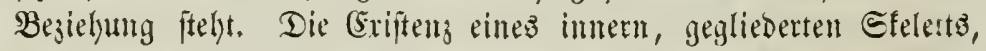

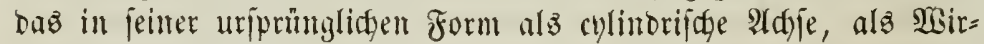
belfäule auftritt, um weldge herum fïth bie serfobiebenen Drgane

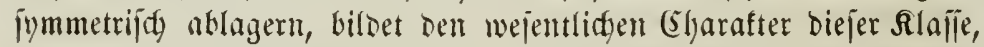

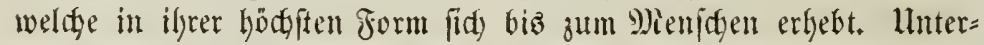

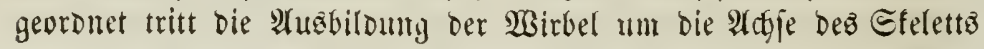

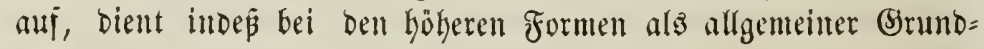
dyarafter.

Betradytent wir Daв Pieidy ber $2 B$ irbelthiere in feiner Bejammt=

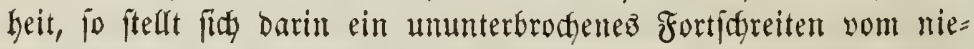
Dern zum höhern Srganijationzispus dar, uno eв war gerabe biefe Erfenntmis ber fortidgreitenden Entwifflung in Dem WBirbelthierreidhe,

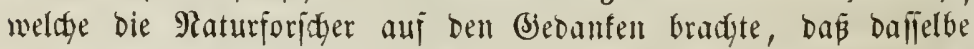

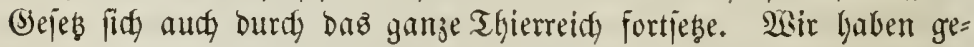

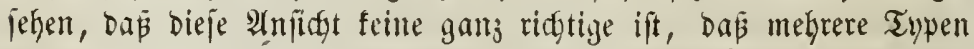
eriftiren, weldge jidh nidgt auf einander zurüffüfren lajfen. Die

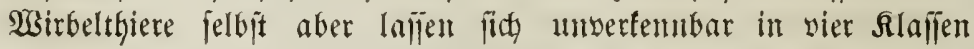
trennen, meldge einte melgr ober minder solfommene Drganijation befizen.

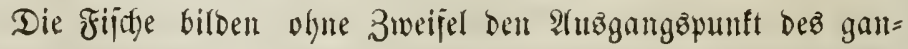
zen $\mathfrak{B}$ irbelthierreich und bieten bie unvolfommenjte Drganijation in jeber Şinjiatt Dar. Shynen allein gehören Thiere alt, bei wel= den baz Efelett noch auf bie einfade cylinbrijate 2 daje bejagränft 


\section{5}

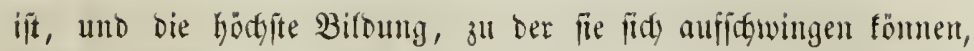

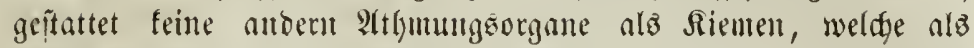
äuperlidge Drgante ben imeren Rungen gegenüber immer eine fefre niebere Stuje der Entwifflung fundthum. Pirgentos läpt fich fo

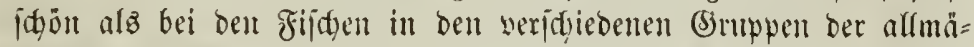
lige Fortidgritt in ber Drganifationt und die mannigfadfe atbivei=

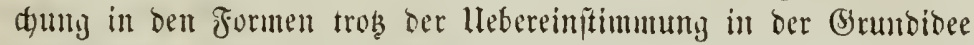
narfweijen. Die miebrigite Stufe nefmen bie Rinorpelfijode ein, bei benen fids nodh bus Efelett in ber lrrform eimez fnorpligen Brallert=

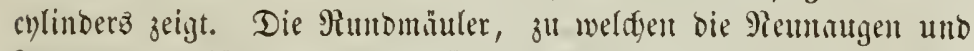

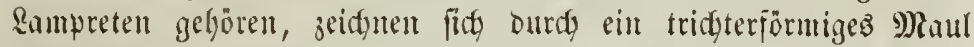

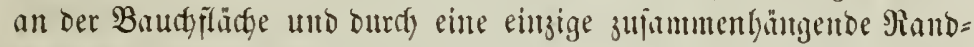
flofie um bent ganzent hintern Thail bes Sörpers anß̧. Bei ben Quermäulern, weldge die Siodgent unt Şaififge umpifien, befteht

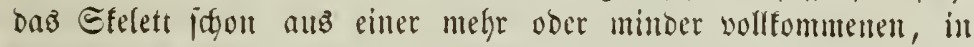
fnorplige Wirbel abgetfeilten Eäule. Eie zeigen inmer parrige Flofien und eine ganz eigenthüutidy gebildete Edywanjflofie, ihre

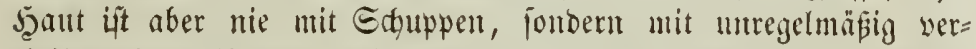
tbeilten ftadyelförminen Şautfnodyen beffeidet. Sine żweite Pieibe

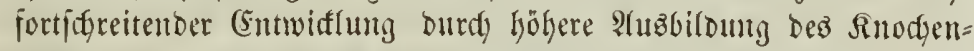

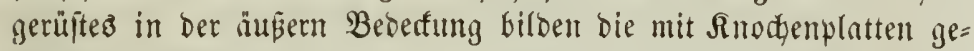

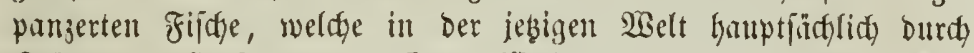

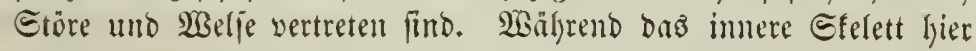

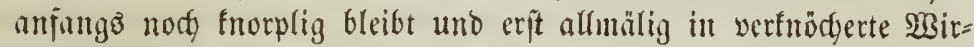

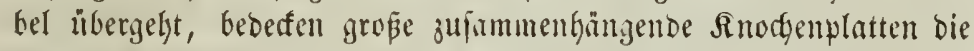

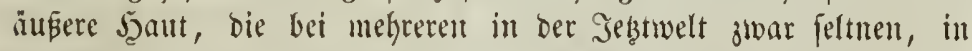
Der Borwelt aber jegr häufigen (befdedederen eine rhombijaje ober aud eine abgerunbete bejtalt haben. In Der ganzen itbrigen gro=

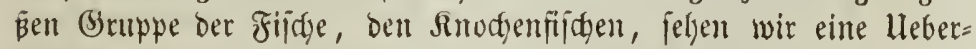

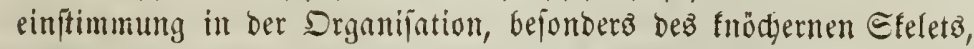
bie fie falt auf cine gleidge Şühe ber Entwiflung ftellt. Rut un= tergeoronete (5haraftere, wie bie Atnorbmung ber Floffen, beuten auf veridjiebene Srganijationgijufent Gin. Die Beobad)tung Der (Ent=

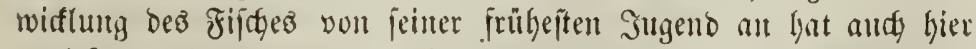

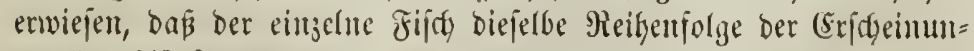
gen burdstäuft, meldge wir in ber Befanmmtgruppe ber jeb̨t lebenton Fiidge beubadgteten. 


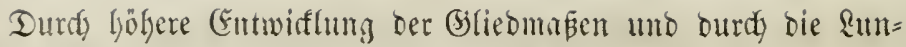

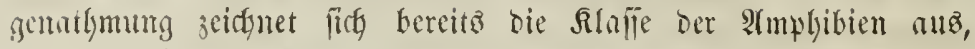

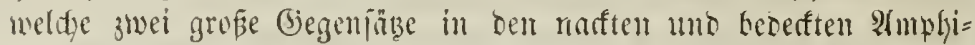

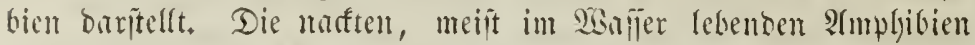

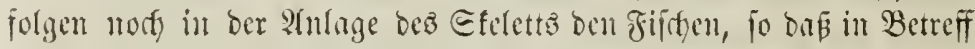

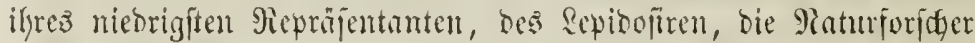

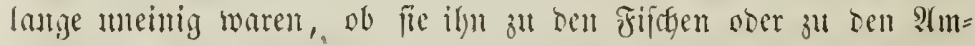

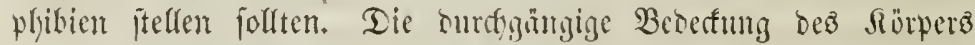

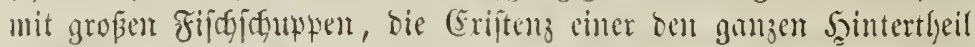

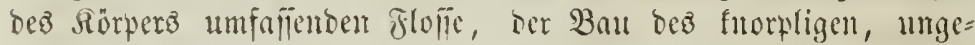

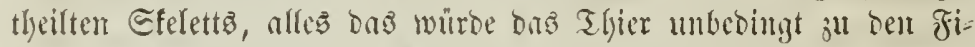

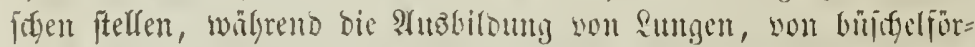

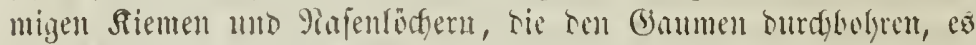

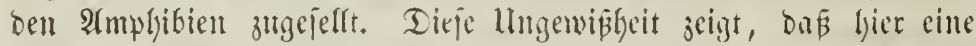

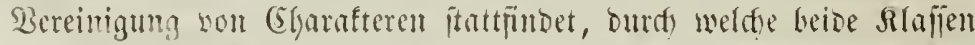

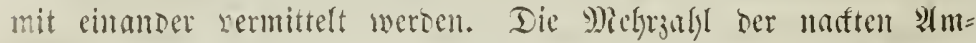

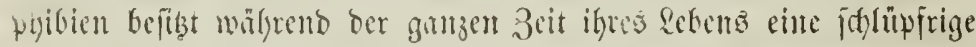

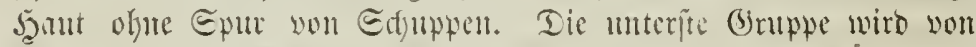

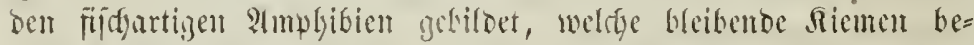
Fiben, zugleidf) aber and) Durch Rungen atlyment tömen. Eie bil=

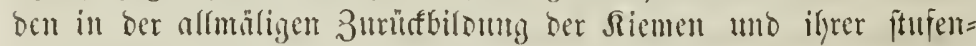

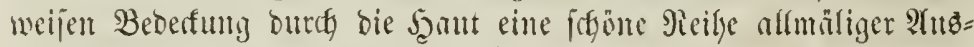
bildung jur Rungenathmung uno fomit zu böherer Drganijation. Die mur burdy Ratrgen atfmentoen 2 mptibien haben theilb Edymänze,

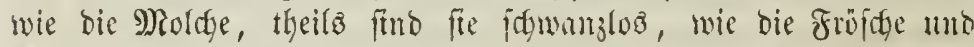
Rröten, jene mit unentwifelten, bieje mit wollfoumen entwiffeltent

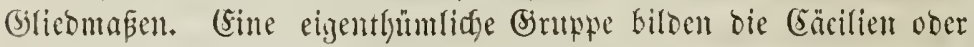
Blimbidgleidjen, weldje wegen Der idglangenartig geitreften Form ilyres Sörpers frülyer mirflidy ben Edylangen beigefellt wutben.

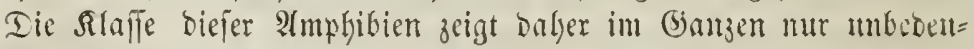

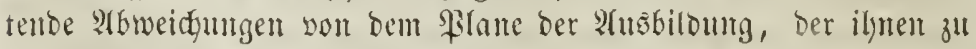

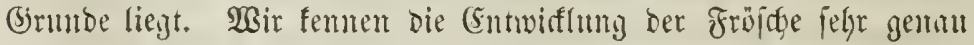

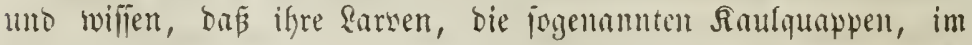

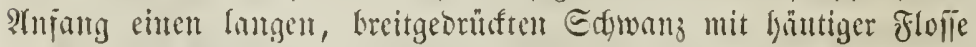

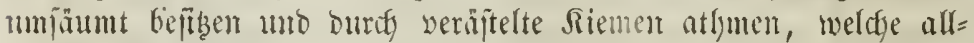
mätig verfdminten und burds imtere, unter ber Saaut werborgene

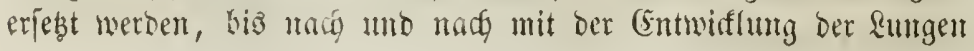


aud) bieje innern Siemen zunüftreten. Estritt für Sdyritt folyt siefer (Entwiffluty ber Pthmungsorgane and bie bes Sfeletts und ber (S)lieber, jo bas in allen (Egaraftern fid) in ben veridgiedenen (Ent=

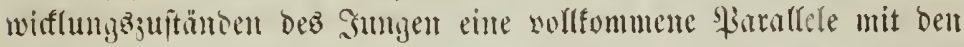

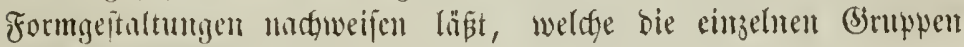
Der Amplyibien zrigen.

In ben bebeuten Hmptibien, ben Peptilien, laffen fith surei Şauptridstument der Drganifation unteridgeiben, bie gleidgjam pa=

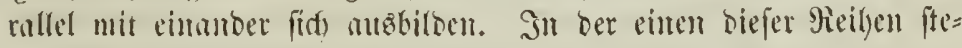

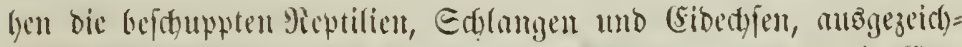

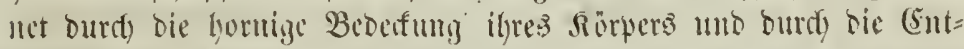

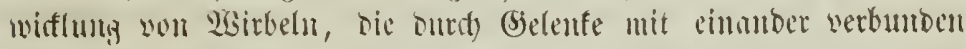

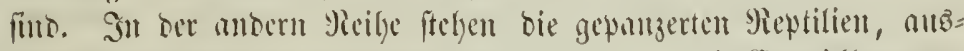
gescidfut burd) ibre bejontoere Buffubiloung und bie Entwidtumy ge= waltiger Snowemplatten in ber ätperen Sant, welde entweber ge= tremt bleiben, wie bei ben Sroforifen, ober fich ju einten einzigen

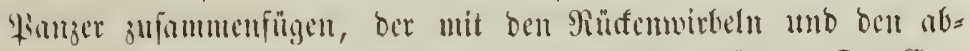

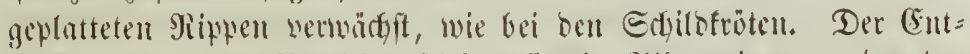

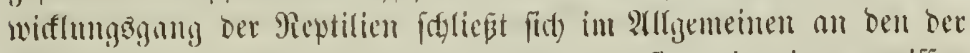
Bö̈get und Einthetbiere an. Die Sungen befizent in einer gewiffen Feriode iljres Eilebens Siemenpalten am Şalfe, bie jebod, nie zut

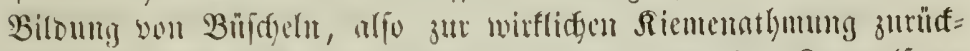

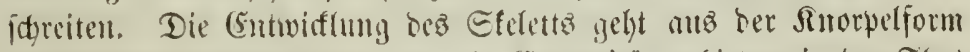
in gelenfte 2 sirbel liber, mo bie Ertremitäten bieten in ber That anfünglids bie befînt wou floffen bur, in weldsen bie eimjelnen

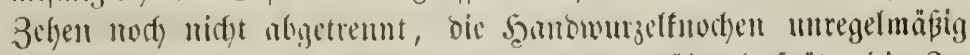

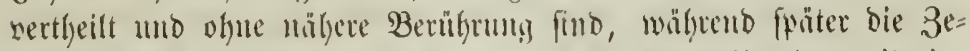
ben fidt) won cimmoer tremen mo bie Santowurgelfnodyen mit ein= ander artifuliten.

Sn ber Slajpe der Bögel, mit denen die mamblütigen Wirbel=

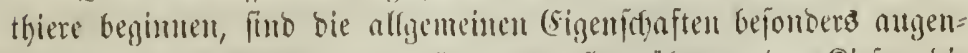

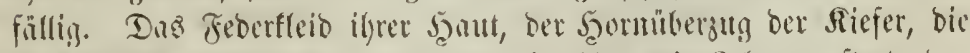

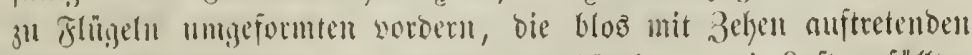
bintern (Ertremitittu, bie berbreitung bäutiger, mit enft gefüllter

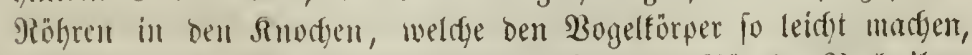

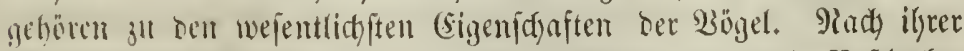

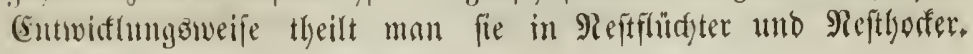


Ulnter erjere gelören bie Edjwimmnögel, Eumpfiögel, Straupe, Rafuare unb Şühner, zu ben andern bie Tauben, Rlettervögel,

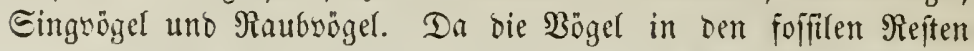

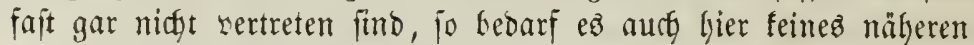
Eingehens auf ifre Dryanijation. -

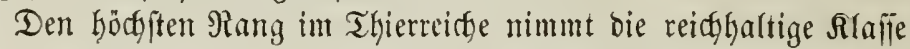

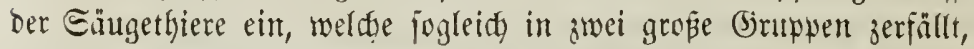
in bie ber Beutelthiere, weldy ein bem unvolltommnen Jugenbzuftante ifrer Sungen offenbar eine nicoere Entwifflungêfitufe Darthun, und in bie weit zahfreidfere ber übrigen Eäugethicre. Dieje reşteren zeigen burdf bie Esntwifflung ber (j)lieder uno Zälne mefrere Rei= Ken, beren niebrigite mit ben pflumgenfreffendoen Eirenen, ben eigent=

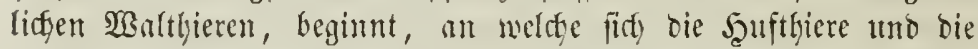
Diffghutter anjofliefen unit ifren maunigfaltigen Formen, bie in

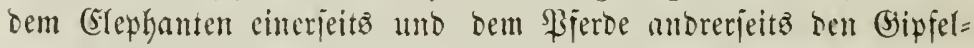
puntt iffer Bolfenoung erreidfen. Die eigentlidgen $\mathfrak{B a l t b i e r e ~ f a b e n ~}$ alle 3ll irgento ciner Zeit ifres Refens ipize, fegefförmige Zähnte, bie unter fith teine Beridgiebentheit zeigen, währent bie Eirenten

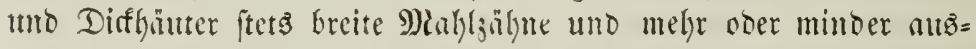

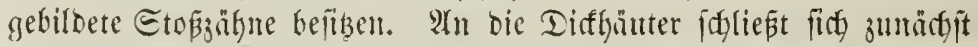
bie fonberbare Srattpe der zalnhlofen Sängethiere an, bie mur Baden=

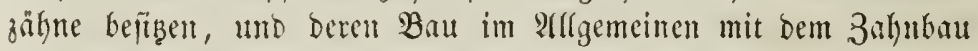
ber pflanjenfrefienton Eirenen nibercinfitimunt. Dieje ourds bie (si=

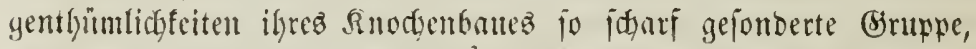
ureldye bie Fanlthiere, (bürteltgiere, Ifmeijenfrefier unt Edynabel= tgiere umidgließst, zeigt offentar in ilyer ganzen Drganifation einen

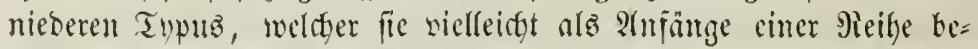

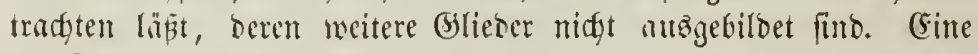

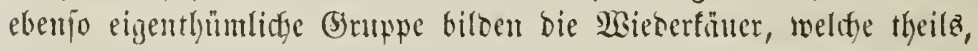

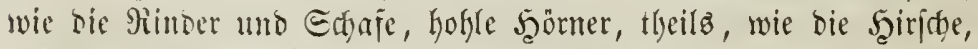

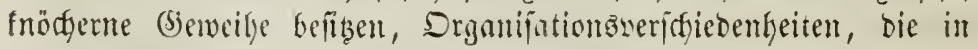
ben Ifntifopen und bajellen ifre Bermittlung finden. -

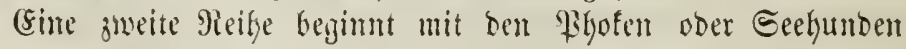

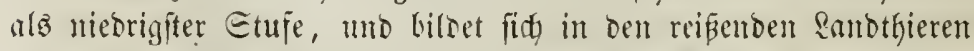

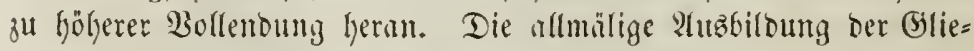

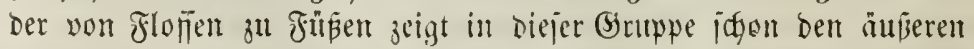
Fortidyritt, wälyento bejonberz bie Etruttur bes Bebjirnz audy in 
ben nieberen Sormungen Derielben ifren geiftigen Borrang vor ber

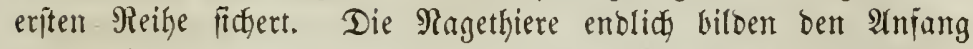
einer britten Sruppe, welde in belt Injeftenfrefiern und Fleber=

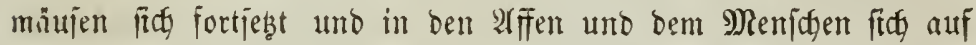
den Sifipel ber Drganijation erfebt. Şier ijt es meniger ber 3nhn= bau, als vielmehr bie Drganijation ber innern Theile, bejonderz

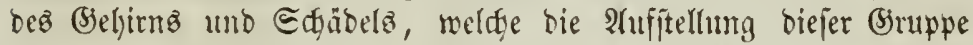

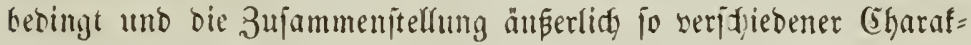
tere begrünbet.

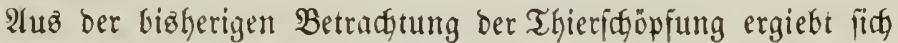
ein gemij̄er \&arallelizmuz zuijhen ber 'mbryonalen Entwiflung eimerjeitz uno den Drganijationztupen anbrerjeits, bie in ben er= wathjenen Thieren ber lebenten Exbopfung bargeftell werben. In

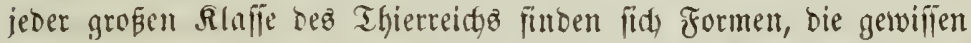

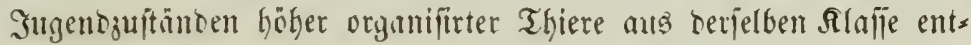

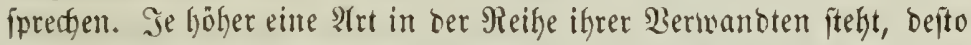
mebr 3uftüne wiro fie zu burdblanfen baben, elye fie bas Enogiel ifyer

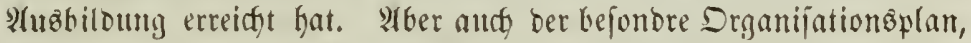

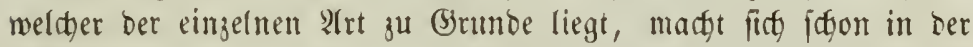
früheften Эugent geltend und mobificirt bie Erideimungen ber all= gemeinen Soee. Eo gleidyt ber Menidy aflerbingż in einer gemiffen

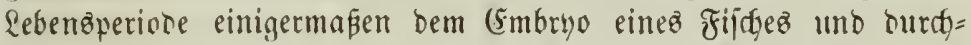

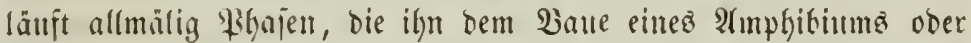
Reptilz ähnlids madyen; allein bieje Ielynlidfeiten gehen nie fo weit, baß man jagen fönte, Der Mienja jei zu irgento einer 3eit

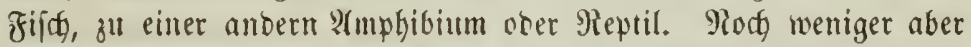

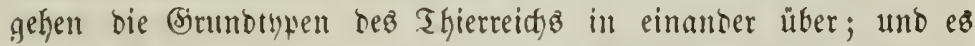
märe vollig lädterlich, behanten zu molten, wie man bizimeilen ge= than hat, oas ber (5mbrt)o eines હängethiers anfangs einem In= fuforium, cann einem Molltafen ober einem Sliebertfiere gleidye. Der (Embryo tritt im Gegentheil rom erften Begim mit Eharafteren auj, bie ifn unzweifelfaft einem tefitimmten Srganifationztypuz, ei=

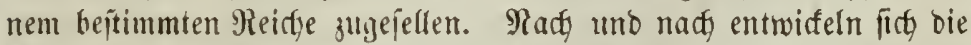
(Sharaftere, welthe ifju einer beftimmten Slafle, Dronung, Familie, (Hattung oder Wtrt heioronen, uno man fam baher als allgemeines

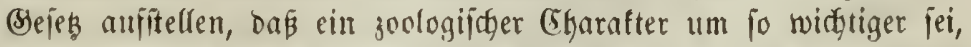
je frïger er fid im Embryonalleben auspräge. Diefe Betradtung 
wirft aud ein Eidyt au bie Srganipation ber Bormelt. 2 ud in

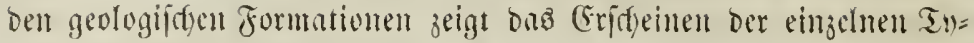

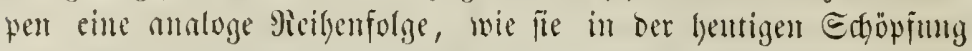

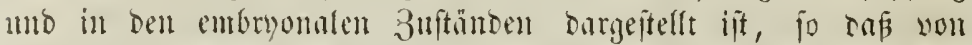

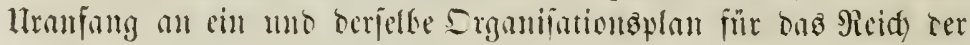

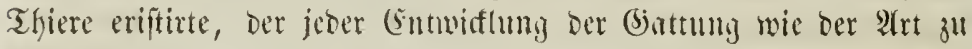
(jrunde liegt.

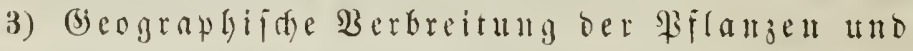
Thiere in ber begenturt.

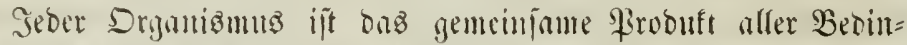

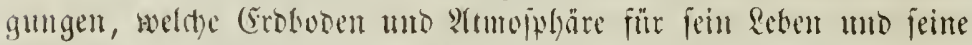

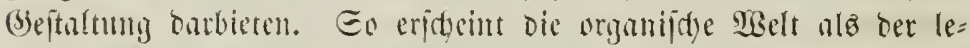

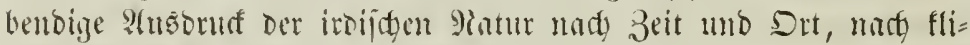

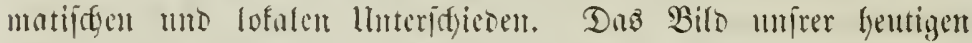

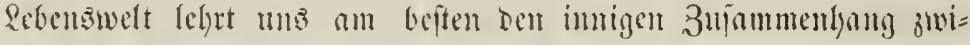

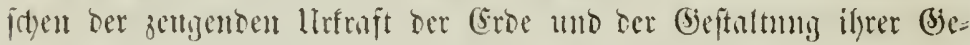

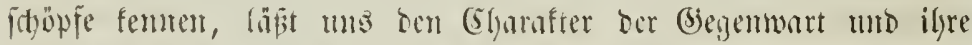

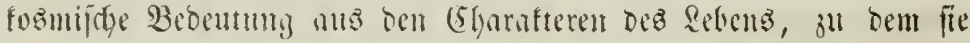

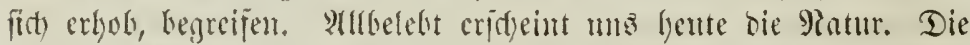

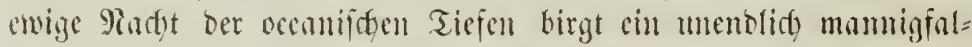

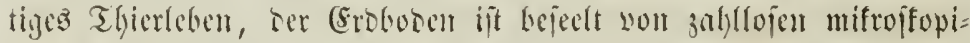

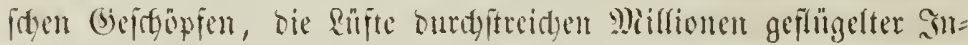

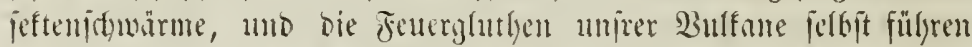

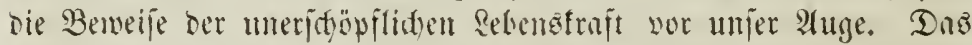

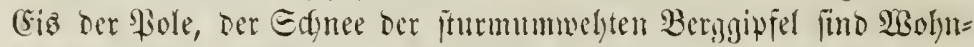

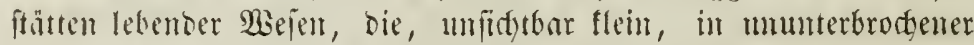

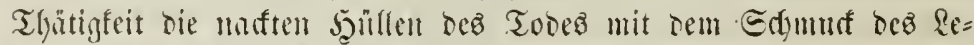

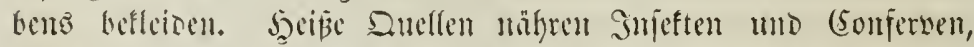

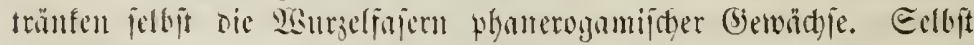

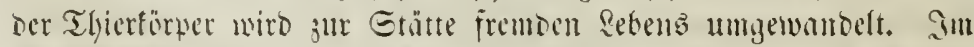

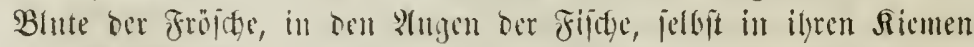

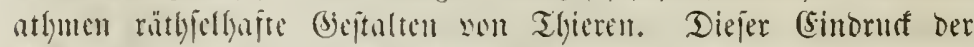

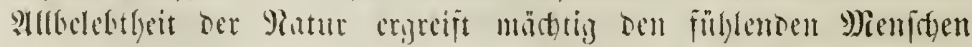
unter jebem simmetsitrid), in jesem Theil ber (5roe.

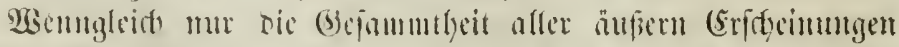

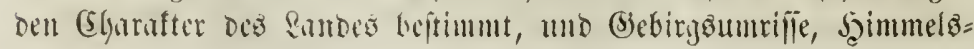




\section{1}

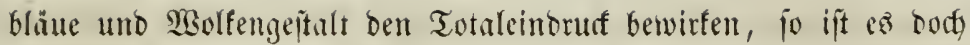

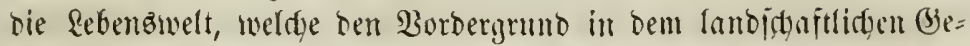
mälbe einnimmt. Wenn aber Dem thierijten Reben bie Mlafje fichlt, wenn tie Bemeglidfeit jeiner Snciniouen tie oft unjern Blifut entzieht, fo wirft die Biflanjenmelt ourdh igre itetige (Bröbe Defto

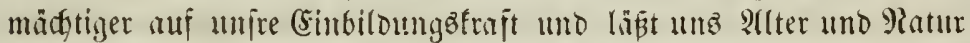

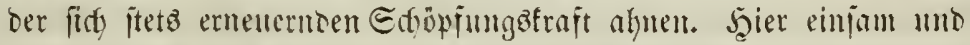

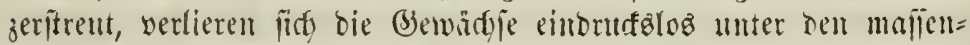
lyaften Gebilden Der rolgen Grofraft, bort gefellig mit eimanoer ver=

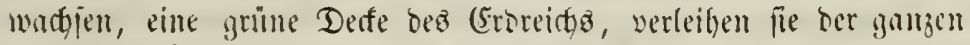

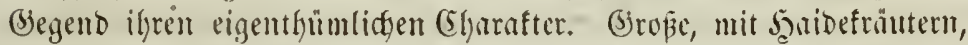
Torjmoojen noer Fledten überbefte Etterfen geben cinter Geijeno

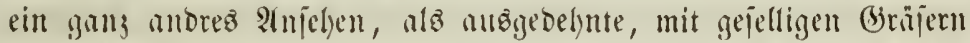

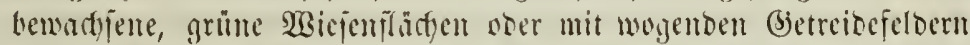

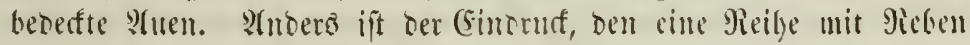

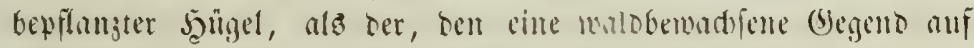
uns madt; anders bas bulftre Bilo cines Tammumatoes, als ber

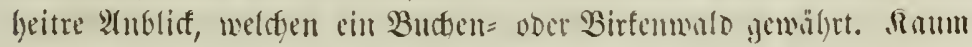

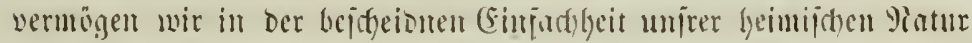

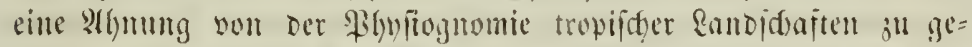

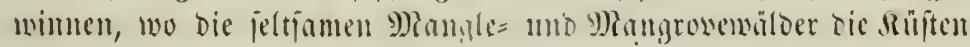

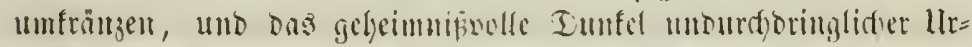

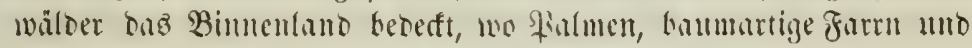

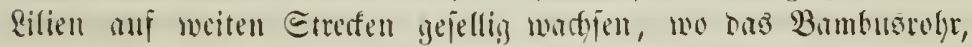
Der Riefe unter ben Bräjern, ganje WBaloungen liftset, woer wo bie Fieberrimenbäume bie hoben Berghänge mit einem umuterbred)enen

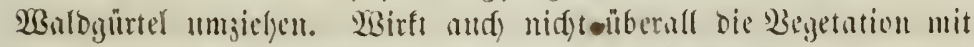

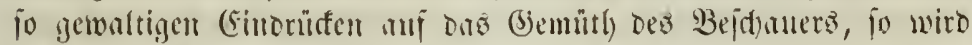
Dods jeoer (begento ourd) Thier= und fiflamgenleben ihr eigenthüm= lidjer Eharafter angepringt.

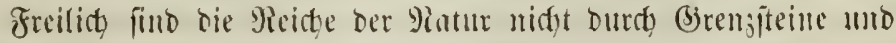

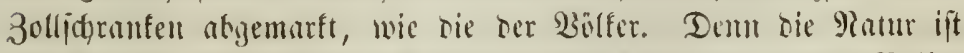

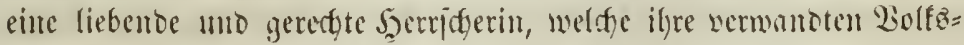

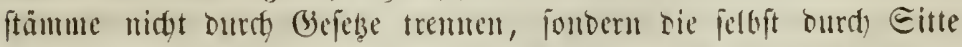

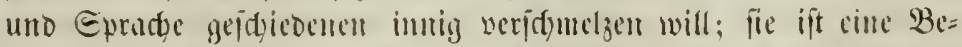

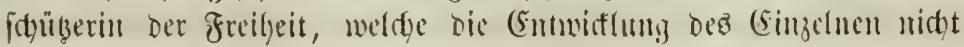
bemun, jonben ifyu frei Dell Boben feiner Thätigfeit zu fudben ge= 


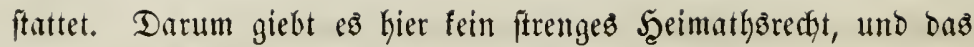

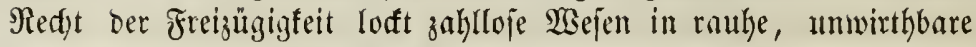
(Sefilde, um audh borthin ben Segen unt ben Sieg ber verflärenten Piatur zu verpfiamjen.

Die gröpte Freiheit herridgt in ben Regionen bes Deeans.

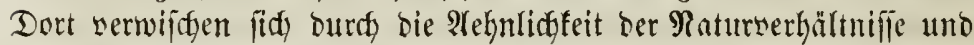
Rebensbedingungen aud bie llnteridfiebe ber Formen, unb biefelbe Ant herridft burd bie weiteften Fernen, yon einem Fole zum andern.

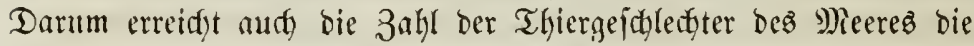

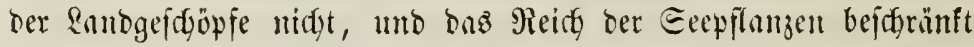
finf faft auf bie einzige gamilie ber Tange, bie int allent ifren Arten

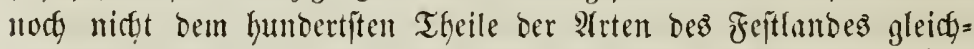

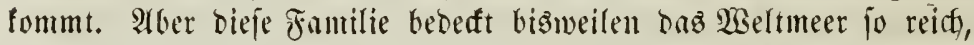

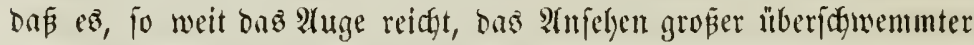

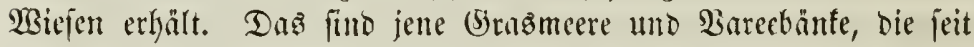

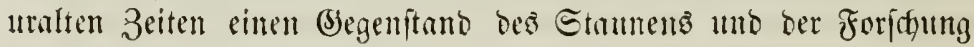

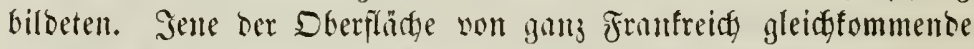

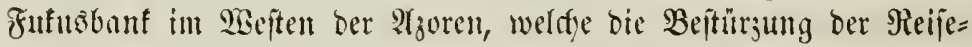
gefährten des Solumbuz erregte, loat jeit Junfrhumberten ihre \&age

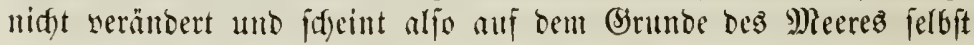

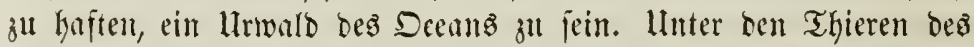
Deenns entwiffeln bie reicfjite Minnigfaltigteit uno frutlle bie Mol=

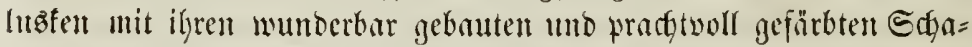
lent. Die raftloz Rlippen und Snfeln aufbauendent 壮olypen, bie Hhunenartigen Etralylthiere, bie zarten Mrebufent uno Duaflen, bie

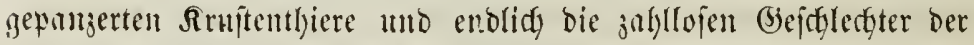
Fifthe, weldye bie Miere bes

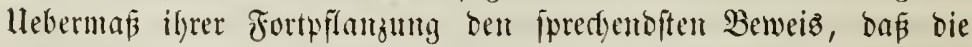

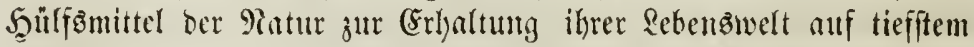

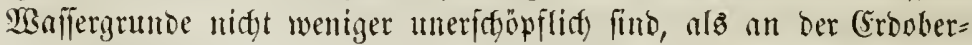

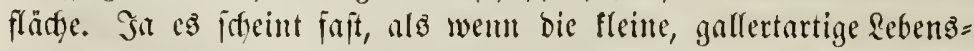

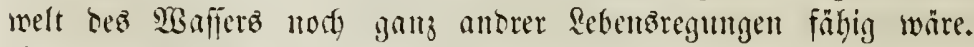

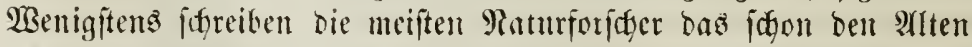
befanute muberbare Qenteften ses Meeres, bas fith in allen Meeren,

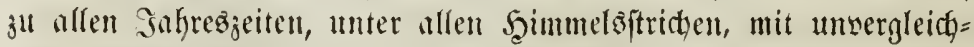
barer Prantyt aber in den Tropen jeigt, lebenten Seethieren, bejon= Derz mehreen mifroffopiliten Brattungen Der Medufenfanilie zu. 


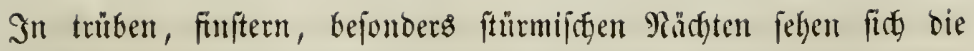
Seefafreer yon Ridyt umringt, ons bald mar bie Edjiffe umipiclt, Galo weitfin bas ganze Meer in Fetter zu hüflen foheint. Saier

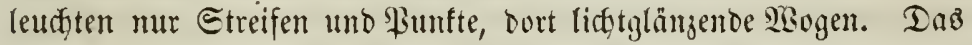

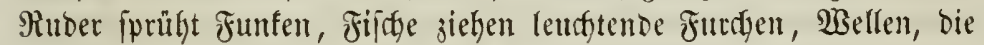

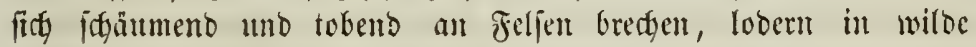
Flammen auf.

Benngleid baz Meer, baz von flimatifđen uno atmojphäri=

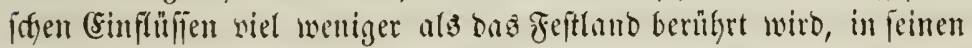
Seichöpfen eine jo gleidymäpige Berfreitumy jeigt, io giebt ez bod)

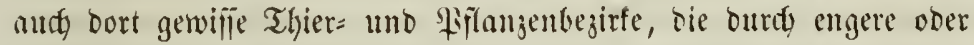

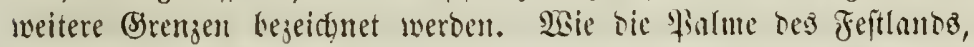

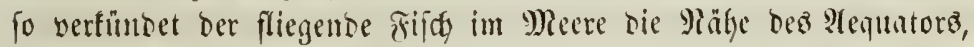

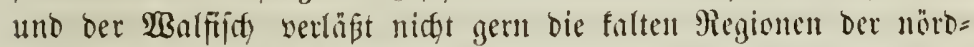

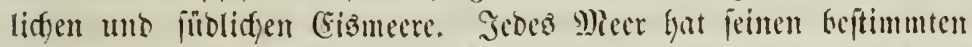

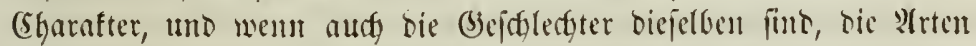
fint antore an jeser Rilfte unt in jeser Ferne bez Deents, an ber Deerflidte unto in jeber Tiefe bez Meerro.

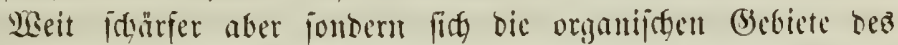
Fefithundes. Faier giebt es EGaraftere ber Begetation, die felbit bie

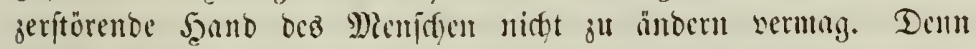

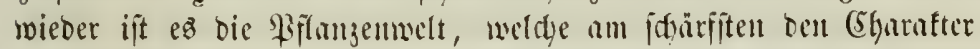

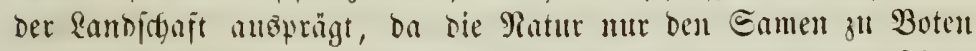
in frembe sünoer maden fann, uno auth biejer nur in bem feiner

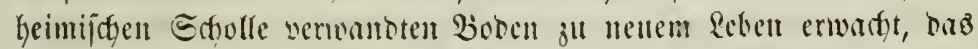

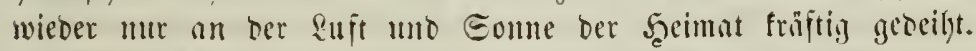

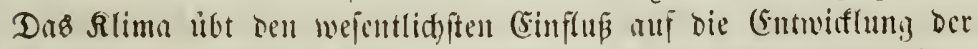
Begetation. In dent ewigen früblinge oer 5̧udedene von sient

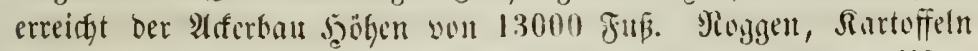

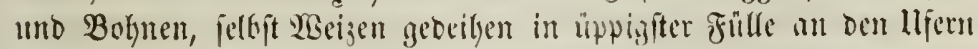

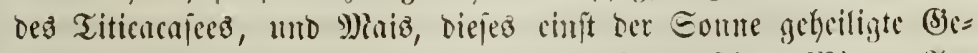

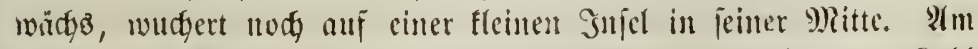

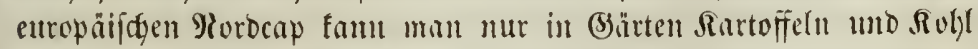

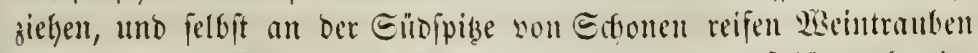

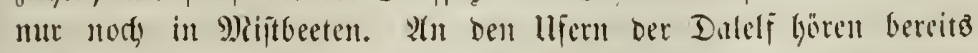

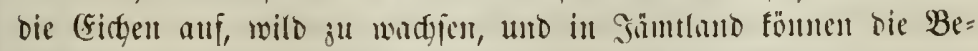

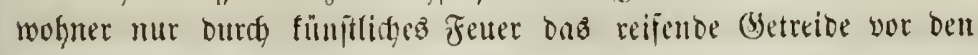




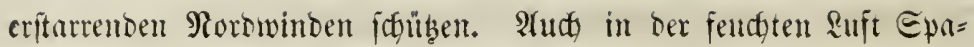

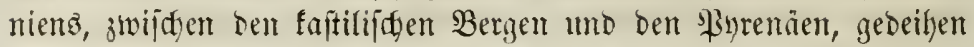

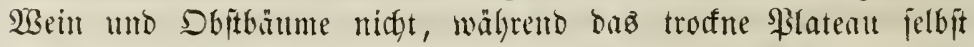
Delbäume trägt, umb bie reijenden Rnnbidaften bez Eüben Dran=

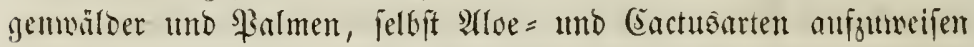
haben. Eo besingen Rlima und Boben ben Charatter ber Bege= tation. Die grüre \$iflamzenbeffe, weldge Berge unt Thäler beflei= bet, jetigt hier höher fimnuf uno jentt fidy oort tiefer himab. Sm Elltgemeinen aber nimmt bie Flora bes Fefflandes einen anbern

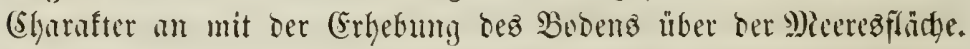
(begen bie Edyneegrenze, jene Rinie, welde dus Pieid) des Rebens

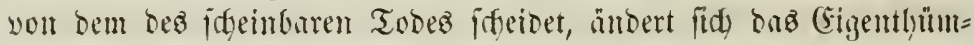

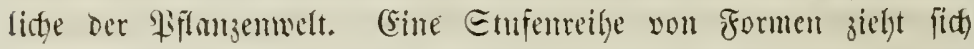

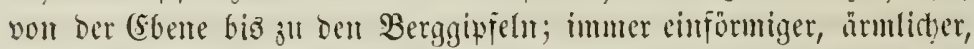

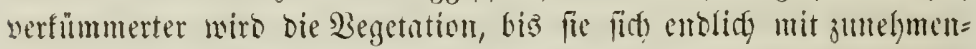
Der Syobe ber (bebirgagelyinge gänzlidy vertiert.

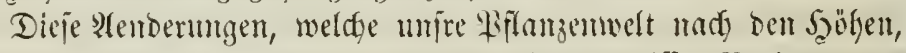
wetdye fie tragen, jeigt, haben jur Slunafme gewiffer Tiegionen ge=

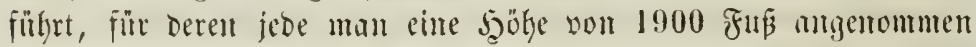
bat. Dody Darf man biefe Grenzen midgt allzu gennu nefymen, ba

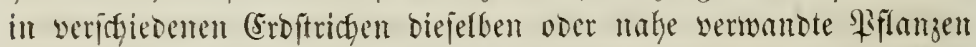
in jehr ungleidfen Erhebungen liber bem Meere gebeiken. Ifud Dorf mun bie oberen Berbreitungägrenzent in Gebirgen nidft bafin

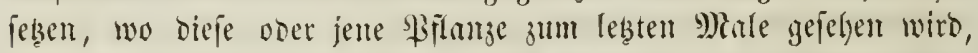

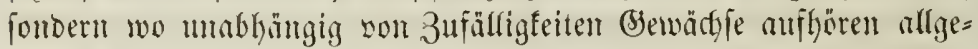

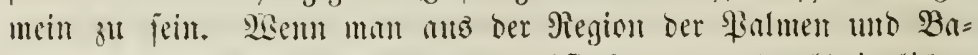

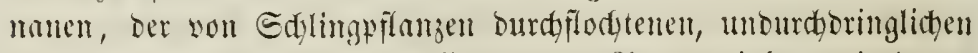

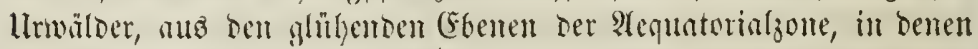

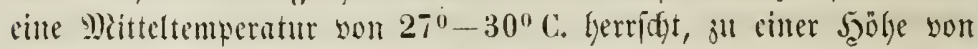
1900 g Farrn und Feigen, in welder eine Temperatur vout $23^{0}, 5$ herrifgt.

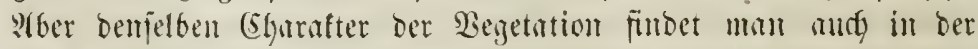
(stene, wein man fids um 15 Breitengrabe som Bequator entfernt.

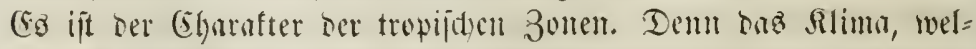

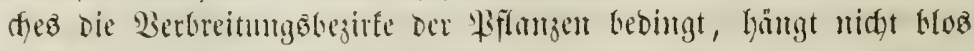

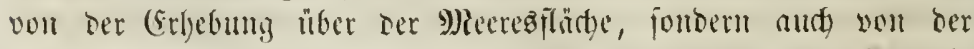

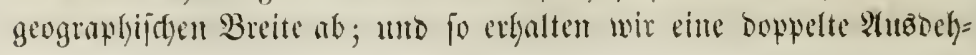




\section{5}

nung für bie Berbreitutgabezirfe, eine loorizontate nadg 3onen uno eine verticale nady Piegiones. WSie auf bie Fiegion ber Banmfarm bie Der M) Jyrthen und Rorbeeren in eitser Mitteltemperatur won $20^{\circ}$ -

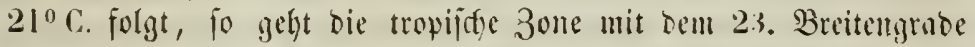
in bie fubtropijde llter, bie in Fialmen und Bannen nody an bie wirmere erinnert. Die giegion ber immergrinen Rnubbäger ent=

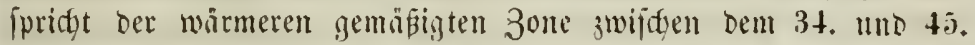
Breitengrabe mit einer y)itteltemperatur von $12^{\prime \prime}-17^{\prime \prime} C$, bie fiton

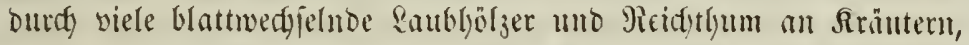
bejonbers sabiaten, an raubere slifte erimmert, aber bod) nod arm

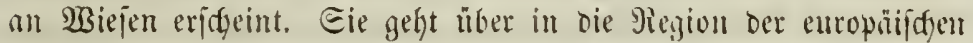
Raubgölzer auf ber einen und in bie fältere gemäbigte Zone auj ber

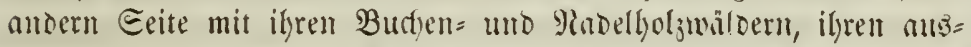
gedelgnten Jäniden uno wisiejen uno den darafteriftiften Dolden= pflanjen uno Rrenjblumen. Die Aiegion ber Mindeltgölzer beginnt mit einer mittleren Temperatur von $11^{\circ} \mathrm{C}$. uno entipridjt ber jubarf"

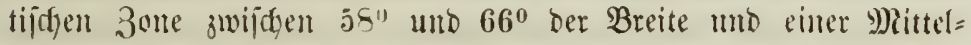

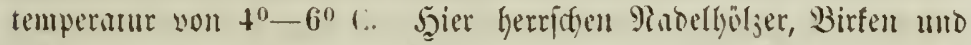

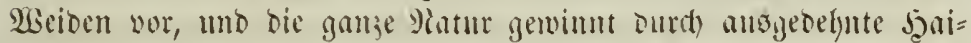
ben uno Siejen, weite mit Fledtent uno Mvejen hibermadjeme

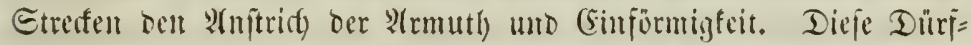

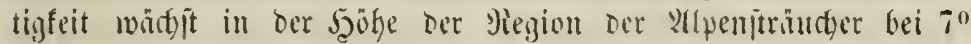
mittlerer Temperatur und in ber arfifiten zente zwiften dem 66.

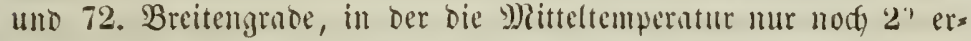

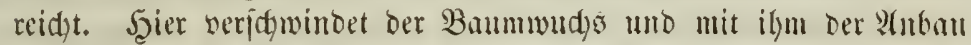

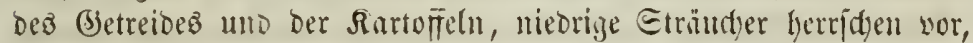
Mrooje und gledten libergieten die einjürmigen Bepilte. (5nolid)

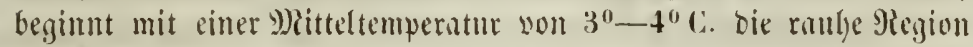
ber Alpenftruter, den falten Bolarzonen jenfeitz des i2. Breiten= grabes entfprectend, in benen bie Mitteltemperatur bio anj $-16^{\circ} \mathrm{C}$.

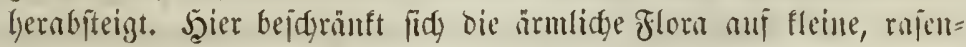

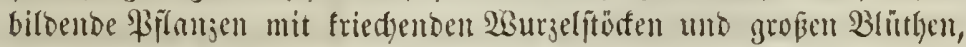

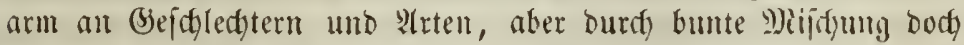
faum bie furdftbare Einförmigfeit ber vorigen Zone barbietent.

So ftuft fidg allmäliy bie lebenbige gatur won den llrwildoen

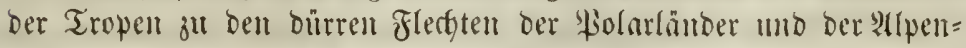
gipfel ab, und bie flora ber tropidgen Edyneegebirge erimert an 


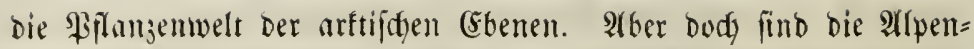

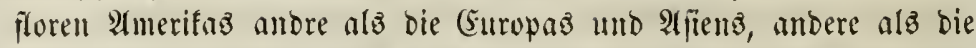

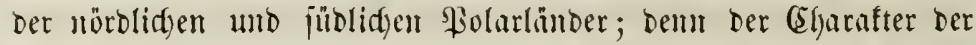
Wflumgenmelt bängt nidgt alfein von Rlima unb Sgöbe ab, er ift

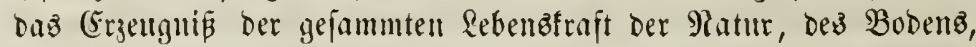

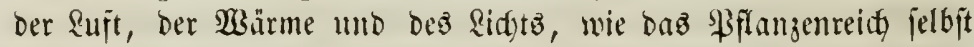

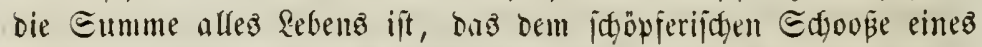

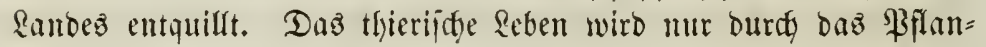
zenleben bebingt, won ifm erjeugt uno ermälyt, das Thier ift bie

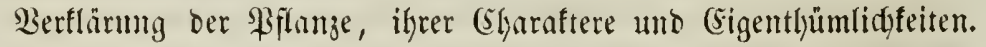
Darun ift jelbjt Das geifítige \&eben Des \$)ienjđen ewig an bie \$flan= zenmelt gebunten, und nidyt ber roke Saturmenidy alfein, fondern

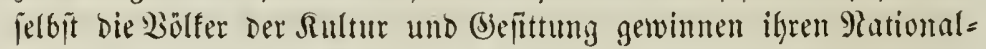
dyarifter auz dem Booen, ber fie erjeugte, uto ber Pflantentwelt, bie ilynen ifye shatgung jollt. Wenn man baher bas gejanmte Pflanjenreid, bes (Erbboocts nady florengebieten gliebern will, fo barf man nidyt vout ben Bebingungen, Sllma, J̨öhe, Bobenbe= idyaffenlyeit, ausgehen, jonbern ınü dieje vielmefr aus den Gharaf= teren ber floren erit erritlyen und erfemten. Die Sirunojormen ber

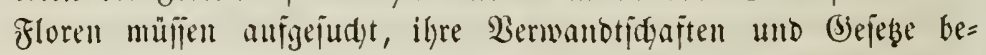

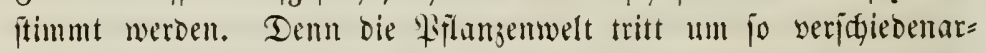

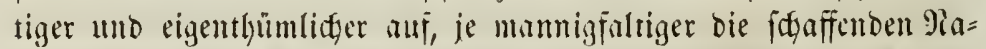

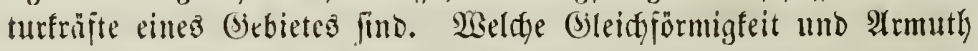
herridt in Den jumprigen 2Ealdungen ber tropifien (butyana, weldse Fülle d)arifteriftipder Formen, weldyer Jieidgthum an Arten, weldge

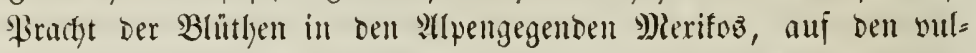
funijaen Injeln Indients, jelbjt in unjern europäijđen Alpengebirgen!

Borlyerritgende Fiflanzenformen werben zun Typuz ber ganjen Flora, bie Doldongemiddje und Eyngenejijten für bie nörblidge, bie

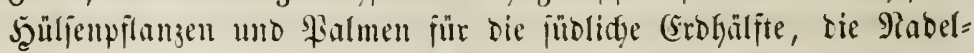
böljer uno Raubwälder für Europa, bie (Eajuarinen uno 9) Mrthen für Meufolland. Girabe bie veridgiebenen Wirfungen berjelben Ero= frị̂te in ben veridfiedenten \&anoern bringen bie Eigenthümlidfeiten Diejer Florengebiete hervor. Darum umfät ein jebez Bjebiet die gefammte Piflanzenwelt von ber Ebene bis zum hödjten Berggipfel. Jebez Sebiet ift bie Seimat bejtimmter Prtell, Battungen oder Familien und burds bieje abgegrenjt ober verwand mit nalyen ober 
fernen Gebieten. Satr ivenige Afrten find heimatloz über ben

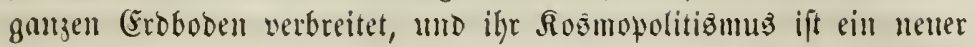

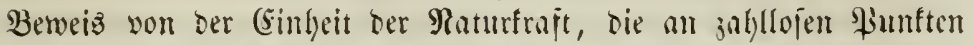

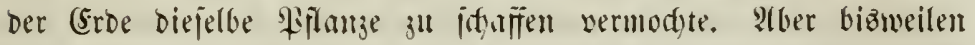

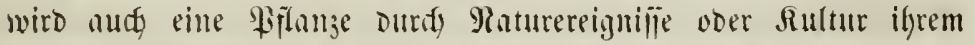
leimatliden Boben entrüft uno als Frembling in jerme Ränber werbannt. Tamm ift fie uns ein Bote ats ber Ferte, ber won Den

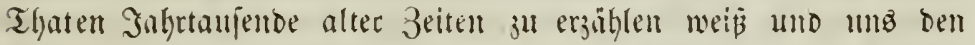

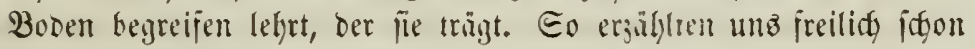

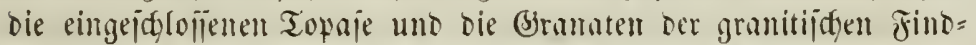

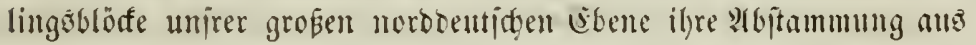
den ifantinavijdent Bebirgen; dẩ aber nody lebende 3engen jenez gewnaltige Ereignis beftätigen fömten, weldyez bieje blöfe in fo weite Fernen führte, ons ahnten wir nidft. Hno bod) finton wir ani ifnen eine fleine Rebenzwelt yon Mroojen uno Fledten, die, ifrer umgebung fremb, mur in Den älpen Efandinaviens ilfre Şei= mat judgen läst.

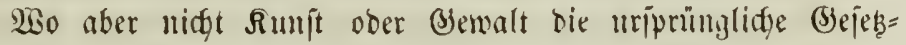

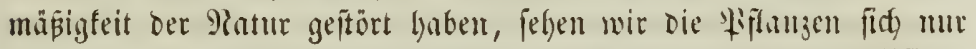

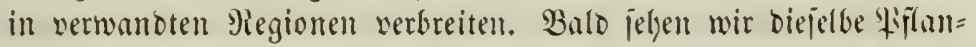
zenfantilie in getremten Floren Durd veridjicoene Buntumgen wertre=

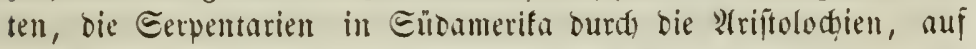
ben Injeln Des indifden Deens burdy bie Miepentheen, bie fleijaji= gen Eaftgewsishje burdh Die prädytigen (Eacteen und Mrejembryanthe=

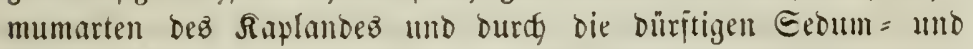
Cempervisumarten unjerz Baterlandes. Balo jeffen wir mur bie Arten einer Bbattung in verífjiedene florengebiete jeritteut. Die

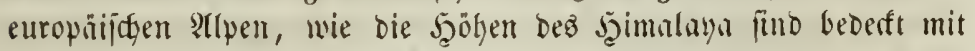

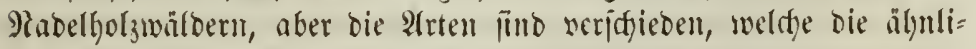
dent Einorüfe auf baz bemith Des Bejfauerz hervorbringen, uno ftatt Tammen uno gidgten bilbet ben builtern Edgmulf ber amerifa= nifden Alpengebirge bie $\mathfrak{A}$ rnucarie. Woobl erinnert bie Altpenflor

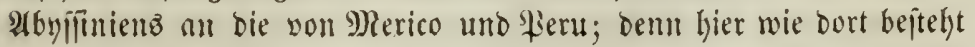

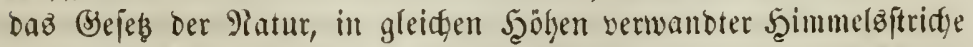
verwambte Irten herborjubringen. Pur ber Rorben und Eilden

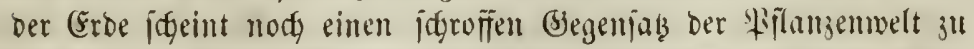
bebingen. Wentige Gruppen verbreiten fith ütere bie ganje (Erbe, 


\section{8}

uno mur auf berjelben (Grblälfte idfeinen bie Arten einer Flora iffe entipreffenten Bertreter zu findert. Darum erimnert bie Ratur

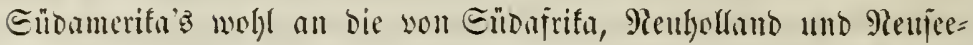
jeeland, aber nidyt in gleider Siseife an bie Miorbamerifa's ober (5)

Wher nidgt bie Gattungen alfein, jelbit bie Frten fimmen bißz=

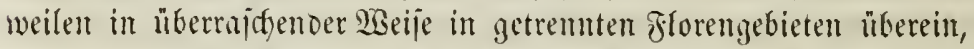
unt mur bie \$yijdgung mit frembartigen Bemädjen serleilyt bann ber Flora ifre Eigentlgumlidffeit. Ier (Europäer glantbt fïb auf

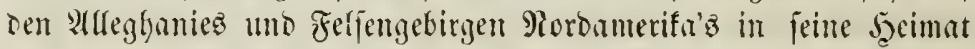

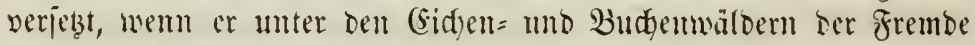
die woblbefanten Mroje und Fledten dez Baterlandez wieber= fintet. So geht eine grora in bie anbre niber, uno cine erinnert

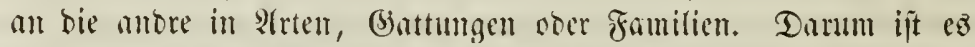

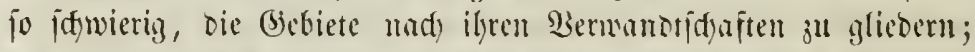

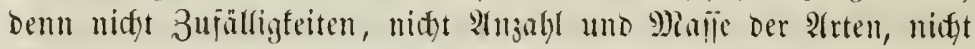

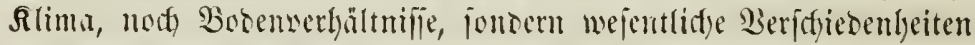
Der Begetation, welde burdy alle auf lie eimvirfenten $\mathfrak{R}$ räfte bes

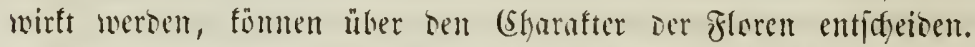

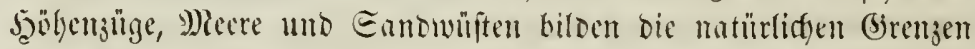

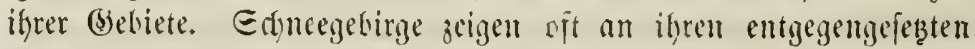
Abbinngen cine meridtedente Begetation, uno Snjeln im Deean befizen gewölynlid rigentgümlidse glorent.

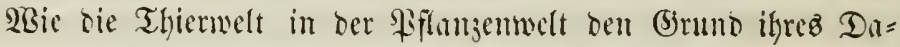

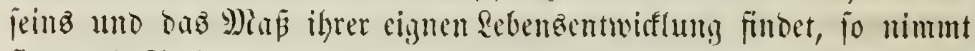

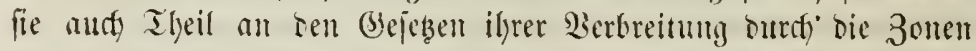

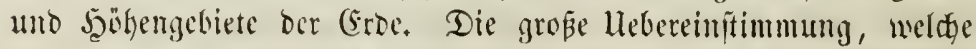
Giz z" genififen Breitengraben in ben florengebieten, weldye bie

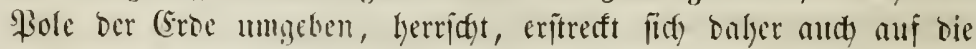
Thimmelt. Saie beise Durd) Bobennatur, Eeen, Eummpe mo

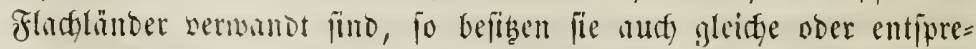

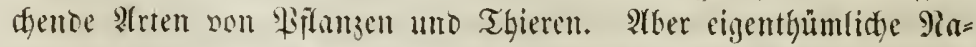
turberbältmifife in Rlima amo gendfrigfeit rufen auds eben fo ent=

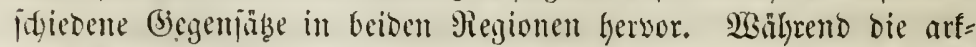
tijçe Flor fiid ber gemäpigten Miegion anjoliefst, geht bie antarfti=

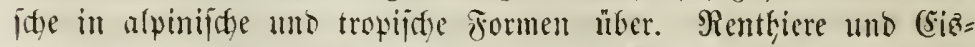
bäre besolfern oen Morden (Guropaz und Afienz, uno wenn audy 


\section{9}

bieje in Suben Reujeetands feine Bertreter finden, jo erimern bodf

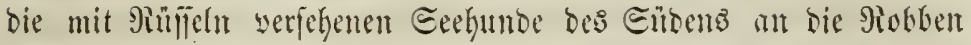
Dez Rorbens.

An ben (Brenjent ber Folarflaren fondern fith bie Giebiete melyr und mefyr nady Der (Sigenthümlidffeit ber Ränber, benten fie angefö= ren. Cellift der Benentirb bes Morben und Eliben fafmindet all=

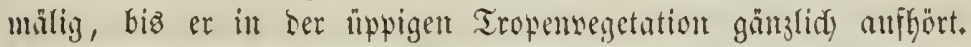
Aber um fo mannigfaltiger wiro bie Giliedernug ber Gebiete wour Difen undy Sisejten. Denn hier erit vermay bie Rebenzfraft, bie

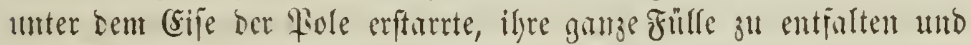

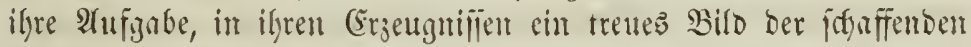
Rräfte wieberzugeben, wallyhnjt zu erfüllen. Co fohen wir in bem

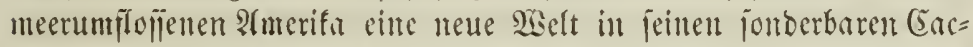
teen, wie in feinen Benteltatten uno Mieerifdweindfen, feinen Fant= thieren und Gürtelthieren erblüfen; und went aud feine langge=

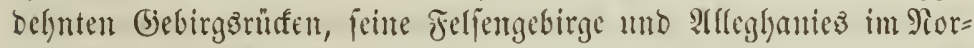
ben und feine ?tnden im Eilden bejondere Gebiete abgrenjen, jo

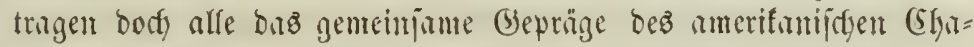

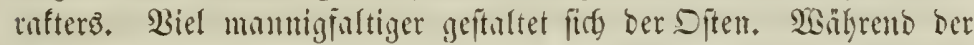

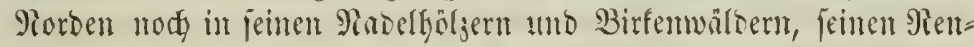

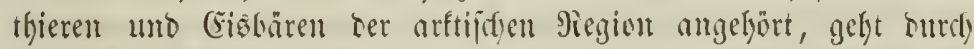

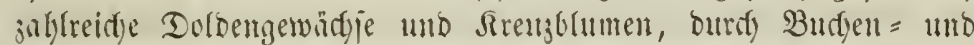

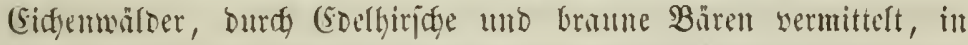
Dem Bebiete bes Mittelmeeres bereits zn Gerrlidgen Rorbeerbänment

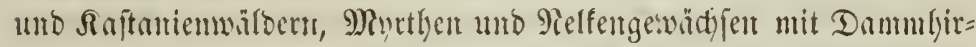

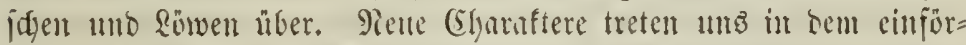
migen Continent vou afrifin mit jeinen endofofr $\mathfrak{B a i f t e n}$ entgegen. Seier weiben bie zierlidfen 2 nntilopen, bie geftreiften Zebrab, bie ge= fpentigen Siraffen neben ben wilden Saynen, den häßlidyen 'sin= vianen, ben ricfigen Etraußen unb den plumpen Mitpferben, währento

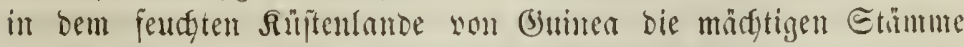
Der S(bouronie mit ben prudtedvolfen Boliathidentäjern auftreten.

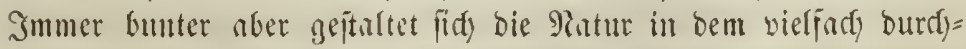

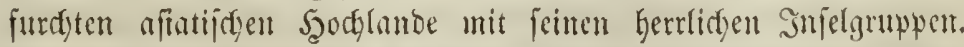
Şier erjofeint ber riefige ESteplyant netent bem rauthütigen Tiger, lier if bie Syeimnat bes 9ieiz und ber Banmwolfe, bes Thees, ber

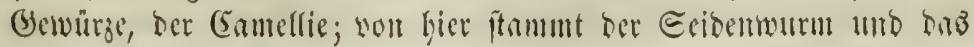
Ille, wettill, 3. 2แ11 


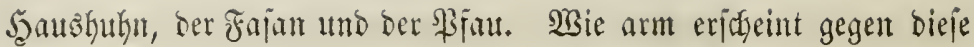

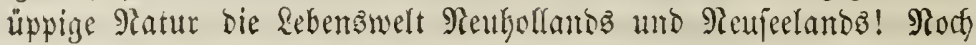
fennt man auf bem Fefitlambe auper ben Beuteltbieren und werrigen

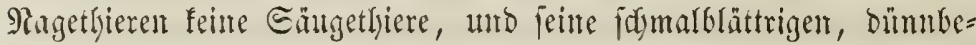
Iaubten Băume, feime luftigent, fuattentofen șälber verleifen ifym

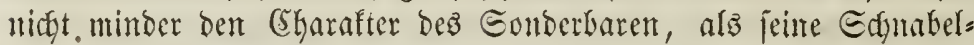

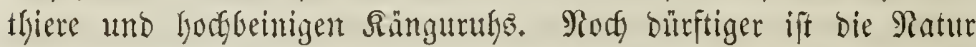

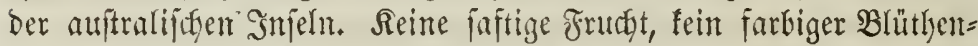

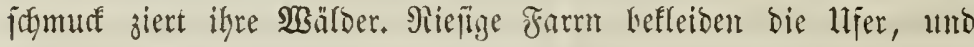
Brobbäume ober burdf Siuftur hierher verpflangte Rofozpalmen gebent

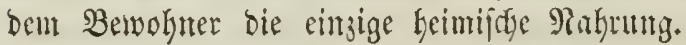

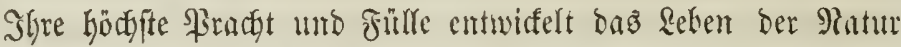

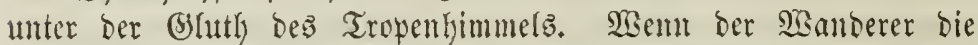

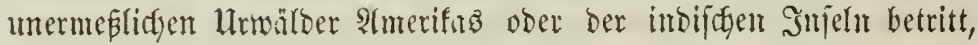
bann ift ez micht bloz ftumme Bemuntermm, bie ifyt in bicjer

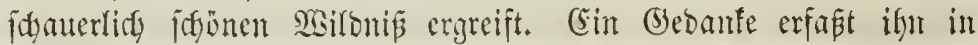
biejem Seciligthum ciner gewaltigen 2 Ratur, ber ifhn in bie geheim=

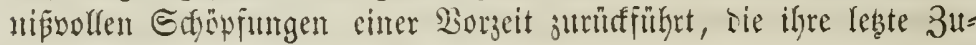

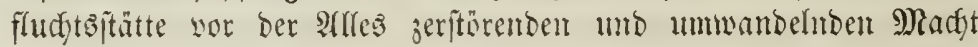

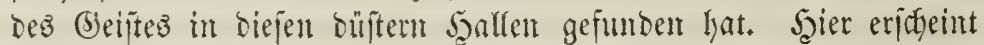
bie Ratur in iffer reinften Bejtalt, wie fie aus bem Edjoope ber Edyöpfurty lyernorging. Sinum reidgt ber Bosen hit, alle fräftig

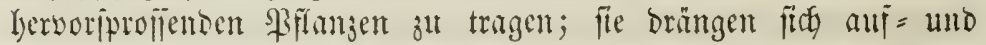

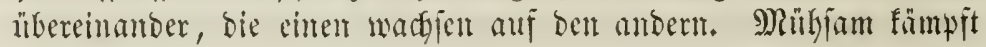

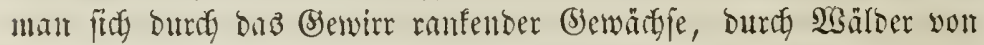

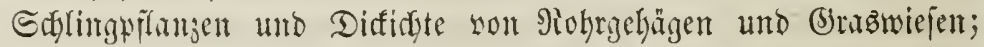

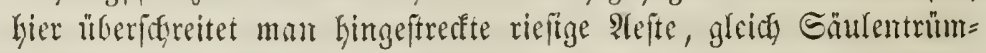
mern auz bem Bobent hervorragentoe Etümpfe, unter grüuem Teppiđ

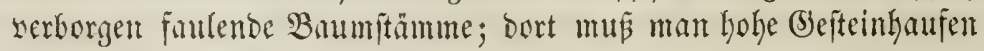

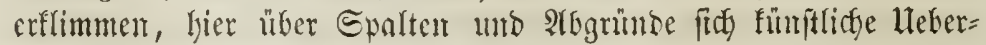

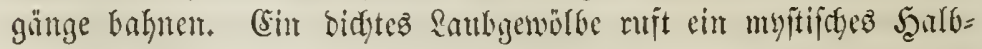

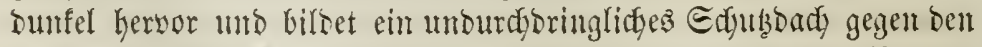

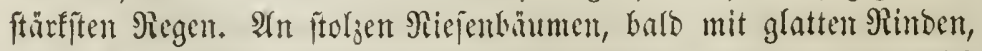
ballo mit Etadyetringent umgeben, mindon Edylingffantzen, namentlict)

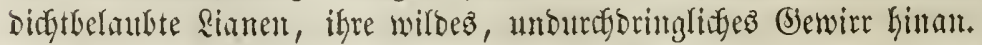
Sn fonberkaren Formen umgütten fie bie Etämme unt verweben 
fing mit ifren-3weigen uno Brätterfronen zu bidjtem fledtemerf.

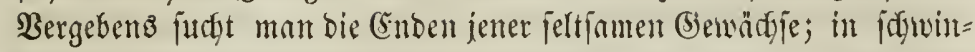

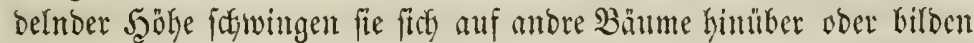

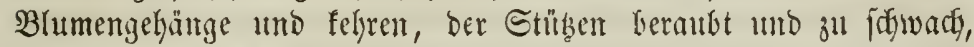

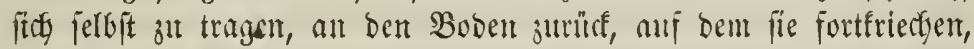

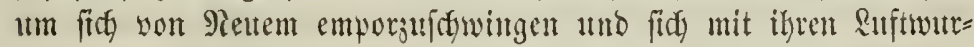
zeln alt bie Stämme zu heften, ben ftärffifen Etürmen jum Troba. Gelbit ber Foridfer yermag fidf in biefem maleriften Edylingmerf

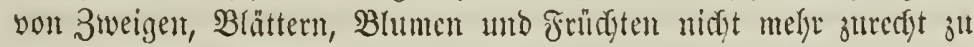

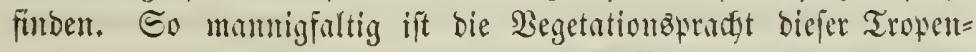

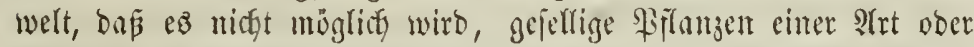

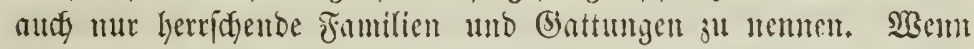

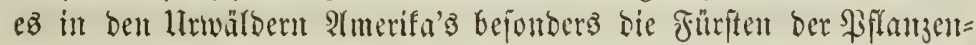

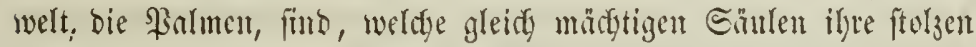
Feberfronten über bie bumflen ?autblyatfen erlyeben, fo ragen in ben

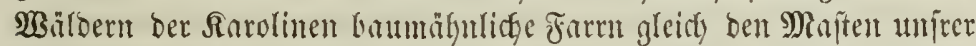
Ficftemwaldoungen mit ifgen hohen graben Etämmen unto jurt gefie= Derten Sisebeln empor. Şier breiten fid ungelyeure Etänme willoer

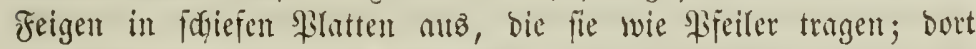
entfalten bie jonberbaren Cactuz ifre frangenden Brumen. Diejen

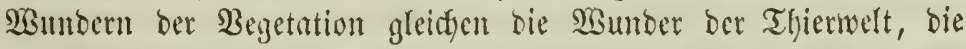
jenten Tempel der Siatur voul ber fojillernben Edjange bis zum

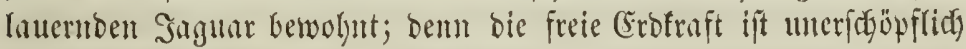
in ifyrer Gjeftaltung.

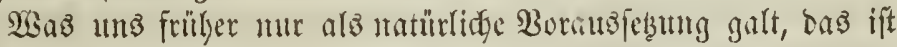

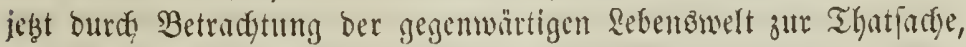

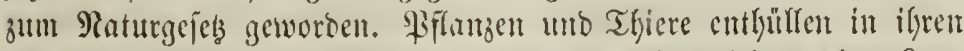

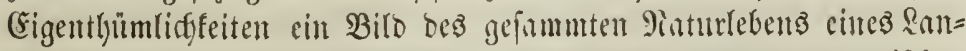

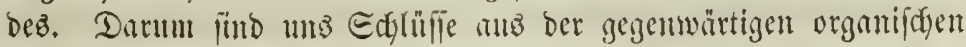
Edjöpfung auf bie untergegnngene geftattet, und wir fönnen atเ

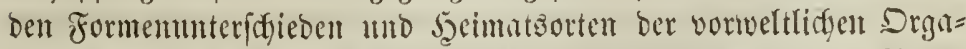

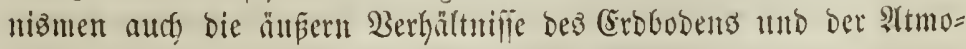
iplare bejtimmen, weldye jene 2sejen umgaben.

4) Die Rebenzwert der Borzeit.

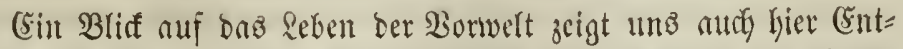

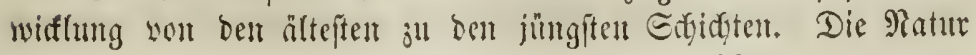




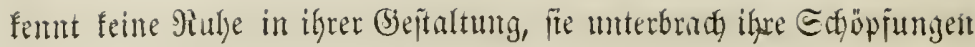

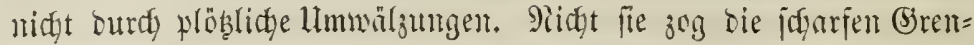
zen, meldye bie grefen Ferioben ber Edjöpfung tremen, fondern

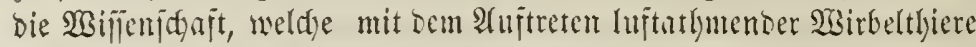

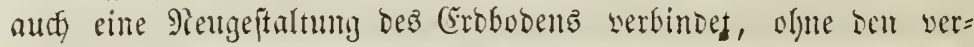
mittelnden Hefergang, bejlen Epuren bie 3eit verwijdt hat, ju gemafyent.

Eeit cine bejometere Paturioridjung ber Bezenmart anigefungen

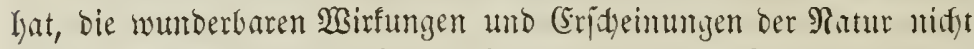

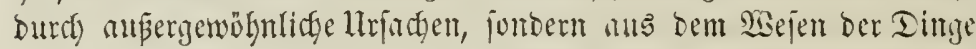
felbjit jut erflären, tritt audd melyr und melyr jene 2rmjicft in ben Seintergrund, welche bie mannigfadjen Weränterungen ber Erbober=

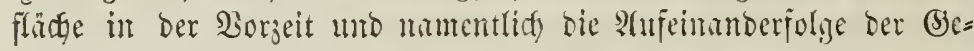

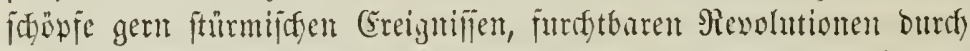

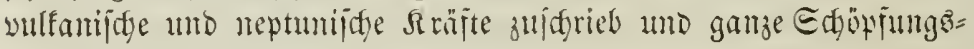

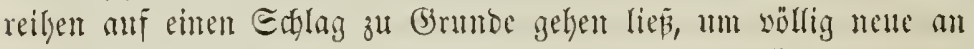

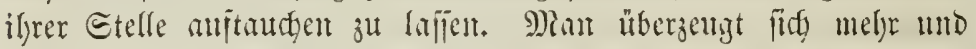

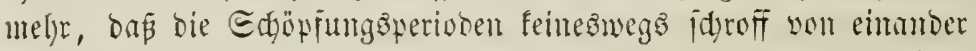
gejdjeben waren, Daz ältere Edjopfungen in ifren leghten Etrablen in jüngere verliefen, ous bie Begemwart jelbit nods gleidjiant ver= loreste Pojten ber Borgeit trïgt. (Ěz glebt gemiffe Typen ber Keuti= gen Edjöpunb, welde gleidjant in bieje nidgt melgr ljutreingehören and wie altertfüunlidge, mindejtens bijarre bebilbe unter ben mo= benten Forment erideinen. Dafin gefjören aus ber Thjerwelt bas

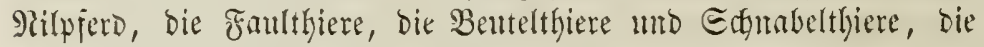
Enfriniten uno Bentafriniten. Sn ber \$flanzenwelt finto es wor=

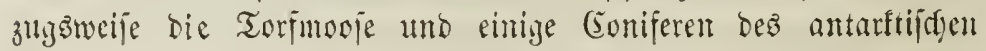

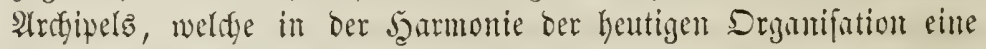
frembartige Etellumy eimtefmen. Die Eoniferen= Siattung Plyyllo_

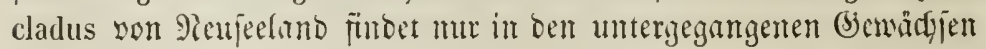

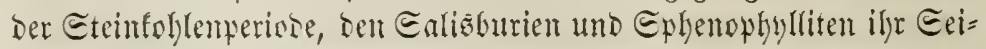

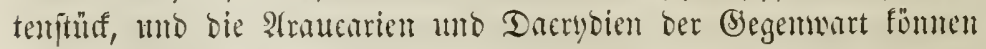
sutr in Den fogentamtent baumartigen Encopodien ober Repiovoen=

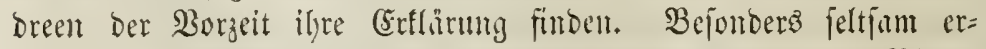

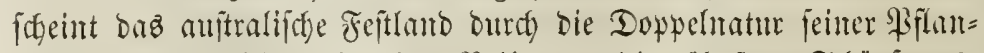
zentwelt, in weldyer bie eine vieife an bie älteften Edjopprumgz=

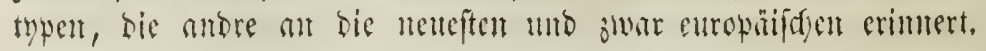




\section{3}

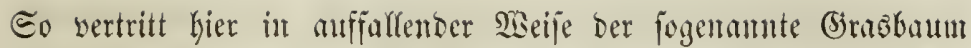
(Nanthorrhoea Hastile) baz untergegangene (jejdfectgt ber Eigilfa= rien, währent banteben ganj europailifge Rräuterformen auftretert.

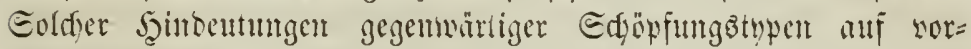
weltlidye hat bie neuere Foridumg bereits jahlreidye anfgefunton, jo in Colifornien burdy jeine riejizen Miamuthfiejern, auf ben

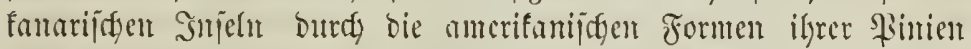

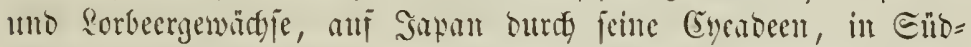

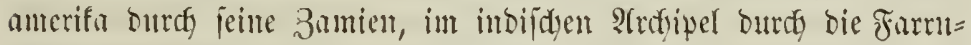
familic ber Marnttinceent. (Es fanm bamit fanm nody jucifecthajt

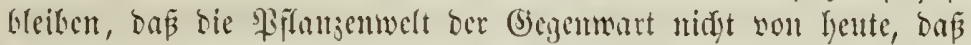

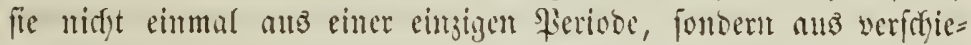

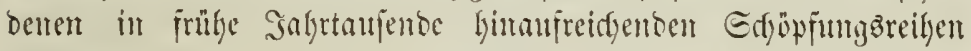
aliftommt.

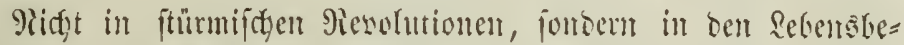

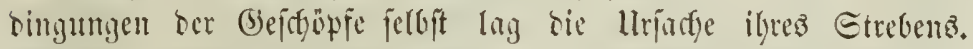
Wie heute nod in ber freien 9atur, in $\mathfrak{B a}$ aldern und auf 2 Siejen,

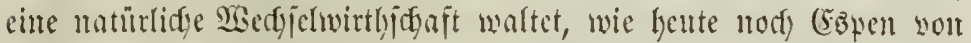

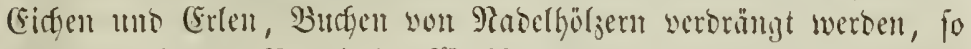

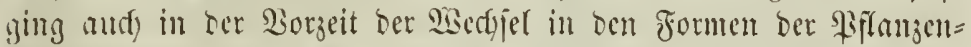
welt wor firfy, fei ca in Folge einer algegrengten Rebensonater ber

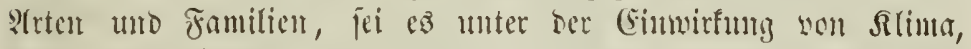

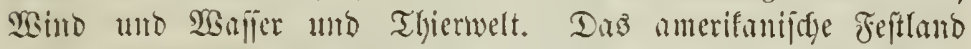
war früfer son riefïgen Thiertypen benilfert, wie nody bie lleber= refte feiner Miftodonten betweifen. Sebt finbet man bort mur nod Dent Tapir, bas Gunnfo, daz Armudillo umo Eapybara, wahre Fingmäcn im Dergleid) ju Den untergegnngenen. Dic meiften, vielfeidyt alfe jene riefigen Bierfübler ber Bormelt lebten in ciner fegre neuen

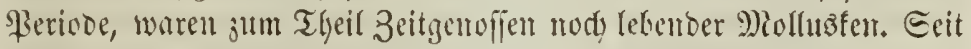

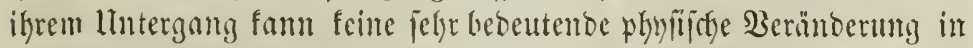

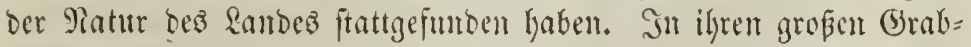

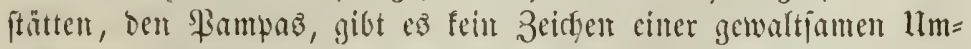

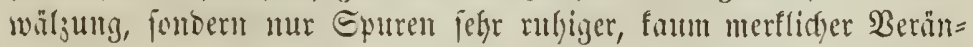

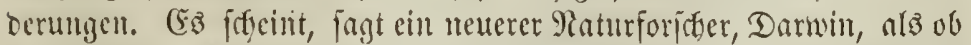

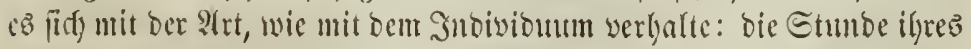

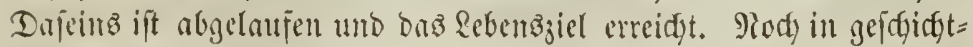

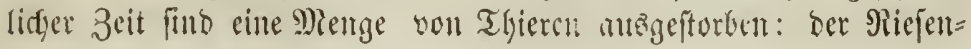


Kirify, bie Etellerijge Eeefuh, bie Dronte, bie Moa, bie man alz

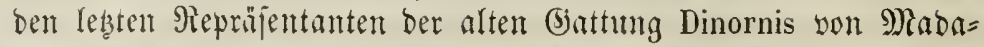
gasfar betradfete unto Der Notornis Mantellii von Reufeeland, von bein man allein bie verifteinerten Meberrefte lange Zeit famte. Nod

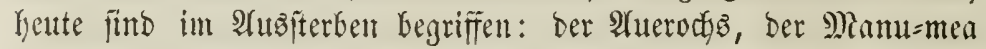
(Didunculus strigirostris), ein Taubervogel ber Snjel Lpo'a, unb bie Columba erythroptera auf Taiti, beibe angehlidf burdf Sagen ver= tilgt, ber Strigops habroptilus, ein Radjtpapagei in ber $\mathfrak{R a ̈ l y e ~ y o n ~}$ Tieujeelanto, unt bie Battung Nestor, ein phumpeß ßrapageienge=

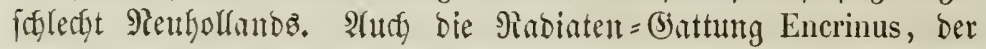

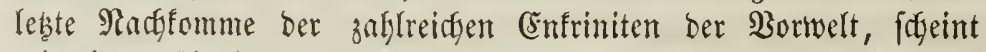
mit einem älynlidgen Edgifffar bebroht; von Encrinus caput Medusae werben mur nody o (Exem= plare in ben Mujeen auf= bewalint.

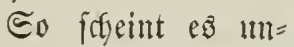
zweifelfaft, Daß Borwelt tuno (Begentwart burds ned lebente Drganisamen ver= Guttoen fint, báp die Bor= günge, welde bie(sejdjöpfe ber Borjeit vernidgteten, feine anbern waren, als bie fidf nod) Geute mie=

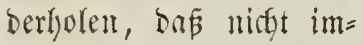
mer Fievolutionş̣türme Grentildeisen jwildeen ben Ecföpfungapperiobent ber

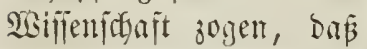
in einem oft Salyetaulente lantgen Tobesfampfe bie Frten und Bseidfedfter er= Iofdent, unto baß wir heute noch Zentgen manctes foll

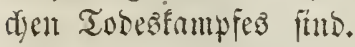

(5z war nôtlyig, mure Boritellumgen won ber or=

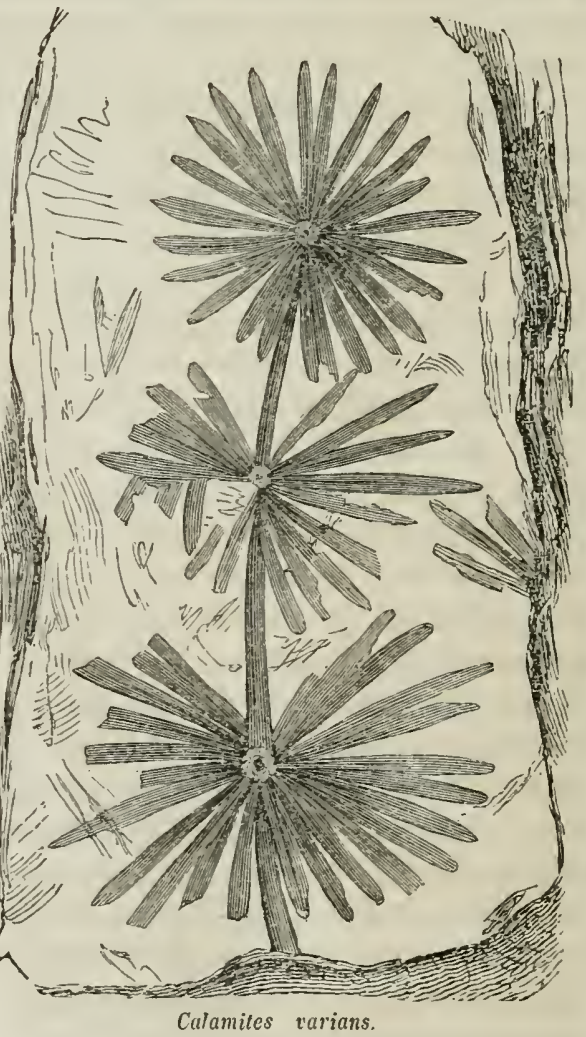




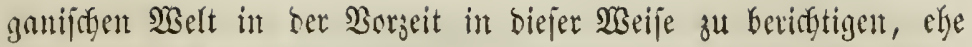
wir fie in ifren eingelnen 3itigen verfolgen fountert. Sebt wollen wir wenigitens eit flüdtiges Bild son ien Forment entwerjen, aus

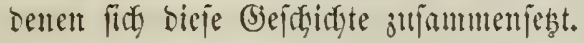

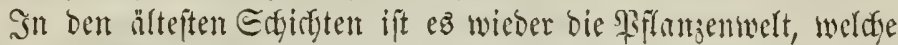

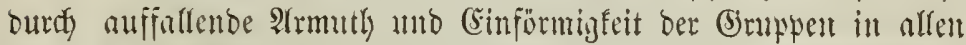
Theilen ber Croe einen eigentfümlicten (Begenjäs ju ber bentigen Minunigfultigfeit des Rebents bilbet. Ilnje Eteiufoblentager haben

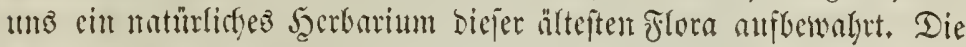

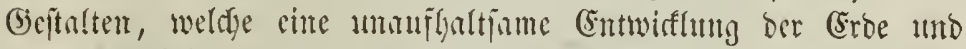

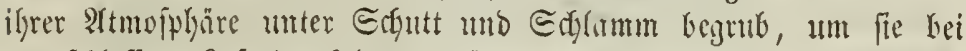

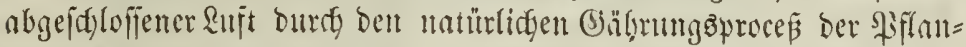
zenmafie affmälig zu verfoblen, find licjert, wie etwa ber $\$$ Sin= ter mit jeinem Edtuee mo sinfler alljülytion abge $=$ forlente Bappclolätter ffe= lettirt, D. K. D.nכ fleifigige Belfgewebe jerjelzt und bie Derberen Rippen uแversึ =

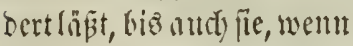
fie nidyt von Edflamm= maffen überbeft werben, ppäter ber 3erjebung it Solkenwajierjtoff antgeim= fallen. Dowolyl verfoblt, fint body bie häteren Theile ber sorweltlidfen Bflanjen entweber jelbit ftänbig jurisfigcblicben, twie Rinben unt Stäume, noer bie zarteren \$flan= jen haben ilyre Epuren in

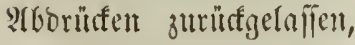
bie fie in ben weidjen atmo exit ipäter verbärteten Ed)lammidyidgten verur=

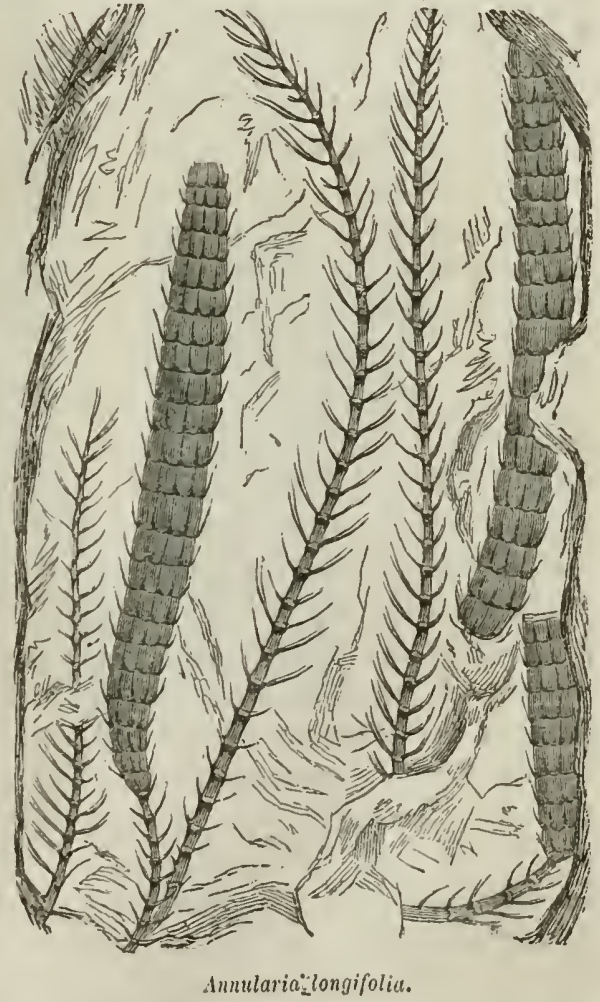

Annularia:longifoliu. 


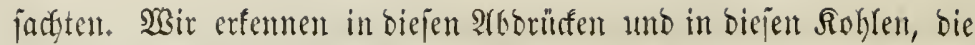
unter bemi Mifrejfop nody beutlich igren innern Bauf frettbar werben

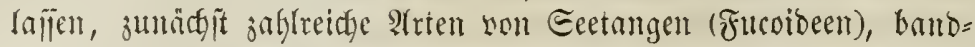

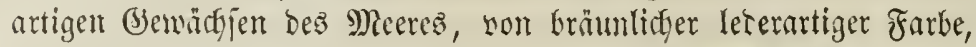
oit beräftelt uno mit jofwimms Wajenartigen beöflungen am Raube verjelyen, oft Єtämme non riepiger (Srïß̈e bildend, bie an ilyrer Exibe mädtige, viele lyun= bert Faben lanige, geichlib̧te palmblattartige Ironent trugen'. Reber ifnen erbliffen wir, in mädytigen boumartigen(s)italtet firf) über ben Eumpf erlyebento, Edyadyteflyalme ober Equijeti= ceen, mit tutenartig in eimander=

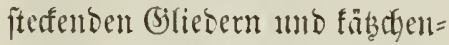
artigen Frürd)ten am (Sipjer. Dahint gefören bie Ealamiten, 2fiterophylliten, Ephenoplyylliten und $\mathscr{S}($ nnularicn. Farmfrüuter, 30 Fu仿 lood mit foflamfen Etämmen empor|trefeno, mit jdyop fartiggeftellten siedeln, bie flunge, Iuffige Brattfronen biltee= ten, bärfappartige (bewiadje uno arautarienartige 3nพfen=Băune fildont ben llevergang zur ?anto= flor. Unter bicjen bewäctjent jeidfyen firth wor allen bie Bis: fofledfter ber Eigillarien oder Eiegelliüume, ber Repitoodentrent oder Edyppenbäume uno ter Etigmarien ans. Mimt pflegt fie gewölyntidy mady Ier eigen= thërmlidyen Eteffuntgifrer $\Subset$ dyup= pen und Blattuarben, wie nady

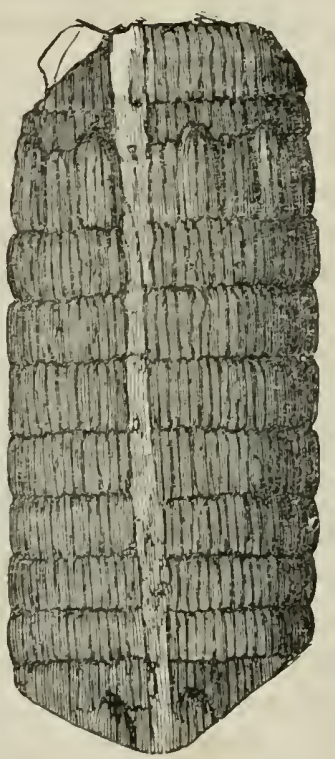

Sphenophyllites angustifolius.

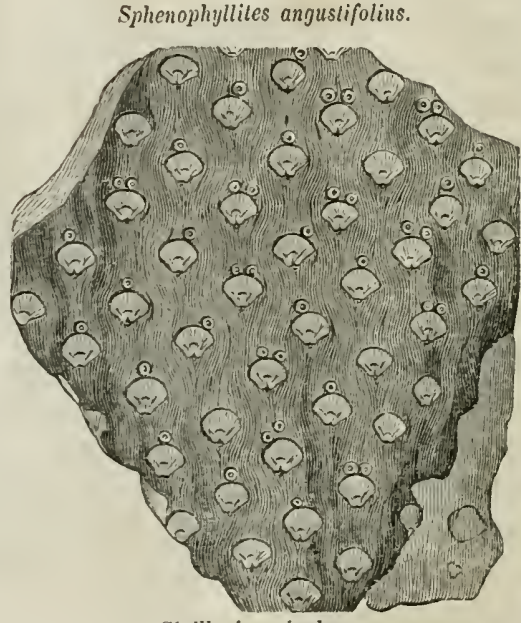

Sigillaria spinulosa. 


\section{7}
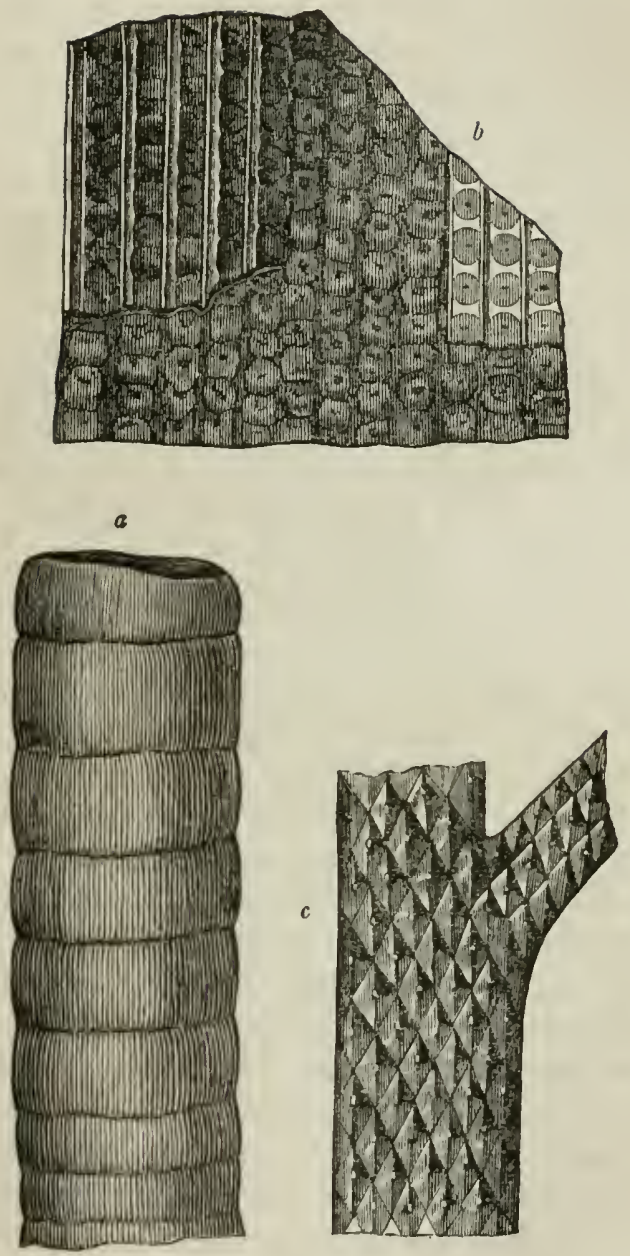

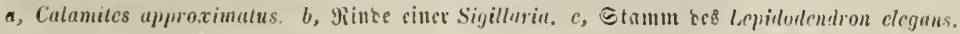

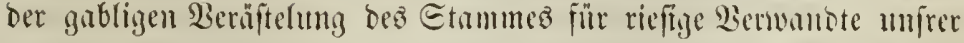

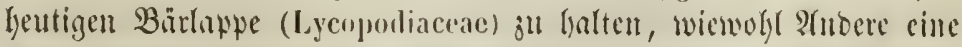

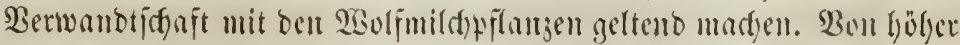

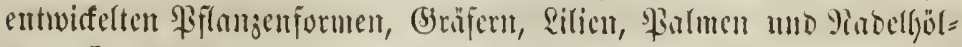
zern find mur wenige und ztweifelfafte Epuru gefunoen worben. 


\section{8}

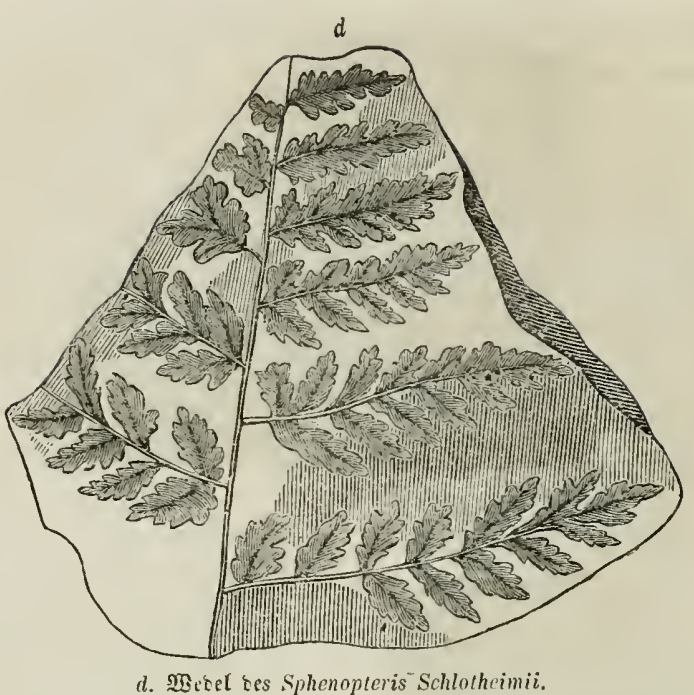

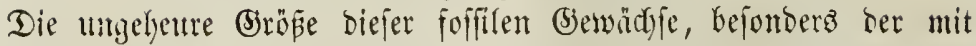
rigentlyümliefyen, bie Etelfen ber abgefalfenen Blätter anbeutenton Figuren bedocten baumartigen Fartu und Edyadjelfalme, von benen

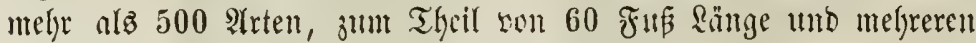

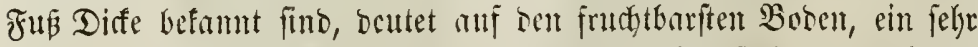

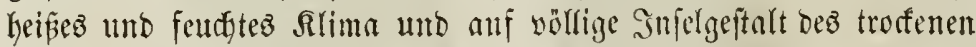

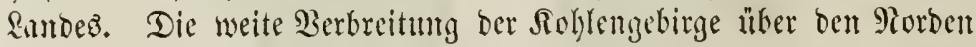
unb Süben beweift ben trepifaten CGGanfter ber ganzen unterge= gangenen Bifanzemwelt, mo bie ungelyeure Mäadtigfeit ber euro=

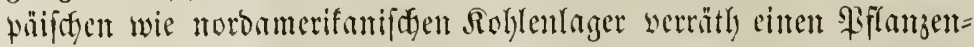
reicfythum, ber mutr mit ben linwaíldern ber heutigen Tropenzone verglichen werben fam. Daß bieje feutften, ifgattigen $\mathfrak{B a l b u n g e n}$

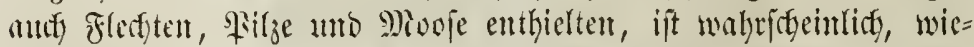

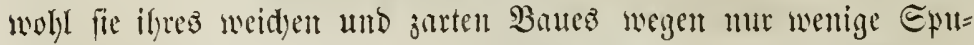
rent, cift mur in ber Färbutng ber Edficften Yintterlaffen Gaben.

Studf bie Thierwelt beftätigt ben tropifden Gharafter jener

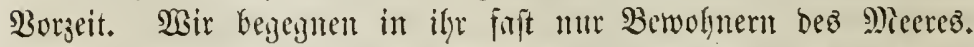

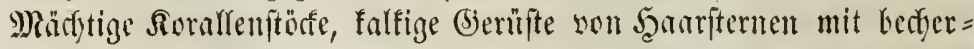
ober fugelartigen fironen und geglieberten Frmen, formen, bie mufrer Kentigen siselt faft fremb finto, fallen uns in ben untern

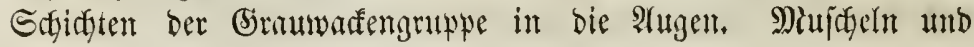




\section{9}

Sdynefen eridgeinen nody felten; ftatt ifrer treten bie eigenthüm=

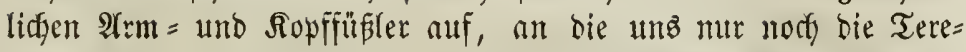

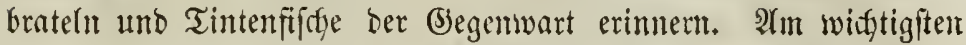
unter ifnen werben für bie Aflterşlefitimmung ber Edfidsten bie

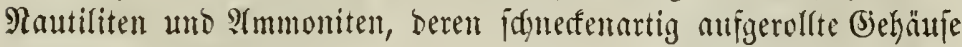
im Snnern burch Suenwänd in Samment getheilt fint, in beren

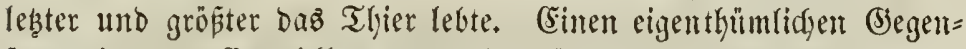
jak zeigt ber Entwifflutgsgang ber äupern Befitalt biejer beiben

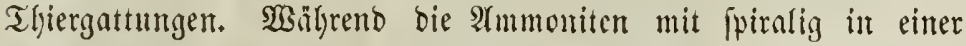
Ebene aufgerollten (bebäujen beginnen, zeichnen fich bie in ben all=

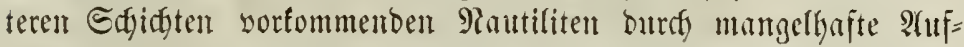

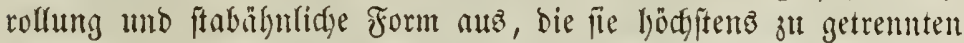
Wintungen entwiffeln. Die Blicberthiere beginnen mit ben frebs= äfnlidyen Trilobiten, weldye bie bevonififfen Sdjidten in groper

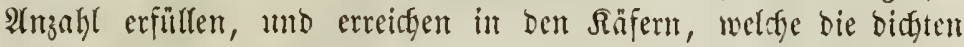

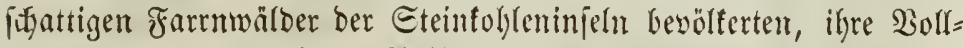

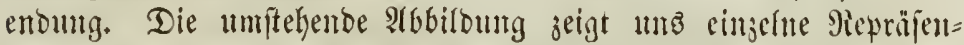

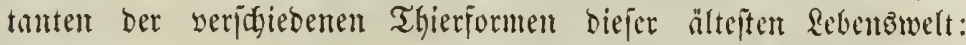

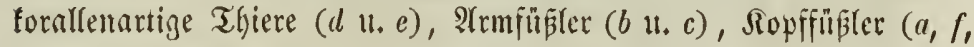
$h \mathfrak{u}, i)$, Trilobiten $(g)$.

Die Slafie ber Wirbelthiere wirb in ber erfiten Edjöpfung mur burdy eine fleine Zahjl von Filfgen vertreten, bie in ifrem Bane jelbit von ilyeen nädyfen Berivanbten ber Meuzeit bebeuteno abuei=

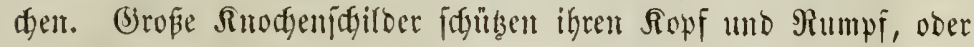
vierjétige, Gald glatte, Gard geftreifte Edyuppen, bie mit glänzen= Dem, feftem Edymelz ḧberzogen fund, bebeffen ben ganzen Sö̈rper. (Sime weidge, fnorplige Reuffenjäule erinnert allein an ben Typuz

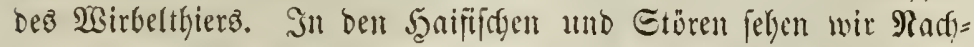

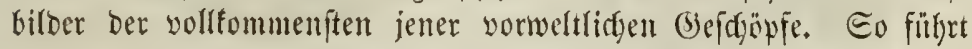

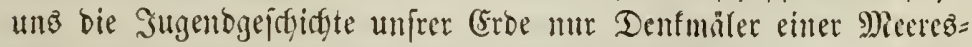

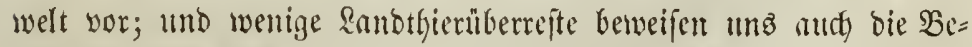
lebtheit einez Fefftantoes, für beffen Dafein nody die reidye Bfan= zenwelt jenter 3eit fo mädytig jentgt. Ranothiere, bejonbers Snjet=

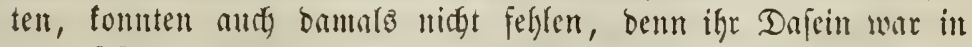

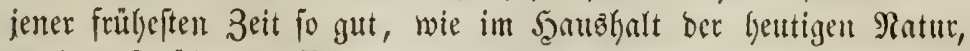

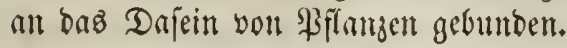




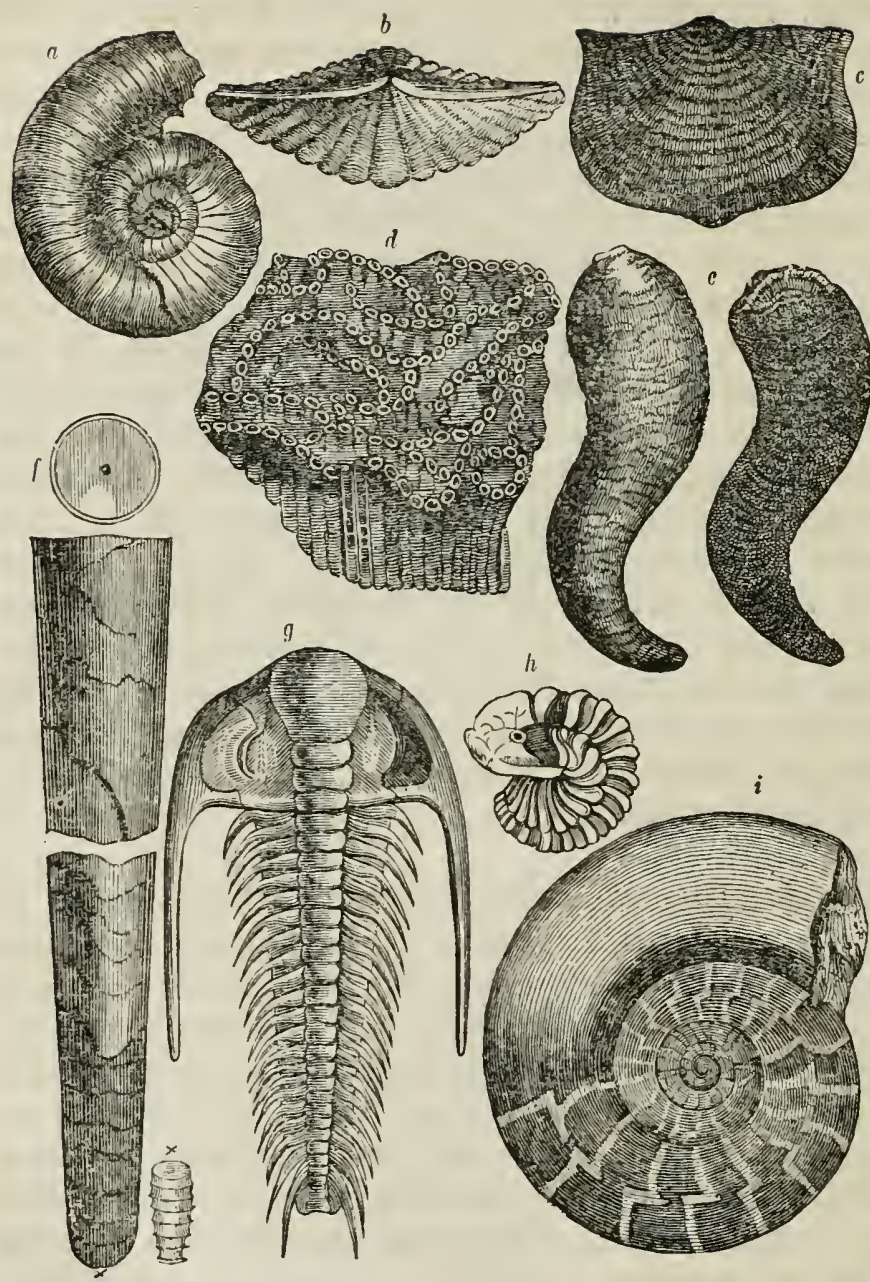

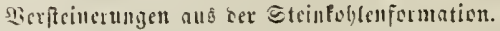

a fontualites comolvens, b Spirifer speciosus, c Leptacua depressa, d Catenipora

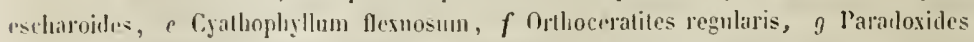
Bolieuicus, 4 Calymene Bumeubachii, $i$ Clymenia inacquistriata.

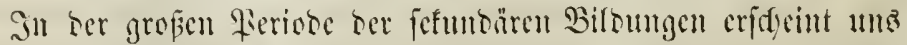
cine immer reiffere formen entfaltente Refenswelt, bie ber leuti=

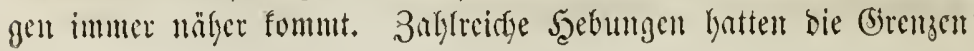




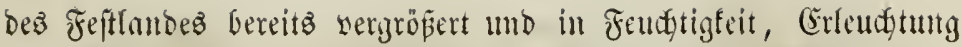
mo (srwärmung, wie burd) Sgähe l̈ber Dem Meere mantigfacte

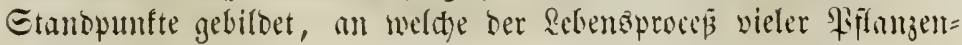

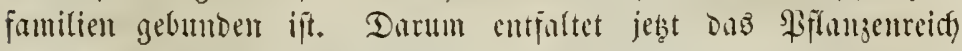

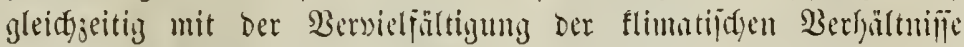
ftatt oer frilferen Miallenlyaftigfeit bie Minntigfaltigfeit ber For=

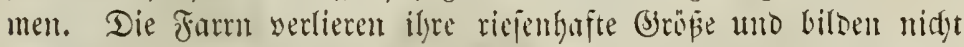
melyr jene bidften Mrmälder der Singendzeit; Dic Exfyadtellyallme und

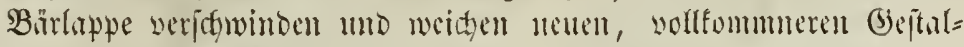

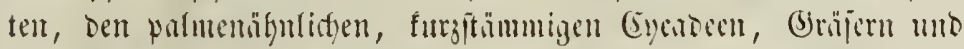
Rilient. Eine göbere Entwiffung beginnt bereits mit bem Shiftreten

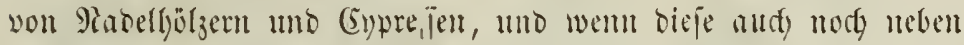

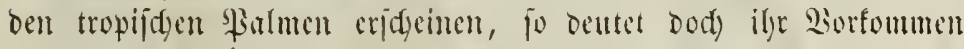

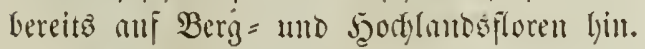

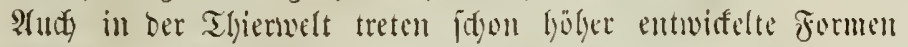
auj. Sieben Soraflen, Etrablthieren, Minjdetu und Edynefen, be= fonberz ben burd Mannigfaltigfeit Der formen mo Brïben über=

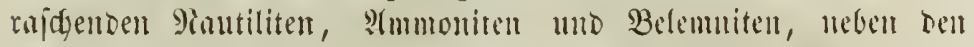
Rrebjen, weldge bie Etelfe ber Tribbiten eimnetyen, neten Ecor=

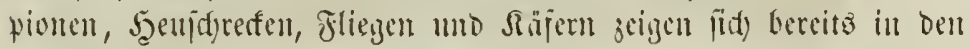

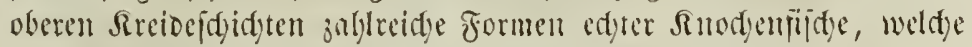
an bie Barjde unb beäringe ber fentigen

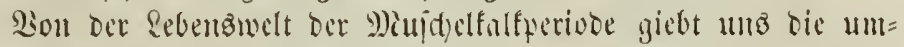

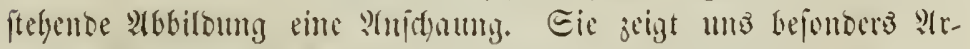

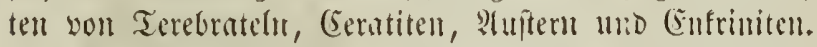

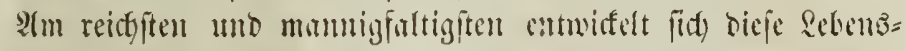

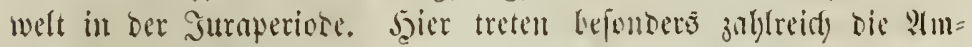
moniten uno Belemniten nuf mo jefbit bie Sorallen, bie in ber

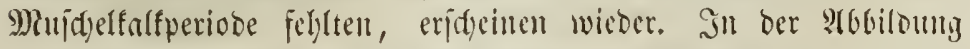
(ธ. 623) fielyt man einige Formen jentr 3eit.

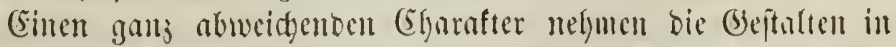
Der seitwerbreiteten Rreideformation an. Die Sinmeniten rolfen

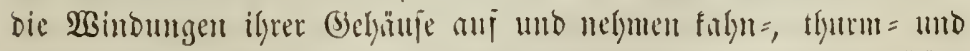

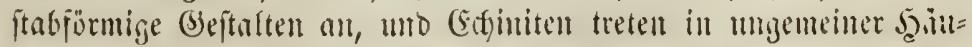
figfeit aur.

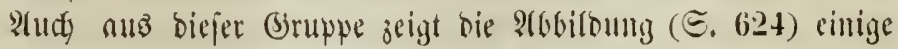
Forment. 


\section{2}
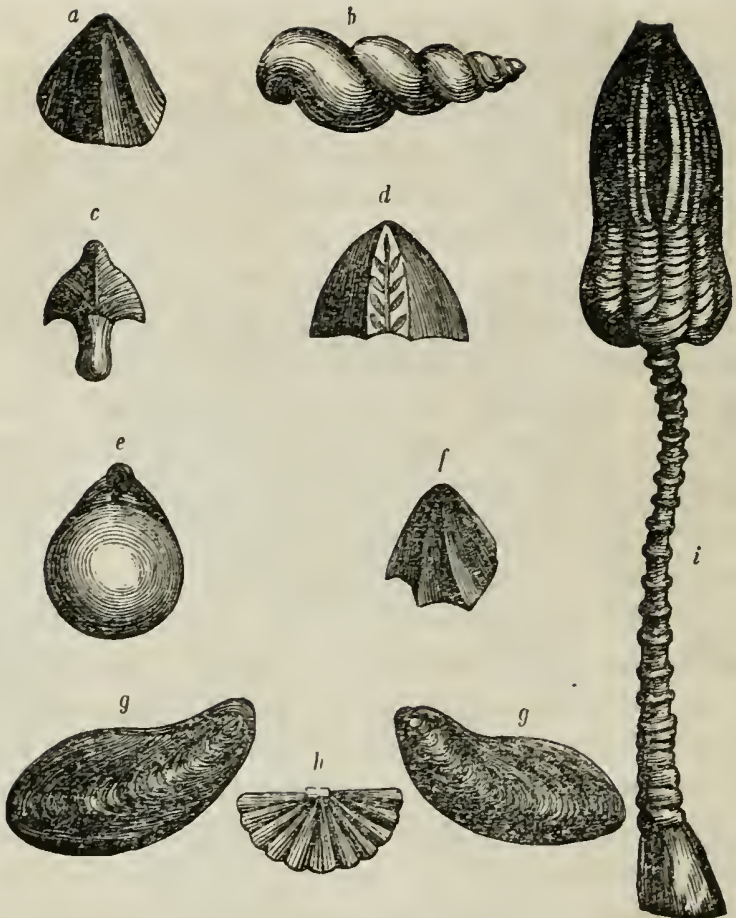

$k$

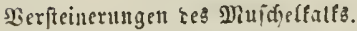

a Mrophoria vulgaris, $b$ Melania turritellaris,

c Rhyncholites hirnndo, $d$ Rh. Gaillardoti, e Terelualula vulgaris, $f \mathrm{~T}$. arculata, $g$ Aricula socialis, 4 Spirifer fragilis, $i$ Encrinites liliiformis, li Ammonites nodosus.

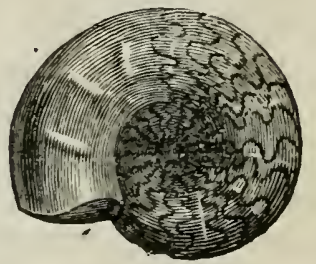

Den eigentlyümlidfen CGgarafter verleiht biejer \$eriobe ber $\mathfrak{B} 0 \mathrm{r}=$ zeit bie 2 mplyibienmelt, bie in ber Suraformation einen wunber=

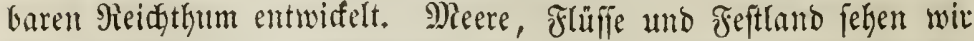
won Edjildfröten uno Gibecfjen bevölfert, berent Formen, jeß̨t wöls lig veriffwunden, zwar zum Theil in ifrem Baute ben heut leben=

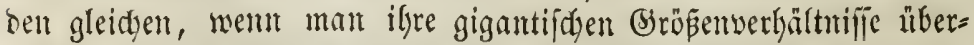

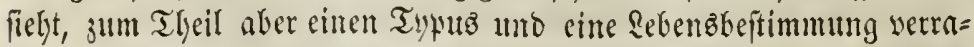
then, wofür es in ber fyentigen Edyopfung fein Beipiel mefre giebt. 


\section{3}

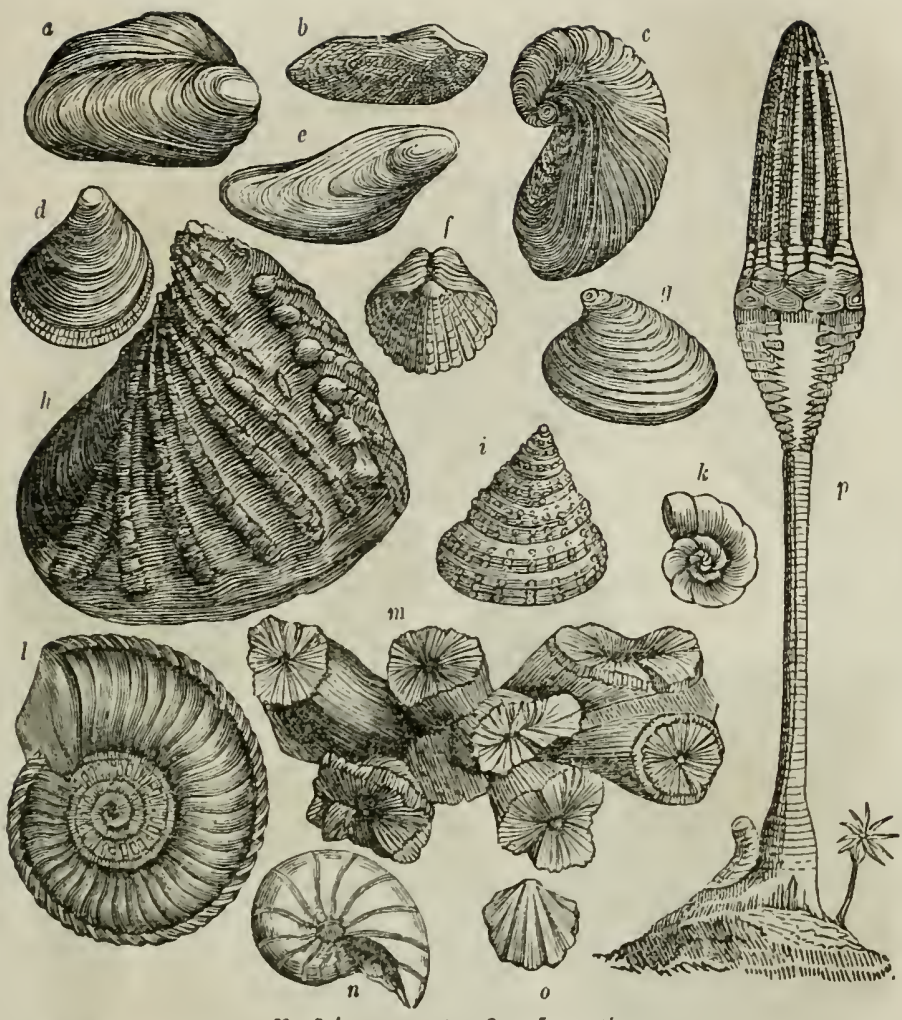

Berpieinerungell Łer Jurafurmation.

a llippopodium ponderosum, $b$ Cucullaca elongata, $c$ Cryphaca incurva, $d$ Pacliyodon Listeri, e Gervillia, f Spirifur verucosus, g Plagiostoma gigantrum, $h$ Trigonia navis, $i$ Pleurotomaria anglica, $l$ Ammonites colabratus, $l$ Am. Amaltheus, $m$ Caryophyllia annularis, $n$ Nautilus decussatus, o Terebratula sulserrata, $p$ Apiocrinites rotundus.

Piejenbafte Ungeheuer treten ums hier entgegen, fabelhafte Bicjdjöpe,

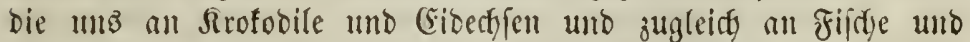
Cäugethiere erimnern. Daz \$ieer ift bevöffert yon 30 Juß langen Fiidjeidedjên unt Ecebradjen, mit naftem Sörper und futren

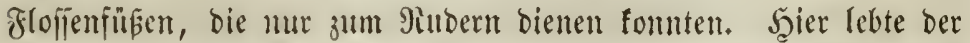

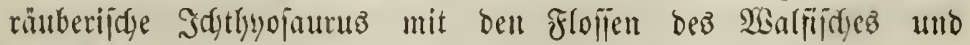

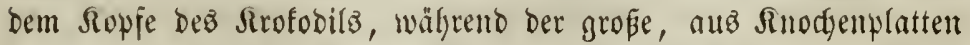

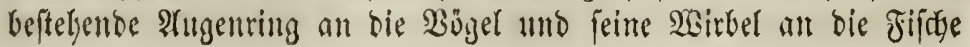




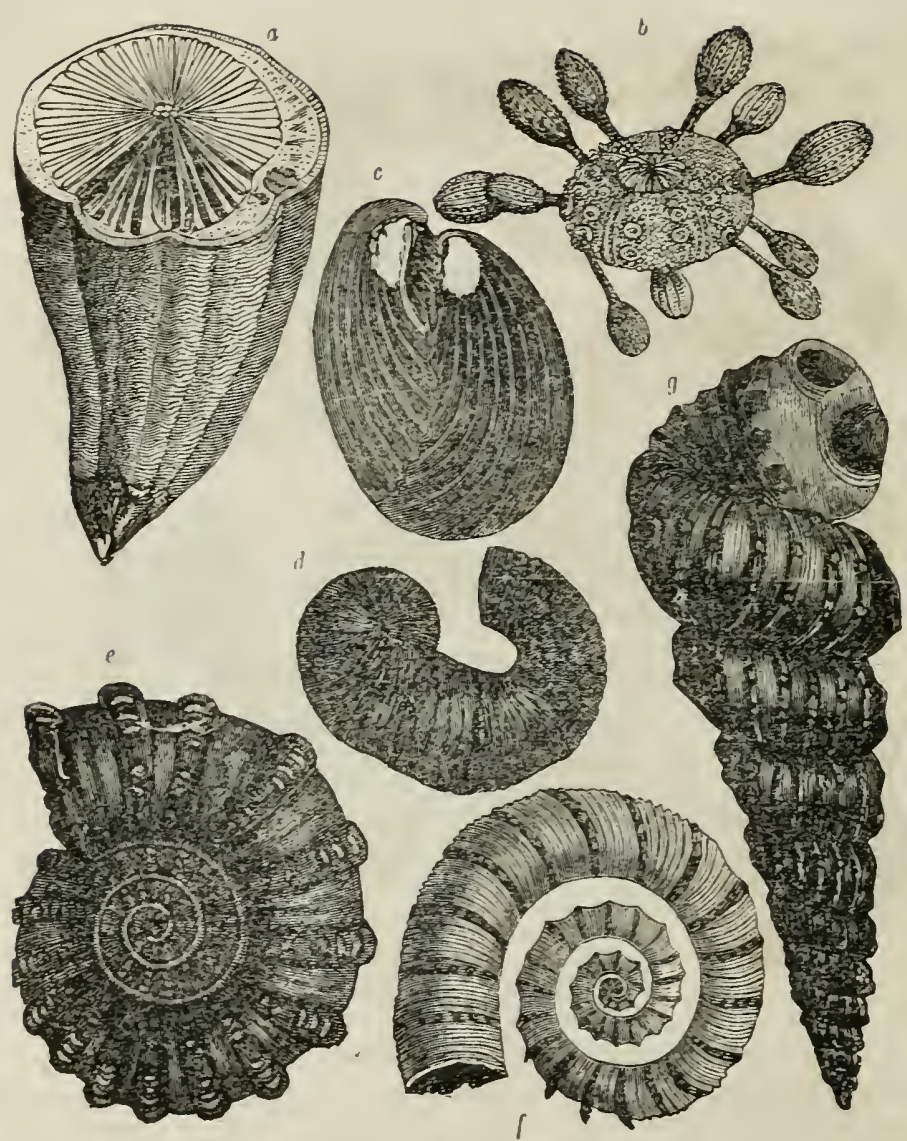

Berpîteinerungen fer fireizẹtrmation.

$a$ Hippurites bisculata, $b$ Cidaris clavigera, $c$ Terebratnla lacunosa, $d$ Scaphites, e Ammonites, f Crioceras, g Turrilites.

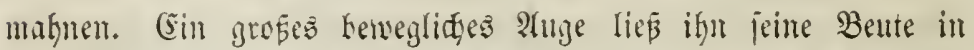
jeder Meerestieje mo fei jerem Ridumedjel eripäfen. Reben ilym

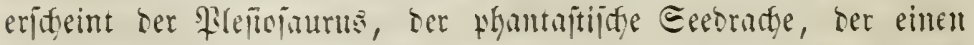
Eidedjenleib mo furgen Edwanz, aber einen ungeheuer langen

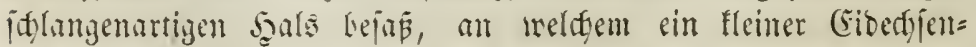
foff king.

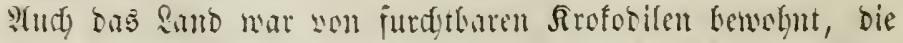

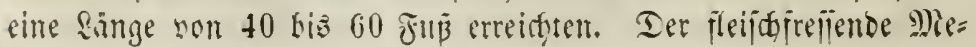




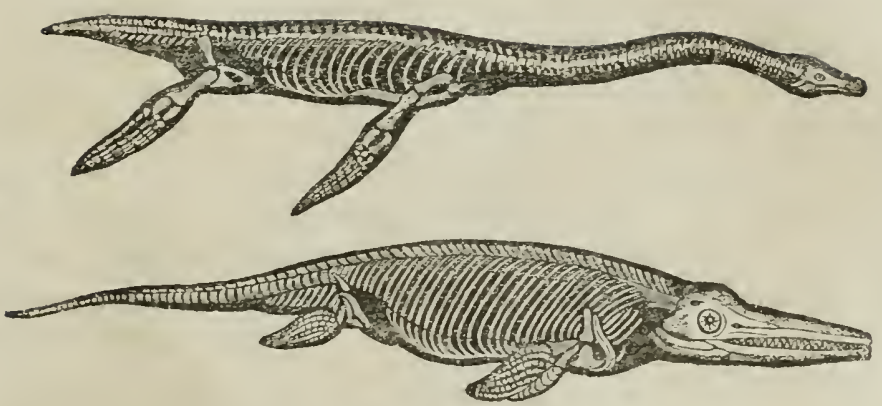

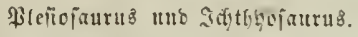

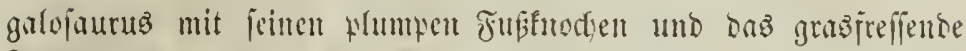
Igunnobon, Das in bem fleinen ?egutu unfer beutigen warmen

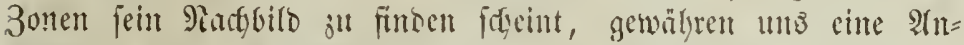

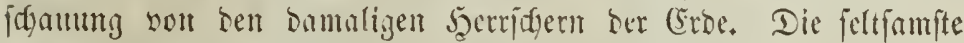
(Sejtalt ber Borgeit ift aber Der \$iterodaftylus, tie fliegende Cribedgie.

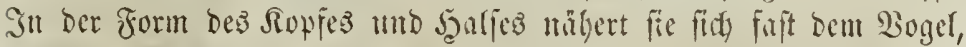

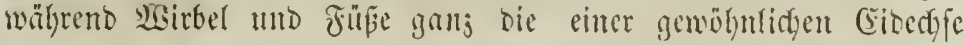

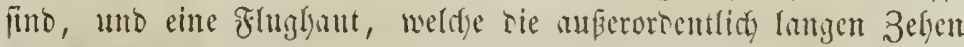
Der Borberfüpe nuşpanten, fie jur flerernans unter ben Repti= lien ftempelt. Diefez jigeuplidy mutberbare Thier war gleidy ge=

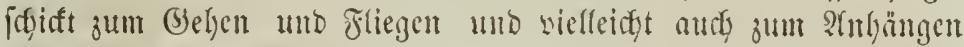

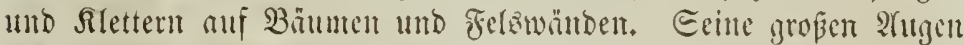

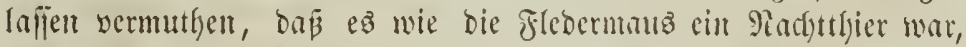

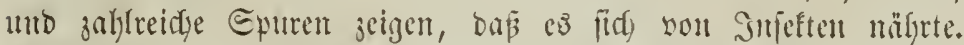

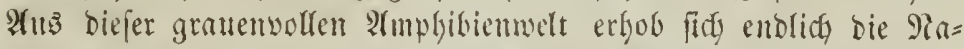
ture auch zur Bildung eblerer Gejobupfe. Edyon auf \$latten bes

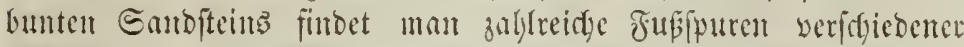

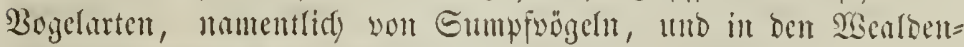

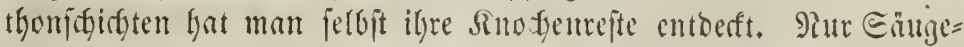

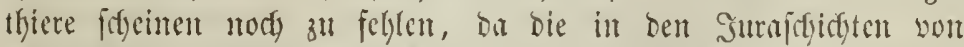

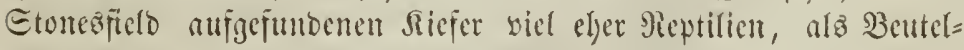
thieren, Senen man fie lange juidricb, angebüres. Siod) fint $\mathrm{es}^{3}$

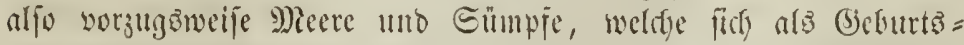

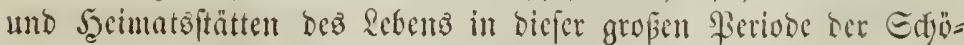
pfittg zeigen.

Sn Den Edjidgtell ber tertiären Formationen ober ber antebi= IIte, weltnll. 3. wuf. 
Lubiantiftgen Feriobe fitmmen im Alfgemeinen bie Stewätfie meit

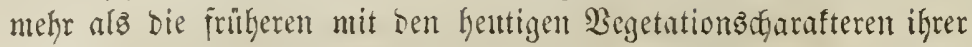
Fumborte überein. Tie frülyeren rein tropilidgen Farm= uno \$al=

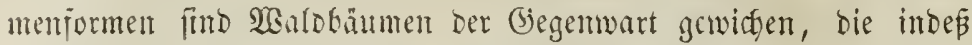
immer nodh auf eine bökere Temperatur, namentlidy ber gemäpigten 3one, Ginweifen. Şier wudjs in üppiger Fülle ber harjreidfe Bern= fteinbaum, ein Berwantoter unjer sisei = Into Motgtanne. Budgen= tno Citfentuäber bebecten bie Ränber, aber neben ifyren gebielyen

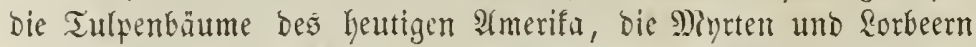
ber warmen 3one. Aluch sie Thierwelt entwifflt fith in neuer (B)e= ftalt. Etatt der \$iolypen fehen wir im Berein mit mitroffopiídyen Riejelpfiamzen bie Enlfịdaligen Siummuliten uno Milioliten mäd)= tige Edfidften erpüllen, unto bie Etelle der frulber io zaftreiden S(mmoniten uno Belemniten nefmen jeßzt nette Mujcheln uno

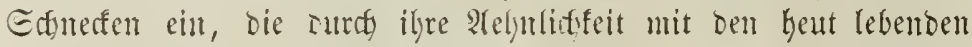

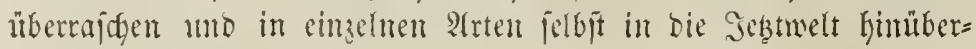
greifert.

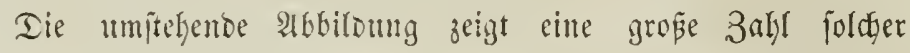
Formen.

Die (s)liebertbiere haben aud jebt nod) eine untergeoronete Rolfe, aber neben ben Rrebjen treten bereit $\Theta_{p i m n e n}$ uno pione uno jahlreidje Injeftemarten auf. Die Pintfgratthiere ser= leifen biejer Edjopjungapperiode ifgren eigenthünlidjent Ëgarafter.

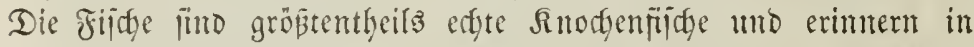

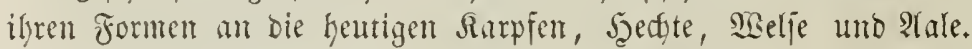
Die Amplibien rerlieren ifre mulnoerbaren Befitalten. Ealamander,

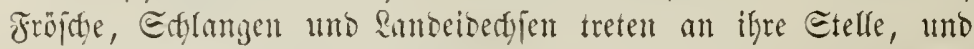
mur riefïge Edfilströten mafmen uns nodh an bie gropaartigen

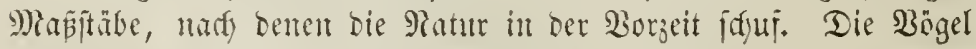
lyaben umb audy in Den Dilusialidgidten nur wenige Heberrefte Ginterla\|jen, aber in auperobentlidger Mentge treten bie Eäugethiere Fervor. Sm locfern Thon = uno Rehmboden, in Eand = und Echutt= maijen, aber am reidyiten in Sobjsen unto Epalten ber bebirge fajt

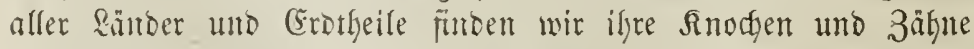
aujgejdjidytet. Şier giebt ez Simnbaffen, bie eimer ungeheuren Eeefuh amzugehören jageinen, mit gropen nady unten geridgteten

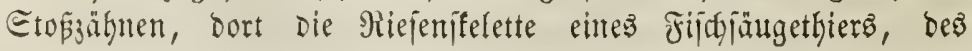




\section{7}

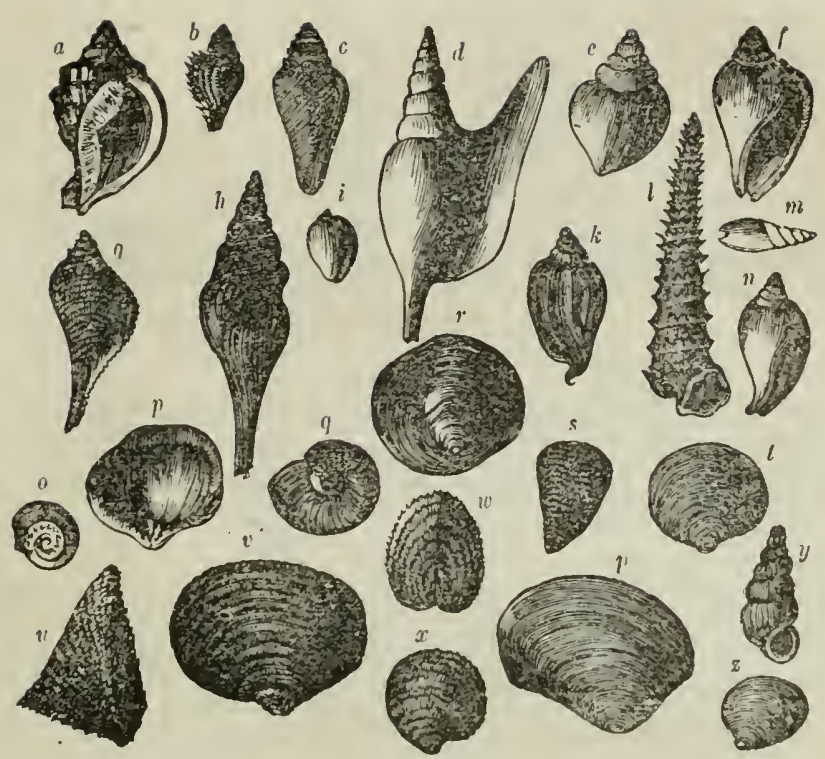

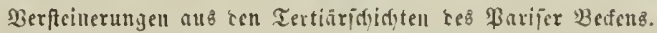

a Cassidaria carinata, $b$ Strombus ornalus, $c$ Couns diversifurmis, $d$ Rostellania columbella, a Ampullaria acuminata, f luccinum strombides, g Pyrula nexilis, h Pleurotona Iranstersaria, $i$ Narginella osulata, $k$ llarpa musica, $l$ Cerishium tricarinatum, $m$ Oliva nitidula, $n$ Fusus lnalsiformis, o Bifrontia laudinensis, $p$ Cypraea depressa, $q$ Nalica crpacea, $r$ Norilina conoidea, $s$ Pileopsis cormucopiae, $\ell$ Lucına concentrica, $u$ Cardimm aviculare, $v$ Corbis Lumida, $w$ Penericardia cor avium, $x$ Chama launellosa, y Cyclustoma mumia, z Venus lurgidula,

Zeuglodon, bie Durdy ifre ungefeuren Dimenfionen unb abweidyen= ben Formen in ber freilid, umwahren uno erfünfelten 3ujammen= ftellung bez Scybrardyoz vor wenigen Safren in ganj Deutfdyland

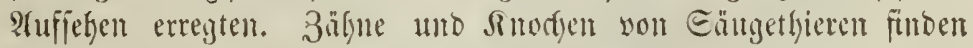
fid aller Drten, und felbjt bie ganjen Reiber eillez vorweltlidjen

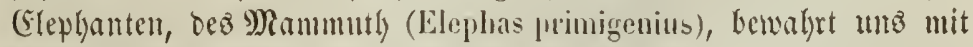
Fleifly uno Saanen der eifige Boden Sibirienz auf. Die burd)

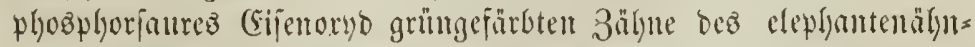
lidgen Majtobon fofmüten alz Türtife lyeute mandje zarte Dament=

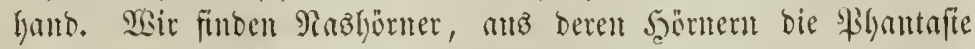
Der Borgeit bie Rrallen Dez Logelz (breif gemadyt hat, und Ta= 


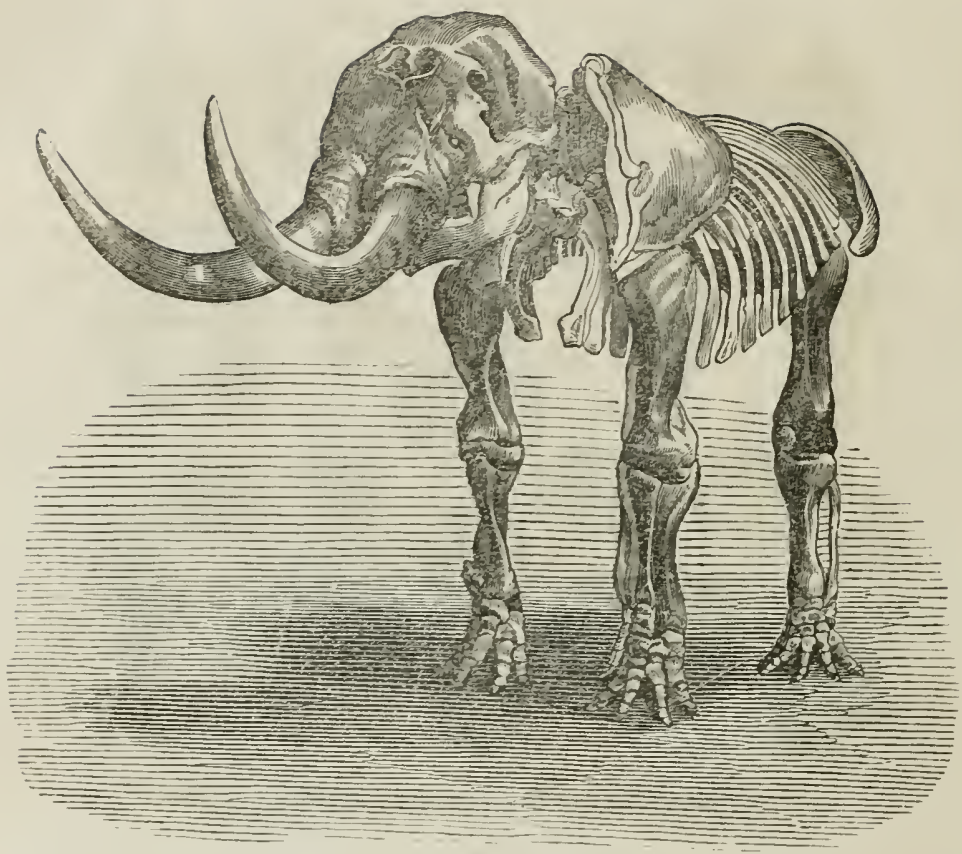

In Shiotfier (Hastodon gigantcus).

pire, bie in Dem łalãotherium an die Gejtalten unjer Edgweine crimern.

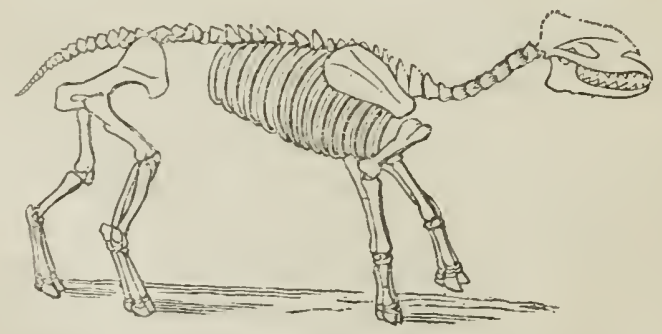

Malảotherium.

Wie abweidgend nody immer mandye Formen you ber Jebtwelt waren, bas kemeift bas Dinotherium, ein Dem Keutigen E(ephan=

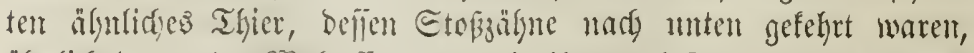
älyntich benten bes 2 alrofles, uno bie ifym wahridgentidy baju bien= ten, fich an fteilen lifern emporzujiehen. 


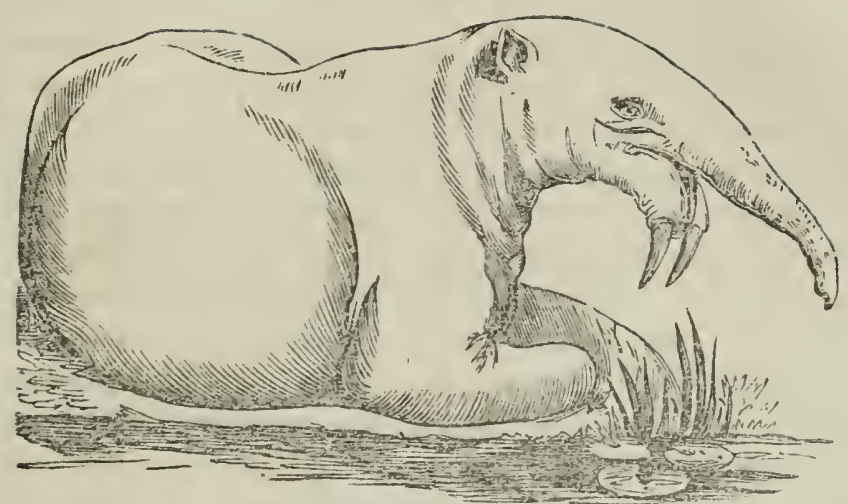

Dinotherium giganteum.

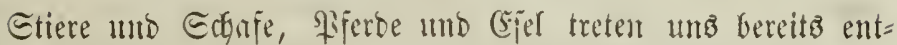

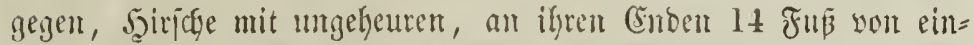

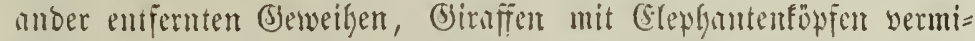
ichen aư in biefer (Bruppe bas (Sewohnte mit Frembartigen. Daju fommen bie faulthierartigen Ungehener, : weldye ben vorweltliden

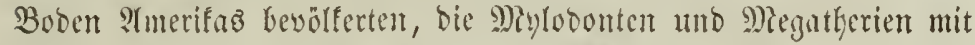
ifrell langen, fódurfent Srallen und flumpen, geigen eimen Fur biffen Extentelfnodyen. Tieben ifmen lebten rieïge bïr= telthiere mit 6 fü laut=

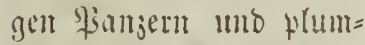
pen füben. 2userorbents (id) zaflereids ijt in jener 3eit Die Finn ilie ber Sisuls= thicre vertweten. lleberall finbelt wir bie Edgäbel und Sinorfent gewaltiger

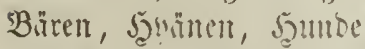
uno Rakgen. Flebermüufe und affen, wertil and

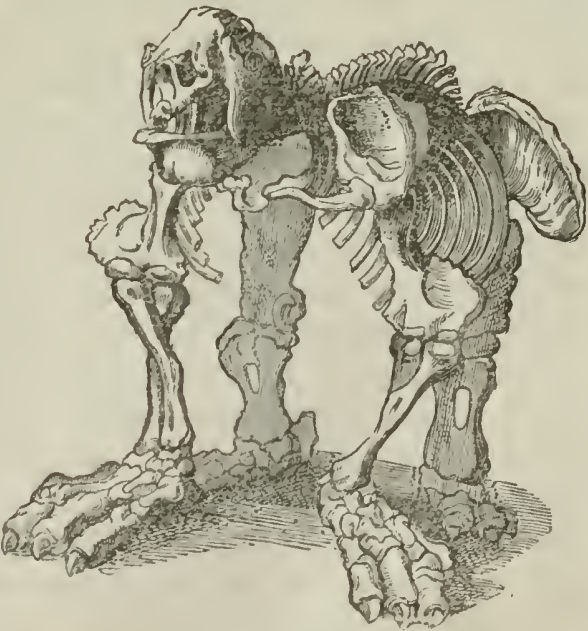

Megntfucrium.

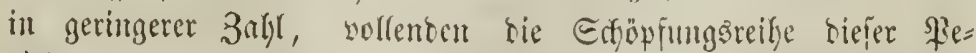
riobe. 
๔o fehen wir afjo bie Ratur in ifrer Rebensentwifflung im=

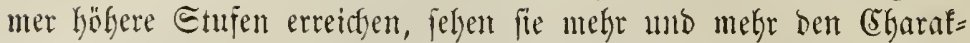

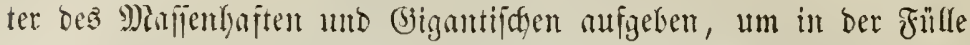

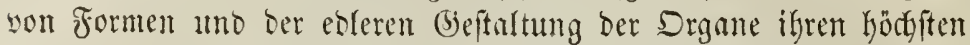

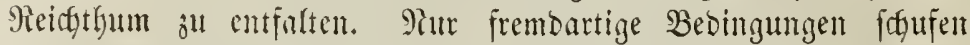
fremburtige Formen. So giebt uns bie Rebensuvelt Der Borzeit

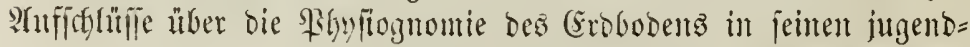

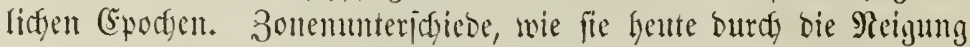
Der Eroure jur bithuelente bedingt werben, fomten erft in ver=

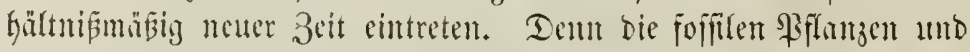
Thiere zeigen lange 3eit linourdy feine lunteridgiebe nadh ber geo=

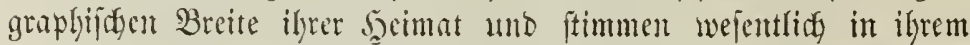
Eharafter mit den Ziflamzen und Thicten ber beutigen Tropen

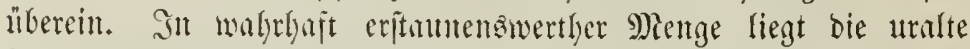

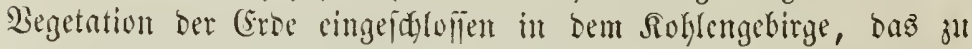

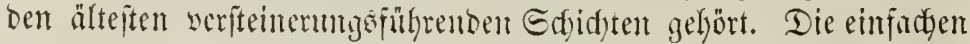

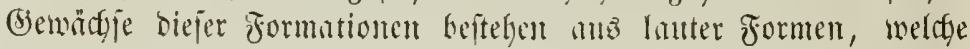

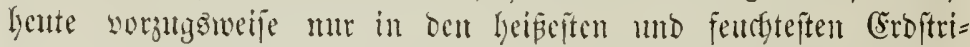
cten entwiffelt werben. SBenn aud fintrn umb Bärlappe gegen=

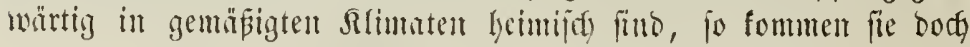

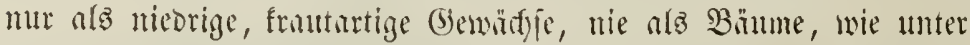
Dest Tropen, ober gar bent Micienftümment deş Eteinfohlengebirgez gleidg, nor. Dieje Eteintwhlen fintoen wir aber nicht mur in bei= feen ober gemäpigten Sänocrn, fie treten felteft in Brönlant umb auf Der Snjer Melvifle auf, in (bigenton, wo ber Eommer jebt faum

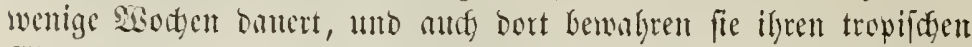
Ĕharafter. Sin Fräteren Formationen treten zwar allmälig böhere und mantigialtigere sifingenformen auf, aber and fie bemobren ifren frembartigen (bharuffer gegen bie Begetation ber Begenwart.

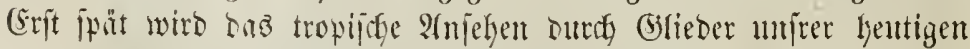
gemiäigten florengebiete werbrin̈tyt; aber and fic bentent auf ein

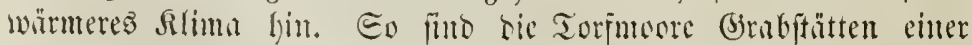

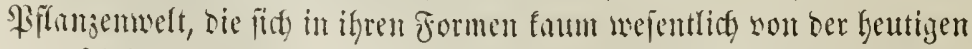

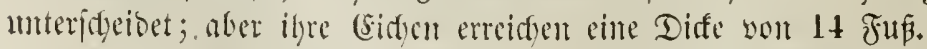

Iatd) in ber foffitten Thierwelt begengen wir Eridgeisungen,

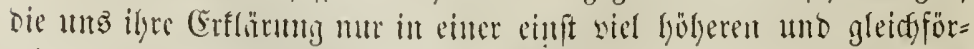

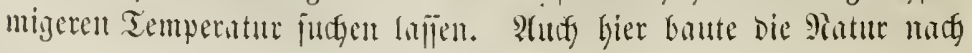




\section{1}

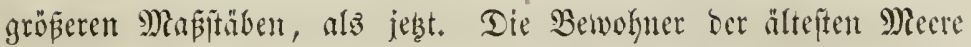
find unter allen Breiten, wo fie anz ben Edjitgten ber Groe ge= graben werben, biejelben unb unterifyeiben ficl) wejentlidy von ben heutigen Mieeristhicren, felbit ben näbjten Berwanden ber tropi=

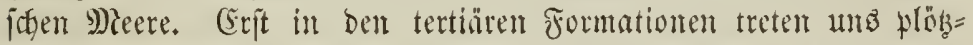
lidy colere formen entgenen, jum Theil gewaltige bicjäpfe in Berein mit jolden, bie fid jebt liber alle ober viele Rlimate ver=

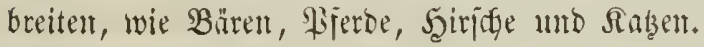

Eo sereinigt firt affer,

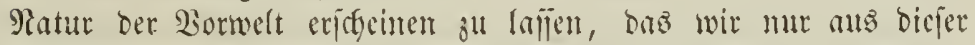
Bejammtheit aller Cintrüfe zu enthülfen uno ju begreifen sermögen.

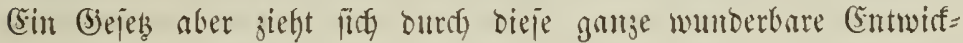

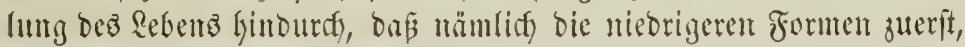
bie höheren päter ins Dajein gernfen wurben, baj fith bas Fejt=

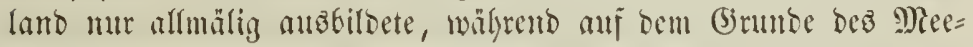
res immer neue Edfidfen nieberiejefligen wuthen, und bar bie Entfaltung ber an Das Rand gebumbenen Thierwelt Damit Erfritt lielt. Eo geminnt Der Forjaer fifyon hierin widytige Saltpunte jur Beftimmung non \$iriodest ber Eedimentbiloung. Ien eigent=

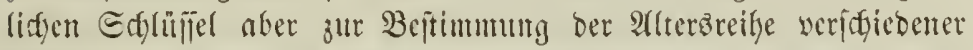
Formationen geben bie Edyalen ber Mecidgtgiere an bie 5ento. Dent

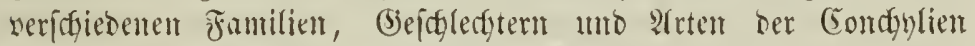
fommen in ifrem 2uftreten, in ifrer 2 (n)

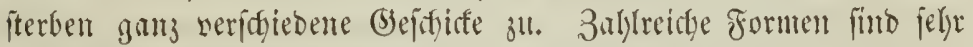
frihh wieber abgetreten, andere bagegen ziehen fich mit zäher $2113=$

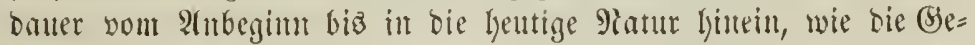

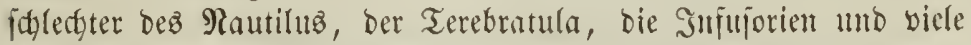
Sorallen. Fajt jebez (Sejd)ledht mit feinen Anten verbält fich hierin wieber anbers. So erjegenen bie 2fmmonten fogn im Roflen=

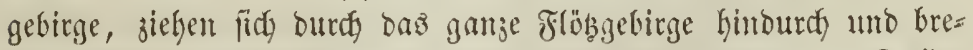
den in ber jïngften Formation ber fefundören Bebirge, Der Sreibe, völlig uno plöglidy ab. Dabei fommen aber gewifie formen ber= felben mur in gewifin Edyidften vor, treten liberall mit ber einen Edyidyt auf und verjdwinden mit ber andern. Fuf biefe Saeife fommen jeber Formation und faft jebem eimzeluen (s)iebe berfelben theils ganz eigenthümlidge Formen son Contdylien zu, theils we=

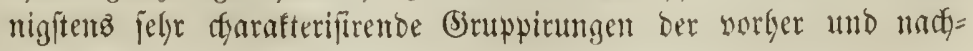


Ger zugleidy eriftirenter. Sisemt fith baher nidgt mur in benfelben, fonbern aurf) in serichiedenten Bifoungsperioben ber Erorinto sie Ralfitein=, Eanditein= mo Thonjdicteten jo einförmig wieberfolen,

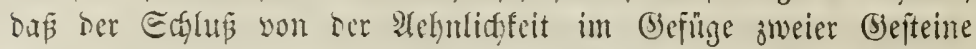

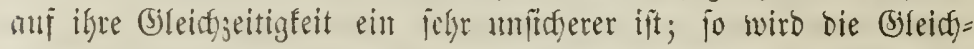
artigfeit ober lingleid)artigfeit ber Edjiçten, bas relative Alter Der

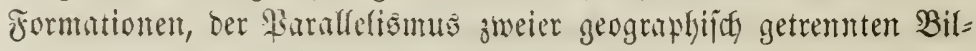
bungen an juserläitijten bejtimmt burch sen Sharafter ber in ifhnen

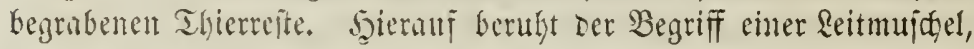
eines ঐetrefatts näm(id), entidjiebenfte 3ettynis üher bie Formation ertheilt, zu weldyer fein

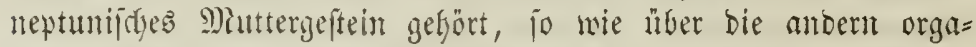

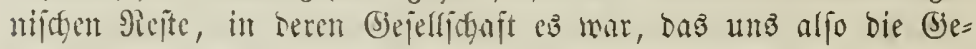

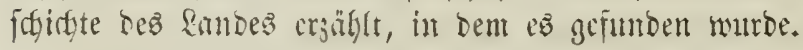

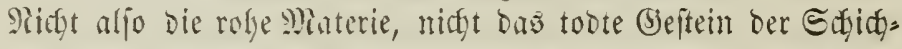

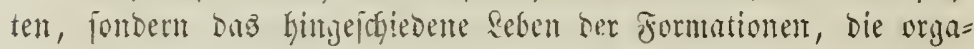

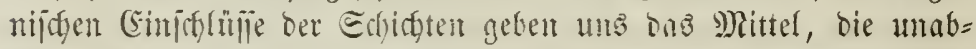

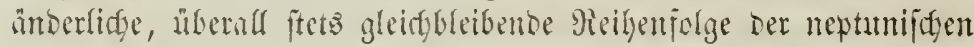

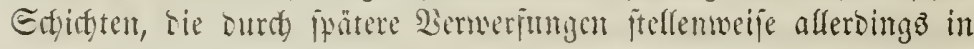

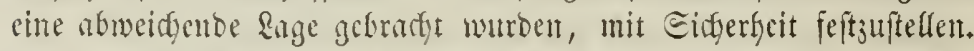
Das Reben ber Borwelt eröfitut uns einen Bhicf auj alle Berbält=

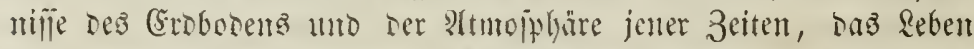
brüft, wie heute bent sintoent, io cinjt den Beiten ber Eroe eigen= thünlidge Çgarnftere nuF.

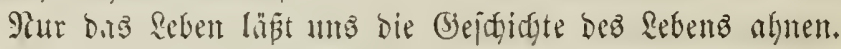

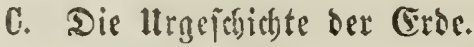

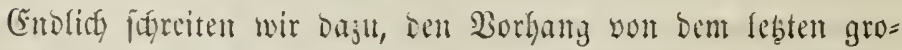

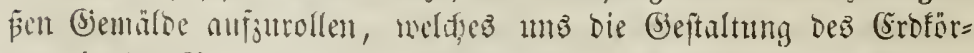

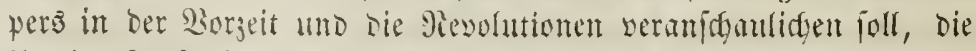

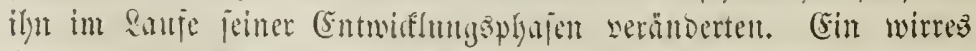

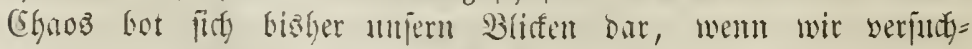

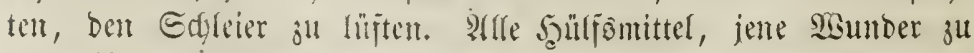

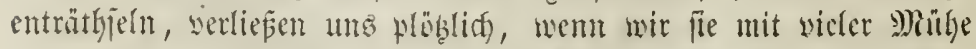
3̆ biejem 3werfe vorbereitet batten. Da wir ung undy nenen um=

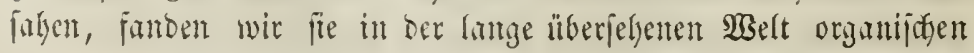


Ultebenz. atber fein Mittel barf angewenbet werbell, ehe man es genau fenut. Darum galt ez zunädfift, dent Etambpunft unfere $\mathfrak{B} e=$

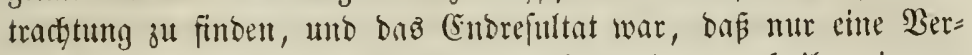

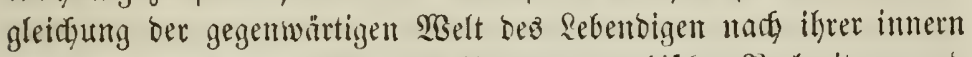

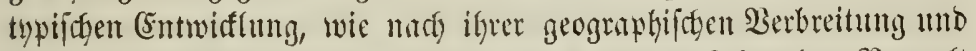

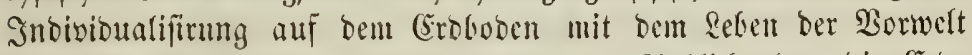

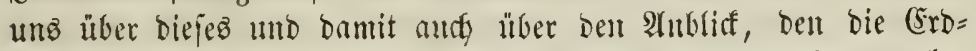
oberflädye in jeber Epodge ifferer Entwiffung bargeboten hat, wahro=

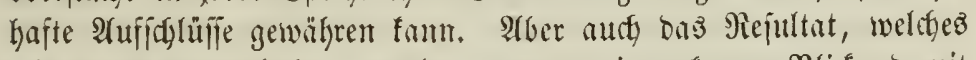
wir zu erwarten haben, verlangt zutwor einen furjen Bliff, Domit

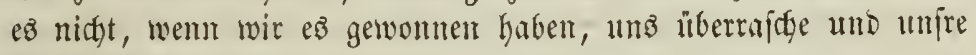
(Erwartungen täujişe.

(Fin in alfen Theilen woflendetes Bild bürfen wir niçt hoffen, unt wer, an herrifgende Trabitionem gewölynt, etwa eine furje : ?h= gabe ber cinzelnen atfeinamber folgenben sterioben in frtenger Edyei=

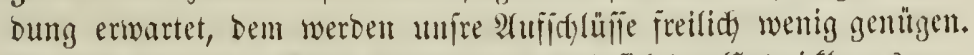

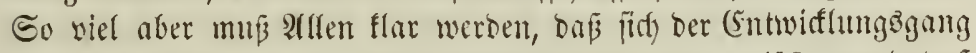

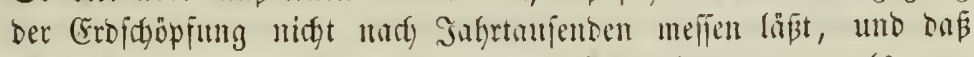
bie Eegenwart mit ifheem hiftorifjen sllter immer nur als ver=

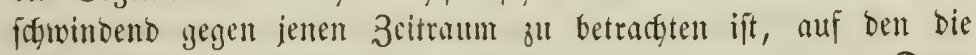

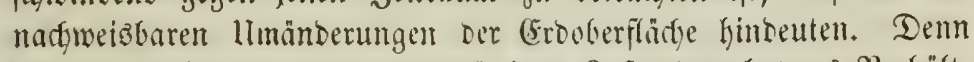
lange vor Eintritt bes gegenmürtigen 3uftandes hat es Berbält= nilife gegeten, bie Den beutigen entipraficn; Dason überzengen unz bie untergegangenten bsidjüpfe. stber jelbit in biefem fo großen

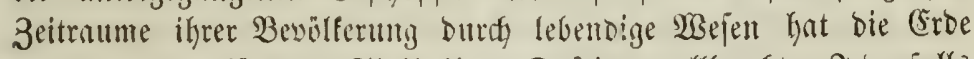
wohl mur bent fürzeren Theil ifres Dafeins volfbradyt. Sebenfalls

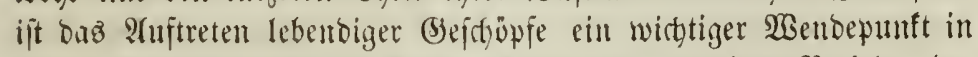

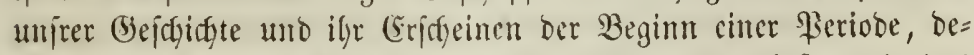

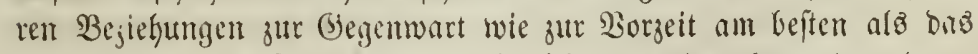
Silnglingzalter umferes filaneten bejeiffuet werben famn, bem bamn

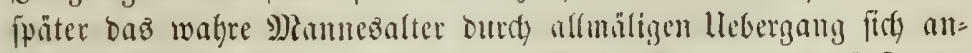

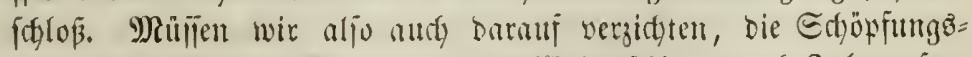

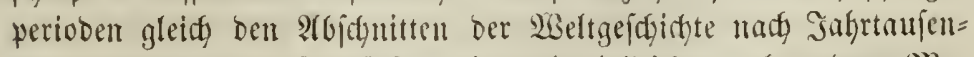

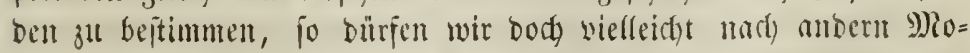

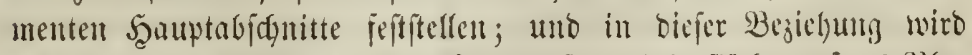

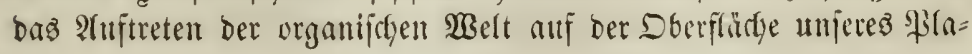




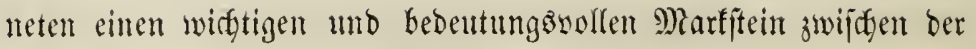

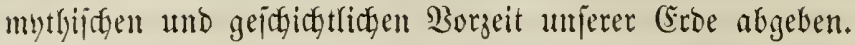

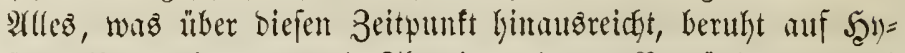
potbejen, Bermutfyungen und Theorien, beren Begrünoung burds befitumte Thatjacten faum möglich ift, uno erinnert an jene 3eit=

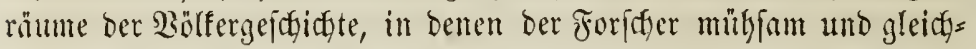

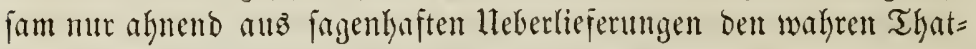
befturb bu entwifferm juct, indem er bie Moythen ihres fdjonjten Scthmutez, Der Didftumg, beraubt unt fie auf ben wirflichent, tarf=

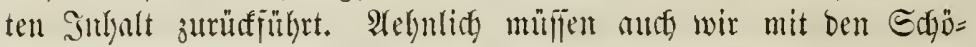
piutgsimythent verfahrent, weldhe ber von jefer über feinen Urjprung, wie über jeine Zufunft bejorgte Menich und ben Berjajicbenbeitent

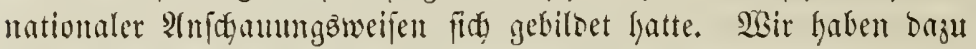

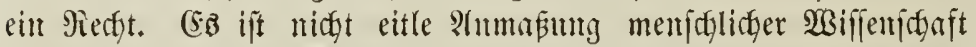
gegenüber geresfen Snnprüchen göttlidfer Sffenburung. Der gött= lide Rame ift figon fo oft unb bejonters son benten, bie ifyn be=

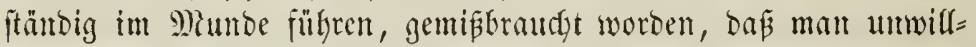

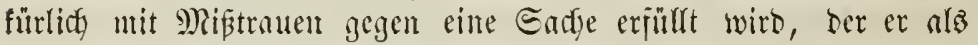
ber Etempel der $\mathfrak{B a b y r k e i t}$ aufgeorihft wirt.

Seine ber altent Engen, andy bie mofaijdge nidft, hat an unto

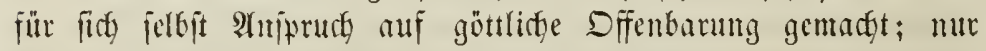
Menidjen thaten utnd thum ez̉ nod, um unter biejer Falgne ben

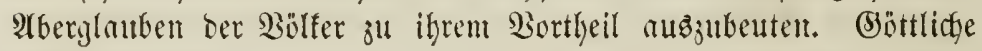

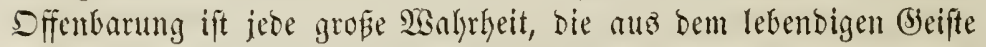

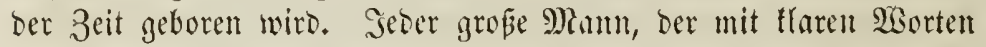

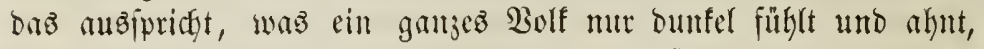

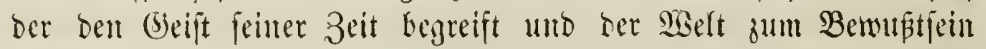
bringt, was fite bislger unberwubt trieb unt bewegte, ber ben $\mathfrak{B o ̈ l}$

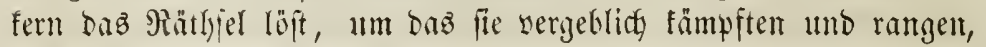

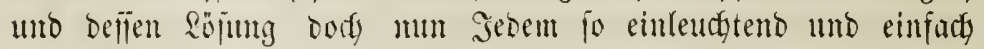
jofeint; jeber foldyer sham wirb getrichen von bem göttlidfent (S)eifte, Der in ifm lebt anto webt, in ifm denft und fipridyt, und

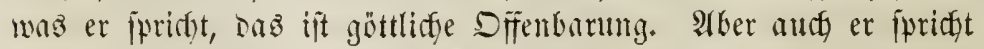
nur aus ber 3eit. Sein Drafer ift mer bie Befammtanichauming. Der Begentwart, nie der 3ufunft. Darum ift jede Dffenbartutg mur einte zeitlidje, eine bedingte, nic einte abjolut wahre. Sie ift

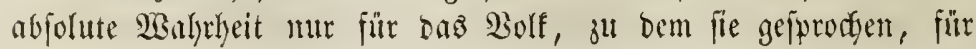


bie 3eit, in ber fie geprothen wirb, aber fortin vergänglidg und

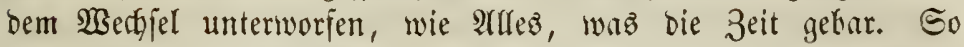
müffen wir jebe Difenbarung beurtheilen, fie acten als bie fwön= ften Blüthen ber 3eit, alz helle Eidbtblife in bem aufoämmernten

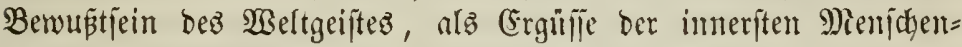
natur, nidyt aโร Stimmen einer jenjeitigen, fremben Siselt, bie mit falter, geheimnipsoller $\mathfrak{S}$ and himübergreift in bas jøöne, warme

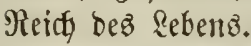

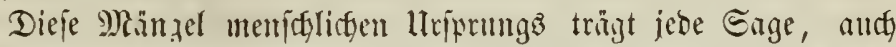
bie mojaiftye Edyopfungsmnthe an fitf. Berabe ilye weite Bertrei= tung unter ben entlegenften Bölfern, die man biz̈weilen alz Beweiz einer Unerinnerung ber Menidheit hat gelten lajien, gernoe bicjer

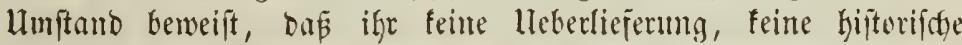
Thatfadye zu Brumbe lag, fonbern mur bie Bfeidgeit ber menjoli=

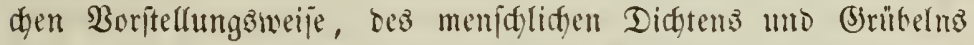
zu ber gleidgon Erflärumg Der gleidyen Ërifteimung fülyrte. Die Eage fudt immer bas Senjeitige mit dem Diesjeitigen, bas (5)e=

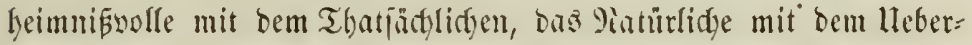

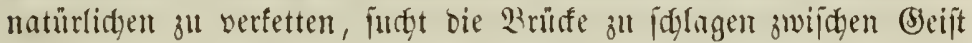
unb Ratur, jwijhen bott und Madt. Das ift wieber ein rein mentdylides Bejtreben. Eie will bie aufer aller Erfahrung lie= gende Eridgeimung bes eriten Entitelyeng Der Drganifation, ber er=

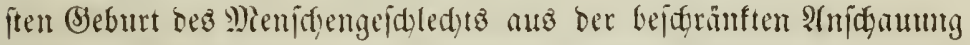
ifrer 3cit berans auj eine innerbalb beutiger Erfabrung liegenbe Weife und jo ertláren, wie in 3eiten, wo das ganje Menjtgent=

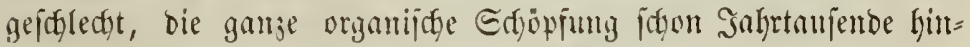
burd) bejtanden butte, eine müte Snjel voer cin abgejondertez (3) birgsithal bevölfert morben fein maj. Şier fann mur bie Pigan= taffe uno ifye lieblidge Iodyter, bie Didytung, walten. Der ermite (Bebanfe wilto fid vergebens in bus Froblem jener erfen \&ebens= entraltung vertiefen, da ber Menjig fo an fein (bejoledst und an

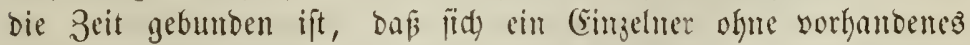

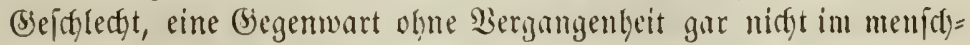
lidgen Dafein faflen läpt. Daber rügrt bie berfobebenlyeit in Den Eagen, wie in ben Raturamidyaunngen ber Bölfer und Zeiten, ba=

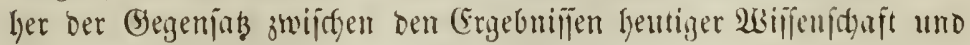
ben mythijaen Didgtungen jübifder Trubitioner. Sie fußen auf 
bem Boden einer unbejaugenen findlidjen Anjdyautung, wir auf

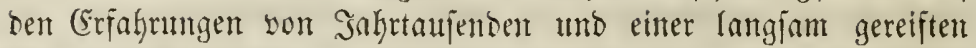
Miijenjogaft ber Ratur.

Mit biefem reinen, unbefangenent Einne, ber nidht umbüftert

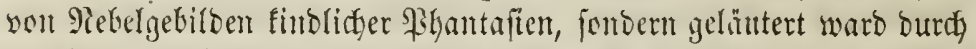

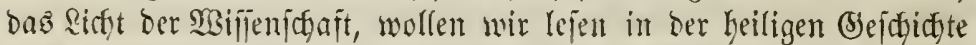
Der Matur, bie nidft von Menjentrand gefdrieben, jonbern mit unvergänglicken 3ihgen wout ber Pature jelbeft eingegraben ift in bem emigen Dentumal ifrer idatfenten Riebe.

\section{1) Das (5hås.}

शtus Eamen und (Erbe geht bie Pillanje herbor, ber fieim

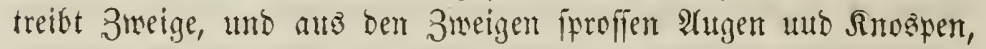
aber bie Snospen entfalten fith ju Rlumen, und bie Blument wer=

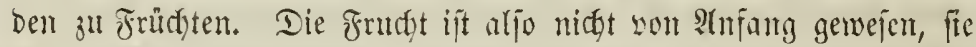
ift ans 2frberem geworben, hat fid entwicfelt, umb ifg Dajein febt

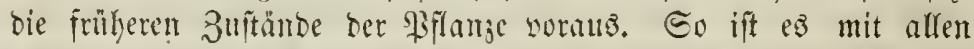

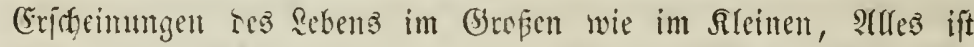
genvorben uno fojon gemejen, intr unter anderer Form und Beffalt,

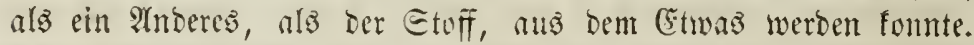

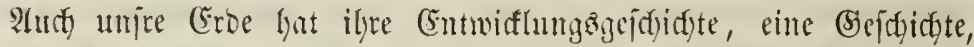

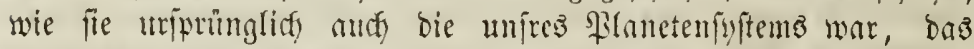
gleidfalls cinft anbers war als jebt umb mur wie afle gemerbenen

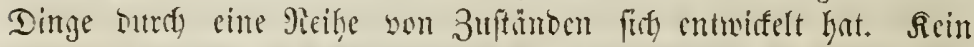

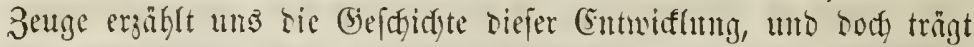

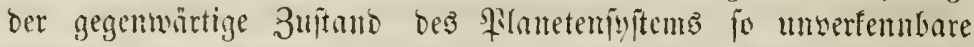

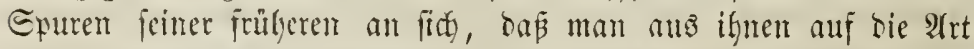
bes Mletergantges ats ber Borjeit in bie Gergemwart Eaflüfje ge= zogen und Theorien alfgebaut hat. Befamt fmo bie Berjuche

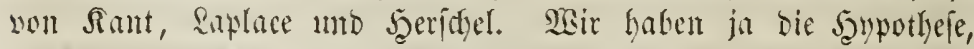
wildyer bie lekgteren gropen 2 (fitrontumen faft bie Form einer mathe=

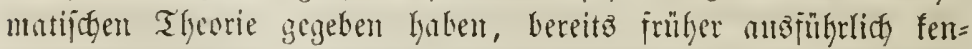

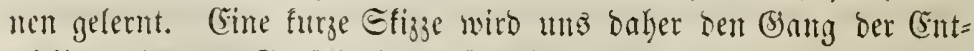

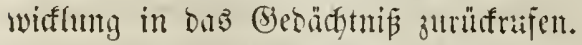

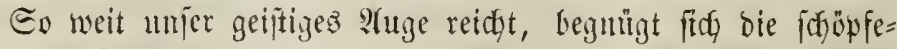

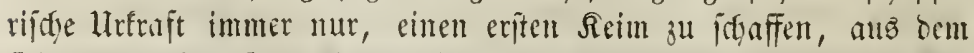

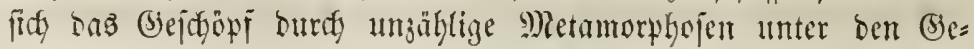




\section{7}

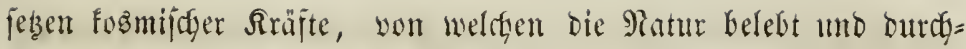

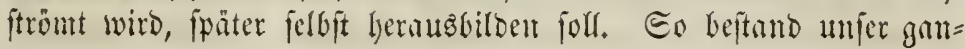

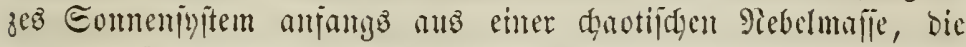

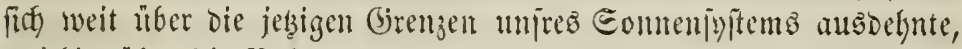
weithin über bie Balgn Dez lez̧ten, von Senerrier entoeften \$lanteten

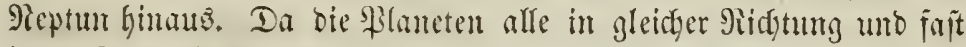

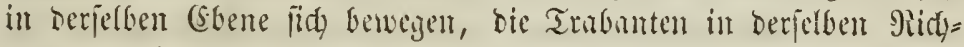

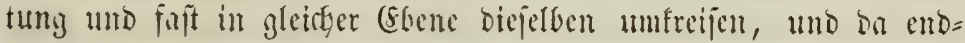
lidg ber Eentrafpunft unfres Eyftems, bie Eomte jelbft, und alle

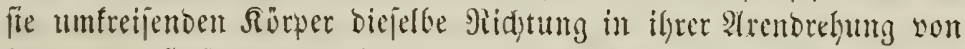

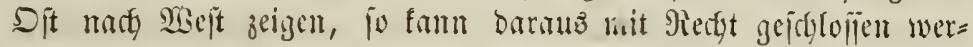

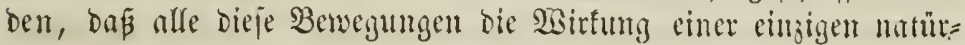

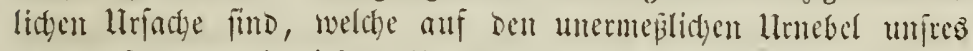

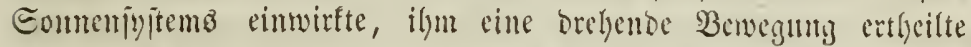

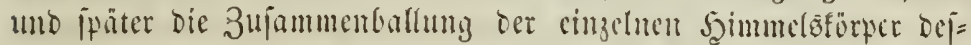

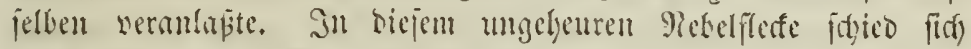
zuerit Der centrale Sern, bie Eomme, aus, und Das Eomnenyiftem

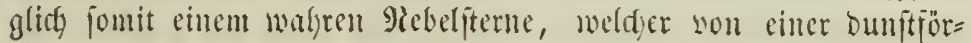

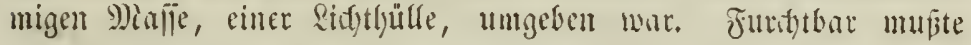
Der Samipf fein, ber in biejer entfifthenben weelt mütlyete, ungebeuer

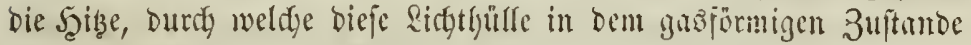

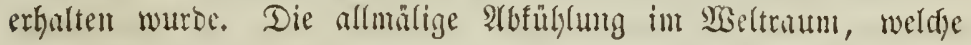

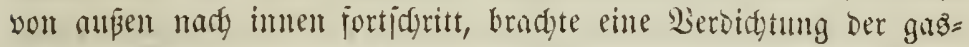

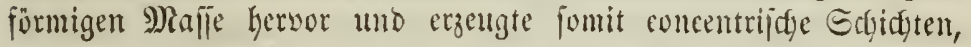

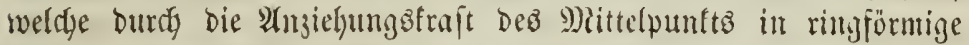
Mailen ungewanbelt wurben. Durd bie ungleide Beweegung bie=

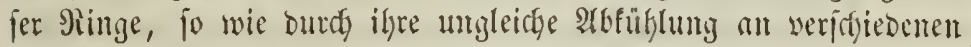
Punften musten biefelben zeripringen, und in Golge ber rotirenten Bewegung Die Eturfe fith in Rugelform zujammenbalfen. Dieje rotirenben, zufammengeballten Etilfe murben bie \$lanten, uno bei

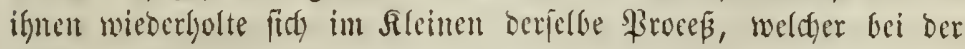
Bilduny des Eomeniyitems in Sropen gewirft garte. Die meifen Blaneten ungaben fich mit Siingen, weldye theila unverüntert blie= ben, theilz and wieber in Etüde zerjprantigen und \$rontoe bildeter.

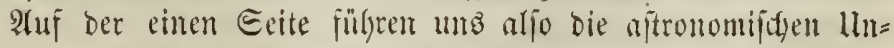

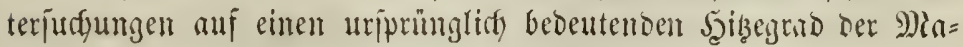
terie lin, wetrfer beren biå̊geftalt bebingt; auf ber andern haben 
Itne aud alle unje bis̆herigen geologijdyen Betradyungen bewiejen, Das bie Erbe früher in einem jeurig = flüjitgen 3ujtande gewejen,

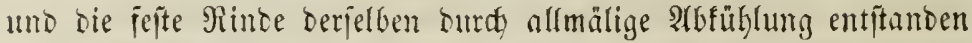

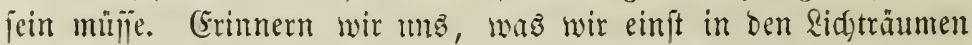
Des Saimmels erbliften, an jene unbegrengten $\mathfrak{N e b e l f l e c t e , ~ a n ~ j e n e ~}$ Rebeliterne mit ijolirten, centralen $\Re$ Rernen, innerbalb beren fid aujer Dem Rerne jelbit Ringbiloungen unb zeripaltene Ringe jeigten, fo fefen wir in Dem Beltramme jelbjt nody alle jene verjobiedenen (Ent=

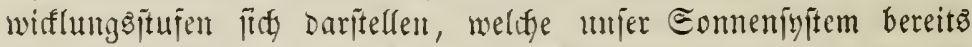
durblampen bat. Eo ergänjt bie 2fitronomie die Ergebnifie ber

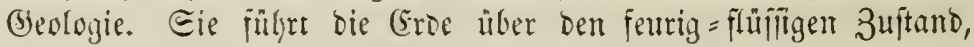
weldger son ber Gieologie nadigeniejen wurbe, Ginaus ju einem nebligen Uranjange, in meldyem die fejten Materien fidf in bem $3 \mathfrak{u}=$ ftande Der Gödyften 24ubehnutg bejanden. So lehrt die Ferne daz

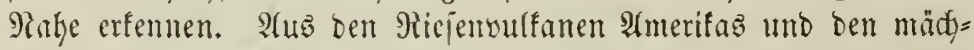

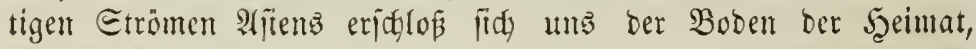

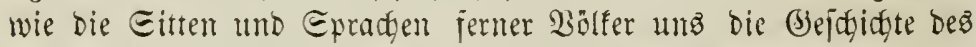
Baterlandez begreifen lehren. Die Frembe fïfhrt zur Seeimat, ber Seimmel zur Erbe; Denn alle 2 sejen und Dinge fino Formen eines einigen Bieifter.

Aber wie tiej auth unjer Bliff in bie Seheimnifie ber Borwelt einbringt, wie rajtloz aud unjer Geijt bie Tiefen ber Croe butrdy= ipäht, immer ijt es mur bie Eđale, welde bie s)iemidyenfyand burdh= blättert. Lleber bie Ratur deż Rennes, liber bie allmälige Berbid $=$ tunggึweije Der Eromaile, über bie Etoffe, aus benen fith ber

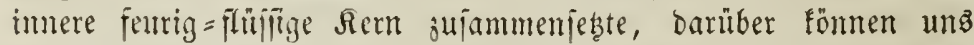

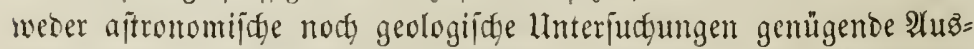

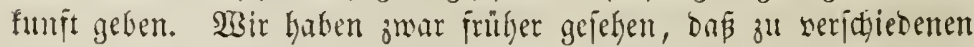
Zeiten jeurig = flitilige, ungleidartige Mafien aus Den Tiefen ber

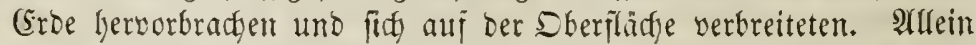
bieje Eridgeinumgen, jo bebeutent fie auds fein mögen, lajien bis jeķt nody feinen Eđfur auj bie 3ujammenjeşung Des innern Gro=

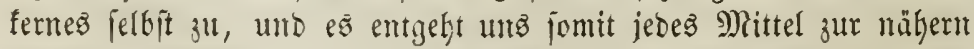
Senntnip ber Sorgänge, weldye fich in bem feurig= flinfifigen $3 \mathfrak{u}=$ ftande ber (Sroe ereigneten.

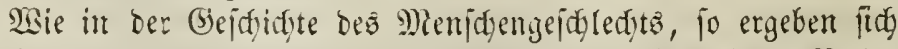

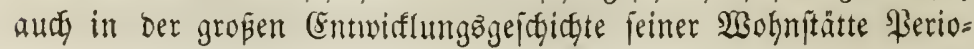




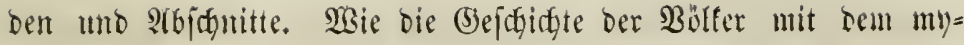

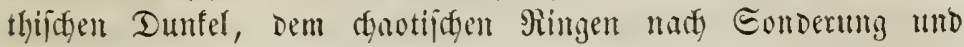
Eelbititundigfeit, nady sefer und Freifeeit beginnt, jo ift auds bie

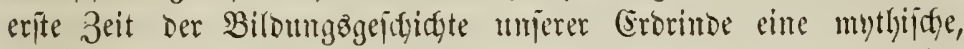

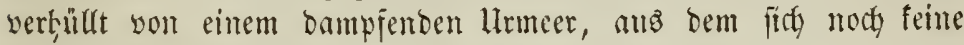
Injel, fein Feftland erhob. Saie aber mit bem (Erwathen ber Böt= fer zum Reben Der Sampf ber Beifter Kegant, weldyer bem Reben Den Charafter ber Beftimmtheit, Der Snbivibualität ju geben frebte,

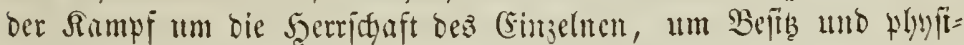

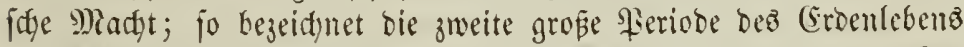

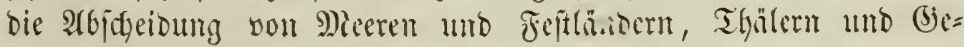

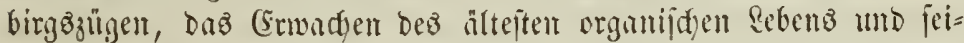
men Sampj mit ben rofen Elementen, jein Drüngen, eine Jecimat

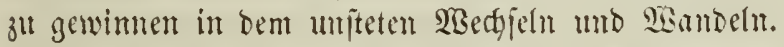

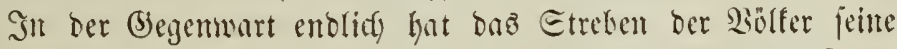

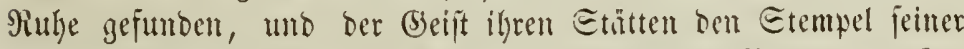
Seerridaft aujgebrintt. Eo hat audf bie (Erbe ifre Ferivoe ber (b)= genwart, in welder bie Natur 3onemunterfitide und Slimate feit=

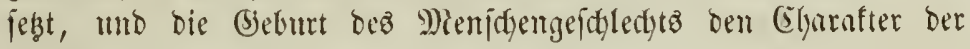
geiftigen Seerifant in ber Ratur auspright.

\section{2) Die Bildung ber Erorinde.}

In dem urjpringliden Gasballe minerer Groe maren mady bem Durdboringungevernighen ber (baje unter eimander mod) alle elementaren Etoffe dgatijds burdyeinander gemijht, biz fidg in bem=

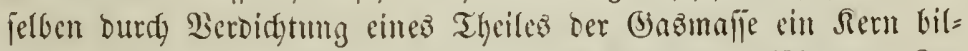
bete, ber nidgt fejt wurbe, jonbern in erweidgtem, glühendem 3 u= ftande verblieb, weil mit Der Berbidfung jeber MAaterie jeto Wärmeentwifflung verbunden ift. Durd 2fnjiel)ung alfer irbifden Materie vergrö̈erte fid biejer Sern allmälig, indem wahridgeinlidy immer bie foweriten Etoffe, aljo Die Metalfe, juerit angejogen und veroidtet wurben. Do fidh aber immer bie Clemente jelbit

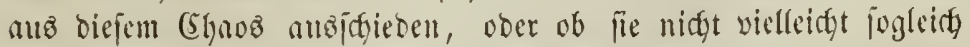
2erbinbungen mit einanber eingingen, baribler bermag bie Wifien= juaft nidjt mehr zu entidgeiben. Denn baß unz bie Elemente

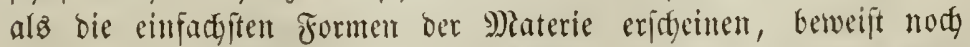

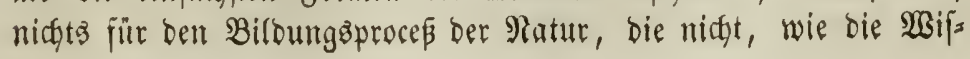


ferridgaft, zu zerlegen uno zut vereinzeln tradtet, fonbern fofon in

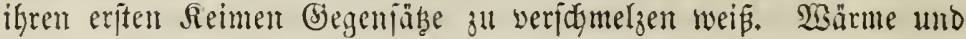

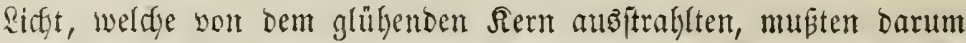

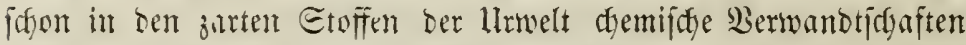
erregen, in Folge beren fith Eroen und Alfatien, Drybe und Salge bilibetert.

Da feine Berbinbung olne große $\mathfrak{B}$ ärmeerzeugutg yor fich geht, fo befiarte Der metullijge Rern fortbauerno in geiffmol $z_{3}$ nem $3 \mathfrak{u}=$ ftante, und aud bie Eroen felbft waren trog ifrer Etrengflüfifg= feit anjangs feurig = früjitg. So bilbeten fie eine Rinde um ben

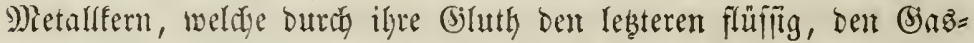

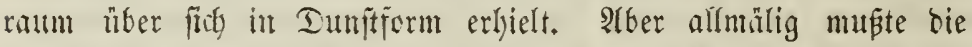

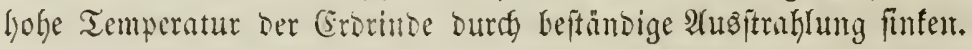
Die Eomnemwäne fonnte Den ungehenren Bärmeverlüt mur un=

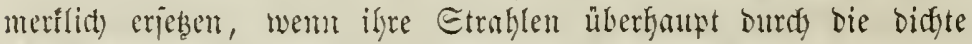

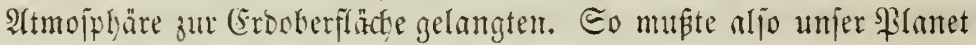

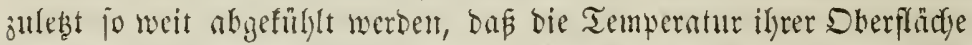

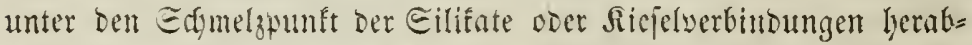
fant, weldye baburdy eritarten, aber jo aflmälig uno ruthig, dak fie

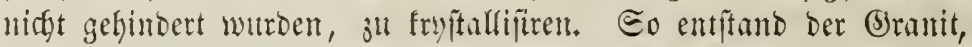

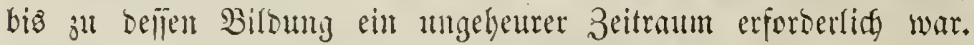
Man lat berecthet, Das, wemt von ber Bitsung ber Eteinfoble bis auj unire 3eit 1,300,000 Sabre verflofien fint, über 50 M)il=

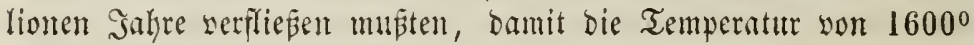
anf $168^{\circ} \mathrm{C}$. herabjant.

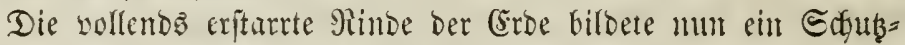

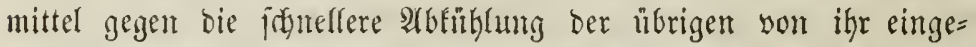

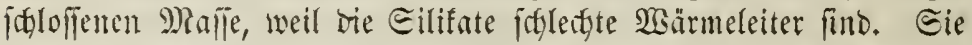

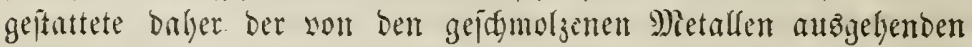
Whäme eine fefr langiame Fortpflanjung, bie mit zunelymender Ers= ftarrung unb Diffe ber Siinbe immer langiamer erfolgte. WBie

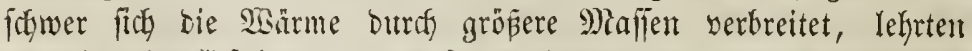

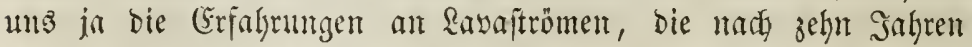

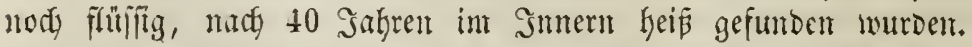

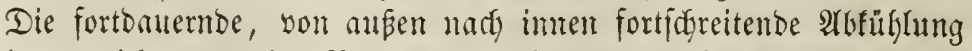
hatte nicht mur eine Berbidftumg, fondern anth cine 3ufamment= ziefyung ber 9tinde zur Folge, weldye in ber Niegel mit einer Ber= 
minberutg Der Temperatur verbumben ift. Dic butd bieje 3ujum=

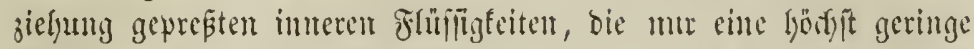

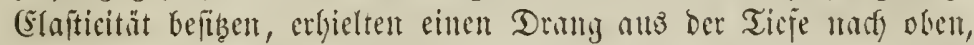

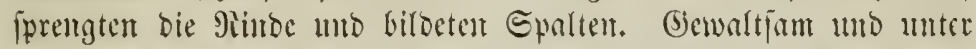

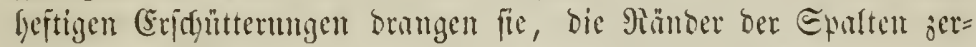

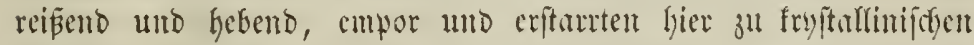

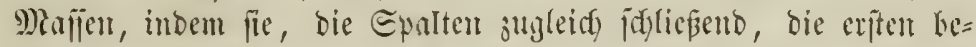

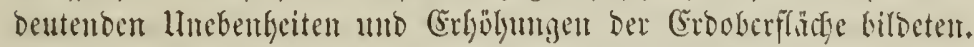

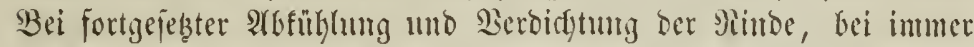

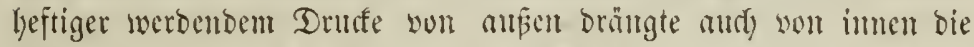

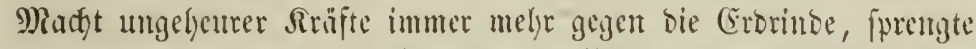

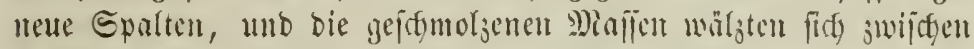

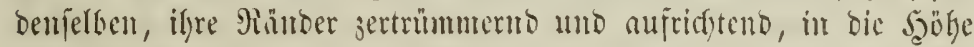
und ulberlagerten in neuen Bergen ben Boden. Sie bilseten $n=$

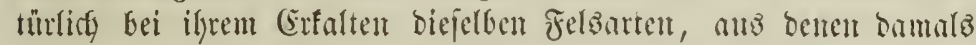

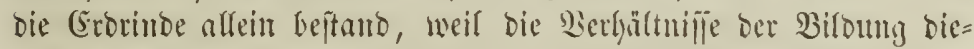

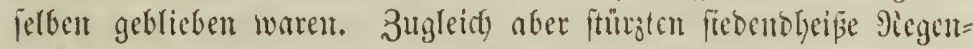

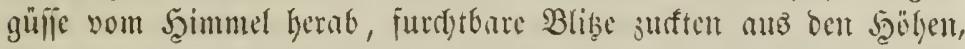

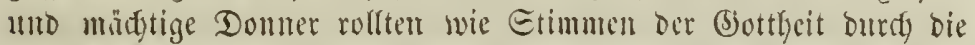

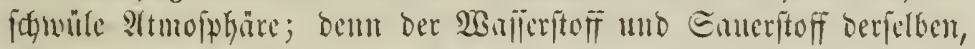

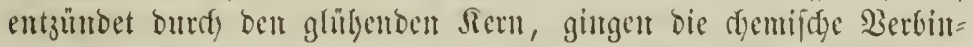

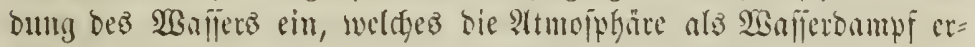

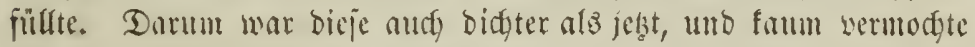
fie ein Sommentrafl 3u burthoringen. Der gewattige Druf, ben fie besbalb ansinte, batte aber aud) einen widytigen (Einflus auf bie Baje jelbit; bemt fie worbent nidyt mur in cinen engern Siaunt 3ufanmentreprefit, fonbern viele von ifnen nafmen, zumal bei ein= tretender Temperaturverminderung, tropfibar flüfige form an. Das

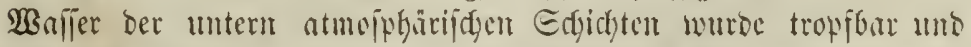

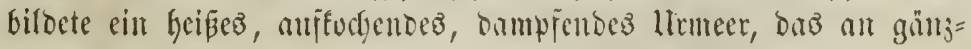

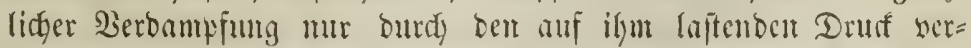

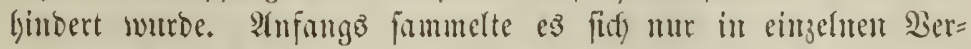

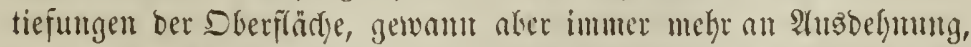

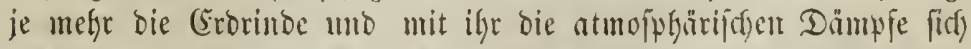

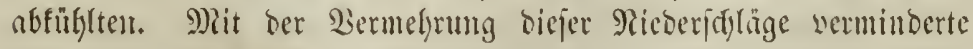

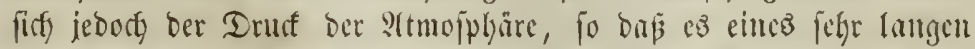

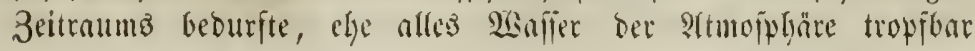
Ille, Meltall, 3. Ituft. 
wurbe, was wohl erit bamn ber Fall war, als bie Temperatur bes (ja)ิraums unter ben હiebepunft gefallen war.

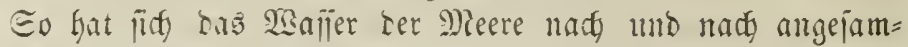

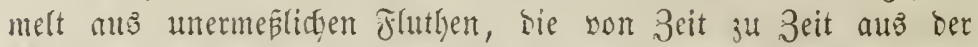
Atmojphäre Gerabjüraten, uno mit ber eriten Fluth begannen aud

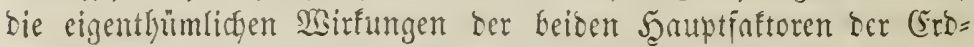

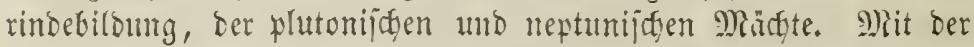
zeritörenten Giewalt bes 2 anjers vereint arbeitete bie von heipen

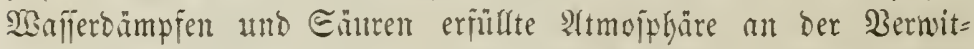
terung ber Gieiteine, bentagte, löjte umb lofferte die Jelsanten, zu Denen fie Sutritt lyatte, und wenn jidyon bie heutigen Regengüjie und Şodyajer Eteimmaijen abzulöjen und zu jertheilen vermögen,

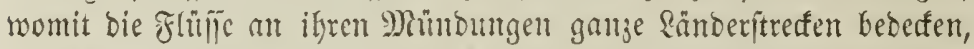

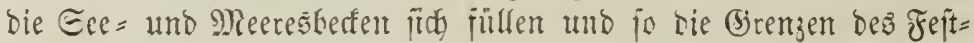

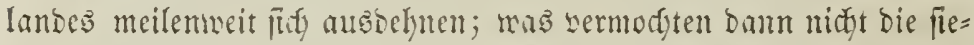

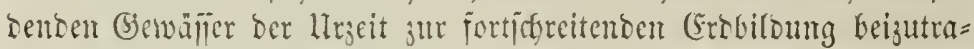
gen? (Ẽ bildeten fid ris altepten fhnfrinnen und Eeen, und in ben Meeren bie exiten geidgiduteten Eteinlager, jujanmengejaß̧t unter

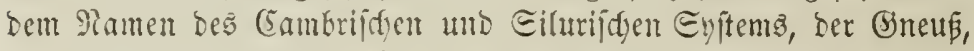

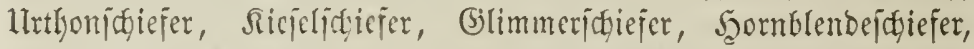

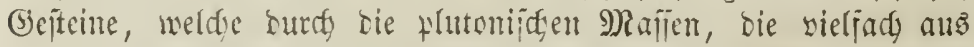
ser Tieje emporbrangen, mannigfidf nmgerwandelt wurbent. Darum wedgjeln bie fryjtafinijden Edyiejer anj bie buntejte Beije mit ben granitipaen Felsmajlen ab und joliefen fid jelbit in ben unmert= lidjiten Hebergängen an je an. Iieje Edbieferbetten, weldge fuäter von ben plutonijacn Sewalten jeriprengt und theilweije ilber bie Flädge des sidajers gehubest wurden, gaben, ifrerjeits som șajper

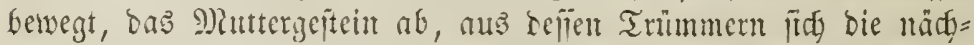
ften Edfidten zujummenjebten. Leberfaupt erjolgte bie ganje $\mathfrak{B i l}=$ Dung ter Edfichten uno ier Sebirge nady benjelben cinfacten (S)

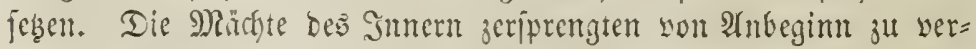
fitiebenen 3eiten und an veridjiedenen Diten bie foriontalen Pic=

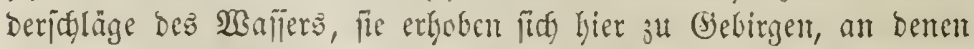

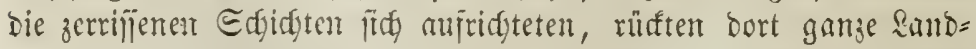
ftridye bes \$lateaus empor, wenn fie bie Minbe nidyt ju jprengen bermodgtent. Daburdy murben eitter cits ber unalifgaltam nagenden

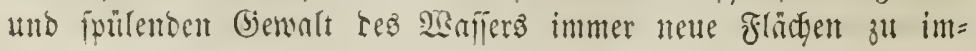


mer neuen Mineralbiloungen bargefoten; anbrerjeits wurbe, als bie Temperatur ter Astmoiphare gejunten war, bie Müglidfeit ber

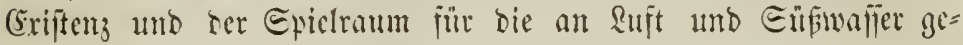
butbene \$iflanjen = und Thierwelt immer melyr vergrö̈ert.

Eo geht von Anfunty an bie Bervielfišltigung ber Minernl=

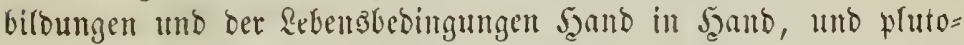

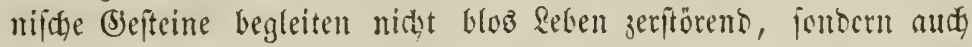

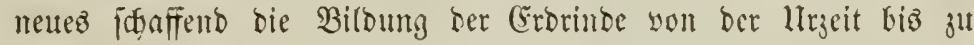

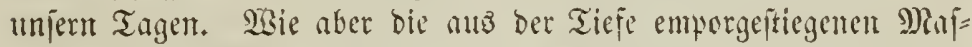

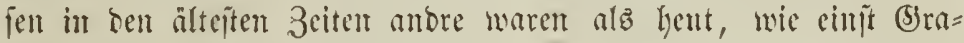
nite, Dann Forphyre, Tratyyte unb Bajalte, jeb̧t Raven Den Epal=

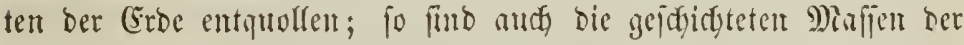
Ilrzeit, bie ficts aus ben ftofferfüllten Meeren nieberjentten, antore,

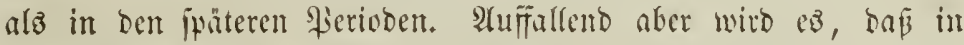
ben älteften Gebirgen menig fohlenfaurer $\mathfrak{R}_{\text {alf }}$ erfidgeint, ber body in ben mittleren uno jüngften in ungelgeuren Majen aufitritt. Erjt

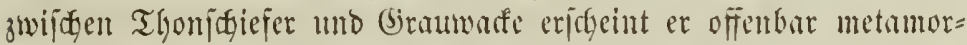

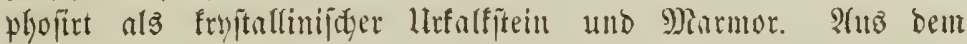
Edyoope ber (Erbe fömen jene verfteinerumgzreidjen Ralfmalien ber

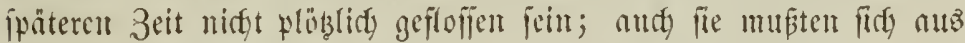

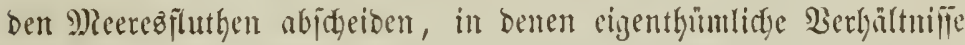

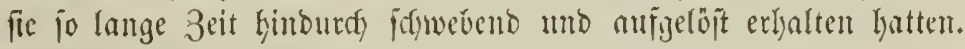

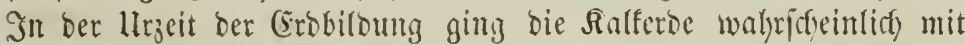

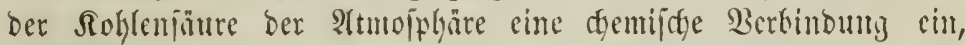
weldye trob ber hohen Temperatur, in weldyer fonft bie Sohlenfüure bon ber Rialferbe zu entweidyen pfiegt, burds ben Druf ber ganzen Itmofphäre geförbert murbe. T(ber nidgt bie gejammte Sobjenfäure founte zur Bildung bes fohlenfauten Salfz verwentot werben; ciute

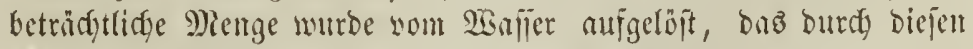
Sohlenjüuregel)alt mun autf) ben fobjemfattren Sialf auflojen founte.

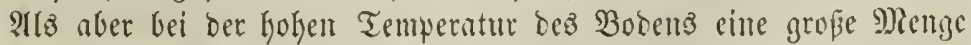
Dez 2 Gajierz wieber verbunftete, io fiel bie aufgelöfte fohfenfinure תalferbe Darauz ju Boben uno warb fejt. Da bieje ?tuzjcteidung

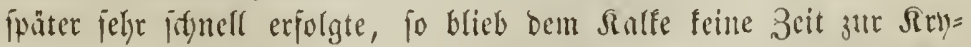

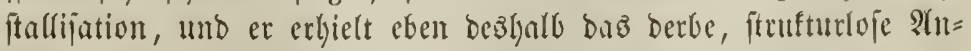

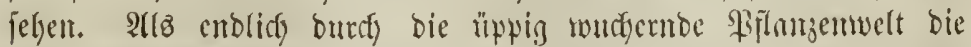

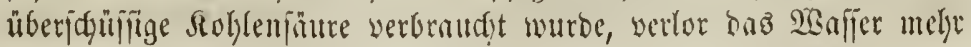




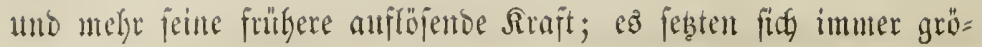

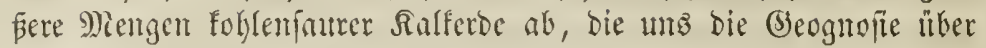
Der Eteinfolyenformation in immer mädytigen Ragent nupweift.

\section{3) Dí (bebirgaerbebutacu.}

Mit bem Einfent ber Temperatur unter ben Eiebepunft bes Bajīers wirb bie Beburt bes älteften orgnnijajen Rebenz bebingt,

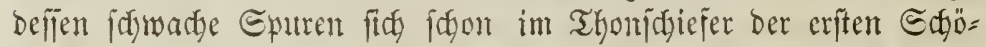
piungäperiobe sth zeigen beginnen. SGe wir aber bieje mette Rebenz=

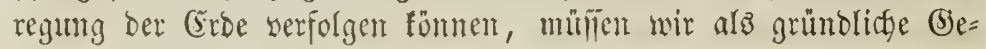

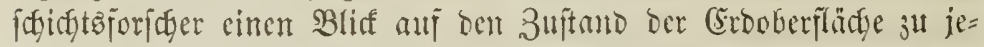
ner 3eit bes Erwadfens weren, auf bie Bertheilung yon Jeptlanto uno Meer, auf bie Beftaltung ber Continente und bie Crethebuty

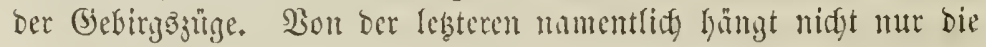
ganje Geftaltumg Der sindermajien, fondern aud Der CGgarafter

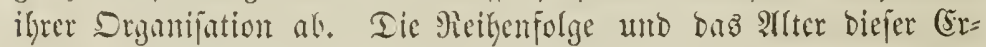

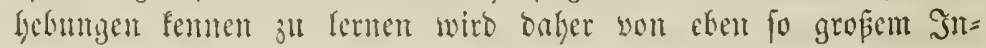

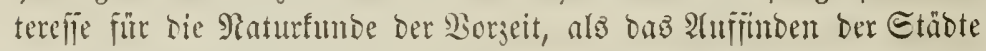

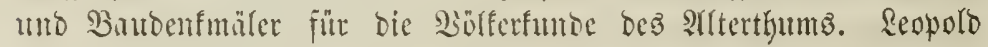
ע. Buth uno Eslie be Beaumont haben Durdy unermübliche Forfdum= gent und idyarintmige 3ujammenifellungent aud bieje serborgenten Thatent ber siatur an das lidgt gebradjt.

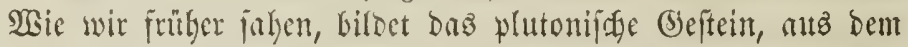

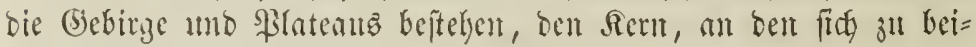

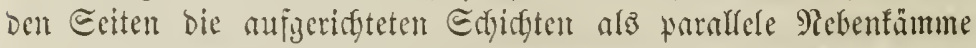

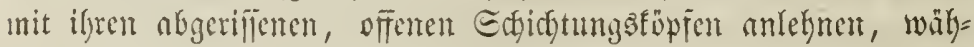
remb fie gegen dic umliegenden Ebenen allmälig abfaflen. 20 urs

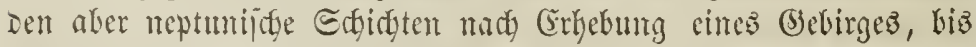

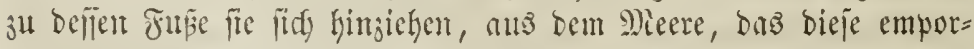

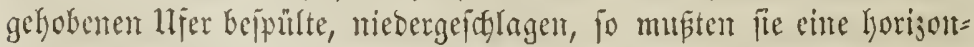

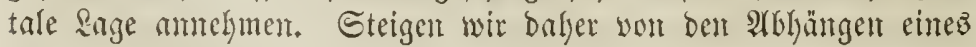

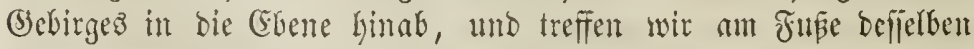
auf cine horizontale Edyidgt, bie im (bebirgababange feylt, fo wif=

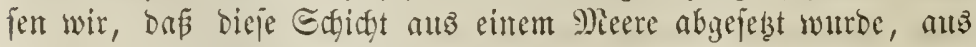
weldyem bas (jebirge bereito Gervorragte. Finden wir aber eine

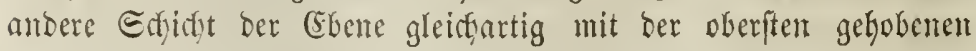

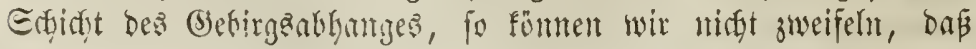




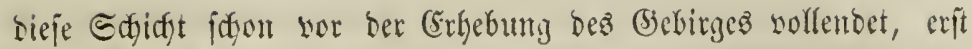
burcts fie aus ber borizontalen Rage aufgeridgtet wurbe, unt ba alio ber Zeitrum ber Bebirgserbebung jwijhen bie Bilbung biejer keiben Edyidgten fält.

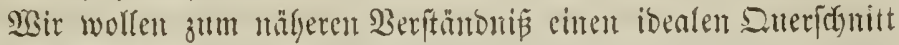

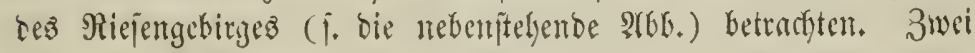

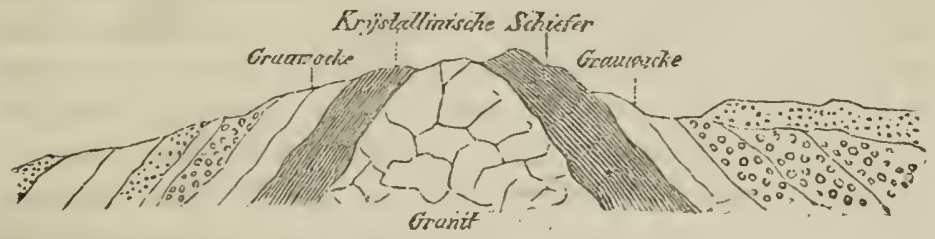

Şcaler Dueriffinitt bez Sicjengebirges.

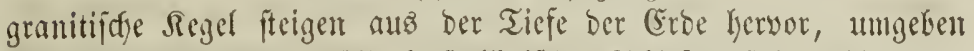

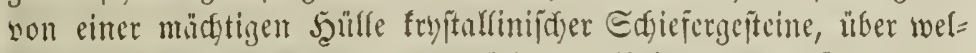
dyen bie Braumaffenbiloungen folgen. Lleber ben anfgeridgteten Edfidften feinter llngrgebung finden wir felbjt bie Sreibegebilde nod)

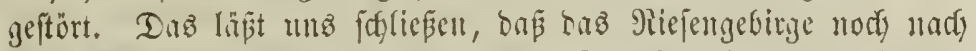
ifrer Arblagerumg gefoben worbent ift. Da aber bie äteren Edjict)=

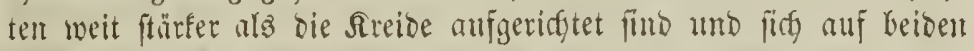
Eeiten Des Sebirges nidgt gants gleidmärig entwiffelt haben, fo

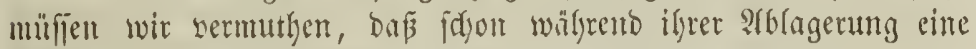

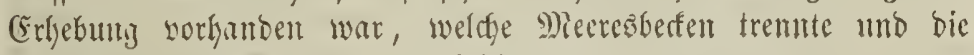
IIngleidyeit ber rolagerungen bebingte.

Went Dafer nidft immer bie Grente ber beiben entidgeibenton Edjidjten eine fondrf befinmte ift, fo musten body fo gewaltige Ereignijie, wie bie Emporfebungen ber Sebirge es waren, wentigitents

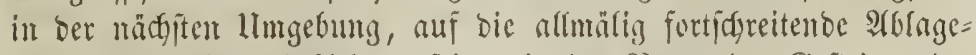
rung neptunifher Exhidten, fei es in her Patur her Sefteine voer

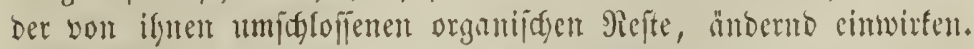
Freifich mag bisweilen bie Dauter biejez Ereignijes fo furz gewejen

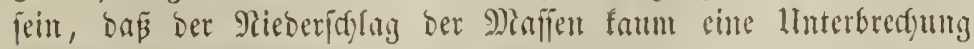
erlitt, und bie Ectidften beiber Bilbungen ummerflidy in cintuloer übergingen. Die Berfteinerungen werken aber attry baun entidei=

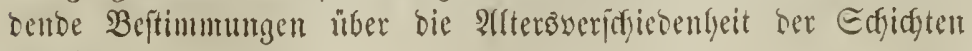
abgebert. 
In jefgr frillger Beit finto immer Bebirge emporgeítiegen, in benen feine ober wenige Edjidgten geholen eridgeinen, während siete

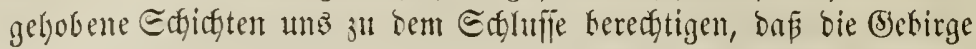
Den lebsten convulfibijach Bemegungen ber Erorimbe ihr Dajein serbanten. Eo gehörent bie am meiften gewutroenen Sdjicftent ber

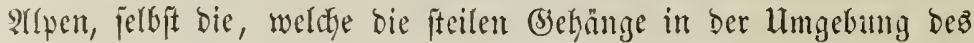

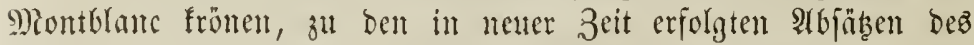

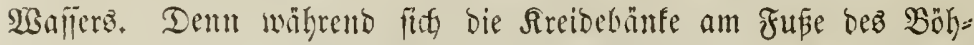
merwaldes nodh in forizontuler Rage Gintzieken, fteigen fie am Fure Der Arpen jeil cmpor, unb an ben Enben ber gewaltigen Rette zei= gen fid) pogar jüntrgere, bie Rrcibe ïllertagernoe Bebil'be geftürt.

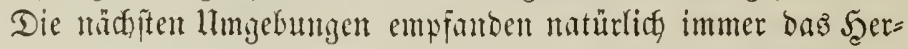
vorbrängen ber Bebirgafetten am keitigiten uno wurben fogar biz= weilen ftänfer gehoben als bie Sitte felbjt. Dafür jpridgt bie Ger=

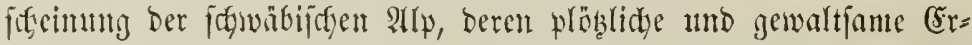
Jebung zugleidy einen grofen Theil dez Edywabenlandez aus bem

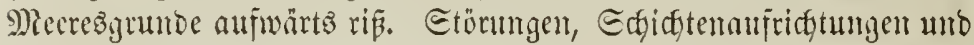
Ulebertürjungen son Feläblöfen fehlen biefer Bergreilge unto müroen

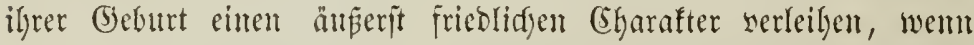

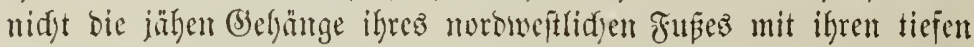

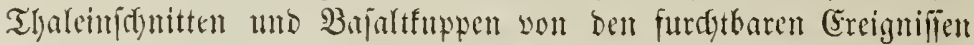

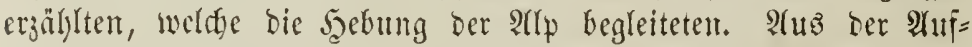
einantorfolge Der Edjichten Der Ebene und Der Bebirgsabhänge und

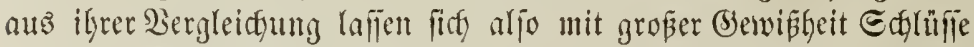

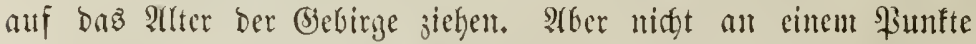
allein war bie erlyebente Sraft einer \$erione thätig, fie foluf oft viele (Jebirgsfetten im weiten umfreife ber Eroe, beren parallele Etreidung

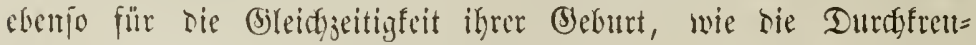

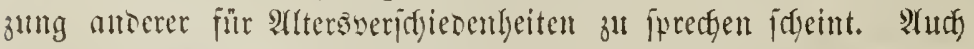
nidgt in einer 3cit unto plöblich wurbe bie Gebirgsfette immer ge=

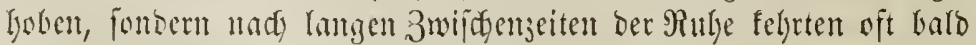

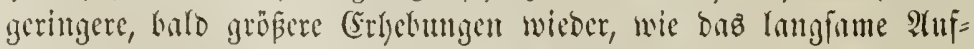
fteigen won (Glili nod) in mrirer Zeit ein Beifpiel aufberwalyrt.

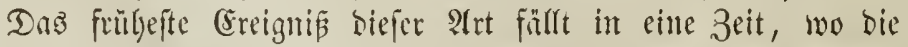

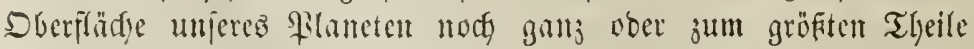

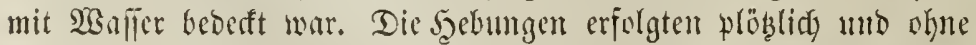
range Dautr. Sic jofufen in Deutidylano bie Edyiefergebirge ber 


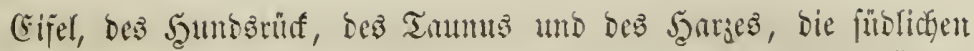

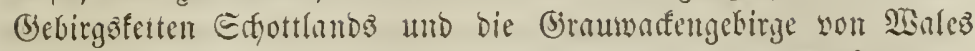

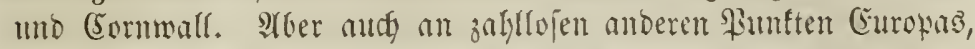
im Thüringerwalde, Fidatelgebinge mo Eragebinge, in Böhmen, in Der Bretagne unt Pormanbie, in sen Pivrenten uno Bogejen fofei=

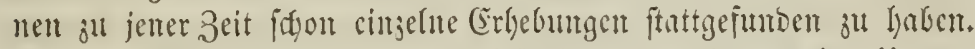

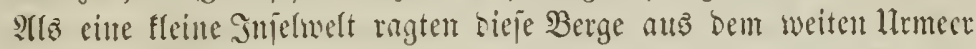
bervor, aus bem fid) bie alten Tlyonithiejer mo Giramarfen ab= lingerten.

Bald Carmi crfolgte die zweite Erhelunty, weldge fidjon bie

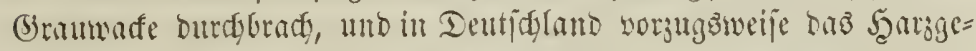

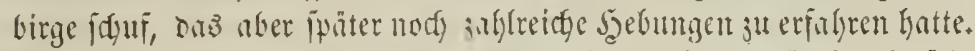

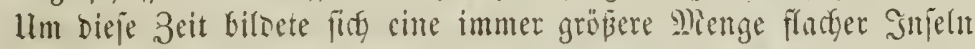

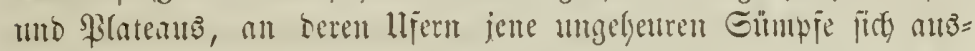
breiteten, in meldsen bie Farnfräuter ber Eteinfohle ïppig mutber=

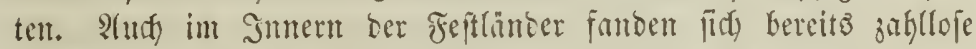
fleine Moriijte und Eimpje, weldye bie Binnennulden unjer Etein= fohlenlager bilteten.

Der beimatlidge Boden des mittleren Europa erjogeint ju jener 3eit unter ser Geptalt grop̧er Snjeln, weldye son jahlreidyen, baz

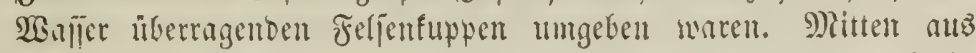
Sem weiten Rolylenmeere erhob fidg eime lange und fdymale Injel trodengelegter llebergangoigebiloe, bie fid) son Rüttidy bio zur meft=

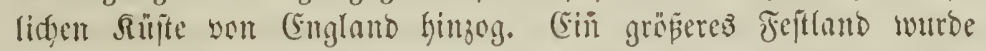

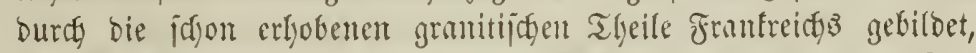

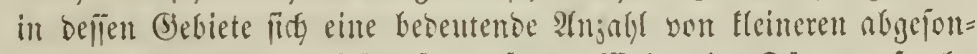
berten Eeebefen und Eunpjen bejand. Weiter im Entoen erftrefte

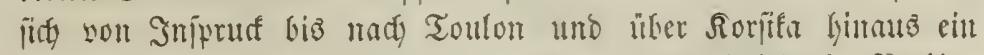
jweites Fejtlano, melđeß vielleidyt mit bem Frantreidgs in Berbin= bung ftand uno gleidjalls నohlenjümpie enthielt. Das mittlere

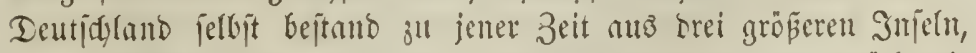

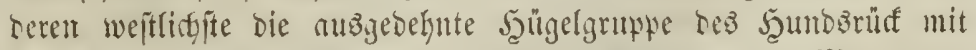
Der Eijel unto ben Arbennen bildete. (Fin iftumaler Miceresarm

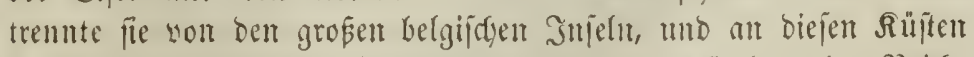
wufferten jene üppigen $\mathfrak{B}$ alsungen, beren lleberrefte Geute ben Sieid)= thum Belgiens und Englando begrïnden. Cin bebeutenter Binnen=

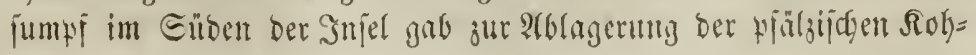




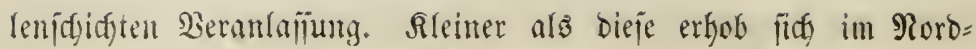
siten alz jotoff aujteigende Ruppe bie Sufel Deż Şarzez, bie mur

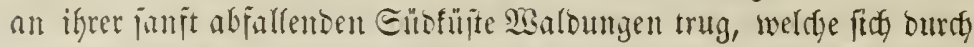

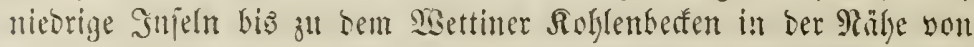

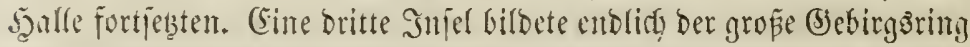

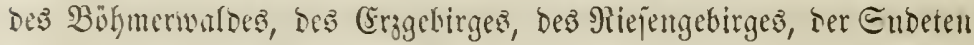

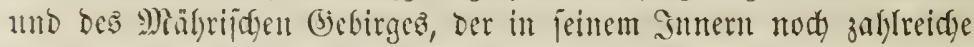

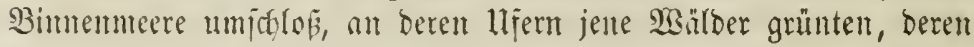

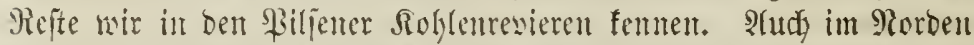

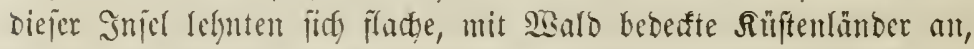

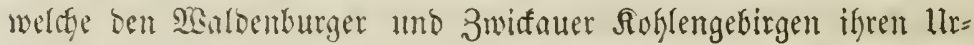
ipriting gaben.

Das ijt aljo Tas Bilo mines Baterlanbes in jener grauen

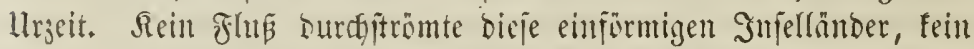

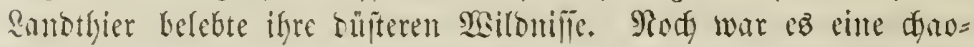

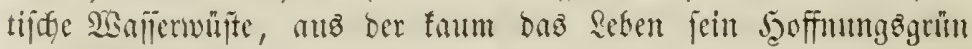
Gerworjämmert liej.

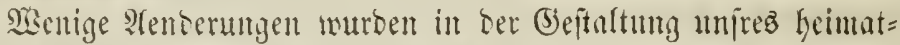
lidyen Bobens burdg bie Sebungen lyerworgebradt, weldye ber Etrin=

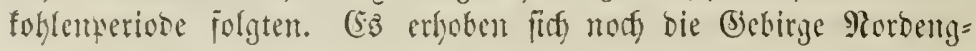
lants, utto cmporbrängente Forklyye verwarfent uno zerbradten bie Edyidten won Eilowalez, Der Ardennen, dez J̧ennegans und

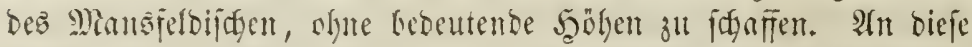
nuf bie fonberbarje sicife gebogenen und gebrehten Edjidjten lehnten fidy bie (biebilac oes 3ectiteins und bunten Eanditeins an.

Darauf erfob fid das Eyftem bes Sifyeins, mur aus juci lan= gen Bergfetten keftehend, Den Bogefen und Dem Edyarzmald, Die

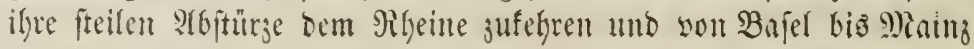

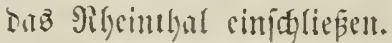

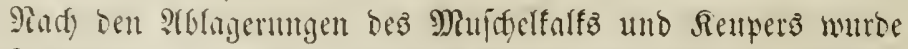
Das Eyftem bes Thüringer $=$ und Böhmerwaldes gehoben, weldyes

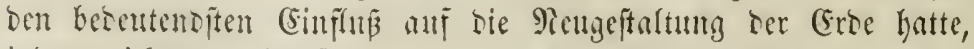
intom nidgt mur cinerjeits bedentende Etrecten feften \&antes, wenu

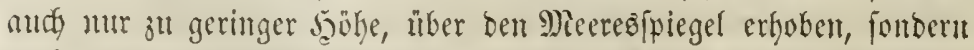

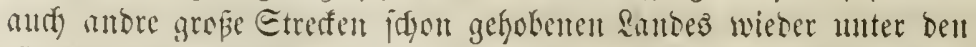
Wafferpiegel werienft wurben. Durd) bie Reupernieberidsläge wa= ren bie fruffer gejonterten orei snjeln Dentidglanto mit ifgen jïb= 
wärtż vorgeidgobenen Feljenriffen, ben Bogejen unb bem Sdjwars= wald, zu einem einzigen gropent Feftlant vereinigt worben, bas fith

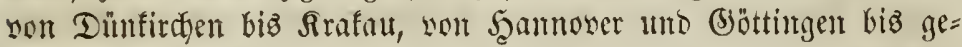

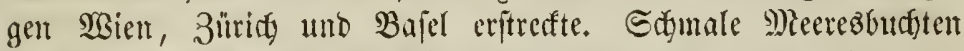

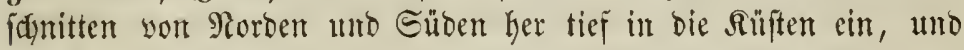

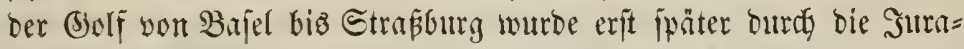
ablagerungen in ein Bintenmeer verwandelt, befien Bewäifer ento=

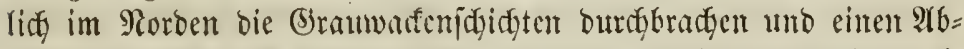

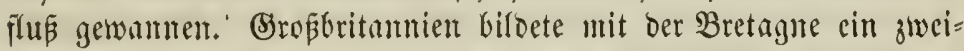

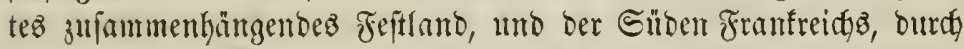

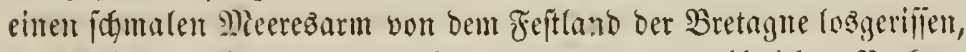

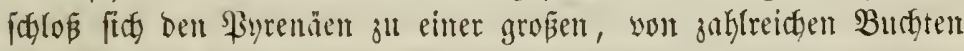

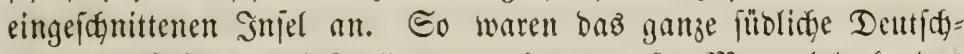

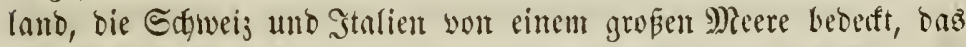

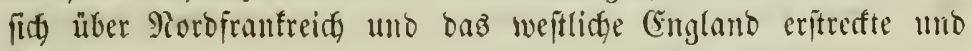

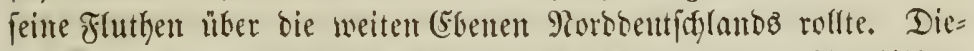

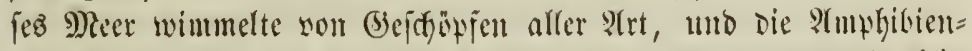
ungeheuer, weldse wir früher fennent Iernten, geben unz gernoe fein

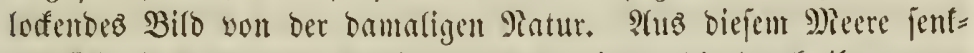
ten fird bie falfreidgen Suraformationen nieber, bie burdy ifre unge=

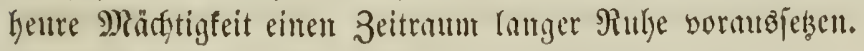

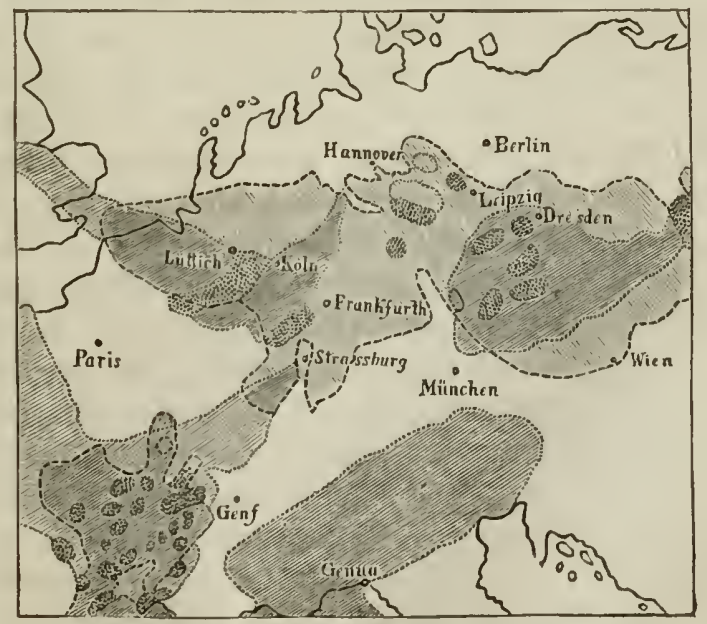

Deutjafatio bäfreno ber Roficn: uno Surnperiooe. 


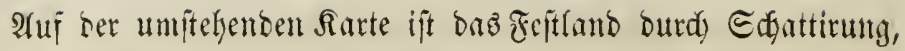

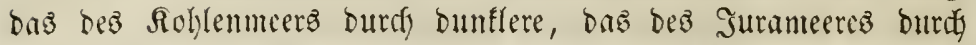
bisfere angebentet. Die punftitten Stellen bejeiffnen bie Sohlen= jïmpje.

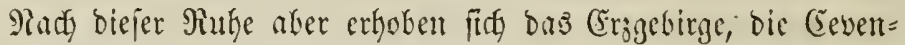

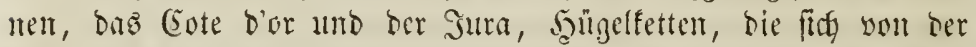

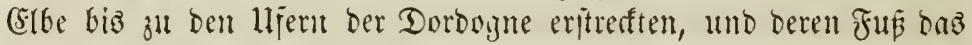

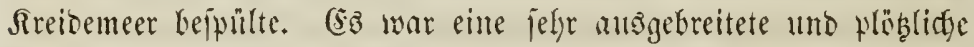

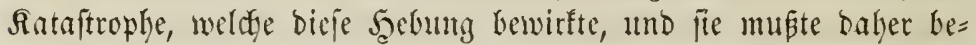

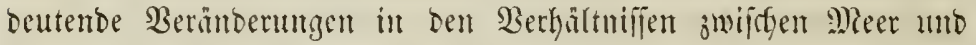
Feiftlanto zur Folge Kaben. Die brei Snjeln son Mitteldentioflant,

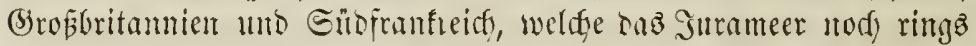
umflós und burd) Miceresurme tremte, find jekgt mit einantor ner= einigt uno bilden ein grofers Fettlanto, bas fid in einem weiten

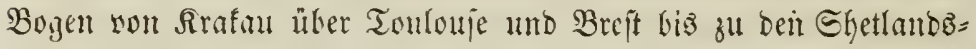

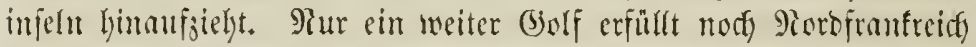
unt Dnå nöroliffe Belgient, umb ein flactez Bimnemmeer bebefft bie Fluren Bafmenz und Endjens, in weldyem find bie Edfidyten bez

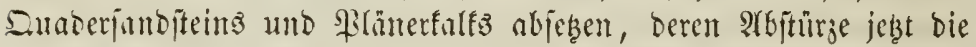

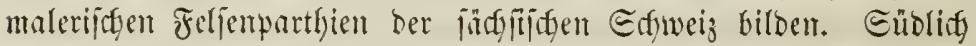
von biejent Feiftrnto Durd) einen langen Meereåarm geidjieben,

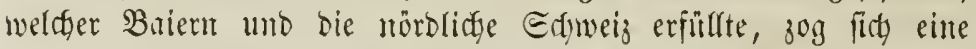

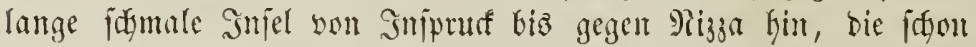
jegt bie fünjtige Etelle der âtpent antoutet. Co war wieber fïr lambe Zeit bem Jefitlante jeine befitalt gegeben; aleer audf fie follte nod) feinen Beftant geminnent und netue Etörungen, Şebutugen uno Eenfungen erfatren. 3war blieb nod) bie balo barauf erfolgente

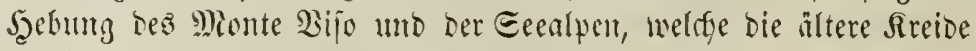
burdforad) unt son ber jüngerent überlagert warbe, obne wejent=

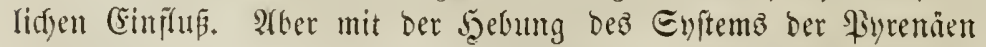

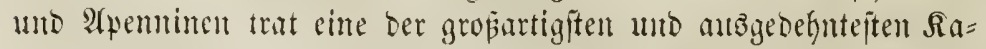

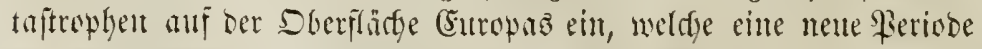
Der Edjöpluty, bie ber Bjegenwart, cinlciter. Eelbjt bie Bhgates in

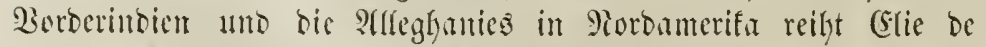

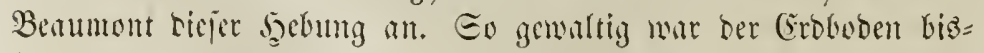

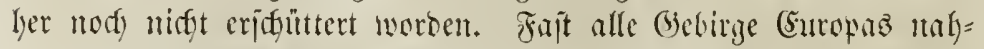

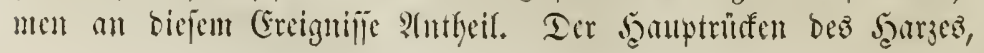




\section{1}

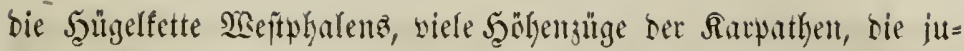

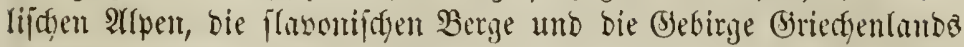
wurben in bicjer 3eit von Renem emporgefyoben ober traten zuerft

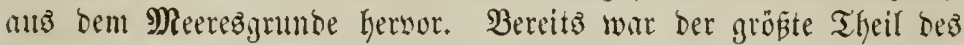

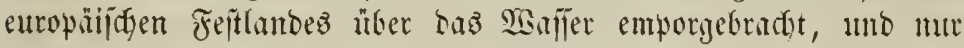

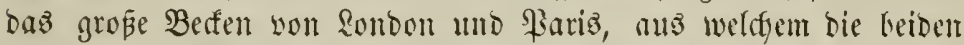

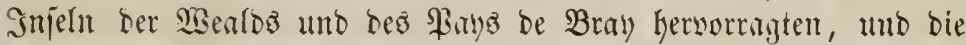

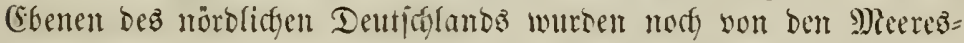
wogen erfintlft. Der weite Meerezintm im Eüben bes alten Ronti=

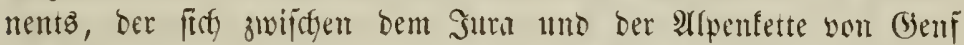

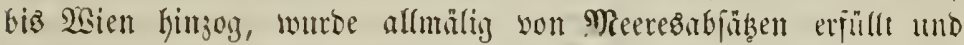

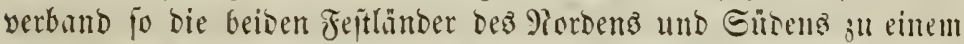

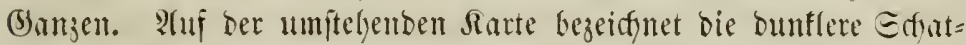

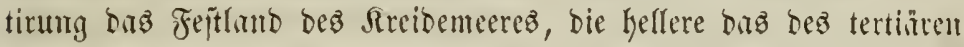
Meeres.

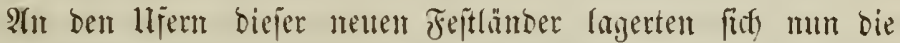
erften Tertiärgebildoe, bejonders ber Grobfalf, ab; aber audf fie wurben balo wieber yon ben Gebirgen (Soriffaz und Earsiniens

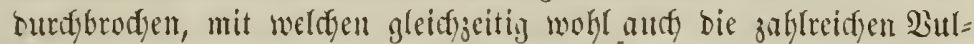

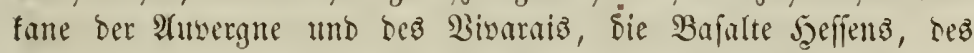

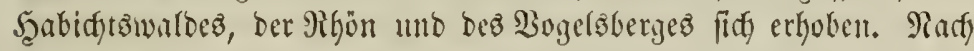

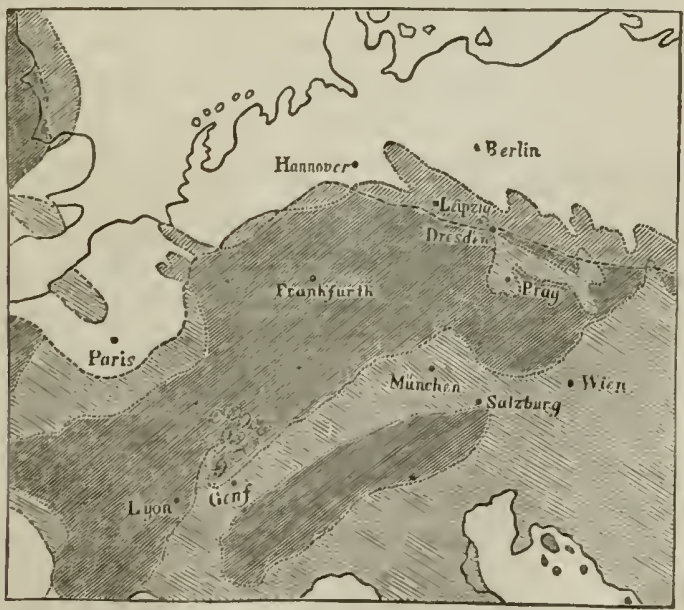

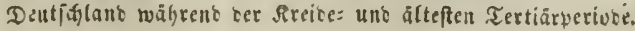


ber Molajiefildung forgte nut bie Seebutng ber Miseftalpent mit bent Montblane. Tieje bödjten Epiben Europas, beren Reme non

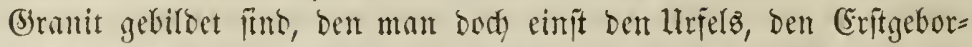

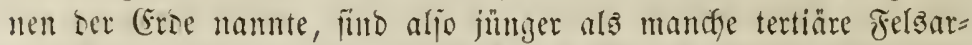

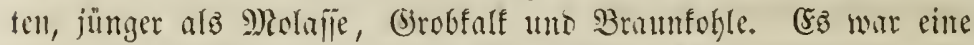

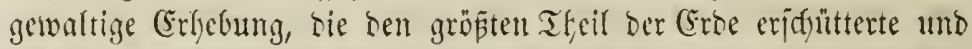
burd) ifye Rreuzung mit andern Eyftement jene eigentfünmlicfen

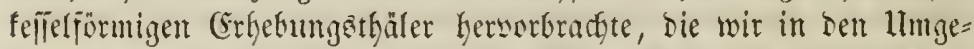
bungen ber Tiablerets uno bes Montblane in jo erhabener Edyön= heit femren lemter. Iie biebirge won Momaja Eemrja, Efantina= vien, Morsidgottland, bie Buffane S\$lands uno bie Bergfetten bez

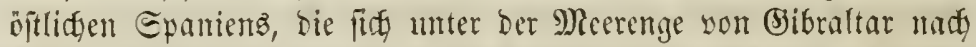

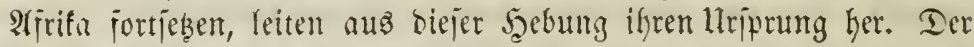
Bontittent (Ëuropas mar jeģt vollentot, unto mur bie jubapenni= nijden Sangel uno Theile Eiciliens uno Ditentglanos waren nudy

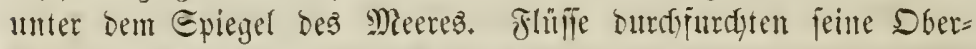
flădje und Eeen freiteten jidy am Juke ber bethirge ats, in wel=

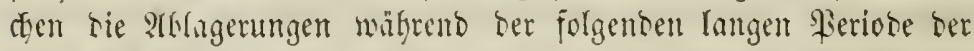
Pitube fortififitten.

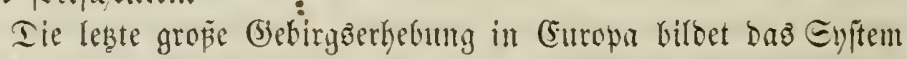
ter Alpen son aufridftete. Moof cinmal nahm ein jehr groper Theil bes Bobenz yon badtenrofa an biejer Bemegung Theil, inbent bie Sberflühe

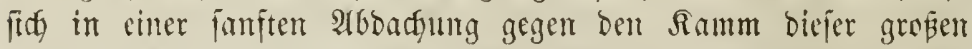

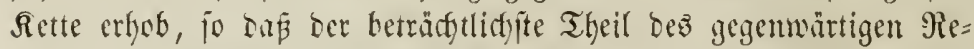

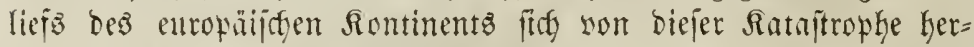

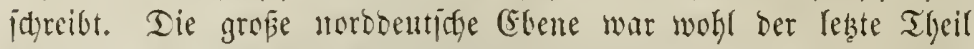

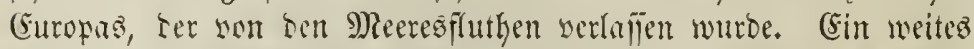
Binnemneer erfüllte bas Beffen zmiīgen Efanbinavien, Dem Ltral,

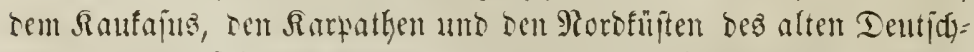

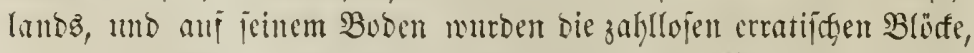

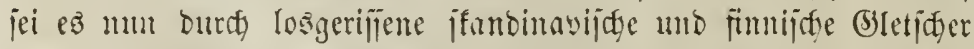
ooer burch allse Tranşportmittel, abgejest. Dos mar jene Zeit, in

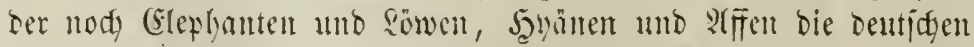
Fluren benofinten, it ber Tulpenbiume unb atgorne neben Eimben

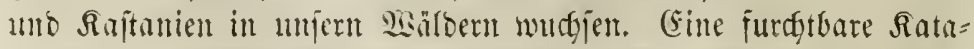
ftrophe vernidgtete aud biefe Sdyoffung und erfob bie norbifafen 


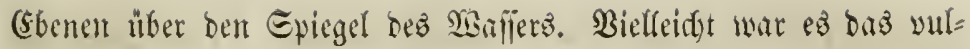
fantidge Cumporiteigen ber gewaltigen Ifnoesfette S(merifaz, weldes

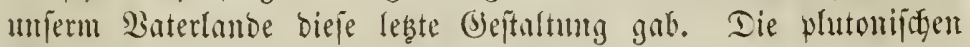

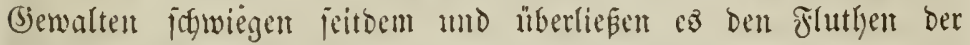
Etröme uno Mcere, "bie genaltjam geiffaffenest Ränter zum frieb=

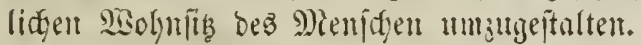

Bergleidyt mast biefe weridgiebenen Syebungen unter eimunber,

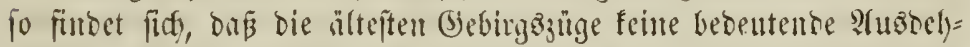
nung Gaben und siebrig finto, wälyent bie jüngeren immer hölyer

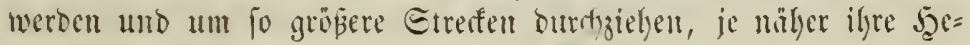

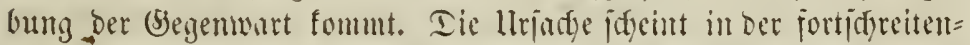

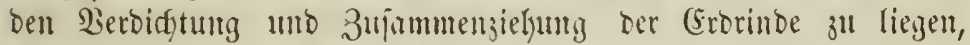

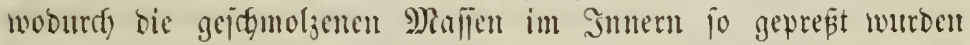

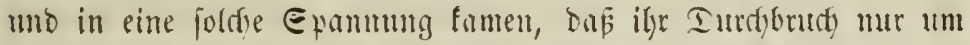

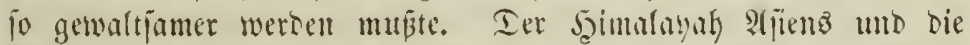

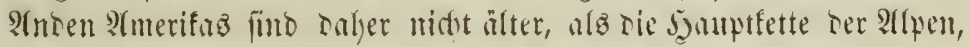
ja bie 2Anden fün entidgicsen jünger. Injür jentgen sie sielen But=

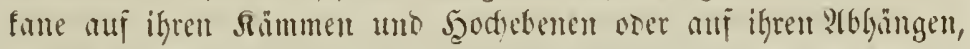

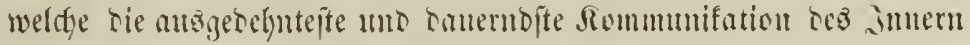
umjercz \$lanteten mit tem Sufffreije sarbieten. Bulfaute fino aber

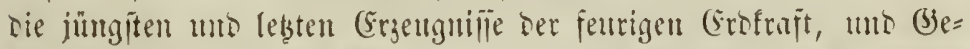

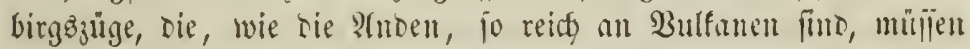
jogon beshalb paiter als alle nidyt von Bulfanten begleiteten Berg= fetten gelyoben unb verintsert worken jein.

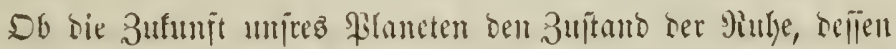

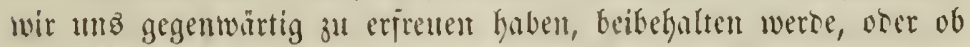
bicje Sithe mer temperär jei, wie in allen zmijdjen Den geologijaten

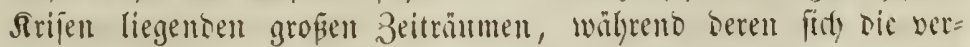

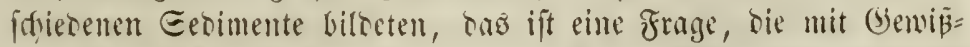

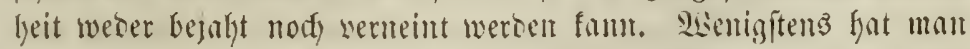

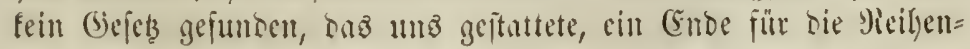

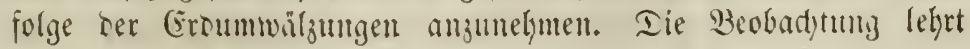

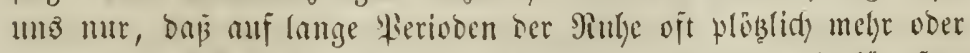
weniger furdjtbare Sintaftrophen eintreten; unto grabe bie jüngften (Frbebungen tez Montblane umb Mionte 9ioja unt jenter Solofle

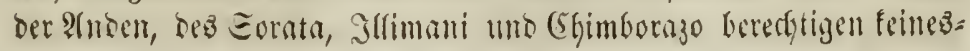




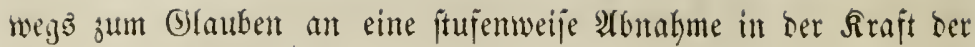
plutonifgen Giervalten.

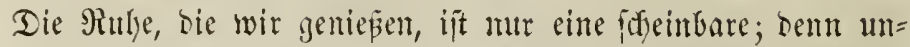

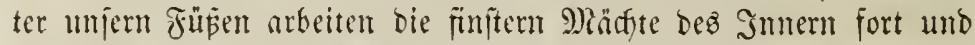
fümpfen gegen ifre fefleln, bie je body einmal jwrengen möchten. Ins Erobeben, weldes hen Boben unter allen Şimmelöjtridgen, in

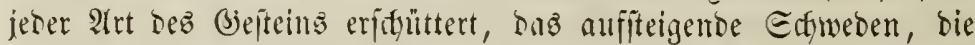

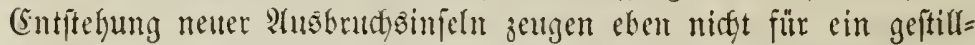

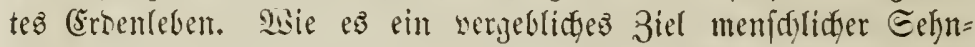
judyt bleibt, einen ewigen Frieben unter ben Balfern einfebren zu

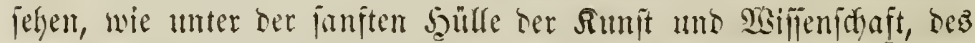

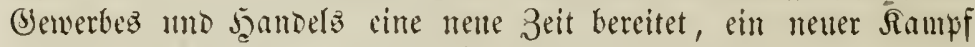
gegen bas Altgewordente eingeleitet wirb, wie aud Das fitlle Antlik

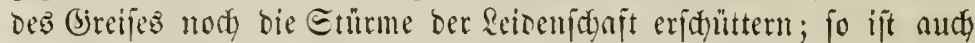

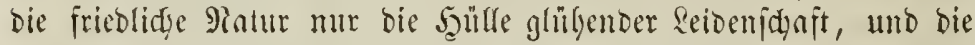

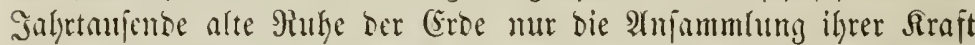

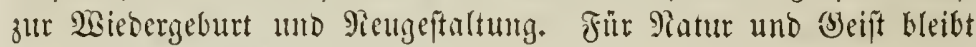
(3)

Das Evige regt jid) jort in Mllem:

Deun :Ites mus in giid)t zerjallen,

2Scun es inl モein belyarten will.

4) Das (5rmaden un Fortidreiten bes organifden Rebens.

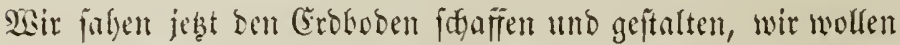

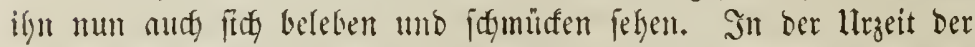
Echopfung war die Stmofphäre unjeres Planeten bei ber hohen

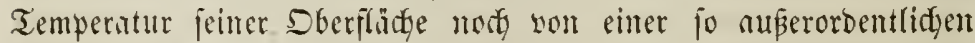

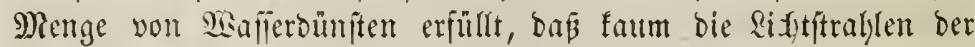
Eonne jur Erone jelbjt gelangten, und tieje Finfternis ifre Fläche bebefte. Dieje Finfterniz in Berbindung mit ber nody herridgenden

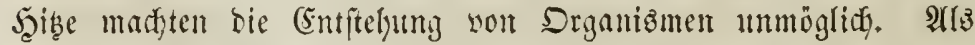
nber bie Temperatur unter ben Eiedepunft erniebrigt wurbe, ale bereits Snjeln mit Bergjïgen und Thälern n̈ter bas Meer empor=

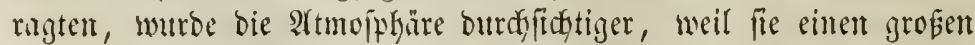
Theil ifrer 2 afferbimpte, iher Soblenfäure und anderer Baje ab= gegeben hatte, und gejtattete beshalb hen belebentoen und erquiden= 
Den Etraflent Der Enme Durdigang unt Berbreitung auf Dem Erro=

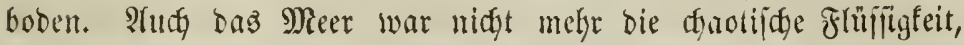

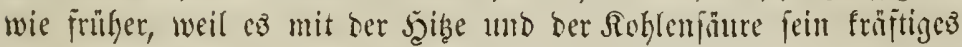

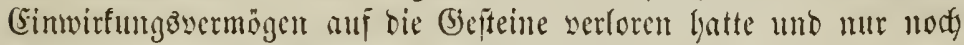
mectgnifd surdy Edflemmung wirlte.

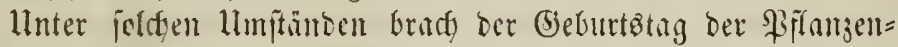
und Thjerwelt an, berent Eigentlyumlidffeit won ber beutigen nidyt fo wejentlich abweidjt, ats man oft antjunchmen geneigt ift. Şan=

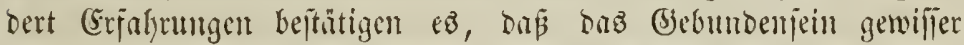

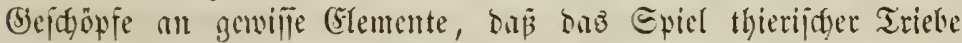

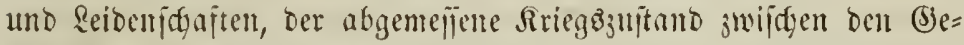

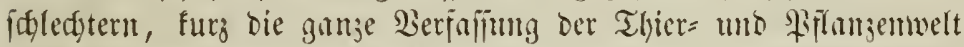

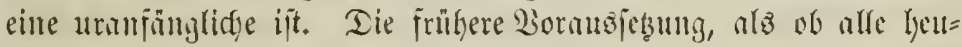
tigen thierijden forment Hoäe Bervolfummuntent älynlider unter= gegangener, und bie ältejten fomit bie einfurfiten und nicbrigften

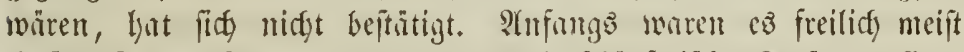

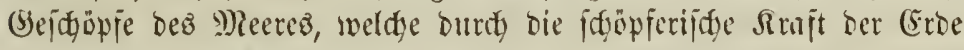
ins Dajein gerufen wurben, weil bas trofente santo mur fier uno

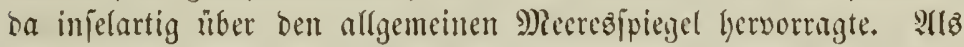
aber burdy bie wiederlyolten Durdybrindje ber flutonijden Miajen

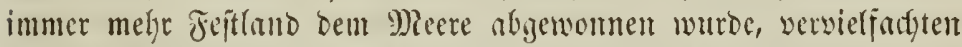
fidf bie Beoingungen, unter benen bie alfyemeine Raturfaft ber Materie organifdę Eeben einlyudyte.

Meben ben Mieerezgeidüpjon traten melye unt meler Drganiz=

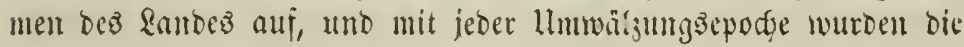
Wejen in immer edleren Forment wicder erzengt. Freilid) musten

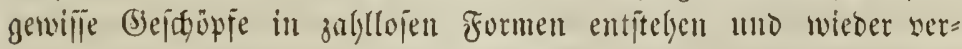

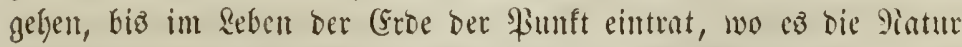

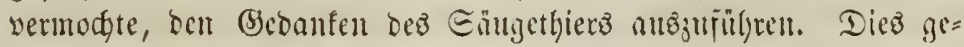

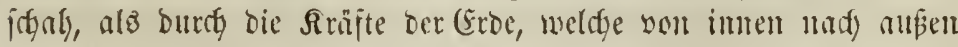

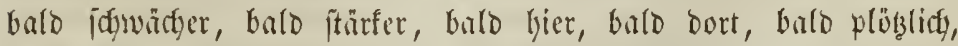
bald allmälig wifftell, nidyt mur Smjelu, fondern immer größere

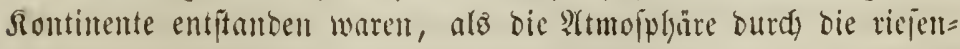

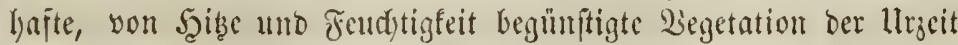

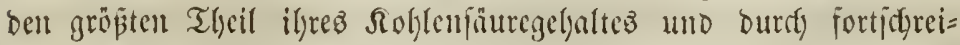

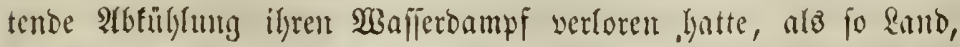

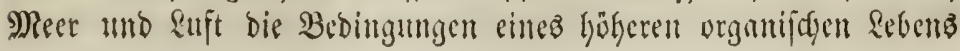




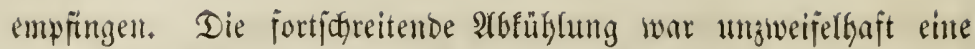
Folge ber sisärmejtraljhung gegen ben Şiunnelaraum, weldye bent

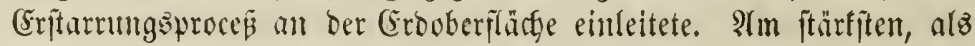
nidjt mur ber glülyente Sern, fontern audy bie (srorinte nod flüjitg

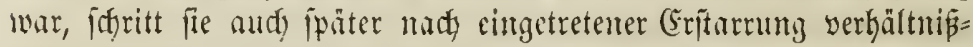

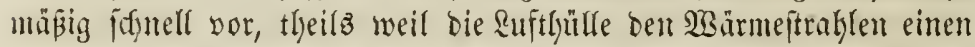
immer freieren Durdygung in ben Şimmetzrautm geftattete, theilz wegent der wiederlyolten Durdbbrildfe platonijdjer Mafjen. Dieje

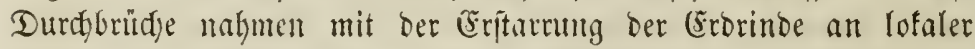
Etärfe 3u, weil butch bie wadgjende Berbidstutig uno 3ufammen=

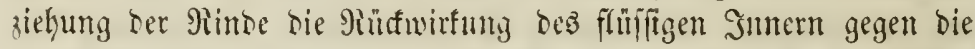
Sberîlädye immer gefpamter uno heftiger weroen muste, biz endolidy

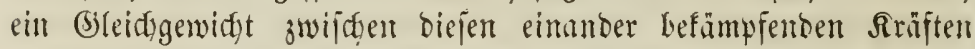
eintrat, wie ez bie Begenwant wor ben früferen Feriohen auşu= zeidfnent idyeint.

Bährend bie siärme, weldye bie phutonifiden Mrafien im ge=

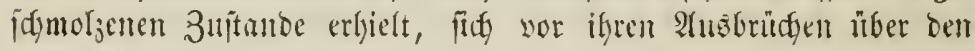
ganzen Croförper vertheilte unto feine Temperatur cryjöte, entzogen

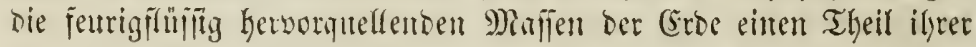

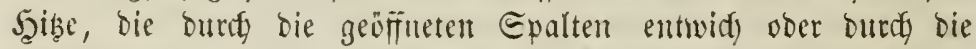

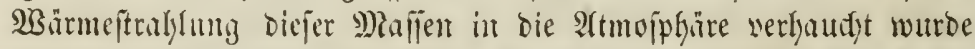
unto ben gleidymäfig tropiidgen Eharafter ber gantsen bewohnten

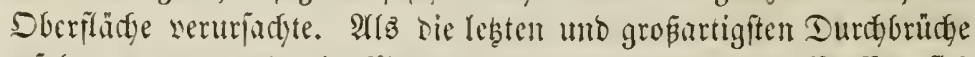
erfolgt warent unt bie sisarme ber emporgeftiegenent Miajen firds burdf Etraljlung in ben siseltraum jerftrent hatte, wurbe bie Tem=

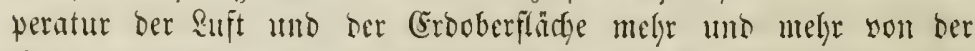
Eomenturirme abyängig; bie Temperatturverbältnifie mäherten fid

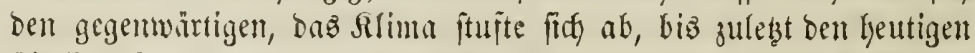

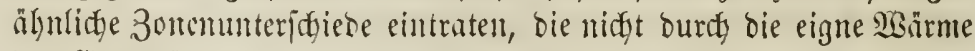
ber (Erbe, jonbern mur burd) bie Etellung derjelben zur Eome be= bingt finto.

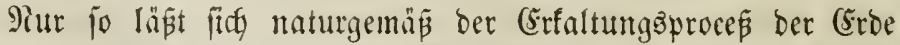

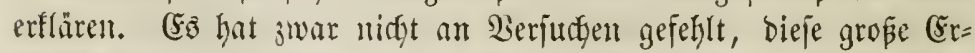

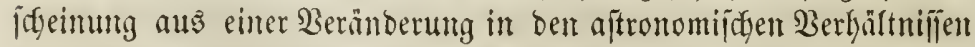
Des Flaneten abjuteiten, namentlich) aus ciner Berrinfung ber \$ole,

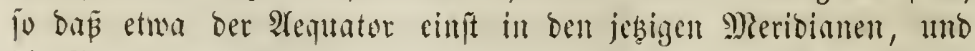

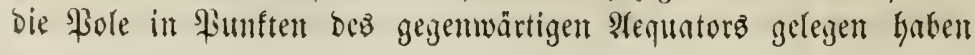




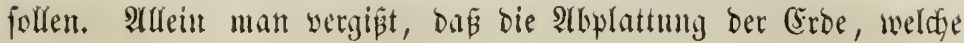
bie notllywentige Folge ilner Slotation ift, eine foldte Berrintung $u=$

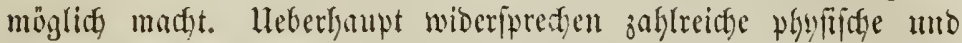

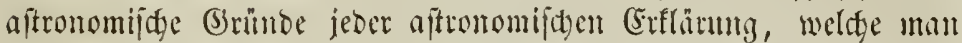
für bie tropifdge Begetation Der Flöbgebirge aller Breiten, für Die Balnenwäloer, bie in ber llzzeit Eibirienz fluren bebeften, für bie elephantenartigen, alipo pflutzenjejpenden Thiere im höbjten 2lorben

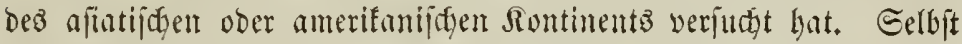
bie Beobadtung crkebt einen Wiberprud. Sä̈tten eimft, bei einer ber lyeutigen älynlidgen flimatijan Berfajumy Der Eroc, bie Fole und bamit alth bie 3onen einte anbre sage gefabt, als jebt, fo

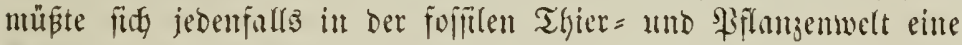
Abjtujung Der תlimate augipred,en, went aud in andrem Berlaufe

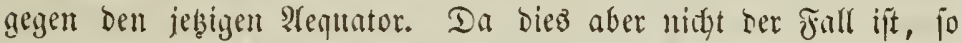
bleibt mur eine Annahme übrig: je năher bie Epodjen bes irbijoth Rebenz bem 3eitpuntte liegen, wo ber gunje \$llntet eine fourig= flüitige Diafie mar, bejto melyr liberwog nody bie eigme (S)lutly der Erbe ben Eommentinflus, befto melyr madte bie bem Boben ent=

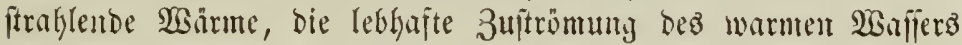
it Den Meeren, bie Menge ber heifen Suellen, welde anz Dem Boden fprubelten, und bie bidgten Dunt = und Piebelmafien, weldye

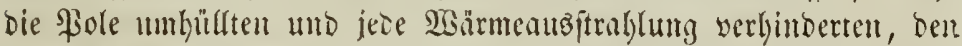
ganjen Croball zu einem Treiblyaje, in bem alles organijdye Reben in ber glïlyenditen fillle unb Siradyt wudyerte. Se melyr bie Eroe alfuantig erfaltete, befto ftärfer traten alfe Cinflifile Gerbor, weldye heute son ber Edgiefe der Sefliptif abhängen, befto mebr entwiffelte

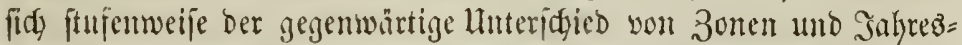

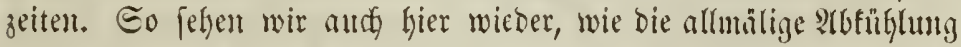

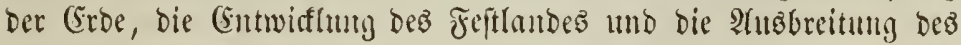
\$flanzen= und Thierreides in immer edleren mo bunteren formen

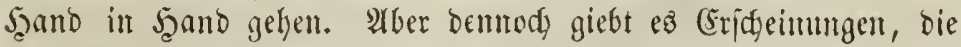
fich jufwer mit biejem Edylufje vereinigen lafien, uno je näher wir jur Edyelfe ber Begemwart idyreiten, befto mehr idjeinen fich bie

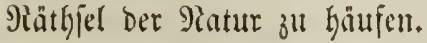

In jenem ungeheuren Treibhauje wntherte die riejentafte $\mathfrak{B}_{e}=$

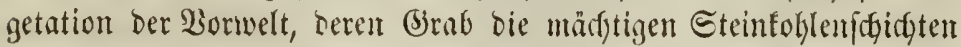

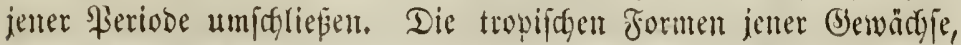

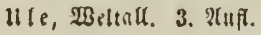


Deren Blätter und Stämme in Roblemfdiefer und Rohfenjanbjtein

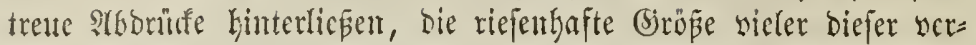
fohyten Biflanjen ferbit unb bie ungelyeure Mienge ber in allen (be= genben ber (Erbe aufgejumbenen Rohlenlager beuten auf eine Frndd)

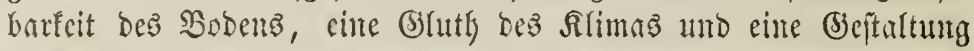

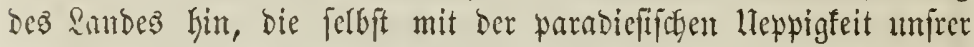

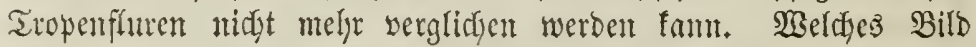
follent wir uns yon ben (Ereignifjen madyen, bie joldje Mafien von Pflamjenreften ablagerten?

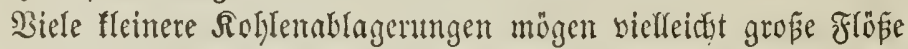

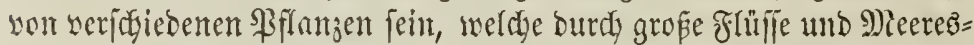
frrime angefdjwenumt unt im Sdylanme begraben wurben, wie nods

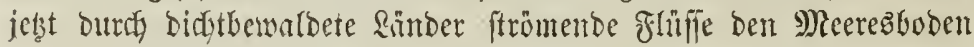

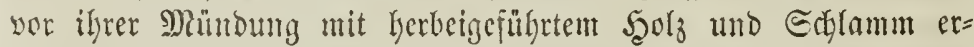
böfen. Stber wem anth jente gewartigen $\Re$ oblentager, welde unjere

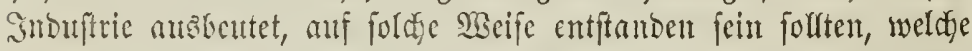

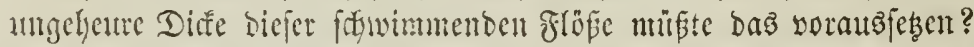

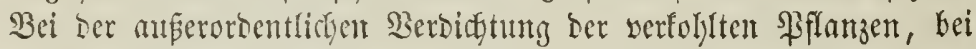

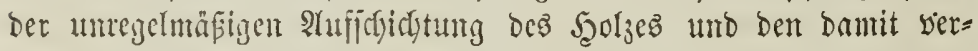
Gunbenen Yeeren Sinumest und bei ber lofferen Siatur jenter Farm=

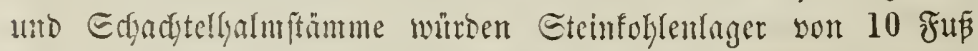

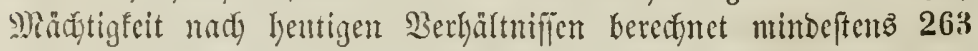

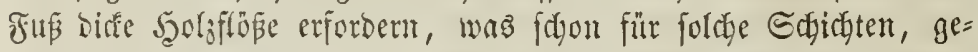

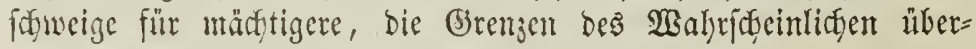
ictreitet.

Stuf folde Sogmierigfeiten fiofft man nidat, wenn man bie

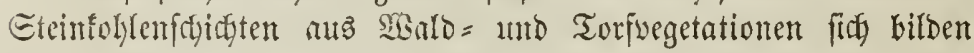
läpt. Ffllerbings fönnte bei einer joldyen (Entfethungâweije bie zur

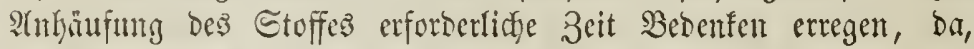

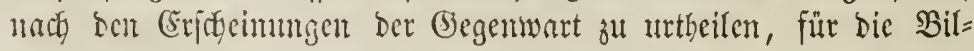

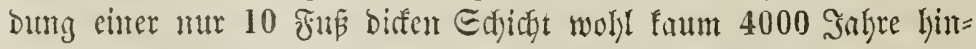

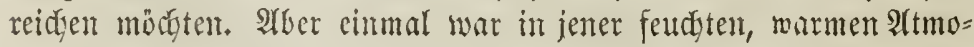
fplyäre ber lirwelt unftreitig bic Begetation unemblich frafftiger als

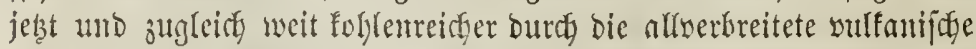
Thätigfeit, Die eine ungelyente 9ienge yon Rohjenfüure Dem Edjooße

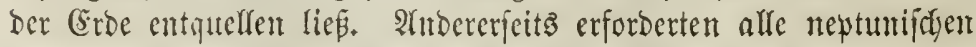

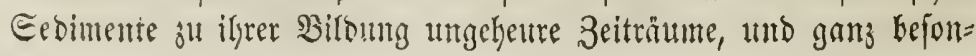




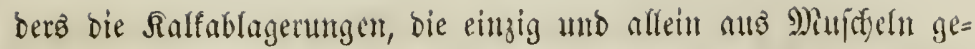

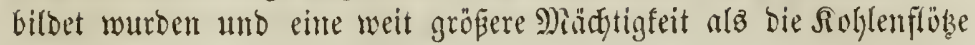
getwannent. Die 3eit barf um jo meniger Sdjwierigfeiten madsen,

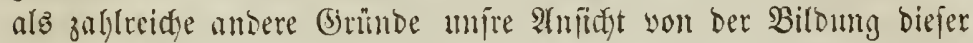

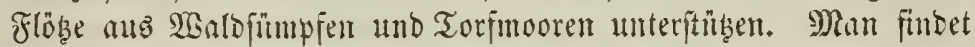

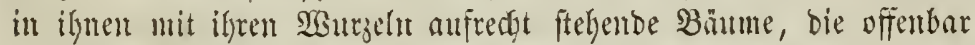
verjanten, wo fie gewadjent waten, uno son angejdyemmtem Sano voer Thout beberft wurben. Die gute Erfyaltung ber Blätter in ber

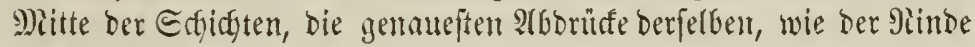
Der Farmitämme oft mit allen iljern lluetertheiten uno ben jartefter linearen 3cidgnungen im Edjefertfon, 'entell unserfentbar anf eine

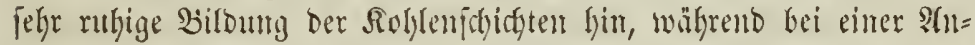
idjwemnnung burd) Fluthen bie weidferen, zarteren Dryante in (S)unbe

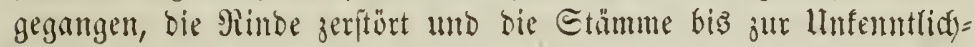
feit bejfäbigt worben wären. (Enblicf fommen bie Torfmoore utnd Eteinfohlenablagerungen audy barin thberein, baj fie mefre ober

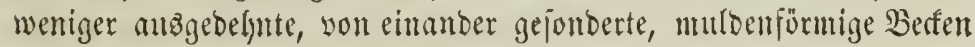
bilden, weldge an grope Eümpje erimmern.

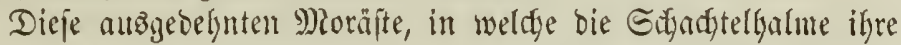
Burjeln verfentten, unt anz benen bie baumartigen Farnt ilyre Wipfel

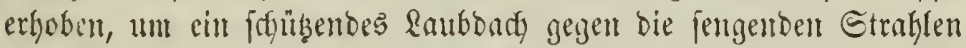
ber Eonne ju entfalten, fifeinem Salyrlyumberte und Salytaufente

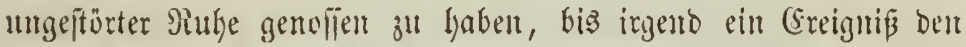

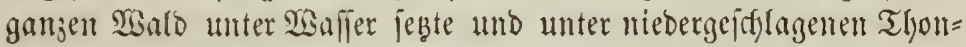

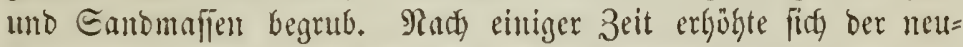
gebildete Boden fo weit, bas wieder Eumpfyflanjen $\mathfrak{F} u \tilde{p}$ fafien uno bie Begetation yon Reuem iffe reidje Edjöpfung beginnen fomnte, biz eine neue Berfentung and fie ilge Brab umter bent fluthen bes

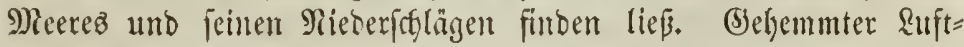
Jutritt, Druff Der aufliegenden Eand= unb Thonjefictsen, Feudytig= feit uno Crowärme fïlgrten bann allmälig ben Berfujt beß̧ früheren organifden Befrïgez Gerbei unb vollenteten fo jene bidgten ftruftur= lojen Malien, weldje wir jest als Eteinfohlen femen. Die unter=

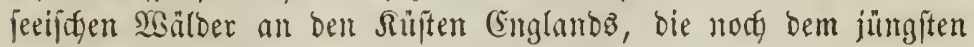
Sahrtaujend angefüren, me bie nodh in geidjidftlider 3eit unter

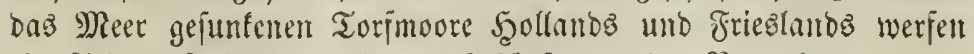
ein Ridgt auf bie gropartigeren Edjopfungen ber Borweit. 


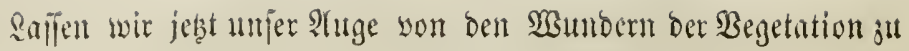

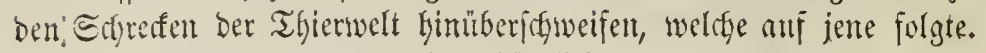

siseldy ein reidges anto eigenth)ümlidjes Reben verrärth bieje Zeit,

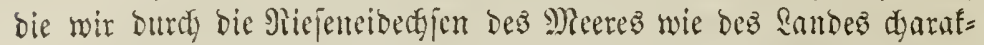
terifirt jefgen! WBie lebguft erwecten jo wunberbare Friedyöfe in bem

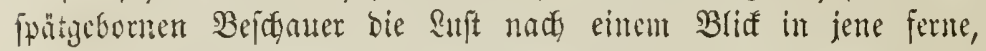
Hiber afle Beftimmungen linausliegende 3eit, wo llitgeheuer ber fellijanftent $\mathfrak{A}$ (rt, won fabelgafter Bejtalt, wie fie gleidffam nur eine

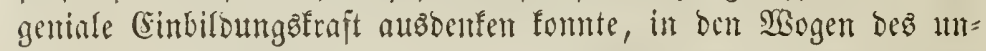

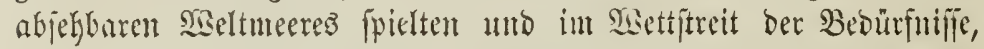

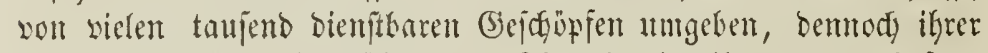
eignen benolien nidyt idjonten. Sie alfe int ifger grautenthaften,

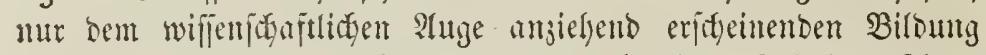
wernidgtete eine Santujtroplye, weldye bem heutigen Giejdfedyt feinen

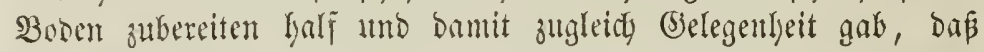

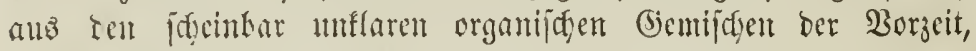
burdy inmer nete uns bejiere Darfîtellungen geläutert, jene innere Satrmonie bes Retens entiftefent funnte, weldye bie Biegenmart in

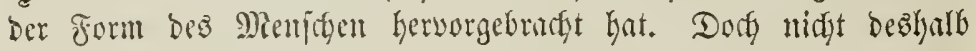

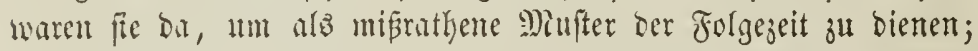

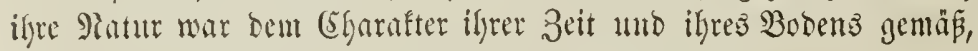
juysublich rof, wie jene, unoulfommen gejtaltet wie biefer.

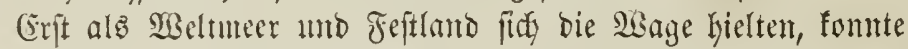

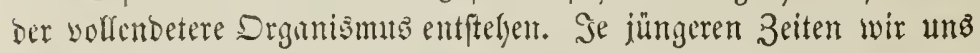

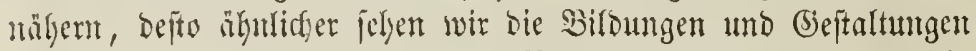
Der Patur ben lentigen werben. Plur bie Diluvialepodye, weldye

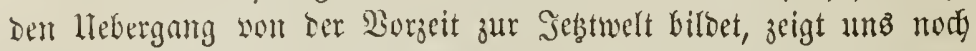

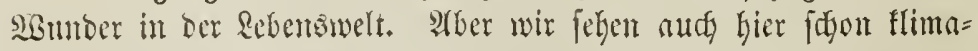

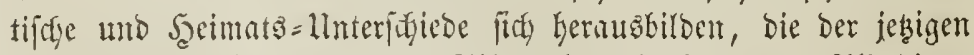
grograpbijifent Berbeeitung Der Thierwelt nake fommen. Afferding

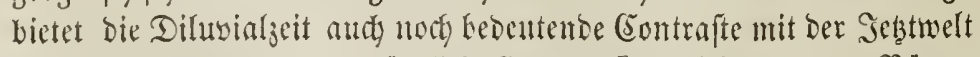
Dar. Englanto unto bus nöroliffe (Europa futto nidft nur von Bären,

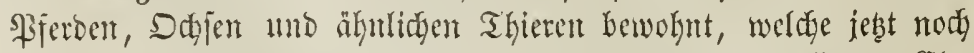
Innalogien bieter, jonbern audg von Sayänen, Röwen, Tigern, Ẹle=

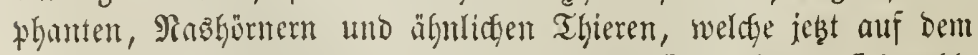

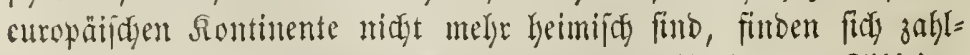

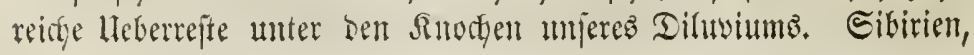




\section{1}

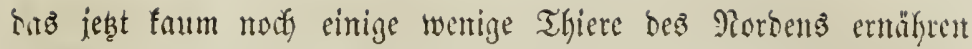

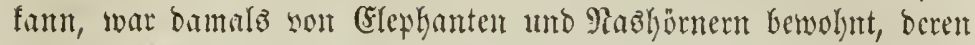
analoge Arten jeşt mur nod in füblidgen 3onen vorfomnen.

Eo lange man aljo bie 2iengleityung anf bie Ränber bez entro=

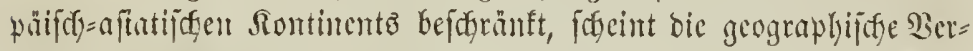
breitung ber Eantuethiere wäfrento ber Dilunialgeit afferbingz feine Bermandiffaft mit berjenigen Der Sebztzeit ju haken. Ther wie jente 3eit, efenfowenig lafft atch bie (Segemment eime jofyarfe (Boremse

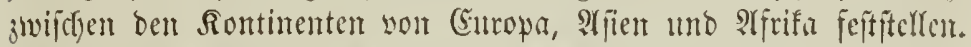

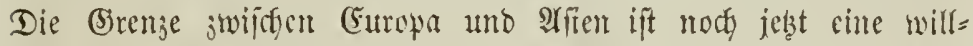

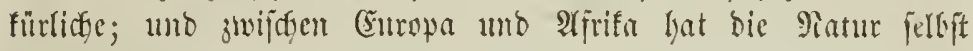
in biftorijder 3eit feine joldye gejogen. Die meiftent Enugetfiere und Piflangen, weldye in Rorbafrifi vorfonmen, ber Röwe, ber

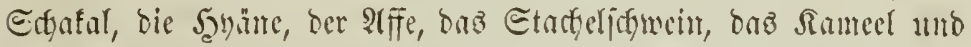
bie Zwergpalme, find entweder nod in ben curopäif

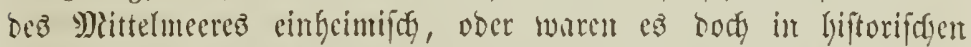
Beiten, und ifgre Entfermung ift nur ciste Folge oer Cinilifation. Wibie aber mody beute, fo tritt and fdyon an ber Eifwelle ber be= genwart cine 2 erichiebentyeit ber Drganifation mady brei groß̈en

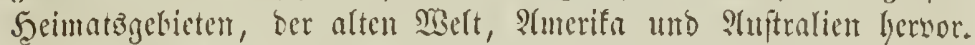

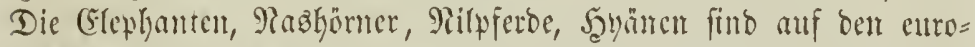

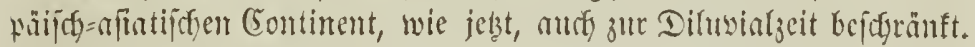
Sn ben amerifanifdyen unb menfollündijgen Thierreften jeigen fids

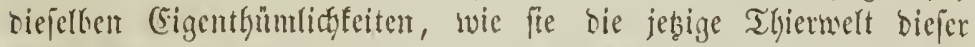

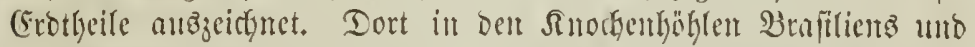

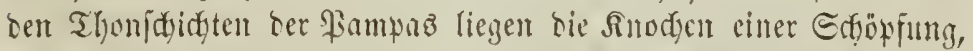

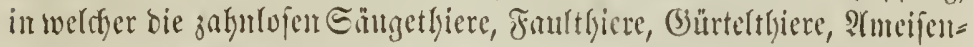

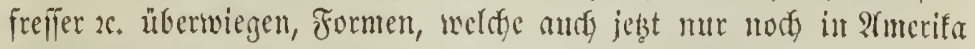

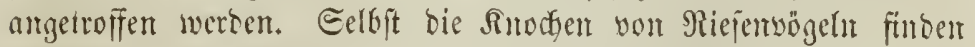

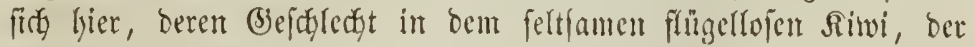

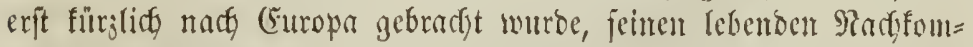

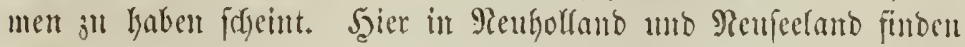
fict) bie Benteltyiere in cigentlyumlityen Formen entwisfelt, beren Fortbiloung in ben jebt lebentoen Bemohnent biejer smbftricte nidut rerfamnt werben fumt. Tuffalleno ijt es allerbings, wem wir in

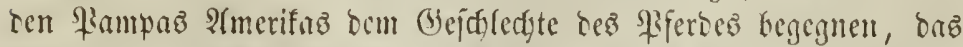
bod in hiftorifager 3eit exft won (Guropa ans bort eingefilfyrt wutro, 


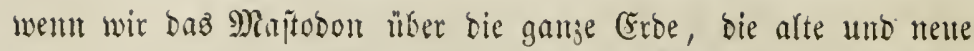

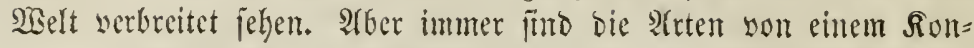
timente zum andern unteridjicben, und nur bas (s)efbledyt ift affge=

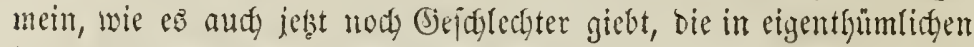
Irten über bie ganze Eroe verbreitet fint.

Co beginnt bie geagraplijde Berbreitung ber Drganismen nad Faunen uno Floren bereits in Diejer frillen Zeit ber Froe,

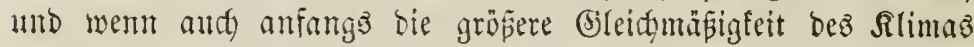
nod Morden und Eliden rerband, fo gewanten bie Rebenseridgei= numgen allmillig ben feiten Beftund Der Begenwart. Wobin nidft

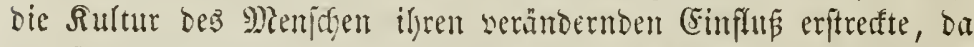
lyat jeit ben älteften gejđidftlidgen 3citen Das Piflangen= uno Thier=

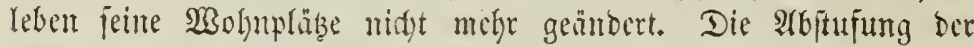
Slimate und ber mittlern Cromintme ijt beut feine andere als vor

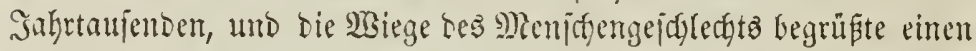

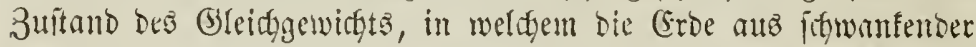
Unrube gleidjam jelbit jur Stulje bejomenen Dentens getommen

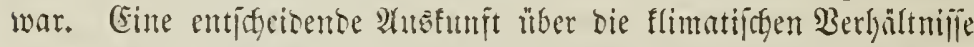

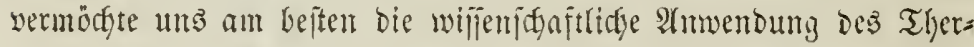
mometers zu geben. Da afer bieje faum erit ben Beitraum won

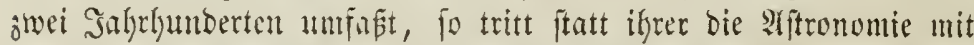
ifren unerifhutterlidgen Beweisgrintoen ein uno jeigt uns aus ber

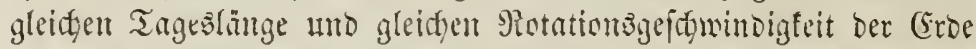

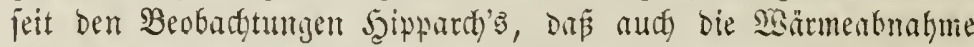
ber Croe in Den lebeten jwei Galgrtaujemben minbeitens feine mert= lide gewejen fein famt. alferdings wirb burds bie norty thätigen

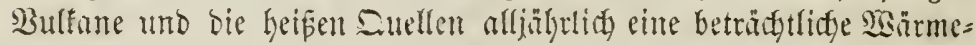
menge ju Tage gefradgt, und eine nody gröpere beftändig an bie Ftmolphinte und aus biejer Durd Etrablung au Den Weltraum ab= gejeben; aber ber Derluit, ben bie Croe an eigner Sistrme erleibet,

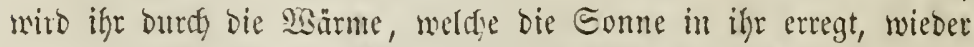

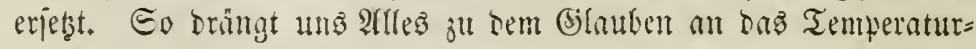
gleichgewidgt ber Begenwwart.

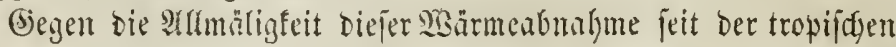
Sorzeit erfoben jidy einige Thatjaden, meldge Darauf himmiejen, da Der llebergang zur Gegemmart burch ein plöblidyes Sinten Der Tem= peratur in ber nörolidgen Eroballfte eingeleitet wurbe. Die grope 


\section{3}

Menge yon Sinugethierreften ber tertiären Sporthe, weldye in bem

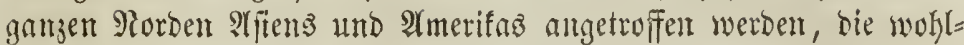

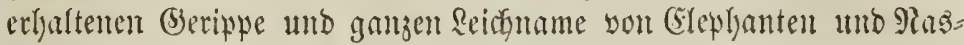

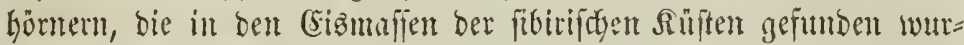

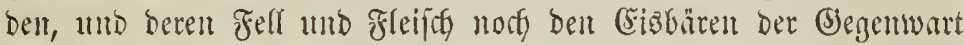

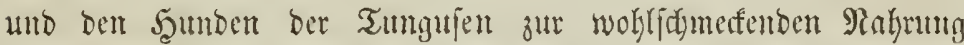
biente, bie Mlammuthfnodjen und 3ähne, eingeichyofien in grofert

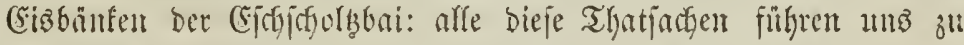

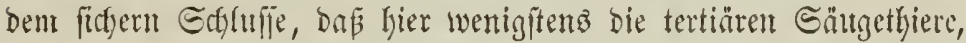

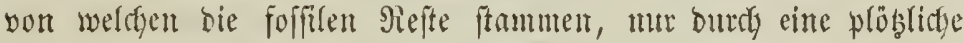

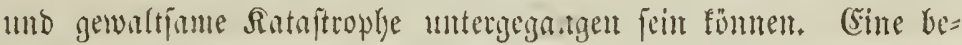

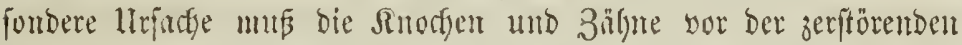

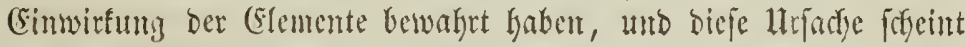
in einer Beränoerung bes Slimas beftatbon ju laben, in ciner

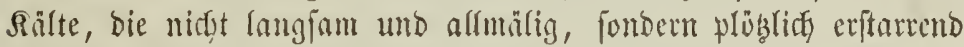

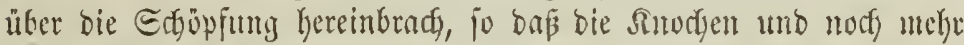

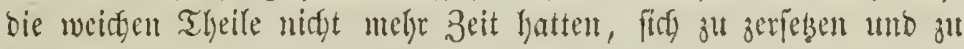
fantent, wie bie, weldye man in ber gemäßigten unt heißen 3one

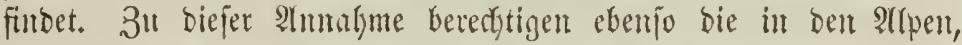
im Stura, im nürblidgen Eurropa und Ifmerifa wahrgenommenen

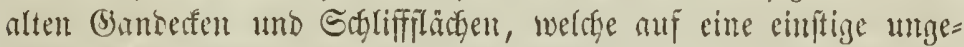

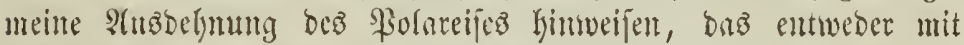

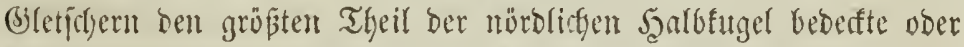

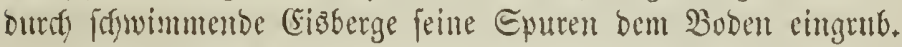

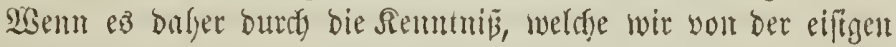

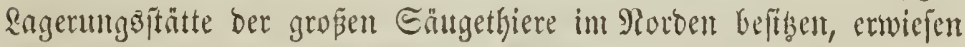

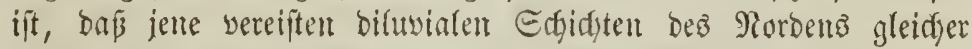
Siatur und gleidgen litrprung mit ben Berüllfdichten finto, in be= nen bie Elepfantenftucten bes mitteren (Eutopas angetroffen wer=

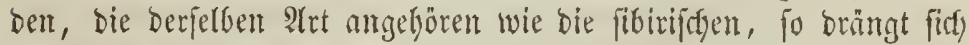
aud) bie Bermuthung auj, bap biefelbe Sataftrophe, weldye bie Thjere bes Morbens jo plöglich tübtete, auth sie Thiere unjeres Di=

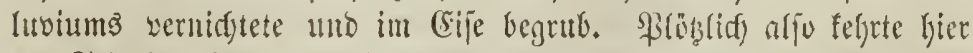
ber Tod in ciner mäctigen Edjöfing ein, mo eifige siuthe trat

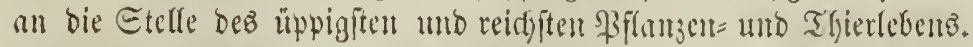

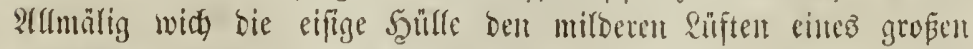

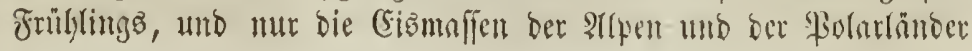


blieben zur Errimerung an jene Erfțartung unjerer beimutlidfent

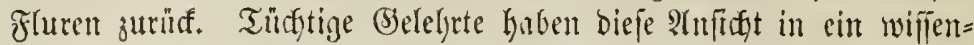

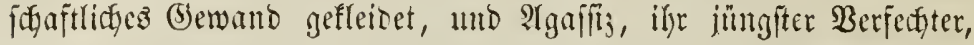

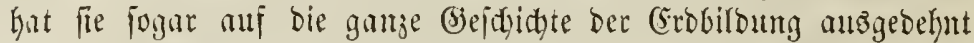

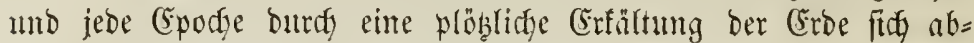

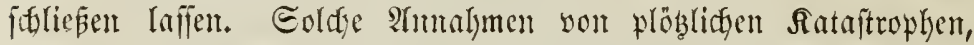

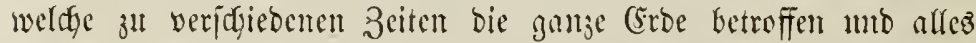
organijiche Reben auf ifgr überall mit einem Maale jerftürt hätten, jo

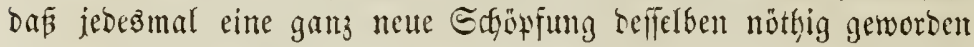
und bie Rebenswelt baburd in eine befimmte 3ahl hifterifds auf

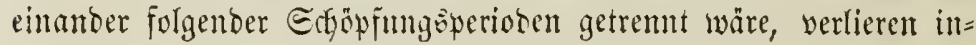

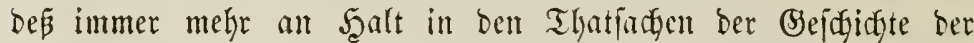
Bormelt, je tiefer bie foridum barin eintringt. Nirgento ift guvi= fiden ben unmittelbar nach eintander gebilbeten solagerungen eine

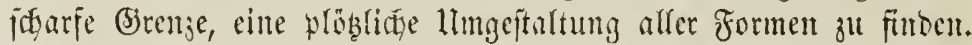

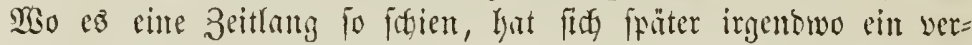

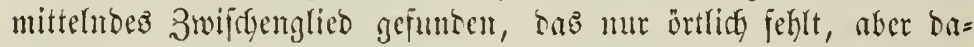

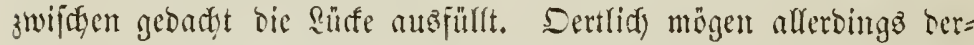
gleidfen vernidgtente Satnitroplent eingetteten fein, wie fie ja nod in ber Begenwart, werm auth in fleitterem Mafiftabe, erfolgen.

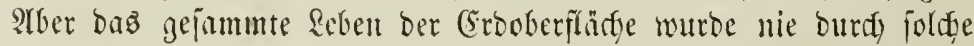

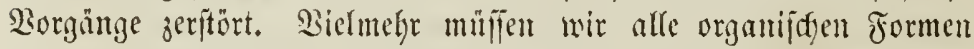

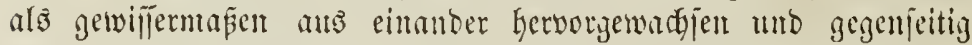
burdh einamber bebingt, alż nad) uno nady ernetsert betradytent.

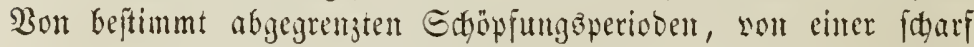
untericticbenten Borwelt barf ftreng grtwommen nidgt mehr bie Fiebe fein. Die Kentigen Drganismen finto, wie wir gejelgen haten, mut

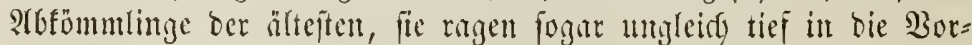

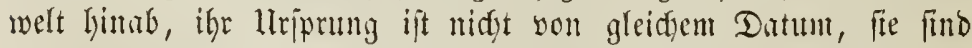

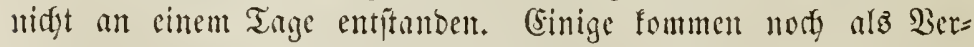

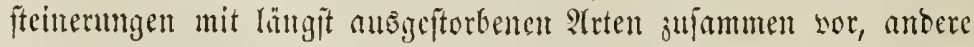
fint erfit in viel steuerer Zeit aufyetreten, mandefe fogar in hiftori=

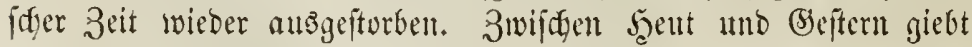
es in ber Miatur fo wertig eine idgarfe Grenje, als zwifden ben Tagent Der $\mathfrak{B o r}$ jeit.

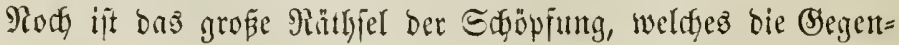

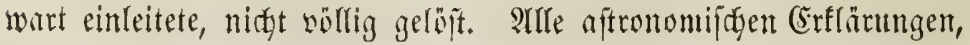




\section{5}

bie man verjudgt hat, wiberlegen fid felbit, unb aud bie trofftoje

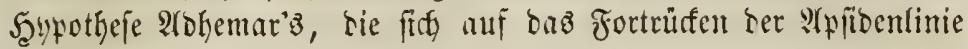

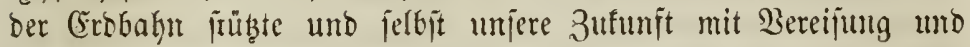

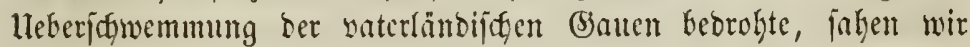
haltlos in fid zujunmenitirisen.

Piicht im Etande, bie Breheimnifife ber nädsiten Bergangen=

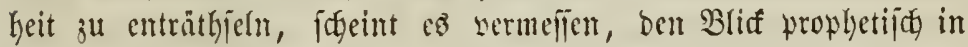

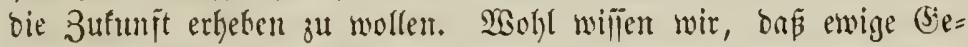

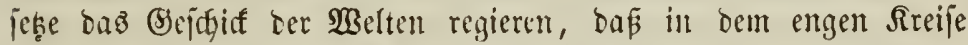

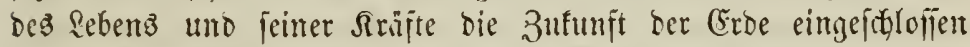

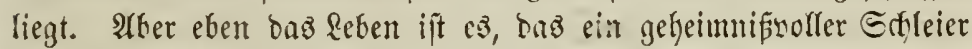

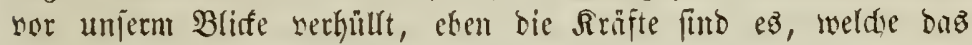

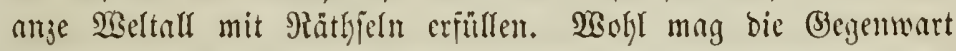

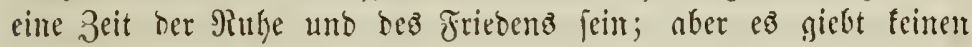

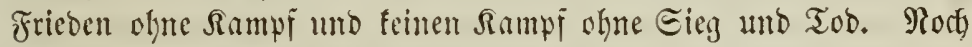

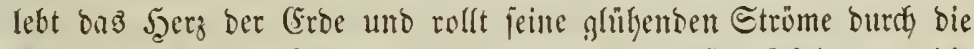

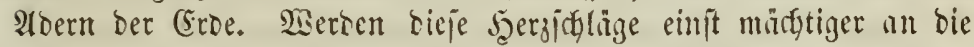
Biorten ber Unterwelt podyen, wiro ter Sebenstampf einjt ftürmi= idser erwadjen unt wieder eine Edjöpung jum Spfer fordern?

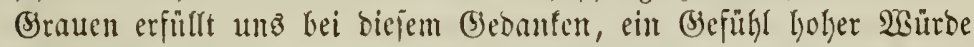
weifit mit $\mathfrak{B}$ iberwilfen bieje Drofyung son fid , weldje ber $\mathfrak{R}$ rone ber Edjöfung gilt. Sisie! Dieje liebliden Fluren, melthe ber

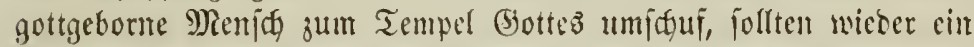
Edfauplat io furdstbarer 3eritörungent werben fömen, wie fie bie

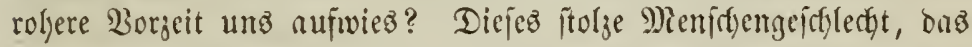
einen uniterblicfen Breift in fict birgt, bas ben Beruf crfaunt hat,

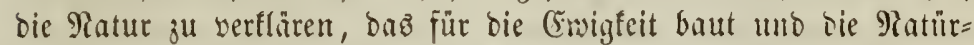
lidffeit überwintet, ez follte im Sampf gegent rohe Maturfräfte un= terliegen? $\mathfrak{S}$ eg mit biefem wiberwärtigen Bedanfen, ber in bem

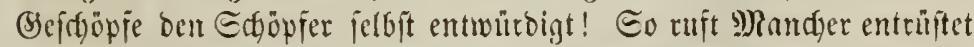

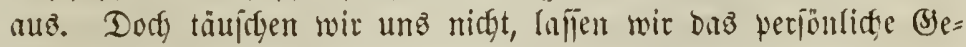

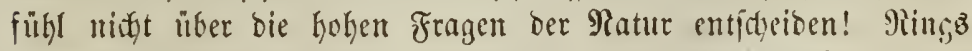

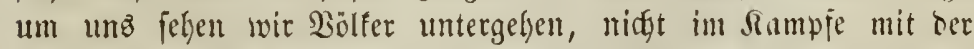

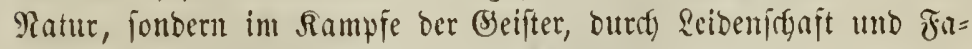

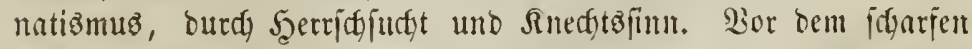
Edgwerote ber Eivilijation widfen die llesuöfer bon Ban Diemens= land, fduminten täglidy bie Etämme ber Esingebornen 2 mmerifaz, 


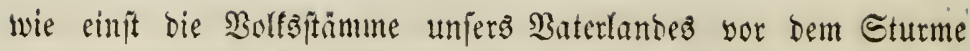
non Diten wie welfes Rautb serweht wurben. Rom, bie ftolje Serr= idyerin ber Selt, ift bafjingejunten, Siriectenland, bie Wiege ber

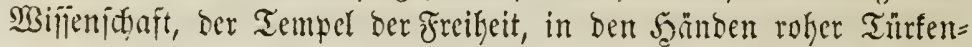
yorben. Ias Rand, in Dem Das Morgenrotl) bes neuen (S)iftez

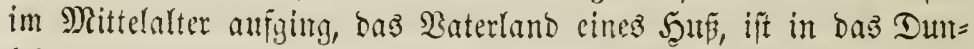

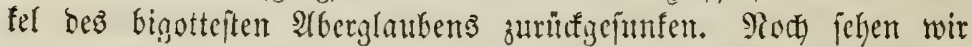

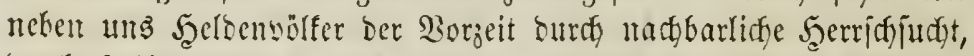

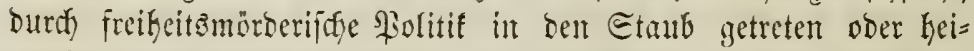
matlos über bie sänber ber (5rbe zerftreut werben. Wisir flagen nidyt. Sisir fülylen fein (5rauen, wemn 3weige des cignen Єtammesz yon ben eignen Britoern veritummelt und afgeknen werben; wir jit=

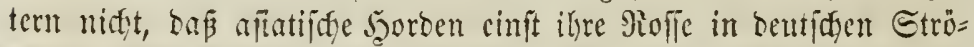
men trïnfen mädyten; wir erjogreffen nicht yor bem Giebanfen, daß Der beutjdye (beijt, nidjt im Sampi mit rohen Paturgewalten, jon= Dern im Rampf mit ber (Scwalt öftlider Barbarei erliegen werbe.

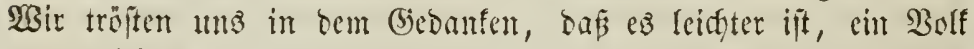

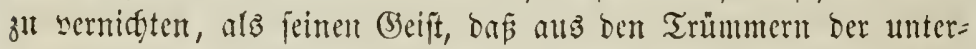
gegangenen freilyeit und Rultur bie neue und berrlifgere erklï= Gen milife.

Ier Bewdyucr Suito's baut jeine Etabt auf bie unfithere

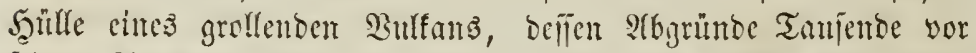
feinen Arugen veridylangen. Der Fiffer ber Sübje fudyt jeine Seimat auf ber miederen Soralfeninfel uno fieft son ben $230 g e n$, bie liber fie babinrolfen, cinte Şütte nady ber anbern bimweginnllen. Der Arlpenbewolner fiebelt fich an unter wild ablyängenden feljen, mitten unter Somternden Sawinen und fradenden Bergftüren. Bas fejlelt jene Meniffen an Den tüfijtgen Bulfan, auf bie

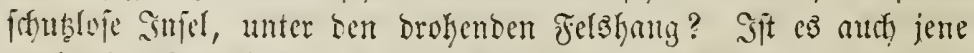
engheraige Eelbitjutt, bie cin Bolf unter ben Siuinen zujammen=

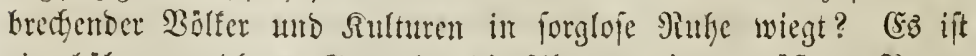

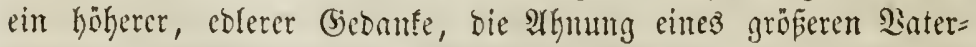

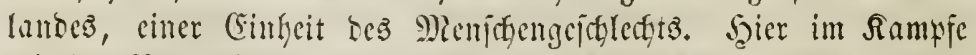

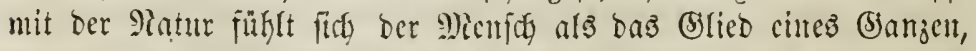
welches das Spfer bes Eimjelnen forbert, und freubig bfift er in

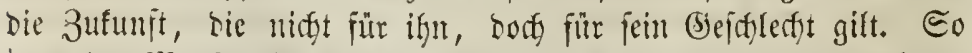

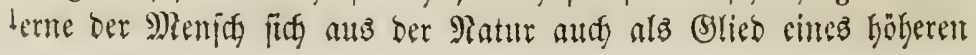




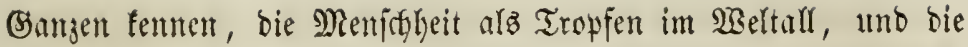

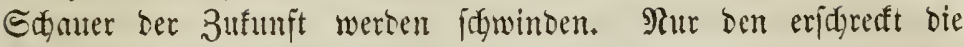

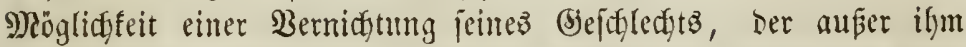

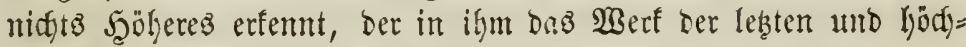

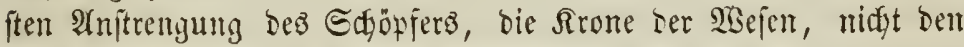

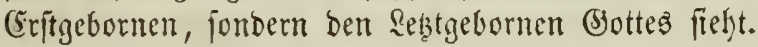

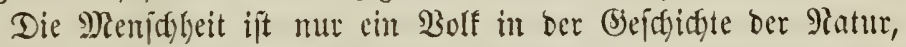
daz wie bie Bölfer ber (Erbe Dem anbern weidyt, weml es feine Siolle ausgefpielt hat, umb Dem (Ěrben jeines Bseiftes, Dem verflär=

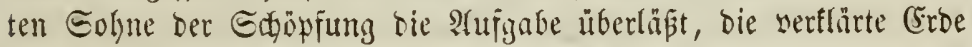

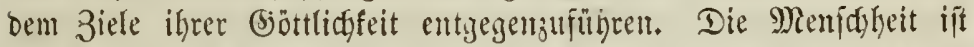

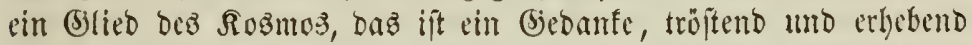
für ben, der ifg begreift, unbegreiflidy unt grmjenerregend aber

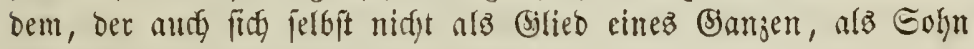
eines Baterlandes ju fülylen vermodgt lyat. -

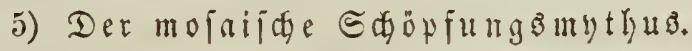

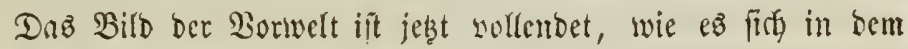

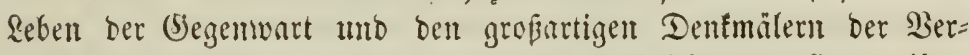

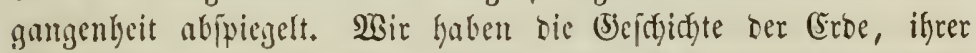
Revolutionen und iffer Refensidjüpfungen aแs ben verworrenen $3^{\not l}=$

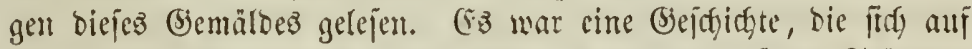

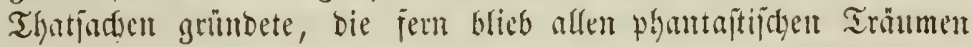

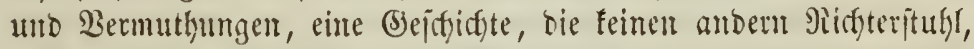

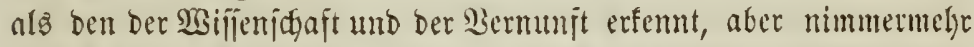
ben finnlojen Forberungen einer aumaß̈enden Theologie uno cinez frömmelnben Blaubens geredgt iverben faum. Dem dieje verlangt

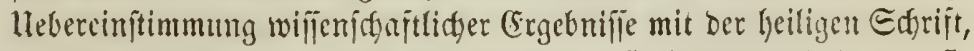

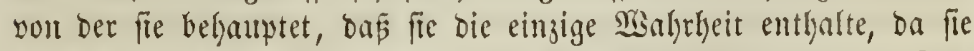
auz göttlidjer Duelle geflofien jei. Bermag man aud in umierm

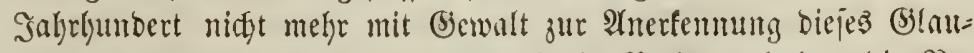
benz zul jwingen, fo meint man body cin Recht zu hatbent, bie Rie=

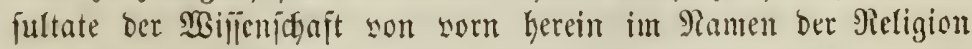

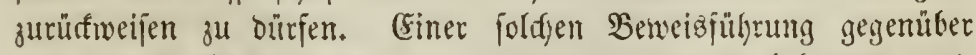
wagt ez bie SBifienidgaft, ifren Unglauben offen zu befermen, und fürdytet nidgt, beşalb für gottlos und undfriftlid) werfdyrieen zu werben. 
Ier wadfjente Triumph ber Bermunt madft firf jelfjit ber Dr=

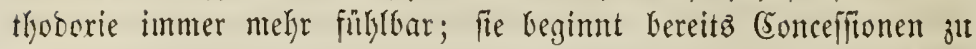
macten. Eie giebt zu, bie göttlicfe Sifenbarung habe nidft attez gegeben, um dem meniकtidfent (beifte einen Exielraum für jein raft= lojes Simnen unto Grïbeln zu gemähren, fie Kabe Rüfen gelajïn,

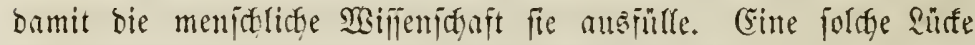
jei zwiiften bem erjen uno zweiten Estöpungstage, uno biejer riele Miflionen Snltre nmfallente Beitraum fönne mit affen ben

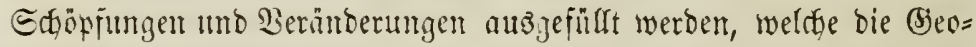
logie als unleugbar nadjweije. Durdf foldte Mittel will mant jeşt lodent, mant will fich felbjt alfe migliden Denteleien unb Einn= verbrehungen im heiligen Terte gefallen lallen, ween nur ber $\mathfrak{B u d}$ ) $=$

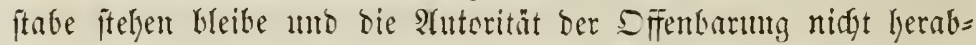

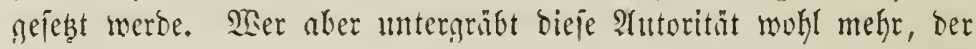

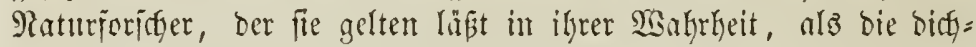

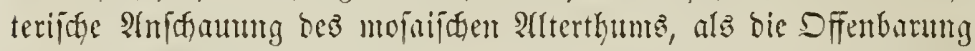

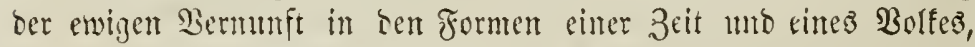

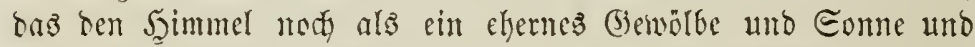
Eterne alş lendfentoe Edfeifen betrudytete, buran bejeftigt, nm bie

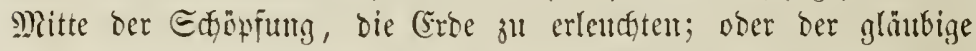

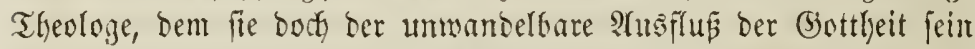

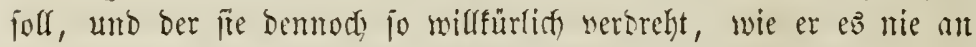
feinen eignen Єdyriften von einem Rritifer bulben müroe?

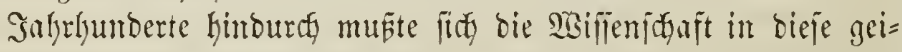
jitige Tyramei fügen, muste firf, wenn fie gebultet fein mollte,

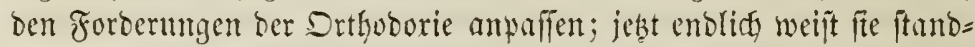
Faft jebe Sfutorität son fid uno erfennt feimen giduter itber fidf,

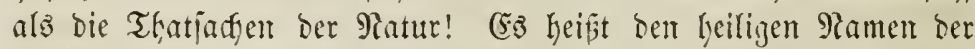

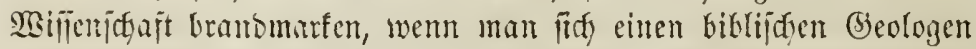

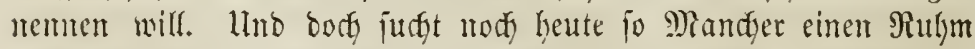

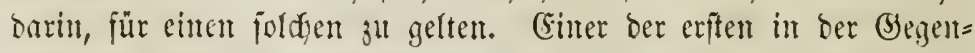
wart und anf beutictem Boben war Dr. 2Atroreas $\mathfrak{B}$ agner, Mit=

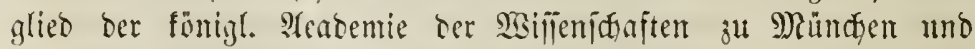
Profelifor ber 3oologie an ber bortigen 1tniverfität. Ceine 1845

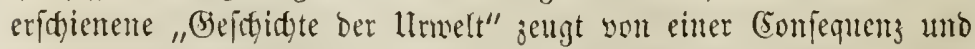

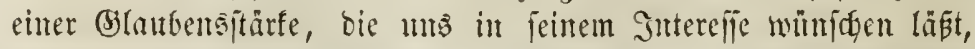
er wäre brei bis vier Gabryunderte frülyer geboren. Wielfeifft lyätte 


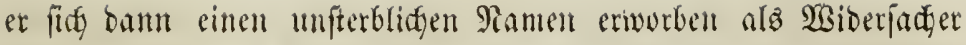
eines Sopernictis, Balitei tmo Seppler. Setzt ift er jut fpät ge=

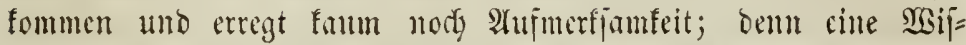

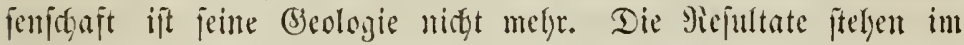

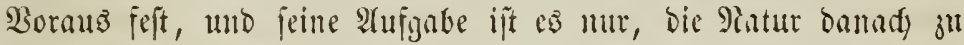
verbreljen. -

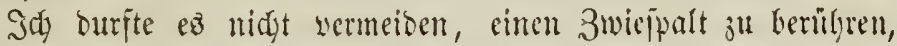

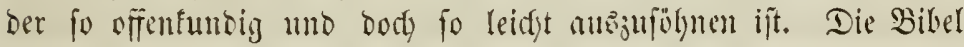

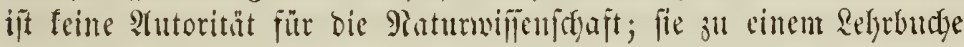

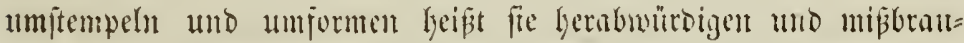

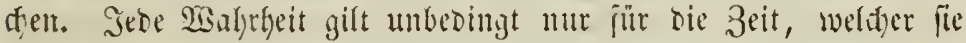

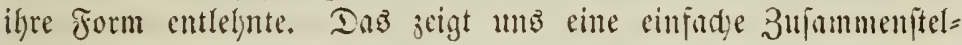

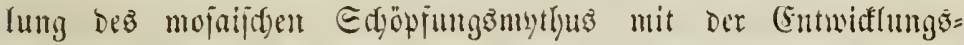
geiddidyte unjerer (Eroe, wie wir fie ans bem buthe der Siatur jelbft heraużlajen.

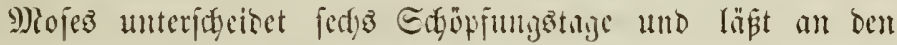
beiden erften Ridft und şimmel geidgaffen merben, wälyento am

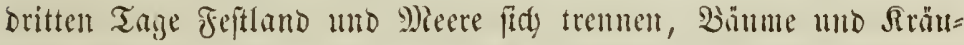

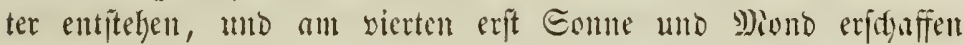
werben. Sonad watr aljo bereits bor Entiftelynty ter Eomne bie

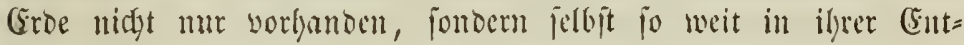

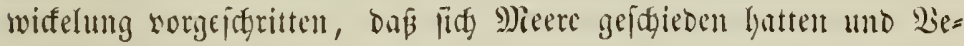
getation bie zeftlintoer bedefte. Banj anders belelyten uns bie Thatfadyen ber Matur. (Sin Centralpunft, eine Gome warb ge=

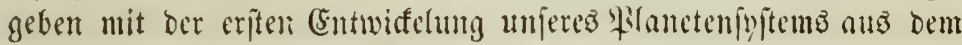

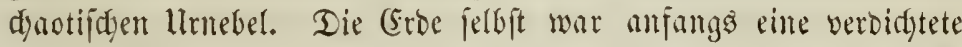

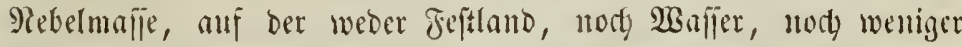

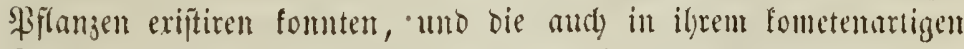

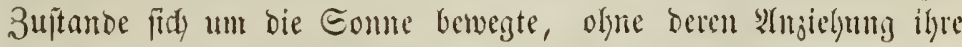

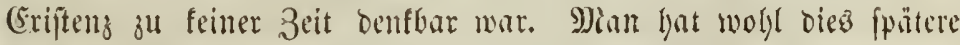

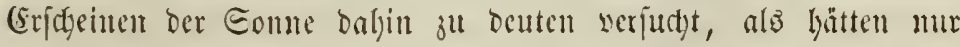
ifje Etrablen an jenem vierten Edjüpingsitage die bidjen Rebel

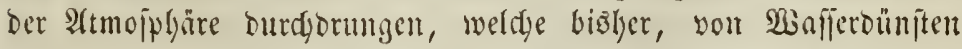

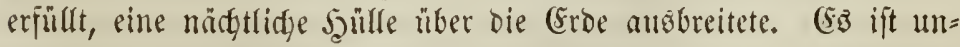
begreiflid, wie man dem befitimmten $\mathfrak{B o r t l a u t e ~ e n t g e g e n ~ e i n e ~ f o l d j e ~}$

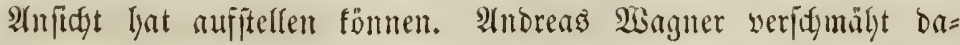
her einte foldge Suconfequenz uno läpt wirflid) bie Eoune und ber 
Grobe entitefen uno bie alte Sdyopfung bon einem Ridftäther um= flofien werben, ber fids an vierten Tage in bie eingelnen leudgten= Dell Şimmelafurper fontoerte.

\$luch in ber Reihenfolge ber orgnilichen Edyöpfungen zeigen

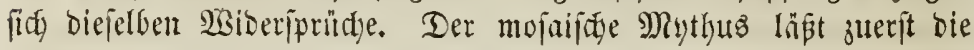
Pfianjen entifelien und zwei Eböpfungsperioben hinburch alfein

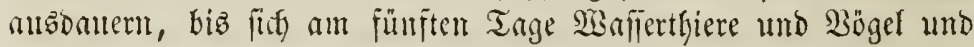

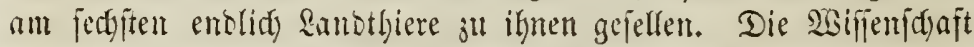
lebrt cime ganz andere Entwifelung. Whir feben Gier bie Pflanzen gleidyeitig mit ben älteiten Thieren auftreten, nidgt burd lange \$e= riobell getremt, wie ja beibe Rebenseethe eimmber wedjeljeitig be= bingen. Wir fehen allerdings bie SBafjerthicre vor ben Ranbthieren erideinen, aber nidyt bie Bügel gleidjeitig mit ben erfteren unb

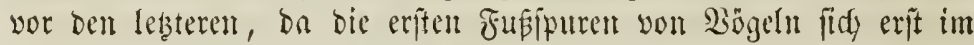
bunten Eanditcin, bie erfitu zreifellojen Entotbierrefte ragegen be= reits im Лupferidjiefer zeigen. Siod, viel weniger wurben Reptilien uno

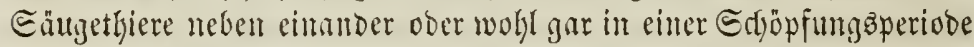
mit Dem 9lenjdyen gefdarfen, wie es ber mofaijde 9)iythus erzählt.

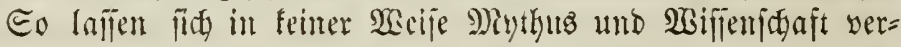
einigen, unt über ben vergeblidfen Berjudsen verliert ber glaubens= volle Theologe Den eimsigen ervigen (Stebanten, ben tiefen und ern= fren Einn biefer ältejten Didytung aus tem Shge, ba bie gange

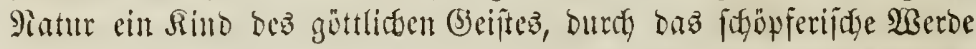

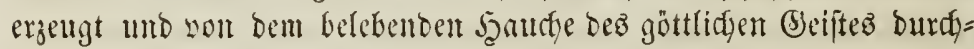

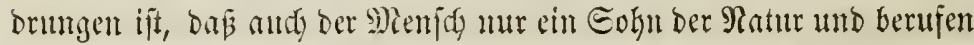
ijt, bie lieblide \$) Wutter mit bem enigen Bater, bem (Beijte, ju serjühnen.

\section{Die Giejuidte bez Meniden.}

Bom Reim jur Blüthe baben wir bie Entwiffelung ber (srobe

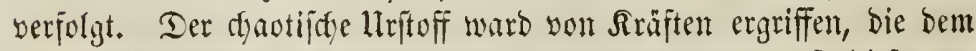
eignen Edyoope ber Materie entquoffen, und in Rampfe biefer ge= ftaltenden und vollendenben Sräfte entfalteten Meer und and bie reidye Fülle bes Rebenz. Eieg und Tob wedyjelten mit einander,

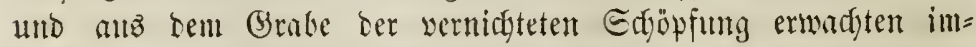
mer neue und edtere, biz endlicy der Menias, als bie Srone ber 


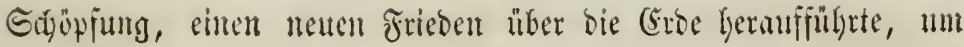

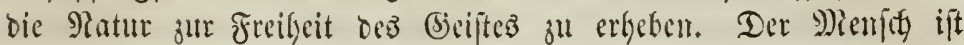

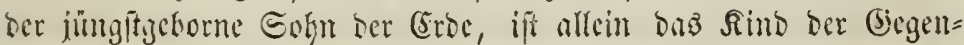
wart, und feine wort alfon furdfotbaren Sataftroplen lyat foin (S)e=

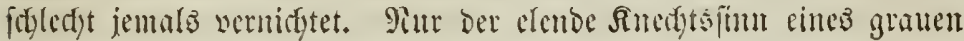

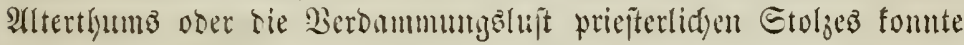

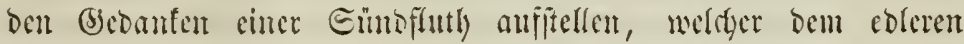

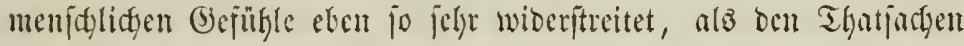
Der Patur.

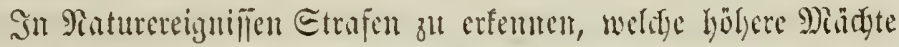

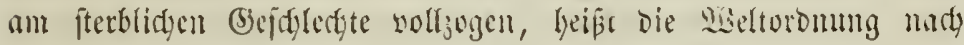

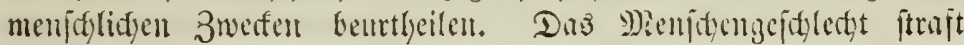
(ï) nur jelbit, uno

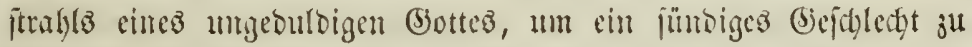

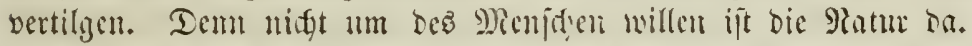

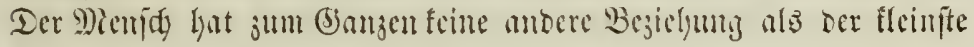

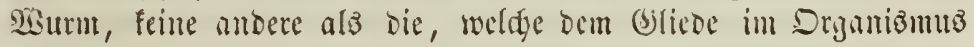
zufommet.

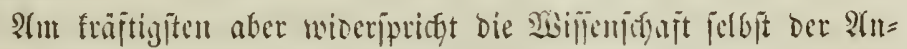
nalgme einer joldfen allgemeinen Günbflutly, wie fie uady Miofez

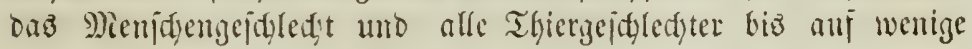

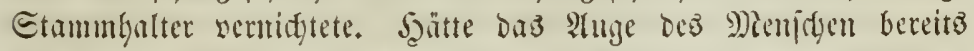

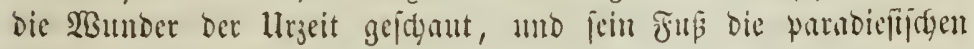

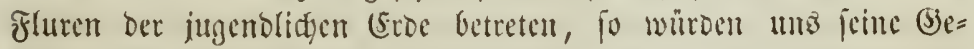
beine und feine 2 serfe ats ben Edjichten ber Erde lernus yon

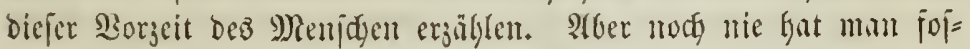
fite Mlenidgenftudaen gefurden, und wo man fie ju finden glaubte, ba zeigte fich immer bald, baf fie aus jüngeren Epodten berjtamm= ten ober gar nidjt MRemidjen angebürter. Die Menjidengerippe,

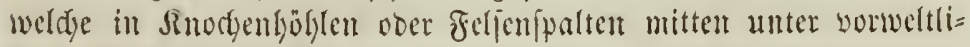

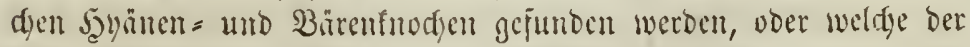

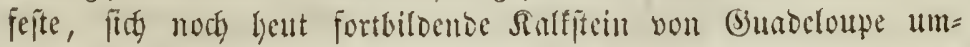

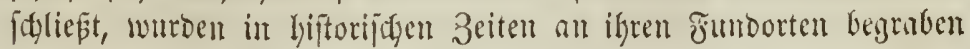

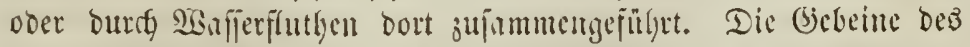

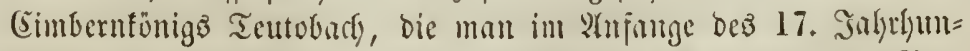
Dertz in ber Dauphiné entoefte, gefören bem siiejenttlier ber Bor= welt, bem Maftodon, und bie releslifagen Enget von Sujern sinem 
unveltliçen Glephaten, bent Mammuth an. Die aus ben Bolfent

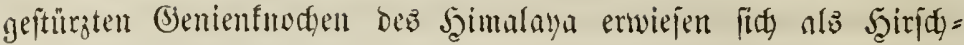

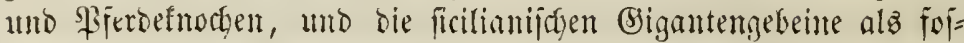
file Milpferbtnoden. Der berifymte prindamitifde Menid) Sdgendy= zer's enorich, Der lez̧te Zeuge der Sünofluth, den man im vorigen Sathrhumbert in Seninger Ralfitein fant und mit iofwärmerijdyer Begeiftermig als marnendeg Dentmal für bie fundhaften (Enfel be

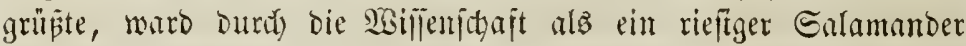
Der Borzeit erfinnt. Eeitbeut ift biejem linjuge Der Cinbildungs:= fraft, weldyer an bem 2lberglauben ber 3eit eime fräpige Stïke fand, Durdy bie emite joridyung Der Paturwifiemityajt ein Ende ge= macht, und bie Einndifutly mit ifren Zutugen in bie Siumpelfommer menidylidyer Srrumben uno Parrbeiten verwiejen.

Wifl man r.ber auj bie weitwerbreiteten Gagen alter Bölfer, nidyt blö ber Szebräer, die nur von einer noadhijden foluth erzäly=

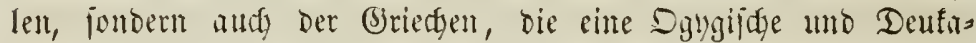
leoniphe und eine Fluth des tijuttros femten, etwas geben, fo Dari man wenigitens ein Coreigní, weldges bie hentige Sdyopfung heimjutgte, nidyt in bem Dilusitm Der Sieologen fudgen. Sn ben Edyidyten ifrer Bebilde finden fids mur bie pojiflen lleberrefte won Thieren, bie den beut lebenden fremb find, währent nady ber bibli=

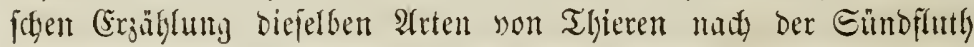

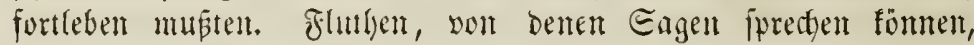
waren lofale und fitiegen nimmermelyr ju ben Bipfeln ber hübjten Berge hinn. Es waren gewaltige lleberidwemmungen, bie viel= leidgt bon burdbredgenden Eeen und Meeren herbeigeführt wurben

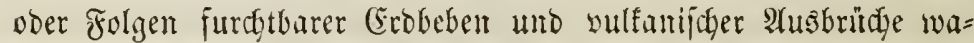
ren. Mur Trabition und 9) Yythe foilderten fie im saufe ber Zeiten als allgemeine. Rody weijen 2llterthümer uno geologijdge Crridtei=

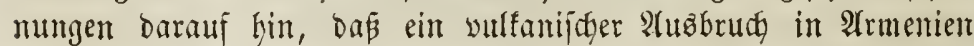
Der noachijdyen Fluth, ein Durdjbrudy des fdwarjen Meeres in

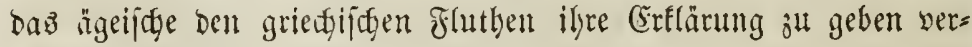
nögen.

1) Die (stuppen des Menfaengefdects.

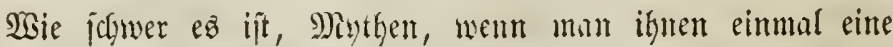
(5)eltung in ber Bijemjagft eingeräumt hat, felbit burds bie 


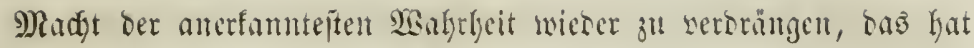

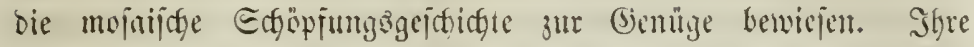
3eitred)mung bat bis bent jefbjt in ber Beologie ein genififes $2(n=$

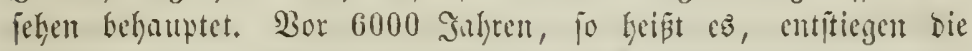

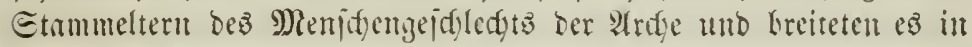

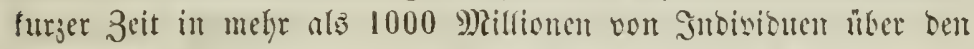

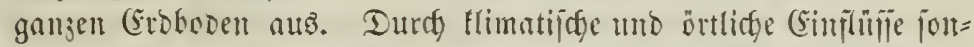

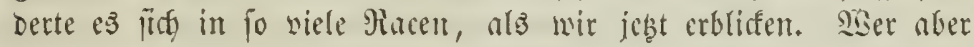

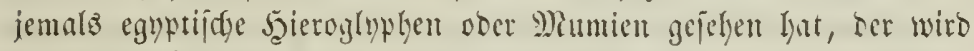
in Dent mefhr als 4000 Sahre alten Büzen jener alten Egypter,

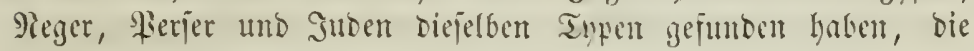

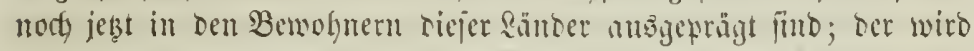

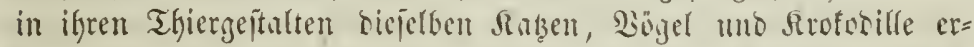

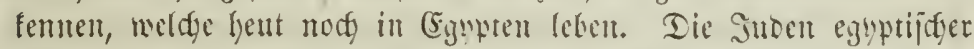

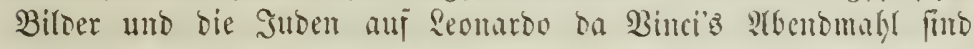

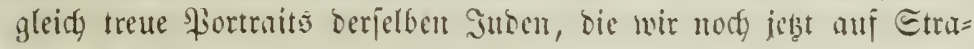
Ben unt Mräften erbliffen. Eo bewohnten aljo feit vier Sngrtau=

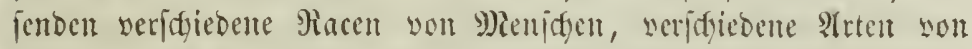

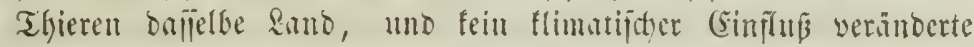

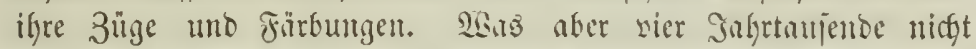

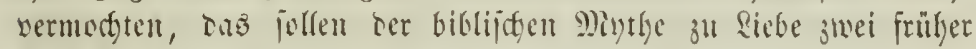

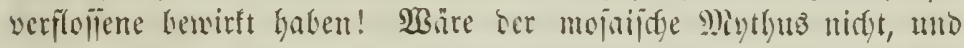
maike biejer nidyt fo eng verflodfen mit dem Iogma von ber Ertb= jürtoe, biejer tiejiten Edymady bes mentididen (bseiftez, fein un= befungenter Siaturbetrad)ter wäre je mif ben (Sebantent gefallen, alle Miniden won einem einzigen \$inare ableiten zu wollen.

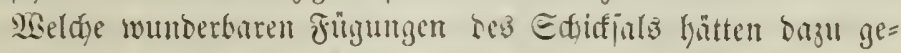
bört, um innerfyatb jentes furzen Zcitrnums wou einem einjigen

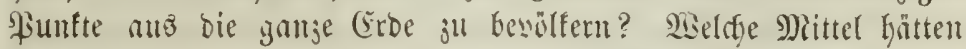

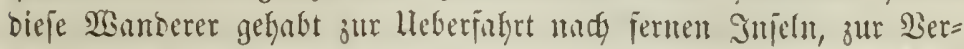

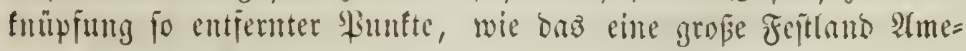
ritns fie bietet? SEarum bliebent fie nidgt in benl gejegneten fluren Der Tropen unt zogen es vor, fid in bie eifitgen Siegionen bev

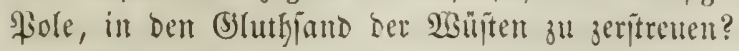

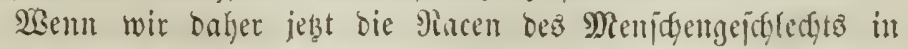
genifile Besirfe vertfeilt jeken, bie unit sen floren unb fanuren= gebieten ber begentwat auf bas llujweibentigite libereinitimmen,

IIle, Weltall, 3. भun. 


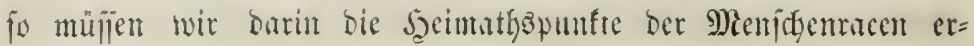
blifen, an benen fie entitanden, und son benten fie autgingent.

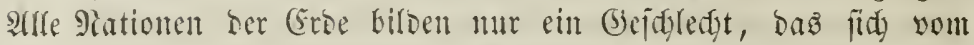

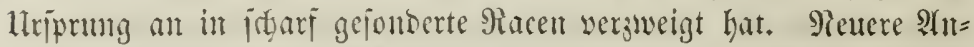

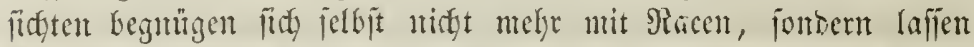
Prten son Menjdyen erifiten, bie, son ciner battung umfápt, ges lünge es mur ber silifenjoujt, fie natysumeijen, felbjt in Der Borzeit

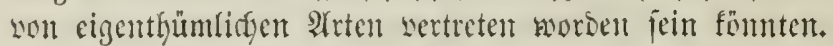

Wemn man Kismeilen bie linterjuiebe ber Menjdyenracen ber

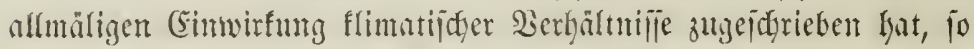
murbe man babei Durdh an Thieren gemadte Besbadtungen gelei=

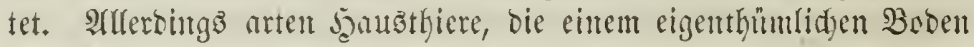

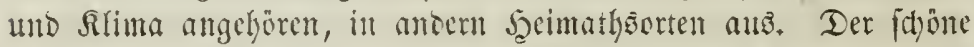

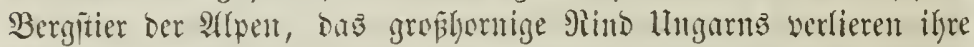

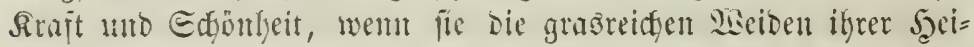
math serlafien, und sas fcimmollige framijde Edaf fefyt auf beut=

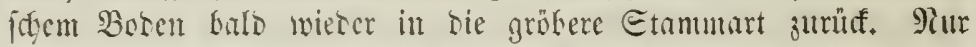

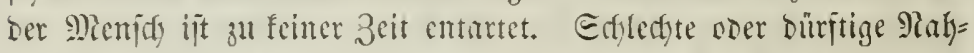
numg werjebte wohl biemeilen ganje Bzolferidfaften in einen 3uftund Ler Sierrigfeit und Rroftlopigteit, aber ber gefunde Dentide ift nods

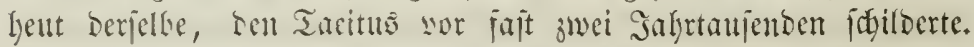

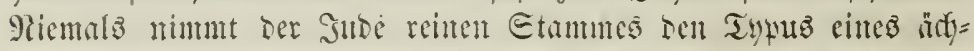

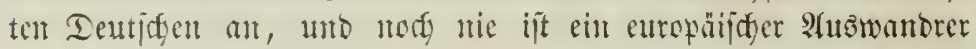

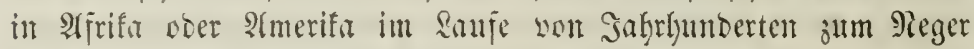
ober Erratien gemorien.

Die Macemunteriffiese wutben mit Sem Menichengeidfedyt ge= boren. Die eriten Meniften waren jwar math gleiffent Typus ge=

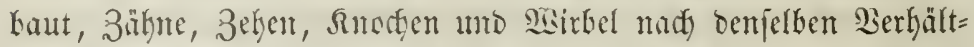

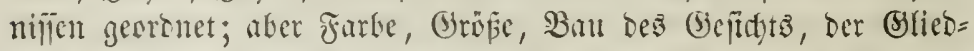

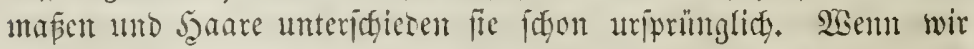
bei Sauthieren Surd Farbe geidiebenen Epicharten begegnen, to

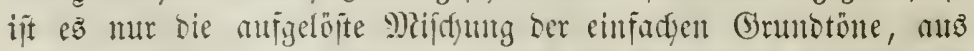

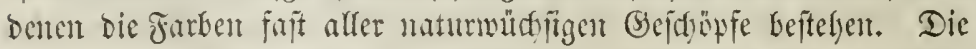

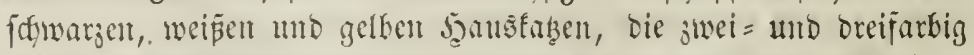
gefleften finto nur enturtete Formen ber wilben $\mathfrak{R}$ nbe, beren Farben= fleib in feinem gelblidgen (5raul bie gemifdte Gruntoforbe triggt.

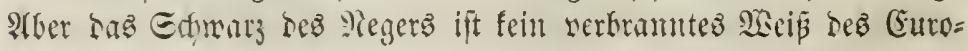


päerz, Das (Selb Des Mongolen und die fupferrothe Farbe des

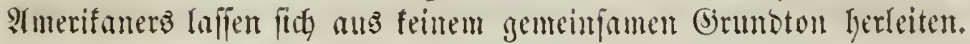

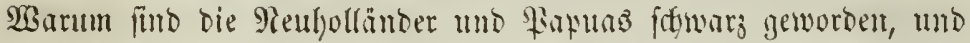

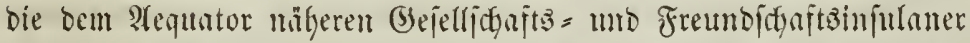
gelbbaum geblieben? Sanrum malymen in Amerifa alle Pationen von ber Baffinzbai biz jum Fenterlande cine rothbrame Farbe an,

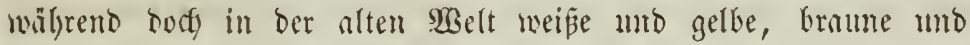
fdwarge Rationen oft bidgt neben eimander wohnen, gleidy ber Thierwelt, bie fie bier in mumigfaltigeren unb eigenthümlidgeren

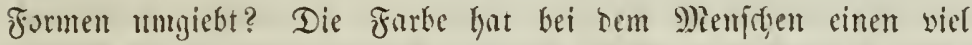
tieferen Grumb, fie lient in cinem Furbepigment, mit bem znhlreidje,

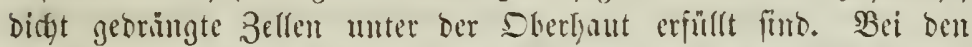

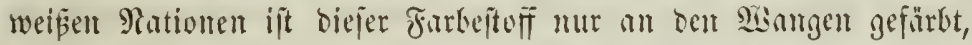
bei ben farbigen Pationen tritt or ftïfer auf, am fturffiten bei ben fowwarzen. (5r ijt mnabgängig yon bem תlima, bem ber Reger

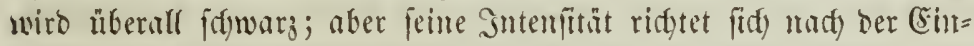
wirfung dez Eommenlidytz. Sieger fömen jwar werbleidyen, wem

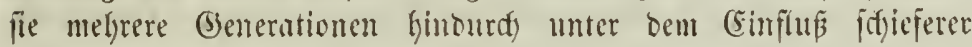
Eomenftrablen leben, aber meiß wic bie Europäer werben fie nic.

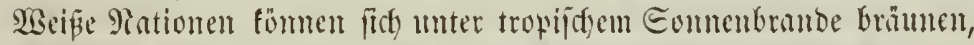
aber fie werben weber fdywas in :Ifrifa, nody roth in :

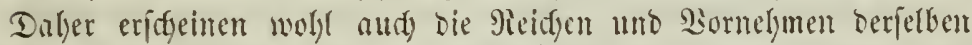
Ration hellarbigen alz Die ämeren Rlajlen; Dem fie fetzen fith

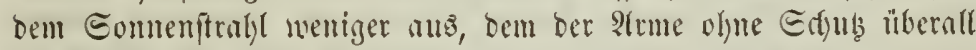
blobieftellt ift. Bei Mationen, wo ez folde Etandesmteridiebe

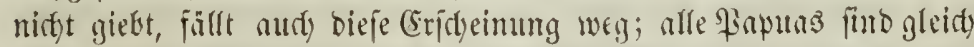

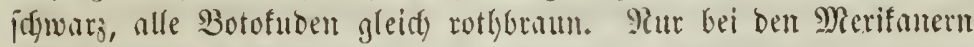
und Peruanern fand man jogen früljer joldge Farbemminancen; bem aud) bei ibnen hatten fih, wie bei ben Europäen, mit ber lyöheren

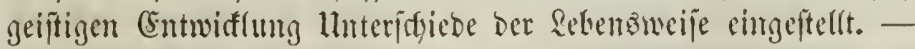

Bie bie Farbe ber 5 ant, fo tremnt and bie Farbe mo $\mathfrak{B} e=$

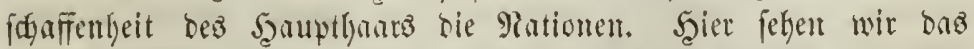
fraufe, wollige, weidge Şanr bez Megerz, bort bas lauge, fdylidte

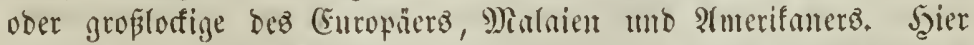
Kerridyt bas tiefite Edywarz, bort verliert es fidy burdy bumflez Braun in lid)tez Selb ober Blond. Dod) mur bei ganz unvermifकten, int

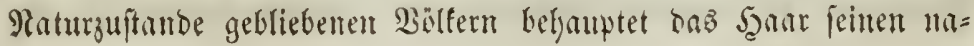




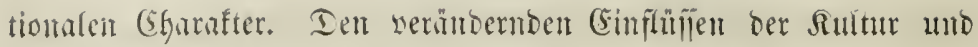

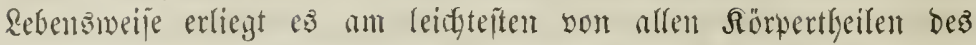
Menídjent. -

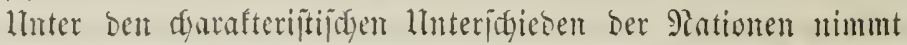

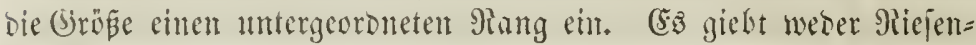
nod) 3wergnationen, und romn nuth eingelne 9ieijente von Bölter= ftämmen der \$atngonier ergäblen, die eitte Scöbe von fieben Fuß erreidgent, wägrend bie benadjbarten Feuerländer unter fümf Fun

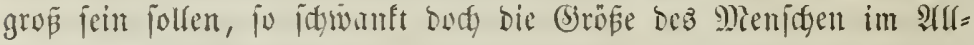

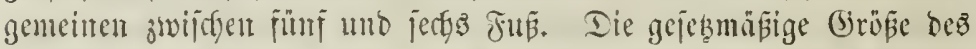

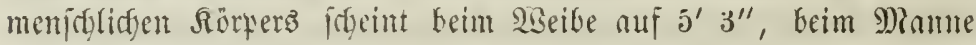
auf $5^{\prime} 6^{\prime \prime}$ beftimmt zu jein, wirb aber von vielen Mämern und

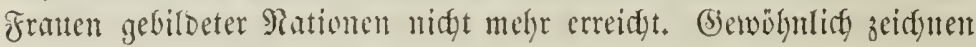

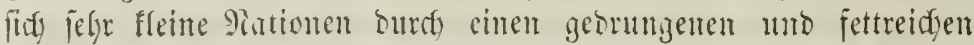

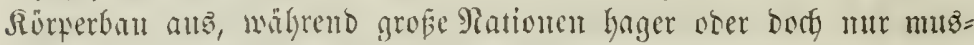

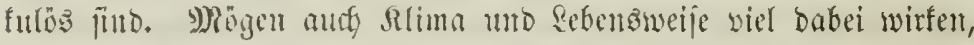

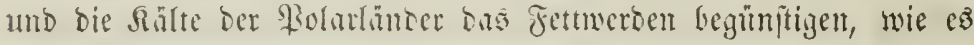

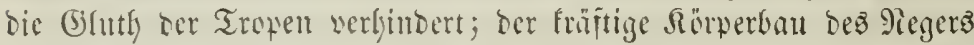
und bie idylante, jierlide beftalt ics Eitojecinjulanters fund mahle Gaft nationale Elyanftere. -

Die widtigitent und, wie man lange glatute, entideibenden Interjatese im menjdylidgen Ban treten in Der Bitoung bes Echä=

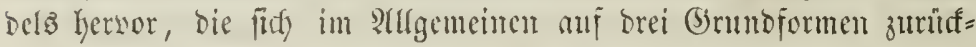

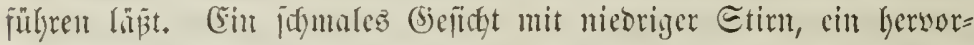

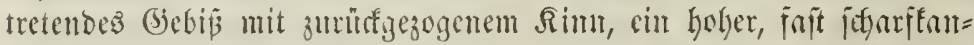

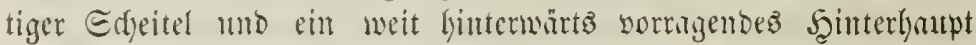

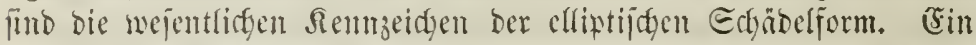

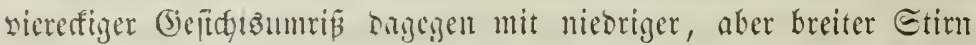

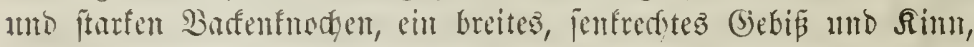

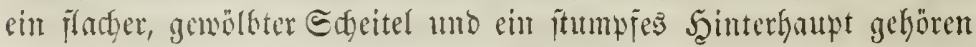
Der quabratijiten Ectiondform an. Die ebclite aller Formen entida,

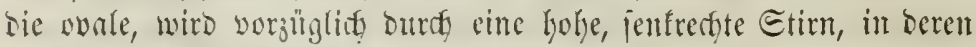
Säbe Der Edyibel bie gröfte Breite erreidt, Durdy fdymale Baffent=

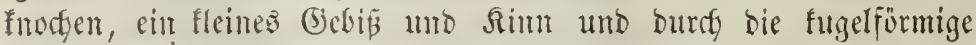

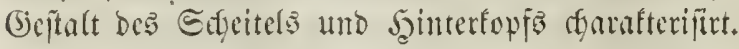

Blumentady war es zuerit, ter anj bie Bebeutjamfeit biejer

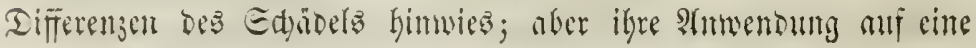




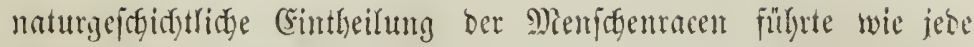

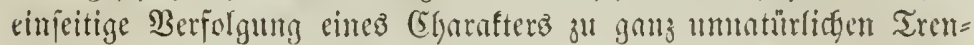
mungen mo Berbinbungen. Tie cinfachfte und allein natürliche

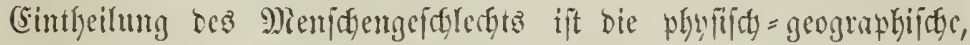
bei weldyer alle (Eigenthümlidfeiten, ganj bejonders andy bie geifiti= gen, in Betradjt gejogen werben mulnen. Tie Epradje aber, bieje

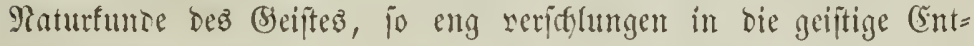
widflung ber Bäleer, offenbart oft an bentlidften bie mationale

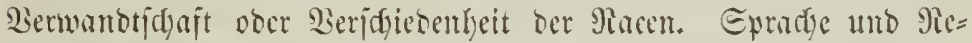

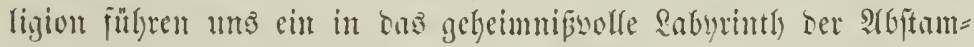

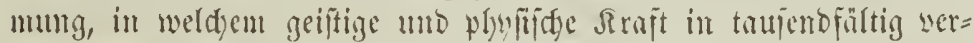

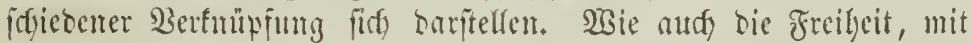

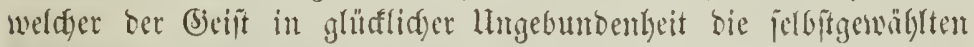
Niidtungen serjoligt, ifjn ber Erogetwalt mädgtig ju entgiclen ftrebt,

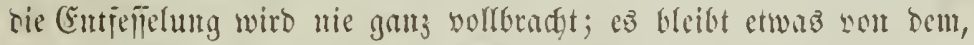

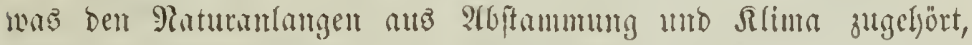
wris Dem Beifite die Form Der Satürlidfeit mupritgt. Die Ratur

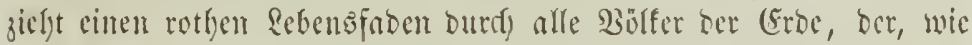

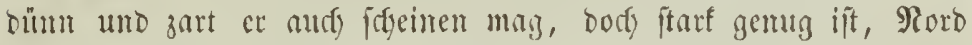

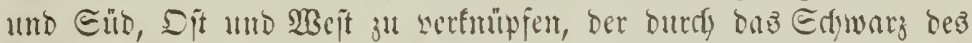

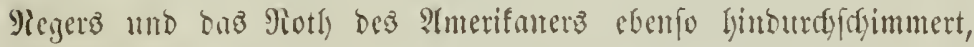

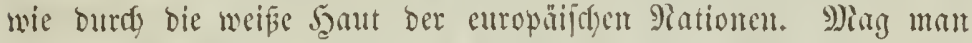
mit Blumentady füm ober mit Sirttaro fieben Piacen amtehmen,

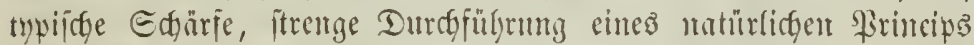

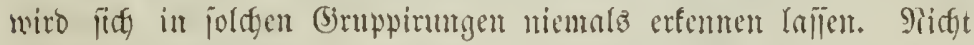

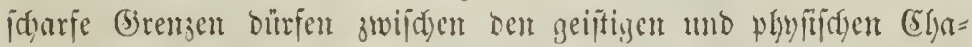
rufteren ber 9)iemidentacen gezogen werben. Die Srmppen des

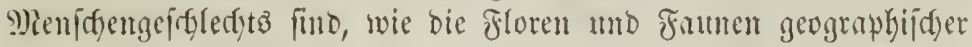

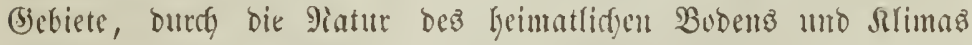
bebingt, fdyroffer gefdeleben, wo die Matur eine mamigfaltigere

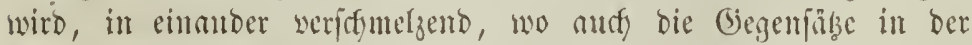
Tiatur fids sermidgten.

2Bir Keginnen bie Reife Der menjalidjen Bilsungen mit bou amerifuniaten Bölferidjaften wegen ber harmonijden llebereinjtim=

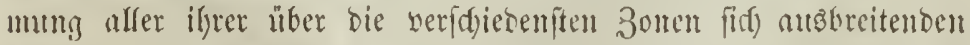
Sblieber, welde bie Blcidyförmigteit Der gunjen Drgunifation alsె ben

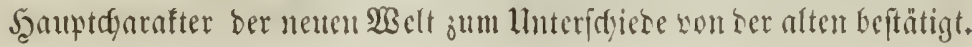




\section{8}
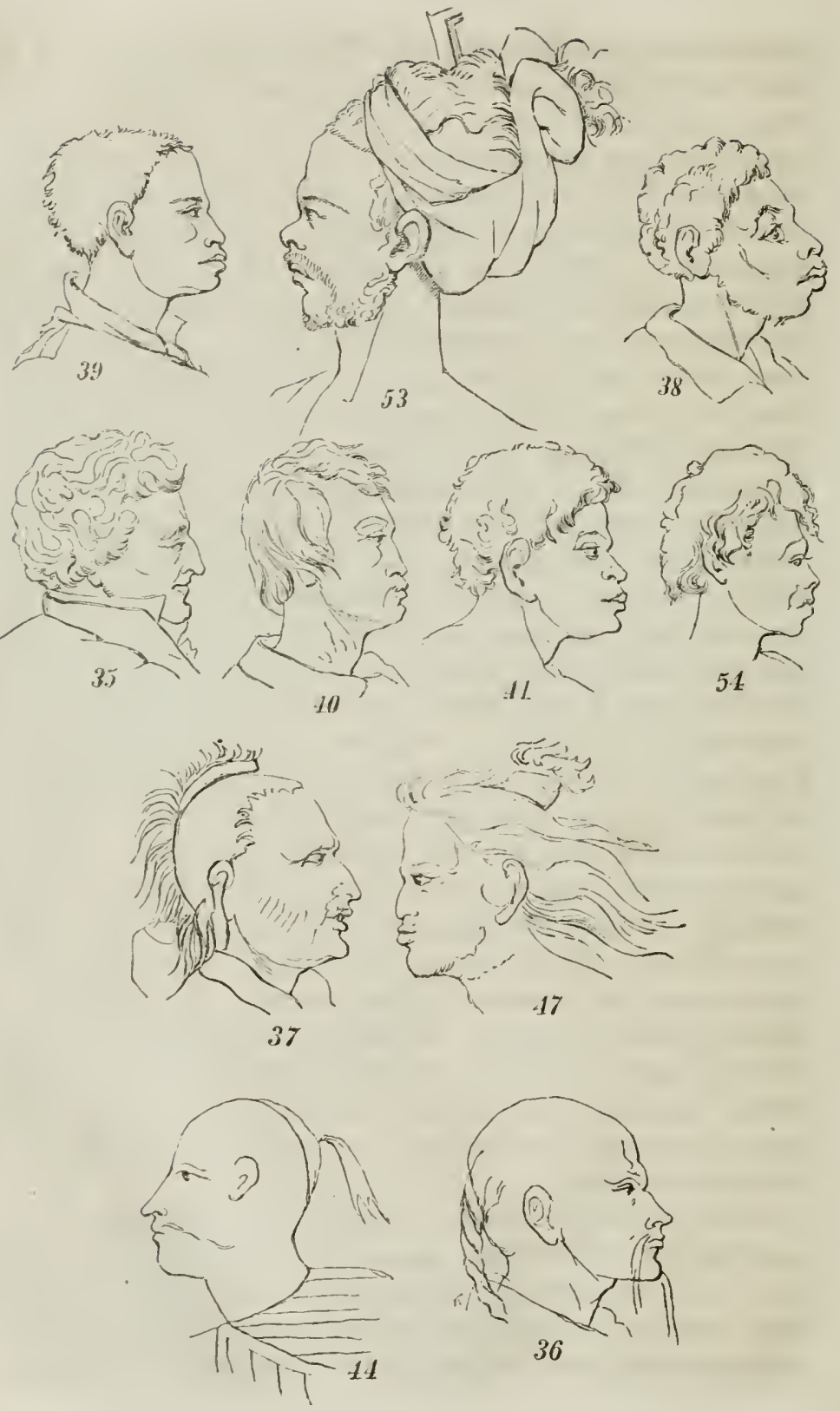


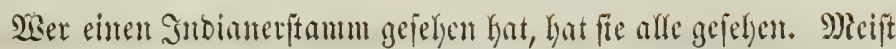

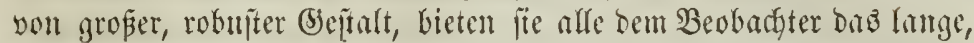

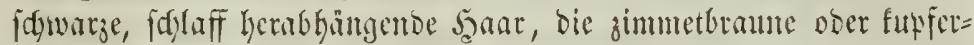

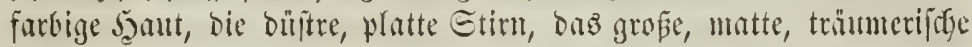

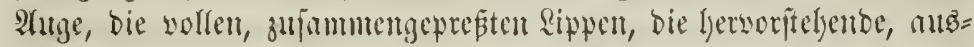
geweitete Siaje uno bie vortretenden, ftarfen Buffenfnodyen bar. Shr

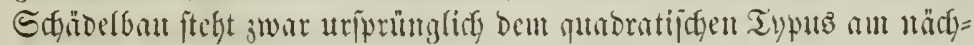

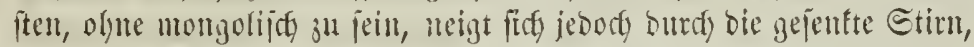

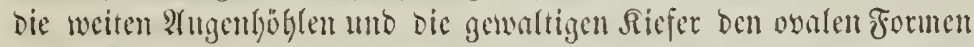

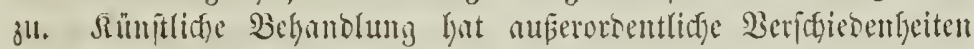

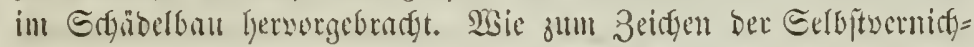
tung unt ber Edfwadde, weldye nidgt bie Siraft lyat, bie auf fidg

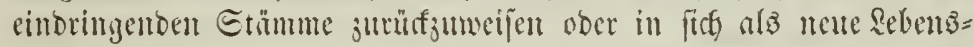
momente aujzuntymen, zeigen bicfe gintonen cinen fonberbaren

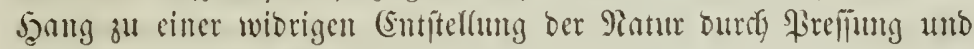

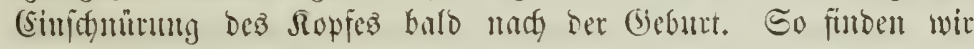

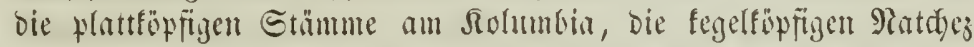

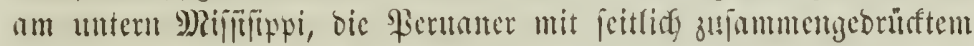

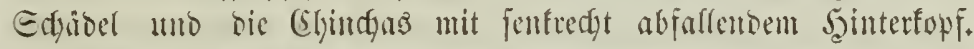
Dieje fümitlidfe Biloung ijt alfmillig fo zur untürlidfen getworben, Daj fie fict figfon bei bem fleinften Sinte jeigt. Daju fommt Daz

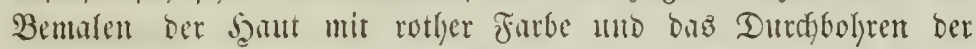

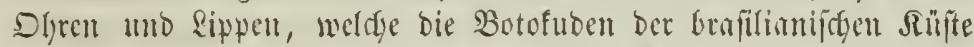

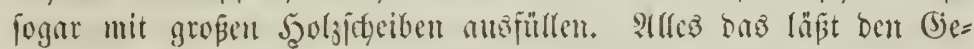

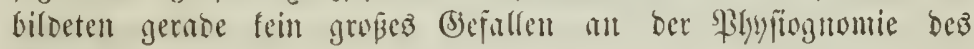
\&merifanterz pintoent.

Sm Allgemeinen find bie Farbemlintent ber 2 merifanter un=

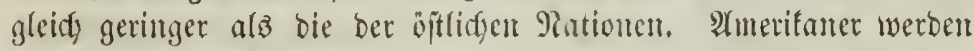

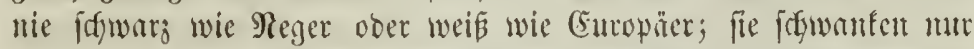

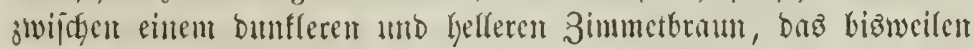

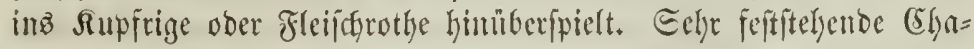

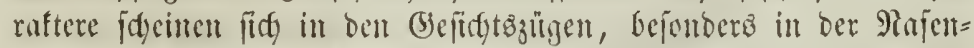

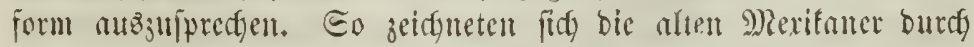

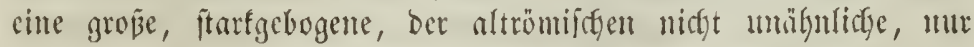

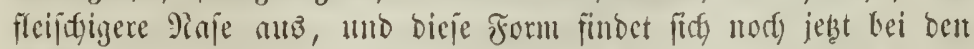

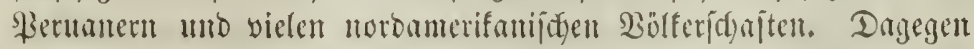

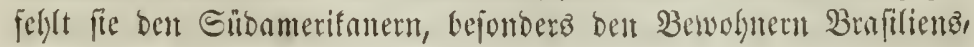


(Efilis, Den ßatagoniern und Feuerländern, bie eine grabe, itumpfe, unten breite Raje son beträdytlidger Brö̈ß̈e byaben. 2(m auffaffend= ften weidgt bie fleine, eingegogene, faum aus bem biefidgt voriprin= gente Raje Der Esafimoz non ber amerifaniijgen Pace ab. Der

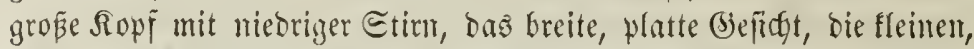

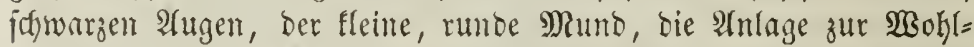
beleibtheit, bie ben Amerifunern burdfweg mantgelt, und eine weipere

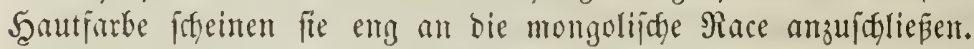
Dieje Eridgeimung fintet ifhe Erflärung wentiger in ber burd) Sagen

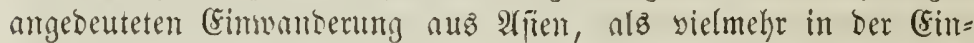
förmigfeit ber norbifdyen Aistur, weldfe fo wenig in ifren Bemolnern, alz in iffem Rlima, ifrem Boben wro ifrer Begetation Sharaftere zu idjaffer vermodjte.

Ifm alferwenigften aber find, wie man woht audg. Gismeilen Keffauptet hat, bie Bölferidgaften bes mittferen Amerifa von elfien

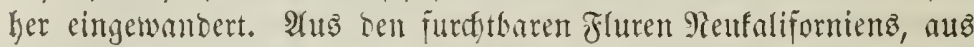

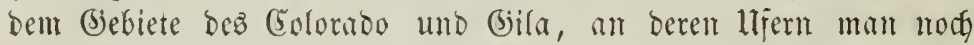

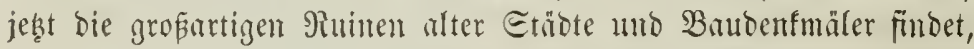
brang cimft ber mädytige Etanm ber Toltefen in Merifo eint, ringz Bjefittumg und geiftige Bifoung verbreitento, Giв ifn um bie MRitte

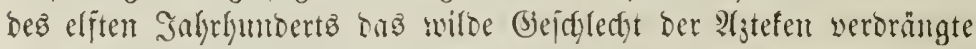

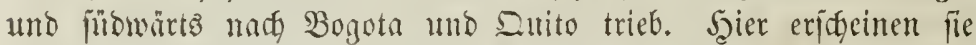

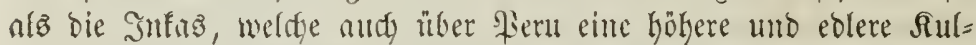

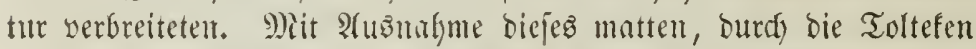

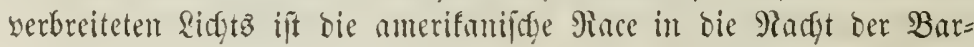

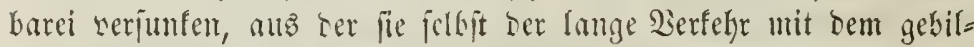

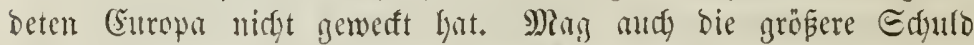

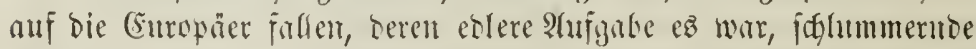

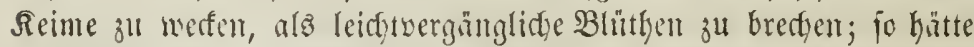
Dods cine Nution, weldye ben Dranly nady geiftigem Rebent in fidg

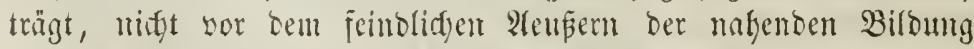

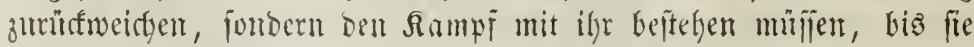

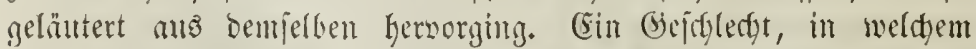
Die Rultur feinen andern Mieis erwerft, als ben der Eimnlidffeit, famt feinem lintergange nidgt entgehen.

Die Eafimos bifoen ben Ulebergany von biejen amerifanijanen

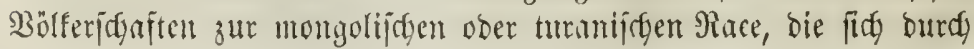




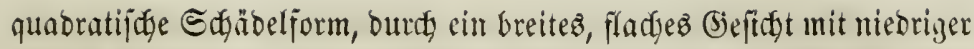
Etin, weit vou einanber entfernte, halb gefdlofiene und juief gejpaltene

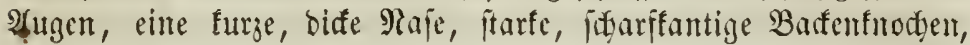

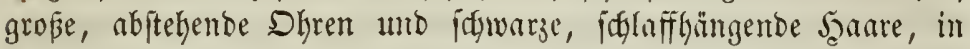
Berbindung mit einer gelblidfen Scautfarbe auszzeidutet. 2 m volf= fommenten findet fid ber (Sharafter biefer burits einen fleinen,

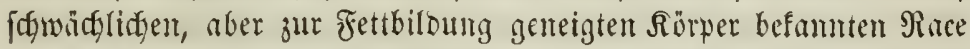

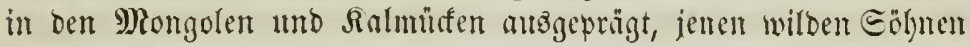
Der Eteppen, beren Edgaren cinft unter Dibingişan alfe Ranber vom japanifgen Meere bis ju ben Rarpathen hiberffwemmten.

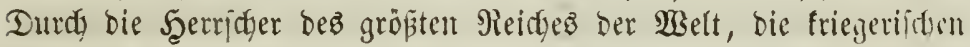

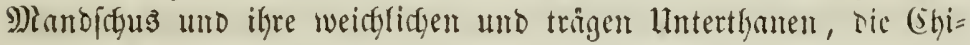

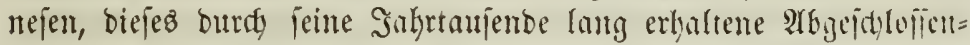

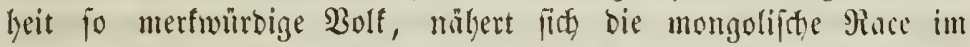

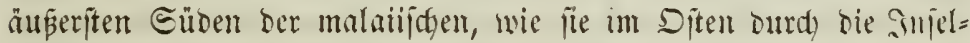
völfer ber Sapanejen, Furilen แnb शllentent ju Den Cafimos 9lort=

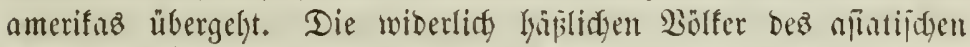
Rorbens endid, bie bunfelfurbigen Samtjdabalen mit worftefendon

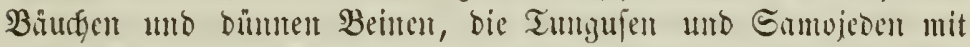

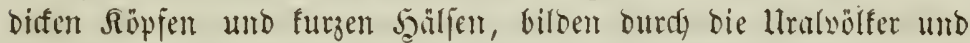

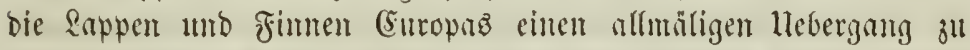

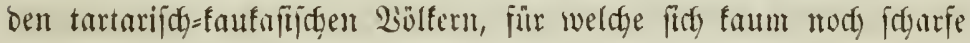
(Srentzen angeben lafiert.

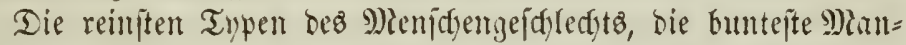
nigfaltigfeit ber Forment und Farben, bie reidgite Entwiflumy ihrer

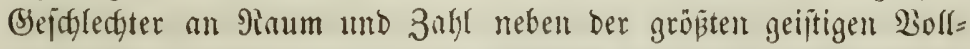

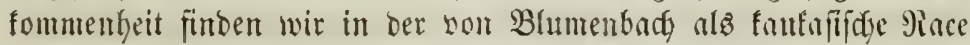

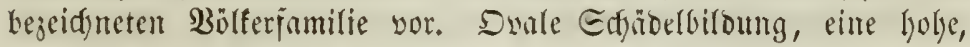
gewölbte Stin, grope, offene Angen, einte gernde Maje, jenfredtes

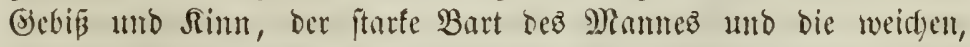
glatten ober groplocfigen Scanre bilden mit ber weiß̈ burdyjajeinen=

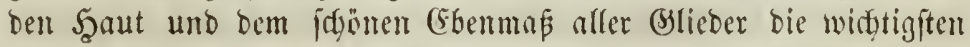
(5haraftere berjelben. Alz wäre ez jebod) eill Bor und Edyönen, ben Poel feitter Fbitammung nidyt in fuarf geprägten Aen Berlicteiten vor fidh herzutragen, als verlantye bie reidyere Ent= wicfelung bes Beiftes auth bie buntere Entfaltumg ber Formen mid Farben, fo tritt uns aud) in biefem (Siejdledgte dez Menidgen bie 


\section{2}

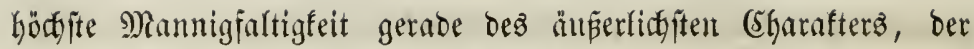

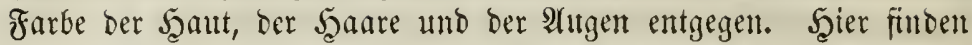

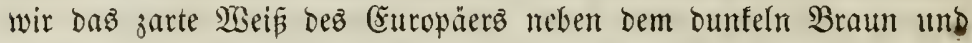

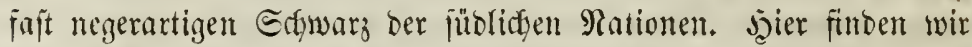

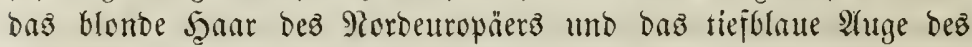
alten (S)ermanen, bort Das braune Şar und fraune 2 uge des

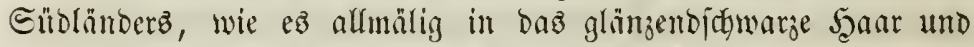
bie feurigiffwarzen Antgenjterne bes Afutaten nubergeht.

Diefe Mannigfaltigfeit zeigt uns wieber bie innige Şarmonie

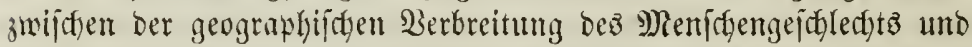
ber ber ganjen orynanijden $\mathfrak{B e l t}$. Die faufafifiden Sationen verbrei=

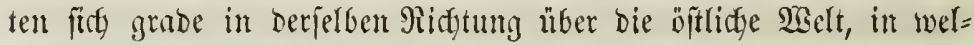
der and bie gröpten Differenjen Der Drganifation neben einanter Gervortreten. Sie bewohnen die Mitte dez offtichen Sontinentz

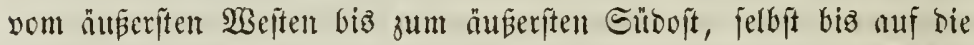

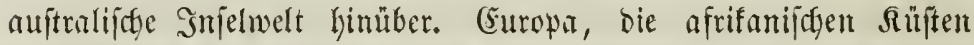

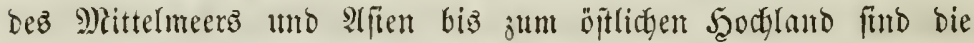

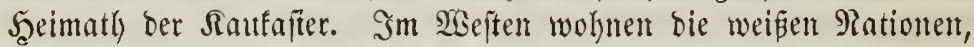

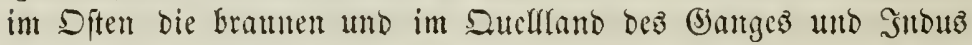

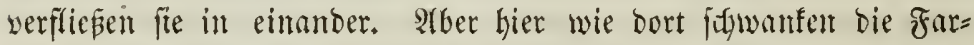

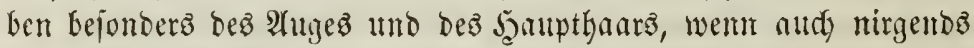

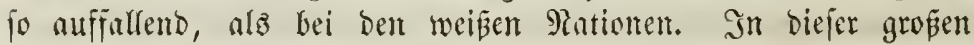
Bölferfamilie fam baher allein bie fpraḑlidye unt geítige Berwant= fogaft über bie Brappirung entibeiben.

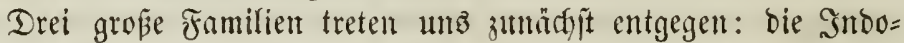
germantr, bie Eemiten und bie Berbern. 3u ber indogermanifden ober iranifaten Fantilie gehören bie $\mathfrak{H}$ rbemofmer (suropas, bie (Eel=

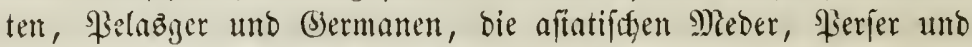
Inter, bie alfe, wie man glaubt, in bem Sanzfrit ihre Stamm=

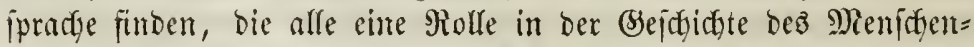
geiftez geppielt habent. $2(m$ nädbjten mus man wohl an fie bie

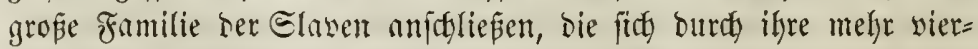
effige Ectübelform, nicoere, Gehnarte Etirn, furzen Paafen unt ftar= fen $\Re$ nodjen = unt Mitusfelbaut unter allen Mintionen, zwilden benen

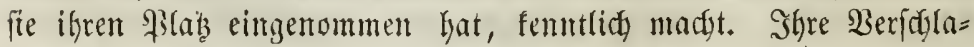

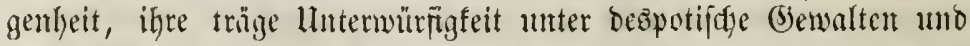

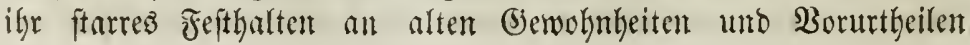


Kaben fie ju einer Bormaner bez Diten gegen bie voriffyeitentbe europäiifue Bildumg gemadt.

Die femitifage Familie umfafst bie Rationen zwiffen ben per= fifchen uno rothen Mieere und Defgnt fidg mur Durdy Solonieen über

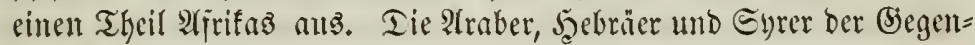

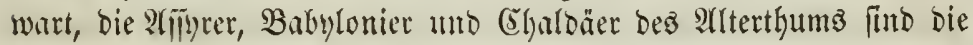

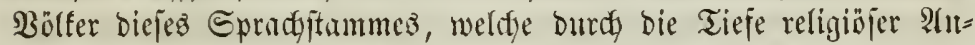

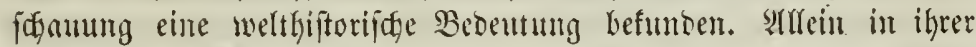

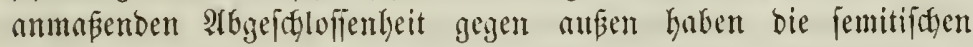

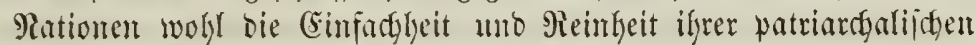
Sitten erhalten, finto aber von jelyer Eflaven ihrer cigenen Sciom=

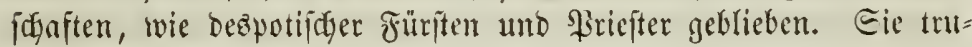

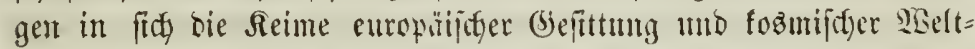

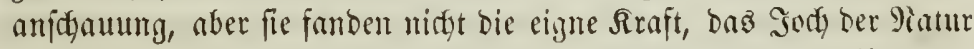

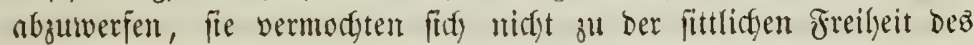

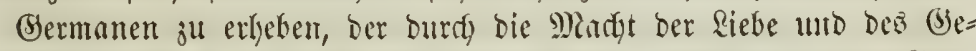

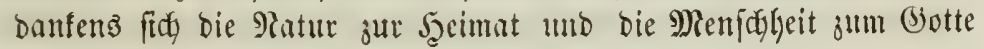
madyt. -

Die Berbern bilden bie britte faufafídge Bölterfamilie am Mittelmeere, wurben aber im Sanfe ter Beiten you bent benadjbar=

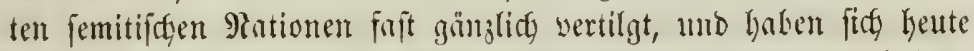

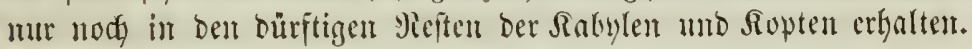

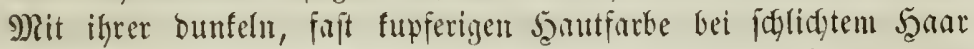

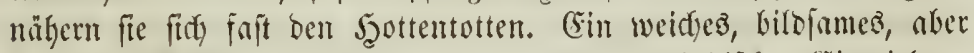
fraftlojes Bolf, erreidtent fie unter frember, inbiisf̧er Eimmirtumy igre hödjpe Blüthe im alten Egypter. 2lber bald wurroen fie cin Epielball weltftürmender Eroterer, und mur jene groß̈artigen

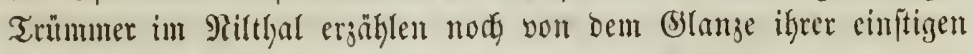
Srö̉ße.

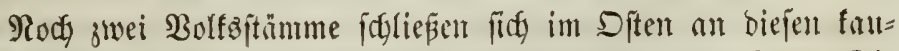

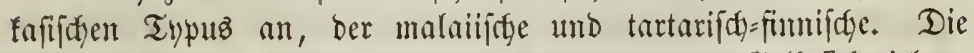

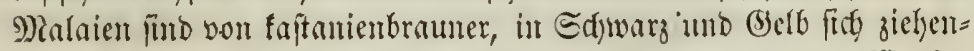

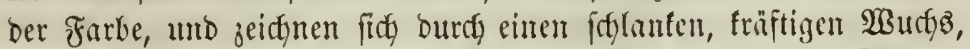

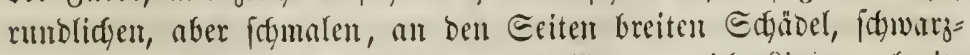

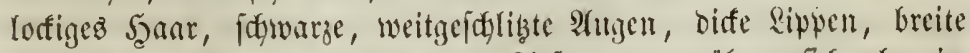

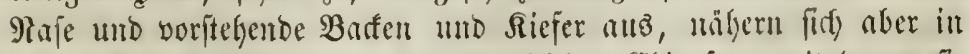

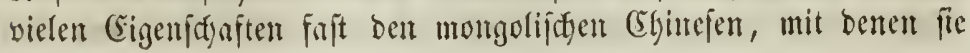


yon jeher im Berfehr ftanden. Bon Den äduten Malnien ber Eumba=

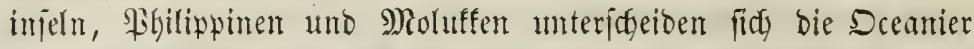

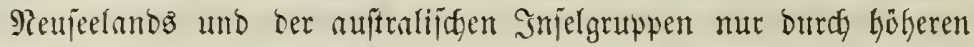

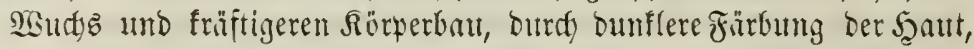
wie ourch geiftige lleberlegenteit, leiber aber ands zum Theil burch größere. Wiloheit uno Eimrlibfeit. Reicht erregbar und beweglicts

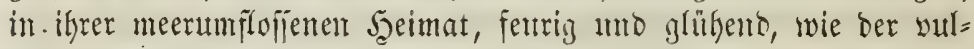
Entijäe Boben, ben fie bewohnen, fund bie Malaien eimer böheren

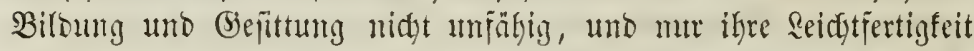
und (jemufind Gielt bie Sultur bisher von einigen ber jeritreuten Injefn fern. In vielen Deenmiern erwertte bereits ber Muthane=

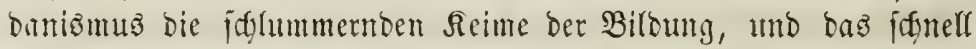

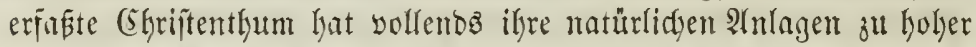

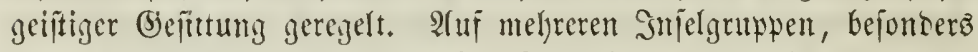

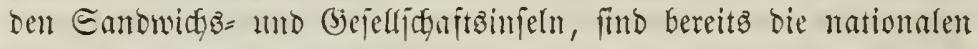

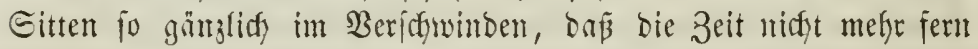

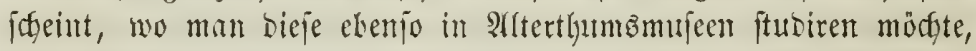
wie jekt bie Gitten unjerer heionijden Borjalyren. Bielleidgt er= ftarfen fie eimft jelbit oll eigner Bolfsthümlidffeit, beren fie bei ifyer

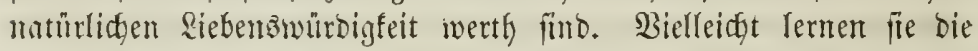
Freumbjhajt ber Eutropäer ridytiger würbigen und bejonbers bie

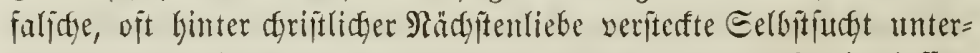
iffeiden, bie fie mit bem befjeren (5) auten nidyt audy bie beffere Sittlidfeit fenmen lehrt.

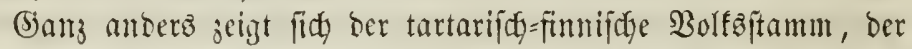
rathe Eofn ber Eteppe. Thierijh in ifren Begierben, ben milden

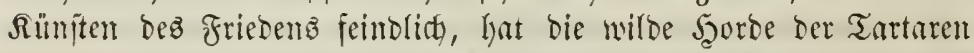
won ben Eteppen Des innern afienz her liber sen gröpten Theil Eibiriens and den Rorben Europis, wohin fie fich manbte, 3eritö= rumg und Edyrefen berbreitet. Ind Dody erreidyt gernoe in ibr ber

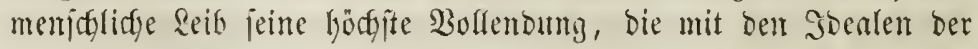

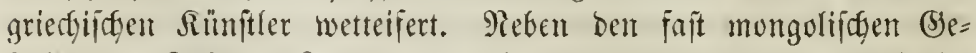
fitten Der Safuten, sappen uno Fimen, Der Tartaren amb Rirgli=

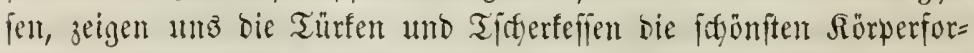

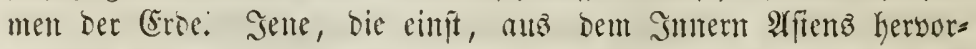

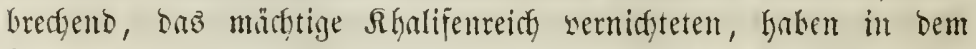

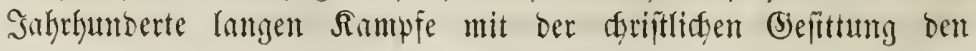




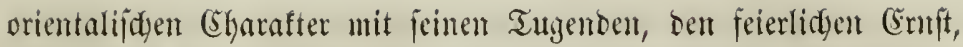
Die Einfadfyeit und Mieinlyeit Der Sitten, bie Trene und (3)ropmuth

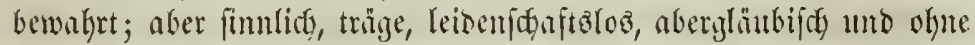
fittliche Siraft, mur Eflaven bez blindon 3ufall(z, wermodten fie fid

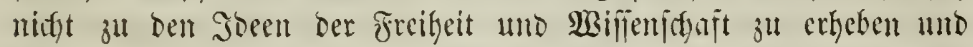

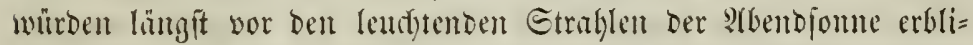

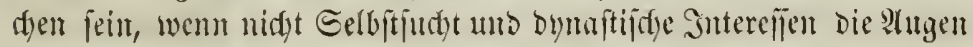
(Eutropaz verblendet yätten. Dieje, sie Tjoferfeffen, ein fleints, aber

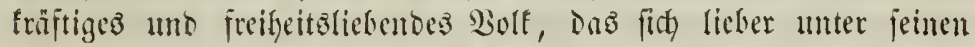

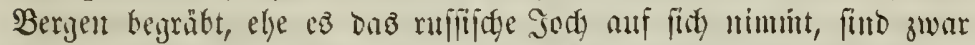
nod) in 9ioblgeit verjunfen, aber ju ebierer befittuty berufen, bie

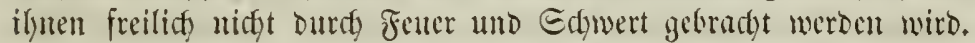

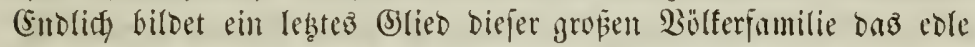

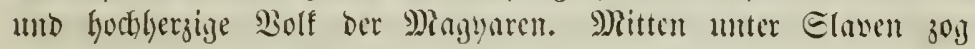

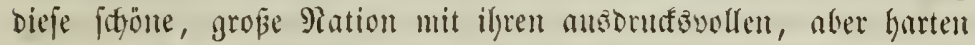

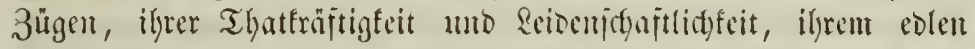

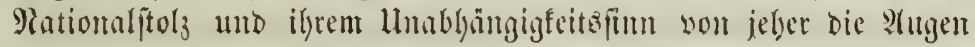

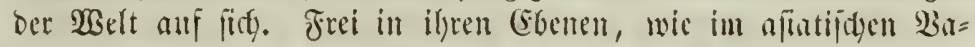

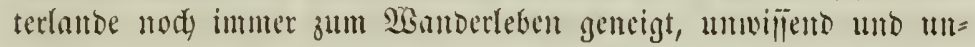

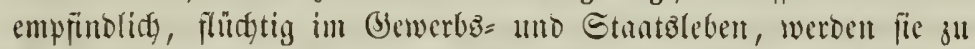

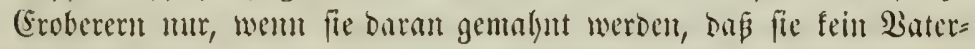
fant, fondern mur eine Pationalität Gaben.

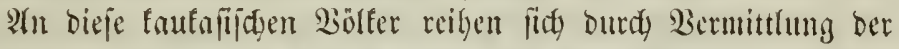
Berbern bie äthiopifden Pationen an, biejen an Epradge und $\Re 0 ̈ r=$ perbau vermont. 2Am fdjärfiten prïgt fid Der Typus biejer Siace

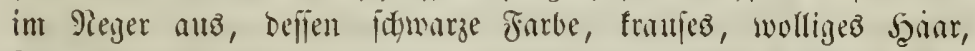

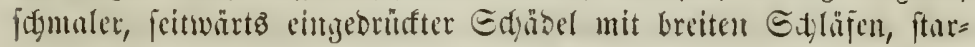

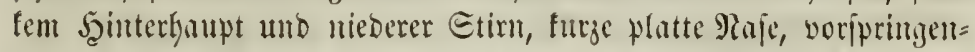

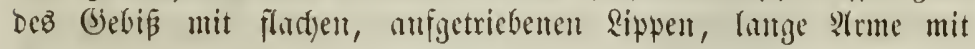

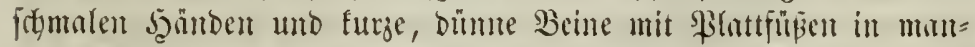

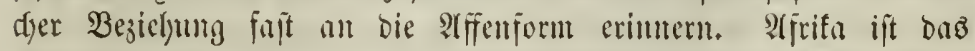

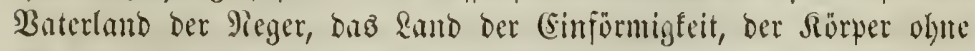

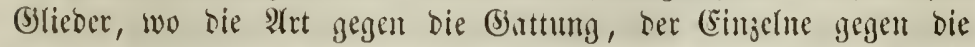

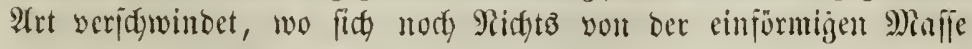

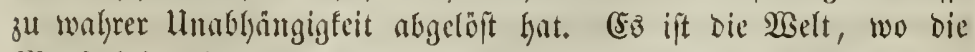

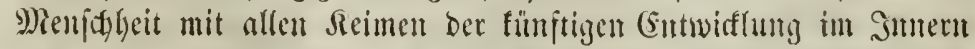

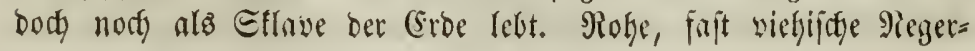




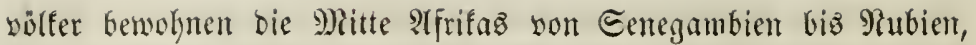
unter ber Jeerridaft wilder Reidenidaft unb Eimtidteit mur fïr die Segentmart lebend. Seder Rultur ungugänglid, bängen fre feft an ifrem alten Fetijdidient, ber fie in jebem Dinge eine finftere, unheilvolfe 9hadit erfenten lefrt. Durdh Den Eflawentandel ber

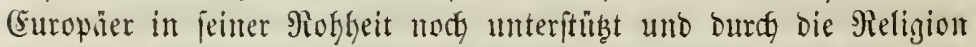
jelbft zun Menichenraub uno Menfigenmoro als Eügnopfer für bie (Sottlyeit aujgejordert, bietet lier ber Rönig jeine Unterthanen feil, treibt Der Bater feine Rimber zul Miarfte und verfauft fie für Flitter uno Epielwaaren an Eflaventänder. 3ur (5)re ber Menidh= Keit bat ber fortidgreitende (beijt ber germanijten Bölfer biejen grïflidyen Miendaentyandel entidy mit Edyande gebrambmarft, und

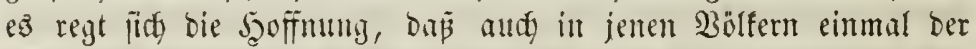

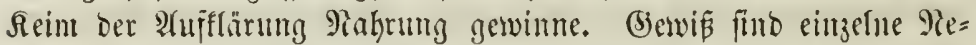

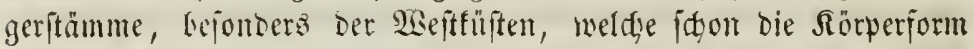

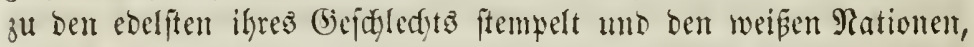

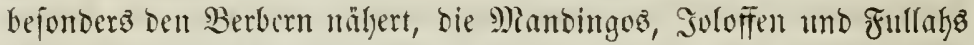
Eentegambiens zu einer bejlern 3ufunft verufen. Bereits bat ber Minkantedanizmus fie zut thätigen, gewerbjamen und gaftfreien $\mathfrak{B o ̈ l}$ fern umgenandelt, und ifyre geiftige lleberlegentyeit itheint fie zu Eroberern und Serridyern ifres Saterlandz beftimmt zu haben. Sm Diten wohnen bie fwönen, fupferfarbigen abyifuifden $30 ̈$ lfer,

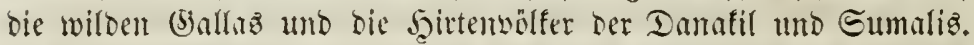

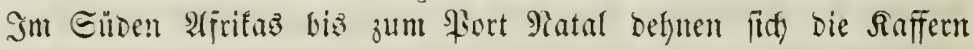

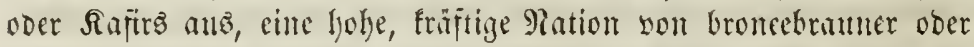
jofwarzer Farbe, mit höherer Etirn und ovalerem Siefidgt. WBeniger

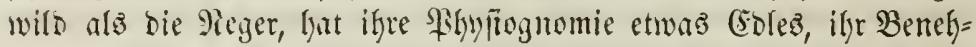
men etwas Intponirentes. Die friegerifden Mongas uno bie ge= werbiamen, afferbatenden Beetjunen, bie fojönten ifres Etammes,

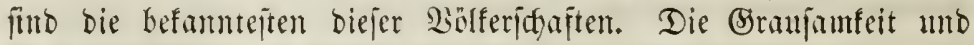
lingeredytigfeit ber (suropäer hat fie ju ben erbittertften Feinden ber Saptolonien gemadyt, aber biejer Jaja gegen ifgre Bebränger hat fie zugleidy fat einzig unter alfen wilben Bölfern vor beren Raftern bewahrt. Wejentlidy non ifnen serjobieben burdy ifge gelblidy=braune

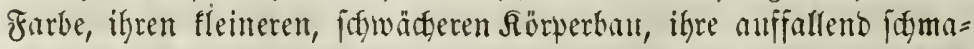

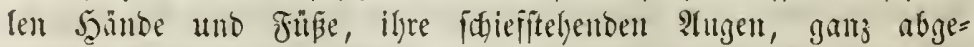
plattete saje mo ibr jomales, lang herworjtehendes Rimn find bie 


\section{7}

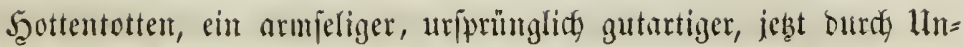

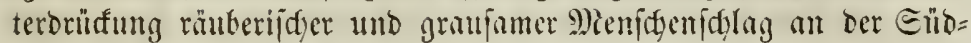

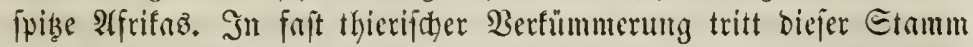
in ben wajierlojen (Ginoben ber Sorenjberge am Drangeflup unter

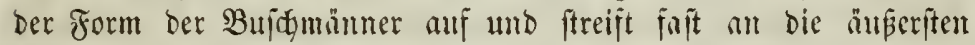
(Srenzen Der Menidakeit, wem lie nidyt an viebifder Miobbeit

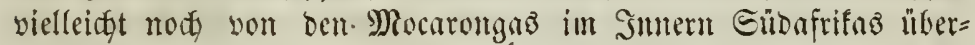
troffen twerbert.

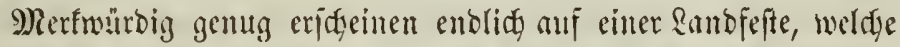
burd) (Einjörmigfeit unt Dürre an 2 (jirifa erinnert, in einer ben

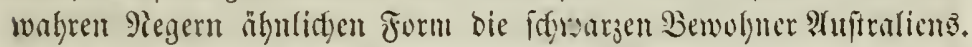

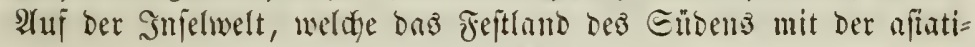

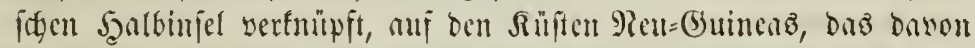

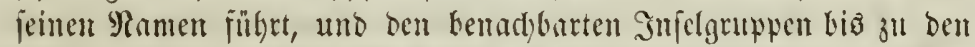

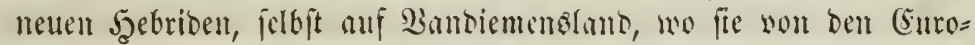

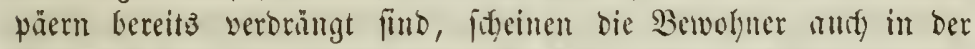
Meniffenwelt Den Mebergang som Meger zum Malaien ju ver=

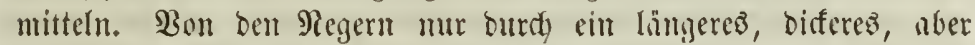
gleidjalls molligez Şanr, fegre grope uno biffe Majen, nidyt aufge= worfene Sippen unt eine höbere, runbe Etirn unteridgieben, ideinen

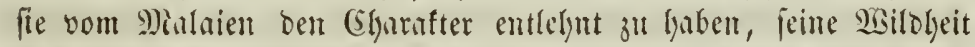

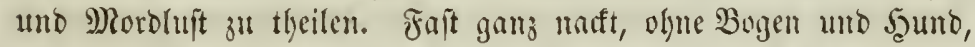
bie erften Begleiter ber erwadyenten Memidgeit, in Enuten redent,

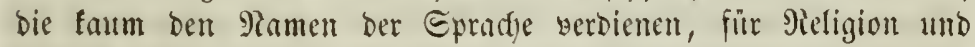
Befittung unempfänglid, fimo biefe nur familienweife untyerjiefent= Den, zum Theil nenijenfrefienden sieger ebenfo unentwistelt, wie

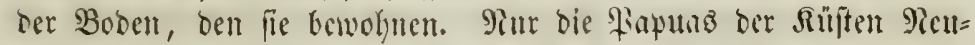
(5)uineas fino fanfterer uno friestidgerer Matur, wie audf ber colere

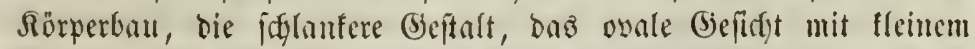
Muto uno wohlgebildeter Saje fie vor aflen Bülfern ibrer Since aแร̧zeidnet.

Eine wie tiefe Etufe aber mads bie ocentuifden Meger in ber

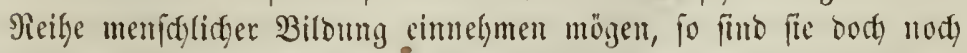

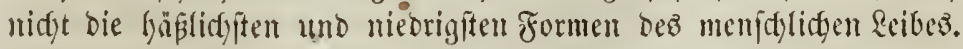
Dieje treten unz in ber llebevölferung Reulyollnomb, biefez 2 Bunder= lambes in jeber Beziefung, entgegen. Der Meulfollänter lyat bie

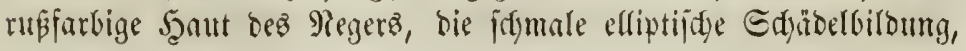




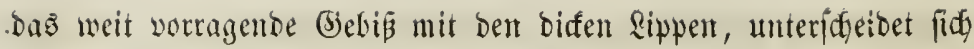

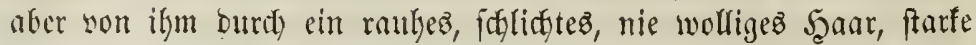
Belgarung bes Rörpers und eine auffallend affenartige Edylantheit Der Gsliebmafen. Slod wiberlidger burdy bie breite, herabfängende Mraje, bie burdbolyrt unb mit Bierrathen verumftaltet ift, burd bie gefärbten Edywielen ber Şauteinjanitte, mit Denen er feinen $\mathfrak{R}^{n} \mathrm{r}=$

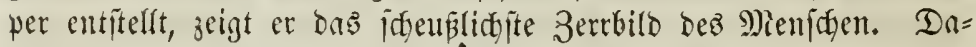

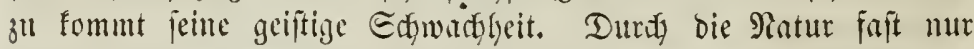
auf bie Sago angewiejen, meiß̄ er ben Epeer und bie Sienle mit

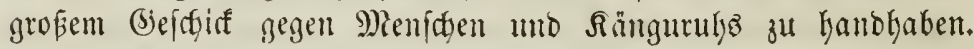
Er ift ber rohe Etlave Der Ratur, olyne Dobady, ohne Sleidung, und faum erfebt er fidg ourty Meligion und Epradge zur Freiheit Dese Biedantens.

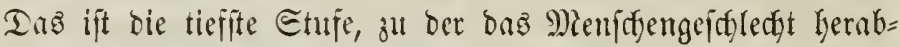
finft, und vielleidft hat mall gar nidgt llneeft, wenn man biefe

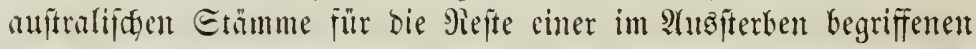
älteren Edjöpung bält. Dennod wollen wir gern mit Şumbold

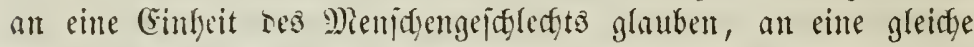
Beredfigung aller Sationen zur Jreilgeit und geiftigen Bildung. (Es ift ein groper Brutberitamm, der einen 3med verjolgt, bie freie Entwifflung innerlidjer Sraft, bieję födjte Biel aller menichlichen (Seferligfeit. Ter Boben, fo weit er fid ausbefnnt, der Seimmel, fo meit bie Gejptrne flammen, bie Belt ift jein, inmerlids jein, ber

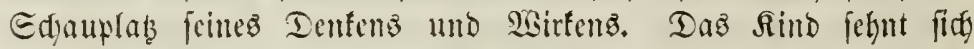

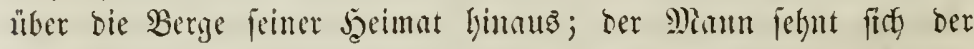

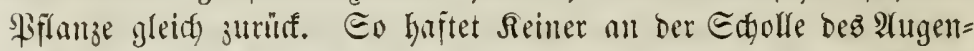
blifaz; Eefniludt nad) (Ermünjhtem und mad) Berlontem ift bie

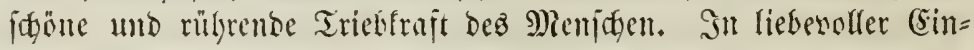
lyeit frebt er fein ganjes bejdled) ju umfajlen, unb jeftgewurzelt in feimer Siatut wiro bies Etreben zur gropen leitenden Soee in Der (sejuidyte ber Mienjalyeit. 
2) Die Crntwi flung Deg Dölferlebenz unter bem Cinfluffe Der $\Re$ atur.

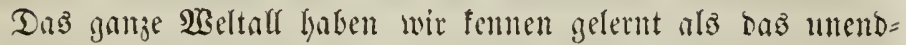
lidfe, leberswolle Wrerf einer eimigen, ewigen Urfraft, mögen wir fie mun Shatur ober Reben, Bermuft oder, in ifger Selbitbenustheit

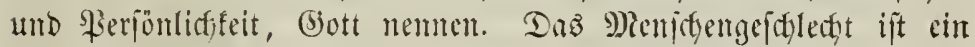

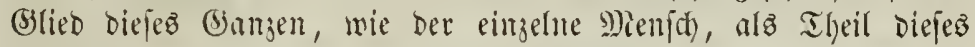

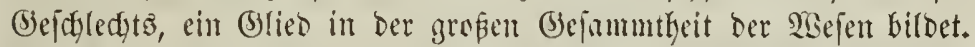

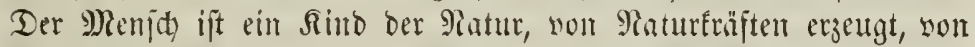

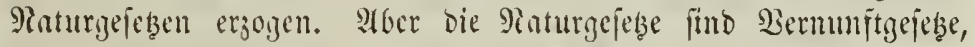
emige (b) banten (Sottes, und fo ift ber Menid wahrhaft ein Sohn

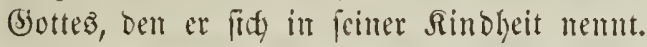

Das findide Memidaenjefdledt erfüllt nody Seimmel and (Erbe

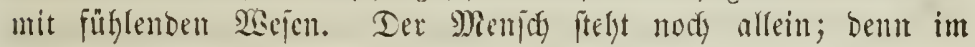
Simnert umfät er in unbefangener llmichulo bie ganze verwante

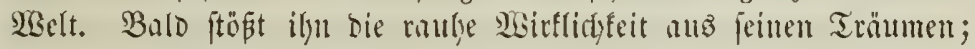
in ben geliebten verwanden 20 ejen ermadjen ifm Feinde und regent

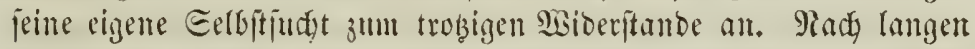

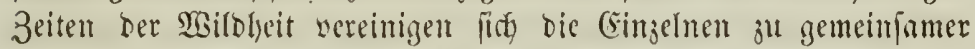

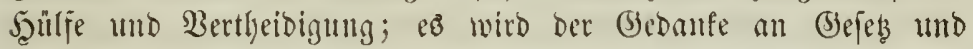
Dronumg herworgerufen, welcte zum gemeinjamen beften gehandhabt

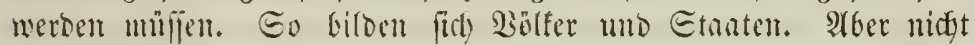

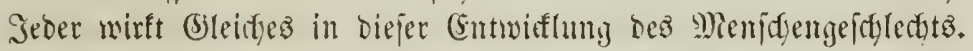

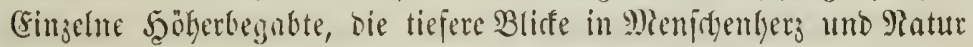
getlyan haben, gefangen juerit zur Rlarbeit Der allgenteinen Begriffe,

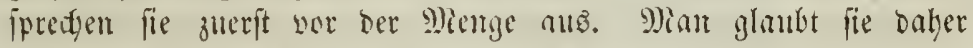
yertraut mit Den Beiftern, bie man in Der Patur ahnt, vertraut mit ben (3)̈ttem; man bewnubert fie uno getjordyt ignen. Sie

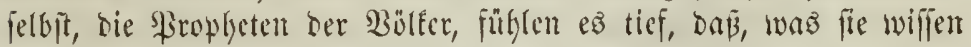

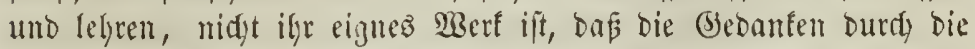

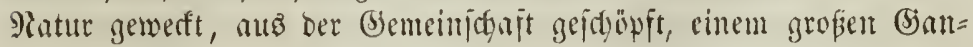
jen angebören, das nur gealynt, nidts begriffen werben fann; fie

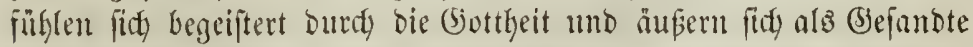

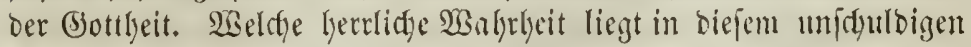

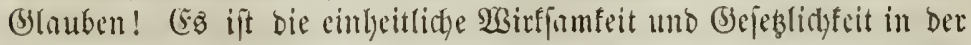
Matur unb im Menidyen, weldye bier zu cinem lebentigen, wenngleich Ille, æcttall, 3. 'tup. 
nidgt beutliden Bemuptiein foumt. Ridjt cin (5ott, Dem bie Menjden

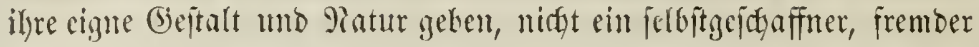

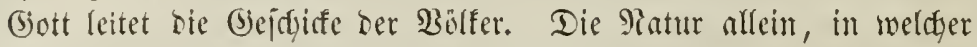

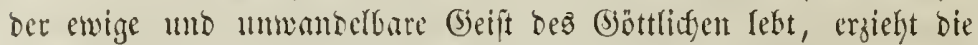
Bölfer, intom fie ifnen ben (Beift bes Șeltalls einlyaudyt.

Heber bie ganje (Erboberflädje hat fids ber Menif verbreitet. Atber wo Bewegung uno Reben erîtarren, ift er ein entanteter Eflawe, wo bie Piatur ful mäctig wiro, ifit er zum Thier berabgejulfen.

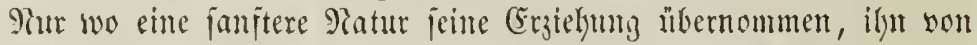

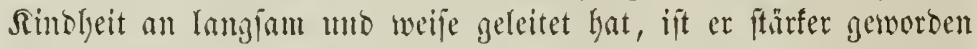
ats fie jelbjt, Gat er ifge Sodh abgeidgüttelt, fie unterworfen uno ver=

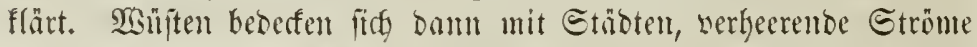
werben cingebämmt, Meerešboben wandolt fitd) in frutdtbare (Sefilde

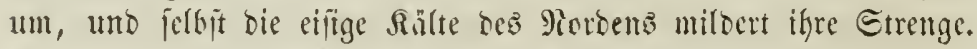

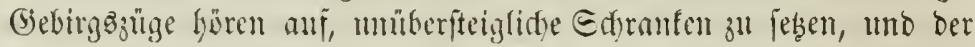

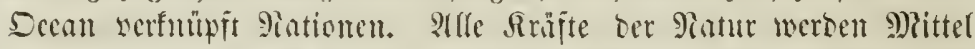

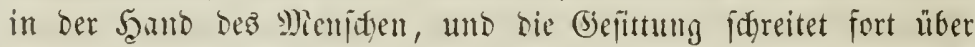
alle Ranber ber (Erbe, judy als allen Mationen ein gropez Bolf

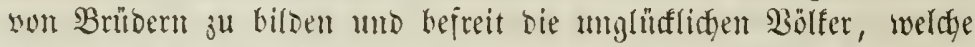
Bflamzen gleid nody unter ber Seerridaft ber Matur idsmadten.

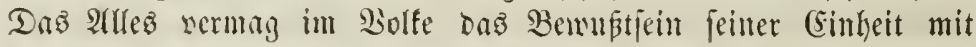
Der Matur, feinter Freifeit wout Der Materie, feiner Etellung in einer

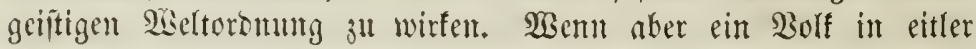

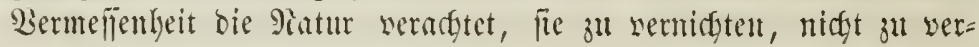

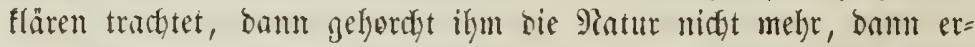

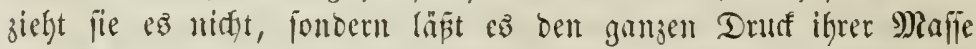
empfinden. Mit ber Matürliçfeit verliert bas Bolf jein Baterlano

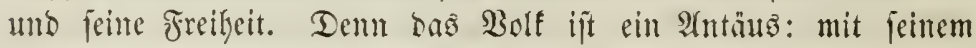
Boben uno jeiner צantur unüberwinblid, lozgerifien ein Epiel bez 3ufaltz unt der $\mathfrak{B}$ Birfentr.

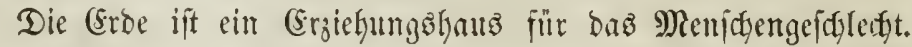

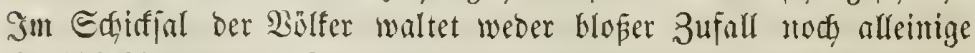
Eelbifbeftimmung. Wie der (Sinjeltue, fo furto audy ganje Bölfer

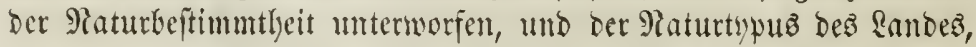

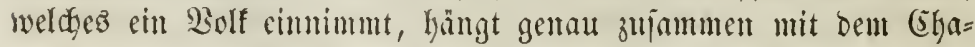

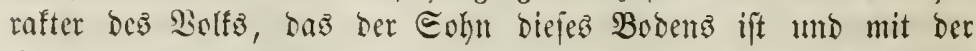

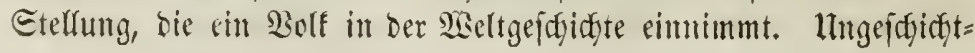




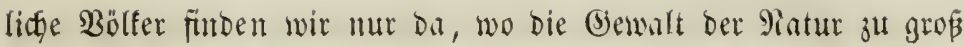

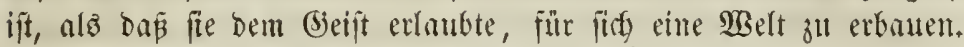

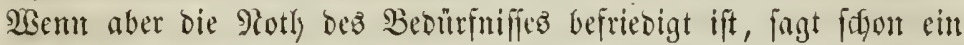

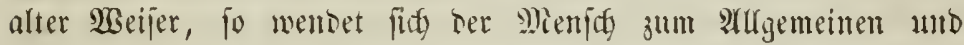

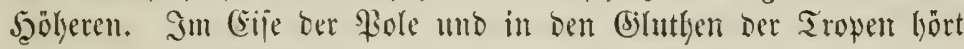
Die Soth nie auf; bort ift ber Menidg beftänbig barmu amgewiefen, feine Plufmerfiamfeit auf bie Matur zu ridften, auf bie glïtenten Etrablen Der Eomue, auj Dent eiftuen Froft.

Dort, wo ber fyelfe Mittag Des Eltoen zul behaglidjer Miufe labet ober zu Grentmenter Reidenidjaft aufregt, find bie $\mathfrak{b u l f e r}$ an bie

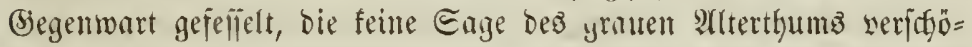
nert, feine Eorge für bie 3ufunft quält, feine Şoffnumg auf ben Flügeln ber \$夕lsuntafé über bie vergänglidge Edyolle erbebt. Dort, wo fid unter bem Folarfern um ben eifigen fiol in meiter, flacter Ecteibe der Morden ber Eroe lagert, ift bas Bebiet ber Mactst, bie mit all ifrem Dunfel, wie mit ifrem Bilange unr bie Sigantafie Dez

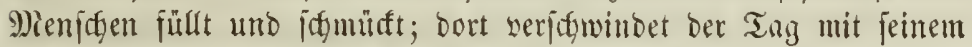
bunten Befolge geiftigen Rebens und eriffeint mur eine Beitlnitg als

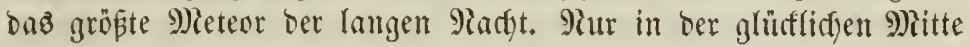

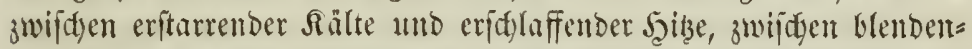

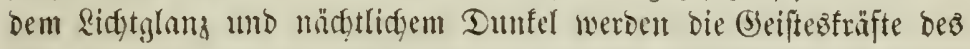
Menjofen fpieleno in Thätigfeit gejebt, uno bie Entmiftung uran= fänglidfer Reime ferbftüntiger Biloung begünftigt. Afuf Der zefte

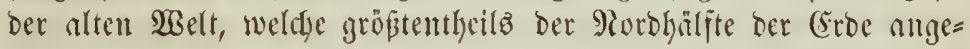

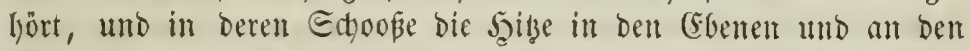
Mieeresfinten nidjt jerftörent, fondern mild und befrudtento wirft,

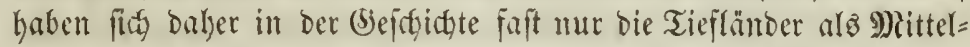
punfte Der Entfaltung geiftiger Bilbung im Reben Der Bölfer gezeigt, wälsento in bem tropifitgen âmerifia nut bie von Eeen bewäjifertent Şodgebenen bie älteiten Eiłze ber Sultur waren.

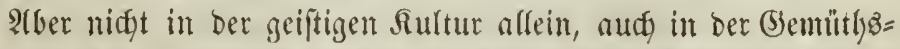
fitimmutrg ber $\mathfrak{B o ̈ l f e r}$ fiflegt fith Die Satur und \$ibyfiognomie ber

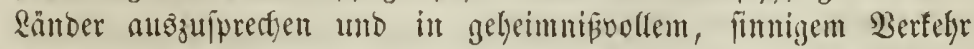
mit bem inmern Reben bes Memidsen zu felyen. Der Menfor ift beiter in ber barmoniffent Matur (briedfenlanbs, fröblich in ben ladjenben Fluren Franfreidjo, würbeyoll in bem Feierlidyen Epanien, errift in ben rauben Thälen Piorwegens, traurig auf bert bürren 
Ebenen unter ben unften Sipjeln Der Anben, fanatija in bem glitfentoen und einförmigen $\mathfrak{A}$ rabien, whantaftich in bem $\mathfrak{M}$ under= fnube Inbiens. Flud nidyt grope Raturgenalten allein beherriden

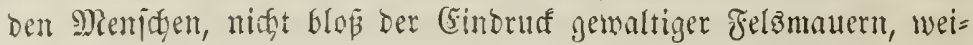

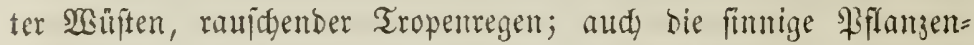
welt hibt ifren Sinflufis ans. Sinen anderst Cintorut erregt das

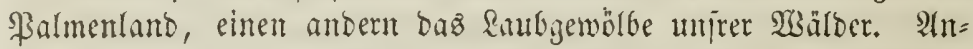
Ders fieft man fich geitinmt in Dem Dunfeln Edatten ber Budben,

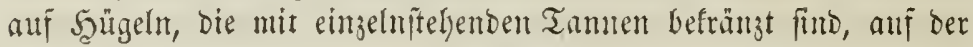

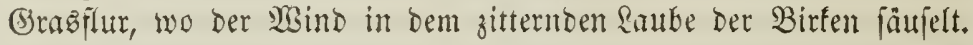
Mielandyolijuge ober ernjterhebende Bilder rujen dieje vaterläubijtgen Fiflangengeitalten in uns fervor. Co übt bie Ratur nidbt mur auf Den Salbwilden ifre ganze Madht aแb, jelbit bie Crntwifflung Der

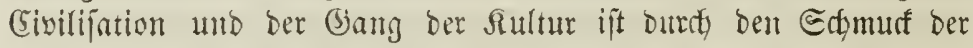
Eroe, Die Fiflanzenmelt, mie Durd bie Form ber Grotgeile und igre (Silieberung bebingt.

Deenu und jejtland fund bie beiben grofen (Segenjäke, aus Deren inniger Turdbringung alleš \&eben ber Froe Gerborgeft. Der

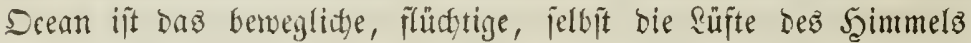
Durdboringente Element, bas jelbit einförunig audg alle Unteridjiebe Der Croe, alle Trenmung Der Sölfer aufuhlieben tradtet. Das ftarre Feftland, mir midjeinemb todt, aber in fity vielfady geftalteno und

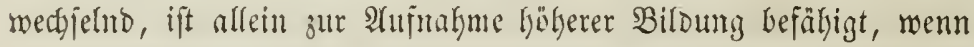
nur ber Reim Durfy ben flüiligen Segenjag bejuchtet wird. Bon biefer Durdboringung beiber Elemente, mug fie mun ăuperlidg Durớt räumlicge Berfectung von \&ant unt Meer ober intterlidy uno un= bemerft Durch atmojplyärijdye Bermittlung geichehen, fängt oas (Sie= Driben ber Menichbeit, wie Der ganjen orgnnijgen Matur ab. Midjt

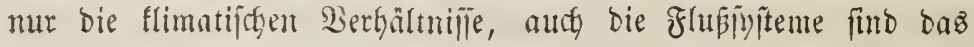
Frodutt ber Turdboringung von Drean und Jeftlano, unb bie Rän= ber felbit fint nidhts als Siebiete ron Etrömen. (5i fann baljer nidgt umwidtig feitr, Dieje Wedjelwirfung in ifren twidgtigften Fol= gen fowohl für bie äußrere Stieberung ber Rontinente hinfidtlidg

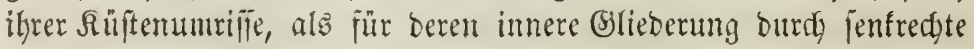

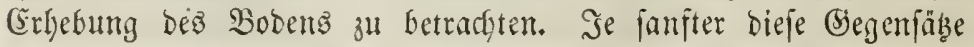
vermittelt find, beito entwiffelter und lebensfäljiger ift ein Lano.

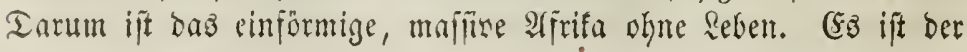




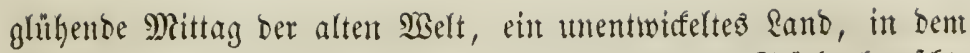

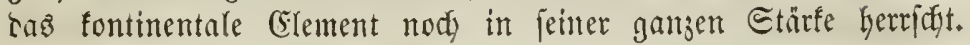
Ifien ift rebentiger und mannigfaltiger; ber Drean theilt fith hier in bie Seerridaft mit bem nod märffitigeren Sambe. Ifien ift ber

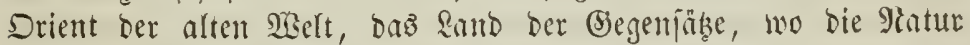

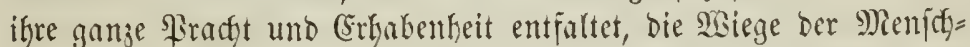

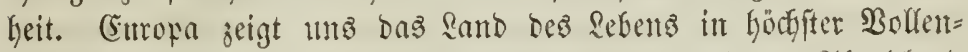

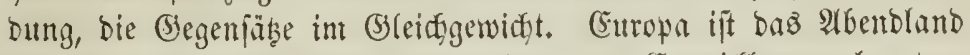
Affens, in bem alle Reime bez Drients fur Entwidflung gelangten,

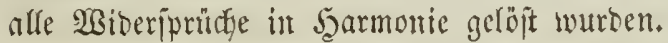

Eo ipricht fid in bem Ineinanbergreifen ber samb = umb

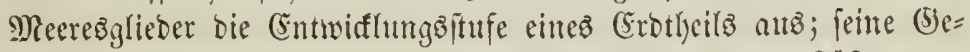
fitaltung ift um io ungunutiger, je einfatfer fidf feine Sillften ent=

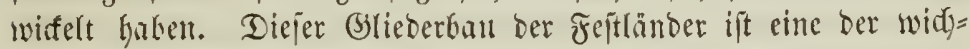
tigiten Urjadjen, weldye auf bie Rutturträhigfeit eines Erotheils yon (Sinfluti junt, weil ron ifr bie Rinltenentwidflung, bie Bercinbung von Eand und Meer abfängt. Die Salbinjeln cines (Erbtheils

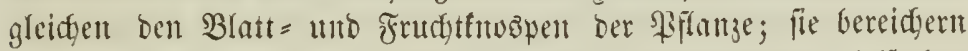
bie ftarre :antoşntatur, ben fontinentalen Etamm mit vielfadjen (beftabeforment unb begünftigen ten 3utritt ber Veweglidgen unt an= fpütenden Meereşylicber, ber Meerbujent unt Binntenmeere, gegen

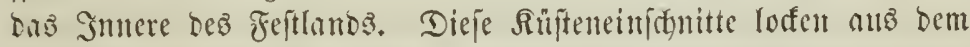
Sinteriten ber Sontinente bie grofent Runbftröne zur Berbindung

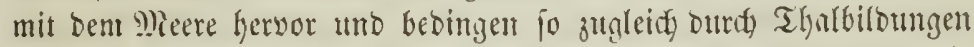

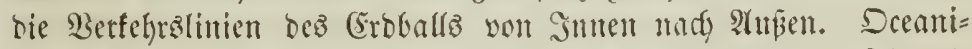

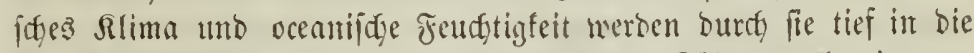
Sontinente bineingeppürt, bie Troffenfeit unt Rälte bes fontinenta= Ien Rlimas wird burd) fie gemildert, Manmigfaltigfeit in ben

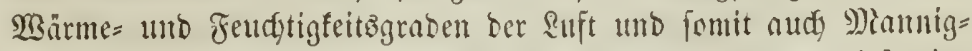

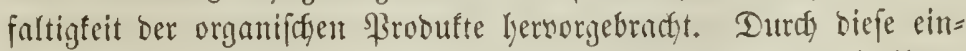
finneibenden Bimtenmeere und Meerbujen uno burdy bie mit ifnen in Berbintung ftelyendon, tief inz Snnere eingreifenden Thalipalten Der Ströme fino in (suropa faft bem gamzen Bimnentante bie $\mathfrak{B} e=$ günjîtigungen ber bef́tabelänber zu Theil gemorden. Eelbft von

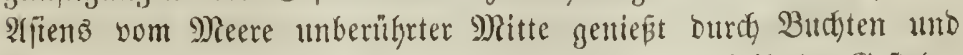
Binnenmeere ein nidgt unbebeutenber Theil bie Bortheife ber Bieftabe, 


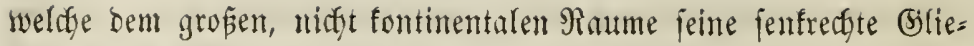
Serung entieft.

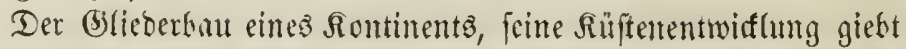

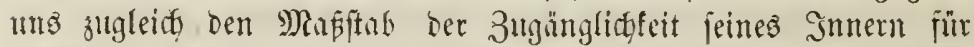

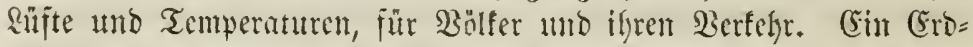

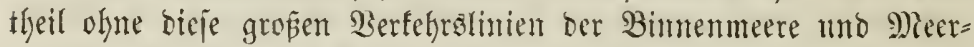
bujen ift eine tobte Malie obne Bölferbewegung und Bölferberïlfrung,

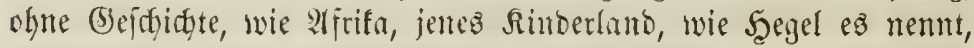

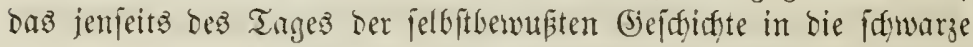

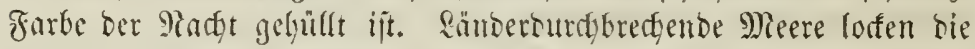

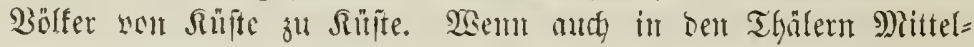
afiens bie Gejefichte crmadjte, fie hatte feinten Cinigungspuntt, fo lange ber Menidy nor bem Scenn ftefen blieb. Stz er ez aber

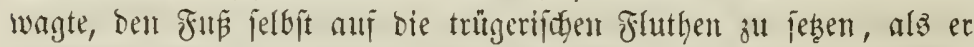
finassichmamm in ein unbefanntes Senjeit, ba wurbe bas Mieer

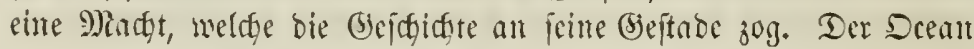
verlor feine Edfrefen, bie Micere trentent nift megr; bent ber

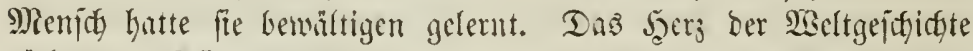

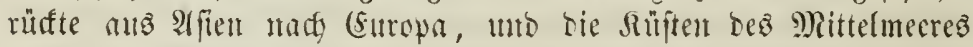

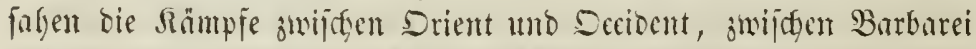

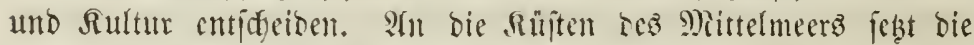
Trubitiont bie criften Edrififiafrt treibenden Bölfer. Şaier grüntoete

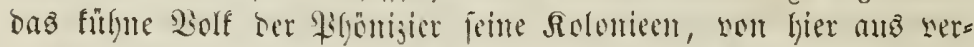

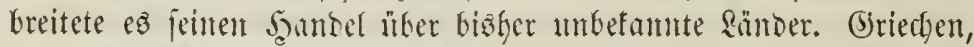
Rarthager, Sï̈mer murben nad, eitntuber bie Grben biejez Rleinods,

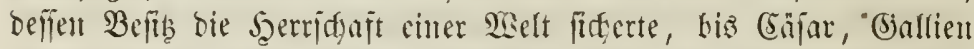

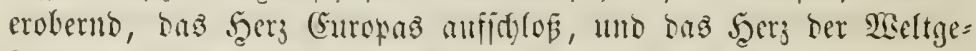

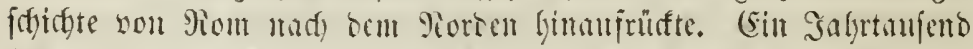

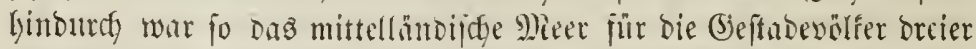

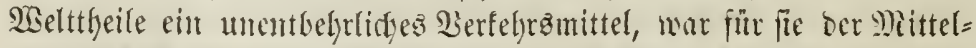

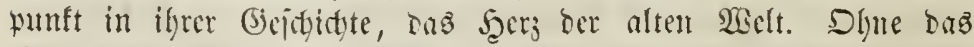

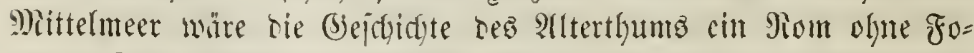
rum. 3war waren in älynlidjer $23 e i f e$ jofon friffer (5nglanto unb bie Bretagure, Miormegen unb Dinnemarf, Edfweben uno Rieslanto burch bie bortigen Binnenmeere mit einnonor verbunten. Afer bis auf Columbus, Bazco de (B)ama und Sabral, biz auj bie Ent=

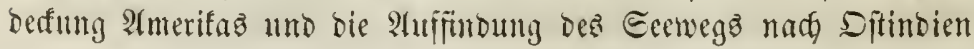




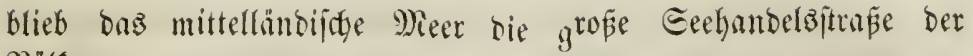
Bölfer.

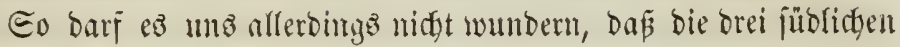
Şalbinjeln (Enropas in gleitfen Breiten, witter gleidy milbem Saim= mel, in ifren Berbialtniffen vielfach veridgwiftert, bie frilleften Seime enropaiiftyer (Eivilijation anj ifrem Boben entwifelten, beren reidye

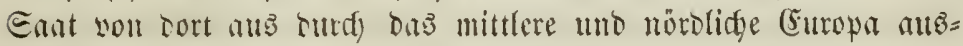
geptreltt ward. -

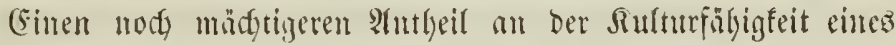

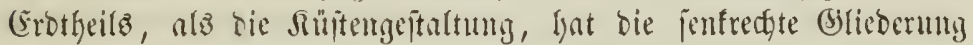

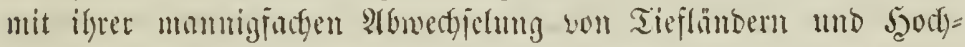
ländern, weldye bie unserifeglidgen $\mathfrak{B a n f i e r j g a n g e ~ b e r g e n . ~ E i e ~ g i e b t ~}$

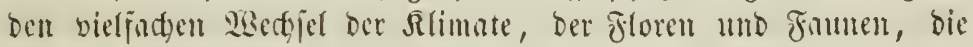

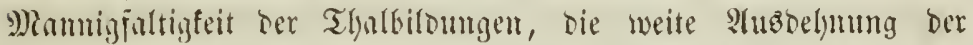

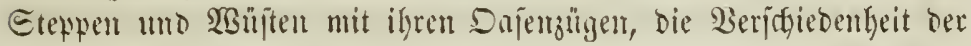

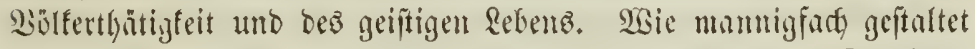

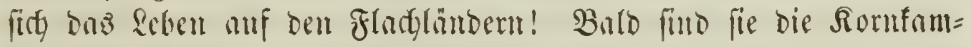

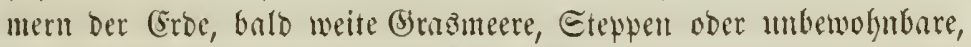
unr vou Sajen unterbrodiente Eambwuiften.

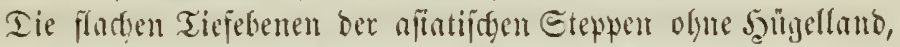

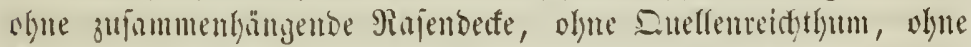

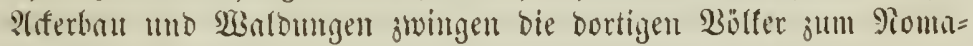

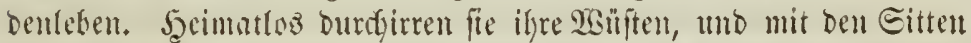

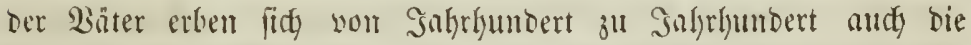

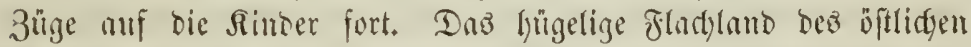
Eutropa bagegen mit jeitrem frudytbaren, queffreidfen Ifferboden,

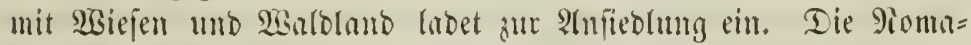

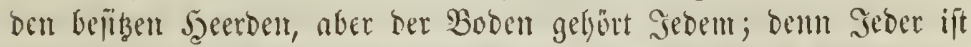
cin Simo biejez Bobenz. Der Menify aber, ber ein Etürf sand

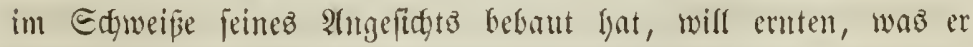

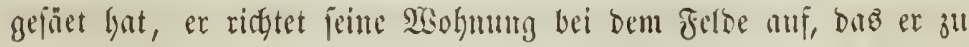
feinem (Eigentfyume erflärt, er will, Daß jein erobertes giedft von

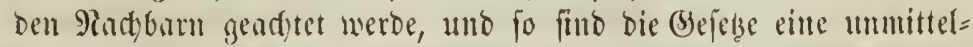

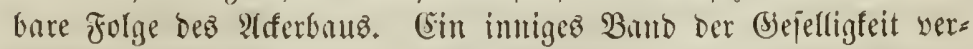

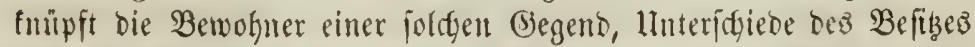

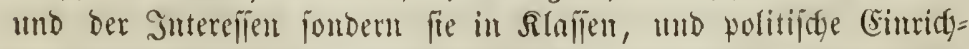
tungen madfen bos Lano zu einem Eize menfdylidyer Sultur, bie 
firb yon Beneration zH Beneration entmifelt. Eo molnt unter Dent Yiferbau treilenten Bölfern allein bie CEivifijation. WBie fie bie Patur befiegen, fteigen fie von Etufe zu Etufe, aber fie ge= ratlen audy in Sierberbuip mb Berfall, wenn fie fich von ber Ratur zut meit entferten; wäfreno bie Pomaden ber Eivilifation zwar fremo, aber ber 9iatur immer nîlyer uno barum immer jung

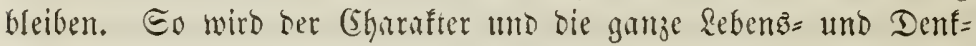
tweife ber Bölfer burch die Bodenbelffaffenlyeit iffer Şeimat bejitimmt.

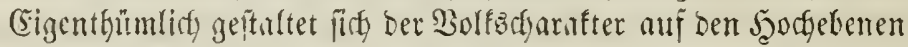

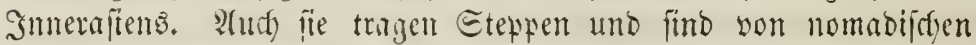

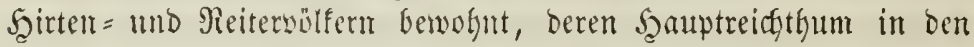

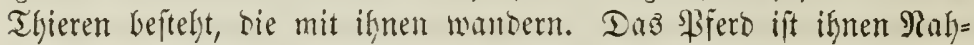

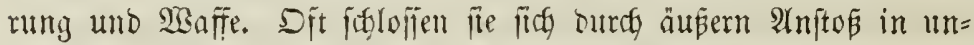
gefeuren Estraren zufammen, und fo friebliche Radgbarn fie aud biahter warent, fieten fie plöblich mie ein sermuliftenter Etrom über die Fulturländer łer, und Die Eputren, bie fie Ginterließenen, maren

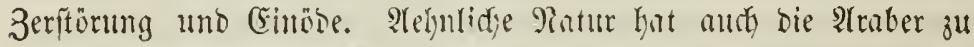

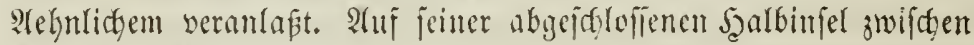

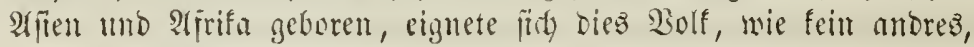

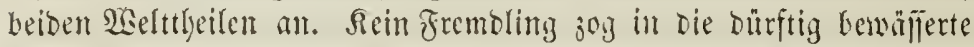

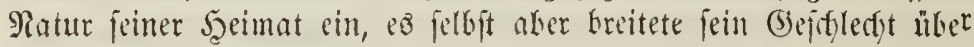

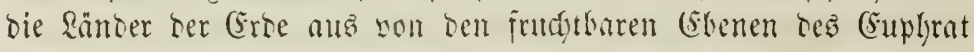

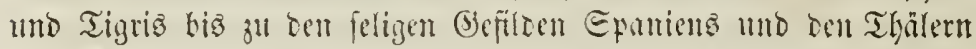

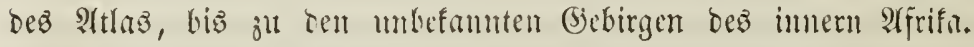
Mit ifm manderten Eprade, Meligion, Eitte uno Rebenzart, mit

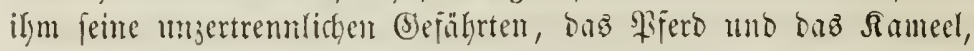

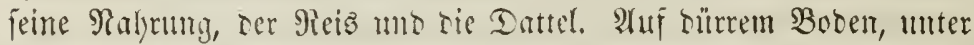

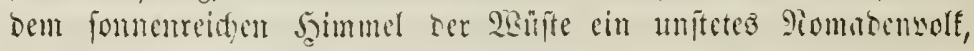

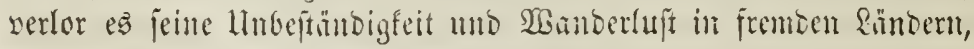

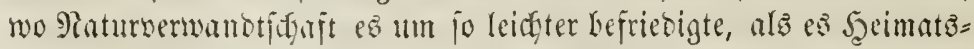

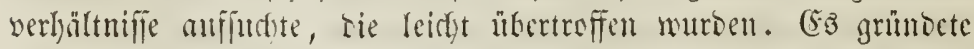

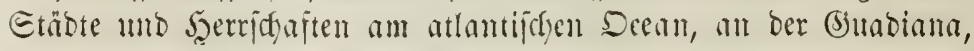
am Riger und 9ril, wie im Terajlenlambe zu Ectiras, zu Eamar.

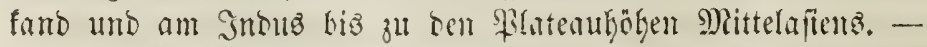

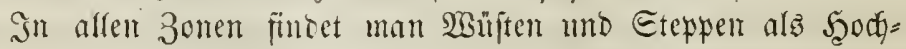

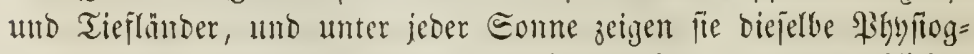
nomie ifrer Piatur mie ifrer Bewolgner. In ben unerméplidfen 
Sinzebenen 24merifas, ben \&lanos son Benejuela, ben ßampas von Buenos 2Yyrez, bell Firairien am Mififfippi und Colorndo, bie Den Reifenden Tage lang an bie glatten 2 Bufferipiegel ber Tropen= meere erinmern, kegegnen wir benjelben Extremen ber (bajtfreunt=

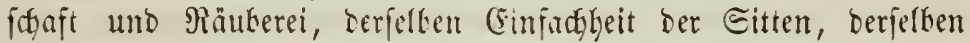
Banderlujt, bemjelben Familienleben ber Bemofner, wie in ben

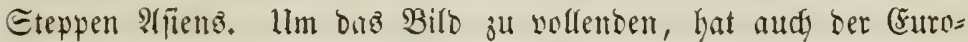

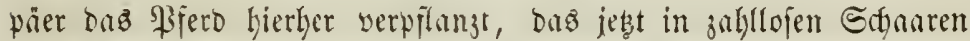

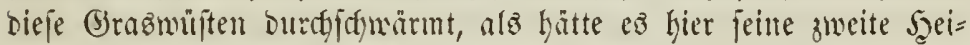
mat gefunden. Eelbit bie Eftenen Guropas rufen serwande Empfin= bungen itt bem 23anterer hersor, ber bald bie Eteppen 2fitens, bald bie Rfanos P(merifis in ifren Borbalfen zu betreten meint. Die Mandya Epanienz, bie Saiben, weldye fid) yon ber Morbipibe Sĭt= Ianto burity Rünebury und Bejtylyalen bis an bie Mlünoung ber Edjelte erftrecten, beínbers nter jente ungebeuten Triften llngarmz

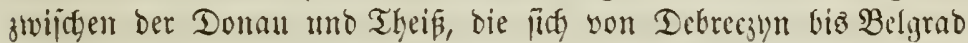

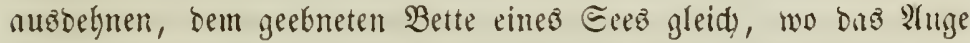
faum am Sorizonte einen Rubepunft findet: audh fie werben von

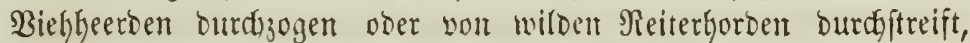

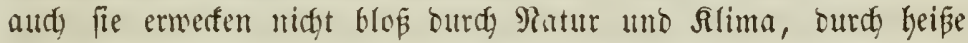
Sommer und falte Winter, burdy trofne Ditwinde, fonbern auds

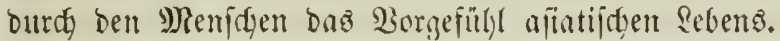

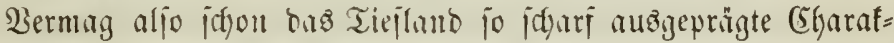
tere ju idaffen, wie viel melyr werben es nidgt bohe und mädatige

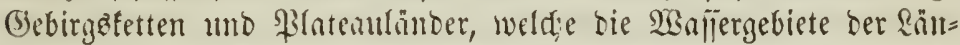

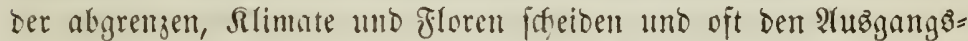
pumft alfer metbjelnoen Crifteinungen in ber $\mathfrak{B}$ ittermng bilben, wie wir es nirgends idüner als in ben Anoen treffen, wo som merifa=

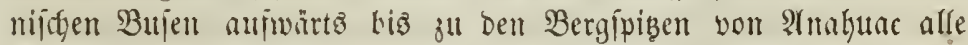
Rlimajonten und \$iflanzenregionen ftujemweije n̈tereinanber folgen! Bald werben bie Sebirgşländer zul Ecteibemanern und Feftungen

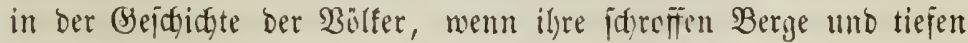
Thäler, wie bie Epalten und Edfludyten bes Rnufajus, bie Berbin=

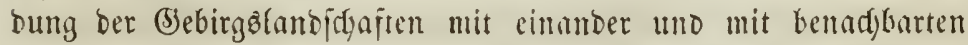

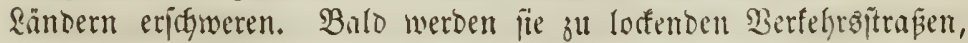
wentn igre Thatler, wie in umiern Afpen, meit und bewolynbar,

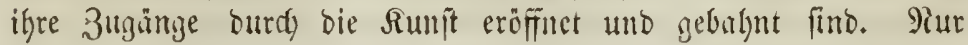




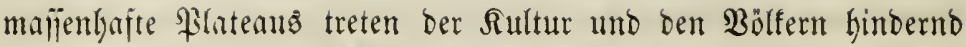
entyegen. Shre fteilen abhänge, bie vereingelten und gefahrvolfen llebergänge madben fie zu Edyeibewintoen für bie umliegenden \&än=

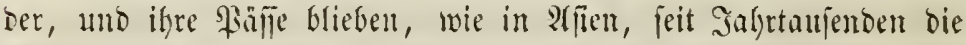
einzigen Serfelyrälinien crobender uno hanbeltreibender Bölter.

SEem aber autg bie Patur bie Gohen Bebirgeländer ber Erbe oft mad) aupen verjolozi, fo fennete fie biefelben bafun im Snmern

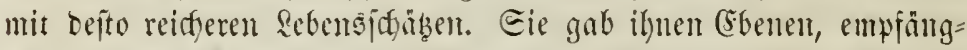
lidy für Den $2(n b a u$, grüne S)inten und Weibelänber neben ben fnlten $\mathfrak{B}$ iloniffen, in Denen bas Tlyier vor ber feindliden Rultur

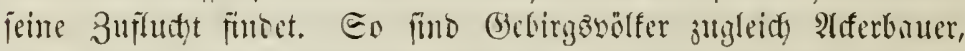
Şirten uno Sänger. Snl igren zaflreidfen Thälern in ehen fo viele

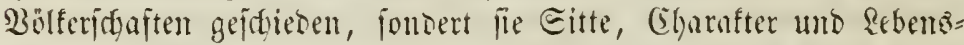
art nidbt. Diejelbe Epradje wirb oft in Der gamben Bebirgatette

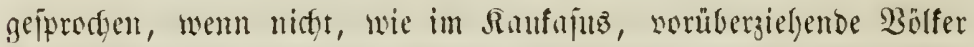

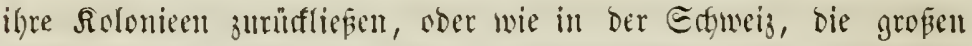
Thäler nady allen Weltgegenden ber fremben Rultur ben Weg siffnes ten. Bon fteten (Sefafjren umringt, in ihren Beburtuifien auf bie

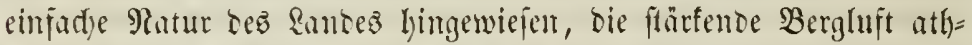
ment und burds bie Jaigs im Soudgebirge geitählt, ift ber bebirgs = bewohner friffig, muthig unb wom Beifte ber freilyeit befelt. Sm Sompfe mit ber Satur geminnt er Bejomenheit unt Fertigfeit bez (5harafters; wanbelloz, wie jeine Felfen, hängt er mit Züfyigfeit an jeinem Keimifden Boben, aber andy an jeinen alten Eitten, jeinem Blanben und feinen Etantseinridutungen. -

F(m mannigfoltigften entwictelt fid bas Reben in Den Etufen= linbern, bie sen llekergang vom Şodyland zum Tiefland bilben.

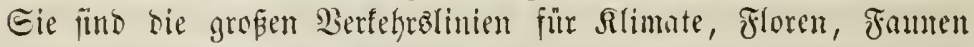

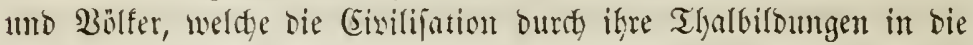
Ebenen hinableiten unb bie einjörmige, weidglidge Patur beß Flad)= lanbes mit ber ranken 3one bes Sadtbirgez voriöhnen. Durds fie serfnipfen fidy sie oceanijden Thieberungen mit ben fontinentalen Binnenlintern, weldge obne fie einjame Injeln im bewegten Meere

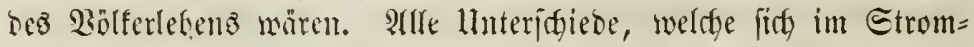
gebiete einez હtufentundez son feinem obern, mittlern und untern Saufe biz zum Deltalanbe an Paturfülle uno biftorifden Eridgei= mungen, in R̂ltur uto geiftiger Bildung in Raufe ber 3eit ergeugt 
haben, werben burdy bas ganje Stromgebiet serbreiter, und waz fith in Bewäjern und ifren Bauten, in Bflanzen= uno Bobenfulturen, in Thieren, 3ölfergruppen uno Etantzerinridytungen vom F̧udjlaute bis zum Meere vorfindet und angigebilset bat, wirb im Deltalande zufammengeführt. Eo erbulten bie Enfentümoer einen eigentyüm=

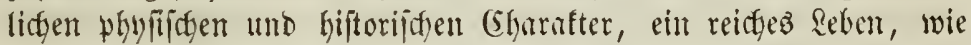
fie Şodyländer ober Rieberungen für fid nidgt aufamweifen haben,

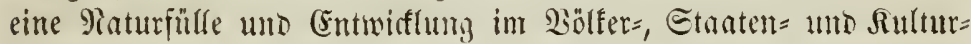
leben, weldge nur im harmonijten 3ufammentirfen aller Satur= uno Beiftegfräfte gejcyaffen warb.

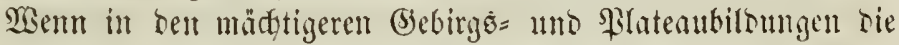

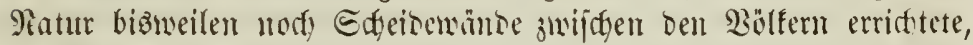

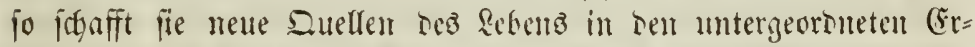
bebungen ter Erorinoe. Fus mammigfaden Sirmplen jufammenge=

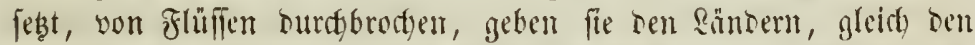

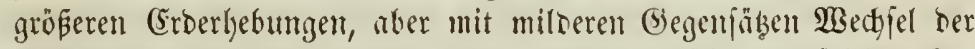
תlimate, ber Floren uno Faunen. (Sin Bemifdy von foldgen (Be= birgzländern unb Tiefländern, wie jie fo glüflidg bas weftlidse und füblidge Eurowa Darbietet, ergengt in jebem (Erojtrich, felbit uster gleidyen Breitegrnten werjdjiebene Bebürjuffe, Deren Befriebigung bie Thätigteit Der Bewohner anf รas 9)hmigfaltigite anregt. So

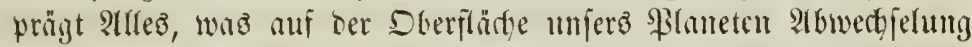
ber Formen ano bielgeftultung ergettgt, Dem Bölferleben cigenthium=

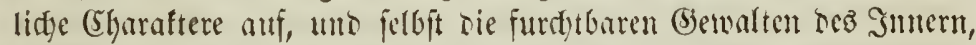
weldye von unten her im plöblichen Plnorange Theile her Crorinde zu mächtigen (Sebingseftten aufritgteten, haben mur baju gebient,

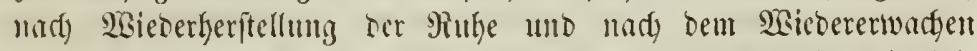

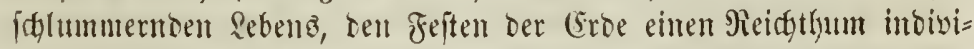

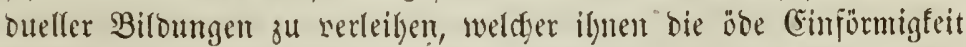
nimmt, bie fo verarmento anf bie phylitge uno geiftige Entwicflung Der Mienjobeit eimvirft.

So fdylingt bie Patur ifye imniges $\mathfrak{B a n d}$ um bie gantge Menld)= heit. Midgt den Eimzelnen allein, gunge bülfer feffelt fie an bie Ratur Des heimatliden Booens. 2lufgabe ter Bölfer uno bödsfte

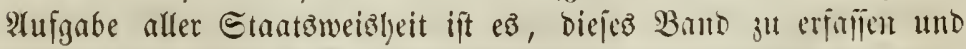

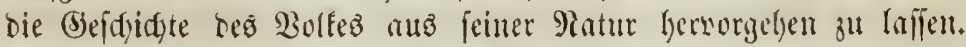
Rur biejer Eintlang zwifgen Bolf uno Baterlans, zwifhen Stellung 
Des Etaatez lour Piatur und zum Menjhenleben, zur Byyfif und Bolitif hat von jeher in her Weltgeidjidte das Bhähen ber Böfer uno Etaaten bebingt uno geförbert. TSo biejer Eintlang nidyt mefyr, wie vielleidft einft in einer jugendictgen Periobe ber Borzeit, bewuêtlos, zugleidy mit ber organifłen Entwifflung ber Bölfer ber= sorquillt, ba mus, wie in unirer Gegenmart, sas (Sejets biefes (Sin= flangs, als ber uniterblicte Suell aller Scamonie und alles Frie=

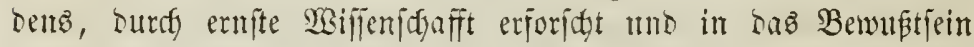
eingetragen werben.

Sat das benticae 2olt bieje 2utgabe begriffen und gelöt?

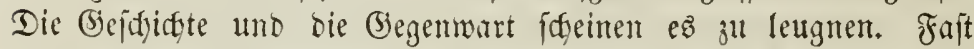

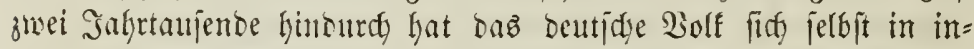
nern Sriegen zerfletidt; um jeine Sirenzen im Innern z" ziegen, hat es̊ feine (Sirenjen nach aufen verloren; um nidgt bon Deutiden beherridt 3n werben, hat es fidy von Elaven und Pomanten befyers= iden laifen. In ber Mitte zwijhen zwei Meeren gelegen, bie gleidh= fam bie groß̈en Şäfen (5uropaz fint, hat es ben Beruf, bie Biloung

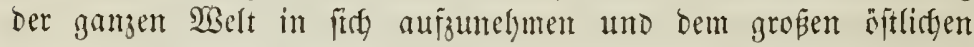
Sontinent, befien Borftufe es bildet, jujufilfren. Die Miatur befahl Dem Deutjen, bie Ditfee, bie jeine Rijiten bejpült, zu einem Mit=

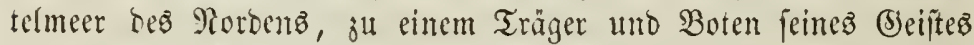

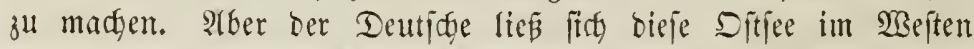

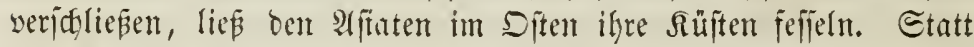
ein $\mathfrak{A}$ poitel bes Diten ju werden, ift er jein Sünger getworben. Deutiolando bscidyde ift ein raftlojes Ringen mady innerer (sin= Geit, ein תampi, Der jmar keinem Rulturbolfe eripart marb, aber nirgentes fo lange withrte, cinte Reife yon Geburtsidymergen einez böheren (Ssifteslebens, ohne weldye freilid cin Bolf int entmerbenter Shuge sormejt noer unter bem @dwwerte einez milden Groberers en=

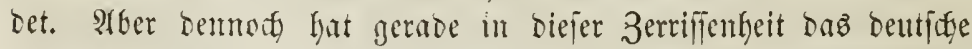

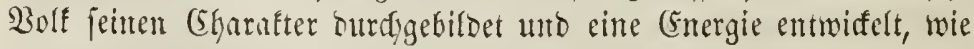
menige 3 ölfer.

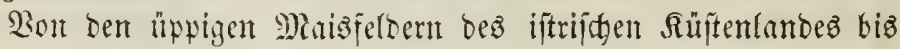

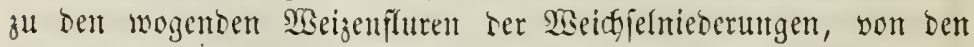

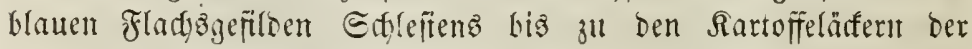
fanbigen Marfen, von ben 2 Beinterrajpen, Dofitgärten uno Soppen=

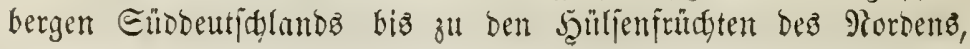


wout ben buttenden Sräutern ber Affenmatten biz zun jaftigen

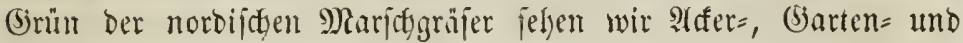

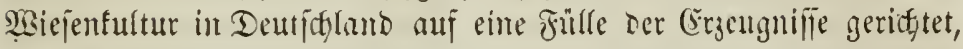
wie fie bon eimem glüflidyen fombe und gebildeten Bolfe unt zu

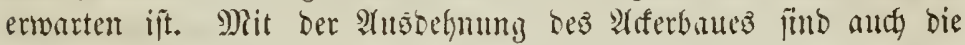

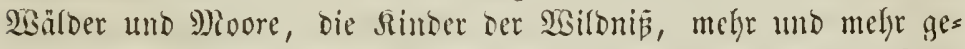

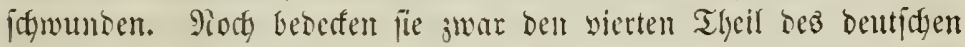

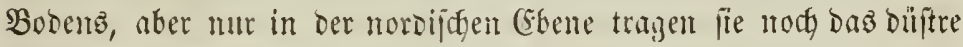

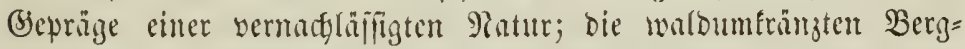

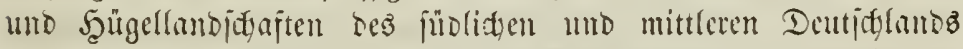
find ber beitere Edomust bunten und fäjtigen Rebens. Dafür er=

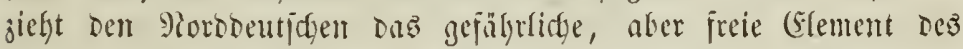

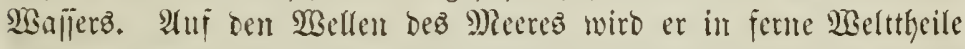
getragen, uno ber jocorjont feiner Thätigleit, feiner Bebanfent ijt frei und weit, wie Daz Element, Dom er jein Reben vertnuft.

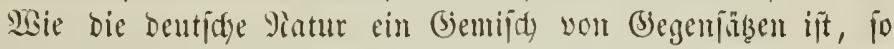
nuth bas bentidye Bolfşleben. Yidgt auf Die weiten Mangen allein, auth in tie entgen Tiejen ter Erbe migt fid ber Icutidse, unto unbefümment um die Edgåse, die er jürbert, füllt er Die \$igntafue mit den 23 mbern der Beifterwelt jeiner joimmernden Bruben.

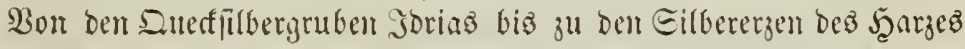

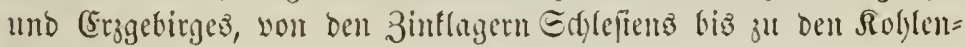

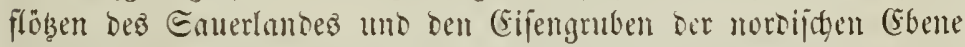
Durdaweht das Bergwerfileben mit jeinem eigenthümlidyen frijden

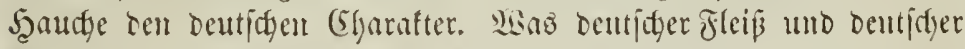
Geift in aflen 3weigen ber Snbuftrie und deş Samtela geleiftet Gaben, das lebrt ber Mublicf Deuticher Mefilen und Bemerbeats= fellungen, beutidyer Fabrif = und Santels̈pläßze. R(ber Diplomatie uno Şandeleppolitif ljedten nidyt immer Edyritt mit ben Fortjuritten

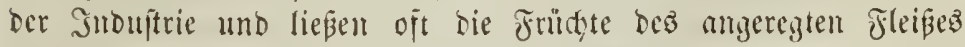
werborren, ftatt ifnen die Balynen bez 2rofazez zu eröfinen. Siur

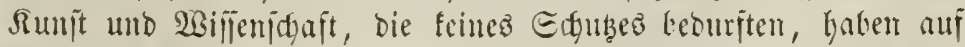
Deutichem Boben eine jeöhe erreidyt, wie nirgents auf Der Erbe. Şier allein fund fie Eigentlyum des Bolfes getworden. Die Disilien=

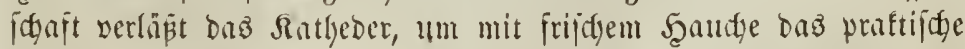
Reben zul Durdyoringen, bie Runjt tritt aus ifgren Sjallen, um jich verederno in bas (Semilth des Bolfes zu jenten. Ier Deutide ift 
ja geboren, um in ber $\mathfrak{S e l t}$ bez Bjeiftez jul leben. Reine Ration

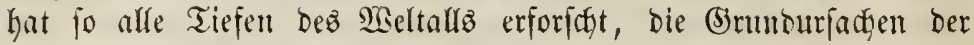

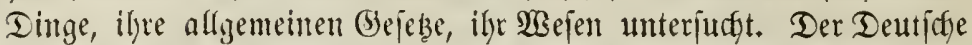

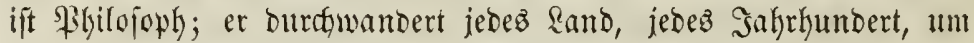

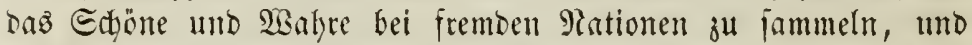
werliert barüber freilid fein eigenes Pationalgefühl. (Er umfapt in

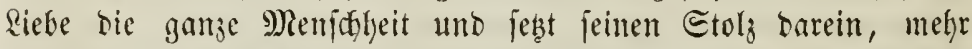

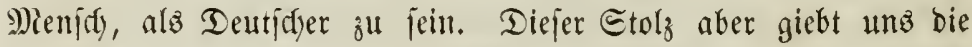

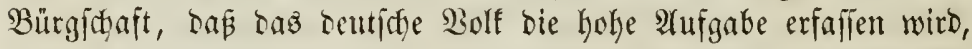

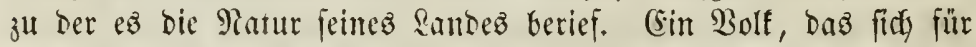
ben Ifpoftel Der Mienifdheit hält, wirb nicht lange bie imnere 3er= rifienteit ertragen; ein Bolf, Das ber Einfeitspunft ber $2 B e f t$ wer= Den will, wird felbjt jul Cintyeit gelangen. Sein Baterfand ift

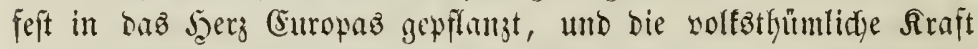
Deß germaniffyen (Elementz miro nidft brecten im Eturme der Beftgeidjidfte. 


\section{Sadjegifter.}

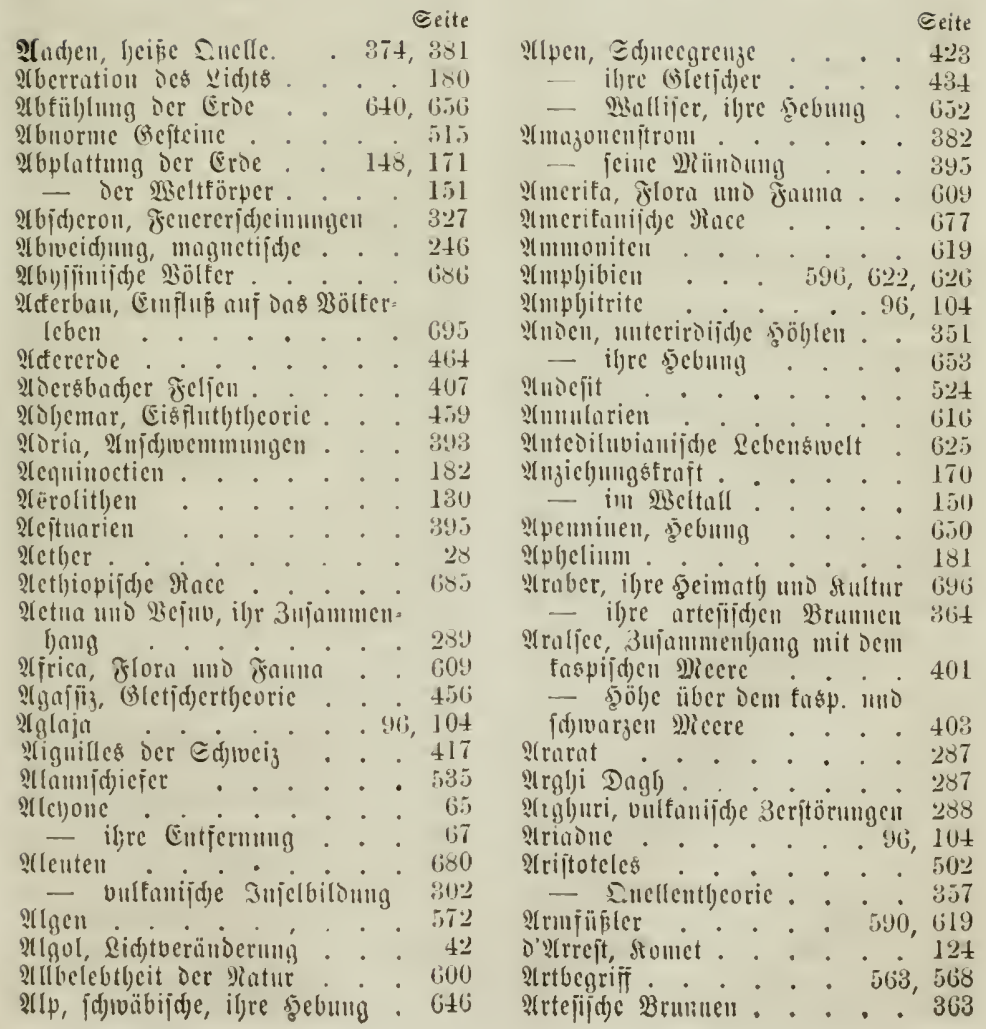




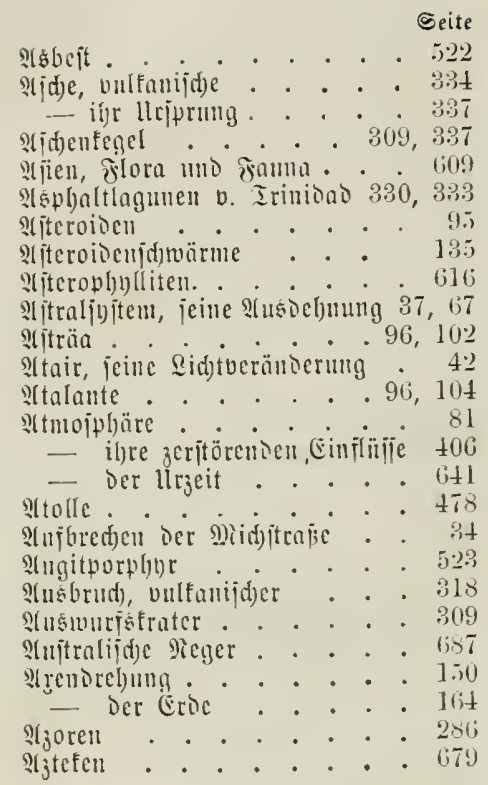

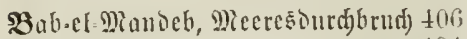
Bacillarien . . . . . $48 t$ Baben in Nargan, beje Scielle 374,381 Baben=Baden, Enelle . . 37t, 381 Baggertori . . . . . 466 Banuetlyal, lleberiduemmung . 419 Balnen Der Sieltföper . . . 158

Bajü, Dampjö̈oer . . . . 333

Bafu, envige jeuer . . . 327

— Sultane. . . . . 331

Bandjaspis . . . . . . . itli

Burancos . . . . . . . 301

Bärlappe . . . . . . . $5 \pi t$

Burometer als Sietterprophet . 221

Barometeridıunfungen . . 217

Barren. . . . . . . 396

Bajalte . . . . . . . 528

Bajaltberge . . . . 34, $52 t$

Bataver im Rlucindelta . . 393

Baututbicre..... . . 588

Banmitämme, unterirdijde . . 468

Ba!nธ̌ . . . . . . 392

De la Bede, Treibeistbeorie . 455

Bectjuanen . . . . . 686

Bel ringşttape, Mecresourdibrud) 406

Bellona . . . . .96, 104 Berarde, fejiltilual . . . 418
Seite

Berbern . . . . . . 683

Bergadern Deǧ Miondes : . 108

Rerniälle . . . . . . . . 411

Berbfalf . . . . . . 537

Bergmebl . . . . . . 488

Bergid)lïpie . . . . . 408, 413

Berliner Injujorieulager . . . 488

Bernjteinbaum . . . . . . 626

Benteltbicre . . . . . . . 598

Bewegung . . . . . . 25

- eigue. Der firiterne . . 61

- jübrlidje, Der Erie . . 179

- pentelartige, D. Planeten 191

Biela's fromet . . . 122, 124

Bieler Brumb . . . . . . 407

Bimsftein . . . . . . 343

-Binnemueere, Einfiln an D. Sultur 693

Sirs bei Dadfifelden . . . $366^{\circ}$

Bijaoj, G., Erobebentbeorie : 351

Bitterwaffer . . . . 374

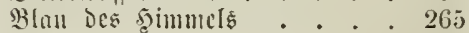

B̉ik . . . . . . . 268

Blume . . . . . . 575, 580

Blmmenbad) . . . . . $676^{\circ}$

Rodejides (3eję . . . 101

Böljmerwald, jebung . . . 648

3olnerzbilduig. . . . . . 376

Bolabola...... . 476

Boll, Erflärung ter erratijafin

Blörte . . . . . . 453

Bomben, vulfanij(t) . . . . 336

Bormio, Therme . . . . 380

Borjüure, vulfnuijoc Dämpje . 329

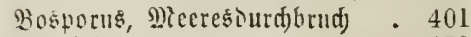

Botofuden . . . . . . 678

Bradjiopoden. . . . 590, 619

Brabler . . . . . 180

Bramau, Neteorftcinfall . . 132

Brameijenitcin, ourdi) Sneflen gebiloet. . . . . 377

Breccien . . . . . . 554

Breitenbenegung Der Flaneten . 192

Bremerbad . . . . . 381

Bretague, fïítenzeritörungen : 399

Brenil, Keilelthal • • 416, 418

Brighton, fiütemzerftörmgen - 399

Brorien's fomet . . . . 124

Brücfen bei Erobeben . . . 281

Bud), \&. v. . . . . . . . 512

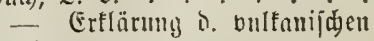

Flamme . . . . 321

- Etromtijeorie : : : 455

- Socbungstbeorie : : 644 
Buifion - Seite - $\mathfrak{a b}$ füblumg Der Erde . 241 Bัunjen, Erflürung Des (S) Burnct . . . . . . 507 Burtjdeit, lecipe Suelle . . . 381 Buј bümıсr . . . . . . . 686

Eacteen . . . . . . 582

Eäcilien . . . . . 596

Ealabrier, Erobeben : . . 279

(Elais, 2)(ecreร์ )urd)brud) . . 405

Calamiten . . . . . . 616

Calanda, folsftïrze . . . 412

Ealdera . . . . 302

Cambrijacs Éfiteu : 535,642

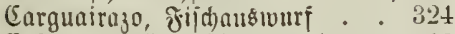

Eajtor u. Pollur, 2idbtocränderung 42

Cabendifl, Neigung Der Erde . 226

Eentraltörver . . . . . 81

Eentraljonne. . . . . 61,65 - ibre Berocgungécrid)einnn.

gen . . . . . 187

Centripetal = uno Eentrifugaltrait 181

Eephalopoden . . . 590, 619

Eeres......... . 96, 101

Ebacornac . . . . . $10 t$

Chagosinjelu . . . . . . 481

Chaos..... . 149,687

(E) brpentier, Bletjuertlyerie . 456

Chemisnus . . . . . . 230

Eljili, Sebun Der Aiijte . 297, 481

Chindas. . . . . . 678

Ehinejen . . . . . . . 680

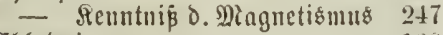

Eblaoni . . . . . 133

Ebloritjdiefer . . . . . . 545

Ehrijppras. . . . . . . 52\%

Ehur, fulfreidje Suellen . . . 372

cimbrijase fluth . . . 454,506

Eirce . . . . .96, $10 t$

Cirque de Trommouje. . . 418

Conts, metamorpljijd) Erjdeimun. gen . . . . . . 543

Conglomerate . . 515, 527, 554

Conjunction Des Miondes . . 198

Eonjtantine, Ralfinterbiloungen 376

Copernicus . . . . 168

Eorona D. Goume. . . . 76

(Coliguina, vulfanijder Musbrud) 334

Eyprejpenjümpfe 9tordamerifus . 469

Dadjijiefer . . . . . 535

Dalton, Suellentheorie . . 358

Danmeride . . . . . . $46 t$

Ule, 3eltall. 3. แนก.
Seite

Dammriffe. . . . . . 476

Dampfqucllen . . . . . 333

Daplone . . . . . . 95, 104

Davl), Ertlürung D. vulfunijocn

ร̌นuerร์...... . 320

Declination, magnetija) . . . 246

Defupoderu..... . . 592

Delta DCs 9iil . . . . . 389

— D. Bangeg . . . . 391

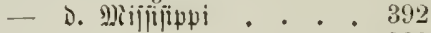

- D. $P_{0}$. . . . 392

- D. Plucir . . . . 393

Deltabilomin. . . . . . 385

- D. Etrömse . . . . 388

Dema cho * • • • 289

Dent of פioi, Einjtury . . 413

Dejaguadero, Iyal . . . 420

Deufulconiidge Flutlyen . . . 403

Dentiduer (E)arafter . . . 701

Deutjd)Ians, jein Beruf u.j. Sultur 700

- icine Matur in D. Etcin.

folleuperiode. . . . . 647

- T. Siat. in D. Inraperiode 649

- - in D. Frcibcueriode 650

- - ind. הllt Tertiärperivde 651

- - in D. Difluvialperiode 652

Devouifdics Eljtem . . . . 537

Diablerets, Einjturz . . . 413

Dinแaguctiร์แแร์ . . . . . 256

Diatomcen . . . . . . $48 t$

Didfbünter . . . . . . . 598

Ditotıledouen . . . . . 577

Diluvinlgebilde . . . 542,652

Dinotherium . . . . . 628

Diorit . . . . . . . 521

Dolocugewäctjje . . . . 582

Dulerit . . . . . . 523

Dollart * . : : 394,400

Dolomit . . . . . . 548

Don, ältere Mlïndung . . . 402

Doman, Etromjunclleu u. Etruod 382

Doppcliteruc . . . . . 53

- iljre Babuberwegumg. . 55

- il)r negenjeitiger \$bjtand 58

- ibre Diajen . . . 59

- iljr Edivuerpunt : . 73

Drelungsgejes Der Wimde . . 220

Dreljuage . . . 224, 226

Dïuen . . . . . . 397

Durdbriidje von Mieeren. . . 401

— von Thäler.n. • . 418

Elobe 1. Fluth D. Plecres . . 211

- — \&. 2tmojphäre . 217 
Seite

Seite

EDoa, erratijde $B$ löcte . . . 4.73

Egeria . . . . 96, 108

ËLechje!l . . . . . . 597

Eifel, bultanijobes (sebiet . . 290

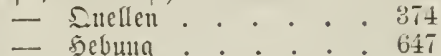

Eişberge . . . . . . 425

- ilje Bildung . . 431, 441

Eišblinten . . . . . 426

Eijengebalt der Suellen . . 376

Eijenjäuerlinge . . . . . 374

Eisfeloer...... . . 424

(Eisflutl) . . . . . . . 461

CEislöd)er D. Gletjder . . . . 443

Eispflanzen . . . . . . 582

Eisjtröne Grönlands . . . . 440

Eisftïrze D. (Sletjder . . . . 437

Eiszeit D. Erde. . . 457, 663

Etliptít. . . . . . 178

Electricität : * 26, 231, 233

— atmoiplyärijde : . 266

- bei vulfauijden Ansbrüden 322 ?

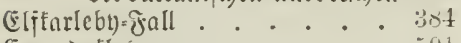

Empedofles . . . . . . . 501

Emร, Sucllen . . . . 374,801

Engadiu. . . . . . . 420

Engel bon \&uzern. . . . . 671

England, früberer 3njammenljang mit Sranfreid) . . . 40.5

Encfe's fomet . . . . . 123

Entomoirs im Jura . . . 365

Eocenformation. . . . . 541

Epatten . . . . . . 208

Epoden D. Erobildutin - .353, 639

Erobalit, Gejtalt 11. Lage . 181

Erobebeli . . . . . . 278

- ilgr 3ujammenlyang mit $\mathrm{D}$.

Htmoiplyare . . . . . 282

— ibre Daller . . . . 284

- an Mbein. . . 291

- Ėinflus auj D. (vemütl) 292

- ilt D. nordDeutiden Ebent 298

- ihre 3erjtörungen . . 294

Erbbeberizonen . . . . . 285

- Deutjd)Lambs: . . 290

Erobejd)reibung, mathematijase Erive

\begin{tabular}{|c|c|c|c|}
\hline $\mathrm{ni}$ & bijic & - & \\
\hline rD & & • & \\
\hline & 1111 & & 0. \\
\hline & ihre sugelgeitalt. & . & • \\
\hline & ibre शloplattung & . & \\
\hline & ibre secjimng & . & \\
\hline & ibre wabre Ecjtalt & & \\
\hline
\end{tabular}

Erde, íbre Bewegung un b. Eome 179

- ibre Beroegung um die

Centra!jonne.... . 187

- ibre Mtalie i. Didbtigfeit 223

- ibr smneres. . . . . 226

— ibre Erwärmumg Durd) $D$.

Eonne. . . . . . 235

- als Gaรู่all . . . 639

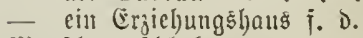

9) (enjidengejdled)t . . . 690

Erdjälle . . . . . . 414

Erotern . . . . . . . 638

Erolid)t . . . . . . 258

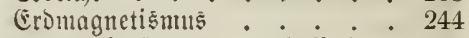

- Berämberungen defijeloen 252

- 1lrjache befielben. . . 254

Erorinde, idealer Euericunitt . 534

- Bildung Derjelben. . . 639

Erdjuattell . . . . . 200

Erojd)lüpfc . . . . . . . . . 408

Eroftöe in Gruben . . . . 282

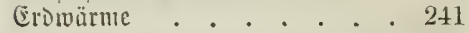

— Eimmirtung auj D. (5ejteine 550

Eribebungftater . . . 301

Eriten . . . . . 580

Erman, Theorie D. Mietcorjtöne 136

Exrofion . . . . . . 407

Eropionsthäler . . . . . 410

Erratijd)e Blöcée . . . 449,452

Erjoütterutgâtreis . . . . . 281

Ẽidjütterminglinie . . . . . 279

Eruptionğgejteine . . . . . 515

Erjerum, Etalaftitenbrüde : . 376

Erzgänge . . . . . . . 552

Erjgebirge, f̧çung. . . . 650

Estimos. . . . . . 679

Eugenia . . . . 96, 104

Eunomia . . . . . . 96, 104

Euplorbien . . . . . 578

Euphroinne : . . . . 96, 104

Euritporplbre . . . . . 521

Euterpe . . . . . 95, 104

Exfrente Der Temperatur . . 238

ซึabricius̊ . . . . . . 42

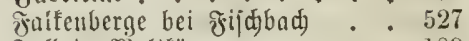

テrall D. Weltförver . . . 189

- D. Edöpjung . : . 561

Fallperjuche . . . . . 165

Tarbe 0. Sgast: : . : 675

jarm . . . . . 573, 616

Jaliathal . . . . . . 548

Jabe's fomet . . . . 124

Jelofteine . . . . . . . 449 
Telojteinporphyr . . . . . 521

Felienmeere . . . . . . 407

- Der Bergítrape . . . 520

Felsftürze . . . . . . 4 $41 \mathrm{~L}$

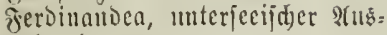
brud) . . . . . 305

Tergulon . . . . . . . 104

Teuerbrunnen in Egina . . 327

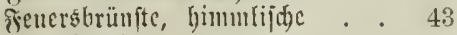

Fenerfugelin. . . . . . 120

visuerlümer . . . . . . . 680

Fenerfteine . . . . . . 488

filies . . . . . . 96, 104

Tilippo, Tampfinellen . . . 333

frindlingsblödfe. . . . 452, 607

ซinnen . . . . . 681, 684

Sfiniternifie . . . . . . . 199

Firn . . . . . . . 432

Firnlinie . . . . . . . 423

frimmecre . . . . . . 432

Fijdamphibien . . . . . . 596

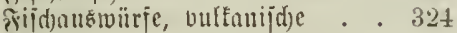

Fifde..... . 594, 619, 626

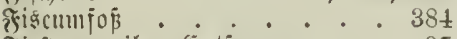

Firfterue, ihre Eีntfernumg . . 37

- ifje eigue Bervegung . 63

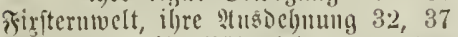

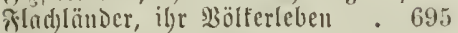

₹̂lammenjäule ๖. Sisulfane . . 320

Sledjten . . . . . . 572

stiebfraft. . . . . . . . 170

Tröbe . . . . . 5 531

Flöggebilie . . . . . . 537

Tllora....... . 95, 103

florengebicte . . . . . 606

- correppondirente . . 607

Floren und Fanuengebiete ber (Begentwart

609

— D. Borzeit . . . . 660

Flup̄betten, ibre Erböbung . . 387

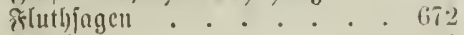

ซfln $[$ d . . . . . . . 540

Foraminiferen . . . . . 490

Formationen, Meifenjolge 532, 536, 558

Fortum . . . . . 96, 104

Foucrult . . . . . . 167

Frantiurt]a. D. D., Findingsblöde 44.9

テranflin, Benj., Ensbefung D.

Bolifitrom

216

Franzensbad, Quellen. . . . 374

Frofdampbibien . . . . . 596

froft, zeritörende Wirtung auf D.

Gefteine

407

orudit รorudjtpflarzen . . . . . 583

รัut)serbe . . . . . . . 465

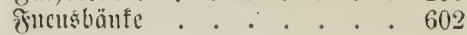

fonllalueger : . . . 686

Timmacdji in Tostana . . . . 329

รtumarolen . . . . . . 333

Gabbrn . . . . . . . 522

Gallngnener • . . . . . 686

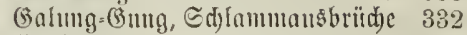

Bandecter . . . . . 443

(3änge, plutoniịd) . . . . 516

Banges, Delta . . . . . 391

- lleberjotwemmm . . 384

Bange fiteine . . . . . 552

Basball D. llrwelt . . . . 149

be Basparis. . . . 103

Baitein, Suellen - . . . 373

Gaftropobell . . . . . 590

Basunlfanc . . . . . . 327

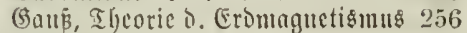

(Bebirge, ilgr glter. . . . . 646

Gehirgserbehungen . . . . 644

(5echirgstänme, ib)e (Beftaltung 408

(sebirnglänذer, ib): Bölferieben 697

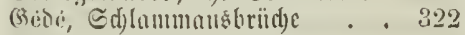

Becit .. . . . . . 393

Gefäfipflanjen . . . . . 573

(Benerationstued)jel . . . 564

(5entertund)en D. Simalabal) : 672

(3emur, wiffeujd)aftlid)er . . 4

(Beograplje D. Bftangen แ. Shiere

ถ.) (segenwart. . . . 600

- i. 2ionzeit . . . 660

(Beologie, ilbre (sejdjidste . . 498

- b. (Bricdfer . . . . 501

- 万. Mittelalters . . 502

- in Rampre mit D. Theo.

logie . . . . . 505

Berölle o. Jliiffe . . . . . 387

Geidjebe D. norboentiden cebene 450

Beftalt D. Eroe. . . 169, 176

- ibre Bejtimmming burd) o.

fienbel...... 172

- ibre Beftimumung Durds b.

Monolauf. . . . . 172

— ibre Beftimmung o. (Brast.

meffungen . . . . . . 173

Gejundbrmuei : . : $: 373$

Getöje, miteriroijdes bei Erobe.

bell. . . . . . 283

Gewitter, magnetifjue : : 261

- electrifde . . . 267

- vultanifde: : : 322 


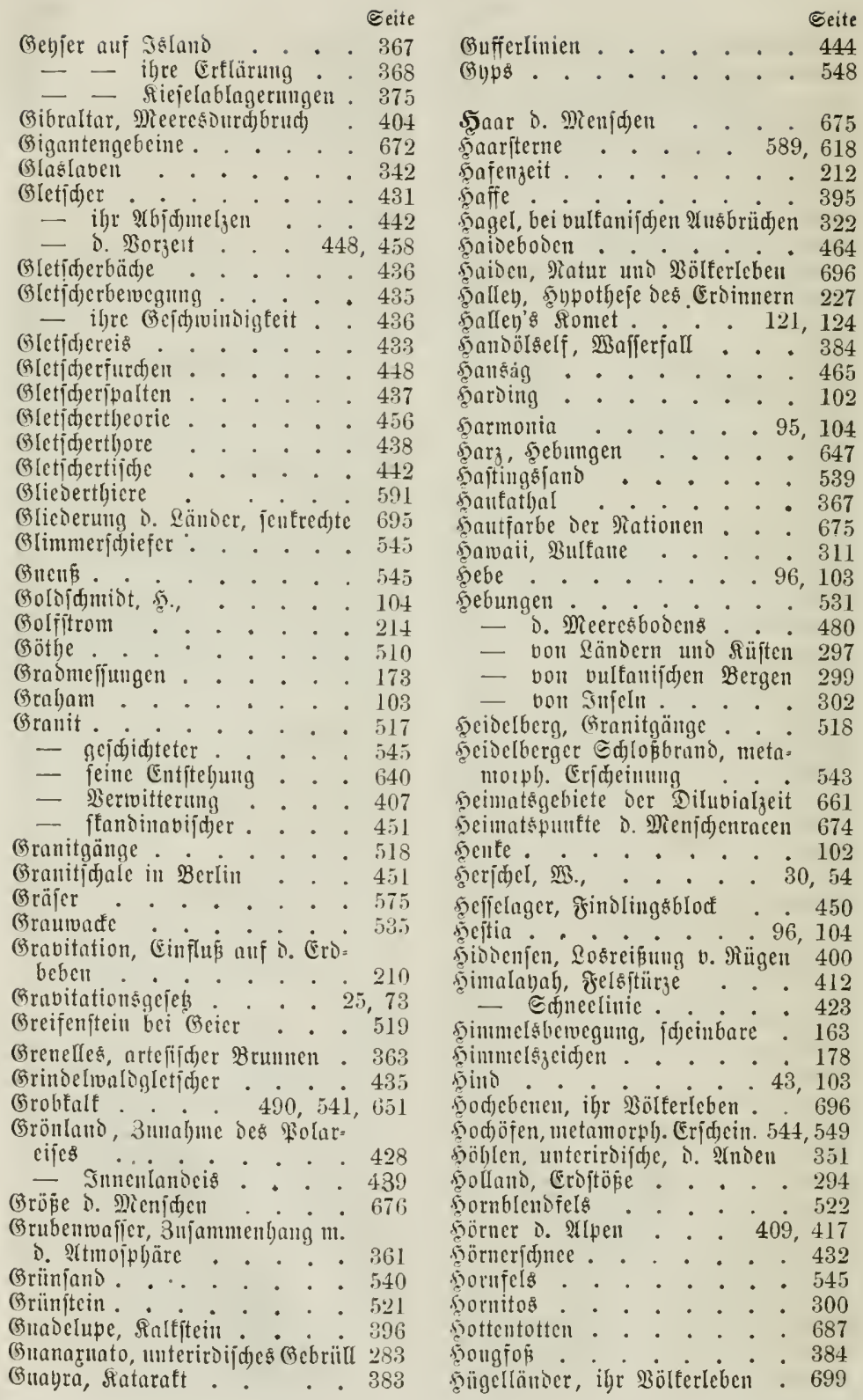




\section{9}

Geite

5ülienpflanzen . . . . . 582

รูumboldt. A. v., . . . . 2, 512

รันเมเ . . . . . . 464

รuntosgrotte bei Reapel . . . 326

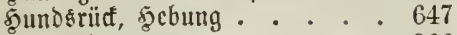

รันngerbrumen . . . • . . 366

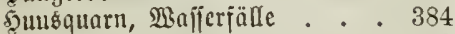

J̆ygica . . . . . 96, 103

syoratjos . . . . . . 627

Jaboe, Einbruct o. 2Reeres 394,400

Jofuten . . . . . . 684

Saparcier . . . . . 681

ฐaba, Sulfane . . . . . . 331

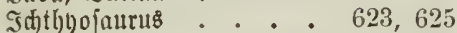

Igltandon . . . . . . . 625

Sinntrafall

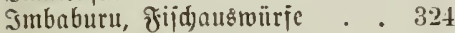

Snclination, nagnetijofe . . . 347

SnDogermanell . . . . . . 681

Sṇ̄iforien . . . . . 485, 588

Snfuprienlager . • • . . 488

รntå . . • . • • . . 680

Smmenlanocis Grönlands . . . 440

Sujefter. . . . . . . 593

Sntenjität, magnetijđje . . . 251

Solmali, Galie. . . . . . 331

Soloffen • . . . . . . 686

Sordanthal . . . . . . . 421

Эorullo, Entitebung . . . . 299

Sreue . . . . . . 96, 104

Эris . . . . . . . 96, 103

Эğd)ia, Dampíbäber . . . . 333

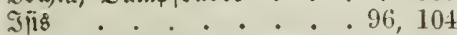

Эaland, Bulfanc . . . . . 323

— frübere Rultur . . . . 429

Siodunamijde Liuicu . . . 252

Siogonifje Linien. . . . . 249

Sioflinijde \&inicn . . . . 250

Sjothermen . . . . . . 235

ฐul10 . . . . . . . . 96, 102

Supiter . . . . . . . . 90

Supitersmonde . . . . 106, 116

Эura, Rorallenbänte . . . . 482

Suraformation . . . . 538, 649

Straberfteinerungeu . . . . 623

Suragehirge, 5ebung . . . 650

Surameer . . . . . . . . 649

siitlano, Erofälle: : . 414

Sorea, Gdjuttuall . . . . . 446

SRafulen . . . . . . 683

Saffern . . . . . . 686

Siatbung o. Eisberge . . . 441 ๔eite

Ralenocr, jutianijđace . . 206

gregorianijøer . . . 207

Salenderftreit . . . . . 207

Ralf, fohlenjourer, in o. Crobil=

Duing . . . . . . 643

SAltablagerungen bei Sucllen . 376

Ralfgehalt bes Sneflwaj̄ers . 372

— D. Diceres . . . . . 474

Salfitcine, ibr Rectantorpbismug 547

Salliope . . . . . 96, 104

Ralmelt . . . . . 218

Ralmïlfell . . . . . . 681

Rältepole . . . . . . . 235

Ralte Tage \$. Miai . . . 138

Rammerbiilhl bei Ëger. . . 348

Ramtidadalcit ${ }^{\circ}$. . . . . 681

Ranada, jriilyerer Picerestboien . 429

Runt, Śbcoric D. Plametenbilomig 153

Rapwolfen . . . . . . 51

Rarlsbaver Gprmit $374,376,378,381$

Rarrenjeloer . . . . . . 407

Rarter, magnetijace : . . 249

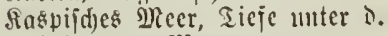

Edjwarzen Mecre . . . 403

Ratubotljra . . . . . . 365

Ratafefaumene in Ryoicu . . 287

Rataitroplen D. Dorzeit 559, 568, 664

Ratwht, Ruuscu . . . . 394

Rantapilidse Race . . . . . 681

Sinfajus, Bulfanbegirf . . 289

- M(j)cuablagerungen . . 33.;

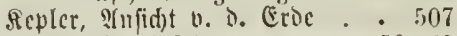

Repleride (seicbe . . . 58,63

Rertjd), Gdjlammbulfane . . . 331

Reijelthäler . . . . . . 417

Sicuper . . . . . 538,648

ficmenfüler . . . . . . 592

ficiclbänte . . . . . . 488

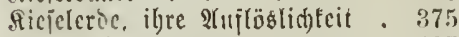

Riciclgulgr . . . . . 487

ricielf́t)iefer . . . . . . 546

Ricjelinitcr . . . . . . 375

Rilnuea, auf samaii . . . 311

- feime Feucrje . . . 314

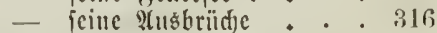

Rings Gpring bei Bath . . . 372

Sirghijen . . . . . . . $68 t$

Rirfwood, Befeb s. filauctenall.

zichunge . . . . . . 98

Rifïngen, Suclle . . . . 372

Rleinafien, Bulfane $\quad . \quad$. $\quad 286$

Plimate . . . . . . 183

- o. Bortvelt . . . 657

凡lingftein . . . . 375,524 
Seite

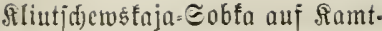
idjatfa . . . . . . . 339

Sinockenifiche . . . . . . 595

Snorpelñide . . . . . . 595

Rodjalz, vulfanijás . . . . 325

froblenformation . . . . 537

Soblemmeer Deutidiands . . 647

Sinl)lenjandjtein . . . . . 537

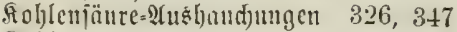

Soblemïure D. Miceres . • . $47 t$

- in D. llzzeit . . . 643

fomet bon $1556 \ldots+. \quad . \quad 125$

fiontetell . . . . . . 117

— ihr $\_i d$ t. . . . . 120

- ibre Marfie. . . . . 119

- ibre Etörmigen . . . 125

- ilje 9lberglaube . . . 127

- vou furzer llmlamiszeit . 123

- Theilung Deš Stopfes . 122

RopT D. Snfa . . . . 336

Sopfifitíler. . . . . 590, 619

Sopter. . . . . 683

fiorallen . . . . 471, 618

Sorallenbanten, ilyre Tiefe . . 475

- ibr 3ujanmenbang mit

Bulfauten . . . . . 480

— D. Borzeit . . . 482, 529

Roralleujels . . . . . 539

Sornllentalt . . . . . . 474

Rorallenriffe . . . . . . 471

Sorallenitöde . . . . . . 473

Sošmogenien D. SAten . . . 500

Rosmopolitijde seflanzen . . 607

frosinos ....... 16

Rntopari, Ausburd) . . . 336

Somalsfy, Bcobaditung D. Rord=

lichter . . . . . . 263

Ströite, fosmijeje : $\quad 26,79,208$

- tcllurijd) u. atmojphärijde 232

- centrale 11. peripherifde. 232

- polare 18. ännatoriale . 283

Srater . . . . . 310

— ๖. Monbễ . . . . 109

Frebje . . . . . . . 591

Rreibe, ihr orgatt. 1lrjprung 490, 530

— d)loritifde . . . . 540

Rreideformation. . . 539, 650

- ifre \$serfteinerungen . . 624

Srcisemeer . . . 650

freidemergel, organijd)erliriprung 488

Rreitetuif

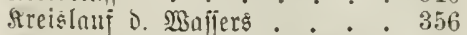

frenzblunten . . . . . 584

Arofodile . . . . . 597
Siruiterojen au \&aadjeriee . . 346

Siruftentbiere. . . . . . 591

firnjtalliniije edjiejer : : . 545

fiulturmittelpunte . . . . . 691

Stupjerjøiejer . . . . . . 537

Sürbiggewädje . . . . . . 580

fturilen . . . . . . 681

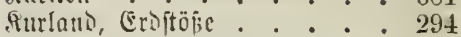

Rïiten, ibre 3erftörmugeи . . 398

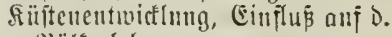

\$sölferleben . . . . 693

Ruaberiee . . . . 290, 345

— Eijenjteinlager . . . 377

Qacadiben . . . . . . 481

Sagoni itt Tosfana . . . 329

உaguten ๖. Rlil . . . . 391

— D. 70 . . . . 392

- D. Soralleninjelı . . . 478

Samont, üher Den llrjprung Der Slanctoisen..... 98 - Ẽrflärung Des 30biafal.

lidgts . . . . . . . 144

Rängenbewegung D. filnuten . 192

Saplace, Theorie Der Erobildutg 153

Sapilli . . . . . . 336

Lappen . . . . . 681, 684

Qätitia.. . . . . . 96, 104

Eanbljölzer . . . . . . 578

\&auburooje . . . . . . 573

Eaแrentius, jenrige Ibränen 135

\&aurcutiusftrom . . . . . 136

\&ava . . . 338,526

- ihre Bejtandtheile . . 342

- ilge ted)uijde anvening 343

Savajtröme, ihre Bervegung . . 340

- ilire Erítarrung . . . 340

- ibre Meädtigfeit . . . 341

Qaminen. . . . . . 435

Qebell . . . . . . 228

Sebenswelt D. Gegentwart . . 569

— D. Borzeit . . . . 611

Qcbermooje . . . . . 573

كCDa....... . 96, 104

Qcibniţ . . . . . . 507

Scitmujue! . . . . . . 632

Qepisonendron . . . . 616

Repisoiren . . . . . . 596

Qeudjtell D. Miectes . . . . 602

Sertother...... . 96, 104

Qeberrier . . . . . . 94

Serell's ficmet . . . . . 126

Qiag . . . . . 538

Ribration o. Pontes . . 106, 197 
Seite

Ridft . . . . 26, 79, 231

- als periplicrija Arajt 233, 264

— unjid)tbares... . . 264

- eignes, ber filaneten . 82

— ๖. Somme ... . 75,81

-. D. Fometer. . . 120

- jeine (3ejá)เvimbigfeit 24, 36

Ridijulyr.

Qidhtivantung ber Eterne . . 41

Lioo . . . . . . 392

Riliengenädjc . . . . . . 576

Qinien obne 9 brocidum, magn. 249,252

Siparijde Sujcln, Bultame . . 286

Riscow .... . . 504

Rilitabon, Erobcben - . 281, 295

Slanos . . . . . 696

Soganrot in Cornmall $\cdot . \quad 520$

Loterzoflus. . . . . . 382

Suit, ilstc Durdjidjtigfeit . . 26.5

Rupittrömungen . . . . . 218

suijenburg in sberiranfen . . 520

Sünebutger saide . . . . 488

Sufetia . . . . . . 96, 104

Sutber . . . . . . . . 104

Quel, Ircibcistbectic . . . 455

Rumpioro, Mrercsourdibrud) . . 400

Mnare . . . . . . 290

9) Racaluba, Galje . . . . 328

DRäbler, Eentraljome . . . 64

MRadeporcu . . . . . . 472

9) Rareporcuinjcln . . . . 471

Dagellanijdse Wolfer . . .51, 68

פ) Zagnetianuǵ . . 26, 231, 244

- eine polare firajt . 233

- D. Erite. . . . 247

- Berbindung แก. D. Wärme 257

Miaguetnabel . . . . . . 246

- il)re Gdjrontungen . . 252

- ibre plöblidjen Etörungen 253

Maguetitein . . . . . 246

maguaren $\quad \cdot \quad \cdot \quad \cdot \quad \cdot \quad \cdot \quad \cdot 685$

9) Raibrmmen • • • • • . . 366

Maina, Salje . . . . . . 329

MRalaicn . . . . . . 683

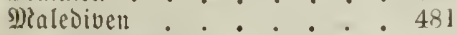

9Ralvengeroädjic $\quad \cdot \quad \cdot \quad \cdot \quad \cdot 584$

פRammutb . . . . 627, 663

Mandingo-Pleger . . . . . 686

Dangaia . . . . . . . 479

MRandiduss

Marccllgletjdicr . . . . . . 444

Mariotte, Duellentljeorie . . . 358

Diartgrajenjtcine
Seite

פiarmor . . . . . . 547

9) Mars. . . . . . . . 88

פ)iarjđländer . . . . . . 394

פlartl) . . . . . . . . 104

9)inifalia . . . . . . . 96, 104

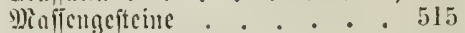

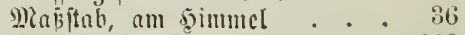

פiateric, ilje Reben . . . . 229

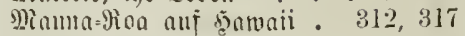

פ) Raurita . . . . . . 477

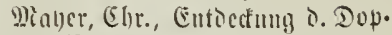
peliteruc . . . . . 5.3

Micct, jcinc Etramobilimingen . 396

— jeinc 3eriförangen . 397

giceresuten, Bcocutung füt

ditltit • . . . . . 698

Micercsourdburïdsc . . . . . 401

פiccresjamo . . . . . . 490

9)iecresitrömunge॥ . . . . . . 213

giegalojaurug . . . . . . . 625

Dicuntlicrimu . . . . . . 629

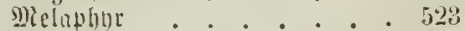

Mclpourue . . . . . . 95, 104

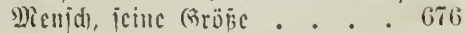

- jeine jantparbe . . . 67t

- Mbitammm v. cin. Fanar 673

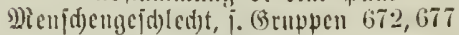

- i. Ërzielıming D. D. Siatur 689

פ)(cnif)cnfmod)cn, foijilc . . . 671

9)(cujd)entacen . . . . . . 677

)(crisian, magnetijucr . . . 246

Dicrtur . • . . . . . 86

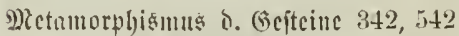

- ícine 1lriad)en . . 550

g) Zetamorplijd) \$ör . . . . 551

Dictanto:plojirte (sejteine 515,542

Mietumorphoje o. Smjecten . . 593

— rürfidtrcitenbe . . . . 591

Metcorftcine . . . . . . . . 130

— ibr tosmijder llejprmg . 133

- ibre MRajje. . . . 134

- ilje ablcitung bou D)?oub.

oulfancis . . . . 134, 336

- ibre Baljucu . . . 136

- ibre Raturbejdaffenbeit . 138

- Alujudeter her (Gried)en . 139

Reter. . . . . . 174

9) Rethone, Entitclum cincs Berges 303

gletis. . . . . . 96, $10: 3$

9)ictonijacr Dionozirtel . 205, 208

2) crifaner . . . . . . 679

๔. )) Riguel, ficjelfinter . . . 375

— beipe Duclle . . . . 381

DRifrofameni, Entjtelung • • 304 


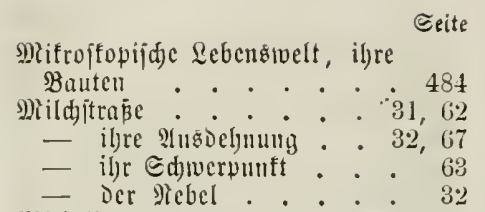

Miliolitben . . . 490, 541, 626

Mrineralquellen . . . . . . 373

Miucralwailer, füuftlidac . . . 378

9)iocenjormation . . . . 541

glira . . . . . . . . 42

3) Rijijippi=Delta $\quad . \quad . \quad . \quad 392$

mittagslöd)er . . . . . . 443

glittelländija) mecer, jriiljer ein

Binnenjec

- - Bcocutung für Das

Sölferlcbcu . . . . . 694

Mocarougas . . . . . 587

9iojetten • . • . 326,346

Miolngewädje . . . . . . 584

Molaifz - . . . 541, 555, 652

gloldie . . . . . . 596

Miolluǵfen . . . . . . . 589

Monaden . . . . . . . 485

Monat, jiderijaer . . . . . 196

— jonodijder . . . . 196

MOnd, feine EntFernung . . . 107

- jeine Bebirge... . 108

- jeine llrgejdidste . . 112

— jecine IItmoiploüre . . . 113

- jeine Tages = $1111 \mathrm{D}$ Sabres $=$

3eitell . . . . 114

- jeine Bemolnubartit. 115

- jeine Belvegung IIII Die

Erde . . . . . . 195

- jeine Potation . . . 197

(5r) jeine $\mathfrak{A}$ uziclunny gegen $D$.

— сеіп Miagnetismus • . 257

gionoc . . . . . . 10.5

Monofinjterniß . . . . . . . 202

Mtondjaljr . . . . . . . 205

Biondinuter . . . . . . . 197

Monopljajell . . . . . . 198

Miondjuatten . . . . . 200

Monoviertel . . . . . . 198

MtondunlEane . . . . . 336

Mcongas . . . . . . . 586

Mongoler . . . . . . 681

Mongolifac Race . . . . . 680

Monofotyledonen . . . . . 574

Montblane, şehming . . . . 652

mont Cervin . . . . . 417

s)
Seite

Mronte ßijo, şebung . . . 650

Moore . . . . . . . 465

Moortori . . . . . . . 466

Dioostorallen . . . . . 489

Mioostorí . . . . . . 466

Moränen . . . . . . 443

Miorgen = und Abeutöthe $\quad .265$

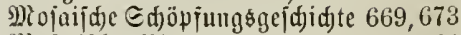

Mtojerijd) Bilder . . . . 264

M?ollfons . . . . . . . 2]9

Miüblbad) bei $\mathfrak{B i c l} \quad . \quad . \quad . \quad 366$

פ2üljlguujen, Meteorjteinfall : 131

刃)ïuzgcıädje . . • • . . 580

ginijdelbänfe . . . . . . 483

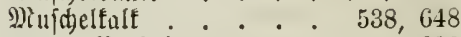

- Beriteinerungen . . . 622

MujdeIn • • • • • • . 589

9)iglodonten . . . . . . 6229

Migrtben . . . . . 5 52, 626

Radjtgleidjen . . . . . . 182

— Wräceifion . . . . 184

Rabelyöljer . . . . 577, 62]

glagelflue . . . . . 541, 555

Sagetbiere . . . . . . 599

Staplytlaquellen . . . 328, 330, 333

Watdjez . . . . . . . 679

Natur, ifre anbelebtheit . . 600

- ifr Einfluis anf (semiitl)

und Bcijt. . . . . 691

Maturgenú . . . . . . . 6

Saturma $\bar{\beta}$. . . . . . . . 174

Sinturipiele . . . . . . 503

Siaturuvifienjajajt, iljr Beruf fïr

Bolfsbildung. . . . . 3

— iljr Mejen . . . . 158

Mauljeim, intermittirende Duellen 367

Sautiliten . . . . . 619

Reapel, Bulfanbezirt . . . 286

Rebelflecte uno giebelfterne . 31, 45

- unauflöslide . . . 34, 51

- ibre Aแฐochumig น. Ent=

fermung . . . 60,67

— ibte Entwidtung . . 59, 154

Yeger . . . . . . , 685

- auftralijue . . . 687

Meljrungen . . . . . . 395

9telfenpflanzen : . . . . . 584

গeocomien . . . . . 539

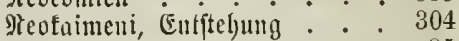

९Reptun • . . . . . . 95

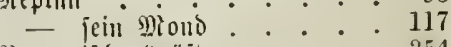

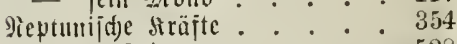

- Gefleitre. . . . . 528 
9evtuniater Eeite

9iejîlin . . 501, 511

Sienlyollano, flora ino jamb 610

Reulollänter. . . . . . Csi

Reunono... . . . 198

Teujalywert, artejijder Brumeu 363

geupiederje. . . . . . 465

Nerwton, Mbplattung icl croe. 171

— Grovitationseje . . 2.:73

Riagarafall . . . . . 30,3

- jeili 3uriidfucidjen . . 409

Siedermendig, Mï̈liteine . . 343

SRiedrige Snjeln . . . . . 479

Ptil, licberjd)wenumungen . . 3st

- Delta. . . . . . 390

Riltbal . . . . . . 391

9ippflutb . . . . . . . 211

gordamerifa, erratijaje Blödfe . 4it

Porbirieśland, llutergang . . 400

Mordat...... . 5 5t7

Miordlidjt . . . . . . 250

- jeine lirjadjen. . . . 261

- jein 3ujamimenbang mit $D$.

Eromagnetismus .

- jen 3ujammenbang mit s. Electricitüt

- jeir 3njammenbang mit o. atmojpljäre

Sorbje, Durdbrud $\cdot 403$

Morojtrano, 3eritörung . . . 400

Porrje, Erojall .... . 414

Simmuliten . . . . 490,626

Sutation D. Ervare . . . $18 t$

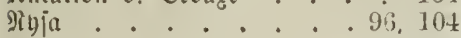

Ebruivi bei Doefīa . . . 416

Dbitidisu . . . . . . 342

Scean, jeine Rebenswelt . . 602

Drean 1110 Fejtlano . . . . $6 \% 2$

Drennicr. . . . . 684

Etertfal . . . . . . 518

Doermü̈durgen $\quad . \quad . \quad . \quad 395$

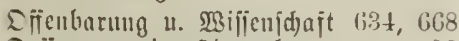

Deifmungen im \$ुimmel . . 33

Slbers, sijpotbeje o. Planetoiven. urjprumgs

Slmitedt, Eertlärung D. Rordidits 201

Dolitbgruppe . . . . . 538

Evale..... 488

Dppoition o. Mionies : . 198

Drangen . . . . . 584

Drbe im 2Batotlano . . . 366

Drdbibeer . . . . . . 5TT

Erganijation, voriveltlidje : . 559
Drgaujution, ibr=-5ortid)ritt . 561

Erganijd)es Q́eben, jein (E)wad)en $65 t$

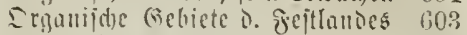

- Edjümugen . . . . 463

Ergnnismus. . . . . 27.

Erinofo, llcberidtucmumigen: 384

Elimucbel . . . . . . 49

Ertinte . . . . . . 267

Ecjar in Edivedon . . . 452

Eitcricit, Bered)uung . . 206, 208

— llefiecipidjt . . . . . 209

Eitergrenzen. . . . . . 208

Sule be conbarmie. . . . 418

Strorntbou . . . . . 539

Shaläofumeni, Ėntitelyng . . $30 t$

Foläntijerimu . . . . . . 628

tolïnoijde (sechilie. . . . 537

米ales..... . . 96, 105

tiallas . . . . .96, 101

Filme, Errbebungfrater . . 302

thatmen . . . . . . 577

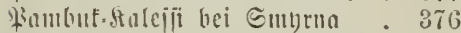

*ampas, Vintur. u. Sölferleben 696

Fapuas . . . . . . 687

faaradicjijc)e Edjöpfung . . . 551

sarallare o. Jiriterme . . . 34

Farmu, Rataraft . . . . 383

fiarthenope . . . . 96, 103

Failate . . . . 218

Batagonicr . . . . . 680

Fieditorí . . . . . 466

隹endel, Berucis j. D. Potation i.

Erve

- Beweis i. D. Rloplattung

D. Eeve . . . . 172

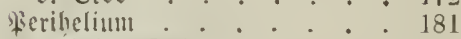

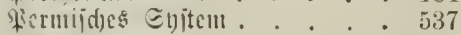

Perte du Rhone. . . . . 366

Fermaner. . . . . . . 679

fiesfïomel . . . . . . 471

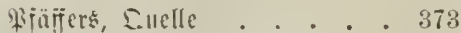

tiflanze . . . . . . 569

fiflauzenreid), jeine (3ruppen . 571

Fiflanzenuelt, ibre Bauten . . 468

- ifre Reģionen u. 30uen 604

- D. Borzeit . . . . 612

fibantafie . . . . . . . . 10

fllilojoplie der sintur . . . 18

93jIegräijd) felder . . . . $9+8$

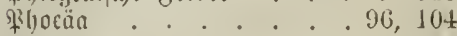

glyoten . . . . . . . . 598

आhonolith : . . . . 52t

9tbonotitbijde Berge . . . 526 


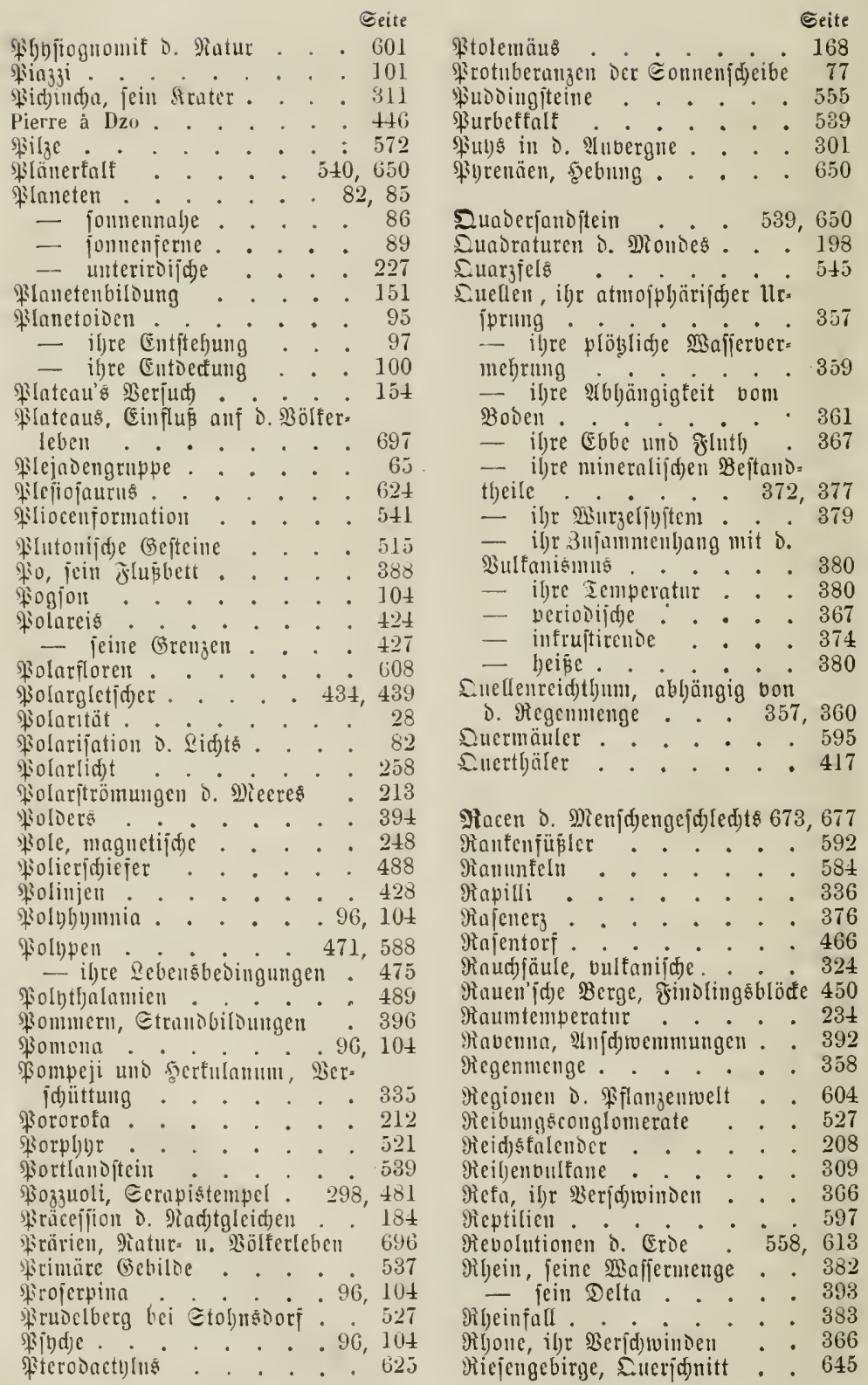




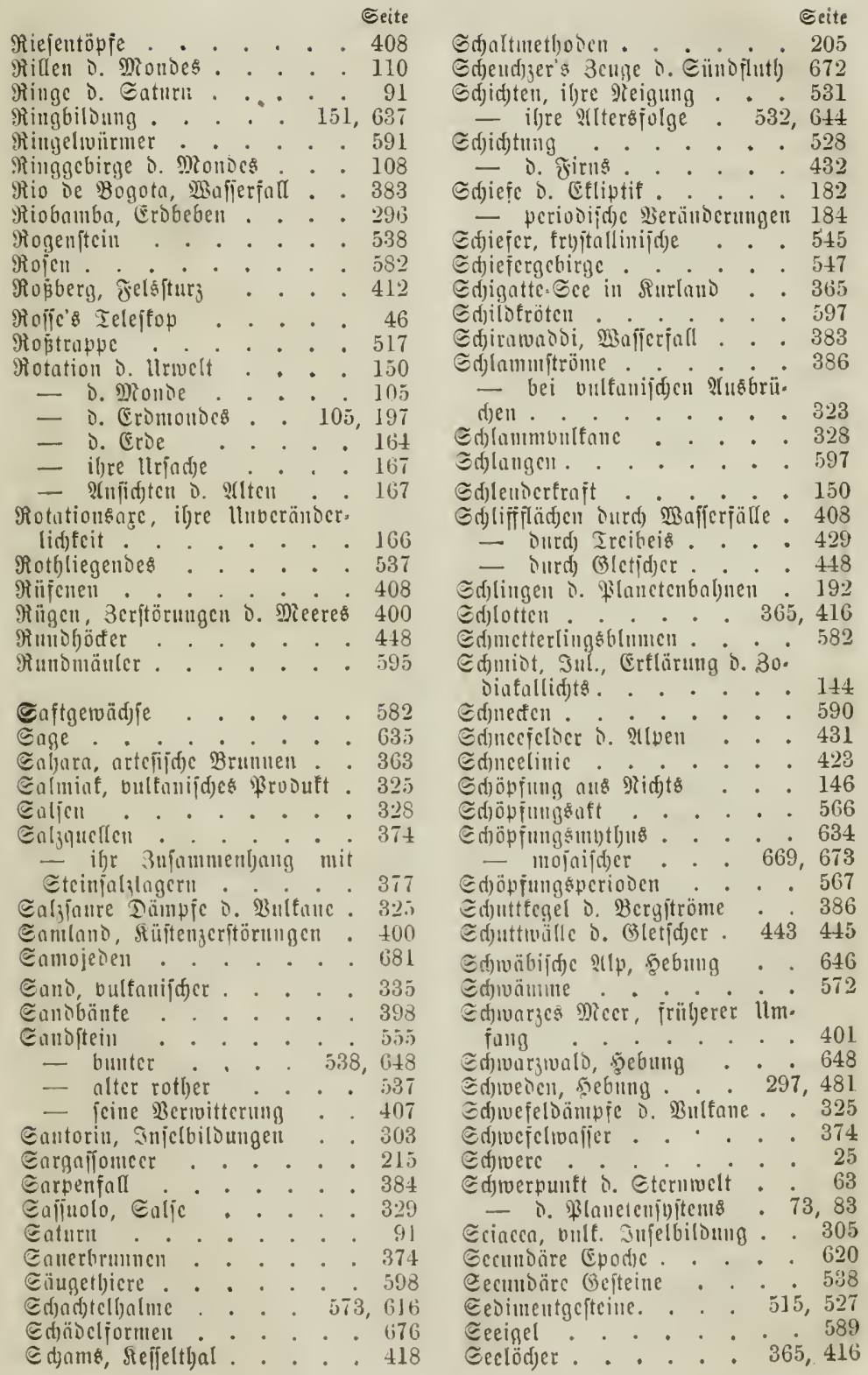


๔eite

Eecu D. Alpen . . 388, 418, 447

Eeen, Durd) Èrojälle gebiloet . 414

Geciteritc. . . . . . 589

Eclters, Inelle . . . . . 874

Eemiten. . . . . . . 633

Ecrfungen D. meeresbodens . 481

Eerapistempel bei $13033110 \mathrm{li} .298$

Eerucutin . . . . . . 522

Eerrièr bei Dicufdutel . . . 360

Eleballian= Errperiment . . . 22t

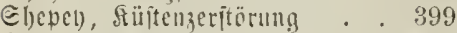

Eibirict, Eisicloer . . . . $\$ 27$

- NTammutbe n. Pusbörner

in Eije . . . . 430,663

Eicilien, bulfonifider foect , 286

Eicuerśs. . . . . . 504

Einillarien . . . . 613, (\$16

Eilurijdes Evitem . . 536, 6 52

Einter..... . . 375

Cirencn . . . . . . 598

Efandinavien, Malleriälle . . 384

Efaptanr-2yöful, Rabajteöine . $3 \pm 1$

Elaven . . . . . . 682

Enags . . . . . . . 392

Eoliatarell . . . . . . 325

Goljtiticn. . . . . . 182

Eomma D. Bcjub. . . . 310

Commertemperatur, mittlere . 236

Gonne . 70

- ibre jocinbare Bröse : 70

— ilje waljre (srö̈se . . 72

- ibre Entfermug D. T. ErDe 71

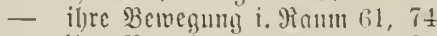

- iljre Rotation . . 73,85

- ilj Difft . . . Tt, 70

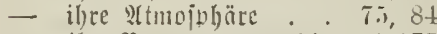

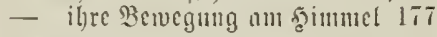

Commeniafeln . . . . . . 75 Ennmenflecten . . . . . 75, 84

— ilse p’eriobicität . . . 81

Eomnenipipterniв . . . . . 200

Єonncujut . • . . . . . 205

巨omncun̈lle und ซerne . . . 181

Eomnenituiten . . . . . . 83

Eolnuentug . . . . . . . 204

Eomncmuärnic : . . . . . . 234

Eommenzit . . . . . 204

Eommengirfel . . . . . . 209

Conntagsbudjube . . . . . 209

Eorgue bei Bancluje. . . . 366

Enan, Duellen . . . . $37 t$

Epalten bei Erobeben . 279, 296

- D. Bletider . . . 437

Eplenophulfiten .

Epimen . . . . . . 593

Enree, Snjujoriculager . . 488

Epringrluth . . . . . . . 211

Ełringancllen. . . . . . 367

Eprudelitcin. . . . . . 376

Eprudclivafier . . . . . . 374

Etübd)entflanjen . . . 484, 572

Etaljluaijer. . . . . . 374

Etumbbad . . . . . . 383

Eterftori . . . . . . 466

Etecu Billc, Reije um die Melt 312

Eteர̈ens, Ducllantbeorie. . . 378

Etcimansioirie, bulfanifóde . . 335

Etcinfublenbräntoe . . . . . 543

Etcinfoblenflöge . . . . 537

Etcinfoblenformation, íne $\dot{\mathfrak{B} e r}$ :

itcinerungen . . 537, 615,648

Eteintohlenlager, ihre Bilsung 658

Etcinfohleuiimufe . . . . . 647

Etcinfohlenvegetation . . 615, 657

Etcinlnuen . . . . . . 342

Etcinjalzlager : . . 377,538

Eteno....... . 506

Etcppen, jiidruijiche . . . 402

- ihr Bölferleben . . . 696

一 ilir Boben . . . . . 465

Etcrnaidungen . . . . . . 38

Eternbilier. . . . . 31,178

Cterme, veränberlide. . . 41, 56

— neлt . . . . . . 41

Eterubañen, . . . . . 33,46

Etcrujdumpten . . . . . . 130

- ibre söbe . . . . . 134

— in ๖. Bolfspoej̃c . . . 139

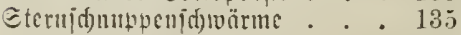

— periodijdse . . . . 136

Etcrijujtente, ibre Riloming , . 155

Etcrutng....... . $20 \pm$

Eternucite. . . . . . 32

Etermuïmer $. \quad . \quad . \quad . \quad . \quad .589$

Etcrmäblumgen . . . . . . 38

Etigmarien . . . . . . 616

Etillätäde D. Rlancten . . . 193

Etirmmall. . . . . . . 444

Etöcte o. भrpen . . . 409,417

Etocfaletidier . . . . . 444

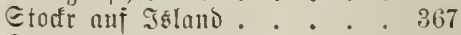

Etörungen †. Erbe . . . . 183

- D. \$lancten . . . . 185

- D. M̂noes. . . . . . 196

Etrablthicre. . . . . . . 589

Etranbbilimigen . . . . . . 396

Etrandrific . . . . . . . 476

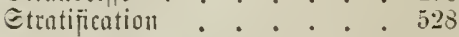


Geite

Etromidunelfen . . . . . 382

Etromibälcr . . . . . . 410

Etromtheorie . . . . . 455

Strömungen D. Mceres . . . 213

— D. Luit . . . . . 218

Etrubel ....... . 382

Strube, Doppeliterne . . . 54

- Pünitlidge झzinernlwajīer 378

Etujenlänier, ibr Bölferleben . 698

Stürme bei Bétvittern . . 269

Etul, alter uno newer . . . 207

Eubappeninellformation . . . $5+1$

Eiibjletlandinjelı, Balfipd)e im

Ěije...... . 430

ङıgoljufu . . . . . . , 328

Eund, Durdjbrud) . . . . 406

Emnderbund. . . . . . 392

Eindoflutl), noadjijde . . 506, (j71

Evinemünde, 3critörungen ics

Miecres . . . . . 400

Eyenit. . . . . . . . 520

El)ngenepiiten . . . . . . 580

El)3tgien.. . . . . . 198

Taiti, Sorallenbilomg . . . 477

Tnlferie im Dolomit . . 548

Ialfjulejer . . . . . . 545

Taman, Bulfane : . . . 331

Tange . . . . . . 572, 616

Tangentialfrujt . . . . J 881

Tartaren . . . . . . $68 t$

Iajdem auf Sava. . . . 332

รัแแแ , รеดแแก . . . . . 647

Temperatur D. Meltraums . . 234

Iemperaturg!eici)gewidst D. Eroe 662

Teneriffa, Erbebungftrater . . 302

sepliz, Encllen . . 37t, 381

- Borphorfugelu . . . 521

I cquendomafall . . . . . 383

Iertiärformation . . $5 \neq 0,651$

- ifje 3 erjtcinerumgen . . 627

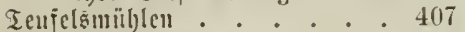

Teutobad, Bebeine . . . 671

Ihalbiloung . . . . . . 400

Tholes. . . . . . . . 501

Thalia $. . .0 .90,10 t$

Thamar, veriduittete Etaot. . 33.

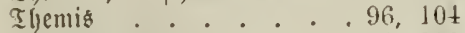

Tlermen . . . . . 333, 300

Thetis...... . . 96, 104

Thier . . . . . 585

— jeine Entuvidflung . . . 586

Thierfreiš . . . . . . 178

Thierfreiglifft . . . . 142
Seite

Thicruclt, ibre $\mathfrak{B a u t e n ~ . ~ . ~} 471$

— D. Borzcit . . . . 660

Ijonlager, ibre Beocutung fïr Sllelle . . . . 362

Tlonjdjicier, ibr Metamorphis: แแย

$5 \pm 6$

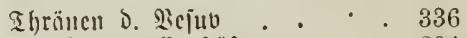

Il)ïringen, Eroîtüßc . . . 294

Thäringer $\mathfrak{B}_{n}(0$, jebung . . 648

Sicjebenen, ibe Bölferleben . 695

Timnuo, feine Euclle . . 366

Titieneajec . . . . . 420

Todestljal alif Juoa. . . 326

Toltefen . . . . . . 679

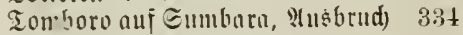

Tongutabu, foralleninjel . . 479

Tori, jeine Entitelumg . . . 466

- jein (scbratid). . . . 467

Torre del Greco, Rabujtröme . $\$ 40$

Trubuntell . . . . . 105

Iracibt . . . . . . . 524

Tradiltberge . . . . . . 526

ז̊n巨́ . . . . . . 343

Trabellers . . . . . 401

Trubertill . . . . . . 376

Ircibeis . . . . . . . 427

— Edjutt แ. Blöđc tragend 429

- Iherförper einj(d)liejend 430

Ireibietheorie. . . . . 455

Ircibljoly . . . . . . 468

Trias?. . . . . . . 538

Irilobiten . . . . . . . 619

Trinfwaller, Bejtandtheile . 373

Tripelerbe . . . . . . 488

Irull)üttofälle . . . . . . 384

Iromben. . . . . . . . 270

Sropen, scimat o. Bewitter 267

Trupien, D. llrgeitult D. Wielt=

förper . . . . . . 149

Iropiid)e Slinta D. Borwelt . 657

Srimmergeitciue . . . 515, 5.54

Tid)erfelien . . . . . . 684

Tuffe, bulfanijde . . . . 337

- hei foncllen . . . . 375

Immora . . . . . . 464

Illnguten . . . . . . 680

Inranifdec Race . . . . . 679

Intbaco, Bulcanitos . . . . 329?

Siltfell . . . . . $68 t$

Tudoo's Etern . . . . . 41

Throl, Gletjder . . . . 4ist

Ucbergangaperiode . . 537, 647

llebergangsfalt. . . . . 536 
๔eite lleberjđ̆vemmungen, plösliđ) . 359 — periodijøe . . . . 384 lliermälle . . . . . . . 396 - o. ril . . . . . 390 - o. Rbeil . . . . 393 - D. \$O . . . . . 392 llualajdfa, vulf. Snjelbiloung . 302 lluendinfeit D. WBelt . . . . 147 llrania . . . . . 96, 104

lltauแs . . . . . . . 93

- jeine Mionde . . . 116

Ilralvölfer . . . . . . . 680

lltpilanze . . . . . . . . .

lligebirge . . . . . . 516

llrmeer . . . . . . . 641

lletjoujdiefer $. \quad . \quad . \quad . \quad . \quad .535$

llrwälber, ibre Begetation . . 610

llrjengung . . . . . 566

Barcebänfe . . . . . . 602

Bariation, magnetijufe . . . 253

Begetation . . . . . 603

Bclay u. Bivarais, Erfehungs.

frater . . . . . . 301

Benus์ . . . . . . . 87

- Durdigang ourd D. Eoune 71

Berbremung . . . . . 79

Berglaite Burgen . . . . . 543

Beriandung D. ₹flubecten . . 387

Beriteinerungen - . 503, 529, 558

Bertoitterung D. Gejteine . . 407

Beita . . . . . 95, 102

Sejuv, ¡ein elemaliger frater . 337

- Beränbermugen $\lceil$. Segel 310

Diamala . . . . . 418

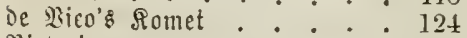

Bictoria . . . . . . 95, 103

Bicliterme . . . .

Biejdyletjder . . . . 444,446

Sirginia . . . . . . . 96, 105

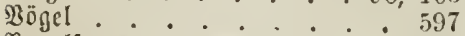

Bogelipuren aui 厄anditein . . 625

Bogejen= \$્⿹еbung . . . . 648

Bolger, Dtto, Theorie D, Ero=

imern . . . . . 243

- Erobebentbeoric . . . 351

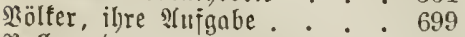

Bollmono . . . . . . . 198

Bormelt, ilyr Reben . . . 611

Bulfanitos v. Surbaco . . . 329

Bulfane . . . . . . . 307

- Smmerajiens. . . 308, 324

— D. MTondes. . . . 336

- erlofdene : . . . 344
Bultane, ibre şöhe . . . . 317

— ibr 2usbrud) . . . . 318

- ibr 3ujammenbang mit $\delta$.

Meere...... 308

— iljr 3ujammentjang m. Ėro:

beben . . . 289, 351

Bulfanijde \$rodute. . . 320

Bulfanijase Erjojeinmon, ibre

llrjadien . . . . . . 349

Bulfanifdide Befteine . 354, 515, 523

Bulfanijdje 3onen . . . . 345

Bulfanijoer jeerd . . . . 351

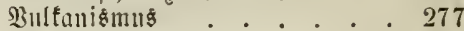

\$ulfanijten . . . . 501, 511

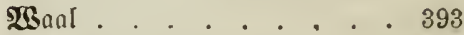

Maguer, 2Horeas . . . . 668

mälder, mtermeerijde . . 468

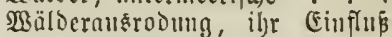

auf Suellen . . . . 360

- ibr Einflus añ D. Eropion 408

Bälicerthon ...... . 539

Mallebenen Des Mondes . . . 108

Wallijer Nllpen, sebung. . 652

Malthiere . . . . . . 598

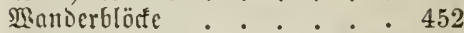

Märnte $\quad . \quad 26,79,231$

- centrale firaft . . . 232

- D. Erbinnern - 240,350

Marten, magnetijde . . . 254

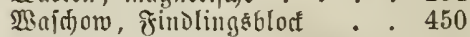

Salier, billente mo zeriförcnde

frnft....... 356

- harter u. meides... 373

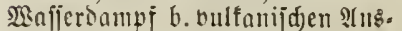

brïden . . . . 324, 350

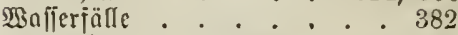

- ibre 3erftörmigen . . . 409

Mafjerfolen . . . . . 270

Mafferitoffga bei bulfan. $2118=$

brücten . . . . . 320, 327

MenlDengruppe . . . . . . 539

Mebr, Eifenjteinlager . . . 377

Mciberitein . . . . . . 344

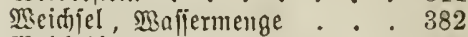

Meidthiere . . . . . . . 589

Meife Berge, Bolarflora . . 431

Melt, i. Entroidlungsgejdichte 59, 145

- ihre Entitel)ung aแs Ricts 146

- iljre llnemolidjteit . . 147

MeItenitofi seridel'g . . . . 52

Meltgebäuse, räumlid) $\mathfrak{B e r b a ̈ l t = ~}$ nilie 22

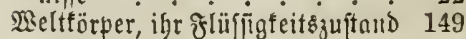




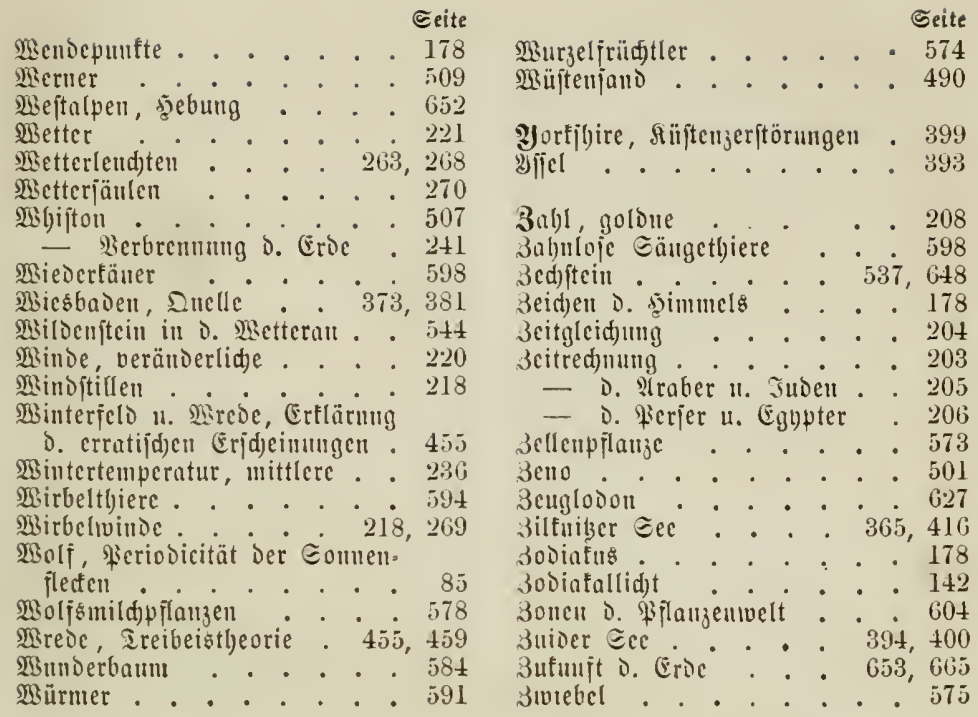

\section{Beridgtigungen.}

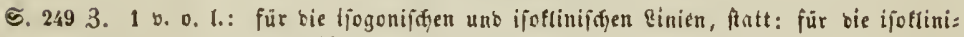
iden Sinietr.

S. 613 3. 16 У. 0.1: Eterbelis, ftatt: Strebens. 
o 




BINDING ミニニ-. JAN 29 1973

\section{PLEASE DO NOT REMOVE CARDS OR SLIPS FROM THIS POCKET}

\section{UNIVERSITY OF TORONTO LIBRARY}

Q

158

Ule, Otto Eduard Vincenz

U37

1859

P\&ASci 
